\title{
Smrt u opusu Vladana Desnice i europskoj kulturi: poetički povijesni i filozofski aspekti: Zbornik radova s međunarodnoga znanstvenog skupa Desničini susreti 2017.
}

\section{Edited book / Urednička knjiga}

Publication status / Verzija rada: Published version / Objavljena verzija rada (izdavačev PDF)

Publication year / Godina izdavanja: 2018

Permanent link / Trajna poveznica: https://urn.nsk.hr/urn:nbn:hr:131:360741

https://doi.org/10.17234/Desnicini susreti2017

Rights / Prava: In copyright/Zaštićeno autorskim pravom.

Download date / Datum preuzimanja: 2023-04-26

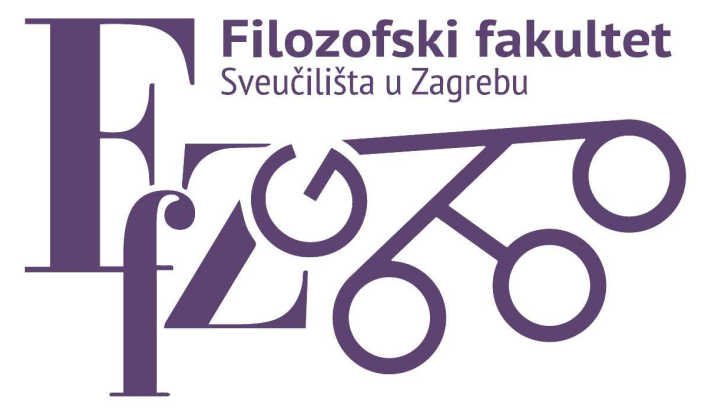

Repository / Repozitorij:

ODRAZ - open repository of the University of Zagreb Faculty of Humanities and Social Sciences
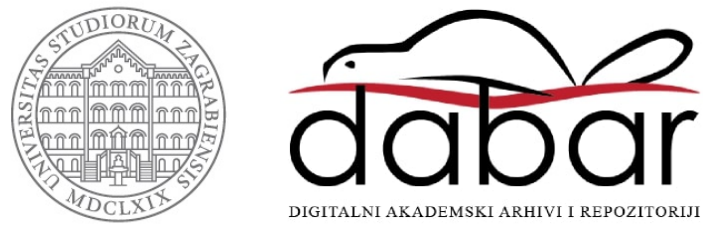
CENTAR ZA KOMPARATIVNOHISTORIJSKE I INTERKULTURNE STUDIJE

\section{SMRT U OPUSU VLADANA DESNICE I EUROPSKOJ KULTURI: \\ POETIČKI, POVIJESNI I FILOZOFSKI ASPEKTII}

Zbornik radova s Desničinih susreta 2017.

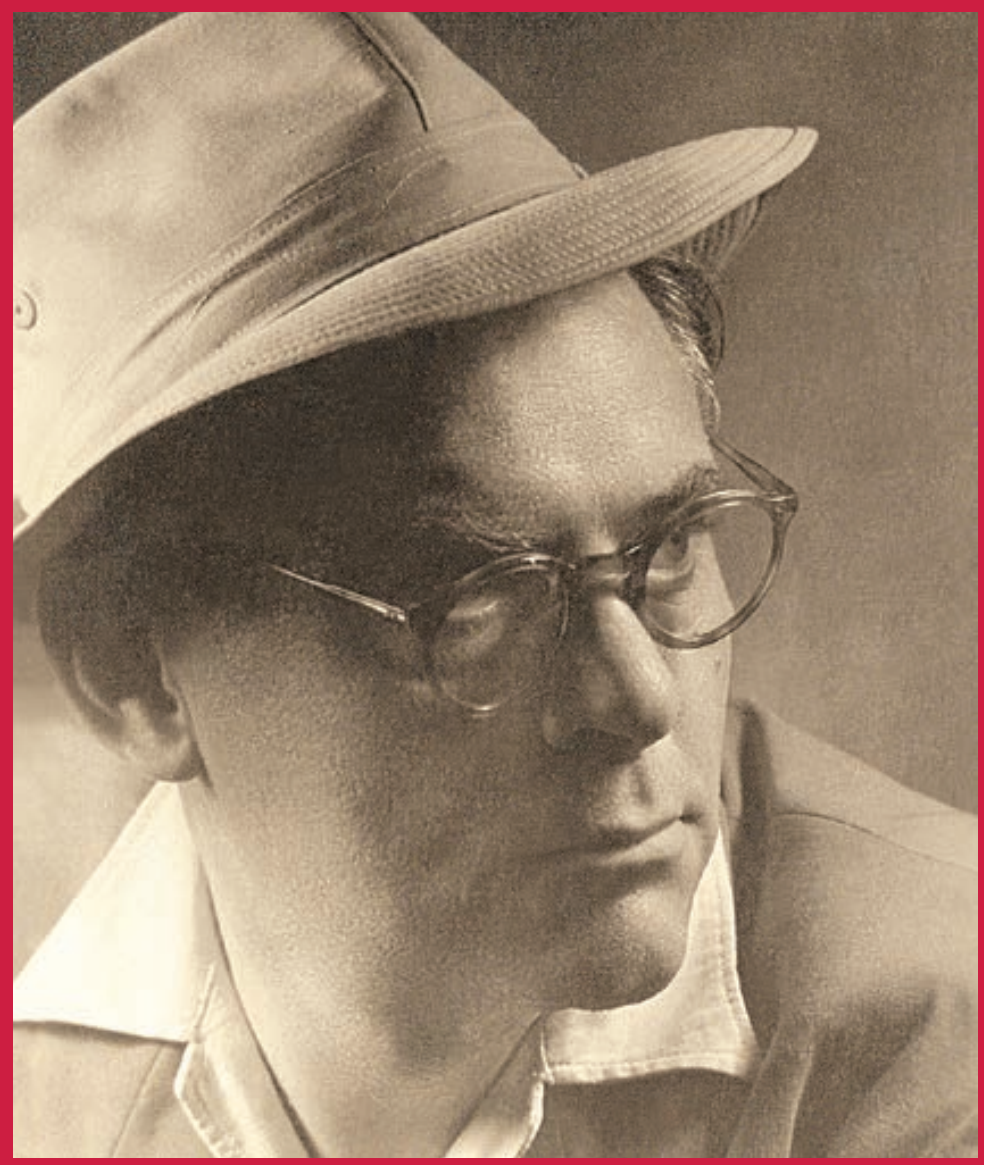

Uredili

IVANA CVIJOVIĆ JAVORINA

DRAGO ROKSANDIĆ 
SMRT U OPUSU VLADANA DESNICE I EUROPSKOJ KULTURI:

POETIČKI, POVIJESNI I FILOZOFSKI ASPEKTI

Zbornik radova s Desničinih susreta 2017. 


\section{Biblioteka DESNIČINI SUSRETI}

sv. 16

co

\section{Nakladnici}

Sveučilište u Zagrebu, Filozofski fakultet,

Centar za komparativnohistorijske i interkulturne studije

Institut za književnost i umetnost u Beogradu

FF press

Za nakladnike

prof. dr. sc. Vesna Vlahović-Štetić

dr. Bojan Jović, znanstveni savjetnik

\section{Urednici}

Ivana Cvijović Javorina, prof.

prof. dr. sc. Drago Roksandić

\section{Recenzenti}

prof. dr. sc. Damir Agičić

prof. dr. sc. Dušan Marinković

Tiskanje ove knjige omogućeno je sredstvima Ministarstva znanosti i obrazovanja

Republike Hrvatske i sredstvima Ministarstva prosvete, nauke i tehnološkog razvoja Republike Srbije
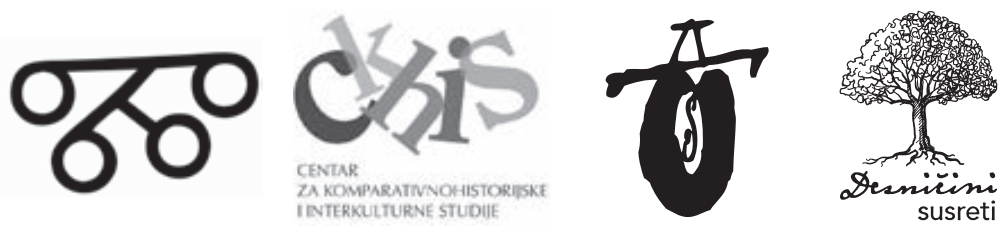

Fotografija na naslovnici

Vladan Desnica (iz fotodokumentacije dr. sc. Uroša Desnice) 


\title{
SMRT U OPUSU VLADANA DESNICE I EUROPSKOJ KULTURI: POETIČKI, POVIJESNI I FILOZOFSKI ASPEKTI
}

Zbornik radova s međunarodnoga znanstvenog skupa Desničini susreti 2017.

\author{
Uredili \\ Ivana Cvijović Javorina \\ Drago Roksandić
}

\section{FF press}

Filozofski fakultet Sveučilišta u Zagrebu Zagreb 2018. 



\section{Sadržaj}

\section{Ivana Cvijović Javorina i Drago Roksandić}

O smrti na Desničinim susretima. Predgovor . . . . . . . . . . . . . . . . 9

\section{Bruna Kuntić-Makvić}

Haronova dobra. Antički motivi u tanatičkom repertoaru Vladana Desnice . . . . 23

\section{Bojan Jović}

Tanatologike Vladana Desnice - igre poetike i smrti . . . . . . . . . . . . . 57

\section{Vladan Bajčeta}

Sedefasti odsjev vječnosti. Tanatološki aspekti književnog djela Vladana Desnice . . 69

\section{Marija Mitrović}

Slovenačka recepcija Vladana Desnice i tematizovanja smrti u njegovim delima . . . 89

\section{Aleksandra Kuzmić}

Dramaturgija slobode i smrti ili o Ljestvama Jakovljevim Vladana Desnice u svetlu Sartrove teorije pozorišta situacija . . . . . . . . . . . . . . . 103

\section{Bojan Đorđević}

Muva na gornjoj usni: narativni prostor smrti u prozi Vladana Desnice . . . . . . 117

\section{Stanislava Barać}

Časopis kao amblem poslednjeg časa: međusobna uslovljenost motiva smrti i motiva periodične štampe u pripovetkama Vladana Desnice . . . . . . . . 129

\section{Sanja Šakić}

Groteskna slika tijela u Olupinama na suncu Vladana Desnice . . . . . . . . . . . 147

\section{Ivan Majić}

Književnost kao odnos pisanja prema smrti - romani Derviš i smrt

Meše Selimovića i Proljeća Ivana Galeba Vladana Desnice . . . . . . . . . . 159

\section{Vladimir Gvozden}

Smisao kraja u Proljećima Ivana Galeba Vladana Desnice. . . . . . . . . . . . . 165

\section{Marin Biondić}

Aspekti analitičke filozofije smrti u romanu Proljeća Ivana Galeba Vladana Desnice . . . . . . . . . . . . . . . . . . . . . . . . . . . . . 179

\section{Virna Karlić}

Pojmovna metafora i konceptualizacija smrti u Proljećima Ivana Galeba Vladana Desnice . . . . . . . . . . . . . . . . . . . . . . . . . . 191

\section{Aleksandra Obradović}

Dani pred smrt u drami Terasa Jovana Hristića i romanu Proljeća Ivana Galeba Vladana Desnice . . . . . . . . . . . . . . . . . . . . . 203 


\section{Melida Travančić}

Strah od smrti u romanu Zimsko ljetovanje Vladana Desnice . . . . . . . . . . . . 211

\section{Svetlana Šeatović}

Smrt građanske elite u Zimskom ljetovanju . . . . . . . . . . . . . . . . . . . 225

\section{Vinko Drača}

Thanatopolitika i imortalizam u Desničinu Pronalasku Athanatika . . . . . . . . 237

\section{Miroslav Artić}

Trajna nedovršivost kao temeljni princip nadilaženja povijesno uvjetovanih identiteta u djelima Vladana Desnice . . . . . . . . . . . . . . . . . . . . .249

\section{Goran Đurđević}

Ekokritičko čitanje romana Pronalazak Athanatika Vladana Desnice. . . . . . . .261

\section{Sanja Roić i Iva Grgić Maroević}

Vladan Desnica, prevoditelj i komentator Foscolovih Grobova . . . . . . . . . . 281

\section{Edin Muftić}

„Smrt je kalež, a čovjek je kušač゙: smrt u starijoj arapskoj poeziji . . . . . . . . . .293

\section{Iva Tešić}

U iščekivanju smrti ili preplitanja života i smrti u Baraci 5 be Miroslava Krleže i Rekonvalescentima Dragiše Vasića . . . . . . . . . . . . . . . . . .303

\section{Vladimir Vukomanović Rastegorac}

Šašava besmrtnost i garava smrt: predstave ljudske smrti u poeziji za decu i mlade Miroslava Antića . . . . . . . . . . . . . . . . . . . . . . . 315

\section{Matko Globačnik}

Uloga smrti u njemačkoj filozofiji egzistencije međuratnoga perioda i njezina recepcija u misli Stjepana Zimmermanna . . . . . . . . . . . . . .327

\section{Nikola Petković}

Smrt i međustanje u radovima Juana Rulfa i Dževada Karahasana . . . . . . . . . 341

\section{Marijana Jelisavčić}

U Zagrobu nešto diše: tema smrti u pripovedačkim zbornicima Nešto diše u mojoj torti i Zagrob. Zbirka hrvatskog horora . . . . . . . . . . . . . 351

\section{Branka Migotti}

Grobni spomenici iz sjeverozapadne Hrvatske u svjetlu odnosa rimske antike prema smrti. . . . . . . . . . . . . . . . . . . . . . . . . . . . . . . .

\section{Mirjana Matijević Sokol}

Epitafi srednjega vijeka: „knjige života i smrti“ . . . . . . . . . . . . . . 381

\section{Zvjezdana Sikirić Assouline}

Oporuke zagrebačkih građana s kraja 17. stoljeća u gradskim knjigama

Zapisnika izjavnica (Protocolla fassionum). 


\section{Nikolina Šimetin Šegvić i Fillip Šimetin Šegvić}

Duh moderne: od kulture življenja do kulture smrti. Fenomen samoubojstva u Europi i Hrvatskoj . . . . . . . . . . . . . . . . . . . . 421

\section{Nikola Anušić}

Kad smrt poždere smrt: utjecaj pandemije španjolske gripe iz 1918. godine na dinamiku patocenične promjene u sjevernoj Hrvatskoj . . . . . . . . . .451

\section{Snježana Banović}

Hrvatsko državno kazalište u Zagrebu 1941. godine - dani smrti, straha i poniženja . . . . . . . . . . . . . . . 463

\section{Monica Priante}

Dva ispraćaja Vladana Desnice . . . . . . . . . . . . . . . . . . . . . . . .483

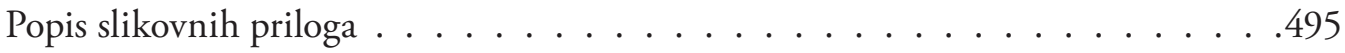

Autori članaka . . . . . . . . . . . . . . . . . . . . . . . . . 498

Recenzenti članaka . . . . . . . . . . . . . . . . . . 500

Bilješka o urednicima . . . . . . . . . . . . . . . . . . . . . . . 501

Imensko kazalo . . . . . . . . . . . . . . . . . . . . . . . . 502 



\section{O SMRTI NA DESNIČINIM SUSRETIMA}

\section{Predgovor}

\section{Ivana Cvijović Javorina i Drago Roksandić}

bornik Smrt u opusu Vladana Desnice i europskoj kulturi: poetički, povijesni i fllozofski aspekti najvećim dijelom čine prilozi nastali na temelju izlaganja na međunarodnom znanstvenom skupu Desničini sureti 2017., održanom u Zagrebu od 15. do 17. rujna. ${ }^{1}$ Skup kojim je obilježena i pedeseta obljetnica piščeve smrti imao je, nakon 2012. godine, najveći broj prijavljenih sudionika, a od četrdeset osam najavljenih izlaganja, održano je četrdeset. Iako su bili spriječeni održati svoja izlaganja, neki su prijavljeni ipak napisali članke te su oni uvršteni u ovaj zbornik. Osim tekstova sudionika Desničinih susreta 2017., zbornik sadrži i dva rada autora čiji su predmeti istraživačkog interesa bliski temi skupa te su na molbu urednika, a i potaknuti pozitivnim odjecima skupa, odlučili napisati svoje priloge.

Većina priloga uvrštenih u ovaj zbornik istraživačke je naravi, a autori su nastojali svoje hipoteze provjeriti i oblikovati na način koji će sadržajno udovoljiti suvremenim standardima znanstvenog diskursa. Slijedeći pravila uređivanja izdanja Biblioteke Desničini susreti, urednici su i ovaj put osigurali najmanje dvije anonimne recenzije za svaki prilog, uglavnom jednu iz Hrvatske i jednu iz inozemstva. U nekoliko slučajeva recenzenti su se dobrovoljno identificirali te su u izravnoj komunikaciji s autorima davali prijedloge za izmjene i dopune u radovima. Sve recenzije, uglavnom opsežne i sadržajne, pridonijele su kvalitetnijoj finalizaciji pojedinih radova, a sigurno su utjecale na podizanje vrijednosti izdanja u cjelini. Kategorizacija radova u najvećoj mjeri slijedi recenzentske prijedloge.

Budući da dio sudionika nije poslao svoje priloge, nekoliko primljenih tekstova nije dobilo pozitivne recenzije, odnosno nije udovoljilo recenzentskim i uredničkim kriterijima, a naknadno su dogovorena još dva priloga, bio je potreban i novi raspored članaka u odnosu na redoslijed izlaganja na skupu. On - prvi put dosad - znatnije odstupa od redoslijeda izlaganja. Iako zborničke cjeline nisu vizualno odvojene, članci u zborniku mogu se grupirati u tri skupine. Prvu, najbrojniju, čine prilozi u kojima se autori bave motivima smrti u

\footnotetext{
Međunarodni znanstveni skup Desničini susreti 2017. i ovaj zbornik realizirani su kao dio dvogodišnjeg Hrvatsko-srpskog bilateralnog projekta „Desničini susreti“ i hrvatsko-srpski/srpsko-hrvatski interkulturalizam Centra za komparativnohistorijske i interkulturne studije Filozofskog fakulteta Sveučilišta u Zagrebu i Instituta za književnost i umetnost iz Beograda, koji su vodili dr. Bojan Jović i prof. dr. sc. Drago Roksandić. Tiskanje knjige omogućeno je sredstvima Ministarstva znanosti, obrazovanja i sporta Republike Hrvatske te Ministarstva prosvete, nauke i tehnološkog razvoja Republike Srbije. Vidjeti programsku knjižicu skupa: Desničini susreti 2017. Smrt u opusu Vladana Desnice i europskoj kulturi - poetički, povijesni i filozofski aspekti (ur. Drago Roksandić, Matko Globačnik i Vladan Bajčeta), Zagreb 2017.
} 
djelima Vladana Desnice, bilo da se radi o opusu u cjelini, određenoj književnoj vrsti (npr. pripovijetkama) ili pojedinom književnom djelu (najčešće romanima Proljeća Ivana Galeba i Zimsko ljetovanje te nedovršenom romanu Pronalazak Athanatka). Slijede potom prilozi u kojima se tematizira motiv smrti u radovima drugih književnika (npr. arapskih pjesnika, Miroslava Krleže, Dragiše Vasića, Miroslava Antića, Dževada Karahasana i Juana Rulfa) i filozofa (Martina Heideggera, Karla Jaspersa i Stjepana Zimmermanna), a završava historiografskom cjelinom, tekstovima koji pokrivaju teme u rasponu od antike do sredine dvadesetog stoljeća. Urednici - nakon neizbježnih višekratnih čitanja svakog priloga - odlučili su napraviti vlastiti izbor naglasaka u svakom uvrštenom prilogu, nastojeći slijediti logiku „velikih tema“ koje integriraju ovaj zbornik.

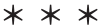

Desnica je mislio i pisao u tradiciji poetike mediteranskog kulturnog krajolika, koje je dijelio s Homerom, Eshilom, Sofoklom, Vergilijem, Danteom i Croceom, pa je ovom prilikom bilo nužno istraživački provjeriti antička izvorišta njegovih mnogobrojnih literarnih refleksija o smrti. Učinila je to Bruna Kuntić-Makvić. Simbolički evocirajući „strahotni lik" Harona, lađara mrtvih iz Vergilijeve Eneide i Danteova Pakla, interdisciplinarnim klasičnofilološkim i historiografskim pristupom otkrila je mnogobrojne antičke motive u umjetničkom opusu Vladana Desnice, s težištem na tanatičkom repertoaru. Uspoređujući različita izdanja njegovih radova, uočila je kako je od ulaganja rukopisa u tisak do izlaska iz tiska bilo mnoštvo aktera koji su svojim intervencijama u tekstu mijenjali smisao antičkih referenci, zaključivši kako su Desničini autografi i/ili njihove autorski ovjerene strojopisne inačice jedini pouzdani predlošci za ovakva istraživanja. Vrijedi naposljetku istaknuti autoričin zaključak: „Ovaj prikaz dokazuje da se [Desnica] snažno oslanjao na tanatičke motive iz antičke baštine, na Haronove darove, bilo kao nadahnuće ili kao na sredstvo iskazivanja. Njihov je značenjski kapacitet golem, a on je bez sumnje očekivao će ga čitatelji prepoznavati. Zato je Haronove darove i utkao u svoja djela. Stoga, da bi se njih razumijevalo, valja poznavati i Haronove darove."

Bojan Jović elaborira tezu da je motiv smrti u Desnice uvijek u vezi s njegovim širim pogledima na egzistenciju i ljudsku stvarnost, što podrazumijeva i estetička shvaćanja, koja iskazuje u dvojstvu „uzvišenog i niskog, misaonog i materijalnog / telesnog, ozbiljnog i humorno-ironičnog, skladnog i grotesknog“. To rezultira „otvorenošću i nedovršenošću tekstova, polifonim spajanjem romana sa esejistikom, poezije sa prozom, pustolovine sa apstraktnim razmišljanjem, eksplicitne sa implicitnom poetikom, uz umetanje manjih žanrova“, a sve to, pak, upućuje „na prisustvo osobina tradicije ozbiljno-smešne / karnevalizovane književnosti“. Budući da je Desnici smrt „temeljn(i), neprestano prisutn(i) i određujuć(i) fenome(n) ljudskog bivstvovanja, koji predstavlja osnovnu, možda i jedinu, filozofsku i umetničku temu“, težište je na unutarnjim doživljajima, kako na emocionalnoj tako i na racionalnoj strani „čovekovoga ja“. Time pisac, prema autoru, uspijeva razviti, pored ostalog, „višedimenzionalnu, 'multiskopsku' sliku (...) tanatologija koje, prožimajući se sa poetikom, 


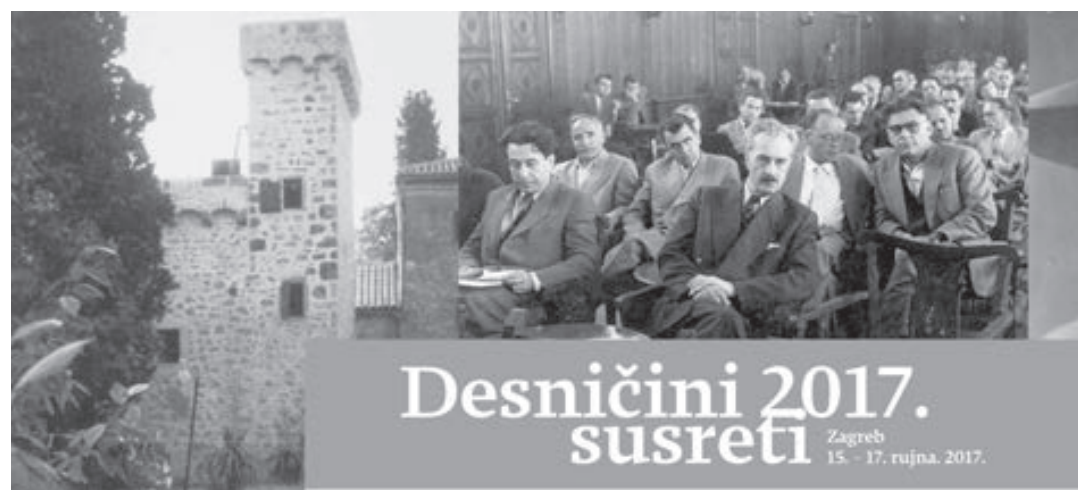

Smrt u opusu Vladana Desnice i europskoj kulturi - poetički, povijesni i filozofski aspekti

\section{Povodom 50. obljetnice smrti Vladana Desnice}

sอธ่รเขอ:

Jans Aleksic (Reogrndt, Nikola Anustic (Zagreto, Miroslav Artic (Zarreb), Vladen Rakiteta (Beograd, Snjeiana kanovic (Zageb). Stanislava llarac (leograd), Maria Biondic (Rijekal Tomisluv Beandolica Qugreb). Suzana Cohs

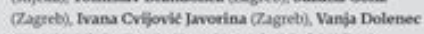
(Zagreb), Vinko Drata (Zagreb), Maja Diante (Bihuce). Bojan Doedevie (Meografin Goran Dardevie (Zadan, Muhamed raiponik (Sarajevol. Matko Globutnik (Z2agreb) Iva Grgite Maroevic (Z)dan, Marija Grupite (Reogradi. Vladimir Gvoadea (Novi Sach, Gordana Janjulevie

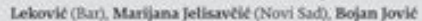
(Beograd). Virma Kantic (Zayeb), Zwonko Kovat (Zagetb). Marko Lovric (Zagreb), Alrua Kantik-Makvik (Zageb), Nekcandra Kuxmic (Beogenda). Tin Lemac (Zagreb), Natada Matukat (Beograd), Ivan Majie (Zagreb), Bojan Markovie (Beograd), Mirjana Matijevic Sobol (Zagreb), Dina Merdan

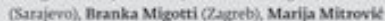
Tres. Tijana Mitrowik CNovi Stad Alekundra Obradorik (Nori Sadd. Nikolu Peitorite (iljeka), Eva Premk Bogated (Ciub)|jna), Moaica Priante (Zagreb), Maja Radonic (Deograd), Sanja Roié (Zagrebdi Drago Roksandic (Zagreb) Mario Strecha (Zagreb) Sanja Sakik (7) meb), Svetlans Seatovic (Beogrado. Flip Simetin Segvik (Zsgreb), Nikotina Simetin Segvie (Z)grebs). Iva Tesic (Beograd), Melids Travanzie (Telani), Vladimit Vukomanovic Rastegorac (Deograt)

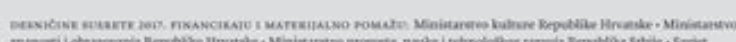

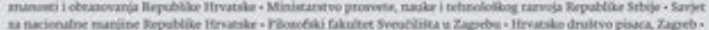

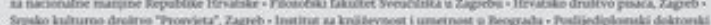

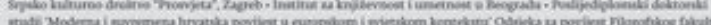

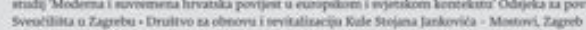

INTEGRALNA VERZIIA PROQRAMAT

http:/Kulajankovicaunizg hr/hr/desnicini-susteti/centar/programske-knjizice-ds
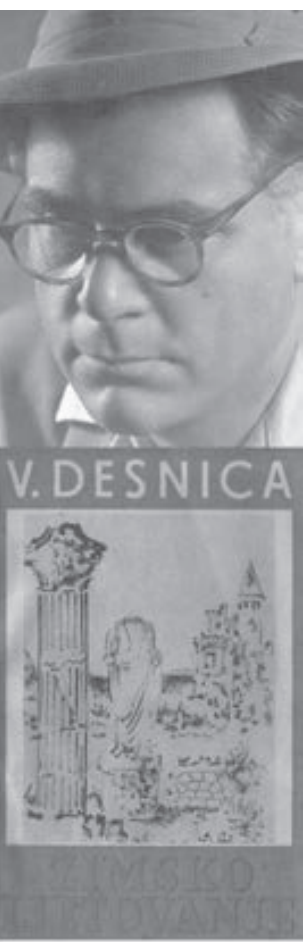

"Ćesto mi pada na um Michelangelova rijec iz jednog pisma Vasariju: Non nasce in me pensier che non vi sia dentro scolpita la Morte.' I rijec̃ onog drugog velikog ludog starea: 'Kad je covjek jednom naučio da misli, ma o cemu mislio, on u stvari uvijek misli na svoju vlastitu smrt.' Svi su filozofi bili takvi! I svi veliki pjesnici, nadodao bih. Smrt je u suštini jedina tema pjesnika. A sto im drugo i preostaje, kad već ne mogu biti vječiti ljetopisci żivota, nego da budu neumorni żreci Smrti?" 20os)

\section{$7 / 1 / 49$}

$\gg$ Migud \&

$$
\begin{aligned}
& \text { (sunt onedije) } \\
& \text { (Con'fuircue. tuth: }
\end{aligned}
$$

Sl. 1. Desničini susreti 2017. 
prerastaju u svojevrsne stvaralačke tanatologike“, a one kao igre poetike i smrti mogu biti jedan od ključeva za tumačenje čitava Desničina književnog opusa.

Kako razumjeti raznolike Desničine predodžbe i poimanja smrti u „različitim modusima njegovog književnog izraza“, u rasponu od metafizičkog optimizma do metafizičkog pesimizma, raspravlja Vladan Bajčeta. Autor se opredijelio za kronološki zasnovano istraživanje tanatoloških aspekata pojedinih Desničinih književnih djela kao jamstvo „hermeneutičke produktivnosti“. Dekonstruirajući „tanatologike“ svakog pojedinačno, razvio je jedinstvenu interpretacijsku matricu. Autor smatra kako „umjetnička uspjelost Desničinog prvog romana umnogome duguje odmjerenoj primjeni grotesknih, humornih, karikaturalnih i drugih elemenata iz komičkog repertoara, koji do stravičnog epiloga vode nepouzdanim putem drastičnog iznevjeravanja čitaočevog horizonta očekivanja“. Slijed romanesknih epizoda Zimskog ljetovanja, sve do jezivog kraja bebe Lizete u raljama golemog krmka Miguda, pred očima prestravljene majke, čitatelja instinktivno vraća na scenu iz razorenog Zadra s početka romana, u kojoj svećenik u haronovskoj maniri iz zaljevskog plićaka izvlači mrtvo dijete žrtvu bombardiranja. Bajčeta zaključuje da se tu zaokružuje misaoni obzor romana jer se selo i grad pred smrću prestaju razlikovati, a „Migud je samo jedna od njenih mogućnosti, podjednako surova kao i ona kojoj su junaci romana privremeno umakli“. Ne prateći autora u tanatološkoj dekonstrukciji drugih Desničinih radova, izdvajamo njegov zaključak: „Desničina književna tanatologija predstavlja izrazito kompleksnu umjetničku viziju smrti. Tražiti u toj složenosti piščev konačni odgovor na temu koju je iznova crpio predstavljalo bi metodološku pogrešku.“ Njegovo je književno umijeće „upravo u toj polifoniji umiranja“ pa je piščev opus „prevashodno artističko savladavanje svih, pa i tih sadržaja“.

Dok je već Desničina pojava u hrvatskoj književnosti izazvala oprečne reakcije, afirmativne recepcije u slovenskoj svjedoče o njegovu iznimnom književnom statusu, tvrdi Marija Mitrović. Desničina pripovijetka Pred zoru objavljena je u slovenskom prijevodu već 1950 . godine u izboru Hrvatski povojni novelisti. Prema T. Potokaru, Desničino umijeće koncentriranja na unutrašnji život ljudskog bića i kondenziranja životnog iskustva duboko je prožeto poetičnošću suptilno građenih rečenica te izuzetne stilske discipline i izraz je majstorske virtuoznosti. Na važnost motiva smrti u opusu Vladana Desnice prvi se među slovenskim kritičarima osvrnuo E. Štampar 1967. godine, nakon piščeve smrti, zaključivši kako se roman Proljeća Ivana Galeba može čitati kao proročku viziju posljednjih mjeseci piščeva života u bolnici, ali i „duhovite eseje raskošne figurativnosti“ koji na inventivan način „objavljuju boj protiv smrti“. Desničina smrt potaknula je Š. Barbariča da krene u Zadar i Islam, pod dubokim dojmom upravo piščeva shvaćanja smrti: „Smrt je ovde u sklopu autorovih razmišljanja o prolaznosti, i to ne samo ljudskog bića, nego i predmeta, navika, shvatanja, razdoblja... Tako posmatrana, smrt prestaje biti tragična, ona je naprosto deo života...".

Ljestve Jakovljeve posljednjih su godina i na Desničinim susretima predmetom novih interpretacija pa je prilog Aleksandre Kuzmić još jedan dokaz da je riječ o vrijednom djelu lucidno izvedenih, a zaoštrenih moralnih dilema u egzistencijalno graničnim situacijama. Autorica propituje suvremena vrednovanja djela u vrijeme praizvedbe u Jugoslovenskom dramskom pozorištu 1961. godine, dakle na prestižnoj sceni, s odličnim redateljem i glumcima te uz autorovo sudjelovanje u pripremi praizvedbe. Kritika ih je ocijenila „isključivo kao psihološku, realističku, odnosno realističko-naturalističku dramu, pisanu pod snažnim 
uticajem Krležine dramaturgije“. Tome je posredno pridonio Desnica tvrdnjom da je zamisao bila „da se prikažu složeni, najdublji intimni porivi ljudske ličnosti koji u vremenu ratnog stradanja dobijaju svoj poseban intenzitet i oblik“. Autorica ih je, pak, interpretirala u ključu Sartreove teorije kazališta situacija, dakle kazališta koje je 1940-ih i 1950-ih otvaralo „univerzalno pitanje odgovornosti pojedinca u dramatičnim okolnostima, pitanje najtešnje povezano sa ličnim moralom i odnosom prema slobodi i smrti“. Referirajući se na Aristotela, Sartre ga je teorijski tumačio kao „obnovu klasičnog tragičkog diskursa u novom vremenu“. Budući da Ljestve „u prvi plan postavljaju intrigantnu priču o čoveku koji, želeći da sačuva život po svaku cenu, kukavički relativizuje svoje moralno posrtanje, dok se ne suoči sa sopstvenim izobličenim licem i posledicama koje ono proizvodi“, teško je ne suglasiti se $s$ autoričinim pristupom.

Polazeći od tvrdnje da se fikcionalni svijet, odvojen od stvarnog svijeta iskustva, „belodano postvaruje u narativnom pristupu smrti i umiranju“, Bojan Đorđević raspravlja o poetskom (samo)osvješćivanju smrti na primjeru pripovijedaka Bunarevac i Oproštaj te romana Proljeća Ivana Galeba. Možemo ovdje istaknuti jedan od najupečatljivijih motiva, apostrofiran već u naslovu rada - motiv muhe, koja se pojavljuje nakon smrti Miloševe supruge Jagode. Autor tvrdi kako Desnica prikazom Jagodine smrti u Bunarevcu „vrhuni čehovljevsku atmosferu besmisla uzaludnosti“, i to, pored ostalog, time što njezino tijelo postaje „objektivitet, egzistencijalna činjenica“. Pojava muhe na gornjoj usni Jagodina leša te izostanak prirodne, uobičajene ljudske reakcije suočila je konačno njezina supruga s činjenicom o njezinoj smrti: „Ojačana junakova svest o simulakrumu kao imitaciji bića, kao subjektivnoj slici o Jagodi, koja se nužno razlikuje od Jagode kao tela, ta svest o diferenciji između stvarnog i ikoničnog, osnažena je gotovo folklornim (jer realističnim) prizorom muve kao označioca smrti." Autor se u svojim interpretacijama referira na moderne europske klasike, pored spomenutog A. Čehova (G. Benn, E. M. Remarque, Th. Mann) ili mislioce poput E. Husserla, nudeći ključeve za pristup Desničinu opusu po najzahtjevnijim europskim intelektualnim kriterijima.

Stanislava Barać istražuje kako se motivi smrti i motivi periodičkih tiskovina ugrađuju u narativnu i semantičku strukturu Desničinih pripovijedaka i kakve se umjetnički inovativne i estetske efekte pritom postiže. Svoj je pristup teorijski utemeljila u tezi Waltera Benjanima iz 1935. godine kako je medijska epoha nakon katastrofe Prvoga svjetskog rata promijenila ljudsko iskustvo i mogućnosti njegova pripovjednog prenošenja. $U$ analizirane pripovijetke (Životna staza Jandrije Kutlače, Juraj Carić - pisac mora, Zlatni rudnik, Konac dana i Oproštaj) ugrađeni su motivi tiskovina, u rasponu od dnevnih novina do stoljetnih kalendara. Autorica zaključuje kako je amblemska uporaba tih motiva pridonijela uspostavljanju ritma, „kako (u slici) umiranja tako i ritma samog pripovedanja“ te da se u doživljaju čitatelja ostvaruju „i efekti samog proticanja vremena, odnosno samog osećaja prolaznosti“. Također ističe da se u ovim pripovijetkama očituju kako cikličko tako i linearno poimanje vremena, odnosno - kada je o motivima ljudske smrtnosti riječ - smjenjuju optimistički i pesimistički intonirani efekti.

Teorijski artikulirajući svoja polazišta (J. Lotman, M. Bahtin, H. Bloom, W. Keyser, K. Nemec, ali i sâm V. Desnica), Sanja Šakić fokusira se na groteskne slike tijela u novelama Olupina na suncu u kontekstu rasprave o Desničinoj tanatologiji. Uočava da Desničinim 
likovima naizgled manjka događajnosti jer se kreću unutar dodijeljenog prostora, „a događajnost se u pravom smislu riječi pripisuje njihovu promišljanju nepromjenjivosti granica“. Iznenađenja u takvu svijetu čine „brojni tragikomični obrati, apsurdističko viđenje svijeta, ironija i humor zbog kojih se nesretni, a ponegdje i jezivi, usudi junaka razumijevaju kao vesela smrt". Ipak, autorica u konačnici Desnicu vidi kao pisca koji svoje novelističke opreke i ambivalencije razrješuje na razini ljudskog tragizma: „Groteskna slika tijela ne staje na suživotu ljudskog i neljudskog, nego njezina ambivalentnost podrazumijeva ukidanje granice između dvaju prostora i omogućuje spoznaje zbog kojih junaci prestaju biti, barem na trenutak, lutke čijim koncima upravljaju sile inercije i ukorijenjenih navika“.

U fokusu je priloga Ivana Majića Blanchotova teza da „pisanje nikada nije moć kojom se raspolaže, što rezultira stanjem u kojem pisac što više piše, to je manje siguran u to da piše, tada pisanje u sebi nosi i stanovitu ezgistencijalnu tjeskobu, gdje je smrt neizbježno odredište tom procesu“. Kako Selimović i Desnica u svojim romanima imaju „zajednički odnos prema propitivanju samog čina pisanja", u obama se slučajevima pripovjedač mora odrediti prema graničnosti svog pripovijedanja („smrt i u pripovijedačâ Nurudina i Galeba“). Referirajući se na Benjaminovu tvrdnju da je „pripovjedač od smrti posudio autoritet", autor kontrastira Nurudinovo i Galebovo shvaćanje smrti kao „besmisla“, odnosno smrti kao „jedine istine“. Prvi rezignira riječima: „...živi ništa ne znaju, poučite me, mrtvi, kako se može umrijeti bez straha, ili bar bez užasa. Jer, smrt je besmisao, kao i život." Galeb se, pak, suočava sa spoznajom da je smrt ,jedina istina koja ne stari, koja se ne otrcava, koja ne gubi svoju snagu i svoju aktuelnost". Ona je moguća samo ako se čovjek suoči s onim što jest ili Galebovim riječima fra Anđelu: „Pa to se i zove čovjek, moj oče: skup intimnih kontradikcija zašivenih u jednu ljudsku kožu! I čim su kontradikcije brojnije i veće, time je potpuniji i cjelokupniji čovjek."

Vladimir Gvozden svoj prilog završava riječima: „Prizivanje proleća stoji u tesnoj vezi sa senkom smrti. Nulta tačka toga poduhvata tačka je ravnodušnosti koja se pretvara u najveću moguću znatiželju, a ova je izraz mišljenja sveta kroz nihilizam, a ne nasuprot njemu." Ovaj književnoteorijski esej izveden je na filozofskim i sociohistorijskim pretpostavkama pa je ključ za razumijevanje Desničina poimanja smisla ljudskog kraja u egzistencijalističkom humanizmu, ali i u specifično Morinovu tumačenju krize u shvaćanju smrti kao krize individualizma u modernom društvu, koje je oličeno u površnosti, konformizmu i „manipulaciji smislom kraja“. Prema autoru, riječ je o piscu koji „pokušava da osmisli kraj, ili - premda jezik ne trpi lako ovu množinu - krajeve svoga života“, neovisno o smislu ili besmislu. Stoga Galeb i odbacuje utjehe, „ali - budući istinski s one strane očajanja - odbacuje i pesimizam“.

Marin Biondić propituje mogućnosti čitanja romana Proljeća Ivana Galeba kao teksta s težištem na analitičko-filozofskoj jasnoći pojmova, preciznosti, konzistentnosti i plauzibilnosti tvrdnji i stavova. Postavljajući pitanja na trima razinama - ontološkoj (Što je smrt?), vrijednosnoj (Je li smrt dobra, loša ili vrijednosno neutralna?) i etičkoj (Je li - ako jest, u kojim slučajevima - opravdano usmrćivati određena bića ili njihove vrste?), autor provjerava što neke Galebove tvrdnje impliciraju i je li skup određenih tvrdnji konzistentan, neovisno o umjetničkoj vrijednosti. Ako je smrt, prema Biondiću, trajni i nepovratni prekid postojanja, ona nema iskustven sadržaj pa se ne može reći je li ona iskustvena praznina ili ništavilo. S vrijednosnog stajališta, u Galebovu slučaju, ,razlikovanjem i analizom iskustvenog i neiskustvenog zla te eksplikacijom Galebovih promišljanja o prirodi zla, proizlazi da je Galeb 
u osnovi epikurejac, tj. da je obvezan na tvrdnju da smrt nije loša za osobu koja umre“. U Proljećima autor nalazi eksplicitne Galebove iskaze koji potvrđuju ovakve i slične „logičke inkonzistencije“, kojih je Galeb ,uostalom, sâm savršeno svjestan. Umjetnička vrijednost teksta, prema autoru, nije predmet analitičko-filozofskog interesa pa je stoga moguće zaključiti da nema nedosljednosti u Galebovim osjećajima i psihičkim stanjima, „ali ih možemo pronaći u logičkim implikacijama argumenata“.

Kognitivnolingvističkim pristupom Virna Karlić otvara problem pojmovnih metafora smrti u Desničinim Proljećima Ivana Galeba. Autorica je utvrdila kako se leksem 'smrt' u romanu javlja dvjestotinjak puta. Šezdeset poetskih metafora smrti zasnovano je na pojmovnim metaforama koje se mogu svrstati u tri skupine s obzirom na izvornu domenu: personifikacije, primarne metafore i prostorne metafore. Personifikacije su najbrojnije i najintrigantnije za interpretaciju romana - smrt dobiva karakteristike živog bića, „zadobiva svojevrsnu funkciju lika, Galebova suparnika“. Izdvajamo i autoričin uvid da „u potpunosti izostaju konvencionalne pojmovne metafore zasnovane na kršćanskim vjerovanjima“. Jedini svećenik koji se u romanu javlja, fra Anđelo, čovjek je iz Galebove prošlosti - važan akter, ali iz pripovjedačevih zavičajnih sjećanja. Bolničko je iskustvo dekonfesionalizirano. Ovaj tekst pokazuje kako i metode kognitivne lingvistike očito mogu olakšati razumijevanje Desničine tanatologije.

Aleksandra Obradović fokusirala se na zajednički motiv smrti u Desničinu romanu Proljeća Ivana Galeba i Hristićevoj drami Terasa i poetske implikacije književne razrade tog motiva. Hristićeva Olga teži k iracionalnom duhovnom osloncu, vjerujući „da za dostizanje mira iz kakvog je rođenjem došla, treba samo - umrijeti“. Na sličan način i Galeb govori iz perspektive samrtnika. Olga napušta najbliže, a Galeb im se ne može približiti. Jedino je rješenje za oboje pomirenost sa smrću: „Pomirenost je sloboda koju bi čovjek u susretu sa svojom smrtnosti morao sebi priuštiti.“"

Prema Melidi Travančić, najveći ljudski strah u egzistencijalno rubnoj situaciji koju dijele Smiljevčani s odbjeglim Zadranima nakon zračnih razaranja grada ujesen 1943. godine jest strah od smrti. Autorica ga izdvaja ne previđajući njegovu prožetost drugim strahovima, npr. strahom od drugog/drugačijeg, od nepoznatog, nasilja itd. Interpretacijom konkretnih epizoda u romanu te referiranjem na radove posvećene, pored ostalog, strahu o smrti (Epikur, Montaigne, Freud, Tugendhat, Konstantinović, Kravar itd.), autorica zaključuje da je u strahu od smrti najveći stradalnik čovjek kao društveno biće jer „kako smrt postaje sve bliža, želja za preživljavanjem je sve snažnije izražena, a strah od smrti zauzima mjesto glavnog pokretača života“.

Svetlana Šeatović otvara s kulturološkog i poetičkog aspekta dva problema o kojima se nesumnjivo još uvijek nedovoljno raspravlja, a to su bijeg „etničkih Italijana“ iz gradova poput Zadra i Splita 1943. - 1945. i aspekti „klasnog prevrata“ u isto vrijeme, koji pojačavaju egzistencijalnu nesigurnost u „građanskoj eliti“. Naglašava i teškoće pri otvaranju rasprave o spomenutim dvama problemima, naročito kada je u pitanju Zimsko ljetovanje. Neovisno o neupitnoj kulturološkoj polarizaciji Smiljevčana i Zadrana, koja je tako izražena u uvjetima egzistencijalno iznuđene kohabitacije, međusobno su itekako raslojeni sami Zadrani kao i sami Smiljevčani. Otvoreno je pritom pitanje „etničkih Italijana“ jer Desnica sâm ističe da zadarsku talijanofonu zajednicu koja pristiže u Smiljevce čine ljudi vrlo različita etničkog 
podrijetla pa je njihovo talijanstvo stvar višeslojnih identitetskih fermentacija, što također utječe na to od čega bježe, čemu teže, o čemu sanjaju itd.

Kontektualizirajući Desničinu „skicu za distopijski roman“ u tradiciji sličnih romana 20. stoljeća (Aldous Huxley, Vrli novi svijet (1932.), George Orwell, 1984. (1949.), Anthony Burgess, Paklena naranča (1962.)) i polazeći od Foucaultova pojma biopolitike, Vinko Drača tumači Desničin Pronalazak Athanatika u ključu pojma tanatopolitike, utemeljenog u hipotezi o neizbježno totalitarnoj kontroli izuma lijeka koji ljude može učiniti besmrtnima. Razmišljajući o ljudskoj smrtnosti, Desnica se suočio i s hipotezama o ljudskoj besmrtnosti, imortalizmom, s njihovim transhumanističkim i posthumanističkim implikacijama. Više od religijsko-ideologijskih implikacija, autora zanimaju ideologijsko-političke, koje propituje konceptualnim instrumentarijem baštinjenim od Hobbesa do Foucaulta. Zadržava se na pojmovima biomoći i biopolitike, izvodeći pojam tanatopolitike, zaključujući kako će „ta tehnologija, ako je znanost bude razvila“ biti ,jedna od onih koja će nas definitivno natjerati da promislimo odnos između vlasti i populacije nad kojom se mehanizmi te vlasti provode“.

Miroslav Artić polazi od tvrdnje da su Proljeća Ivana Galeba posvećena ljudskom mirenju s vlastitom smrtnošću, a da je Pronalazak Athanatika ogled o implikacijama pretpostavke o mogućnostima znanstveno utemeljene ljudske besmrtnosti. Zajednička im je „vječit(a) čovjekov(a) potreb(a) za propitivanjem vlastite smrtnosti, mogućnostima ljudske besmrtnosti i poimanjima vječite regeneracije života“. Za razliku od Proljeća, stvaranih tri desetljeća, Pronalazak se čitateljima nudi kao skica za roman od osamsto stranica - dakle, mnogo više nego što je opseg Proljeća - te se može čitati i kao „fantastičan roman koji prerasta u roman budućnosti“. Time Pronalazak potencijalno postaje romaneskni antipod Proljećima. Proljeća su kao autorsko djelo proizvod ukorijenjen u humanističkoj tradiciji, dočim su u slučaju Pronalaska sve opcije otvorene, pa tako i one posthumanističke.

Distopijsku fikciju Pronalaska Athanatika Goran Đurđević komparira s kronološki recentnijim trendovima u ekokritici, u bestseleru Homo Deus Yuvala Noaha Hararija te u suvremenim hrvatskim distopijskim romanima Josipa Mlakića i Ede Popovića. Budući da je ekokritika - citiranim riječima Cheryll Glotfelty - studij veza između književnosti i okoliša, odnosno istraživanje međupovezanosti prirode i kulture, napose kulturalnih artefakata jezika i književnosti, očito je da kao metoda ima teškoća pozicionirati se u postmodernim „obratima“. No, takvi trendovi autoru omogućuju kreativna čitanja Desničina Pronalaska i čine ga ne samo danas aktualnim nego i referentnim za razumijevanje razvitka ekokritike u njezinim ključnim izazovima, među kojima je i pitanje ljudske smrtnosti, odnosno besmrtnosti.

Prilog Sanje Roić i Ive Grgić Maroević traduktološkom analizom svjedoči o Desničinoj stvaralačkoj južnoslavensko-romanskoj interkulturalnosti, koja je formativne naravi kada je riječ o njegovim shvaćanjima ljudske smrtnosti. Autorice zaključuju da se u analiziranom slučaju radi „o jednom od najzahtjevnijih, ako ne i najzahtjevnijem prevoditeljskom zadatku što ga je Desnica sebi postavio i ostvario“. Foscolovi Grobovi (Dei Sepolcri), napisni 1806. godine, povodom Napoleonova edikta o grobljima, a objavljeni 1807., posvećeni su Ippolitu Pindemonteu, autorovu suvremeniku, klasicističkom pjesniku i prevoditelju Odiseje na talijanski jezik. Iako funkcioniraju na više razina, Grobovi su među suvremenicima bili doživljeni prije svega kao apologija talijanske Prirode i Kulture u dugim povijesnim trajanji- 
ma. Autorice su mišljenja da bi ovaj prijevod mogao biti i svojevrstan hommage ocu Urošu, preminulome 1941., te stricu Bošku, koji je umro 1945. godine, a koji je u svojim mladim danima prevodio ovaj Foscolov ep.

Ovim prilogom ujedno se zatvara prva zbornička cjelina, u kojoj su predmetom analize primarno bila Desničina djela u različitim komparatističkim ozračjima i interkulturnim uzajamnostima.

Edin Muftić bavi se motivom smrti u arapskoj poeziji, upućujući na velike razlike uvjetovane vremenom njezina nastanka. Dok predislamski arapski pjesnik strah od smrti konvertira u svojevrsni hedonizam, islamizacija Arapa velika je prekretnica i u odnosu prema smrti, odnosno životu poslije smrti. Riječima autora, dok je „predislamski Arapin bio ograničen trenutačnim postojanjem", islam je pomogao čovjeku da se sa smrću nosi na drugačiji način i da ne očajava, to jest ideja besmrtnosti, „koja je predstavljala nerješiv problem ranijim pjesnicima“, postala je „dostižna, s one strane obzora postojanja“.

Prilog Ive Tešić komparativna je analiza tematsko-motivskih i ideoloških aspekata Krležine i Vasićeve pripovijetke o vojnicima, teškim ranjenicima koji u frontovskim bolnicama Prvoga svjetskog rata, s austrougarske i srpske strane, živ(otar)e iščekujući smrt. U obama su slučajevima primjeri ekspresionističke poetike u suočavanju s iskustvom ratnog umiranja i smrti. Autorici je analiza ovih dviju pripovjedaka povod da se vrati Frueudovim tezama o ratu i smrti, tim više što su one suvremene Vasićevu i Krležinu iskustvu te literarizaciji tog iskustva. Imajući na umu da ekspresionizam i psihoanaliza uvelike dijele iste epohalne izazove, pa i reagiraju na njih na usporedljive načine, autorica otvara pitanje može li se ove dvije pripovijetke čitati u Freudovim kategorijama tanatosa i erosa, nagona smrti i vitalističkog instinkta, tim više što Freud „ističe uzajamnost i nerazlučivost pomenutih instinkata, tvrdeći da je erosu neophodan tanatos ne bi li ostvario sopstvene porive“.

Prilog Vladimira Vukomanovića Rastegorca posvećen je dječjim predodžbama ljudske smrti u poeziji Miroslava Antića, jednog od klasika srpske poezije za mlade i stare. Težište je na slikama ljudske smrti u dvjema pjesnikovim knjigama, u Šašavoj knjizi (1972.) i Garavom sokaku (1973.): „Prva donosi neposredniji govor o tamnoj strani detinjstva, a na svom kraju dakle, na markiranom mestu unutar kompozicije zbirke - Besmrtnu pesmu. Druga ne samo da u pojedinim pesmama dotiče temu smrti, već se i rađa iz grobnice Jevreja, Roma i Srba, u kojoj leži i Mile Dileja, Antićev drug i jedan od protagonista Sokaka..."Autor zaključuje kontrastirajući poetike ovih dviju zbirki: „Prvi je plod ekstatičnog iskustva kontemplacije, drugi gole egzistencije marginalizovanog čoveka; prvi baštini veru u telo satkano od svetlosti, dok se drugi ne libi da o lešu govori naturalistički; prvi groblje definiše kao mesto laži, drugi ga vidi kao prostor nade i platno za projekciju želja onoga ko o groblju govori; prvi insistira na životnom optimizmu i intenzitetu proživljenog, drugi akcentuje širok raspon osećanja u vezi sa smrću (bol, strah, ravnodušnost i dr.), a nju samu katkad predstavlja kao mogućnost bega iz tegobnog trajanja na ovome svetu, i vid protesta protiv takvoga trajanja..."

Temeljna problematika smrti u njemačkoj filozofiji egzistencije između svjetskih ratova, s težištem na Martinu Heideggeru i Karlu Jaspersu, te njezina kritička recepcija u radovima Stjepana Zimmermanna, hrvatskoga katoličkog mislioca istog doba, u središtu je pozornosti Matka Globačnika. Da bi argumentirao svoje shvaćanje njegove recepcije, autor kontekstu- 
alizira kontroverze u raspravama o njemačkoj neokantovskog tradiciji, prije i poslije Prvoga svjetskog rata, i sažima pregled misaonog razvitka spomenute trojice. U zrelog Heideggera smrt je „kraj 'bitka-u-svijetu'“, a u Jaspersa „'granična situacija' u kojoj se naslućuje ono transcendentno“. Obojica znatno utječu na razvitak filozofije egzistencije i kulturnog senzibiliteta „obilježen(a) tjeskobom, nesigurnošću, potragom za smislom čovjekova postojanja i njegovim položajem u svijetu“. Prema autoru, Zimmermann je kao skolastičar također sazrio u novokantovskoj tradiciji, u raspravama o kritici Kantova subjektivizma, pitanju nedokazivosti kategoričkog imperativa i racionaliziranju vjere. Kasnije se bavio i noetikom, „koja je davala odgovor na pitanje je li moguće dobiti sigurni, konačni odgovor na životna pitanja“ te psihologijom, što ga je sve potaknulo da se kritički razgraniči prema filozofiji egzistencije.

Prilog Nikole Petkovića komparativni je ogled o romanima Juana Rulfa Pedro Paramo (1955.) i Dževada Karahasana Noćno vijeće (2005.), koji dijele motiv lutajuće smrti „kao nedovršenog egzistencijalističkog i etičkog procesa te ontološkog stanja“. Elaborirajući međusobne sličnosti sâmih romanâ, autor se analitičkofilozofskim pristupom - koristeći se kategorijama i analitičkim modelom Stephena T. Davisa - fokusira na romanesknu spoznaju neupokojenih duša. To su „duše u boli“ koje se „čitatelju objavljuju u prividu cjeline s tijelom - čekaju(ći) na spas i trenutak kada će netko od njih odagnati bol u suodnosu s duboko ljudskim radnjama, koje su ipak pretežno mentalne“. Referirajući se na Meksiko i Bosnu, autor zaključuje kako je „tragično zajedništvo njihova vremena“ upravo „u tragediji međustanja međuprostora nedovršenih prošlosti: u povijesnom (trajnom) prezentu poviješću unesrećenih regija, kao što je to rubni jug američkog sjevera i marginalni jug Srednje Europe“.

Tekst Marijane Jelisavčić otvara pitanje o ambivalentnom statusu horora u suvremenoj hrvatskoj i srpskoj književnosti, a posebno u masovnoj kulturi. Premda je horor u njima žanrovski, stilski i motivima duboko ukorijenjen, tvrdi autorica, i unatoč nešto većoj popularnosti tog žanra, primjerice, na filmskome platnu, tek su 2006. i 2012. u Zagrebu i Beogradu objavljene dvije zbirke horor-priča koje su skrenule veću pozornost na ovaj književni žanr. Autorica tipološki predstavlja recentna ostvarenja spomenutih zbornika, povezujući ih sa svjetskim trendovima.

Treći tematski blok otvara prilog Branke Migotti o grobnim spomenicima pretkršćanske rimske baštine. On svjedoči na koji način arheologija danas - interdisciplinarno otvorena prema socijalnoj i kulturnoj historiji, a krećući se različitim područjima od povijesti prava do povijesti mentaliteta i svakodnevice - rješava specifične probleme odnosa rimske antike prema smrti. Ovi su grobni spomenici - preostali kao artefakti materijalne kulture, tek dijelom s manje ili više sadržajnim epitafima i likovnim elementima - već time višestruke enigme. Čuvanje uspomena na preminule u antičkom je Rimu bila zakonska obveza, „kao zaloga svojevrsnog vječnog života“. Budući da su grobni spomenici bili privatne naravi, u politeističkom Rimu uključivali su različita prava na dopuštene obmane, po kojima su „ljudi bili skloni ne prikazivati se na grobnim spomenicima u stvarnom društvenom položaju, već u priželjkivanom, primjerice, u odjeći koja im nije bila statusno propisana“. Različita shvaćanja sjećanja na pokojnika ili pokojnike i različita shvaćanjima života poslije smrti čine svaki rimski grobni spomenik u načelu studijom slučaja. Autorica je prednost dala upravo problemu (samo)predstavljanja na grobnim spomenicima. Izabrani primjeri nalaza sa sjeve- 
rozapada Hrvatske obrađeni su - unatoč svim otvorenim pitanjima koje autorica apostrofira - kao minijature u maniri nove kulturne historije.

Sažimajući problematiku srednjovjekovnih epitafa u hrvatskom prostoru od ranokršćanskih vremena do ranoga novog vijeka, Mirjana Matijević Sokol raspravlja o njihovim memorijalnim karakteristikama u vremenu nastanka i religijskoj kulturi, napose o odnosu prema smrti i poimanju vjere u zagrobni život. Latinski pisani epitafi zrcale duhovnu i svjetovnu kulturu vremena nastanka, a manjih su ili većih poetoloških vrijednosti. Riječ je o bogatoj baštini, bez koje je teško vrednovati kulturu hrvatskog prostora u dugom trajanju. Mnoštvo korištenih literarnih referenci svjedoči koliko je važna i istraživački živa. U odnosu spram pretkršćanskih grobnih spomenika i epitafa razlika se očituje - prema autorici - „u upotrebi termina koji nose nova značenja pa tako grob nije 'vječni dom' (domus aeterna), nego tek privremeno boravište u koji je pokojnik 'odložen' (depositus) i 'počiva' (requiescit) do usksnuća“. Ujedno, zorno predočuje autorica, epigrafski spomenici omogućuju egzaktnu raspravu i o nekim najsloženijim pitanjima rane hrvatske povijesti.

Zvjezdana Sikirić Assouline analizira oporuke kao izvor za istraživanje povijesti i kulture smrti, odnosno mnoštva fenomena u vezi s ljudskom smrtnošću i smrti te životom poslije smrti, ali i odnosom oporučitelja spram svijeta koji napušta. Koristeći se s dvanaest zagrebačkih oporuka u privatnopravnom smislu i tridesetak izjava (fasija) s oporučnim sadržajima, nastalih između velikog požara u gradu 1674. godine i Bečkog rata (1683. - 1699.), ali i u vremenu promjena u urbanoj kulturi i kulturi svakodnevice, autorica istražuje proces „nastajanja individuuma“ u iskazivanju posljednje volje. Zanimaju je i odnosi oporučitelja prema obiteljskim zajednicama, bratovštinama, Crkvi i gradu, a formule notarske naravi u oporukama autorica tumači u horizontu religijske kulture tog doba. Oporuke otkrivaju guste mreže novčanih i materijalnih dugovanja i potraživanja, transfera nekretnina itd. Autorica se suglašava $s$ ranijim istraživanjima, prema kojima se iznenadna smrt bez oporuke, izjave i svjedoka smatrala sramotnom i nečasnom jer je oporuka „prije svega sredstvo sređivanja računa sa svijetom i s Bogom".

Filip Šimetin Šegvić i Nikolina Šimetin Šegvić fokusiraju se, u širim sociokulturnim kontekstima u Europi i Hrvatskoj, na prividno paradoksalni fenomen razdoblja 1870. 1900., koji se očituje u proturječnim međuodnosima različitih shvaćanja kulture življenja i kulture smrti te koji u slučaju niza umjetnika završava samoubojstvom. Srednjoeuropski kontekst austrougarske, posebno bečke „vedre apokalipse“, bitan za razumijevanje i distinktivnih hrvatskih situacija, privlači posebnu pozornost autora. Interdisciplinarnim čitanjem referentnih radova iz svjetske i hrvatske literature te analizom umjetničkog stvaralaštva i različitih diskursa u suvremenim medijima, ponajviše tisku, autori raspravljaju o više aspekata ove problematike i konkretnih slučajeva samoubojstava. Samoubojstvo kraljevića Rudolfa 1889. godine bilo je svojevrstan „okidač“ jer je mnogim mladima bio simbol budućnosti Austro-Ugarske. Međutim, budimpeštanski Pester Lloyd u listopadu 1895. godine piše o „tajni samoubojstva“, racionalizirajući je novim shvaćanjem života, nepostojanjem straha od smrti, manjkom pobožnosti te stavom da je život teret, a smrt - rasterećenje. U hrvatskom slučaju, $\mathrm{k}$ tome, poseban naglasak stavljaju i na siromaštvo, kao važno obilježje djela hrvatske inteligencije od 19. do polovine 20. stoljeća. 
Recentna istraživanja u povijesnoj epidemiologiji i ekohistoriji - posebno kada je riječ o razdobljima moderne i suvremene povijesti za koja je moguće koristiti se serijama vjerodostojnih izvora - omogućuju kvalitetno sadržajnije historijskodemografske uvide u problematike povijesti smrti, tvrdi Nikola Anušić. U konkretnom slučaju, operacionalizirajući koncepte patocenoze i patocenične tranzicije Mirka Grmeka, autor historijskodemografski i epidemiološki istražuje pandemijski komorbiditet španjolske gripe i tuberkuloze u Banskoj Hrvatskoj 1918. godine. Formuliravši istraživačko pitanje - „koliko je izuzetno letalna megapandemija influence iz 1918./1919., tzv. španjolska gripa, utjecala na patocenozu tuberkuloze u sjevernoj Hrvatskoj, odnosno je li kauzalni komorbiditet tuberkuloze i španjolske gripe tijekom pandemije mogao izazvati promjene u patoceničnoj dinamici i kasniju tranziciju patocenoze" - te koristeći se rezultatima višegodišnjeg istraživanja, autor sažima svoje spoznaje, izvodeći ih s referencama na europsku literaturu. Zaključuje kako - neovisno o tome što među njima nema etioloških poveznica - dvije bolesti povezuju brojne podudarnosti prema drugim osnovama. Tuberkulozni su bolesnici tijekom pandemije iz 1918. godine bili najizglednije žrtve španjolske gripe, tj. „s obzirom na veliku raširenost tuberkuloze, kumulativan učinak komorbiditeta ovih dviju bolesti mogao je 1918. izazvati katastrofičan rast pandemijskog mortaliteta", što se uistinu i dogodilo.

Snježana Banović rekonstruira proizvodnju straha od smrti nakon 10. travnja 1941. godine u Hrvatskom narodnom kazalištu (tada Hrvatskom državnom kazalištu), u jednoj od najvažnijih ustanova moderne hrvatske kulture, a u to doba najprestižnijoj u komunikaciji s javnošću. Proglašenje ustaške vlasti u zemlji koju su okupirali nacistička Njemačka i fašistička Italija, omogućuje ustašama ostvarivanje njihova državnopravnog programa. Strelovito proglašavane „zakonske odredbe“ $\mathrm{i}$ mnoštva provedbenih propisa - uime „časti“ i ,životnih interesa" hrvatskog naroda - izravno stavljaju izvan zakona najmanje trećinu stanovništva novoproglašene Nezavisne Države Hrvatske. Kazalište je u (samo)predstavljanju ustaških vlasti moralo biti uzoran akter „duhovne obnove“ i ustaškog poimanja pohrvaćivanja države. U ustanovi u kojoj je svaki čovjek imao svoje mjesto u sastavu mnogobrojnog ansambla, odvodili su se ili su nestajali ljudi doslovno iz dana u dan, od glumačkih pripravnika do glumačkih zvijezda i redatelja, po različitim eliminacijskim logikama - političkima (npr. komunisti, masoni), nacionalnim, odnosno rasnim (npr. Židovi, Srbi, Rusi), vjeroispovijednim (npr. pravoslavni) itd. Budući da su ustaške vlasti forsirale izvođenje brojnih kazališnih manifestacija u kojima su se isprepletale ideologija, politika, umjetnost i komemoracije - pod stalnim nadzorom okupacijskih aktera - ansambl je za mnoštvo njegovih članova postao kuća „smrti, straha i poniženja“. Ipak, brojni članovi ansambla - ističe autorica - „nisu (se) predali posluhu, već otporu, koji će vrhunac doseći odlaskom grupe umjetnika na čelu s Vjekoslavom Afrićem iz HDK-a na oslobođen teritorij 22. travnja 1942.“.

Prilog Monice Priante nastao je istraživanjem fenomena dvaju „posljednjih ispraćaja“ Vladana Desnice nakon piščeve smrti u subotu, 4. ožujka 1967. godine, u zagrebačkom KBC-u Rebro. Prvi, komemorativne naravi, održan je u ponedjeljak, 6. ožujka, u Zagrebu, ispred mirogojske mrtvačnice. Drugi, održan u utorak, 7. ožujka - kada je sahranjen u obiteljskoj grobnici, u crkvici sv. Đurđa u Kuli Jankovića - bio je dijelom komemorativne, a dijelom obredne naravi. Prvi su pripremili Društvo književnika Hrvatske i Matica hrvatska, 
a nazočio je „veliki broj Zagrepčana“, mnogobrojni književnici, umjetnici i kulturni javni radnici te članovi odbora za sahranu. U drugom je obitelj tek marginalno bila akter pa je sahrana u Islamu Grčkom po svojoj masovnosti, oglašavanju pozvanih i nepozvanih, prožimanju pučkih i intelektualnoelitnih posmrtnih obrazaca, referiranjima na njegovo umjetničko stvaralaštvo, ali i na njegovo mjesto u obiteljskoj baštini Jankovića i Desnica bila događaj bez presedana u tadašnjim društvenim uvjetima. Koristeći se konceptom „dva ispraćaja“, autorica slučaj Desničine sahrane stavlja u širi europski teorijski i istraživački kontekst rasprava o povijesti smrti. Ipak, u Islamu Grčkom očituju se osebujnije percepcije, evokacije i rituali „posljednjeg ispraćaja“. Kao da su potjecale iz svjetova Desničinih djela.

$* * *$

Brojni uvršteni prilozi, ovisno o temi, referiraju se u većoj ili manjoj mjeri na europsku i svjetsku literaturu, ovisno o autorskim uvidima i afinitetima. Držimo da je vrijednost izdanja kao cjeline zbog toga veća, a izdanje korisnije za sve one koji imaju interesa za povijest i kulturu umiranja i smrti. Stoga ovom prilikom kao povjesničari osjećamo potrebu ograničiti se na svega nekoliko napomena u vezi s poviješću smrti.

Budući da se moderne društvene i humanističke znanosti najvećim dijelom konstituiraju u 19. i 20. stoljeću, povijest umiranja i smrti u historijskoznanstvenom smislu - za razliku od kulture umiranja i smrti - znatno je mlađeg podrijetla. Svojim inicijalnim spoznajama ona je dužnik filozofiji i teologiji, većem broju društvenih, humanističkih, a ništa manje prirodnih i medicinskih znanosti. Ipak, problemski i konceptualno postupno je proistjecala iz historiografske tradicije fracuskih Annales, s tim što se „očevima utemeljiteljima“ povijesti smrti općenito smatra Philippea Arièsa (1914. - 1984.) i Michela Vovellea (1933.). Spomenuta francuska tradicija svojom je besprimjernom inter- i transdisciplinarnom otvorenošću omogućila i podržavala mnogobrojne istraživačke prodore u područja kojima se povjesničari ranije nisu bavili na znanstveno poticajan način. Ariès nije bio samo povjesničar smrti nego i povjesničar francuskih odnosa prema životu, kontracepciji, a bio je i utemeljitelj povijesti djetinjstva te, na vrhuncu svoje profesionalne karijere, s Georgesom Dubyjem, urednik višesveščane Povijesti svakodnevnog života. Dakle, povijest umiranja i smrti nisu bili njegova opsesija. Bio je pasionirani istraživač ljudskih života od rođenja do smrti - zanimalo ga je kako su ljudi živjeli i radili te što su mislili, osjećali, vjerovali itd. Zajednički je nazivnik njegovih istraživanja prije svega povijest mentaliteta, što mu je zajedničko $s$ drugim „ocem utemeljiteljom" povijesti umiranja i smrti, Michelom Vovelleom. Međutim, Vovellea nisu zanimale samo promjene odnosa prema umiranju i smrti nego i kulturne i socijalne transformacije $u$ francuskom ancien régime s njima u vezi, bez kojih nije smatrao mogućim razumjeti dekristijanizaciju Francuske revolucije 1789. - 1799. godine, kao i posljedice za shvaćanje umiranja i smrti u „revolucionarnom mentalitetu“. Iako je na glasu kao jedan od vodećih povjesničara orijeniranih prema korišstenju serijalnim izvorima (testamenti) $\mathrm{i}$ kvantitativnim metodama $u$ istraživanjima povijesti mentaliteta - svjetski je čuvena Piété baroque et déchristianisation en Provence au XVIII siècle. Les attitudes devant la mort d'après les clauses de testaments (1973.) 
- više je njegovih djela, počevši od Mourir autrefois (1974.), nastalo kritičkom uporabom narativnih izvora i kvalitativnih metoda. Arièsu i Vovelleu zajednički je interes i za novovjekovno nastajanje individua u modernom europskom društvu, pa time i za promjene odnosa prema umiranju i smrti, ali ih oštro razlikuje svjetonazorski utemeljeno razumijevanje smisla razdjelnice u francuskom društvu 1789. - 1799. godine, koja je imala dalekosežne učinke u promjenama u francuskoj religijskoj kulturi. Arièsova desna politička kultura i Vovelleova lijeva politička kultura, koliko god bile inkluzivne, dijaloške, $s$ vremenom su ih sve više udaljavale jednog od drugog.

Obojica imaju mnoštvo sljedbenika, koji objavljuju nepregledan broj novih sve zahtjevnijih radova, ali se javni odnos prema povijesti umiranja i smrti osjetno promijenio. ${ }^{2}$ Po odnosu prema smrti - koliko god ona bila „zabranjena“ (Ariès) u individualističkom shvaćanju privatnosti u modernom društvu - obojica pripadaju epohi na izmaku. Postmoderna epoha, koliko god baštinila krize građanskog identiteta, pa s time u vezi i odnos prema umiranju i smrti, banalizirala je ljudsko umiranje i smrt globalnom medijskom diseminacijom slika i riječi koje kapilarno prodiru do svakog stanovnika Zemlje, replicirajući stereotipe o životu i smrti „drugih“, ovisno o tome s koje su strane razdjelnica koje iskrivljuju naše predodžbe o svijetu i nama u svijetu.

Imajući na umu spomenutu godišnjicu i činjenicu da je umjetnički opus Vladana Desnice uvelike posvećen smrtnosti i smrti, ali i potrebu da se u projektne rasprave uključe i kapitalne spoznaje spomenutih stvaralaca, priređivači skupa osjetili su potrebu njegove realizacije pod navedenim naslovom. Odlučili su to učiniti s nepodijeljenim uvjerenjem da smrtnost i smrt nisu u hrvatskoj i srpskoj kulturi u društveno-humanističkim znanostima ni izdaleka bile predmetom rasprava koje korespondiraju s inovatnivnim europskim i svjetskim trendovima u posljednjih pola stoljeća. Odlučili su to i zbog paradoksa da se u kulturama koje su inače javno prezasićene iskustvima nasilja i smrti u svojoj suvremenoj povijesti na znanstven način nedovoljno propituju pretpostavke, dosezi, pa i implikacije takva stanja. Ovaj je zbornik, pored ostalog - nadamo se - skroman doprinos promjeni takva nezadovoljavajućeg stanja.

Zahvaljujemo svima koji su na bilo koji način pridonijeli realizaciji ovog zbornika, a to su prije svega autori i recenzenti. Hvala dr. sc. Urošu Desnici što nam je omogućio korištenje slikovnim prilozima iz ostavštine Vladana Desnice. Zahvaljujemo lektoricama Samanti Paronić i Grozdi Pejčić, prevoditeljici sažetaka na engleski jezik Mariji Marčetić te dr. sc. Jadranki Brnčić na izradi kazala. Na kraju, zadovoljstvo nam je što se i ovaj svezak, kao i brojni prethodni, ostvaruje u odličnoj suradnji s izdavačkom službom FF press Filozofskog fakulteta Sveučilišta u Zagrebu. Njezin voditelj Boris Bui spremno nam je izlazio ususret u vrlo kratkim rokovima i omogućio da i ovom knjigom održimo jednogodišnji ritam izlaženja zbornika radova s Desničinih susreta.

2 V. Thomas MACho, „Tod“, u: Christoph Wulf (ur.), Vom Menschen. Handbuch Historische Anthropologie, Weinheim - Basel 1997., 939-954; David G. Troyansky, „Death“, u: Peter N. Stearns (ur.), Encyclopedia of European Social History, sv. 2, New York 2001., 219-233; Michael Kerrigan, The History of Death, London 2017. 


\section{1. \\ HARONOVA DOBRA. \\ ANTIČKI MOTIVI U TANATIČKOM \\ REPERTOARU VLADANA DESNICE}

\section{Bruna Kuntić-Makvić}

UDK: 821.163.42Desnica, V.:821.124

Izvorni znanstveni članak

Sažetak: Klasična izobrazba, široka kultura i vlastiti izbor Vladana Desnice učinili su vrlo brojnima raznovrsne referencije na antiku i na antičko nasljeđe u njegovim djelima. Korijeni njegova zanimanja za antiku sežu u djetinjstvo, u krug obiteljskih prijatelja i u školu. Znalački se koristi terminima koji su potekli iz vokabulara klasičnih jezika te izvornim grčkim i latinskim riječima, izrazima i izrekama. Poziva se na antičku civilizaciju, kulturu i umjetnost, osobito na grčku književnost i mitologiju. Spominje konkretne domaće i svjetske spomenike. Takav aparat iziskuje veliku brižnost i odgovornost urednika i izdavača. Zaokupljen promišljanjima o životu i smrti, Desnica uvodi i antičke motive iz te sfere. Može to biti etimologija riječi (atanatik), značenje pojma (simulacrum), kameni nadgrobni spomenik (žara, nadgrobni natpis), strahotni lik iz podzemnog svijeta (Haron, Himera), pothvat u podzemlju epskoga junaka ili smrt dramskoga (Odisej, Eneja, Agamemnon, Antigona, Edip), spoj spomenika i epske predaje (Memnon), pa i filozofska misao o odnosu života i smrti (Prometejeve riječi u Eshilovoj drami). Najupečatljivijim smatramo lik Harona, lađara mrtvih, koji je sazdan prema Vergilijevoj Eneidi i Danteovu Paklu. Stoga sve antičke motive iz tanatičkog repertoara Vladana Desnice nazivamo Haronovim dobrima. Pripada im konstitutivan udio u njegovu promišljanju i pisanju o smislu i prestanku života.

Ključne riječi: Vladan Desnica, klasična gimnazija, antika, Homer, Eshil, Sofoklo, Prometej, Plutarh

nogi su primijetili i zabilježili da se klasična izobrazba i poznavanje antike jasno proniču u stvaralaštvu Vladana Desnice. ${ }^{1}$ Njegova pripadnost sredozemnom krugu nedvojbena je, ${ }^{2}$ a Sredozemlje podrazumijeva grčku i rimsku antiku. Povezanost Vladana

1 Usp. Stanko Korać, „Predgovor“, u: Vladan Desnica, Zimsko ljetovanje. Pjesme. Ljestve Jakovljeve (= Sabrana djela Vladana Desnice, knj. I), Zagreb 1974., 10 i 28-29; usp. i bilj. 152; Ivanka BEŠEvić, „Između muzike i literature. Razgovor s književnikom Vladanom Desnicom“, u: Vladan DesnicA, Hotimično iskustvo: diskurzivna proza Vladana Desnice. Knjiga druga (prir. Dušan Marinković), Zagreb 2006., 81; Vladimir Rismondo, Oblici i slova, Split 1979., 135-136 i 211; Vlatko Pavletić, „'Svako djelo vrijedi tačno onoliko koliko poetskog sadrži u sebi'“, u: V. DeSNiCA, Hotimično iskustvo. Knjiga druga, 58; v. bilj. 51.

2 Sam se o tome očitovao nekoliko puta. Usp. V. Desnica, Hotimično iskustvo. Knjiga druga, 103, 121, 123,125 i 131. I drugi su to znali lijepo formulirati. Usp. npr. I. BEšEvić, „Između muzike i literature“, 81; Zlatan Jukić, „Puno ... 
Desnice s antičkom baštinom nije potekla samo iz dalmatinskog zavičaja, iz školskih klupa i s pravnih studija, koji su podržavali njegovo znanje latinskog jezika, a njega su zadržavali u sferi rimske civilizacije. Baveći se cijeloga života umjetnošću riječi u različitim njezinim oblicima i iz različitih aspekata, koristio se baštinom klasičnih jezika, antičke književnosti i misli. Predznanje ga je osposobilo da to suvereno čini, kako u stručnome diskursu (pišući, npr. o povijesti i teoriji umjetnosti, posebno književnosti) tako i u fikcionalnom stvaralaštvu. Brojne referencije u svim vrstama njegovih tekstova pokazuju da je kao zreli stvaralac po slobodnom izboru rabio, proširivao i dograđivao iz antičke baštine ono za što je u djetinjstvu i mladosti bio doznao kao učenik.

Međutim, u njegovu životopisu ima i podataka koji bi mogli voditi drukčijim zaključcima - a naoko bi ih mogla potkrijepiti i neka mjesta iz vlastitih djela. Uspoređujući pak više izdanja raznih vrsta njegovih tekstova, utvrdila sam da se antičke sastavnice previđaju, zanemaruju, iskrivljuju, čak i uništavaju, te su općenito slabije vidljive današnjem čitateljstvu. $^{3}$

Dušan Marinković uključio je u životopis Vladana Desnice podatke o njegovu školovanju. ${ }^{4}$ Raspolagao je i ocjenama iz tadašnjih nižih gimnazijskih razreda koje je polazio u Zadru, a u trećem i četvrtom razredu (današnjem sedmom i osmom osnovne škole) među Desničinim „ocjenama iz grčkog i latinskog jezika ... dominiraju trojke“.5 Marinković to smatra pokazateljem njegova otpora "formalnom, nepametnom učenju“.

Iluzija je da je učenje klasičnih jezika ikada bilo nepametno, pa i otkad su latinski i grčki, svaki u svoje vrijeme, prestali biti svjetskim jezicima diplomacije i znanosti. Nastava oba jezika osposobljava učenika da točno prepoznaje dijelove sustava, da ih logički povezuje, ispravno razumije, da valjano formulira dobiveni rezultat i da ga umije priopćiti. To su izrazito „pametne“ sposobnosti. Kad se traži da učenik pamti riječi, gramatičke paradigme i pravila, potiče ga se da usvoji oruđa koja će samostalno primjenjivati. Tko iskoristi mogućnosti toga programa, itekako će razviti svoje intelektualne sposobnosti. Možda će se, pogotovo u mlađoj dobi, na formalnoj razini mučiti usvajajući gradivo iz kategorije oruđa, pa i zapeti. ${ }^{6}$ Međutim, svaki jezik otvara put do civilizacije koja se njime koristi(la). Klasični latinski i grčki jezik omogućuju izravan pristup antičkoj baštini, mediteranskoj stečevini u temeljima zapadnoga svijeta. Njezine sastavnice tisućljećima ne gube privlačnost, a to može pretegnuti. Desnica je kao zreo polemičar izričito spomenuo što je dječak mogao ponijeti iz škole kao rezultat čitanja, na primjer, Sofoklovih djela. ${ }^{7}$ Vladimir Rismondo, Desničin

puno sunca ... Razgovor s umjetnikom Vladanom Desnicom“, u: V. Desnica, Hotimično iskustvo. Knjiga druga, 89; V. Rismondo, Oblici i slova, 183 i 213; S. Korać, „Predgovor“, 31.

3 Stoga sam, prije nego se prihvatim Haronovih dobara, morala izložiti argumente za teze koje sam iznijela u uvodu. Dušan Marinković, „Biografija Vladana Desnice“, u: V. Desnica, Hotimično iskustvo. Knjiga druga, 221-220.

Najviša ocjena bila je 10.

Takav bi doista mogao osjetiti da je učenje klasičnih jezika formalno i nepametno i ustrajati doživotno u tom uvjerenju. „A taj dio dječačkog srednjoškolskog elementa - budimo i dalje iskreni! - nije baš identičan s onim drugim dijelom tog elementa koji je još iz kratkih hlača i srednjoškolskih klupa ponio u sebi ljubav i nagnuće za umjetnost, pa makar to i ne bila umjetnost crno-bijelog, već, na primjer, umjetnost Sofokla, (...)"Vladan Desnica, Hotimično iskustvo: diskurzivna proza Vladana Desnice. Knjiga prva (prir. Dušan Marinković), Zagreb 2005., 116. Sve što je u citatima Vladana Desnice i drugih autora podcrtano, istaknula je autorica. Ostali načini isticanja potječu iz izdanja kojima se koristila. Kad Vladan Desnica „s početkom profesionalne pravničke karijere otpočinje intenzivno proučavanje opusa renomiranih autora evropske književnosti (Eshil, Sofoklo, L. N. Tolstoj, Dostojevski, Dante,..." itd.), kako to navodi Marinković, to posve sigurno nije početak, već produbljivanje staroga, školskog poznanstva. Usp. D. MARinković, „Biografija Vladana Desnice“, 226. 
prijatelj i zakratko suučenik u splitskoj Klasičnoj gimnaziji, posvjedočio je upravo kako je u glavama voljkih učenika izgledao prijelaz od usvajanja oruđâ u nižim razredima gimnazije na izravnu percepciju antičke književnosti u višima. ${ }^{8}$ Razvije li se pak nekadašnji đak po vlastitom daru i životnom putu u književnika i književnog prevoditelja, mladenačka će se muka pokazati doživotnom prednošću. Tko je ima, prepoznaje ju i ne odriče je se. Reklo bi se da se upravo to dogodilo između Desničinih dječačkih trojki iz grčkoga i latinskog jezika i njegova književnog djelovanja.

Ako je štogod i zamjerao poduci dok ju je primao, sam je pokazao i višestruko posvjedočio da je bila izrazito učinkovita čak i na razini oruđa. Dva su tipična postupka klasičarskih gojenaca: iz škole ponesu zalihu latinskih riječi, izraza i izreka i rado se njima koriste (pravnici i liječnici još je i povećaju), a silno su osjetljivi na greške koje se drugima u tome omaknu. Vladan Desnica bio je itekako voljan tu vrstu nepismenosti zamjeriti i već uglednome i utjecajnom Marinu Franičeviću i Vlatku Pavletiću, mladom kritičaru „koji veoma mnogo obećava“. Lekcija koju im je očitao ostala je u nedatiranom rukopisu, a pokazuje da je savršeno pamtio latinski pravopis i gramatiku. Olako posezanje za blagom latinskog jezika, neuko ili nemarno, smatrao je sramotnim. ${ }^{9}$ Proturječno je što ima naznaka da pisac s takvim mjerilima nije bio siguran kako grčke i latinske riječi i izraze uklopiti u vlastiti tekst. Primjeri nasilnih i posve neispravnih kongruencija češći su u diskurzivnoj prozi (gdje je njegov nadzor nad konačnim oblikom teksta bio slabiji), ali ih ima i u beletrističkoj pro-

$\overline{8}$ „I jedna tako životvorna vizija klasike, doživljena neposredno poslije prvih gramatičkih priprema i na samom pragu čistih humanističkih studija, odstranjujući tešku historijsko-filološku opremu, kojom se često našim današnjim očima tijelo klasike ukazuje zatrpano, bila je kadra da osposobi čitave generacije da neposredno i bez velikih napora osjete žive treptaje njezine neuništive puti. Zato smo već kao đaci, odvraćajući glavu od učmaloga tradicionalizma, inkviniranog duhom baroka, koji se još uvijek provlačio kroz naše škole sa svim njegovim konsekvencama na moralnom i intelektualnom planu, osjećali žeđ za Safom i Arhilohom, za presokratskim filozofima, za Lukrecijem i Katulom, koji su svi kasnije, više ili manje, bili uvedeni u naše škole." V. Rismondo, Oblici i slova, 223.

9 „Uvaženi pjesnik i književni teoretičar Marin Franičević, u jednom članku u »Republici br... " piše da nešto treba / ili ne treba, svejedno/ posmatrati »sub spaetiae aeternitatis«. Da nikako ne valja posmatrati »sub spaetiae«, to smo unaprijed znali. Marin Franičević trebao je samo dokazati da u konkretnom slučaju ne valja promatrati ni "sub spetie aeternitatis«. Gotovo svima kod nas mnogo se dopada »jedna marginalija«, ma da je »marginalia«, plural srednjeg roda a ne singular ženskoga, tako da postoji izvjesna razrožnost kontradiktornost [sic!] između "jedne« i »marginalije«. No to se nažalost već uvriježilo. Ali jedan naš mladi kritičar, koji veoma mnogo obećava, Vlatko Pavletić, piše i "jedna lucida intervalla", ma da je i tu ono »lucida intervalla" plural srednjeg roda, a Pavletić nije tako davno izišao iz gimnazijskih klupa da bi to smio zaboraviti. Isto tako, on ispisuje, kao naslov jednom svom napisu: "Ave, criticus!«, ma da mora znati da zaziv uz "ave«/baš kao i kod nas/ ide vokativ, dok je »criticus« nominativ. Njega je u tom očevidno zavela fraza: „Ave, Caesar! « No u toj je osveštanoj frazi Cesar ostao nepromijenjen prosto zato što u deklinaciji kojoj on pripada vokativ glasi jednako kao i nominativ, čega se Pavletić također mogao još sjećati." V. DeSNICA, Hotimično iskustvo. Knjiga druga, 203-204. Na Pavletićeve latinštinske grijehe V. Desnica se, izgleda, nije višekrat osvrtao, no u polemici s M. Franičevićem bio je povodom zlosretne speties spreman na još klasičarskih ujeda koji su također ostali u rukopisu: „I zato ono što Marin izriče ima gotovo snagu jednog administrativnog akta i autoritet jedne enuncijacije »sub specie aeternitatis« (ili »sub spetiae aeternitatis«), kao što Marin - predsjednik Društva književnika, nastavnik književnosti na jednoj visokoj školi i »stalni urednik« jedne vodeće revije - voli da piše: ko ne vjeruje, neka zaviri u časopis »Republiku«, broj .../195., strana ..., redak ... odozdo). (...) eto tako izgleda Renesansa "sub spetiae Marinitatis«, (...).“ V. Desnica, Hotimično iskustvo. Knjiga prva, 388-389.

10 Npr. „s Petroniusom Arbitarom“ (V. Desnica, Hotimično iskustvo. Knjiga prva, 185), ali se na popisu autora ipak nalazi stavka „Petronije, Gaj /Arbiter/“ (Dušan MArinković, „Abecedarij autora“, u: V. DesnicA, Hotimično iskustvo. Knjiga druga, 313). Zatim, „pisac se poslužio jednostavno deusom ex machina“ (V. DesnicA, Hotimično iskustvo. Knjiga prva, 258; usp. Dušan Marinković, „Desničin pojmovnik“, u: V. Desnica, Hotimično iskustvo. Knjiga druga, 326 s. v. „deus ex machinae“) i „u nezahvalnoj ulozi »advocatus-a diabuli““ (V. Desnica, Hotimično iskustvo. Knjiga prva, 347; u D. Marinković, „Desničin pojmovnik“, 319 s. v. ipak „advocatus diaboli“). U Proljećima Ivana Gale$b a$ : „iz formalnog curriculum-a vitae“ ili „između thymoeidés-a i epithymetikón-a“. Usp. Vladan DesnicA, Proljeća 
zi. ${ }^{10}$ Valja uzeti u obzir da standardi nisu bili uspostavljeni dok se školovao, a i danas u tom pogledu ima žaljenja vrijedne nesigurnosti. Bez uvida u originalne rukopise i u vlastoručne ispravke tiskanih tekstova ne možemo znati koliko je griješio sam, a za što su krivi sugovornici, lektori, urednici i priređivači. ${ }^{11}$

U misli svojih likova upleo je i naoko gorke opaske o klasičnoj izobrazbi. Tu su posredno ili izričito najčešće na tapeti Plutarhovi životopisi velikih povijesnih ličnosti staroga svijeta. ${ }^{12}$ Najžešća paljba po klasičnim jezicima i antičkoj povijesti kao beskorisnima u svakidašnjici čita se u promišljanjima Miloša, potištenoga i ogorčenoga nastavnika koji je na bunarevačkoj nižoj gimnaziji po vlastitim riječima predavao upravo klasične jezike i „povijest staroga vijeka", 13 a učenici su mu većinom bili iz okolnih sela. ${ }^{14}$ Dvije rečenice iz latinske vježbenice, tri gramatičke napomene i dvije povijesne referencije ${ }^{15}$ suprotstavljene su snuždenosti jednoga učenika nad volom koji je na jad njegova oca i braće uginuo tako da ne smiju upotrijebiti nijedan ukusan i koristan sastojak njegova tijela. Nasuprot Demostenu nađe se atraktivni žuti bicikl mjesnoga škopitelja jer učenici ne znaju birane riječi književnoga jezika koje se rabe u prijevodima vježbeničkih rečenica. ${ }^{16}$ Prizor Cezarova ubojstva ${ }^{17}$ podsjeća učenika na sukob zbog međe kojemu je pribivao, a završio je šikljanjem krvi iz kosirom prerezana grkljana jednoga zavađenog susjeda. Tirada je, očekivano, dokončana mišlju da bi bunarevačkim učenicima trebala posve drukčija poduka, ali i referencijom na plutarhovski prizor Katona Starijega s kartaškim smokvama u rimskome senatu, kojom je bila i započela. ${ }^{18}$

Ivana Galeba. Igre proljeća i smrti. Pronalazak Athanatika (Nedovršeni roman) (= Sabrana djela Vladana Desnice, knj. II), Zagreb 1975., 135 i 210; Isti, Proljeća Ivana Galeba. Igre proljeća i smrti, Zagreb 1977., I 27 i 199; Isti, Proljeća Ivana Galeba. Igre proljeća i smrti, Zagreb 1990., I35 i 2 IO; Isti, Odabrana djela, Vinkovci 1998., I29 i I96; Isti, Igre proljeća i smrti, Zagreb 2008., 153 i 228. U Zimskome ljetovanju: „Brebentiuma“ (Isti, Zimsko ljetovanje. Pripovijesti, Zagreb 1968., 96 i 97), „B r e b e n t i u m u“ (Isto, 128); „Brebentium-a“ (Isti, Zimsko ljetovanje. Pjesme. Ljestve Jakovljeve [= Sabrana djela Vladana Desnice, knj. I], Zagreb 1974., 110), „Brebentiuma“ (Isto, 112), „Brebentiumu“ (Isto, 152). Usp. i bilj. 49.

11 Znamo da je negodovao nad neispravnim otiskom Proljeća Ivana Galeba. Usp. Isti, Hotimično iskustvo. Knjiga dru$g a, 111$. Marinković upozorava da su Desničini tekstovi bili modificirani višekratnim redigiranjem i lektorskim zahvatima, a priređivači Hotimičnog iskustva većinom nisu mogli pribaviti i usporediti izvorne rukopise. Usp. Dušan Marinković, „Predgovor“, u: V. Desnica, Hotimično iskustvo. Knjiga prva, 9.

12 Usp. V. Desnica, Proljeća Ivana Galeba (1977.), 220-22 I; Isti, Odabrana djela, 216; Isti, Igre proljeća i smrti, 250-251. U izdanju iz 1975. i 1990., Ivan Galeb, promišljajući o neizlječivoj bolesti i umiranju drugoga pacijenta, generala: „O, blažena »romansirana historijo«, o plutarhovska lektiro pubertetskih godina! O vječito naličje stvari! (...) Odlažem kraju romansirane biografije mog mladog doktora. Ta idite, molim vas! Što mi pričate! Historije jakih su priče o pojedincima, Plutarh! A historija slabih - to je povjesnica čovječanstva." Naoko neznatna razlika u interpunkciji utječe na smisao. Usp. Isti, Proljeća Ivana Galeba (1975.), 232-233; Isti, Proljeća Ivana Galeba (1990.), 232-233.

13 Isti, Zimsko ljetovanje. Pripovijesti, 304-306.

14 Isto, 303.

15 „Luscinia cantat. Ut finale, akuzativ s infinitivom. Prvi, drugi, treći punski rat. Smokve u senatu. (...) Plural: P u e 11 a et $\mathrm{lu}$ s c i n i a c a n t a n t." Isto, 304. U prijevodu: „Slavuj pjeva. Namjerno $u t$, (...) D j e v o j k a i s l a v u j p j evaju." Prevela BKM.

16 ,"Učimo se ljubiti kreposti!«Demosten nije volio dokolicu."A krasnalijebila ona žuta dvokolica u kojoj se proljetos dovezao živinar kad je jalovio ždrijepca gazde Nikole Đuđe! Čudan čovjek taj Demosten! Neki mudrac - a ne voli dvokolicu!" Isto, 305.

17 „Prvi, drugi »trijumfirat«. Cezara je ubio posinak Brut. Svojom krvlju poštrapao Pompejev kip. T u q u o q u e, m i fil i ...! (Pazi! nepravilni vokativ!)“ Isto.

18 „- U što mi tratimo vrijeme s njima, o čemu im pričamo - mislio je s gorčinom Miloš. - Mjesto da im otvaramo oči na njihov život, mjesto da ih učimo da se ne mire s njim, da ih upućujemo što da čine - mi im bajemo o »ribici čovječjoj«, o smokvama u senatu!..." Isto, 305-306. Usp. i bilj. 15. 
Književni su analitičari spremni rutinski prepoznavati autobiografske sastavnice u Desničinim likovima. Nema sumnje da se u vježbeničkim rečenicama i gramatičkim napomenama iz pripovijesti o Bunarevcu smije gledati i veza s davnim zadarskim trojkama (a i potvrda da je tamošnji trening gramatike dao trajne rezultate). Međutim, Desničin interes za povijest u školskim danima nije dvojben i potvrđen je visokim ocjenama. ${ }^{19}$ Sam je posvjedočio da ga je i kasnije sačuvao, da je čitao i povijesne dokumente i literaturu. ${ }^{20}$ Popis zagrebačkog dijela obiteljske knjižnice pokazuje da mu je takva literatura stalno bila pri ruci. ${ }^{21} \mathrm{U}$ nizu bunarevačkih proturječja povijesne referencije je dosljedno navodio u paru s jezičnima, očito ne zato što bi i s poviješću bio imao đačkih poteškoća. Odnose se na znamenite osobe (Katon Stariji, Demosten, Cezar, Pompej, Brut) i na junačke epizode rimske povijesti (punski ratovi, prvi trijumvirat). U podlozi se naziru biografije slavnih Grka i Rimljana, iz Svetonijeva pera ${ }^{22}$ i osobito iz Usporednih životopisa već spomenutoga Plutarha. ${ }^{23}$

Intelektualni krug oko piščeva oca i strica u Zadru mogao je također biti izvorom znanja o klasičnoj starini. Višekrat je imenovao njegove članove ističući da su utjecali na nj. ${ }^{24} \mathrm{Za}$ ovu je temu važan Marko Car, ${ }^{25}$ kojega je spomenuo u svakom nabrajanju. Podatci o Carevom javnom djelovanju i naslovi objavljenih djela mogu se naći u sekundarnoj literaturi, ${ }^{26}$ ali se u pravilu ne navodi knjiga Glasoviti muževi staroga vijeka koja je, međutim, stajala u obiteljskoj knjižnici. ${ }^{27} \mathrm{U}$ podnaslovu knjižice i u bibliografskoj jedinici u katalogu Nacionalne i sveučilišne knjižnice u Zagrebu stoji da je Car životopise priredio „po Rol(l)inu“. ${ }^{28}$

19 Usp. D. Marinković, „Biografija Vladana Desnice“, 221.

20 „Ja često i rado čitam historijsku literaturu i historijske dokumente naročito. Ali kako nisam pisao historijskih radova, to nisam imao prilike ni da se služim tim materijalom, osim ponešto ljudskog materijala koji se u svakom historijskom dokumentu nađe." V. Desnica, Hotimično iskustvo. Knjiga druga, 123. Usp. i bilj. 90.

21 U knjižnici su se nalazili, primjerice, Povijest staroga Orijenta G. Manojlovića, Povijest rimska do careva P. Tomića, Povijest carstva rimskoga I. I. Rabara, Le donne dei Cesari G. Ferrera, Povijesna citanka S. Srkulja, Izvori za povijest S. Srkulja, Uspomene Marka Aurelija (tal.), Svetonijevi životopisi rimskih careva (lat.), Gregoroviusova biografija cara Hadrijana (tal.), Opća povijest 2 (Asirija i Grčka) C. Grinberga i Povijest počinje u Sumeru S. N. Kramera (obje na francuskom). Usp. Uroš Desnica - Dušan Marinković, „Popis kućne biblioteke Vladana Desnice“, u: V. DesnicA, Hotimično iskustvo. Knjiga druga, 268-271. Svaki podatak o inventaru ove knjižnice samo je ilustrativan i ne može voditi nikakvom konačnom zaključku iz tri temeljna razloga. Objavljeni popis ne uključuje podatke kako je i kada koja knjiga stigla u knjižnicu. Neke su knjige mogle biti otuđene (vlasnikovom voljom ili bez nje) prije popisivanja inventara pa nema traga da su bile u sastavu knjižnice. Trenutno ne znamo što je stajalo u većoj knjižnici u Islamu. Npr., u Zagrebu prema objavljenome popisu nema hrvatskih ili srpskih prijevoda atenskih tragediografa ni Svetonijevih carskih biografija, a Plutarhovih ili Nepotovih životopisa znamenitih ljudi nema ni na kojem jeziku. Usp. i bilj. 27, 30 i 86.

22 Cezarovo ubojstvo i samrtni povik u Svet. Caes. 82 = Gaj Svetonije Trankvil, Dvanaest rimskih careva, Zagreb 1956., 55.

23 Usp. Plut. Cat. Cens. 27 = Plutarh, Usporedni životopisi, sv. 1, Zagreb 1988., 505. Usp. i Zvonimir Doroghy, Blago latinskog jezika, Zagreb 1966., 67. Za Cezarovo ubojstvo i samrtni povik usp. Plut. Caes. 67 = Plutarh, Usporedni životopisi, sv. 3, 131, te Plut. Brut. 17 = Isto, 474. Demostenovu biografiju v. u Plutarh, Usporedni životopisi, sv. 3, 276-302, Pompejevu u Isto, sv. 2, 350-403. Za Desničino pisanje referentne su i Romulova, Aleksandrova i biografija Katona Mlađega (Isto, sv. 1, 58-81; sv. 3, 5-96 i 166-211).

24 Usp. V. Desnica, Hotimično iskustvo. Knjiga prva, 135; Isti, Hotimično iskustvo. Knjiga druga, 124 i 144.

25 Herceg Novi, 1859. - Beograd, 1953. Mnogostran, ali ne odveć uspješan pisac (pjesnik, pripovijedač, putopisac, književni kritičar, prevoditelj, urednik), zaposlen kao državni činovnik. Aktivan u kulturi i politici. Član Srpske akademije nauka.

26 Najiscrpnije: Martin Kaminski, „Car, Marko“, Hrvatski biografski leksikon, sv. 2, Zagreb 1989., 577-578.

27 Usp. U. Desnica - D. Marinković, „Popis kućne biblioteke Vladana Desnice“, 269. Knjiga sadrži dvanaest životopisa: lidijskoga kralja Kreza, atenskog vojskovođe Miltijada, filozofâ Sokrata i Platona, povjesničara Ksenofonta i govornika Demostena, epirskoga kralja Pira, te rimskih pisaca Kornelija Nepota, Tita Livija, Vergilija, Horacija i Ovidija.

28 Francuski povjesničar i pedagog Charles Rollin (Pariz, 1661. - 1741.) autor je iznimno utjecajne Histoire ancienne u četrnaest svezaka (1730. - 1738., stari Istok i Grčka), a 1741. započeo je izdavati Histoire romaine, koja je u devet knjiga trebala doprijeti do bitke kod Akcija, odnosno do kraja Rimske Republike. Sam je izdao prvih pet svezaka. U 


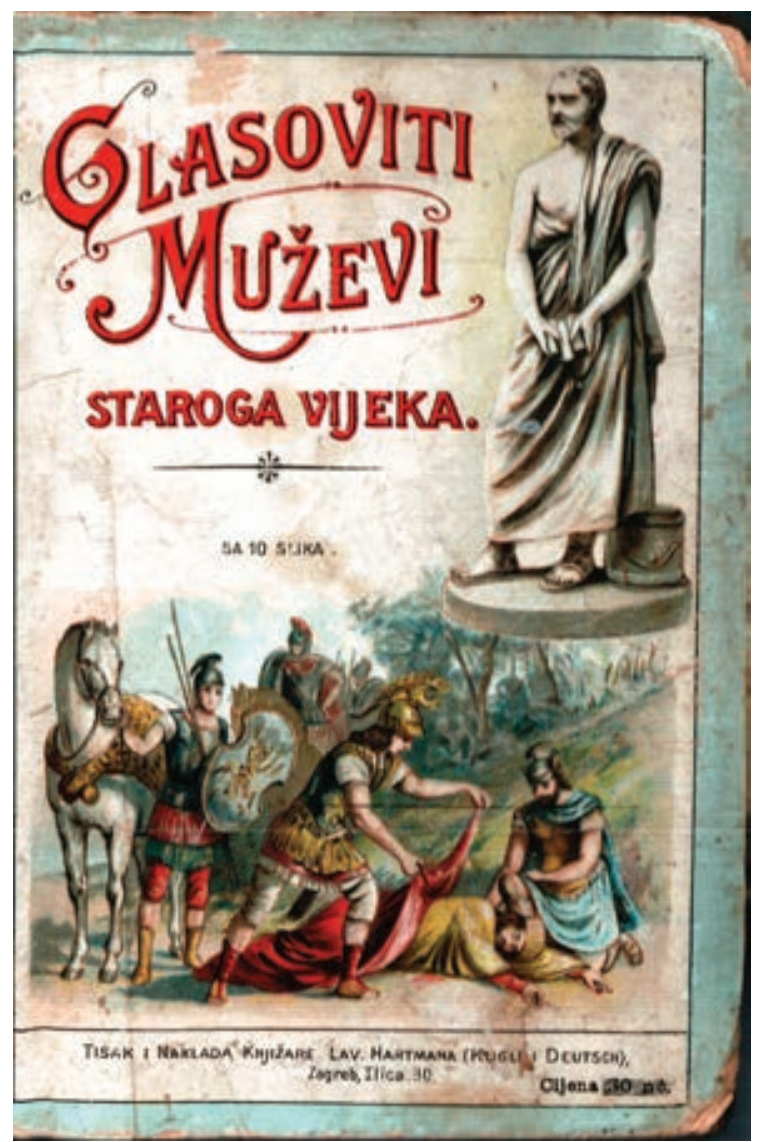

Sl. 1. Korice izdanja koje je priredio Marko Car, primjerak iz privatne knjižnice, Zagreb

Knjižica je objavljena u nizu za mlade koji je u Zagrebu otpočeo tiskar i nakladnik Lavoslav Hartman, a nastavili su ga Stjepan Kugli i Albert Deutsch. ${ }^{29}$ Knjige su kolale i čitale se i za djetinjstva Vladana Desnice. Baveći se slavnim ličnostima klasične starine, Marko Car je kao prijatelj obitelji mogao potaknuti i podržavati njegovo zanimanje za klasičnu starinu i izravno, razgovorima, i posredno, ovim djelcem. ${ }^{30}$ Upravo Marko Car recenzirao je one zlosretne rukopise pripovijedaka i stihova koje je Vladan Desnica uoči 2. svjetskog rata bio uputio na tiskanje Gezi Kohnu u Beograd i ostao bez njih. ${ }^{31}$ Odabir recenzenta i prihvaćanje recenzentske odgovornosti ukazuju na uzajamno povjerenje, na poštovanje mlađega pisca prema starijemu i na potporu starijega mlađemu, pa potvrđuju i mogućnost Careva utjecaja na Vladana Desnicu. ${ }^{32}$

Referencije na predaju o slavnim antičkim muževima naviru s različitim svrhama iz raznih vrsta njegovih tekstova, otvoreno ili prikriveno, uz ime staroga pisca ili bez njega. Upotrebljava ih kao usporedbeni materijal koji očito smatra općerazumljivim. Savjetnik dr. Mato Baričević u Ljudima staroga kova ironizira referencijom na Katona neočekivano ozbiljan pristup sudskih kolega prijestupu koji drži banalnim..$^{33}$ Ivan

drugoj polovini 19. st. zaredali su njemački prijevodi i preradbe, npr. Biographies d'hommes celebres de l'antiquite [sic! BKM] Mit Anmerkungen zum Schulgebrauch herausgegeben von Dr. Gerhard Franz, Oberlehrer an der Kreuzschule zu Dresden, I Teil, 1886.

29 Nizovi ovih nakladnika imaju dvije krajnje neugodne osobine. U pravilu nisu otiskivali godinu kad su izdali knjigu, a u nizu za mlade često su pod u inozemstvu afirmiranim naslovom objavljivali vrlo skraćene verzije $s$ reduciranom opremom. Tako je i s Životopisima, koji su očito vrlo uzak izbor iz dvotomnih predložaka. Razumno je pretpostaviti da Car nije radio prema golemoj Rollinovoj povijesti, nego prema nekom izvodu za mlade.

30 U obiteljskoj je knjižnici stajalo uz druge knjige o grčkoj i rimskoj povijesti i starinama (usp. U. DesnicA - D. MARINKOvić, „Popis kućne biblioteke Vladana Desnice“, 268-269 i 279), a nije završilo, recimo, u skupini školskih knjiga, iako se moglo smatrati i školskim priručnikom.

31 V. Desnica u molbi za umjetničku mirovinu 1959. godine, citirano prema: D. Marinković, „Biografija Vladana Desnice“, 229. Usp. i Stanko Korać, „Tematski krugovi i stil romana 'Proljeća Ivana Galeba”“, u: V. Desnica, Proljeća Ivana Galeba (1990.), 377.

32 To ne znači da Desnica nije mogao biti kritičan prema Carevu opusu. Usp. V. Desnica, Hotimično iskustvo. Knjiga prva, 223.

33 „Na koncu, bilo bi čisto smiješno da se postavimo u neku katonsku pozu, da mrštimo nos nad jednim bijednim mitničarom za nešto što je, recimo iskreno gotovo svaki od nas učinio!“ Isti, Fratar sa zelenom bradom, Zagreb 1959. $193-194$. 


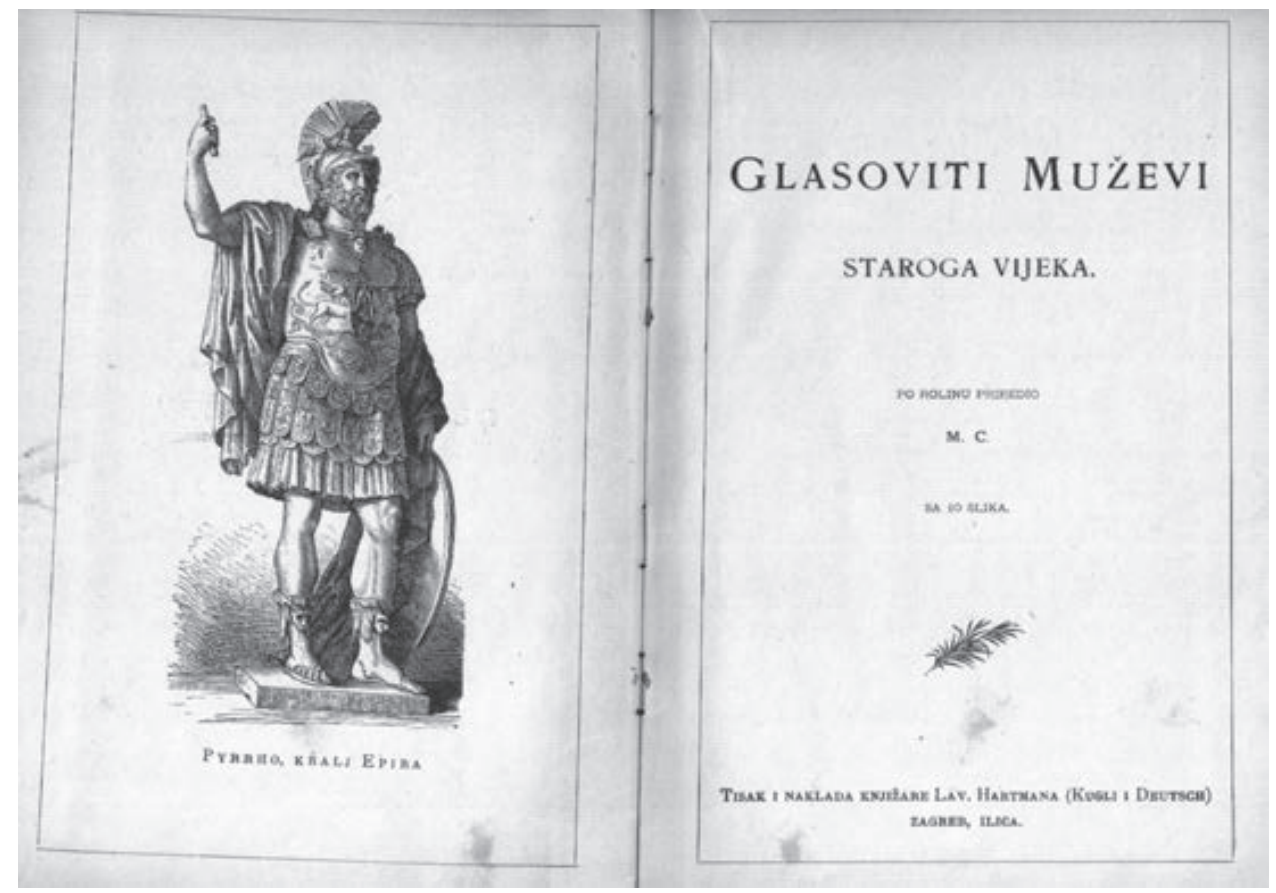

Sl. 2. Marko Car, Glasoviti muževi staroga vijeka, naslovnica s Carevim inicijalima

Galeb naziva plutarhovskom anegdotu koja se u obiteljskoj blagovaonici pripovijedala o visokom časniku koji je spartanski suspregnuo svoju potrebu za nikotinom. ${ }^{34}$ Jednoga od Dva pretendenta okarakterizirao je V. Desnica vrlo prepoznatljivim Cezarovim svojstvima. ${ }^{35}$ Mili Srdareviću-Prkutu odredio je u Koncu dana neka se prisjeti, gledajući s brijega na gradić kojim je nekoć upravljao, da su ovdje možda sidrili Pompejevi brodovi tijekom rata s Cezarom. ${ }^{36}$ Pišući o „Vučjoj djeci“ očekivano se referirao na Romula i Rema. ${ }^{37}$ Aleksandra Makedonskog stavio je na čelo ljudi od akcije koji nemaju vremena za kontemplativnost. ${ }^{38}$ Oba su Katona, Stariji i Mlađi, bila vrsni govornici i strogi branitelji rimskih vrlina pa je ponekad teško biti siguran na kojega misli, ne spomene li kakvo dodatno određenje. No, kad se Katonovim imenom podrugnuo Novaku Simiću jamačno je imao u vidu Katona Starijeg Cenzora. ${ }^{39}$ Unuk Ivan uspoređuje uspon djeda Galeba u vinograde s Hanibalovim prelaskom Alpa, a činjeničnost vlastitih čuvstvovanja s realnošću i historičnošću Cezarova prelaska preko Rubikona. ${ }^{40}$

34 Usp. Isti, Proljeća Ivana Galeba (1975.), 274.

35 Usp. Isti, Fratar sa zelenom bradom, 84; Isti, Pravda i druge pripovijetke, Zagreb 1997., 72. „Tip čovjeka koji voli biti u onom nekom selu prvi nego u Rimu drugi.“, parafraza je poznate Cezarove izreke prema Plut. Caes. 11. Muškarac je i polućelav - a ćelavost je, prema Svet. Caes. 45 i 51 mučila velikog Julija i zabavljala njegove vojnike. Usp. Isti, Fratar sa zelenom bradom, 176.

37 Usp. Isti, Hotimično iskustvo. Knjiga prva, 46.

38 Isto, 101.

39 „Tome svom trogubom - ljudskom, književničkom, javno-radničkom - moralu, i tome svom pravedničkom gnjevu dao je oduška Novak Simić, opće priznati Katon našeg javnog i, posebnije, našeg književnog života, na jednom sastanku Društva književnika (kome, nažalost, nisam prisustvovao), i u jednom članku u novogodišnjem »Vjesniku«"“ Isto, 366. Usp. i bilj. 15 i 23.

40 V. Desnica, Proljeća Ivana Galeba (1975.), 81 i 155. Kratak, ali impresivan opis Hanibalova prelaska Nepos, Hannib. 3 = Kornelije Nегот, $O$ istaknutim vojskovodama stranih naroda, Zagreb 1999., 175. Cezarov prelazak Rubikona 
Tražeći usporedbu američkom pomagalu za poduzetnike u proboju - Carnegievoj knjizi Psihologija uspjeha - Vladan Desnica izričito je evocirao odgojnu funkciju Plutarhovih biografija u europskoj tradiciji. ${ }^{41}$

Držimo da dvije dosad prikazane skupine referencija pokazuju da je prihvatio i temeljito upio klasičarska znanja koja su mu bila ponuđena tijekom školovanja te da ih je cijenio i koristio se njima u kasnijem stvaralaštvu. Neće biti da gorkim mislima bunarevačkoga profesora Miloša i usklicima Ivana Galeba o Plutarhu ${ }^{42}$ poriče vrijednost tih stečevina. Njima valja tražiti drugi smisao.

Niz dramatičnih bunarevačkih proturječja nesumnjivo je kreirao i zato da bi pojačao tamošnju mračnu atmosferu i zato da bi podcrtao osjećaj promašenosti glavnoga junaka. Osim toga, suprotstavio je obrazovanoga građanina i neuke, preživljavanjem iscrpljene i ogrubjele seljake i snažno naglasio da među njima nema razumijevanja i stvarnoga suosjećanja. $\mathrm{Na}$ isti se način istoga odnosa taknuo, na primjer, u pripovijestima Proljeće u Badrovcu i Oko, a najtemeljitije ga je razradio u Zimskome ljetovanju, gdje ga analitičari najbolje prepoznaju. ${ }^{43}$ Miloševa ponuda klasičarskih znanja suprotnost je mislima njegovih učenika o ugibanju, loju i mesu, kastriranju i krvi, kao što su ljupkost i nježnost tetošenoga gradskoga djetešceta suprotnost golemosti i ubojitoj ješnosti krmka Miguda. U oba slučaja urbana strana nema nikakvih izgleda. Klasična izobrazba zadugo je bila vrhunac građanskoga školstva. Ovdje su njezine sastavnice poslužile da se ocrta razdor između urbanog i ruralnog.

I referencije Ivana Galeba na Plutarhove biografije ponajprije razgolićuju ljudskost bolesnoga generala koji je nekoć smiono počinio velika djela, a sada mu se banalno bliži običan smrtnički kraj. ${ }^{44}$ Povjesničar koji pročita dva Galebova zaziva Plutarhovih biografija zatim nužno asocira dvije činjenice iz povijesti svoje struke. $U$ teoriji historiografije stalno se propituje koliko su biografije vrijedan historiografski produkt, odnosno kako treba istraživati i strukturirati ih da bi to bile. Pri tome se u načelu konstatira da su drevne antičke paradigme, upravo Nepot, Svetonije, Plutarh, pa i Tacit, sve do modernoga doba imale velik utjecaj, upravo zato ograničavajući - dakle, štetan. Povrh toga, u razdoblju Desničina djelovanja u njegovu je okruženju prevladalo učenje da su u povijesnom tijeku bitne mase, a ne pojedinci - kojima se zbog toga i ne treba previše baviti. Stoga je prvi dojam da su dva usklika Ivana Galeba u skladu s upravo takvim mišljenjima, da je pisac preko njih prezreo, zanijekao i odbacio svoju lektiru iz školskih dana.

Međutim, ni on ni njegov lik nisu povjesničari i ne more ih dileme o tumačenju povijesti. Prije antičkih biografija Ivan Galeb spominje i suvremene romansirane, koje je mu je bio po-

Svet. Caes. 31-32 = Svetonije, Dvanaest rimskih careva, 31-32; Plut. Caes. $32=$ Plutarh, Usporedni životopisi, sv. 3,114 .

41 „Što je Carnegieva knjiga? Za Ameriku, ona je nešto između etičkog brevijara i praktičkog priručnika za mladog poslovnog čovjeka. Vjerojatno ona tamo među mladim ljudima vrši onu funkciju i onaj uticaj koje je nekad u staroj Evropi vršio Plutarh. Primjeri iz života velikih poslovnih ljudi njihove zemlje imaju da bodre mlađe naraštaje i da im ukazuju svijetle primjere predaka." V. Desnica, Hotimično iskustvo. Knjiga prva, 408.

42 V. tekst uz bilj. 12 i $15-17$.

43 Vlastito opširno tumačenje što je o odnosu grada i sela, građana i seljaka nastojao prikazati u Zimskom ljetovanju, namijenjeno radijskom intervjuu, poznajemo preko nedatiranog rukopisa iz ostavštine. Usp. V. DesnICA, Hotimično iskustvo. Knjiga druga, 143-146.

44 Desnica razlaže to proturječje kroz dva razmaknuta poglavlja Proljeća Ivana Galeba, XLV. i XLVII. Usp. Isti, Proljeća Ivana Galeba (1975.), 209-211 i 230-233. 
sudio dobronamjerni liječnik..$^{45}$ One krivotvore veličinu gdje je nema pa je njihov raskorak sa stvarnošću drukčiji nego raskorak plutarhovske lektire školskih godina. Stoga njih sada odlaže i prestaje čitati. ${ }^{46}$ Premda junaci obje skupine biografija gube bitku sa smrću, koja ih sve izjednačuje, za Plutarhovima upravo vapi. Kako smo mogli vidjeti iz gore navedenih primjera, daleko je od toga da se odrekne sjećanja na sudbine antičkih velikih ličnosti pa možemo smatrati da to nije učinio ni preko Ivana Galeba. Prema vlastitom svjedočanstvu, u povijesnom štivu različitih vrsta tražio je „ljudski materijal“ ${ }^{47}$ likove i sudbine koje bi mogao uključiti u svoje književno stvaralaštvo. Slažući se s mišljenjem da su osobe glavni njegov predmet i da ih je umio vrhunski okarakterizirati ${ }^{48}$ smatramo da su biografije antičkih velikana za nj bile poput bogatog, zrelog usjeva ljudi i djelâ, uvijek pri ruci da požanje koji snop nadahnuća.

Daljnje sastavnice antičkog nasljeđa koje uvelike sudjeluju u Desničinu stvaralaštvu su grčko i latinsko jezično blago, filozofsko i književno spisateljstvo te grčke i rimske privatne i javne starine svih vrsta.

Razumije se da se koristio posuđenicama iz klasičnih jezika koje su postale internacionalizmima, prilagođene su mnogim živim jezicima i koriste se ili kao stručni termini, ili čak posve uopćeno. Prema gore spomenutoj klasičarskoj navici, rabio je i riječi, izraze i izreke iz latinskoga jezičnog blaga koji se u nelatinskom kontekstu i dalje prepoznaju kao aloglotski. ${ }^{49} \mathrm{I}$ jednih i drugih ima u svim vrstama Desničinih tekstova, ali je za ovu raspravu najindikativnije koliko ih je i kako upotrebljavao u diskurzivnoj prozi. ${ }^{50}$ Tu se njima koristio uglavnom spontano i radi sebe sama, a ne da bi obilježio neki lik ili da bi gradio atmosferu u kojoj likovi djeluju. Činio je to tako prirodno i lako da je pomalo frustrirao sugovornike. ${ }^{51}$

45 Isto, 211.

46 Usp. bilj. 12.

47 Usp. bilj. 20 i bilj. 90.

48 Usp. npr. prema Vlatko Pavletić, nenaslovljeni predgovor, 16-17 i Tonko Maroević, „Osunčane strane, sjenovite strune“, 13 .

49 Njih bi trebalo dosljedno pisati kurzivom (italikom). U uspoređenim izdanjima to je rješenje primijenjeno rijetko i nedosljedno. Latinski ili se ne izdvaja ničime, ili je pod navodnicima. Ponekad je upotrijebljen deblji tip slova (fet, bold) ili spacioniranje. U različitim izdanjima istoga beletrističkog teksta mogu se iste riječi naći različito tiskane. U ovom smo radu reproducirali po jednu verziju, osim kad su razlike imale ozbiljne posljedice. Čini se da su u Hotimičnom iskustvu tipovi slova preuzeti iz predložaka, bez pokušaja da se tekstovi sustavno urede za tu ediciju. Grčke je riječi V. Desnica rjeđe posuđivao, katkada se koristeći nepotpunom transliteracijom. Zabilježili smo malo primjera. Naslov Eshilove drame Prometheus desmotes navodi u Pronalasku Athanatika i u odgovarajućem poglavlju Proljeća Ivana Galeba. Usp. V. Desnica, Proljeća Ivana Galeba (1975.), 252; Isti, Proljeća Ivana Galeba (1977.), 240; Isti, Proljeća Ivana Galeba (1990.), 252; Isti, Odabrana djela, 234; Isti, Pronalazak Athanatika, Zagreb 2006., 79; Isti, Igre proljeća i smrti, 271. Za Platonove pojmove thymoeidés i epithymetikón v. prema bilj. 10. Nedatirani rukopis iz ostavštine (Isti, Hotimično iskustvo. Knjiga druga, 144) pokazuje da je želio ispravno transliterirati grčku riječ za trg: agorà je podcrtana, što je trebalo naznačiti kurziv. Naglasak joj je gravis, kako ga i prenosimo. I to je relikt iz nekadašnjeg školskog treninga: grčki pravopis traži da se oštri naglasak na posljednjem slogu riječi napiše kao gravis ako za njom ne slijedi interpunkcija. Međutim, pravilo nije trebalo primijeniti, jer interpunkcija u rukopisu slijedi (bar je tako objavljeno). Moralo je ostati agorá. Grčka riječ u ironiziranom imenu lapadske »VILLA ATARAXIA“ posredovana je u pripovijesti Spiriti (Isti, Fratar sa zelenom bradom, 291; Isti, Igre proljeća i smrti, 426) u romanskom izričaju, no u Pronalasku Athanatika (Isti, Pronalazak Athanatika, 39) jest djelomično transkribirana grčka posuđenica.

50 Iznimno su zahtjevne za svakoga tko objavljuje njegova djela. Od petnaest monografskih izdanja kojima smo se koristili, deset ima priručne rječnike različita opsega i kvalitete, samo se jedan referira na paginaciju izdanja (D. MARINKOvić, „Desničin pojmovnik“), a nijedan ne pokriva sve što bi iziskivale Desničine referencije na antiku.

51 Primjerice, čini se, upravo V. Pavletića: „Ne, Desnica nije pripovjedač, on je pisac, umjetnik koji teško rađa svaku riječ svoga teksta upravo zato što zna cijenu prave riječi. U svemu traži preciznost, ne zadovoljavajući se ni u razgovoru improvizacijom. Kad ne nađe odmah riječ kojom bi potpuno izrazio svoju misao, Desnica će navesti i strani termin (talijanski, latinski, francuski), čak nekoliko izraza, i nekoliko posrednih figura govora, tražit će pojačanje u intonaciji i saveznika u gesti, samo da se što bliže prikuči definitivnome, da ne kažem baš definiciji." V. Pavletić, "Svako djelo vrijedi tačno onoliko koliko poetskog sadrži u sebi'“, 58 . 
Marinković je u Desničinu pojmovniku marno popisao internacionalizme, ${ }^{52}$ ali je drastično zanemario izravne posudbe.

Razmjerno površnim pregledom evidentirali smo pedeset i tri različite izravne posudbe iz latinskoga jezičnog blaga, u rasponu od jedne riječi do čitavih izreka. Nekima se Desnica koristio više puta (v. Prilog 1.). ${ }^{53}$ Neke je smjesta upario s vlastitom parafrazom ${ }^{54}$ ili izmijenio da podcrta „svoj“ smisao. ${ }^{55}$ Od slavnih je izreka znao uzeti i parafrazirati dio koji mu odgovara, ${ }^{56}$ očito pretpostavljajući stanovito predznanje publike ili sugovornika. Marinković je uvrstio samo petinu ovoga materijala u Desničin pojmovnik. ${ }^{57}$ Čak i puko osnovno tumačenje ovih zasad zanemarenih, a nesumnjivo konstitutivnih djelića svakako bi pridonijelo da se Desničini tekstovi ispravnije razumiju i primjerenije vrednuju, pogotovo ako se po potrebi protumači i civilizacijska odnosno starinarska pozadina pojedinih primjera. ${ }^{58}$

Čini se da u Proljećima Ivana Galeba nalazimo primjer da je bio potpuno voljan i sposoban na isti način postupati i s posudbama iz grčkoga jezika. U XXIV. poglavlje umetnuo

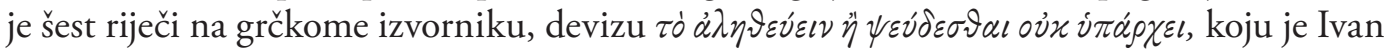
Galeb napisao na tablici i objesio nad svoj stol. ${ }^{59}$ Glavni junak piše da je, prije nego je to

52 Marinković je, naravno, obuhvatio i posuđenice iz drugih jezika, no prevladavaju pojmovi grčkog i latinskog podrijetla. Književni analitičari automatski posvećuju pozornost referencijskom aparatu fikcionalnih tekstova, dok su ga u diskurzivnoj prozi skloni zanemariti - što potvrđuje i da tu ima drukčiju vrijednost. Od četiri sveska Sabranih djela Vladana Desnice, koje je bio priredio Stanko Korać, četvrti svezak (Eseji, kritike i pogledi, Zagreb 1975.) jedini nema priručni rječnik, što je nadoknađeno u izdanju Hotimično iskustvo. Kako pokazuje rezultat Marinkovićeva truda, i opseg je mogao biti razlogom da se taj posao odgodi.

53 Dakako, uzimamo u obzir samo primjere iz vlastitoga diskursa Vladana Desnice, a ne i iz odlomaka kojima su autori Desničini sugovornici ni iz citata trećih autora.

54 Altera natura: prima natura (V. Desnica, Hotimično iskustvo. Knjiga prva, 189-190) i - rugajući se Franičevićevoj latinštini - sub specie aeternitatis : sub spetiae Marinitatis (Isto, 388-389).

55 Habent sua sidera libelli! = Knjige imaju svoje zvijezde! U bilješci uz tekst $O$ jednom gradu i o jednoj knjizi (Isti, Hotimično iskustvo. Knjiga prva, 133) nabrojio je pozitivne domaće i inozemne prikaze koje je dobilo Zimsko ljetovanje, suprotstavivši ih (čini se, poput Michelinovih zvjezdica) napadačkim domaćim ocjenama. Izvorni je oblik izreke Habent sua fata libelli = Knjige imaju svoju sudbinu. To je druga polovina heksametra iz poučnog spjeva Terencijana Maura, 2./3. st. Usp. Z. Doroghy, Blago latinskog jezika, 135.

56 U tekstu Transsupstancija dolara (1954.) riječima „America capta“ evocira prvu rečenicu slavnih Horacijevih stihova Graecia capta ferum victorem cepit et artes / intulit agresti Latio (Horat. Epist. II, 1, 156-157) da bi već tada dijagnosticirao amerikanizaciju europske popularne kulture. Usp. V. Desnica, Hotimično iskustvo. Knjiga prva, 408. Dakako, grčko-rimska poanta u drugoj mu rečenici ne odgovara i ne treba pa ju i ne navodi. („Osvojena Grčka osvojila je divljega pobjednika i unijela umjetnosti u priprosti Lacij“. Prev. BKM. Usp. Z. Doroghy, Blago latinskog jezika, 132.) Posudbe iz grčkog jezičnog blaga su u uvjetima hrvatskog izdavaštva riskantan pothvat $s$ lošim ishodima. V. tekst uz bilj. 59-64 i 143-152.

57 Precizno, deset različitih stavki potpuno, a dvije nepotpuno. Usp. Prilog 1., br. 7-9, 12, 19, 24, 37, 38, 41, 48 te 23 i 53. Nijednu sintagmu s prijedlogom ( $a$, ad, de, ex, in, pro, sub) nije uvrstio kao samostalnu stavku. Primjerice, ad hominem je svrstao među podpojmove natuknice argumen/a/t/ (D. Marinković, „Desničin pojmovnik“, 321), a sintagmu in patrimonio nije registrirao, iako kroatizirani patrimonij jest (Isto, 364). Nije uvrstio nijednu složeniju izreku. Značenja su, čini se, protumačena u bilješkama uz tekst samo ako je predložak imao takve bilješke. Ponekad ni u kontekstu nije lako odlučiti treba li riječ ili izraz shvatiti kao internacionalizam ili kao izravnu posudbu iz latinskoga jezičnog blaga, ali bi svakako bilo bolje da u Pojmovniku jesu i sve latinske posudbe. Povećale bi kakvoću toga pomagala, za početak redom i sustavnošću. Sada, npr., altera natura jest uvrštena, a njezin par - prima natura - nije. Jedna vis comica (V. Desnica, Hotimično iskustvo. Knjiga prva, 167) jest registrirana, druga, uz koju je objašnjenje (Isti, Hotimično iskustvo. Knjiga druga, 60), nije. Čini se da je latinski ometao priređivače do te mjere da je Desničin uzvik Ignoramus et ignorabimus! u rukopisu spriječio da razaznaju gdje završava Desničin umetak u tekst stanovitoga N. St. koji je naveo jer s njim polemizira (Isti, Hotimično iskustvo. Knjiga prva, 384). Uzvik nije registriran u Pojmovniku, kao ni jednostavnije ignoramus, kojim se Desnica poslužio najmanje još dvaput.

58 Npr. ibis - redibis Desnica je upotrijebio u polemici o suvremenim interpunkcijskim pravilima. U tom kontekstu svakako dobiva pun smisao i čitatelj može u njemu uživati ako/kad zna kako su funkcionirali dvoznačni odgovori uglednog i utjecajnog Apolonovog proročišta u Delfima. Usp. Isti, Hotimično iskustvo. Knjiga druga, 185.

59 Isti, Proljeća Ivana Galeba (1975.), 89; Isti, Proljeća Ivana Galeba (1977.), 83; Isti, Proljeća Ivana Galeba (1990.), 89; Isti, Odabrana djela, 89; Isti, Igre proljeća i smrti, 109. Citat nije atribuiran ni u jednom uspoređenom izdanju, 
učinio, „(...) nekad, čeprkajući i prevrćući po knjigama naišao na to da su ljudi umujući o umjetnosti još davno otkrili da je lučenje između istine i laži tu bespredmetno“. Prema tome, teško da bi Desnica uzeo Ivanovom devizom „Nije moguće i govoriti istinu i lagati“, kako je prevedena u nekim izdanjima. ${ }^{60}$

Slavno djelo gdje bi svaki filozof najprije potražio umovanje o umjetnosti i gdje uistinu stoji da u umjetničkom djelu nema mjesta cjepidlačenju što je istina, a što laž (fikcija), jest Aristotelovo Pjesničko umijeće. ${ }^{61}$ Sigurno je da se misli na nj. Ondje ipak nema ovakvoga sklopa, a niti infinitivâ "govoriti istinu“ $i$ "lagati“ pojedinačno. Koristeći se njima, Aristotel je u više spisa raspravljao o različitim kombinacijama odnosa istine i laži, ${ }^{62}$ a u spisu $O$ tumačenju nalazi se pokriće za ovu devizu. Ona nije doslovan citat, već parafraza dobivena ispuštanjem dijelova Aristotelove rečenice. ${ }^{63}$ Ivan Galeb napisao je na gore navedenom mjestu i da je otkrivenu „istinu protegnuo na čitavo područje misli i na čitavu površinu života“ prije zapisivanja devize. „Protezanje“ nije bilo samo u mislima, već je ostvareno intervencijom u grčkom tekstu. Dobiveni smisao „Ne postoji govorenje istine ili laganje ${ }^{“ 64} \mathrm{u}$ skladu je s promišljanjima glavnoga junaka. Ne možemo dokazivati je li V. Desnica devizu odnekud preuzeo kakva jest, sročio je uz nečiju pomoć ili sam, no jasno je da ju je u tekstu želio imati u izvorniku, da je ta želja potekla iz dobroga poznavanja Aristotelova opusa i da ju je znalački ostvario.

Razgovarajući 1964. godine s J. M. Milovićem tumačio je kako je nadijevao imena svojim likovima. ${ }^{65}$ „Dolores“ i „Kalpurnija“ naveo je kao primjere upotpunjavanja ličnosti imenom, a naglasio je da je drugo uzeo iz latinskoga jezika. Kalpurnija je dječja ljubav Ivana Galeba, „paunska ljepotica“, nježna, profinjena i ponosita pojava koje se ne dotiče

a njegova je erozija tijekom godina drastična. Savršeno je ispravno bio otisnut 1975. i 1990. Već 1977. pojavile su se greške. Druga riječ je infinitiv „govoriti istinu“, u transliteraciji alethenein (podcrtan je vokal koji u izgovoru treba naglasiti). No, zapravo je otisnuto almtheueien jer je eta u drugom slogu zamijenjeno s mi, a pri kraju je ubačeno epsilon viška. Treća riječ, veznik „ili““ (izgovor e)), iz nepoznatih je razloga dobila potpisano jota i oštri spiritus (hak) pa je zapravo otisnuto he(j). Peta riječ, negacija „n“", dobila je na kraju slovo khi umjesto prvobitnoga kapa. To je „pametna greška“ jer je u skladu s pravilom da se negaciji ou pridodaje aspirirani gutural khi počinje li sljedeća riječ oštrim spiritusom - a počinje. Međutim, ono kapa iz prethodnih izdanja vrlo je važno i nije se u nj smjelo olako dirati (v. bilj. 63). Naposljetku, u najnovijem je izdanju broj grešaka podignut do maksimuma: preuzete su sve ranije greške, a svi znakovi koji su se nalazili bilo iznad kojeg vokala zamijenjeni su po jednim oštrim naglaskom. Jedno dobro je što je eta u „ili“ “izgubilo potpisano jota.

60 U izdanju iz 1977. pojavio se sub calce prijevod devize. Preuzet je i u izdanjima iz 1998. i 2008., nije točan sam po sebi, a Desničinom kontekstu izričito proturječi. Vrhunac nekorektnosti vidi se u izdanju iz 1998., gdje je grčka deviza izostavljena iz teksta (koji se nastavlja kao da iza dvotočke ništa nije stajalo), ali je zlosretni prijevod podmetnut kao moto na početku poglavlja. Usp. V. Desnica, Odabrana djela, 88-89. Usp. i bilj. 143.

61 Točnije, u najvećoj mjeri Aristot. Poet. III, 25 (izdanje Bekker 1460b, 18-1461a, 4) = Aristotel, O pesničkoj umetnosti, Beograd 1966., 34-35; Isti, O pjesničkom umijeću, Zagreb 1983., 52-54. Npr. u 9. knjizi Metafizike, u 3. knjizi $O$ duši, u spisu $O$ sofističkim pobijanjima.

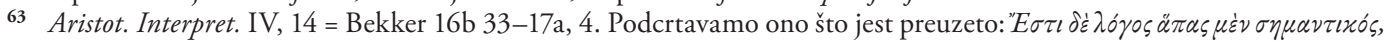

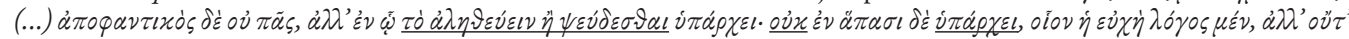

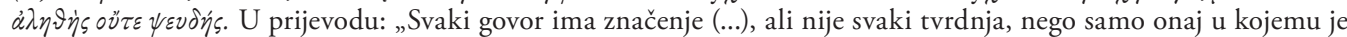
govorenje istine ili laži. Nije pak u svima. Takav govor je molitva, koja nije niti istinita niti lažna." Minimalistički prijevod, što doslovniji i hrvatski loš, ali funkcionalan ad hoc (BKM). Usp. i ARistotel, O tumačenju, Zagreb 1989., 30-31. Pokazatelj da je deviza mogla upravo tako nastati jest ono kapa u negaciji ởx. Stoji potpuno pravilno, jer sljedeća riječ u izvornom diskursu počinje samoglasnikom. Netko je, slažući devizu, zaboravio na to pravilo. Međutim, znao je probrati riječi tako da dobije potreban smisao.

64 V. Josip Kostić - Franjo Maiksner - Franjo Petračić, Gèrčko-hèrvatski rěčnik za škole, Zagreb 1875., s. v. hypárkhō: „b) u obće jači siva“". Usp. i Stjepan SENC, Grčko-hrvatski rječnik za škole, Zagreb 1910.: „3. osnova biti, tu biti, (...) uop. biti.“; Henry George LidDell - Robert Sсотт, A Greek-English Lexicon, Oxford 1968.: „B. 2. to be in existence, to be there, to be ready (...) 3. simply to be". 
neuredan, bučan i neotmjen život vlastite obitelji. Da bi se sklopila potpuna pripovijest o njezinu životu, treba pabirčiti po deset poglavlja Proljeća Ivana Galeba ${ }^{66}$ Antički predložak koji prema svemu rečenome treba asocirati da bi se ispravno percipirao taj ženski lik jest slavna Rimljanka, Cezarova supruga Kalpurnija, pojam čiste i bezuvjetno odane matrone. Njezino ponašanje uoči Cezarova ubojstva prikazali su već spomenuti antički biografi, a Shakespeare je prema njima kreirao svijetao, nježan i dostojanstven lik u Juliju Cezaru.

Čita li se pripovijetka Florjanovićc, ${ }^{67}$ činit će se da je lik supruge i majke ponio ime Dolores (lat. „boli“, „žalosti“, n. pl.) zbog veze s latinskoameričkim dijelom svijeta, a tek se razvitkom radnje razumije da ime izražava i trpnju zbog nesređene egzistencije i žalost zbog bolesti i smrti jedinoga, voljenoga djeteta. Ime kćeri koja roditeljima doista život znači također je pomno odabrano: Zoe (grč. „život“, „postojanje“). Pripovijest je uključena u Proljeća Ivana Galeba, gdje je Dolores prva supruga Ivana Galeba. Veze s latinskom Amerikom tu je nestalo, a Dolores prvenstveno trpi zbog suprugova nemira, čestih i dugih odsutnosti. ${ }^{68}$ Ženino je ime u svakom slučaju u skladu s njezinom sudbinom.

Ako su studij i prakticiranje prava podržavali i povećavali Desničina znanja iz latinskorimskog kruga, bavljenje filozofijom i književnošću, posebno kazalištem, podržavalo je znanja iz grčkoga kruga. Imena antičkih pisaca u diskurzivnoj je prozi većinom spominjao jer su se njima bavili ili njihova djela prevodili kasniji pisci čiji je rad prikazivao. ${ }^{69}$ Vlastite je tekstove posvetio samo trojici na koje se i inače najčešće poziva: Homeru, Eshilu i Sofoklu. Homerskom se predajom koristio kao gradivom za obrazloženje svojih stavova u polemikama, ${ }^{70}$ no Homera je povrh toga u zasebnom kratkom zapisu prikazao kao uzor pjesnikâ. ${ }^{71}$

$\overline{66}$ Od XVI. - gdje doznajemo kako je dobila ime i kako izgleda - do XXVI. - gdje odlazi s glumačkom družinom, a Ivan rezimira njezin kasniji neveseli život i zamišlja posljednji susret. Usp. Istı, Proljeća Ivana Galeba (1975.), 58-108.

67 Usp. Isti, Izbor pripovijedaka, Zagreb 1966., 149-171; Isti, Zimsko ljetovanje. Pripovijesti, 219-241.

68 Kći ovoga para, Maja, također će se razboljeti i umrijeti od tuberkuloze, ali majka nije prikazana kako dijeli brige i materijalne teškoće nastojanja da se ona održi na životu. Ivan Galeb započinje se prisjećati svojega prvog braka u L. poglavlju, prijelomne trenutke (raskid s Dolores i vijest o njezinoj smrti), spominje u LI. i LII., a pripovijest zapravo dovršava Majinim pogrebom na kraju LXI. poglavlja. Cjelina je ispresijecana drugim pripovijestima, prisjećanjima i praćenjem Ivanova zdravlja. Usp. Isti, Proljeća Ivana Galeba (1975.), 254-306.

69 Poimence Dante, Foscolo, Montaigne, Pindemonte i osobito Leopardi. Marinković je registrirao petnaest antičkih autora. Na popisu se nalaze: Anakreont, Aristotel, Epiktet, Epikur, Eshil, Heziod, Homer, Izokrat, Katon, Petronije Arbitar, Platon, Plaut, Plinije Stariji, Plutarh i Sofoklo. Previdio je još dvojicu, Horacija i Plotina, i jedan dodatni spomen Plutarha. Referencije u citatima tuđih tekstova razlučio je kosim brojevima stranica od vlastitih Desničinih. Nije registrirao kad se Desnica ili drugi autori bez piščeva imena pozivaju na naslove antičkih djelâ ili na njihove teme i junake. Stoga izgleda kao da uopće nema referencije na Vergilija (a ima, na Eneidu), a nije evidentirao ni izbliza sve referencije na homersku predaju i na atenske dramatičare. Referencije na antičke pisce i njihova djela u beletrističkoj su prozi Desničin slobodan izbor. Najviše ih je u Proljećima Ivana Galeba, no među njima je velik udio isti kao u Pronalasku Athanatika, pa čak i kao u nekim diskurzivnim tekstovima. Gore navedeni popis uvećava se za grupu filozofa, Demokrita, Euklida, Heraklita, Parmenida i Zenona. Usp. D. MARınković, „Abecedarij autora“, 305-317.

70 Ironizirao je protivnička inzistiranja na aktualnosti tematike kojom se ima baviti filmska umjetnost i glupo sročenu recenziju: „Na koncu, i Trojanski rat je nekad bio aktuelnost, i ona je, kao takva, već davno zastarjela, ali umjetničko djelo sagrađeno na toj aktuelnosti još ni danas nije baš sasvim zastarjelo." V. Desnica, Hotimično iskustvo. Knjiga prva, 58. Ili: „Tom zgodom primijetio sam Šnajderu da mi se takav način pisanja čini neozbiljan i da bi se po toj logici moglo napisati otprilike ovo: „Radnja Ilijade odvija se v j e r o v a t n o za vrijeme Trojanskog rata, jer kad bi se pretpostavilo da se ona odvija na pr. za vrijeme rusko-japanskog rata kako bi se moglo objasniti što se junaci bore strelicama a ne mitraljezima, što nose šljemove s konjskim repovima, što ne kliču Banzaj Nipon, itd, itd." Šnajder se osjetio povrijeđen (...).“ Isto, 399. Na Ilijadu se pozvao i u Proljećima Ivana Galeba kao na primjer teksta koji čitatelj u sebi inscenira tijekom čitanja. Usp. Isti, Proljeća Ivana Galeba (1975.), 218.

71 Isti, Hotimično iskustvo. Knjiga prva, 78. Bilješka „Slijepi Homer“ bila je objavljena u nizu „zapisa o umjetnosti“" 1952. godine, a G. Olujić-Lešić citirala ju je u opremi intervjua 1958. godine. Usp, Grozdana Olujıć-Lešıć, „Pesnik tuge i nade. Razgovor s Vladanom Desnicom“, u: V. Desnica, Hotimično iskustvo. Knjiga druga, 52-53. 
Zapis se valjano razumije kad se poveže s pjesmom Slijepi aed, naslovljenom po Homeru. Desnica je u njoj opjevao duševno i osjetilno stanje koje podrazumijeva pjesničkom sljepoćom. ${ }^{72}$ Pjesmu je bio objavio 1956. godine u zbirci Slijepac na žalu, a naslovom zbirke povezao je poetske likove slijepoga aeda iz te pjesme i mudraca koji umuje na suncu iz druge. ${ }^{73}$ V. Rismondo prepoznao je Desničinu težnju da se identificira s idealom koji je tako opisao. ${ }^{74}$ Dvojica velikih atenskih tragediografa, Eshil i Sofoklo, ${ }^{75}$ rjeđe su izravan predmet Desničine diskurzivne proze ${ }^{76}$ a češće su postojane evaluacijske točke u njegovim komparativnim razmatranjima. ${ }^{77}$ Držeći se antičke klasifikacije, njihove drame naziva „velikim djelima poezije ${ }^{\text {“ }}{ }^{78}$ Eshilova i Sofoklova sabrana djela nalazila su se na policama obiteljske knjižnice, a on izrijekom svjedoči kako je za njima posezao da se oporavi od recentnih kazališnih iskustava. ${ }^{79}$ Čitanje (ili bar slušanje) Sofoklove Antigone priziva da bi razobličio sebi suvremenog bahatog i neukog napadača na antičku dramsku baštinu ${ }^{80}$ Eshilu i Sofoklu pripalo je zbog tragičnih smrti njihovih junaka iznimno mjesto u Pronalasku Athanatika, pa po tome i u Proljećima Ivana Galeba. Obrazlažući zašto pripovijest o atanatiku ne može sretno završiti, njezin autor nabraja nizove veličajnih nesretnih ishoda u vrhunskim i paradigmatskim štivima (Stari zavjet, Milton, Dostojevski). Tu je i više Shakespeareovih likova, dodana je Flaubertova Ema, ali najviše je Eshilovih i Sofoklovih likova. ${ }^{81}$

72 Usp. V. Desnica, „Slijepi aed“, Zimsko ljetovanje. Pjesme. Ljestve Jakovljeve, 215.

73 „Umuje mudrac na suncu“, Isto, 253. Prepričana u prozi, pjesma je uključena u LXXII. poglavlje Proljeća Ivana Galeba. Usp. Isti, Proljeća Ivana Galeba (1975.), 337.

74 Zapravo je u neku ruku rezimirao obje pjesme na kraju teksta Poezija Vladana Desnice (1956.), a zatim je sam sebe plagirao u Sjećanju na Vladana Desnicu (1967.): „To je ona vječnost u čijem se krilu mogu smiriti naše izmučene misli i osjećaj, a koju je u podnevnoj uvali na moru Vladan Desnica bio otkrio u ritmu iskonskih slika i pokreta, koje je on iza ondašnjih svojih šupljih očiju, kao slijepi Aed, vidovito naslućivao."V. Rismondo, Oblici i slova, 213. Usp. i 135-136. Eshilov Okovani Prometej i Sofoklova Antigona standardne su stavke u školskom kurikulu grčkoga jezika. Nismo istraživali nastavni program gimnazija koje je V. Desnica pohađao pa ne možemo tvrditi je li kao đak morao čitati i nešto iz djelâ trećega velikana, Euripida. S obzirom na dokazan interes i ljubav za dvojicu starijih, mogao za njim posegnuti kasnije. Međutim, nigdje u uspoređenim tekstovima nismo našli izričitu referenciju na Euripida, a nismo ni prepoznali neku prikrivenu. Tradicionalniji atenski suvremenici smatrali su Euripidovo stvaralaštvo nevrijednim, provokativnim, heretičkim, pa i kažnjivim, stoga se u građanskom školstvu nije smatrao prikladnim ad usum delfnorum kao Eshil i Sofoklo. Općenito se uzima, bar od sredine 20. stoljeća, da su njegova djela pristupačnija publici današnjega senzibiliteta nego li njihova. Zasad se čini da je Desnica dijelio tradicionalne rezerve prema Euripidu.

Usp. podsjećanje na raniju predstavu Sofoklove Antigone na Splitskome ljetu u očekivanju izvedbe Sofoklova Edipa Kralja na Peristilu 1955. godine i kritika te predstave u dva pisma: V. Desnica, Hotimično iskustvo. Knjiga prva, 302-307. Dio rasprave iz tih tekstova uključen je u razgovor I. Galeba sa znancem glumcem u XLVI. poglavlju Proljeća Ivana Galeba. Usp. Isti, Proljeća Ivana Galeba (1975.), 215-219.

Usp. Isti, Hotimično iskustvo. Knjiga prva, 69-70 (Eshil), 91 (Eshil), 116-117 (Eshilov Agamemnon i Sofoklova Antigona), 300 (Sofoklovi Antigona i Edip kralj); Isti, Hotimično iskustvo. Knjiga druga, 195 (Eshil).

79 Autori popisa iz 2006. godine registrirali su u Zagrebu samo talijanske prijevode: „Sofocle, Tragedie, Firenze 1872“ (U. Desnica - D. Marinković, „Popis kućne biblioteke Vladana Desnice“, 267); „Eschilo, Tragedie, Milano“ (Isto, 272). U skupnim stavkama „Grčki klasici / školske knjige“ i „Rimski klasici / školske knjige“ (Isto, 279) nesumnjivo se kriju i izvatci iz djela atenskih dramatičara koja su u klasičnom školskom programu uobičajena ad usum delfinorum. No, oni ne bi bili prikladni za potpun doživljaj književnoga djela u primjercima iz vlastite knjižnice o kakvome svjedoči Desnica povodom izvedbe Sofoklova Edipa kralja na Peristilu u Splitu 1955. godine: „Tko ne pamti one pokunjene povratke poslije predstave, $s$ još jedamput potkrijepljenim uvjerenjem da uistinu velika djela dramske poezije ne bi trebalo prikazivati, da njihov goli tekst ne treba nikakve integracije ili nadopune, da su ona i bez prikazivanja u sebi potpuna i cjelokupna, sama sebi dovoljna, dokraja dorečena? Koliko smo puta, poslije pretrpljene predstave, u noćnoj tišini naše sobe, posegnuli za knjigom na polici, da između dviju sklopljenih stranica opet nađemo ona velika i kroz vjekove zračeća mjesta, koja smo na predstavi izgubili! V. Desnica, Hotimično iskustvo. Knjiga prva, 302.

80 Usp. Isto, 116-118.

81 Usp. Isti, Proljeća Ivana Galeba (1975.), 247 i 252-253. 

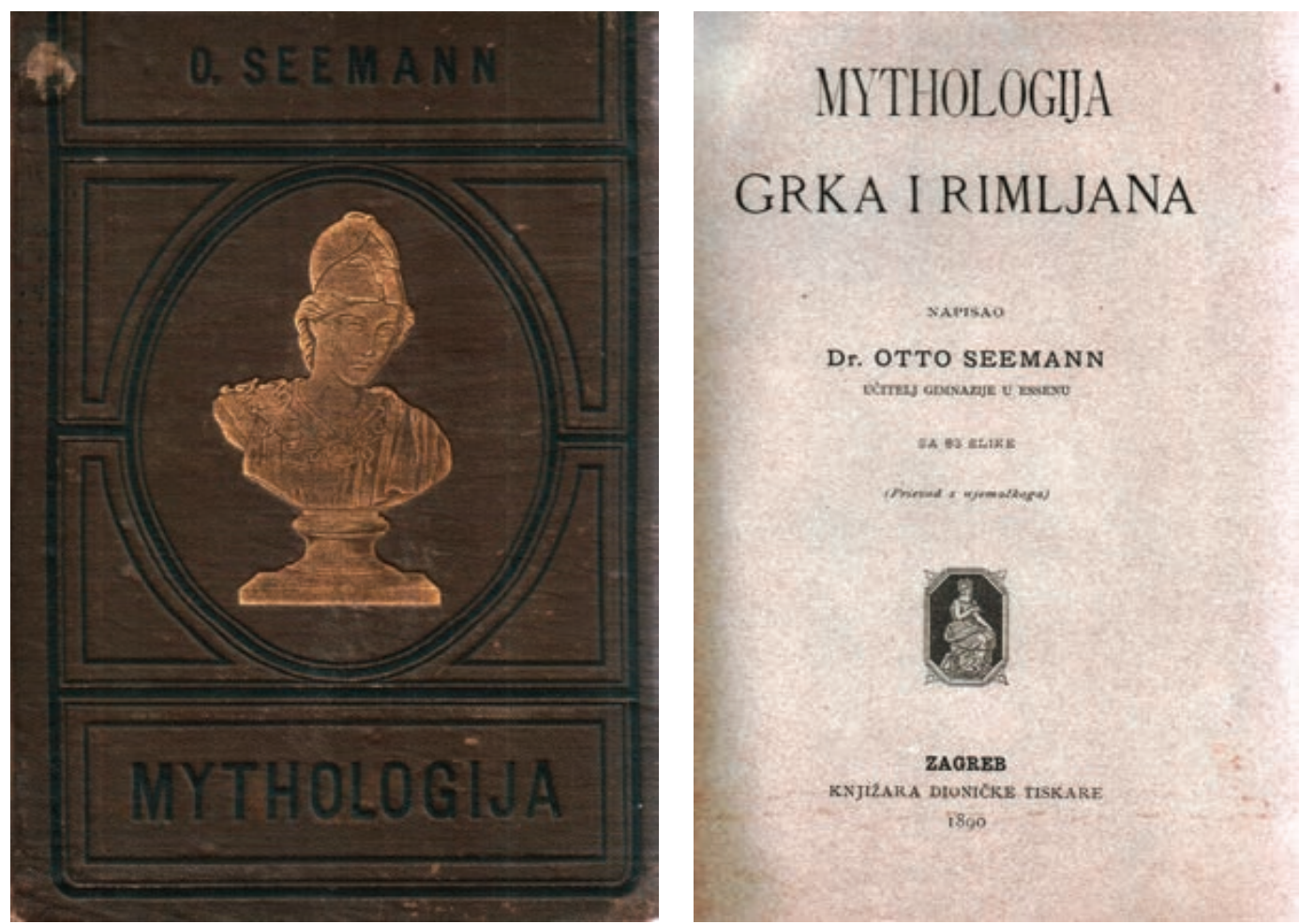

Sl. 3. Otto Seemann, Mythologija Grka i Rimljana, Zagreb 1890.

Brojne referencije na antičku civilizaciju, grčke i rimske privatne i javne starine, također se mogu naći u svim vrstama Desničinih tekstova. ${ }^{82}$ Čak i izostavimo li likove iz tebanskog i mikenskog ciklusa ${ }^{83}$ i Prometeja ${ }^{84}$ mitologija još uvijek prevladava. ${ }^{85}$ Bez sumnje najutjecajniji dio antičke baštine u umjetnosti svih kasnijih vremena, mitologija se transformira i regenerira čak i u recentnoj popularnoj kulturi. Vladan Desnica ju je još upoznavao u tradicionalnom obliku. Vrlo rašireno pomagalo za tu vrstu znanja napisao je gimnazijski profesor u Essenu, dr. Otto Seemann. Ilustrirano je brojnim crtežima antičkih umjetnina

$\overline{82}$ Npr., u diskurzivnoj prozi, ne uzimajući u obzir stručne grecizme kojima se koristio u raspravama o književnosti (posebno dramskoj) i u osvrtima na filozofske teze, kao ni referencije koje su zapravo načinili autori o čijim djelima raspravlja. Primjeri ispred razdjelnice III ili bez nje su iz prvoga, a iza nje iz drugoga sveska Hotimičnog iskustva. Možemo utvrditi da evocira gradski život (Zadar - stara i napredna rimska naseobina, 133; Pietas Iulia - Pula, 182 \|\| gradski trg, agorà, 144 - naglasak i podcrtavanje iz izdanja, op. BKM), spomenike (još pomalo ukočen i nevješt osmijeh arhaičkih skulptura, 217; Memnonov stup, 285), mentalitet i obrede (špartanska odluka: ili - ili, 45 \|II hekatombe, 87), mitološku i povijesnu predaju (Romul i Rem, 46; Trojanski rat, 58 i 399; furije, 72; kolo muza, 114 i 121; Hekuba, 169; Odisej, 206; Dit/Pluton, 218; Talija, 218; Elektra, 252; Kasandra, 252; Scila i Haribda, 283; Pegaz, 369 ||| Protej, 72) te da razotkriva antički podsloj u Danteovih likova (kod Dantea je Odisej prometejski lik, a Farinata degli Uberti koriolanski, 206 i 213).

83 Njih spominje zbog dramskih djela (dakako, i zbog ideja koje su promicali njihovi autori): Edip, Antigona, Jokasta, Kreont i Hemon. Vrlo jasno podrazumijeva Agamemnona i druge likove iz kuće Atrejevića kad u usta autoru pripovijesti o atanatiku stavlja upit „Gdje je (...) ta Orestija u kojoj je povratnik s ratišta našao kod kuće sve u najboljem redu,.... Usp. bilj. 81.

84 Njega, doduše, najčešće spominje u Eshilovoj verziji iz drame Okovani Prometej, ali više zbog zamislî o ljudskoj egzistenciji koje uključuje mit o njemu negoli zbog zapleta drame.

85 Osim likova evidentiranih u diskurzivnoj prozi (bilj. 82), od kojih se neki pojavljuju i u beletrističkoj, samo ilustracije radi abecednim redom: Danaide, Dijana, Dioskuri, Eskulap, furije, Ikar, Kairos, Kron, Mentor, Minotaur, Nioba, Orfej, Pan, Piram i Tizba, Prijap, Sizif, Tantal, Zeus. 
koje prikazuju junake i heroje, uz navod gdje se koja čuva. Hrvatsko izdanje iz 1890. godine na popisu je Desničine knjižnice. ${ }^{86}$

Dok se Desničini likovi kreću dalmatinskim prizorištima, nužno nailaze na tragove ranijih civilizacija. Zabilježene su i prapovijesne gradine, koje se u krajoliku ne mogu previdjeti. Gradina kod Smiljevaca spominje se u Zimskome ljetovanju više puta prije nego se izbjeglice iz napadnutoga Zadra upute onamo na izlet. Čitatelj može doznati da su na njoj nekoć logorovale VII. i XI. rimska legija i da joj je staro ime Brebentium. Zadarski se poluotok s nje vidi kao na dlanu, okolno se stanovništvo njome koristi kao pasištem i izvorom kamena za gradnju. Ostatci staroga naselja ne naziru se, a pastiri u XXII. poglavlju prepričavaju predaje o turskome vremenu kao o najdrevnijoj prošlosti Gradine.$^{87}$ Opis stanja vrijedio je pred sredinu 20. stoljeća praktički za sve gradine Ravnih kotara i Bukovice. Nešto je pak posuđeno od konkretnih lokaliteta. Okol gdje su boravile spomenute rimske legije nalazio se u Ivoševcima kod Kistanja, nad zapadnom obalom Krke, nasuprot gradini u Puljanima nad istočnom obalom. Staro ime Gradine očito je kreirano prema impresivnoj gradini Bribirska glavica kod Skradina, antičkoj Varvariji. Zadar se posve sigurno ne vidi ni s jedne od ovih gradina u dubljem zaleđu. Smiljevačka gradina u Zimskome ljetovanju je, dakle, fikcija. Ipak, sazdana je od mješavine autorovih znanja o prošlosti i uvida u sadašnjost kraja.

U epizodi talijanske vlasti nad Smiljevcima ušle su u roman referencije na rimske starine. ${ }^{88}$ Spominju se i njihovi poznavaoci i istraživači, profesor Vitaliano Bogdani i kanonik Claccich, „zaslužni zadarski trudbenik na polju domaće historiografije“. ${ }^{99} \mathrm{Za}$ Bogdanija je Desnica izričito spomenuo da pripada onome „ljudskom materijalu“ koji je tražio u povijesnim djelima i dokumentima. ${ }^{90}$ Nije teško u njemu prepoznati Vitaliana Brunellija, autora vrlo vrijedne, ali i talijanaški pristrane Storia della città di Zara. ${ }^{91}$ Claccicha se ne može tako sigurno identificirati. Može biti da se njegovim likom podrazumijeva više osoba. ${ }^{92}$ Desnica je očito pratio domaću povjesničarsku produkciju različitih razina i razlučivao što je u njoj pouzdano i može se upotrijebiti, a što ne valja uzimati ozbiljno.

Pjesmu o sadašnjem trenutku naslovio je Kairos, prema imenu grčkoga božanstva sretne prilike. Znameniti reljef Kairosa iz Trogira bio je objavio Mihovil Abramić skoro četvrt

86 Otto Seemann, Mythologija Grka i Rimljana, Zagreb 1890. Usp. U. Desnica - D. Marinković, „Popis kućne biblioteke Vladana Desnice“, 269.

87 V. Desnica, Zimsko ljetovanje. Pripovijesti, 125-128.

88 Proteže se od XII. do XV. poglavlja. Spominju se gradnja akvedukata, stupanje legija, rimska stela, rimska vučica, fasces i žara za pepeo pokojnika, o kojoj podrobno nešto kasnije.

89 Bogdani sudjeluje u radnji i podrobno je opisan (Isti, Zimsko ljetovanje. Pripovijesti, 85-86 i 93-97), dok je Claccich spomenut jedanput, kao autor rukopisa o starinama iz kojega je Bogdani doznao za rimsku urnu u Smiljevcima (Isto, 93). Talijanski naslovi koje je Desnica dao njegovim djelima podrugljivi su.

90 Isti, Hotimično iskustvo. Knjiga druga, 123. Usp. i bilj. 20.

91 Vitaliano Brunelli, Storia della città di Zara dai tempi più remoti sino al 1409 compilata sulle fonti e integrata da tre capitoli sugli usi e costumi, Trieste 1974. Prvotisak je objavljen 1913. u Veneciji. Vitaliano Brunelli rođen je u Ankoni 1848. godine, a umro u Zadru 1922. Predavao je na gimnazijama u Splitu i Kopru, a najdulje u samome Zadru. Vodio je gimnazijsku knjižnicu i knjižnicu Paravia. Vrhunski obrazovan i kvalitetan istraživač, zbog žarkog zaratinskog domoljublja i potcjenjivanja „Slavena“ slabo je razumijevao i loše je obrađivao hrvatski dio zadarske i dalmatinske povijesti.

92 Prezime Klačić postoji, no oblik Claccich asocira talijanizirana hrvatska prezimena svećenika poput Paola Clementea Miossich-Cacicha (Makarska, 1784. - 1837.) i Luigija Cesarea Pavissicha (Makarska, 1823. - ?, 1905.). Svu trojicu povezuje zanimanje za djelo De Regno Dalmatiae et Croatiae Ivana Lučića, koje je Cacich bio počeo prevoditi na talijanski, a Pavissich preveo. Usp. Giovanni Lucio, Storia del regno di Dalmazia e di Croazia, Trieste 1983. Prvotisak je objavljen u Trstu 1896. 
stoljeća prije objavljivanja zbirka pjesama Slijepac na žalu ${ }^{93}$ Otada je među biserima antičke umjetnosti u Hrvatskoj. ${ }^{94}$ Takav spomenik Desnici nije mogao promaći i vjerujemo da ga je nadahnuo za naslov, iako on pjeva o „času sadašnjem“ koji je daleko složeniji od Kairosovih nadležnosti.

Posljednje: Vladan Desnica je kao tridesetgodišnjak sastavio esej o Kistanjaninu Mirku Koroliji. ${ }^{95}$ Vrednujući njegovo pjesništvo, ustvrdio je da se u životu i djelu književnika dalmatinskozagorskih korijena razvio sklop vezâ između zavičajne kulturne baštine koja uključuje vlastitu antiku, između njezinoga univerzalnijeg oblika na obližnjoj obali i klasične izobrazbe. Prema tome, upoznati se u zavičaju s izvornom antikom i poduprti to školovanjem, znači razviti s njome prisnu i istinitu vezu, izravno je zavoljeti s njezinom pravom bîti, stopiti se $s$ njezinim duhom i s njezinom suštinom. ${ }^{96}$

Ovo je razmjerno dugačak uvod pod naslovom koji je najavljivao vrlo usku temu. Proemij je, međutim, bio neophodan da bi antički motivi u tanatičkom repertoaru Vladana Desnice dobili kontekst koji će potvrditi da ih je vrijedilo prepoznati i pokušati odrediti odakle potječu i kakvo im je mjesto u autorovu djelu.

Iz velikog niza svakovrsnih referencija na antiku odlučili smo, u skladu $s$ temom $D e-$ sničinih susreta 2017. godine, izdvojiti i prikazati nekoliko povezanih sa smrću. Odabrali smo primjere iz cijeloga raspona koji se u njegovim tekstovima proteže od pojedinih riječi do čitava koncepta zagrobnoga života i za ovu ih priliku nazvali darovima Harona, lađara mrtvih u grčkom podzemnom svijetu.

Riječi „athanatik“ nema u hrvatskim rječnicima stranih riječi, pa ni u najnovijoj monografiji o grecizmima u hrvatskome jeziku.${ }^{97}$ Desnica je svjesno upotrijebio generički tip

93 Zbirka je objavljena 1956. Pjesma je otisnuta i u Sabranim djelima, gdje su u priručnom tumaču stranih i manje poznatih riječi i dijalektalizama objašnjene Kairosove božanske kompetencije, pa je čak i citiran Pozidipov epigram o Lizipovom reljefu boga u trku. Nije, međutim, spomenut trogirski reljef. Usp. V. Desnica, Zimsko ljetovanje. Pjesme. Ljestve Jakovljeve, 228-229 i 338.

94 Usp. Mihovil Aвramić, „Novi relijef božanstva Kairos“, Vjesnik za arheologiju i historiju dalmatinsku, 50/1928. 1929., 1-12; Nenad Cамві, „Kairos“, Radovi Filozofskog fakulteta u Zadru. Razdio društvenih znanosti, sv. 20 (9), 1980. - 1981., 7-14; Nenad Cambi, Antika, Zagreb 2002., 33-35.

95 Kistanje, 1886. - Šibenik, 1934. Po obrazovanju pravnik, kao pisac uspješniji od M. Cara (usp. bilj. 25). Također pjesnik, pripovijedač, putopisac i književni prevoditelj, a povrh toga i dramatičar. Politički izrazito djelatan, ideolog, čelnik i aktivist Organizacije jugoslavenskih nacionalistâ. Usp. Simun Jurišıć - Ankica ŠunjIć, „Korolija, Mirko (Mirko Uroš)“, Hrvatski biografski leksikon, sv. 6, Zagreb 2009., 637-638.

96 „A osim toga, on se je s Antikom upoznao neposredno na izvorima i u školi koja je nosila njezinu direktnu tradiciju, i zato je s njom u mnogo prisnijoj i istinitijoj vezi nego oni koji su je upoznali zavoljeli iz treće ruke, lišenu prave njezine biti, u ruskim i germanskim vizijama; koji su je, nepopravljivi, gledali kroz prizmu romantizma, i preuzeli samo njezine rekvizite i pokoju skroz formalnu oznaku, a ostali savršeno strani njenom duhu i njenoj suštini." V. DESNICA, Hotimično iskustvo. Knjiga prva, 33-34. Voljni smo smatrati da je Vladan Desnica to iskustvo umio prepoznati i opisati jer ga i sam dijeli. S. Korać ocijenio je esej o Mirku Koroliji kao programski. Ako je tako, Desničin program posve jasno uključuje antičku baštinu zavičaja. Usp. S. Korać, „Tematski krugovi i stil romana 'Proljeća Ivana Galeba'", 377.

97 Klaić registrira apelativ atanazija (besmrtnost, neumrlost) i vlastito ime Atanas/Atanazije. Usp. Bratoljub KLAIĆ, Veliki rječnik stranih riječi, izraza i kratica, Zagreb 1968. Autori rječnika iz 1998. ne donose vlastita imena, ali osim atanazije tumače i atanatizam/atanizam (vjerovanje u besmrtnost duše) i atanatologiju (naučavanje o besmrtnosti duše). Usp. Šime Anić - Nikola Klaić - Želimir Domović, Rječnik stranih riječi, Zagreb 1998. Anić i Goldstein ostavili su samo atanaziju, a Kovačić nema ni nju. Usp. Vladimir Anić - Ivo GoldsteIn, Rječnik stranih riječi, Zagreb 2009.; Marko Kovačıć, Grecizmi u suvremenom hrvatskom jeziku, Zagreb 2007. Grafija -th- za aspirirani dental thêta izvorna je Desničina. Riječ inače kroatiziramo kao atanatik, u skladu s pravilom koje je prevladalo u književnoj štokavštini. Usp. Damir SAlopeK, Transkripcija i adaptacija grčkih imena, Zagreb 1986., 33-34, 160-164 i 187-189; M. Kovačić, Grecizmi u suvremenom hrvatskom jeziku, 27-28. Po primjerima iz rječnika koje smo naveli vidi se da je pravilo aktivno. 
naziva za ljekovito sredstvo protiv neke tegobe. ${ }^{98}$ To obrazlaže i Krezubi, ${ }^{99}$ jedan od sugovornika Ivana Galeba, zamišljeni autor pripovijesti o pronalasku. ${ }^{100}$ Klasični grčki jezik raspolaže riječima analognog sastava za besmrtnost i za darivanje besmrtnošću. Sastoje se od niječnoga $a$-, tzv. alfa privativum, i od osnove koja se prepoznaje u imenici thánatos - smrt. Takvi su pridjevi „besmrtan“, athánatos i athanásios, glagol „činim besmrtnim“ athanatizo i imenica athanasia „besmrtnost“. Pridjev „smrtan“ $\mathrm{i}$ „smrtonosan“, thanatikós, potvrđen je u klasičnom grčkom jeziku, ${ }^{101}$ a zatim i kao internacionalizam. Pripada medicinskom i pravnom kontekstu. U pravnom je najčešće u izrazu „smrtna kazna“, thanatiké díkē. Nećemo se čuditi ustanovimo li da nekoliko lijepih primjera takve uporabe potječe iz Plutarhovih životopisa. ${ }^{102}$ Pridjev athanatikós njegova je negacija, ${ }^{103}$ a nije potvrđen ni u klasičnom, ni u bizantskom grecitetu. Desnica je supstantivirao oblik njegova muškog roda. Čini se da bi Vladana Desnicu iz perspektive hrvatskog jezičnog okruženja valjalo smatrati promicateljem, možda i tvorcem, te znalački složene i vrlo uspješne posuđenice iz grčkoga jezika. ${ }^{104}$

U pripovijesti o deprimantnom Bunarevcu poslužio se pak latinskom riječju simulacrum kojom se naziva sve slično (similis, -e) ljudskome liku, od kipova do prikaza u snu, osobito pokojničkih. ${ }^{105}$ Simulacrum oponaša (simulo 1 ) čovjeka, ali u njemu nema ljudskosti, prazan je i strahotan. ${ }^{106}$ Pojam je dvaput pao na um glavnome junaku Milošu, profesoru

98 Poput antipiretik - protiv vrućice, antiemetik - protiv povraćanja, antihipnotik - protiv bolesne pospanosti, antispastik - protiv grčeva i sl.

99 „Ali ako vas baš smetaju ti izrazi, možemo za novi lijek iznaći neko drugo ime. Na primjer "Athanatik«. To će biti podesno, jer se može načiniti i plural, za slučaj da se daljnjim istraživanjima iznađe čitav niz, red, familija takvih sredstava. "Grupa athanatikâ«. To dobro zvuči... Dakle, iznađen je Athanatik." V. Desnica, Proljeća Ivana Galeba (1975.), 239-240. Gotovo identičan citat nalazimo i u V. DesnicA, Pronalazak Athanatika, 10.

100 Usp. i čitavo XLIX. poglavlje. Isti, Proljeća Ivana Galeba (1975.), 237-255.

101 J. Kostić - F. Maiksner - F. Petračić, Gèrčko-hèrvatski rěčnik za škole, s. v.; S. Senc, Grčko-hrvatski rječnik za škole, s. v. thanásimos, 2., thanatikós, 3. i poz. thanatóeis; H. G. Liddell - R. ScotT, A Greek-English Lexicon, s. v. .

102 Doslovce u Plut. Pericl. 10, 6; Cat. Min. 44, 1 i Gracch. 24, 7, a s varijacijom thanatiké gnómè u Cic. $21,3$.

103 U izdanjima Proljeća Ivana Galeba tumačenje ili izostaje (npr. u izdanjima iz 1977. i 1998.) ili nije ispravno: npr. „athanatik (a-thanatos) (grč.) - besmrtnost“. Usp. V. Desnica, Proljeća Ivana Galeba (1990.), 348. Isto se tumačenje pojavljuje i u izdanjima Pronalaska Athanatika kao samostalnog djela. Usp. u priručnom rječniku u: Isti, Pronalazak Athanatika, 95. Iako K. Nemec ponavlja što ondje stoji, interpretacija koju dodaje jest ispravna. Usp. Krešimir Nemec, „Pronalazak Athanatika - između utopije i distopije“, u: V. Desnica, Pronalazak Athanatika, 86.

${ }^{104}$ Provjeravali smo i rabi li se riječ u živim europskim jezicima (osim u prijevodima Desničinih djela). Pronašli smo je u neslužbenoj mrežnoj komunikaciji na francuskom kao pridjev athanatique u pravnom kontekstu, na engleskom kao pridjev athanatic također u pravnom kontekstu, a kao improviziranu imenicu athanatic u privatnom mrežnom diskursu. Međutim, kao i za hrvatski, nismo je uspjeli pronaći u meritornim rječničkim pomagalima tih jezika.

105 Usp. Mirko Divković - Franjo Petračić - Mato Valjavec - Sebastijan Žepić, Latinsko-hrvatski rječnik za škole, Zagreb 1881., s. $v$. „b) ${ }^{*} \dagger$ p r il i k a, s j e n pokojnika, p rilik a n a s n u“. Zvjezdicom su u ovom rječniku označene „pjesničke riječi“, a križićem one koje nisu bile klasične prema mjerilima koja su bila na snazi kad je rječnik tiskan. Križić je zapao i izraze kojima su se koristili npr. Plinije Mlađi, Tacit i Svetonije, velikani koji ne pripadaju ni zlatnom ni srebrnom razdoblju rimske književnosti. Usp. „Tumačenje znakova i kraticâ“, Isto, v. s. p. Rječnik iz 1881. bio je namijenjen školskoj djeci kao i izdanje iz 1961. (Milan ŽEPIĆ, Latinsko-hrvatskosrpski rječnik, Zagreb 1961.), ali je u izdanju iz 20. stoljeća natuknica simulacrum drastično skraćena, značenja su nanizana bez tumačenja i bez primjera, ne razumije se kako su se razvila. To je dobar primjer procesa koji je zahvatio gradivo čitava rječnika. U 20. stoljeću manje ga je i nije uređeno da bi pružalo stvarno znanje (tj. s razumijevanjem). Već se sredinom 20. stoljeća dobrano zagazilo putem koji je smrtonosan za humanističke znanosti, a vodi današnjemu učenju obrazaca koji omogućuju vještine, a ne znanje. Znanje, naime, podrazumijeva razumijevanje.

106 Usp. Charlton T. Lew Is - Charles SHorT, A Latin Dictionary, Oxford 1975., s. v.: „I.a likeness, image, form, representation, semblance (class.; syn.: imago, effigies, signum). I. Lit., of images formed by art, reflected in a mirror, or seen in a dream; of apparitions, visions, etc. (the latter mostly poet. and in post-Aug. prose). (...) B. An image, form, shade, phantom seen in a mirror, in a dream, etc.; analogous to the Gr. ei $\delta \omega \lambda$ ov ... II. In partic., with the predominant idea of mere imitation (opp. to that which is original or real), a shadow, semblance, appearance, etc. (...." 
klasičnih jezika, dok je gledao svoju ženu u mrtvačkoj postelji. Suprugu više nije ljubio, pa mu je iz podsvijesti navrla riječ potaknuta istodobno gnušanjem, nečistom savješću i olakšanjem, donoseći mu izliku i opravdanje. Hvata se za nju i opetuje ju kako bi sebe uvjerio da je slobodan poći drugoj ženi - jer prva je postala simulacrum. ${ }^{107}$ Pisac očito poznaje sve nijanse pojma kojim eksplicitno iskazuje, upravo dijagnosticira, tijek Miloševih osjećaja, a zatim i misli. Ranije je spomenuo da njegov junak predaje latinski pa čitatelj zbog toga mora podrazumijevati da je Miloš simulacrum asocirao kao znalac, jer je s njegova gledišta po nečemu konvenirao situaciji. Pitanje je samo hoće li znati dovoljno da bi osjetio što je to i povezao što simulacrum znači liku, a što njime tvori pisac.

Horacije je svoju pjesničku oporuku i imaginarni epitaf započeo u najboljem rimskom duhu, samouvjerenim i ponositim riječima o spomeniku koji je podigao, a trajniji je od mjedi. To su njegove pjesme, zbog kojih ne samo što neće posve umrijeti, već će mu slava rasti i obnavljati se dok bude Rima. ${ }^{108}$ Pjesma je izvor sentencija ${ }^{109} \mathrm{i}$ školsko štivo sve do danas. Desnica je svoju pjesmu naslovio riječima Non omnis, nepotpunim početkom šestoga Horacijeva stiha. ${ }^{110} \mathrm{U}$ njegovome „Ne sav..." ne spominju se književno djelo, ponos, slava ni neumrla domovina. Taj se pjesnik pita hoće li ikoje njegovo ćućenje trajati poslije smrti. Jedino što očekuje su nijeme klice i blijedi odraz u gluhoj praznini... Uz pretpostavku da je čitatelj u naslovu prepoznao Horacijeve riječi, da zna što je on bio napisao i da je asocirao njegovu viziju pjesnikova prežitka prije uranjanja u Desničinu, njihov će golemi kontrast iznimno pojačati poetski učinak Desničine.

Veza između riječi o smrti i tvari uspostavlja se na nadgrobnim spomenicima. Kameni su nadgrobni spomenici tipična stavka u baštini iz antičkog doba. Brojni su stajali na nekropolama uz ceste pred gradskim vratima. Izlaze na svjetlo dana i bez arheoloških istraživanja, zemljoradnjom ili gradnjom, a vide se i uzidani u građevine na mjestu nekadašnjih grčkih i rimskih naselja. Takva je situacija i u Hrvatskoj, osobito u dva grada gdje je Desnica duže živio, u Zadru i Splitu. Spomenici su, naravno, dostupni i u muzejskim zbirkama. U pjesmi „Madrigal“ krije se nadgrobni spomenik s epitafom kakav je smišljen u antici, postao je općim mjestom i proširio se u pogansko rimsko doba, a ostao je u uporabi i kroz stoljeća kršćanstva sve do danas. Pokojnik se obraća prolazniku - putniku, u Desničinoj verziji u stihovima 21-26 i 39-41:

\footnotetext{
107 Usp. V. Desnica, Zimsko ljetovanje. Pripovijesti, 321-322.

108 Horacije, uz Vergilija i Ovidija suvremenik i svjedok preobrazbe rimske republike u carstvo. Sva su trojica vrhunskih pjesnika svojim djelima sudjelovala u promicanju Augustove vladavine. Usp. Horat. Carm. III, 30, 1-9. U prijevodu BKM: „Podigao sam spomenik trajniji od mjedi, / viši od kraljevskih piramida, / koji neće moći razoriti jetkava kiša, / niti siloviti vjetar ili slijed / bezbrojnih godina i vrijeme što teče. / Neću umrijeti sav i mnogi će dio mene / izbjeći Libitinu. Rast će mi slava, uvijek / nova, dok se god bude pontifik / uspinjao na Kapitolij uz šutljivu djevu. (...)“

109 Prvi stih, „Exegi monumentum aere perennius“, upravo se zlorabi, a početak šestoga, „Non omnis moriar“, donekle je zaštićen sumornijim sadržajem. Usp. Z. Doroghy, Blago latinskog jezika, 111 i 235.

110 U 2. svesku Sabranih djela (V. Desnica, Zimsko ljetovanje. Pjesme. Ljestve Jakovljeve, 254) nema nikakve naznake da je naslov dio neke sintaktičke cjeline. Očekivale bi se točkice iza omnis. U priloženom „Tumaču stranih i manje poznatih riječi i dijalektalizama“ (Isto, 335-342) dodan je predikat moriar, cjelina je prevedena i ugrubo protumačena, Horacije je identificiran imenom, bez ikakva biografskog podatka. Nema u struci obvezatne odrednice citata naslovom djela, brojem knjige, pjesme i stiha, a opširnijoj informaciji o kontekstu u takvom pomagalu ne bi ni bilo mjesto.
} 
(...) Ja se sjetih

neke rimske grobne ploče

gdje putniku mrtvi piše:

"Pamti, prolazniče! I ti

ovakav ćeš nekad biti,

al'ja takav - nikad više!«

(...)

"Nekad i ja takav bijah,

i ti ćeš ovakav biti,

al ja [sic!] takav - nikad više! «111

U prvoj se kitici najprije spominje buduće stanje putnika-namjernika, na kraju druge najprije nekadašnje pokojnikovo stanje, a na oba mjesta poanta je da iz toga stanja nema povratka. Minimalistički oblik takva klasičnog epitafa glasi: FVI QVOD ES / ERIS QVOD SVM, tj. „Bio sam što si, / bit ćeš što sam“. ${ }^{112}$ Epitaf je toliko čest da se, do eventualne referencije u autorovoj ostavštini na konkretan spomenik, ovo mora smatrati pozivom na topos antičkoga postanka. S druge strane, prizor rimske grobne ploče, što god na njoj bilo, najvjerojatnije doista dolazi iz sjećanja na antičku baštinu pjesnikova zavičaja. ${ }^{113}$

Od svih ostataka koji svjedoče o drevnom kultu mrtvih, a mogli bi se vidjeti u okolici Zadra, najveću je ulogu dobila kamena žara u Zimskom ljetovanju. ${ }^{114}$ Kružne i četvrtaste urne i sarkofazi, kameni recipijenti u kojima su nekoć počivali ostatci antičkih pokojnika, na cijelom se Sredozemlju mogu naći u funkciji gospodarstva kasnijih vjekova, kao kamenice za ulje, korita na pojilima i dr. Sam je Desnica mnogo puta svjedočio da se u Zimskom ljetovanju držao zadarske urbane i okolne ruralne stvarnosti. ${ }^{115}$ Žaru je uveo u radnju rukopisom zadarskoga istraživača koji je stručnim terminom urna cineraria zabilježio da se nalazi u Smiljevcima, kod kuća Pozder. U naravi je zatim zadarski poznavatelj starina ${ }^{116} \mathrm{i}$ talijanski federale nalaze u Smiljevcima, u dvoru Ićana Brnosa, sadašnjega vlasnika nekoć Pozderove kuće, „u samom uglu, pod murvaćem“. Tu u nju „sipaju prasetu“, istom onom Migudu koji će tragedijom dokrajčiti zimsko ljetovanje zadarskih izbjeglica. Ićan i majka uznemireni su - potječe li žara s obližnje gradine, kako rekoše pridošlice, mogli bi ih op-

111 Isto, 221-222.

112 Ili obrnutim redoslijedom Eris quod sum. Fui quod es. Postoje verzije u množini, s više riječi: Quod sumus, hoc eritis. Fuimus quandoque, quod estis. Inverznim slijedom: Quod fuimus, estis; quod sumus, eritis. itd. Usp. Z. Doroghy, Blago latinskog jezika, 499.

113 Pjesnik je takav epitaf mogao vidjeti i izvan zavičaja i na spomenicima iz kasnijih razdoblja. Ipak, budući da se poziva na svoje sjećanje i na rimsko doba, vrlo bismo to rado potkrijepili primjerom epitafa koji je nađen na području današnje Republike Hrvatske ili nekadašnjih rimskih pokrajina Panonije, Dalmacije i istarskoga dijela Desete italske regije - naravno, bez pretenzija da smo naišli baš na spomenik iz pjesme. U pretraživanju mrežnih natpisnih baza pomogli su doc. dr. Jelena Marohnić i doc. dr. Dino Demicheli. Usprkos uvjerenju da takav epitaf postoji na našim antičkim spomenicima (koje dijelimo), geografski su najbliže potvrde zasada našli samo u susjedstvu, po jednu u provinciji Meziji (EDCS-10000578), Šestoj regiji Italije (EDCS-23200545) i u venetskom dijelu Desete italske regije (EDCS-01500354). Zahvaljujem im na pomoći.

114 Pripovijest o žari započinje u XIV. poglavlju, a završava na kraju XV. Usp. V. DesnicA, Zimsko ljetovanje. Pripovijesti, 93-104.

115 Isti, Hotimično iskustvo. Knjiga druga, 137, 139 i 143-146.

116 V. tekst uz bilj. 89-92. 
tužiti da su je odande otuđili. Stoga se jedno za drugim zaklinju da je urna ondje bila i za dvojice prethodnih vlasnika kuće, što je njima sinonim duboke prošlosti („otkad je svijeta i vijeka").

Do ovdje je povijest urne posve u skladu s čestim kurikulom antičkih grobnih spomenika oko Sredozemlja: ne samo što se stoljećima koriste u razne praktične svrhe, nego zbog toga vlada stalna napetost između korisnika $\mathrm{i}$ istraživača, da ne spominjemo pripadnike razmjerno nove službe za zaštitu spomenika. Epizoda s urnom ipak nije u romanu samo zato što odražava opću regionalnu stvarnost, već i njezino posebno, kratko izobličenje. Zbivala se dok su Smiljevci bili pod talijanskom vlašću. Unna je od inventara seoskog dvorišta prerasla u bitan dio fašističkog spomenika koji je oblikovan kao rimska stela. Kad je pak talijanska vlast propala, spomenik je prepušten propadanju, a urna vraćena na raspolaganje Migudu. ${ }^{117}$

Talijanske su vlasti antičku baštinu prisvojenih područja smatrale dokazom rimstva, a time i talijanstva. Bile su sklone njome podupirati svoje pretenzije na prekojadranske teritorije. Desnica je svoje okupacijske likove naveo da u nerazumijevanju domaće situacije izaberu posve nedostojnog Smiljevčanina za paradigmu heroja, a onda još i da mu sačine spomenik od krmkova pojila. Iz toga sijeva oštrica britke mediteranske poruge. No skloni smo vidjeti još jednu razinu, izvan ratnoga konteksta.

Kamenom posudom u kojoj su u nekoć bili brižno pohranjeni ostatci pokojnika Ićanovi se koriste bez ikakva obzira prema njezinoj prvoj funkciji. To jest svojstveno mediteranskom okruženju. No, povrh toga, na kraju Zimskog ljetovanja pokazuje se da je „pod murvaćem“ nešto što pisac naziva "gromilom“, oba puta pod navodnicima. ${ }^{118}$ Upotrijebio je domaći naziv za kružnu gomilu kamena koja je često vidljivi ostatak drevnoga grobnog humka. To je pak mjesto gdje je stajala kamenica, po Ićanovu i majčinu svjedočanstvu oduvijek, pa je lako moguće da je i pripadala grobu. „Gromila“ je naznaka da kuća Ićanova, prije toga Pozderova, prije toga popa Adama, leži na tisućljećima prošlosti toga kraja. Njezini vlasnici imaju u vlastitome dvorištu nečiji grob. Kamenicu su in situ upotrijebili za pojilo svojega prasca, a gromila je - ujedno - i mjesto za vlasnikovo večernje mokrenje... S urbane strane ove pripovijesti stoje osoba koja je identificirala i pribilježila urnu, osoba koja je pozorno pročitala rukopis i zapamtila podatak te skupina osoba koja je pošla na izlet na gradinu, „rimski Brebentij“, s kojim je urna povezana. Cijela epizoda s kamenicom ima značajan udio u suprotstavljanju grada i sela kao i u podcrtavanju bijednih životnih uvjeta i neukosti seljana.

Pripovijest Posjeta $^{119}$ nadahnuta je, prema vlastitim autorovim riječima, promatranjem „jednog starog, oronulog, seniliziranog intelektualca“. ${ }^{120}$ Nekoć umna i po tome ugledna osoba, starac na pragu smrti ne pokazuje više nikakve duševne sposobnosti. Promatrač neko vrijeme dvoji je li ih zaista izgubio ili ih ne može pokazati jer ga sprečava tijelo: nepo-

\footnotetext{
$\overline{117}$ „- ... I tad -završio je Ićan priču - uzmem ja opet onu kamenicu i postavim je na staro mjesto, tamo pred Miguda, gdje i sad stoji, i gdje je stajala otkad je svijeta i vijeka, (...)." Usp. V. Desnica, Zimsko ljetovanje. Pripovijesti, 104.

118 Isto, 173-174.

119 Isti, Fratar sa zelenom bradom, 18-32. Usp. i Isti, Olupine na suncu. Pravda i druge pripovijetke, Varaždin 2005., 11-24.; Isti, Pripovijetke (= Sabrana djela Vladana Desnice, knj. III), Zagreb 1974., 5-17.

${ }^{120}$ Isti, Hotimično iskustvo. Knjiga druga, 139.
} 
kretan je, nemoćan, gluh, komunicira neartikuliranim zvukovima, a glas mu se „utanjio, postao jedva čujan i piskutliivo mu je cvilio u grlu kao strujica zraka u Memnosovu kipu“. ${ }^{121}$

Slikar Ivan u Posjeti ima pred sobom nesretnika kojega je poznavao samo po čuvenju, no Ivan Galeb u Proljećima opisuje autopsiju istoga bijednog stanja prisno poznatih:

Izlaze mi pred oči agonije bliskih osoba. Još kuca, i dosta punano, arterija pod koljenom. Mišić srca još se besmisleno steže i rasteže, po snazi navike. U pluća i iz pluća još struji tračak zraka, mehanički i bestrasno, kao u Memnosov kip. (...) ${ }^{122}$

Obojici promatrača povremeno se čini da su nazreli neki znak konvencionalnog razuma $\mathrm{u}$ dvojice patnika preko čijih likova pisac u dvije različite proze istom asocijacijom priziva istu čudovišnu kombinaciju, neživu tvar koja se sama od sebe glasa. U bolje opremljenim uspoređenim izdanjima ${ }^{123}$ priređivači su nastojali protumačiti egipatski dio ove referencije. Približno su naveli gdje se nalaze dva golema kipa faraona Amenofisa (Amenhotepa) III. i kad su podignuta, koji se od njih, zašto i kada glasao i kad je prestao. ${ }^{124}$ Grčki su dio zanemarili, izuzevši trud da bar kao alternativan navedu jedini ispravan oblik Memnonova imena. ${ }^{125}$ Spomenuli su da su Grci kipovima nadjenuli ime junaka iz Trojanskog rata, no nisu iznijeli ništa o Memnonovoj sudbini. Težište Desničine referencije je, naravno, u njoj. Pripovijest o Memnonu sazdana je od nemirenja sa smrću, od nastojanja da joj smrtnik izmakne i od čudovišnih ishoda toga nastojanja. Za početak, Memnon je sin božice Zore i lijepoga smrtnika Titona. Božica se toliko zaljubila da je od Zeusa izmolila besmrtnost za svojega dragana, ali je zaboravila moliti i vječnu mladost. Rezultat: Titon je ostario i podlegao svim staračkim tegobama, a nije mogao umrijeti. U takvu je stanju dotužio Zori te je naposljetku pretvoren u cvrčka. Sin toga nejednakog para, etiopski kralj Memnon, došao je u pomoć Trojancima. Iznimno je lijep, mudar, smjeran prema starijima, savršen vojvoda

$\overline{121}$ Isti, Fratar sa zelenom bradom, 20.

122 Vrijedi pogledati cijeli odlomak. Naime, ono što se u tom tijelu događa netom prije smrti i u svemiru nakon preminuća uvelike podsjeća na pjesmu Non omnis, kojom smo se bavili zbog Horacija. Usp. Isti, Proljeća Ivana Galeba (1975.), 328-329.

123 Isti, Izbor pripovijedaka, 37 i Isti, Zimsko ljetovanje. Pripovijesti, 273 (bilješka sub calce); Isti, Olupine na suncu, 13 (bilješka na margini).

124 Točnije, preuzeli su, bez citata, jedno mišljenje o tome. Najstarije osobno svjedočenje o zvukovnom fenomenu sačuvano je iz pera geografa i povjesničara Strabona, koji je u Egiptu boravio 20. pr. Kr. (Strab. XVII, 46), pa odatle pretpostavka - koju su prenijeli - da su Memnonovo ime s faraonskim kipovima povezali tek aleksandrijski Grci. Međutim, kompleks Amenhotepova grobnog hrama pred čijim su ulazom stajala dva golema kipa faraona na prijestolju nalazio se u tebanskoj nekropoli od njegove vladavine u 14. st. pr. Kr. Grci su u nilskoj delti nastanjeni od 8. ili 7. st. pr. Kr. Odisej spominje Memnona (Odyss. XI, 522), a u oba homerska spjeva egipatska je Teba pojam sjajnog i bogatog grada (Il. IX, 381 - 384; Odyss. IV, 126 - 127). Memnonova je sudbina opisana u kikličkim epovima koji se datiraju između 8. i 5. st. pr. Kr. Među njima se zaseban spjev, Etiopida, bavio upravo onim dijelom Trojanskog rata nakon Hektorova pogreba (tj. završetka Ilijade) u kojemu je Memnon sudjelovao i poginuo. Što je ondje pisalo, saznaje se, doduše, preko kasnih prepjeva i preradbi, ali posve sigurno nije trebalo čekati helenističko vrijeme da bi se u Grčkoj znalo za goleme kipove u Egiptu, a njihovo glasanje nije tek posljedica oštećenja u potresu 27. pr. Kr. No to ovdje ne možemo podrobnije elaborirati.

125 U grčkome izvorniku bilježi se samo jedan oblik Memnonova imena, nom. Mémnōn, gen. Mémnonos. Latinizirani je oblik u skladu s time: n. Memnon, g. Memnonis. Sigmatski nominativni oblik ne postoji. Jedina je moguća kroatizacija Memnon. Lektor je vlastan ispraviti oblik „Memnos“, jer to nije stvar stila i jezika, već - ne pokažu li izvorni rukopisi što drugo - autorova zabluda. Dobro bi se uklopila u gore spomenute nedaće s prilagodbom aloglotskih izraza (usp. bilj. 10). Tipična je za osobe koje znaju da su imenice muškoga roda s nominativom na -os česte u grčkom, baš kao i ekvivalentne na -us u latinskome. Stoga će muško ime ili imenicu koja označava mušku osobu, a nisu sigurni kako zapravo glasi, pokušati oblikovati prema toj paradigmi. 
i borac. Među bogovima se znalo da mu je suđeno poginuti pa je Zora bila spremna zbrinuti sinovo tijelo, a ishodila mu je trajnu čudesnu počast na grobu. ${ }^{126}$ Prema najoptimističkijem završetku mita, uspjela je i da joj sin u podzemnom svijetu obitava među blaženim pokojnicima. Znatno je mračniji ishod da postoji njegov kip koji se svake zore glasa kad se majka ukaže na obzoru, a Zora na to plače. ${ }^{127}$ To se pak može razumjeti kao da je neki dio Memnona živ zatočen u kamenu ili kao da Memnon s onoga svijeta komunicira s ovim. ${ }^{128}$ Mitski udes grčkih junaka, sina Memnona i oca Titona zajedno, odgoneta zašto se Vladan Desnica poziva na egipatski kip kad opisuje stvarne zarobljenike propalih tijela.

Homerski lik koji je uspješno svladao sve prepreke, zašao u podzemni svijet i sretno se vratio, zatro neprijatelje i iznova zadobio obitelj i kraljevstvo - Odisej/Uliks - postaje u pripovijesti Delta sinonimom za potencijalnog pokojnika čiji je mogući prežitak za obitelj i udovicu veći problem nego što bi bila sigurna smrt. ${ }^{129}$ Prema Odiseji, u podzemnom je svijetu imao priliku susresti samo sjene ljudskih bića. Vergilije ${ }^{130}$ je prema slavnome predlošku otpravio po proročanstvo u podzemni svijet i glavnoga junaka Eneide, ali je preda nj doveo strašnoga lađara mrtvih Harona i agresivne sjene pokojnih čudovišta.

U svim vrstama Desničine proze ističu se stalnim pojavljivanjem i nestandardnim oblikom imenica „šimera“ i pridjev „šimerični“. ${ }^{131}$ Upotrebljava ih naoko samo s danas uobičajenim značenjem (nerealne) zamisli koja zaokuplja duh i progoni čovjeka sve do granice ludila. ${ }^{132}$ Imenica i pridjev doista nikada nisu otisnuti $s$ velikim početnim slovom. Najčešće ih rabi u Proljećima Ivana Galeba, u ozračju neprekidnoga promišljanja o smrti. ${ }^{133}$ Poznavatelj antičkih starina asocirat će u tom kontekstu i biće iz grčke mitologije, pogubno

126 Kanonska je verzija da je sama odnijela tijelo s bojišta ili da je poslala druge svoje sinove, bogove vjetra, da ga odnesu. Zatim mu je priređen normalan pogreb, tj. sa svim je počastima spaljen na lomači. O Memnonovu grobu i o pticama koje mu ondje vječno priređuju bojne igre v. Jelena Marohnić, „Diomedove ptice“, Vjesnik za arheologiju i povijest dalmatinsku, 103/2010., 49-51.

127 Srž je oba mita etiološka: Titonovo je ime za grčke uši bilo onomatopeja cvrčkovog glasanja, a Zorine su suze rosa.

${ }^{128} \mathrm{Na}$ takvo shvaćanje u kontekstu Desničina opusa upućuje on sam, pozivajući se na Memnonov stup/kip i u kritici izvedbe Vojnovićeva Sutona: „Već je u tradicijama izvedaba Trilogije da se od Saba - koji je jedan gosparski »rebambit« i ništa više - prvi neka astralna sablast, potpuno dehumanizirana pojava pepeljastog lica čiji tračak glasa poput glasa iz Memnosova stupa dopire kao s nekog drugog svijeta." V. Desnica, Hotimično iskustvo. Knjiga druga, 285.

129 Isti, Fratar sa zelenom bradom, 298. Pripovijest je kao LVI. poglavlje uključena u Proljeća Ivana Galeba pa se i tamo može čitati citirano mjesto: „Familija je iščekivala sa zebnjom. Jer tužno je to imati negdje u svijetu neizvjesnog mrtvaca. Neki osjećaj nesigurnosti, neko vječito čekanje na Uliksov povratak, koje svojom stalnom, iscrpljujućom napetošću počinje sličiti na strahovanje od tog povratka; a to strahovanje opet rađa nejasno osjećanje krivnje." IsTI, Proljeća Ivana Galeba (1977.), 266-267. Usp. i Isti, „Delta“, u: Branimir DonAt - Igor Zidić, Antologija hrvatske fantastične proze i slikarstva, Zagreb 1975., 307-312.

130 Usp. bilj. 69.

131 U standardnom obliku zapravo samo jedanput - „himerična, beciljna i intenzivna sanjarenja“. V. DESNICA, Hotimično iskustvo. Knjiga prva, 15.

132 Priručni rječnici uspoređenih izdanja ponekad ih ignoriraju ili ostaju samo pri tome tumačenju. Usp. npr. „šimera (himera) (grč.) - neostvariva zamisao, fantazija“ (Isti, Zimsko ljetovanje. Pripovijesti, 257) i „šimera, himera (grč.) ovdje: nestvarna zamisao, mašta, tlapnja, priviđenje“ (Isto, 329). U priručni rječnik toga izdanja riječ nije uključena. Usp. Bratoljub KLAIć, „Rječnik“, u: Isto, 367-374.

133 Ukupno deset puta. Ivan Galeb kazuje o smiješku na licima patnika (V. Desnica, Proljeća Ivana Galeba [1975.], 16), o salonu oslikanoga stropa u djedovoj kući $($ Isto, 34), o sveopćoj akciji protiv smrti („Kakav će biti i u čemu će se sastojati taj napor, iz kakvih će tamnih dubina našeg bića šiknuti ta nova šimera, iz kakvog će mraka našeg staničja pokuljati ta stihija i u kakvoj će se novoj opsjeni ona ovaplotiti, to ne može da se sagleda. Ali životnost te šimere ležat će u mračnim snagama našeg najprisnijeg bića, njena realnost u realnosti čovjekove strasne patnje, u vrelini njegove samoobmane, u neumitnosti njegove propete težnje prema životu. Ona će crspti svoje sokove i svoju istinitost odatle što će, kao i sve druge, ranije čovjekove šimere, kao i sva čovjekova božanstva, biti sazdana od krvi i mesa, od bunila i od stradanja onih koji je u sebi nose i koji joj služe.“ Isto, 74), o vjerovanjima (Isto, 82), o otuđivanju vlasti od naroda („Čovjek nosi u sebi nekakve svoje ideje, zanose, težnje, stremljenja, šimere. Ali kad se ideje 'ovaplote', kad se šimere 'konkretiziraju', kad se težnje i stremljenja 'odjelotvore', tad započinje jad.“'Isto, 235) i o bijegu iz shematiziranog življenja (Isto, 269). 


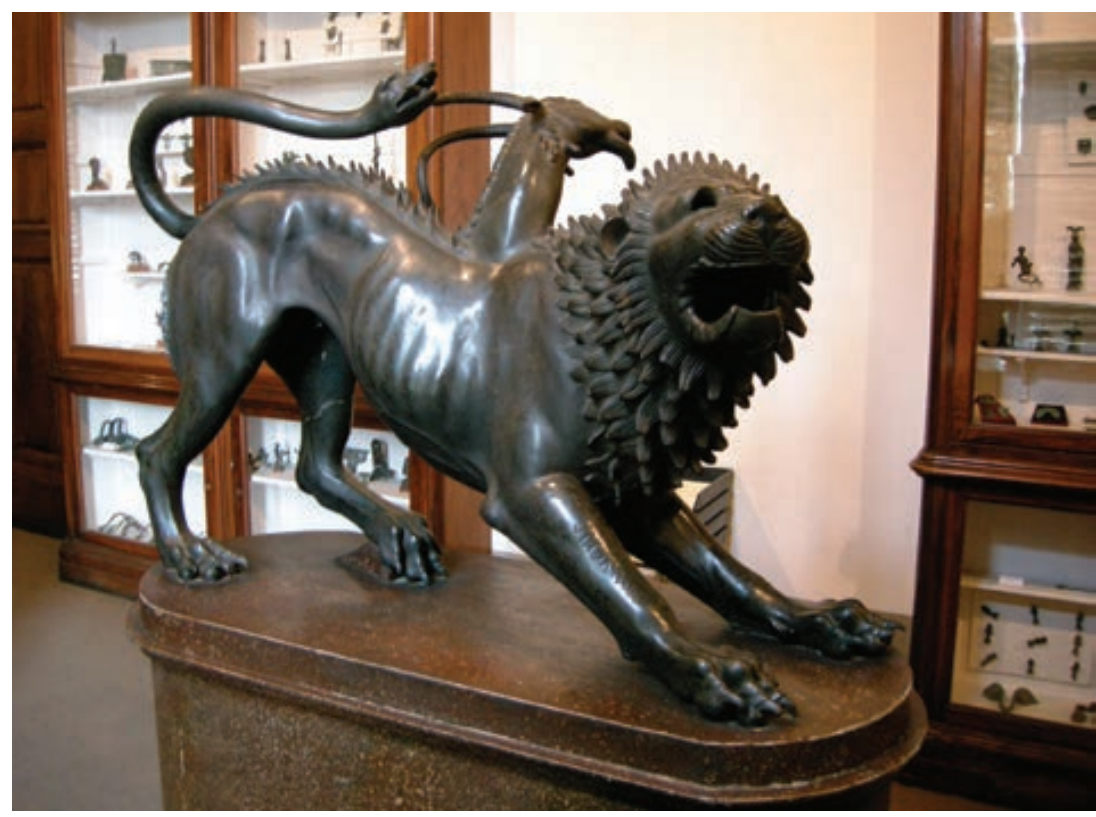

Sl. 4. Himera iz Arezza, bronca, lijevanje à cire perdue (5. - 4. st. pr. Kr., etruščanska umjetnost), Firenze, Museo archeologico nazionale

čudovište Himeru. Unuka Geje i Tartara, kći diva Tifona i zmije Ehidne, harala je stadima i rigala vatru uništavajući okoliš, tako da je Argolidi prijetila glad. Usmrtio ju je junak Belerofont te kao opasna sjena živi u podzemnom svijetu među sjenama drugih čudovišta. Kompozitna neman (kombinacija koze, lava i zmije) najpoznatija je u obliku koji su joj dali etruščanski brončari. Oštećeni kip nađen je 1553. godine kod Arezza u ne baš posve jasnim okolnostima, a prvi ga je restaurirao Benventuo Cellini za Cosima I. Medicija. ${ }^{134}$ Danas je jedan od bisera arheološkog muzeja u Firenzi. U odlomku iz XIX. poglavlja Proljeća Ivana Galeba šimerom postaje sama zamisao o borbi protiv smrti, utjelovljuje se i opisana je nizom riječi koje pristaju bićima (šiknuti, staničje, pokuljati, propet, sokovi, sazdan od krvi i mesa $)^{135}$ i upravo prizivaju Himeru. ${ }^{136}$

Vergilijev opis podzemnoga svijeta u Eneidi iznimno je utjecajan u umjetnosti, dijelom i preko Dantea, kojemu je bio nadahnućem. Eneju vodi proročica Sibila, koja ga, uostalom, sprečava da se mačem baci na sjene Himere i drugih pokojnih, ali vrlo živahnih čudovišta koja na nj pište i sikću vatru:

Mnogo čudovište ovdje i neman se nakazna krije, dvolike skile uz vrata i pleme kentaursko divlje, storuki tu je Brijarej i siktava lernejska Hidra, ognjena tu je Himera i Harpije još i Gorgone,

$\overline{134}$ Usp. Benvenuto Cellini, Moj život, Zagreb 2002., 434-435.

135 Isto.

136 U skladu s time, u opremi uspoređenih izdanja Proljeća Ivana Galeba pojavljuju se i potpunija i uz Desničin tekst funkcionalna tumačenja, koja uključuju mitološki dio objašnjenja. Usp. npr. neautorizirani priručni rječnik u V. DEsnica, Proljeća Ivana Galeba (1990.), 369 i Dubravko Jelčıć, „Rječnik“, u: Vladan Desnica, Proljeća Ivana Galeba (1977.), 348. 
tu je i ona strahota što imaše do tri života.

Ustrašen gleda Eneja i ruka mu mača se laća, te bi čudovište svako savladao željezom lako, i da provodilja mudra ne reče da to su tek sjene, slike bestjelesnih bića, u kojima neima žića, on bi pojurio tamo i sjekao utvare samo. ${ }^{137}$

Nemani su predstraža. Probivši se kroz nju, tek nekoliko stihova dalje, Eneja će doći do neugodnog starca Harona koji prevozi duše pokojnika preko rijeke Aheronta:

Evo i Harona groznog, vozara i vodi čuvara, halja mu gnusna je tralja, i sijeda ga obrasla brada, čupava, kuštrava, gusta; a očima vatrenim gleda, plašt mu se prljavi klati što u čvor ga sapeo sprijeda. Motkom otiskuje lađu i plovidbom upravlja njenom, duše preminulih vozi u čunu od rđe crvenom, star je, no bogu su sile i u starost krepke i čile. ${ }^{138}$

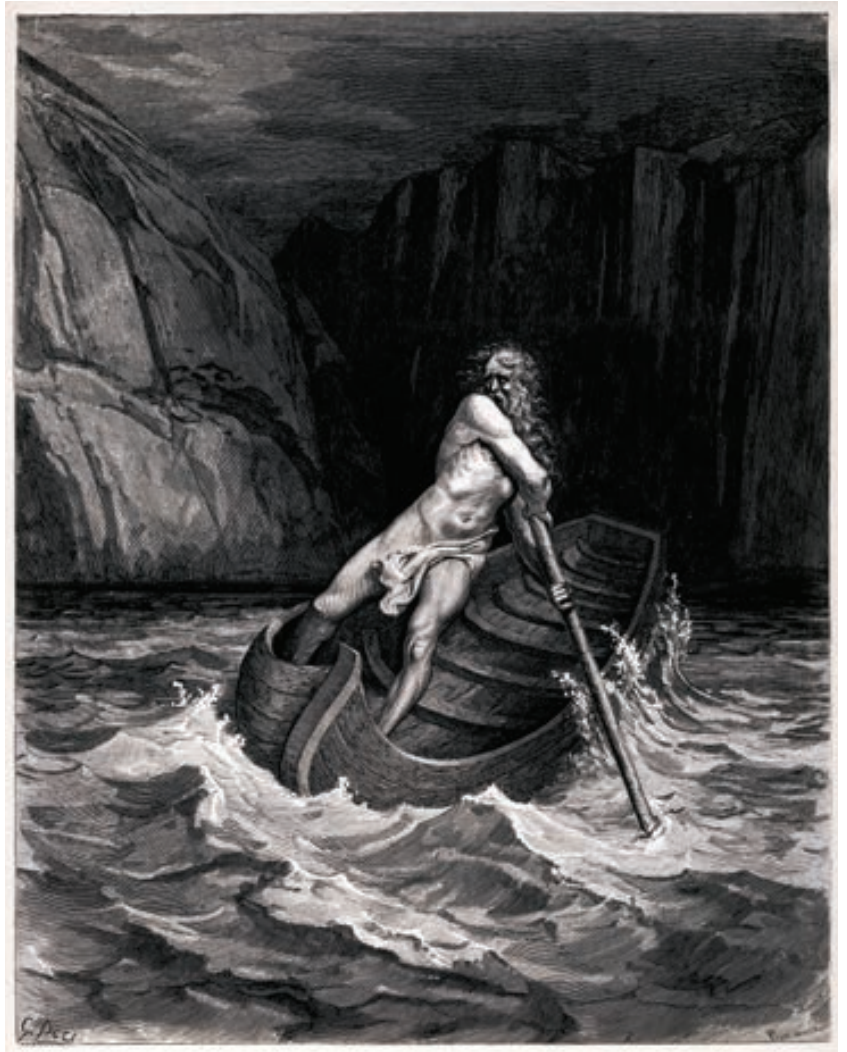

Sl. 5. Paul Gustave Doré, Haron, drvorez (1857.)

137 Verg. Aen. VI, 280-294 = Publije Vergilije Maron, Eneida (prev. i koment. Bratoljub Klaić), Zagreb $1970 ., 149$. Usp. stariju verziju prijevoda T. Maretića, Verg. Aen. VI, 285-294 = Djela P. Vergila Marona, Zagreb 1932., $241-242$.

138 Verg. Aen. VI, 298-304 = Vergilije, Eneida, 149-150; u Maretićevoj verziji Verg. Aen. 298-304 = Djela Publija Vergila Marona, 241. 
Glasovitu zloslutnu pojavu s motkom prikazivali su brojni likovni umjetnici ilustrirajući treće pjevanje Danteove Božanske komedije, gdje se Haron ukazuje na rijeci Aherontu pred Danteom i Vergilijem. ${ }^{139}$ U Eneidi se Vergilije bio usredotočio na Haronovu pojavu, dok je Danteu bilo važnije što Haron govori i čini. Često reproducirana grafika Gustavea Doréa (Sl. 5.) više odgovara stihovima starijeg pjesnika. Mirko Rački ilustrirao je Božansku komediju i u više je navrata slikao prizore s Haronom ${ }^{140}$ izravno nadahnute Danteovim Paklom.

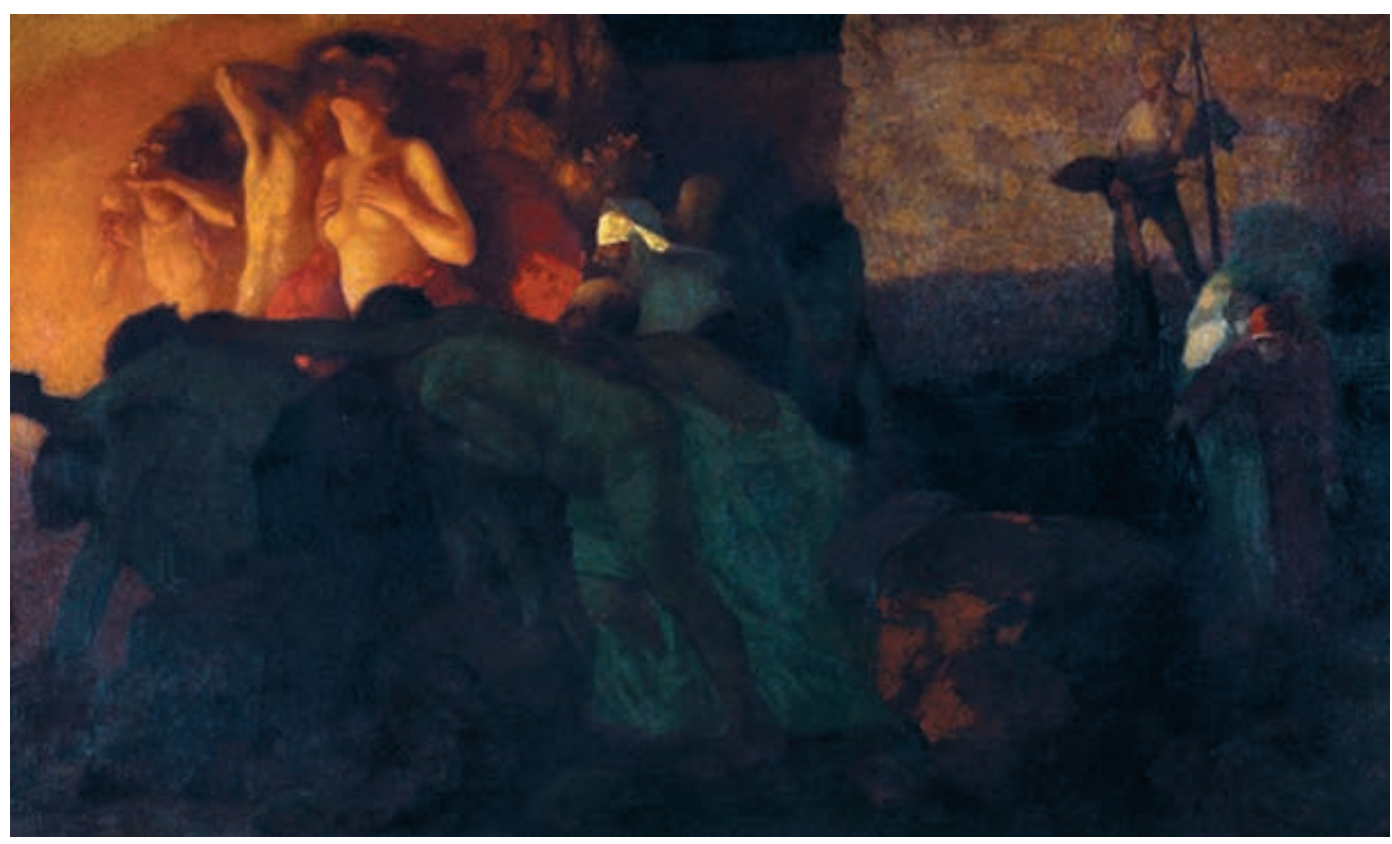

Sl. 6. Mirko Rački, Prijelaz preko Aheronta, ulje na platnu (1910.), Muzej za umjetnost i obrt, Zagreb

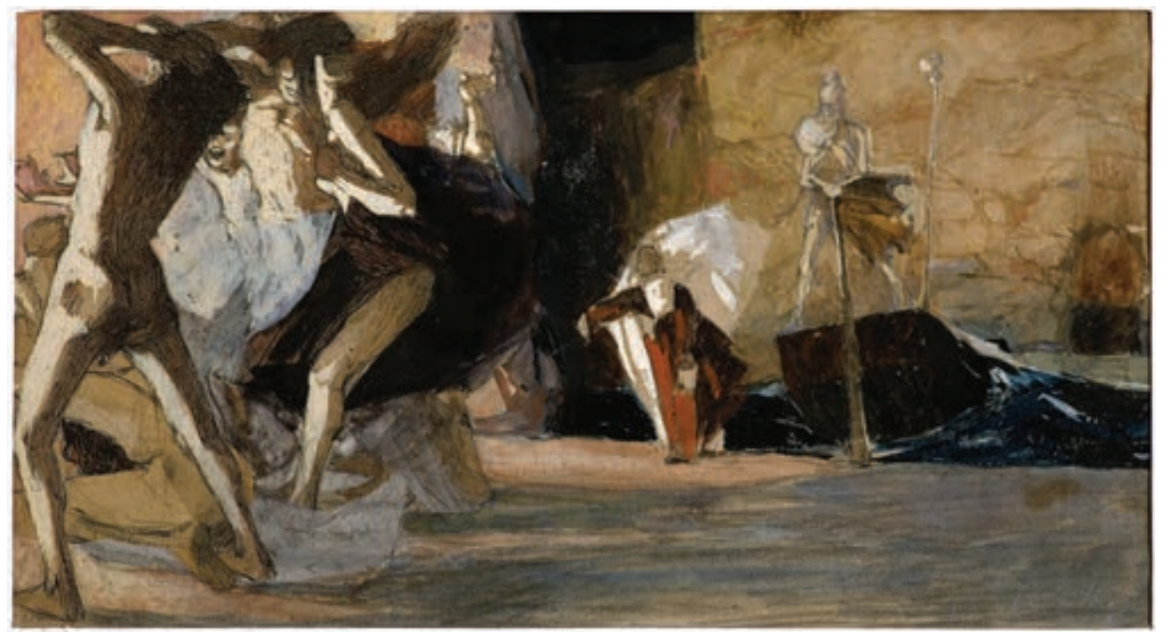

Sl. 7. Mirko Rački, S onu stranu Aheronta, tuš i akvarel na papiru (1907.), Galerija umjetnina, Split

139 Dante, Inferno III, 82-84; 97-99; 109-111. Usp. Dante Alighieri, Božanstvena komedija, Zagreb $1976 ., 24$.

140 Najčešće se reproducira ulje na platnu Grad Dis (1906.), koje se čuva u Modernoj galeriji Hrvatske akademije znanosti i umjetnosti u Zagrebu. Osim prijelaza preko Aheronta, Rački je prikazao lađara i pjesnike i na drugoj podzemnoj rijeci, Stigi (ulje na platnu, 1914., Muzej za umjetnost i obrt, Zagreb). Na obje je slike varirao Haronovu ikonografiju. 
Haron se pojavljuje pri početku Zimskog ljetovanja kao posljednji prizor koji će obitelj Doner ponijeti u pamćenju na izlasku iz bombardiranog Zadra. S Haronovom je pojavom Desnica povezao lik svećenika koji kukom nastoji iz mora izvući kolica s poginulim djetetom:

(...) mala gomilica gledala je s obale kako mršav slabunjav popić, nesumnjivo iz Italije (to se vidjelo po šeširu ravna oboda, $s$ vrpčicama koje poput paučine spajaju glavu $s$ obodom), stojeći u lađici, kao Karon, lovi po moru nekakvom kukom leševe žrtava iz pogođenog parobrodića koji je prevozio iz grada u predgrađe Brodaricu. Malo po strani, blijed i potpuno odsutan, stajao je geometar Skurinić. Donerovi saznadoše od posmatrača da mu je žena s nejakim djetetom poginula u parobrodiću. (...) Sad je popić lovkao kukom krov djetinjih kolica koji se bjelasao na dnu. ${ }^{141}$

Stradanje ovoga djeteta i Haronov lik uz njega i poginulu majku - s kojom je gospođa Doner dijelila roditeljska iskustva - najavljuju smrt vlastitoga djeteta Donerovih, nesreću kojom će se zimsko ljetovanje dokončati. Imamo riječ Vladana Desnice da je tijekom bombardiranja Zadra osobno svjedočio strahotama koje je zatim točno opisao u Zimskom ljetovanju. ${ }^{142}$ Stoga smijemo pretpostaviti čak i to da tumačenje popića Haronom nije umjetnikov naknadni izbor, već duboko proživljena asocijacija.

Najizričitija je referencija na antičke tanatičke koncepte u XIX. poglavlju Proljeća Ivana Galeba, prvome od samo dva koja započinju motom u romanu od ukupno sedamdeset tri poglavlja. Dok je drugi moto uglavnom popraćen razjašnjenjem, ${ }^{143}$ nijedan se priređivač

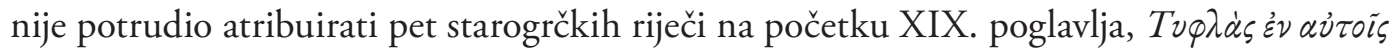
$\varepsilon \dot{\varepsilon} \pi i \delta \alpha \varsigma x \alpha \tau \hat{\omega} \varkappa \iota \sigma \alpha$. Što dalje, to su netočnije otisnute. ${ }^{144} \mathrm{U}$ jednome su izdanju naprosto zamijenjene prijevodom „Slijepe sam nade u njima zakopa““. ${ }^{145}$ On se bio pojavio kao neautorizirana bilješka sub calce uz citat izvornika u izdanju u nizu Pet stoljeća hrvatske književnosti..$^{146}$ Kasniji su ga priređivači nekritički preuzeli. ${ }^{147}$

Prijevod, međutim, niti je točan niti funkcionalan u Desničinu kontekstu. Možda autor i nije uz sam grčki citat naveo odakle je, ali je Ivan Galeb u XIX. poglavlju najprije počeo promišljati o prometejstvu i Prometeju, pod navodnicima je među iluzijama čovjekovim spomenuo „slijepe nade što mu napučuju srce“ i izričito je naveo da je noću u bolnici „prečitavao" Eshilova Okovanog Prometeja. Poglavlje završava citatom od pet redaka:

$\overline{141}$ V. Desnica, Zimsko ljetovanje. Pripovijesti, Zagreb 1968., 57.

142 Isti, Hotimično iskustvo. Knjiga druga, 139.

${ }^{143}$ Drugo je poglavlje XLVI. Moto je referencija na mjesto gdje je umro Lav Nikolajevič Tolstoj. Opširno objašnjenje za nju v. u: Isti, Proljeća Ivana Galeba (1977.), 200. Uz neznatne varijacije u pravopisu i interpunkciji preuzeto je i u: Isti, Odabrana djela, 198 i Isti, Igre proljeća i smrti, 230. U nekim izdanjima može izgledati kao da i XXIV. poglavlje ima moto. Usp. bilj. 60.

144 Bile su potpuno točno otisnute u izdanjima: Isti, Proljeća Ivana Galeba (1975.), 73 i Isti, Proljeća Ivana Galeba (1990.), 73. Prve greške pojavile su se u: Isti, Proljeća Ivana Galeba (1977.) - u posljednjoj riječi slovo kapa dvaput je zamijenjeno slovom hi. Greške su drastično pojačane u izdanju Isti, Igre proljeća i smrti, 93. Preuzeta je pogreška iz izdanja iz 1977. godine (69), omega u posljednjoj riječi izgubilo je potpisano jota, spiritus lenis je na početnim vokalima triju riječi zamijenjen oštrim naglaskom, jota sa zavinutim naglaskom u trećoj riječi pretvoreno je u tau, omikron ispred njega je ispalo.

145 Isti, Odabrana djela, 75.

146 Isti, Proljeća Ivana Galeba (1977.), 69.

147 Isti, Odabrana djela, 75 - gdje stoji umjesto izvornika - i Isti, Igre proljeća i smrti, 93 - gdje je opet bilješka sub calce uz tragično krivo otisnut izvornik. 
Da nisi možda još i dalje drznuo?
Smrtniku uskratih da sagleda svoj kraj.
A kakav li mu lijek za to nade ti?
Njegovu grud napučih slijepim nadama.
O, blagodat si silnu dao čovjeku!... ${ }^{148}$

Citat je u svim izdanjima identičan, uključujući uvlake i tip slova, ali ga nijedan priređivač nije popratio nikakvom napomenom. Predzadnji redak i parafraza Ivana Galeba koju smo gore citirali uvelike se poklapaju. U stvari, završni citat, sadržaj i moto XIX. poglavlja najuže su povezani. Citat je, dakako, iz Eshilova Okovanog Prometeja. ${ }^{149}$ Dio je dijaloga između zborovođe, koji ispituje zašto je Prometej tako okrutno kažnjen, i glavnoga junaka, koji mu odgovara. Četvrti je redak Prometejeva replika, ${ }^{150}$ a ujedno i moto XIX. poglavlja - koji je, dakle, preveden na kraju istoga poglavlja na čijem početku stoji u izvorniku. Jedno je s drugim trebalo povezati. Dok to nije učinjeno, čitatelji uspoređenih izdanja zapravo ne mogu valjano percipirati XIX. poglavlje Proljeća Ivana Galeba, pogotovo ne uz pogrešan prijevod mota koji ne odgovara ni izvornom Eshilovu smislu, ni variranom Desničinu. ${ }^{151}$ Teško je razumjeti kako su ove unutarnje veze uspjele promaknuti priređivačima, ${ }^{152}$ osobito jer je Vladan Desnica perom Ivana Galeba najavio citat kao „najvišu pjesničku (a i ljudsku) riječ koja je ikad rečena“. Na Prometejeve riječi iz ovoga dijaloga i na sadržaj ovoga mota vraća se još dvaput. ${ }^{153}$

Prije tiskanja Proljeća Ivana Galeba prijevod Eshilovih drama na hrvatski jezik objavili su Koloman Rac u Zagrebu, u nakladi Matice hrvatske, ${ }^{154}$ a na srpski Miloš N. Đurić u Beogradu, u nakladi Srpske književne zadruge. ${ }^{155}$ Prijevod u Proljećima Ivana Galeba bit-

\footnotetext{
148 Isti, Proljeća Ivana Galeba (1975.), 77.

149 Aesch. Prom. desm. 247-251 broje li se stihovi kontinuirano, odn. Aesch. Prom. desm. II, 55-59 broje li se u svakome činu od početka.

150 Aesch. Prom. desm. 250, odnosno II, 58.

151 Netko je prevodio ad hoc, ne znajući i ne pitajući što zapravo prevodi i nesvjestan da je blizu vrlo konkretan kontekst, čak i stvaran prijevod. Grčki je znao toliko da je ispravno preveo objekt s atributom („slijepe nade“) i da je ispravno prepoznao prilošku oznaku mjesta, ali ga je upravo to navelo da za predikat loše izabere glagol („zakopati“, a kod Desnice „napučiti“) i u prijevodu i u parafrazi.

152 Iznimka je Stanko Korać, koji je savršeno odredio važnost ovoga poglavlja i citata iz Eshilova Okovanog Prometeja u opusu Vladana Desnice i povezao takav književnikov izbor s njegovom klasičnom izobrazbom. Smatrao je, čak štoviše, da je tim jednim primjerom dovoljno za svoj Predgovor predstavio sve elemente antičke kulture u djelima Vladana Desnice. Ipak, ni on nije izričito povezao moto na grčkome s citiranim stihovima. Usp. S. Korać, „Predgovor", 28-31.
}

153 Usp. V. Desnica, Proljeća Ivana Galeba (1975.), 70 i 276-277.

154 „Zborovođa Da nisi možda dublje kud zabrazdio?

Prometej Smrtniku ne dah da unaprijed vidi smrt.

Zborovoda A kakav li mu nađe lijek za bolju tu?

Prometej U njemu nadu slijepu ti udomih ja.

Zborovoda Blagodat silnu na dar dade čovjeku."

Eshil, „Okovani Prometej“, Eshilove tragedije, Zagreb 1918., 111.

155 „Kolovođa Da nisi negde još i dalje pošao?

Prometej Ne pustih žitku svom da ljudi vide kraj.

Kolovoda A kakva leka tome jadu iznađe?

Prometej Naselih duše njihne slepim nadama.

Kolovoda Obdario si ljude darom velikim.

Eshil, „Vezani Prometej“, Eshil i Sofokle. Odabrane tragedije, Beograd 1926, 15. 
no se razlikuje od oba. Ne možemo nagađati je li odnekud preuzet kakav jest ili je dijelom prilagođen za Proljeća Ivana Galeba - pa možda čak i načinjen za njih - i prema kakvom predlošku. Nešto bi svjetla u to mogli unijeti talijanski prijevodi Eshila iz zagrebačkog dijela obiteljske knjižnice, ${ }^{156}$ a pogotovo inventar knjižnice u Islamu Grčkom - kad bude dostupna. U međuvremenu valja reći nešto o stvarnom značenju izvornika i usporediti rješenja u prijevodima.

Mit o Prometejevim zaslugama za čovječanstvo - kojemu je, uostalom, bio tvorcem doživio je tijekom tisućljeća mnoštvo reinterpretacija u različitim civilizacijskim kontekstima pa se tako i ovi stihovi različito shvaćaju. Valja se vratiti u Atenu u 5. st. pr. Kr. da bi se najprije dokučilo što su iz Eshilovih stihova razumijevali njegovi suvremenici. Za čovjeka, pozemljara, smrt je neupitna i neizbježna. Samo su rijetki povlašteni da ih besmrtnici uzdignu među sebe ili da dospiju na Otoke blaženih. Pokojnikova sjena traje besvjesna u vrlo neveselom podzemnom svijetu (ako je tijelo propisno predano zemlji). Ključan dio dijaloga koji prethodi replici sa „slijepim nadama“ Prometejeva je prethodna replika gdje je infinitiv glagola prodérkomai koji znači „vidjeti unaprijed“. Njegov je direktni objekt u akuzativu imenica móros. Ona najprije znači sudbinu, a tek zatim i smrt (kao dio sudbine). Treba se sjetiti likova iz homerske tradicije i iz velikih atenskih drama obdarenih proročkim darom. Među njima su i Eshilovi junaci, sam Prometej i trojanska kraljevna Kasandra. Sofoklo je više puta izvodio na scenu nepogrešiva proroka Tiresiju. Proricatelji su na teškim mukama jer je sudbina nepromjenljiva. Oni ne mogu spriječiti zlo koje dolazi, iako ga točno poznaju i mogu ga iskazati. Oni koji su tražili savjet oglušuju se, a proroka čak i pogrđuju. Jad onoga koji zna, a nemoćan je, po zborovođinim je riječima bolja/jad/bolest (nósos) koju valja liječiti, pa on pita Prometeja kakav je lijek (fármakon) našao za nju - a ne za samu smrt. Užas koji je doživjela Kasandra i koji očekuje Edipa, Jokastu i Kreonta nije konačan počinak u smrti, već ono što im se događa prije. Eshilova je misao da je Prometej smrtnicima poklonio veliku korist kad im je oduzeo sposobnost da unaprijed vide svoju sudbinu, dakle i životni tijek do smrti, ne samo nju. „Slijepe nade“ koje je Prometej nastanio (nipošto pokopao!) u smrtnicima, da bi u njima trajno živjele, lijek su protiv uvida u cijeli životni put. Pogani se prije širenja soterioloških kultova ne nadaju izbjeći smrt, već živjeti i umrijeti dostojno i sretno. Sljepoća sprečava da unaprijed saznaš da toga neće biti.

Želi li prevoditelj kako-tako odraziti izvorne značajke antičkoga dramskog teksta (pjesništvo, izmjena dugih i kratkih, naglašenih i nenaglašenih slogova u propisanom broju stopa - to jest, stih i metar), u pravilu mora odabrati što će od smisla koji je bio bjelodan

Đurić je dotjerivao prijevod pa se već u sljedećemu izdanju, 1948. godine, drama više ne zove Vezani Prometej, već Okovani Prometej. Tako je i u svim kasnijim izdanjima. Usp. Zlatko ŠEšELJ, Prijevodi klasične grčke i rimske književnosti u knjigama 1800 - 1980, Zagreb 1991., br. 223, 271, 315, 329, 379, 421, 455, 463, 490, 564, 587, 627. Usporedili smo i četvrti reprint posljednjeg izdanja koje Šešelj spominje pa se vide i promjene u prijevodu:

HorovoĐa Da nisi nekud još i dalje pošao?

Prometej Ne pustih da unapred ljudi vide smrt.

HorovoĐA A kakv lek im za tu bolest iznađe?

Prometej Naselih duše njine slepim nadama.

HorovoĐA Obdario si ljude darom velikim.

Eshil, „Okovani Prometej“, Eshil-Sofokle - Euripid. Grčke tragedije, Sarajevo 1988., 41-42.

156 V. bilj. 79 
Eshilovim suvremenicima prenijeti vrlo malim brojem riječi. Zbog toga je u Racovom i Đurićevom prijevodu veza između lijeka i vidovitosti izblijedjela, a današnjem će se čitatelju, nakon stoljeća kršćanstva, svakako činiti da gleda vezu lijek - smrt. Prijevod koji je Vladan Desnica citirao u tekstu ne izaziva takvu zabludu. To bi svakako trebalo značiti da je bio potpuno svjestan značenja u izvorniku. Dvije Prometejeve replike parafrazirao je obrnutim slijedom pod navodnicima u XX. poglavlju s „čovjekom“ kao subjektom koji ne želi vidjeti kraj svojega bitka. $\mathrm{Na}$ „slijepe nade“ vratio se elaborirajući u LV. poglavlju nesposobnost Ivana Galeba da stvarno pojmi vlastitu smrtnost. ${ }^{157}$ To je njegova specifična nadogradnja eshilovskom smislu „slijepih nada“.

Nastojanje čovjeka da se nosi sa sviješću o vlastitoj prolaznosti velika je i stalna tema Desničina stvaralaštva, to je poznato i prema tome je odabrana tema za Desničine susrete 2017. godine. Ovaj prikaz dokazuje da se snažno oslanjao na tanatičke motive iz antičke baštine, na Haronove darove, bilo kao nadahnuće ili kao na sredstvo iskazivanja. Njihov je značenjski kapacitet golem, a on je bez sumnje očekivao će ga čitatelji prepoznavati. Zato je Haronove darove i utkao u svoja djela. Stoga, da bi se njih razumijevalo, valja poznavati i Haronove darove. Nadamo se da smo tome pripomogli.

\section{$\cos$}

\section{Izdanja izvora i literatura ${ }^{158}$}

Mihovil Aвramić, „Novi relijef božanstva Kairos“, Vjesnik za arheologiju i historiju dalmatinsku, 50/1928. - 1929., 1-12.

Aeschyli septem quae supersunt tragoediae (ur. Gilbert Murray), Oxford: Clarendon Press 1955. ${ }^{2}$

Šime Anić - Nikola Klaić - Želimir Domović, Rječnik stranih riječí, Zagreb 1998.

Vladimir AnIĆ - Ivo Goldstein, Rječnik stranih riječi, Zagreb 2009.

Aristotel, $O$ pesničkoj umetnosti, $\mathrm{S}$ originala preveo i objašnjenja u registru imena dodao D-r Miloš

N. Đurić, Beograd: Zavod za izdavanje udžbenika SR Srbije 1966.

Aristotel, O pjesničkom umijeću, Prijevod i objašnjenja Zdeslav Dukat, Zagreb: August Cesarec 1983.

Aristotel, O duši, preveo Milivoj Sironić; Nagovor na filozofju, preveo Darko Novaković. Predgovor i redakcija Branko Bošnjak, Zagreb: Naprijed 1987.

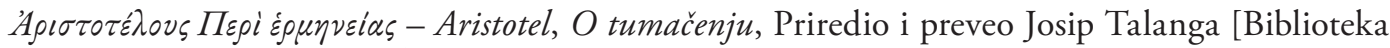
L\&G Knj. XXV], Zagreb: L\&G 1989.

Ivanka BešEvić, „Između muzike i literature. Razgovor s književnikom Vladanom Desnicom“, u: Vladan Desnica, Hotimično iskustvo: diskurzivna proza Vladana Desnice. Knjiga druga (prir. Dušan Marinković), Zagreb 2006., 80-82.

157 V. bilj. 153.

158 Izdanja i prijevodi djela starih pisaca na ovom su popisu navedena u punom obliku, prema ustaljenim pravilima njihova navođenja, dok su u bilješkama radi preglednosti i ujednačenosti odlukom urednika primijenjena pravila citiranja uobičajena za radove objavljene u ovoj zborničkoj seriji (nap. ur.). 
Vitaliano Brunelli, Storia della città di Zara dai tempi più remoti sino al 1409 compilata sulle fonti e integrata da tre capitoli sugli usi e costumi, Trieste 1974.

Nenad Cambi, Antika, Zagreb 2002.

Nenad Cambi, „Kairos“, Radovi Filozofskog fakulteta u Zadru. Razdio društvenih znanosti, sv. 20 (9), 1980. - 1981., 7-14.

Marko CAR, Glasoviti muževi staroga vijeka, Po Rolinu priredio M(arko) C(ar). Sa 10 slika. Tisak i naklada knjižare Lavoslava Hartmana (Kugli i Deutsch): Zagreb s. a.

Benvenuto Cellini, Moj život (prev. Tin Ujević, redakt. Snježana Husić), Zagreb 2002.

Dante Alighieri, Božanstvena komedija, prev. Mihovil Kombol i Mate Maras [Dante Alighieri, Djela sv. II, prir. Frano Čale i Mate Zorić], Zagreb: Sveučilišna naklada Liber i Nakladni zavod Matice hrvatske 1976.

Uroš Desnica - Dušan Marinković, „Popis kućne biblioteke Vladana Desnice“, Hotimično iskustvo: diskurzivna proza Vladana Desnice. Knjiga druga (prir. Dušan Marinković), Zagreb 2006., 251-279.

Vladan Desnica, „Delta“, u: Branimir Donat - Igor Zidić, Antologija hrvatske fantastične proze i slikarstva, Zagreb 1975., 307-312.

Vladan Desnica, Eseji, kritike, pogledi (= Sabrana djela Vladana Desnice, knj. IV), Zagreb 1975.

Vladan Desnica, Fratar sa zelenom bradom, Zagreb 1959.

Vladan Desnica, Hotimično iskustvo: diskurzivna proza Vladana Desnice. Knjiga prva (prir. Dušan Marinković), Zagreb 2005.

Vladan Desnica, Hotimično iskustvo: diskurzivna proza Vladana Desnice. Knjiga druga (prir. Dušan Marinković), Zagreb 2006.

Vladan Desnica, Igre proljeća i smrti (prir. Tonko Maroević), Zagreb 2008.

Vladan Desnica, Izbor pripovijedaka (prir. Dubravko Jelčić), Zagreb 1966.

Vladan Desnica, Odabrana djela, (prir. Krešimir Nemec), Vinkovci 1998.

Vladan Desnica, Olupine na suncu. Pravda i druge pripovijetke (prir. Renata Perković), Varaždin 2005.

Vladan Desnica, Pravda i druge pripovijetke (prir. Ivo Zalar), Zagreb 1997.

Vladan Desnica, Pripovijetke (= Sabrana djela Vladana Desnice, knj. III), Zagreb 1974.

Vladan Desnica, Proljeća Ivana Galeba. Igre proljeća i smrti. Pronalazak Athanatika (Nedovršeni roman) (= Sabrana djela Vladana Desnice, knj. II), Zagreb 1975.

Vladan Desnica, Proljeća Ivana Galeba. Igre proljeća i smrti (prir. Vlatko Pavletić), Zagreb 1977.

Vladan Desnica, Proljeća Ivana Galeba. Igre proljeća i smrti (prir. Stanko Korać), Zagreb 1990.

Vladan Desnica, Pronalazak Athanatika, Zagreb 2006.

Vladan Desnica, Zimsko ljetovanje. Pjesme. Ljestve Jakovljeve (= Sabrana djela Vladana Desnice, knj. I), Zagreb 1974.

Vladan Desnica, Zimsko ljetovanje. Pripovijesti (prir. Vlatko Pavletić), Zagreb 1968.

Mirko Divković - Franjo Petračić - Mato Valjavec - Sebastijan ŽEepić, Latinsko-hrvatski rječnik za škole, Zagreb 1881.

Zvonimir Doroghy, Blago latinskog jezika, Zagreb 1966.

„Okovani Prometej“, Eshilove tragedije, preveo Koloman Rac, Zagreb: MH 1918., 97-145.

„Vezani Prometej“, Eshil i Sofokle, Odabrane tragedije, Sa grčkog preveo Miloš Đurić, Predgovor Veselin Čajkanović [Srpska književna zadruga Kolo XXIX br. 195], Beograd: Štamparija „Ujedinjenje“ A. D. V. Puljević 1926, 3-40.

Eshil, Okovani Prometej, Preveo Bratoljub Klaić, Zagreb: Dramska biblioteka „Scena“ 1965. 
„Okovani Prometej“, Eshil-Sofokle - Euripid, Grčke tragedije, preveo Miloš N. Đurić, Sarajevo: Veselin Masleša 19884, 29-77.

„Okovani Prometej“, Eshil, Sofoklo, Euripid, Sabrane grčke tragedije, Preveli Koloman Rac i Nikola Majnarić, Predgovore napisali Veljko Topalović i Branislav Brkić, Beograd: Vrhunci civilizacije $1989^{2}, 13-27$.

„Okovani Prometej“, Grčke tragedije I: Eshil i Sofoklo, Preveli Koloman Rac i Nikola Majnarić, Ljubljana, Zagreb: Založba Mladinska knjiga 1990, 41-75.

Eshil, Okovani Prometej, Preveo Bratoljub Klaić [Hrvatska kazališna knjižnica, 2. kolo br. 1], Zagreb: Grech 1994.

Eshil, Okovani Prometej, Prijevod Koloman Rac, Zdeslav Dukat, Predgovor Zdeslav Dukat [Lektira dostupna svima 5. kolo, knj. 40], Zagreb: SysPrint 1998.

Dubravko Jelčić, „Rječnik“, u: Vladan DesnicA, Proljeća Ivana Galeba. Igre proljeća i smrti (prir. Vlatko Pavletić), Zagreb 1977., 331-349.

Zlatan Jukić, „Puno ... puno sunca ... Razgovor s umjetnikom Vladanom Desnicom“, u: Vladan Desnica, Hotimično iskustvo: diskurzivna proza Vladana Desnice. Knjiga druga (prir. Dušan Marinković), Zagreb 2006., 89-91.

Šimun JurišIĆ - Ankica ŠunjıĆ, „Korolija, Mirko (Mirko Uroš)“, Hrvatski biografski leksikon, sv. 6, Zagreb 2009., 637-638.

Martin Kaminski, „Car, Marko“, Hrvatski biografski leksikon, sv. 2, Zagreb 1989., 577-578.

Bratoljub Klaić, „Rječnik“, u: Vladan Desnica, Zimsko ljetovanje. Pripovijesti (prir. Vlatko Pavletić), Zagreb 1968., 367-374.

Bratoljub KlaIĆ, Veliki rječnik stranih riječi, izraza i kratica (prir. Željko Klaić), Zagreb 1968.

Stanko Korać, „Predgovor“, u: Vladan Desnica, Zimsko ljetovanje. Pjesme. Ljestve Jakovljeve (= Sabrana djela Vladana Desnice, knj. I), Zagreb 1974., 7-33.

Stanko Korać, „Tematski krugovi i stil romana 'Proljeća Ivana Galeba'“, u: Vladan Desnica, Proljeća Ivana Galeba. Igre proljeća i smrti (prir. Stanko Korać), Zagreb 1990., 375-403.

Josip Kostić - Franjo Maiksner - Franjo Petračić, Gèrčko-hèrvatski rěčnik za škole, Zagreb 1875.

Marko Kovačıć, Grecizmi u suvremenom hrvatskom jeziku, Zagreb 2007.

Charlton T. Lewis - Charles Short, A Latin Dictionary, Oxford 1975.

Henry George Liddell - Robert Scott, A Greek-English Lexicon, Oxford 1968.

Giovanni Lucio, Storia del regno di Dalmazia e di Croazia, Trieste 1983.

Dušan Marinković, „Abecedarij autora“, u: Vladan Desnica, Hotimično iskustvo: diskurzivna proza Vladana Desnice. Knjiga druga (prir. Dušan Marinković), Zagreb 2006., 305-317.

Dušan Marinković, „Biografija Vladana Desnice“, u: Vladan DesnicA, Hotimično iskustvo: diskurzivna proza Vladana Desnice. Knjiga druga (prir. Dušan Marinković), Zagreb 2006., 217250.

Dušan Marinković, „Desničin pojmovnik“, u: Vladan Desnica, Hotimično iskustvo: diskurzivna proza Vladana Desnice. Knjiga druga (prir. Dušan Marinković), Zagreb 2006., 319-398.

Tonko Maroević, „Osunčane strane, sjenovite strune. Pogled na književno djelo Vladana Desnice“, u: Vladan Desnica, Igre proljeća i smrti, Zagreb 2008., 5-23.

Jelena Marohnić, „Diomedove ptice“, Vjesnik za arheologiju i povijest dalmatinsku, 103/2010., 41-61.

Krešimir Nemec, „Pronalazak Athanatika - između utopije i distopije“, u: Vladan Desnica, Pronalazak Athanatika, Zagreb 2006., 81-94. 
Kornelije Nepot, O istaknutim vojskovodama stranih naroda, Preveo i priredio Josip Miklić [Grčki i rimski klasici 3], Zagreb: MH 1999.

Grozdana Olujıć-Lešić, „Pesnik tuge i nade. Razgovor s Vladanom Desnicom“, u: Vladan Desnica, Hotimično iskustvo: diskurzivna proza Vladana Desnice. Knjiga druga (prir. Dušan Marinković), Zagreb 2006., 52-54.

Vlatko Pavletić, nenaslovljeni predgovor, u: Vladan Desnica, Zimsko ljetovanje. Pripovijesti, Zagreb 1968., 7-32.

Vlatko PAvletić, „Svako djelo vrijedi tačno onoliko koliko poetskog sadrži u sebi'“, u: Vladan Desnica, Hotimično iskustvo: diskurzivna proza Vladana Desnice. Knjiga druga (prir. Dušan Marinković), Zagreb 2006., 58-74.

Plutarh, Usporedni životopisi I - III, Prijevod i bilješke Zdeslav Dukat, Zagreb: August Cesarec 1988.

Vladimir Rismondo, Oblici i slova (ur. Branko Bavčević), Split 1979.

Damir SALopeK, Transkripcija i adaptacija grčkih imena, Zagreb 1986.

Otto Seemann, Mythologija Grka i Rimljana, Zagreb 1890.

Stjepan Senc, Grčko-hrvatski rječnik za škole, Zagreb 1910.

Gaj Svetonije Trankvil, Dvanaest rimskih careva, Preveo, uvod i bilješke napisao prof. Stjepan Hosu, Zagreb: „IBI“ poduzeće za izdavanje, prodaju i distribuciju knjiga 1956.

Zlatko ŠEŠELJ, Prijevodi klasične grčke i rimske književnosti u knjigama 1800 - 1980, Zagreb 1991.

Djela Publija Vergila Marona, preveo i protumačio dr. Tomo Maretić [Znanstvena djela za opću naobrazbu knj. X], Zagreb: JAZU 1932.

Publije Vergilije Maron, Eneida, preveo i komentirao Bratoljub Klaić, pogovor prof. dr. Veljko Gortan, Zagreb: MH, Zora 1970.

Milan ŽEpić, Latinsko-hrvatskosrpski rječnik, Zagreb 1961. 


\section{Prilog}

Latinske riječi, izrazi i izreke u diskurzivnoj prozi Vladana Desnice ${ }^{159}$

1. a priori II, 146

2. aberatio ictus II, 196

3. ad hoc II, 115

4. ad hominem I, 386

5. ad usum Delphini, I, 258

6. ad vocem II, 192

7. advocatus diaboli I, 347; DP, 319 s. v. ${ }^{160}$

8. altera natura I, 189, 190; DP, 320 s. v.

9. ambitus I, 147; DP, 320 s. $v$.

10. America capta I, 408

11. amicus Vjekoslav [sc. Kaleb, op. BKM], sed magis amica itd. [sc. veritas, op. BKM] I, 395

12. amor vitae I, 32; DP, 320 s. v.

13. ars longa, vita brevis II, 71 (sub calce tuđe objašnjenje u bilješci)

14. aut-aut I, 117

15. Ave, Caesar! II, 204

16. credo quia absurdum I, 206

17. culpa in eligendo I, 374

18. de quibusdam aliis I, 349

19. deus ex machina I, 258; DP, 326 s. $v$.

20. distantia loci I, 132

21. ergo I, 176

22. ex abundantia I, 211

23. forma mentis I, 202, 348; DP, 336 s. v. registrirana je samo druga referencija

24. formaliter I, 129; DP, 336 s. v.

25. Habent sua sidera libelli! I, 133 (u autorskoj bilješci sub calce)

26. ibis-redibis II, 185

27. ignoramus I, 125; II, 197
28. Ignoramus et ignorabimus! I, 384

29. in actu II, 17, 188

30. in articulo mortis II, 145

31. in medias res I, 129

32. in nuce II, 61 (sub calce tuđe objašnjenje u bilješci)

33. in patrimonio II, 124,222

34. in pectore II, 18, 79, 96

35. in peius I, 189

36. incredibile dictu! I, 43

37. limes I, 180; DP, 353 s. v.

38. loca credibilia I, 129; DP, 353 s. v.

39. memento II, 87

40. mutatis mutandis II, 125,131

41. numerus clausus I, 114, 121; DP, 360 s. v.

42. per antonomasiam I, 94 (u autorskoj bilješci sub calce)

43. per definitionem II, 195

44. prima natura I, 189

45. prius I, 36, 72; II, 168

46. pro bono pacis I, 190

47. rem tene, verba sequentur, I, 94

48. scilicet I, 131, 175; II, 187, 205; DP, 381 s. $v$.

49. sub specie aeternitatis I, 388; usp. i I, 389 i II, 203

50. Tenebrae factae sunt I, 89

51. verba sequentur I, 79

52. via facti II, 245

53. vis comica I, 167; II, 60; DP, 395 s. v. registrirana je samo prva referencija, iako je uz drugu i cijela eksplikativna bilješka sub calce

\footnotetext{
159 Prema izdanju V. Desnica, Hotimično iskustvo. Knjiga prva (dalje: I) i Isti, Hotimično iskustvo. Knjiga druga (dalje: II). Tip slova u ovome popisu ne odgovara tipu slova u tom izdanju. Usp. bilj. 49.

${ }^{160}$ Izrazi s oznakom DP uvršteni su u D. Marinković, „Desničin pojmovnik“. Usp. bilj. 57.
} 


\section{$\cos$}

\section{Charon's goods: Classical motifs in VladAN Desnica's THANATIC REPERTOIRE}

Vladan Desnica's work abounds with various references to classical antiquity and ancient heritage. Upon identifying and cataloguing these references, it becomes clear that Desnica's interpretation of a particular motif can only be fully grasped by viewing the totality of references to it in his short stories, poems or non-fiction (Homer). Desnica's interest in classical antiquity dates back to his childhood, to his family's circle of friends as well as his education. Among the former, Marko Car played an especially important role, having edited a book about notable figures of classical antiquity, aimed at young readers. At school, in turn, Vladan Desnica acquired a substantial knowledge of Latin and Greek grammar, which he used in his fiction and non-fiction alike. In accordance with the classicist curriculum, this is where his first impressions of Homer, Aeschylus, Sophocles, Virgil and others were formed. He demonstrates a command of loanwords originating in Latin and Greek, as well as words, idiomatic expressions and sayings in those two languages. He repeatedly alludes to ancient civilizations, culture and art, particularly Greek literature and mythology. He makes specific mentions of local and international ancient monuments. Such an apparatus requires great care and responsibility on the part of the editor and publisher. References to the antiquity have a wide variety of functions and meanings in his fiction and non-fiction, and are treated accordingly. In some ways, this obfuscates the extent to which Desnica intersperses his works with them. Ancient motifs appear in Desnica's meditations on life and death, too, ranging from the etymology of individual words (athanatic), their meanings (simulacrum), in addition to mentions of funerary monuments of stone (urn, epitaph), the fearsome dwellers of the underworld (Charon, the Chimera), the epic hero's quest in the underworld and the death of the tragic hero (Odysseus, Aeneas, Agamemnon, Antigone, Oedipus), the combination of a monument and epic tradition (Memnon), as well as the philosophical deliberations on the relationship between life and death (the words of Prometheus in Aeschylus's play). The character of Charon, the ferryman of the dead, inspired by the one from Virgil's Aeneid and Dante's Inferno, is considered the most interesting. It is for this reason that we refer to classical elements in Vladan Desnica's thanatic repertoire as Charon's goods. They play a fundamental part in his views and writings on the meaning of life and its cessation.

Key words: Vladan Desnica, classical high school, classical antiquity, Homer, Aeschylus, Sophocles, Prometheus, Plutarch 


\section{TANATOLOGIKE VLADANA DESNICE - IGRE POETIKE I SMRTI}

\section{Bojan Jović}

UDK: 821.163.42Desnica, V.:612.013

Izvorni znanstveni članak

Sažetak: U radu se istražuju vidovi oblikovanja tematsko-motivskog kompleksa bolesti, umiranja i smrti u opusu Vladana Desnice, u koji je uključena i problematika samoubistva, nasilnog okončanja života, mogućnosti lečenja i iskorenjivanja bolesti, i postizanja besmrtnosti. Navedena tematika, i u delima u kojima to nije vidljivo na prvi pogled, podrazumeva dvojstvo uzvišenog i niskog, misaonog i materijalnog / telesnog, ozbiljnog i humorno-ironičnog, skladnog i grotesknog. Navedene osobine, praćene otvorenošću i nedovršenošću tekstova, polifonim spajanjem romana sa esejistikom, poezije sa prozom, pustolovine sa apstraktnim razmišljanjem, eksplicitne sa implicitnom poetikom, uz umetanje manjih žanrova, upućuju na prisustvo osobina tradicije ozbiljno-smešne / karnevalizovane književnosti. Stoga se naznačava važnost istraživanja genealoške perspektive smehovnog i karnevalizovanog uobličavanja problema bolesti i smrti kao jedan od mogućih ključeva za obuhvatno i slojevito tumačenje Desničinog književnog dela. ${ }^{1}$

Ključne reči: Vladan Desnica, tematika smrti, žanrovi ozbiljno-smešne književnosti, karnevalizacija, groteska

(...) osjećaja života koji me je, makar i nespoznat, neprepoznat, makar $i$ prerušen u svoju suprotnost, u igru poigravanja s ništavilom, u žed samouništenja, kroz čitav život vitlao i pratio.

Vladan Desnica, Proljeća Ivana Galeba

D ela Vladana Desnice sadrže brojna mesta tematizacije fenomena (ljudske) smrt(nost)i, koja se u nekolikim prilikama razvijaju u šire, zaokružene celine, poput refleksivnog, patetikom obojenog poglavlja XIX romana Proljeća Ivana Galeba. U navedenom poglavlju iznose se zapažanja o smrti kao temeljnom, neprestano prisutnom i određujućem fenomenu ljudskog bivstvovanja, koji predstavlja osnovnu, možda i jedinu, filozofsku i umetničku temu. Misao (o) smrti, dalje, nije dana svima, već pripada samo izabranima

1 Rad je nastao u okviru naučnog projekta Instituta za književnost i umetnost iz Beograda ON178008 Srpska književnost u evropskom kulturnom kontekstu, koji finansira Ministarstvo prosvete, nauke i tehnološkog razvoja Republike Srbije. 
- za nju je potrebna stvaralačka fantazija, budući da što je veći čovek to je veća i njegova smrt: „s ponekim umiru čitave galaksije“.2 Suprotstavljanje smrti je „revolt, to je borba, to je akcija“. Nadalje: „To je podvig. Najviša akcija i vrhovni podvig: borba za nemoguće. To je prometejstvo. “3 Poglavlje se završava navođenjem prevedenih stihova iz Eshilovog Okovanoga Prometeja koji, po mišljenju Desničinog junaka Ivana Galeba, predstavljaju „najvišu pjesničku (a i ljudsku) riječ koja je ikad rečena: Da nisi možda još i dalje drznuo? / Smrtniku uskratih da sagleda svoj kraj. / A kakav li mu lijek za to nađe ti? / Njegovu grud napučih slijepim nadama. / O, blagodat si silnu dao čovjeku!“4

Navedeno poglavlje, međutim, ima i svoj pandan u poglavlju XL, koje predstavlja otklon i svojevrsni samokritično-ironični komentar prethodno iznesenih stavova. U njemu se najpre, kao uznošenje, samodopadljivost i loš ukus, odbacuje kontemplacija smrti, kao i intimizacija sa smrću, koja je obično prati - kozerija i koketerija, da bi se, na kraju, sa čovekomumetnikom konačno javila i neprihvatljiva stilizacija smrti, njen umetnički preobražaj. Ivan Galeb daje i konkretan primer takve stilizacije u obliku provizornog, kič i farsičnog scenarija za balet u kome kostimirana smrt, vitlajući kosom, progoni druge likove, mladića i devojku. Sve ove manifestacije čovekovog misaonog i umetničkog uobličavanja smrti, međutim, postaju ništavne u trenutku stvarnog suočavanja sa bolešću ili umiranjem, u kome jedinka, zaboravljajući na razmišljanja o kosmosu i ljudskoj vrsti, ostaje ogoljena i sama.

Upravo ovo dvojstvo, koje odslikava, problematizuje i izokreće iskazano, nagoveštava jednu od bitnih crta Desničinog književnog postupka: razvijanje i sučeljavanje suprotnosti. Ozbiljnom i patetičnom se kod Desnice suprotstavlja šaljivo i ironijsko; unutrašnjem i kontemplativnom - spoljašnje i materijalno / telesno; mladom, životnom i zdravom - staro umorno i bolesno; strogoj (ili, pak, „strogoj“) refleksiji - farsični umetnički igrokaz, itd. Desnica neprekidno relativizuje i podriva iskaze svojih junaka, pripoved(a)nih iskaza, pa čak i teksta u celini, polifonijskim naslojavanjima značenja odnosno dijaloškim sučeljavanjima, ili pak, namernim protivurečnostima, omaškama i izostavljanjima izvođenja logičkih posledica iznesenih mišljenja, čineći to ili neposredno ili naknadno, sa odloženim dejstvom.

Ovakav pristup, dat u daleko drastičnijem i sniženijem registru, možda je najupečatljivije prisutan u nevelikom Desničinom ranom radu, u tekstu Nobelovac, označenom kao „humoreska“, u kome slavni pisac i Nobelov laureat Norbert Bruk na jednom mestu razmišlja o svom romanu u nastajanju, naslovljenom I pojest će vas djeca vaša. Brukov slojeviti unutrašnji dijalog, iskazan kroz pripovedanje u trećem licu, u više tokova živo pretresa nekolika moguća rešenja raspleta. Početno otkrivanje mrtvog tela oskrnavljene devojčice menja se u scenu u kojoj nju deda davi zbog „greha“, odnosno u potonje detetovo ubijanje dede sekirom po zatiljku, praćeno naglašeno grotesknim detaljima (starčevo volujsko samrtničko mukanje; šakali pod stolom rskaju kosti; krv koja šiklja do plafona pretvarajući se najpre u vodoskok, potom i u pravu poplavu), korenitom promenom okolnosti (ubistvo iz afekta / straha zbog dedinog besa pokazuje se zapravo kao ubistvo s predumišljajem) te

\footnotetext{
Vladan Desnica, Proljeća Ivana Galeba, Beograd 1982., 77.

Isto, 78 .

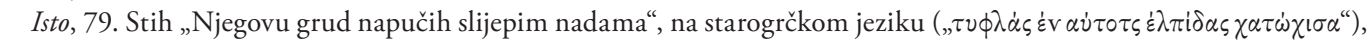
stoji i kao moto poglavlja.
} 
još grotesknijim piščevim „kritičkim“ komentarima (nalaženje silovane i ubijene devojčice u staničnom lavabou jeste „Zahvalno“ ali previše „naturalističko“; rešenje sa kasapljenjem dede je „već bolje“, „dobro“, „od-lič-no“).5

Ispostavlja se, dalje, da je Brukov roman u nastajanju u potpunoj opreci s njegovom uobičajenom javnom pozom (opštečovečanski izraz, vidovit pogled „preko glava savremenika, u zamagljeno krilo budućnosti“) i sa uvek istim visokoparnim kič govorima koje drži, što značenje Desničinog teksta u celini usložnjava, dodajući mu i element svojevrsne strukturne ironije. ${ }^{6}$ Ona se, naknadno, uočava i u napetosti između žanrovske oznake rada i samoga teksta, budući da „humoreska“ podrazumeva vrstu novele i kratke priče koja se „odlikuje vedrinom humora, veselošću i jednostavnošću obrade“, ona „uvek zadržava zabavan ton i predstavlja svoju sadržinu u optimističkom, šaljivom svetlu“,7 što je sasvim udaljeno od Desničinog složenog štiva i u osnovi tamnog i grotesknog humora. „Humoreska“ Nobelovac tako ubedljivo pokazuje da se već u ran(ij)oj fazi Desničinog stvaralaštva, osim već pomenutih, u zgusnutom vidu javljaju i drugi elementi bitni za njegovu poetiku - pre svega nezaobilazna tematizacija fenomena (ljudske) smrt(nost)i u mnogo neposrednijem vidu, s izrazitim prisustvom grotesknog i šokantnog, jedenje / proždiranje i komadanje tela u prenosnom (I pojest će vas djeca vaša), asocijativno-slikovitom (šakali) i doslovnom (udaranje sekirom) smislu, kao i naročiti odnos tela i prostora (tj. širenje telesnih sastojaka u prostor - poplava krvi). ${ }^{8}$

U dosadašnjim razmatranjima Desničinog opusa navedene osobine sporadično su dovođene u vezu s osobinama žanrova ozbiljno-smešnog i karnevalizacije, ${ }^{9}$ naročite književne tradicije koja je u evropskoj istoriji književnosti prisutna od njenih početaka, a koju je

5 „Sinu mu mogućnost jednog novog rješenja: kako bi bilo - umjesto da malu Moniku, prerano razvijeno i nervno istančano jedanaestogodišnje siroče o djedovoj brizi, nađu silovanu i umorenu u kolodvorskom 'lavabou' (što bi doduše bilo zahvalno, ali malko previše naturalističko) - kako bi bilo, umjesto toga, da sam djed, impulzivan do neuračunljivosti, saznavši za djetinji 'grijeh', zadavi nesretno dijete?... Ne, ni to ne valja! - Ili možda (da, da, to je već bolje!) da dijete, u ludom strahu pred djedovim bijesom kad dozna cijelu stvar, iskoristi momenat, dok joj on za stolom dotjeruje domaću zadaću, pa ga šine sjekiricom po zatiljku?... Da, to će biti dobro! (Pred očima mu počeše spremno nicati detalji: starome od udarca vrče naočali preko stola, i kasnije, pod nogama susjeda koji pritrče na njegovo volujsko samrtničko mukanje, stakla tih naočala jezivo krčkaju, kao da šakali pod stolom rskaju kosti; pojedinosti su nicale dalje - na prvi nesiguran udarac starac se podupire dlanovima o sto i pokušava se okrenuti, našto mala - ne više zato da ga usmrti, nego naprosto iz straha da ne sagleda njegove zakovrnute oči i da učini kraj tom njegovom nepodnosivom mukanju - nastavlja da udara, gotovo mehanički, sve brže i sve jačim zamasima; a zatim, kad se već umorila, opazi da je krv šiknula do stropa, visoko po zidovima, vidje se u nemogućnosti da ispere i ukloni tragove, kao što je u prvi mah bila naivno smislila, i učini joj se kao da se nalazi posred bujnog, nepresušenog vodoskoka krvi, u poplavi krvi koja raste i raste, koja ju je svu opkolila, od koje je već obnevidjela...) Da, da, tako će biti odlično, od-lič-no!“ Vladan Desnica, „Nobelovac“, Ilustrirani vjesnik (Zagreb), br. 184, 5. 3. 1949., 12. Još jedan primer kod Desnice izuzetno retkog uživljavanja u svest ubice može se naći u rukopisu nedovršene drame Gadni mali gnom, u liku Dr Petjoa, serijskog ubice Jevreja tokom Drugog svetskog rata. Videti: Vladan DesnicA, „Gadni mali gnom“, Republika, 64/2008., br. 3-4, 3-21.

6 „Jutros, (za riječju se dobro osjećao zarez)... Jutros, čim sam izišao iz stanice, pogled mi je pao na dvije figure vaših seljanki s korpama divnoga voća: u bistrom jutarnjem zraku nezagađenu dimom iz fabričkih dimnjaka, stasite i mirne, one mi se prividiše kao dvije karijatide koje stražare na ulazu u neku bajoslovnu baštu prepunu sočnih plodova zemlje..."V. Desnica, „Nobelovac“, 12.

7 Rečnik književnih termina (gl. ur. Dragiša Živković), Beograd 1992., 274.

8 Takođe, krajnje retki motivi telesnog erotizma podrazumevaju spoj nasilja i pervertirane seksualnosti, poput prigušene, posredno prikazane pedofilske epizode u pripoveci Spiriti. Up. Vladan Desnica, „Spiriti“, Književnost, 9/1954., br. 7-8, 78-79.

9 Vladimir Biti, Doba svjedočenja. Tvorba identiteta u suvremenoj hrvatskoj prozi, Zagreb 2005., $135-171$. 
svojim istraživanjima u prvi plan stavio Mihail Bahtin. ${ }^{10} \mathrm{U}$ tome svetlu, u ovom radu će se istaći samo neke osobenosti umetničkog postupka Vladana Desnice vezanog za tanatopoetiku, onako kako se, upućujući na prisustvo osnovnih elemenata iz navedene tradicije, na najupečatljivije načine protežu kroz različite oblasti i žanrove njegovog dela. U središtu pažnje naći će se za smrt vezano preplitanje različitih vrsta prostora / područja - psihološkog, fizičkog, estetskog i društvenog, utemeljeno na (humorno / ironičnom) suprotstavljanju, variranju i inverziji naročitih motiva odnosa duševno / duhovno - telesno, dete - čovek, pojedinac - grupa, narod - država; pri tome će se naglasak staviti na sinoptički sinhronijski pregled, bez nastojanja da se podrobno prikaže hronologija / dinamika odnosno žanrovske specifičnosti navedenih postupaka / osobenosti u okviru Desničine poetike / opusa.

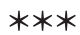

Razmatranje smrti kod Desnice polazi od unutrašnjeg doživljaja - pitanju smrti (jedinke) najpre se pristupa kao unutarnjem, najšire psihološkom problemu, koji obuhvata kako emocionalnu tako i racionalnu (filozofsko-antropološku) stranu ljudskoga bića, čovekovoga ja. U Proljećima Ivana Galeba glavni junak, osvrćući se na detinjstvo, na nekolikim mestima daje viđenje dečijeg doživljaja života i smrti, na osnovu sopstvenog i opšteg iskustva: polazeći od uverenja brojnih religija i filozofija o beskrajnosti i besmrtnosti čovekove duše, Galeb ističe za njega začudnu činjenicu da (u njima) ne postoji razmišljanje o posebnosti dečijeg bića, iskazanom u stavu da dete ima beskrajnu i besmrtnu dušu, koju kasnije, kad odraste, izgubi. ${ }^{11}$ Navedeno polazište razvija se u svojevrsnu raspravu o umiranju drugog i o sopstvenom skončanju, koja podrazumeva razliku između vanvremenog i neuništivog, besmrtnog ja, i spoljašnjeg i efemernog, ,širokog, prostranog, nebrojenog ne-ja koje naspram nama i svud oko nas stoji baš kao i smrt". ${ }^{12} \mathrm{Na}$ taj način spoljašnji, fizički prostor-vreme i njemu pripadajuće telo određuju se kao domen $s m r t i ;{ }^{13}$ sa druge strane, budući da je jastvo

10 Navedena književna tradicija u istoriji evropske književnosti podrazumeva nedovršenost / otvorenost forme, uključivanje mnoštva drugih kako književnih (proznih i poetskih) tako i neknjiževnih oblika. Odricanje od stilskog jedinstva književne vrste ili dela dovodi i do prisutnosti više stilova i glasova u njima (spoj uzvišenog i prizemnog, ozbiljnog i smešnog, korišćenje „pristupnih“ žanrova - pisama, otkrivenih rukopisa, parodija na visoke žanrove, parodijski preosmišljenih citata; mešavina proznog govora i stiha, uvođenje živih dijalekata i žargona, pojava najrazličitijih autorskih maski). Pored toga, polazna tačka ocene i oblikovanja stvarnosti u njima jeste sadašnjost, područje ovovremenog, neposrednog, ponekad i grubo prisnog kontakta sa živim savremenicima (često kroz ismevanje i izrugivanje). Oslanjajući se na iskustvo, ponekad i slobodno maštanje ili filosofsku inspiraciju, žanrovi ozbiljno-smešnog razvijaju duboko kritičan, ponekad i cinično razgolićujući odnos prema predanju, ideološkim dogmama i prema savremenosti, spajajući potragu za istinom sa narušavanjem društvenih i jezičkih konvencija, kroz scene skandala, ekscentričnog ponašanja, neumesne govore i ispade; oštre kontraste i oksimoronske spojeve, nagle prelaze i promene, smenjivanje uzvišenog i prizemnog, čovekovih uzleta i padova. Videti: Mihail Bahtin, Problemi poetike Dostojevskog, Beograd 1967., 169-170.

11 V. Desnica, Proljeća Ivana Galeba, 47. Pri tome Galeb / Desnica u svom razmišljanju provlači malu logičku omašku: ako odrasli čovek gubi besmrtnu dušu koju je imao kao dete, ona je u navedenom slučaju jednostavno privremena i potrošna, i, kao takva, ne zadovoljava polaznu pretpostavku. Hotimično ili slučajno prelaženje preko protivurečnosti prisutno je i na drugim mestima u romanu, naročito u poglavlju o athanatiku, gde uzbudljivost i zaraznost priče potiskuje razmišljanje o krajnjim posledicama iznesenog.

12 „Naše ja sastoji se iz golog fakta bivstvovanja i iz primarnog, slijepog osjećaja tog bivstvovanja." Isto, 286.

13 Kod Lisjena iz Bente-Guštera prisutno je razmišljanje o spoljašnjem materijalnim svetu kao mrtvom: „(...) milioni tona mrtve materije koji mehanički uništavaju milijarde tona druge mrtve materije. Njegovom je umu bila bliža, i punija draži, pomisao kako jedan mali, neznatni, skroz nematerijalni pomak u ljudskoj misli ili u ljudskoj psihi izaziva ogromne učinke u brdima inertne materije vanjskog fizičkog svijeta." Vladan DesniCA, „Benta-gušter“, 
takođe i vanvremeno (,ja nema dobi“), ${ }^{14}$ vremenska dimenzija (lične) prošlosti (ali i „neizvesne" budućnosti) takođe potpada pod istu oblast, što Desnica tematizuje na drugom mestu, prožimajući, u pesmi Kairos, vremensko-prostorne i telesne aspekte: „Dragocjen si, o času sadašnji! / U raspadnutom tijelu vremena / što pružilo se sivim prostorom / ti jedina si živa ćelija. Sve što nisi ti, / ne postoji. / Ti si bljesak svijetla / u tamninama. (...) Jučerašnji moj ja je meni stran, / i dušmanin, / i jezivo me gleda svojim mrtvim očima. / A moje se živo srce seli bez kraja / iz umrloga ja u živo, današnje. / Odatle moja grozničava žurba, / odatle moja žeđ nezajazna!“15

Vrsta opozicije prošlost / sadašnjost (odnosno dete / odrasla osoba) sprovodi se upravo u slučaju dveju epizoda iz Proljeća, kroz reakciju devojčice na smrt bake naspram obrnute situacije u kojoj ista devojčica, sada kao odrasla, smrtno bolesna leži u bolnici. U prvom slučaju, intenzivno ali kratkotrajno, ona oponaša majčinu reakciju - orošenog čela i ulepljene kose plače i stisnutom šačicom rastrljava suze po licu, da bi se nekoliko trenutaka kasnije zaigrala, i u čudu gledala majčinu žalost: „Što plačeš? Ta nije umro Bog!"“16 Ovo (dečije) unutrašnje neshvatanje smrti drugog, iskazano patvorenim i privremenim spoljašnjim iskazivanjem žaljenja, dobija pandan u potonjem vremensko-prostornom aspektu sopstvene smrti. „Pregažena“ životom, bivša devojčica umire od raka utrobe, pri čemu su lekari odstranili sve što se iz nje moglo odstraniti; ono što ostaje predstavlja samo puku koru. ${ }^{17}$ Narušavanje granica između ljudskog tela i spoljašnjeg prostora tako se u očima pripovedača javlja kao siguran znak blizine smrti: osim prodiranja prostora u telo (oči - rupe; telo - šupljina) kod Desnice to važi i za kretanje u obrnutom smeru - za (hiperbolisano) širenje tela u prostor, karakteristično za terminalne stadijume bolesti. ${ }^{18}$

Motiv rasprostiranja tela kao znak smrti sreće se i u duševnom domenu - razmišljanje o beskrajnosti prostora i bezbrojnosti svetova kod deteta izaziva strah od razdvajanja ličnosti, praćen željom za dejstvom grube fizičke sile koja bi ličnost zadržala na okupu. ${ }^{19} \mathrm{Ta}$ sila, koja u Proljećima Ivana Galeba sprečava telo da se rasprostre izvan svojih granica, i razdvoji, u Zimskom ljetovanju prisutna je u razornoj spoljašnjoj fizičkoj snazi obrnutog dejstva, koja rasparčava telo u prostor(u) bombardovanjem, proizvodeći „rasporene utrobe, otrgnute udove, raskoljene lubanje“ odnosno „raskasapljena tjelesa“, ${ }^{20}$ groteskne slike poput

Pripovijetke (= Sabrana djela Vladana Desnice, knj. III), Zagreb 1974., 364. Ovakav postupak ospoljašnjenja duševnog prisutan je i u drugim prilikama tematizovanja (dečijeg) doživljaja sveta, vremena i prostora, u kome se odigrava naročita vitalizacija, u kojoj svaka „mrtva stvar oko mene dobijala je tada živo srce i u njoj su damari odbrojavali časove nepovratnog“. Bez tog specifičnog oživljavanja, spoljašnji, fizički vreme-prostor i telo beznadežno su obeleženi kao područje smrti.

14 V. Desnica, Proljeća Ivana Galeba, 285.

15 Vladan Desnica, „Kairos“, Zimsko ljetovanje. Pjesme. Ljestve Jakovljeve (= Sabrana djela Vladana Desnice, knj. I), Zagreb 1974., 228-229.

16 V. Desnica, Proljeća Ivana Galeba, 48. „Dva crno zaobručena oka ležala su kao dvije rupe u jastuku. Gledao sam je kao šupalj dud, ulište klica smrti. Eto, i nekadašnja plava djevojčica sa suncem u kosi sada je postala samo jedno drago, ubogo, pregaženo ne-ja!" Isto, 49. „Naše iznureno tijelo na bijelim kolicima, već nabuhlo gasovima smrti, bit će sve što postoji; ono će rasti i rasti, nadimat se do visokoga svoda, prerastati granice svijeta, granice svemira." Isto, 193.

19 „Nejako tijelo svo je drhtalo. Slabila je sila što drži na okupu njegovu cjelokupnost, udovi su htjeli da se raspu i rasture. Čitavo je biće stremilo da sobom, kao laganim prorijetkim plinom, ispuni prostor. I taj je poriv rastvaranja, razdvajanja ličnosti bio tako snažan i tako stvaran, da sam osjećao potrebu da me neka gruba i slijepa fizička sila spolja sa svih strana pritisne, da me zgrune, da me suzbije natrag u granice tijela." Isto, 46. 
nemačkog vojnika koji, ravno presečen preko pasa, sa desnom rukom podignutom uvis, kao da harangira ili doziva, s ustima otvorenim kao u kriku, nalikuje na prevaljenu bistu. Do rasparčavanja tela, međutim, dolazi i na druge načine: dok Desnica u vezi sa bolešću (rakom) po pravilu upotrebljava metaforu rasta / nadimanja, u jednom slučaju humorno personifikuje i antropomorfizuje bolesti, objašnjavajući njihov „džentlmenski sporazum“, koji podrazumeva red(osled) nastupanja „sa viljuškom“ ${ }^{21}$ Metaforično izjedanje tela svoj konkretni oblik dobija u motivima doslovnog jedenja / proždiranja, takođe datih u inverznom paru: u Zimskom ljetovanju najpre se sreće naglašeno groteskna slika koja obuhvata emocionalne reakcije deteta / odrasle osobe prilikom jedenja mesa (delova tela) domaćih životinja koje su im neposredno poznate. ${ }^{22}$ Stepen najvišeg užasa u navedenom romanu dostignut je upravo obrnutom situacijom u kojoj krmak Migud - takođe slasno - pred užasnutom majkom - proždire malu Mafaldu / Špižmicu, komadajući pre svega njeno lice. ${ }^{23} \mathrm{U}$ drugoj verziji romana (Beograd, 1957) ovaj je opis, međutim, značajno prerađen i skraćen, sa potpunim izostankom drastičnih detalja; posredno, i ova izmena može se dovesti u vezu sa razmišljanjima o smrti, osvrtanjem na Desničine oglede: iako se, naime, u esejističkim spisima praktično ni na jednom mestu ne razvija tanatološka problematika, upravo igra neraskidivo povezanih suprotnosti života i smrti baca svetlo na njegovo određenje književnog detalja, ${ }^{24}$ time i na (moguću) prirodu intervencije u tekstu Zimskog ljetovanja.

Vratimo se ponovo odnosu smrti i prostora. Pored psihološkog i fizičkog, u tanatopoetičku igru Desnica uvodi i društveni prostor: ako je, sa stanovišta (samo)svesnog / spoznajnog subjekta, smrt sopstvenog bića, kao male tačke svesti okružene beskrajem ništavila, za

21 Tako „u internom saobraćaju među bolestima postoji gentlemen's agreement. Tu nema otimačine ni presizanja. Možda tek izuzetno neka nova, nevaspitana bolest, koja još ne poznaje pravila igre, zaleti se preko reda sa svojom viljuškom. Ali je odmah klopnu po nadlanici.“V . Desnica, Proljeća Ivana Galeba, 259.

22 „Svi znamo očajni vrisak djeteta kad dozna da je batak koji gricka batak njegove drage, prijateljske kokice Pirke; znamo kako se grčevito tada stisne grlo te više nikako ne može da guta.

A slično je i s odraslima. Jer ako nam se, dok slasno jedemo hladetinu, najednom iz ljigave mase promoli ona čisto ljudska trepavica i ispod nje virne u nas, s hladnim prijekorom, ono mrtvo, već bestrasno oko, kao da kaže: 'eh, ljudi, to li vi dakle učiniste od mene!' - zaludu, to je kadro da obeshrabri, to je kadro da olabavi viljušku u ruci. “V. DEsNiCA, Zimsko ljetovanje, 57.

23 „Dirnuta kao nekim predosjećajem (- tako joj se bar kasnije činilo -), Lisetta pograbi tek uzavreo lončić i pohita $\mathrm{k}$ prozorčetu. Krmak je slasno mljackao podigavši gubicu da mu ne bi ispao kakav komadić iz žvala, i treskao glavom kako bi pomogao oklizanje samljevene hrane u grlo; gledao je ravnodušno u Lisettu. Na rubu žvala bio mu je rumenkast trag. Tek onda pogled joj pade na kolica. Uhvati letimičnu sliku: djetetu je falilo pola lica, s okom i komadom čela; na izmusanom okovratniku rub od blijede krvi i pjenaste sline u kojoj je bilo slijepljeno nekoliko šiljatih ječmenih zrna.

Ruke joj se zaletiše u kosu, i samo što začu oštar krik - svoj vlastiti krik ali dalek i tuđi.“ Isto, 192-193.

24 „Pitanje je (stvar je), dakle, naprosto u ovom i jedino u ovom: da li ti takozvani 'detalji' nešto grade, da li nam pisacumjetnik sredstvom tih detalja oblikuje pred očima žive, u sebi logične, kongruentne ljudske likove, da li nam vjerno i živo predočava atmosferu, sredinu, životni ritam, da li nam uspjelo slika i prikazuje sklop života, odnose itd. koje je uzeo za predmet svog djela; da li se, nadalje, sva ta živa materija kreće usmjerena onom cilju koji je (više ili manje svjesno) ležao u namjerama pisca; i da li je - last not least - pisac sve to uspio da učini na dovoljno zanimljiv način.“ Vladan DesnicA, „Dva kratka eseja: 'Marginalije o iracionalnom' i 'Zloupotreba jednog termina: detalj“, Eseji, članci, pogledi (= Izabrana dela Vladana Desnice, knj. IV), Beograd 1993., 150-151. Desnica ovde pet puta upotrebljava poliptotonsko-paregmenonske varijacije reči sa korenom „Živ-“ („žive“; „Života“, „Životni“; „živa“, „Živo“), jasno određujući (uspeli) književni detalj u vitalističkim terminima. Shodno tome, u svetlu opozicije i inverzije prisutne u Desničinim pogledima, može se pretpostaviti da neuspeli detalj, koji ne zadovoljava ove preduslove, predstavlja suprotnost, odnosno - da je (estetički) mrtav. Stoga je samokritička intervencija jedan od mogućih razloga za skraćivanje / ublažavanje opisa Špižmicine pogibije: razvijanje detetove smrti do drastičnih detalja estetski je neuspelo 
Desnicu zapravo smrt celoga sveta / svega što postoji („umrlo sâmō načelo postojanja“), ${ }^{25}$ a smrt drugoga nestanak tek jedne jedinke, sa stanovišta društvene zajednice smrt pojedinca izdvojenog u četiri zida njegove sobe predstavlja samotnu stvar („sitna, privatna smrt“). ${ }^{26}$ Smrt drugog, u očima ljudi iz okruženja, proizvodi paralelni svet mnjenja: (ne)znanje (lažne ili istinite) vesti vezane za smrt pojedinca dovodi do posledica u stvarnosti društvenog okruženja, kako pravoj tako i virtuelnoj - umišljena smrt šjor Karla u Zimskom ljetovanju uzrokuje u zadranskom zbegu paralelnu, do najsitnijih tančina razvijenu spekulativnu realnost (malograđanskog) javnog mnjenja, kao što, u umetnutoj pripoveci iz Proljeća Ivana Galeba, zajednica, svesna stvarne pogibije dečaka, izbegava da majci saopšti vest o smrti njenog sina, uljuljkujući je izmišljenim opravdanjima u lažni spokoj i nadu, i istovremeno posmatrajući, sa (licemernim) sažaljenjem, čuđenjem i osudom, njeno nepromenjeno svakodnevno ponašanje.

Sa druge strane, ,aktivno“ umiranje u okruženju drugih ljudi, nehotično ili hotimično - poput samoubistva učinjenog pred svedocima, ${ }^{27}$ ili junačke / ,junačke" pogibije u ratu ili u atentatu - predstavlja delatnu ,javnu“ smrt, posledicu neke vrste činjenja osobe. Razmišljanja, u velikoj meri ironična, o privatnoj i javnoj smrti, odnosno o istoriji (smrti) jakih pojedinaca naspram „povjesnica čovječanstva“ - istorije „slabih“ ljudi, vode do razmišljanja o političkoj povesti naroda, u kojoj se kao osnovno pitanje javlja odnos vlasti i građana, države i naroda. Upravo uverenje o doglednom odumiranju države, koje priziva i upitanost o odumiranju samih podanika, uvodi „digresivnu“ pripovest (naj)višeg društvenog nivoa, „nedovršeni roman“ o pronalasku leka za smrt - athanatika. ${ }^{28}$

U navedenom delu Desnica polazi od motiva rešavanja problema ljudske konačnosti putem primene naučnih (medicinsko-farmaceutskih) znanja, tematizujući najširi raspon mogućih posledica koje besmrtnost može da ima na ljudsko društvo. Ovakav pristup razrešenju najvećeg, i praktično jedino preostalog, pitanja „u jednoj fantastičnoj zemlji u kojoj su već prethodno svi socijalni, ekonomski i slični problemi riješeni, sve nejednakosti ukinute a bijeda obješena u klin“, ${ }^{29}$ podveden pod opštu borbu dobra i zla, već je unekoliko najavljen u karakterizaciji šjor Karlovog lika u Zimskom ljetovanju, kroz predsta-

- mrtvo - i stoga je uklonjeno. Drugi razlog, međutim, može biti mnogo prozaičniji: upravo je izdvajanje prizora smrti devojčice često prisutno u (negativnim) kritičkim prikazima ovog romana. Pomenuta scena doživljava se kao filmski verna, međutim sa primedbom da je odraz užasa u ljudima veoma bled i nevešto oblikovan. Videti: Živko Jeličić, „Zimsko ljetovanje Vladana Desnice“, Hrvatsko kolo, 3/1950., br. 2, 551.

V. Desnica, Proljeća Ivana Galeba, 48.

26 Isto, 245.

27 „I, jednoga dana - skočio je. U prijepodnevne sate, oko deset i po. I to baš na ulicu a ne u dvorište. Nikome na glavu, ali opet među prolaznike. Valjda iz nagona da ipak nekako obilježi, da ipak nečim podvuče svoju smrt; da ona ne bude baš sasvim neznatna, sasvim nezapažena. Da ipak saljude zainteresira, kointeresira, za se i za nju.“ Isto, 87.

Već samo posredovanje kroz razgovor pripovedača sa nekim „paranoidnim pričalom“, „krezubavim vjetrogonjom“ koji neprestano izlazi „sa novim zamislima i planovima“ (Isto, 237) diskvalifikuje potencijalnu intelektualnu i umetničku vrednost dela i svrstava ga u „niže“ žanrove. Beleške nesuđenog romanopisca služe kao izvor za izlaganje osnovnih postavki fantastičnog proznog ostvarenja u nastajanju; samostalna verzija naslovljena Pronalazak Athanatika, tj. „nedovršeni roman“ o skicama i beleškama, od nekoliko listova, za nenapisani roman koji bi trebalo da obuhvati negde oko 800 stranica, pri tome je znatno većeg obima od poglavlja u Proljećima i sadrži i mnogo više izrazito neuobičajenih ideja i teorija. Objavljena je posthumno u: Vladan Desnica, Proljeća Ivana Galeba. Pronalazak Athanatika (= Sabrana djela Vladana Desnice, knj. II), Zagreb 1975., 349-406. 


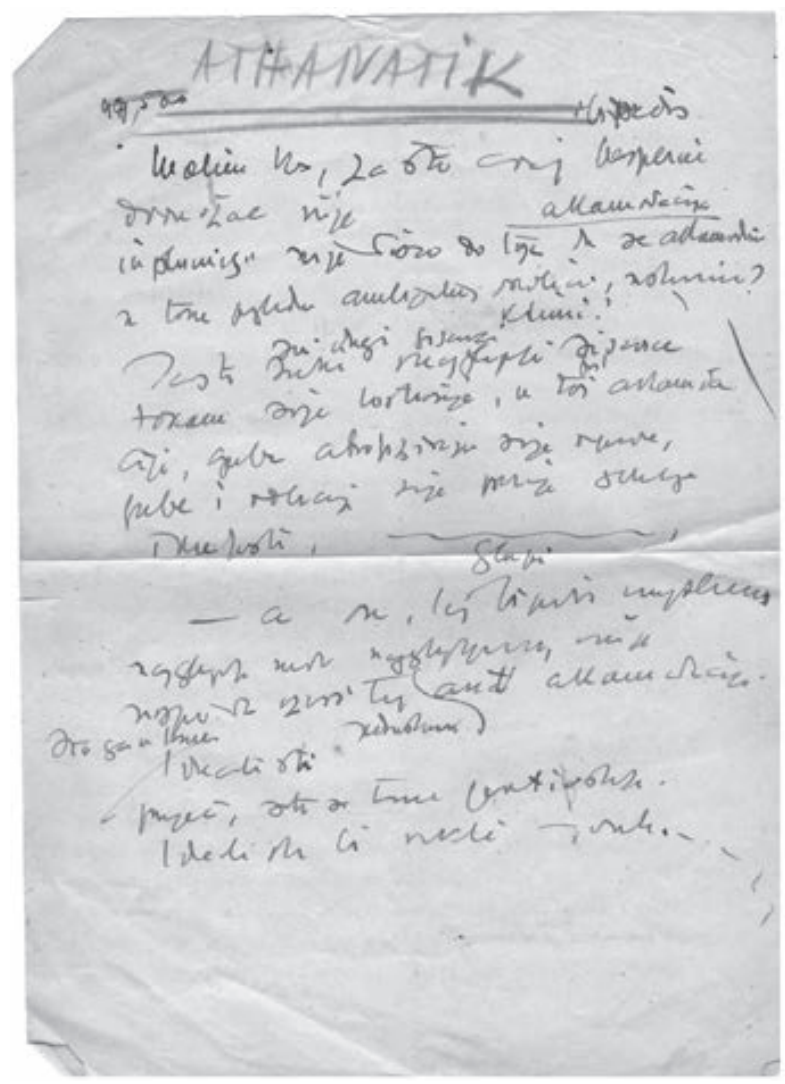

Sl. 1. Fragment autografa romana Pronalazak Athanatika

$\mathrm{vu}$ „naučenjački uporne metodičnosti dobra“ u kojoj se „na svakom koraku bolest pobija lijekom". ${ }^{30} \mathrm{U}$ fantastičnoj pripovesti, athanatik u svojoj prvoj verziji $(A)$ predstavlja lek svih lekova - ultimativni medikament, podjednako delotvoran i kod spontane prirodne smrti i kod fatalnog udesa, ubistva i samoubistva. Ostvarivost besmrtnosti, praktično i ljudske neuništivosti, međutim, iz temelja menja međuljudske odnose - pre svega, primena i raspodela leka služe kao instrument moći i temelj nove, najviše diskriminacije među ljudima: nejednakosti pred smrću. Stvorena je pravna ustanova „Izuzeća od smrti“ (nem. Todesenthebung); nimalo neočekivano, utvrđivanje „socijalne dužnosti življenja“ proteže se, počev od vladara države, preko ministara, sudija, akademika, do najnižih slojeva državnog činovničkog aparata. Sa druge strane, selektivna raspodela uzrokuje (veštačke) nestašice i krivotvorenja kako leka tako i Todesenthebung-a, i stvaranje razvijene mreže crnoberzijanstva i šverca; u takvom okruženju plava devojčica sa „suncem u kosi“ dobija u Athanatiku još jedan groteskni inverzni odraz - društveni pandan u obliku kolektivnog subjekta, i doslovno i prenosno podzemnog, neposredno uključenog u nezakonitu raspodelu leka, koji priziva drastične slike snižavanja i animalnih poređenja (štakori; čopori koji skviče „kao mali šakali“). ${ }^{31}$

Nemogućnost oduzimanja života tokom kratkog razdoblja postojanja i raspoloživosti athanatika $A$, koji ne samo što zaustavlja starenje, nego i razvija otpornost na povrede, ima za posledicu obesmišljavanje najtežih kazni. Smrt streljanjem na licu mesta zbog nezakonitog posedovanja leka postaje stoga farsično besmislena u odnosu na mučnu tematizaciju kritičnog trenutka pogubljenja u Desničinoj pripoveci Pred zoru. Dok četnički simpatizer

30 V. Desnica, Zimsko ljetovanje, 133.

31 Šverc ampulica „najviše se širio putem dobro organizovane podzemne mreže ženske djece. Dočekivale su vas iza ugla djevojčice crnih zuba, od dvanaest, od deset, od osam godina, i odvlačile vas za rukav ružno namigujući. Poveli su veliku hajku na te štakore iz podzemlja. Opkolili bi kvart, spuštali policijske pse u vodove kanalizacije i istjerivali čitave čopore djevojčica koje su skvičale kao mali šakali. Neke su se branile da to čine radi iznurenih očeva na samrtničkoj postelji. Po gradovima u unutrašnjosti bilo je slučajeva da su ih na buljuke izvodili pred zidove i likvidirali mitraljezima. Ali sve to nije mnogo pomoglo." V. Desnica, Proljeća Ivana Galeba, 260. 
Bogdan, čekajući streljanje, proživljava užas poslednjih trenutaka života, maštajući da se od spoljašnje propasti sakrije u utrobi drugog živog bića, ${ }^{32}$ besmrtni i neuništivi posedovalac athanatika, izjednačen sa veleizdajnikom, ima sasvim drugačiji, drsko-bezbrižni pristup i doživljaj pogubljenja. ${ }^{33}$ Desnica tako razvija antiutopijsku / distopijsku viziju najrazličitijih zloupotreba i negativnih posledica leka protiv smrti, protkanu humornom notom u rasponu blage do sardonične ironije, preobraćajući uobičajeni odnos prema umiranju, ali i izvodeći (opet prividno) dosledno posledice - pronalazak athanatika, čak i kada je zamenjen drugom, „poboljšanom verzijom“, athanatikom $B$, delatnom samo kod prirodne smrti, dovodi do potpunog izvitoperenja međuljudskih odnosa $\mathrm{i}$ - kroz bujanje totalitarizma i izbijanje sveopštog nemilosrdnog rata - do propasti društtvenih struktura, preteći da na kraju potpuno uništi ljudsku civilizaciju. ${ }^{34}$

Sa izglednom propašću država i naroda, krajnji nivo razrešenja problema besmrtnosti na taj se način poverava naddržavnom telu, $u$ kome su zastupljene i angažovane sve zemlje i nacije, i koje predstavlja samo čovečanstvo. Na kraju, paradoksalno, na osnovu sveopšteg zahteva populacije („VRATITE NAM NAŠ RAK! VRATITE NAM NAŠU SMRT!“), ${ }^{35}$ dolazi se do svesti o neophodnosti uništenja athanatika i o izvornom, osnovnom, neotuđivom pravu čoveka na bolest i umiranje - neprirodno produžena čovekova egzistencija na taj se način pokazuje kao bolest na smrt, a lek za nju predstavlja upravo smrt sâma.

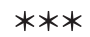

Već i provizorni pokušaj razmatranja načina na koje se u stvaralaštvu Vladana Desnice razlaže i razvija tanatološka problematika pokazuje da se može govoriti ako ne o svojevrsnoj opsednutosti temom smrti onda o njenom nesumnjivom obuhvatnom i temeljnom prisustvu u Desničinom književnom delu. Raznolikost razvijanja problematike smrt(nost)i, umiranja, pogrebenja, nasilnog i prirodnog životnog kraja, samoubistva, bolesti i mogućnosti

32 „U Bogdanu sve prenaglo splasnu, skljoka se tako nisko da više iz njega ne vrisnu ni očaj ni pobuna - činilo mu se da evo kroči u smrt već po treći, po četvrti put. Iz nedaleka grma ispade do po trupa krava meljući utrgnutu grančicu: zastala, uprla mirne oči i vlažnu njušku u grupu ljudi. Bogdan je spazi; iz pomirene pregorenosti laznu očajno želja za životom: osjeti silnu, neodoljivu privlačnost prema toj kravi - ujedno i zavist i nostalgiju -, zaželi svom snagom da mu je uteći u nju, skriti se u mračnoj i dobroj toploti njene nutrine, i poživjeti tako, slijepo i zaštićeno, bez kraja i konca... Vojnici ga privedu k hrastu, odstupe nekoliko koraka i podignu puške. Gluha lupa srca u njemu stade da buja, buja, da prerasta van njega, da mu odjekuje bolno u ušima, zaglušujući i zamagljujući sve uokolo, i zvukove, i slike, i misli. I kad grunu plotun, njemu se učini da dopire s nekog drugog svijeta, i da to ne puca u nj već u njegovu praznu košulju.“"Vladan Desnica, „Pred zoru“, Pripovetke, Beograd 1993., 272.

33 „Fućkam ja na strijeljanje', govorio je čovjek odlazeći na stratište, 'ako sam prethodno primio moju ampulicu Athanatika!' Više-manje, rupa na leđima kaputa bila je sva šteta. Zato su u tom periodu radnje za umjetno krpljenje nicale kao gljive poslije kiše. Strijeljani bi se potajao, noću ustao od mrtvih, u prvoj radnji zakrpio rupu na leđima, pa zviždućući odšvrljao u mjesto gdje ga ne poznaju." V . Desnica, Proljeća Ivana Galeba, 265-266.

34 „U pojedinim zemljama buknule su revolucije. Ljudi su provalili iz svojih kaveza, iz svojih brloga i jazbina, mračni, crni u licu, žedni krvi. Kroz masu je provrvjela praznovjerica da krv besmrtnih produžuje život smrtnima. Po ulicama ste mogli vidjeti rojeve kosmatih smrtnika sakupljenih oko lešine kakvoga besmrtnika: na koljenima, pobožno su joj sisali krv ispod grla..." V. Desnica, Proljeća Ivana Galeba, 249. I potom: „Odigravali su se neopisivo krvavi prizori. (...) Zaređale su masovne egzekucije, u industrijskom opsegu. Stupili su u akciju i bojni otrovi. Unutrašnjost je bombardirana iz specijalnih aviona kratkog radijusa, za domaću upotrebu. Ponegdje su osposobljene i stare gasne komore iz ranijih vremena..." Isto, 251.

35 Isto, 268. 
lečenja i iskorenjivanja (smrtonosnih) oboljenja, odnosa prema mrtvima - sa psihološkog, filozofskog, sociološkog, ili, pak, medicinsko-farmaceutskog stanovišta - svedoči o širini Desničinog promišljanja i raznovrsnosti poimanja problema skončanja. Pri tome, smrt kod Desnice nikada nije samostalna ili samo(za)dovoljna tema, već podrazumeva i relativizovanje, dovođenje u vezu sa širim piščevim pogledima na egzistenciju odnosno (ljudsku) stvarnost u celini, podrazumevajući tu i specifična estetička shvatanja.

Učestalost i zastupljenost tematizacija smrti u praktično svim vidovima i oblastima Desničinog stvaralaštva (naslovi, lokalni motivi u poeziji i prozi, tematske okosnice pojedinih dela, psihološka motivacija likova, predmet rasprava, estetičko-poetički uticaj, činjenica par excellence itd.) svedoče o tome da su tanatološka pitanja nezaobilazni strukturni činilac opusa. Razmatrajući, dalje, odgovarajuće književno modelovanje motiva vezanih za smrt, pokazuje se da su kod Desnice oni po pravilu uobličeni na brojne i različite načine, pri čemu se istovetni motivi drugačije razvijaju u zavisnosti od okolnosti, ${ }^{36}$ ili se pak u različitim situacijama uočava istovetni model oblikovanja / argumentacije, čime se uspostavlja izrazita raznolikost umetničkih postupaka odnosno ističe njihova funkcionalna uslovljenost. ${ }^{37}$

$\mathrm{Na}$ širem planu, zastupljenost i razvijanje problematike smrti kod Desnice osvetljava naročite književne postupke i žanrovske izbore (spajanje motiva vezanih za smrt sa nizovima ideja, slika i postupaka koji deluju u najmanju ruku neočekivano ili neobično, katkada i šokantno - groteskno prikazivanje tela, njegovo komadanje ili jedenje / proždiranje, smrt praćena šalom i smehom, pervertirana seksualnost; otvorenost i nedovršenost dela; polifono spajanje romana sa esejistikom, poezije sa prozom, pustolovine sa apstraktnim razmišljanjem; eksplicitne sa implicitnom poetikom, uz umetanje manjih žanrova - solilokvija, dijaloga, ispovesti, priče, pesme, itd. - u veće). Ovakva osobenost nalaže da se u mnogobrojnim Desničinim tematizacijama smrti, i sa njima uže i šire povezanim motivima, potraži dejstvo poetičkih načela koja, osim utemeljenosti u ličnoj poetici, podrazumevaju i određenu „višu logiku“ - upliv opštijih književnoumetničkih modela odnosno tradicija, vezanih pre svega za istoriju žanrova „ozbiljno-smešne“ / karnevalizovane književnosti evropskog kulturnog prostora.

Navedene optike stapaju se u posebnu višedimenzionalnu, „multiskopsku“ sliku Desničinih tanatologija koje, prožimajući se sa poetikom, prerastaju u svojevrsne stvaralačke tanatologike. Stoga ove naročite igre poetike i smrti mogu predstavljati jedan od ključeva za obuhvatno i slojevito tumačenje Desničinog književnog opusa.

\footnotetext{
$\overline{36}$ Poput pogubljenja streljanjem; način oblikovanja često zavisi i od društvene odnosno rodne pripadnosti likova, kao kod motiva (samo)ubistva.

37 V. Biti, Doba svjedočenja, 160-161.
} 


\section{$\cos$}

\section{Izvori i literatura}

\section{Izvori}

Vladan Desnica, Eseji, članci, pogledi (= Izabrana dela Vladana Desnice, knj. IV), Beograd 1993.

Vladan DesnicA, „Gadni mali gnom“, Republika, 64/2008., br. 3-4, 3-21.

Vladan Desnica, „Nobelovac“, Ilustrirani vjesnik (Zagreb), br. 184, 5. 3. 1949., 12.

Vladan Desnica, Pripovetke, Beograd 1993.

Vladan Desnica, Pripovijetke (= Sabrana djela Vladana Desnice, knj. III), Zagreb 1974.

Vladan Desnica, Proljeća Ivana Galeba, Beograd 1982.

Vladan Desnica, Proljeća Ivana Galeba. Pronalazak Athanatika (= Sabrana djela Vladana Desnice, knj. II), Zagreb 1975.

Vladan Desnica, „Spiriti“, Književnost, 9/1954., br. 7-8, 78-79.

Vladan Desnica, Zimsko ljetovanje, Zagreb 1950.

Vladan Desnica, Zimsko ljetovanje. Pjesme. Ljestve Jakovljeve (= Sabrana djela Vladana Desnice, knj. I), Zagreb 1974.

\section{Literatura}

Mihail Bahtin, Problemi poetike Dostojevskog, Beograd 1967.

Vladimir Biti, Doba svjedočenja. Tvorba identiteta u suvremenoj hrvatskoj prozi, Zagreb 2005.

Živko Jeličıć, „Zimsko ljetovanje Vladana Desnice“, Hrvatsko kolo, 3/1950., br. 2, 551.

Rečnik književnih termina (gl. ur. Dragiša Živković), Beograd 1992.

\section{$\cos$}

\section{VladAN Desnica's THANATOLOgIES - THE GAMES OF POETICS AND DEATH}

The paper examines aspects of the theme-motif complex of disease, dying and death in the work of Vladan Desnica, which addresses such problems as suicide, violent death, the possibility of curing and eradicating disease, and achieving immortality. Desnica's vision of human decay and vanishing raises important issues concerning the nature of human existence on the individual and the collective levels, as well as thought and creation, moral responsibility for one's own death and the deaths of others, even pondering possible solutions to the problem of human finality and the potential impact of immortality on society. The latter produces an anti-utopian vision, with all kinds of abuses and harmful practical consequences of immortality. On the other hand, even though this is not immediately evident in all of his work, that subject matter tends to be accompanied by a wide variety of grotesque motifs, images and ideas, including different kinds of humor. Desnica's treatment of these themes and motifs implies the duality of the high and the low, the notional and the physical, the serious and the humorous or ironic, the harmonious and the grotesque. It also encompasses the the open-endedness and the incompleteness of a work, the polyphonous melding 
of the novel and the essay, of poetry and prose, adventure and abstract thought, as well as explicit with implicit poetics, in addition to inserting smaller genres (soliloquies, dialogues, confessions, stories, poems, etc.), which indicate certain features of seriocomic/carnivalized literature. Therefore, the importance of exploring the genealogical perspective of the humorous and carnivalized approach to the problem of disease and death as one of the possible keys to a comprehensive and multilayered interpretation of Desnica's work.

Key words: Vladan Desnica, the topic of death, seriocomic literature genres, carnivalization, the grotesque 


\section{3. SEDEFASTI ODSJEV VJEČNOSTI. TANATOLOŠKI ASPEKTI KNJIŽEVNOG DJELA VLADANA DESNICE}

\section{Vladan Bajčeta}

UDK: 821.163.42Desnica, V.:129

Izvorni znanstveni članak

Sažetak: Viziju smrti u opusu Vladana Desnice nije moguće svesti na jednoznačno kritičko određenje. Desničina književna tanatologija pretpostavlja izrazitu raznolikost u prikazivanju i poimanju čovjekove egzistencijalne konačnosti. U rasponu između metafizičkog optimizma sa jedne i pesimizma sa druge strane, Desničini književni tekstovi pokrivaju najšire područje. Rad ispituje odnos Desničinih tanatoloških varijacija u različitim modusima njegovog književnog izraza i pokušava da odgovori na pitanje kako razumjeti predstavu smrti kod pisca koji je u svojim tekstovima na najraznovrsnije načine literarno oblikuje. ${ }^{1}$

Ključne riječi: smrt, umiranje, pogreb, vječnost, sedef, apokaliptično, non omnis moriar

\section{UvoD}

agledan u perspektivi naznačenoj naslovom rada, književni opus Vladana Desnice ukazuje se u svijetlu dvije važne pretpostavke: prva je da smrt predstavlja njegovu tematsko-motivsku dominantu, a druga da je taj fenomen u njemu umjetnički preispitan iz nekoliko nesaglasnih, nerijetko oprečnih uglova. Posmatrajući ga u kontekstualnoj ravni, Desničino djelo upoređeno, s jedne strane, sa djelom Borisava Stankovića i Ive Andrića, a s druge, sa stvaralaštvom Miloša Crnjanskog, otkriva, uz izvjesnu generalizaciju, da je, u odnosu na pomenute pisce, smrt kod Desnice prikazana u daleko većoj smisaonoj heteronomnosti. Naime, dok je u Andrićevom i Stankovićevom književnom svijetu smrt dominantno poimana sa naglašeno tragičnim predosjećanjem, a kod Crnjanskog u slutnji postojanja jedne onostrane, kako je to kritika označila, „povlašćene“ sfere, ${ }^{2}$ kod Desnice je vidna misaona kolebljivost povodom smrti u svakom pojedinačnom domenu njegovog

$\overline{1}$ Rad je nastao u okviru projekta Kulturološke književne teorije i srpska književna kritika (178013), koji finansira Ministarstvo prosvete, nauke i tehnološkog razvoja Republike Srbije.

2 Петар ЏАџит, Повлашћени простори Милоша Црнанског, БеограА 1993. 
umjetničkog ispoljavanja. Ta specifična razlika sama po sebi ne predstavlja afirmativni kvalitativni predznak u smislu Desničine prednosti u odnosu na pomenute autore, niti, pak, u pogledu „filozofske“ inkoherentnosti njegovoga opusa. Međutim, u toj distinkciji otkriva se jedno važno obilježje - Desnica je, pridajući, bilo implicitno bilo u vidu eksplicitnih refleksija, krajnje suprotstavljena značenja odgovoru na pitanje čovjekove smrtnosti, taj prostor umnih napora podredio estetskim zakonima književnog stvaranja. Shvatanje smrti je u svakom Desničinom radu funkcionalizovano u datom kontekstu, i njegov smisao uvijek je time determinisan. Ukoliko bi se, ipak, fenomen smrti posmatrao izdvojeno, onakvim kakvim ga Desnica iznova umjetnički propituje, različitost njegovih imanentnih „zaključaka“ mogla bi biti shvaćena i kao pokušaj da razmatranje metafizičkih nijansi (ta riječ pokazaće se prikladnijom nego što na prvi pogled izgleda), uzetih u rasponu njihovih najudaljenijih krajnosti, pronađe izlaz u određenom smjeru. Stoga jedno hronološki zasnovano istraživanje tanatoloških aspekata Desničinog književnog djela vodi potencijalnoj hermeneutičkoj produktivnosti, utoliko što piščev umjetnički odnos prema smrti ne isključuje lični pogled na svijet, u njegovoj podrazumijevanoj podložnosti permanentnoj promjeni.

\section{OZBILJNO-SMIJEŠNA SMRT - ZIMSKO LJETOVANJE}

Opštepoznato i razložno prihvaćeno kritičko stanovište o Zimskom ljetovanju kao romanu susreta dvaju kulturnih paradigmi, o umjetničkoj viziji nesvakidašnje civilizacijske disparatnosti geografski susjednih svijetova, pronalazi u temi smrti svoju konačnu potvrdu, ujedno i tačku nove analitičke provjere. ${ }^{3} \mathrm{U}$ pripovijednom mizanscenu toga romana smrt predstavlja motivsku dominantu oko koje pisac oblikuje svoju umjetničku zamisao. Desnica razvija jedno, za tada aktuelni književnoistorijski kontekst apartno viđenje smrti, varirajući ga u ozbiljno-smiješnom registru sve do konačne, najdubljim tragizmom prožete vizije. Pretežno realističko-naturalistički prosede sa izraženom komičkom crtom označava upravo taj, u poetičkom smislu prevratnički karakter Zimskog ljetovanja. Međutim, pisac se nije zadržao na nivou makar i superiorne literarne igre, već je na djelu očigledno stvaralački promišljena i skrupulozna realizacija plana čiji je ishod estetsko-antropološka objektivizacija konkretnog istorijskog iskustva smještenog u sjevernodalmatinski ratni hronotop.

Umjetnička uspjelost Desničinog prvog romana umnogome duguje odmjerenoj primjeni grotesknih, humornih, karikaturalnih i drugih elemenata iz komičkog repertoara, koji do stravičnog epiloga vode nepouzdanim putem drastičnog iznevjeravanja čitaočevog horizonta očekivanja. Naime, učestalost i kolektivnost umiranja u opisanom svijetu doprinijela je izvjesnoj devalvaciji smrti, u čemu je pisac prepoznao i iskoristio postojeći smjehovni potencijal. Čovjekovu paralisanost pred iznenadnim i sveopštim stradanjem, koja je u njemu pokrenula psihološki mehanizam poricanja, Desnica prikazuje u groteskno-komičnoj sceni prvog susreta preživjelih u romanu Zimsko ljetovanje:

Klasifikacija i opis identitetâ položenih u osnovi date opozicije precizno su sprovedeni u studiji: Davor Dukić, „Nekoliko imagoloških opaski o Zimskom ljetovanju i Desničinim susretima“, Desničini susreti 2005. - 2008. Zbornik radova (ur. Drago Roksandić i Ivana Cvijović Javorina), Zagreb 2010., 149-156. 
Iz puste uličice ispadne preda njih čudna spodoba čovjeka - na prvi mah ne prepoznaše je li muško ili žensko: lice mu je potpuno pepeljasto, naježena kosa strši mu na glavi, prosjeda od pepela i prašine; izbečio oči kao tenac i ide uličicom s osjećanjem živa zakopana, pogotovo $s$ nevjericom da je zbilja živ i da vidi žive ljude. Upućuje se prema njima, hoće mu se da se osjeti među svojima, među živima, da oćuti njihovu toplinu. Ali u njima pobuđuje ludi strah i nagon da bježe, s prastarom panikom s kojom su ljudi bježali od gubavaca. Nepoznati krene ravno na Ernesta, koji je bio zaostao: da mu je samo malo bliže prišao ili pružio ruku da ga dohvati, Ernesto bi bio dreknuo. On požuri i probije se usred gomile. ${ }^{4}$

Ovaj pasus predstavlja značajnu tačku u motivacijskom sistemu romana, budući da, osim što prološkom pozicijom inicira tretman teme u spektru ozbiljno-smiješnog, smisaono korespondira sa prvim pojavljivanjem građana u Smiljevcima:

U selo banuše u sam sumrak, bijeli od prašine i mrtvi umorni. Seljani su ih gledali u slutnji, raskolačenih očiju, kao ljude koji dolaze sa drugog svijeta. ${ }^{5}$

Mada nisu iskusili haos masakra sa ulica razrušenog Zadra, seljani, kako pripovjedač sugeriše, došljake posmatraju „u slutnji“ onog što se zbilo, i njhova reakcija podudarna je sa prizorom iz prethodnog navoda. I „čudna spodoba“ i grupa gradskih izbjeglica u knjizi su predočeni kao povratnici „sa drugog svijeta“, čime apokaliptički strah od smrti, koji je rat donio među likove romana, prvi put građane i seljane izjednačava pred licem sablasno izmijenjene stvarnosti.

Jedno od središnjih mjesta (u kompozicionom smislu) u Zimskom ljetovanju zauzima opis smrti popadije Darinke: XVIII, XIX i XX poglavlje posvećeni su pripremama za sahranu i sam ukop, pri čemu se pripovjedač, prema već razvijenoj praksi sučeljavanja oprečnih kulturnih perspektiva, fokusira na razlike u pogrebnim običajima gradskih i seoskih sprovoda. Svojevrsni povratak u „svakodnevnost“ od rata „nezavisne“ smrti, označio je i nov pristup temi. Smijeh se sada ne pojavljuje u tragovima pripovijedne stilizacije, već komika postaje njenim supstancijalnim određenjem:

Građanke umuknu slušajući naricaljke seoskih žena. Anita se zamisli. Da, nekad se i u tome znao red. Nisu to bila baš stroga pravila, ali postojao je neki osjećaj - nešto kao ukus - koji je u tom rukovodio, jednako kao i u njenom krojačkom zanatu, i kazivao što odgovara a što ne odgovara, što kome pristaje a što ne pristaje. I po tom osjećaju, po tom ukusu, čovjek je nepogrešivo pogađao pravu mjeru, osjećao na vlas svaku nijansu... Da, znalo se nekad!... Po tim nepisanim pravilima koja je diktirao ukus a koja su važila u njene dane, ridalo se samo za bračnim drugom, ako je brak mlađi od godine dana, ili najviše do 18 mjeseci, i za vjerenikom, ako su postojale formalne zaruke; iznimno, i bez formalnih zaruka, među umjetnički taknutim svijetom (kad je zaručnik nosio dugu kosu i kravatu la v a ll i é r e; u tom je slučaju čak vjerenica mogla koračati za sprovodom sa raspletenom kosom). Za vjerenikom ili suprugom sa štucanim brcima, kosom podšišanom „četkasto“ i sa očalima na štipaliku - za čovjekom od energična izgleda i od aktentaše - ni u kom slučaju nije se ridalo, nego jednostavno plakalo; a ako je prešao 55 godina, eventualno i samo suzilo. Isto tako suzilo se za zetom, za dobrim poslodavcem kod koga smo u službi dulje od 3 godine, za mužem najbolje prijateljice (naravno, ako nije bivao grub prema njoj), te eventualno za svakim dobrim čovjekom koji za sobom ostavlja troje ili više djece. Sto se tiče jecanja, jecanje

4 Vladan Desnica, Zimsko ljetovanje, Sarajevo 1966., 18.

5 Isto, 30. Podvukao V. B. 
uopće nije stil (i zato, kad neko počne da kontinuirano jeca, prekinu ga kao čovjeka koji je krivo zapjevao). Jecaj se upotrebljava pojedinačno, kao p i z z i c a t o, na tačno određenim mjestima: kad Pop intonira nazalno „r e q u i e m a e t e r n a m..."; kad se začuju prvi kucaji čekića koji prikucavaju poklopac lijesa; u času kad četiri crna čovjeka (s onim groznim crnim epoletama s resama!) dignu lijes sa poda; ili kad lijes - crn, uglat, naoko nepokretan zalebdi skoro bez težine na užetima u zraku nad otvorenom rakom, kao da plutâ. I možda još u dva do tri takva slučaja. ${ }^{6}$

Očito je kako pisac na nekoliko nivoa humorno razobličuje Anitino viđenje naricanja seoskih žena: građanske konvencije suprotstavljene seljačkom rutinerstvu komične su u ozbiljnosti kojom junakinja katalogizuje bizarne kriterijume za „ridanje“ prema onome što imenuje „nešto kao ukus“. Na drugom stupnju, za šta navedeni pasus daje uzoran primjer u romanu obilato primjenjivane tehnike, uočava se kako Desničin pripovjedač svoj glas upliće u frazeološko-psihološku tačku gledišta kojom je tekst u datom trenutku posredovan, i na ovom mjestu razvija poređenje ,jecanja“ sa specifičnom tehnikom muziciranja („pizzicato “), efektno karikirajući posmrtni protokol građana u njegovoj operetskoj izvještačenosti. Čitava epizoda dovedena je do crnohumornog paroksizma u završnoj sceni, kada Petrina silazi u raku da bi u sanduk (,između dvije letve [...] kao u poštansko sadnuče“) ${ }^{8}$ ubacio pismo iz šibenske ludnice, kojim pokojnicu „posthumno“ obavještava o pogibiji njenog sumasišavšeg sina tokom posljednjeg „bombardmana“. Desnica je, očigledno sa punom autorskom sviješću, od početka prema sredini romana smrt prikazivao gradacijski, u pravcu ozbiljnog ka smiješnom, da bi sliku umiranja ka završetku poveo u sasvim suprotnom smjeru.

Prizor smrti bebe Špižmice predstavlja kulminatornu tačku romana. Pažnju prije svega treba obratiti na nagovještaje kojima je Desnica diskretno sugerisao epilog radnje. Jedna vrsta umjetničke elegancije odlikuje piščeve simboličke anticipacije, budući da je njihov metasemantički karakter neupadljivo pridodat osnovnom značenjskom nivou teksta. Prvi opis dječje smrti u trećem poglavlju, karakteristično bezosjećajan - saobrazno načinu na koji su prikazane i ostale žrtve bombardovanja („vise tako dječja tjelešca, presumićena preko žica kao djetinje haljinice izvješane na sušenje“) $)^{9}$ - kritika je već dovela u vezu sa završnom scenom. ${ }^{10}$ Međutim, dosadašnja tumačenja propustila su Desničinu suptilnu simbolizaciju zooloških motiva, koja analizu neminovno usmjerava u sasvim određenom pravcu. Već na samom početku romana narator signalizira čitaocu:

6 Isto, 105-106.

7 Izrazito subjektivno obojen glas pripovjedača Zimskog ljetovanja kritika je istakla u više navrata: „Ovu knjigu s ironičnim oksimoronom kao naslovom, ne možemo nazvati romanom u pravom smislu riječi, jer umjesto radnje, zapleta i raspleta, sadrži eruditivno pričanje autora, koji ne krije svoju intelektualnu nadmoćnost i gotovo nezainteresiranost za temu o kojoj izvješćuje“" Vlatko Pavletić, Analiza bez koje se ne može, Zagreb 1961., 247. „Zanimljivo je da im se u eksploataciji toga tematskog horizonta rado priključuje i pripovjedač, u čijem se 'sveznajućem' diskursu likovi i njihove sudbine uglavnom i uspostavljaju, jer je Zimsko ljetovanje pretežno pripovjedački roman, s razmjerno malo dijaloških partija." Zoran Kravar, "Zimsko ljetovanje Vladana Desnice pod ideološkokritičkim lećama“, Desničini susreti 2010. Zbornik radova (ur. Drago Roksandić i Ivana Cvijović Javorina), Zagreb 2011., 10.

8 V. Desnica, Zimsko ljetovanje, 111.

Isto, 19.

10 „Neotklonjiva brutalnost ove deskripcije, stilski, ali ne i značenjski ublažena tek završnim poređenjem, objašnjiva je, možda, tek iz perspektive završnice celog romana, koja i sama prikazuje brutalnu, iako - makar na prvi pogled - kulturološki oprečnu scenu detinjeg stradanja, ne u strci bombardmana, nego u čeljustima životinje." Тихомир Брајовић, „Облик празнине. Културни идентитети и њихова наличја у Зимском љетовағу Владана Аеснице“, 
Ali selo ima jednu naročito ružnu stranu: to su zmije! Ima ih sva sila; svagdje i na svakom mjestu; stvore se čudom, kao iz ničega. One se odgone vonjem zapaljene krpe. Podmukle su, kao i njihovi gospodari seljaci (koje ujedaju mnogo rjeđe i mnogo manje rado nego građane); ima ih i takvih koje strelovitom brzinom jure za čeljadetom sikćući jezivo, pri čemu taj fijuk raste u tonu uporedo s brzinom zmijina kretanja, od čega se jadnom bjeguncu noge ukoče a srce skoči u grlo te ne može dalje ni makac. (Jednom je jedna majka našla smotanu zmiju pod uzglavljem svog djeteta. $)^{11}$

Odlomak svojim prvim stepenom značenja pripada onom sloju romana koji konstituiše ukrštanje suprotstavljenih imagoloških perspektiva. Međutim, njegov povlašćeni položaj u prvom poglavlju, kao i činjenica da je fokalizovan u optici Špižmicine majke Lizete, značajno doprinosi metaforičkoj čitljivosti posljednje rečenice (dodatno istaknute zagradom) u smislu tradicionalne simbolizacije smrti. Tom malom, usputnom napomenom da je majka pronašla smotanu zmiju pod uzglavljem svog djeteta Lizetina kobna pomisao na delikatan način najavljuje ishod izbjegličkog boravka u selu. Ovakvo razumijevanje uporište pronalazi i u drugim Desničinim tekstovima. Naime, u LXI poglavlju Proljeća Ivana Galeba, kada se glavni junak prisjeća smrti svoje kćerke, on njenu nasljednu porodičnu bolest metaforički imenuje riječima: „Pitoma zmija pokućarka“. ${ }^{2}$ Sličan motiv pronalazi se i u pojedinim Desničinim pjesmama. ${ }^{13} \mathrm{Zmija}$ predstavlja uobičajenu simboličku oznaku smrti u Desničinoj umjetnosti, pa tako i u Zimskom ljetovanju.

Piščeva narativna signalizacija istančano se razvija u IX poglavlju, u cjelosti posvećenom prascu Migudu. ${ }^{14}$ Migud uživa poseban tretman u zajednici kojoj pripada; kaže se, sa upadljivo humornom intonacijom, da je Migud „glavna ličnost u Ićanovom kućanstvu“. 15 Njegova privilegovanost istaknuta je i vlastitim imenom koje se obično ne daje svinjama; a „monumentalna“ pojava pripovjedački je upadljivo prokomentarisana: „izgledao je ne pojedinačni, živ krmak, nego sam spomenik svinjskom rodu“. ${ }^{16}$ Višestruko je, dakle, indicirana važnost uloge koju Migud posjeduje. Međutim, jednom marginalnom opaskom, prikrivenom u usputnosti poređenja, pripovjedač Miguda uvezuje u simbolički sistem teksta. Ićanov povratak sa sajma, na kome je kupio svog mezimca, upečatljiv je u pogledu stila:

Vozi se Ićan između njiva, pod zvijezdama; zagrnuo se crnim suknenim haljkom preko glave, klati se pijano na sjedištu i bugari nekakav napjev bez kraja i konca koji se nejasno izvija kroz grubo sukno haljka, a za njim cijuče kolo oko izlizane osovine i ocrtava u prašini zmijast trag. ${ }^{17}$

Књижевно дело Владана Аеснице. Зборникрадова поводом 100-годишњице рођења (ur. Јован Радуловић, Аушан Иванић), Београд 2007., 106.

11 V. Desnica, Zimsko ljetovanje, 8-9.

12 Владан АЕсницА, Прољећа Ивана Галеба, Београд 1990., 304.

13 Vladan DesnicA, „Začarano popodne“, Slijepac na žalu, Zagreb 1956., 9.

14 Zapažen privilegovani status ovog „junaka“ knjige potvrđuje stav o Zimskom ljetovanju kao romanu u tradiciji ozbiljno-smiješne književnosti: „Štoviše, ne može se zaboraviti da u ovom romanu jedan od aktera jeste čak jedan krmak, Migud, koji je jedini sa pravom - takoreći - biografskom karakterizacijom (poglavlje IX), što označava i ironijsku notu pripovjedača, i tragičnu grotesknost prikazane stvarnosti, i spomenutu problematizaciju figure protagonista.“ Luca VAGLIO, „Vidovi policentrizma i problematičnosti u romanu Zimsko ljetovanje Vladana Desnice“, Desničini susreti 2010. Zbornik radova (ur. Drago Roksandić i Ivana Cvijović Javorina), Zagreb 2011., 104.

15 V. DesnicA, Zimsko ljetovanje, 50.

16 Isto.

17 Isto, 51. Podvukao V. B. 
Desnica je, kako se vidi, prefinjen vodič svom čitaocu: Migud u selo dolazi putem po kojem ostaje „zmijast trag“, kao u nekakvom stravičnom ovaploćenju, ili metamorfozi Lizetine mračne slutnje sa početka romana. $\mathrm{Na}$ taj način jedan tradicionalni životinjski simbol smijenjen je novim, umjetnički individualizovanim, sa namjerom da se neselektivnost nasilne smrti proizvedene civilizacijskim posrnućem Drugog svjetskog rata u svojoj strahotnosti izjednači sa smrću u praiskonskom, prirodnom okruženju. Tu se zaokružuje misaoni obzor romana: selo i grad pred smrću gube svoje razlike, a Migud je samo jedna od njenih mogućnosti, podjednako surova kao i ona kojoj su junaci romana privremeno umakli. To je razlog zbog koga Desnica dosljedno održava ravnomjernu ekspresivnu „bezosjećajnost“ kojom su prikazani i mrtvi građani nakon bombardovanja i Špižmicina stravična smrt. Otuda tema smrti razrješava dualizam Zimskog ljetovanja - sistemi kulture, ili njeni nivoi, suprotstavljeni su sa ciljem da se pred licem opisanih stradanja izbrišu njihove razlike.

\section{NeZnATNOST POJEDINAČNE SMRTI - PRIPOVIJETKE}

U svojim pripovijetkama Desnica će proširiti umjetnički i misaoni opseg vlastitih tanatoloških varijacija. Ukoliko bi se tražio imenitelj pristupu naznačenoj tematici u tome dijelu piščevog opusa, sintagma neznatnost pojedinačne smrti pokrila bi njegovo načelno određenje. ${ }^{18}$ Pretežan broj Desničinih, naročito ranih pripovijedaka, završava smrću glavnih ili sporednih junaka, pri čemu se posredstvom pripovjedačeve koncentracije na trivijalnost úzrokâ njihovog stradanja, kao i na sam proces umiranja, potcrtava sudbinska i ljudska nezainteresovanost: njihov nestanak, uprkos imanentnom i konkretnom tragizmu, prikazan je u atmosferi opšte indiferentnosti. Desničine likove odnosi starost, bolest, samoubistvo, egzekucija, puka slučajnost, ali je svim tim smrtima zajednička ravnodušnost u kojoj se one događaju. To temeljno određenje uslovilo je niz filozofskih, etičkih, antropoloških i drugih pitanja, koja su u većem broju pripovijedaka uzorno umjetnički promišljena. Uzorna je u tom smislu priča Oko iz piščeve prve zbirke Olupine na suncu. ${ }^{19}$

U toj pripovijeci prepoznaje se jedna od Desničinih čestih tematskih preokupacija: kolizija ruralnog i urbanog mentaliteta. Za razliku od Zimskog ljetovanja, žrtva toga sudara sada dolazi iz seoske sredine, mada je veći dio života provela u gradu. To postaje glavnim uzrokom tragedije služavke Kate: neautentična pripadnost bilo kojem od dvaju svijetova proizvela je odbačenost uslovljenu, s jedne strane, Vandinom malograđanskom osvetoljubivošću, a sa druge, primitivnom beskrupuloznošću Bariše i njegovih ukućana. Desnica

18 Ivan Galeb kaže da je u mladalačkom doživljaju smrt poimao kao „znamen neznatnosti ljudske jedinke“. B. АЕсница, Прољећа Ивана Галеба, 81.

19 Sam pisac sažeo je svoju pripovijetku: „Ja bih ukratko njenu temu sažeo ovako: u učmalom, jednoličnom životu jedne sredine, jednog skupa lica - životu koji bi inače tekao tako, bez potresâ i bez znatnijih promjena, sve do smrti - desi se mali, neznatni događaj: dr Lovro okapa pogrešne kapljice u oko nekom pacijentu, i ovaj gotovo oslijepi. Od tog događaja sve se uzmrsi, uznemiri, poremeti, sudbine aktera poteku drugim tokom - i često tokom sasvim protivnim onome koji bi se mogao pretpostaviti: 'slipcu' gubitak oka postaće osnov njegovog blagostanja i značiti početak 'dostojnijeg života'; Lovri će taj događajčić biti prekretnica u njegovom bračnom životu i u njegovom sretnom živovanju uopće; a bijednu Katu koja je u čitavoj toj stvari najmanje zainteresirana i za obje strane najzaslužnija, od tog događaja nit njene sudbe odvesti će - ravno u bunar. - Eto, to je ono što sam htio da ispričam." ВАадан АЕсницА, Есеји, илании, погледи, БеограА - Приштина 1993., 180-181. 
autorskoj eksplikaciji psihološke i etičke degradacije već po sebi dekadentne Vande i lažnog prosperiteta sirotog i sirovog Bariše pretpostavlja pripovjedni prikaz neurotičnog bijega u „nemirni duh novotarija“, u prvom, i skorojevićko šepurenje pribavljenim „ugledom“, $\mathrm{u}$ drugom slučaju. ${ }^{20} \mathrm{U}$ tom smislu posebno su učinkovita Desnici svojstvena lajtmotivska uvezivanja narativnih sekvenci, koja njegove tekstove drže na najvišem stupnju umjetnič-

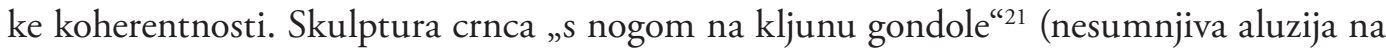
nedostižnu Veneciju iz Vandinih maštanja), koji je dočekivao pacijente u hodniku ispred ordinacije, nošen Vandinom manijom preuređivanja dobija novo mjesto u kući -

dospio je u jedan zabačeniji kutak na sumračno stubište koje je vodilo u vrtić, gdje je bio izložen vlazi tako da su uskoro počele od njega otpadati korice i ljuštiti se sedefasti odsjevi sa čalme. Sad su na kljun njegove gondole naslanjali probijeni lavor sa mekinjama za kokoši. ${ }^{22}$

Kičersko otjelovljenje filistarskog sna o životu u velikom svijetu skončava u jednom kućnom budžaku, kao simbol ćiftinog poraza od strane podlog varvarina. $\mathrm{Na}$ isti način, samo u suprotnom smjeru, semantički je funkcionalizovano poređenje u posljednjoj rečenici pripovijetke, kojim je stilizovan Katin leš na dnu bunara: „slična razapetu kišobranu nadula se mokra oblina Katine suknje“. ${ }^{23}$ Ta stilska figura u svijesti pažljivog čitaoca aktivira jednu raniju scenu: „dr. Pivčević, vragoljan bolnice i maza časnih sestara; stojeći iza leđa Furatu koji se natezao sa podosta otvrdnulom špricom, stade oponašati njegove kretnje otvarajući i zatvarajući kišobran“. ${ }^{24}$ Povezujući, u samoj završnici, posredstvom upečatljive jezičke slike dva prizora, pisac aluzivno poentira ko je prava žrtva Furatove profesionalne nemarnosti. Budući da nòsēći amblemi pripovijetke - skulptura i kišobran - bilo u svojoj materijalnoj pojavnosti bilo u naratorskoj stilizaciji postaju krhotine, dakle olupine ranijih ukrasnih, odnosno upotrebnih predmeta, Desničinom viđenju smrti pojedinca kao neznatnog događaja pribavljaju željeni umjetnički izraz.

Istovrsna „bagatelizacija“ smrti sreće se i u drugim Desničinim pripovijetkama. Florjanović je, prema poetičkoj reprezentativnosti, u tom smislu egzemplaran. Ta pripovijetka, zajedno sa pripovijetkom Oko, kao i još nekim naslovima, poput priča Pred zoru ili Bunarevac, reprezentuje u svojoj značenjskoj pregnantnosti i formalnoj dovršenosti najviši nivo Desničine novelistike. Interesantna je činjenica da sve te pripovijetke pripadaju onoj grupi u koju je sam pisac svrstao svoje „proze (...) pretežno regionalnog vida“, odvajajući ih od pripovijedaka „općenitijeg, sasvim neregionalnog karaktera“, koje, kako je isticao, „predstavljaju njegovu preču preokupaciju“. ${ }^{25}$ Desnica se ogradio od vrednosnog suda („bez obzira na valutacije“) ${ }^{26}$ ali je nesumnjivo da je opšti narativni model prvih - prevlast naracije nad refleksijom, nasuprot naglašenoj diskurzivnosti drugih - pružio više prostora njegovim stvaralačkim mogućnostima. ${ }^{27}$

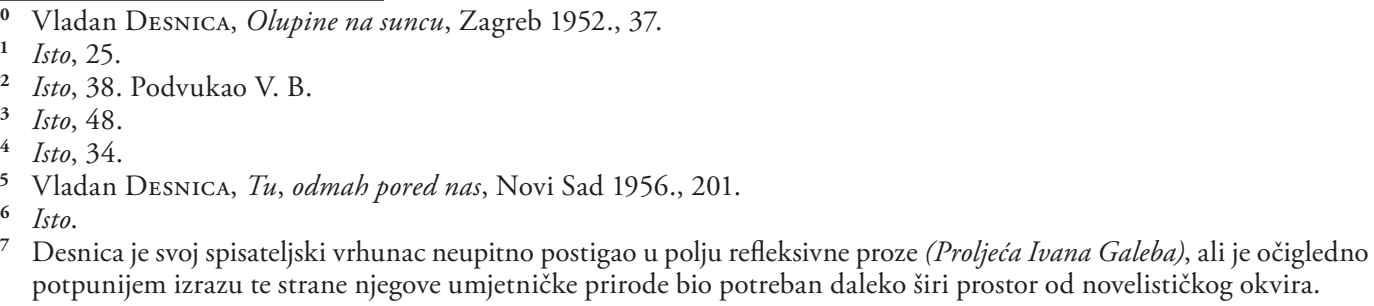
potpunijem izrazu te strane njegove umjetničke prirode bio potreban daleko širi prostor od novelističkog okvira. 
Nasuprot pripovijeci Oko, samoubistvo Celsa Florjanovića ne dolazi kao čin oslobođenja od svekolike ljudske nepravde, već kao bijeg pred zemaljskom pravdom. Pisac svog junaka spasava jednodimenzionalnosti, budući da se Florjanović u izvjesnom smislu žrtvuje za porodicu, i njegov karakter ne podliježe bez izuzetka čitaočevim antipatijama. I tu do izraza dolazi Desničina umjetnička suptilnost kada je riječ o odnosu pojedinosti i cjeline. Uopšte posmatrano, Desničina stilematika rijetko se zadovoljava primarnim, kod osrednjih pisaca i pogrešno shvaćenim zadatkom slikovitosti prikazivanja: njegova poređenja samo u perifernim, digresivnim pasusima mogu ostati na nivou jezičkog artizma sa ulogom stilske dekorativnosti. Njima se češće, sa vidnom autorskom intencijom, pridaje noseći semantički potencijal. U nesumnjivoj važnosti njegove uloge lako uočljiv detalj jeste oružje kojim će Florjanović sebi oduzeti život. Pripovjedač ga opisuje iscrpno, uz primjetno uplitanje junakove svijesti o predmetu:

Bio je to mali revolver poniklovane cijevi i s drškom od sedefa. Izgledao je bezazleno, kao da spada u garnituru s isto tako sedefnim dogledom za teatar i kao da služi samo za to da se iz njega, uz osmijeh i reverans, puca iz lože u ložu, među znancima u fraku i s papirnatim fesom na glavi. ${ }^{28}$

Napuštajući početno komični napor da oduzme svaku ozbiljnost funkciji „te spravice“, Florjanović se zatim prisjeća kada ju je prvi i jedini put upotrebio: bilo je to na povratku sa jednog porodičnog izleta, kada ih je napala „nekakva crna ptičurina“, koja se njegovoj supruzi Dolores učinila "gotovo kao nekim rđavim znamenom“ ${ }^{29}$ Metak je pticu promašio, ali je ona odletjela i izletnici su nastavili put. I tu je opet na djelu Desničino prepoznatljivo nagovještavanje - pogled unatrag osvjetljava jedan deskriptivni pasaž, vezan za trenutak neposredno pošto inspektor Raše otpočinje pregledanje Florjanovićevih sudskih knjiga, a momenat prije nego Florjanović potone u svoje evokacije - pripovjedač tada predočava ambijent u kojem će se pripovijest dalje odvijati:

Napolju se bilo skoro već sasvim smračilo. Ipak, sa visine drugog kata vidjela se u daljini, nad lukobranom, zadnja pruga svijetla na zreniku. Pred otvorenim prozorom prolijetale su kosim strelimičnim letovima lastavice bljeskajući kao sedefne strijele i smještale se sa živim predvečernjim cvrkutom u gnijezdima pod prozorskim podbojem. ${ }^{30}$

Čitalačka svijest koja, u završnici pripovijetke, taj segment teksta drži aktivnim u sjećanju, ostvaruje jednu od njegovih idealnih konkretizacija: njoj se predočava sofisticirana projekcija unutrašnjeg stanja protagoniste u hronotop priče, kojom je diskretno označena neopozivost njegove odluke. Početak istrage povezan je sa prvim Florjanovićevim pucnjem u pticu, i ishod je već tada simbolički nijansirano obilježen neminovnošću. Ukras na dršci

28 Isto, 298. Podvukao V. B.

29 Isto, 299.

30 Isto, 281. Podvukao V. B. Jedan deskriptivni intermeco u Proljećima Ivana Galeba, koji uvodi u Ivanov „mit“ $O$ čovjeku nad kojim smrt nije imala vlast dok god se kretao, preoblikuje identičan motiv: „Brujala je nad našim glavama predvečernja zvonjava, rujna, vruća, obilata - onakva kakvu je znam i nosim u sebi iz djetinjstva. Padala je na naša pogrbljena pleća oslonjena o mlake crljenkaste zidine trijema kao topli purpurni pokrov. Izgledalo je da joj nema kraja. Kao potop. Najzad je zamukla. Krošnja brončane zuke, koja kao da nije zvuk već samo golo treptanje zraka, držala se još samo oko zvonika; kroz nju su se zalijetale sa svojim crnim cijukom sedefaste strijele lastavica. Pa je umuklo i to. Tišina je sada bila sasvim prazna.“ В. АЕсницА, Прољећа Ивана Галеба, 171-172. Podvukao V. В. 
pištolja stopio se u motivu lastavice sa zloslutnim znamenjem crne ptice, a njen drugi dolazak označava Florjanovićev neumitni kraj. Florjanovićeva smrt trivijalizovana je mjestom događanja - to je sudski zahod; a sam opis toga prizora uvodi u aspekt Desničine književne tanatologije vezan za proces umiranja:

Na pucanj priskoči Raše a za njim dotrča i Šarić iz prizemlja. Florjanović je ležao u lokvici krvi. Užurbaše se oko njega, otvoriše slavinu i stadoše ga škropiti po licu. Poče mu se pomalo vedriti u glavi. Ležeći nauznak, osjećao je kao da se strmoglavljuje u prazninu, $s$ glavom nizdol. Najprije neodređeno i daleko, pa bliže i jasnije, doprije mu do svijesti tabanje njihovih nogu, sve jače i jače, udeseterostručeno, kao neko pijano i teško kolo, a on nikako ne može da se sjeti ko su ti ljudi i što to rade... Zatim se svi zvukovi počeše opet povlačiti, postepeno blijediti i gubiti se, u nekom ugodnom zanosu, kao pred usnuće. Tabanje koraka uskladi se u ritam koji uljuljkuje a štropot vode dođe mu kao šuškanje svile - i on osjeti da se nad njim nagnula i da mu se osmjehuje njegova Zoe, u ružičastom taftu, zadihana od sreće, s nakrivljenim diademom na glavi... Upinjao se da otvori oči, ali nije nikako mogao: na vjeđe mu je legla neka čudna težina, težina bez pritiska, pamučasta a nesavladiva. Sum vode u gruboj školjki bivao je sve tanji i tanji, pa se sasvim profini, ufitilji - i najzad se prometnu u srebren mlaz talijanske česme što šikće u plavo nebo, sva u suncu... A čas zatim - sve isplinu. ${ }^{31}$

Slike prestanka vitalnih funkcija organizma i rasplinjavanja svijesti junaka Desnica uobličava sa nesvakidašnjom uvjerljivošću. Pripovijetka Pred zoru, koja uz dvije prethodno analizirane ide u najuži krug piščevih vrhunskih ostvarenja, takođe posebno obrađuje trenutak nastupanja smrti. Na samom početku Desnica uvodi jednu epizodnu junakinju Zimskog ljetovanja, koja postaje slučajnom žrtvom nasumičnog noćnog puškaranja:

Ovog je puta jedina žrtva bila gluhonijema djevojka, „mutava Sava“, koja je baš u taj čas bila izašla napolje da prepne konja u djetelini. Neobjašnjiv ubod pod plećkom, gust i topao mlaz u ustima; pod njom se posjekle noge, i dok još ne zna da li da se povinuje ili da se odupre tom porivu što je baca na koljena - a već leži izvijena nauznak na ledini: nad sobom vidi modrinu neba na kome krotko žmirka bezbroj sitnih zvijezda, glava joj šumi i misao se mrsi, nekud odlaze snage i ovladava neka slatka nemoć... Primila je i to sa onim istim zadivljenim neshvatanjem kojim je primala i sve drugo u životu: štogod bi naišlo, dočekivala je pokorno, kao jedinu mogućnost - valjda nije ni znala da se stvarima može tražiti objašnjenja i pitati za smisao i razlog. ${ }^{32}$

Oba navoda ilustruju začudnu vjerodostojnost sa kojom Desnica uobličuje prizore umiranja, u dosadašnjoj kritici najčešće vezivanu uz pojam naturalizma. Uočljivo je da narator minimum pažnje posvećuje fiziološkoj strani umiranja, već da svu koncentraciju usmjerava ka posljednjim fazama čovjekovog psihičkog postojanja. Čak i kada fokus uputi na „fizički aspekt“ smrti, Desnica se usredsređuje na njegove odjeke u svijesti umirućeg: „neobjašnjiv ubod pod plećkom“" (podvukao V. B.) ne označava izmicanje van dometa pripovjedačevih izražajnih mogućnosti, već je riječ o junakinjinoj zbunjenosti koja ni sa čim ne može da uporedi iznenadni osjećaj. Pisac, takoreći, smrt opisuje „iznutra“, i u ovakvim slučajevima prije bi se moglo govoriti o psihološkom naturalizmu, nego o naturalizmu u njegovom

31 V. Desnica, Tu, odmah pored nas, 301.

32 Isto, 303. 
uobičajenom značenju. Naročito se izdvaja momenat savladavanja čovjekove volje - on predstvalja prelomni trenutak između postojanja i nepostojanja: „na vjeđe mu je legla neka čudna težina, težina bez pritiska, pamučasta a nesavladiva“; ,još ne zna da li da se povinuje ili da se odupre tom porivu što je baca na koljena“. To je čas u kome tijelo klone i preostali tračak svijesti predstavlja posljednji eho biološkog trajanja. Takvom načinu prikazivanja smrti implicitna je „filozofija“ Desničinih pripovijedaka: smrt je bezglasno urušavanje, implozija bića bez znatnog uticaja na okruženje u kojem se događa.

U pripovijeci Pred zoru Desnica umjetnički promišlja timor mortis - čovjekov strah od smrti. Glavni lik pripovijetke - Bogdan - strijeljan je odlukom prijekog suda jer je tokom okršaja partizanskih snaga i seoske straže iz svoje kuće potajno pucao na komšiju Petraša, sa kojim je odranije imao neraščišćene račune. Iako je Petraš pripadao suprotstavljenim redovima, Bogdanova priznanja, koja dolaze nakon pokušaja da prikrije svoju umješanost, neuvjerljiva su partizanima koji su upali u selo. Kao i u Florjanoviću, završni pasus prikazuje junakove posljednje časove, stavljajući akcenat na njegov doživljaj samrtničke izbezumljenosti:

U Bogdanu sve prenaglo splasnu, skljoka se tako nisko da više iz njega ne vrisnu ni očaj ni pobuna - činilo mu se da evo kroči u smrt po treći, po četvrti put. Iz nedaleka grma ispade do po trupa krava meljući utrgnutu grančicu: zastala, uprla mirne oči i vlažnu njušku u grupu ljudi. Bogdan je spazi; iz pomirene pregorenosti laznu očajno želja za životom: osjeti silnu, neodoljivu privlačnost prema toj kravi - ujedno i zavist i nostalgiju - zaželi svom snagom da mu je uteći u nju, skriti se u mračnoj i dobroj toploti njene nutrine, i poživjeti tako, slijepo i zaštićeno, bez kraja i konca... Vojnici ga privedu k hrastu, odstupe nekoliko koraka i podignu puške. Gluha lupa srca u njemu stade da buja, buja, da prerasta van njega, da mu odjekuje bolno u ušima, zagušujući i zamagljujući sve uokolo, i zvukove, i slike, i misli. I kad grunu plotun, njemu se učini da dopire s nekog drugog svijeta, i da to ne puca u nj već u njegovu praznu košulju. ${ }^{33}$

Trenutak spoznaje neopozivosti smrti Desnica prikazuje kao jednu fazu umiranja. Zaglušujuće rastući strah dovodi Bogdana do postepene psihičke redukcije: od osjećanja zavisti prema životinji, preko krajnje inhibicije čula, do iluzije smrti momenat prije samog njenog nastupanja. Pripovjedačko uživljavanje u Bogdanovu prestravljenost prikazuje posljednju etapu svijesti čovjeka koji, ne videći apsolutno nikakvu mogućnost bijega od smrti, izlaz apsurdno traži u njoj samoj. Kada je Bogdan prvi put istinski spoznao šta mu se sprema, narator njegov unutrašnji psihološki obrt opisuje upečatljivim poređenjem: „On gotovo nagonski osjeti u sebi poriv prema istini, kao što pritiješnjena zvijer pogodi na izlaz iz zatvorenog obruča. “34 Taj obruč se pred streljačkim vodom sasvim zatvorio i njegova svijest, pritisnuta neizdrživim strahom, instinktivno otpočinje svoju dezintegraciju čas prije nego je puščano zrno faktički inicira. Pucanj „u njegovu praznu košulju“ može se uzeti kao najizrazitija metonimija poimanja neznatnosti pojedinačne smrti, kakvom je Desničine pripovijetke u piščevim najboljim stvaralačkim trenucima uobličuju. Ovoga puta takvo viđenje smrti posredovano je sviješću umirućeg subjekta, i pripovijetka predstavlja konačni izraz

33 Isto, 313-314.

34 Isto, 308. 
autorovih nastojanja da svojoj viziji pribavi umjetničku i misaonu punoću, pridružujući je najvišim dometima u toj tradiciji evropske proze. ${ }^{35}$

\section{DJETINJI DOŽIVLJAJ, KARNEVAL SMRTI I METAFIZIČKO PREDOSJEĆANJE - PROLJEĆA IVANA GALEBA}

Smrt u Proljećima Ivana Galeba predstavlja jednu od kontrapunktskih tematskih linija, upravo onako kako sam podnaslov knjige sugeriše: Igre proljeća i smrti. Fundamentalna strukturna karakteristika romana - njegova preovlađujuća homodijegetička perspektiva predodredila je autorov pristup „u suštini jedinoj temi pjesnika“ ${ }^{36}$ Dominantni naturalizam Zimskog ljetovanja i u osnovi realistički postupak u Desničinim pripovijetkama smijenjeni su poetsko-fenomenološkom esejizacijom - meditativnom analizom tanatoloških aporija glavnog junaka. Proljeća Ivana Galeba umjetnički istražuju čovjekovu neposrednu antagonizovanost sopstvenoj konačnosti, njegovo izravno misaono sučeljavanje sa neizbježnim epilogom svake egzistencije. ${ }^{37}$

Desnica je u svom kapitalnom djelu sumirao, ali i prevrednovao vlastita umjetnička promišljanja smrti. Proljeća Ivana Galeba u tom smislu predstavljaju i jednu vrstu autopoetičke ratifikacije piščevog lirskog opusa, budući da se jedino u njegovoj poeziji, kako u zbirci Slijepac na žalu, tako i u nepublikovanim pjesničkim tekstovima, mogu pronaći tragovi i temeljnije literarne razrade antropološkog i metafizičkog optimizma. ${ }^{38}$ Slika vedrog dana, kao metafora transcendencije sa ne sasvim oprečnim, ali bitno drugačijim predznakom u odnosu na pesimističko predosjećanje praznine - bešćutna, lelujava prisutnost minimalnog ostatka bića na granici ovozemaljskog postojanja i onostranosti, to su varijacije Galebovih refleksija, začetih u nekim Desničinim pjesmama. ${ }^{39}$

35 Uр. Виктор Иго, Последюи дан насмрт осуђенога, Крањево 1987.; Fjodor Mihajlovič Dostojevsкі, Idiot, Beograd 1983.

36 „Smrt je u suštini jedina tema pjesnika.“ В. АЕсницА, Прољећа Ивана Галеба, 80.

37 „Zimsko ljetovanje Vladana Desnice je posredno traženje odgovora o smislu egzistencije. (...) Prvi je roman šire postavljena slika sraza dvaju načina egzistencije: primitivne i civilizirane, a drugi, Proljeća Ivana Galeba, individualni je revolt protiv postojećeg živovanja.“ Gajo Peleš, Poetika suvremenog jugoslavenskog romana, Zagreb $1966 ., 120$.

O tome vidjeti: Vladan BAjČEta, „Slijepac na žalu. Poezija Vladana Desnice“, Vladan Desnica i Split 1920. - 1945. Zbornik radova sa znanstvenog skupa Desničini susreti 2014. (ur. Drago Roksandić i Ivana Cvijović Javorina), Zagreb 2015., 125-145; Vladan BajČETA, „Gozba u poljima. Fragmenti rekonstrukcije pjesničke zbirke Vladana Desnice u rukopisu“, Split i Vladan Desnica 1918. - 1945.: umjetničko stvaralaštvo između kulture i politike. Zbornik radova sa znanstvenog skupa Desničini susreti 2015. (ur. Drago Roksandić i Ivana Cvijović Javorina), Zagreb 2016., 459-481; Vladan BAJČETA, „Nekoliko pjesama Vladana Desnice u rukopisu“, Hrvatsko-srpski/srpsko-hrvatski interkulturalizam danas. Zbornik radovas međunarodnoga znanstvenog skupa Desničini susreti 2016. (ur. Drago Roksandić), Zagreb 2016., 259-282.

Desnica je preosmislio i nadgradio tradicionalne predstave smrti bliske takvom poimanju, uobličivši osobeno umjetničko shvatanje smrti u duhu jednog panteističkog spiritizma. Up. „Zar nije umrli kod spiritista lutalačka duša i slabi dašak, utvarna replika vidljivog oblika? U stvari, ta filozofija lišavanja, zamenjujući kvantitativne degradacije razlikama, po samoj prirodi jeste ujedno filozofija antropomorfnih ili biomorfnih analogija, jeste filozofija koja zagrobni život smatra nekom vrstom podživota, odnosno onemoćalog, prigušenog i razređenog života. Takav je podzemni svet u Odiseji, oslabljena kopija zemaljskog života, takav je taj podzemni pod-svet u kom je utvarni Ahil pandan ovozemaljskom Ahilu od krvi i mesa, svet u kom je sve magluština i dim, prigušeni odjek i izbledela senka; tamo se život stvarnog sveta svodi na neprimetno brujanje, na šapat, na pijanisimo."Viktor JANkELEvič, Smrt, Beograd 2017., 97. Ta Desničina predstava rezonira i sa različitim mišljenjima u tradiciji evropske filozofije. Na primjer, saglasno joj je Lajbnicovo uvjerenje da je „nepostojanje minimalno postojanje“ (Isto, 368) ili Hajdegerovo shvatanje 
Prvo pominjanje smrti u romanu vezano je za sudbinu Galebovog oca. Priča o misterioznom nestanku mladog pomorca, zapovjednika na jedrenjaku Margarita, obojena je pučkim nagađanjima tipično romantične imaginacije. Konsekventno umjetničkoj i idejnoj koncepciji romana, glavnom junaku se od svih pretpostavki najuvjerljivijom činila jedina koja je po svojim odlikama zaobišla njihov preovlađujući karakter. Prihvatajući intimno najvjerovatnijom mogućnost da mu je otac umjesto u brodskoj pobuni ili u tajanstvenom životu u Južnoj Americi skončao na pučini od zapleta crijeva, Galeb već tada otkriva jednu stranu svoje opsesije smrću, vezanu za tjelesni i donekle trivijalni vid čovjekove propadljivosti. ${ }^{40}$ Međutim, odaljujući se od pseudoodisejskih narativa sitnograđanske mašte, Galeb ne odlazi u ekstrem banalizacije očeve smrti, pa i smrti same po sebi, već između krajnosti neprijatno očigledne biološke trošnosti organizma i slutnje višeg, paralelnog, ili ma kakvog drugog oblika egzistencije izvan fizičkog postojanja, pronalazi ishodište u jednoj individualnoj mitologiji. Otuda i dolazi zaključak o očevoj tragediji kao nekakvom ipak mitskom događaju: „I taj mal del miserere je jedna od riječi koje su onda u mojoj nutrini odjekivale, a i danas odjekuju, golemim mitskim odjekom. ${ }^{\text {" }}$

Ivan Galeb tu svoju „mitologiju“ smrti gradi na suprotstavljanju čovjekove infantilne ravnodušnosti, sa jedne, i zrele zabrinutosti pred vlastitom konačnošću, sa druge strane. Stoga on već u uvodnim poglavljima iskazuje čuđenje nad činjenicom da svekolika religioznost nije pronašla izraza jednoj takvoj viziji smrti:

Bilo je sijaset religija i filozofija koje su tvrdile da čovjek ima dušu, i da je ta duša beskrajna i besmrtna. A često mi je bivalo čudno što nikad i nigdje nije postojalo vjerovanje da dijete ima beskrajnu i besmrtnu dušu, pa da je kasnije, kad odraste, izgubi. ${ }^{42}$

Ovaj iskaz posjeduje eksplikativno jezgro Galebove tanatologije, a umjetnička uspjelost Desničinog junaka najvidljivija je upravo u načinu na koji je u romanu razvijen takav njegov odnos prema smrti. Hipersenzibilni dječak veoma rano, u predmetima i pojavama iz svog okruženja, predosjeća prazninu postojećeg svijeta:

$\mathrm{Na}$ stolu u blagovaonici stajala je, kao ukras, blistajući među ispijenim šoljicama kave i pepeljarama prepunim čikova, srebrna kutija za biskvit u obliku globusa. Na laki dodir skrivene opružnice, gornja bi polutka naglo zijevnula i podvukla se pod donju. Kad bi mi dosadili razgovori starijih i zamorila me moja zapažanja, uzeo bih se igrati tom kutijom. Nebrojeno puta uzastopce pritiskao sam opružnicu i nalazio kao neko malo čudo u tome kako se sjajna, ispupčena oblina gornje polutke odjednom preokrene i kako, mjesto nje, najedanput zijevne praznina: nabubrela punoća oblika naglo se preobrati u šupljinu, u prazan prostor, u jedan mali bezdan mraka, postojanje se odjednom prometne u nepostojanje. Nebrojeno

relacije tubitka i fiziološke smrti: „Završavanje Živoga nazvali smo skončavanje. Utoliko što i tubitak 'ima' svoju fiziološku, životu sukladnu smrt, ali ne izoliranu kao ontičku, nego suodređenu njegovom izvornom vrstom bitka, i utoliko što se pak tubitak može završiti a da ne umre zapravo." Martin HeidegGer, Bitak i vrijeme, Zagreb 1985., 281. Pisac, dakle, misaono uporište ima u različitim filozofskim pretečama, što je od značaja jer ističe činjenicu da je originalnost umjetničke forme njegovog djela prvo što ga vrijednosno obilježava u kontekstu tradicije na koju se prirodno nadovezuje.

40 Ivan Galeb se, prema prirodi okolnosti, često osvrće na proces bolesničkog umiranja, naročito u njegovoj nemilosrdnoj nasumičnosti koja neumoljivo zatiče i djecu. Uр. В. АЕсницА, Прољећа Ивана Галеба, 54-56; 56-58; 91-93.

41 Isto, 25-26.

42 Isto, 53. 
puta, velim, ponavljao sam tu igru, nebrojeno se puta naslađivao i draškao tim spremnim, reskim zijevanjem jedne male, automatske smrti. Sklapao sam oči da bih na tankoj kožici vjeđa osjetio te male zapahe ništavila. ${ }^{43}$

Pisac dosljedno uobličuje Galebovo apokaliptičko poimanje ljudske smrti, zasnovano na pretpostavci o mikro-makrokosmičkoj homologiji. Svaka smrt je, kako će biti zapisano na drugom mjestu, ,jedan mali kataklizam“. ${ }^{44}$ Galebova percepcija iznova se zadržava na onim fenomenima koji u njegovoj svijesti potvrđuju tu ontičku podudarnost: u slučaju igre sa srebrnom kutijom za biskvit na isti način kao i u nekadašnjoj „igri miša“. ${ }^{5}$ Budući da Galeb ishod svoje igre naziva „automatskom smrću“, globusni oblik predmeta njegove fascinacije nedvosmisleno sugeriše ideju o pojedinačnoj smrti kao katastrofi opštih razmjera. Činjenica da i u ovom motivu dječja igra uzrasta do metafore demijurškog ludizma (kao i u igri miša) vodi shvatanju da Galeb intenzivno sluti fatalnu nezainteresovanost ma kakve onostrane instance za čovjekov život, odnosno za njegovu smrt. Takvoj metafizici Desnica je dao umjetnički izraz koji u sebi spaja čovjekovu prigušenu jezu apsolutne prepuštenosti volji slučaja sa vedrinom dječje zanesenosti u igri.

To paradoksalno viđenje smrti produkuje i Galebov komički pristup dominantnoj temi romana, ispoljen na jezičkom planu. ${ }^{46}$ Oduzimajući prvobitno prihvatljiv iskupljujući karakter završnici života („Smrt je ono što stvarima daje posvetu“), ${ }^{47}$ Galeb insistira na promašenosti individualnih napora da se izborom smrti pribavi izvjesno iskupljenje. Patetici herojske žrtve on suprotstavlja pasivno kliničko odumiranje:

General umire. Nastojim da ga žalim. Trudim se da saosjećam s njim. Na koncu, to mi je i dug samrtničke solidarnosti!... Jest, moj tužni generale! Ovo nije herojska smrt, smrt u švipsu slave, smrt kao činjenje. Ovo je privatna, pasivna smrt, smrt kao podnošenje. Smrt nauznačke. "Ja umirem", "Ja dajem život!", "Ja ću poginuti“! Dakako, tu sam ja onaj koji nešto čini, tu sam ja glavno lice, gospodar situacije! Ne, dragi gospodine! Ovdje se ne umire tako! Nećeš ništa ti, nego će nešto tebe. Nećeš ti nišsta dati, nego će ti nešto biti oduzeto! Nećeš ti poginuti, nego ćeš naprosto biti poginut!... ${ }^{48}$

Subjekatsko-objekatska inverzija u rečenici „Nećeš ništa $t i$, nego će nešto tebe intenzivira se, u zaključnom iskazu, do svojevrsnog sintaksičkog apsurda, kao izraza piščevog nastojanja da čovjekovoj bezuslovnoj podređenosti smrti pronađe odgovarajući pandan u stilskoj ravni. Komička učinkovitost ovakvoga obrta počiva na implicitnoj dekonstrukciji jezičke logike, koja „podsvjesno“ u sebi nosi upisanu težnju za aktivnim učešćem u činu ultimativne negacije ukupne čovjekove volje: „Nećeš ti poginuti, nego ćeš naprosto biti poginut.“

43 Isto, 46.

44 Isto, 80.

45 „To malo stakalce u djetinjim rukama i jedna zarobljena zraka božjeg sunca bili su kadri da djetetu dadu iluziju da je i samo postalo jedan mali gospod bog. Besprostoran i posvudašan; i, onako pritajen iza žaluzija, nekako ugodno odsutan iz svijeta i zbivanja, a opet ne sasvim bez uvida u njih, ne sasvim bez saznanja o njima." Isto, 23-24.

46 Na postojanje ironijsko-parodijske dimenzije u tretiranju teme smrti već je skrenuta određena pаžnја: Јован АЕ $и$ Ћ, „Чежња за бесмртношћу и негативна утопија (О једној тематској минији у роману Прољећа Ивана Галеба Вцадана Аеснице)“, Книжевно дело Владана Аеснице, 35-50.

47 В. АЕсницА, Прољећа Ивана Галеба, 80.

48 Isto, 234-235. 
Stihijsko umiranje u Zimskom ljetovanju, kako je već predočeno, posredovano je neutralnom deskripcijom koju ne prate neposredne naratorske refleksije inače personalizovanog i zainteresovanog pripovjedača. Ivan Galeb će i povodom takvih, katastrofičkih, kolektivnih stradanja, iznijeti karakteristično mišljenje:

Tek u izuzetnim vremenima, u epohama općih poremećaja, revolucija, kataklizama, život zna da odstupi od linije i da upadne u stilske nedosljednosti. Tad ljudske sudbine poprimaju nevjerovatne tokove, a ljudski životi završavaju čudnovatim, nezamislivim završecima. To su kao neka pokladna doba čovječanstva. Svijet izgleda kao neki fantastični vašar, kao neki pijani tête masquée, u kome svak nosi na glavi jednu neodgovarajuću, apsurdnu smrt kao jednu ludu karnevalsku kapu. ${ }^{49}$

Ivan Galeb je ovim zaključkom u svoju fenomenologiju smrti uveo novu perspektivu, budući da su njegova promišljanja posvećena prevashodno njenim suštinskim određenjima, izvan odgonetanja fatumskih putanja pojedinačnih, kao i zbirnih umiranja. Upadljivo je poređenje kojim se Galeb služi: epiteti pokladni, vašarski, karnevalski upućuju na temeljna obilježja ozbiljno-smiješne, karnevalske koncepije umjetnosti. Otuda se može pretpostaviti da je Desnica na izvjestan način eksplicirao pojedine ideje koje su u nekim njegovim ranijim djelima, osobito u Zimskom ljetovanju, bile tek u jednoj mjeri nagoviještene i kritički prepoznate.

Ishod svojih, na različite načine razrješavanih tanatoloških nedoumica, Ivan Galeb sažima u završnim poglavljima romana. Posljednja operacija, koja iznova uzrokuje prelazak iz budnog stanja u obamrlost, dovela je do graničnih okolnosti u kojima cjelokupno Galebovo iskustvo dospjeva do tačke svoje esencijalizacije. ${ }^{50} \mathrm{U}$ jednoj poetski inventivnoj sintagmi sabira se njegovo završno predosjećanje, pa djelimično i iskustvo zagrobne egzistencije:

Misao se mrsi. Na mahove oko mene zjape bezdane bijele praznine kroz koje propadam. Pa prestaje i to. Bijela tišina bez vremena. Sedefasti odsjev za vjeđama. Vječnost. ${ }^{51}$

To su završne rečenice LXXII, pretposljednjeg poglavlja djela, svojevrsnog romanesknog krešenda Galebove postnarkotičke levitacije između postojanja i ništavila. U tome sintagmatskom spoju, obilježenom sublimnim umjetničkim osjećanjem jezika, koncentrisana je ona epifanijska energija književnog izraza koja semantički ozračuje sve ostale, naročito tematski umrežene koordinate. Da bi se potpunije razumio epilog Galebovih igara proljeća i smrti, potrebno je sa te tačke uputiti pogled ka ključnom mjestu njenog saoznačavanja:

Za školjku, zajedno s njom umire nebosklon njezine sedefne kore. Za marvinče, s njim umiru samo jasle; jasle i rudo. Do Kolumba, s čovjekom su umirala tri kontinenta; poslije Kolumba četiri, a još kasnije pet. A s ponekim umiru čitave galaksije. ${ }^{52}$

Mada Desničin duhoviti katalog eksplicira da sve što je iskustveno, čulno i racionalno spoznato, bez izuzetka nestaje sa smrću, ipak je u njegovom razrješenju poetski nagovije-

\footnotetext{
Isto, 260.

50 Istaknuto je da se smrt kod Desnice „pojavljuje kao izuzetna i nezamenljiva saznajna pozicija“. Араган СтојАновит, „Јас живота и јас смрти“, u: ВАадан АЕсницА, Прољећа Ивана Галеба, Београд 1982., 430.

51 В. АЕсницА, Прољећа Ивана Галеба, 340. Podvukao V. В.

52 Isto, 80. Podvukao V. B.
} 
štena mogućnost transcendentnog opstojanja jednog, svjetlosnog sloja bića, lišenog onog što je tokom života opaženo i doživljeno. Prelivanje, neodređenost boje sedefa, poslužili su Desnici da pruži odgovarajući izraz Galebovoj konačnoj spoznaji. Desnica krajnju mogućnost izrecivosti njegove metafizičke slutnje pronalazi u opalescentnoj kolebljivosti sedefne materije. Veličanstvenost Galebove vizije svoju najvišu tačku time pronalazi u onome sloju iskaza koji fenomenologija književnosti imenuje mjestom neodređenosti: iza spuštenih vjeđa, kao iza sklopljene školjke, čitalačka imaginacija otkriva biser u simboličkoj dvoznačnosti, koja podrazumijeva njegovu dragocjenost i trajnost.

\section{NeMOguĆNOST NAPUŠTANJA EgZISTENCIJE I POVRATAK SMRTNOSTI - LJESTVE JAKOVLJEVE I PRONALAZAK ATHANATIKA}

U svojoj jedinoj objavljenoj drami Ljestve Jakovljeve $e^{53}$ Desnica se umjetnički intenzivnije koncentrisao na određene etičke probleme, kao što je to činio i u nekim drugim svojim djelima, naročito u pripovijetkama Pravda, Formalista, Bog sve vidi, ili Susjedi. ${ }^{54}$ Dijalozi esejističke iscrpnosti u prvom činu drame, vođeni između prijatelja Jakova Pećine i Petra Orljaka, tematizuju moralnu kredibilnost izvjesnih intelektualnih načela i građanskog ophođenja pod okolnostima nacističke okupacije, u, kako je u zaglavlju istaknuto, „nekoj evropskoj zemlji“. 55 Tu se, naime, postavljaju pitanja smisla pobune, odnosno držanja linije manjeg otpora pred konkretnim istorijskim i ideološkim izazovima. ${ }^{56}$ Opsežno teoretizujući svoj svjesno oportunistički stav, koji je u stvari vješta racionalizacija suštinskog kukavičluka, Jakov Pećina je, nakon sve opresivnijih mjera vlasti nad njegovim bližnjima, primoran da zatraži pomoć od druga iz djetinjstva Jozefa Hubera, sada šturmfirera u svom zavičaju. Tokom raspleta - koji dolazi sa Jakovljevom oniričkom vizijom u drugom činu,

53 Osim Ljestava Jakovljevih, Desničino življe zanimanje za dramsko književno stvaranje svjedoči nedovršeni rukopis pronađen u piščevoj ostavštini pod naslovom Gadni mali gnom, od kojeg su ispisana dva od tri predviđena čina. Interesantna je činjenica da se i taj dramski tekst bavi istom istorijskom epohom kao i Ljestve Jakovljeve. O tome opširnije vidjeti u: Dušan Marinković, „Nove spoznaje o Vladanu Desnici“, Desničini susreti 2005. - 2008. Zbornik radova (ur. Drago Roksandić i Ivana Cvijović Javorina), Zagreb 2010., 251-252.

54 Up. „U Proljećima Ivana Galeba i u većem dijelu novelistike Desnica je stavio u središte svojih analitičkih razmatranja ljudsku jedinku izoliranu od pripadajućeg društvenog konteksta. Njega je zanimao čovjek po sebi, oljušten od utjecaja ideologije, religije, politike. Ni odnos Ja-drugi ne postavlja se u tim djelima kao problem: pitanje ljudske 'samoodgovornosti' ostaje izvan žarišta Desničina interesa. Desničin je čovjek potpuno slobodan, bez definiranih moralnih obveza, upućen jedino na intelektualističko seciranje sama sebe. Posljedica je takva opredjeljenja bila ta da je jedan značajan krug prije svega etičkih pitanja ostao zaobiđen." Krešimir Nemec, Vladan Desnica, Zagreb 1988. 109.

55 Vladan Desnica, Zimsko ljetovanje. Pjesme. Ljestve Jakovljeve (= Sabrana djela Vladana Desnice, knj. I), Zagreb 1974., 269. Up. „Drama Ljestve Jakovljeve nastala je 1961. i svojom se radnjom vezuje za 'neku europsku zemlju pod okupacijom' (kako autor Desnica navodi u uvodu svoje drame), a zapravo uz prostor grada Zagreba početkom Drugoga svjetskog rata.“ Helena Peričić, „Jezik ideologije i ideologija jezika u Desničinoj drami Ljestve Jakovljeve“, Desničini susreti 2010. Zbornik radova (ur. Drago Roksandić i Ivana Cvijović Javorina), Zagreb 2011., 50.

56 Up. „U Ljestvama Jakovljevim ljudska je autarkičnost podvrgnuta žestokoj kritici. Drama počiva na svojevrsnoj moralnoj kazuistici: konformistički kompromis, neangažiranje u presudnom trenutku, neodgovornost prema bližnjima i davanje prednosti osobnim interesima - sve to završava moralnom katastrofom. “Jadranka Brnčić, „Problem etičkog angažmana u Desničinim Ljestvama Jakovljevim“, Intelektualci i rat 1939. - 1947. Zbornik radova s medunarodnog skupa Desničini susreti 2012. (ur. Drago Roksandić i Ivana Cvijović Javorina), sv. 1, Zagreb 2013., 48. 
a čija se prava priroda otkriva tek u posljednjoj sceni (čitaocu / gledaocu Jakovljev san predočen je kao razvoj situacije), u dijaloški prostor ulazi i tema smrti, tretirana na način bitno drugačiji u odnosu na ostale Desničine književne tekstove. Razgovor između Jakova i njegove bivše ljubavnice Vere središnje je mjesto piščevih novih tanatoloških propitivanja:

JAKOV: Čekaj!... Ostani uza me još časak!... Tako sam neizrecivo sam!... Kaži, što je tamo? Mi smo ovdje tako željni nekog otkupljujućeg saznanja!... Je li tamo odmor, zaborav, san? Bezbolnost i šutnja?... (Hvatajući je za oba zapešća.) Reci mi, Vera: kakvu poruku donosišs? Što je zapravo smrt? Kako izgleda nepostojanje? Nikako ne uspijevam da to sebi predočim!...

VERA: Moram da te razočaram, prijatelju moj! Grdno su se prevarili u računu oni koji su sav život sračunali na to konačno ništa.

JAKOV (bolno pogođen): Zar dakle nema te tačke gdje prestaje ova nesnosna podvojenost bića, gdje se najzad smiruje vječita dijalektika nadvagivanja tanjirâ na tezulji? Zar ni u samom krilu smrti ne prestaje jeza bitisanja, strah od smrti, strah od straha?...

VERA: Ne tješi se obećanim rajem ništavila! Jedina poruka koja može da se donese, glasi: sve je postojanje. Samo ništa ne postoji. Ništa je ljudski izmišljaj - jedini ljudski izmišljaj: sve što su ljudi, u tami gluhih tisućljeća, uspjeli da doista izmisle - to je ništa!... U tome i jest strahota, mili moj!... Svijet je robijaškim lancem prikovan za postojanje - Mazepa na hatu postojanja što juri ko zna kamo i ko zna zašto!...

JAKOV (jekne): O, grozne kazne!... Ni pakao gore ne bi izmislio... (Ostaje utučen, s licem među dlanovima. $)^{57}$

Desničino umjetničko shvatanje smrti - od Zimskog ljetovanja, gdje je ta tema prikazana u ozbiljno-smiješnom registru, preko pripovijedaka, koje umiranje dominantno predstavljaju kao tragični trenutak ispražnjen od svoje suštine, do Proljeća Ivana Galeba, u kojima je smrt na kraju viđena kao put u jednu ambivalentnu vječnost - zaokružuje se Ljestvama Jakovljevim kroz krajnje pesimističku viziju nemogućnosti napuštanja egzistencije. Desnica je sada uobličio sliku smrti u polaznom smislu podudarnu pojedinim njegovim pjesmama, ali prema suštinskim karakteristikama posve opozitnu tim poetskim refleksijama. Riječ je o horacijevskom non omnis moriar, lirski preformulisanom u dva potencijalna vida redukovanosti bića. ${ }^{58}$ Naime, dok je u Desničinoj poeziji smrt prizivana „da poštedi samu jednu zraku svijesti“ nosti vječnog trajanja u jednoj opskurnoj postegzistenciji.

Ništavilo je sada prikazano kao nedohvatni izlaz iz opšte torture straha i satiranja, koja kroz istoriju iznova premašuje spoznate granice čovjekove infernalne prirode. Dati navod predstavlja zgušnjavanje piščeve psihologije apsurdnog bijega od nasilne smrti u samu smrt, razvijene u pripovijeci Pred zoru. Stoga je ova „drama intelektualca“, barem u toj zamisli, umjetnički uspjela predstava nedostatnosti razumskog napora da se smrt pojmi u njenoj suštini. Ujedno, tu se nalazi zaključak piscu očevidno intrigantne ideje da okolnosti umiranja mogu odrediti njegov metafizički ishod. Čežnja Ivana Galeba za smrću „u suncu i

\footnotetext{
57 V. Desnica, Zimsko ljetovanje. Pjesme. Ljestve Jakovljeve, 320-321.

58 U pitanju su pjesme Slijepi aed, Molitva razočaranog Isusa, Dobrostiva smrt i Non omnis. Up. V. DesnicA, Slijepac na žalu, 7, 41, 52 i 57.

59 V. Desnica, Slijepac na žalu, 52.
} 
jasu“ i njegov vapaj „umrijeti u jedrini dana"60 mjesta su kristalizacije takvog umjetničkog viđenja sveopšte egzistencijalne izvjesnosti. ${ }^{61}$

Desničin nedovršeni roman Pronalazak Athanatika radikalizuje zaokret u tematizaciji smrti započet dramom Ljestve Jakovljeve. Riječ je o umjetničkom pokušaju da se smrt sagleda u svijetlu graničnih trenutaka moderne civilizacije, ovoga puta kao pokretač, a ne kao posljedica totalitarnih koncepata epohe. Serum besmrtnosti koji bi odredio konačni kriterijum društvenog raslojavanja čovječanstva poslužio je piscu kao motiv inspirativan za satiričnu obradu. Haos nastao otkrićem athanatika doveo je do ultimativnog paradoksa humaniteta - izbora između potencijalne besmrtnosti i opstanka same zajednice. Razvijajući sliku društva ,izliječenog“ od smrti, Desnica je u takvoj antiutopijskoj mogućnosti na izvjestan način dovršio tanatološki

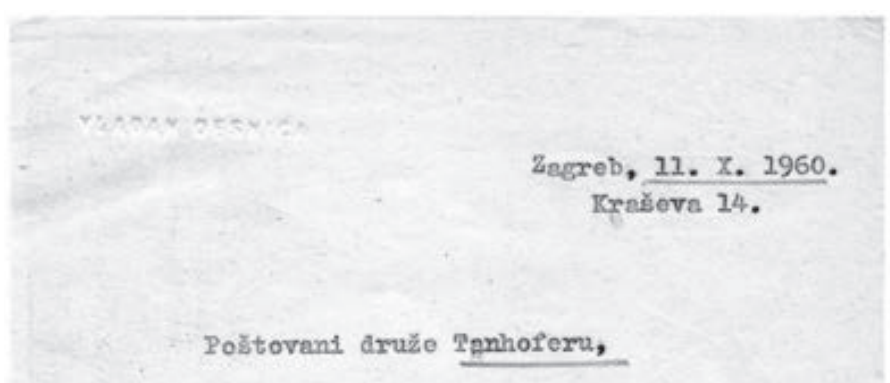

Telent "Ijestava" noreo sam da deden sa nokekav jubilernt aborntle kogi će 1z1ó1 poǒetron jenuara, u snclicu proslave, a sndržavet to soden

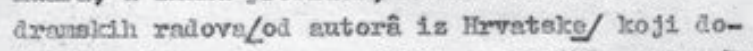
Eั1v1 javaju proul joru u jubilarnoj 1961 godint/Bo.

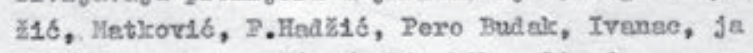
- sedmos se no ajob́an/. B10 hih volio da sell nogeo sečlenti pronif jeru, ali eto 1spalo jo talco. $\mathrm{U}$ tolcatu ses Ircsiv, IROC̆KU 1mijenio u VERU, Vi RoČxग, s "Zap1se na xubu stvernost1" $u$ "Zap1se na ivta1 atvomosti, 1 1zbscio one dvije atren1ce - scenu budjenja ne leoneu I. đ̀ine. Drugo je sve ostalo kelco jest. Tollko da mate. Alco Ven padno ne un ds b1 јоษ̆ nešto telcvo trobalo 1 . mijentti doif je etvax $u$ štanpi, jav1te ni.

Kelco ste V1? Ind ćete a Beogred? Nko nunjexnvate preleinuti put u Zagrebu, javite mi kertom pa da se enetenoso.

Srdac̆no Ves pozdravijou Vaă

Sl. 1. Pismo Vladana Desnice Tomislavu Tanhoferu o Ljestvama Jakovljevim spektar svoje literature. „Jedina tema pjesnika“ pronašla je, dakle, u „lirskom“ modelu Desničinog rada, umjetničke odjeke metafizičkog optimizma, dok je u epskim i dramskim djelima više na snazi misao obilježena antropološkim pesimizmom. Zimsko ljetovanje, pripovijetke, Ljestve Jakovljeve i Pronalazak Athanatika, za razliku od Slijepca na žalu i Pro-

60 В. АЕСницА, Прољећа Ивана Галеба, 78.

61 Tu ideju Desnica je autoironizovao u pripovijeci Proljeće u Badrovcu kroz naratorski komentar posljednjeg pokušaja junákâ da umiruću kravu podignu na noge: „Bolje da umre ovde, ako već mora! Neka ponese sobom, u ušima i očima taj meket jaganjaca i to blistavilo livade, kao što ustrijeljen zec ponese u zubićima još svježu vlatku utrgnute trave! Neka ponese puna čula te svjetlosti i tog svježeg proljetnog mirisa na onaj kravlji drugi svijet (kojega, znam, nema, kao što nema ni našeg ljudskog, ali koji ipak, onim neuništivo djetinjskim dijelom mog bića koji zaklanjam dlanovima da ga vjetri ne ugase, volim zamišljati da postoji)!“Vladan Desnica, Proljeće u Badrovcu, Beograd 1955., 120 . 
ljeća Ivana Galeba, smrt prikazuju kao metafizički nepovoljan epilog egzistencije. Stoga se za Desničino poimanje smrti, uprkos ponuđenim analogijama, može zaključiti da je u obzoru evropske književnosti krajnje apartno, budući da ga određuje kontekst u kojem se opisivana smrt događa, i da takvo shvatanje prati konsekventna distinkcija u pogledu književne genologije.

\section{ZAKLJUČAK}

Desničina književna tanatologija predstavlja izrazito kompleksnu umjetničku viziju smrti. Tražiti u toj složenosti piščev konačni odgovor na temu koju je iznova crpio predstavljalo bi metodološku pogrešku: upravo u toj polifoniji umiranja, koja se ispoljava u pojedinačnim i kolektivnim stradanjima, egzekucijama i samoubistvima, skrajnutim bolničkim propadanjima i tihim sobnim dotrajavanjima, trivijalnim i tragičnim skončavanjima, Desnica je, naročito u Zimskom ljetovanju i pripovijetkama, težio prikazivanju raspona mogućnosti u kojima se smrt neprekidno manifestuje. Njegov najviši stvaralački domašaj, roman Proljeća Ivana Galeba, odveo ga je u tom nastojanju ka sintezi svojih razmišljanja, odakle je piščeva stvaralačka putanja skrenula u začudnu metafiziku njegove jedine drame i, naročito, antiutopijsku fantazmagoričnost nedovršenog romana Pronalazak Athanatika. Sve to govori da Desničin opus nije nekakva književno zaodjenuta proklamacija određenog pogleda na svijet, odnosno na smisao smrti, koja je u njemu sveprisutna, već prevashodno artističko savladavanje svih, pa i tih sadržaja, kakvi su se u određenim okolnostima i stvaralačkim fazama piscu nametali. Njegovo umjetničko viđenje smrti u Galebovom sedefastom odsjevu za vjeđđama primiče ga, po vrsti metafizičke slutnje i jezičkoj snazi njenoga uobličenja, Desničinom najvećem prethodniku, piscu koji ga je značajno odredio - Petru II Petroviću Njegošu. Odatle proizlazi, a u ovom radu je nizom nedvosmislenih primjera još jednom, na datom tematskom kompleksu potkrijepljeno, da Desničino mjesto u nacionalnoj i svjetskoj literaturi ne samo dvadesetog vijeka daleko nadilazi njegov aktuelni status.

\section{$\cos$}

\section{Izvori i literatura}

\section{Izvori}

ВАаАан АесницА, Есеји, иланщи, погледи, БеограА - Приштина 1993.

Vladan Desnica, Olupine na suncu, Zagreb 1952.

ВАадан АесницА, Прољећа Ивана Галеба, БеограА 1990.

Vladan Desnica, Proljeće u Badrovcu, Beograd 1955.

Vladan Desnica, Slijepac na žalu, Zagreb 1956.

Vladan Desnica, Tu, odmah pored nas, Novi Sad 1956.

Vladan Desnica, Zimsko ljetovanje, Sarajevo 1966.

Vladan Desnica, Zimsko ljetovanje. Pjesme. Ljestve Jakovljeve (= Sabrana djela Vladana Desnice, knj. I), Zagreb 1974. 


\section{Literatura}

Vladan BAJČEta, „Gozba u poljima. Fragmenti rekonstrukcije pjesničke zbirke Vladana Desnice u rukopisu“, Split i Vladan Desnica 1918. - 1945.: umjetničko stvaralaštvo između kulture i politike. Zbornik radova sa znanstvenog skupa Desničini susreti 2015. (ur. Drago Roksandić i Ivana Cvijović Javorina), Zagreb 2016., 459-481.

Vladan BAJČETA, „Nekoliko pjesama Vladana Desnice u rukopisu“, Hrvatsko-srpski / srpsko-hrvatski interkulturalizam danas. Zbornik radova s međunarodnoga znanstvenog skupa Desničini susreti 2016. (ur. Drago Roksandić), Zagreb 2016., 259-282.

Vladan BAjČEta, „Slijepac na žalu. Poezija Vladana Desnice“, Vladan Desnica i Split 1920. -1945. Zbornik radova sa znanstvenog skupa Desničini susreti 2014. (ur. Drago Roksandić i Ivana Cvijović Javorina), Zagreb 2015., 125-145.

Тихомир БрАјовић, „Облик празнине. Културни идентитети и њихова наличја у Зимском ьетовану Вцадана Аеснице“, Кюижевно дело Владана Аеснице. Зборник радова поводом 100-годишғищерођења (ur. Јован Радумовић, Аушан Иванић), Београд 2007., 87-117.

Jadranka BRNČIĆ, „Problem etičkog angažmana u Desničinim Ljestvama Jakovljevim“, Intelektualci i rat 1939. - 1947. Zbornik radova s medunarodnog skupa Desničini susreti 2012. (ur. Drago Roksandić i Ivana Cvijović Javorina), sv. 1, Zagreb 2013., 41-51.

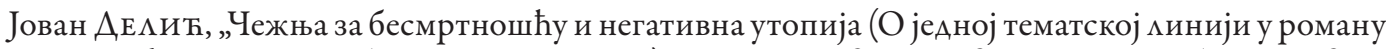
Прољећа Ивана Галеба Владана Аеснице“", Книжевно дело Владана Аеснич. Зборник радова поводом 100-годишғище рођења (ur. Јован Радуловић, Аушан Иванић), Београд 2007., 35-50.

Fjodor Mihajlovič Dostojevski, Idiot, Beograd 1983.

Davor Dukić, „Nekoliko imagoloških opaski o Zimskom ljetovanju i Desničinim susretima“, Desničini susreti 2005. - 2008. Zbornik radova (ur. Drago Roksandić i Ivana Cvijović Javorina), Zagreb 2010., 149-156.

Петар ЏАџић, Повлашћени простори Милоша Црғанског, Београд 1993.

Martin Heidegger, Bitak i vrijeme, Zagreb 1985.

Виктор Иго, Последюи дан на смрт осуђенога, Крањево 1987.

Viktor JANKelevič, Smrt, Beograd 2017.

Zoran Kravar, „Zimsko ljetovanje Vladana Desnice pod ideološkokritičkim lećama“, Desničini susreti 2010. Zbornik radova (ur. Drago Roksandić i Ivana Cvijović Javorina), Zagreb 2011., 9-17.

Dušan Marinković, „Nove spoznaje o Vladanu Desnici“, Desničini susreti 2005. - 2008. Zbornik radova (ur. Drago Roksandić i Ivana Cvijović Javorina), Zagreb 2010., 241-254.

Krešimir Nemec, Vladan Desnica, Zagreb 1988.

Vlatko Pavletić, Analiza bez koje se ne može, Zagreb 1961.

Gajo Peleš, Poetika suvremenog jugoslavenskog romana, Zagreb 1966.

Helena Peričić, „Jezik ideologije i ideologija jezika u Desničinoj drami Ljestve Jakovljeve“, Desničini susreti 2010. Zbornik radova (ur. Drago Roksandić i Ivana Cvijović Javorina), Zagreb 2011., 49-61.

Араган СтојАновит, „Јас живота и јас смрти“, u: Владан Аесница, Прољећа Ивана Галеба, Београд 1982., 425-450.

Luca VAGLIo, „Vidovi policentrizma i problematičnosti u romanu Zimsko ljetovanje Vladana Desnice“, Desničini susreti 2010. Zbornik radova (ur. Drago Roksandić i Ivana Cvijović Javorina), Zagreb 2011., 101-108. 


\section{$\cos$}

\section{THE PEARLESCENT REFLECTION OF ETERNITY. The thanatological aspects of the work of Vladan Desnica}

It is impossible reduce the vision of death in the work of Vladan Desnica to a single critical determination. Desnica's literary thanatology is immensely varied in the ways it depicts and conceives human existential finality. In the span between metaphysical optimism on the one hand and pessimism on the other, Desnica's work is the most encompassing. His range in that aspect becomes evident in the parallel analysis of the Desnica's short stories, lyrical and reflexive fiction, as well as his play. In Desnica's narrative fiction and Zimsko ljetovanje (Summer vacation in winter), a bleaker vision of human transience is established, one which often veers towards the grotesque. In his poetry, especially the poems found among his manuscripts, there is a clear vitalist charge in the way man faces death, stoically, and at peace with the cyclic nature of life. Desnica's central work Proljeca Ivana Galeba (The Springs of Ivan Galeb), as his crowning achievement, unites and in a way reconciles the extremes of the effort to overcome this basic anthropological fear. The paper examines the relationships between Desnica's thanatological variations in the different modes of his literary expression, while attempting to answer the question of how to understand the image of death in the work of a writer who has tackled it in countless different ways.

Key words: death, dying, funeral, eternity, pearlescent/mother-of-pearl, the apocalyptic, non omnis moriar 


\section{4. \\ SLOVENAČKA RECEPCIJA \\ VLADANA DESNICE I TEMATIZOVANJA \\ SMRTI U NJEGOVIM DELIMA}

\section{Marija Mitrović}

UDK: 821.163.42Desnica, V.:821.163.6

Pregledni članak

Sažetak: Desnica je u slovenačkoj književnosti bio prisutniji nego brojni drugi njemu suvremeni hrvatski ili srpski pisci. Brojni su i visoko informativni posebno književnokritički tekstovi o Desničinoj prozi. Rad nastoji da odgovori na pitanje na koje je sve načine Desnica bio prisutan na slovenačkom književnom području. Posebnu zanimljivost čine nekolika lična sećanja književnih kritičara na Vladana Desnicu za njegova života ili neposredno nakon njegove smrti.

Ključne reči: recepcija, prevodi, studije, sećanja

1 rva Desničina priča prevedena na slovenački jezik objavljena je već 1950. godine: u antologiju Hrvatski povojni novelisti ${ }^{1}$ uvrštena je priča Pred zarjo (Pred zoru), koja je u originalu izašla u časopisu Republika samo godinu dana ranije. Desnica je u ovoj antologiji bio jedini autor koji još nije imao samostalnu zbirku, što je i istaknuto u napomeni o piscu.

Ovako rano pojavljivanje Desničine proze pred slovenačkom publikom privlači pažnju već i zato što je u domaćoj sredini baš ova priča naišla na negativnu kritiku, i to ne odmah po objavljivanju, nego 1951. godine, kada je bila uvrštena u zbornik Put u slobodu, posvećen desetogodišnjici Ustanka. ${ }^{2}$ Od trideset autora, koliko ih sadrži ovaj zbornik, pažnja kritičara lista Naprijed Đure Šnajdera ${ }^{3}$ zadržala se samo na ovoj Desničinoj priči, odričući joj „objektivnost“ $\mathrm{i}$ ističući da je njen autor „pisac mračne i nehumane knjige Zimsko ljetovanje“. 4 Pišući odgovor na ovu kritiku, preciznije manipulaciju tekstom, odgovor koji tada niko nije hteo da objavi, ${ }^{5}$ Desnica napominje da je posle objavljivanja pomenute priče

\footnotetext{
Slavko Kolar - Marijan Matković (ur.), Hrvatski povojni novelisti. 1945-1949, Ljubljana 1950.

Grigor Vitez (ur.), Put u slobodu. Zbornik pripovijedaka i zapisa iz Narodnooslobodilačke borbe, Zagreb 1951.

Šnajderova kritika objavljena je 19. oktobra 1951. u listu Naprijed. Šnajderov tekst i Desničin odgovor na ovaj napad citiramo prema knjizi: Vladan Desnica, Progutane polemike (prir. Jovan Radulović), Beograd 2001.

4 V. Desnica, Progutane polemike, 99.

5 V. Desnica, „Pozadina i metoda jedne kritike“, Progutane polemike, 102-109.
} 
u Republici on lično dobio čestitke od Petra Šegedina, ${ }^{6}$ da je priča potom, 1950. godine, preštampana u knjizi Socijalistički preobražaj našega sela, u izdanju Matice hrvatske, pod uredništvom Jože Horvata i već pomenutog Šegedina, te da je prevedena na slovenački i uvrštena u antologiju Hrvatski povojni novelisti. Ali sada, dodao je Desnica, nakon što je u delu kritike roman Zimsko ljetovanje osuđen kao „mračan“ i „nehuman“ - eto gde se ista etiketa lepi i za ovu priču. No, kao što rekosmo, Desničin odgovor Šnajderu nije objavljen, pa je tako u hrvatskoj književnoj sredini i vest o prevodu ove priče skrajnuta, zaboravljena.

U Sloveniji, međutim, priča je i posle toga imala zanimljivu sudbinu: objavljena je još dva puta, i oba puta u novom prevodu. Bilo bi zanimljivo uporediti sva tri prevoda: godine 1950. priču je preveo Božidar Borko; godine 1963. ona je uvrštena u antologiju Pomlad v Badrovcu, koju je uredio i preveo Tone Potokar; ${ }^{7}$ treći put priča je objavljena 1976. godine a preveo ju je Miha Matè i uvrstio u antologiju jugoslovenske kratke proze pod naslovom Na sončni strani, koju je sam sačinio i objavio. ${ }^{8}$

Diskurzivno predstavljanje Desnice slovenačkoj publici u brojnim kritikama i dužim esejima stvara sasvim osoben lik ovog književnika. Desnica nije jednostavno prevođen, on je reinterpretiran, o njemu je stvarana posebna slika; prevodi, osobito kraće proze i odlomaka iz romana, samo su jedan deo te recepcije. I kada se radi o istom naslovu, sadržaj knjige ne mora biti isti. Godine 1963. Cankarjeva založba iz Ljubljane objavila je knjigu Pomlad v Badrovcu, ali se ona poprilično razlikuje od knjige Proljeće u Badrovcu, objavljene 1955. u Beogradu. Slovenačko izdanje obuhvata dvanaest od ukupno petnaest priča Desničine zbirke (izostavljene su Proljeće, Božićna priča i Bunarevac), a dodato je još sedam novih: Pisana škatlica (Šarasta kutijica), Delta, Sveti Sebastijan, Benta-kuščr (Benta-gušter), Zgodba o fratru z zeleno brado (Priča of fratru sa zelenom bradom), Modrijan z Jutrovega (Mudracs Istoka) i Athanatik. Među pričama uvrštenim u ovu antologiju njih sedam su bile već ranije objavljene u slovenačkim novinama i časopisima, ${ }^{9}$ a dve (Pravica i Zgodba o fratru z zeleno brado) svoje će mesto naći u drugim antologijama, nakon što su objavljene u ovoj knjizi. ${ }^{10}$

Kako ovu prvu Desničinu knjigu objavljenu na slovenačkom, tako i najveći deo njegove proze preveo je Tone Potokar (1908-1985), publicista i prevodilac sa srpskohrvatskog na slovenački i obrnuto, pisac informativnih tekstova o delima koja je sam prevodio ili smatrao da ih valja približiti publici tadašnje Jugoslavije. Njegov propratni tekst za Pomlad v Ba-

6 „Drug Petar Šegedin tad mi je toplo čestitao što mi je navodno uspjelo ocrtati likove partizana živo, uvjerljivo, sa njihovom istinskom životnom ljepotom, humanošću, pravednošću, bez traga parolizma i retorike." Isto, 107.

7 Vladan Desnica, Pomlad v Badrovcu, Ljubljana 1963.

8 Miha Matè, Na sončni strani. Izbor sodobne jugoslovanske kratke proze, Ljubljana 1976. Desničina priča Pred zarjo objavljena je na str. 42-51, a beleška o Desnici na str. 132-134.

9 Ova zbirka iz 1963. sadrži ukupno dvadeset pripovedaka. Osim priče Pred zarjo slovenačkoj publici su već bile poznate i neke druge: Pravica (Pravda) u Potokarevom prevodu objavljena je još 1953. godine, i to dva puta: u Ljubljanskom dnevniku (br. 106, 9. 5. 1953., 4) i u nedeljniku Mladina (11/1953., br. 19, 4-5). Dvaput su objavljene Pisana škatlica (Šarasta kutijica) u prevodu T. Potokara (Ljubljanski dnevnik, br. 260, 1955., 8; Delo, br. 149, 2. 6. 1963., 7) i Delta, koja je u prevodu Jožeta Zupančiča i sa ilustracijama Melite Vovk objavljena u Tedenskoj tribuni (br. 36, 10. 9. 1958., 8), a u prevodu T. Potokara u Ljubljanskom dnevniku (br. 153, 30. 6. 1958., 4). U prevodu T. Potokara objavljene su još: Pomlad v Badrovcu (Proljeće u Badrovcu) u listu Slovenski poročevalec (br. 259, 6. 11. 1955., 5), Sveti Sebastijan u Ljubljanskom dnevniku (br. 153, 30. 6. 1956., 10) i Obisk (Posjeta) u časopisu Naša sodobnost (6/1958., br. 1, 44-54).

10 Uvrštene su u antologiju Sodobna hrvaška noveleta (ur. Radoslav Dabo), štampanu u Mariboru 1974. Druga je objavljena i u antologiji Pomlad v Badrovcu (1963). 
drovcu nosi skroman naslov Zapisek o pripovedništvu Vladana Desnice, ${ }^{11}$ tj. beleška o prozi Vladana Desnice, ali je ovaj publicista-amater ${ }^{12}$ umeo da sakupi i u jedinstven i elegantno jednostavan tekst objedini sve relevantne osobine Desničine proze. Gotovo da bi se moglo reći da ovaj tekst, koji broji ukupno osam strana, čini osnovicu za sve docnije recenzije koje su izlazile u periodičnim publikacijama u Sloveniji. Potokar polazi od konstatacije da u tadašnjoj hrvatskoj prozi dominiraju - kvantitetom i kvalitetom - pisci rodom iz Dalmacije, s otokâ i iz Primorja. Navodi čak jedanaest tada aktivnih pisaca, od kojih „trojicu svrstavamo u sam vrh današnje jugoslovenske proze: to su Desnica, Kaleb i Marinkovićc" ${ }^{13}$ Prešavši na samu poetiku pripovedanja, Potokar ističe da za ovu prozu nije najvažnija fabula niti celovitost dela. Desnica se koncentriše na unutrašnji život ljudskog bića, donosi u izvesnom smislu kondenzaciju životnog iskustva, životnu filozofiju, koja je sva prožeta poetičnošću. Iako je prostorno vezana za okolinu Zadra i Šibenika, to nipošto nije regionalna proza, kakva je bila, na primer, Matavuljeva. Jedina sličnost sa ovim realistom jeste upravo to što obojica svoju prozu smeštaju u isti geografski prostor, ali „psihološka analiza karaktera, suptilan način građenja rečenice, izuzetna stilska disciplina, govore u prilog Desnici kao daleko virtuoznijem majstoru". ${ }^{14}$ Desnica ume da se podsmehne ljudima-olupinama, mada u svakome od njih ruje neki crv, nešto što im je zagorčavalo život. No, u sav taj svet pisac ume da udahne veliku meru životne poezije, mnogo toplih, ljupkih detalja.

Teško je - kaže Potokar - već tada, početkom šezdesetih, razumeti one kritičare koji su samo deceniju ranije polemički istupili kada je objavljeno Zimsko ljetovanje. Srećom, mlađi kritičari, pre svega Vlatko Pavletić i Čedo Prica, a nešto kasnije i Marjan Matković, odlučno su stali u odbranu pisca - koji je i sam pokušao da obrazloži svoj prvenac, ali mu tekst tada nije objavljen. Potokar zatim citira jedan duži paragraf iz Desničinog teksta $O$ jednom gradu i o jednoj knjizi, napisanog 1950. godine a objavljenog u Zadarskoj reviji $1954 .{ }^{15}$

Zanimljivo je da se Potokar najduže zadržava na "najdubljem proznom tekstu“, na romanu Proljeća Ivana Galeba, a ne na novelama koje knjiga donosi, jer će o njima sam čitalac moći da donese sud. ${ }^{16} \mathrm{Za}$ razliku od podeljenih kritičkih mišljenja izraženih povodom Zimskog ljetovanja, ovaj Desničin roman „naišao je na izuzetno pozitivan prijem“ te „od rata naovamo kritika nije toliko pisala ni o jednom delu domaćih autora koliko je pisala o Desnici“ “. ${ }^{17}$ Roman za Potokara predstavlja novinu u sadržajnom u formalnom pogledu, u okviru jugoslovenske književnosti. Nastajao je, kaže, čitavih dvadeset godina; to je

(...) intelektualno-filozofski roman, mozaički komponovana proza velikog formata, nekakav roman-dnevnik, sačinjen od najrazličitijih životnih manifestacija. (...) Roman je sim-

11 Tone Potokar, „Zapisek o pripovedništvu Vladana Desnice“, u: V. Desnica, Pomlad v Badrovcu, $419-427$.

12 Po struci je bio mašinovođa, a potom službenik državne železnice. Službovao je u raznim krajevima Jugoslavije, a radni vek završio je u Zagrebu, gde je i umro.

13 T. Ротокar, „Zapisek o pripovedništvu Vladana Desnice“, 420. Sve citate sa slovenačkog prevela M. M.

14 Isto, 424.

15 Potokar ne navodi gde je i kada objavljen Desničin odgovor na napade, pa smo podatak preuzeli iz knjige V. DESNICA, Progutane polemike, 122-131.

16 Zanimljivo je i da kao godinu objavljivanja romana stavlja 1954, dakle vreme kada roman još nije doživeo objavljivanje u formi knjige.

17 Isto, 424. 
fonija, kako u formalnom, tako i u sadržajnom pogledu. Po strani namerno ostaju i priča i akcija. ${ }^{18}$

Po veoma izraženoj prisutnosti refleksivnog sloja u romanu Potokar Desničinu prozu stavlja u blizinu Prusta i Bunjina. Tekst završava pohvalama stilu i jeziku ovog pripovedača, kao i nizom korisnih podataka o Desničinim izletima u svet muzike, poezije, filmskog scenarija, drame. Obaveštava nas i o prevodilačkoj delatnosti pisca, kao i o uspesima njegove proze u prevodu na druge jezike.

O knjizi Pomlad v Badrovcu objavljene su četiri književne kritike, izišle su u značajnoj dnevnoj (Delo), nedeljnoj (Tedenska tribuna) i mesečnoj periodici (Sodobnost i Nova obzorja), a pisali su ih tada značajni književni kritičari (Milan Šega, Rapa Šuklje, Stanko Šimenc, Jože Filo). ${ }^{19}$ One su svakako bile važne kao divulgativna sredstva, kao svojevrsna reklama za knjigu, koja je inače bila objavljena u 1200 primeraka. Nema sumnje da sve te kritike uzimaju u obzir informacije koje je o piscu i njegovom delu dao Tone Potokar. Ovde ćemo istaći samo ona svojstva te proze na koja ukazuju ovi kritičari, a ne nalazimo ih u Potokarovom tekstu.

Stanko Šimenc istakao je da je ovaj „protivnik pseudosocijalne literature“ gajio negativan odnos prema „literaturi zasnovanoj na lirizmu u kojoj pisac dugo među prstima mesi kakav bolni trenutak sve dok ga ne umesi u nekakvu zdruljanu, lepljivu ganutost “. ${ }^{20}$ Ova proza uopšte nije opterećena nostalgijom i romantičarskim odnosnom prema prošlosti; umesto toga tu je „blaga ironija i deziluzija“. ${ }^{21}$ Kada gradi likove, Desnica pre svega traga za onim što je u njima latentno, a što dolazi do izražaja u trenucima kada je čovek posebno uznemiren. Otud želja da likove prati dok su usamljeni i kada i sami nastoje da prodru u svoju podsvest. Ali i unutar ovih prodora u podsvesno Desnica nas opet iznenađuje time što izražava uverenje da se „dve suprotstavljene istine ne isključuju, već mašti nude istu onakvu spoznaju različitosti, kakvu čovekovom oku nude različiti cvetovi u istoj vazi“ ${ }^{22}$

Iz teksta koji je Jože Filo objavio u mariborskom časopisu Nova obzorja izdvojili bismo rečenicu:

Uprkos tome što pripovedanje prožimaju sarkazam i ironija, uprkos tome što pisac izvrgava podsmehu stari svet, čitalac oseća da autor poštuje ono što je u tom svetu ljudsko i humano. I upravo ga to čini pravim umetnikom. ${ }^{23}$

Vest o smrti Vladana Desnice objavljena je na petoj strani glavnog slovenačkog dnevnog lista Delo u utorak 7. marta 1967, dakle na sam dan sahrane:

U subotu pre podne u univerzitetskoj klinici Rebro u Zagrebu umro je, nakon višemesečne teške bolesti, pisac Vladan Desnica. Njegovi posmrtni ostaci će biti prevezeni u Islam Grčki

18 Isto.

19 Milan ŠEgA, „Pomlad v Badrovcu“, Delo (Ljubljana), br. 147, 31. 5. 1963., 5; Rapa Šuklje, „Med Sutjesko in Badrovcem“, Tedenska tribuna, 12/1964., br. 4, 7; Stanko Šmenc, „Pomlad v Badrovcu“, Sodobnost, 11/1963., br. 10, 946-947; Jože Fılo, „Vladan Desnica, Pomlad v Badrovcu“, Nova obzorja, 16/1963., br. 9-10, 474.

20 S. ŠImenC, „Pomlad v Badrovcu“, 946.

21 Isto, 947.

22 Isto.

23 J. Filo, „Pomlad v Badrovcu“, 474. 
kraj Novigradskog mora (severoistočno od Zadra) i danas, utorak, pokopani u porodičnoj grobnici. ${ }^{24}$

Tako počinje vest o odlasku pisca kojega kritika smatra „najznačajnim proznim piscem na srpskohrvatskom jezičkom području“, ističe Tone Potokar, pisac ovog in memoriam teksta. Istina je, kaže dalje Potokar, da Desnica već duže vremena, osobito posle iznenadnog gubitka supruge, nije objavljivao svoju prozu, bavio se pre svega prevođenjem, pa je pored ostalog preveo Kročeove eseje iz estetike. Iako se kao prozni pisac javio tek u petoj deceniji svog života, postao je vrlo brzo majstor kratke proze, novele, kratkog romana, a vrhunac postigao u romanu-dnevniku o Ivanu Galebu. Kada je u Poljskoj objavljen ovaj roman, koji broji preko 400 strana, postao je tamo najčitanija knjiga. O Proljećima Ivana Galeba Potokar zaključuje sledeće:

Tu je pisac sažeo svoje ukupno životno iskustvo pa je ovaj mozaički komponovan intelektualno-filozofski roman u najboljem smislu te reči jedno od najdubljih dela u jugoslovenskim književnostima. ${ }^{25}$

Svoju prozu Desnica najčešće locira u rodni kraj, mada ga zanima i šire područje unutrašnjosti. Potokar posebno ističe savršenu kompoziciju Desničnih proza, njegov izbrušen jezik i majstorski stil.

U godini Desničine smrti objavljena su još tri značajna teksta: tada najčitaniji četrnaestodnevni list Naši razgledi doneo je svojevrsni in memoriam iz pera Emila Štampara, a oba tada glavna književna časopisa - Sodobnost iz Ljubljane i Dialogi iz Maribora - doneli su ozbiljne duže studije o ovome piscu. ${ }^{26}$ Kako Štefan Barbarič, autor teksta u Sodobnosti, tako i Gregor Kocijan, koji je tekst objavio u časopisu Dialogi, ističu - po prvi put među slovenačkim kritičarima - značaj teme smrti za Desničin opus.

Iz Štamparovog teksta, naslovljenog Smrt bojevnika proti smrti, vredi navesti sledeće rečenice:

Desnici odgovara forma novele jer u biti on ne poseduje pravi epski zamah koji bi ga vodio u širinu. (...) Kroz spoljašnja zbivanja polako i uverljivom psihologijom prodire u unutrašnji svet likova, kako seljaka sa njihovom primitivnošću i lukavošću, tako i onih koji pripadaju propalom građanskom mentalitetu. $S$ te strane su veoma ilustrativne novele: Oko, Posjeta, Bunarevac i posebno Pred zoru, s motivom borbe partizana protiv četnika. ${ }^{27}$

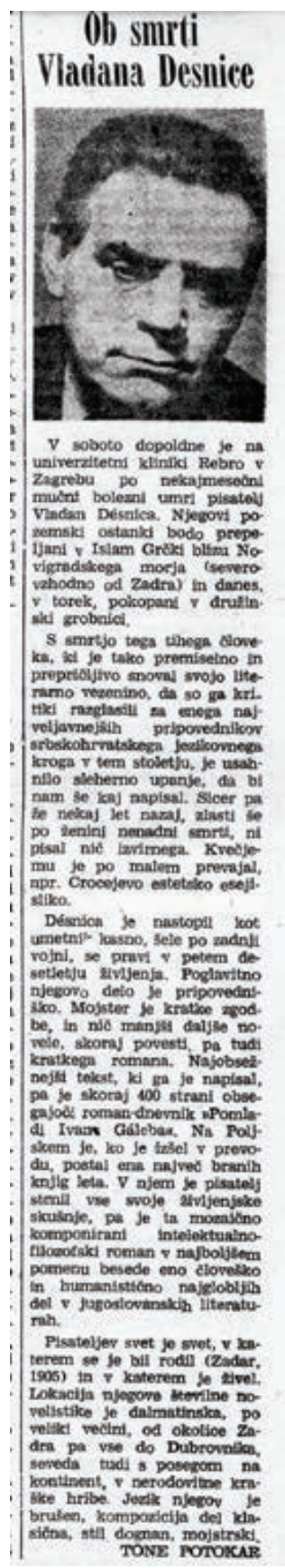

Sl. 1. In memoriam

Vladanu Desnici u listu Delo

24 Tone Potokar, „Ob smrti Vladana Desnice“, Delo (Ljubljana), br. 63, 7. 3. 1967., 5.

25 Isto.

26 Emil ŠTampar, „Smrt bojevnika proti smrti“, Naši razgledi, 16/1967., br. 8, 190; Štefan Barbarič, „Podnebja Vladana Desnice“, Sodobnost, 15/1967., br. 7, 738-744; Gregor Kocijan, „Proza Vladana Desnice“, Dialogi, 3/1967., br. 9, 455-459.

27 E. ŠTAMPAR, „Smrt bojevnika proti smrti“, 190. 
Kao da je, makar i posthumno, odao počast pripovedaču koji je zbog ove poslednje priče pretrpeo nepravednu negativnu kritiku. Priču Pravda, pak, Štampar izdvaja kao prvu u kojoj je Desnica primenio pirandelovsku tehniku prikazivanja relativnosti istine. Na kraju, navodeći jedan duži citat iz romana Proljeća Ivana Galeba, Štampar ističe da se on može čitati kao kakva „proročka vizija poslednjih meseci piščeva života u bolnici“, 28 i baš tu pisac nudi čitaocu „duhovite eseje raskošne figurativnosti“ koji na inventivan način „objavljuju boj protiv smrti, tog krvnika ljudskoga roda“ ${ }^{29}$

Štefan Barbarič svoj tekst započeo je kao sećanje na susrete sa Desnicom za njegova života, ali i posle smrti, kada ga je, nekih desetak dana nakon piščevog pogreba, nešto neobjašnjivo poteralo da hodočasti na piščev grob:

Ne znam kako mogu okarakterisati ono što sam poduzeo u nedelju, deset dana nakon pogreba; ne znam je li to bilo hodočašće iz pijeteta ili samo studijski izlet što me nateralo da krenem na put ka Islamu Grčkom. O tom selu egzotičnog imena slušao sam i ranije, naravno, uvek u vezi sa Desnicom i njegovim nasleđenim posedom, imenovanim „dvori Stojana Jankovića“. Znao sam i da je Stojan Janković junak iz narodne epike, da se krajem 17. veka istakao u borbi protiv Turaka, koji su upravo tada bili potisnuti iz Dalmacije do sve preko Dinare. Kada je autobus skrenuo sa asfaltne magistrale na sporedan, izlokani put, tresli smo se i nejednako poskakivali, učinilo mi se da je to baš onaj put kojim su se vozili pripovedač i veterinar Priester ka Mijatovima, kojima je bila obolela krava. I predeo Ravnih kotara je izgledao kao u prozi: vesela zelena boja polja, „skroman pejzaž diskretnih, nežnih odnosa boja nevelikog raspona i bez izrazitijih kontrasta". $\mathrm{Na}$ istom ovom mestu (Proljeće u Badrovcu) pisac je predstavio čudnu lepotu proleća na proplancima koji se prostiru od Velebita do Zadarskog kanala. A sasvim je drukčije ovde kada to bujno zelenilo progutaju vrućine, ili u poznu jesen, kada se mutno obzorje pomiče u nedogled (Zimsko ljetovanje). Nije, naravno, današnji Islam Grčki takav kakvi su bili Smiljevci, gde su utočište potražili begunci iz Zadra: to mi je bio prvi utisak kada se autobus zaustavio pred krčmom koja nosi ime junaka Stojana Jankovića. Nije mi bio potreban vodič, iako je civilizacija i ovamo prodrla, u ovim se krajevima održalo tradicionalno gostoprimstvo. ${ }^{30}$

Opisuje Barbarič zatim izgled i namenu Jankovića kule, ističući kako današnjem čoveku smeta što u kuli nema struje, ali zato u vrtu postoji „blago koje je iznad svih blaga - živa voda“. Približava se zatim „zapuštenoj starinskoj kapeli, Sveti Đorđe“. Tu su u porodičnoj grobnici sahranili Vladana, kako ovog pisca oslovljava domaćin Mihajlo Gračan. Opelo je trajalo tri sata, priča dalje meštanin. U ovoj savršenoj samoći završene su, dakle, „igre proljeća i smrti“. Na nadgrobnoj ploči i duž zidova ,još su poređani pomalo uvenuli venci“ ${ }^{31}$ Prelazi zatim na predstavljanje piščevog opsesivnog motiva, smrti, na Desničino doživljavanje ovog egistencijalnog trenutka, pa ga poredi sa sličnom obradom toga motiva u pričama Georgesova maska i Očetova maska, dakle sa delima Juša Kozaka, ali i sa Montenjevim kontemplacijama, te obradom teme smrti kod Tomasa Mana.

Zapravo se Barbarič, prvi od slovenačkih kritičara, duže zadržao na temi smrti u Desničinom delu. Smatra da je ovaj pisac ovoj temi pristupio spajajući, s jedne strane, intelek-

\footnotetext{
28 Isto.

29 Isto.

30 Š. BARbarič, „Podnebja Vladana Desnice“, 738-739.

31 Isto, 739.
} 
tualnu introspekciju, a s druge, emocionalnu pogođenost. Podseća da je „mladi bosanski kritičar" (ne kaže koji) u romanu Proljeća Ivana Galeba nabrojao galeriju od dvadeset smrti, od kojih je - ističe Barbarič - svaka drukčija. Karakteristična je za Desnicu ova spoznaja o individualizovanom umiranju: svako umire u skladu sa sopstvenim životom i karakterom. U svoj umetnički postupak stvaranja portreta ljudi Desnica uključuje, kao bitnu karakternu crtu velikog broja likova koje opisuje, upravo smrt toga lika. Iako je ova tema tako često prisutna, u toj prozi nema ničeg od predromantičarske atmosfere grobova i ruševina. Smrt je ovde u sklopu autorovih razmišljanja o prolaznosti, i to ne samo ljudskog bića, nego i predmeta, navika, shvatanja, razdoblja... Tako posmatrana, smrt prestaje biti tragična, ona je naprosto deo života: „Rađanje i nestajanje su dva dijalektička pojma, jedan uslovljava drugoga, kako je to istaknuto u noveli Anthanatik, koja je inače uključena u roman. “"

Gregor Kocijan je temu smrti kod Desnice još više produbio. Istakao je da je ovom piscu neobično stalo do toga „da prikaže čoveka u različitim životnim situacijama i detektuje njegove emotivne i misaone reakcije, poteškoće, depresije, etičke probleme, svetle i tamne strane ljudske prirode“.$^{33}$ Tema smrti je kod ovog pisca, osobito u njegovoj zreloj fazi, u biti neminovna konsekvenca piščevog dubokog psihološkog prodora u čovekov intimni svet, njegove dosledne okrenutosti ka unutarnjem biću. Izdvaja posebno priče Proljeće u Badrovcu, Spiriti i Solilokviji gospodina Pinka. One, smatra Kocijan, čine most od prve ka drugoj fazi Desničinog stvaralaštva. Tek ovu drugu fazu, koju predstavlja pre svega roman Proljeća Ivana Galeba, karakteriše

(...) izrazita okrenutost ka unutarnjem svetu i pojačana refleksivnost. (...) Njegovo pisanje dobija pravu oštrinu posebno onda kada se kod ljudi ispoljava pakost, bezosećajnost, plitkost i dvostrukost morala. ${ }^{34}$

Igra „proljeća i smrti“, „svjetlosti i sjenke“ u romanu Proljeća Ivana Galeba zapravo je samo radikalno razvijanje ovih zapažanja, koja su obeležena kako intelektualnim, tako i emotivnim osvetljavanjima etičke strukture čovekovog unutrašnjeg sveta. Za Kocijana nema dvojbe: roman o muzičaru Ivanu Galebu stremi ka prevladavanju smrti i rađanju u novom proleću. A to je posledica spoznaje da se pravi mir i sloboda mogu naći samo u sopstvenom unutarnjem biću; tek tako i tek tada čovek postaje u pravom smislu humano ljudsko biće.

Ono što se može uočiti kao manjak, kao karika koja nedostaje u prezentaciji Vladana Desnice slovenačkoj publici, jeste prevod romana Zimsko ljetovanje. To ne znači da se o tom romanu nije pisalo - dapače! Ne samo Potokar u pogovoru za antologiju Pomlad v Badrovcu, nego i niz drugih kritičkih osvrta se tako reći redovno zadržavaju i na ovome delu, ocenjujući ga uvek izuzetno pozitivno, a tekst Kajetana Koviča iz godine 1959. to ističe već u naslovu svoga priloga: Vladan Desnica, Zimsko ljetovanje in Proljeća Ivana Galeba. ${ }^{35}$ Ipak, ovaj manjak, ovaj dug Desnici, ni do danas nije nadoknađen.

\footnotetext{
Isto, 741 .

33 G. Kocijan, „Proza Vladana Desnice“, 456.

34 Isto, 457.

35 Kajetan Kovič, „Vladan Desnica, Zimsko ljetovanje in Proljeća Ivana Galeba“, Tedenska tribuna, 7/1959., br. 38, 5.
} 
S druge strane, ono što se takođe lako uočava, ali ovoga puta s pozitivnim predznakom, jeste činjenica da je Desnica bio jedan od retkih hrvatskih i srpskih savremenih pisaca o kojem je neki slovenački autor svoje studije objavio i izvan slovenačkog kulturnog prostora: Janez Rotar, svakako najplodniji i najuporniji analitičar Desničinog opusa u slovenačkoj sredini, objavio je rezultate svojih istraživanja o ovome piscu ne samo u Sloveniji, nego i na srpskohrvatskom, u svim tadašnjim republikama, u različitim publikacijama i zbornicima: svaki njegov tekst o ovome piscu objavljen je barem dva, a nekada i tri puta. ${ }^{36}$

Prevod romana Proljeća Ivana Galeba ${ }^{37}$ izišao je tek nakon piščeve smrti, i to dva puta u neobično kratkom vremenskom razmaku, kod dva različita izdavača, ali u oba slučaja u prevodu Toneta Potokara i sa predgovorom Janeza Rotara: godine 1974. mariborska izdavačka kuća Obzorja izdala je ovaj roman u 1200 primeraka, a već 1976. isti je roman objavljen pri Mladinskoj knjizi iz Ljubljane, u ediciji Beseda sodobnih jugoslovanskih avtorjev, u čak 7000 primeraka! ${ }^{38}$ Roman je tom prilikom podeljen u dva toma, u dve knjige čvrstog poveza, i štampan na veoma finom papiru - danas nezamislivo za bilo koji roman suvremenog domaćeg autora u bilo kojoj sredini na teritoriji bivše Jugoslavije! Iako je pisac predgovora za oba izdanja romana ista ličnost, propratni tekst objavljen u drugome izdanju nipošto nije isti. Janez Rotar je za svako od ova dva izdanja napisao izuzetno temeljite i inovativne analize ne samo ovoga romana, nego i ukupne Desničine proze, zadržavajući se pre svega na analizi kompozicije dela i svih njegovih formalnih odlika.

Već na početku studije Rotar navodi rečenicu Andrea Žida u kojoj ovaj ističe da lepa osećanja rađaju loša književna dela, ${ }^{39}$ čime ovaj tek izabrani docent za srpsku i hrvatsku književnost pri Filozofskom fakultetu u Ljubljani želi da unapred zaštiti pisca čiji je prvi roman Zimsko ljetovanje bio svojevremeno naišao na seriju napada kritičara i „kritičara“, ali i da „opravda“ svoju neobično detaljnu studiju o piscu koji u to vreme još nije imao auru velikog pisca. Barem ne u Sloveniji. Nju je tek trebalo graditi.

Rane sedamdesete godine su - kako ističe Radina Vučetić - godine čestih zabrana; na udaru su se umela naći književna, filmska i likovna dela koja su stvarnost slikala tamnim bojama. ${ }^{40}$ Andre Žid, dobitnik Nobelove nagrade (1947), imao je u to vreme visoku po-

36 Osim radova koji će biti pomenuti u ovom tekstu, u bibliografiji J. Rotara ima još nekoliko bibliografskih jedinica koje se odnose na radove o Desnici. Godine 1974. u sarajevskom časopisu Izraz (18/1974., br. 2, 155-176) Rotar je objavio „Misaoni i izražajni slojevi u strukturi Proljeća Ivana Galeba“, tekst koji je iste godine izišao kao predgovor prvom izdanju prevoda romana pod naslovom „Miselne, snovne in izrazne plasti Desničevih Pomladi Ivana Galeba“. Godine 1976. u časopisu Dialogi (12/1976., br. 9, 546-553) izišao je tekst „Novo v oblikovanju Vladana Desnice“, a iste je godine ovaj tekst - samo malo izmenjenog naslova - objavljen kao pogovor drugom slovenačkom izdanju romana Proljeća Ivana Galeba. Oba su ova teksta potom - ponovo sa malim izmenama - objavljena i u knjizi J. Rotara Književnost in spoznavanje. Videti i beleške 47 i 50.

37 Već godine 1958. u dnevnoj štampi objavljena su dva odlomka iz ovog romana: „Brazgotina nad čelom'. Odlomek iz romana Proljeća Ivana Galeba. Prev. B. Verbič“, Ljudska pravica (Ljubljana), br. 103, 4. 5. 1958., 8; „'Okno v svet’. Iz romana Pomladi Ivana Galeba. Prev. T. Potokar“, Ljudska pravica (Ljubljana), br. 62, 15. 3. 1958., 8. Uobičajeno se fragmenti nekog romana u novinama objavljuju kao svojevrsna najava prevoda celog romana. Valjalo bi posebno istražiti zašto je prevod ovoga romana izišao čitavih šesnaest godina kasnije.

38 Vladan Desnica, Pomladi Ivana Galeba. Igre pomladi in smrti, Maribor 1974.; Vladan Desnica, Pomladi Ivana Galeba. Igre pomladi in smrti, 2 sv., Ljubljana 1976.

39 Židovu misao citira Rotar i u originalu, na francuskom jeziku, iz njegove knjige o Dostojevskom, objavljene 1923: "C'est avec les beaux sentiments l'on fait la mauvaise littérature."

40 Videti: Radina VučEtıć, Monopol na istinu. Partija, kultura i cenzura u Srbiji šezdesetih i sedamdesetih godina XX veka, Beograd 2016., 96-114. 
ziciju u jugoslovenskom kulturnom životu: romani su mu prevođeni, a u Prosvetinoj $M a-$ loj enciklopediji iz 1968. o njemu se kaže da ga „odlikuje velika iskrenost, prezir prema predrasudama i utvrđenim mišljenjima“. ${ }^{41}$ Tako i u Desničinom romanu Proljeća Ivana Galeba „iz tamnih osećanja i teških resantimana nastala [je] kvalitetna literatura“, koja se „snažno udaljava od uobičajenih književnih formi, te se ne može jednostavno označiti ni kao roman, ni kao povest ili biografija“. ${ }^{42} U$ zadatak ovoj studiji autor stavlja: „objasniti unutarnje i spoljašnje ustrojstvo ovog dela, koherentnost (međuzavisnost) tog unutrašnjeg i spoljašnjeg, te opisati najznačajnije strukturne slojeve: sadržajne, misaone, stilske“. ${ }^{43}$ Pritom se „ne možemo osloniti ni na jednu u praksi oprobanu ili uzornu metodologiju, nego valja poći od imanentnih svojstava ovog dela i njegove prirode te tako pokušati da budemo konkretni i delu verni““44

Ali pre nego što pređe na stvarnu analizu dela, Rotar skrupulozno navodi (u fusnoti) bibliografiju do tada obelodanjenih studija o ovom Desničinom romanu, da bi tekst „začinio“ jednim dragocenim ličnim sećanjem na Desnicu. Priseća se, naime, svog višegodišnjeg službovanja na Sveučilištu u Zadru (od 1957. do 1964 godine), pa kaže:

Pre neku deceniju, pisac je sam samcat i sporoga koraka posećivao svoj rodni Zadar, pa sam tada u nekoliko navrata imao prilike da ga sretnem. Ostavljao je utisak zamišljenog, ka svom unutrašnjem svetu okrenutog, pomalo umornog, ne suviše druželjubivog, a povremeno silovitog, već osedelog intelektualca, koji nema baš mnogo kontakata s ljudima. Možda ga je već tada pritiskala bolest jer se čini da se tada ni u svom rodnom Zadru, gde se rodio godine 1905, nije baš najbolje osećao. I među malobrojnim prijateljima bio je tih i suzdržan, ali imajući na umu lik Ivana Galeba, čovek je mogao ne samo da ga razume, nego i da ga veoma poštuje. ${ }^{45}$

U drugom, najkompleksnijem i najdužem delu ove četverodelne studije koja broji trideset strana, autor najpre ističe da roman polazi kako od iskustvenih, životnih detalja koji se odnose na vreme i sredinu u kojoj roman nastaje (uz odlično poznavanje bolničke atmosfere), tako i od sećanja na detinjstvo, ali i od nastojanja da na hiljade načina pokaže koliko je za čoveka značajan irealni, osećajni, emotivni svet. Rotar razmatra sadržaj, strukturu i međusobnu povezanost, odnosno fragmentarnost nejednako dugačkih poglavlja romana, ističući da je Desnici stalo pre svega do toga da čitaocu prenese spoznaje o junakovom, ali i emotivnom i unutarnjem svetu čoveka uopšte, a manje o njegovoj delatnoj, stvarnoj prirodi. Posebnu pažnju posvećuje spretnom Desničinom ukazivanju na pogubnost dogmatizma i ideologizma. Duže se zadržava na dijalozima, odnosno imaginarnim dijalogiziranim monolozima, solilokvijima Ivana Galeba i Ivana Glavana, te zaključuje da ovi dijalozi za predmet imaju izrazito ontološke preokupacije, kao što su pojmovi Istina, Spoznaja, Akcija, a na kraju se uvek dođe do zaključka da su „osećanja i razmišljanja vredniji i značajniji nego volja i akcija “. ${ }^{46}$ Desnici je - ističe Rotar - svaki Apsolut teret, a ono što mu je blisko

41 „Žid Andre“, Mala enciklopedija Prosveta. Opšta enciklopedija, sv. 1: A-LJ, Beograd 1968., 497.

42 Janez Rotar, „Miselne, snovne in izrazne plasti Desničevih 'Pomladi Ivana Galeba”, u: V. Desnica, Pomladi Ivana Galeba, 1974., 5 .

43 Isto, 6.

44 Isto.

45 Isto, 6-7.

46 Isto, 18. 
jeste fluid, fluid individualnoga. S druge strane, međutim, Galebov antipod / dvojnik Ivan Glavan jeste čovek volje i moći. Ova antiteza je za roman veoma bitna.

Ne kao antiteza, već kao vrednosni emotivni ekvivalent na delu je sve vreme - osama, usamljenost. Na ovoj tački Rotar uvodi, kao komparativni član, prozu Ivana Cankara i njegove crtice Slike iz snova (Podobe iz sanj) iz 1917. Slovenačkom čitaocu približava on Desnicu postavljajući ga u blizinu klasika Cankara, podsećajući da i Cankar, govoreći, u crticama iz pomenute zbirke, o vrednosti samoće, ovu misao metaforički zaodeva u sliku o „skriti kamrici“ - tajnovitom sobičku ljudskog srca. Obojica autora - ističe Rotar - priznaju da ih ovakvo zatvaranje, povlačenje, samovanje, ka unutra okrenuto razmišljanje i emocije zamaraju, iscrpljuju. Zbog svega toga, sav taj unutrašnji svet i mora ostati samo u nagoveštajima, fragmentima, sasvim kratkim crticama i poglavljima.

Poglavlja jesu razmrvljena - što od čitaoca zahteva pažnju i saradnju - ali, ističe Rotar, pisac nije zanemario značaj „vezivnog tkiva“. Tu ulogu ima, pre svega, Galebova svest, ali od ništa manjeg značaja nisu ni piščeva etička razmišljanja: neprestana su autorova opredeljivanja, a u skladu s etičkim nazorima. On stoji na onoj strani na kojoj su skromnost, dubina razmišljanja, smirenost, ljudska dobrota, poštenje u samoposmatranju, zatim psihološka sugestivnost i sposobnost velike neposrednosti doživljavanja najrazličitijih stanja.

U završnom delu studije Rotar pažnju posvećuje jezičkim i stilskim vrednostima Desničina romana. Ono što čitaocu sa štokavskog govornog područja može biti posebno interesantno jeste čitav niz lokalizama kojima se služe Desničini likovi, a koje Rotar pronalazi u vrlo živoj primeni u slovenačkim govorima: brlog, zibka, kresnice, navadan, pravdanje (parničenje), luknja, stiska... U zaključku, Rotar prozu Vladana Desnice smešta uza sam bok tada najznačajnijih jugoslovenskih prozaista Ive Andrića i Meše Selimovića.

Naslov Rotarove studije iz drugog izdanja prevoda romana Proljeća Ivana Galeba glasi: Novine Vladana Desnice v oblikovanju pripovednistva, ${ }^{47}$ što upućuje na zaključak da će sada reč biti ne samo o romanu, nego o ukupnom Desničinom opusu, i njegovom mestu u prozi (ovu imenicu ne ograničava nikakvim epitetom: ne misli samo na hrvatsku i srpsku prozu, nego na prozno stvaralaštvo kao takvo). Tu na prvo mesto postavlja savršen sklad i čvrstu povezanost izabrane tematike, te njene motivacije i stilske izvedbe. Desnica je pisac meditativne proze, okrenut ka unutrašnjem svetu bića, stvari i ukupnog sveta. Stil, jezik, morfologija, sintaksa, ukupan narativni ustroj - sve je tu usklađeno i podređeno fluidnosti izabrane građe: „Vrednost Desničinih proza jeste dakle poetičnost i istovremeno životna istinitost, tu nema mesta za artizam kao takav niti za samodopadljivost. ${ }^{\text {"48 }}$ Poetika ovoga autora iščitava se neposredno iz njegovih dela, u kojima ne manjka ni ekstrapolacija odlomaka iz eseja u kojima Desnica eksplicite razmišlja o proznoj tehnici, što navodi na zaključak da je roman pisan izuzetno modernom proznom tehnikom. Podloga, polazište te nove

47 Janez Rotar, „Novine Vladana Desnice v oblikovanju pripovedništva“, u: V. Desnica, Pomladi Ivana Galeba, 1976. 259-279. Priređujući ovaj tekst za objavljivanje u knjizi Književnost in spoznavanje, Rotar je malo izmenio naslov, pa on glasi „Novo v proznem oblikovanju Vladana Desnice“. I prvi Rotarov esej, onaj iz 1974. godine, izmenjen je u „Miselne prvine v strukturi Desničevih Pomladi Ivana Galeba“. Videti: Janez Rotar, Književnost in spoznavanje. Recepcija del 20. stoletja, Ljubljana 1985., 109-121 i 123-143. Kao i sam Desnica, Rotar se stalno vraća svojim ranije objavljenim radovima te u njih unosi izmene i dopune.

48 J. Rotar, „Novine Vladana Desnice v oblikovanju pripovedništva“, 260. 
tehnike pisanja jeste „relativizacija apsolutnoga: oslabljena je granica i ublažena suprotnost odnosa onoga što je racionalno i onoga što je iracionalno u čoveku“ “ ${ }^{49}$ Rotar odlično opisuje suštinsku razliku između proze i poezije sa socijalnim motivima (izričito navodi imena Slavka Kolara, Ivana Dončevića, Novaka Simića, Vjekoslava Kaleba), nastale u hrvatskoj književnosti između dva rata, i proze sa socijalnim motivima kod samoga Desnice. Na primeru priče Proljeće u Badrovcu pokazuje kako, kojim se narativnim sredstvima Desnica udaljava od sentimentalizma tako karakterističnog za raniju prozu: nova, moderna proza, kakvu zastupa Desnica, odriče se svake eshatologije, svih doktrina, ma kako one delovale ili uveravale da jesu spasonosne. Od proze se zahteva da bude poetizovana, ali istovremeno i životno uverljiva. Iako je ovakvu poetiku Desnica primenjivao već od prve svoje duže proze, romana Zimsko ljetovanje, što je kod kritičara stvorilo velike nedoumice u definisanju književnoga žanra, eksplicitno je o ovome načelu svoje poetike Desnica progovorio u najdužem romanu, Proljećima Ivana Galeba - banalni, sasvim sitni, jedva primetni događaji, a ipak unutarnja napetost i izuzetna senzibilnost i psihološko uživljavanje u stanja, realna i irealna, što sve preuzima funkciju kohezivnosti pripovednog tkiva. Ukratko, Rotar je prostor pogovora za knjigu u izuzetno visokom tiražu iskoristio kako bi što bolje opisao poetiku Vladana Desnice, koja u prozu unosi nove kvalitete, ukidajući centralnu ulogu fabule, a unoseći u tekst poetičnost i refleksivnost, ostajući pritom verna pojmu životne uverljivosti.

U knjizi Književnost in spoznavanje mesta je našao i treći tekst o Desnici, koji nosi naslov Trije romani iz leta 1957.50 Romane objavljene 1957. godine - Lelejsku goru Mihaila Lalića, Baladu o trubi i oblaku (Balada o trobenti in oblaku) Cirila Kosmača i Proljeća Ivana Galeba Vladana Desnice - Rotar posmatra u svetlu činjenice da su sva tri naknadno doživela značajne prerade: u Desničinom romanu iz 1961. nalaze se dva poglavlja kojih nije bilo u izdanju iz 1957; Lalić je izmenjenu, novu varijantu romana Lelejska gora objavio 1962, a Kosmač je konačan oblik duže priče Balada o trobenti in oblaku objavio tek 1964, čitavih sedam godina nakon prvog izdanja. Druga međusobna sličnost jeste da sva tri romana kao temu imaju „borbu pojedinca za život, a protiv smrti“: „U sva tri romana temu označava antitetični odnos između života i smrti. ${ }^{\text {"S1 }}$ Kod Lalića i Kosmača vreme zbivanja radnje je konkretnije prikazano (Drugi svetski rat), dok kod Desnice vreme nije posebno definisano, ali je ipak istaknuto da Ivan Galeb živi u „nespecifičnim“ istorijskim okolnostima. Posebnu srodnost između Desnice i Kosmača Rotar potvrđuje i jednim osobnim svedočenjem. Pošto se duže bavio Desnicom, učinilo mu se da postoje sličnosti između diskurzivnih i esejističkih interpolacija u prozama Desnice i Kosmača, koje su kod oba pisca uvek u korelaciji s ontološkim dimenzijama dela. Prilikom jednog susreta sa Kosmačem Rotar je pomenuo ovome piscu to svoje zapažanje, a Kosmač mu je „iskreno obradovan to potvrdio i dodao da izuzetno ceni Desničino delo i njegov opus, a i da su njih dvojica prijatelji“. 52 Iako

49 Isto, 261.

50 J. Rotar, Književnost in spoznavanje, 207-222. Ovaj je tekst Rotar pročitao na skupu o Mihailu Laliću, održanome u Titogradu, a objavio ga na slovenačkom u Našim razgledima (33/1984., br. 39, 594-596). Potom je tekst uvršten u zbornik Mihailu Laliću u počast (ur. Radonja Vešović), Titograd 1984., 109-121. Ovde citiramo samo knjigu Književnost in spoznavanje.

51 J. Rotar, Književnost in spoznavanje, 208-209.

52 Isto, 210. 
Desnica i Kosmač roman usredsređuju na glavnog junaka, dok Lalić preko Lada Tajovića razmatra problematiku koja se širi na čitavu etničku celinu, na sve Crnogorce, i to ne samo u vremenu Drugog svetskog rata, nego i na njihove stoletne osobine, ove autore zapravo duboko spaja način pripovedanja. Posebnu pažnju Rotar posvećuje specifičnim oblicima prisustva autora u ovim delima: kod Lalića i Desnice se autorovo stajalište izražava preko glavnog junaka, dok je kod Kosmača ovo prisustvo izraženo na više načina: od eksplicitnog autorovog komentara uključenog u delo, preko izjava jednog od likova, do zamaskiranog pojavljivanja autora u samoj organizaciji pripovednih slojeva. Tu je zatim i tema čovekove usamljenosti, tehnika samootkrivanja i samospoznaje, kako u stanjima svesti, tako i bunila ili podsvesti, što sve približava ova dela psihološkom tipu romanu. Svuda se pojavljuje i dvojnik glavnog junaka, što doprinosi otkrivanju ontoloških problema kroz sudbinu tih likova. Ukratko, Rotar je ova tri pisca pročitao na veoma inventivan način, otkrivajući u svakome od njih karakteristike koje se inače, bez tog zajedničkog konteksta, ne bi tako jasno mogle sagledati.

I najzad, godine 1985. u časopisu Slavistična revija Rotar je uporedio, i nastojao da definiše, tip fikcije u prozi Vladana Desnice i Danila Kiša. ${ }^{53}$ U uvodnih nekoliko paragrafa nastoji on da skicira različite vidove književne fikcije u prozi od 19. veka pa nadalje - govori o razlici između mitskog, bajkovitog, sanjanog i nadrealnog - ali ga pre svega zanima moderna apstraktna imaginacija i njena funkcija u prozi Desnice i Kiša. Kod Desnice je motivacija prisustva fantastike čisto psihološka, kod Kiša je osim psihološke motivacije važna i politička: apsurdnost totalitarnog sistema on prikazuje upravo kao apsurd zamene pojmova istine i laži - i ono što propaganda ističe kao istinito, u biti je lažno. Kod Desnice je prisustvo fiktivnih, irealnih momenata u službi što detaljnijeg opisivanja čovekovog unutrašnjeg sveta; kod Kiša postoji i to, ali i mnogo više od toga: on se, kao i brojni drugi moderni pisci, poigrava dokumentarnošću, proglašava apokrife za dokumente, i obrnuto.

U tekstovima Janeza Rotara, koji se Desnicom bavio najduže i o njemu napisao čak četiri opsežne studije, središnje mesto zauzima formalna struktura pripovedanja. Rotara privlače strukturalne inovacije koje je Desnica uveo u prozu svoga vremena. Iako je svoje bavljenje Desnicom Rotar započeo upravo kada je na slovenački preveden roman Proljeća Ivana Galeba, njemu se tema smrti neće nametnuti kao značajna i izuzetna ni u jednoj od njegovih studija; on će je pomenuti samo kao jednu od niza opsesivnih tema u tome opusu. Ali analiza tematskih nivoa teksta i nije bila u žiži interesovanja ovog književnog kritičara i istoričara; u prvi plan on je stavio strukturalne inovacije koje je u prozu uveo Vladan Desnica.

Nema ovde prostora za detaljnije prikazivanje recepcije Vladana Desnice u Sloveniji nakon njegove prerane smrti. Neki od tih tekstova ne zaslužuju samo veću pažnju, nego možda i prevod na hrvatski, u nekoj antologiji koja bi okupila najznačajnije književne kritike objavljene o Desnici izvan jezičnog područja na kojem je delovao. Valjalo bi, jednom prilikom, pregledati i oceniti i Desničinio prisustvo u antologijama proze, te sastaviti pouz-

53 Janez RotaR „Fiktivno v prozi Vladana Desnice in Danila Kiša“, Slavistična revija, 33/1985., br. 2, 271-280. Jedino je ovaj Rotarov tekst objavljen samo na jednom mestu. Videti belešku 36. 
danu i pedantnu bibliografiju svih tragova ovoga pisca na slovenačkom jeziku. ${ }^{54}$ To ostaje za neku drugu priliku.

\section{$\cos$}

\section{Literatura}

Štefan BArbarič, „Podnebja Vladana Desnice“, Sodobnost, 15/1967., br. 7, 738-744.

Vladan Desnica, Pomlad v Badrovcu, Ljubljana 1963.

Vladan Desnica, Pomladi Ivana Galeba. Igre pomladi in smrti, Maribor 1974.

Vladan Desnica, Pomladi Ivana Galeba. Igre pomladi in smrti, 2 sv., Ljubljana 1976.

Vladan Desnica, Progutane polemike (prir. Jovan Radulović), Beograd 2001.

Jože Filo, „Pomlad v Badrovcu“, Nova obzorja, 16/1963., br. 9-10, 473-474.

Gregor Kocijan, „Proza Vladana Desnice“, Dialogi, 3/1967., br. 9, 455-459.

Slavko Kolar - Marijan Matković (ur.), Hrvatski povojni novelisti. 1945-1949, Ljubljana 1950.

Kajetan Kovič, „Vladan Desnica, Zimsko ljetovanje in Proljeća Ivana Galeba“, Tedenska tribuna, 7/1959., br. 38, 5 .

Miha Matè, Na sončni strani. Izbor sodobne jugoslovanske kratke proze, Ljubljana 1976.

Tone РотокаR, „Ob smrti Vladana Desnice“, Delo (Ljubljana), br. 63, 7. 3. 1967., 5.

Tone Potokar, „Zapisek o pripovedništvu Vladana Desnice“, u: Vladan Desnica, Pomlad v Badrovcu, Ljubljana 1963., 419-427.

Janez Rotar „Fiktivno v prozi Vladana Desnice in Danila Kiša“, Slavistična revija, 33/1985., br. 2, 271-280.

Janez Rotar, Književnost in spoznavanje. Recepcija del 20. stoletja, Ljubljana 1985.

Janez Rotar, „Miselne, snovne in izrazne plasti Desničevih 'Pomladi Ivana Galeba”, u: Vladan Desnica, Pomladi Ivana Galeba. Igre pomladi in smrti, Maribor 1974., 5-34.

Janez Rotar, „Novine Vladana Desnice v oblikovanju pripovedništva“, u: Vladan Desnica, Pomladi Ivana Galeba. Igre pomladi in smrti, sv. 2, Ljubljana 1976., 259-279.

Janez RotaR, „Trije romani iz leta 1957“, Književnost in spoznavanje. Recepcija del 20. stoletja, Ljubljana 1985., 207-222.

Milan Š EGA, „Pomlad v Badrovcu“, Delo (Ljubljana), br. 147, 31. 5. 1963., 5.

Stanko ŠIMENC, „Pomlad v Badrovcu“, Sodobnost, 11/1963., br. 10, 946-947.

Emil ŠTAMPaR, „Smrt bojevnika proti smrti. Vladan Desnica 1905-1967“, Naši razgledi, 16/1967., br. 8, 190.

Rapa ŠUKLJE, „Med Sutjesko in Badrovcem“, Tedenska tribuna, 12/1964., br. 4, 7.

Grigor Vitez (ur.), Put u slobodu. Zbornik pripovijedaka i zapisa iz Narodnooslobodilačke borbe, Zagreb 1951.

Radina VučEtić, Monopol na istinu. Partija, kultura i cenzura u Srbiji šezdesetih i sedamdesetih godina XX veka, Beograd 2016.

$54 \mathrm{Na}$ adresi https://isllv.zrc-sazu.si/sl/zbirka/kartoteka-tujih-avtorjev-v-slovenskem-periodi\%C4\%8Dnem-tisku\#v mogu se pronaći podaci o postojanju veoma korisne kartoteke, na žalost još uvek samo u formi bibliotečkih listića, o prisustvu pojedinih stranih pisaca u periodičnim publikacijama na teritoriji Slovenije od 1770. do 1970. Desnica tamo ima 191 listić! Prvi pomen ovoga autora je iz 1948. godine (Primorski dnevnik, br. 979, 2): anonimni autor izveštava o časopisu Hrvatsko kolo i samo uzgred spominje Desnicu. Za podatke zahvaljujem dr Alenki Koron, voditeljici Biblioteke Inštituta za slovensko literaturo in literarne vede pri ZRC SAZU u Ljubljani. 


\section{$\cos$}

\section{The CRitical Reception of Vladan Desnica and his WRITING ON DEATH IN SLOVENIA}

Desnica had a stronger presence on the Slovene literary scene than many of his Croatian and Serbian contemporaries. Literary criticism of Desnica's prose fiction is particularly abundant and highly informative. It could, perhaps, even be said that this critical reception resulted in the emergence of a particular, Slovene Vladan Desnica. Tone Potokar was Desnica's most prolific translator, as well as the author of the first comprehensive overview of his prose fiction. Janez Rotar, on the other hand, penned the most extensive body of theoretical work on Desnica. The aim of this paper is to provide an overview of the ways in which Desnica was represented on the Slovene literary scene. The personal recollections of literary critics Štefan Barbarič and Janez Rotar concerning Desnica's life and the period immediately after his death are of particular interest.

Key words: reception, translations, memoirs, recollections 
5.

\section{DRAMATURGIJA SLOBODE I SMRTI \\ ILI O LJESTVAMA JAKOVLJEVIM \\ VLADANA DESNICE \\ U SVETLU SARTROVE TEORIJE \\ POZORIŠTA SITUACIJA}

\section{Aleksandra Kuzmić}

UDK: 821.163.42-2Desnica, V.

Izvorni znanstveni članak

Sažetak: U radu se ispituju veze Desničinih Ljestava Jakovljevih sa pozorištem situacija, čije je osnove postavio i razradio Žan-Pol Sartr u teorijskim spisima o teatru. Tema je istraživana komparatistički, uz korišćenje odgovarajućih metoda teorijske dramaturgije i istorije pozorišta. U središtu Ljestava Jakovljevih je čovek u ratnom vremenu, pred kojim je životno značajno ali i univerzalno pitanje odgovornosti pojedinca u dramatičnim okolnostima, pitanje najtešnje povezano sa ličnim moralom i odnosom prema slobodi i smrti. A upravo ove elemente autor postavlja u osnove ideološkog, tematskog i dramaturškog tlocrta svog dramskog prvenca, uvodeći ga time u žanrovske okvire koje Sartr označava kao obnovu klasičnog tragičkog diskursa u novom vremenu, jer junak strada svojom krivicom, u sudaru sa istorijskim datostima. Desnica se, gradeći lik Jakova Pećine, opredeljuje da ovog junaka predstavi kao karakter u nastajanju, da predoči trenutak izbora, slobodnu odluku koja angažuje moral $i$ čitav jedan život. Dramski sukobi utemeljeni su na sukobima aktuelnih prava vezanih za svakodnevni život, te se stoga ovo delo, premda su ga i autor i kritičari posmatrali ili kao psihološku, ili kao realističku, odnosno realističko-naturalističku dramu, pokazuje kao značajno i čvrsto oslonjeno na temeljne poetičke odrednice pozorišta situacija. Ljestve Jakovljeve se, zahvaljujući načinu na koji se u delu, eksplicitno i implicitno, ispoljavaju sloboda i smrt, velikim delom uklapaju u tadašnji novatorski manir svojstven francuskim autorima, iako ga ni Vladan Desnica ni ondašnji pozorištnici ne čitaju u tom dramskom ključu. ${ }^{1}$

Ključne reči: Ljestve Jakovljeve, pozorište situacija, sloboda, smrt, sukob prava, izbor, mit

\section{PitAnje ŽAnRA}

『] napisima koji su osvanuli u beogradskoj štampi februara hiljadu devetsto šezdeset prve godine, povodom premijere Ljestava Jakovljevih Vladana Desnice, pozorišni kritičari ovaj dramski tekst pominju isključivo kao psihološku, realističku, odnosno realistič-

$\overline{1}$ Rad je nastao u okviru naučnog projekta Instituta za književnost i umetnost iz Beograda ON 178008 Srpska književnost u evropskom kulturnom prostoru, koji finansira Ministarstvo prosvete, nauke i tehnološkog razvoja Republike Srbije. 
ko-naturalističku dramu, pisanu pod snažnim uticajem Krležine dramaturgije. ${ }^{2}$ Istovremeno, Ljestvama Jakovljevim odriču bilo kakvu vezu sa „savremenim, novatorskim manirom svojstvenim francuskim autorima", 3 što se odnosi prvenstveno na Sartra, Kamija, Anuja i Koktoa te na obeležja njihovih dramskih dela. Za ovo jednostrano određenje nisu zaslužni samo tadašnji teatarski znalci - podstakao ga je i autor komada. Naime, u članku kojim se u Politici najavljuje premijera, Desnica kaže:

Ljestve Jakovljeve je psihološka drama u kojoj nema velikih spoljnih zbivanja. To su intimna, unutrašnja raspinjanja, puna samoosuđivanja glavnih junaka. Kada to kažem, mislim da nije bitno šta se sve zapravo u životu događalo ili moglo događati. Nije u prvom planu njihova stvarna, životno verodostojna sudbina. Zamisao je bila da se prikažu složeni, najdublji intimni porivi ljudske ličnosti koji u vremenu ratnog stradanja dobijaju svoj poseban intenzitet i oblik. ${ }^{4}$

\section{Tomislav Tanhofer, reditelj predstave, ${ }^{5}$ intervjuisan istim povodom, izdvojio je}

(...) briljantna i veoma tanana psihološka samoispitivanja junaka puna (...) dramskih valera, koji pružaju mogućnost stvaranja veoma intenzivnih scenskih zapleta u kojima dominira, pored sve košmarske mističnosti, veliki humanistički ideal pisca u kome on nalazi izlaz i rešenje za sva intimna preživljavanja i sukobe. ${ }^{6}$

Zašto se u vezi sa Desničinim Ljestvama Jakovljevim uopšte bavim pitanjem književnog odnosno dramskog žanra, koje bi se u dvadeset prvom veku, posle radova Fraja, Pavisa, Lemana, Gerde Pošman, Sarazaka i niza drugih teoretičara pozorišta i drame, moglo smatrati itekako prevaziđenim? Odgovor bi bio da postojeća, uvrežena oznaka dramske vrste sužava polje komparativnog tumačenja ovoga komada i vodi prenebregavanju značajnih uvida koji se tiču uzajamnosti Desničinog dela i evropske dramske produkcije nastale tokom i posle Drugog svetskog rata. Uz to, da bi se utvrdila saglasja, uticaji i dometi, neophodno je da se Ljestve Jakovljeve pogledaju okom nezamagljenim preuskim okvirom realističke, psihološke, ili naturalističke drame, jer će to omogućiti da se ne zapostave obeležja koja ovo delo čine ne samo bliskim pozorištu situacija već pokazuju da je značajno oslonjeno na njegove idejne postavke. Govoreći u prilog toj zasnovanosti potcrtala bih Desničine reči prema kojima „u prvom planu“ nije „stvarna, životno verodostojna sudbina“, nego „porivi ljudske ličnosti“

2 Reč je o četiri teksta čiji su autori Eli Finci („Интелектуанне распр““, Политика, br. 17019, 18. 2. 1961., 10), Slobodan Selenić („ВАадан Аесница: Һестве Јаковьеве“, Борба, br. 40, 18. 2. 1961., 7), Miloslav Mirković („Ljestve Jakovljeve“, Mladost, 6/1961., br. 228, 7) i Vladimir Stamenković („Sumnja u intelektualnu akciju“, Književne novine, 12/1961., br. 139, 7).

3 С. СЕленит, „ВАадан Аесница: Фестве Јаковьеве“, 7.

4 И[ванка] Б[Ешевић], „, Вестве Јаковљеве ВАадана Аеснице“, Политика (БеограА), br. 17017, 16. 2. 1961., 11.

5 Čini mi se neophodnim da naglasim kako je predstavu režirao Tomislav Tanhofer, o čemu svedoče kako plakat predstave, tako i najava premijere, te kritike objavljene u ondašnjoj štampi. Naime, u nekim se veoma analitičnim tekstovima o Desničinim Ljestvama Jakovljevim ponavlja jedna te ista pogreška: kao reditelj ovog komada u Jugoslovenskom dramskom pozorištu navodi se Nikola Tanhofer. Videti: Helena Peričić „Izdaja / krivnja / ideologija u Desničinoj drami Ljestve Jakovljeve", Tekst, izvedba, odjek. Trinaest studija iz hrvatske i inozemne dramske književnosti, Zagreb 2008., 121-135; Ista, „Jezik ideologije i ideologija jezika u Desničinoj drami Ljestve Jakovljeve“, Desničini susreti 2010. Zbornik radova (ur. Drago Roksandić i Ivana Cvijović Javorina), Zagreb 2011., 50; Jadranka BRnčić, „Problem etičkog angažmana u Desničinim Ljestvama Jakovljevim", Intelektualci i rat 1939. - 1947. Zbornik radova s medunarodnog skupa Desničini susreti 2012. (ur. Drago Roksandić i Ivana Cvijović Javorina), sv. 1, Zagreb 2013., 46.

6 И. БЕшевит, „Дестве Јаковљеве ВАадана Аеснице“, 11. 
u „vremenu ratnog stradanja“, i Tanhoferovo izdvajanje „velikog humanističkog ideala pisca“, u kojem autor pronalazi „izlaz i rešenje za sva intimna preživljavanja i sukobe“. I jedno i drugo upućuju na udaljavanje od realističke odnosno naturalističke poetike i iskorak u, kako ga imenuje Jovan Hristić, Sartrovo „retoričko pozorište svesnih odluka“7
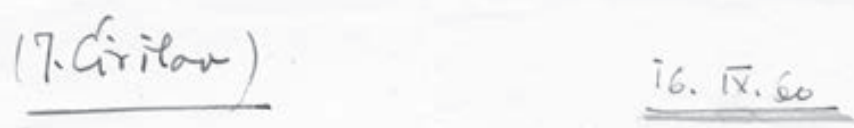

Poxtovan1 aruže Desnica, (Zagrcele)

Neobiðno m1 je drago ăto Vas mogu obavestiti da je rad na Vařen dramskon delu "Ljestve Jakovljeve" poð̌eo proăle nedelje 1 - poale jednog kraceg prekida zoog bolest1 Milivoja Z1vanoví́a - nastavio ae juð̌e pod rukovodstvom Tom1slava Tanhofera. Jloge su podeljene nar̉im najtminentnjjIm clanovima: Milivoju Zivanovibu, Marij1 Crnobor1, Viktoru Starčló, Nad1 R1zn16, Jož1 Rut16u, Dubravk1 Per16 1 glumo1ma nă̌e najmladje generaclje za woge \$rojevaca. Scenografiju smo poverill veoma talentovanom mladom scenografu $1 \mathrm{z}$ Priatinskog pozoriăta, koji Je prořle sezone bio narodito zapažen u Beogradu prilikom svog gostovanja sa scenografskim nacrtima za Soovu komed1ju "N1kad se ne sna", a ove sezone dao je scenograf1ju za pretstava "Stenica" od "ajakovakog koju Miroslav Belovió režira za naĕu Malu scenu. Kod njega postoj1 sreban spoj talents za 11 kovne valere 1 veliko praktiono pozoríno 1skustvo, koje 6e bit1 veoma ră̌no sa $V_{a}$ ăe delo.

U žlj1 da budete upoznat1 sa tokon rada 1 da blate stupill u kontakt aa narim ansamblom 1 glumol b1l1 u mogucnost1

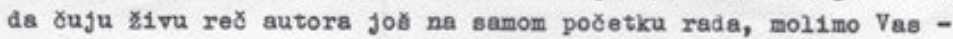
ako Vam je to ikako moguóno + da dodjete u Beograd u utorak, 20 septembra na dva-tr1 dans ( samo se po seb1 razume da Vam Pozorírte plaba put 1 dnevnice). U to vreme dod1 ce u Beograd 1 scenogral retar Pario pa bete prisustvovat1 1 prv1m razgovorima reditelja o scenografskom oblikovanju tă̌e drame. Ansambl, koj1 je pokazeo velikin interes 1 odủevljenje za Văe delo ved prilikon prvog ditanja, s nestrpljenjez ocekuje $v_{a}$ dolazak. Javite telegranon kad ot1rete rad1 obebbedjenja sobe u hotelu.

Sxdačno Vaa pozdravlja,

Beograd, 16.IX.1960 god.
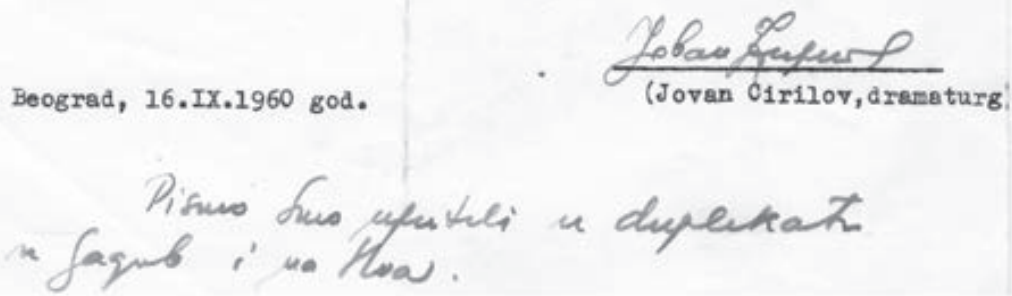

Sl. 1. Pismo dramaturga Jovana Ćirilova Vladanu Desnici

7 Jovan Hristić, „Beketovo pozorje ljudskog života“, Studije o drami, Beograd 1986., 134. 
Argumentovano poredeći tematske, idejne i dramaturške osobenosti Desničinog komada sa premisama Sartrove teorijske dramaturgije, nastojaću da izbegnem zamke danas tako čestog naučnog relativizma, i pokažem po čemu su, i u kojoj meri, Ljestve Jakovljeve saobražene tragičkom diskursu svojstvenom pozorištu situacija.

\section{SARTROVA TEORIJSKA DRAMATURGIJA -}

\section{ZA POZORIŠTE SITUACIJA}

Pošto Sartr osmišljava celovit pogled na pozorišnu praksu, Jovan Hristić s razlogom navodi da se „Sartrovi napisi o pozorištu“ mogu „po ozbiljnosti osnovnih misli (...) meriti ako ne s Brehtovom teorijom epskog teatra, a ono sigurno sa onim što je Strindberg mislio i pisao o pozorištu“. ${ }^{8}$ Osnovu „tog strogog, moralnog, mitskog i ritualnog pozorišta iz kojeg su nastali pozorišni komadi u Parizu tokom okupacije i neposredno posle rata" čini mreža čvrsto uvezanih i jasno definisanih ideja i pojmova poput slobode, opšte situacije, sukoba prava, smrti, karaktera u nastajanju, zajedništva gledalaca, pozorišta kao kolektivnog religioznog fenomena. Premda je ideja slobode zasnovana u autonomiji volje i njome uslovljenom biranju stvarnosti jedan od oslonaca Sartrove egzistencijalističke filozofije i književnog stvaralaštva, opredelila sam se da u ovom članku ostanem pri nevelikom broju tekstova ${ }^{10}$ koji se najdirektnije odnose na pozorište. Reč je o četiri relevantne teatrološke rasprave: $Z a$ pozorište situacija, ${ }^{11}$ Dramski stil,${ }^{12}$ Stvoriti mitove ${ }^{113}$ i Epsko i dramsko pozorište. ${ }^{14} \mathrm{U}$ radu je, kao teorijska osnova za bolje razumevanje pozorišta situacija, korišćen i intervju koji je Žan-Pol Sartr 1961. godine dao Kenetu Tajnanu. ${ }^{15}$

Iščitavanje teorijskih premisa Sartrovog pozorišnog organona nameće - što nije neočekivano - izvesna poređenja s Aristotelovim viđenjem tragedije, uprkos tome što francuski filozof i pisac tvrdi da on i oni u čije ime piše ne žele obnavljanje tragedije, niti stvaraju filozofske komade. Istovremeno, Sartr ne poriče „da ima nešto istine u tim etiketama“. ${ }^{16}$ Ako antička tragedija odražava antičko shvatanje čoveka, moglo bi se sa mnogo razloga pretpostaviti da pozorište situacija odražava shvatanje čoveka svojstveno generaciji mladih

\footnotetext{
8 Isto, 115.

9 Žan-Pol SARTr, „Stvoriti mitove“, Drame. Tekstovi o pozorištu, Beograd 1981., 404.

10 Svi tekstovi na koje se pozivam objavljeni su u prevodu Mirjane Miočinović u knjizi Žan-Pol SARTr, Drame. Tekstovi o pozorištu (= Izabrana dela, knj. 5), Beograd 1981. Posredi je izbor iz obimne knjige Un théâtre de situations (Gallimard, Paris 1973), u kojoj su sabrani brojni Sartrovi napisi, predavanja i intervjui vezani za pozorište i dramska dela.

11 „Tekst objavljen u La Rue, br. 12, novembar 1947.“ Ž.-P. SARTr, Drame. Tekstovi o pozorištu, 390.

12 „Tekst je prvi put objavljen u knjizi Un théâtre de situations, a na osnovu neredigovanog Sartrovog predavanja održanog 10. juna 1944. po želji Žana Vilara, koji je organizovao čitav niz predavanja-rasprava o pozorištu." Ž.-P. SARTR, Drame. Tekstovi o pozorištu, 398.

13 „Predavanje koje je Sartr održao u Njujorku godine 1946. objavljeno je prvi put u američkom časopisu Theatre Arts (Vol. XXX, 6, 1946) pod naslovom Forgers of Myths: The Young Playwrights of France. U Francuskoj je tekst štampan prvi put u knjizi Un théatre de situations, Paris, Gall., 1973, str. 55-67." Ž.-P. SARTr, Drame. Tekstovi o pozorištu, 404.

14 „Neznatno skraćen tekst predavanja koje je Sartr održao 29. marta 1960. godine u velikom amfiteatru Sorbone. Prvi put objavljeno u knjizi Un théâtre de situations. "Ž.-P. SARTr, Drame. Tekstovi o pozorištu, 429.

15 „Sartrov razgovor s Kenetom Tajnanom prvi put je objavljen u londonskom The Observeru 18. i 25. juna 1961.“ $\check{Z}$.-P. SARTR, Drame. Tekstovi o pozorištu, 439.

16 Ž.-P. SARTr, „Stvoriti mitove“, 399.
} 
francuskih ${ }^{17} \mathrm{i}$ - neću pogrešiti ustvrdim li - evropskih pisaca, obeleženoj Drugim svetskim ratom. ${ }^{18}$ Poput generacije stvaralaca koja je stasavala kroz Prvi svetski rat, i pisci Sartrovog odnosno Desničinog naraštaja ratno će iskustvo, i iz njega proistekao odnos prema svetu i umetnosti, ispoljavati kroz različite modalitete. Činjenica je, međutim, da rat, sa moralnim dilemama i izopačenom ljudskošću, postaje rodno mesto problema koje oni u svojim delima tematizuju. ${ }^{19}$ Sartr i njegovi savremenici posebno ispituju „problem cilja i sredstava, problem opravdanosti nasilja i posledica određenog delanja, problem odnosa između pojedinca i zajednice, problem individualnog sukoba sa istorijskim datostima “. ${ }^{20}$ Desničine Ljestve Jakovljeve, koje ispituju ponašanje i odgovornost pojedinca, uz to i intelektualca, za ono što se dešava u ratom zahvaćenom svetu, postavljaju pred likove, ali i pred gledaoce / čitaoce pitanje može li, sme li čovek biti indiferentan i pasivan pred zločinom i institucionalizovanim nasiljem. Da li je strah od smrti dovoljno opravdanje za njegovo povlačenje i nesuprotstavljanje fašističkom, ili bilo kakvom drugom, pogromu? Iščezavaju li ljudskost i humanizam kad je glava u torbi? I da najdirektnije povežem ove tematsko-idejne zapitanosti sa likovima: Da li u trenutku monstruoznih egzekucija postoji razlika između prećutne saglasnosti i pasivnosti koju Jakov Pećina bira kao svoje vidljivo ja? Da li Jakov Pećina, i pored toga što ne odobrava nacizam i njegove metode, sa gestapovcem Huberom deli breme odgovornosti za zločine? Ovakva tematska usmerenost, i raspon duhovnih dilema koje izražava i predstavlja Vladan Desnica u Ljestvama Jakovljevim, posve se uklapaju u problematiku koju Sartr označava kao savremenu, ali i u njegovu zamisao teatra koji na scenu izvodi čoveka slobodnog „, granicama sopstvene situacije“, čoveka „koji hteo ili ne, pravi izbor za sve druge, kada ga pravi za sebe samog“. ${ }^{21}$

Šta je cilj teatra situacija i kakve zahteve on postavlja pred stvaraoca? Jedna od ključnih postavki proističe iz Sartrovog uverenja da „pozorište postoji tek kad se postigne zajedništvo svih gledalaca“, što praktično znači da situacije koje se predstavljaju moraju biti „toliko opšte da mogu biti zajedničke svima“. ${ }^{22}$ Težnja da se sasvim različiti ljudi koji sede u publici ${ }^{23}$ povežu i stope u celinu počiva na ideji da „bi pozorište trebalo da bude: jedan veliki kolektivni i religiozni fenomen “. ${ }^{24}$ Stoga i ne čudi što takvo pozorište mora biti moralno, odnosno što se kroz konfrontiranje prava, koja Sartr vidi kao čvorište sukobljavanja, ono

$17 \quad$ Isto, 398.

18 Vladan Desnica i Žan-Pol Sartr ne samo da su rođeni iste godine (1905) i preživeli ratnu golgotu, već rat i njegove posledice, zločini, moralna iskušenja i zastranjivanja nalaze značajno mesto u njihovom stvaralaštvu. Navešću kao primer dve Sartrove drame - Prljave ruke i Zatočenike iz Altone. Kad je o Desnici reč, takođe ću ostati pri dramskim delima, pa pored Ljestava Jakovljevih pomenuti nedovršeni komad Gadni mali gnom, koji je u piščevoj zaostavštini pronašao i objavio Dušan Marinković. Videti: Vladan DesnicA, „Gadni mali gnom“, Književna republika, 6/2008., br. 3-4, 3-21.

19 Sartr navodi da „umetničko delo, čak i kad nije političko, nastaje iz shvatanja svog vremena i mora biti u skladu sa svojim vremenom“. Up. Ž.-P. SARTr, „Razgovor sa Kenetom Tajnanom“, Drame. Tekstovi o pozorištu, 434.

20 Ž.-P. SARTr, „Za pozorište situacija“, Drame. Tekstovi o pozorištu, 390.

21 Ž.-P. SARTr, „Stvoriti mitove“, 400.

22 Ž.-P. SARTr, „Za pozorište situacija“, 390.

23 Ne mogu se oteti utisku da je Sartrovo ukazivanje na to kako u gledalištu „gojazan poslovni čovek sedi kraj kakvog trgovačkog putnika ili profesora, čovek sedi pokraj žene, i svako od njih ima sopstvene brige“ (Ž.-P. SARTR, „Stvoriti mitove“, 402) u stvari izvestan omaž Geteu, tačnije Predigri u pozorištu iz Fausta.

24 Ž.-P. SARTr, „Stvoriti mitove“, 402. 
bavi sukobima „sistema vrednosti, sukobi[ma] čovekovih moralnih i pojmovnih sistema“.25 Iako bi se moglo pretpostaviti da je u takvoj konstelaciji elemenata najvažniji karakter, Sartr, koji ne odbacuje sasvim psihološku dimenziju karaktera, ${ }^{26}$ ipak tvrdi da je presudna situacija, i to potkrepljuje prilično ubedljivim primerima:

Nisu bitne razlike u karakteru između jednog staljiniste i jednog trockiste; godine 1933. jedan antinacista i jedan SS nisu dolazili u sukob zbog razlika u karakterima; teškoće u međunarodnoj politici ne potiču od karaktera ljudi koji nama upravljaju; štrajkovi u Sjedinjenim Državama nisu prouzrokovani sukobima karaktera između industrijalaca i radnika. ${ }^{27}$

A univerzalne, opšteljudske situacije na koje se poziva, opredmećene kroz „velike mitove smrti, progonstva, ljubavi“ “ ${ }^{28}$ neophodno je prikazati u trenutku kulminacije. Taj trenutak, koji liku omogućava, primorava ga da izabere u novonastalim okolnostima, povoljnim, nepovoljnim, blagonaklonim ili pretećim, u isti mah je oličenje sistema vrednosti i aktuelnih prava koja junak brani, ali i ogledalo slobode kojom raspolaže. Delanje proisteklo iz slobode izbora u datoj situaciji jeste, prema Sartru, „nešto najuzbudljivije što pozorište može da prikaže“, jer je posredi „karakter u nastajanju, trenutak izbora, slobodna odluka koja angažuje moral i čitav jedan život“. ${ }^{29}$ Razlažući ovakvo viđenje teatra Sartr objašnjava da „čovek kog sticaj okolnosti neminovno vodi u propast nije kadar da nas gane. Nema veličine u njegovom padu do ako strada svojom krivicom. " ${ }^{30}$ Drugim rečima, krivica koja izvire iz slobode izbora, iz prava na koje se polaže pravo, koja ističe ličnu odgovornost, snažno deluje na gledaoca

(...) koji je istovremeno i običan čovek, i neko kome je data uloga moralnog sudije; on sudi o potezima i kaže: ovaj je u pravu, ovaj nije; a samo iznenađenje u pozorištu skoro uvek dolazi otud što se odjednom pokaže da i onaj za kog se mislilo da nije u pravu, ima, bar donekle, naravno, pravo. (...)

Pozorište tako postaje poput zatvorenog polja u koje ljudi dolaze da bi dokazali svoja prava. Potrebno je još i da nas ta prava zanimaju i stoga je nužno da to budu aktuelna prava... ${ }^{31}$

Prema Sartru, pravo je aktuelno ako je značajno i intrigantno u savremenom trenutku. Međutim, koliko god ukazivalo na nešto skorašnje, koliko god se odnosilo na autoru i gledaocima blizak i poznat istorijski i društveni kontekst, aktuelno pravo nosi u sebi dvostrukost, barem kad su posredi dela neupitne vrednosti, jer se u njemu susreću aktuelno i univerzalno. ${ }^{32}$ Ono što dodatno pojačava utisak, spaja pojedince u gledalištu i doprinosi

25 Isto, 401.

26 Sartrov odnos prema udelu psihologije u dramskom delu i teatru menjao se tokom godina. Dok 1946. tvrdi: „Mi ne odbacujemo psihologiju, što bi uostalom bilo besmisleno: mi je integrišemo u život “ (Ž.-P. SARTR, "Stvoriti mitove“, 401), četrnaest godina kasnije je izričit: „pozorištu nije potrebna psihologija. U pozorištu psihologija je samo gubljenje vremena. (...) A stvoriti pozorišni komad to upravo znači gurnuti ljude u poduhvat; psihologija nije potrebna.“ Ž.-P. SARTr, „Epsko i dramsko pozorište“, Drame. Tekstovi o pozorištu, 425.

27 Ž.-P. SARTR, „Stvoriti mitove“, 401.

28 Isto, 402.

29 Ž.-P. SARTR, „Za pozorište situacija“, 389.

30 Isto.

31 Žan-Pol SARTr, „Dramski stil“, Drame. Tekstovi o pozorištu, 395.

32 Naravno, aktuelnost prava je promenljiva kategorija jer se, shodno događanjima na jednom široko zasnovanom planu, univerzalno pravo zaodenuto individualizovanim okolnostima ciklično aktuelizuje. Stoga se reditelji i pozorišne kuće odlučuju da postave ili da ponovo pročitaju određena, a ne neka druga, dela u određenim društveno-istorijskim situacijama. 
prerastanju pozorišnog čina u kolektivni religiozni fenomen jeste alternativa koja se ukazuje junaku. Premda se sloboda ne zadobija spremnošću na umiranje, odnosno premda cena slobode nije smrt, pred junakom se, u vezi sa onim što bira da čini, kao jedna od dveju mogućnosti naglo otvaraju vrata iza kojih vreba smrt, jer „u smrt se ne ide korak po korak, čovek je odjednom suočen sa njom“. ${ }^{33}$ Ovakvim uvođenjem smrti - tragičnog ljudskog usuda kojem ni najprivilegovaniji ne mogu umaći, Sartr otvara prostor za dramsko promišljanje najbolnije čovekove zapitanosti, kako na idejnom planu tako i u pogledu dramaturške funkcionalnosti. Sveprožimajuća prisutnost smrti se u skladu s tim višestruko ispituje: i kroz činjenja koja izazivaju smrt ili trasiraju put do smrti (doslovna, moralna itd.), i kao direktna pojavnost (ubistvo, smrt na pozornici, na primer), i kao značajna dramaturška poluga koja pokreće ili usmerava radnju. Istina, Sartr „zaboravlja“ da prokomentariše neminovnost smrti, moguće zbog njene aksiomatske pozicije u ljudskom životu, pa se mudro usredsređuje na slobodu i čovekov angažman proistekao iz sudara sa okolnostima koje ne bira, ali spram kojih se mora postaviti, pre svega delanjem. Time se krug zatvara: delanje je uslovljeno pravom koje je autentični izraz onoga što je lik u situaciji sa kojom se nosi. Tako sagledavajući i predstavljajući čovekov položaj, pozorište situacija omogućava gledaocu da stekne uvide o sebi samom, o sopstvenim dilemama i iskušenjima, i to kroz potvrdu / osporavanje određenih prava „kao što su građanska prava, porodična prava, individualni i kolektivni moral, pravo da se ubije, pravo da se ljudima otkrije njihova ništavna sudbina, i tako redom". ${ }^{34}$

\section{LJESTVE JaKOVLJEVE I SaRtrovo POZORIŠTE SITUACIJA}

Po čemu su i u kojoj meri Ljestve Jakovljeve saobražene Sartrovom pozorištu situacija? Prvo, Desničina drama, po problematici kojom se bavi, ne pripada takozvanoj građanskoj drami, u čijem se tematskom okrilju razvija psihološka i naturalistička dramaturgija. Naime, Ljestve Jakovljeve u prvi plan postavljaju intrigantnu priču o čoveku koji, želeći da sačuva život po svaku cenu, kukavički relativizuje svoje moralno posrtanje, dok se ne suoči sa sopstvenim izobličenim licem i posledicama koje ono proizvodi. Otrežnjenje nastupa prekasno, te posledice problematičnog (ne)̌̌injenja postaju zamajac ishoda koji gledalac prividno neće videti na sceni. Kažem prividno, budući da se on u anticipirajućem snu protagoniste već odigrao pred publikom, donoseći Jakovu Pećini anagnorizam (anagnorisis). Stoga će ovaj tragički lik Desničinog komada, ničiji mrtvac i prividno živ čovek, pre spuštanja zavese shrvan, kao u ropcu, reći: „Strahota!... Sad čitava priča započinje iznova!..." ${ }^{35}$ Pošto je noćna mora mučnim doživljajem upozorila snevača da je nešto u njegovom životu duboko pogrešno, buđenje će postati prolog more na javi: lik je spoznao sopstveni položaj, učinjene pogreške i njihovu štetnu dalekosežnost. Ali povratka nema, sloboda da se donese

33 Ž.-P. SARTR, „Stvoriti mitove“, 403.

34 Isto, 401.

35 Vladan Desnica, Zimsko ljetovanje. Pjesme. Ljestve Jakovljeve (= Sabrana djela Vladana Desnice, knj. IV), Zagreb 1974., 333. 
odluka u dramatičnim okolnostima je iskorišćena, pravo na koje se profesor Pećina pozivao pokazalo je svoje naličje, a rečenica „Običan privatni čovjek nije dužan da bude heroj", 36 kojom je prao ruke uzmičući pred sopstvenom moralnom odgovornošću, i maskirao strah od smrti, preobrazila se u prvorazrednu demagošku frazu. Pravo koje brani Jakov Pećina, pravo da ostane neutralan, skrštenih ruku u momentu kad se svet raspolućuje nadvoje, razotkriva kukavicu i izdajnka skrivenog u čoveku. Jakovljevu uspaničenu malodušnost, čiji je simbolički vrhunac zastrašenost „fantomom nekakvog Biserka-Triserka “, ${ }^{37}$ još uočljivijom čini društveni status - profesor Pećina je uvaženi član društva, viđeni intelektualac. A ulog je za svakog pojedinca neprocenjivo velik - sopstveni život odnosno sopstvena smrt, čime se dodatno osnažuju pitanje morala i sukobljavanja prava: da li se boriti, aktivno se suprotstaviti neprijatelju, sa svešću da možeš biti mučen i ubijen, da možeš stradati zbog svog angažmana, ili živeti između juče i sutra, u svojevrsnoj neutralnosti koja bi trebalo da obezbedi i preživljavanje po svaku cenu uz - kako sam sebe ubeđuje protagonista Ljestava Jakovljevih - neokaljani obraz.

Situacija u koju Desnica postavlja svoje likove, davši im slobodu da biraju sopstveni identitet u sudaru s istorijskim neprilikama, priča je o čovekovoj odvažnosti i slabićstvu, o ličnoj odgovornosti pred sobom i drugima u vremenu kad se sve vrednosti jednog sveta raspadaju pred institucionalizovanim nasiljem. Drugim rečima, to je priča kojom se može podstaći jedinstvo u gledalištu, jer je posredi arhetipska situacija koja je toliko opšta da može biti zajednička svima. Vladan Desnica na to upućuje i znakovitim naslovom, kojim se, kao i postavljanjem biblijskog citata za moto dela, odnosno aludiranjem na biblijskog Jakova, uspostavlja daleko obuhvatniji značenjski i idejni kontekst drame u celini. Time se siže, zatim situacija koja zahteva da Jakov Pećina izabere kako će postupiti na osnovu prava koje brani, jednako kao i etičke implikacije njegovog ponašanja, povezuju s mitom na jednom dubljem, suštastvenom nivou, i postaju deo svevremene priče o čovekovom moralu, sistemu vrednosti, izdaji i krivici.

I Sartrova ideja da lik slobodno bira šta mu je činiti u određenoj situaciji, gradeći tako, kroz radnju, sopstveni identitet, pokazuje se kao princip delatan u Desničinoj drami. U „situaciji koja je poziv, koja hvata u mrežu i predlaže rešenja, likovima ostaje da odluče“. ${ }^{38}$ Petar Orljak, profesor, u vreme okupacije, represalija i egzekucija, talaca, likvidacija jataka i saslušanja u specijalnoj policiji - postaje aktivni zagovornik i potpora pokreta otpora i partizana. Njegova kći Dunja, maturantkinja, kao i njeni vršnjaci i drugovi Ognjen i Miško, nešto mlađi Zdravko, te Grga mlekar, od učenika na pragu zrelosti izrastaju u herojske figure. A Jakov Pećina, koji je u nekoj davnašnjoj ratnoj situaciji izabrao da bude na frontu u Galiciji, gde je i ranjen, od čega mu je ostalo ukočeno desno koleno, taj i takav Jakov u novoj ratnoj situaciji gradi potpuno nov identitet. Bivši ratnik i ugledni intelektualac motivisan je isključivo željom da ne nastrada, ne pogine slučajno, nehotice, ali i da ne dovede život u opasnost kao saradnik „rebelâ, čvrsto veruje da mu se ništa ne može prebaciti“ ${ }^{\text {“39 }}$ jer

\footnotetext{
36 Isto, 281.

37 Isto, 317.

38 Ž.-P. SARTR, „Za pozorište situacija“, 389.

39 V. Desnica, Ljestve Jakovljeve, 279.
} 


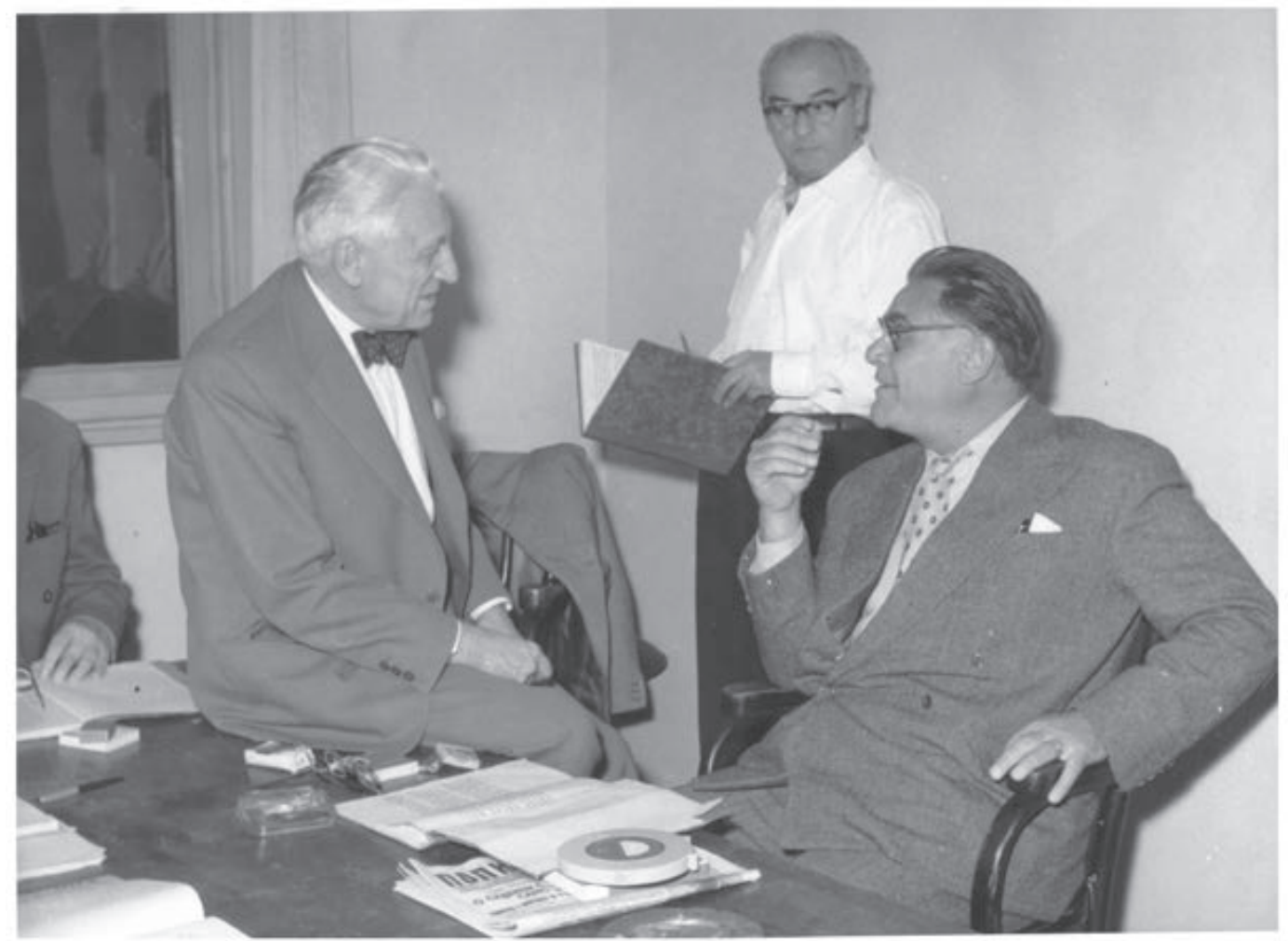

Sl. 2. Fotografija sa čitaćih proba Ljestava Jakovljevih 1960. godine: Tomislav Tanhofer, Viktor Starčić i Vladan Desnica

se „potpuno povukao, nikome ne ide, ništa ne piše“ ${ }^{40}$ Strah od smrti je toliki da on svom prijatelju, ali i oponentu Petru Orljaku iskreno kaže:

Kad se iznenada nađemo licem u lice s tim biti ili ne biti, tad opet rukne iz nas ona primarna zvijer! Padaju sva načela i osvjedočenja, i na njihovo mjesto stupa jedan jedini imperativ: spasiti glavu!... ${ }^{41}$

Jakov moralni kodeks kojim se rukovodi obrazlaže i rečima:

Taj sitni individualni životić, ta otrcana krpa mesa koju teglimo i po cijenu svega i svačega spasavamo, odjednom postaje vrhovno, jedino dobro. ${ }^{42}$

Njegovi postupci prema Veri, ali i oni sadržani u njegovom predikativnom snu, koji svedoče o nepojmljivom podlaštvu, nisu samo slika krajnje niskosti koju lik dotiče pre samospoznaje, nego su i izraz jednog poremećenog sistema vrednosti utabanog pravom koje Jakov Pećina predano brani, a to je pravo na odbranu sopstvenog života po svaku cenu. Gotovo da je tragikomično što, opredelivši se za takav stav, očekuje da ostane čistih ruku. Birajući

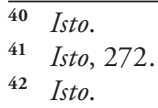


sebe takvog Jakov je odabrao i za druge - izdaće i Veru, i Orljakove, i mlade revolucionare. Taj novi Jakov zadobija i novo mesto među drugima. Ono se prepoznaje po oštrim jetkim kritikama i prebacivanjima koja mu upućuje Petar, po Huberovim mefistofelovskim marifetlucima i poigravanju, ali i po Dunjinom prezrivom distanciranju. Hrabra, neustrašiva borkinja za slobodu, ova devojka ne posustaje ni pred specijalnom policijom, ni pred izvesnošću smrti. U teskobnoj situaciji njena sloboda progovara kroz pravo na otpor nasilju. I zato Dunjini odgovori Jakovu, porodičnom prijatelju i nekadašnjem uzoru, odišu jedva prikrivenom hladnoćom.

U Ljestvama Jakovljevim je kroz još jedan lik - lik šturmfirera Josefa Hubera - i implicitno potvrđena Sartrova ideja da je situacija poziv. U tekstu je baš Jakovu Pećini dato da progovori o tome:

Čudno krivudaju životne putanje u današnjim poremećajima! Bez tih ratova i revolucija, moj bi Huber bio mirno zaplovio u akademsku karijeru. (...) Zakamufliran profesorskom bradom i očalama, iživljavao bi svoju perverziju u zatvorenim okvirima univerzitetskih programa i solidnog obiteljskog života. Ovako, prvi ga je rat srozao s akademskih visina u privatne činovnike, a drugi isturio iz privatnih činovnika u šturmfirere. ${ }^{43}$

Takođe, kroz reči koje izgovara Petar Orljak mogu se posmatrati i druga implicitna poetička poklapanja Desničine drame sa idejama Sartrove teorijske dramaturgije. Ljestve Jakovljeve se otvaraju dijalogom dvojice prijatelja koji se naročito bave pitanjem šta da se radi u ratnoj situciji. Kao zagovornici oprečnih sistema vrednosti i različitog vrednovanja moralnosti određenih postupaka, što na videlo izlazi u prolećnoj noći u okupiranom gradu, konfrontiraće se Petar Orljak, profesor i predstavnik onih koji se bore protiv okupatora, i Jakov Pećina, profesor i demagog, koji iz straha za goli život odbija da rečju i delom javno iskaže svoj stav. Jedno od ključnih pitanja koje će se ispoljiti u žaru diskusije jeste i pitanje slobode - okupacija i nasilje iziskuju da se bez odlaganja donesu odluke, ali i da se preduzmu određeni koraci. Petar Orljak pojam slobode doživljava u sartrovskom ključu, jer je izjednačava sa donošenjem odluke i delanjem u situaciji sa kojom se čovek suočava:

Uprav zato što svak posmatra stvar iz jedne subjektivne vizure, svak je nužno angažovan, bilo na jednoj ili na drugoj strani. I čovjek se, ni sam pravo ne znajući kako, odjednom nađe pred nekom tragičkom dilemom. ${ }^{44}$

Jakov Pećina, relativizujući objektivne okolnosti, govori o unutrašnjoj slobodi, što Petar kvalifikuje kao oslobođenost od svake moralne odgovornosti prema drugima. Pokazujući mu neodrživost relativizovanja kojem pribegava, Petar navodi:

Ali same prilike, događaji, postupci drugih, neodoljivo te povuku za sobom, dovedu te u situaciju kad ta tvoja odluka dođe u sukob s najosnovnijom ljudskom dužnošću, s najprirodnijim ljudskim osjećanjem. (...) Hoćeš li, da bi zaštitio sebe, popustiti presiji i posvjedočiti neistinu o svome kolegi, svome prijatelju? Nećeš? Već si se našao pred tragičkom dilemom, već si aktivno angažiran. ${ }^{45}$

$\begin{array}{ll}43 & \text { Isto, } 291 . \\ 44 & \text { Isto, } 281 . \\ 45 & \text { Isto, } 282 .\end{array}$ 


\section{ZAKLJUČAK}

Povest o odgovornosti pojedinca u dramatičnim istorijskim danima, koju Desnica kroz Ljestve Jakovljeve iznosi pred svoje savremenike, ali i pred sve one koji danas gledaju / slušaju / čitaju ${ }^{46}$ njegov komad, idući od pojedinačnog ka opštem, oživljava, u novom ruhu, mit o odgovornosti pojedinca u problematičnom i zahtevnom vremenu, progovarajući o kukavičluku, izdaji, malim i velikim ljudskim strahovima, ali i o odgovornosti, odvažnosti i idealizmu. Ovaj mit, sazdan na sukobljavanju oprečnih vrednosti, za koje se zalažu zagovornici različitih prava - Petar Orljak i njegova kći sa svojim drugovima, kao oličenje prava na otpor nasilju, naročito institucionalizovanom, naspram Jakova Pećine, koji brani pravo da spase glavu po svaku cenu, pravo da bude neutralan i neprimetan - provokativan je i savremen u svakom vremenu, a ne samo u ratnom, okupacionom, u koje Desnica postavlja svoje likove. Jer svako vreme ima svoje silnike, mnoga istorijska razdoblja i sistemi vlasti počivaju na nasilju i prinudi, pa je suočavanje gledaoca / slušaoca / čitaoca sa dramatičnim posledicama odluka proisteklih iz izbora koje pojedinac pravi prilika da se zagleda u sebe sama i zapita: $A$ šta bih, kako bih ja? ili možda Šta učinih? Drugačije rečeno, posredi je univerzalna egzistencijalna situacija u kojoj se, pre ili kasnije, nađe svaki čovek, budući da ličnu odgovornost i lični moral na probu stavljaju okolnosti čije je naličje smrt, neminovnost stradanja - sopstvena i drugih ljudi. Motivi zbog kojih se pojedinac ponaša na određeni način, naporedo sa njegovim postupcima, definišu pojedinčev identitet u situaciji kojoj je izložen, i pokazuju kuda ga vodi sloboda da izabere, da se opredeli između dve mogućnosti. Vladan Desnica se ovakvim udaljavanjem od realističko-naturalističko-psihološke drame, odnosno od uskih tematsko-sadržajnih i idejnih okosnica građanske drame, opredelio za svojevrsni tragički diskurs svojstven onome što je sredinom dvadesetog veka imenovano kao novatorski manir francuskih autora. Odnosno, Desnica se Ljestvama Jakovljevim na mapi dramaturških traganja, eksperimenata i ména, u prošlom veku, upisao među dramske pisce čije pozorišne komade odlikuju „žive rasprave među ličnostima koje sa strašću brane svoja individualna prava“, 47 čiji komadi svojim stilom „umesto da probude osećanje prisnosti, povećavaju distancu između dela i publike “ ${ }^{48}$ napose, čiji komadi o čoveku govore „sa ozbiljnošću, autoritetom i univerzalnošću tragedij ““.99 Sudbina koja sustiže likove „samo je naličje slobode“ ${ }^{50}$ a piscu i njegovom delu ,je jedino stalo do toga da ispita čovekov položaj u njegovoj sveukupnosti i da savremenom gledaocu pruži portret njega samog, sa svim njegovim problemima, nadanjima i borbama". ${ }^{11}$ Uvidi koje omogućava tematska, idejna i

\footnotetext{
46 Prema podacima koje sam dobila od Lade Martinac Kralj, dramaturškinje i urednice Radio drame na Hrvatskom radiju, Ljestve Jakovljeve su kao radio drama emitovane dva puta: premijerno 7. 5. 2011. u emisiji Radio scena na Prvom programu, a reprizno 14. 7. 2011. na Trećem programu Hrvatskog radija, u emisiji Radio drama. Režiju ovog izvođenja potpisuje Dejan Šorak, adaptaciju Lada Martinac Kralj, muzički ga je uredio Žarko Joksimović, ton majstor je bio Srđan Nogić, a glumili su: Franjo Kuhar, Vinko Kraljević, Ana Kraljević, Damir Šaban, Pjer Meničanin, Asja Jovanović, Andrej Dojkić i Sven Mađarević.

47 Ž.-P. SARTr, „Stvoriti mitove“, 403.

48 Isto, 403-404.

49 J. Hristić, „Filozof u pozorištu“, 115.

50 Ž.-P. SARTR, „Za pozorište situacija“, 389.

51 Ž.-P. SARTr, "Stvoriti mitove“, 402.
} 
dramaturška analiza Ljestava Jakovljevih, kao i sagledavanje eksplicitnih i implicitnih poetičkih poklapanja između ovog Desničinog komada i tekstova kojima je uobličena Sartrova teorijska dramaturgija, svedoče da se ne smeju zanemariti veze koje postoje između sartrovskog retoričkog pozorišta svesnih odluka i drame Vladana Desnice. Još preciznije, današnjem izučavaocu se Desničino dramsko delo pokazuje kao izrazito i suštinski utemeljeno u poetiku pozorišta situacija.

\section{$\cos$}

\section{Izvori i literatura}

Izvori

Vladan Desnica, Zimsko ljetovanje. Pjesme. Ljestve Jakovljeve (= Sabrana djela Vladana Desnice, knj. IV), Zagreb 1974.

Žan-Pol SARTr, Drame. Tekstovi o pozorišstu, Beograd 1981.

\section{Literatura}

И[ванка] Б[Ешевит], „Дестве Јаковљеве ВАадана Аеснице“, Политика (БеограА), br. 17017, 16. 2. 1961., 11.

Jadranka BRNČıć, „Problem etičkog angažmana u Desničinim Ljestvama Jakovljevim“, Intelektualci i rat 1939. - 1947. Zbornik radova s medunarodnog skupa Desničini susreti 2012. (ur. Drago Roksandić i Ivana Cvijović Javorina), sv. 1, Zagreb 2013., 41-51.

Vladan Desnica, „Gadni mali gnom“, Književna republika, 6/2008., br. 3-4, 3-21.

Ели Финци, „Интелектуанне распре“, Политика (БеограА), br. 17019, 18. 2. $1961 ., 10$.

Jovan Hristić, Studije o drami, Beograd 1986.

M[ilosav] M[ırković], „Ljestve Jakovljeve“, Mladost, 6/1961., br. 228, 7.

Helena Peričić, „Izdaja / krivnja / ideologija u Desničinoj drami Ljestve Jakovljeve“, Tekst, izvedba, odjek. Trinaest studija iz hrvatske i inozemne dramske književnosti, Zagreb 2008., 121-135.

Helena Peričić, „Jezik ideologije i ideologija jezika u Desničinoj drami Ljestve Jakovljeve“, Desničini susreti 2010. Zbornik radova (ur. Drago Roksandić i Ivana Cvijović Javorina), Zagreb 2011., 49-61.

Слободан Селенић, „ВАадан Аесница: Фестве Јаковьеве“, Борба (БеограА), br. 40, 18. 2. 1961., 7.

Vladimir Stamenković, „Sumnja u intelektualnu akciju“, Književne novine, 12/1961., br. 139, 7. 


\section{$\cos$}

\section{The DRAMATURGY OF LIBERTY AND DEATH, OR, ABOUT VLADAN DESNICA'S LJESTVE JAKOVLJEVE IN LIGHT OF SARTRE'S CONCEPT OF THE THEATER OF SITUATIONS}

In this paper, Desnica's play Ljestve Jakovljeve (Jacob's Ladder) is analyzed in light of the key tenets of the theater of situations, as defined and developed by Jean-Paul Sartre. The topic is approached comparatively and the appropriate methods of theoretical dramaturgy and the history of theater are used in the study. The play centers on an intellectual in wartime circumstances, one who faces the vital, universal problem of individual responsibility in uncertain times, inextricably linked to core values and attitudes towards liberty and death. It is those very issues that Desnica focuses on in the ideological, thematic and dramaturgical outline of his playwrighting debut, thus placing it within the framework of the genre which Sartre considers the contemporary revival of classical tragedy, since the hero's downfall is his own doing, a result of a clash with historical givens. While creating the character of Jakov Pećina, Desnica chooses to represent him as a work in progress and show the moment of choice, a freely made decision with repercussions for morality and an entire lifetime. Dramatic conflict in the play arises from the conflict of current rights related to everyday life: Petar Orljak, his daughter and their comrades are the embodiment of the right to oppose violence, particularly structural violence, whereas Jakov Pećina, who defends his right to survive no matter what, embodies the right to be neutral and inconspicuous at a time of persecution. Desnica's play, thus, going from the individual to the general, revives the myth of individual guilt and responsibility in complicated historical circumstances in a new form. The permanence of this myth is underscored by the pointed title and the connection with the biblical figure of Jacob.The insights provided by the thematic, conceptual and dramaturgical analysis of Ljestve Jakovljeve, as well as the overview of explicit and implicit ways in which Desnica's play corresponds to the texts which define Sartre's theoretical dramaturgy, especially with regards to understanding and addressing the themes of freedom and death, clearly demonstrate that the connections between Sartre's rhetorical theater of conscious decisions and this play by Vladan Desnica should not be overlooked. More precisely, although neither Desnica himself nor his contemporaries read the play in that light, to a contemporary scholar, the play seems distinctly and fundamentally based in the poetics of the theatre of situations, comparable to the innovative manner typical of French authors.

Key words: Ljestve Jakovljeve (Jacob's Ladder), the theater of situations, freedom, death, the conflict of rights, choice, myth 



\section{6. \\ MUVA NA GORNJOJ USNI: \\ NARATIVNI PROSTOR SMRTI \\ U PROZI VLADANA DESNICE}

\section{Bojan Đorđević}

UDK: 821.163.42-3Desnica, V.:612.013

Izvorni znanstveni članak

Sažetak: U radu se analiziraju narativni postupci u Desničinim pripovetkama Bunarevac i Oproštaj, kao i u završnim poglavljima romana Proljeća Ivana Galeba. Ukazuje se na tanatološki okvir pripovedanja i na postupke koji na višestruki način utemeljuju istorijsku fikciju ovih proznih ostvarenja. Pokazuje se razlika u pristupu narativnim poljima tako što se junak u pripoveci Bunarevac konstituiše kao biće izvan ontološke pozicije shvatanja smrti, dok se junaci pripovetke Oproštaj i romana Proljeća Ivana Galeba iz ravni smrti kao nepostojanja prevode u ravan umiranja kao, paradoksalno, konačnog dokaza egzistencije.

Ključne reči: naracija, smrt, umiranje, telo, prostor, trajanje

I.

D

a je roman Proljeća Ivana Galeba barem jednim svojim delom duboko ukorenjen u tokove srednjoevropske romaneskne i pripovedačke tradicije svedoči amblematična oznaka bolnice kao mesta umiranja. Za razliku od Manovog sanatorijuma - koji jeste, naravno, obeležen bolešću, ali je prvenstveno simbolični kôd vremena i svih temporalnih označilaca - bolnica ili sanatorijum u onom diskursu koji je imanentan i Desnici predstavlja tanatološki okvir. Taj okvir se dalje sužava, u vidu levka, i vodi do mikrotoposa tzv. sobe za umiranje - šterbecimera (nem. Sterbezimmer) - kao svojevrsne granice dvaju svetova. Šterbecimer je tematsko-motivska tačka koju nalazimo i u prozi i u poeziji pisaca nemačkog jezičkog područja, od Gotfrida Bena (pesme Žena umire od raka i Čovek $i$ žena idu kroz baraku za rak) i Eriha Marije Remarka (roman Na zapadu ništa novo) do Tomasa Bernharda (roman Dah). Šterbecimer je, najzad, u Desničinom romanu onaj deo narativnog prostora u kome se stiču dve referentne tačke pripovedanja - fikcionalno i stvarno, tj. ono što je „zamišljeno“ $i$ „realno“. Bolesnik u Desničinom romanu, koji je nesvestan mesta na kome se nalazi, može fikcionalizovati svoj položaj i ljutiti se na svoje sapatnike. No, u 
jednom trenutku - zahvaljujući obaveštenju bolničara - on se suočava sa stvarnim, kao neminovnim „prekoračivanjem granice koja je dotle bila nedostupna stvarnim očima“. ${ }^{1}$ Ontološka pretpostavka za ovakvo suočavanje sa „stvarnim“ jeste, naravno, smrt. Fikcionalni svet kao drugi, odvojen od stvarnog sveta iskustva, ${ }^{2}$ upravo se belodano postvaruje u narativnom pristupu smrti i umiranju. $U$ tome narativnom polju odnos između fikcionalnog sveta i sveta zbilje ponajviše nalikuje alegorijskoj slici dizanja zavese u pozorištu, pri čemu je agonija umiranja zapravo čin spuštanja zavese, posle koje se i književni junak i narator i čitalac iz fikcionalnog sveta „prevode“ u „vrhovnu stvarnost svakodnevnog života“.” Tako pisac zapravo ostvaruje svojevrstan neformalni pristup fikcionalnom diskursu, koji ima svoju logiku koja ne mora nužno odgovarati realnom diskursu. Ono što bi Delejni nazvao „nivoom subjunktivnosti“ “ jeste zapravo naratorovo nastojanje da opažajne i strukturalne postavke naracije što više saobrazi vizuri junakâ, iz koje će se onda izvući implikacija saobražena narativnoj logici. Ovakav pristup procesu umiranja u fikcionalnoj prozi odlično ilustruju pripovetke Vladana Desnice Bunarevac i Oproštaj, kao i završna poglavlja romana Proljeća Ivana Galeba.

\section{2.}

Prikaz Jagodine smrti u pripoveci Bunarevac vrhuni čehovljevsku atmosferu besmisla i uzaludnosti. Miloševo osećanje stida zbog protraćenog života i nemoći da se učini nešto korisno, ${ }^{5}$ tako slično onome Astrovljevom u drami Ujka Vanja, klimaks dostiže u času Jagodine smrti. Narator nije insistirao na detaljima procesa umiranja, ali je utoliko pre eksponovao sliku mrtve Jagode, koja je - sada oslobođena patnje i bola - u tome trenutku sušta suprotnost Milošu koji „,ne osjeća ništa nego goli fakat: mrtva je“. ${ }^{6}$ Mrtva Jagoda upečatljivija je predstava života nego živi Miloš sa svojim malim, neznatnim bolom. Trenutak smrti, pak, ogolio je Jagodu kao objekat - objekat ljubavi, a potom, sve više, objekat besmisla, objekat bolesti, najzad i objekat smrti. A - rečima Edmunda Huserla - „kada se modelira prema nečemu što percipiramo kao objekat, onda je interpretacija nužno naturalistička“? Stoga i Jagoda kao leš, dakle telo u svome ogoljenom vidu, zaprema ceo Milošev vidik, čitavu njegovu percepciju, a samim tim i povlašćeni prostor naracije:

Jagoda je ležala nauznak, otvorenih usta. Ispod gornje usne provirivala su dva sjekutića, suha, bez sjaja, neovlažena slinom, kao da na njima nema cakleni. Kukasti nosić, jasno ocr-

$1 \quad$ Dorrit Conn, Transparent Minds. Narrative Modes for Telling Consciousness in Fiction, Princeton 1978., 84.

2 Videti: Brian McHale, Postmodernist Fiction, New York - London 1987., 26-27.

3 Peter L. Berger - Thomas Luckmann, The Social Construction of Reality. A Treatise in the Sociology of Knowledge, New York 1966., 24-25.

4 Samuel R. Delany, „About 5750 words“, The Jewel-Hinged Jaw. Notes on the Language of Science Fiction, Elizabethtown 1977., 37.

5 „Ali što da čine? Gdje je izlaz? Zar mi znamo gdje je izlaz i što treba da se radi? Što smo s našim vlastitim životom umjeli da učinimo?" Vladan Desnica, „Bunarevac“, Pripovetke, Beograd 1993., 206.

6 V. Desnica, „Bunarevac“, 225.

7 Edmund Husserl, „Ideen zu einer reinen Phänomenologie und phänomenologischen Philosophie“, Jahrbuch für Philosophie und phänomenologische Forschung, 1/1913., sv. 1, 183. 
tan i već kao voštan, oštro se isticao, s jače naglašenom zakrivljenošću; iz njega je izmilila, kao crvak, tanka nit krvi. ${ }^{8}$

Telo postaje objektivitet, egzistencijalna činjenica, koja za Miloša, doduše, predstavlja pretpostavku određenog duševnog i emocionalnog stanja, ${ }^{9}$ ali stanja koje se ispoljava samo na mahove, i u očiglednom nerazumevanju smrti kao golog fakta:

S već pripravljenim ćutilom na osjet studi Miloš pruži ruku i dohvati joj podlakticu. Ipak ga hladan dodir iznenadi, i on se lecne... ${ }^{10}$

Počeo je postepeno prema lešu osjećati neku tuđost - to nije ona, to je samo njeno tijelo, njen simulacrum, prazni simulacrum. ${ }^{11}$

Sa stanovišta junaka još se, dakle, nije desilo ono što se u ravni naracije već zbilo. Smrt je u tim trenucima za junaka još uvek „čista uslovnost“, ${ }^{12}$ neka vrsta iluzije koja mu omogućava konstrukciju paralelne stvarnosti:

A ona, prava ona, gleda odozgo (gore, malo udesno) u njega pognuta i zabavljena nad tijelom. Pade mu na um kako je sasvim pojmljivo što su ljudi došli na pomisao o duši koja napušta mrtvo tijelo i odlijeće uvis. ${ }^{13}$

Emocionalno izmeštanje Jagode iz njenoga tela kao leša na simboličkoj razini predstavlja i čežnju samoga junaka za izlaskom iz oskudnog, bremenitog i jednolikog prostora sobe. Jer, Miloševa i Jagodina soba, po njenom povratku iz sanatorijuma, nije ništa drugo nego šterbecimer! Kao takva, ona pripada tzv. tekstualnom, stvarnom svetu naracije, dok je Miloševa potreba da ženu vidi izmeštenu i oslobođenu tela ništa drugo do kontrafaktualna, hipotetična situacija. ${ }^{14}$ Međutim, trajni boravak junaka u hipotetičnom prostoru nije moguć. Telesne promene koje Miloš uočava na Jagodinom lešu (koji, u vremenu naracije, nije više Jagoda) nisu postepene i sukcesivne, već nagle, istovremene i višestruke. Tako telesne promene usmeravaju i potencijalizuju pravac naracije ${ }^{15}$ kome se, prema zakonitostima pripovedanja, mora povinovati i sam junak. Fizički dokaz toga jeste Milošev neuspeh da obuče mrtvu Jagodu, tj. da se izbori sa mrtvačkom ukočenošću. Tako rigor mortis biva tzv. regulativni model narativnog sveta, ${ }^{16}$ a junak pripremljen da dospe do konačne istine smrti.

Ta istina Milošu se otkriva posredno, u trenutku kada na Jagodinu usnu - koja više ne pripada osobi, već telu - sleće muva:

\footnotetext{
V. Desnica, „Bunarevac“, 225.

Zoltan Kanjo, „Prilog proučavanju početka pripovednog teksta“, Rečc, 2/1995., br. 13, 97.

V. Desnica, „Bunarevac“, 225.

Isto, 227.

12 Lee T. Lemon - Marion J. Reis (prir.), Russian Formalist Criticism. Four Essays, Lincoln 1965., 142.

13 V. Desnica, „Bunarevac“, 227.

14 O ovoj distinkciji opširno: Marie-Laure Ryan, „The Modal Structure of Narrative Universes“, Poetics Today, 6/1985., br. 4, 717-755.

15 O spoljašnjim uslovima za oblikovanje prostora naracije videti: Uri MARGolin, „Individuals in Narrative Worlds: An Ontological Perspective“, Poetics Today, 11/1990., br. 4, 843-871.

16 Paul M. Churchland, „Eliminative Materialism and the Propositional Attitudes“, A Neurocomputational Perspective. The Nature of Mind and the Structure of Science, Cambridge, Massachusetts 1989., 7.
} 
Jedna muha (odakle li se samo stvori?) hodala je po rubu gornje usne. To što muha nesmetano šeta po tako golicavu mjestu, ne izazivajući nikakve reakcije, nikakva pokreta, ni najmanjeg ježura kože, činilo mu je uočljivijom nepomičnost smrti. A time $i$ shvatljivijom samu smrt-njenu mramornu hladnoću i mrtvu nepomičnost. Simulacrum, predmet. ${ }^{17}$

Ojačana junakova svest o simulakrumu kao imitaciji bića, kao subjektivnoj slici o Jagodi, koja se nužno razlikuje od Jagode kao tela, ta svest o diferenciji između stvarnog i ikoničnog, osnažena je gotovo folklornim (jer realističnim) prizorom muve kao označioca smrti. Ovakva „folklorna psihologija“ ${ }^{18}$ koju narator koristi da transcendentira junaka u realiju prihvatanja konačnosti, ospoljena je nižim oblikom života. Nižim, ali nadmoćnim. Toliko nadmoćnim da ga u agoniji i Ivan Galeb priziva u svest kao supstituciju ljudskih glasova nad svojom bolesničkom / samrtničkom posteljom: „Ponekad je šum tih glasova, koji su se oko uboda skupili kao muhe, mutniji i dalji..."19

Dakle, tek fakat muve i nedostatka prirodne, žive reakcije na nadražaj, svedoče smrt kao činjenicu - onu koje junak dotle nije bio dokraja svestan. Ne može se reći da Miloš u tom trenutku doživljava neku vrstu epifanije, ali se, u svakom slučaju, kao živi subjekt sadružuje sa Jagodom kao objektom! Naime, dok je bolovala, Jagoda se postepeno udaljavala od njega, i u emotivnoj i u duhovnoj sferi - pripadala je ne samo prostoru bolesti, već i vanprostornom i vanvremenskom diskursu smrti koje je sve više bila svesna: „Katkad se po njenim riječima moglo vidjeti da misli i na konac. “20 U tim trenucima ona je „izabrana“- od onih je kojima je, rečima Ivana Galeba, ${ }^{21}$ dato da „misle smrt“. Miloš, međutim, nije ontološki predodređen za to, jer je zdrav. Takav, u punoj snazi, ne mogavši da kontemplira - on mora biti stavljen u odgovarajuću narativnu situaciju. Njome se prevazilazi tzv. ikonična argumentacija ${ }^{22}$ - mrtvo telo kao nesavršena kopija živog bića - i zalazi u područje kodne intencije što jasno distingvira prisutno od odsutnog. Prisutna Jagoda i odsutna njena reakcija na muvu - sve to kontrastivno povezuje različite elemente naracije: Jagodu i Miloša, jedinku i svet, život i smrt. Tako u Desničinoj pripoveci muva nije samo obična metafora, ona postaje najznačajniji činilac pripovedanja.

\section{$3 \cdot$}

Ako je u pripoveci Bunarevac svest o smrti transponovana u junaka kao posmatrača, dok je osoba koja umire svedena na telo / leš - onda je u pripoveci Oproštaj, i u završnim poglavljima romana Proljeća Ivana Galeba, Desnica na izrazito naturalistički način pružio sukcesivnu i faznu sliku samoga umiranja, tj. čovekove agonije. Realema ${ }^{23}$ smrti tako je u

17 V. Desnica, „Bunarevac“, 227. Podvukao B. Đ.

18 P. M. Churchland, „Eliminative Materialism and the Propositional Attitudes“, 10.

19 Vladan Desnica, Proljeća Ivana Galeba, Beograd 1993., 451. Podvukao B. Đ.

20 V. DesnicA, „Bunarevac“, 220.

21 V. Desnica, Proljeća Ivana Galeba, 102.

22 Paul Ricoeur, „Writing as a Problem for Literary Criticism and Philosophical Hermeneutics“, A Ricoeur Reader, (ur. Mario Valdés), Toronto - Buffalo 1991., 331.

23 Ovaj termin kao atributiv tzv. fiktivnog narativa uvodimo prema: Itamar Even-ZohaR, „Constraints of Realeme Insertability in Narrative“, Poetics Today, 1/1980., br. 3, 65-74. Detaljno ga razrađuje Brajan Mekhejl. Videti: B. McHale, Postmodernist Fiction, 84-96. 
Desničinoj naraciji opredmećena i istorijski i kulturološki. Istorijski - smrt je činjenica koja bitno određuje ljudsku egzistenciju. Ako se sama smrt kao činjenica i može negirati na filozofsko-teološkoj ravni (pre svega stavom o besmrtnosti duše), dotle se smrt kao realema potvrđuje upravo procesom umiranja koji se nikakvim verovanjem u vrhunaravno biće ne može ni negirati ni transcendentirati. Jer:

I samo to je bog. Bog je naličje smrti. Jedan oblik borbe protiv smrti, i ništa drugo... Svi bezumni pokušaji, sve vrele samoobmane snagom kojih čovjek nadrasta i prevladava smrt - sve je to bog. ${ }^{24}$

Kulturološki - umiranje je proces koji ima svoje tačno određenje, svoje svrhovite i sukcesivne faze. Kao takav, ovaj proces je nužno realističan i samim tim spada u domen „istorijske fikcije“. ${ }^{25}$ Osim toga, ovaj proces je univerzalan, i samim tim repetitivan, pa se i kod Desnice ponavlja. Tako umiranju kao agonički određenom i preciznom narativu bivaju izloženi i Antun, u pripoveci Oproštaj, i Ivan Galeb, u Proljećima Ivana Galeba. Jedina distinkcija je što Antunovu agoniju posmatramo posredstvom naratora koji je u dosluhu sa junakom, a Ivanovu posredstvom naratora koji je sâm junak. U svemu ostalom Desničina istorijska fikcija potpuno je saobrazna kulturnim realemama i kompatibilna sa fizičkim pojavnostima kojima se proces umiranja materijalizuje.

Zalažući se upravo za ovakav realistični prosede i pristup pripovedanju, koji proizlazi iz kulturno i društveno konstruisanog realiteta (stoga Ivan Galeb celoga života nastoji da svoje „misli i zapažanja zaodjen[e] u što nenapadniju, znači u što banalniju formu ${ }^{(26)}$ ), Desnica razume da su izvan tih realema „drugačije stvarnosti“ $i$,enklave unutar vrhovne stvarnosti “. ${ }^{27}$ Stvarnost umiranja Antun opaža dvostruko - kao pounutrašnjenu stvarnost gašenja funkcija sopstvenog tela i uma, i kao eksternu stvarnost ljuštenja maltera sa zida. No, Desnica je suviše dobar pripovedač da bi se zadržao na jednostavnoj analogijskoj simbolici, pa se posle konstatacije o promeni na zidu Antun utapa u nemoć i fluktuaciju sopstvenog „ljuštenja“. Kada i „prijateljska odrtina“ na zidu počne da se zatamnjuje, zatvara se „nevidljiv krug zbivanja“ i nastupa terminalna faza agonije.

Ali, kao što je u prostoru naracije početak agonije jasno lociran, tako su i sve njene faze izdvojene i prepoznate kao niz stanja u koje junak zapada. U mnogo čemu one se poklapaju sa fazama agonije Ivana Galeba pri kraju romana. Jedina razlika je što je Antunova agonija narativno kompaktnija, a njen kontinuitet sačuvan, jer je posredovana pripovedačem. Ivanova agonija je faktualno nestabilnija i narativno razlomljena jer se priča o njoj odvija iz svesti onoga koji tu agoniju proživljava.

Ono što je, međutim, veoma važno, jeste činjenica da se faze agonije Desničinih junaka gotovo u dlaku poklapaju sa terminalnim fazama koju su uočene tokom umiranja neizlečivih bolesnika, a koje u svojoj kapitalnoj studiji sintetiše Elizabet Kjubler Ros. ${ }^{28}$ Jedan od

\footnotetext{
V. Desnica, Proljeća Ivana Galeba, 107.

B. McHale, Postmodernist Fiction, 87.

V. Desnica, Proljeća Ivana Galeba, 202.

P. L. Berger - T. Luckmann, The Social Construction of Reality, 24.

28 Ovu studiju Rosova je prvi put objavila još 1969. godine, i od tada je ona doživela više izdanja. Navode donosimo prema srpskom izdanju: Elizabet KJubler Ros, O smrti i umiranju, Beograd 2010.
} 
referencijalnih pokazatelja agonije jeste bolesnikovo stalno zapadanje u dremež, koji se, doduše, prekida, ali i odmah nastavlja. To uočava Kjubler Ros: „Umoran je i u većini slučajeva slab, pa drema često i nakratko... To je povišena potreba da se produži vreme spavanja - kao kod bebe. ${ }^{\text {(29 }} \mathrm{U}$ takvom stanju nalazi se Antun:

Sve je više zapadao u drijem. U onu nemjerljivu, bezvremenu oazu drijema kojoj kao da nema početka ni kraja. ${ }^{30}$

Takođe i Ivan Galeb:

Ali misao mi se prekida, brzo se zamaram. Drijemam, i kao da sve češće zapadam u neke bijele oaze bez vremena. (...) Sklapam oči i tonem u polusan, u stanje satkano od lijenog odlaganja, od dragovoljnog strpljenja, i od istrganih vlakanaca vremena. ${ }^{31}$

Nastupaju tek kratkotrajni periodi svesti, pre ponovnog potonuća u dremež: „Tek ponekad bolesnik se vraća u spoljašnji svet sa osećajem olakšanja i prihvatanja neminovnosti. ${ }^{\text {“32 }}$ Taj je momenat prisutan i kod Desnice:

Misao bi zamorena, neprimjetno, skliznula sa olakšanjem na što drugo... i najzad se gubila kao potočić u travi. ${ }^{33}$

O kako je to prijatno: isplutati začas iz drijemeža, konstatirati da živiš, pa ponovo, umiren, utonuti u drijemež. ${ }^{34}$

Još jedna odlika ovoga procesa jeste odsustvo temporalnosti. „Gospodin G. nije imao svest o vremenu“, reći će Kjubler Ros. ${ }^{35}$ Subjektivno osećanje samrtnika da vreme ne prolazi postaje za njega fakticitet jači od realne činjenice vremenskog kontinuuma:

Sad nije više ni noć ni dan... Dva-tri dana bez svijesti o bilo kakvom zbivanju, kao preskočene, bijele stranice bez ubilježaba. ${ }^{36}$

Ne znam koliko je dug bio taj časak koji je protekao između onog sklapanja i ponovnog podizanja vjeđa: jedan trenutak ili nekoliko dana.37

Fazu prihvatanja, kako je naziva Kjubler Ros, fazu terminalne agonije kroz koju prolaze Antun i Ivan Galeb, odlikuje i odsustvo emocionalnosti - stanje koje „ne prate gotovo nikakva osećanja“.38 Tačnije, reč je o nemogućnosti da se ona ispolji usled rastrojenosti misli, koja se prepušta svesti o sopstvenoj nemoći i bliskoj smrti:

I kad sklopi oči, sve mu dođe jednako. ${ }^{39}$

Uistinu mi se čini da niti što želim, niti što pravo osjećam. ${ }^{40}$

29 Isto, 92.

30 Vladan Desnica, „Oproštaj“, Pripovetke, 122-123.

31 V. Desnica, Proljeća Ivana Galeba, 450 i 453.

32 E. Kjubler Ros, O smrti i umiranju, 128.

33 V. Desnica, „Oproštaj“, 122.

34 V. Desnica, Proljeća Ivana Galeba, 454.

35 E. Kjubler Ros, O smrti i umiranju, 104.

36 V. Desnica, „Oproštaj“, 123.

37 V. Desnica, Proljeća Ivana Galeba, 451.

38 E. Kjubler Ros, O smrti i umiranju, 92.

39 V. Desnica, „Oproštaj“, 121.

40 V. Desnica, Proljeća Ivana Galeba, 455. 
Gubljenje veze sa spoljnim svetom ima dvostruki smisao. Kjubler Ros piše: „Pošto je pacijent našao mir u prihvatanju, sve manje spoljnih stvari ga interesuje i ne želi da bude uznemiravan vestima i problemima. Posetioci često nisu dobrodošli..." ${ }^{\text {“1 }} S$ jedne strane, dakle, to je posledica otupelosti posle perioda patnje i bolova. $S$ druge, to je gotovo metafizička svest o efemernosti pojavnih stvari i taštih ljudskih potreba i sudbina:

Sve se izmaknulo van njegova dohvata. Malo predsoblje bilo je drugi svijet. Hodnik - predvorje nepoznatog. A kuhinja - do nje su daleki i zamorni puti i za samu misao! (...) Uopće, sve što se očima gleda i spoznava, ne postoji. ${ }^{42}$

Svrstavaju se u jednu ravninu, svi jednako važni odnosno nevažni, svi jednako živi odnosno neživi. ${ }^{43}$

Prestanak bola posledica je koliko medicinskog tretmana - lekova i morfijuma ${ }^{44}$ - toliko i samrtnikovog prihvatanja konačnosti: „Bolovi kao da su prestali, borba se završila. “45 Slično nalazimo i u Proljećima Ivana Galeba:

Samo ne više patnje! Probudim se u noći i skrušeno šapućem: samo ne više patnje! $!^{46}$

Pa ipak, tanka linija života još se ne da preći tako lako. Ni Antunom ni Ivanom još ne ovladava ona rezigniranost predaje. Ambivalencija njihovog dugotrajnog stanja bolesti nagoni ih na makar podsvesnu, makar agonijom i lekovima posredovanu, borbu, koja je sada svedena na misao o trajanju - ako ne sopstvenom, onda trajanju onih realema koje su činile i njihov svet. I tu je Desnica pokazao dobro poznavanje psihologije samrtnika:

To nije bespomoćno i rezignirano predavanje uz pitanje „,̌emu više“ ili „,ne mogu više da se borim“... To još uvek ne znači da bolesnik prihvata svoju sudbinu. ${ }^{47}$

U Antunovom umu taj osećaj nepristajanja posredovan je zvukom, „srebrnom niti“, koji možda i ne postoji ali ga Antun svojim unutarnjim uhom čuje, i vezuje se za njega u želji da produži trajanje:

Tanji se, blijedi, sad ga čuješ - sad se izgubi, pritaji se, ali nezavisno od tebe, nezavisno od toga da li ga ti čuješ ili ne čuješ, on traje, traje... ${ }^{48}$

To trajanje kao antipodni pandan umiranju biva ideal i Ivana Galeba:

Ipak, ne želim potpuno spokojstvo, potpuno mrtvilo. To ne! Volim da vrhom spuštenih trepavica osjećam vanjsko trajanje, protjecanje stvarnosti. Samo da ja ostanem izvan njega,

\footnotetext{
E. KJubler Ros, O smrti i umiranju, 93.

V. Desnica, „Oproštaj“, 121-122.

3 V. Desnica, Proljeća Ivana Galeba, 456.

44 Uporedi, na primer, sledeće citate: „I Antun i Ivan Galeb bivaju trgnuti iz dremeža i izmaglice misli zahvaljujući injekcijama: Doktor umotava špricu i iglu u bijelu krpicu i sprema u metalnu kutiju..." (V. Desnica, „Oproštaj“, 124) i „Opet transfuzija krvi. Ubod u lijevu podlakticu“ (V. Desnica, Proljeća Ivana Galeba, 459).

45 E. KJubler Ros, O smrti i umiranju, 92.

46 V. Desnica, Proljeća Ivana Galeba, 458.

47 E. KJubler Ros, O smrti i umiranju, 92.

48 V. Desnica, „Oproštaj“, 123.
} 
da ne učestvujem u njemu. Jer, biti u njemu, učestvovati u njemu, to je previše zamorno. Ali neka ono ipak traje. Neka samo traje, neka promiče mimo mene. ${ }^{49}$

Šta je, međutim, to što i Antuna i Ivana Galeba drži na granici života i smrti, bića i tela, šta je to što fikcionalni svet pripovedanja u Desničinoj pripoveci Oproštaj i romanu Proljeća Ivana Galeba čini „argumentovanim prostorom junakove egzistencije“, ${ }^{0}$ koji se postvaruje čvornim tačkama preloma? To je potreba za drugim i svest o prisustvu drugog kao veze sa spoljnim svetom. To je više od utehe ili simboličke oznake empatije:

Bolesnik nije raspoložen za razgovor i traži prisustvo određene osobe. Ona treba da ga uzme za ruku ili samo da bude prisutna... Pacijent se fiksira na određenu osobu i može da ga prene samo prisustvo te osobe. ${ }^{51}$

Za Antuna - to je Ana. Neodređena emocija koju on oseća prema staroj dvorkinji transformiše se u osećaj njenog postojanja. Ona je više od veze sa stvarnim svetom i okolinom, od koje se samrtnik postepeno odvaja. Ona je „nadneseno lice sa dva velika oka kao dva sunčana časovnika“ ${ }^{52}$ Ona je i stalno bivanje - egzistencijalni korektiv emocionalnog diskursa umiranja, ${ }^{53}$ neko ko stoji po strani i vrši obrnutu funkciju htonskog bića. Jer, dok se u mitološkoj predstavi takvo biće pojavljuje da samrtnika prevede u podzemlje, u drugi svet, dotle Ana, orfejski, Antuna prevodi iz drugog sveta nazad, u svet živih. Zato je tu, ali sa strane, kao treća osoba - između Antuna i Smrti:

Otvori umorno oči i vidi podno kreveta Anu - donijela mu čašu topla čaja i zove ga; a on ne zna da li je to sad ušla u sobu i zazvala ga, ili je već odavna tu pored njega i zove već po treći, četvrti put... Ponovno kao da ga neko zove. Vjeđe se teško rasklapaju - Ana je tu, u svojoj vunenoj kapi i kaputu... ${ }^{54}$

Za Ivana Galeba, pak, to mitsko biće koje ga prevodi u stanje svesti o sebi i životu jeste bolničarka - koja, kao i Ana prema Antunu, naginje lice prema Ivanu, a njen glas je funkcionalni pandan onom zvuku koji čuje Antun, i koji svedoči o trajanju:

Ponekad, opet, čujem nad sobom jedan glas. Prodro je do moje svijesti svojom upornošću. A ta upornost sastoji se u tome što više puta ponavlja jedno te isto. Nametnuo mi se tom upornošću ponavljanja... Najzad otvaram oči i vidim nad sobom lice bolničarke i njene usne što se miču. Da, sad mi je jasno da je taj glas bio prisutan još prije nego što sam ga počeo razabirati; da je on i bio ono što me iznosilo, polako, kao na rukama, sa dna moje besvjesti na površinu... Ponovo ugledam nad sobom poznato lice i usne što se miču... ${ }^{55}$

I baš to - prisustvo drugog - biva ona narativna situacija koju Desnica vešto gradi da bi svoje junake izveo u svet van šterbecimera. Oni, paradoksalno, u istorijskoj fikciji umiru

\footnotetext{
49 V. Desnica, Proljeća Ivana Galeba, 454.

50 Jerome Bruner, Actual Minds, Possible Worlds, Cambridge, Massachusetts 1986., 113.

51 E. Kjubler Ros, O smrti i umiranju, 93. Podvukao B. Đ.

52 V. Desnica, „Oproštaj“, 123.

53 Derek Edwards, „Emotion Discourse“, Culture \& Psychology, 5/1999., br. 3, 284.

54 V. Desnica, „Oproštaj“, 123. Podvukao B. Đ.

55 V. Desnica, Proljeća Ivana Galeba, 451. Podvukao B. Đ.
} 
- ali u tzv. aistorijskoj fikciji ${ }^{56}$ i dalje bivaju, dakle osećaju i kontempliraju. Naznake smrti i dalje su prisutne. Tako Antun u pripoveci Oproštaj „liježe uređen i smireno čeka“. 57 Ali koga? Smrt ili Anu? A Ivan Galeb, takođe pomiren, oseća da „sve želje šute i čula dremlju, a misli imaju prazničko ruho i bijele skrštene ruke" ${ }^{58} \mathrm{~A}$ kada se leži, kada se na sebi ima svečana odeća i kada su ruke skrštene - onda je jasno da je fakticitet smrti zapremio čitavo narativno polje. Antun i Ivan Galeb su, za razliku od Jagode - jer Miloš nije bio obdaren htonskim moćima percepcije drugog, koje bi poslužile da se taj drugi prevede na ovu stranu - izašli iz šterbecimera, ali to ne znači da se njihovom gornjom usnom nije već prošetala muva. I da „tekstualni stvarni svet ${ }^{\text {" } 59}$ Desničine proze nije, konačno i neopozivo, prostor Tanatosa.

\section{$\cos$}

\section{Izvori i literatura}

\section{Izvori}

Vladan Desnica, „Bunarevac“, Pripovetke, Beograd 1993., 181-229.

Vladan DesnicA, „Oproštaj“, Pripovetke, Beograd 1993., 118-125.

Vladan Desnica, Proljeća Ivana Galeba, Beograd 1993.

\section{Literatura}

Peter L. Berger - Thomas Luckmann, The Social Construction of Reality. A Treatise in the Sociology of Knowledge, New York 1966.

Jerome Bruner, Actual Minds, Possible Worlds, Cambridge, Massachusetts 1986.

Paul M. Churchland, „Eliminative Materialism and the Propositional Attitudes“, A Neurocomputational Perspective. The Nature of Mind and the Structure of Science, Cambridge, Massachusetts 1989., 1-22.

Dorrit CoHn, Transparent Minds. Narrative Modes for Telling Consciousness in Fiction, Princeton 1978.

Samuel R. Delany, „About 5750 words“, The Jewel-Hinged Jaw. Notes on the Language of Science Fiction, Elizabethtown, New York 1977., 25-42.

Derek Edwards, „Emotion Discourse“, Culture \& Psychology, 5/1999., br. 3, 271-291.

Itamar Even-ZohaR, „Constraints of Realeme Insertability in Narrative“, Poetics Today, 1/1980., br. 3, 65-74.

Edmund Husserl, „Ideen zu einer reinen Phänomenologie und phänomenologischen Philosophie“, Jahrbuch für Philosophie und phänomenologische Forschung, 1/1913., sv. 1, 1-323.

Zoltan Kanjo, „Prilog proučavanju početka pripovednog teksta“, Reč, 2/1995., br. 13, 97-105.

Elizabet KJubler Ros, O smrti i umiranju, Beograd 2010.

56 Marie-Laure Ryan, „Possible Worlds and Accessibility Relations: A Semantic Typology of Fiction“, Poetics Today, 12/1991., br. 3, 11.

57 V. Desnica, „Oproštaj“, 125.

58 V. Desnica, Proljeća Ivana Galeba, 466.

59 Marie-Laure Ryan, „The Modal Structure of Narrative Universes“, Poetics Today, 6/1985., br. 4, 723. 
Lee T. Lemon - Marion J. Reis (prir.), Russian Formalist Criticism. Four Essays, Lincoln 1965.

Uri Margolin, „Individuals in Narrative Worlds: An Ontological Perspective“, Poetics Today, 11/1990., br. 4, 843-871.

Brian McHale, Postmodernist Fiction, New York - London 1987.

Paul Ricoeur, „Writing as a Problem for Literary Criticism and Philosophical Hermeneutics“, $A$ Ricoeur Reader (ur. Mario J. Valdés), Toronto - Buffalo 1991., 320- 337.

Marie-Laure Ryan, „Possible Worlds and Accessibility Relations: A Semantic Typology of Fiction“, Poetics Today, 12/1991., br. 3, 553-576.

Marie-Laure Ryan, „The Modal Structure of Narrative Universes“, Poetics Today, 6/1985., br. 4, 717-755.

\section{$\cos$ \\ THE FLY ON HER UPPER LIP: THE NARRATIVE SPACE OF DEATH IN VLADAN DESNICA'S FICTION}

Desnica's historical fiction is realized in the narrative approach to death and dying. In that narrative field, the relationship between the fictional and the real is akin to an allegorical image of a curtain rising in the theater, with the agony of death being parallel to the dropping curtain, after which the literary hero and the narrator, as well as the reader, are "transported" into the "supreme reality of everyday life". Thus, Desnica actually achieves a sort of an informal approach to the fictional discourse, whose logic does not necessarily match the real. What Delany would refer to as "a level of subjunctivity" is in fact the narrator's attempt to conform the perceptional and the structural postulates of narration to the narrator's perspective, from which an implication conforming to the narrative logic will be derived. Such an approach to the process of dying is best illustrated by the short stories Bunarevac and Oprostaj (The Parting), as well as the final chapters of the novel Proljeća Ivana Galeba (The Springs of Ivan Galeb). Jagoda's death in Bunarevac is the culmination of a Chekhovian atmposphere of senslessness and futility. Milošs chagrin over his wasted life and inability to do something useful reaches its high point in the moment of Jagoda's death. The narrator avoids focusing on the details of her expiring, bringing that much more exposure to the image of Jagoda in her death. Free of pain and suffering, in that moment Jagoda becomes the total opposite of her husband. Jagoda's body becomes an objective, existential fact and although it does of suggest a certain spiritual and emotional state for Miloš, this state manifests itself only occasionally, determined by the obvious incomprehension of death as a pure fact. The hero's raised awareness of the simulacrum as the immitation of a being, a subjective image of Jagoda which is inevitably different from Jagoda as a body, the awareness of the difference between the real and the iconic, is emphasized by an almost folkloric (due to its realism) image of the fly as the sign of death. It is only the presence of the fly and the absence of a natural, living reaction to the stimulus that it represents which testify to death as a fact, whose finality had heretofore escaped the hero. The presence of Jagoda combined with the absence of her reaction to the fly juxtapose different elements of narration: Jagoda and Miloš, the individual and the world at large, life and death. In Desnica's story, the fly is more than just a metaphor: it becomes the central narrative element. If the awareness of death is transposed into the hero as the observer in Bunarevac, while the dying person is reduced to a dead body, then the short story Oproštaj (The Parting) and the novel Proljeća Ivana Galeba (The Springs of Ivan Galeb) provide a successive, phase image of dying itself, i.e. the agony of death. Therefore, the realem of death becomes historically and culturally reified in Desnica's 
narration. However, just as the beginning of the agony is clearly located within the narrative, so are all its stages isolated and recognised as a series of states the hero is endures. In many ways, they correspond to the stages of Ivan Galeb's agony at the end of the novel. The only difference is that Antun's suffering is narratively more compact, and its continuity intact, seeing as it is mediated the narrator. Ivan's suffering is factually less stable and more narratively fractured because the story about it takes place in the consciousness of the one who is enduring it. The stages of agony that Desnica's heroes go through correspond almost exactly with the stages of grief observed in terminally ill patients and described by Elizabeth Kübler-Ross in her capital study On Death and Dying. Unlike Jagoda, Antun and Ivan Galeb exit the Sterbezimmer, but that does not mean that the fly has not already walked over their upper lip. Thus the narrative space in Desnica's fiction is, in the end revealed to be the space of Thanatos.

Key words: narration, death, dying, the body, space, duration 



\section{ČASOPIS KAO AMBLEM POSLEDNJEG ČASA: MEĐUSOBNA USLOVLJENOST MOTIVA SMRTI I MOTIVA PERIODIČNE ŠTAMPE U PRIPOVETKAMA VLADANA DESNICE}

\section{Stanislava Barać}

UDK: 821.163.42-32Desnica, V.:393

Izvorni znanstveni članak

Sažetak: U četiri pripovetke Vladana Desnice periodična štampa upotrebljena je kao motiv koji će amblematski potkrepiti opštiji motiv odnosno temu umiranja, smrti i ljudske prolaznosti. Desnica koristi niz raznolikih periodičnih žanrova (kalendar / almanah, kulturnopolitički časopis, esnafski polumesečnik, dnevne novine) kako bi umetnički konkretizovao metafizičku temu i filozofsku poruku koju preko nje prenosi. Cilj ovog rada je da ukaže na raznovrsnost načina na koje se navedeni motivi ugrađuju u narativnu i semantičku strukturu pripovedaka i na umetničku inovativnost i estetske efekte ovog pripovednog postupka. Takođe, cilj rada je da opiše kako dati motivi funkcionišu u okviru poetike Vladana Desnice. Oni, naime, učestvuju u oblikovanju semantičke opozicije selo - grad (suprotnost ruralnog i urbanog shvatanja vremena i prolaznosti ističe se pomoću motiva kalendara-stogodnjaka u pripoveci Životna staza Jandrije Kutlače), i u povlašćivanju teme smrti: u oblikovanju slike umiranja kao procesa (što se postiže uvođenjem imaginarnog Glasnika udruženja poštanskih službenika u pripovetku Oproštaj), u prikazivanju smrtnosti kao biološkog usuda (čemu služi Večernji list u pripoveci Zlatni rudnik) i u iskazivanju ideje ljudske prolaznosti preko prikazivanja nestalnosti i varljivosti društvene slave, bilo političke (što je postignuto preko motiva izmišljenog lista $\mathrm{No}$ va zora u pripoveci Konac dana), bilo umetničke (pomoću Večernjeg lista u Zlatnom rudniku).

Ključne reči: Vladan Desnica, pripovetke, poetika, periodična štampa, vreme, prolaznost, konkretno, univerzalno

Drvi put je zamisao o uzajamnosti motiva smrti i periodične štampe Vladan Desnica oblikovao već u svojoj prvoj pripoveci, Životna staza Jandrije Kutlače, objavljenoj 1935. godine u „sopstvenoj“ periodičnoj publikaciji, Magazinu Sjeverne Dalmacije, godišnjaku čiji je bio urednik. ${ }^{1}$ Trenutak u kome je Magazin osnovan (1934) pripada epohi u kojoj

1 O složenosti institucionalnih i ličnih odnosa iz kojih je nastao, a zbog kojih je potom ugašen ovaj almanah videti: Drago Roksandić, „Vladan Desnica i Magazin Sjeverne Dalmacije: književnik i (ne)moć tradicije“, Vladan Desnica i 
se čitalačka publika Kraljevine Jugoslavije intenzivno diferencirala zahvaljujući procesima društvene stratifikacije i (ograničene) modernizacije. To je rezultiralo stalnim pokretanjima novih i specijalizovanih periodičnih publikacija koje su izražavale programe i interesovanja najraznovrsnijih grupa i pokreta, kako onih sa istorijskim kontinuitetom, tako i potpuno novih društvenih činilaca. ${ }^{2}$ I sam Magazin je, dakle, proizvod datoga trenutka, a Vladan Desnica samosvesni i upućeni akter aktuelne medijske scene. Zato nije neobično što je ova važna činjenica Desničine intelektualne biografije, ali i porodične istorije, dobila svoj izraz, makar i amblematski, ${ }^{3}$ u fikcionalnom svetu njegovih pripovedaka.

Reč je, međutim, i o mnogo širem fenomenu: o globalnoj društvenoj sveprisutnosti periodične štampe u drugoj polovini 19. i prvoj polovini 20. veka. Ona se u evropskoj književnosti reflektuje ne samo na planu prikazane predmetnosti, u učestalosti odgovarajućih „periodičarskih“ "tema i motiva odnosno likova koji uređuju i štampaju časopise, već bitno utiče na samu prirodu pripovedanja. Valter Benjamin 1936. godine u danas čuvenom eseju Pripovedač. Razmatranja uz delo Nikolaja Ljeskova iznosi tezu da je medijska epoha, naročito nakon katastrofe Prvog svetskog rata, promenila ljudsko iskustvo (,iskustvo je pretrpelo pad u svojoj vrednosti“), kao i mogućnosti njegovog pripovednog prenošenja (,zanemelost“, „siromaštvo u saopštivom iskustvu“). Benjamin uočava da je

(...) s prodorom dominacije građanskog sveta, a među najvažnije instrumente te dominacije u poznom kapitalizmu spada štampa, na poprište izbio izvestan oblik saopštavanja koji, koliko god se davno začeo, nikad pre toga nije na presudan način uticao na epski oblik. ${ }^{4}$

Informacija, taj novi oblik saopštavanja, u suprotnosti je sa duhom priče i, po Benjaminovom uverenju, utiče na to da je sve manje „značajnih povesti“, usmenih i pisanih. Pripovetke Vladana Desnice, koje su nastajale upravo u to vreme, ${ }^{5}$ kao i delovi romana Proljeća Ivana Galeba, spadaju među one koje u epohi kraja priče čuvaju veru u saopštivost iskustva, iako je i problematizuju.

Split 1920. - 1945. Zbornik radova sa znanstvenog skupa Desničini susreti 2014. (ur. Drago Roksandić i Ivana Cvijović Javorina), Zagreb 2015., 181-234.

2 O tome sam pisala u članku „Implicitni čitalac Magazina Sjeverne Dalmacije: pokušaj rekonstrukcije“, Vladan Desnica i Split 1920. - 1945., 157-180.

3 Pojam amblem ovde se koristi u prenesenom značenju. Motivi periodične štampe se u Desničinim pripovetkama upotrebljavaju kao znak koji dodatno potcrtava situaciju i značenje koji su u pripoveci iskazani i drugim sredstvima. On je nalik znački na reveru junakovog kaputa, koja čitalačku pažnju dodatno fiksira na ideju koja je izrečena i celinom pripovetke, slično kao što Zdenko Škreb u odrednici „Amblem“ u Rečniku književnih termina objašnjava poreklo ovog pojma: „S druge strane, od kraja se 14. st. raširio običaj, najprije u Burgundiji i Francuskoj, a onda u Italiji, da građani patriciji i učenjaci na šeširu ili odijelu nose medalje s natpisima koje su se zvale imprese. Taj duh primitivne simbolike 16. st. našao je svoju kodifikaciju u djelu Alciatusa; u njemu se svaki amblem sastoji od tri dijela: slike, natpisa (inscriptio) koji joj tumači simboličko značenje, i teksta ispod nje (subscriptio), u vezi sa slikom, većinom u stihu, ali i u prozi, uzeta najčešće iz antikne književnosti. Npr. slika prikazuje kako kiša pada na biljke, a inscriptio tumači da božji blagoslov donosi bogatstvo; pas požudno gleda kako lav razdire plijen, a inscriptio tumači da je to želja bez nade da se ispuni - tekst ispod slike primjenjuje se na baštinika koji požudno očekuje smrt bogata rođaka, u duhu se naslađuje ali usta mu ostaju suha.“ Zdenko ŠKREB, „Amblem“, Rečnik književnih termina, Beograd 1992. 20.

4 Валтер БенјАмин, „Приповедач. Разматрања уз дело Николаја Вескова“, Искуство и сиромаштво, БеограА 2016., 68 .

5 Cela jedna zbirka priča pripremljena za beogradskog izdavača Gecu Kona izgubljena je u Drugom svetskom ratu, zbog čega su one većinom rekonstruisane i objavljene neposredno posle rata. 
Na pomenutom je Benjaminovom eseju Vladimir Biti zasnovao izvrsnu analizu Desničinog Proljeća Ivana Galeba, izloženu 1994. godine u nacrtu, a objavljenu u proširenoj verziji 2004. Ta je analiza u isto vreme i svojevrsno preispitivanje teorija pripovedanja u 20. veku. Bitijeva studija, između ostalog, jasno pokazuje koliko Benjaminova razmatranja i Desničino romaneskno pripovedanje jedno drugo uzajamno objašnjavaju. Biti podrazumeva da Benjaminova razmatranja prethode Desničinoj pripovedačkoj poetici, pa na početku svoje studije kaže:

Kada je ustvrdio kako je „smrt sankcija svemu o čemu pripovjedač može izvjestiti“ te kako je pripovjedač „od smrti posudio autoritet“, Walter Benjamin kao da je anticipirao pojavu Desničina pripovjedača Ivana Galeba. ${ }^{6}$

Reč je, međutim, o naporednim epohalnim pojavama, koje se kao takve ukazuju kada se u obzir uzmu i Desničine pripovetke. $\mathrm{Na}$ istom je Benjaminovom eseju, pozivajući se i na Bitija, analizu Proljeća Ivana Galeba u velikoj meri zasnovao i Milomir Gavrilović (2017).? Autoru je upravo Benjaminov pojam iskustva pomogao da preosmisli pojam enciklopedijskog modela proze, u koji je onda mogao da uključi i Desničin roman. U svakom slučaju, Benjaminove se postavke sistematski primenjuju na Desničin roman, dok se njegove pripovetke u tom kontekstu zapostavljaju, iako je nemački teoretičar u ovom uticajnom eseju govorio upravo o pripovetkama, smatrajući roman, uz periodičnu štampu, jednim od neprijatelja "klasičnog“ načina pripovedanja.

Časopisni motivi pojavljuju se u većem broju Desničinih pripovedaka, a u četiri pripovetke periodična štampa upotrebljena je specifičnije - kao motiv koji će amblematski potkrepiti opštiji motiv odnosno temu umiranja, smrti i ljudske prolaznosti. Desnica je iskoristio niz raznolikih periodičnih žanrova (kalendar / almanah odnosno godišnjak, kulturno-politički časopis, esnafski polumesečnik i dnevne novine) kako bi umetnički konkretizovao metafizičku temu i filozofsku poruku koju preko nje prenosi. Ovi motivi-amblemi učestvuju, naime, u oblikovanju semantičke opozicije selo - grad (i odgovarajućih koncepcija vremena), a zatim i u povlašćivanju teme smrti: kroz oblikovanje slike umiranja kao procesa, kroz prikazivanje smrtnosti kao biološkog usuda i kroz iskazivanje ideje ljudske prolaznosti preko prikazivanja nestalnosti i varljivosti društvene slave. Specifična umetnička vrednost Desničine proze ne leži, međutim, samo u inovativnom prikazivanju aspekata smrtnosti i iskazivanju ideja u tome domenu, već i u proizvođenju određenog estetskog / čulnog doživljaja. Pomoću datih slika i semantema, u sveukupnom dejstvu pripovedačkih postupaka, u čitalačkom se doživljaju, naime, ostvaruju i efekti samog proticanja vremena, odnosno samog osećaja prolaznosti. ${ }^{8}$

6 Vladimir Biтi, „Mama-Yumba i Mumbo Jumbo: Proljeća Ivana Galeba Vladana Desnice“, Doba svjedočenja, Zagreb 2005., 135.

7 Videti: Milomir Gavrilović, „Odlike enciklopedijskog modela proze u Proljećima Ivana Galeba Vladana Desnice i Peščaniku Danila Kiša“, Hrvatsko-srpski / srpsko-hrvatski interkulturalizam danas. Zbornik radova s mecunarodnoga znanstvenog skupa Desničini susreti 2016. (ur. Drago Roksandić), Zagreb 2017., 236-248.

8 Izbor izraza efekat u kontekstu pitanja umetničke vrednosti motivisan je i jednim Desničinim objašnjenjem iz 1958. godine: „U našoj tekućoj kritici i u razgovorima naše književne svakidašnjice kao da se daleko više pretresa o tehničko-literarnim načinima i postupcima nego o efektu koji je tim načinima i tim postupcima postignut, i kao da se estetska vrijednost traži i pronalazi ne u ostvarenim rezultatima već u upotrebljenim sredstvima." Vladan DesNiCA, „Ličnost i prosede“, Eseji, kritike, pogledi (= Sabrana djela Vladana Desnice, knj. IV), Zagreb 1975., 113. 
Već, dakle, u svojoj prvoj pripoveci, Životna staza Jandrije Kutlače, Desnica višestruko upotrebljava motive periodične štampe. Na osnovnom nivou, ovi su motivi u funkciji izgradnje likova. Kao opštiji motiv, periodika je prisutna u karakterizaciji lika Leopolda, starijeg sina glavnog junaka. To „dijete ni da čuje za kadetsku školu, nego udarilo u politiku, u novine, u pokret. - Bog bi ga znao na šta je okrenuo! - jadao se Jandrija. - Biću veli novinar, te ovo, te ono, te prosvjećivati i urazumljivati narod. “9 Konkretniji motiv dnevnih novina, zatim, Desnica je upotrebio kao znak političkih transformacija i stranačko-političke strasti lika. Glavni junak Jandrija Kutlača, kada se „obrete u svojoj narodnoj državi i pitomome primorskome gradu“, ${ }^{10}$ navikne „na jedne novine, pa ih uvijek kupuje i čita. Čita ih od az do ižice, u svako doba dana i na svakom mjestu: hoda polako i čita, zastajkiva i sriče. Naročito pred izbore jako se zanima. "“11 Nekadašnji verni službenik Austrougarske monarhije, štaviše njen vojnik, Jandrija Kutlača se, kao oličenje konformizma i oportunizma, lako saživljava sa novom državom („svojom narodnom“), nastalom na ruševinama prethodne, i posebno se vezuje za jedan list. Čitaoce Magazina Sjeverne Dalmacije, prve čitaoce ove pripovetke, asocijacije su svakako vodile ka vantekstovnoj realnosti i dnevnim novinama Politika. Iako je za temu ovoga rada od mnogo veće relevantnosti upotreba drugog „periodičkog“ motiva, kalendara-stogodnjaka, nužno je ipak zadržati se na trenutak na slici starca nestrpljivog da stigne do kuće ili kafane kako bi pročitao dnevne vesti. U karakterizaciji junaka - kojeg postupno, do kraja pripovetke, Desnica u mnogo čemu određuje kao negativnog (konzervatizam ${ }^{12}$ i militarizam) - istovremeno postoje elementi koji ga čine oličenjem solarnog principa i pobede života nad smrću. Naime, upravo je, pri kraju pripovetke, uronjenost $\mathrm{u}$ (svako)dnevno zbivanje, pa u tom smislu efemerno, prolazno, $\mathrm{u}$ isto vreme znak junakovog pristajanja na (novi) život, i svoju (prolaznu) ulogu u njemu. Zato na samom kraju pripovetke stoji groteskna slika glavnog junaka kako, obasjan suncem, zadovoljno sedi $u$ sopstvenom budućem grobu („,kad je poslije rada sjedio na suncu u grobu“). ${ }^{13}$

Upravo ta slika pomirenosti sa životom / smrću, ali i sjedinjenosti sa zemljom, vraća čitaoca na početak pripovetke, gde je uveden motiv kalendara-stogodnjaka kako bi se izgradila karakterološka opozicija između starijeg brata Petra i mlađeg Jandrije, čijem će se liku, potom, priča isključivo posvetiti. Tu se, posebno u izmenjenoj drugoj verziji, u zbirci Olupine na suncu, nalazi jedan iskaz važan za ovu temu. U Magazinu Sjeverne Dalmacije u uvodnom delu pripovetke stoji:

\footnotetext{
9 ВАадан АЕсницА, „Животна стаза Јандрије Кутлаче (скица за роман)“, Магазин Сјеверне Аалмащије, 2/1935., 161.

10 Isto, 169. U drugoj verziji pripovetke država više ne nosi epitet narodne, a primorski grad je imenovan: „A kad sve to minu, on se obrete u novoj državi, u pitomome primorskome gradu, na toplom suncu - preselio je ono nešto kućnih stvari u Split i tu se nastanio“. Vladan Desnica, „Životna staza Jandrije Kutlače“, Pripovijetke (= Sabrana djela Vladana Desnice, knj. III), Zagreb 1974., 80.

11 В. АЕсницА, „Животна стаза Јандрије Кутмаче“, 170.

12 Desnica jasno aludira na Jandrijine političke simpatije prema Nikoli Pašiću: „Ali on je ipak znao za koga će se opredijeliti. (...) Nije njemu zaludu Stari dao pensiju po novom zakonu. (...) Naslutio Jandrija u Starome onaj red i starješinstvo, ono državno načelo - sve kao ono carsko što je bilo." Isto, 170.

13 Isto, 172.
} 
Petar, kao stariji, uze upravljati kućom. To je bio ozbiljan i uravnotežen težak, pravi zemljoradnik; nikad nije ni pomislio na drugo podneblje ili na drugačiji život; bio je zadovoljan da jedan dan sliči drugom i jedna godina drugoj. Izmjenu, prilično pravilnu, rodnih godina sa gladnim, ljutih zima i kišljivih proljeća sa sušnim ljetima i lijepim jesenima primao je gotovo kao jednu kalendarsku određenost i ona je zadovoljavala potpuno svu potrebu njegove duše za promjenom. ${ }^{14}$

U drugoj i proširenoj verziji iste pripovetke, u zbirci Olupine na suncu (1952), Desnica je u dati deo uneo izmene koje su išle upravo u smeru eksplicitnog povezivanja ruralnog, preciznije ratarskog načina života i samih kalendarskih publikacija, odnosno razotkrivale da je pod „kalendarskom određenošću“ Desnica doslovno podrazumevao i kalendarsku periodiku:

Petar se po očevoj smrti naglo uozbilji; uzme odmah upravljati kućom i odnositi se prema Jandriji s očinskom vlašću. Bio je to šutljiv i uravnotežen seljak, pravi ratar. Bio je zadovoljan da jedan dan sliči drugome i jedna godina drugoj. Izmjenu, prilično pravilnu, osrednjih godina sa gladnim, ljutih zima i kišljivih proljeća sa sušnim ljetima i vedrim jesenima, što se redalo tačno onako kako je kazano u kalendaru-stogodnjaku, primao je gotovo kao neku kalendarsku određenost, i to očekivano i unaprijed znano smjenjivanje zadovoljavalo je potpuno njegovu potrebu za promjenom. ${ }^{15}$

Da bi se potpunije razumela suprotna priroda Jandrije Kutlače, kojem će sva dalja priča biti posvećena, potrebno je podsetiti šta je to „kazano“ u kalendaru-stogodnjaku. „Izvornim“ čitaocima pripovetke, kao čitaocima Magazina Sjeverne Dalmacije, bila je poznata pa i intimno bliska kalendarska i almanaška kultura, i to kako na srpskom i hrvatskom tako i na italijanskom jeziku, dok je već za dobar deo publike koja ju je čitala unutar zbirke, nakon Drugog svetskog rata, to mogla biti potpuno nepoznata pojava. Ljubitelj prosveštenija. Srbsko-dalmatinski almanah (1836-1873), ${ }^{16}$ izabrani preteča Desničinog godišnjaka, sadržao je, naime, na početnim stranicama tada obavezni kalendarski segment. ${ }^{17}$ Taj se segment sastojao iz „letočislenija“, pashalije, (crkvenog) kalendara, prikaza mesečevih mena po mesecima, astrološkog predviđanja za datu godinu, rodoslova vladarske (u ovom slučaju austrijske) porodice i popis „funkcionera“ srpske pravoslavne crkve. U odeljku s astrološkim predviđanjima nalaze se, samo u ekstenzivnijem vidu i vezani za konkretnu godinu, upravo onakvi opisi godišnjih doba kakve daje i Desničin pripovedač. Tako, na primer, 1836. godinom carstvuje planeta Venus Danica - „imamo se nadati jakoj i držećoj zimi“, „biće proleće dovoljno vlažno, ali i suviše vetrovito“, „leto mnogo zapare i danju i noću obećava“, a jesen će biti „više vlažna nego suva, i zato teško ćemo postolna vina imati“ 18

14 Isto, 155.

15 V. Desnica, „Životna staza Jandrije Kutlače“, Pripovijetke, 59. Kurziv S. B. Oba su ova citata prisutna u pomenutom radu „Implicitni čitalac Magazina Sjeverne Dalmacije: pokušaj rekonstrukcije“, ali se ovde razmatraju u kontekstu drugog problema, pa ih je nužno ponovo i navesti.

16 Od 1838. Srbsko-dalmatinski magazin.

17 Kalendarski deo postojao je samo u prva dva godišta, a posle ga više nema. Upravo ovaj godišnjak pokazuje kako se odvijao prelaz od izvornih almanaha (kalendara zabavnika) ka „čistim“ almanasima tj. magazinima (časopisima), odnosno ilustruje kako su se na periferiji Habzburške monarhije u 19. veku odvijali procesi urbanizacije, scijentizacije i emancipacije - kao deo procesa modernizacije.

18 „Звеъздочетное Предувъщаніе на мьто Хрїстово 1836.“, АЮБИТЕАБ ПРОСВБШТЕНІЯ. СРБСКОАААМАТИНСКІЙ ААМАНАХЬ ЗА АБТО 1836., 21-22. 


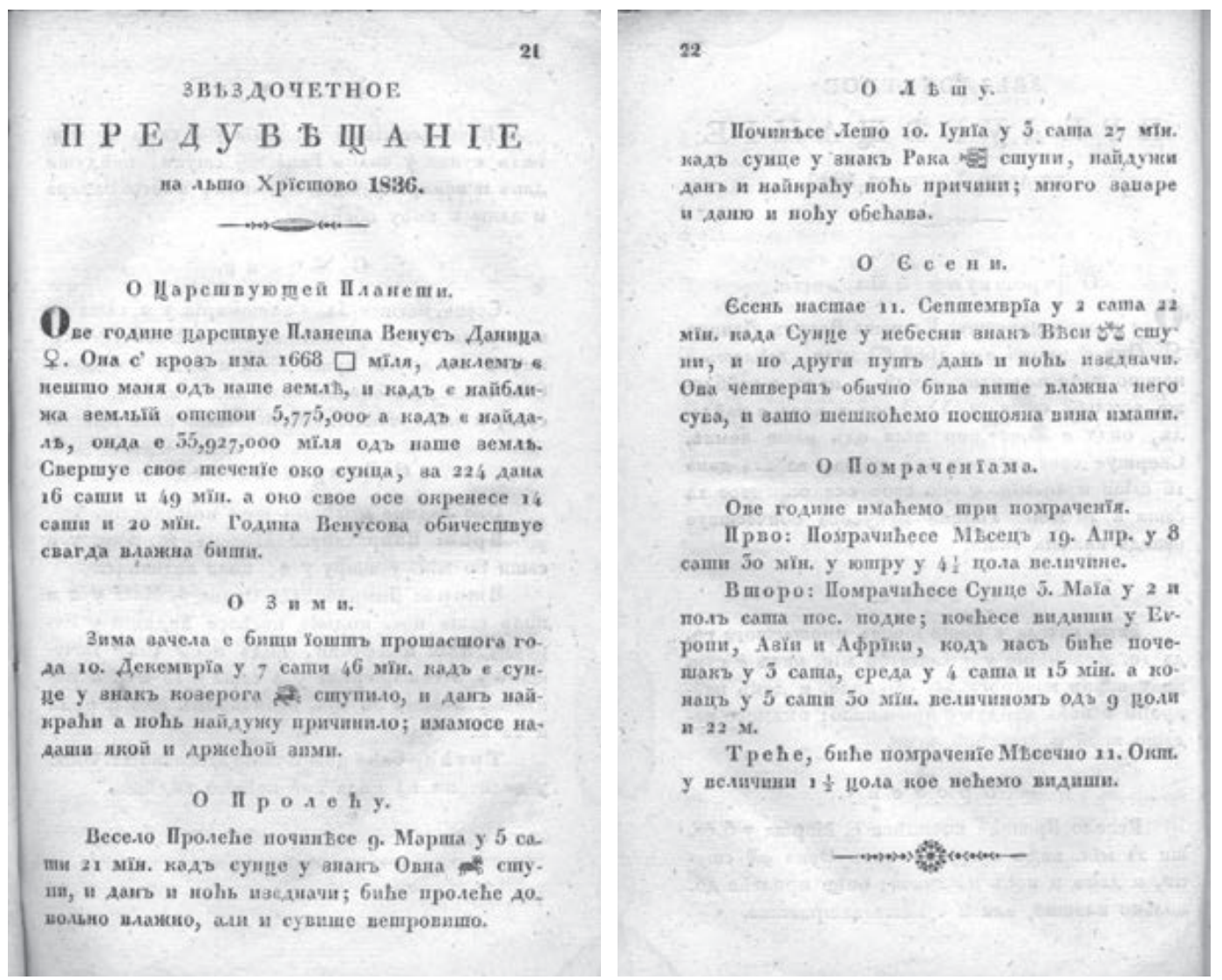

Sl. 1. Astrološka predviđanja za 1836. godinu u Srbsko-dalmatinskom almanahu

Takvi opisi, koji su se, uz varijacije, ponavljali iz godine u godinu, podrazumevali su cikličnu koncepciju vremena koja, dalje, podrazumeva i nekonfliktni odnos prema smrti. Čitaoci odnosno zemljoradnici prihvatali su ova astrološka predviđanja kao datost, i u odnosu na njih se upravljali. U pripoveci je takvoj koncepciji neposredno suprotstavljena koncepcija progresivnog pravolinijskog vremena tako što pripovedač odmah prelazi na opis drugog brata:

Jandrija je bio drukčiji. Nemirne ćudi i žive mašte, žustriji, spretniji, osjećao je u sebi pomalo puste porive i želju za značajnijim doživljajima. Nikad nije kovao dugoročne planove kao što čine ljudi koji računaju da će ostati dovijeka ondje gdje su se rodili. U njemu je želja za „širokim svijetom“ bila jaka još u doba kad o tom svijetu nije mogao da ima nikakvih određenih predstava. U tome kraju nije rijedak kod ljudi taj poriv. Odatle se, kao iz rasadnika, jači i otporniji primjerci presađuju u druge krajeve i novače u druge društvene redove; slabiji ostaju tu da rode spretnije i izdržljivije od sebe. ${ }^{19}$

Međutim, kao što je rečeno, Desnica ne ostaje na oblikovanju pojednostavljene opozicije, već glavnog junaka, nosioca principa linearne „progresivnosti“, na kraju postavlja u pozici- 
ju „pravog ratara“, koji prihvata princip cikličnog. Iz Jandrijine perspektive pripovedač, na kraju životne staze / priče, saopštava:

Ponekad mu se činilo kao da je u životu imao zadaću da iz postojbine u sebi iznese nešto dragocjenije i od sebe samoga i da to nešto njemu samome neznanim i nepronicavim stazama ovdje prenese i staloži. Tek sada, u starosti, osjetio je po prvi put potrebu da se stani i da pusti žile u tlo. Pa, i u toj brizi oko gradnje groba progovorila je njegova polusvijesna želja da svoje potomstvo veže za ovaj kutić zemnog šara i da ga u neku ruku učini nepokretljivim. ${ }^{20}$

Dva lika, koja oličavaju dve suprotstavljene koncepcije vremena, pa tako i smrti, na kraju su pomirena. Čitaoci iz ovakvog pripovedanja ne mogu da izvedu jed(nostr)an pripovedački odnosno autorski epistemološki i aksiološki stav, već je, kao što je ranije detektovano u analizi Desničinog Proljeća Ivana Galeba, reč o poziciji gnoseološkog relativizma ili integralizma, odnosno ambivalencije. Davor Dukić i Goranka Šutalo, usvajajući postavku Dragana Jeremića „o integralizmu kao Galebovoj (kod njega i Desničinoj) viziji života“, dalje preciziraju da „tu dubinsku semantičku potku Proljeća možemo na najapstraktnijoj razini označiti kao binarizam, a konkretnije kao dvojstvo kontradiktornih pojmova / pojava / načela“. Autori ističu da „dijalektika te kontradiktornosti ne pretpostavlja uzajamno isključivanje ili nadilaženje nekom trećom dimenzijom već upravo mirnu koegzistenciju suprotstavljenih polova“. ${ }^{21}$

O ovoj se karakteristici Desničine pripovedačke poetike raspravljalo najviše povodom romana Proljeća Ivana Galeba (1957), ali je vrlo važno istorizovati je i istaći da je upadljiva već u prvom pripovedačkom Desničinom delu (uostalom, Desnica je i roman počeo da piše u isto vreme). Takav integralizam ili ambivalenciju moguće je tumačiti kao odliku same figure pripovedača. Bar tako je u tom trenutku u svojoj književnoj odnosno teorijskoj imaginaciji vide Vladan Desnica i Valter Benjamin. Naime, figure i vrednosne perspektive ratara-sedeoca i nomada-lutalice se u pripovednoj instanci Desničine prve pripovetke objedinjuju, integralizuju, baš onako kao što Benjamin u eseju Pripovedač slikovito predstavlja velike pripovedače:

Iskustvo koje teče od usta do usta izvor je iz kojeg su crpli svi pripovedači. A među onima koji su priče zapisivali, veliki su oni čiji se zapis ponajmanje razlikuje od govora mnogih bezimenih usmenih pripovedača. Uostalom, među ovim poslednjim postoje dve grupe koje se uzajamno višestruko prožimaju. Sam pripovedačev lik poprima svoju punu telesnost samo za onoga ko ima predstavu o obe grupe. „Ko je putovao, ima šta da priča“, kaže narod i zamišlja pripovedača kao nekog ko dolazi iz daleka. Ali, ne manje rado slušamo i onog koji je, časno se prehranjujući, ostao u zemlji i poznaje njene priče i legende. Ako bismo obe te grupe hteli da predstavimo posredstvom njihovih arhaičnih zastupnika, onda je jedna oličena u sedelačkom zemljoradniku, a druga u trgovačkom pomorcu. ${ }^{22}$

Odnosno, kako Vladimir Biti sažima i parafrazira ovaj Benjaminov stav:

20 Isto, 172.

21 Davor Dukić - Goranka Šutalo, „Todesenthebung aus dem Sterbzimmer: koncepti ideologije i vlasti u recepciji Desničinih Proljeća Ivana Galeba“, Desničini susreti 2010. Zbornik radova (ur. Drago Roksandić i Ivana Cvijović Javorina), Zagreb 2011., 71-72.

22 В. БенјАмин, „Приповедач. Разматрања уз дело Николаја Һескова“, 61-62. 
Pripovjedač se tako prikazuje kao sjeditelj koji je za sobom ostavio nomadska lutanja, ratar $s$ nemirnom prošlošću pomorca, šegrt koji se okućio kao obrtnički gazda ne bi li osmislio svoje dugogodišnje potucanje. ${ }^{23}$

Koliko je Desničina pripovedačka (samo)svest proizlazila iz srodnih - ali i neposrednijih - izvora, kao i Benjaminova teorija pripovedanja, pokazuje njegov članak Juraj Carić - pisac mora (1954). Nazivajući Carića „pomorskim piscem“ i opisujući ovog moreplovca koji je postao pisac, Desnica otkriva jedan od živih primera kakvi su poslužili i Benjaminu u uobličenju teorije epskih oblika. Kod Carića Desnica izdvaja upravo neposrednost u prenošenju iskustva, kao i isprepletenost estetičkog i praktičkog:

Razumljivo, živeći i radeći u doba kad je širim redovima naše čitalačke publike pojam „knjige“ u svom punom dostojanstvu, zvučao još dosta unitarno, i kad duboko strahopočitanje prema tom pojmu nije ostavljalo mnogo mjesta preokupaciji za odveć strogim i teoretskim lučenjem takozvane „lijepe knjige“ od poučne i korisne, i Carić je svoje prisno poznavanje mora i života na njemu, svoju prisnu povezanost s ljudima na njegovim obalama i njegovim pučinama, svoje zanose pred njegovim prizorima i njegovim dramama, prosuo u svom djelu ispremiješano $\mathrm{i}$ isprepleteno $s$ poučnim umecima o golim praktičkim faktima. ${ }^{24}$

Upravo na takvu isprepletenost mislio je i Benjamin kada je govorio o „rođenim pripovedačima“ ${ }^{25} \mathrm{i}$ „istinskoj priči“. ${ }^{26}$ Takvi se pripovedači zanimaju i za praktične delatnosti, a svojim čitaocima dele najrazličitije savete, pa njihove priče „otvoreno ili prerušeno“ donose u sebi ono u čemu su od koristi. Jednom rečju - mudrost, koja u vreme opadanja pripovesti nestaje. ${ }^{27}$ Kao primer rođenog pripovedača Benjamin i jeste istakao baš pomorca, „kapetana O..." u eseju / priči Maramica (1932), u kojem se začinju i sve postavke razvijene u Pripovedaču. U Maramici, uostalom, Benjamin definiše i ulogu amblema u priči.

Vratimo li se periodičarskom motivu koji je odveo ka dalekosežnijim problemima Desničine pripovedačke poetike, ali i teorije pripovedanja uopšte, moglo bi se sažeto reći sledeće: motiv kalendara-stogodnjaka predstavlja, dakle, amblem koji učestvuje u karakterizaciji lika odnosno likova, zatim preko njih u oblikovanju semantičke opozicije selo - grad i odgovarajućih koncepcija vremena i smrti, a preko relativizacije datog binarizma i u oblikovanju Desničinog integralizujućeg i ambivalentnog pripovedača.

\section{3 .}

U pripoveci Zlatni rudnik ${ }^{28}$ Desnica je pomoću motiva dnevnih novina, Večernjeg lista, oblikovao dve semanteme iz domena tematsko-motivskog kompleksa smrti: jednu, o smrti kao biološkom usudu ljudske vrste i, drugu, o njenom društvenom aspektu - o prolaznosti

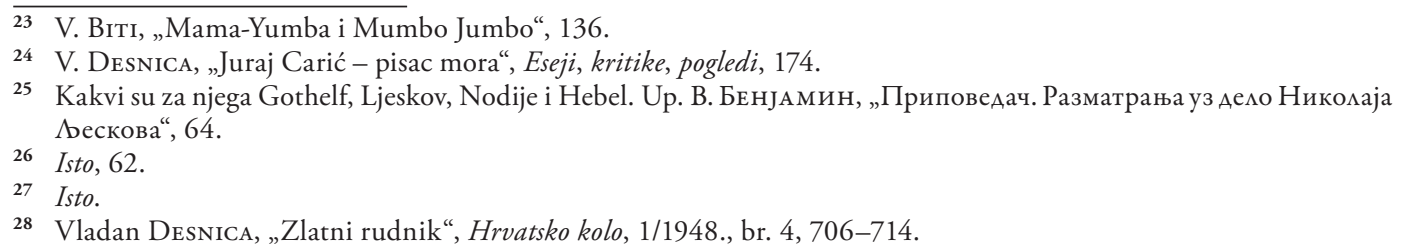


umetničke slave. Te dve semanteme Desnica je objedinio učinivši ih delom životne priče istog junaka. I „uvijajući“ ih u istu novinsku hartiju. Uz to, kombinujući ove motive i sugestivne pripovedačke komentare na odgovarajućim mestima narativnog toka Desnica je stvorio efekat samog vremenskog proticanja.

Zlatni rudnik priča je o Joži Grabeku, koji od siromašnog šegrta u jednoj pekari postaje poznati operski pevač u svome gradu (Zagrebu). Slučajno otkriće profesora, koji u prolazu čuje izuzetni Jožin glas, i nagli prelazak iz anonimnosti u, najpre, gradsko čudo a ubrzo i u opersku zvezdu, proizvode onu vrstu događajnosti koja stvara iluziju zaustavljanja vremena. Pripovedač kaže:

Neosjetno je prolazilo vrijeme (kako se to u filmu prikazuje spontanim odlijetanjem listića $s$ kalendara) - deset godina - i prvi, neslužbeni jubilej došao je kao od šale. ${ }^{29}$

Ovaj pripovedački komentar s fokalizacijom na svest junaka - naročito blizina reči neosjetno i značenje polurečenice u zagradi (spontanost i brzina) - opisuje paradoks subjektivnog doživljaja vremena u danima uspona i slave. Vreme stoji i u isto vreme brzo protiče. Kada prođe vreme stalnog uspinjanja a nastupi vreme karijerne stabilnosti, javlja se isti paradoks: vreme protiče tromo, a opet brzo prođe čitava dekada. Pripovedač pozivanje na stereotipnu filmsku sliku ovog puta izvlači iz zagrada. „Ponovo odlijetanje listića s kalendara", signalizuje on ukratko, i objašnjava:

U jednoličnom slijedu jednakih dana, Joža je išao neprimjetno i prema drugom, dvadesetipetogodišnjem jubileju, a još se nije dogodilo ništa od onog čudesnog, neodređeno izvanrednog što čovjek, htio ne htio, do nekih godina uvijek iščekuje. ${ }^{30}$

U tom trenutku Desnica uvodi motiv Večernjeg lista, i to tako kao da je u pripovedanju on već bio pomenut: „A Večernji list će svejednako pisati 'naš omiljeni Joža Grabek' a već nikad više 'naš proslavljeni Joža Grabek'."31 Ova je pripovedačeva rečenica data iz perspektive glavnog junaka, ali u njoj je iskazano i Desničino zapažanje o dnevnom novinarstvu kao direktnom izrazu dominantnog javnog mnjenja. Kroz osetljivo reagovanje junaka na „sitnu“ promenu u jednoj reči, Desnica se zapravo predstavlja kao kritički analitičar medijskog diskursa: implicitna značenja medijskog govora sadrže onu pravu i, što je još važnije, društveno delotvornu poruku. Onu koju autor / novinar / mnjenje / javnost ne želi eksplicitno da izrazi, a koja bi u ovom slučaju glasila: vreme Jožine slave već je prošlo.

Sliku prolaznosti Desnica je, međutim, proširio na većinu likova ove pripovetke. Ona je posebno ubedljivo prikazana preko ženskih likova: najpre, u grotesknoj slici Jožine koleginice, koja, već prestarela, igra ulogu Madam Baterflaj, zatim na liku / licu Jožine supruge, koja propada zbog siromaštva i, na kraju, kroz nezadovoljstvo i isfrustriranost Jožine kćeri:

Zdenka postaje čudna, ćudljiva, vječito se gloži s materom; zbog najmanje sitnice padne u vatru ili brizne u grčevit plač. U toku godine izmakle su joj dvije prilike za udaju, i sad

\footnotetext{
Isto, 707.

30 Isto, 708.

31 Isto.
} 
je u nju umilila nesigurnost. Malo pomalo miri se s tim da se uposli kao daktilografkinja. Ali onda se odjenom prene, pobuni se: poplaši je duga, siva perspektiva koja se time otvara pred njom; osjeća da bi to značilo odreku, kraj... Pa opet premišlja, skanjiva, odlaže... Neočekivano - obično to biva podveče - uđe u nju i uznemiri joj srce panično osjećanje vremena: čisto osjeća kako ono otiče nezaustavljivo, kako joj izmiče između prsta kao pijesak... ${ }^{32}$

I upravo u tome opisu ekspliciran je čulni doživljaj koji pripovedač postupno nastoji da izazove kod čitalaca - panično osé́anje vremena, u vidu lupanja srca, i njegov taktilni ekvivalent, osipanje peska kroz prste. U ovome posebnu ulogu igra jedan dogadaj smrti koji je deo nezaustavljivog toka Jožine prolaznosti, ali stoji i sam za sebe - kao izdvojena slika. Jožina supruga, naime, u trenutku Jožinog zenita / propadanja donosi na svet mrtvorođenče. Zatičući ih, Joža „razmisli malo pa dohvati s ormara dva tri stara broja Večernjeg lista, uze iz lavora klimavo tjelešce i zamota ga u novine; u kuhinji iza vrata dohvati kotlju kojom su okopavali povrće, i iziđe u vrt “. ${ }^{33}$ Večernji list Desnica je, dakle, vrlo promišljeno upotrebio kao znak smrtnosti i prolaznosti. U ovom slučaju, groteskna slika - obmotavanje mrtvorođenčeta dnevnim novinama - potencira ideju o upisanosti smrti u životni (pret)početak, odnosno o smrti kao biološkom usudu.

Kako bi (pr)oticanje vremena junakove slave dobilo na ubrzanju, pripovedač u radnju uvodi policijski uviđaj, zbog sumnje da je reč o čedomorstvu. Joža je tako proveo jedno veče na ispitivanju u policijskoj stanici, posle čega mu se, nakon što biva pušten i oslobođen sumnji, ,jače nego ikada ranije“, učini da je svet mesto besmislenih i uzaludnih događaja i sudbina. Taj doživljaj Desnica ponovo pojačava periodičarskim amblemom:

Šćućureni pod kandelabrima, slični pokislim ćurkama, prodavači novina izvikivali su svježi broj Večernjeg lista. Snagom navike, Joža se uputi prema njima s dvodinarkom među prstima. Ali na pola puta zastade - učini mu se da zna već unaprijed što može da u njima piše: da je novopostavljeni poslanik kakve Venezuele predao svoje akreditive ili da se u općini Sv. Martin opet pojavila svinjska kuga.

On odmahnu rukom, spremi dvodinarku u džep, i krenu prema kući. ${ }^{34}$

U pominjanom Benjaminovom eseju nalaze se pasusi direktno prizvani ovim Desničinim odlomkom. Kada eksplicira kako štampani mediji (posebno dnevna štampa) i informacije deluju na štetu pripovedanja, Benjamin to slikovito objašnjava:

Vilmesan, osnivač lista Figaro, okarakterisao je suštinu informacije glasovitom formulom: „Mojim čitaocima“, obično je govorio, „važniji je požar na tavanu u Latinskom kvartu nego neka revolucija u Madridu. ${ }^{\text {"35 }}$

Benjamin time dokazuje kako se u vreme dominacije periodične štampe „manje obraća pažnja na vest što dolazi iz daleka nego na informaciju koja nudi oslonac da se obavestimo o onome što nam je najbliže“, što sve zajedno govori priča „rado otvorena prema čudesnom“,

\footnotetext{
32 Isto, 710.

33 Isto, 711.

34 Isto, 715.

35 В. БенЈАмин, „Приповедач. Разматрања уз дело Николаја Бескова“, 69.
} 
a „za informaciju je neophodno da zvuči plauzibilno“, pa se na taj način pokazuje kao nepomirljiva sa duhom priče. ${ }^{36}$

Desničini junaci u trenucima simboličkog ili stvarnog umiranja, kada osete sopstvenu prolaznost, ne pridaju više važnost ni bliskim ni dalekim događajima, ni običnim ni revolucionarnim vestima, jer za njih sve postaje jedno isto. I to je u Desničinoj pripovednoj semantologiji znak da je vreme stalo, odnosno da je junakovo vreme isteklo.

\section{4 .}

Oblikovanje političke biografije lika uvođenjem novin(ar)skog motiva prisutno je i u pripoveci Konac dana, čiji je glavni junak opštinski prvak Mile Srdarević-Prkut. „U malim dalmatinskim gradovima" Desnica je, kako svedoči u pismu Aleksandru Tišmi od 23. marta 1952. godine, susreo „čitav niz ljudi na kalup dra Mile Srdarevića-Prkuta“ i „ta je pojava nesumnjivo tipična za dato vrijeme i sredinu“, zbog čega je smatrao smislenim „literarno fiksirati taj tip čovjeka i ocrtati turobnu životnu krivulju izgubljene egzistencije“. ${ }^{37} \mathrm{U}$ prezimenu Srdarević prisutna je i aluzija na najbliže članove Desničine porodice, čiji se biografski momenti mogu prepoznati i u „životnoj krivulji“ junaka. Na planu obima pripovetke, najveći deo te krivulje posvećen je pak simboličkoj, odnosno političkoj smrti glavnog lika, samom procesu političkog umiranja, i njegovog (ne)mirenja sa tom činjenicom.

Mile Srdarević-Prkut, nekadašnji bečki student prava, nekoliko godina pred Prvi svetski rat osniva list Nova zora, paralelno sa sopstvenom političkom partijom. Međutim, ovaj list - naziva karakterističnog za glasila kakva je pokretala južnoslovenska omladina u Austrougarskoj monarhiji, usmerena protiv monarhije i opredeljena za jugoslovensko ujedinjenje nije samo znak konkretnog političkog profila junaka. Naime, budući da Desnica prikazuje kako date ideje i njihovi nosioci vremenom gube prvobitni, pa i svaki društveni značaj, (p) ostajući tek olupine na suncu, dalja upotreba istog novinskog motiva u pripoveci u tom je znaku. Čitalac će u daljem toku razvoja „radnje“, uveliko posle rata, kada Mile Prkut izgubi i funkciju predsednika opštine, zateći ovog junaka kako sa setom prelistava stare ukoričene godišnjake Nove zore, da bi ga na kraju gledao suočenog sa činjenicom da nijedan list više ne želi da objavi bilo kakav njegov članak:

Zatim je poslao članak jednom prestoničkom listu s poduljim pismom u kome ih je podsjećao na svoju političku prošlost, koje se oni sigurno sjećaju, i iscrpno im naslikao prilike na općini. Odgovorili su mu učtivo upućujući ga na provincijski dnevnik, kod čijih će čitalaca stvar nesumnjivo naići na kudikamo veći interes, jer se radi o mjesnim ljudima i prilikama. Poslušao je taj savjet, no provincijski dnevnik nije mu ni odgovorio na pismo. ${ }^{38}$

Desnica je pažljivo gradio i ritmičke efekte ove pripovetke. Motiv časopisa Nova zora javlja se u tri ključna trenutka: na početku junakovog političkog prodora (osnivanje stranke

\footnotetext{
Isto.

37 „Vladan Desnica o svom književnom radu i pogledima na književno stvaralaštvo“, Eseji, kritike, pogledi, 247.

38 Владан АЕсницА, „Конац дана“, Brazda, 4/1951., br. 7-8, 516.
} 
i časopisa), ${ }^{39} \mathrm{u}$ trenutku najvišeg uspona (propagandna delatnost Nove zore u balkanskim ratovima $)^{40}$ i u trenucima političkog odumiranja, kada se Nova zora više ne objavljuje već je junak čita ukoričenu i samim tim - arhiviranu: „Listao je godišnjake 'Nove zore' i trljao prozeble ruke, jer je u toj daščanoj izbi nerado ložio malu gvozdenu peć.“41

Ovako naglašenu, pomoću amblema Nove zore, Desnica je u ovoj razuđenoj pripoveci ideju političke smrti i prolaznosti iskazao na svim nivoima pripovedanja: kroz doživljeni govor junaka, karakterizacije drugih likova i njihove reakcije, razvijanje lokalnog političkog zapleta, ali i filozofsko-gnomske iskaze. Pripovetka, naravno, intertekstualno komunicira sa dve ranije priče iste tematike. $U$ danima po oslobođenju i osnivanju Kraljevine, junaka, naime, progoni „neki nejasni osjećaj da još mnogošta ima da se učini, i to jako hitna i važna; ali što - toga se nije pravo prisjećao“. 42 Kao i Joža Grabek u pripoveci Zlatni rudnik, tako i ovaj junak očekuje nešto, nešto izuzetno, važno i veliko, ali to veliko delo ili događaj po pravilu izostaju. Kao i Joža Grabek, i Mile Srdarević-Prkut nije uspeo da predvidi početak svog karijernog kraja, blizinu društvene smrti. Isto tako, ponavlja se ideja o postojanju jedne paradoksalne životne tačke, u kojoj zenit uspeha znači početak njegovog kraja, odnosno, još preciznije, trenutak koji se subjektivno doživljava kao novi životni početak, objektivno znači simboličku smrt. Ta je ideja najsažetije i najopštije izražena u rečenici: „I sad kad je računao da je napokon dočekao svoje doba, počeo je shvaćati da je njegovo doba već prošlo. “43 Ona je ubrzo i varirana kroz konkretniju sliku:

I u jedno sivo nedjeljno popodne kad mu je prijetnja kiše osujetila šetnju i zadržala ga u sobi, Mili se prvi put prokrala glavom pomisao da je čas kad je doživio ostvarenje svojih snova iz mladosti bio pravi čas da umre. ${ }^{44}$

Uopšte, u ovoj je pripoveci Desnica na mnogo načina varirao iste ideje i slike, postižući i tim postupkom utisak ponavljanja, ritmizirajući samo pripovedanje, kako bi ostvario efekat vremenskog toka i osećaj postupnog umiranja. Pored periodike, u Koncu dana uvodi se kao motiv još jedan komunikacijski format / žanr koji ima istu funkciju - da otkucava časove života, i da daje ritam životu odnosno samoj njegovoj prolaznosti. Reč je o slanju čestitki za rođendane, imendane i praznike, čega se junak doseti kao spasonosne aktivnosti, ,porađajući mu prijatnu iluziju da je još živ u pamćenju ljudi““活 U pomenutom pismu Aleksandru Tišmi Desnica je eksplicirao upravo ove aspekte svoje poetike: iznoseći opštiju

39 „I doista, Mile se sasvim bacio na ono drugo polje. Pokrenuo je svoj list, 'Novu zoru', i osnovao stranku u koju je povukao mahom seljake iz mjesta i okolnih sela. Ta je stranka bila gotovo Milina lična svojina; prostorije su joj se nalazile u njegovoj kući, on je snosio njene troškove i finansirao njene pothvate.“ В. АЕсницА, „Конац Аана“, 506.

40 „Početak Balkanskog rata zatekao je Milu u Beogradu gdje je bio poveo grupu uglednijih seljaka iz stranke, a po povratku razvio je u 'Novoj zori’ živu propagandu za saveznike. (Protivnici su se zlurado podsmijevali govoreći da Balkanskom savezu treba pribrojiti još jednu silu: Milinu općinu.) Sve to nije izmaklo pažnji vlasti, pa čim je buknuo Svjetski rat, Mile je uhapšen i s drugim viđenijim dalmatinskim ljudima interniran, a njegova općina raspuštena upravo u jeku priprema za proslavu Milina dvadesetgodišnjeg jubileja. A kad je rat svršio, Mile je uspostavljen u časti i odlikovan Svetim Savom II stepena." Isto, 508.

41 Isto, 513.

42 Isto, 508.

43 Isto.

44 Isto, 509.

45 Isto, 515. 
tezu da tema, „materija“, određuje formu pripovetke, otkrio je da pod formom podrazumeva specifično i ritam („Ona diktira tempo, ritam, dramatičnost, način pristupanja...“). ${ }^{46}$

Uz teme političke smrti i prolaznosti političke slave, koje su u prvom planu, Desnica je u pozadini priče prikazao i smrt imperije. Pošto pripovetka jasno sugeriše kako se tek zahvaljujući tome što jedni umiru a drugi se rađaju, teme osnivanja jugoslovenske kraljevine ili „rađanja“ $i$ uspona novih političkih generacija takođe se mogu shvatiti kao motivi unutar istog tematskog kompleksa. Odnosno, u slici uspona novih lokalnih moćnika i nove države čitaoci već vide i njihovu (političku) smrt.

Fiktivni list Glasnik udruženja poštanskih službenika pojavljuje se u pripoveci Oproštaj. U ovoj kratkoj priči, koja opisuje postupno umiranje junaka Antuna, „petnaestdnevni“ esnafski glasnik poprima dvostruko značenje: kao i u drugim pripovetkama, jedan je od znakova prolaznosti života, ali je i „sredstvo“ odbrojavanja poslednjih junakovih dana. Kako je ovaj časopis pomenut samo jednom u pripoveci, i nije eksplicitno naznačen duži protok vremena u vezi sa njim (kao npr. osnivanje i prvi brojevi Nove zore, i njihov kasniji arhivski, ukoričeni oblik; ili slike Večernjeg lista koje ocrtavaju „krivu“ od mladosti do starosti junaka), pitanje je pojedinačnog čitalačkog doživljaja da li će junakovo umiranje, ukoliko ga uopšte vremenski precizira, videti kao poslednjih petnaest dana njegovog života ili će se pak činiti da je reč o višemesečnom procesu u kojem se vidljivije promene fizičkih i mentalnih sposobnosti odvijaju na dvonedeljnom nivou. Zbog uverljivog opisa fizičkog onemoćavanja i „obesvešćivanja“, ${ }^{47}$ čitaoci su navedeni i na ovakve biomedicinske pretpostavke, ali je upravo izabranim postupkom - da pripovedač samo jednom pomene polumesečni Glasnik - Desnica postigao efekat gubljenja osé́aja za vreme i proticanje vremena.

Kao dodatni ritmički signali, koje pripovedač „uzgredno“ nudi čitaocima, tu su podaci o dolascima služavke Ane, na početku priče (ona dvaput nedeljno briše prašinu, odnosno dolazi svakog dana u posetu), i jedan od poslednjih deskriptivnih pasusa. Na samom kraju priče, naime, kao završni akord u postizanju ritmičkog efekta u opisu umiranja junaka, pripovedač je prizvao jedan melodijski doživljaj: poslednji zvuci koje junak čuje jesu zvuci motorne testere kojom komšija seče drva. Pripovedač ih predstavlja kao zvuke koji se javljaju u pravilnom ritmu, jer „iz ujednačene ulične vreve isplivavaju u jednakim razmacima reski rzaji zupčastog koluta kao delfinove peraje s pramom srebrne pjene iz mora“" ${ }^{4} 8$

U ovoj pripoveci Vladan Desnica se potpuno približio samom iskustvu umiranja. Središnja slika umiranja, data istovremeno i spolja i iznutra, kroz junakovu svest odnosno obesvešćivanje, uokvirena je drugim slikama umiranja i smrti. U jednoj od Desničinih najkraćih priča sve zapravo vrvi od mrtvih i umirućih likova: druga Antunova supruga, od njega mnogo mlađa, umire iznenada, u trenutku kada je i njegovo umiranje počelo, pa joj

\footnotetext{
Isto, 246.

47 Videti tekst Bojana Đorđevića u ovom zborniku.

48 Вцадан АЕсницА, „Опроштај“, Аemonuc Mamuцe срnске, 127/1951., br. 4, knj. 368, 299. Kurziv S. B.
} 
Antun zato ne može otići ni na sahranu; u danima umiranja Antun se seća prerano umrle prve žene i prerano umrlog sina (dečak se sa sedam godina polio kipućom vodom); a pod vrata ubačena mu je „osmrtnica“ nepoznatog čoveka. Ove raznovrsne smrti (prirodne ili nesrećnim slučajem izazvane, očekivane ili neočekivane), smeštene u različite tačke „subjektivnog“ i „objektivnog“ fabulativnog (vremenskog) niza, oblikuju svojevrsnu koordinatnu osu motivskog kompleksa smrti, u koju je smeštena i glavna tema. Ovim je postupkom Desnica pojačao sugestivnost osnovne teme, ocrtao joj ram koji će je učiniti vidljivijom.

Amblemska upotreba časopisa, kao upadljivog detalja na toj slici, ogleda se ne samo u uspostavljanju ritma (umiranja i pripovedanja), već i produbljivanju saznajne perspektive - upravo u opisu časopisa, kroz omalovažavanje vesti i dnevnih događaja, pripovedač favorizuje prolaznost ljudskog života. On, naime, kaže:

Od novina je primao jedino petnaestdnevni Glasnik udruženja poštanskih službenika koji je donosio uglavnom samo „stručne i staleške vijesti“. Tek u jednom stupcu na četvrtoj strani bila je rubrika „Događaji u svijetu kroz petnaest dana“. Ali je tu svim vijestima dat neki statistički vid; nizovi riječi bivali su isprekidani mnogoznamenkastim brojevima preko kojih klizne pogled ne zadržavajući se. Nijedna vijest iz te rubrike nije bila kadra da poprimi vid slike: područje na kome hara kuga u Indiji proširilo se za... (cifra s mnogo ništica) kv. kilometara; ili „u Sjedinjenim Državama broj neuposlenih porastao je na... (opet cifra s ništicama)", i tome slično. Čak i vijest, da je u jednoj južnoameričkoj državi izbila revolucija i da je, nakon šest dana ogorčenih borbi, došao na vlast vođa pobunjenika general Florencio Garigo, bila je suha kao upis u maticu, dokraja doigrana i već bačena iza leđa. ${ }^{49}$

Ovaj odlomak kao da je pisan u dijalogu sa Benjaminom. Pored asocijacije na već citirani odlomak o lokalnim i globalnim vestima, ovde je prizvano mesto na kojem Benjamin uspešnim pripovedanjem definiše ono što pripovedni događaj smešta na pravo mesto u „istoriju prirode“. „U uzornom se obliku to izražava“, smatra on, „u jednoj od najlepših priča koje nam je podario nenadmašni Johan Peter Hebel“ ${ }^{50}$ Reč je o priči „Nenadani ponovni susreti“, štampanoj u Kovčežiću s blagom rajnskog kućnog prijatelja. Benjamin to posebno ne napominje, ali je ovde važno istaći da je Kovčežić zapravo kalendar-almanah, blizak imaginarnom „kalendaru-stogodnjaku“ iz Desničine prve priče, Srbsko-dalmatinskom magazinu koji mu je predložak, ali i modernom almanahu u kom je Desnica priču objavio. I Hebel je, kao i Desnica, urednik kalendarske publikacije u kojoj objavljuje svoju priču, a te se priče u nemačkoj tradiciji i nazivaju - kalendarskim.

Opis postupanja rođenih pripovedača u Hebelovoj priči i sličnost Desničinog postupka u Oproštaju, sličnost koja je vid ironijskog otklona, ukazuje na tradiciju kalendarskih priča iz koje je Desničino pripovedanje poteklo i od koje se jednovremeno i emancipovalo. Benjaminu omiljena Hebelova priča, prepričava on tako da ujedno i sam pripoveda,

(...) započinje veridbom mladića koji radi u rudnicima Faluna. Veče uoči venčanja, u dubini rudarskog okna, iznenadi ga uobičajena rudarska smrt. Njegova verenica ostala mu je verna i posle smrti, a živela je dovoljno dugo da, kad su iz napuštenog okna na svetlo dana izneli leš koji se zasićen kristalima gvozdenog sulfata bio očuvao od raspadanja, kao već

$49 \quad$ Isto, 296.

50 В. БенЈАмин, „Приповедач. Разматрања уз дело Николаја Вескова“, 79. 
prastara bakica ona prepozna svog verenika. Posle tog ponovnog susreta i nju prizove smrt. Kad se sad Hebel, tokom pričanja, našao pred neophodnošću da dočara dugi niz godina, učinio je to ovim rečenicama: „U međuvremenu je u Portugalu zemljotres razorio grad Lisabon, i završio se sedmogodišnji rat, i umro je car Franja Prvi. (...) Napoleon je osvojio Prusku, Englezi su bombardovali Kopenhagen, a seljaci su sejali i žnjeli. Mlinar je mleo i kovači su kovali i rudari su kopajući tražili minerale u svojoj podzemnoj radnji. A kad su rudari u Falunu 1809. godine..." ${ }^{\text {.51 }}$

Benjamin će u karakterističnom sugestivnom tonu istaći da „nikad nijedan pripovedač nije dublje smestio svoj izveštaj u istoriju prirode nego što je to učinio Hebel u svojoj hronologiji “ 52 Ono što, pak, teoretičar traži od čitalaca jeste da primete kako se u takvom pripovedanju pozicionira smrt: u pravilnom ritmu jednog pravilnog ciklusa. Desničin pripovedač u Oproštaju smešta svoj izveštaj u istoriju prirode, ali u isto vreme se i ironijski ograđuje od toga postupka, budući da događaje prikazuje kao vesti, a vesti onako kako ih u trenutku umiranja vidi njegov junak - kao beznačajne. Novinske vesti, nisu, međutim, predstavljene kao beznačajne samo zato da bi se time ubedljivo opisao junak koji umire, već zato da bi se saopštilo kako su one beznačajne i za samog pripovedača. U Hebelovoj pripoveci, veliki i mali događaji još uvek su imali vrednost, kao donekle i u Desničinoj prvoj pripoveci, dok su ovde predstavljeni kao informacije, pa ni smrt nije moguće smestiti u neku jasnu istoriju prirode. Kao što Vladimir Biti primećuje povodom romana Proljeća Ivana Galeba, oslanjajući se na ovaj segment Benjaminovog eseja:

U iščašenom vremenu smrt više ne pripada nepomućenoj „povijesti prirode“ gdje „dolazi u tolikom pravilnom turnusu kao da je to kosac u procesijama koje u podne obilaze oko crkvenog sata". 53

U ovom se odlomku jasno razlikuju nivoi rascepa između dve vrste trajanja. Naime, sam svet esnafskih časopisa (koji donose pretežno stručne i staleške vesti) jeste svet bez promena, bez događaja, svet pukog trajanja, u kojem nema individualnih postignuća; zato, i kada u taj svet prodre događaj, u obliku vesti, dodeli mu se „statistički vid“ i on utone u uspostavljenu bezličnost („Nijedna vijest iz te rubrike nije bila kadra da poprimi vid slike“). ${ }^{54}$ Ako je tako i inače u svetu poštanskih službenika (pa samim tim i njihovih glasila), još je veći otpor prema Događaju u trenutku njihovog silaska sa pozornice sveta. Drugi deo opisa časopisa, koji govori o konkretnoj vesti, ne pripada više samo instanci pripovedača, već je prelomljen i kroz perspektivu junaka: umirućem Antunu, kojem ništa više nije važno, vest o revolucionarnoj promeni izgleda beznačajno, beznačajnije nego što bi je mogao predstaviti i njegov staleški časopis. 


\section{6.}

Analiza četiri pripovetke Vladana Desnice pokazala je kako je periodična štampa upotrebljena kao motiv koji amblematski potkrepljuje opštiji motiv odnosno temu umiranja, smrti i ljudske prolaznosti. Amblemski potencijal periodike leži u analogiji između datih motiva: i jedno i drugo počivaju na vremenitosti, na određenosti vremenom, što je Vladan Desnica umetnički i saznajno uspešno iskoristio u ovim pripovetkama. Amblemska je upotreba motiva periodične štampe doprinela uspostavljanju ritma, kako (u slici) umiranja tako i ritma samog pripovedanja. Analiza pripovedaka nastojala je, dakle, da ukaže da specifična umetnička vrednost Desničine proze ne leži samo u ubedljivom prikazivanju aspekata smrtnosti i iskazivanju ideja u tome domenu, već i u proizvođenju određenog čulnog doživljaja. Pomoću datih slika i semantema, u sveukupnom dejstvu pripovedačkih postupaka, u čitalačkom se doživljaju, naime, ostvaruju i efekti samog proticanja vremena, odnosno samog osećaja prolaznosti.

Raspon i hronologija izabranih pripovedaka, od Jandrije Kutlače do Oproštaja, ujedno pokazuje i kako se odvijala svojevrsna evolucija pripovedača u Desničinoj prozi. U objašnjenju date evolucije kao adekvatan teorijski oslonac poslužila je teorija epskih oblika Valtera Benjamina, a posebno njegov esej Pripovedač, pisan u isto vreme kada i Desničina prva pripovetka. Zanimljivo je, najpre, da se Benjaminova teorijska imaginacija i eksplikacija idealnog pripovedača podudara sa književno realizovanom pripovednom instancom u $\check{Z} i$ votnoj stazi Jandrije Kutlače: obe u sebi spajaju (saznajno-psihološke) perspektive ratara i nomada. Drugo važno podudaranje jeste povlašćenost teme smrti. Oblikovanje ambivalentnog i integralizujućeg pripovedača u Desničinom proznom prvencu rezultira i relativizujućim odnosom prema konačnosti smrti jer uključuje ciklični model vremena. S tim u skladu, i završetak pripovetke, u kojem se iščekuje smrt, nosi optimistički prizvuk, posebno u izvornoj verziji iz 1935. godine. Nije nimalo čudno što će u narednim verzijama optimističnost završetka biti prigušena, budući da, kako tri sledeće odabrane pripovetke pokazuju, Desnica sve više povlašćuje temu smrti, a instanca pripovedača sve je manje epistemološki ambivalentna - bliža je konceptu progresivnog toka vremena, a samim tim i neumitnosti smrti, odnosno tragičnom viđenju prolaznosti.

Ukoliko se posle prve pripovetke udaljio od usmenog konteksta pripovedanja (za koji ga je, pored stila, vezivao sam časopisni kontekst - objavljivanje pripovetke u jednom almanahu), Desnica je u naredne tri pripovetke sačuvao drugi benjaminovski pripovedački ideal, koji je pred izazovom u medijskoj eri: sposobnost prenošenja i saopštavanja (celovitosti) iskustva odnosno mudrosti, uprkos dominaciji (fragmentarnih) informacija. Desnica je pomenuti ideal realizovao zapravo kroz narativni postupak u kojem periodična štampa postaje amblem, upečatljivo ali podređeno sredstvo ukupnog narativnog sklopa i značenja. Posle primene datog postupka u pripovetkama Zlatni rudnik i Konac dana, u pripoveci Oproštaj, koja hronološki dolazi na kraju, Desnica ga je doveo do njegovih krajnjih konsekvenci: pripovedač je temu prolaznosti ljudskog života favorizovao kroz potpuno omalovažavenje dnevnih događaja i medijskih vesti. 


\section{$\cos$}

\section{Izvori i literatura}

\section{Izvori}

Vladan DesnicA, „Jedan zakašnjeli prilog diskusiji o tipičnome“, Eseji, kritike, pogledi (= Sabrana djela Vladana Desnice, knj. IV), Zagreb 1975., 71-91.

Vladan Desnica, „Juraj Carić - pisac mora“, Eseji, kritike, pogledi (= Sabrana djela Vladana Desnice, knj. IV), Zagreb 1975., 173-177.

Вцадан АЕсницА, „Конац дана“, Brazda, 4/1951., br. 7-8, 505-524.

Vladan Desnica, „Ličnost i prosede“, Eseji, kritike, pogledi (= Sabrana djela Vladana Desnice, knj. IV), Zagreb 1975., 113-116.

Владан АЕсницА, „Опроштај“, Аетопис Mатице срnске, 127/1951., br. 4, knj. 368, 295-299.

Vladan DesnicA, „Zlatni rudnik“, Hrvatsko kolo, 1/1948., br. 4, 706-714.

Владан АЕсницА, „Животна стаза Јандрије Кутлаче (скица за роман)“, Магазин Сјеверне Аалмачије, 2/1935., 155-173.

Vladan Desnica, „Životna staza Jandrije Kutlače“, Pripovijetke (= Sabrana djela Vladana Desnice, knj. III), Zagreb 1974., 57-88.

АЮБИТЕАЬ ПРОСВБШТЕНІЯ. СРБСКО-ААЯМАТИНСКІЙ АЯМАНАХЬ ЗА АБТО 1836. Издао га на свет Теодор Петрановић, обои права доктор. У Карлштадту, печатано у Типографији Иоана Н. Претнера.

„Vladan Desnica o svom književnom radu i pogledima na književno stvaralaštvo“, Eseji, kritike, pogledi (= Sabrana djela Vladana Desnice, knj. IV), 246-253.

\section{Literatura}

Stanislava BARAĆ, „Implicitni čitalac Magazina Sjeverne Dalmacije: pokušaj rekonstrukcije“, Vladan Desnica i Split 1920. - 1945. Zbornik radova sa znanstvenog skupa Desničini susreti 2014. (ur. Drago Roksandić i Ivana Cvijović Javorina), Zagreb 2015., 157-180.

Валтер Бенјамин, „Приповедач. Разматрања уз дело Николаја Бескова“, Искуство $u$ сиромаштво, БеограА 2016., 59-103

Vladimir Bıтı, „Mama-Yumba i Mumbo Jumbo: Proljeća Ivana Galeba Vladana Desnice“, Doba svjedočenja, Zagreb 2005., 135-171.

Milomir Gavrilović, „Odlike enciklopedijskog modela proze u Proljećima Ivana Galeba Vladana Desnice i Peščaniku Danila Kiša“, Hrvatsko-srpski / srpsko-hrvatski interkulturalizam danas. Zbornik radova s medunarodnoga znanstvenog skupa Desničini susreti 2016. (ur. Drago Roksandić), Zagreb 2017., 236-248.

Davor Dukić - Goranka Šutalo, „Todesenthebung aus dem Sterbzimmer: koncepti ideologije i vlasti u recepciji Desničinih Proljeća Ivana Galeba“, Desničini susreti 2010. Zbornik radova (ur. Drago Roksandić i Ivana Cvijović Javorina), Zagreb 2011., 62-77.

Drago Roksandić, „Vladan Desnica i Magazin Sjeverne Dalmacije: književnik i (ne)moć tradicije“, Vladan Desnica i Split 1920. - 1945. Zbornik radova sa znanstvenog skupa Desničini susreti 2014. (ur. Drago Roksandić i Ivana Cvijović Javorina), Zagreb 2015., 181-234.

Zdenko ŠKreB, „Amblem“, Rečnik književnih termina, Beograd 1992., 20. 


\section{$\cos$}

\section{The MAGAZINE AS AN EMBLEM OF THE FINAL HOUR: THE INTERDEPENDENCE OF THE MOTIFS OF DEATH AND PERIODICALS IN THE WORKS OF VLADAN DESNICA}

In several of Vladan Desnica's short stories, periodicals are a motif which emblematically supports the more general motif, or rather, the theme of dying, death and transience. Desnica uses a variety of types of periodicals (the calendar/almanac, i.e. the yearbook, a magazine of politics and culture, the bimonthly newsletter, the daily newspaper) to represent the metaphysical theme and the philosophical message he wishes to convey. The purpose of this paper is to show the variety of ways in which these motifs are built into the narrative and semantic structures of the short stories and to point out the artistic innovativeness of such a procedure. Additionally, the paper aims to show how the aforementioned motifs function within the larger poetics of Vladan Desnica. They contribute to shaping the semantic opposition between the village and the city (the opposition between the rural and the urban perception of time and transience is highlighted through the motif of the hundred-year calendar in the short story Životna staza Jandrije Kutlače [The Life and Times of Jandrija Kutlača]), to depicting dying as a process (achieved by introducing the imaginary Postal Workers' Gazette in the short story Oproštaj [The Parting]) and mortality as biological destiny (the purpose of the newspaper Večernji list in the short story Zlatni rudnik [The Goldmine]), as well as expressing the idea of human transience through showing the impermanence and the deceptiveness of glory, be it political (achieved through the motif of the imaginary paper Nova Zora and other periodicals in the short story Konac dana [The end of the day]), or artistic (again by using Večernji list in The Goldmine). Set up like this, the analysis of those short stories shows that the specific artistic value of Desnica's prose lies not only in the convincing depiction of mortality and expressing ideas in that domain, but also in producing a certain sensory effect. Through the provided images and semantemes, by the effect of the totality of narrative procedures, the sense of passing time and the feeling of transience itself are created in the reader's mind. In addition to this, the example of the interdependence of the motifs of periodicals and death is indicative of the ways in which Desnica implemented an explicit poetic understanding of expressing the universal through the specific on the level of the inherent poetics: not only can the ephemeral nature of periodicals in this context be understood as something notably specific, as opposed to the universal nature of death and the awareness of transience, but these stories also show clear signs of the autobiographical, which is successfully transformed into something artistically specific, and thus universal.

Key words: Vladan Desnica, short stories, poetics, periodicals, time, transience, the specific, the universal 


\section{8. \\ GROTESKNA SLIKA TIJELA \\ U OLUPINAMA NA SUNCU \\ VLADANA DESNICE}

\section{Sanja Šakić}

UDK: 821.163.42-32Desnica, V.:7.049.2

Izvorni znanstveni članak

Sažetak: Analiza grotesknih slika u zbirci novela Olupine na suncu (1952.) polazi od pretpostavke da se pripovjedni svjetovi Vladana Desnice grade na jasnim opozicijama te da je prostor važan za razumijevanje motivacije likova. Izdvojene varijantne opozicije i opis prostornog modela svijeta uspostavljenog njima upućuje na činjenicu da prostorno modelirani pojmovi imaju neprostorne karakteristike koje se ogledaju u razumijevanju dvostrukosti svijeta i ljudskoga života. U središnjem dijelu rada autorica analizira ambivalentnost pripovjednog svijeta izdvajanjem grotesknih slika Desničinih novela koje proizvode specifičan komični efekt, a koje se tumače u terminima Bahtinove koncepcije grotesknog realizma. Grotesku u novelama Vladana Desnice odlikuju pripovjedno suspendiranje čitateljeva suosjećanja, ambivalentnost i čovjekova tjelesna nedovršenost, koja prevodi disonantnost ljudskog karaktera i moralnih vrijednosti. U zaključku, groteskna slika ljudskog tijela pokazuje se važnom za razumijevanje motiva smrti, a ona u novelama ove zbirke nije tek kraj života, nego izvor obnavljanja i smijeha.

Ključne riječi: Olupine na suncu, prostorni model svijeta, groteska, humor, smrt

\section{TEKST I ŽIVOT BEZ SMISLA}

7 birku pripovjedaka Vladana Desnice Olupine na suncu (1952.) prati kratka autorova napomena koja objašnjava okolnosti njezina nastanka i opisuje likove koji se njome kreću:

(...) ljudske olupine među olupinama ustanova, mentaliteta i oblika života, što griju svoje kosti na božjem suncu i migolje kao jesenje muhe, pokretane više silom inercije i ukorijenjenih navika nego snagom vlastite volje i vlastitog uvjerenja. ${ }^{1}$

Autor u paratekstualnom dodatku ističe kako likovi nisu pripadnici stabilnih uređenja i društvenih krugova - upravo suprotno - sva su uređenja „pometena“, a pripadnici nesre-

1 Vladan Desnica, Olupine na suncu, Zagreb 1952., 327. 
đenog društva „dezorijentirani“ i bez smisla. Desnica je gajio veliko povjerenje u književni rod novele smatrajući je estetski jednako vrijednom i zahtjevnom u odnosu na tadašnju (i sadašnju) popularnost romana jer, ,ako ne zahtijeva dulji dah i sposobnost za veći obuhvat i razgranatiju zamisao, on [rod novele - op. a.], s druge strane, iziskuje veću rigoroznost forme i precizniji osjećaj za proporcije, i nameće strože kompozicione okvire i smišljeniju ekonomiju izraza“. ${ }^{2}$ Dezorijentirane likove bez smisla u ovom slučaju ne pronalazimo u besmislenim tekstovima, nego u onim umjetničkim, čija stroga kompozicija i rigorozna forma sugeriraju određenu stabilnost i uređenost. Opisujući književnoumjetnički jezik, Lotman će u Strukturi umjetničkog teksta, studiji kojom se koristimo kao polazišnom točkom ovog rada, reći da je umjetnički tekst „složeno izgrađeni smisa“" i da su svi njegovi elementi smisleni elementi. ${ }^{3}$ Desničini pripovjedni svjetovi grade se na jasnim opozicijama ${ }^{4}$ koje su po svojoj prirodi stabilne, ali da bi umjetnički tekst prikazao „dezorijentiranost“, on će, pretpostavljamo, dovesti stabilnost ovih opozicija u pitanje.

U dijelu rada koji slijedi nastojat ćemo opisati varijantne opozicije, odnosno njihovu realizaciju ili nerealizaciju u tekstu. Polazimo od pretpostavke da u Desničinoj prozi pejzaž ima funkciju koja nadilazi opis atmosfere ili prostora. U studiji Svijet, ljudi i realizam Vladana Desnice Stanko Korać primjećuje kako je motivaciju likova nemoguće razumjeti bez uočavanja atmosfere nekoga kraja:

Desnica je, napokon, i takav pisac koji, s jedne strane, ljude obilježava prostorom, a s druge, prostor ljudima. U oba slučaja pejzaž ima istaknuto mjesto, jer bismo bez njega uzalud tražili atmosferu nekoga kraja, a ponašanje određenog tipa ljudi ne bi nam bilo tako jasno. ${ }^{5}$

U opisu prostornog modela svijeta izgrađenog na varijantnim opozicijama uočavamo začuđujuće komične obrate, koji svoj izraz pronalaze u grotesknim slikama tijela, pa u središnjem dijelu rada analiziramo kako se oblikuju zapanjujuće i komične slike čovjeka.

\section{Prostorni model svijeta}

Raspravljajući o problemu okvira u umjetnosti, Lotman navodi kako je umjetničko djelo prikaz beskonačnoga u konačnome: „Modelirajući bezgranični objekt (stvarnost) sredstvima konačnog teksta, umjetničko djelo svojim prostorom ne zamjenjuje dio (točnije, ne samo dio) prikazivanog života, nego sav taj život u njegovoj cjelokupnosti.“6 Razumijevanje

2 Isti, „O književnom rodu novele“, Teorija priče. Panorama ideja o umijeću pričanja 1842. - 2005. (ur. Tomislav Sabljak), Zagreb 2007., 108.

3 Jurij M. Lotman, Struktura umjetničkog teksta, Zagreb 2001., 19.

4 Desničini čitatelji uočili su princip „dvojnosti“ kao jedan od temeljnih zakona čovjeka u opusu ovog autora te da dolazi od autorove vizije svijeta utemeljene na polaritetu svega: „Sopstvenu viziju sveta Desnica je temeljio na shvatanju da je polarnost osnovna crta svega. Polarnosti kao što su biće - nebiće, večnost - prolaznost, beskonačno - konačno itd. smjenjuju se u svom delovanju, i od te igre naizmeničnosti sastoji se život. "Usp. Nikolina Konjević MilošEvić, „Poetika umetničke proze Vladana Desnice“, Vladan Desnica i Split 1920. - 1945. Zbornik radova sa znanstvenog skupa Desničini susreti 2014. (ur. Drago Roksandić i Ivana Cvijović Javorina), Zagreb 2015., 336. Pored toga, na planu sadržaja Desničini tumači ističu suprostavljanje gradske i seoske sredine te autorovu zaokupljenost odnosom života i smrti. Usp. npr. Dušan Rapo, Novele i romani Vladana Desnice, Zagreb 1989., 6-9.

5 Stanko Korać, Svijet, ljudi i realizam Vladana Desnice, Beograd 1972., 66.

6 J. M. Lotman, Struktura umjetničkog teksta, 282-283. 
umjetničkog djela kao razgraničenog prostora usko je povezano s problemom umjetničkog prostora pa Lotman demonstrira kako potpuno apstraktni pojmovi za većinu ljudi imaju prostoran karakter: „prostorna struktura teksta postaje modelom prostorne strukture univerzuma, a unutarnja sintagmatika elemenata unutar teksta - jezikom prostornog modeliranja “7 Iscrpnom analizom mahom pjesničkih tekstova Lotman pokazuje da se prostorno modeliraju pojmovi koji nemaju prostorni karakter i - dokazuje - da je prostorni model svijeta organizacijski element „oko kojeg se formiraju i njegove neprostorne karakteristike“. 8

Imajući u vidu ove napomene uz umjetnički tekst, možemo uočiti kako već naslov Desničine zbirke novela predlaže prostorni model svijeta jer se „olupine“ u odnosu na „sunce“ nalaze dolje. Opozicijski par gore (sunce) - dolje (covjek) u novelama se obogaćuje dodatnim značenjima: gore (sunce, bog, misao, život, cikličnost) - dolje (zemlja, čovjek, tijelo, smrt, prolaznost). Ovu osnovnu os zbirke, pored naslova, možemo uočiti u pripovjedačevim komentarima, opisima pejzaža i govoru likova. Nekoliko se novela, na primjer, otvara konstatacijom o sunčevu izlasku i početku dana, nakon čega se uvode likovi „olupina“ (npr. početak dana sljubljen je s početkom pripovijedanja u novelama Posjeta, Pravda, Oko, Formalista, Zlatni rudnik, Od jutra do mraka, Pred zoru). Šjor Miće iz novele Bog sve vidi svjestan je kako Bog vidi i ono što je običnom čovjeku nevidljivo, a njegov licemjeran odnos prema poštenju i grijehu pripovjedač ironično komentira prizivajući naslovnu opoziciju: „Osjeti po leđima njegovu toplinu, kao da se na nj prosu milost božja. “9 U zbirci se na brojnim mjestima može uočiti granica između ovih dvaju prostora, a ovdje nam je važno primijetiti da prividno neprobojna granica između dvaju svjetova podrazumijeva određenu stabilnost i pravila. Likovima je, naime, nedostupan prostor gore, a pravila tog prostora oblikuju njihove živote na zemlji koji su prolazni, monotoni, predvidljivi i predodređeni te je samo rijetkima dopušteno zaći u gornji svijet i donijeti u donji svijet znanje - znanje o supostojanju dvaju svjetova koji se međusobno ne isključuju. Preciznije, samo rijetkim likovima umjetnika novela „dopušta“ da prijeđu granicu između dvaju svjetova i zađu onkraj prvotnog dojma i ljudske predodređenosti (npr. slikar Ivan u noveli Posjeta ili mladi klerik Ivo Čavra u noveli Odjutra do mraka).

Nemoć likova da promijene predvidljivi tijek života koji neumoljivo završava smrću ili stradanjem govori o tome kako je konstruiran svijet kao bezgraničan objekt u konačnom umjetničkom tekstu. Ako život junaka završava smrću, njegov kraj poklopit će se sa završetkom priče (npr. novele Oko, Bunarevac, Oproštaj, Florijanović i Pred zoru završavaju u trenutku junakove smrti). Lotman objašnjava kako se i na primjeru najbanalnijeg shvaćanja „kraja“ (junakovo vjenčanje kao sretan, a njegova smrt kao nesretan kraj) razotkriva dvostruka priroda umjetničkog modela: dobar ili loš kraj „ne svjedoči samo o završetku nekog sižea, nego i o konstrukciji svijeta u cjelini “. ${ }^{10}$ Čak i kad novela ne završava pucnjem u glavu, njezini su junaci svjesni pravila prolaznosti i monotonosti ljudskog života. Tako, na primjer, pjevač Joža iz novele Zlatni rudnik ništa ne može promijeniti, nego samo konsta- 
tirati da to „ne valja“: „Neopazice je prestao i da čeka ono buduće-nepoznato, i u njemu se pomalo ustalilo osjećanje da je sav dalji tok života predodređen i nepromjenjiv. ${ }^{\text {"11 }}$ Nezadovoljstvo i ojađenost monotonijom zemaljskog života možda su ponajbolje preneseni agonijom koju prolazi mladi klerik Ive Čavra: „I kao da se od te njene uzaludnosti širi val svuda ukrug, osjećaj besciljnosti i bespredmetnosti prenosio se na sve naokolo: na građevine, na ljudska kretanja i ljudske sudbine." ${ }^{\text {"12 }}$

Prostorni model novela sugerira određenu nepomičnost, statičnost i nemogućnost djelovanja, a kao takav, u vezi je s Desničinim razumijevanjem vremena. Krešimir Nemec tumači da su prostor i vrijeme u njegovim djelima „dva modusa istog fenomena“: „Taj prustovski problem dokidanja vremena i uspostavljanja trajuće sadašnjosti ili bezvremene vječnosti posebno je tematiziran u romanu Proljeća Ivana Galeba, ali je i u novelama dobio istaknuto

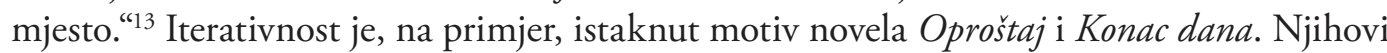
protagonisti doživljavaju vrijeme kao ponavljanje: u prvoj priči Antunovo iščekivanje smrti prekidaju samo pravilni dolasci dvorkinje Ane, a u drugoj Mile Srdarević zaključuje kako se nalazi u jednom od onih „od jutra do mraka“ dana u kojima se sve ponavlja. Kako je riječ o likovima koji su mahom određeni skučenim prostorom i statičnim „kretanjem“, u njihovim promišljanjima veliku ulogu imaju sjećanja i očitovanja vremenskih dimenzija kao što su prolaznost, starenje, bliženje smrti. ${ }^{14}$ Razmatrajući vremenske i prostorne dimenzije ovih novela, najveći broj priča opisuje jednolične živote likova bez prave događajnosti. Međutim, na bešćutnost vremena i prostora ne gledaju svi likovi podjednako ozbiljno i tragično jer kad bi priča samo ponavljala uspostavljena pravila bez varijacija, onda priče ne bi ni bilo. Desničinim likovima naizgled manjka događajnosti jer se kreću unutar dodijeljenog prostora, a događajnost se u pravom smislu riječi pripisuje njihovu promišljanju nepromjenjivosti granica. Lotmanovim rječnikom, nesižejni tekst utvrđuje nepromjenjivost, a „sižejni se tekst izgrađuje na osnovu nesižejnog kao njegova negacija “. ${ }^{15}$ Ono što u ovako surovom i pravilnom svijetu predstavlja iznenađenje jesu brojni tragikomični obrati, apsurdističko viđenje svijeta, ironija i humor zbog kojih se nesretni, a ponegdje i jezivi, usudi junaka razumijevaju kao vesela smrt.

\section{Groteskna slika tijela}

Karnevalom i groteskom se Mihail Bahtin bavio u opširnoj analizi književnog stvaralaštva Françoisa Rabelaisa. Za ovu prigodu izdvojimo to da Bahtin ističe dvostruko razumijevanje svijeta i života koje je važno za njegovu interpretaciju obredno-predstavljačkih formi organiziranih na načelima smijeha. One su podrazumijevale postojanje poprilično jasne granice između smijeha i ozbiljnih ceremonija, a značenje karnevala ogledalo se u ukidanju hijerarhijskih odnosa: „One su pružale jedan sasvim drukčiji, naglašeno neoficije-

\footnotetext{
11 V. Desnica, Olupine na suncu, 116-117.

12 Isto, 172

13 Krešimir Nemec, Vladan Desnica, Zagreb 1988., 26.

14 Usp. Isto.

15 J. M. Lotman, Struktura umjetničkog teksta, 316.
} 
lan, vancrkveni i vandržavni pogled na svet, čoveka i ljudske odnose. ${ }^{\text {"16 }}$ Vratimo li se prostornom modelu svijeta novela koji podrazumijeva jasno razlikovanje svijeta gore, koji upravlja životom na zemlji, i svijeta dolje, koji ne može utjecati na zakon predodređenosti ljudskoga života, dvostrukost Desničina novelističkog svijeta dade se promatrati u terminima Bahtinove estetičke koncepcije grotesknog realizma. Opisujući distanciranost Desničina pripovjedača, Nemec uočava kako „ironična distanca i intelektualna superiornost“ omogućuju „specifičan Desničin humor kojem jedan pol valja tražiti u sarkazmu, a drugi u grotesci“ ${ }^{17}{ }^{17}$ Bilo da je riječ o tragikomičnom kraju priče ili o produžavanju životne agonije, Nemec zaključuje kako usudi protagonista imaju tragikomičnu dimenziju: „Stoga kraj novele u pravilu i nije točka slabljenja: u njoj često ima jetkog humora i ironijske napetosti bilo da je riječ o smrti ili o nastavljanju životne

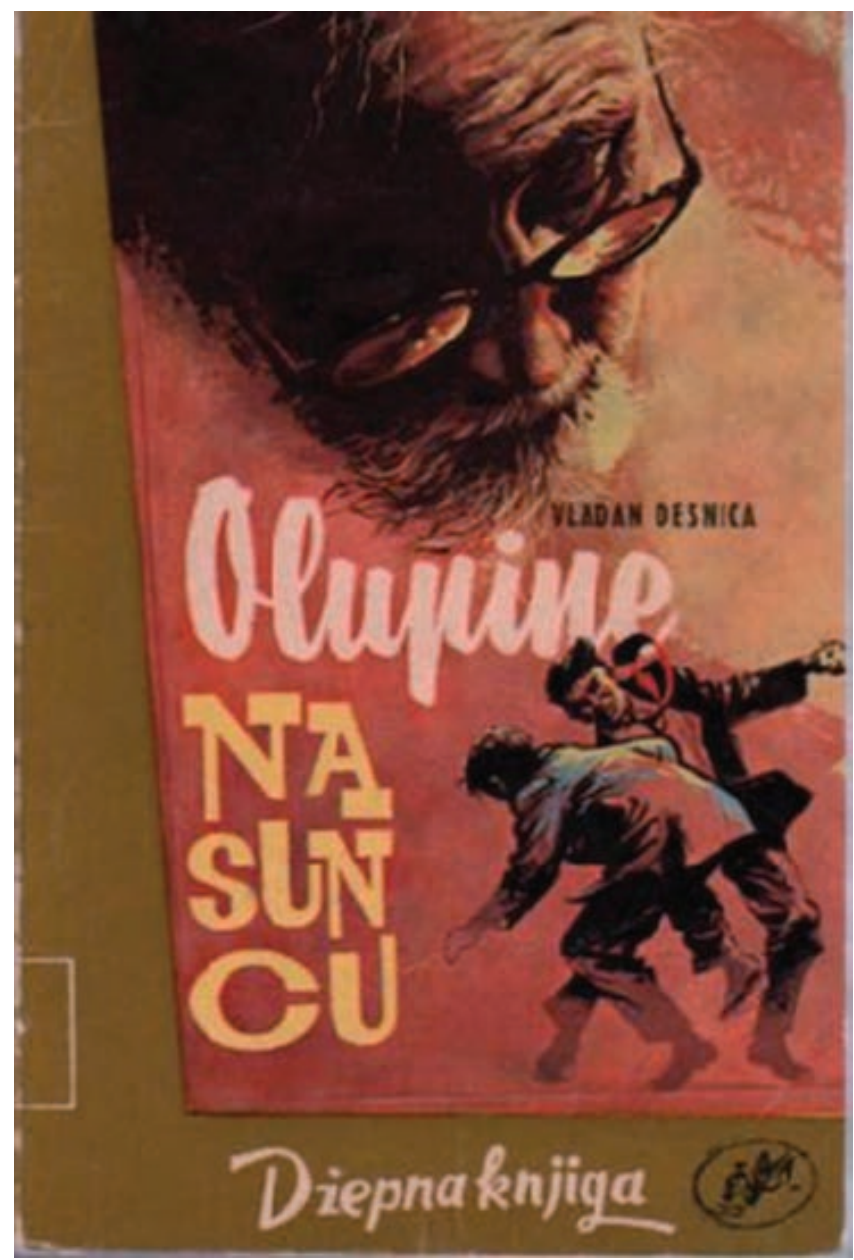

Sl. 1. Korice sarajevskog izdanja zbirke novela Olupine na suncu iz 1962. godine agonije. ${ }^{\text {18 }}$ Bahtin tumači da su slike materijalno-tjelesnog načela u Rabelaisa nasljeđe tipa slikovnosti narodne smjehovne kulture te da je osnovno načelo grotesknog realizma snižavanje, odnosno „prevođenje visokog, duhovnog, idealnog, apstraktnog na materijalno-telesni plan, na plan zemlje i tela u njihovom neraskidivom jedinstvu“ ". ${ }^{19} \mathrm{U}$ odnosu na Bahtinove opise groteske, groteska se u književnosti 20. stoljeća učestalo tumači kao jezivo-komičan efekt koji ona ima na čitatelja i kao „struktura otuđenja“. ${ }^{20}$

Distanciranost oblikuje dojam da pripovjedač na likove i radnju gleda bez suosjećanja i simpatije, a nerijetko ironično komentira njihove postupke i zablude, što rezultira gro-

\footnotetext{
16 Mihail Bahtin, Stvaralaštvo Fransoa Rablea i narodna kultura srednjega veka i renesanse, Beograd $1978 ., 12$.

17 K. Nemec, Vladan Desnica, 18.

18 Isto, 20.

19 M. Bahtin, Stvaralaštvo Fransoa Rablea, 28.

20 Usp. Geoffrey Harpman, „The Grotesque: First Principles“, The Journal of Aesthetics and Art Criticism, 34/1976., br. 4, 461-468.
} 
tesknim humorom. Pravda (Scena sulice), novela koja zorno ilustrira intelektualnu poziciju Desničina pripovjedača, izgrađena je na anegdoti o uličnoj tučnjavi u koju se lančano uključuju akteri različitih motivacija. Pripovjedač promatra scenu sa strane i zadovoljava se promišljanjem svoje potencijalne „čovjekoljubačke intervencije“, a neaktivnost omogućuje mu da scenu raščlani, analizira i donese općenite zaključke o ljudskom životu. Pozicija pripovjedača-svjedoka stvara dojam o autentičnosti događaja, ali Viktor Žmegač uočava da pripovjedač nije nositelj moralnog težišta priče te da je njegovo znanje o istini relativizirano jer ne zna više od drugih likova: „Objektivistička je narav nositelja diskursa samo $\mathrm{u}$ tome što on formulira pitanja i sugerira probleme; no s onu stranu tih pitanja prestaje njegova moralna težina. " 21 Jedna je od posljedica neutralnog promatranja scene na ulici i efekt groteskne komike ${ }^{22}$ koji se ovdje pojavljuje samo u naznakama. Opis čovjeka koji bije ženu na ulici teži komičnom efektu, ali izaziva istovremeno određenu odvratnost spram njegova izgleda: „Lice mu je imalo razjaren, upravo živinski izraz.“23 Ova je čovjekova nedovršenost i prikazivanje dvaju tijela (ljudskog i životinjskog) u jednome jedna od tendencija groteskne slike. ${ }^{24}$

Groteskna se slika u punom zamahu razvija u noveli znakovito smještenoj na sâm početak zbirke. Novela Posjeta dobiva posebno mjesto pri interpretaciji zbirke u cjelini zbog toga što je, u liku umjetnika, duboko zaokupljena umjetničkim promatranjem i posredovanjem stvarnosti. ${ }^{25}$ Slikar Ivan posjećuje osamdesetogodišnjeg profesora čiji portret treba naslikati, a tom prilikom Ivan treba upoznati predmet svoje slike. Susret sa starcem razvija se kao Ivanov prijelaz od nerazumijevanja i odbojnosti do prepoznavanja i veze „nemuštog sporazumijevanja“. Umjetničko poniranje u predmet podrazumijeva ambivalenciju koju slikar prepoznaje u predmetu slike (profesorov „profil čovjeka od misli“ skriva njegovu duhovnu ishlapjelost), ali i u sebi:

Polazeći od postavke da umjetnik mora da prisno razumije i osjeti sve oblike ljudskog duha i sve načine ljudskog mišljenja i osjećanja, da mora umjeti da se uživi u svaku čovječju dušu i uvuče pod koru svake čovječje lubanje (po tome, na koncu, umjetnik i jest umjetnik!), dolazio je do toga da je nerijetko mislio i osjećao u isti mah sasvim suprotne stvari. ${ }^{26}$

Grotesknu sliku, prema Bahtinu, odlikuje ambivalentnost i specifičan odnos prema vremenu koji autor opisuje kao „nezavršenu metamorfozu“. Naime, „u grotesknoj slici uopšte ne postoji individualno telo: takva slika se sastoji od otvora i izbočina, koji su već drugo

21 Viktor ŽmegAč, „Svagdašnji Hamlet. Pravda (Scena s ulice) Vladana Desnice“, Hrvatska novela. Interpretacije, Zagreb 1998., 331.

22 Krešimir Nemec zaključuje kako je za stvaranje grotesknog naboja važno distancirano posredovanje scena koje, ,iako na prvi pogled smiješne, izazivaju jezu, nelagodu, zapanjenost, pa i odvratnost“. Usp. K. Nemec, Vladan Desnica, 19.

23 V. Desnica, Olupine na suncu, 20.

24 Usp. M. Bahtin, Stvaralaštvo Fransoa Rablea, 33-35.

25 Analizom nekoliko fragmenata Desničinih novela Mihajlo Pantić razmatra autorove „priče o priči“ i narativizaciju poetičkog znanja kao jednu od karakteristika modernističke hrvatske i srpske književnosti 20. stoljeća. Usp. Mihajlo Pantić, „Desničina priča o priči“, Desničini susreti 2010. Zbornik radova (ur. Drago Roksandić i Ivana Cvijović Javorina), Zagreb 2011., 78-84. Iako autor ne analizira posebno Posjetu, ova se novela također može razmatrati kao primjer poetičke eksplikacije u fikciji koja se iznosi u vidu autoreferencijalnog komentara. Naime, metoda nepristrane analize umjetničkog predmeta koju primjenjuje slikar Ivan sukladna je s pripovjedačevom pozicijom i analitičkom metodom primijenjenom u ostalim novelama.

26 V. Desnica, Olupine na suncu, 17. 
telo u začetku; ona je dvorište $s$ dva ulaza života koji se večno obnavlja, bezdani sud smrti i začinjanja “. ${ }^{27}$ Slika tijela koje će Ivan naslikati posreduje se kao groteskna slika tijela koje živi u simbiozi s trakavicom:

Sud u kome živi trakavica - eto to i ništa više! Svrsihodna životna zajednica, razumnom ekonomičnošću proveden parazitizam, po načelu maksimalnog iskorištavanja: islužen genije još uvijek je dobar i korisno upotrebljiv za jednu takovu „poradnu“, „starosnu“ službu: da trakavici bude prebivalište. ${ }^{28}$

Slika ne staje na suživotu ljudskog i životinjskog tijela jer Ivan zapaža da profesor ima pristup prostorima koji su ljudima nepristupačni i da je zapravo superioran ograničenosti ljudske misli: „Oslobođen svirepe vezanosti sa stvarnošću, mora da gleda s unutrašnjim

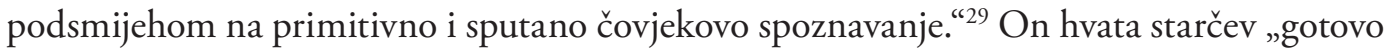
apokaliptičan“ izraz lica koji, paradoksalno, statična slika ne može obuhvatiti i spoznaje da je čovjekovo vegetativno stanje zapravo „prastanje“: ,jedna zaboravljena i vjekovima zatrpana mogućnost, ali koja latentno živi u čovjeku i koja se opet dade lako zadobiti, naučiti ili, još lakše, nesvijesnim oponašanjem usvojiti““.30 Uočavamo da groteskna slika nije isključivo tjelesna te da ona podrazumijeva i izvantjelesno iskustvo istovremenog boravka u dvama različitim prostorima. Prema Haroldu Bloomu, groteska je sredstvo stvaranja zapanjenosti, ali je u svojoj biti „nešto čemu ne vjerujemo, skrivena demonska fantazija koja nas muči i istovremeno privlači, sjena koju potiskujemo jer se ne želimo suočiti sa središnjim problemom našega društva“. ${ }^{31}$ Odvratnost ljudskog tijela jedan je od disonantnih elemenata koji karakteriziraju grotesku, ali groteskno tijelo, prema Bloomu, uvijek dovodi u pitanje ljudski idealizam i pretenzije. ${ }^{32}$ Autor navodi brojne primjere gdje groteskna nepodudarnost izaziva snažan dojam odbojnosti koji potpuno potiskuje komične aspekte. ${ }^{33}$ Međutim, u prethodno navedenim primjerima (kao i u onima koji slijede) distanciranost Desničina pripovjedača onemogućuje potiskivanje komičnog efekta groteske.

Groteskna slika ljudskog tijela koja prevodi nekongruentnost ljudskog karaktera i morala, posredovana distanciranim pripovjedačem, čiji uvidi razotkrivaju prava lica protagonista (ali ih ne osuđuju), pojavljuje se na poseban način u dužoj noveli Oko. Novela pripovijeda priču o sluškinji Kati koja je neposredno optužena da je pomiješala bočice s lijekovima, zbog kojih je doktor Lovro Faruto greškom oslijepio Barišino zdravo oko. Nesretna zbog nametnute krivnje likova koji ne mogu riješiti međusobne konflikte i niza stalnih poniženja, Kata se odlučuje na samoubojstvo, a slikom njezina izobličenog tijela novela se privodi kraju: „Luca se nadnimi na otvor i nazrije u mračnoj dubini sklupčanu spodobu: sličnu

\footnotetext{
M. Bahtin, Stvaralaštvo Fransoa Rablea, 334.

V. Desnica, Olupine na suncu, 15.

Isto.

30 Isto, 19.

31 Harold Bцоом, The Grotesque, New York 2009., 2.

32 Usp. Isto, 14.

33 Michael Stieg, u svom pokušaju definiranja groteske, navodi kako studije koje definiraju grotesku često ne nude samorazumljive metode razlikovanja groteske od samo užasnog i samo komičnog. Usp. Michael STIEG, „Defining the Grotesque: An Attempt at Synthesis“, The Journal of Aesthetics and Art Criticism, 29/1970., br. 2, 253. Međutim, i Stiegov pokušaj sinteze ostaje u konačnici nedorečen pa se stječe dojam da je groteska uvijek fleksibilna kategorija koju je nemoguće definirati i opisati a da bude primjenjiva na sva umjetnička djela i različite stilske formacije.
} 
razapetu kišobranu nadula se mokra oblina Katine suknje. “34 Groteskna slika proizvod je i vrhunac različitih postupaka u oblikovanju Katina lika tijekom cijele novele koji suspendiraju čitateljevo suosjećanje. Naime, likovi novele jasno uočavaju opozicije vid - svjetlostbog i sljepilo - mrak - vrag te nehotično pripisuju Kati sve osobine Nečastivog: lijek postaje „prokleta bočica“, njezina pojava podsjeća na „staricu-zimu“, Kata intrepretira svoju krivnju kao „praroditeljski grijeh“ ili „grijeh nezakonitog rođenja“, doktorova supruga u njezinoj blizini osjeća stranu i neugodnu prisutnost, a tik prije nego što saznamo za njezinu smrt oni se pitaju „gdje li je vrag sad odnese?“. U noveli izostaje moralni sud, a Kata se na kraju pretvara u grotesknu sliku oblikovanu onime što su joj pripisali drugi likovi. Polemizirajući s definicijom groteske Wolfganga Kaysera, Bahtin uočava da smrt u grotesknoj slici uvijek sadrži elemente smiješnoga te da se tema smrti (barem na primjeru Rabelaisova romana) pojavljuje kao vesela smrt, obnavljanje i sjedinjavanje smrti i rađanja. ${ }^{35}$ Međutim, groteskna slika Katina tijela bliža je Kayserovu konceptu grotesknog smijeha ${ }^{36}$ jer se ona postupno gradi u noveli te u konačnici dobiva prizvuk podrugljivog demonskog smijeha.

Oprimjerit ćemo raspravu još jednom Desničinom novelom koja ponešto eksplicitnije uvodi podrugljiv demonski smijeh u opis agonije protagonista priče. Duža pripovijetka $\mathrm{Od}$ jutra do mraka pripovijeda priču o krizi mladog klerika Ive Čavre. Kao što naslov sugerira, doba dana igra važnu ulogu u Ivinim psihološkim kolebanjima koja su opisana kao „bolan rascjep u duši“ $i$, „sutonja agonija “. ${ }^{37}$ Opis Ive od početka do kraja priče naglašava ambivalenciju groteskne slike u kojoj su, prema Bahtinu, „data (ili naznačena) oba pola promene i staro i novo, i ono što umire i ono što se rađa i početak i kraj metamorfoze “. ${ }^{38}$ Ivo je rođen nakon očeve smrti, kao „posmrče“, a novela opisuje ga kao živog mrtvaca:

Iza okruglih zlatnih naočara koji mu daju izgled sovuljage koluta očima i povremeno mota ustima kao da hoće da se oslobodi neugodna ukusa što mu je ostavio pokvaren zalogaj ili gorak lijek. U tim grimasama katkad se pomaljaju blijede desni s velikim žutim zubima koji izgledaju mrtvi, vještački. ${ }^{39}$

Njegov nemir majka i svećenik doživljavaju kao ludilo (koje može smiriti ili žensko tijelo ili Božja riječ), ali krizno mu stanje u kojemu iščezavaju granice između nestvarnog i stvarnog omogućuje uvide i dopušta postupke koje možemo poistovjetiti s karnevalskim principom dehijerarhizacije. Ivi, naime, „ambivalencija“ dopušta neprikladno ponašanje i izokretanje obiteljskih i društvenih vrijednosti:

U jednu riječ, da je čovjek (a naročito veliki, odabrani čovjek) svakakav. Jedino sitni, obični ljudi, ona svagdanja mizerija, mogu da budu s dosadnom trajnošću i negipkom postoja-

\footnotetext{
34 V. Desnica, Olupine na suncu, 48.

35 Usp. M. Bahtin, Stvaralaštvo Fransoa Rablea, 55-62.

36 Kayserovu definiciju navodimo prema Bahtinu: „Smeh pomešan s gorčinom pri prelaženju u groteskno dobija crte podrugljivog, ciničnog i, konačno, demonskog smeha."Bahtinov se prigovor Kayseru odnosi, između ostalog, na izostanak stvaralačkog trenutka smijeha koji oslobađa. Usp. Isto, 61.

37 Usp. V. Desnica, Olupine na suncu, 171.

38 M. Bahtin, Stvaralaštvo Fransoa Rablea, 33.

39 V. Desnica, Olupine na suncu, 129.
} 
nošću stalno isključivo onakvi ili ovakvi. Viši, iznimni ljudi (kao što to dokazuje ne samo njegov nego i Danteov primjer) mogu da budu i faktično bivaju svakakvi u isti mah. ${ }^{40}$

Ivino je „karnevalsko ja“ prosto, neugodno, provokativno, vrijeđa majku i svećenikamentora, razgovara sâmo sa sobom, grohota se, sikće, mahnita - a sve sa sviješću da sâmo vlada svojim postupcima. Ivina mahnitost ruši ustaljen poredak vrijednosti koji ni Bog ni vrag više ne mogu popraviti. Popravit će ga, međutim, ambivalentna Rita-Beatrice koja miri „najgrublje puteno“ s „ljupkim i produhovljenim“ razmišljanjem o ljubavi. ${ }^{41}$ Poslije seksualne epizode, stabilnost opozicija uspostavlja se, a Ivu napušta život pa se u replikama likova opisuje kao „lešina“. 42

Koliko je Ivo svjestan svojih neprimjerenih postupaka, toliko je protagonist novele Formalista iznenađujuće nesvjestan svog izokretanja konvencionalnih društvenih vrijednosti. Mojo je kradljivac koji na smrtnoj postelji odbija priznati grijeh krađe jer dosljedno vjeruje u vlastitu nevinost, a njegova granična pozicija između života i smrti nerazrješivo sukobljuje istinu i laž, Boga i vraga. Mojo se iskreno poziva na Božju riječ, a razumijevanje „beštije šporke“ nemoćni ispovjednik prepušta vragu: „Vrag neka ga razumije! Ako misli da će Boga prevariti, ne misli valjda da će prevariti nas ovdje koji ga znamo kao stari groš! “43 Ambivalentnost Mojina lika nije realizirana tek kao slika živog mrtvaca, nego i kao groteskna simbioza čovjeka i vraga od koje obični ljudi zaziru: on je mršav, „ispijena žuta lica“, duge kose i rijetke bradice, hrama na jednu nogu i pokazuje „izvjesnu nježnost“ prema pripitomljenoj vrani. ${ }^{44}$ Ovakvo utjelovljenje disparatnih ljudskih osobina proizvodi komično-jeziv efekt kojim se narušavaju jasne granice uspostavljene prostornim modelom.

Budući da se ovdje zaustavljamo s analizom grotesknih slika tijela u Olupinama na suncu, treba naglasiti da se groteska ne iscrpljuje navedenim primjerima te da neke novele imaju potencijal da se razviju u punokrvnu grotesku. Takve su, primjerice, novele Bunarevac, Pred zoru, ali i Životna staza Jandrije Kutlače, jedina novela ove zbirke koja ne završava smrću i stradanjem, nego slikom Jandrije koji je u dubokoj starosti „procvjetao kao bajam u blagu zimu“. ${ }^{45}$ Boravak likova na graničnom prostoru između života i smrti omogućuje privremeno ukidanje uspostavljenih granica i konvencionalnih društvenih normi. Dubinsko poniranje u ambivalentnost ljudskog karaktera kazuje, između ostalog, i da nam je autor u paratekstualnom dodatku ponešto prešutio i skrio te da „olupine“ ipak izlaze iz strogo zacrtanog prostora u potrazi za smislom. 


\section{ZAKLJUČAK}

Prostorni model svijeta u Olupinama na suncu sugerira određenu statičnost i nemogućnost promjene života junaka koji žive u prostoru dolje, a komični se efekt postiže depatetiziranjem tragičnih ljudskih sudbina na temelju pripovjedačeve dubinske analize i raščlambe, iz kojih izostaju moralni sudovi i empatija. Distancirani pripovjedač suspendira tragično razrješenje i suosjećanje pa motiv smrti, toliko čest u Desničinoj prozi, dobiva prizvuke smijeha, podrugljivosti, mahnitosti, ludila i veselja. Svijet novela izgrađuje se na stabilnim opozicijama koje se dovode u pitanje grotesknim tjelesno-materijalnim slikama junaka koji se nalaze na granici između života i smrti, ljudskog i životinjskog, ali i ljudskog i vražjeg. Groteskna slika tijela ne staje na suživotu ljudskog i neljudskog, nego njezina ambivalentnost podrazumijeva ukidanje granice između dvaju prostora i omogućuje spoznaje zbog kojih junaci prestaju biti, barem na trenutak, lutke čijim koncima upravljaju sile inercije i ukorijenjenih navika.

\section{$\cos$}

\section{Literatura}

Mihail Bahtin, Stvaralaštvo Fransoa Rablea i narodna kultura srednjega veka i renesanse, Beograd 1978.

Harold Bloom, The Grotesque, New York 2009.

Vladan Desnica, „O književnom rodu novele“, Teorija priče. Panorama ideja o umijeću pričanja 1842. - 2005. (ur. Tomislav Sabljak), Zagreb 2007., 107-108.

Vladan Desnica, Olupine na suncu, Zagreb 1952.

Geoffrey Harpman, „The Grotesque: First Principles“, The Journal of Aesthetics and Art Criticism, 34/1976., br. 4, 461-468.

Nikolina Konjević MilošEvić, „Poetika umetničke proze Vladana Desnice“, Vladan Desnica i Split 1920. - 1945. Zbornik radova sa znanstvenog skupa Desničini susreti 2014. (ur. Drago Roksandić i Ivana Cvijović Javorina), Zagreb 2015., 33-342.

Stanko Korać, Svijet, ljudi i realizam Vladana Desnice, Beograd 1972.

Jurij M. Lotman, Struktura umjetničkog teksta, Zagreb 2001.

Krešimir Nemec, Vladan Desnica, Zagreb 1988.

Mihajlo Pantić, „Desničina priča u priči“, Desničini susreti 2010. Zbornik radova (ur. Drago Roksandić i Ivana Cvijović Javorina), Zagreb 2011., 78-84.

Dušan Rapo, Novele i romani Vladana Desnice, Zagreb 1989.

Michael Stieg, „Defining the Grotesque: An Attempt at Synthesis“, The Journal of Aesthetics and Art Criticism, 29/1970., br. 2, 253-260.

Viktor Žmegač, „Svagdašnji Hamlet. Pravda (Scena s ulice) Vladana Desnice“, Hrvatska novela. Interpretacije, Zagreb 1998., 322-338. 


\section{$\cos$}

\section{THE GROTESQUE IMAGE OF THE BODY IN VLADAN DESNICA'S WRECKS IN THE SUN}

This analysis of grotesque images in the collection of short stories Olupine na suncu (Wrecks in the sun) (1952) begins with the hypothesis that Vladan Desnica's narrative worlds are built on clear oppositions, which are stable by their very nature, and that space is significant for understanding the characters' motivations. The highlighted oppositions and the description of the spatial model of the world that is established through them point to the fact that the spatially determined terms have non-spatial features which are reflected in the understanding of the duality of the world and human life. The spatial model of the world suggests that characters are deprived of the ability to act and change, which is why the focus on the characters whose liminal position enables them to comprehend the coexistence of two worlds whose features are not mutually exclusive. The duality of the characters is reflected in the coexistence of the human and the animal body, life and death, and the divine and the demonic in man. The central part of the paper analyzes the ambivalence of the narrative world by highlighting those grotesque images in Desnica's stories which produce a specific humorous effect, interpreted in terms of Bakhtin's aesthetic concept of grotesque realism. In Vladan Desnica's novel, the grotesque is characterised by the narrative suspension of the reader's empathy, as well as ambivalence and human physical incompleteness which translates into the incogruity between the human character and moral values. In Desnica's work, humor does not rely only on the grotesque image of the body, but also on the narrator's aloofness, reflected in the depathetization of the plot and an analytical approach to the characters. Consequently, the realizations allowed to those exceptional characters dwelling on the border between life and death are singled out. In the conclusion, the grotesque image of the human body proves important for understanding the motif of death in the collection Wrecks in the sun, since in the stories death represents more than just the end of life and the story itself - rather, it is a source of renewal and laughter.

Key words: Olupine na suncu (Wrecks in the sun), the spatial model of the world, the grotesque, humor, death 

9.

\section{KNJIŽEVNOST KAO ODNOS PISANJA PREMA SMRTI - ROMANI DERVIŠ I SMRT MEŠE SELIMOVIĆA \\ I PROLJEĆA IVANA GALEBA VLADANA DESNICE}

\section{Ivan Majić}

UDK: 821.163.42-311.1Desnica, V.:821.163.4(497.6)-311.1Selimović, M. Izlaganje na skupu

Sažetak: Premda se književni postupci u dvama najpoznatijim romanima Meše Selimovića i Vladana Desnice znatno razlikuju, zajednički im je ipak odnos prema propitivanju samoga čina pisanja. U pozadini je dublje pitanje na koje pripovjedači romanâ Derviš i smrt i Proljeća Ivana Galeba pokušavaju pronaći odgovor, a tiče se inicijalnog pitanja statusa književnosti koja nastaje tim zapisivanjem. I dok priča nastaje, nerijetko uz kolebljiva pripovjednog subjekta, neizbježno se upravo taj subjekt promeće istovremeno i u heroja i u žrtvu vlastita zapisivanja. I Selimovićevu i Desničinu pripovjedaču prvu prepreku u suočavanju s vlastitim identitetom predstavlja sâm medij jezika kojemu su, nužno, izručeni. Složimo li se s Blanchotovom tvrdnjom da pisanje nikada nije moć kojom se raspolaže, što rezultira stanjem u kojem pisac što više piše, to je manje siguran u to da piše, tada pisanje u sebi nosi i stanovitu egzistencijalnu tjeskobu, gdje je smrt neizbježno odredište tom procesu. Prisutnost smrti i u Desnice i u Selimovića, i to baš one smrti koja je suprotstavljena ili omjerena o proces pisanja kao nastajanja književnoga djela, jasno je istaknuta već samim naslovima romana (podnaslov Desničina romana znakovit je: Igre proljeća i smrti). Smrt je za obojicu pripovjedača izuzetno važna jer se sâm pripovjedač mora pozicionirati prema graničnosti svoga pripovijedanja, a to je smrt i u pripovjedačâ Nurudina i Galeba. U tom se smislu u ovom radu analizira odnos pisanja i smrti, kako na formalnoj tako i na sadržajnoj razini spomenutih romana.

Ključne riječi: pisanje, smrt, književnost, Vladan Desnica, Meša Selimović, Proljeća Ivana Galeba, Derviš i smrt

opustite mi da ovo svoje izlaganje započnem digresijom. Možda bih u svoju obranu, kao i u obranu digresije, trebao reći da je upravo potonja omiljena figura pisaca kojih sam se primio ne bih li razmišljao o odnosu književnosti i smrti. Selimović, a još vi- 
še i Desnica mogu se nazvati majstorima digresije. Međutim, u tim se digresijama njihovi pripovjedači, reklo bi se, osjećaju pomalo krivima zbog toga što glavnu pripovjednu nit prekidaju. I to biva tako sve do točke kada uoče da romana zapravo ne bi ni bilo da nije tih digresija. Pa se tako nešto rubno i ono što im ispočetka dolazi kao smetnja i prepreka promeće u sastavni dio; štoviše, digresija postaje, na neki način, središnja figura samog čina pisanja. Tomu nije tako samo zbog Selimovićeve i Desničine sklonosti digresijama, već i zbog same prirode romana, koji, kako su nas još ruski formalisti poučili, jednostavno traži digresije i, figurativno rečeno, roman „živi“ od digresija. Na koji način roman, paradoksalno, „živi“ i od smrti, pokušat ću na primjeru romanâ Derviš i smrt i Proljeća Ivana Galeba ukazati u ovom izlaganju. Ali, najprije digresija!

Vjerujem kako Vam neće biti potrebno dodatno pojašnjavati zašto mi je Desničina pripovijest Priča of fratru sa zelenom bradom privukla pozornost. Riječ je o kratkoj, šest stranica dugoj pripovijesti, objavljenoj 1955. godine, koja me je tek nedavno, u franjevačkoj samostanskoj knjižnici, privukla možda i prvom rečenicom. Ona glasi: „Sasvim jednostavna priča." ${ }^{\text {"1 }} \mathrm{U}$ toj pripovijesti lik sanja fratra sa zelenom bradom. Kasnije, kad se probudi, on ne razmišlja o tom snu, ali mu se on ponovi i sljedeće noći. Potom počne razmišljati o snu, ali fratra više ne sanja. I kada, zbog užurbanosti, jednoga jutra propusti razmišljati o snu, sljedeće noći sanja opet isti san. Potom slijedi cijeli niz misaonih analiza, nakon čega pripovjedač dolazi do svojevrsne rekapitulacije, koja se meni, možda još donekle mladom, ali ne i golobradom fratru, ùčini pogodnom za ovu digresiju kojom ću obilježiti vlastiti identitetski odnos s fratrom koji postajem, „tim čudom koje ne poznajem“2 (reći će Selimović). S druge, pak, strane, citat će na lijep način možda obilježiti desetu obljetnicu od prvog sudjelovanja na Desničinim susretima, simpoziju za koji me vežu divne uspomene i neka divna, životna prijateljstva, simpoziju na kojem se ove, 2017. godine, prvi put pojavljujem kao fratar-franjevac, doduše, bez zelene brade, i da, vi uistinu ne sanjate. Citat glasi: „(...) misliti na fratra, ako ćemo pravo, nije baš ista stvar kao i misliti o svojoj misli na fratra (...). U onom prvom slučaju, fratar je nešto što gospoduje mnome, tu je gospodar on, a ja samo njegov objekt. U ovom drugom slučaju, naprotiv, on je podređen meni, on je moj objekt: objekt moje misli. Tu sam još uvijek gospodar ja!“3

Međutim, ta prvotna euforija pobjede nad fratrom vrlo brzo postaje kapitulacija pred njime kada lik sanja fratra koji mu „podmigujući lijevim okom i odmahujući kažiprstom“ kaže: „Varaš se, prijatelju, varaš! Ovako ili onako, u snu ili na javi, kao danji posjet ili kao

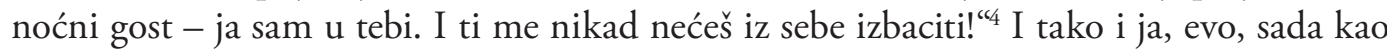
fratar, usuđujem se digresijom započeti svoje izlaganje, digresijom zbog koje se donekle osjećam nelagodno jer sam već trebao govoriti o najavljenoj temi. Međutim, i ovdje se radi o digresiji onog istog tipa kao i u Vladana Desnice ili Meše Selimovića, gdje bez digresije možda ne bi ni bilo djela. I ja bih na ovom mjestu, kao i Ivan Galeb, digresiju vrednovao drukčije od uvriježenog mišljenja; pripovjedač Vladana Desnice započinje jedno poglavlje: „Eto, opet sam odlutao! Na svakom ćošku pobjegnem sam sebi s lanca. Stalno mi se mrsi i

Vladan Desnica, „Priča o fratru sa zelenom bradom“, Zimsko ljetovanje. Pripovijesti, Zagreb 1968., 344.

Meša Selimović, Derviš i smrt, Zagreb 2013., 10.

V. Desnica, „Priča o fratru sa zelenom bradom“, 348.

4 Isto, 349. 
prekida nit. (...) Kao da je 'nit' ono najvažnije i najbitnije što čovjek čovjeku ima da saopći! I činilo mi se da baš u tim 'digresijama' leži sama suština onoga što želim da iskažem. Nastavimo.“"

\section{2.}

U književnim usporedbama, svojevrsnim poredbenim analizama kada se dva djela stanu proučavati i pročitavati, a nerijetko (ostanemo li ponešto kritični) i prečitavati, pa i prečuti, analitička se pozicija usmjeri najprije prema onim mjestima koja su zajednička dvama djelima. Zapravo, preduvjet usporedbe i jest nekakav zajednički interpretacijski kontekst unutar kojega je uopće moguće dva književna djela uspoređivati. Nadalje, tu je pitanje roda i književne vrste. Romani se s romanima uspoređuju, pjesme s pjesmama itd. Premda sam u tekstu sažetka ovoga rada najavio zajedničke elemente Selimovićeva i Desničina romana, pogotovo u odnosu književnosti i smrti, potrebno je napomenuti i neke ključne razlike koje stoje između ovih dvaju romana.

Prije svega, Selimovićev pripovjedač Nurudin protagonist je vremenski bačen u povijesno vrijeme osmanske Bosne, dok je Ivan Galeb vremenski ipak u kolikom-tolikom sinkronicitetu s vremenom izlaska romana - radnja je smještena u 1935. i 1936. godinu, s brojnim reminiscencijama na djetinjstvo. Nadalje, ono što mi se čini posebno zanimljivim odnos je čina pripovijedanja sa samom pričom i rekao bih da je u ovim romanima taj odnos različit do razine komplementarnosti. Odnosno, da konkretiziram, fabula romana Derviš i smrt, čiji je pokretač Nurudin, naizgled je vrlo dinamična i aktivna. Već u drugom poglavlju stoji - „sve je počelo da se zapliće prije dva mjeseca i tri dana, (...) brat je već deset dana ležao zatvoren u tvrđavi““. ${ }^{6}$ Međutim, to je samo naizgled jer je riječ o pasivnom protagonistu, čija ga pasivnost gura u introspekciju, u misaone i samoanalitičke digresije, propitivanja i preispitivanja. U Desničina Ivana Galeba situacija je upravo obratna. Fabula je u romanu Proljeća Ivana Galeba teško odrediva jer protagonistu kao da nije ni stalo do kronologički usmjerena pripovijedanja. Ivanu Galebu dani prolaze iz perspektive bolničkoga kreveta i bolesnikova perspektiva, već sama po sebi, prilično je pasivna. Međutim, upravo se ta pasivnost pripovjedača, ali i radnje promeće u pravu aktivnost samoga pripovijedanja. Pasivnost pripovjedača zapravo omogućuje aktivno, dinamično pripovijedanje sve do točke kada se pripovjedač na neki način u potpunosti ne demaskira dajući svojevrstan credo vlastita pisanja: „Da ja pišem knjige, u tim se knjigama ne bi događalo ama baš ništa. Pričao bih i pričao što mi god na milu pamet padne, povjeravao čitaocu, iz retka u redak, sve što mi prođe mišlju i dušom. Ćaskao bih s njim. (...) Punio bih mu uši svakojakim buncanjem i maštanjima."7

U pozadini je zapravo odnos prema djelovanju, dok je pasivni Nurudin, poput Kafkina Josefa K.-a, ubačen u „proces“ gdje mora aktivno donositi odluke, što ga dovodi do samo- 
optuživanja, kao npr. u citatima: „Odlučiću po strahu, odlučiću po užasu, i dići ću ruke od sebe sanjanog. Sramota neka padne na njih, natjerali su me da budem ono čega sam se gadio “8 $\mathrm{i}$ „nije čovjek ono što misli, već ono što čini“". Ivan Galeb ima, naprotiv, potpuno drugačiju situaciju - njegovo je djelovanje svedeno na minimum, što mu daje aktivno-pripovjedan odnos prema priči: „Prisutan sam. Prisutan sam, ali ne učestvujem. I volim to. Pritajeno prisutan. Prisutan bez zapremnine. Kao pomisao, kao sušta pomisao. Kao život sjene. ${ }^{“ 10}$

\section{3 .}

Ono, međutim, što ova dva romana približava jedan drugome upravo je naslovom i temom ovoga simpozija zadan odnos prema smrti. Ima nešto u Benjaminovoj tvrdnji da je „pripovjedač od smrti posudio autoritet“. ${ }^{11}$ U Dervišu i smrti ta ključna uloga smrti najeklatantnija je na samom kraju romana, kada Nurudin kapitulira pred smrću govoreći: „živi ništa ne znaju, poučite me, mrtvi, kako se može umrijeti bez straha, ili bar bez užasa. Jer, smrt je besmisao, kao i život", ${ }^{12}$ dok pripovjedač u romanu Proljeća Ivana Galeba, kad govori o istinama koje dolaze i prolaze, zaključuje ,jedina istina koja ne stari, koja se ne otrcava, koja ne gubi svoju snagu i svoju aktuelnost, to je smrt. (...) smrt je najviša istina. ${ }^{\text {"13 }}$

O smrti je, kako smo i do sada u izlaganjima vidjeli, moguće na jako puno načina govoriti i promatrati je na različitim razinama is različitih teorijskih polazišta. Međutim, ne znači li to isto tako da je o smrti nemoguće nešto nedvojbeno reći?! Ako se o smrti svašta može reći, onda je vjerojatno da je o njoj nemoguće reći nešto što ne bi bilo podvrgnuto sumnji. Umjesto šutnje i tišine, a isto tako odustajući od filozofski dosljednih koncepata, baš birajući biti zaveden Desničinim tekstom Proljeća Ivana Galeba, pristupit ću i ja misli o smrti s dozom sumnjičavosti, kao i pripovjedač u romanu, koji savjetuje kako se „treba svakodnevno umivati sumnjom, kao vodom “. ${ }^{14}$ Uistinu je zanimljiv način na koji autorski ,ja“ u tandemu s pripovjedačem Galebom postavlja mine konceptu promišljanja koje bi pod svaku cijenu izbjegavalo paradoks. Zanimljivo je i da je baš fra Anđelu, još jednom fratru, Galeb morao eksplicirati svoju misao, a, kada on govori jednom fratru, dopustit ćete, valjda govori i drugom fratru, a tako i svima nama kojima je toliko stalo da misao o smrti u djelima Vladana Desnice nekako usustavimo i pronađemo konzistentno teorijsko polazište. Citat započinje time što fra Anđelo Galebu - a dok to čitam, kao da se i meni osobno obraća - spočitava kontradiktornost: „Ti si, Ivane, pun kontradikcija! Jedno klupko intimnih kontradikcija!" ${ }^{15}$ Galeb njemu, a vjerujem i nama koji se upiremo oko vjerodostojna tumačenja, odgovara: „Pa to se i zove čovjek, moj oče: skup intimnih kontradikcija zašivenih u jednu ljudsku kožu! I čim su kontradikcije brojnije i veće, time je potpuniji i

\footnotetext{
M. Selimović, Derviš i smrt, 390.

9 Isto, 147.

10 V. Desnica, Proljeća Ivana Galeba, 319.

11 Walter Benjamin, Estetički spisi, Zagreb 1986., 175.

12 M. Selimović, Derviš $i$ smrt, 418.

13 V. Desnica, Proljeća Ivana Galeba, 163-164.

14 Isto, 301.

15 Isto, 161.
} 
cjelokupniji čovjek. (...) Kontradiktornost je jedan od temeljnih zakona ljudske psihe, i ko to nije shvatio, nije shvatio ama baš ništa o čovjeku!" 16

Na ovom mjestu želim naglo svoje promišljanje zaokrenuti prema jednom neuobičajeno samozatajnom francuskom teoretičaru 20. stoljeća čiju su misao prešutno preuzimali i kopirali mnogi razvikaniji teoretičari. Riječ je o Mauriceu Blanchotu, čija briljantna knjiga L’espace littéraire objavljena daleke 1955. u nas biva prevedena tek 2015., a imala je golem utjecaj na kasniji Deleuzeuov, Derridaov i Lacanov rad. ${ }^{17} \mathrm{U}$ jednom svom drugom tekstu, Književnost i pravo umiranja iz 1949. godine, Blanchot započinje svoj tekst zanimljivom mišlju: „pretpostavimo da književnost započinje onda kada postaje problemom" ${ }^{18}$ Blanchot propituje razloge zbog čega književnost, iako nije mistifikacija ili obmana, nudi nešto što bi bilo važno u spoznajnom smislu. Iako se „književnost priznaje vrlo važnom za kulturu, ona, istovremeno, nije lišena onog shvaćanja koje ju promatra objektom sumnje“. ${ }^{19}$ U tom smislu, meni osobno jedna od najljepših mogućih definicija književnosti, Blanchotova je tvrdnja da „bi književnost mogla biti jedna od onih stvari koje zaslužuju biti pronađene, ali ne i zatražene “. ${ }^{20}$

Za Blanchota se književnost dogodila baš onda kada se dogodio problem, kada je „drhtava ruka što povlači redove na hartiji“"21 ili kao Desničin „svrbež pisanja“22 postao problematičnim za subjekta iskazivanja jer se smrt dogodila samom činjenicom napisanoga teksta. Blanchot obrće uobičajen redoslijed: ne vrijedi više „pisati kako bi se moglo umrijeti“, nego „umrijeti kako bi se moglo pisati“. On književnost promatra kao „govor koji se svemu

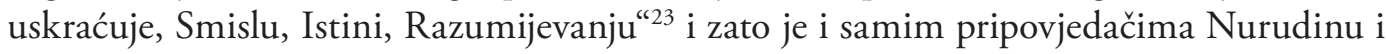
Galebu zapis ono što im izmiče te je zanimljiva u tom smislu opsesija dopunjavanja, ispravljanja, tumačenja vlastita teksta. Kao da se time oplakuje vlastita smrt koja je zapravo morala nastupiti da bi tekst mogao živjeti. Jer, umrijeti se mora svakako, a započeti umirati najljepše je upravo onda kada tom smrću nastaje zapis (testament u Proljećima), tekst, književnost. Za Blanchota, „bježanje od smrti je moguće samo zato što je i sama smrt vječni bijeg pred smrću, jer je dubina prikrivanja. Stoga je na neki način skrivanje od nje zapravo skrivanje u njoj. “24 I toga je svjestan Ivan Galeb te pripovijedanje nastaje kao spoznaja čvrstog veza između pisanja i smrti koju on u sljedećem citatu naziva oslobođenjem: „Prilično mi je prihvatljiva misao da je osnovni, ili bar najglavniji poticaj za pisanje težnja za oslobođenjem, (...) za racionizacijom iracionalnoga. ${ }^{\text {" } 25}$

Zaključno, odnos pisanja i smrti u dvama romanima Desnice i Selimovića zapravo je inicijalan odnos na kojemu počiva mogućnost književnosti. Kažem mogućnost jer da bi književnost postojala, opstojala i opstala, pripovjedači moraju mirno počivati na stranicama romana, živi, a opet mrtvi. Autori pak, premda živi, moraju biti mrtvi svome djelu ne zaboravljajući da „pisac pripada djelu, ali ono što pripada njemu jedino je knjiga, nijemo

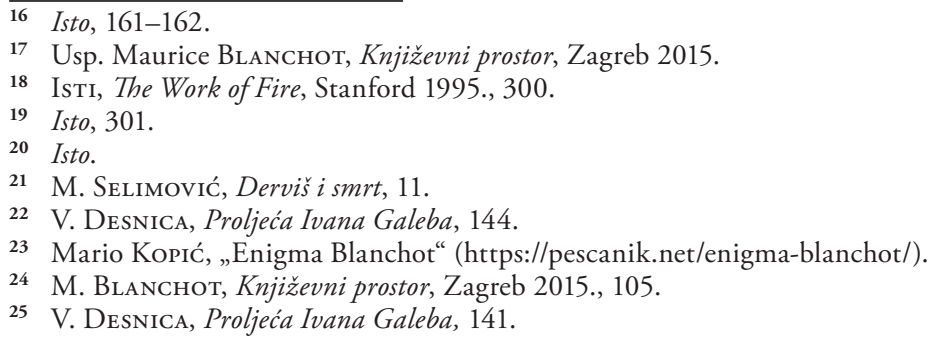


mnoštvo sterilnih riječi“. ${ }^{26} \mathrm{U}$ toj smrti pisca koji pušta djelo da živi novi život, književnost nam se otkriva skrivajući se u igri iznalaženja uvijek novih hermeneutičkih rješenja.

\section{$\cos$}

\section{Literatura}

Walter Benjamin, Estetički spisi, Zagreb 1986.

Maurice Blanchot, Književni prostor, Zagreb 2015.

Maurice Blanchot, The Work of Fire, Stanford 1995.

Vladan Desnica, „Priča o fratru sa zelenom bradom“, Zimsko ljetovanje. Pripovijesti, Zagreb 1968., $344-348$.

Vladan Desnica, Proljeća Ivana Galeba, Zagreb 1977.

Mario Kopıć, „Enigma Blanchot“ (https://pescanik.net/enigma-blanchot/).

Meša Selimović, Derviš i smrt, Zagreb 2013.

\section{$\cos$}

\section{LITERATURE AS THE RELATIONSHIP BETWEEN WRITING AND DEATH - THE NOVELS DERVIŠ I SMRT BY MEŠA SELIMOVIĆ and Proljé́a IVANa Galeba by Vladan Desnica}

Although literary procedures implemented in Vladan Desnica's and Meša Selimovićs most acclaimed novels differ greatly, they share an approach to questioning the very act of writing. This is underpinned by a deeper issue which the narrators of both these novels attempt to address, one that concerns the status of literary works produced by this act. As the story takes form, often with a reluctant narrative subject at its helm, the subject inevitably emerges both as the hero and the victim of his own act of writing. The first obstacle Selimovićs and Desnica's narrators face when confronting their own identity is the medium of language itself, which they, by nature, cannot escape. If we accept Blanchot's claim that writing is never a power at one's disposal, resulting in the condition in which the more a writer writes, the less he is certain of doing so, then it also stands that a certain amount of existential anxiety is inherent to the act of writing, with death as the inevitable end point of that process. In the works of both Selimović and Desnica, the presence of death, of the very kind juxtaposed to or measured against writing as the process of creating a piece of literature, is evident in the very title (Desnica's novel is subheaded Igre proljeća $i$ smrti - The games of spring and death). For both narrators, death carries an enormous significance, since they have to determine their own position in relation to the liminal nature or their narration, represented by death in the case of Nurudin and Galeb alike. In this sense, this paper provides an analysis of the relationship between death and writing in content as well as form.

Key words: writing, death, literature, Vladan Desnica, Meša Selimović, Proljeća Ivana Galeba (The Springs of Ivan Galeb), Derviš i smrt (Death and the dervish)

26 M. Blanchot, Književni prostor, 11. 


\section{0. \\ SMISAO KRAJA \\ U PROLJEĆIMA IVANA GALEBA \\ VLADANA DESNICE}

\section{Vladimir Gvozden}

UDK: 125:821.163.42-311.1Desnica, V.

Izvorni znanstveni članak

Sažetak: Gotovo da nema stranice u romanu Proljeća Ivana Galeba na kojoj se ne pominje imenica smrt, u skladu sa znamenitim podnaslovom Igre proljeća i smrti. Ivan Galeb izlaže tipologiju smrti, fenomenologiju umrlosti: smrt bližnjih, ljubavnika, moćnika, prijatelja, beznačajna smrt... Junak se bavi različitim uzrocima smrti: od smrti od starosti, bolesti, tuge ili zlostavljanja, sve do samoubistva, a diskutuje se čak i o besmrtnosti. U radu je tema smrti u romanu povezana sa idejom o smislu kraja (Frank Kermode), kao i s elementima egzistencijalističkog humanizma. Filozofija apsurda je oblik lucidnosti naspram društvene iluzije pa se na trenutke stiče utisak da Galeb reflektuje o problemima života i smrti onako kako bi to činio Mersault da je kojim slučajem bio intelektualac, odnosno umetnik: svestan vlastite situacije, on odbacuje lažne utehe, ali - budući istinski s one strane očajanja - odbacuje i pesimizam. Samrtnička perspektiva kraja uslovljava Galebovo izgovaranje da životu koji je proživeo, a koji je, pre odlaska u bolnicu, bio stvar samozaborava. Roman je istrajno i mukotrpno formulisanje mogućnosti govorenja o ljudskom stanju - reč je ovde o neprestanom potvrđivanju da je perspektiva kraja uslov razumevanja apsurda egzistencije. Ako je tačna dijagnoza Edgara Morina da se od druge polovine 19. stoleća ispoljava kriza u shvatanju smrti kao kriza individualnosti pred smrću, onda Desnica kroz lik Ivana Galeba uistinu rehabilituje čovekovu individualnost tako što podrobno prikazuje komplikovanu, ne-trivijalnu, protivrečnu modernističku potragu za smislom (ili smislovima) kraja.

Ključne reči: modernizam, smisao, egzistencijalizam, smrt, bol, individualnost, humanizam, građanstvo

osedujemo našu samoću / I naše žaljenje sa kojim gradimo eshatologiju." Ovo su završni stihovi pesme The Historians Call Up Pain (Istoricari prizivaju bol) australijskog pesnika 09 Petera Portera. ${ }^{1}$ Njih je Frank Kermode iskoristio za moto prvog poglavlja knjige The Sense of an Ending (Smisao kraja), objavljene 1967. godine, a mislim da se mogu, bez ostatka, dovesti u vezu s atmosferom i intelektualnom pozadinom Desničinog romana Proljeća Ivana Galeba.

1 Peter Porter, „The Historians Call Up Pain“, Australian Poetry Library, https://www.poetrylibrary.edu.au/poets/ porter-peter/the-historians-call-up-pain-0287035 (datum pristupa: 23. 1. 2018.). Up. Frank Kermode, The Sense of an Ending. Studies in the Theory of Fiction with a New Epilogue, Oxford 2000., 2. 
Valja objasniti kako. Niko, naravno, neće osporiti da uvek možemo da posedujemo samoću, čak i kad nam život u svakom drugom pogledu izmiče - ili baš zato što nam izmiče. Isto tako, često nas obeležavaju žaljenje i samosažaljenje, na temelju kojih gradimo ideju smisla života koji se redovno već izmigoljio iz njenih okova. Pri kraju romana „usamljeni šetač" Galeb, krećući se putem posve suprotnim od samosažaljenja, ali ipak ne u pravcu euforičnog egoizma (koji on sâm naziva ,grijeh uznošenja“, „grijeh samodopadnosti“), ${ }^{2}$ govori o tome kako je „za dugih samotničkih solilokvija u bolnici“ naučio da je „žurba uzaludna“ i „nemir jalov“, jer se svejedno dočeka sve, „svejedno se otkrije smisao ili besmisao svega“. 3 Proljeća Ivana Galeba mogu se posmatrati kao romaneskni komentar o samoći, o subjektu koji pokušava da osmisli kraj, ili - premda jezik ne trpi lako ovu množinu - krajeve svoga života, bez obzira na njihov smisao ili besmisao. Podsećanja radi, krajeva u egzistenciji svakog pojedinca ima bezbroj, i isti taj jezik određuje ih kao kraj detinjstva, mladosti, školovanja, studija, prijateljstva, ljubavne veze, časa, radnog vremena, čitanja knjige, utakmice, putovanja... Vredi se, povodom smisla kraja, podsetiti Galebovog detinjeg igranja kraja sa kutijom za biskvit u obliku globusa:

Nebrojeno puta, velim, ponavljao sam tu igru, nebrojeno se puta naslađivao i draškao tim spremnim, reskim zijevanjem jedne male, automatske smrti. Sklapao sam oči da bih na tankoj kožici vjeđa osjetio te male zapahe ništavila. ${ }^{4}$

Naizgled bezazlena „psihoanalitička“ igra prizivanja kraja i ništavila - setimo se još jednom podnaslova u množini igre proljeća $i$ smrti - govori nešto veoma važno: kraj je, prosto rečeno, imanentan egzistenciji i Galebova igra krajem uz pomoć kutije što nalikuje na globus zapravo je, kao i mnogo šta drugo iz njegovog detinjstva, „mala“ slika celokupnog „velikog “ života. Ovoj dečjoj igri slična je ona istočnjačka priča koju prepričava Galeb, samo što bi ona pre bila igra koju igraju odrasli:

Vjerovatno postoji neki istočnjački mit ili legenda (a ako ne postoji, trebalo bi je stvoriti) o čovjeku koga je smrt mogla da zaskoči samo na spavanju, samo dok miruje. I zato se bez časka predaha vrtio, kretao, koprcao - živa pregršt ucrvanog nemira. Neka vrsta istočnjačke Tantalove muke i Sizifova posla u isti mah.

Čim čovek zastane, javlja se opomena u obličju smrti; iscrpljen od stalnog kretanja, poput samog Galeba koji nam o tome priča, taj čovek leži i čeka smrt:

I smjesta se javlja odgovarajuća filozofija: smirenje je najveća sreća, najveće dobro; ono je posljednja mudrost, vrhovna radost, smrt je najviša istina. ${ }^{6}$

Ali čim klone, ovaj „istočnjak“ skače i nastupa filozofija: život je sve! I sada se, poput igre kraja sa kutijom za biskvit u obliku globusa, ponovo pokreće ciklus života.

Sličnu ulogu igra i Galebov rukopis koji nastaje pred nama: književnost u njemu postaje odgovor na „zapahe ništavila“, na nejasan i nesmislen svet koji se, kroz perspektivu kraja,

\footnotetext{
Vladan Desnica, Proljeća Ivana Galeba, u: Vladan Desnica (prir. Željko Milanović), Novi Sad 2013., 238.

Isto, 352 .

Isto, 139.

5 Isto, 233.

6 Isto, 232.
} 
svodi na meru ljudskog. Galebova teorija o strelici dobro ilustruje ovakav smisao kraja. Naime, svaki ljudski stvor „kreće se pod znakom takve jedne nevidljive strelice“? A kad te „strelice nema, ili kad je izgubila svoju naelektrisanost magnetske igle, kad je u nama 'legla’ - čovjek je ugašen, mrtav. Razumije se, ne mrtav u doslovnom, fizičkom smislu (...).“8 Strelica nas vodi kroz prostor ka krajevima naših egzistencija, u pravcu naših slepih, nama nejasnih stremljenja. Primer za to može biti smrt glumca. Priča se razvija nakon što u novinama, dobijenim od bolničarke, Galeb pročita vest o smrti glumca, zanimljive osobe koja nije ostavila nikakvog traga: „Umro je negdje u provinciji, u nekoj bolnici, poput ove moje. Sasvim daleko od Astapova! (") Ali ostao je ipak iza njega trag, malena strelica, odnosno Galebov zapis o tome da je ovaj čovek imao šta reći upravo o smislu kraja: „Od krhotina jednog razočaranja ne gradi se novi kumir: na njegovom mjestu ostaje praznina... Eto, to je ono od čega strahujem. "10

Naravno, ako postoji kraj, postoji i početak, a postoji i vreme između njih. To je, kako kaže Galeb, vreme „okrutnog pamćenja“, ${ }^{11}$ a njegov roman je u isti mah izraz takvoga pamćenja i niz komentara o njegovom delovanju. U stvari, uspostavljanje odnosa prema početku i kraju ispoljavanje je naše najdublje potrebe da pripadamo vlastitoj vrsti. Pritom nije nužno da svaki kraj bude pravi kraj, to se prosto tako kaže; često se dešava da kraj zapravo samo liči na kraj - kao i operacija na koju odnose Galeba na početku romana, a koja ga privremeno isključuje iz vremena, ali i vraća u život. Njegovo uključivanje u vreme, ulaženje u zbivanje - on, naime, ne zna da li je subota i nedelja - praćeno je onim mersoovskim „svejedno“. Ubrzo, kao što je znano, saznajemo i šta nije svejedno: vreme pripovedanja smešteno je u prvi sunčan dan, nakon tamnih, smrtnih oblaka, a oblačni dani su za pripovedača „dani smrti“" ${ }^{2}$

Diskusiju o smislu kraja valja, naravno, početi od kraja romana jer, kako kaže Kermode u pomenutoj knjizi, romani moraju imati kraj čak i onda kada ga poriču. Na samom kraju Desničine knjige nalaze se poznate agnostičke rečenice:

Na koncu sviju staza stoji šutnja i mir sa svime: široki mir sa bolom, s ljudima, sa životom - sa samim sobom. U meni tišina, nada mnom podne bez ruba, uokolo prizori zemlje u dobroj poplavi sunca.

Zar se na tako malo život sveo? Je li to starost, preživjelost, umor? Ili posljednja, vrhovna mudrost: krajnja odreka svega?

Ne znam. Osjećam samo da nema stvarnijeg dobra od toga: mir sa radošću, $s$ bolom - i preplavljenost suncem. ${ }^{13}$

Pravo i istovremeno teško pitanje glasi: Kad je zaista kraj? Antički filozof iz 5. veka pre naše ere, Alkmeon iz Krotona, čiju misao spretno oživljava Kermode, smatrao je da čovek umire zato što više ne može da nađe sponu sa početkom i krajem. Dok je živ, on to čini

\footnotetext{
Isto, 191.

8 Isto.

$9 \quad$ Isto, 272.

10 Isto, 269.

11 Isto, 135.

12 Isto, 146.

13 Isto, 355.
} 
tako što stvara sklad među stvarima; on stvara, drugačije rečeno, modele sveta. Kermodeova glavna teza je da su egzistencija i fikcija bliske delatnosti, jer i jedna i druga proizvode kongruencije porekla i cilja, kako bi životu i romanu podarili smisao. Da bismo našim životima podarili smisao sa mesta gde smo (uvek negde između), potrebne su nam fikcije o počecima i fikcije o završecima, fikcije koje objedinjuju početak i kraj i daruju smisao intervalu između njih. Njih Kermode naziva fikcije-saglasnosti (concord-fictions). U Proljećima Ivana Galeba Vladan Desnica ispituje upravo načine na koje gradimo fikcije-saglasnosti, što posredno znači da ispituje odnose između tragedije i komedije, između biografije i priče, između zagonetke prolaznosti sećanja i zauvek promašenih, ali i trajno potrošenih mogućnosti egzistencije.

Pripovedač pripoveda mnoštvo priča, i prepušta nam da sami odredimo koja je među njima najvažnija. Stoga se javljaju prekidi, pa i odbijanje pisanja, pluralne interpretacije istih događaja, nepouzdana i pouzdana sećanja, svesni izbori, ali i oni nesvesni, koji docnije bivaju racionalizovani. Postoji, osim toga, nešto što bi se moglo nazvati Galebova tišina, koja je znak stoičkog odnosa prema životu, rudimentaran oblik ravnodušnosti, ključan za razumevanje Desničinog odnosa prema pisanju. Ta tišina je neka vrsta modernističkog upozorenja spram lažnosti svojstvene ne samo egzistenciji, već i književnom diskursu:

Pokušavam da čitam. Ali ubrzo odlažem knjigu. Zamara me. Još do nekidan činila mi se zanimljiva, a sad mi se čini tako prazna. $\mathrm{O}$, kad bi oni koji pišu knjige znali kako na samrtničkoj postelji malo koja knjiga da ne izgleda potpuno lažna! Trebalo bi uopće da ljudi češće vide stvari onakvima kakve nam se ukazuju na samrtničkoj postelji. ${ }^{14}$

Ničeovsko rešenje, u Onfrayovom spretnom sažetku, glasi: „Život je apsurdan, završiti s životom je apsurdno. Šta onda ostaje? Živeti. ${ }^{\text {“15 }}$ Ili: prepoznati da je čovek ime za „skup intimnih kontradikcija zašivenih u jednu ljudsku kožu“ ${ }^{16}$ odnosno priznati konfuziju, protivrečnost života i znanja o njemu znači zapravo reći da egzistenciji. Roman Proljeća Ivana Galeba kao da potvrđuje Nietzscheovu tezu da će život poći za umetnošću, jer se život rađa postepeno, kroz pisanje, jer „naopako proživljen život“, kako Galeb kaže pri kraju romana, vodi ka pisanju knjige, premda najčešće slabe. ${ }^{17} \mathrm{~Pa}$ ipak, Galebovog života ne bi ni bilo da nema upravo te „slabe“ knjige: u tom smislu je život pošao za umetnošću, jer mu je umetnički čin, ponikao na tlu perspektive smrti kao kraja, podario smisao. U slučaju ovog romana bol je nešto što u egzistencijalnom smislu osnažuje pripovedača, onako kako to Nietzsche izražava u jednom važnom fragmentu:

Izuzetno važan uslov govorenja da egzistenciji (Bejahung des Daseins) zamišljen je tako da je čak bol, svaka vrsta bola večno uključena u nju kao sredstvo osnaživanja: tragičko-dionizijski uslov. ${ }^{18}$

\footnotetext{
14 Isto, 340.

15 Mišel Onfre, „Metafizika apsurda“, Polja, 59/2014., br. 488, 63.

16 V. Desnica, Proljeća Ivana Galeba, 230.

17 Isto, 353

18 Friedrich Nietzsche, „Aus dem Nachlass der Achtzigerjahre“, Werke in drei Bände (ur. Karl Schlechta), sv. 3, Wien - München 1956., 693. Sve citate s engleskog i nemačkog preveo V. G.
} 
Ovaj iskaz se kod Nietzschea odnosi na tragediju, dok ga Galeb, kao modernista, smešta u ravan umetničkog izraza uopšte, čak i onda kada ga poriče (jer je taj izraz uslov toga poricanja). U stvari, kada se prenese na širi estetski plan, ovaj uslov zapravo potvrđuje mogućnost umetnosti da govori bitne stvari o egzistenciji uprkos nadnetosti nad njenom prazninom: „Ako uopće ima poezije, tad je poezija ono na što naša misao i naša senzibilnost naiđe lutajući pustopašicom. “19 Pisanje je u povlašćenoj vezi sa pravom stvarnošću života, premda je često kritična prema toj stvarnosti, što Galeba vodi do nimalo lagodne pozicije, koje je u svojim izlaganjima o ljudskoj protivrečnosti uistinu svestan: naime, ukoliko njegovo izlaganje shvatimo kao nadahnuto kritikom zatečenog stanja (a za to ima mnogo argumenata), onda je jasno da je njegovo pisanje u velikoj meri zavisno od banalnosti koju osuđuje.

Ali postoje u ovom romanu dva motiva koja se uvek, kako se čini, opiru banalizaciji: sunce i smrt. La Rochefoucauld je jednom rekao da se ni sunce ni smrt ne mogu netremice gledati ${ }^{20}$ Ivan Galeb pokazuje koliko mnogo ih je zapravo moguće gledati i ostati živ. Setimo se samo epizode o smrti Galebove kćeri Maje, kod koje se bolest pojavila odjednom, „s uznemirujućim znakovima “, ${ }^{21}$ pa je sve vreme do smrti provela u sanatorijumima i klimatskim mestima. ${ }^{22}$ Ona umire u proleće, i to je još jedna igra proljeća $i$ smrti, jer nakon njenog pogreba Galeb je, kako nas izveštava, požurio da napusti to mesto ,još isto popodne, za sunca“. ${ }^{23}$ Za Desničin roman važi ono što na jednom mestu beleži Edgar Morin, u Smrti na Zapadu:

Prema tome, tamo gde je jedinka raskinula sve spone koje su je spajale sa društvom, tamo gde se ona ukazuje kao usamljenička i blistava individualnost, na njenom horizontu pomalja se smrt, isto toliko samotna i blistava, kao njeno Sunce. ${ }^{24}$

Galeb, ograđen - ali i izgrađen - u svojoj bolničkoj egzistenciji, izlaže čitavu tipologiju smrti: smrt bližnjih, ljubavnika, moćnika („smrt sa majonezom“), beznačajna smrt Mate Piskvićevića iz Brgudovca... Isto tako, zanimaju ga različiti uzroci smrti: od smrti od starosti, bolesti, tuge ili zlostavljanja, sve do samoubistva, a diskutuje se čak i o besmrtnosti. Nije teško primetiti da gotovo da nema stranice u romanu na kojoj se imenica smrt ne pominje, u skladu sa znamenitim podnaslovom igre proljeća i smrti. Galeb kaže da bi na čelu stranica koje piše mogao da stoji natpis: „Jedan neosmišljeni životopis“. ${ }^{25}$ No roman bi se, zavisno od pristupa, mogao nazvati i osmišljenim ili neosmišljenim smrtopisom. Ulog u takvome pisanju jeste istina, i za Desnicu važi prividni paradoks o kojem u jednom od pisama govori Flaubert:

Poezija je nešto isto tako tačno kao i geometrija. Indukcija vredi koliko i dedukcija, a zatim kad se dođe do izvesne tačke, ne vara se više ni u čemu što se tiče duše. ${ }^{26}$

\footnotetext{
Isto, 177.

20 Edgar Moren, Čovek i smrt, Beograd 1981., 19.

21 V. Desnica, Proljeća Ivana Galeba, 325.

22 Isto, 326.

23 Isto, 327.

24 E. Moren, Čovek i smrt, 55. O Proljećima Ivana Galeba kao solarnom romanu videti: Vladimir GvozDEn, „Solarni hobi Vladana Desnice“, Il SoleLuna presso gli slavi meridionali (ur. Ljiljana Banjanin, Persida Lazarević Di Giacomo, Sanja Roić i Svetlana Šeatović), sv. 2, Alessandria 2017., 213-226.

25 V. Desnica, Proljeća Ivana Galeba, 214.

26 Gistav Flober, Izabrana pisma, Beograd 1955., 11.
} 
Galeb mukotrpno nastoji da kroz predvorje ili čak vrata smrti dospe do sopstvene duše. Postoje i duše koje su „mrtvo more“. ${ }^{27}$ Njegova svakako nije takva.

Roman, bitno je istaći, izlaže katalog smrti, fenomenologiju umrlosti u određenom istorijskom razdoblju. On započinje opisom šire i uže Galebove porodice, koja ostvaruje intenzivno, problematično prisustvo smrti u njegovoj egzistenciji. Njega zanimaju velika i mala istorija u međusobnom preplitanju, pa se tako povest najpre odnosi na oca, ,jadnog Franu“, pomorca koji je rano preminuo. Ivan ga nije upamtio, ali se oseća kao da je stariji od njega. U stvari, očeva smrt je samo jedna u nizu jer su umrla još dva brata mlađa od oca, što je za Galeba povod da unutar zagrada saopšti jednu metafizičko-filozofsku šalu u makabrističkom stilu:

(Njihova imena znao sam s mramorne ploče na porodičnoj grobnici. Pobuđivala mi je smijeh pomisao na te stričeve u kratkim hlačicama ili čak u povojima: prema mom zamišljaju, pojam strica morao je kao neminovni atribut imati brkove. Zamislite dijete u garde-enfantu s brkovima! $)^{28}$

Umro je i očev nekoliko godina mlađi brat - on je u sećanju Ivana Galeba bolešljivi čovek koji je čitavog dana, poput stabljike filadendrona, boravio u trpezariji, i koji je bio svakidašnja opomena na „djedov“ životni neuspeh. Bolest je ovde slika neuspeha, ali i nekakve superiornosti u „stanju bez nužde i želje“.

Fizička smrt praćena je različitim simboličkim znakovima utisnutim u tkivo teksta. Galeb gleda predstavu one zaglavljene italijanske trupe i sluša stentorski (vojni) poklič Vegliate, arcieri! koji, po principu slobodnih asocijacija „, one strane pojmljivoga“, nagoveštava majčinu smrt u formi opomene. ${ }^{29}$ Majka, žena iz „boljih pučkih redova“, umrla je naglo, od upale pluća, posle jednog izleta koji su svi upamtili kao jedan od najlepših. ${ }^{30}$ Ali to nije samo kraj majčinog života, to je još jedan kraj:

Uskoro zatim, samih nekoliko nedjelja poslije majčine smrti, otišao sam i ja iz mjesta na škole u grad. A time se nekako završava i moje djetinjstvo. ${ }^{31}$

Detinjstvo se okončava, ali smrt traje, jer naša čovečnost uslovljena je našim manjkavostima. Smrt je, tako, povezana i sa prolaznom ljubavnom avanturom sa Egidijevom kćeri, Kalpurnijinom najmlađom sestrom Aldom. Smrt kao da pobuđuje smrt: devojka se otrovala, posle ove epizode nastupa i bakina iznenadna smrt (što prekida Galebovu poslednju sentimentalnu vezu sa kućom), a onda je "djed“ udaren od kapi, što označava još jedno odvajanje, odnosno kraj! ${ }^{32}$

Ali, potreban je oprez: Kada je, u stvari, nastupio bakin kraj? Kao dete Galeb se igrao njenim tušem, u stvari nekakvom posudom, zgodnom za put, koja se mogla obesiti pa je iz nje tekao skroman mlaz vode. Povodom tuša rasplamsava se igra želje koja u pripoveda-

\footnotetext{
27 V. Desnica, Proljeća Ivana Galeba, 317.

28 Isto, 131.

29 Isto, 185.

30 Isto, 128.

31 Isto, 186.

32 Isto, 209.
} 
čevom diskursu priziva kraj. On, naime, želi da mu, kad poraste, baka pokloni taj tuš, što u stvari znači:

A u sebi sam zapravo mislio: „hoćeš li ga meni ostaviti kad umreš. I možda sam joj, zbog tog tuša, nesvjesno želio što skoriju smrt. Svakako, neku idiličnu, raznježenu smrt, $s$ mnogo rujne zvonjave zvona, s mnogo cvijeća, i vijenaca, i sažalnih brzojava, i služinskog bugarenja, i s pogrebom kakav se u mjestu ne pamti. ${ }^{33}$

U Proljećima se iščitava egzistencijalistički humanizam oličen u iscrpnoj individualnoj potrazi za meandrima (vlastitog) života i smisla usred društvenih i ekonomskih pritisaka (malo)građanskog društva oličenog u površnosti i konformizmu i - reklo bi se - u manipulaciji smislom kraja. Ključne su, u odnosu prema društvu, one rečenice kojima Galeb opisuje stare drugove iz gimnazije: „Boljela me njihova smirenost. Većinom su bili dosta dobro uščuvani; nisu mi izgledali stari: izgledali su mi mrtvaci. “" ${ }^{34}$ Sve njihove radosti i vesti svodile su se na činjenicu da vreme protiče. Stoga je njihova sreća „tužna sreća“, ${ }^{35}$ oni su, spolja posmatrano, „smireni ljudi“, dok su za Galeba, iz njegove egzistencijalističke perspektive, oni tek „pogašeni ljudi“ “. ${ }^{36}$ Galeb podržava neku vrstu filozofije slobode utemeljenu na pretpostavci da možemo živeti i reflektovati svoje izbore, svoje činove - njegovo pisanje iscrpljuje se u ovoj refleksiji. Dok čitamo roman, postaje očigledno da je Galeb zapravo mnogo više od onoga što naizgled jeste, dakle više od bolničkog pacijenta, samrtnika, propalog umetnika. Konačno, u pozadini onoga što Galeb pripoveda uočava se etička komponenta, poziv da ispitamo autentičnost naših ličnih života, i našega društva. Tako je Galebova istina više stvar odluke nego otkrovenja.

Ali, kako su ostvareni izbori? On pomno analizira izbore koji su dali jedinstvo i pravac njegovom životu. Sve to se, pritom, odvija na fonu smrti - da nema perspektive smrti, ne bi, paradoksalno, bilo ni Galebovog života koji nam je predočen. Život biva istinski vrednovan tek iz ugla bliske smrti. Ritam pisanja prati ritam društvene bolesti, ali je ono pozvano da se, čak i u kontekstu bolnice, otkrije kao moguće, premda uvek ugroženo zdravlje. Galebov drugačiji govor pokušava da dovede u pitanje neprikosnovene strukture sveta, čemu doprinosi i širi kontekst: filozofski impulsi modernosti koji pripovedača neprestano provociraju. Shodno tome, njega zaokuplja fenomen bolničke smrti:

Pitam se: zar dakle zbilja po bolnicama, pa i po bolje uređenim, bolesnici umiru u sobama u kojima boluju? Zar je, dakle, zbilja samo bajka ono što sam u djetinjstvu (i s kolikim unutrašnjim odjekom!) slušao o naročitim prostorijama za tu svrhu, o poznatoj „šterbecimer““汭

Kad je reč o pomenutoj sobi, postavlja se niz pitanja, a Galeba najvećma kopka sledeće: „Kad dođu da bolesnika prenesu u 'šterbecimer' (razumije se, ukoliko šterbecimer uopće postoji), kako mu pristupe? Što mu kažu? Čime ga zavaraju? “38

\footnotetext{
Isto, 220.

Isto, 241.

Isto.

Isto, 240.

Isto, 236.

38 Isto, 237.
} 
S obzirom da je roman smešten u tridesete godine prethodnog stoleća, valja se podsetiti na promenu u odnosu prema smrti na Zapadu, na koju spretno ukazuje Ariès: „Ne umire se više u svom domu, među svojima: čovek umire u bolnici i to sam. ${ }^{\text {"39 }}$ Smrt u bolnici nije više prilika za ceremonijal, u toj smrti nema ničeg svečanog i herojskog ${ }^{40}$ - ona je slika otuđenja čoveka od zajednice. Ariès podvlači da je bliskost sa smrću trajala sve do romantizma, a nakon toga dešava se promena: „U moderno doba je smrt, uprkos prividnom kontinuitetu tema i rituala, stavljena pod sumnju i kao da se krišom udaljava iz sveta običnih, životnih stvari. “41 Bolnička smrt je

(...) raskomadana, podeljena na niz malih etapa i na kraju se ne zna koja od njih stvarno predstavlja smrt. (...) Sve te male, tihe smrti zamenile su i izbrisale dramatičnu akciju smrti i niko više nema snage ni strpljenja da sedmicama čeka trenutak koji je delimično izgubio svoj smisao. ${ }^{42}$

Galebov doživljaj generalove smrti demonstrira pomenutu promenu: „Pomišljam: ako umre, to će biti smrt sa majonezom!“ ${ }^{43}$ To bi, dakle, trebalo da bude pompezna, svečana smrt, ali to neće biti tako jer je zapravo istorija slabih prava povesnica čovečanstva. ${ }^{44} \mathrm{Smrt}$ moćnika je još jedna prilika da pripovedač opiše građanski doživljaj smrti, koji je povezan sa strahom:

Tako, dakle. Znači, ni generalima, ni primjercima iznad prosječne ljudske mjere, nije dobro reći golu istinu. Zar se, dakle, i heroji pod kožom tako malograđanski boje smrti? ${ }^{\text {(45 }}$

Nakon ovog sledi opis promene o kojoj je uverljivo, decenijama posle Desnice, govorio i francuski istoričar Ariès:

Sasvim logično. Jedno je javna smrt, smrt u punom ornatu, a drugo je sitna, privatna smrt. Jedno je izložiti se zalutalom tanetu „na polju časti“, atentatorskom metku u krunidbenoj povorci, pasti prosvirana šešira s perjem, „pod ešarpom izvršene dužnosti“, a drugo je pasivno dotrajavanje sred četiri zida našeg tmurnog doma, među našim altdajč kredencima, rastočena trbuha pod kordonom kućne haljine, iz koje davno upijeni mirisi jela, kućevnosti, ishlapljena naftalina već čudno udaraju mirisom smrti. ${ }^{46}$

Galeb naizgled govori o distinkciji između javne i privatne smrti, ali je ovde zapravo reč o trijumfu bolničke, horizontalne smrti: „Ovo je privatna, pasivna smrt, smrt kao podnošenje. Smrt nauznačke. ${ }^{\star 47}$ Ma koliko grandiozno i moćno, $j a$ tu jednostavno nije gospodar situacije:

$\mathrm{Ne}$, dragi gospodine! Ovdje se ne umire tako! Nećeš ništa $t i$, nego će nešto tebe. Nećeš ti ništa dati, nego će ti nešto biti oduzeto! Nećeš ti poginuti, nego ćeš naprosto biti poginut!... ${ }^{48}$

\footnotetext{
Filip Arijes, Eseji o istoriji smrti na Zapadu, Beograd 1989., 68.

40 Isto, 69.

41 Isto, 81.

42 Isto, 69.

43 V. Desnica, Proljeća Ivana Galeba, 259.

44 Isto, 275.

45 Isto, 274.

46 Isto.

47 Isto.

48 Isto, 275.
} 
Bolnička smrt je čisto trpljenje smrti, bez ikakve ceremonije: jedino što je pobeđuje jeste govor, jeste nevoljni, nemotivisani, a ipak sasvim životni čin govorenja ili pisanja.

Očigledan egzistencijalistički sloj u Proljećima Ivana Galeba očituje se već i u samom remećenju granice književnosti i filozofije, koje Galeb posmatra kao možda i najbolji deo sebe. Osim toga, čini se da Desnica pišući, na tragu Alberta Camusa, „filozofsku književnost i književnu filozofiju“, ${ }^{49}$ produbljuje koncept ravnodušnosti, koja u slučaju Ivana Galeba znači mešavinu nemogućnosti da oseća i protesta protiv neautentične emocije. Potonja je u romanu označena katkad kao malograđanska - setimo se, na primer, kratke rasprave o nedeljnim ručkovima. Filozofija apsurda oblik je lucidnosti naspram društvene iluzije, pa se na trenutke čak čini da Galeb govori kako bi govorio Mersault da je kojim slučajem bio intelektualac, odnosno umetnik.

Neupitno je da Galeb otvara nekoliko ključnih tema egzistencijalizma. ${ }^{50}$ Najpre, kod Galeba egzistencija prethodi esenciji, odnosno ono što on jeste rezultat je njegovih izbora: Galeb je ono što je učinio od sebe, umivajući se svakodnevno sumnjom „kao vodom“.51 Isto tako, pripovedač je biće fundamentalno povezano s vremenom. No, za razliku od merljivog, normativnog vremena, proživljeno vreme (ali i bolničko vreme) kvalitativno je. Pripovedač (ili pisac) kao da ima na umu odlomak iz knjige Franka Kermodea, koji vredi navesti u opširnijem izvodu:

Uzmimo jedan prost primer, kucanje sata. Pitamo se šta on govori i slažemo se da on kaže tik-tak. Pomoću ove fikcije mi ga humanizujemo, činimo da govori našim jezikom. (...) Naravno, mi smo ti koji omogućavaju fikcionalnu razliku između dva zvuka; tik je naša reč za fizički početak, tak je naša reč za kraj. (...) Tik-tak časovnika se može posmatrati kao model onoga što zovemo zaplet, ustrojstvo koje humanizuje vreme tako što mu podaruje formu..$^{52}$

U tom smislu, a nasuprot uvreženom stanovištu, Proljeća Ivana Galeba su roman ispunjen mnogobrojnim zapletima. Kermode nekoliko stranica kasnije dodaje da u svakome zapletu postoji beg od sinhroniciteta i dolazi do, barem u izvesnoj meri, devijacije od norme „realnosti“. 53 Upravo to govori i pripovedač Ivan Galeb, odmah na prvoj stranici - proticanje vremena je podložno menama, postoji „zemno vreme i sudbina ljudska“. Refleksija je kratka i jasna. Ono što sledi jeste priča koja nas vraća u pripovedačevo detinjstvo: pripovedač nije siguran u stvarne događaje, ali tvrdi da može da ostane veran utiscima koje su činjenice i okolnosti proizvele. Galeb je u izvesnoj meri apsurdni čovek, „netremice i strastveno gleda u smrt i ta opčinjenost njome oslobađa ga ", 54 a njegova elokvencija izrasta naspram perspektive kraja. Čovek je, kako kaže Galeb, rascepljen ${ }^{55}$ - čak se, na primer, za sebe pita da li je naivan ili pokvaren. ${ }^{56}$ Galeb je naslednik egzistencijalizma, svakako barem po tome što, svestan vlastite situacije, odbacuje lažne utehe, ali - budući istinski s one strane očajanja - odbacuje i pesimizam. Galeb insistira na tome da je smrt teret u nama:

\footnotetext{
49 M. Onfre, „Metafizika apsurda“, 49.

50 Ovde se oslanjam na Thomas R. Flynn, Existentialism. A Very Short Introduction, Oxford 2006., 8 i dalje.

51 V. Desnica, Proljeća Ivana Galeba, 335.

52 F. Kermode, The Sense of an Ending, 44-45.

53 Isto, 50.

54 E. Moren, Čovek i smrt, 343.

55 V. Desnica, Proljeća Ivana Galeba, 171.

56 Isto, 236.
} 
Jest, svijet je prepun uspomena, svijet je preopterećen prošlošću. Čudo kako pod tim teretom još diše. Čudo kako današnjica još uspijeva da proklija kroz te naslage umrloga. (...) Duša nam je puna mrtvih čaura tuđih saznanja i tudih razočaranja. ${ }^{57}$

Svet je prepun uspomena, svet je zgažen od prošlosti. Ali Galeb je čovek apsurda, a ne nostalgije. On spretno osporava svest koja Zapad prati od njegovih povoja, a koju naš savremenik Jean-Luc Nancy opisuje na sledeći način:

U svakom trenutku njegove povijesti on [Zapad] se već odao nostalgiji za nekom arhaičnijom a iščezlom zajednicom, žaljenju za izgubljenom obiteljskom prisnošću, za izgubljenim bratstvom, za izgubljenom druževnošću. ${ }^{58}$

Galeb se vraća unazad, ali ne upada u napast nostalgije, jer vlastito ja suočeno sa smrću stavlja ispred svakog mi. U tom smislu izgleda da je moguće tvrditi da se u naraciji romana međusobno bore apsurd (vezan isključivo za $j a$ ) i eshatologija (uteha našeg projektovanog $m i)$, odnosno da je ova borba sámo izvorište romana.

Takva perspektiva kraja uslovljava Galebovo izgovaranje da životu koji je proživeo, a koji je, pre odlaska u bolnicu, bio stvar samozaborava. U pitanju je formulisanje mogućnosti govorenja o ljudskom stanju. Reč je o zapitanosti o tome koja nam perspektiva može pomoći u razumevanju egzistencije. Kada se prenese na širi estetski plan, ovaj uslov zapravo potvrđuje mogućnost umetnosti da govori bitne stvari o egzistenciji, odnosno verovanje da ona stoji u povlašćenoj vezi $s$ „pravom“ stvarnošću bola. Slika tame ljudske unutrašnjosti, skrivenog sveta bola, vrhunac doživljava u opisu tavana - koji počinje uskličnom rečenicom, istinskim izrazom pripovedačevog oduševljenja: „Koliko li smrti na tim tavanima!“ Predmeti leže rasuti a ipak zbratimljeni „u zajedničkoj umrlosti i“. ${ }^{59}$ A potom saznajemo da se upravo tu, u tome kabinetu čudesa, kabinetu umrlosti što obeležava različite krajeve života, rodila i Galebova umetnost: život umetnosti rodio se, u svakom smislu, iz smisla kraja.

Postoji u romanu i kolega romanopisac: to je paranoični brbljivac koji je Galebu natenane ispripovedao „sadržaj fantastičnog romana koji 'namjerava napisati'“ “ ${ }^{60} \mathrm{I}$ taj roman je, poput Proljeća Ivana Galeba, roman o smrti, samo popularni, žanrovski, naučno-fantastični roman o nekakvoj „fantastičnoj zemlji u kojoj su već prethodno svi socijalni, ekonomski i slični problemi riješeni, sve nejednakosti ukinute, a bijeda obješena o klin" ${ }^{61}$ a koji pripoveda o laboratorijskom otkriću leka protiv „smrti uopće“, koji se zove athanatik. Taj lek je, međutim, zbog svoje dalekosežne delotvornosti, stavljen pod kontrolu, što je rezultiralo elitističkom, koruptivnom i neravnomernom distribucijom. Posledica je slom najveće mudrosti do koje smo, povodom smrti, stigli: „I eto, odjednom je pukla nejednakost, dublja i veća od ma koje druge, nejednakost kakvoj nije bilo ravne u povijesti čovječanstva: nejednakost pred smrću. " ${ }^{26}$ Naravno, ovde je, ne bez ironije, data uobičajena politička imunizacija, samo premeštena na prerogativ večnog života: „Stvorena je pravna ustanova 'Izuzeća

\footnotetext{
$57 \quad$ Isto, 331.

58 Jean-Luc Nancy, „Razdjelovljena zajednica“, Dva ogleda, Zagreb 2004., 16.

59 V. Desnica, Proljeća Ivana Galeba, 147.

$60 \quad$ Isto, 278.

61 Isto, 280.

62 Isto, 281.
} 
od smrti', takozvana Todesenthebung..." ${ }^{\text {63 }}$ Ostatak priče je poznat: čovečanstvo podeljeno na smrtne i besmrtne upada u haos, smrtni sisaju na ulici krv besmrtnima - besmrtnost je samo još jedan oblik samouništenja, pa se athanatik mora uništiti jer čovek ne može živeti u paralelnim svetovima. Ljudi konačno traže da im se vrati smrt.

Ova priča može se posmatrati i kao Galebov ironični odgovor na najčešću mudrost o smrti, u kojoj se nije stiglo mnogo dalje od slepog seljaka koji zuri u Galeba, nemo i spokojno, kako bi odjednom saopštio filozofsku utehu („He, što ćete. Svi ćemo tako!“), i potom zaćutao. ${ }^{64}$ Ova uobičajena uteha samo je naizgled suprotna od Galebove detinje ljubavi za apsurdizam na liniji verovanja / neverovanja u vlastitu smrtnost:

Još nešto: u djetinjstvu sam čvrsto vjerovao da nikad neću umrijeti. Bože moj, znao sam da je to apsurd. Ali šta to mari? To je apsurd; a ja u to vjerujem; čvrsto vjerujem, ergo: ja vjerujem u apsurd. ${ }^{65}$

Junak je racionalno znao da je smrtan, ali je iracionalno, odnosno apsurdistički verovao u vlastitu besmrtnost. Verovati u smrt je apsurd, neverovati u smrt je apsurd. Da li to znači da okončavamo u Galebovom stavu da smrt kao stvarni događaj života obesmišljava naša znanja i verovanja i umesto projektovanih vrednosti bivstvovanja ustanovljava egzistenciju, puku temporalnost kao jedini smisao naspram perspektive kraja?

Pitanje kraja povezano je s pitanjem smisla života, kako nas uverava Kermode na početku svoje knjige:

Ne očekuje se da nam kritičari, niti pesnici, pomažu da pronađemo smisao naših života; oni su spremni samo da pokušaju manji podvig da nađu smisao putevima pomoću kojih nastojimo da damo smisao našim životima. ${ }^{66}$

Kako saznati oblik života u odnosu na perspektivu vremena? Da li živimo u skladu sa obrascem ili u skladu sa činjenicama, ili je dobar deo činjenica već stvar obrazaca i vrsta koje proizvodimo? Kako se i da li se pomiriti sa svetom u kojem živimo? „Postoji nužna korelacija između fikcija pomoću kojih uređujemo naš svet i sve veće kompleksnosti onoga što smatramo da je 'stvarna' istorija tog sveta“, ${ }^{67}$ beleži Kermode, a Proljeća Ivana Galeba tu korelaciju nalaze u figuri smrti:

Smrt je ono što stvarima daje posvetu. Ona im pridaje znamen realnosti, ozbiljnost odistinskog. Ona svakoj stvari daje njeno dostojanstvo pred licem života. Ima ništavnih, beznačajnih života. Beznačajnih smrti nema. Svaka je smrt sveopći događaj, svačiji događaj. Jedan mali kataklizam. Jedna crna rupa bez dna u tijelu kozmosa. Smrt iskupljuje svaki život. Živjeti se može i neozbiljno, i neodgovorno. Čitav naš život može da bude puka jedna fikcija, jedna strasna igra u zagrljaju bunila, jedna usijana iluzija prosanjana na rubu stvarnosti. Jedino smrt je realna. Ona je jedino što nam se u životu stvarno događa. ${ }^{68}$ 
Galeb, „čovek po zanimanju“69 - dakle, gotovo jedan egzistencijalistički humanista smisao traži u poštovanju smrti kao (kraja) života. Za Galeba je biće doslovno „mala tačka svijesti, okružena beskrajem ništavila“. A tome on dodaje: „I, najzad, čovjek i umire sam.“70 Svest se hrani sumnjom ${ }^{71}$ koja bi trebala da vraća na pravi put poštovanja smrti:

Eto opet sam se uhvatio u grijehu uznošenja, u grijehu samodopadnosti! Jer govoriti o smrti bez strahopoštovanja, to znači uznošenje, pa i loš ukus. A taj se grijeh (ili je i to samo bolesničko sujeverje) ljuto osvećuje. ${ }^{72}$

Galeb sebe naziva samrtnikom, ${ }^{73}$ a upravo to je njegova kopča sa univerzalnim. Tako Galeb može da kritikuje generalovu glupost: „Neustrašivost pred smrću može da bude samo plod neinventivne, uprav oficirske bijedne uobrazilje pred riječju: smrt"; ali i da prema tom istom generalu oseća suviše ljudski „,dug samrtničke solidarnosti “ "74 Pa ipak, taj dug ne potiče iz malodušnosti, već iz činjenice da je Galeb pred smrću sačuvao moć rasuđivanja, da nije zapao u „samrtničku lakovjernost“ ${ }^{\text {"75 }}$

„Ne uči se umiranju“, glasi podnaslov jednog odeljka knjige Smrt Vladimira Jankeleviča. ${ }^{76}$ Smrt nije mysterium mortis, već razrešenje samoće i žaljenja kojim gradimo eshatologiju; smrt je, paradoksalno, sam život (o čemu svedoči violina sa tavana); ona je razrešenje fikcije i ukidanje nostalgije za stvarnim. Proljeća Ivana Galeba jesu fikcija koja se, kroz strasnu igru, kreće rubovima stvarnosti, ispituje granice materijalnosti i iluzije. Ovde se valja podsetiti Heideggerovog razlikovanja ontičkog i ontološkog pojma smrti. Ontičku smrt, naime, treba razumeti kao faktički kraj ljudskog života; egzistencijalna, ontološka smrt je, pak, krajnja mogućnost tubivstva (čoveka), ispunjenje njegove egzistencije. ${ }^{77}$ Potonja, ontološka smrt je Galebova glavna tema, a ona je nesumnjivo većma povezana sa životom i smislom kraja. „Apokalipsa je deo modernog Apsurda“, reći će Kermode, ${ }^{78}$ a to se možda može, za ovu našu diskusiju, parafrazirati na sledeći način: smrt je deo modernog apsurda.

Još jednom se ovde, dakle, pokazuje da je razmišljanje o smrti razmišljanje o životu. Znana Morinova dijagnoza glasi da se od druge polovine 19. stoleća ispoljava kriza u shvatanju smrti kao kriza individualnosti pred smrću. ${ }^{79}$ Desnica kroz lik Ivana Galeba uistinu rehabilituje čovekovu individualnost tako što podrobno prikazuje komplikovanu, ne-trivijalnu potragu za smislom (ili smislovima) kraja. Ali, postoji ovde još nešto: Galeb, kako se čini, ispunjava ono delezovsko stanovište da pisati znači „postati nešto drugo no što je pisac" ${ }^{\text {"80 }}$ - a to, neko bi rekao, nije bogzna šta: to je samo jedan čovek koji rehabilituje život iz perspektive smrti. Kod Desnice je, tako, smrt drugo ime za pravi život, a Proljeća Ivana

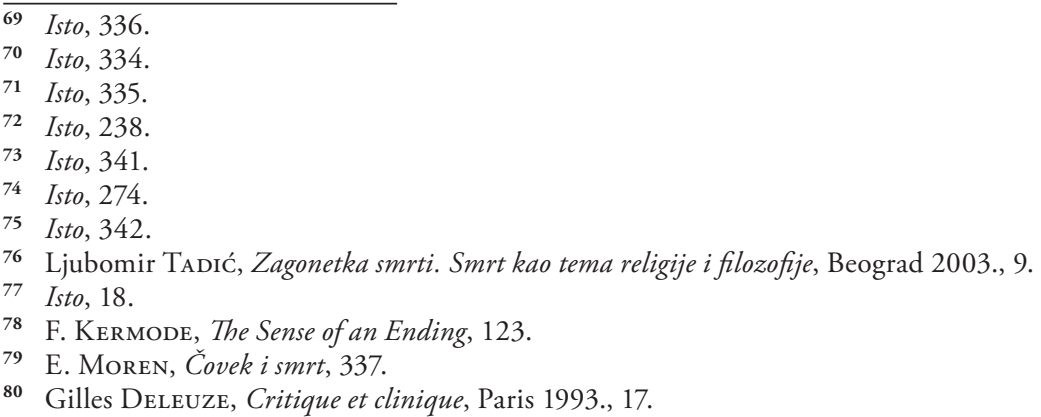


Galeba podučavaju o umiranju. Međutim, ko podučava o umiranju taj, kako je skeptik Montaigne odavno rekao, podučava o življenju. Proljeća Ivana Galeba su, kako je to rekao Sartre za Stranca, roman koji ne objašnjava. Štaviše, ovaj roman je implicitna kritika razumevanja, što je srodno određenim modernističkim preokupacijama nestabilnom prirodom smisla i kritikom metafizike prisustva - jer kraj već jeste jedna slutnja metafizičke odsutnosti. Zaista, retko ko je kao Desnica umeo život, viđen kao zbir protivrečnosti, da postavi u centar mišljenja i pisanja, a da ga pritom ne svede na metafizičku metaforu, zavođenje smislom, ili zanosnu ili patetičnu utehu. Uzimajući u obzir ovaj momenat, kao i druge, Galebovo shvatanje proleća, odnosno „igre proljeća i smrti“, trebalo bi posmatrati kao razradu jednog navoda iz Da Vinčijevih Dnevnika:

Čovek koji sa radošću čeka svako novo proleće, svako novo leto, svaki novi mesec i godinu

- verujući da to što čeka uvek dolazi prekasno - ne shvata da čezne za sopstvenim uništenjem. ${ }^{81}$

U slučaju Ivana Galeba prolećno klijanje dešava se zahvaljujući simboličkom i doslovnom radu sunca, ali to ne spasava dušu koja je „puna mrtvih čaura tuđih saznanja i tuđih razočaranja“. Prizivanje proleća stoji u tesnoj vezi sa senkom smrti. Nulta tačka toga poduhvata tačka je ravnodušnosti koja se pretvara u najveću moguću znatiželju, a ova je izraz mišljenja sveta kroz nihilizam, a ne nasuprot njemu. Stoga se i smrt mora posmatrati kao granica diskursa, ali granica koja je u Proljećima Ivana Galeba pozitivna, delatna, utemeljujuća.

\section{$\cos$}

\section{Literatura}

Filip Arijes, Eseji o istoriji smrti na Zapadu, Beograd 1989.

Leonardo DA VINCI, The Notebooks of Leonardo da Vinci (prir. Irma A. Richter), Oxford 1998.

Gilles Deleuze, Critique et clinique, Paris 1993.

Vladan Desnica, Proljeća Ivana Galeba, u: Vladan Desnica (prir. Željko Milanović), Novi Sad 2013., 117-355.

Gistav Flober, Izabrana pisma, Beograd 1955.

Thomas R. Flynn, Existentialism. A Very Short Introduction, Oxford 2006.

Vladimir Gvozden, „Solarni hobi Vladana Desnice“, Il SoleLuna presso gli slavi meridionali (ur. Ljiljana Banjanin, Persida Lazarević Di Giacomo, Sanja Roić i Svetlana Šeatović), sv. 2, Alessandria 2017., 213-226.

Frank Kermode, The Sense of an Ending. Studies in the Theory of Fiction with a New Epilogue, Oxford 2000.

Edgar Moren, Čovek i smrt, Beograd 1981.

Jean-Luc NANCY, „Razdjelovljena zajednica“, Dva ogleda, Zagreb 2004., 5-51.

$\overline{81}$ Leonardo DA VINCI, The Notebooks of Leonardo da Vinci (prir. Irma A. Richter), Oxford 1998., 276. 
Friedrich Nietzsche, „Aus dem Nachlass der Achtzigerjahre“, Werke in drei Bände (ur. Karl Schlechta), sv. 3, Wien - München 1956.

Mišel Onfre, „Metafizika apsurda“, Polja, 59/2014., br. 488, 47-65.

Peter Porter, „The Historians Call Up Pain“, Australian Poetry Library, https://www.poetrylibrary. edu.au/poets/porter-peter/the-historians-call-up-pain-0287035 (datum pristupa: 23. 1. 2018.).

Ljubomir TADić, Zagonetka smrti. Smrt kao tema religije i filozofije, Beograd 2003.

\section{$\cos$}

\section{The SEnse of AN ENDing in VLAdAN Desnica's NOVEL THE SPRINGS OF IVAN GALEB}

Ivan Galeb expounds on the typology and the phenomenology of death: the death of those closest to us, the death of a lover, the death of powerful men, the death of friends, inconsequential death... He also meditates on the various causes of death, ranging from the death of old age, illness, sorrow or abuse, to suicide, and even touches on immortality. This paper links the topic of death in the novel with the idea of the sense of an ending (Frank Kermode), as well as some elements of existential humanism. An obvious existential level in The Springs of Ivan Galeb reveals itself in the blurring of the lines between fiction and philosophy, which Galeb regards as the best part of himseIf. Moreover, it would appear that Desnica, by writing - after Camus - "philosophical literature and literary philosophy", explores the concept of indifference, which, in the case of Ivan Galeb, refers to a mixture of the inability to feel and the protest against inauthentic emotion. In the novel, the latter is occasionally labeled as bourgeois, as in the short discussion of Sunday lunches. The philosophy of the absurd is a form of lucidity in the face of societal illusion, so that at times Galeb is what Camus's Mersault would have sounded like if he had been an intellectual or an artist. Aware of his own situation, he rejects any form of false consolation, but he also rejects pessimism, being truly beyond despair. Galeb is, at least to a certain extent, a man of the absurd "gazing at death unblinking and with passion, so that he is liberated by his enthrallment", while his eloquence is a reaction to the imminence of the end. The nearness of his deathbed is what allows him to say yes to the life he has lived, which had largely been defined by self-oblivion before he entered the hospital. The novel represents a persistent and painstaking articulation of the possibility of addressing the human condition, a constant confirmation that the imminence of an ending is a prerequisite for understanding the absurdity of existence. If Edgar Morin's assertion that since the second half of the 19th century there has been a crisis of death expressed as a crisis of individuality in the face of death, then Desnica manages to rehabilitate that individuality through the character of Ivan Galeb, by depicting a complicated, contradictory, non-trivial modernist search for the sense (or multiple senses) of an ending.

Key words: modernism, sense, existentialism, death, pain, humanism, individuality, the bourgeoisie 
11.

\section{ASPEKTI ANALITIČKE \\ FILOZOFIJE SMRTI U ROMANU \\ PROLJEĆ IVANA GALEBA \\ VLADANA DESNICE}

\section{Marin Biondić}

UDK: 129:821.163.42-311.1Desnica, V.

Izvorni znanstveni članak

Sažetak: Autor analizira temeljne ontološke i vrijednosne tvrdnje o smrti koje možemo eksplicirati u romanu Proljeća Ivana Galeba Vladana Desnice. U prvom dijelu bavi se ontološkom analizom, tj. utvrđivanjem odgovora na pitanje što je smrt. Određenje smrti kao ništavila koje pronalazimo u romanu Proljeća Ivana Galeba odgovarat će određenju smrti koje zastupaju suvremeni analitički filozofi. Blisko s određenjem smrti kao ništavila povezana je i fenomenološka greška - projekcija reduciranog iskustva u iskustvenu prazninu - koju možemo uočiti u promišljanjima Ivana Galeba. U drugom dijelu analizira se vrijednosno određenje prema smrti Ivana Galeba i uspoređuje s pozicijama u suvremenim filozofskim analitičkim raspravama. Iako se čini da Galeb zastupa tvrdnju da je smrt loša za osobu koja umre, razlikovanjem i analizom iskustvenog i neiskustvenog zla te eksplikacijom Galebovih promišljanja o prirodi zla, proizlazi da je Galeb u osnovi epikurejac, tj. da je obvezan na tvrdnju da smrt nije loša za osobu koja umre. U završnom dijelu navode se skupovi logički mogućih tvrdnji o smrti koje možemo imati, kako bismo mogli konzistentno misliti o vrijednosti smrti.

Ključne riječi: epikurizam, deprivacionizam, fenomenološka greška, neiskustveno zlo, ništavilo, smrt

\section{UvoD}

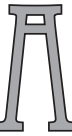

nalitička filozofija relativno kasno uzima smrt kao temu na koju se mogu primijeniti filozofski alati logičke analize. ${ }^{1}$ Međutim, nakon početne suzdržanosti, analitička filozofija smrti postaje jedna od najplodnijih filozofskih rasprava koja se trenutačno vodi na anglosaksonskom govornom području. ${ }^{2}$ Naprosto, čini se da nema razloga zašto i prema smrti ne bismo mogli primijeniti strog analitički pojmovni aparat i logička pravila

1 Kao početak suvremene analitičke filozofije smrti uzima se članak Thomasa Nagela Death iz 1970. godine.

2 Navest ću samo najvažnije autore i djela: Fred Feldman, Confrontations with the Reaper: A Philosophical Study of the Nature and Value of the Death, New York 1992.; Jay F. Rosenberg, Thinking Clearly About Death, Indianapolis 1998.; Steven Luper, The Philosophy of Death, Cambridge 2009. 
argumentiranja. To što je smrt fenomen koji sa sobom nosi čitav niz različitih društvenih praksi i čitav niz emotivnih stavova, s aspekta filozofske analize nije bitno. Ono što je bitno jest logička jasnoća pojmova, preciznost, konzistentnost i plauzibilnost argumenata. Filozofsku raspravu o smrti možemo kategorizirati prema trima temeljnim područjima:

1. Ontološka rasprava: Što je „smrt“?

2. Vrijednosna rasprava: Je li smrt dobra, loša ili vrijednosno neutralna?

3. Etička rasprava: Je li (ako jest, u kojim slučajevima) opravdano usmrćivati određena bića ili njihove vrste?

S druge strane, književno-umjetnička tematizacija smrti prvenstveno problematizira ljudske emotivne stavove i određene društvene prakse prema fenomenu smrti. Logička „hladnoća“ u drugom je planu, a važno je ono što osjećamo, doživljavamo i vjerujemo prema činjenici vlastite smrtnosti i smrti drugih bića. Ili, pak, kako se suočavamo s činjenicom smrtnosti i smrti nama bliskih bića. Tako smo skloni negiranju činjenica o smrti, bijegu od misli o njoj ili snažnim emocionalnim reakcijama kao što je strah. U svakom slučaju, važne karakteristike psiholoških stanja jesu promjenjivost, nestalnost, ovisnost o raspoloženju i izvanjskim faktorima itd. Dakle, $s$ jedne strane stoje zahtjevi filozofije da se o svemu, pa tako i o smrti, treba misliti jasno ${ }^{3}$ bez ikakvih mistifikacija, a s druge stoji književnoumjetnička, prvenstveno psihološka tematizacija smrti, koja dopušta „nezauzdanu“ slobodu mišljenja i doživljavanja.

Međutim, ono što je važno jest to da naš psihološki aspekt u odnosu prema smrti uvijek pretpostavlja određenu ontologiju i vrijednost. Svaki čovjek koji iznosi svoje psihološke stavove o smrti barem implicitno pretpostavlja određene ontološko-vrijednosne tvrdnje. Npr. ako netko tvrdi da se ne boji smrti, onda on pretpostavlja da smrt nije loša ili da je uopće nema, tj. da postoji zagrobni život. Ako, pak, tvrdi da se boji smrti, onda pretpostavlja da je smrt loša, da nema zagrobnog života ili da on postoji, ali nije siguran u njegovu kvalitativnu vrijednost. ${ }^{4}$

Jednako tako, psihološki stavovi u književno-umjetničkom stvaranju pretpostavljaju određenu ontologiju i vrijednost. U ovom kontekstu potpuno je svejedno „tko“ iznosi stavove i tvrdnje. Je li to sâm autor, autorov pripovjedač, lik ili lirski subjekt, u ovome kontekstu nije važno. Bitno je da su u samome tekstu iznesene - ako jesu - određene tvrdnje i stavovi. Filozofska analiza može nam otkriti što navedene tvrdnje impliciraju i je li skup određenih tvrdnji konzistentan, bez obzira na njihovu umjetničku vrijednost ili umjetničku vrijednost djela u cjelini. Dakle, u ovome radu primijenit će se analiza i spoznaje suvremene analitičke filozofije smrti na određeno književno-umjetničko djelo, tj. na roman Vladana Desnice Proljeća Ivana Galeba. Kao što je već napomenuto, analizirat će se tvrdnje i stavovi koje nalazimo u tekstu, bez obzira na to govorimo li o Desničinim tvrdnjama, onima Desničina pripovjedača ili onima lika Ivana Galeba. ${ }^{5} \mathrm{U}$ prvom dijelu rada izvršit će se ontološka analiza, tj. analiza odgovora na pitanje što je smrt, a u drugom dijelu rada vrijednosna

3 Ovdje upućujem na naslov već navedenog djela J. F. Rosenberga Thinkink Clearly About Death.

4 Moguće je i da se naprosto bojimo smrti, a da ne možemo eksplicirati čega se točno bojimo, npr. zagrobnih muka, smrti kao ništavila, nepoznatog itd.

5 U daljnjem tekstu upotrebljavat će se izraz Galebove tvrdnje. 
analiza, tj. odgovor na pitanje je li smrt loša, dobra ili vrijednosno neutralna. Analiza bi nam trebala omogućiti uvid u konzistentnost filozofskih tvrdnji iznesenih u djelu.

\section{ONTOlogija SMRTi ANALITiČKE FILOZOFiJe I ONTOLOGIJA SMRTi IVANA GALEBA}

Roman Vladana Desnice Proljeća Ivana Galeba nedvojbeno nam pruža dubok uvid u psihološka stanja lika suočenog s vlastitom smrtnošću i s prolaznošću sebe i svega oko sebe. Prolaznost, smrt i vječita mijena svega naprosto odzvanjaju sa svake stranice. Međutim, jednako tako, u djelu možemo iščitati određene filozofske pretpostavke, tvrdnje i vrijednosne stavove. Neke su filozofske tvrdnje gotovo pa eksplicitno dane, ali također moguće je i konstruirati određene argumente na temelju navedenih tvrdnji. Budući da je, kada se o nečemu raspravlja, važno dobro definirati što je to o čemu se raspravlja, započet ću ontološkom problematikom, tj. odgovorom na pitanje što je smrt. Pogledajmo najprije kako se smrt definira u suvremenoj analitičkoj filozofiji.

Definicija smrti u suvremenoj analitičkoj filozofiji odmiče se od platonističkog shvaćanja smrti kao odvajanja duše od tijela. Budući da većina suvremenih filozofa brani neki oblik materijalističkog koncepta živih bića, pa tako i ljudi, platonistički se koncept ne smatra relevantnim. Ono što se smatra relevantnim jest koncept smrti kao trajnog i nepovratnog prekida postojanja. Smrt predstavlja konačno uništenje organizma i svijesti. Kada smrt ovako definiramo, očito je da ona nema nikakav iskustven sadržaj pa u terminima iskustva možemo reći da je smrt iskustvena praznina ili ništavilo. ${ }^{6}$

Sada pogledajmo kako se prema definiranju smrti odnosi Ivan Galeb. Na prvom mjestu određenja smrti možemo naići na Lukrecijevo epikurejsko ${ }^{7}$ gledanje na smrt, u kojemu je prenatalno nepostojanje izjednačeno s postmortalnim nepostojanjem:

Krug se sužuje i sužuje, a zatim - ništa. Jedno veliko, bezmjerno ništa. Kao i ono koje je bilo prije početka... ${ }^{8}$

Sužavanje je kruga, naravno, približavanje kraju života, a kada dođe kraj, slijedi - ništa, a to ništa je već jednom bilo, prije našega rođenja. Dakle, i s jedne i s druge vremenske strane postojanja čovjeka stoji - ništa. Ovo određenje smrti kao ništavila pronaći ćemo i na drugim mjestima:

Biće - mala točka svijesti, okružena beskrajem ništavila. ${ }^{9}$

Ovdje možemo uočiti da se uz ništavilo veže i predikat beskrajnosti, što znači da je smrt, kada nastupi, trajno i bespovratno stanje, što je definicija koju smo naveli u analitičkoj fi-

6 Za definicije smrti v. F. Feldman, Confrontations with the Reaper, 56-71.

7 Usp. Lukrecije, O prirodi, Zagreb 2010. Lukrecije ovim izjednačavanjem dvaju vremena nepostojanja nastoji dokazati da smrt nije loša za osobu koja umre i da se ne trebamo bojati smrti.

8 Vladan Desnica, Proljeća Ivana Galeba, u: Igre proljeća i smrti (ur. Tonko Maroević), Zagreb 2008., 92.

9 Isto, 335 . 
lozofiji smrti. Također, možemo pronaći i određenje koje nije dano u terminima ništavila, već u terminima trajnog i nepovratnog prestanka postojanja:

On ne zna da na toj međi prestaje sve, da se tu svako svodi na golu i drhtavu jedinku zapahnutu dahom ništavila. ${ }^{10}$

Ili, na drugom mjestu:

Gotovo je. U svemiru je nešto nestalo. ${ }^{11}$

Dakle, termini „ništa“, „ništavilo“, „gotovo“ i „,nestalo“ jesu samo varijante kojima se tvrdi da je smrt trajan i nepovratan prekid postojanja. To su izrazi koje upotrebljavamo kada želimo reći da u smrti ne postoji nikakvo iskustvo. Jednostavno rečeno, smrt je iskustveno ništa. Dakle, određenje smrti kao ništavila, prema kojemu kasnije tražimo opravdanje za vrijednosne tvrdnje, početna je točka suvremene filozofije smrti, a isto to određenje pronalazimo i u romanu Vladana Desnice Proljeća Ivana Galeba. Međutim, nakon što smrt definiramo kao ništavilo, lako je skliznuti u ono što se u suvremenoj analitičkoj filozofiji smrti naziva fenomenološka greška.

\section{1. Fenomenološka greška}

Vjerojatno je najčešća greška koju ljudi čine kada misle o smrti ona fenomenološka, koja predstavlja projekciju reduciranog iskustva u iskustvenu prazninu, tj. ništavilo. ${ }^{12}$ Tako ljudi često zamišljaju svoju smrt na način da se zamisle kako leže u crnilu mrtvačkog sanduka, u vlažnoj zemlji ili, pak, govore o odmoru koji će nastupiti, vječnom miru itd. Međutim, ako smrt zamišljamo ovako, očito je da zamišljamo određena iskustvena stanja, bez obzira na to što smo reducirali iskustvo.

Traženje odgovora na pitanje „Kakva je smrt mrtvima?“, pod pretpostavkom prethodnog definiranja smrti kao prestanka postojanja, odnosno ništavila, zapravo predstavlja primjer besmislenog pitanja. ${ }^{13}$ Iako je ono ispravno gramatički formulirano, logički je protuslovno. Tvrditi da je smrt ništavilo, pa tom ništavilu pripisati reducirano iskustvo, znači tvrditi da smrt nije ništavilo. Mislimo da govorimo o ne-bivanju, a zapravo govorimo o reduciranom bivanju. Predikati „nešto“ i „ništa“ jesu kontrarni; oni ne mogu biti istiniti za istu stvar u isto vrijeme. ${ }^{14}$ Ili imamo iskustvo ili ga nemamo.

Fenomenološka greška česta je greška kako svakodnevnog govora o smrti tako i književno-umjetničkog izražavanja, ali također i filozofske literature. ${ }^{15}$ Vjerojatno ćemo je najčešće

10 Isto, 346.

11 Isto, 348.

12 Usp. Paul Edwards, „Existentialism and Death: A Survey of Some Confusion and Absurdities“, Philosophy, Science, and Method. Essays in Honor of Ernest Nagel (ur. Sidney Morgenbesser, Patrick Suppes i Morton White), New York 1969., 473-505.

13 Kao npr. „Koliko je dugačka četvrta stranica trokuta?“. Ako je nešto trokut, onda ne može imati četvrtu stranicu. Ako je nešto mrtvo, onda ne može imati iskustva.

14 Usp. J. F. Rosenberg, Thinkink Clearly About Death, 31.

15 Valja razlikovati fenomenološku grešku (u kojoj najprije smrt definiramo kao ništavilo, a zatim pripisujemo iskustvo ništavilu) od učenja o zagrobnom životu ili, pak, transcendiranom iskustvu, prema kojemu smrti zapravo nema, već se život i iskustvo transformiraju u druge forme. 
uočiti u poetskom diskursu, raznim metaforama snova, spavanja itd. ${ }^{16}$ Uočit ćemo je na nekoliko mjesta i u Ivana Galeba:

...kakvo ništa? Kakvo? Bijelo ili crno ništa? Eto samo to se pitam. (...) Što me kod smrti najviše plaši to je predstava mraka s kojom je ona skopčana. ${ }^{17}$

Ili dalje u tekstu:

...provalije smrti mraka. ${ }^{18}$

Dakle, nakon određenja smrti kao ništavila, Galeb se pita o iskustvenoj prirodi ništavila, je li ono bijelo ili crno? Ali, ako je smrt iskustveno ništa, onda ne može biti ni bijelo ni crno. Jednako tako, „predstava mraka“ koja plaši može biti samo naša pogrešna anticipacija smrti, nikako smrt sama. Upravo takvu anticipaciju smrti nalazimo prilikom opisa Galebove kćeri pred smrt:

...slutnja velikog mraka prešla bi joj licem... ${ }^{19}$

Naglašavam, u ovom slučaju „velikog mraka“ radi se o anticipaciji smrti, tj. pokušaju nekakvog iskustvenog predočavanja onoga što se u principu ne može iskusiti. Možda i najočitiji primjer fenomenološke greške u djelu nalazimo prilikom vrednovanja smrti:

$\mathrm{Da}$, dobra je smrt. Trebalo bi samo da poštedi jednu tanku zraku svijesti: toliko da se njome može iskusiti dobrota ništavila. ${ }^{20}$

Kada bi postojala „tanka zraka svijesti“ u ništavilu, očito to više ne bi bilo ništavilo. To više ne bi bila smrt, niti bi to bila dobrota ništavila. To bi bila dobrota maksimalno reduciranog iskustva. Dakle, kao i mnogi drugi, Ivan Galeb upada u psihološku zamku pokušaja predočavanja nečega za što je prethodno utvrđeno da nema nikakav sadržaj.

Nadalje, osim fenomenološke greške, zanimljivo je da se prije određenja smrti kao ništavila i prekida postojanja, na jednom mjestu tvrdi da je smrt nepojmljiva:

Pa opet - nepojmljiva. Nepojmljiva i nevjerovatna. ${ }^{21}$

Međutim, kao što kasnije uočavamo, smrt je pojmljiva. Pojmljiva kao trajan i nepovratan prestanak postojanja, tj. kao ništavilo. Možemo pojmiti smrt, tj. imati definiciju pojma, ali psihološki iskustveno ne možemo zamisliti ništavilo. Ne zato što je to nekakvo mistično i nevjerojatno iskustvo, već zato što iskustva uopće nema i što se u principu nema što zamisliti. Dakle, filozofski gledajući, smrt je pojmljiva. Psihološki gledajući, ljudi se teško mire s činjenicom da ih jednom više neće biti i lako je skliznuti u zamišljanje vlastitog (iskustvenog) ništavila, ali to i dalje ne znači da ne možemo imati pojam smrti kao iskustvene praznine, tj. trajnog i nepovratnog prekida postojanja.

16 Možda je najpoznatiji primjer Matoševa pjesma Utjeha kose u stihu „u smrti se sniva“.

17 V. Desnica, Proljeća Ivana Galeba, 92.

18 Isto, 100

19 Isto, 324.

20 Isto, 357.

21 Isto, 95. 


\section{Problematika vrijednosti smrti}

Vrijednosna rasprava suvremene analitičke filozofije smrti odvija se između dvaju suprotstavljenih tabora. Prvi je tabor nastavljač Epikurove škole, prema kojoj smrt nije loša za osobu koja umre. ${ }^{22}$ Kako kaže Epikur, „dok smo mi nema smrti, kada nastupi smrt nema više nas“. ${ }^{23}$ Čini se da u slučaju smrti nema subjekta koji trpi zlo, nema vremena kada je smrt loša za osobu i nije nam jasna kakva bi to bila zla priroda smrti kada u potonjoj više nema nikakvog iskustva. Epikurejska pozicija glede vrijednosti smrti svodi se na tvrdnju da ako nešto ne možemo ni u principu iskusiti, tada to ne može biti loše za nas. Smrt je ono što ne možemo ni u principu iskusiti, dakle smrt ne može biti loša za nas.

Drugi tabor čine tzv. deprivacionisti, filozofi koji tvrde da smrt može biti loša za osobu koja umre (često i jest), iako je smrt iskustvena praznina, tj. ništavilo. Smrt je loša, kada je loša, zato što svoju žrtvu lišava mogućeg iskustva, odnosno iskustva koje bi osoba imala da nije umrla tada kada je umrla. Zato su smrti mladih ljudi tragičnije od smrti staraca. Smrt lišava mladog čovjeka u većoj mjeri određenog iskustva nego što lišava devedesetogodišnja$\mathrm{ka}$. To što u smrti nema iskustva za deprivacioniste ne predstavlja značajan problem zato što smrt spada u kategoriju neiskustvenih zala. Neiskustvena zla jesu određene činjenice koje su protiv našeg interesa. Tako je npr. izdaja prijatelja ili prijevara partnera za koju nikada ne saznamo loša za nas, iako ne trpimo nikakva neugodna iskustva. Deprivacionisti tvrde da je naprosto loše biti izdan ili prevaren, a jednako je tako naprosto loše da smrt lišava svoju žrtvu mogućeg iskustva. Rasprava se zapravo odvija u pokušajima da se, $s$ jedne strane, dokaže, ili barem učini uvjerljivim, tvrdnja da uistinu postoje neiskustvena zla i da je smrt jedno od njih, a s druge da, prema epikurejskim tvrdnjama, ne postoje neiskustvena zla i da, prema tome, smrt nije zlo.

Čitajući Desničin roman Proljeća Ivana Galeba, ne možemo se oteti dojmu da je čitavo djelo prožeto averzijom prema smrti. Iako na jednom mjestu Galeb kaže, kao što je već gore u tekstu citirano „Da, dobra je smrt...", ${ }^{24}$ u cijelom nizu njegovih promišljanja možemo iščitati da je smrt loša:

Treba mrziti smrt. Treba pobijati smrt, bez predaha, svim sredstvima, na svakom koraku. ${ }^{25}$ Jeza ništavila pokretač je svega u našem bivstvovanju... ${ }^{26}$

Mržnja prema smrti i strah od ništavila mogu biti produkti bioloških mehanizama koji nemaju jasno logičko opravdanje, ali čini se da je prije slučaj kako Ivan Galeb implicitno pretpostavlja da je smrt loša i da nas je upravo zbog toga i strah. S obzirom na gornje citate, pretpostavit ću da je Galebova implicitna tvrdnja da je smrt zlo, što bi ga svrstavalo u deprivacionistički tabor. Dakle, tri su tvrdnje koje možemo pripisati Ivanu Galebu:

\footnotetext{
22 Usp. Stephen E. Rosenbaum, „How to Be Dead and Not Care: A Defense of Epicurus“, American Philosophical Quarterly, 23/1986., br. 2, 217-225.

23 EpıKur, „Pismo Menoikeju“, u: Branko BošNJAK, Filozofija od Aristotela do renesanse i odabrani tekstovi filozofa, Zagreb 1983., 145.

24 V. Desnica, Proljeća Ivana Galeba, 357.

25 Isto, 94.

26 Isto, 96.
} 
1. smrt je iskustvena praznina, tj. ništavilo;

2. smrt je loša za osobu koja umre;

3. strah nas je smrti ili prema njoj imamo neku drugu negativnu emociju.

\section{1. Neiskustveno zlo i određenje vrijednosti smrti}

Da bi gore navedene tri tvrdnje bile konzistentne, Galeb mora pretpostavljati da postoji neiskustveno zlo. Ako bi se tvrdilo, kao što to tvrde epikurejci, da neiskustveno zlo ne postoji, onda smrt ne može biti loša za osobu koja umre. Pogledajmo najprije jedan misaon eksperiment kojim se nastoji dokazati da postoje neiskustvena zla, a zatim Galebov primjer iz romana.

Majka i smrt kćeri

Majka ima petnaestogodišnju kćer, koja joj predstavlja najveću životnu vrijednost. Sve što majka radi, za konačni cilj ima dobrobit njezine kćeri. Možemo reći da je u interesu majke da njezina kći ima što više dobra u životu i to bez obzira bila majka živa ili ne. Igrom slučaja, njih dvije se razdvoje, zbog poslovnog putovanja majke u drugi grad. Za vrijeme razdvojenosti kći pogine 15. rujna 2017. u 12.00 u prometnoj nesreći. Majka, koja je trenutno udaljena nekoliko stotina kilometara, ne zna za nesretni događaj. Pitanje je, je li smrt kćeri loša za majku, i ako da, kada je to slučaj? ${ }^{27}$

Svi će se složiti s time da je loše za majku kada sazna da joj je kći umrla. Međutim, ako majka sazna da joj je kći umrla nakon dva dana, 17. rujna 2017., je li kćerina smrt loša za majku i prije nego što je saznala za događaj? Ili, zamislimo da majka odmah sazna da joj je kći poginula te doživi srčani udar 15. rujna 2017. u 12,05. Je li kćerina smrt loša za majku samo u tih 5 minuta? Ili, što ako majka umre 17. rujna 2017. i nikada ne sazna da joj je kći poginula? Je li i u ovom slučaju kćerina smrt loša za majku? Do 17. rujna majka ne zna da joj je kći mrtva, od 17. rujna majka više ne postoji. Je li relevantan faktor majčino iskustvo, samo postojanje majke ili puka činjenica da joj je kći mrtva?

Deprivacionisti će na sva gornja pitanja odgovoriti pozitivno, tj. tvrdit će da je kćerina smrt loša za majku bez obzira na to zna li ona za smrt ili ne i bez obzira na to je li majka živa ili nije. Činjenica da joj je kći umrla loša je za majku bez obzira na njezino iskustvo. Činjenica da joj je kći umrla loša je za majku bez obzira na postojanje potonje. Dakle, prema deprivacionistima, postoji neiskustveno zlo, a to su činjenice o nama. Epikurejci će, pak, s druge strane, na gornja pitanja odgovoriti tako da kažu da je kćerina smrt loša za majku samo ako ona sazna ili barem postoji mogućnost da sazna kako joj je kći mrtva. Ako nikada ne sazna i ako ne može saznati (kada majka umre), onda ne može biti loša. Dakle, prema epikurejcima, ne postoje neiskustvena zla.

Gotovo pa identičan primjer kakav nalazimo u suvremenoj literaturi filozofije smrti iznosi Galeb u jednoj epizodi svoga djetinjstva koja mu se duboko usjekla u sjećanje:

27 Primjer potječe iz: John Martin Fischer, Our Stories. Essays on Life, Death, and Free Will, New York 2011., 8. 


\section{Majka i smrt sina}

Samohrana majka ima maloljetnog sina, koji joj je sve na svijetu. Jednoga dana dječak s ostalim učenicima ode na školski izlet u obližnje selo. Na izletu se dogodi nesreća, dječak se posklizne i padne u jamu te na mjestu pogine. Sva djeca s učiteljima vrate se u mjesto, a na selu ostanu jedan učitelj i stariji dječak čekati mrtvozornika. Majci nitko ne želi reći tragičnu vijest već joj govore da je dječak s učiteljem ostao brati bilje za školski herbarij. Kako prolaze sati tako se vijest širi mjestom, ali nitko nema hrabrosti majci saopćiti vijest. Jedina osoba koja u mjestu ne zna za smrt dječaka, jest njegova majka. Pitanje je, je li smrt dječaka loša za majku u vremenu dok ona ne zna da joj je sin poginuo? ${ }^{28}$

Galeb će u svojim promišljanjima o ovom slučaju krenuti od reakcije sumještana majke koji, kada saznaju da je dječak mrtav, s određenim prijezirom prate majčino ponašanje. Majka se, naime, dok ne zna da joj je sin mrtav, bezbrižno i ležerno ponaša:

Činila im se luda: gle, sin joj tamo leži mrtav - a ona baza po mjestu, zaviruje u ribarnicu, razgovara o koječemu s dućandžinicom na pragu, zadirkuje Vinku da joj je momak u svijetu našao drugu curu; nosi u ruci svoje srdelice za ručak, samo što ne pjevuši ulicom! ${ }^{29}$

Ovakav prikaz događaja čini se da ide u smjeru gore iznesenog deprivacionističkog argumentiranja da samo iskustvo nije presudno u određenju vrijednosti, već da su primarno važne objektivne činjenice o nama. Sumještani zapravo kažu „Kakvo zlo ti se dogodilo, a ti se ponašaš kao da nije ništa“, tj. oni pretpostavljaju da se dogodilo zlo za majku bez obzira na njezino iskustvo, što možemo vidjeti i u sljedećoj rečenici:

Istina, ona ne zna što se dogodilo. Ali to što se dogodilo - to je stvarnost. ${ }^{30}$

Međutim, kada očekujemo konačnu potvrdu da je ono što je važno objektivna stvarnost, tj. da su to činjenice o nama, Galebovo se promišljanje stubokom mijenja u korist znanja i iskustva subjekta:

I činilo mi se da bi ta stvarnost, ta objektivna stvarnost, ipak na neki način morala biti pretežija, jača od tog krhkog fakta što sirota majka za tu stvarnost ne zna. Međutim, ne! Taj krhki fakat bio je jači, kudikamo jači $!^{31}$

U konačnici, slijedi Galebovo jasno opredjeljenje prema epikurejskoj poziciji, odnosno prema znanju i iskustvu subjekta kao nužnom uvjetu za vrijednost:

Nije tu važan sam fakat, ono što se gore u planini dogodilo, ono što jest: važno je naprosto to da li majka za taj fakat zna ili ne zna. Sve je u tome, samo u tome. ${ }^{32}$

Dakle, na pitanje „Može li nešto biti loše za nekoga kada on/ona ne zna ili ne može iskusiti taj događaj ili stanje stvari?"“, Galeb će u konačnici tvrditi da ne može, što je očito

\footnotetext{
$\overline{28}$ Moja rekonstrukcija primjera prema: V. Desnica, Proljeća Ivana Galeba, 105-108.

29 Isto, 107.

30 Isto.

31 Isto.

32 Isto.
} 
epikurejska pozicija. Prema njemu, nisu važne činjenice o nama, već to znamo li za njih ili ne i osjećamo li što naspram tih činjenica ili ne. Kada majka nikada ne bi saznala što se dogodilo s njezinim voljenim sinom ili kada bi umrla prije saznanja o tome što se dogodilo, tada sinova smrt, prema epikurejskoj poziciji, nije loša za majku. Dakle, ne postoji neiskustveno zlo. Ako je ova analiza točna, onda ona ima zanimljive implikacije. Pogledajmo ih.

\section{2. Implikacije Galebove epikurejske pozicije}

Imajući u vidu sve što je do sada rečeno, možemo eksplicirati tri Galebove tvrdnje:

T1: Smrt je ništavilo (konačan kraj).

T2: Smrt je loša.

T3: Ne postoji neiskustveno zlo (primjer: majka i sin).

Međutim, ove tri tvrdnje, logički gledajući, ne mogu stajati skupa. Ovo je primjer inkonzistentne trijade; drugim riječima, barem jedna je od ovih triju tvrdnji neistinita. $\mathrm{Ne}$ može se tvrditi da je smrt (ništavilo, iskustvena praznina) loša i u isto vrijeme da ne postoje neiskustvena zla. Kada definiramo smrt kao ništavilo i tvrdimo da je smrt loša, onda moramo braniti tvrdnju da postoje neiskustvena zla. Ako je smrt zlo, onda je to zlo neiskustvene prirode. Ako ne postoje neiskustvena zla, onda ni smrt nije zlo. Nadalje, ako smrt nije zlo, nema logičkog opravdanja za negativne emocionalne reakcije prema smrti za osobu koja umre ili će umrijeti; preostaju jedino psihološka objašnjenja.

Prema tome, tri su načina izbjegavanja ove logičke inkonzistencije. Prvo, odbaciti T1, a zadržati T2 i T3. Drugo, odbaciti T2, a zadržati T1 i T3. Treće, odbaciti T3, a zadržati T1 i T2.

Ako se odlučimo za prvu opciju, zapravo negiramo smrt kao prekid postojanja i kao ništavilo, tj. tvrdimo da postoji nekakav oblik transcendiranja ovozemaljskog života. Ako nastavljamo u nekom obliku transcendiranog postojanja, moguće je da je takvo postojanje loše (npr. zagrobne kazne za ovozemaljske moralne poroke), što je, naravno, iskustvene prirode. Međutim, nigdje u Desničinu djelu nećemo naići na ovakvo shvaćanje smrti, tako da ovu opciju smatram neprihvatljivom u ovom kontekstu. Ona je u suprotnosti svim određenjima smrti kao ništavila koje nalazimo u romanu.

Ako se odlučimo za drugu opciju, prema kojoj smrt nije loša, nalazimo se na epikurejskom „tlu“. Ova opcija proizlazi iz tvrdnje da ne postoje neiskustvena zla, što smo vidjeli na primjeru majke i sina. Međutim, smatram da ona nije u skladu s cjelokupnim duhom romana. Roman se može tumačiti kao elegičan žal za prolaznim životom, a ako žalimo za nečim što je dobro, onda ono što prekida dobro mora biti loše. ${ }^{33}$ Dakle, smrt je loša. Iako je negacija T2 privlačna i branjiva opcija, duhu romana prikladnija je tvrdnja da je smrt loša.

Preostaje nam treća opcija, tj. prihvaćanje tvrdnje da postoje neiskustvena zla. $\mathrm{Na}$ filozofskom primjeru majke i kćeri te Galebovu primjeru majke i sina vidjeli smo kako se in-

33 Kažem „može se tumačiti“ zato što u romanu zasigurno možemo pronaći elemente stoičke pomirenosti sa smrću i budističke težnje za ništavilom koje otvaraju drugačija čitanja i interpretacije ovog složenog romana (zahvala recenzentu na isticanju ovih elemenata romana). 
tuicije mogu prelomiti na deprivacionističku ili epikurejsku stranu. Galebovo razmišljanje prelomilo se na onu epikurejsku, ali ako se žele zadržati T1 i T2, ono se treba prelomiti na deprivacionističku stranu. Dakle, da zaključimo, skup konzistentnih tvrdnji može biti:

T1: Smrt nije ništavilo (postoji nekakav oblik zagrobnog života).

T2: Smrt je loša.

T3: Ne postoji neiskustveno zlo.

Ili:

T1: Smrt je ništavilo (konačan kraj).

T2: Smrt nije loša.

T3: Ne postoji neiskustveno zlo.

Ili:

T1: Smrt je ništavilo (konačan kraj).

T2: Smrt je loša.

T3: Postoji neiskustveno zlo.

Prva opcija s ove liste, naravno, u ovom kontekstu nije prihvatljiva. Druga je prihvatljiva, ali ako smrt nije loša, pitanje je onda čemu čitav niz negativnih emocionalnih reakcija i stavova prema smrti koje nalazimo u romanu? S obzirom na cjelokupan odnos prema smrti u romanu, smatram da bi Galebovim promišljanjima najviše odgovarala posljednja opcija, ali u tom se slučaju jednostavno mora tvrditi da je sinova smrt loša za majku i kada ona za to ne zna.

\section{ZAKLJUČAK}

Analizirane su temeljne ontološke i vrijednosne tvrdnje koje možemo eksplicirati u romanu Vladana Desnice Proljeća Ivana Galeba iz perspektive suvremene analitičke filozofije smrti. Nakon ontološkog određenja smrti kao ništavila, tj. iskustvene praznine, u djelu možemo uočiti dvije logičke inkonzistencije. Prva se sastoji od projekcije reduciranog iskustva u prethodnu definiciju smrti kao ništavila. Ovakav postupak u filozofskoj literaturi o smrti poznat je kao fenomenološka greška. Ona je zapravo naš psihološki pokušaj da zamislimo nešto što se ne može ni u principu zamisliti, a to je naša vlastita smrt. ${ }^{34}$ Ova prirodna ljudska sklonost zamišljanja sebe kako smo mrtvi, iako psihološki razumljiva, predstavlja logičku grešku miješanja psiholoških i ontoloških pitanja. Druga logička inkonzistencija proizlazi iz vrijednosnog određenja smrti i tvrdnje da ne postoje neiskustvena zla. Naime, čini se da se u isto vrijeme tvrdi da je smrt loša i da ne postoje neiskustvena zla. Međutim, upravo negacija neiskustvenog zla implicira tvrdnju da smrt nije loša. Ako, pak, jest, onda spada u kategoriju neiskustvenih zala. Dakle, ili Galeb zastupa epikurejsku poziciju prema kojoj smrt nije loša ili je upao u logičku inkonzistenciju. Strah od nedosljednosti, a ne netočnosti prilikom razmišljanja nije nešto što je Galebu strano:

$\overline{34}$ Smrt kao ništavilo, kao neiskustveno bivanje mrtvim. Ono što možemo zamisliti vlastiti je proces umiranja. 
Nadalje, ja oduvijek zazirem, panički zazirem od toga da mi ne dobace: „To je kontradikcija, čista kontradikcija! Ti si nedosljedan, ti si u protuslovlju sa samim sobom!“ - Toga se uprav, mitski, preuveličano bojim, bojim čitavim jednim skrivenim kompleksom u meni. (...) A zašto toliko zazirem od prigovora nedosljednosti - to ne znam. Valjda (i sasvim vjerojatno) baš zato što sam uistinu nedosljedan. ${ }^{35}$

Možemo zaključiti kako je taj strah od inkonzistentnosti u nekoj mjeri opravdan. Opravdan je u onoj mjeri u kojoj svatko od nas prilikom promišljanja može upasti u logičku inkonzistenciju. Logičke implikacije argumenata i temeljne pretpostavke na kojima se baziraju naše tvrdnje često nam ostaju skrivene i možemo ih uočiti tek nakon filozofske analize. U tom smislu filozofska djela o smrti nude nam drukčiji spoznajno-vrijednosni aspekt od književno-umjetničkih djela o smrti. Ova posljednja, kao što je roman Proljeća Ivana Galeba, nude nam prvenstveno duboke psihološke uvide u ljudska suočavanja sa smrću, tj. ponajprije psihološke spoznaje. Dakle, nema nedosljednosti u osjećanjima i psihološkim stanjima Ivana Galeba, ali ih možemo pronaći u logičkim implikacijama argumenata.

\section{$\cos$}

\section{Literatura}

Vladan Desnica, Proljeća Ivana Galeba, u: Igre proljeća i smrti (ur. Tonko Maroević), Zagreb 2008., 27-364.

Paul Edwards, „Existentialism and Death: A Survey of Some Confusion and Absurdities“, Philosophy, Science, and Method. Essays in Honor of Ernest Nagel (ur. Sidney Morgenbesser, Patrick Suppes i Morton White), New York 1969., 473-505.

EPIKur, „Pismo Menoikeju“, u: Branko Bošnjak, Filozofija od Aristotela do renesanse i odabrani tekstovi filozofa, Zagreb 1983., 144-153.

Fred Feldman, Confrontations with the Reaper: A Philosophical Study of the Nature and Value of the Death, New York 1992.

John Martin Fischer, Our Stories. Essays on Life, Death, and Free Will, New York 2011.

Lukrecije, O prirodi, Zagreb 2010.

Steven Luper, The Philosophy of Death, Cambridge 2009.

Thomas NaGel, „Death“, Nô̂s, 4/1970., br. 1, 73-80.

Stephen E. Rosenbaum, „How to Be Dead and Not Care: A Defense of Epicurus“, American Philosophical Quarterly, 23/1986., br. 2, 217-225.

Jay F. Rosenberg, Thinking Clearly About Death, Indianapolis 1998.

35 V. Desnica, Proljeća Ivana Galeba, 109. 


\section{$\cos$}

\section{Aspects of THE ANALYTICAL PHILOSOPHY OF DEATH IN Vladan Desnica's novel The SPRINGS of IVAN GALEB}

The literary discourse on death, subjectivist as it is, is often terminologically vague, marked by ambiguous, even contradictory claims. Philosophical analyses and scientific discoveries are often in the service of artistic expression, experience, as well as the expression of emotion related to the phenomenon of death. The philosophical discourse of analytic philosophy, however, strives for utmost clarity and accuracy. To think about anything means, first and foremost, to think clearly. The fact that death is inherently emotionally charged does not mean the standards of rationality should be lowered. Death is thus defined as the permanent and irreversible end of existence, the final destruction of a being - in other words, as an experiential void. This is the starting point for any further evaluative discussions and definitions of the topic. If we take works of fiction to be a source of insight into death, the attitudes towards death and facing death, then it must be made clear what exactly those works are talking about. Are they addressing death (as defined above) or something else? Dreams, gloom, darkness, faraway lands, roads, journeys, ports and other metaphors of death found in literature are in fact certain forms of experience, thus, when we project a mysterious, reduced form of experience onto death, we are making a phenomenological error. We think we are discussing non-being, when what we are actually describing is a reduced form of being. With this in mind, the aim of this paper is to examine the basic ontological and evaluative claims that can be analyzed in Vladan Desnica's novel Proljeća Ivana Galeba (The Springs of Ivan Galeb), such as projecting certain reduced experiential states onto death, or evaluating death either through an epicurean lense (death is not detrimental to the person who is dying) or a deprivationalist one (death is detrimental to the person who is dying because it deprives them of possible experience). Therefore, contemporary philosophical analyses can shed a light on basic assumptions authors draw from when they write about death, which enables us to evaluate their contribution to the ways humans understand, experience and face death.

Key words: epicureanism, deprivationalism, phenomenological error, non-experiential knowledge of evil, nothingness, death 
12.

\section{POJMOVNA METAFORA \\ I KONCEPTUALIZACIJA SMRTI \\ U PROLJEĆIMA IVANA GALEBA \\ VLADANA DESNICE}

\section{Virna Karlić}

UDK: 821.163.42-311.1Desnica, V. :612.013

Prethodno priopćenje

Sažetak: Autorica se bavi analizom pojmovne (konceptualne) metafore smrti u romanu Proljeća Ivana Galeba Vladana Desnice. Rad se otvara kratkim pregledom književnih i lingvističkih teorija metafore, s posebnim osvrtom na kognitivistički pristup metafori kao mentalnom mehanizmu s pomoću kojeg čovjek poima i organizira stvarnost, a koji se odražava u jeziku. Nadalje slijedi prikaz najfrekventnijih konvencionalnih pojmovnih metafora smrti u svakodnevnoj jezičnoj upotrebi, koje se potom uspoređuju s metaforama smrti u Proljećima Ivana Galeba. U završnom poglavlju raspravlja se o rezultatima provedenog istraživanja te se otvara pitanje funkcija koje utvrđene metafore smrti vrše u Desničinu romanu.

Ključne riječi: poetska metafora, pojmovna metafora, konceptualna analiza, Vladan Desnica, Proljeća Ivana Galeba

od pretpostavkom da čovjek konceptualizira svijet oko sebe (uspostavlja pojmove) na temelju svojeg fizičkog, osjetilnog, emocionalnog i intelektualnog iskustva, teorija pojmovne ili konceptualne metafore zasniva se na hipotezi da jednostavne i konkretne pojave iz svijeta koji nas okružuje doživljavamo izravno, a one apstraktne i složene posredstvom poznatih, bazičnih iskustava. Utoliko kognitivna semantika značenje definira kao subjektivnu konceptualizaciju stvarnosti, a jezik smatra ključnim pokazateljem načina na koji razmišljamo (,jezik je prozor u ljudski um“). Dok se u okviru teorije književnosti metafora promatra kao stilska figura, u okviru kognitivne semantike ona se tumači kao mentalni mehanizam s pomoću kojeg čovjek poima i organizira stvarnost. Ovaj rad bavi se pitanjem kako je konceptualiziran kompleksan i apstraktan pojam smrti u Proljećima Ivana Galeba Vladana Desnice, romanu u kojemu je smrt jedan od središnjih motiva. Rezultati se analize potom uspoređuju s rezultatima istraživanja pojmovne metafore smrti u svakodnevnom, nepoetskom jeziku. Pritom se otvara pitanje odnosa i granica između leksičke (nepoetske) metafore i metafore kao tropa (poetske), kao i pitanje odnosa i granice 
između nepoetskog i poetskog jezika. Analiza se zasniva na pretpostavci da će utvrđivanje modela pripovjedačeve konceptualizacije smrti u Proljećima Ivana Galeba pridonijeti interpretaciji romana, posebice na planu razumijevanja strategija oblikovanja njegova glavnog lika (ujedno i pripovjedača).

\section{Metafora u KNJiŽEVnOsti i IZVAN NJE: PRISTUPI I TUMAČENJA}

Pristupi metafori brojni su i raznoliki, a iz njih proizlaze njezine različite definicije i tumačenja. Metafora je jedan od središnjih pojmova suvremene književne teorije, a u novije vrijeme i lingvistike, filozofije, psihologije, teologije, sociologije i drugih znanosti. ${ }^{1}$ Iako se o njoj najčešće razmišlja kao o stilskoj figuri, ${ }^{2}$ postoje još dvije njezine razine - pojmovna i leksička. ${ }^{3}$ Metafora se kao trop uglavnom definira kao „prijenos značenja jedne riječi na drugu“, ${ }^{4}$ odnosno kao „zamjenjivanje jedne riječi drugom prema značenjskoj srodnosti ili analogiji“.5 Njezino je uspostavljanje moguće zahvaljujući pojmovnoj metafori kao mehanizmu mišljenja koji omogućava da apstraktne i složene pojave doživljavamo posredno, konkretiziranjem i pojednostavnjivanjem, odnosno svođenjem na poznato iskustvo. Tako se u navedenom primjeru iz Desničina romana Proljeća Ivana Galeba upotreba glagola prezati zasniva na pojmovnoj metafori SMRT je žIVO BIĆE:

Smrt preza pred vedrim djetinjim okom (...) (40)

Leksička (nepoetska) metafora također je odraz pojmovne metafore u jeziku, a podrazumijeva ustaljen prijenos naziva s jednog pojma na drugi na temelju njihovih sličnosti (npr. ustaljen prijenos na kojem se temelji metaforički izraz gledati smrti $u$ oči također se zasniva na pojmovnoj metafori SMRT je ŽIVO BIĆE).

Prema podjeli Elene Semino i Gerarda Steena, ${ }^{7}$ teorijski pristupi metafori dijele se na dvije skupine: (1) teorije koje naglašavaju razlike između leksičke (nepoetske) metafore i metafore kao tropa $\left(\right.$ poetske) ${ }^{8}$ te (2) teorije koje ukazuju na njihovu međusobnu povezanost i uvjetovanost.

Prva skupina okuplja teorije različitih tradicija (od formalističke škole, preko angloameričke stilistike do kognitivne poetike) koje povezuje zajednička pretpostavka da metafora

\footnotetext{
Vladimir Bıтı, Pojmovnik suvremene književne teorije, Zagreb 1997., 221.

2 „Još od antike metafora se promatra kao najsnažnija i najčešća figura, kao kraljica figura.“ Usp. Krešimir BAGić, Rječnik stilskih figura, Zagreb 2012., 187.

3 Rajna DragićEvić, Leksikologija srpskog jezika, Beograd 2007., 147.

4 Milivoj Solar, Teorija književnosti sa rječnikom književnoga nazivlja, Beograd 2012., 412.

5 K. BAGIĆ, Rječnik stilskih figura, 187.

6 Svi primjeri iz romana pretraženi su i preuzeti iz elektroničkog izdanja: Vladan Desnica, Proljeća Ivana Galeba, Beograd 2010. (https://gimnazijadg.files.wordpress.com/2012/04/vladan-desnica-proljeca-ivana-galeba.pdf). Usto se koristilo i tiskano izdanje: Vladan Desnica, Proljeća Ivana Galeba, Varaždin 2005.

7 Elena Semino - Gerard STEen, „Metaphor in Literature“, The Cambridge handbook of metaphor and thought, Cambridge 2008., 232-246.

8 Autori se u studiji izvorno koriste terminima poetska i nepoetska metafora u smislu pripadanja poetskome ili nepoetskome jeziku (jeziku književnosti).
} 
nije isključivo književni fenomen, ali da je odnos između metafore u književnosti i one izvan nje diskontinuiran. Glavni je cilj pristupa ove skupine odrediti upotrebu, obilježja i funkcije metafora u pojedinim književnim tekstovima, žanrovima ili autorskim opusima. Naglasak se pritom stavlja na jedinstvenost pojedinačnih primjera metafore u književnim djelima. Predstavnici ove struje leksičku (nepoetsku) metaforu vide kao mrtvu, a time i manje vrijednu od metafore kao tropa (poetske).

Osamdesetih godina prošlog stoljeća nastupa velik obrat na planu proučavanja metafore. Najednom „mrtve“, leksičke ili nepoetske metafore počinju igrati središnju ulogu u razvoju kognitivne teorije metafore Georgea Lakoffa i njegovih kolega i sljedbenika (Raymond Gibbs, Mark Johnson, Mark Turner i drugi). Ta je teorija donijela novi pogled na uloge metafore u svakodnevnoj komunikaciji i bacila drugačije svjetlo na metaforu kao trop. Lakoff i Turner iznose stav da je metafora kao stilska figura u književnim djelima kreativna realizacija konvencionalne pojmovne metafore. Predstavnici ovoga pristupa metaforu u svakodnevnom jeziku vide kao primarnu, a metaforu u književnosti kao kreativnu izvedenicu ustaljenih, leksičkih metafora.?

Navedeni su pristupi metafori u mnogočemu različiti i nepomirljivi, međutim, umnogome su i komplementarni jer se usmjeravaju na njezine različite aspekte. Dok se predstavnici prve skupine teorijskih pristupa fokusiraju na ulogu specifičnih metaforičkih obrazaca u pojedinim djelima, opusima autora ili žanrovima (idiografski pristup), predstavnici one druge ne bave se pojedinačnim primjerima, već općim obilježjima pojmovne metafore. Iako se proučavatelji metafore (neovisno o pristupu i teorijskoj podlozi) načelno slažu s time da su metafore u književnosti kreativnije i inovativnije od onih izvan nje, tu je tvrdnju teško empirijski dokazati. Ključan problem predstavlja škakljivo pitanje granice između poetskog i nepoetskog jezika, kao i činjenica da jezik književnosti varira na brojnim razinama, ovisno o vrsti i žanru književnog djela. Dosad provedena kvantitativna istraživanja o toj temi potvrđuju pretpostavku da je poetski jezik više metaforičan nego nepoetski, a da je poezija bogatija metaforikom od proze. Osim toga, novije lingvističke (diskurzivne i korpusne) studije pokazuju da kreativna upotreba metafora nije ograničena samo na književnost te otvaraju pitanje karakteristika, okidača i funkcija metaforičke kreativnosti u diskursu. ${ }^{10}$

\section{Metafora u OČima KOGNitivne ZNANOSTI}

Dok tradicionalni književni pristupi metaforičnosti prilaze prvenstveno kao jednoj od temeljnih značajki jezika književnosti, suvremeni lingvistički pristupi rasvjetljavaju i inzistiraju na činjenici da i svakodnevni jezik obiluje metaforičkim izrazima te da metafora nije samo ukras u pjesničkom jeziku, nego način svakodnevnog izražavanja. U okviru kognitivne lingvistike, jedne od grana kognitivne znanosti, ${ }^{11}$ metafora se promatra kao

9 Usp. George Lakoff - Mark Turner, More Than Cool Reason: A Field Guide to Poetic Metaphor, Chicago 1989. Valja naglasiti kako ovaj pristup zanemaruje inovativne metafore koje se ne mogu povezati s konvencionalnim pojmovnim metaforama.

10 Za kratak pregled spomenutih istraživanja usp. E. Semino - G. STEen, „Metaphor in Literature“.

11 Sedamdesetih godina 20. stoljeća kognitivna znanost počinje se profilirati kao zasebno znanstveno područje te kao nova akademska disciplina koja se bavi proučavanjem uma i inteligencije. Kognitivna znanost veliko je polje i 
način ustroja znanja i konceptualizacije svijeta koji nas okružuje. U kognitivnoj se lingvistici jezik smatra odrazom ljudskog uma i spoznajnih procesa, a značenje se poistovjećuje s konceptualizacijom - „obrazovanjem pojmova na osnovu čovekovog fizičkog, čulnog, emocionalnog i intelektualnog iskustva o svetu koji ga okružuje“. ${ }^{12}$ U tom je smislu značenjska struktura jezika po svojoj prirodi subjektivna te odražava i razotkriva razne aspekte ljudske kognicije:

Konceptualnoj metafori prilazimo kao jednom od kognitivnih procesa koji se zrcale u jeziku. Jeziku također pristupamo kao spoznajnoj pojavi - leksik i gramatiku smatramo motiviranim konstrukcijama simboličke naravi. Dakle, jezik smatramo neodvojivo vezanim za naš um. Temeljna je značajka jezika da je on vezan uz nas kao ljude pa se u njemu odražava naša spoznajnost, naša tjelesnost, naša društvenost. Baš je takva i konceptualna metafora - ona je tjelesna, neurološka, spoznajna, jezična (konstrukcijska), komunikacijska, kulturološka. ${ }^{13}$

Tradicionalnu definiciju metafore kao poetske figure koja podrazumijeva prijenos imena s jednog pojma na drugi Lakoff i Johnson nadograđuju u svojem kapitalnom djelu Metafore koje život znače ${ }^{14} \mathrm{u}$ kojem ističu kako esencija metafore leži u razumijevanju i proživljavanju jednog pojma putem drugog. Time se tumačenje metafore kao tropa proširuje na njezino razumijevanje kao mentalnog mehanizma koji se zasniva na preslikavanju strukture jednog pojma ili domene na drugi pojam ili domenu. ${ }^{15}$ Pritom se prijenos odvija u smjeru od konkretnog, lakše pojmljivog (npr. ljudsko tijelo, životinje, biljke, svjetlost/tama, toplo/ hladno) prema apstraktnom (npr. emocije, mišljenje, ljudski odnosi, vrijeme, smrt):

Taknula me njegova ljubaznost i obazrivost, koju redovno ne možemo tražiti od ljudi sviklih da po svom zvanju vječito gledaju ljudskoj patnji i smrti licem u lice. (26)

Tako se u navedenom primjeru iz Desničina romana apstraktni pojmovi patnja i smrt konceptualiziraju posredstvom konkretne domene živog bića (PATNJA/SMRT je žIVO BIĆE) njihovim poimanjem kao stvorenja s kojima se možemo gledati licem u lice.

Prema klasifikaciji Lakoffa i Johnsona ${ }^{16}$ pojmovne se metafore dijele na tri temeljne skupine: (1) strukturne - jedan se pojam metaforički strukturira s pomoću drugog (npr. izraz počivati u miru odražava strukturnu pojmovnu metaforu SMRT je SPAVANJE); (2) orijentacijske - metafore koje se zasnivaju na prostornoj orijentaciji; čije su izvorne domene prostorni odnosi (npr. izraz pasti u grob odražava pojmovnu metaforu SMRT je DOLJE); (3) ontološke - metafore koje se zasnivaju na razumijevanju apstraktnih pojmova poput emocija ili ideja posredstvom entiteta ili situacija (npr. već spomenut izraz gledati se sa smrću licem u lice). Budući da se često zasnivaju na svim ljudima zajedničkim iskustvima, pojmovne su metafore nerijetko univerzalne, međutim, zbog kulturalnih specifičnosti i različitog fizičkog

pokriva širok spektar tema o kogniciji, a podrazumijeva interdisciplinarno proučavanje koje povezuje razna relevantna znanstvena područja poput psihologije, psihijatrije, neuroznanosti, lingvistike, antropologije, biologije i dr.

12 R. DragićEvić, Leksikologija srpskog jezika, 90.

13 Mateusz-Milan Stanojević, Konceptualna metafora. Temeljni pojmovi, teorijski pristupi i metode, Zagreb $2013 ., 15$.

14 George Lakoff - Mark Johnson, Metaphors we live by, Chicago 1980. Hrvatski prijevod knjige, objavljen 2015. godine, nosi naslov Metafore koje život znače (prev. Anera Ryznar).

15 Usp. R. DragiĆević, Leksikologija srpskog jezika.

16 Usp. G. Lakoff - M. Johnson, Metaphors we live by. 
okruženja one mogu biti i jezično specifične (npr. izrazi predati duh Gospodu, otići na posljednji sud, otići na bolje mjesto zasnivaju se na vjerovanjima u judeo-kršćanskoj tradiciji).

Pojmovne metafore mogu biti dio ustaljenog jezičnog znanja (konvencionalna metafora) ili se mogu konstruirati u diskursu - kako književnom tako i neknjiževnom (inovativna metafora). Prema tradicionalnim podjelama, metafore se dijele na žive i mrtve, dok konceptualna teorija ne vjeruje u „mrtvilo“ mrtvih metafora te ih radije naziva „uspavanima“. ${ }^{17}$ Pritom žive metafore podrazumijevaju metafore koje iznenađuju i za koje nema puno potvrda u korpusu te su teško razumljive izvan konteksta i bez dodatnog objašnjenja. Mrtve ili „uspavane“ metafore ustaljene su i govornici često nisu svjesni metaforičnosti takvih izraza (npr. grlo žarulje, planinski lanac). U analizi romana Proljeća Ivana Galeba obuhvaćene su sve metafore s ciljnom domenom SMRT, bez obzira na njihovu vrstu i stupanj ustaljenosti.

\section{Metafore kOJE SMRT ZnaČE}

(Pojmovna) metafora smrti u književnim djelima i drugim oblicima jezične produkcije predmet je brojnih istraživanja. ${ }^{18}$ Za potrebe ovoga rada posebno se korisnom pokazala studija Juane I. Marin-Arrese, u kojoj su popisane i uspoređene najučestalije konvencionalne pojmovne metafore smrti i umiranja u svakodnevnom španjolskom i engleskom jeziku. ${ }^{19}$ U nedostatku istraživanja konvencionalne pojmovne metafore smrti u hrvatskom ili srpskom jeziku, studija Marin-Aresse smatrala se zadovoljavajućim izvorom i polazištem za analizu upravo zbog već spomenute činjenice da se pojmovne metafore uglavnom zasnivaju na općim ljudskim iskustvima te su stoga nerijetko univerzalne. Zbog kulturne bliskosti među govornicima španjolskog, engleskog te slavenskih jezika, nisu očekivane značajne jezične specifičnosti na planu konceptualizacije smrti. Analiza rezultata ove studije takva je očekivanja potvrdila jer su njezini rezultati umnogome podudarni sa stanjem u hrvatskom i srpskom jeziku. Zato u nastavku slijedi prikaz autoričine podjele najzastupljenijih pojmovnih metafora smrti na pet glavnih skupina s obzirom na tip izvorne domene. Podjela je popraćena primjerima iz hrvatskoga jezika. ${ }^{20}$

(1) Fizički efekti smrti. Primjerice, vrlo je raširena pojmovna metafora SMRT je sPAVAnje, koja se zasniva na sličnostima između osobe koja spava i koja je mrtva (obje leže i mirne su). Ta se eufemistička metafora ostvaruje u ustaljenim izrazima i frazemima kao što su počivati u miru, vječni počinak, posljednje počivalište, smrtna postelja, spavati vječnim

17 M. Stanojević, Konceptualna metafora, 90.

18 Ovdje ćemo navesti tek nekoliko takvih primjera: Zenaida Meco, „Konceptualna analiza smrti na primjeru pjesme Modra rijeka Maka Dizdara“, Zbornik pedagoškog fakulteta u Zenici, 6/2008., 261-267; Elena FAUR, The Metaphors for Death and the Death of Conceptual Metaphors in Poetry. An Analysis Based on Emily Dickinson's Poem „Because I Could Not Stop For Death“ (http://www.dacoromania.inst-puscariu.ro); Cristina Flores Moreno, „Time, Life and Death Metaphors in Shakespeare's Sonnets: The Lakoffian Approach to Poetic Metaphors“, RESLA 13/1998. - 1999., 287-304; Eliecer Crespo FernandÉz, „The Language of Death: Euphemism and Conceptual Metaphorization in Victorian Obituaries", SKY Journal of Linguistics, 19/2006., 101-130.

19 Juane I. Marin-Arrese, „To Die, to Sleep: A Contrastive Study of Metaphors for Death and Dying in English and Spanish“, Language Sciences, 18/1996., br. 1-2,37-52.

20 Većina primjera frazema preuzeta je iz rada: Maja OpAšrć - Maja Gregorović, „Smrt u hrvatskoj frazeologiji“, Croatica et Slavica Iadertina, 6/2010., 55-72. 
snom, usnuti vječni mir itd. Ovakav značenjski prijenos motiviran je čovjekovom težnjom za pojašnjenjem onoga najnepoznatijega onim najpoznatijim: ljudskim tijelom, općenito njegovim okruženjem. ${ }^{21}$

Projekcije ili proširenja značenja zasnivaju se na metonimiji - procesu prijenosa reference, to jest referiranju na jednu istaknutu karakteristiku koja predstavlja cijelu značenjsku domenu. Tako u navedenim izrazima pojedini fiziološki efekti smrti predstavljaju umiranje: izdahnuti, sklopiti oči (zauvijek), otegnuti papke, obladiti pete i slično, što je slučaj i s aspektima pokapanja ili raspadanja tijela u izrazima: završiti pod zemljom, biti hrana crvima, postati prah i prašina, pretvoriti se u prah (pepeo).

(2) Personifikacija. Pridavanje ljudskih obilježja apstraktnim pojmovima vrlo je česta pojava. Tako u mnogim jezicima smrt dolazi po nekoga, odvodi galje ili zatječe; ljudi bivaju $u$ raljama smrti, bore se sa smrću ili gledaju smrti u oči. ${ }^{22}$

(3) Religija i sustav vjerovanja. U svim slavenskim jezicima postoji cijeli niz izraza za smrt utemeljenih na vjerovanjima u judeo-kršćanskoj tradiciji (vjerovanje u život poslije smrti, vjerovanje da se raj nalazi na nebesima, da je smrt trenutak posljednjeg suda i tome slično). Otuda potječu pojmovne metafore i na njima zasnovani izrazi: vječni život, sjediniti se s Bogom, otići na posljednji sud, otići na bolje mjesto, otići na nebo, dati/predati dušu Bogu/Gospodu, ispustiti dušulduh.

(4) Druga sociokulturna vjerovanja i prakse također bivaju osnovom za određene pojmovne metafore smrti. Takve su, primjerice, pojmovne metafore proizašle iz nasilnih praksi koje uzrokuju smrt: platiti krvlju/glavom, zamastiti konopac/kolac.

(5) Prostorni i vremenski odnosi. Pojmovne se metafore smrti često zasnivaju na spacijalnim izvornim domenama kao što su, primjerice, žIVOT NA ZEMLJI je OMEĐEN PROSTOR (napustiti ovaj svijet, biti između života i smrti); SMRT je ODLAZAK (izrazi za smrt s glagolima otići, napustiti, rastati se); SMRT je DOLJE (biti ispod zemlje, leći/pasti/sići u grob). Isto je slučaj $s$ vremenskim odnosima, pa se tako, primjerice, na pojmovnoj metafori SMRT je POSLJEDNJi ČAs zasnivaju izrazi: vrijeme mu/joj je isteklo, došao je čas, odbrojeni su mul joj dani, kucnuo muljoj je čas/ura.

Predstavljena tipologija najučestalijih konvencionalnih pojmovnih metafora smrti u analiziranim jezicima otkriva sklonost njihovih izvornih govornika upotrebi eufemističkih metaforičkih izraza za smrt i umiranje. Jedan od uzroka nastajanja metafora skriva se upravo u tabuističkom ponašanju, koje se očituje u preimenovanju stanovitih smislova i njima pripadajućih designata. ${ }^{23}$

21 Ante Stamać, Teorija metafore, Zagreb 1983., 68.

22 Ovdje valja naglasiti da se u retorici i stilistici personifikacija promatra kao zasebna, „kompleksna stilska figura koja se od prigode do prigode realizira pomoću metafore, sinegdohe i metonimije“, a definira se kao „pridavanje ljudskih osobina, misli, osjećaja i ponašanja kakvu predmetu, stvari, pojavi, apstrakciji, biljci ili životinji; oljuđivanje“. Usp. K. BAGIĆ, Rječnik stilskih figura, 245. Iz perspektive teorije pojmovne metafore, pa tako i u studiji autorice MarinAresse, personifikacija se promatra kao vrsta metafore. Inače, antropomorfno poimanje svijeta smatra se jednim od temeljnih uzroka nastajanja metafore jer se na temelju njega „smislovima pojava u prirodi odnosno u duhovnoj sferi pridijevaju imena što pripadaju stvarnosti čovjekova tijela i duha“. Usp. A. Stamać, Teorija metafore, 67.

23 Isto, 74. 


\section{Pojmovna metafora smrti u romanu PROLJEĆA IVANA GALEBA}

U ovome poglavlju rada prikazuju se rezultati provedene analize metafora s ciljnom domenom smrti u Proljećima Ivana Galeba Vladana Desnice. Analizom se željelo utvrditi koji tip metafora prevladava u romanu, posebice stoga što je smrt jedan od njegovih centralnih motiva, a riječ je o proznom djelu. ${ }^{24}$ Nadalje, željelo se utvrditi koje su najzastupljenije izvorne domene pojmovnih metafora smrti u romanu te usporediti rezultate analize s prethodno predstavljenim popisom najučestalijih konvencionalnih pojmovnih metafora u svakodnevnoj jezičnoj upotrebi. U konačnici je cilj uvidjeti kako rezultati ovakvog tipa (lingvističke) analize mogu pridonijeti tumačenju romana.

Leksem 'smrt' u romanu eksplicitno se pojavljuje dvjestotinjak puta. Na temelju pretrage metaforičkih izraza prema ciljnoj domeni zabilježeno je šezdeset poetskih metafora smrti zasnovanih na pojmovnim metaforama koje se mogu svrstati u tri temeljne skupine $s$ obzirom na izvoru domenu.

\section{(I) Personifikacija}

Čak trećina zabilježenih metaforičkih izraza u romanu zasniva se na pojmovnoj metafori SMRT je ŽIVO BIĆE, što najavljuje i sâm podnaslov romana Igre proljeća i smrti. Metaforički izrazi ove skupine dijele se nadalje na potkategorije.

(1a) smrt kao ljudsko biće:

Za njenim prolaskom [smrti], kud je ona pomela svojim crnim skutom, ostaje vir praznine (...) (26)

Smrt je tačno našeg stasa i uzrasta (...) (60)

(...) imam iluziju da smrt ne može da stavi ruku na moje rame. (132)

Vjerovatno postoji neki istočnjački mit ili legenda (...) o čovjeku koga je smrt mogla da zaskoči samo na spavanju, samo dok miruje. (132)

Ovdje se kao posebna podskupina izdvajaju izrazi u kojima smrt predstavlja neprijatelja:

Trebat će sve drugo ostaviti kraju i poduhvatiti se, udruženim snagama, u jedan veliki, vrhovni napor da se ona [smrt] pobijedi, da se prevlada. (59)

Svi naši napori, sva naša djela samo su vidovi borbe protiv smrti. (61)

Veliki su osjećaji jedan oblik borbe protiv smrti (...) (223)

(1b) smrt kao životinja ili biljka:

Smrt preza pred vedrim djetinjim okom. (40)

$\overline{24}$ Do sada se znatno veća pozornost posvećivala metafori kao tropu (u novije vrijeme i pojmovnoj metafori) u poeziji. 
Smrt se začinje i gnijezdi u ustajalim klimama jučerašnjice. (242)

Gledao sam je kao šupalj dud, ulište klica smrti. (40)

(1c) smrt kao živi entitet koji nastanjuje ljudsko biće (pritom je biće konceptualizirano posredstvom pojmovne metafore DUŠA/TIJELO je OMEĐEN PROSTOR):

Negdje duboko zapretana u djetinjem biću leži jedna ćelija u kojoj tinja besmrtnost. A odmah do nje, u neposrednom susjedstvu, druga ćelija u kojoj drijema smrt. One žive u dobrim susjedskim odnosima. (40)

Grud mu je puna ljeskanja bića i nebića, u njoj se motaju smrt i besmrtnost, sad uhvaćene u koštac, sad obujmljene u zagrljaj. (63)

Gledao sam kako se u njoj nose mladost i smrt. (132)

\section{(2) Primarne metafore}

Druge po zastupljenosti u romanu, pojmovne metafore, utemeljene su na utjelovljenim vezama, zasnovane na ljudskim osjetilima: ${ }^{25}$ SMRT je TAMNA, SMRT je HLADNA, a vezano uz aspekt raspadanja tijela, pojavljuju se metaforički izrazi u kojima smrt predstavlja izvor mirisa.

(2a) smrt je tamna:

U oblačne dane, u dane smrti (...) (41)

Veliki su osjećaji jedan oblik borbe protiv smrti, krhki mostovi između konačnog i beskonačnoga što presvođuju bezdane mraka. (223)

(...) život - to je tvoja „ideja“; a smrt, naličje, tamna strana tog žetona, kojim se poigravaš (248)

(2b) smrt je hladna:

Dijete je ne prepoznaje, još joj ne zna imena ni slova, ali već se ježi od njezina hlada. (40) (...) dijete joj [smrti] ne zna imena ni slave, ali u oblačne i besunčane dane osjeća na licu hladan dah vjetra za njenim prolaskom. (40)

(2c) smrt kao izvor mirisa:

(...) mirisi jelâ, kućevnosti, ishlapljela naftalina već čudno udaraju mirisom smrti. (177) Kao da je mirisala smrt (...) (235)

25 Upravo je intersenzorno percipiranje jedan od glavnih uzroka nastanka metafore - „ovaj tip uzroka širi ljestvicu percipiranja na slušno, dodirno, okusno pa i njušno polje, ukoliko se ta polja osjetilnosti mogu izraziti govorno, tj. jezičnim znakovima.“A. Stamać, Teorija metafore, 73. 


\section{(3) Prostorni odnosi}

U romanu se na više mjesta pojavljuje orijentacijska metafora SMRT je DOLJE:

\section{Jedno je izložiti se zalutalom tanetu, (...) pasti prosvirana šešira (177)}

Pojavljuje se i konvencionalna spacijalna metafora SMRT je OMEĐEN PROSTOR, koja se odražava u izboru prijedloga 'u' uz imenicu 'smrt' u akuzativu ili lokativu:

odlazi se $\mathbf{u}$ smrt (65)

pričanja o devojci na odru, (...) poljepšanoj u smrti kao Trnoružica (106)

Uz navedene tri najzastupljenije skupine metafora, u romanu važnu ulogu imaju i pojmovne metafore SMRT je PREDMET (smrt pripada samo stvaraocu, str. 61), SMRT je BOLEST (lijek od smrti, str. 184) te SMRT je KRAJ (Idealan završetak, kakav se samo poželjeti može, str. 174).

\section{ZAKLJUČCI: OBILJEŽJA I FUNKCIJE METAFORE U ROMANU}

Analiza Proljeća Ivana Galeba pokazala je da roman obiluje metaforama smrti, koje se s obzirom na izvornu domenu mogu svrstati u tri skupine - personifikacije te primarne i prostorne metafore. U skladu s očekivanjima, ${ }^{26}$ pokazalo se da su gotovo svi zabilježeni primjeri inovativnih metafora u romanu kreativne izvedenice uobičajenih, konvencionalnih pojmovnih metafora. O tome svjedoče podudarnosti između pojmovnih metafora smrti na kojima se zasnivaju najučestaliji metaforički izrazi u nepoetskom jeziku ${ }^{27}$ i pojmovnih metafora iz kojih proizlaze metafore smrti u romanu. Međutim, uočljiva su i neka odstupanja i specifičnosti - primjerice, u potpunosti izostaju konvencionalne pojmovne metafore zasnovane na kršćanskim vjerovanjima te na fizičkim efektima smrti (npr. SMRT je SPAVA$\mathrm{NJE}^{28}$ ), koje su u svakodnevnoj komunikaciji vrlo učestale.

Kako ovakvi podaci mogu pridonijeti interpretaciji književnog djela? Pretpostavka da su (pojmovne) metafore „prozor u ljudski um“ povlači za sobom ideju da im se u kontekstu analize Proljeća može pristupiti kao „prozoru“ u um Ivana Galeba, odnosno da se mogu tumačiti kao jedno od sredstava koje autor primjenjuje uslijed procesa vokalizacije - „davanja glasa“ glavnome liku i pripovjedaču romana. ${ }^{29}$ Budući da je roman ispripovijedan u prvome licu, metafore smrti u djelu vrše značajnu funkciju pri profiliranju lika Ivana Galeba. One odražavaju njegov odnos prema smrti na eksplicitnoj i implicitnoj razini. Tako, primjerice, izostanak

$\overline{26}$ S obzirom za žanrovsku pripadnost i obilježja djela te u skladu s prethodno predstavljenim tumačenjem Lakoffa i Turnera.

27 Usp. J. Marin-Arrese, „To Die, to Sleep“.

28 U romanu se ipak pojavljuje implicitna poredba smrti i spavanja, npr. „Na takav prizor uvijek mi se navraća pomisao da bi lica spavajućih, iz pijeteta, trebalo samilosno zastrijeti maramom, kao lica umrlih." (27)

29 Ovaj termin u književnoj pragmatici podrazumijeva „davanje glasa“ liku u književnom djelu. Vokalizacija je iznimno složen proces zbog toga što on ne podrazumijeva samo doslovno „davanje riječi“ liku, već i otkrivanje njegove perspektive iz koje pristupa drugim likovima i svojoj okolini - prenošenje čitatelju njegova pogleda na svijet. Usp. Jakob Mey, Concise Encyclopedia of Pragmatics, Oxford 2009., 553. 
metafora zasnovanih na kršćanskim uvjerenjima te načelno eufemističkih metafora (inače dominantnih u svakodnevnoj komunikaciji) posredno otkriva Galebov svjetonazor, posebice stav i odnos prema smrti. Smrt za njega nije tabu-tema - štoviše, smrt je njegova opsesija. $S$ obzirom na to da se u romanu otvoreno suočava sa smrću, Galeb s razlogom ne poseže za eufemističkim metaforama, već za onima koje više ili manje eksplicitno odražavanju njegovo poimanje smrti - kao nemilosrdnog neprijatelja, kao vlažnog i mračnog prostora, izvora neugodnih mirisa, kao bolesti i neizbježnog kraja. Drugim riječima, izbor metafora s polaznom domenom smrti kojima se pripovjedač služi igra značajnu ulogu u procesu posredne vokalizacije njegova straha. Šire promatrano, metaforika smrti u romanu sudjeluje u konceptualizaciji Galebova svijeta, a time i svijeta djela u cjelini. Nadalje, za interpretaciju Proljeća Ivana Galeba značajan je i podatak da najzastupljenija pojmovna metafora smrti u romanu glasi SMRT je žIvo BIĆE, posebice u užem smislu ljudskog bića. Njezinom čestom aktualizacijom motiv smrti zadobiva svojevrsnu funkciju lika, Galebova suparnika (sMrT je NEPRIJATELJ). Rezultati provedene analize pokazali su da metafore - kako nekonvencionalne tako i one konvencionalne - vrše značajne funkcije u procesu konstituiranja romana na više razina.

Pitanje odnosa između pojmovne metafore i metafore kao stilske figure i danas je predmet rasprava i prijepora među teoretičarima književnosti i lingvistima. Rezultati analize metaforike smrti u Desničinu romanu potvrdili su njihovu izravnu povezanost, ali i određena odstupanja. Analizom pojmovne metafore u Proljećima Ivana Galeba željelo se ukazati na mogućnosti i specifične uvide koje kognitivna i pragmatička (lingvistička) perspektiva mogu donijeti proučavanju prozne metafore te tumačenju književnoga teksta. Također se željelo ukazati na ograničenja do kojih dolazi uslijed strogog razgraničavanja poetskog i nepoetskog jezika, a time i književnoteorijskog i lingvističkog pristupa metafori. Ovim se radom težilo dokazati da se njihovim udruživanjem mogu steći novi, drugačiji uvidi koji mogu poslužiti kao polazište ili doprinos daljnjim interpretacijama.

\section{$\cos$}

\section{Literatura}

Krešimir BAGIĆ, Rječnik stilskih figura, Zagreb 2012.

Vladimir Biti, Pojmovnik suvremene književne teorije, Zagreb 1997.

Eliecer Crespo Fernandéz, „The Language of Death: Euphemism and Conceptual Metaphorization in Victorian Obituaries", SKY Journal of Linguistics, 19/2006., 101-130.

Vladan Desnica, Proljeća Ivana Galeba, Varaždin 2005.

Vladan Desnica, Proljeća Ivana Galeba, Beograd 2010. (https://gimnazijadg.files.wordpress. com/2012/04/vladan-desnica-proljeca-ivana-galeba.pdf)

Rajna DraGićEvić, Leksikologija srpskog jezika, Beograd 2007.

Elena FaUr, The Metaphors for Death and the Death of Conceptual Metaphors in Poetry. An Analysis Based on Emily Dickinson's Poem „Because I Could Not Stop For Death“" (http://www.dacoromania.inst-puscariu.ro)

Cristina Flores Moreno, „Time, Life and Death Metaphors in Shakespeare's Sonnets: The Lakoffian Approach to Poetic Metaphors", RESLA, 13/1998. - 1999., 287-304.

Duška Klikovac, Metafore u mišljenju i jeziku, Beograd 2004. 
George Lakoff - Mark Johnson, Metaphors we live by, Chicago 1980.

George Lakoff - Mark Turner, More Than Cool Reason. A Field Guide to Poetic Metaphor, Chicago 1989.

Juane I. Marin-Arrese, „To Die, to Sleep: A Cotrastive Study of Metaphors for Death and Dying in English and Spanish", Language Sciences, 18/1996., br. 1-2, 37-52.

Zenaida Meco, „Konceptualna analiza smrti na primjeru pjesme Modra rijeka Maka Dizdara“, Zbornik radova Pedagoškog fakulteta u Zenici, 6/2008., 261-267.

Jakob Mer, Concise Encyclopedia of Pragmatics, Oxford 2009.

Maja Opašıć - Maja Gregorović, „Smrt u hrvatskoj frazeologiji“, Croatica et Slavica Iadertina, 6/2010., 55-72.

Elena Semino - Gerard Steen, „Metaphor in Literature“, The Cambridge handbook of metaphor and thought, Cambridge 2008., 232-246.

Milivoj Solar, Teorija književnosti sa rječnikom književnoga nazivlja, Beograd 2012.

Ante Stamać, Teorija metafore, Zagreb 1983.

Mateusz-Milan Stanojević, Konceptualna metafora: temeljni pojmovi, teorijski pristupi i metode, Zagreb 2013.

\section{Conceptual METAPHOR AND THE CONCEPTUALizaTion OF Death in Vladan Desnica's PROLJEĆa IVANA Galeba}

While in literary theory metaphor is defined as a figure of speech, cognitive semantics views it as the mental mechanism through which humans understand and organize their perception of reality. The conceptual metaphor theory is based on the hypothesis that simple and concrete phenomena from the world around us are experienced directly, while more abstract and complex ones are grasped via more familiar, basic experiences. Thus, cognitive semantics defines meaning as the subjective conceptualization of reality and considers language the key indicator of the way we think. This paper deals with the ways in which the complex and abstract idea of death is conceptualized in Vladan Desnica's novel Proljeća Ivana Galeba (The Springs of Ivan Galeb), where it is one of the central motifs. The insights gained from this analysis are then compared to the results of a study of conceptual metaphors of death in ordinary, non-poetic language. The relationship between lexcial (non-poetic) metaphor and metaphor as a figure of speech (poetic metaphor) is also analyzed, as is the relationship between poetic and ordinary language and the boundaries between them. The paper contains four chapters. The introductory chapter provides a short overview of the literary and linguistic theories of metaphor and divides them into two groups: those which stress the differences between metaphors as tropes (poetic metaphors) and lexical (non-poetic) metaphors, and those which stress the correlation and interdependence between the two types of metaphors. The second chapter provides a short introduction to the cognitive approach to metaphor as a mental mechanism through which humans conceptualize reality, which is reflected in language - in its poetic function as well the non-poetic. The third chapter lists the most commonly used conventional conceptual metaphors of death, while the fourth chapter compares them to those used in the novel Proljeća Ivana Galeba. The final chapter presents the results of the study, with a particular focus on the types and functions of the conceptual metaphors of death in Desnica's novel.

Key words: poetic metaphor, conceptual metaphor, conceptual analysis, Vladan Desnica, Proljeća Ivana Galeba (The Springs of Ivan Galeb) 



\section{3. \\ DANI PRED SMRT \\ U DRAMI TERASA JOVANA HRISTIĆA \\ I ROMANU PROLJEĆA IVANA GALEBA \\ VLADANA DESNICE}

\section{Aleksandra Obradović}

UDK: 821.163.42-311.1Desnica, V.:821.163.41-21Hristić, J.

Stručni članak

Sažetak: Rad donosi komparativnu analizu nekih segmenata romana Proljeća Ivana Galeba Vladana Desnice i drame Terasa Jovana Hristića. Polazno tumačenje svoju osnovu pronalazi u dominatnom motivu smrti koji je razvijen u oba književna djela. Pogled na razvoj motiva sužavamo ka analizi dana pred smrt, odnosno predsmrtnog perioda nekoliko Desničinih junaka iz poznatog romana - Ivana Galeba, čovjeka samoubice i čovjeka iz poglavlja o delti - i jedne Hristićeve junakinje čija je smrt izvjesna. Konkretan prostor romaneskne i dramske radnje u vidu terase, balkona i bolnice tumači se kao prelazan u odnosu na graničnu poziciju junaka između života i smrti. Pozitivno semantizovanje ništavila pred Galebovu operaciju i Olgina potreba za Bogom, na kraju Hristićeve drame, markiraju se kao razlike u razvijanju motiva, dok se preplavljenost suncem nakon ozdravljenja i svijest da treba samo umrijeti markiraju kao dva tipa olakšanja nakon drame egzistencije.

Ključne riječi: Vladan Desnica, Jovan Hristić, kontemplacija, prelaz, pomirenost, smrt

Unapred misliti o smrti znači unapred misliti o slobodi. Mišel de Montenj

okušavajući da pronađemo nova značenja i drugačija razumijevanja ljudskog kraja u književnosti, stavljamo u istu ravan dva krajnje različita književna ostvarenja. Njihova žanrovska i poetička različitost ukazuju na različite puteve kojima se dolazi do odgovora na isto pitanje, u čemu ćemo pokušati pronaći suštinsku srodnost prilikom bavljenja vječnim pitanjem postavljenim pred čovjeka. U tom smislu ćemo vidjeti razliku između Desnice i Hristića na planu (ne)prepuštenosti književnih junaka, ali i njihovu sličnost u dostizanju olakšanja neophodnog da bi drama egzistencije dobila svoj epilog.

Prisustvo smrti koja se neprestano naslućuje, nagovještava i otvoreno očekuje jeste ono što najviše spaja ovaj Desničin roman o violinisti koji leži u bolnici kontemplirajući o proljećima i smrti i Hristićevu dramu u kojoj je dramska napetost koncentrisana oko bolesti mlade žene čiji je kraj izvjestan od početka, i čija neizlječiva bolest zaokuplja ostale juna- 
ke. Budući da same fabule ne ostvaruju mnogo analogija, istraživačku pažnju potrebno je usmjeriti na razvoj zajedničkog im motiva smrti i njegove implikacije u djelima. Pri tome se misli na veze između pojedinačnih detalja, koje otvaraju mogućnosti komparativnog tumačenja i postavljanja obojice autora u širi kontekst. Na početku, potrebno je uočiti da oba ova djela, iako pripadaju različitim književnim rodovima, zanemaruju radnju u pravom smislu te riječi. Ona zanemaruju onu aktivnost književnih junaka koja nam pomaže pri oštrom ocrtavanju fabule. Umjesto akcije imamo, dakle, posla sa kontemplacijom. Umjesto kretanja prisutno je mirovanje. Galeb je upućen na bolnicu u kojoj se nalazi, i na sjećanja o kojima govori, ali ne i na neki konkretan pokret, na akciju. Hristićevi junaci, slično tome, svoje vrijeme provode na terasi, u razgovoru ili u mnogoznačnoj tišini. Mogli bismo postaviti pitanje da li upravo blizina smrti utiče na takvu koncepciju i da li u danima do nje mora izostajati konkretno kretanje kako bi se smrt odložila ili kako bi se vrijeme usporilo. Kraj Hristićeve drame biva ispunjen naglim pokretima svih junaka - odlascima sa terase nakon važnih odluka. Poređenje pomenutog sa sudbinama Desničinih junaka do kraja će nam pomoći da provjerimo izrečenu pretpostavku. Mjesto njihovog boravka, bolnicu i terasu, označićemo kao prelazne prostore na kojima su se književni likovi zaustavili kako bi sagledali pređeni put, ali i kako bi potencijalno nastavili dalje. Sadržajni obrisi dana pred smrt upućuju na različite rukavce njihove zaokupljenosti koja se pred neminovnošću gotovo identično sužava u jedno korito. U oba slučaja nastupa olakšanje, a ono se može tumačiti na nekoliko načina.

U poredbenoj situaciji koju postavljamo između Desnice i Hristića imamo posla sa prirodnom smrću posredstvom bolesti. Motiv bolesti uključuje ljekare i medicinu kao činioce njenog mogućeg odlaganja, ali ne i sprječavanja, kao što se to na jednom mjestu u drami i kazuje. Na početku drame zatičemo doktora Ivana koji prvim uzvikom sugeriše suvišnost svakog objašnjavanja pred neminovnošću koja slijedi, a koja će dramsku radnju pritiskati do njenog kraja: „Šta da kažem?" njava prostor između Hristićevih junaka. Doktor koji priznaje da nema načina da se spase, a kao prijatelj bolesne žene ne može da joj ispriča ,jednu od onih lekarskih priča “2 sam predstavlja svoju profesiju kao pokušaj odlaganja smrti koji hoće da bude njeno sprječavanje. Istu svijest sa druge strane, iz perspektive pacijenta, izražava Ivan Galeb kojem doktor kaže da će im svirati kad ozdravi, što on, iako neočekivano ganut, racionalno komentariše: „Bolesnik voli i takav površan optimizam. “3 Desnica ipak ostavlja prostora za sunčan dan koji će medicina Galebu donijeti, nasuprot Hristiću, koji suočavanje ljekara s neizlječivom bolešću predstavlja kao izliv apsolutnog obesmišljenja čitave profesije. Hristićev Ivan od bolesti pravi doktorsku disertaciju, i u tome prepoznaje samo zanat i ništa drugo, jer ništa više nije sposoban da uradi, a prema njegovom ljudskom osjećanju morao bi. Ovakvi prvobitni stavovi prema mogućnostima ozdravljenja pokazuju čitaocu izvjesnost Olgine smrti i neizvjesnost Galebove. U Olginom odnosu prema bolesti nema prostora ni za neočekivanu ganutost, koja bi bila trenutno zavaravanje da je sve u redu, kao što joj je pri izlasku iz bolnice rečeno.

Jovan Hristić, Terasa, Beograd 2004., 9.

Isto.

Vladan Desnica, Proljeća Ivana Galeba, Beograd 1981., 59. 
Doktorove pretpostavke o ljudima koji svijest o skorašnjoj smrti projektuju u samoubistvo realizovane su u priči koju je Desnica inkorporirao u svoj roman. Junak te priče medicini nije pružio priliku. Riječ je o pripovjeci poznatoj pod nazivom Balkon, a koja tematizuje čovjekov strah od smrti pod samoiniciranom pretpostavkom da ima rak. Provodeći svoje dane pred smrt na balkonu jedne zgrade, posmatrajući odatle svijet od kojeg se udaljava, neimenovani čovjek implicitno izražava skepsu prema medicinskoj pomoći - nije joj povjerio ni običnu provjeru simptoma koje osjeća, a obdukcija nakon smrti pokazuje da on rak nije ni imao. Narator taj podatak smatra nevažnim za samu priču, kao neki post scriptum koji se tek onako nadodaje priči. U tome, $s$ jedne strane, čitamo neminovnost smrti koja se u datom času dogodi bez obzira na konkretne okolnosti, a sa druge strane, taj post scriptum biva ono najvažnije što je autor imao da kaže. Čovjekova potreba „da ipak nekako obilježi, da ipak nečim podvuče svoju smrt; da ona ne bude baš sasvim neznatna, sasvim nezapažena “4 objašnjava suvišnost činjenice da on nije ni bio bolestan, odnosno - njemu je bilo potrebno „da ipak saljude zainteresira, kointeresira, za se i za nju“.

Upotreba ovih riječi sa saučesničkim značenjem naglašava ljudski strah od smrti u kojoj se biva sam. Ovaj junak upravo zato skače na ulicu, među prolaznike. I Olga iz Hristićeve drame zato želi da se vrati u bolnicu iako je puštena kući: kod kuće osjeća jaz koji njena bolest pravi između nje i njenog muža. U istom kontekstu Olga ne pronalazi način da zauzme svoje mjesto u njihovoj kući, u haosu koji bez nje funkcioniše; ona ne želi ni da siđe do plaže, da započne bilo šta, suočena sa sviješću o svom neizvjesnom trajanju. Ona se od početka pribiližava iracionalnom svijetu Blankine umrle porodice - što na nivou sličnosti sa njenom preminulom kćerkom i osjećanjem pripadnosti u toj nepoznatoj kući u kojoj nema pravog života, što insistiranjem na upotrebi predmeta preminulih, i do kraja svjesnim prepuštanjem muža mladoj djevojci u postupku poklanjanja haljine, o čemu će još biti riječi. Olgin prezir prema životu, kakav joj je do kraja preostao, van konteksta ljudskog straha od smrti biva ono zbog čega je njeno ljetovanje postalo samo ćutanje na terasi. Još je Montenj pisao o osjećanju života pri svijesti o skorašnjoj smrti:

Ako je smrt brza i nasilna, nemamo vremena da od nje strahujemo; ako nije takva, primećujem da što dublje ulazim u bolest, to prirodnije počinjem da osećam izvestan prezir prema životu. ${ }^{6}$

Zanimljivo je da samoubica bira balkon kao mjesto svoje fantazije o smrti. Privremena utjeha koju je na tom mjestu sticao poticala je od male krpice vedrine koja je naslućivala lijepo vrijeme i „nešto neodređeno obećavala“.7 Istovremeno, to je i mjesto njegovog posljednjeg koraka, koraka kojim je skočio u smrt. Hristićevi junaci dolaze na ljetovanje iznajmivši kuću izvjesne Blanke - posljednjeg živog ukućanina, što implicira svojevrstan prostor umrlih - kako bi pobjegli od Olgine smrti, ili kako bi se $s$ njome suočili. Terasa te kuće biva mjesto na kojem provode najviše vremena, i predstavljena je kao prostor nji-

4 Isto, 108. Videti i: Vladan Desnica, „Balkon“, Pripovijetke (= Sabrana djela Vladana Desnice, knj. 3), Zagreb 1974., 341-343.

5 V. Desnica, Proljeća Ivana Galeba, 108.

6 Mišel de Montenj, Ogledi, Beograd 1967., 35.

7 V. Desnica, Proljeća Ivana Galeba, 108. 
hove kontemplacije, prostor tišine i slutnje, jer se sa terase mora nekuda krenuti. I terasa i balkon su ovdje simboli prostora odluke i suočavanja sa situacijom kakva jeste. Potreba za izmještanjem prisutna je i kod Desnice i kod Hristića. Izmještanje je moguće vidjeti kao bježanje i kao vid pokušaja introspekcije. S jedne strane, primjećeno je da se Desničini junaci ne kreću ka nečemu, nego gotovo uvijek od nečega, što „znači da kretanje u sebi sadrži komponentu bežanja“ “, 8 dok, sa druge, imamo neprestano suočavanje: „Probdio sam duge noći, sred bijele mistike bolnice, u kontemplaciji smrti. Licem u lice s njom. ${ }^{\text {“9 }}$ Takve dve perspektive ogoljene su i u sljedećem Olginom iskazu:

Negde sam pročitala: „Sama sam i siromašna sam, jer mi ne treba ni ono što imam.“ To je rekao neko ko se već oprostio, ko je već na drugoj strani... Izgledalo mi je strašno, zato što sam videla samo ovu stranu, našu stranu. Ona je strašna. To je zato što sam gledala sa pogrešne strane, a treba samo sve preokrenuti. Kao da izlazim iz kuće, i sobu u kojoj sam živela gledam spolja, sa ulice. Postane drukčija, i odjednom shvatim da u onome zašta sam mislila da je nered postoji neki red... Htela sam da uredim, ali sad vidim da ne treba ništa uređivati. Treba samo izaći. Jednostavno se okrenuti i izaći. ${ }^{10}$

Konkretan arhitektonski izgled terase / balkona upućuje na prostor koji se nastavlja na unutrašnji ali stremi ka spoljašnjosti koja se ne može potpuno doseći. U tome kontekstu se usuđujemo da ga tumačimo kao prelazni prostor između dva stanja. Na to se nadovezuje i bolnica u kojoj Galeb boravi u procesu ozdravljenja. Sva tri mjesta bivaju prostori kontemplacije i razmišljanja o smrti, između ostalog. U tome kontekstu dani pred smrt u ovim djelima prepoznaju se kao postupni polazak iz života i navikavanje na misao o sopstvenom kraju. Analogno tome, govoreći o smrti Montenj na jednom mjestu navodi kao prvu stavku:

Da bismo tom dušmaninu oduzeli najveću prednost nad nama, postupimo obratno od onog što većina čini. Oduzmimo mu neobičnost, opštimo sa njim, navikavajmo se na njega, i najčešće od svega mislimo na smrt. ${ }^{11}$

Ako je to ono što čine i Desničini i Hristićevi junaci, pa i pisci pišući o tome, onda njihova djela moramo razumjeti kao borbu protiv iste te smrti, ali ne u kontekstu vječnog života posredstvom književnosti, već u smislu navikavanja na nestajanje kao takvo. Budući da ono što nam je blisko doživljavamo kao obično i poznato, smrt bi mogla, ako je učinimo običnom, postati upravo bliža, a čovjek u toj bliskosti, kao u svakoj drugoj, slobodniji. U razrađivanju te misli Montenj i zaključuje da „unapred misliti o smrti znači unapred misliti o slobodi“" 12 što, navedeno kao moto ovoga teksta, upućuje upravo na krajnju otvorenost i potencijalnu smirenost koju dani pred smrt u ovim djelima nude, paradoksalno, sa strahom i neprihvatanjem u svijesti o smrti koja je predstavljena iz perspektive Ivana Galeba kao dječaka ili doktora Ivana i Vladana u Terasi.

\footnotetext{
8 Slobodan Vladušić, „Desnica i postmoderni plutajući subjekt“, Godišnjak Filozofskog fakulteta u Novom Sadu, 41/2016., br. 1, 507.

9 V. Desnica, Proljeća Ivana Galeba, 97.

10 J. Hristić, Terasa, 45.

11 M. Montenj, Ogledi, 30.

12 Isto.
} 
Naime, mladi Ivan Galeb u svom djetinjstvu, u pregršti besmrtnosti, smatrao je da je smrt samo za druge, da „ona pripada ne- $j a^{\text {“ }},{ }^{13}$ jer je dijete svjesno samo onoga čemu je mjerilo njegovo sopstveno postojanje. „Iz svesti o jedinstvenosti i nenadoknadivosti svoga 'ja' izrasta stalna intenzivna zaokupljenost Desničinog junaka problemima nestajanja“, reći će Nikola Milošević. ${ }^{14} \mathrm{Da}$ i odrasli ljudi žive u zabludi da se smrt i bolest dešavaju samo drugima, primjer nam je Hristićev Vladan, koji odbija da registruje podsvjesno saznanje da će mu žena, Olga, umrijeti. On se brani jednom vrstom razonode od onoga što je neminovno: odlazi na kupanje, da roni, u lov. Zarad bježanja od smrti Vladan se okreće Veri i novoj, nabujaloj životnoj struji kojom njen lik odiše. Nasuprot Olgi, koja pravi svečanu večeru koristeći posuđe preminulih ukućana, i koja skuplja rasute dijelove Ivanove disertacije koju u stvari čini njena bolest, Vera djeluje kao jedini lik u drami koji nema dodira sa smrću. I ona do kraja ostaje takva, ne prihvatajući ni haljinu koju joj Olga poklanja - kao simbol onog života koji više nije njen. Gledajući u Veri sve ono što je u njoj bolest pregazila, osjećajući se starom i sebi stranom u ogledalu, Olga joj poklanja haljinu koju je to veče prvi put obukla, i shvatila da u njoj nema više onoga što bi haljinu mladosti moglo da nosi. Saznajući za njihov zajednički odlazak, Olga na taj simbolički način prihvata njegov izbor da pobjegne od nje koja nestaje i da počne nešto iz početka.

Vladan dolazi iz njihove sobe pod svježim utiskom Olginog buncanja u snu: „Hteo sam da pružim ruku, da je umirim. Ali to je odjednom za mene bila druga žena, žena koju ne poznajem. ${ }^{\text {"15 }}$ Ovaj iskaz podsjeća na motiv koji Desnica razvija u Proljećima, a vezan je za lica spavajućih, i Galebovo zaziranje od njih. Galeb priznaje, na više mjesta, da je to uvijek u njemu rađalo „neki panični provalijski nesrazmjer“ te, analogno Vladanovom zaziranju od žene, zaključuje da „između usnulog i budnog supružnika (...) legne udaljenost od čitavih eona, od čitavih geoloških doba" ${ }^{16}$ udaljenost koja između bolesnog i zdravog supružnika postaje još veća. U ovakvom poređenju sa Galebovom panikom od lica spavajućih otkriva se da Vladan svoju ženu ne poznaje, zato što se na njenom licu usnule, i u njenom buncanju, ogleda sva istina o njenoj bolesti i smrti, istina od koje je on pokušavao pobjeći. Galebova analogija između lica umrlih i lica spavajućih, koja bi, kao i ova prva, trebalo prekriti maramom, otvara upravo pitanje straha od smrti i svega što je nalik na nju. Otuda Olga ne prepoznaje samu sebe u ogledalu, plašeći se suočavanja sa nestajanjem, kao što Vladan ne prepoznajući je dok spava, nju onu koja je bila, okreće nov list, list života koji obećava nešto više nego što su predsmrtni dani i unapred izgubljena bitka. Taj život je Vera i Pariz, ali prvo odlazak sa terase, koji djeluje kao prelomni trenutak i za njega i za Ivana, koji nedugo za njim takođe izlazi sa svojim stvarima, i odlazi.

Značajan dio Terase, važan za ovu temu, jeste Olgin monolog na kraju drame. Ta žena koja je smrtno bolesna, iako je jedno od značenja njenog imena upravo paradoksalno zdrava, „kao da polako nestaje tokom drame, kao da je već postala sena“. ${ }^{17}$ Ona ne dobija

13 V. Desnica, Proljeća Ivana Galeba, 74.

14 Nikola Milošević, „Duh modernog vremena u Proljećima Ivana Galeba“, Zidanica na pesku, Beograd 1978., 63.

15 J. Hristić, Terasa, 26.

16 V. Desnica, Proljéća Ivana Galeba, 60.

17 Vesna D. Crepuljarević, „Čin peti: Terasa“, Zbornik Matice srpske za scenske umetnosti i muziku, 49/2013., 157. 
odgovor na molbu upućenu Ivanu da ostane još malo, niti odgovor na posljednja pitanja koja se odnose na izbrojani ostatak života. Didaskalije navode kako „Olga načini nekoliko koraka po terasi, onda odjednom krikne, kao životinja izbezumljena od straha“ ${ }^{18}$ pokušavajući da potvrdi da je još tu, iako uplašena i sama, ali još prisutna. Taj krik proizvodi saznanje da su njeni dani, nakon odlaska dvojice najbližih ljudi, postali samo dani pred smrt.

U petoj slici ona je i dalje sama na terasi, ali vidno pribranija. Pokušavajući da skupi ono malo egzistencije što joj je ostalo, i svijesti o sebi, ona se otvara tek tu, na kraju. Slično Galebu, koji je sam i zahvalan što je sam jer zna kako je mučno posjećivanje samrtnika, Olga konstatuje da je bolje što su svi otišli. Obraća se zamišljenom Ivanu iskazujući da zna sve što je tonulo u njihovo ćutanje:

Sećaš li se kako sam otišla iz bolnice? (...) Bilo mi je važno da izađem, da što pre dođem kući. I tek kad si otišao, meni je palo na pamet da me tog dana nijednom nisi pogledao u oči. Stalno si gledao nekud pored mene, kao da više ne postojim. (...) Kada sam se iz bolnice vratila kući, sve je bilo onako kao što sam mislila da će biti, u spavaćoj sobi nenamešten krevet, u Vladanovoj nered, u kuhinji gomila prljavih tanjira i praznih flaša. Taj nered mi se odjednom učinio kao neki red, koji se napravio bez mene. Kao da više nisam potrebna, kao da više i ne postojim. (...) Ali ti samo ćutiš, Vladan stalno odlazi nekuda, kad se vrati i on ćuti. I ja propadam u to vaše ćutanje kao u provaliju. ${ }^{19}$

U njenim riječima čitamo jasan nesrazmjer između čovjeka kojem je predodređeno skoro nestajanje i onih koji to nestajanje prate nastavljajući svoje živote. Tim njihovim nastavljanjem života, u kojem ona gubi svoje mjesto, Olga tone u nepostojanje dublje nego posredstvom bolesti. Na sličan način Galeb govori iz perspektive samrtnika, konstatujući neiskupivu samoću u smrti:

U takvim časovima i najbliži nam postaju tuđi. Pored nas su - a opet tako daleki. (...) Tako bismo trebali nečiju prisnu blizinu, a tako smo neiskupivo sami! Između njih i nas raspukla je jedna granica, jedan uski no nepremostivi jaz: spadamo u dvije različite vrste, u dva različita svijeta: oni u svijet živih, mi u svijet umirućih. A nema te razlike koja ljude razdvaja tako duboko kao ta. (...) I eto, u krajnjem času, kad nam najviše treba nečija prisna blizina, između nas i naših najbližih, između nas i svega, zaleglo je nešto podmuklo, zalegla je jedna neprelazna tuđost, tuđost laži. I tu nema pomoći. Vidimo ih gdje se pate, a ne možemo da osjetimo njihovu toplinu. Traže riječ u koju bi legla sva prisnost, sva duša, ali takva riječ ne postoji. Skrivaju nam istinu, iz samilosti. Skrivaju nam samilost, iz obzira. (...) Između nas i njih leži nešto premučano, nešto tamno, kao umotan leš..$^{20}$

Njihovo poimanje ono malo preostalog života biva suženo u doživljaj postojanja koje je već sada, dok smrt još nije nastupila, upitno. Olga to vidi u Ivanovom skretanju pogleda i rasporedu zajedničkih stvari u kući u kojoj je živjela sa Vladanom, dok Galeb tu sumnju konstatuje budući u postoperativnom stanju: „U potpunoj tišini, na mahove posumnjam da li uopće postojim.“21 Svjesna da „mora da se sredi, da mora nešto da uradi“", kako govori u svom monologu, Olga više ne pronalazi nikakav smisao i počinje da se pita, eksplicirajući potrebu za jednim iracionalnim osloncem:

\footnotetext{
18 J. Hristić, Terasa, 50.

19 Isto, 51-52.

20 V. Desnica, Proljeća Ivana Galeba, 335.

21 Isto, 341.
} 
Ne znam da li ti postojiš ili ne postojiš, ali ne bi smeo da nas ostaviš. Mora postojati neko ko će nam pomoći. Mora postojati neko ko će biti jači od nas i moćniji od nas. Mi smo suviše slabi i suviše nemoćni da bismo na svetu mogli postojati samo mi, i niko više. Počni da postojiš. Počni da postojišn $!^{22}$

Njeno obraćanje Bogu na kraju djeluje kao očajnički pokušaj borbe sa samoćom pred smrt koja je čeka. Kao zamišljeni odgovor ili konkretizovano ćutanje Hristić u dijaloškom rasporedu navodi vjetar i more. Olgine uzvike zamjenjuje smijeh i potom smirena konstatacija: „I šta onda? To je sve! Treba samo..." ${ }^{23}$ Stiče se utisak da zamišljenim odgovorima dobija potrebno olakšanje. Ona takođe odlazi sa terase, kao prelaznog prostora, ali, za razliku od Ivana i Vladana, Olga ne odlazi sa svojim, ili bilo kakvim stvarima, već zbacuje sa sebe sve, sluteći da joj tamo kuda ide ništa ne treba.

Njen odlazak u nagosti, zbacivanjem ogrtača, može predstavljati simboličku smrt, odlazak iz života doveden u analošku vezu sa dolaskom u život, sa rođenjem. Osim toga, ovakav njen gest asocira nas na Desničinog junaka koji kreće svim putevima delte, oslobađajući se svega što je do tada činilo njegov identitet, uključujući i odjeću. I Hristić i Desnica na ovom mjestu iskazuju potrebu svojih junaka da odahnu od misterije smrti i dosegnu lakoću kojom pobjeđuju ovozemaljske granice. Desničin narator smišlja priču kojom pokušava riješiti enigmu nestanka jednog bezimenog, po svemu neodređenog čovjeka. Njegova rekonstrukcija događaja ide u pravcu odlaska putem koji vodi uvijek napred, a ne dovodi nikamo, u pravcu kretanja deltom mogućnosti koja je rješenje problema izbora, jer predstavlja izbor svega. Obrnuto proporcionalna, Olgina situacija, u kojoj je pravi problem nemanje izbora, kao razrješenje sluti jedino apsolutnu rezignaciju. No ne čini se da je Hristić kraj svoje drame označio tako. Hristićeva junakinja se od Desničinih junaka razlikuje po težnji ka iracionalnom, duhovnom osloncu koji joj može dati nadu da terasa sa koje odlazi nije posljednje što će vidjeti, i da za dostizanje mira iz kakvog je rođenjem došla, treba samo - umrijeti. Čovjek koji polazi deltom mogućnosti čezne samo da se ne probudi, jer bi život značio izbor, i njegovu težinu. Otuda i on i Olga bivaju simbolički laki u nestajanju.

Imajući u vidu da Desničin čovjek samoubica, kao i čovjek iz delte, te sam Ivan Galeb teže ka jednom vidu ništavila koje njihovom biću, nespremnom za akciju i izbor, najbolje odgovara, primjećuje se da predsmrtni dani u njihovom slučaju djeluju kao pokušaj olakšanja od tjeskobe egzistencije. Gradeći potpuno drugačije aktere sa sličnom nespremnošću u stvarnim životnim okolnostima, Hristić u svojoj drami junakinju dovodi do potrebe za Bogom kao osloncem, a onda do simboličnog povratka u prenatalno. Galebovo ozdravljenje sugeriše Desničin optimizam uprkos kontemplacijama o ništavilu, dok Olgina nagost pomireno kreće ništavilu u susret, u ubjeđenju da će tamo nešto početi da postoji. Prihvatanje da se umre donosi mir, i odlazak sa terase i iz bolnice implicira kraj predsmrtnih dana, jer smrt je, pomirenošću s njom samom, pobijeđena. Pomirenost je sloboda koju bi čovjek u susretu sa svojom smrtnosti morao sebi priuštiti.

22 J. Hristić, Terasa, 52-53.

23 Isto, 53. 


\section{$\cos$}

\section{Literatura}

Vesna D. Crepuljarević, „Čin peti: Terasa“, Zbornik Matice srpske za scenske umetnosti i muziku, 49/2013., 153-168.

Vladan Desnica, „Balkon“, Pripovijetke (= Sabrana djela Vladana Desnice, knj. 3), Zagreb 1974., 341-343.

Vladan Desnica, Proljeća Ivana Galeba, Beograd 1981.

Jovan Hristić, Terasa, Beograd 2004.

Nikola MilošEvić, „Duh modernog vremena u Proljećima Ivana Galeba“, Zidanica na pesku. Književnost i metafizika, Beograd 1978., 59-77.

Mišel de MontenJ, Ogledi, Beograd 1967.

Slobodan Vladušıć, „Desnica i postmoderni plutajući subjekt“, Godišnjak Filozofskog fakulteta u Novom Sadu, 41/2016., br. 1, 497-510.

\section{$\cos$}

\section{The Days PRECEDing DEATH IN JOVAN HRISTIĆ'S PLAY Terasa and Vladan Desnica's novel Proljé́a IVANa GALEBA}

The paper contains a comparative analysis of some segments of Vladan Desnica's novel Proljeća Ivana Galeba (The Springs of Ivan Galeb) and Jovan Hristićs play Terasa (The Terrace). The initial interpretation draws on the central motif of death, which is explored in both literary works. While analyzing the motif of death, we focus on the days preceding death, that is, the premortal period of several characters from Desnica's well-known novel: Ivan Galeb, the man who commits suicide and the man from the delta chapter, as well as a woman from Hristićs play whose death is also imminent. Our focus is then expanded in the context of the philosophy reflected in the experience of death, as depicted in these two literary works. The typological analogies with Montaigne's and Pascal's understanding of death are also addressed. The setting of the hospital and the balcony, or the terrace, is interpreted as a transitional space in terms of the characters' position in the space between life and death. The positive connotations ascribed to death before Galeb's surgery and Olga's need for God at the end of Hristić's play are seen as differences in treating the motif, while being flooded by sunlight after recovery and the awareness that dying is the only thing that all one really has to do is die are seen as two types of relief following existential drama. Galeb's recovery after having spent so many endless days teetering on the brink of death is a reflection of Desnica's optimism. Hristić's female protagonist, on the other hand, symbolises a return to the prenatal, a closing of the circle of life, while waiting for God, who must not abandon us, to begin to exist. The drama of existence precedes a reconciliation with the world and with oneself, either in life or in death.

Key words: Vladan Desnica, Jovan Hristić, contemplation, transition, reconciliation, death 


\section{STRAH OD SMRTI U ROMANU ZIMSKO LJETOVANJE VLADANA DESNICE}

\section{Melida Travančić}

UDK: 821.163.42-311.1Desnica, V.:364.27

Prethodno priopćenje

Sažetak: Autorica se bavi jednim od dosad slabije istraženih značenjskih slojeva romana Zimsko ljetovanje - strahom od smrti. Roman prati sudbinu grupe ljudi koji nakon bombardiranja Zadra bježe iz grada u obližnje selo Smiljevci. Desnica koristi povijesni okvir Drugoga svjetskog rata da bi prikazao sudbine malih, marginalnih ljudi, ali rat u ovom romanu nije tema po sebi, već je prikazan kao povijesni uzročnik koji proizvodi susret dvije grupe ljudi i njihovih kultura, koje se teško ili nikako ne prihvataju, a koje su prisiljene živjeti u zajednici. Strah od smrti zapravo je tematsko-motivska okosnica romana, dok rat ostaje tek mizanscenski prisutan. Roman donosi psihološku sliku stradanja pojedinaca, nad čijim se životima oslikava smrt kao posljedica povijesne tragedije čovječanstva. U Zimskom ljetovanju smrt je data kao sastavni dio života, ona je u svijesti i podsvijesti te pokreće i određuje stvari i događaje.

Ključne riječi: Vladan Desnica, Zimsko ljetovanje, strah, smrt, rat, psihološki lom, drugi

oman Zimsko ljetovanje (1950.) Vladana Desnice prati sudbinu grupe ljudi koji zbog ratnih dešavanja ostaju bez zavičaja, pripadnosti i perspektive. ${ }^{1}$ Radnja obuhvata period od 1943. do 1944., odnosno počinje bombardiranjem Zadra od strane savezničkih snaga. Iako je radnja smještena u povijesni kontekst Drugoga svjetskog rata, ovaj roman nije primjer klasične ratne, odnosno poslijeratne književnosti. Izuzmu li se drugo - unutar

1 O ovom je romanu već bilo riječi na dosadašnjim Desničinim susretima, ali su se autori bavili drugim aspektima. V. Davor Dukić, „Nekoliko imagoloških opaski o Zimskom ljetovanju i Desničinim susretima“, Desničini susreti 2005. - 2008. Zbornik radova (ur. Drago Roksandić i Ivana Cvijović Javorina), Zagreb 2010., 149-156; Zoran Kravar, „Zimsko ljetovanje Vladana Desnice pod ideološkokritičkim lećama“, Desničini susreti 2010. Zbornik radova (ur. Drago Roksandić i Ivana Cvijović Javorina), Zagreb 2011., 9-17; Tihomir Brajović, „Ironija i kolektivna memorija: Desnica, Krleža, Andrić“, Isto, 31-38; Luca VAGLio, „Vidovi policentrizma i problematičnosti u romanu Zimsko ljetovanje Vladana Desnice“, Isto, 101-108; Miljenko BulJAC, „Poetika Zimskog ljetovanja - prvi tipološki krug literarnosti Vladana Desnice“, Vladan Desnica i Split 1920. - 1945. Zbornik radova sa znanstvenog skupa Desničini susreti 2014. (ur. Drago Roksandić i Ivana Cvijović Javorina), Zagreb 2015., 343-358; Vladimir Rismondo, „Roman Zimsko ljetovanje Vladana Desnice u svjetlu kulturalnih studija“, Split $i$ Vladan Desnica 1918. - 1945.: umjetničko stvaralaštvo izmedu kulture i politike. Zbornik radova sa znanstvenog skupa Desničini susreti 2015. (ur. Drago Roksandić i Ivana Cvijović Javorina), Zagreb 2016., 131-143; Marina Protrka Štimec, „'Kineskim zidom odvojeni’. Politike identiteta, nejednakosti i isključivanja u Desničinu Zimskom ljetovanju“, Hrvatsko-srpski / srpsko-hrvatski interkulturalizam danas. Zbornik radova s medunarodnoga znanstvenog skupa Desničini susreti 2016. (ur. Drago Roksandić), 
kojeg se najavljuje ratna katastrofa - i treće poglavlje - u kojem se direktno govori o avionskim napadima i njihovim posljedicama - tokom cijelog romana rat nije u prvom planu. On jeste svojevrsni pokretač radnje, jer od njega, to jest od njegovih posljedica, grupa Zadrana bježi u obližnje selo. Međutim, čim pronađu utočište, rat se potiskuje u drugu stranu. Tako da je i u govoru likova rat „prisutan onoliko koliko je odgovoran za njihov trenutni inkomoditet, ali je odsutan kao političkopovijesni događaj“.2 „Buka istorije“ (Kiš) ovdje se javlja u pozadini radnje; iako autor nastoji da se ogradi od tog historijskog loma, on je ipak mizanscenski kontinuirano prisutan. Unutar Zimskog ljetovanja umnogome se potvrđuje upravo ono što Hamvaš izdvaja kao karakteristiku romana s historijskim diskursom u pozadini: „Pored takozvane realne istorije roman postavlja čovekovu ličnu povest. Katkada i nasuprot njoj. Ali u svakom slučaju s odvojenim početkom, onu prethodnu katkada presecajući, nekada ostajući izvan nje, nekad prodirući u nju (...).“3

U romanu se prikazuju realistični događaji, indirektno se govori o traumama prouzrokovanim ratom, bilježi se potpuni lom (i fizički i duhovni), a sve to na primjeru jedne manje skupine ljudi, izbjeglica. Iz razorenoga grada, pod teretom historijskog loma, u nastojanju da prežive ratne strahote, grupa Zadrana utočište traži u selu Smiljevci nadomak grada, koje je, činilo se, udaljeno od ratnih katastrofa. Desnica koristi povijesni okvir da bi prikazao sudbine malih, marginalizovanih ljudi, ali rat u ovom romanu nije tema po sebi; on je prikazan kao povijesni uzročnik koji proizvodi susret dvije grupe ljudi koji su „podijeljeni civilizacijskom demarkacijom “ ${ }^{\text {“4 }}$ - oni se teško ili nikako ne prihvataju, a prisiljeni su na suživot. Dolaskom i smještanjem u Smiljevce, Zadrani su uvjereni da pronalaze spas od rata i smrti, ali silom prilika nalaze se u novoj, donekle nepoznatoj i umnogome različitoj sredini - za njih je selo „terra incognita, mjesto bez značenja, od kojeg kao da su 'odijeljeni kineskim zidom ili pojasom pustoši', hiljadama, a ne petnaest kilometara“.5 Iako nisu bili udaljeni hiljadama kilometara, ovo je njihov prvi stvarni susret sa selom. Stoga je dolazak na selo za njih „imao donekle čar puta u dalek i egzotičan kraj“, dok su ih seljani „gledali u šutnji, raskolačenih očiju, kao ljude koji dolaze sa drugog svijeta“. ${ }^{6}$ Izbjeglice i mještani u neprestanom su ambivalentnom odnosu privlačenja i odbijanja, primorani ponekad zajedno djelovati (kao što je to slučaj smrti stare popadije), ali su, veoma često, u različitim oblicima sukoba te, na koncu, bez mogućnosti pronalaska vrijednosti koje bi njihove razlike poništile ili barem neutralizirale. ${ }^{7}$ Zadrani prema Smiljevcima i njegovim stanovnicima za-

Zagreb 2017., 199-212. U ovom radu fokus je na strahu od smrti kao pokretaču radnje. O romanu Zimsko ljetovanje napisane su mnogobrojne studije i gotovo da nema ni jednog značenjskog sloja romana koji detaljno nije opserviran, osim možda straha od smrti, koji su mnogi književni teoretičari i kritičari uočili, ali mu nije posvećena dovoljna pažnja. Ponešto je kazano tek u naznakama, no cjelovitog teksta nema. Smrt je prisutna od prvog do posljednjeg poglavlja romana, ona je u svijesti i podsvijesti likova te je zanimljiv način na koji se likovi sa njom nastoje (ne) suočiti.

Bela Hamvaš, Teorija romana, Beograd 1996., 19.

4 Z. Kravar, „Zimsko ljetovanje Vladana Desnice pod ideološkokritičkim lećama“, 12.

5 M. Protrka Štimec, "Kineskim zidom odvojeni'“, 202.

6 Vladan Desnica, Zimsko ljetovanje, Zagreb 1968., 41.

7 Od samog je početka romana egzistencijalna pozicija izbjeglica (razaranje doma, bijeg te dolazak u Smiljevce) beznadežnost i nepripadnost. Oni s vremena na vrijeme odlaze u Zadar (nadziru imovinu, donose preostale vrijednosti, traže dozvolu od vlasti da napuste Zadar i život nastave u Italiji), ali mu više ne pripadaju, ne sudjeluju aktivno u 
uzimaju superioran stav te je jasno postavljena razlika između kulture grada i sela, odnosno „napredne i nazadne kulture“. ${ }^{8}$

Roman obiluje primjerima koji ocrtavaju Desničinu ironiju i distancu od malograđanskih svjetonazora. To je zapravo suština njegove narativne strategije, a ogleda se prije svega kroz reprezentaciju razlika, odnosno predodžbe koje građani „srednje ruke“ imaju o selu i njegovim stanovnicima. Prostor sukoba kultura predočen je odmah na početku te je on jedan od osnovnih slojeva romana koji je realiziran „nizom postupaka u kojima postaje vidljivo da se prividna distanciranost i verizam pripovjedača udružuju s ironijskim iskazima“, a distancirani pripovjedač prikazuje se kao „svjesno hinjeni“ te su opisi likova „na strateškim mjestima obojeni suptilnom ironijom, bezglasnim čuđenjem ili tek znakovitom šutnjom“.? Veliki dio radnje romana postavljen je na odnosu grad - selo, odnosno predodžbama koje imaju jedni o drugima i na tim relacijama može se pratiti asocijativno-aluzivna priča o nesporazumu, nerazumijevanju, time i neprihvatanju drugih, drugačijih kao trajnom stanju čovjekove egzistencije.

Radnja romana prati život u Smiljevcima, sa akcentom na izbjeglicama, čija se sudbina, na kraju, manifestira kao tragična priča o ljudima koji nisu imali nikakav izbor: njihov grad i dom razorio je rat, zatim istom jačinom i njihovu porodicu, a na koncu i njih same. Brojni su primjeri unutar romana o tome kako se rat manifestira i preseljava u/na čovjeka te na koji način uzrokuje potpuni moralni i psihološki lom individue. U potpunosti je ocrtana unutrašnja borba likova da prevladaju nedaće koje su ih zadesile. Najprije se moraju suočiti sa zlom i uništenjem (s početka romana nesvjesni su ozbiljnosti situacije te su prikazani kako hladnokrvno posmatraju bombardiranje), neposredno potom suočavaju se sa smrću (kroz prizore mrtvih na ulici), a zatim bijegom iz grada nastoje spasiti vlastiti život. Međutim, i u Smiljevcima, za koje misle da su sasvim sigurni, nailaze na razne nedaće. Ni ovo mjesto nisu mimoišle ratne katastrofe, koje se nešto drugačije manifestiraju, npr. kroz ubistva suseljana pod okriljem noći, o kojima Smiljevčani kolektivno šute jer se i sami plaše smrti. S jedne strane, roman prikazuje ljudsku težnju da se od smrti umakne, dok je, $s$

njegovom životu. S druge strane, nastanjujući se u Smiljevcima, prestali su biti dio svoga dosadašnjeg svijeta, a nisu u mogućnosti da se integriraju u život sela. Smiljevci zauzimaju takav geografski položaj da Zadrani jasno vide rušenje svoga dosadašnjeg života, čuju eksplozije, posmatraju velike tamne oblake koji se izdižu iznad grada. Razaranje Zadra i smrt sugrađana kod njih ne izaziva nikakve emocije; oni kao da su vremenski daleko od rata, kao da su Smiljevci izmješteni iz realnosti i postoje u „paralelnoj stvarnosti koja samo registrira događaje iz urbanog realiteta“. Posrijedi je zapravo šok, zatim bespomoćnost i apsolutna nemogućnost da se na bilo šta utiče. $S$ druge strane, Smiljevčani nisu neutralni posmatrači, nego „likuju nad sudbinom grada i njegovih stanovnika“ jer Zadrane doživljavaju ,iz perspektive vlastitog normativnog ' jastva'“. Pozicija Smiljevaca, kao i njegovih stanovnika, spram grada, je marginalna. Usp. V. Rismondo, „Roman Zimsko ljetovanje Vladana Desnice u svjetlu kulturalnih studija“, 134.

8 Mirna Sindičić Sabljo, „Predodžbe o ruralnoj sredini u Zimskom ljetovanju Vladana Desnice“, Fluminensia, 23/2011., br. 1, 140. Kroz interdisciplinarnu oblast imagologije autorica se bavi isključivo posmatranjem predodžbi koje u ovom romanu Zadrani imaju spram sela i njegovih stanovnika te se rad i temelji na istraživanju konstrukcije i reprezentacije njihovog/ih identiteta. Predmet istraživanja jesu iskrivljene heteropredodžbe koje Zadrani imaju spram sela i njegovih stanovnika, a takve predodžbe nastale su isključivo zbog nedovoljnog poznavanja drugog. Autorica polazi od činjenice da su urbana i ruralna kultura u potpunosti različite, ali je prvenstveno zanimaju predodžbe i predrasude koje jedna kultura ima o drugoj te način na koji su ove dvije kulture povezane, odnosno kako se slika koju Zadrani grade o selu reflektira (tzv. faza ogledala) na njih same. Rad nema za cilj istinski prikazati pripadnike jedne grupe (Smiljevčane), niti odgovoriti na pitanje ko su i kakvi su oni, već prikazati kako su drugi oblikovani pomoću književnog diskursa.

9 M. Protrka Štimec, „'Kineskim zidom odvojeni'“, 201-202. 
druge strane, prikaz „izgubljene“ grupe ljudi, koja se očajnički trudi prilagoditi životu u vremenu velikih historijskih promjena koje presudno određuju ljudske sudbine, pretvarajući ih nerijetko u tragične.

Tema smrti „opsjeda“ čovječanstvo od njegovog postanka pa nije iznenađujuće što je predmetom brojnih opserviranja u različitim oblastima, a zavisno od fokusa istraživanja pripisuju joj se različita značenja - od sociološkog, psihološkog, medicinskog, teološkog, filozofskog. Također, smrt je veoma česta i značajna tema u umjetnosti (slikarstvo, muzika, film, književnost). Ovdje je, prije svega, važno kazati da se smrt, odnosno strah od nje, u savremenoj kulturi gotovo potpuno negira i prema tom strahu odnosimo se kao da on uopće ne postoji. Freud tvrdi da je naš strah od smrti veoma čudan, jer čovjek se ponaša tako što nastoji smrt „eliminirati iz života“ ili još eksplicitnije konstatira da mi, zapravo, želimo smrt „mrtvo prešutjeti; mislimo na nju - kao na smrt“ ${ }^{10}$ Iz našeg života i ponašanja ne može se zaključiti da smo mi svjesni smrti te da je prepoznajemo kao nešto što je neizbježno i što će sasvim sigurno doći prirodnim slijedom. ${ }^{11}$ Veoma često se zanemaruje činjenica da svi umiremo i da se sasvim sigurno na neki način i u nekom periodu života suočavamo sa strahom od smrti.

Kada govorimo o razumijevanju fenomena smrti i strahu od nje u današnjem društvu, ističu se različita filozofska razmišljanja, koja se mogu podijeliti na dva oprečna gledišta. $S$ jedne strane, filozofi ustrajno nastoje da pronađu zadovoljavajuće osmišljavanje smrti i da životu daju smisao. S druge strane, nemoguće je u današnjem kontekstu govoriti o smrti a da se ne istakne Epikurovo promišljanje koje umnogome karakterizira današnjeg čovjeka. Epikur naglašava da nas se smrt ništa ne tiče, jer provesti život u stalnom promišljanju i strahu od smrti nema nikakvog smisla ni vrijednosti, čovjek se tako lišava sreće jer „dok ima nas nema smrti, kada nastupi smrt tada više nema nas". ${ }^{12}$ Smrt se tako ne tiče ni živih ni mrtvih jer žive ne dodiruje, a mrtvi ne postoje više. Prema Epikuru, glavni uzrok ljudske patnje jeste strah od smrti koji ne dopušta uživanje u životu. Zapravo, epikurejska misao temelji se na tome da se nemamo čega plašiti u slučaju smrti, jer mi smo mrtvi i ništa više ne osjećamo, a zanemaruje se činjenica da se strah od smrti ne sastoji u strahu od stanja koje dolazi nakon nje (barem ne isključivo od tog stanja), već u strahu od blizine smrti. Nema sumnje da je ova Epikurova tvrdnja odličan način potiskivanja osjećaja stra-

10 Sigmund Frojd, Mi i smrt. Našs stav prema smrti: dosad neobjavljeni rukopisi i predavanja (prir. Žarko Martinović i Milica Martinović), Beograd 2001., 39.

11 Sigmun Freud u navedenom predavanju govori o načinu na koji čovjek pretpovijesti i današnji čovjek razumijevaju smrt. Čovjek pretpovijesti se prema smrti odnosi proturječno. $S$ jedne strane, smrt je predstavljala uništenje života, čemu je težio kada je bila riječ o drugom. S druge strane, poricao je smrt, smatrajući je ništavnom. Postavlja se pitanje kako je ovako drastično promišljanje o smrti moglo biti sadržano u jednoj individui. Freud tvrdi da jeste, jer se čovjek odnosi drugačije prema smrti drugog, stranog, neprijatelja, smatrajući je uništenjem života koje on nastoji uzrokovati (rat, ubistvo neprijatelja). Radikalno drugačije stajalište zauzimao je prema vlastitoj smrti ili smrti bližnjih, tako što je smrt poricao i smatrao je ništavnom. Odnos prema smrti od pretpovijesnog čovjeka do danas nije se mnogo promijenio. Smrt kao okončanje (vlastitog) života uvijek je za čovjeka bila nezamisliva i nezbiljska, jer „naše nesvesno zauzima prema smrti isto ono stajalište koje zauzima čovjek pretpovesti“" a takvo stajalište prema smrti jeste da naše nesvjesno uopće ne vjeruje u vlastitu smrt i ne može je pojmiti, tako da je i danas skoro neprihvatljivo govoriti o smrti.

12 Epıkur, „Pismo Menoikeju“, u: Branko BošNJAK, Filozofija od Aristotela do renesanse i odabrani tekstovi filozofa, Zagreb 1983., 145. 
ha od smrti, ali samo do onog trenutka kada se suočimo sa smrću. Svojom blizinom smrt nameće razmišljanje u kojima se strah redovno javlja. Prihvatiti smrt (bez straha) u takvim je situacijama rijetkost. ${ }^{13}$

$\mathrm{Na}$ samom početku romana Zimsko ljetovanje, u trećem poglavlju, smrt je prikazana kroz uništenje grada i iskasapljena tijela koja leže na ulici. Još je potresnija slika ubijenih mališana čija tijela eksplozija podiže u zrak „pa su padajući s visine zapeli na telegrafske žice pored puta; vise tako dječja tjelešca, presumićena preko žice kao djetinje haljinice izvješene na sušenje“. ${ }^{14}$ Pred takvim prizorima smrt preživjelima postaje konkretna i bliska te je nastoje prihvatiti na što jednostavniji i praktičniji način. Likovi se kreću u „prostoru smrti“ (Blanchot), a njenu blizinu osvijestili su i opredmetili onog trenutka kada se suočavaju sa mrtvima na ulici. Nakon bombardiranja i ugledanih prizora mrtvih na ulici preživjelima se otvarala ,jedna nova dimenzija“ $\mathrm{i}$ uporedo $s$ njom ,jedan novi oblik straha" ${ }^{\text {"15 }}$, strah pokrenut recentnim događajem: ratom i smrću. Ovakvo, slobodno možemo kazati, iznenadno suočavanje sa mrtvima, preciznije sa smrću - jer ništa nije dalo nagovijestiti kobne posljedice po građane Zadra - budi u preživjelima spoznaju o jedinoj izvjesnoj čovjekovoj istini: smrti.

Likovi s početka romana uopće ne razmišljaju o smrti, ${ }^{16}$ čak i kada padaju prve bombe, oni ne bježe, jer misle da je sve to „kratkog daha“ i da se njima ništa ne može dogoditi. U potpunosti izostaje svijest o blizini smrti, a time nema ni straha od nje. Međutim, kako smrt postaje sve bliža, želja za preživljavanjem je sve snažnije izražena, a strah od smrti zauzima mjesto glavnog pokretača života. Ovdje je, zapravo, riječ o ljudima koji se nalaze u neposrednoj blizini smrti te su je za jedan trenutak izbjegli, odnosno odgodili. To su učinili bijegom od mrtvih, ali i živih kojima treba pomoć, bijegom od bombi, razaranja, rata, bijegom od/iz doma. Likovi u ovom poglavlju romana u potpunosti su koncentrirani na sebe, na vlastiti opstanak, pri čemu zaboravljaju i na vlastitu porodicu. Ako se u takvim momentima mogu zaboraviti najbliži, onda nije iznenađujuće da u suočavanju sa mrtvima na ulici nema drame svijesti i savjesti. Pored mrtvih tijela prolazi se užurbano, šuteći, pa i ravnodušno, ni jednog trenutka nema emotivne reakcije. U preživjelima preovladava, dakle, „ludi strah i nagon da bježe, s prastarom panikom s kojom su ljudi bježali od gubavaca“. ${ }^{17}$

13 Postoje dva različita mišljenja o tome kako se u čovjeku oblikuje strah od smrti. Prema jednima, on je prirodni fenomen. To je strah koji je u čovjeku prisutan od njegovog rođenja, jer čim se rodimo, počinjemo nositi sa sobom strah od smrti. Nju niko ne može izbjeći; možda samo u nekim periodima našeg života nismo svjesni neizbježnosti smrti, ali strah je prožimajući faktor koji dominira našim životima. Prema drugima, strah od smrti nije urođen, već se javlja tokom čovjekovog razvoja i usko je vezan sa nagonom smrti o kojem je Freud govorio.

14 V. Desnica, Zimsko ljetovanje, 51.

15 Isto, 49.

16 U ovom kontekstu važno je napomenuti da postoje dva suprotna mišljenja o tome kako savladati, odnosno kako se suočiti sa strahom od smrti. Prema jednima, čovjek ne može djelovati ako će stalno misliti na smrt. Jednostavno rečeno, ne bi bilo moguće funkcionisati ako će nam smrt stalno biti „pred očima“ i ako ćemo neprestano biti opterećeni činjenicom da ćemo jednog dana umrijeti. Da bi pojedinac mogao normalno funkcionisati u savremenom svijetu, on ne može i ne smije misliti na smrt. $S$ druge strane, javlja se i mišljenje da čovjek neprestano mora misliti na smrt jer će jedino tako smanjiti svoj strah od nje. Tako npr. Michel de Montaigne u knjizi Ogledi, u poglavlju „Da filozofirati znači navikavati se na smrt", ističe da je meta našeg životnog puta smrt. Ako se nje plašimo, ne možemo da napravimo ni korak naprijed. Neprestano misliti na smrt, znači s njom se suočiti i prevladati strah od umiranja. Čovjek koji u tome uspije, naglašava Michel de Montaigne, jeste slobodan čovjek. V. Mišel de Montenj, Ogledi, Beograd 1967., 30-31. 
Ovaj dio romana reprezentativan je pokazatelj malograđanskog morala u jednoj vanrednoj situaciji, u kojoj je do detalja prikazana zaostalost i egoizam. Spomenimo samo susret s čovjekom u potpunosti izgubljenim i prekrivenim prašinom, pred kojim oni bježe kao pred „spodobom“, strahujući da ih ne dodirne. Preživjeli mrtve ignoriraju jer tako nastoje potisnuti užas koji vide, ne bi li na taj način eliminirali smrt iz svoje neposredne blizine. ${ }^{18}$

U ovom dijelu romana centralno mjesto zauzima Ernesto Doner, čovjek koji se kreće kroz bombardovani grad, bježi od mrtvih uvjeren da tako spašava vlastiti život. ${ }^{19} \mathrm{I}$ on, ali i ostala grupa likova koji se javljaju s početka te preživljavaju zračni napad, pognute glave prolaze pored mrtvih. Nereagiranjem, šutnjom i potiskivanjem prizora mrtvih likovi se brane od činjenice da je smrt sasvim blizu, dok je, s druge strane, njihov bijeg od mrtvih, odnosno smrti, zapravo nesvjesni odbranbeni mehanizam i želja da sve što u tom času vide, užas koji ih okružuje, izbjegnu i prežive. Ovdje je posrijedi racionalni strah za vlastiti život, koji je sasvim realan i u datoj situaciji opravdan jer u čovjeku preovladava nagon da izbjegne ili da barem pokuša izbjeći opasnost. Uvjereni da mrtvima ne mogu pomoći, preživjeli se fokusiraju na sebe i kreću u neizvjesnu borbu za opstanak.

Također, potrebno je naglasiti da je u ovom poglavlju romana riječ o smrti drugog, nekoga ko likovima nije blizak, mrtve čak i ne poznaju ili ih - zaokupljeni sobom - ne mogu prepoznati te zbog njih ne tuguju. Nameće se pitanje šta smrt drugog znači za preživjele, šta ona u njima izaziva? Smrt je uvijek na neki način potresna i podsjeća da ćemo i mi umrijeti, posebno kada je riječ o nasilnoj smrti, a u ovom slučaju riječ je o smrti uzrokovanoj ratom, to jest avionskim bombama. Tako da smrt drugih opominje da se i njihov život ili život njima bliskih ljudi može prekinuti na isti način i svakog časa. $S$ jedne strane, pogled na mrtve stvara strah koji paralizira - pred prizorom otkinutih udova, popolovljenih tijela, otkinute glave, živih zatrpanih ljudi u podrumu bez mogućnosti izbavljenja. S druge je, pak, strane smrt drugog jedini mogući pristup sopstvenoj smrti jer se u trenutku kada gledamo mrtvog drugog mi suočavamo sa svojim najvećim strahom - strahom od smrti, umiranja, raspadanja. Pored svih navedenih značenja, smrt drugog u ovom slučaju ima i značenje javnog događaja koji pokreće zajednicu da reagira, što oni čine bijegom. Tako iz pasivnog stanja - kada na početku romana lijeno posmatraju avione, nesvjesni opasnosti -

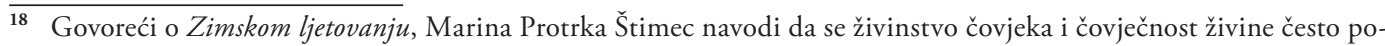
javljuje kao motiv ovog romana. Autorica, pored nekoliko scena koje svjedoče o tome, izdvaja i onu bombardiranja Zadra, naglašavajući da „zaborav drugih, čak i najbližih, okretanje glave od stradalih pod ruševinama dovodi do zaključka o tome kakva je čovjek živina.“ V. M. Protrka Štimec, „Kineskim zidom odvojeni”“, 206. Osim što se ovom slikom prikazuje kolika je čovjek, zapravo, živina, s druge strane, prikazuje se izgubljenost i nemoć čovjeka pred prizorima ratnog užasa, koje za sobom ostavlja avion. Posrijedi je situacija u kojoj se likovi prvi put nalaze šokirani prizorima koje vide, potpuno su izgubljeni, što svakako nije opravdanje za bijeg od povrijeđenih. Iz takve situacije u likovima se isključivo javlja „slijepi nagon samospasavanja“, kako to imenuje Desnica, nemar i nebriga za ostale članove kolektiva, pa i za najbliže.

19 U nastojanju da spasi vlastiti život, Ernesto Doner je u tolikoj mjeri koncentriran na sebe da zaboravlja na porodicu. U tome nije usamljen jer su i ostali ljudi iz grupe prikazane na početku romana, koji bježe pred bombama, zaokupljeni isključivo sobom. Dio u kojem Doner „iznenada“ pomisli na porodicu, zapravo je onaj koji na najreprezentativniji način svjedoči o čovjekovoj koncentriranosti isključivo na sebe i spas vlastitog života: „Nego, tamo negdje, kako je izgledalo baš u pravcu njegove kuće, dizao se velik stup dima. 'Gle boga mu! Dosad nisam ni pomislio na moje! Kao da sam sâm na svijetu!’... Osjeti da je u taj isti čas i u drugima proklijala ista misao. Jer su se svi naglo pokunjili i ponovo ušutjeli. 'Sto mi je od žene, od djeteta?' upita se. Ali ih ni sad ne spomenu. Tek pogleda ispod oka na ostale da provjeri. - Ma l'uomo è proprio una bestia! - izvali Minuči, naoko bez veze. 'A-ha! I kod ostalih je isto!' odlakne Ernestu."V. Desnica, Zimsko ljetovanje, 52. 
prelaze u aktivno stanje, koje se manifestira kroz užurbano sakupljanje neophodnih stvari i bijegom u sela nadomak Zadra.

Ernst Tugendhat u knjizi $O$ smrti postavlja elementarno pitanje: Šta je tačno to od čega strahujemo kada je riječ o strahu od smrti? Tugendhat ne nudi konkretan odgovor, jer takav odgovor i ne postoji, nego objašnjava da je strah od smrti proces koji neizbježno ima subjektivnu polaznu tačku, a na njega utiče pretpostavka o blizini/daljini smrti. ${ }^{20}$ Ovdje likovi vjeruju da će, ako ostanu u gradu, uskoro umrijeti. To je strah od jasno definiranog događaja, u ovom slučaju rata, odnosno bombardiranja kao vanjske prijetnje životu. Tugendhat to imenuje „vegetativnim strahom od smrti“ ${ }^{21}$ On se ispoljava kada neko počne vjerovati da je u opasnosti i da će uskoro umrijeti. Uzrokuje ga niz vanjskih faktora. Takva vrsta straha javlja se, na primjer, u slučaju kada je neko progonjen - jedna prijeteća situacija koja često može da ima (ali i ne mora) smrtni izhod. Ljudi iz grada bježe pred smrću jer su progonjeni užasom rata, a bombe su jasna i dovoljna vanjska prijetnja koja ih pokreće. Tako se i radnja romana premješta iz Zadra u Smiljevce, mjesto u kojem izbjeglice pokušavaju normalno živjeti.

Međutim, ni u Smiljevcima neće naći svoj mir. Prvo se suočavaju sa smrću stare popadije, čiji život, doduše, nije nasilno okončan. I Zadrani i Smiljevčani njenu smrt prihvataju kao nešto neminovno i prirodno. Ta smrt ni na koji način ne utiče na kontinuitet njihovog života. Ravnodušnost nad nesrećom, odnosno smrću drugog, ovdje nije ništa drugačija nego što su to likovi pokazali bježeći od iskasapljenih tijela. I ovdje oni, uslovno kazano, bježe od mrtvaca. Popadija tako ostaje nesahranjena nekoliko dana jer su ljudi zaokupljeni sobom, ne žele remetiti vlastite planove i niko ne može dati kola i konje da se njen leš odveze na groblje i tamo pokopa. U ovoj sceni, prema navodima Radomira Konstantinovića, javlja se osjećanje „opšte samoće i napuštenosti, saznanje da svaki živi samo za sebe“ te ono „raste do monstruoznih razmera". 22 To će potvrditi i Ićan na sprovodu - bacajući grumen zemlje u raku, on će uzviknuti: „Eto joj. Dosta se i naživila!“23

Ni nakon ove smrti nema tugovanja, žalosti ni suza jer bilo bi „deplasirano da su [se], za tako starom i skoro sasvim tuđom osobom, brisale suze ili držale rupčić pod nosom“ “ ${ }^{24}$ Smrt stare popadije još je samo jedan pokazatelj koliko je „prisilna“ zajednica Smiljevčana i Zadrana disfunkcionalna. Naime, riječ je o tome da grupa koja dopušta da neko od njenih članova umre, a da ne bude žalovanja za njim, tj. da ne bude oplakan, samim tim svjedoči koliko toj zajednici nedostaje moralno jedinstvo i kohezija. Nakon ove smrti život se nastavlja uobičajenim tokom, vode se isprazni razgovori da bi se ispunila svakodnevnica. $\mathrm{Ni}$ jednog trenutka u romanu smrt ne budi razmišljanja o onostranom i metafizičkom, već

20 Ernst Tugendhat, $O$ smrti, Loznica 2010., 14. Tugendhat smatra da filozofija može doprinijeti razumijevanju smrti. Polazi od poznatih mišljenja o smrti, za koja smatra da ih, prije svega, treba objasniti, a zatim dopuniti njihove „praznine“. Ističe da ga ne zanimaju mišljenja postavljena na vjeri u život poslije smrti - na ljudsko biće gleda isključivo kao na segment biološkog razvoja. Njega, prije svega, zanima jasna svijest o konačnosti života i blizini/daljini smrti. U fokus svoga istraživanja postavlja pitanje zašto ljudi (čak i veoma stari) žele da odlože trenutak smrti? Naglašava da je nejasno čega se to plašimo kada se plašimo smrti, ako se smrti uopće i plašimo.

21 Isto, 12.

22 Radomir Konstantinović, „Vladan Desnica ili konačna forma“, u: V. Desnica, Zimsko ljetovanje, 183.

23 V. Desnica, Zimsko ljetovanje, 169-170.

24 Isto, 113. 
isključivo o ovozemaljskom i materijalnom. I sami će likovi nekoliko puta ponoviti da je smrt nemoguće izbjeći i da je ona jedino iskustvo koje dijele svi ljudi u svijetu. Tako poslije sprovoda popadije šjor Karlo kaže Ernestu na talijanskom: „Cosi finiremo tutti!“25 Sličnu rečenicu izgovorit će i Zadranin Baldasar Dètriko. Na vijest da je po svoj prilici umro šjor Karlo konstatirat će: „He, šta se može! Tako ćemo, prije ili poslije, svi!“" ${ }^{26} \mathrm{Ni}$ bolest šjora Karla izbjeglice mnogo ne dotiče, vrlo brzo ga prebole i ne znajući sa sigurnošću da li je mrtav ili živ, oni razmišljaju kako da ga pokopaju, da se iznova ne bi suočili sa problemima kakve su imali prilikom sahrane popadije. Bez obzira na smrt koja ih neprestano okružuje, niko od likova ne vjeruje da će baš on uskoro umrijeti jer, riječima Ernesta Donera, „kad smrt najzad dođe, došla je iznenada“. ${ }^{27}$ Potom nastavlja: „To vječito iznenađujuće kod smrti, to je, valjda, njeno, njeno svojstveno, jedan vid njene suštine - naprosto ona sama!" ${ }^{28}$ Prema psihoanalitičkoj školi, ovo je sasvim prirodna čovjekova reakcija jer „duboko u sebi - niko od nas - ne veruje u sopstvenu smrt. Nju uopšte ne možemo da zamislimo. U svim pokušajima da odslikamo ono što će biti posle naše smrti, ko će nas žaliti (...) primećujemo da smo uistinu još uvek tamo, kao posmatrači. “29

Mnogo su strašnije i potresnije vijesti o ubistvima suseljana pod okriljem noći. Ukazujući na neideologičnost Desničinog romana, Zoran Kravar ova ubistva karakterizira kao „krvave obračune među seljacima“, naglašavajući da Desnica njihove protagoniste ne povezuje ni sa jednom ideologijom, odnosno zaraćenom stranom, nego sa „privatnim svađama, sa zapamćenim uvredama i nepravdama i, ponajviše, s moći kojom posjedovanje vatrenog oružija djeluje na dušu seoskog primitivca“. ${ }^{30}$ Strah i uznemirenje za Zadrane, veće i od samih ubistava, predstavljala je nemogućnost govora o tome jer u takvim razgovorima Smiljevčani nisu željeli učestvovati, niti izričito spomenuti počinitelje tih (ne)djela. Razlog za kolektivnu šutnju Smiljevčana o temi ubistava lako je pronaći: strah za vlastiti život. Niko ne zna, možda bolje reći, ne želi da zna, zbog čega se ubistva događaju, ko ih naređuje, niti ko ih izvršava; niko od Smiljevčana ubistva ne osuđuje, čak njihove počinitelje ne naziva pogrdnim imenima, nego se sve prešutno pripisuje momcima od šesnaest, sedamnaest godina koji su uzeli oružje. Pored toga što osjećaju strah za vlastiti život, Smiljevčani šutnjom zapravo ignoriraju te događaje, te u njima ne žele učestvovati ni na koji način, dakle, ni kroz razgovor. Osim straha od smrti, ovdje je prisutan i strah od skrivenog i opasnog drugog.

Smiljevčani od ubistava okreću glavu, jer u njima vide direktnu opasnost za vlastiti život. Na taj način smrt se nastoji potisnuti, ignorirati, a s moralne strane ne čini se ništa da se zločini spriječe. Tako i oni postaju poput Zadrana s početka romana, koji pored mrtvih, ali i povrijeđenih, prolaze šuteći te za spas vlastitog života žrtvuju moralno i etičko u sebi. Za razliku od Smiljevčana, Zadrani će nastojati pronaći odgovor, više iz radoznalosti nego zbog istinskog žaljenja stradalih, pa će tako šjor Karlo nekoliko puta upitati Ićana o ubi-

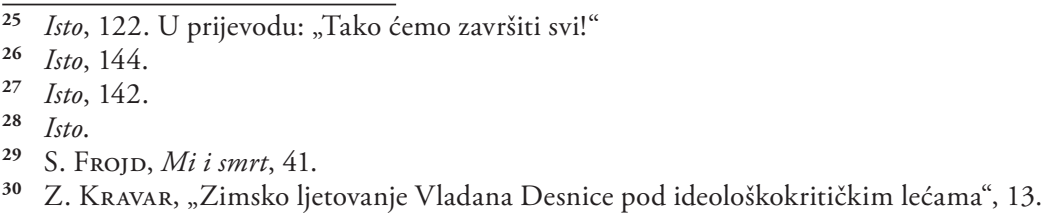


stvima i insistirati na odgovoru. Ićan će, pomalo nervozno, ubistva pripisati ratu, vremenu kada svako može ubiti svakoga, bez bilo kakvih posljedica: „Poškvario se svijet, eto ti! Ovaj rat, ovaj đava, mladost nezaglavljena, svak ima pušku - eto ti šta je."31 Tako rat, odnosno njegove posljedice svoj odjek nalaze i u Smiljevcima, ulivajući strah u njegove stanovnike. Iako su kroz cijeli roman prikazani u nekoj vrsti sukoba, bez mogućnosti preovladavanja razlika, suživota ili uvažavanja onog drugog, Smiljevčani i Zadrani imaju nešto zajedničko: strah od smrti i želju da se preživi rat. $S$ tom razlikom da je intenzitet straha od/pred smrću umnogome drugačiji kod likova ovog romana i nije isti u gradu i selu, za koje se činilo da je udaljeno od ratnih katastrofa. Strah od smrti kod Zadrana s početka romana izuzetno je jasan i konkretan: bombardiranju su izloženi svi stanovnici Zadra. U Smiljevcima je situacija znatno drugačija, nije jasno izražen objekat straha, ubistva se događaju u noći i stradaju „odabrani“. Niko ne zna pravi razlog takvih okrutnosti, ali su svi stanovnici Smiljevaca u strahu - to je strah od nepoznatog, stranog, drugog. Iako se strah drugačije manifestira, ipak je rat svojevrsni pokretač straha jer su i ubistva u selu posljedica rata.

Ovdje je važno upozoriti na još jednu važnu razliku između dvije skupine ljudi i njihovog suočavanja sa strahom: Zadrani pred svojim strahom postaju aktivni. Bježeći iz grada, to jest bježeći od rata kao uzroka straha, oni poduzimaju nešto da svoj strah savladaju, u čemu umnogome i uspijevaju. Dolaskom na selo potiskuju, a ponekad i potpuno zaboravljaju strah od smrti. Smiljevčani, naprotiv, ne poduzimaju ništa da se oslobode svoga straha, odnosno da se suoče s njim te su zapravo pasivni posmatrači događaja. Iako o njemu ne govore, strah pred smrću, odnosno strah da bi i sami mogli postati žrtve, jasno je izražen.

$\mathrm{Na}$ osnovu navedenoga možemo konstatirati da na razini cijelog romana dominira diskurs straha. On se javlja u različitim intenzitetima - snažnije u gradu, a na selu u nešto blažem obliku, no i tamo je itekako prisutan. Osim straha od smrti kao najsnažnije izraženog, ujedno i pokretača radnje romana, javlja se i strah od drugog/drugačijeg, strah od nepoznatog i strah od nasilja. Različito je i na koji način svaki od likova podnosi vlastito stradanje. Ovdje se pod stradanjem ne misli samo na okončanje života ili fizičku bol, nego i na paniku, razaranje doma, gubitak voljene osobe te osjećaj nemoći ili krivnje.

$\mathrm{Na}$ koncu, sve ono od čega su pobjegli, vremenom počinje da proganja likove. Odraz užasnih i mučnih događaja kojim su svjedočili i koje su zatvorili u sebe, smještajući se na sigurno, iz dubine psihe izranja na površinu. Prije svega se to događa kod Enesta Donera. Naknadno i nesvjesno javlja se „prigušeni osjećaj krivnje“ koji se odražava u snovima. Prema Freudu, „san je rezultat naše sopstvene duševne delatnosti““, 32 dok Maury naglašava da „sanjamo o onome što smo videli, rekli, željeli ili uradili““.33 U ovom slučaju Doner je, prvo, svjedočio zastrašujućem prizoru i, drugo, nije ništa uradio za ljude koji umiru. Stoga se u snovima javlja svojevrsni osjećaj krivnje. Tako je vremenom „mirni i bezbrižni Ernesto počeo gubiti živce i zapadati u čamotinju“ te je dvaput „usnio one pokopane u podrumu za bombardmana, ali nekako čudno, u isti mah kao da je i on pokopan s njima". ${ }^{44}$ Simboličnim snom Desnica zapravo osvjetljava unutrašnje stanje Ernesta Donera. On sanja da je

\footnotetext{
V. Desnica, Zimsko ljetovanje, 156.

Sigmund Frojd, Tumačenje snova, sv. 1, Beograd 1970., 52.

33 Isto, 11.
} 
zarobljen zajedno sa ostalim, što zapravo i jeste, samo se to ocrtava na nešto drugačiji način. Posrijedi je dvostruko zarobljeništvo. S jedne strane, riječ je o fizičkom „zarobljeništvu“, koje se manifestira ograničenom putanjom kretanja, životom na selu, kojem ni po čemu ne pripada, bez mogućnosti odlaska/pomjeranja. S druge strane, tu je i moralno „zarobljeništvo“, uzrokovano ravnodušnošću nad tuđom nesrećom. Stoga bismo njegov postupak mogli okarakterizirati kao svojevrsni oblik grijeha, koji se manifestira kroz slike umrlih/ umirućih kojima je svjedočio u budnom stanju, a koje u snovima počinju da ga proganjaju, stvarajući osjećaj krivnje, koji se javlja znatno kasnije, ali se ipak javlja. ${ }^{35}$

Ernesto Doner nije počinio nikakvo zlo, ali nije učinio ni nešto dobro. On je, spašavajući vlastiti život, užurbano prošao pored mrtvih, kao i ljudi zatrpanih u podrumu, kojima je pomoć bila potrebna. Upravo zbog toga što ništa nije učinio, krivnja se manifestira kroz snove, a funkcionira kao moralna opomena. Njegov osjećaj krivnje je racionalan i ima funkciju moralnog usavršavanja jer se neprestano „hvata u koštac“ sa samim sobom, iznova propituje svoje postupke, a osjećaj tuge i mrzovolje jasan je pokazatelj da Doner žali zbog onoga što je propustio uraditi.

$S$ druge strane, njegov se san u simboličkom smislu može protumačiti i kao najava koja dolazi iz dubine nesvjesnog i koja mu arhetipskim šiframa signalizira neumitni kraj, odnosno predskazuje nesreću koja će se uskoro dogoditi. Nesreću sa kojom će se i ostali likovi romana suočiti, ali najprije Ernesto - lik kroz koji se ponajbolje ocrtavaju tragika, apsurdnost rata i čovjekovo nastojanje da od smrti pobjegne. Mirnog i sunčanog poslijepodneva dogodit će se tragedija jača i veća od bilo kakve eksplozije: seoski prasac Migud otkida i proždire dio Špižmičinog lica. Slika stradanja bebe, u kojoj je do detalja opisano kako životinja grize dijelove djevojčičinog tijela, najpotresnija je slika cijelog romana i efektan prizor čovjekovog nestajanja:

Po mekom licu razlio se strah, da se čas kasnije raspline u osmijeh u kome iz krezubih ustašca sinu dva donja sjekutića i umijesi se rupica na obraščićima. (...) Ali, očice su uvijek, i kroz osmijeh, malko zaplašene, i taj osmijeh kao da hoće da učara nepoznatu zlu silu. Migud ponovo njuška; četiri mala udaha, pa izdah (...) dakle, ipak je šala, to se samo igra!... Ali onda, jednim mahom Migud poremeti redoslijed, prekide igru grdnim groktanjem - dijete se uskosi, razložno zamlatara ručicama - i razvaljene ralje životinje padoše po djetencetu. Mala se zacenu - prejak bol zakašnjavao je provalu glasa, tako da je trebalo jezivo dugo vrijeme od ugriza do vriska - lice se jarko zacrveni, vjeđe nabreknuše u debele nabore koji su postepeno modrili, a u četvrtasto razjapljenim ustašcima pokaza se resica pod jezikom.

34 V. Desnica, Zimsko ljetovanje, 147.

35 Marin Biondić objašnjava to ovako: „Osjećaj krivnje može biti racionalan s obzirom na moralno zlo koje smo počinili ili iracionalan ako nismo učinili ništa loše, a ipak osjećamo krivnju. Ovakvo određenje racionalnosti osjećaja krivnje ima svoje opravdanje u samom činu, koji može biti moralno ispravan ili pogrešan. To je prikladnost osjećaja krivnje spram samog čina. S druge strane; bez obzira na prikladnost osjećaja krivnje spram čina; možemo biti racionalni ili iracionalni u stupnju u kojemu dopuštamo da taj osjećaj vlada našim životom. Ukoliko osjećaj krivnje ima funkciju moralnog usavršavanja, možemo ga smatrati racionalnim, ali ako osjećaj krivnje djeluje destruktivno na samu osobu i uništava sve ostale aspekte života, možemo ga smatrati iracionalnim. To je racionalnost osjećaja krivnje spram življenja osobe uopće." Marin Biondić, Smrt. Priroda i vrijednost prenatalnog i postmortalnog nepostojanja, Zagreb 2015., 181. 
Drugi ujed pade na djetinje lice i zbrisa izraz bola prije nego je vrisak i prolomio. Tako se sve svrši bezglasno. ${ }^{36}$

U završnom segmentu naracije Desnica donosi snažan i neočekivan prevrat u radnji i sudbini likova te jednu sasvim drugačiju sliku smrti. Smrt bebe nije rezultat ni ratnog ni ljudskog nasilja, nego životinjske potrebe za hranom. Ova smrt, pored toga što uzrokuje stres i egzistencijalno ništavilo, simbolički ukazuje na svirepost rata i nesreće od koje su ljudi s početka romana pobjegli, uvjereni da

(...) strahote koje su doživjeli i svojim očima vidjeli predstavljaju krajnji ili jedan od krajnjih stepenova zla koje se na svijetu može dogoditi; nešto više i gore od toga njihova mašta nije mogla da zamisli. Odatle je slijedila sigurnost da sve to u najkraće vrijeme mora da prestane, već i zato što se više od toga ne bi moglo podnijeti. ${ }^{37}$

Sigurni da su dolaskom u Smiljevce izbjegli nasilnu smrt uzrokovanu ratom, likovi ovog romana na kraju se suočavaju sa „tragičnim događajem simboličke vrijednosti“ kojim se njihov boravak u Smiljevcima okončava, jer smrću bebe „kao da se najavljuje ishod rata po zadarske građane; neovisno o nacionalnoj i ideološkoj pripadnosti, oni u konačnici bivaju pojedeni od 'drugih'“. 38 Smrt bebe zapravo je pokazatelj u kojoj mjeri rat uništava svaki oblik racionalnog kontinuiteta. Događaj je najtragičniji za roditelje, Ernesta i Lizetu. Upravo su oni, pored Špizmice, najviše stradali jer, prema Freudu, smrt djeteta za roditelje predstavlja uništenje života, vlastitih nada, ponosa i sreće. Ali nakon Špižmičine smrti ništa više nije isto ni za ostale likove; izgubljena je svaka nada i vjera u svijetlu budućnost, a ostaju samo muk, nevjerica, praznina i jasan pokazatelj da nema bijega od smrti i da su oni dolaskom u Smiljevce ne pobjegli, nego za neko vrijeme pomjerili/odgodili vlastitu smrt.

U konačnici romana događa se upravo ono što Maurice Blanchot naglašava kada govori o smrti i čovjekovoj želji da se od nje pobjegne. Zadrani se, na jedno vrijeme, uspijevaju skriti pred smrću, ali „to skrivanje moguće je upravo zato što je sama smrt neprekidno bekstvo ispred smrti, jer je ona dubina prikrivanja. Tako skriti se od nje znači na izvestan način skriti se u njoj. “39 Iako smrt bebe nije njihova vlastita smrt, ona je ta koja ih „uzima“ na kraju - i takvi neodoljivo podsjećaju na posljednju sliku koju su sa sobom ponijeli iz Zadra, sliku mačke zarobljene u pustoj magazi sa zatvorenim prozorima, koja se „verala nemoćno po glačini stakla izgladnjela i užasno omršala“. ${ }^{40}$ Upravo ova slika efektan je prikaz ljudi, izbezumljenih od užasa koji se oko njih događa, a podrum nije nišsta drugo do metafora njihovog života.

Tokom cijelog romana neprestano se nameće pitanje koje u završnici svoga rada $O$ smrti opservira Tugendhat: Zašto se plašimo da uskoro umremo? Prema Tugendhatu, jedini mogući egzistencijalističko-filozofski odgovor glasi: zato što „smrću gubimo priliku da životu

\footnotetext{
6 V. Desnica, Zimsko ljetovanje, 169-170.

Isto, 61.

38 V. Rismondo, „Roman Zimsko ljetovanje Vladana Desnice u svjetlu kulturalnih studija“, 132.

39 Moris Blanšo, Eseji, Beograd 1960., 22.

40 V. Desnica, Zimsko ljetovanje, 66.
} 
damo smisao ili da mu damo više smisla“. ${ }^{41}$ U Zimskom ljetovanju situacija je pomalo drugačija od očekivane, likovi ostaju na životu, ali smrt drugih, posebno smrt bebe, za svakog od likova predstavlja gubljenje smisla i nade u izbavljenje, a život postaje besmisao društvene i pojedinačne egzistencije. Likovi tako, uslovno kazano, umiru jer gube svaku priliku da životu daju neki viši smisao, kako navodi Tugendhat. Smrt je u ovom romanu prisutna od samog početka, i u svijesti i podsvijesti likova, te se reflektira na različite načine: od iskasapljenih tijela na ulici, starosti (popadija Darinka), bolesti (Lina, šjor Karlo, Nikica), preko straha od smrti i misli o nestajanju, koje postaju sastavni dio života.

$\mathrm{Na}$ početku romana bijeg iz razorenoga grada pruža grupi Zadrana nadu da je moguće savladati rat, pobjeći od nesreće i smrti, a na kraju romana ta se nada smrću bebe u potpunosti slama. Bijeg od rata i njihovo uvjerenje da su u tome uspjeli nije ništa drugo do konstantna opomena koliko su, zapravo, blizu smrti. Tematsko-motivsku okosnicu romana čini strah od smrti, koja je ovdje data kao sastavni dio života, ona je u svijesti i podsvijesti, pokreće i određuje stvari i događaje. Iz razorenoga grada smrt se preseljava u čovjeka, prisutna je u svim segmentima njegovog života, postaje dio njegove svakodnevnice, ono bitno egzistencijalno i društveno. Uništenje i prolaznost eksplicitno ili implicitno prisutni su na razini cijelog romana. Osim što prikazuje jedan od najvećih strahova - strah od smrti - te čovjekovo suočavanje sa promjenama u sebi odnosno oko sebe, Desnica ovim romanom „prelazi granice tematiziranog vremena i prostora otvarajući mogućnost čitateljske identifikacije/prepoznavanja u drugim vremenima i na drugim prostorima“. ${ }^{42}$ Prikazom pojedinačnih ljudskih sudbina i konkretnim udesom pojedinaca, kao i prikazom bombardiranja i razaranja grada, Desnica nastoji dati što obuhvatniju i efektniju sliku snažnih historijskih promjena, koje se najčešće i najrazornije odražavaju na živote malih, običnih ljudi, pretvarajući njihove sudbine nerijetko u tragične.

\section{$\cos$}

\section{Literatura}

Marin Biondić, Smrt. Priroda i vrijednost prenatalnog i postmortalnog nepostojanja, Zagreb 2015.

Moris Blanšo, Eseji, Beograd 1960.

Tihomir Brajović, „Ironija i kolektivna memorija: Desnica, Krleža, Andrić“, Desničini susreti 2010. Zbornik radova (ur. Drago Roksandić i Ivana Cvijović Javorina), Zagreb 2011., 31-38.

Miljenko Buljac, „Poetika Zimskog ljetovanja - prvi tipološki krug literarnosti Vladana Desnice“, Vladan Desnica i Split 1920. - 1945. Zbornik radova sa znanstvenog skupa Desničini susreti 2014. (ur. Drago Roksandić i Ivana Cvijović Javorina), Zagreb 2015., 343-358.

Vladan Desnica, Zimsko ljetovanje, Zagreb 1968.

Davor Dukić, „Nekoliko imagoloških opaski o Zimskom ljetovanju i Desničinim susretima“, Desničini susreti 2005. - 2008. Zbornik radova (ur. Drago Roksandić i Ivana Cvijović Javorina), Zagreb 2010., 149-156.

$41 \quad$ E. Tugendhat, $O$ smrti, 36.

42 D. Dukıć, „Nekoliko imagoloških opaski o Zimskom ljetovanju i Desničinim susretima“, 153. 
EpIKur, „Pismo Menoikeju“, u: Branko Bošnjak, Filozofija od Aristotela do renesanse i odabrani tekstovi filozofa, Zagreb 1983., 144-153.

Sigmund Frojd, Mi i smrt. Našstav prema smrti: dosad neobjavljeni rukopisi i predavanja (prir. Žarko Martinović i Milica Martinović), Beograd 2001.

Sigmund Frojd, Tumačenje snova, sv. 1, Beograd 1970.

Bela Hamvaš, Teorija romana, Beograd 1996.

Radomir Konstantinović, „Vladan Desnica ili konačna forma“, u: Vladan Desnica, Zimsko ljetovanje, Sarajevo 1966., 181-186.

Zoran Kravar, „Zimsko ljetovanje Vladana Desnice pod ideološkokritičkim lećama“, Desničini susreti 2010. Zbornik radova (ur. Drago Roksandić i Ivana Cvijović Javorina), Zagreb 2011., 9-17.

Mišel de Montenj, Ogledi, Beograd 1967.

Marina Protrka Štimec, „Kineskim zidom odvojeni'. Politike identiteta, nejednakosti i isključivanja u Desničinu Zimskom ljetovanju“, Hrvatsko-srpski / srpsko-hrvatski interkulturalizam danas. Zbornik radova s medunarodnoga znanstvenog skupa Desničini susreti 2016. (ur. Drago Roksandić), Zagreb 2017., 199-212.

Vladimir Rismondo, „Roman Zimsko ljetovanje Vladana Desnice u svjetlu kulturalnih studija“, Split i Vladan Desnica 1918. - 1945.: umjetničko stvaralaštvo izmecu kulture i politike. Zbornik radova sa znanstvenog skupa Desničini susreti 2015. (ur. Drago Roksandić i Ivana Cvijović Javorina), Zagreb 2016., 131-143.

Mirna Sindičić SABljo, „Predodžbe o ruralnoj sredini u Zimskom ljetovanju Vladana Desnice“, Fluminensia, 23/2011., br. 1, 131-142.

Ernst Tugendhat, O smrti, Loznica 2010.

Luca VAGLIO, „Vidovi policentrizma i problematičnosti u romanu Zimsko ljetovanje Vladana Desnice“, Desničini susreti 2010. Zbornik radova (ur. Drago Roksandić i Ivana Cvijović Javorina), Zagreb 2011., 101-108.

\section{$\cos$}

\section{FEAR of DEATh in Vladan Desnica's NOVEL ZIMSKO LJETOVANJE}

The author explores an often neglected aspect of the novel Zimsko ljetovanje (Summer vacations in winter) - fear of death. The novel follows a group of people who escape the bombing of Zadar and take refuge in the nearby village of Smiljevci. Desnica uses the narrative framework of World War II to show the fates of common, marginalized people, yet the war itself is not a major theme in the book. Instead, it brings about the encounter between two groups of people and their respective cultures. Although unable or outright unwilling to accept each other, these two groups are forced to coexist in the same community. The central theme of the novel is the fear of death, while the war serves as a mere historical backdrop. The novel focuses on the suffering of individuals whose lives are overshadowed by death due to tragic historic circumst ances. Through these individual tragedies, Desnica describes the destructive power of war and evil inherent to all of history. In the novel, death is viewed as a part of life, the driving force behind circumstances and events. In the novel, characters encounter forms of death which, although not caused by bombs, are nevertheless part of the effect that war and its horrors have on the world and the human psyche. An example of this are the murders which take place in the dead of night, leaving the community reluctant to 
find the perpetrators. The most representative example of the way war reaps death even without guns is the tragic death of baby Špižmica which, laden with symbolism, takes place at the end of the novel and is brought about by Migud, the village pig. The fear of death is then replaced by despair and a confrontation with the evil within, as well as without. Thus, in Zimsko ljetovanje, death is portrayed as a part of life, always on the characters' minds either consciously or unconsciously, moving and shaping events and circumstances.

Key words: Vladan Desnica, Zimsko ljetovanje, fear, death, war, mental breakdown, the others 


\section{5. \\ SMRT GRAĐANSKE ELITE \\ U ZIMSKOM LJETOVANJU}

\section{Svetlana Šeatović}

UDK: 821.163.42-311.1Desnica, V.:316.42“194“

Prethodno priopćenje

Sažetak: U radu je analiziran kulturološki i poetički aspekt smrti odnosno skoro potpunog nestanka iz Dalmacije etničkih Italijana, pripadnika srednje i više građanske klase, u Desničinom romanu Zimsko ljetovanje (1950) i, komparativno, u romanu Dalmacijo stara Dalmacijo (1979) Ivana Katušića. Motiv smrti, ratne opasnosti i neposrednog ratnog okruženja predstavljaju istorijske okolnosti Drugog svetskog rata u Zadru, njegovom zaleđu, i u drugim dalmatinskim gradovima. Prva seoba građanskog stanovništva pod velom preteće smrti predstavlja pomeranje u zaleđe, koje predstavlja drugu, ruralnu sredinu. Strah od smrti u građanima iz Zadra podstiče složena antropološka, kulturološka i verska pitanja. Analizom likova pojedinih građana i seljaka ukazuje se na susret i sukob različitih kultura i civilizacija. Smrt će za građane Zadra biti dvostrukog karaktera - prvo seoba i potom konačno iseljavanje. Zimsko ljetovanje najavljuje, mada sa skepsom, klasni prevrat, koji će biti osnova novog socijalističkog uređenja na prostorima Jugoslavije, pa će rad ukazati i na smenu društvenih uređenja koja će se odvijati tokom Drugog svetskog rata i konačan epilog dobiti upravo krajem rata. ${ }^{1}$

Ključne reči: egzil, kontrapunkt, identitet, mentalitet, društvene promene, građanska klasa, urbano, ruralno

[3 opusu Vladana Desnice Dalmacija je sveprisutna zemlja dvojnosti. S jedne strane more i gradovi, Zadar i Split, a sa druge zaleđe, imaginarni Smiljevci, Zagora, rodni Islam Grčki. Nijedan pisac sa prostora Dalmacije nije u modernom periodu bolje razumeo, tumačio i umetnički izatkao antipodnu sliku ovoga regiona. Vladan Desnica je to mogao svojim svestranim obrazovanjem, životnim iskustvom čoveka koji je poreklom iz zaleđa, odrastao u Zadru i Splitu, poznavanjem mentaliteta Vlaja, srpskog i hrvatskog stanovništva u Zagori, ali i visokog građanstva slovenskog i romanskog porekla u urbanim sredinama Zadra i Splita. Zimsko ljetovanje je i taj oksimoronski spoj dvojne Dalmacije, paradoksalnih i bizarnih situacija u kojima su život i smrt dva lica jednog prostora i vremena. Malo

1 Rad je nastao u okviru naučnog projekta Smena poetičkih paradigmi u srpskoj knjževnosti 20. veka-nacionalni i evropski kontekst (178016) Instituta za književnost i umetnost, koji finansira Ministarstvo prosvete, nauke i tehnološkog razvoja Republike Srbije. 
bi koji antropolog bolje od Desnice - u njegovom eseju o Mirku Koroliji - opisao taj svet, geoistorijski i mentalitetski:

Dalmacija u svojoj cjelini obuhvata i sjedinjuje razna područja koja se, pod djelovanjem posebnih prirodnih uslova i različitih istorijskih udesa, među sobom dosta oštro razlikuju. U toj zemlji gdje raste i oleandar i grab; gdje uz obalu u maistralu leprša dašak romanskog duha i vije se laka zapadna melopeja, a po zaleđu u buri struji duboko rasni narodni život i gudi primitivni monokord; gdje uz katedrale sa Ticijanima i Veronezima postoje i manastiri u kojima tinja duh srednjevjekovne srpske manastirske obrazovanosti, u kojima caruju krute bizantinske ikone i u kojima se čuvaju zavjeti Nemanjića; gdje pored primorskog trubadura nalazimo i mrgodnog brđanskog kaluđera ljetopisca - u toj zemlji, među raznovrsnim osobitostima koje je uslovila priroda i stvorila istorija, i sjevernodalmatinski kopneni kraj, naseljen izbjeglicama koji su se od 15 . vijeka dalje sklanjali pred Turcima na njegov goli krš i sure visoravni, predstavlja, po svojim specijalnim kulturnim, psihičkim i ekonomskim momentima, jedno izdvojeno područje. ${ }^{2}$

Desnica u eseju o Mirku Koroliji obrazlaže koliko je narod koji je doseljen na taj sirov i primitivan kršs, sa svojom narodom epikom, jednostavno zalutao u latinsko primorje, obeleženo duhovnim uticajem zapadne kulture i politike. U takvom sudaru stanovništva u zaleđu Zadra i građana, neminovan je razdor, zjap koji nastaje već na vratima grada. $\mathrm{Na}$ takvoj liniji se susreću likovi Zimskog ljetovanja iz seoskog ambijenta sa stanovnicima Zadra građanskog i romanskog porekla u jesen 1943. i zimu 1944. godine. Egzil italijanskog građanskog stanovništva iz Splita, u romanu Dalmacijo stara Dalmacijo Ivana Katušića, predstavlja temu veoma blisku Zimskom ljetovanju, ali sa preciznijom slikom i razumevanjem seoskog stanovništva sa pozicije građana. Delimično razumevanje između likova memoarskog romana Ivana Katušića Dalmacijo stara Dalmacijo nalazimo u komunikaciji šjor Bepa, romanskog predstavnika visoke srednje klase Splita, sa stanovnicima sela u Zagori. Šjor Bepo je junak koji ume da prilagodi čak i jezički izraz, prilikom komunikacije sa seljankama od kojih kupuje višnje, ali i da njegov sin Turiddu pomogne pri oslobađanju Marinog sina iz zatvora u Splitu. Svest o pripadanju visokoj građanskoj klasi obrazovanjem, materijalnim statusom, kulturološkim nasleđem ima upravo šjor Bepo Ivaneo. Gospar Ivaneo ume da percipira drugu stranu, koju čine Vlaji, znajući da kultura i obrazovanje nisu u te krajeve stigli voljom njegovih stanovnika, već političkim odlukama vladara.

Likovi Zimskog ljetovanja, koji su predstavnici nižeg građanskog sloja Zadra, nemaju tako široko obrazovanje ni sposobnost da tumače ruralnu stranu iza gradskih vrata. Desničini junaci Zimskog ljetovanja, kao niža građanska klasa, ne znaju sve istorijske razloge koji su njihove domaćine u Smiljevcima doveli na tako nizak civilizacijski nivo. Najistaknutiji lik, šjor Karlo, jednom je bio u pokrajini Alto Adiđe, kod brata poštara, i to je među Desničinim likovima najviši domet saznanja o svetu „preko mora“. Možemo samo da pretpostavimo da je Desnica svesno izabrao baš niži sloj građana, jer bi viša klasa verovatno razumela smiljevačke stanovnike, a sigurno ne bi ni čekala u zaleđu, već bi odmah krenula na drugu stranu Jadrana. Vladan Desnica u eseju o Koroliji može da tumači zaostalost jer je i sam bio predstavnik više građanske klase najšireg obrazovanja:

2 Vladan Desnica, „Mirko Korolija i njegov kraj“, Eseji, članci, pogledi, Beograd 1993., 29. 
Tuđinske vladavine držale su smišljenim programom ovaj živalj u kulturnoj zaostalosti i svim sredstvima ugušivale svaki njegov napor za kulturnim pridizanjem. (...) I kobne posljedice zaostalosti i nerazvijenosti pokazuju se jasno još i danas na psihi tog naroda. Odatle, kao glavna negativna strana, ono jako izraženo nedostajanje duhovnosti i poriva na viši razmah. (...) Dok je nedostajala svaka disciplina duha, razvila se je prirođena bistrina uma i izoštrilo ničim nezamagljeno uočavanje i spoznavanje realnog. Tako se je skorjela ona toliko karakteristična određenost jednog naziranja na svijet, praktičnog, duboko i neumitno materijalističkog. ${ }^{3}$

Zimsko ljetovanje, kao realistički roman, predstavlja izuzetan primer kontapunktnog odnosa dva sveta, dve civilizacije, ruralnog i urbanog, verskih antipoda pravoslavnih seljaka i građana katolika. Do sada je dosta pisano i o sukobu ideoloških tokova u vreme Drugog svetskog rata, koji se odslikavaju u pozadini romana - istovremeni tok četničkog pokreta, partizana i, sa druge strane, fašističkih predstavnika, italijanske vlasti - $\mathrm{u}$ formi reminiscencija kroz epizodu sa Milom Plačidrugom - i aktuelne nemačke okupacione vlasti, koja je preuzela prostor posle kapitulacije Italije u jesen 1943. godine. Uprkos svim dvojstvima na kojima je konstruisana kompozicija i semantika romana, iz te celine možemo sagledati opštiji pogled na Dalmaciju sa zaleđem, koja je mesto smenjivanja vladara, ideologija, naroda. Na tu najdublju istorijsku strukturu Dalmacije ukazuje Ernesto, prilikom polaganja zakletve četničkom vojvodi Duletu. Posle položene zakletve izbeglice iz Zadra smatrale su da je logično, da je to njihova obaveza - jer su ipak dobili azil u zaleđu grada - da se pokore prvoj vlasti koja to od njih zatraži. Međutim, Ernesto posle zakletve jednostavnim iskazom ukazuje na istorijsku kompleksnost Dalmacije: „Jesmo se mi Dalmatinci nazaklinjali kao niko drugi! Ali da ćemo i ovu zakletvu morati da damo, to, bogami, niko ne bi mogao predvidjeti!“4

Apsurd u polaganju četničke zakletve, kao vrhunac kontrapunkta zadarskih izbeglica i ruralnog zaleđa, predstavlja odluka građana da, posle tako neočekivanog gesta u Žagrovcu, svrate u lokalnu krčmu i razvesele se uz jagnjeće pečenje i vino. Tu vrstu odluke, koju je inicirao upravo Ernesto, vidimo kao oblik katarzičkog doživljaja celokupne situacije topla jagnjetina sa ražnja i vino zbrisaće sve besmislice ljudi građanskog sloja, uglavnom romanskog porekla i katoličke vere. Dakle, apsurd je bio potpun, kao i oksimoron kojim je šjor Karlo njihov boravak na selu nazvao „zimsko ljetovanje“. Boravak građana u Smiljevcima predstavlja, dakle, oblik egzotičnog putovanja; on će, dok traje lepo vreme, imati odlike avanture, a kada stignu kiše i sumorno vreme, oko katoličkog Božića i Nove godine, izbeglicama iz Zadra doneće tugu i gorčinu. Zbog toga njihov položaj možemo imenovati pozicijom „emigranata“ i „egzota“, kako ovaj termin uvodi Cvetan Todorov. ${ }^{5}$ Prisilno izgnanstvo ili emigrantstvo, egzil, doživljavaju se kao egzotično putovanje, čime se anesteziraju prvi utisci i doživljaji realnog stanja.

Vraćajući se sa četničke zakletve, noću, u Smiljevce, šjor Karlo, kao junak filozofskih opservacija, izvrsno opisuje kako je i boravak na selu u ratno vreme dovoljan da čovek do-

Isto, 30-31.

$4 \quad$ Vladan Desnica, Zimsko ljetovanje, Beograd 1993., 129.

5 Videti: Cvetan Todorov, Mi i drugi. Francuska misao o ljudskoj raznolikosti, Beograd 1994., 332-333. 
živi svetska i neverovatna čuda. Svako mesto na svetu je teatar u malom pa zbog toga i šjor Karlo, koji je obrazovan, koji je čak video italijansku pokrajinu Alto Adiđe, zaključuje:

Razlagao je kako nam se život, i pored njegove prividne jednoličnosti, ako se samo malo dublje i pozornije razmotri, pokazuje u stvari vrlo složen, pun neočekivanog i, ukoliko samo nije tragičan, vrlo zanimljiv. Da stoga, na koncu konca, čovjek može da doživi u Smiljevcima ili u Žagrovcu neke čudne i neobjašnjive stvari i da dođe u svakojake situacije, ne manje nego u San Francisku ili u Jokohami. ${ }^{6}$

Teritorijalna, verska i nacionalna razlika građana iz Zadra i seljaka iz Smiljevaca veoma je slikovito predstavljena i iskazom šjor Karlovog prijatelja Pompe Bauka, koji nije hteo da napusti grad iako je on već sav u ruševinama, obrazlažući svoju odluku ovako:

(...) tu sam se rodio i tu hoću i da umrem. A osim toga, bojim se da me tamo, u Morlakiji,

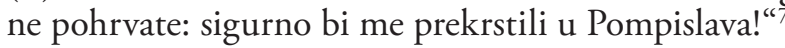

Dakle, prethodno usađene predstave stanovnika Zadra o narodu u zaleđu i u najgorim egzistencijanim trenucima izazivaju stereotipne predstave obeležene međusobnim nepoverenjem:

Susreti među kulturama otpočinju od nulte tačke, od tabula rasae. Gotovo svaki susret je - uglavnom nesvesno - određen i ranijim kontaktima ili istorijskim iskustvom sa drugom kulturom, sačuvanim u kolektivnom pamćenju. Gotovo svaki kulturni kontakt stoga je određen i sopstvenim ili prenesenim iskustvom koje je ostavilo konkretan trag ili dobilo izraz u specifičnim predstavama o drugom. ${ }^{8}$

Desnica tek ovlašno provlači, kroz glas pripovedača ili izveštaje likova izbeglica, da ljudi iz Zadra odlaze i „preko mora“, i tako posredno saznajemo za dobrovoljni egzil brojnih stanovnika koji napuštaju grad emigrirajući u Italiju. Reč je svakako o građanskom srednjem i višem sloju stanovništva romanskog porekla, koji su želeli da napuste Zadar izložen stalnom bombardovanju, mesto na kome posle kapitulacije Italije nisu videli nikakvu perspektivu. Tako Desnica iz centralnog odnosa stanovnika Smiljevaca i izbeglica iz Zadra razvija i posredne tokove, koji ukazuju na složenu situaciju u jeku Drugog svetskog rata. Tome doprinosi i posredna informacija, koja stiže do smiljevačkih izbeglica, da je čak i porodica Vidošević otišla u Italiju, a ona sasvim sigurno nije samo romanskog porekla.

Ićanova grupa izbeglica, na čelu sa Ernestom, planirala je takođe odlazak u Italiju jer u Zadru nisu videli mogućnosti za nastavak života. Iz toga se isključuje samo šjor Karlo sa Anitom. On otvoreno kazuje da je njima ostalo još malo godina, i da u nekim godinama nema smisla odlaziti „preko mora“. Osim egzistencijalnh razloga i veoma diskretno nagoveštenih smena društvenih uređenja, nalazimo i starosni faktor kao odlučujuću okolnost koja likove dovodi u poziciju prve seobe ili trajnog iseljenja u Italiju. Tako se u Smiljevcima oko Nove godine donose odluke o egzilu građana koji su se nadali povratku u Zadar, da bi

\footnotetext{
V. Desnica, Zimsko ljetovanje, 130-131.

7 Isto, 152.

8 Klaus Rot, Slike u glavama. Ogledi o narodnoj kulturi u jugoistočnoj Evropi, Beograd 2000., 270.
} 
tokom jeseni i zime shvatili da je odlazak preko mora jedino rešenje. Tada se gube njihovi egzotični doživljaji prve seobe, da bi se, potom, brzo transformisali u tugu, žaljenje na teške uslove života, vlagu, na stalne priče o „udaranju krmka“ i, na kraju, u bizarnu naturalističku scenu u kojoj svinja Migud jede malu Špižmicu. Na taj način se, i direktno, junaci Zimskog ljetovanja uvode u izbeglička putešestvija, koja se neće završiti u Smiljevcima, već se taj put nastavlja u pravcu Italije (mada će se za neke od njih završiti upravo tragičnim krajem devojčice Špižmice).

Prvo iseljenje iz Zadra građana srednje i niže klase romanskog porekla odvija se pod okolnostima neposrednog bombardovanja, i predstvalja za sve njih samo privremeno rešenje. Međutim, druga seoba, i konačan egzil, mnogo je kompleksnija odluka, koja je posledica ratnih okolnosti, ekonomskih prilika i postojanja tri različita vojna tabora. $\mathrm{Na}$ jednoj strani su, posle italijanskih fašista, u zaleđu nemački vojnici, ali se istovremeno smenjuju i četnički i partizanski odredi. U tako složenoj vojnoj i ideološkoj situaciji, gde jedno selo ili njegova okolina polažu zakletve, gde mladi ljudi odlaze u šumu da bi se priključili partizanskom pokretu dok Nemci pokušavaju da kontrolišu celo to područje - za građane iz Zadra italijanskog porekla tu nema mesta. I tu počinje sasvim izvesna „simbolička smrt“ niže građanske klase u Zadru i zaleđu.

Na drugoj liniji je antipodna situacija između grada Zadra i Zagore; to je vekovni sukob više i niže civilizacije, mešavine kultura, Morlakije, Vlaja i građana Zadra. Taj sukob stvorio je odnos dubokog nepoverenja - antropološku podelu u kojoj nema mogućnosti za razumevanje jer su razlike jezičke, mentalitetske, verske i duboko civilizacijske.

Jovan Cvijić u studiji Psibičke osobine Južnih Slovena razdvaja jadranski i zagorski varijetet na prostoru Dalmacije. Jadranski varijetet predstavljaju doseljenici iz dinarskih krajeva i staro romansko stanovništvo, ali u gradovima duž obale Jadrana. Zagorsku grupu čine doseljenici koji su ostali u krševitim područjima, gde žive u zadrugama tj. porodičnim grupama koje broje i do 80 članova. Odnos stanovništva u zaleđu i predstavnika gradova, pa čak i ostrva, Cvijić opisuje i kroz njihov humor i nadimke, koji nose i jezičke i karakterne osobine. Tako možemo razumeti brojne nadimke i lokalna imenovanja seljaka u Smiljevcima. Cvijić kaže:

Često se u Zagori naiđe na mentalitet, naročito na duh i humor, varijeteta Ere. Porodični nadimci su kod njih češći nego po drugim dinarskim oblastima. Svi, i žene i ljudi, pa čak i deca, imaju nadimke kojima se ukazuje više na njihove moralne ili umne nego na telesne osobine. Uživaju da učine smešnim Bodule, stanovnike jadranskih ostrva, ali im ovi odvraćaju nazivajući ih Vlasima ili Morlacima.

Vladan Desnica, odgovarajući u tekstu „O jednom gradu i o jednoj knjizi“ na brojne negativne kritike i tekst Jože Horvata, podseća na kontekst: istoriju grada Zadra, mentalitet i odnos urbanog stanovništva i naroda koji je živeo u zaleđu grada. Podstaknut, dakle, veoma oštrim kritičkim tekstovima, Desnica prikazuje složene istorijske, političke, ideološke i kulturološke odnose u Zadru, odmah ukazujući budućim čitaocima i tumačima ovoga

9 Jovan Cvijıć, Psihičke osobine Južnih Slovena, Beograd 2006., 127. 
romana da je realistički postupak samo prividan, a da se najkomplikovaniji sudari različitih svetova nalaze u pozadini osnovnog pripovedačkog toka obeleženog kontrastima i oksimoronskim spojevima. Zimsko ljetovanje prevazilazi tu osnovnu liniju sudara urbanog i ruralnog, građanskog ${ }^{10}$ sveta i seoske sredine, koji se odvija i kroz ideološke i mentalitetske razlike, a potom otkriva i u diskretno nagoveštenom egzodusu građana italijanskog porekla. Zadar je, za Desnicu, grad u kome su se vekovima smenjivale tuđinske vlasti, ali napominje da to pitanje nije rešeno ni 1918. godine. U Drugom svetskom ratu Zadar će, kao malo ostrvo pod italijanskom kontrolom, ostati izolovana zona, koja će epilog doživeti posle kapitulacije Italije 1943. godine, što će se najbolje ispoljiti u odlukama izbeglica romanskog porekla tokom jeseni i zime u Smiljevcima. Desnica zatim, kao izuzetan poznavalac prilika u Zadru i zaleđu, obrazlaže posledice formiranja zadarske enklave:

(...) u Rapallu Zadar biva dodijeljen Italiji i pada u posljednje, i možda najteže, svoje sužanjstvo - četvrtstoljetno sužanjstvo Italiji i fašizmu - da najzad tek godine 1944. bude konačno oslobođen i prisajedinjen svojoj pravoj majci zemlji. (...) U novije vrijeme, favoriziran političkom linijom Austro-Ugarske monarhije, koja je podržavala anemičnu i njoj neopasnu talijansku manjinu kao utuk i protutežu slavenskoj većini, taj službeni, birokratski Zadar dosta je brzo asimilirao ne samo dio seoskog življa, koji je neprekidno u nj priticao, nego i onaj činovnički i vojno-činovnički element, koji je Austrija tu dovodila iz svojih gornjih krajeva na više upravne položaje i na skromna činovnička zvanja. Pa, čak i donedavna, za talijanske dominacije između dva svjetska rata, taj birokratski otuđeni Zadar uspijevao je da k sebi privuče i smota po kojeg sirovog sina iz kulturno-zaostalog zaleđa - pokojeg Milu Plačidruga. ${ }^{11}$

U okviru naše teme, koja prati kontrastni odnos ruralnog stanovništva i egzil italijanskih građanskih porodica u Zadru, komparativno nalazimo, i veoma precizno i umetnički kompleksno opisanu sudbinu porodice Ivaneo iz Splita, u romanu Ivana Katušića Dalmacijo stara Dalmacijo. Pozicije Zadra i Splita nisu istovetne, ali je egzil italijanskog građanstva veoma sličnog karaktera. Ivan Katušić se u svom memoarskom romanu usmerava na poziciju porodice italijanskog porekla u Dalmaciji između dva rata, i na njihov dobrovoljni egzodus 1943, prilikom kapitulacije Italije, ali mnogo eksplicitnije i sa manje umetničkih i estetskih postupaka ukazuje na dvojstvo dva sveta. Desničini stavovi o poziciji Zadra u tome periodu veoma su dragocen izvor za razumevanje istorijske, kulturološke i antropološke opozicije selo - grad. Mada je Split bio sasvim drugačije organizovan, posle Rapalskog sporazuma, pozicija italijanske manjine i širi građanski odnos prema zaleđu vrlo su slični onima u Zadru, s tom razlikom što je u Zadru građanska elita bila na još višem nivou, pa je odnos prema Morlakiji bio samo zaoštreniji. Desnica ističe da se upravo u Zadru razvila izuzetna građanska sredina, nažalost zatvorena u sebe i odvojena od svoga zaleđa. Ipak, treba imati u vidu da je takva građanska sredina, ma-

\footnotetext{
10 Videti: Vladimir Rismondo, „Roman Zimsko ljetovanje Vladana Desnice u svjetlu kulturalnih studija“, Split i Vladan Desnica 1918. - 1945.: umjetničko stvaralaštvo između kulture i politike. Zbornik radova sa znanstvenog skupa Desničini susreti 2015. (ur. Drago Roksandić i Ivana Cvijović Javorina), Zagreb 2016., 131-143. Rismondo u navedenom radu ističe odnos "narodnjaštva“ $i$,talijanštva“ kao jedan od osnovnih kulturnih i civilizacijskih oblika u kojima se sudaraju nasleđa likova iz zaleđa i građanskog stanovnišstva.

11 Vladan Desnica, „O jednom gradu i o jednoj knjizi“, Eseji, članci, pogledi, Beograd 1993.,114-115.
} 
da je predstavljala - kako kaže Desnica - „steriliziran prostor“, bila veoma podsticajna u kulturološkom razvoju. Desnica posebno naglašava koliko je daleko otišao taj građanski svet Zadra:

Po toj urbanosti Zadar ne samo da je predstavljao nesumnjivo najgradskiji i najgrađanskiji ambijent kod nas, nego je pripadao valjda među najgrađanskije ambijente evropskog $\mathrm{Za}$ pada. ${ }^{12}$

Do sada je u novijoj literaturi bilo nekoliko novih pogleda na sliku drugog, koja se najbolje razume imagološkim studijama. Davor Dukić u radu „Nekoliko imagoloških opaski o Zimskom ljetovanju i Desničinim susretima“ pruža osnovne pravce u kojima bi se ovaj roman mogao tumačiti kao dobar primer za imagološke studije. U veoma precizno definisanim okvirima Dukić pravi selekciju imagoloških elemenata u Desničinom romanu:

(...) Vladan Desnica je građanski elitist i kozmoplit koji prezire identifikacije ispod razine svjetonazorskog (filozofskog) - etničko, jezično i konfesionalno za njega je akcidentalno i kao takvo ga zapravo ne zanima. To ne znači da pojam identiteta nije operabilan u analizi semantike njegovih djela, kao uostalom i bilo kojeg drugog modernog zapadnog proznog opusa. Rijeć je samo o jednom od onih autora koji tradicionalno shvaćanje kolektivnog identiteta demistificira, ironizira, razgrađuje. Riječima teorije književne semantike Gaje Peleša, u Desničinom romanu psihemsko, a naročito ontemsko važniji su od sociemskog. ${ }^{13}$

Sa ovoga aspekta možemo se složiti sa dosadašnjom selekcijom imagoloških nivoa koje je dao Davor Dukić, na osnovu najbolje literature savremene imagologije. Veoma je značajan Dukićev stav da je psihološki i ontološki status likova značajniji od socioekonomskog, i tu je pravi put na kome se mogu definisati razlike građanskog sloja Zadra u susretu sa seoskim imaginarnim selom Smiljevci. Dubina njihovog razdora nije samo u različitosti ekonomskih i socijalnih slojeva kojima pripadaju, već je ona u psihologiji i mnogo složenijoj antropologiji čoveka zaleđa Dalmacije. Likovi Zimskog ljetovanja iz seoske sredine nisu svesni te antropološke odlike koja je određena istorijskim okolnostima poslednjih 500 godina, oni su prosto određeni svojim naslednim načelima junačkog, herojskog kulta, koji potiče iz narodnog stvaralaštva, jedinog dostupnog izvora saznanja o sopstvu, vremenu i prostoru na kome se obitava. Uza sve to, vremenom su se razvile stereotipne predstave o građanima, koje se neće nikada promeniti, kao što ni građani nikada neće imati poverenja u seosko stanovništvo. Prema već citiranom Klausu Rotu, naše predstave uvek su posledica iskustava i prethodno usađenih saznanja. Posle svega, dakle, između jednih i drugih ostaje samo zid nepoverenja. Samo će šjor Bepo, u Katušićevom romanu Dalmacijo stara Dalmacijo, imati tu vrstu svesti o svome i složenom identitetu Morlakije, ali je za takvo poimanje bila potrebna visoka srednja građanska klasa vanrednog obrazovanja. Zbog toga smo i odabrali ovaj roman, u kome je moguće da junak razume i sebe i drugoga. U Zim-

\footnotetext{
V. Desnica, Zimsko ljetovanje, 116.

13 Davor Dukić, „Nekoliko imagoloških opaski o Zimskom ljetovanju i Desničinim susretima“, Desničini susreti 2005. - 2008. Zbornik radova (ur. Drago Roksandić i Ivana Cvijović Javorina), Zagreb 2010., 155.
} 
skom ljetovanju to nije moguće zbog stereotipnih predstava i nivoa obrazovanja izbeglica iz Zadra. Zoran Kravar u Desničinom romanu vidi te nasleđene stereotipe, i oštru liniju razdvajanja bez mogućnosti samorazumevanja, i zbog toga kaže:

Napokon, u Zimskom ljetovanju na istom se prostoru susreću, zadržavajući naslijeđene stereotipe jedne o drugima, građani i seljaci, ljudi podijeljeni civilizacijskom demarkacijom koja u južnoslavenskim književnostima rijetko ostaje bez ideološke nadinterpretacije, bilo da se pisac, poput Miroslava Krleže u Povratku Filipa Latinovicza ili Milana Begovića u Gigi Barićevoj, oprezno priklanja modernističkom kozmopolitizmu, ili da ostaje na poziciji konzervativnoga ruralizma, poput većine hrvatskih i srpskih realista, ali i niza pisaca iz međuratnoga razdoblja, podjednako onih iz krugova „naprednjačke“ socijalne književnosti i onih okupljenih oko seljačkih i nacionalnih ideologija. U geokulturnom i povijesnom kontekstu koji okružuje tematiku Zimskoga ljetovanja ideologije su, dakle, bile i prisutne i djelotvorne. Kao subliminalne motivacije ili kao deklarirani programi pokretale su milijune ljudi, odlučivale o sadašnjosti i budućnosti velikih političkih sistema, gospodarile životom i smrću. Usprkos tome, Desničin je roman prema toj gigantomahiji ideoloških opcija ostao rezerviran, pozabavivši se diskurzivnom praksom koju danas prepoznajemo kao ideološku samo u usputnim epizodama. ${ }^{14}$

Dakle, neke od novijih analiza idu u pravcu definisanja imagoloških aspekata ili tragaju za ideološkom osnovom koja se pojavljuje samo u pojedinim usputnim epizodama. Tako, posle više od pedeset godina od objavljivanja romana Zimsko ljetovanje, vidimo da su oštre osude Jože Horvata i niz kritika oslonjenih na ideološku osnovu bile samo odjek jednog vremena, kada nije bilo korektno pisati o divljim i surovim egzekucijama mladih partizanskih četa u selima Dalmacije. Naprotiv, danas se jasno vidi da je ta vrsta recepcije bila upravo u ulozi ideologije socijalizma, da je Desničin pripovedački postupak bio usmeren na dvojstvo Dalmacije, koje je mnogo starije od modernih političkih ideologija 19. i 20. veka. Zbog toga možemo danas govoriti o smrti građanske elite, koja nije bila isključivo ideološkog karaktera, već je taj egzil srednjeg i visokog sloja građanskog stanovništva Zadra i Splita bio posledica i identitetskih pripadnosti. Šjor Bepo u Katušićevom romanu, kao antifašista i veletrgovac čija porodica već vekovima živi u Splitu, napušta taj grad sa koferom kostiju svojih predaka i dragim stvarima, 1943. godine, spremajući se za odlazak i pre kapitulacije Italije. Kao predstavnik italijanske manjine jasno zaključuje u kome smeru ide njegov život i život njegovih predaka, čije kosti nosi u koferu. Ipak, mesto koje je odabrao za preseljenje predaka određeno je i putevima drugih izbeglica iz Evrope koje su građanskog porekla, i u seobu polaze iz ideoloških razloga:

Ukratko, već sam kupio grob u Veneciji, na otoku svetog Mihovila... U neposrednom susjedstvu naše grobne parcele - jedan prognani madžarski grof, zatim nepoznati operski pjevač iz Beča i još jedan anonimni pokojnik, kojemu po imenu i prezimenu ne možeš odrediti nacionalnost... Ispada kao da sam se upisao u legiju stranaca (...) ja nemam ništa zajedničko s Mussolinijem, ali on za mene gubi rat... On ga za mene nije mogao dobiti, jer njegova pobjeda nije moja pobjeda, a njegov poraz je i moj poraz. ${ }^{15}$

\footnotetext{
14 Zoran Kravar, „Zimsko ljetovanje Vladana Desnice pod ideološkokritičkim lećama“, Desničini susreti 2010. Zbornik radova (ur. Drago Roksandić i Ivana Cvijović Javorina), Zagreb 2011., 12.

15 Ivan Katušić, Dalmacijo stara Dalmacijo, Split 1979., 291.
} 
Šjor Bepo upisuje svoje pretke i sebe u „legiju stranaca“ $\mathrm{i}$ - iako nije fašista - odlazi jer nije birao Musolinija, ali njegov poraz, kao predstavnika svih Italijana, poraz je i porodice Ivaneo, mada ni na koji način nije učestvovala u ratu.

Komparativnim pogledom na Katušićev roman, mnogo manjih estetskih dometa ali veoma bliske teme - egzila građanskog stanovništva iz Dalmacije, pre svega Zadra i Splita - nalazimo bliske veze sa najdubljim razlozima i namerama Vladana Desnice kada je pisao roman Zimsko ljetovanje. Tu su ideološki razlozi za iseljenje, pa ekonomski, ali pre svega to je pitanje nacionalnog identiteta te dve Dalmacije, latinske i urbane sa jedne strane, a sa druge - slovenske i ruralne. U Katušićevom romanu nalazimo i eksplicitno iznetu sliku o Dalmaciji koju su činili izmešani narodi slovenskog i romanskog porekla, ali je ideologija fašizma postavila nepremostive razlike, i delimično osudila čak i nevine antifašiste italijanskog porekla. Zbog toga će Bepo Ivaneo, i njegov sin Turiddu, koji se još u Rimu priključio komunističkom pokretu, ipak napustiti Split, na iznenađenje njihovog prijatelja Prošpe, auktorijalnog pripovedača romana Dalmacijo stara Dalmacijo.

Desničini junaci nisu spremni da vode ovako složene razgovore o istoriji Dalmacije, smeni ideoloških sistema - njihov pogled dopire samo do sopstvenih malih zanatlijskih radnji i višeg higijensko-sanitarnog oblika života od junaka Smiljevaca i okoline. U Zimskom ljetovanju je odluka o odlasku preko mora više ekonomskog karaktera. To su izbeglice koje su se našle u mutnim vremenima, gde nije jasno kada će prestati savezničko bombardovanje Zadra, a još manje ko će tu vladati. Uprkos saznanju da je Italija kapitulirala, stanovnici Zadra spremaju se za egzil i prijavljuju na liste koje ih vode na brodove što idu na drugu stranu Jadrana. Nigde nema ni reči o učešću u fašističkom pokretu u Zadru bilo kog izbeglice u Smiljevcima, tako da njihova namera da krenu u drugu i konačnu seobu predstavlja samo pokušaj da se sklone u zemlju kojoj pripadaju identitetom, a ne ideološkim opredeljenjem, bežeći tako od komunizma. U Katušićevom romanu i šjor Bepo će potvrditi upravo takav stav, samo sa mnogo više političke i identitetske svesti:

(...) gdje se nalazi Ivaneo - tu je i Italija! Ali poslije crnih skvadrista, kvesturina, karabinjera i Svetog Roka, poslije bičeva i ricinusa - ja više ne mogu ostati na ovoj obali Jadrana. Cijeli Split, cijela Dalmacija znade da Bepo Ivaneo nije bio fašista, ali bih ipak do kraja života morao tumačiti zašto nisam bio fašista, kad su toliki drugi dalmatinski Talijani nosili crne košulje; morao bih pričati kako su crne košulje za mene od samog početka bile znak žalosti! A možda bi bilo najgore, što bi dobrodušna priznanja pojedinaca nosila u sebi blagi okus samilosti. ${ }^{16}$

U Katušićevom romanu nalazimo i Marka, oficira Kraljevine Jugoslavije, koga šjor Bepo štiti, skriva ga na svom imanju izvan Splita, i kada porodica Ivaneo napušta grad, u firmi ostaje ovaj vojnik prethodne države. Markova odluka da ostane u Splitu istovremeno je izbor čoveka koji nije hteo da se pridruži četničkom pokretu a nije mogao da pogazi zakletvu koju je dao kralju, tako da nije bilo ni reči o pristupanju partizanima. Major Marko u Katušićevom romanu kazuje tešku istinu ljudi koji su po sredini, neopredeljenih i odanih sta- 
roj ideji. Svoju sudbinu major definiše jednostavnim iskazom: „ja sam krhotina potonulog broda, krhotina na valovima “. ${ }^{17}$ Sin Bepa Ivanea želi da se, na kraju romana, pre konačnog egzila, pridruži dalmatinskim partizanima jer smatra da je Dalmacija njegov zavičaj, iako se godinama školovao u gimnaziji u Zadru, kao italijanskoj teritoriji, i potom studirao u Rimu. Ipak, osećaj pripadništva Dalmaciji i bliskost s idejama komunizma upućuju ga na ovakav čin. Otac Bepo Ivaneo oštro se protivi toj odluci, ali ne zbog ideoloških razloga, već zbog najsloženijeg saznanja da sa novom Jugoslavijom i stvaranjem novog, jugoslovenskog naroda - Dalmacija nestaje. Taj dijalog oca i sina u Splitu, u trenutku kapitulacije Italije, ideološko je i identitetsko pitanje. Sin Turiddu Ivaneo u dijalogu sa ocem, svesnim svih političkih i viševekovnih naslaga kulture i mentaliteta, odražava stvarno pitanje italijanske manjine koja će napustiti Dalmaciju:

- Želim da postanem Turiddus Dalmaticus - odgovorio je moj prijatelj nakon kratkog razmišljanja. - Dalmaticus? - nasmijao se šjor Bepo, prisilno, gorko. - Nema više Dalmaticus - postoji samo Jugoslavus... - Umjesto Jugoslavus, bolje bi bilo reći: Slavus meridionalis... (...) Doći ćeš u brigadu, imat ćeš crvenu zvijezdu na kapi, ali ćeš im svejedno, morati dokazivati da nisi bio fašista, ni ti ni tvoj otac...18

Tako se u razgovoru oca i sina otkrivaju pravi razlozi zbog kojih nije moguće ostati u Dalmaciji - jer nje više nema, ona je sada projekat komunističke Jugoslavije. Dalmacije nije nestalo u Kraljevini Jugoslaviji jer je kapitalističko uređenje ipak ostavilo stare odnose građanskih klasa, dok nova promena ideološkog tipa sad menja sve konture jednog geografskog, istorijskog, kulturološkog i antropološkog prostora određenog mešavinom naroda. To geografsko i klimatsko dvojstvo sada se potencira, i u njemu više nema mesta za građanstvo. Upravo tako izgleda smrt građanske klase na prostoru Dalmacije, i to posebno onih predstavnika koji su romanskog porekla.

Sudbina takvih porodica dvostruko je uslovljena. Šjor Bepo će sina podsetiti na zavet nona Tona, koji im je ostavio u amanet da moraju biti uz Italiju i kada propada, i zato otac pita sina: „Smijemo li mi napustiti Italiju u ovom trenutku kad je ona na rubu propasti?"19 U memoarskom romanu Dalmacijo stara Dalmacijo kao da progovara Vladan Desnica iz eseja, i sa porodičnim iskustvom predstavnika visoke građanske klase. Sudbina italijanske porodice Ivaneo određena je koliko ideološkim promenama, u kojima oni nisu ni na koji način učestvovali, toliko i osećanjem nacionalne pripadnosti matici zemlji. Tako se preko porodica koje su vekovima živele na jednom prostoru, a identitetski pripadale drugom, manjinskom narodu, prelamaju smene ideoloških sistema.

Katičić je glavnom junaku romana šjor Bepu pružio mogućnost da se jezički slojevito diferencira, pa on govori i kao vlaške seljanke: oponaša njihovu mimiku, gestikulaciju, logiku života, i u potpunosti razume onog drugog predstavnika niže klase i drugog identitetskog porekla. U Desničinom romanu likovi iz grada ni posle nekoliko meseci provedenih na selu, u Smiljevcima, ne mogu jezički da se sporazumevaju sasvim jasno, a logika i isto-

\footnotetext{
7 Isto, 300.

18 Isto, 303-305.

19 Isto, 305.
} 
rijsko nasleđe za njih su apsolutna nepoznanica. Kao što je i sam Desnica kazao - da je u Zimskom ljetovanju pokušao da pokaže fizionomiju grada i sela, kontrapunktnost njihovih mentaliteta i odnos prema osnovnim životnim pojavama, tako možemo videti da je druga seoba zadarskih izbeglica uslovljena ekonomskim, identitetskim i ideološkim razlozima. Katušićev roman Dalmacijo stara Dalmacijo nam, sa manje oštrine, prikazuje dvojstvo Dalmacije - ukazuje se viši stepen u razumevanju drugih, ali nam pruža i kompleksniju umetničku sliku sudbine italijanske porodice visokog građanskog sloja, koja je svesna svih podela i nužnog egzila kao jedinog oblika opstanka. Smrt građanske klase, i one niže u Zimskom ljetovanju i više u Katušićevom romanu, svedoči nam o surovosti istorijskih procesa u kojima pojedinac, bez obzira na ekonomski status, postaje žrtva već pripadanjem određenom narodu i društvenom položaju.

Drugi svetski rat je u Dalmaciji izmenio i strukturu stanovništva i društveno uređenje sa kojim je stigao novi svet, sa drugim vizijama kulture i razvoja. Zimsko ljetovanje je, osim realističkog pripovedanja, dalo i sliku tihe seobe, sa kojom je nestao jedan svet koji je na prostorima Dalmacije živeo vekovima.

\section{$\cos$}

\section{Literatura}

Jovan Cvijić, Psihičke osobine Južnih Slovena, Beograd 2006.

Vladan Desnica, „Mirko Korolija i njegov kraj“, Eseji, članci, pogledi, Beograd 1993., 29-48.

Vladan Desnica, „O jednom gradu i o jednoj knjizi“, Eseji, članci, pogledi, Beograd 1993., 112_ 127.

Vladan Desnica, Zimsko ljetovanje, Beograd 1993.

Davor Dukıć, „Nekoliko imagoloških opaski o Zimskom ljetovanju i Desničinim susretima“, Desničini susreti 2005. - 2008. Zbornik radova (ur. Drago Roksandić i Ivana Cvijović Javorina), Zagreb 2010., 149-156.

Ivan Katušić, Dalmacijo stara Dalmacijo, Split 1979.

Zoran Kravar, „Zimsko ljetovanje Vladana Desnice pod ideološkokritičkim lećama“, Desničini susreti 2010. Zbornik radova (ur. Drago Roksandić i Ivana Cvijović Javorina), Zagreb 2011., 9-17.

Vladimir Rismondo, „Roman Zimsko ljetovanje Vladana Desnice u svjetlu kulturalnih studija“, Split i Vladan Desnica 1918. - 1945.: umjetničko stvaralaštvo izmedu kulture i politike. Zbornik radova sa znanstvenog skupa Desničini susreti 2015. (ur. Drago Roksandić i Ivana Cvijović Javorina), Zagreb 2016., 131-143.

Klaus Rot, Slike u glavama. Ogledi o narodnoj kulturi u jugoistočnoj Evropi, Beograd 2000.

Cvetan Todorov, Mi i drugi. Francuska misao o ljudskoj raznolikosti, Beograd 1994. 


\section{$\cos$}

\section{The DEATH OF THE BOURGEOIS ELITE IN THE NOVEL ZIMSKO LJETOVANJE}

The paper analyses the cultural and social aspects of the metaphorical death, or more specifically the exile, of middle and upper-middle-class ethnic Italians from Dalmlatia, as depicted in Vladan Desnica's 1950 novel Zimsko ljetovanje (Summer vacations in winter) and Ivan Katušić's 1979 novel Dalmacijo, stara Dalmacijo (Dalmatia, old Dalmatia). The motifs of death, the threat of war and its immediate circumstances reflect the events of the Second World War in Zadar, its hinterland and other Dalmatian cities. Drawing from anthropological, historical and geographical interpretations, we have highlighted the many differences between the urban population of Zadar and the rural population of its hinterland. The refugees from Zadar who arrive in Smiljevci belong to the lower middle class and their stereotypical attitudes towards the Morlachs and Maurovlachia are the first source of misunderstanding between the two groups. The first migration of the urban population, caused by the fear of death, represents an encroachment on the hinterland, which is the other, rural environment. The fear of death raises complicated anthropological, cultural and religious issues for the citizens of Zadar. For them, death is twofold, coming first in the form of the move to Smiljevci and then later, because of economic downturn and imminent social changes, in the form of the eventual exile to Italy. The analysis of Katušić's novel Dalmacijo, stara Dalmacijo, with its protagonist, šjor Bepo Ivane, shows the upper class of the Italian bourgeoisie as having a much better understanding both of its own identity and the rural population of the hinterland. Zimsko ljetovanje foreshadows class revolt, which formed the basis for the new socialist system on the territory of the Yugoslavia. Katušić's novel, however, depicts the divide at the heart of Dalmatia as less insurmountable and paints a more complex picture of the fate of a former haute-bourgeois family, aware of social divisions and the inevitability of exile for survival. The death of the bourgeoisie, the lower middle class in Zimsko ljetovanje and the upper middle class in Dalmacijo, stara Dalmacijo alike, indicates the implacability of history, which can make victims out of individuals regardless of their wealth, for the mere fact of belonging to an ethnicity or a social class. World War II changed the structure of the population in Dalmatia, as well as the social system, precipitating the emergence of a new world, with different visions of culture and progress.

Key words: exile, counterpoint, identity, mentality, social change, the bourgeoisie, urban, rural 
16.

\section{THANATOPOLITIKA I IMORTALIZAM \\ U DESNIČINU \\ PRONALASKU ATHANATIKA}

\section{Vinko Drača}

UDK: 821.163.42-311.9Desnica, V.:612.013-047.64

Izvorni znanstveni članak

Sažetak: Pronalazak Athanatika, skica za distopijski roman Vladana Desnice, problematizira pronalazak lijeka koji može učiniti ljude besmrtnima. U ovom radu pokušat će se dokazati kako problem primjene athanatika kao svojevrsnog „eliksira vječne mladosti“, kako je predstavljen u Pronalasku Athanatika, zapravo proizlazi iz sredstava kontrole nad populacijom koje vlade primjenjuju kako bi ograničile širenje lijeka. U samom djelu razlozi ograničavanja širenja lijeka namjerno proizlaze iz upitne neomaltuzijanske pozicije, koja zapravo prikriva želju vladajućih elita, najbolje personificiranih u diktatoru Mamanu/Mamonu, da prigrabe potpunu kontrolu nad životom i smrti stanovništva s pomoću athanatika kao imortalističke tehnologije. Analizom pojmova imortalizma, biopolitike i iz njega izvedenog pojma thanatopolitike nastojat će se prikazati politička dimenzija tehnologije besmrtnosti onako kako je izražena u djelu te će se na temelju te analize pokušati doći do slike političke moći i čovjeka kao političkog bića u Pronalasku Athanatika.

Ključne riječi: Vladan Desnica, thanatopolitika, biopolitika, imortalizam, Athanatik, besmrtnost, moć, distopija

\section{Mammon i POlitičKa Religija: PronalaZAK ATHANATIKA KAO DISTOPIJSKA PROZA}

\footnotetext{
Dronalazak Athanatika prvi je put, u nešto kraćem izdanju, objavljen 1957. godine u časopisu Literatura. ${ }^{1}$ To smješta objavljivanje ove „skice za roman“ pred kraj tridesetogodišnjeg zlatnog razdoblja distopijske književnosti, koje počinje objavljivanjem $\mathrm{Vr}$ log novog svijeta Aldousa Huxleyja 1932. godine, a završava Paklenom narančom Anthonyja Burgessa, objavljenom 1962. Taj trend distopije u visokoj i popularnoj književnoj kulturi nastavit će se u šezdesetima u okviru sve popularnijeg žanra znanstvene fantastike, a većina

1 Krešimir Nemec, „Pronalazak Athanatika - između utopije i distopije“, u: Vladan Desnica, Pronalazak Athanatika, Zagreb 2006., 85.
} 
ključnih djela iz tog perioda dobit će svoje holivudske adaptacije i učiniti distopiju općim mjestom u zapadnjačkom promišljanju svijeta i budućnosti. Ono što se ističe kao zajedničko gotovo svim distopijama nastalim u ovom periodu jest korištenje razvijenom tehnologijom za bolji nadzor populacije: taj motiv javlja se od naprednih sredstava biološkog inženjeringa i subliminalnih poruka u Vrlom novom svijetu, preko telekrana u 1984. Georgea Orwella, do kontrole ponašanja pojedinaca s pomoću klasičnog fiziološkog uvjetovanja u Paklenoj naranči. Pisci distopija opsjednuti su kontrolom, načinima na koje se neograničena moć može protezati i do najmanjeg i najbeznačajnijeg aspekta ljudskih života. Uloga je tehnologije u tom procesu uvijek asimetrična - dok brojne znanstvene utopije nastale u tom vremenu prezentiraju optimističnu viziju tehnološkog napretka, u distopijama tehnologija služi postojećim hijerarhijama, koje se trude učiniti je nedostupnom običnom čovjeku: ona je oruđe koje se usavršava i razvija s ciljem učinkovitijeg očuvanja statusa quo.

Tehnologija u svijetu Pronalaska Athanatika možda nije tako detaljno opisana kao u brojnim drugim znanstveno-fantastičnim romanima; kao i u Orwellovoj 1984., ona se bazira na jednom tehnološkom otkriću - lijeku protiv smrti. Priču o lijeku protiv smrti pripovjedaču govori stanovito „paranoidno pričalo“, odnosno „krezubi vjetrogonja“ za vrijeme jednog dugog kišnog poslijepodneva. ${ }^{2}$ Postavljena je kao skica za roman, odnosno kao razgovor pripovjedača s Krezubim, autorom tog romana. Tijekom cijele radnje pripovjedač iskazuje cinizam prema temi planiranog djela i prema filozofskim promišljanjima na kojima se zasniva radnja: ponegdje se čini kao da Desnica tom pričom izvrgava podsmijehu neke od apokaliptičnih premisa o ljudskoj budućnosti, a nekad kao da uistinu propituje ulogu smrtnosti u političkoj misli. Sâm athanatik proizveden je u jednoj „fantastičnoj zemlji“, u kojoj su već prethodno riješeni svi „socijalni, ekonomski i slični problemi“. ${ }^{3} \mathrm{U}$ priči, doduše, ne znamo ništa o znanstveno-tehnološkim ili političkim mehanizmima s pomoću kojih su ti problemi riješeni, ali umjesto toga dobivamo opis „lijeka za smrt“. Athanatik je sredstvo čija je proizvodnja nevjerojatno jeftina. Budući da se proizvodi od „prezrene, krajnje jeftine materije“, „vrijednost dviju cigareta bolje vrste, približno odgovara cijeni triju ampulica Athanatika". Jedino mu je ograničenje to da mora biti pažljivo doziran jer u manjim dozama uzrokuje neugodnosti i biva potpuno neefikasan. ${ }^{5}$ Unatoč takvoj maloj cijeni proizvodnje i percipiranoj blagodati za čovječanstvo, masovna proizvodnja athanatika nikad nije zaživjela jer je athanatik podvrgnut rigoroznoj kontroli. Potreba za tom kontrolom, čini se, postoji isključivo iz egzistencijalnih i maltuzijanskih strahova. Kako ističe Krezubi: „Vi dobro znate da po ljudskim zakonima mišljenja pravo da zauvijek traju imaju samo stvari koje oduvijek postoje." ${ }^{\text {" }}$

Čini se da u svijetu athanatik koncepcija „postojanja“ mora imati početnu i konačnu točku, odnosno mora biti omeđena. Nažalost, Krezubi nije detaljnije pojasnio iz koje tradicije izvlači svoje „ljudske zakone mišljenja“, već samo da postojanje koje se proteže u be-

\footnotetext{
V. Desnica, Pronalazak Athanatika, 7.

Isto, 10 .

Isto, 20 .

Isto, 14 .

6 Isto, 21.
} 
skraj samo na jednoj strani, tj. koje ima početak, ali ne i definiran kraj, smatra zazornim: „Kako vi to zamišljate, čemu bi sličila ta vječnost, na jednom kraju zatupljena kao lenjir, a na drugom zašiljena kao strijela."

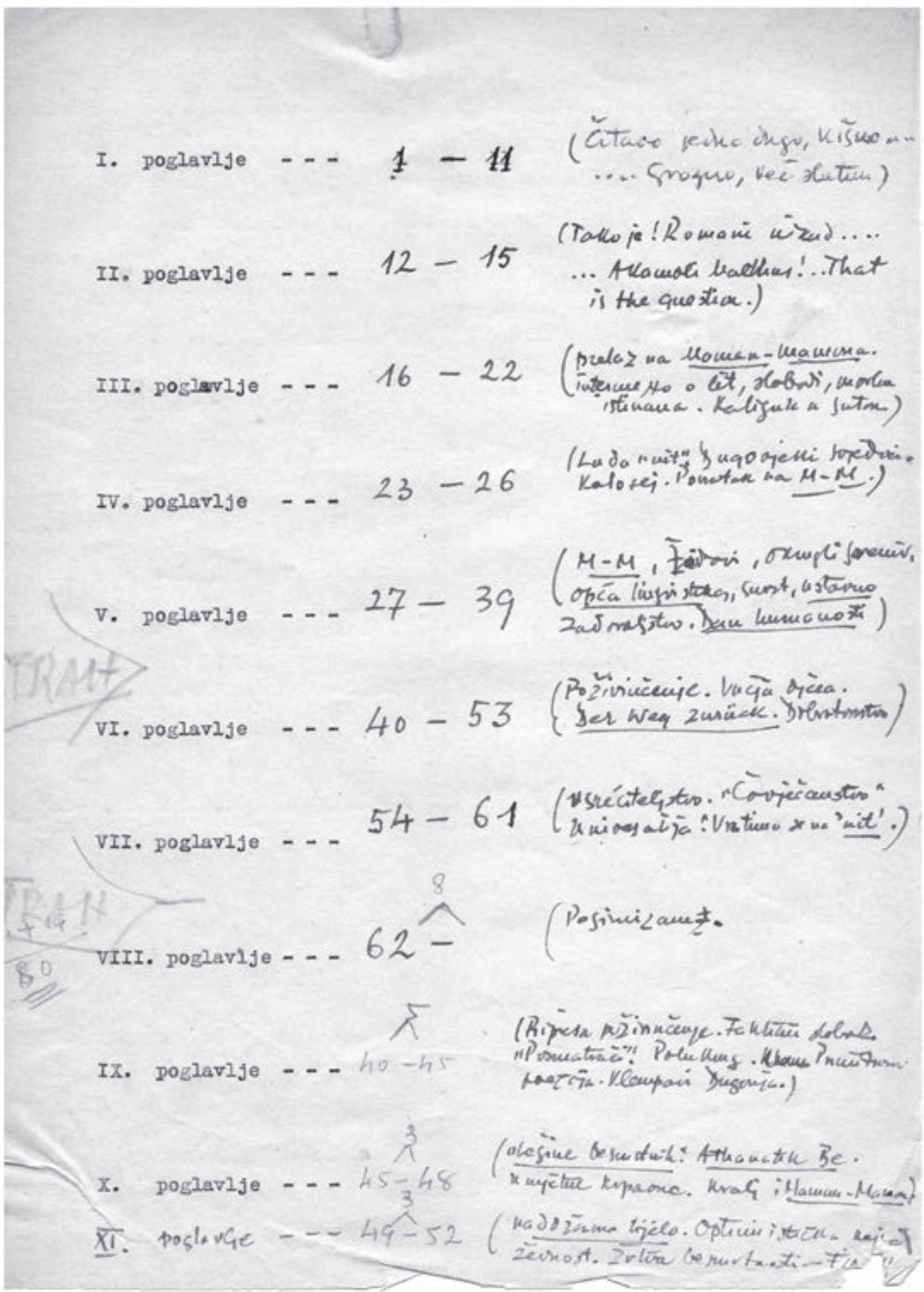

Sl. 1. Pregled poglavlja nedovršena romana Pronalazak Athanatika 
Teško, doduše, možemo zamisliti da je pozivanje Krezubog na neke nedefinirane „ljudske zakone mišljenja“ ovdje slučajno. Čini se da sama ta konstrukcija, kojom se Krezubi koristi kako bi naturalizirao potrebu za kontrolom athanatika unutar svog nenapisanog romana, zapravo služi razotkrivanju ideološkog karaktera te kontrole. Kako bismo lakše vidjeli na koji se način s pomoću ovog citata naznačuje prisutnost političke ideologije kao pokretača radnje u Pronalasku Athanatika, moramo se na trenutak odmaknuti i vidjeti kako taj citat možemo gledati kao iskaz tipičan za religijsko mišljenje te pokušati iznaći poveznicu između religijskog i političkih simboličkih sustava u okviru suvremenih kritičkih proučavanja ideologije.

Prema antropologu Cliffordu Geertzu, religijom možemo nazvati onaj simbolički sustav koji nastoji proizvesti snažna, sveobuhvatna i dugotrajna raspoloženja i motivacije u ljudima formulirajući koncepcije generalnog reda postojanja te zaodijevajući ih u auru činjeničnosti tako da se raspoloženja i motivacije čine jedinstveno stvarnima. ${ }^{8}$ Osjećaj straha i zebnje koju otkriće athanatika prema Krezubom proizvodi u masama i zbog kojeg je njegova proizvodnja ograničena, a primjena podložna političkoj kontroli, ${ }^{9}$ utemeljen je na općenitom zaključku kojim je postojanje kategorija ili vremena zadano definiranim početkom i krajem ili potpune bezvremenosti koja funkcionira onkraj povijesnih kategorija „početka“ $\mathrm{i}$ „Završetka“. Taj pogled na svijet bit će ekspliciran u ustanovljenju religijskog reda „Bratstva poniznih“, koje biva formirano kao reakcija na otkriće besmrtnosti i čija slika svijeta počiva na tabuiziranju geometrijske forme kruga koji za njih predstavlja ljudsku oholu želju da spozna beskonačnost u kojoj se početak i kraj stapaju..$^{10}$ Čini se da je ograničenost ljudske egzistencije ovdje nametnuta kao svojevrsna ideološka koncepcija stvarnosti koja se dovodi u pitanje otkrićem athanatika i koja se onda mora reetablirati kao stvarnija stvarnost s pomoću ritualne zabrane kruga u okviru religije „Bratstva poniznih“. No, taj „ljudski zakon mišljenja“ kao eksplicitno religijska dogma počinje egzistirati tek nakon što nelagoda zbog postojanja athanatika rezultira porastom vjerskog fanatizma - potreba za političkom kontrolom athanatika postoji i prije i čini se da je posljedica određenog maltuzijanizma koji Krezubi također smatra samorazumljivim:

A što bi tek značilo kad bi se ljudski vijek produžio, neću da kažem ad infinitum, ali za samih petnaest ili dvadeset godina. Ta čovječe u roku od par decenija ova bi planeta morala da istodobno hrani dvije, tri, četiri kompletne garniture čovječanstva! A gdje bismo se tek našli za pet, za šest, za deset decenija? Kalifova šahovska tabla s početnim ulogom od zrna pšenice! A kamoli Malthus, moj gospodine! ${ }^{11}$

Svijest o ograničenosti resursa koje zemlja može pružiti populaciji još je jedna ekonomsko-politička dogme na temelju koje se, uz egzistencijalnu dogmu o nužnoj ograničenosti čovjekova postojanja, athanatik ne može neograničeno primjenjivati. Kritike su maltuzijanskih i neomaltuzijanskih koncepcija egzistencije brojne i mnoge su od njih bile prisutne

\footnotetext{
Clifford Geertz, The Interpretation of Cultures, New York 1973., 90.

V. Desnica, Pronalazak Athanatika, 10.

10 Isto, 64-65.

11 Isto, 21.
} 
i u Desničino vrijeme - ideja da besmrtnost znači nekontroliran rast populacije i da rast populacije automatski rezultira nestašicom resursa daleko su od zdravorazumskih, no bez ulaženja u njihovo sveobuhvatno opovrgavanje, kontekst u okviru kojeg su spomenute od strane krezubog paranoika daje naslutiti da su one ideološke prirode i da služe tek kao racionalizacije kontrole nad athanatikom. A kako bi se bolje analizirala priroda te kontrole nad besmrtnošću i vidjelo kako sâm athanatik tom istom logikom postaje sredstvo kontrole, trebamo posegnuti za Foucaltovim pojmom „biomoći“.

\section{BiOMOĆ, IMORTALIZAM I ATHANATIK}

U svojoj seriji predavanja „Društvo se mora zaštititi“, održanoj na Collège de France 1975. i 1976. godine, Michel Foucault uvodi pojmove „biomoći“ i „biopolitike“ kako bi opisao pojavu novih mehanizama kontrole koji se u zapadnom društvu javljaju krajem osamnaestog stoljeća. Pri tome značajna je transformacija iz moći suverena u moć nadzora te moći nadzora u biomoć. Razliku iz tih koncepcija moći možemo jasno pratiti u Foucaultovoj periodizaciji. Moć suverena na način na koji je opisana u Levijatanu Thomasa Hobbesa izvire iz koncepcije države kao tijela koje na neki način u sebi objedinjuje cjelokupnu populaciju i sve funkcije potrebne za upravljanje istom:

Jer umijećem je stvoren onaj veliki LEVIJATAN, nazvan ZAJEDNICOM ili DRŽAVOM (na latinskom CIVITAS), koja nije ništa drugo do umjetni Čovjek, premda je većeg stasa i jačine od onoga prirodnog, čijoj zaštiti i obrani je namijenjena; u njemu je vrhovna vlast umjetna duša, jer daje život i kretanje čitavome tijelu; suci i drugi službenici sudbene i izvršne vlasti su umjetni zglobovi; nagrada i kazna su živci (koji vezuju svaki zglob i ud za sjedište vrhovne vlasti i potiču ga na vršenje svoje dužnosti), jer vrše isto i u prirodnome tijelu; imutak i bogatstvo svih pojedinih dijelova su snaga, njezina namjena je salus populi (dobrobit naroda); savjetnici su pamćenje koje pruža sve stvari nužne za znanje; pravda i zakon su umjetni razum i volja; sloga je zdravlje; pobuna je bolest, građanski rat je smrt. I konačno, sporazumi i ugovori putem kojih su najprije bili stvoreni udovi ovoga političkog tijela, nalikuju, kad ih se skupi i ujedini, onome fiat ili „Stvorimo čovjeka!“ koje je Bog izgovorio pri stvaranju. ${ }^{12}$

Foucault postulira da je Hobbesov koncept suverene vlasti kao duše jedinstvenog tijela zapravo model vladanja zemljom i proizvodima zemlje, a ne ljudima ili populacijom: jedinstveno tijelo zato obuhvaća administrativna tijela, imutak i bogatstvo te sve pravne i političke elemente društvenog ugovora; ono osigurava simboličku apsolutnu moć kojoj se pokoravaju svi sustavi unutar države, ali ne predviđa unificirajući i kontinuiran sustav nadzora koji bi osiguravao djelovanje tih sustava i njihovu direktnu primjenu na populaciju. ${ }^{13}$ Krajem sedamnaestog i početkom osamnaestog stoljeća Foucault percipira nastanak nove vrste moći - moglo je se percipirati još ranije u samostanima i školama, no usavršavanjem

$\overline{12}$ Thomas Hobbes, Levijatan ili grada, oblik i moć crkvene i gradanske države, Zagreb 2004., 11.

13 Michel Foucault, „Society Must Be Defended“. Lectures at the Collège de France 1975-1976, New York $2003 ., 36$. 
tehnika moći ona učinkovito prožima sve aspekte društva. Radi se o moći nadzora nad tijelima kako bi se osigurala njihova puna produktivnost. ${ }^{14}$ Moć nadzora nad individualnim tijelima širenjem sustava kontrole poput državnih cenzusa, popisa stanovništva, javnu medicinu i uvođenje popisa vojno sposobnih stanovnika u svrhu novačenja pretvara u moć koja za svoje subjekte ima cjelokupne populacije. Promjenom kvalitete te moći mijenja se i način na koji ona djeluje na same koncepte života i smrti.

Moć suverena bila je tradicionalno moć nad životom i smrti svojih podanika, no moć nad životom i smrti zapravo ovdje znači upravljanje samo jednim aspektom te binarne opozicije: označava pravo suverena da oduzme nekom život, odnosno da ga ubije. Tu se ne radi o moći da se život podari ili da se pojedincu ili populaciji osigura smrt, već jednostavno o pravu da se ili nekome život oduzme ili ga se pusti da živi. ${ }^{15}$ Biomoć, koja se manifestira potpunijom kontrolom populacije kao tijela (prije svega, njezinom klasifikacijom, segmentiranjem i statističkim opisivanjem svih tijela unutar populacije, na čemu se konstruira jasno opisiva ideja biološkog čovjeka) ima moć izgradnje i oblikovanja života ili njegova onemogućivanja mjerama kontrole populacije. ${ }^{16}$ Jedino utemeljenjem razrađenih i minucioznih sustava kontrole nad populacijom moglo se intencionalno prouzročiti pomore poput Holokausta i Holodomora - moć suverena bila je ograničena na direktnu primjenu sile protiv individualnih tijela, dok biomoć uspijeva djelovati na tijelo populacije s pomoću indirektnih mehanizama nadzora koje nazivamo biopolitikom.

U Pronalasku Athanatika Desnica se koristi žanrom spekulativne fikcije kako bi istražio granice biopolitike koja funkcionira pod uplivom nove tehnologije - one koja omogućuje neograničeno produljenje života. To nije jedino djelo u kojem se Desnica poigravao tim konceptom. Kratka priča Benta Gušter govori o učenjaku koji otkrije lezardin, lijek za sve bolesti, da bi naposljetku počeo spekulirati o načinima izbavljenja besmrtne i uzdignute ljudske vrste ,jednom unitarnom naukom uništenja “. ${ }^{17} \mathrm{U}$ nedovršenoj noveli Čovječanstvo problematiziraju se, pak, problemi altruizma i etike odgovornosti kroz lik znanstvenika Albina koji radi na novom revolucionarnom lijeku ${ }^{18}$. No, tek u Pronalasku Athanatika Desnica dovodi imortalizam u vezu s političkom tehnologijom kontrole. Prije nego što se ekspliciraju tehnologije kontrole koje se u predlošku koji iznosi Krezubi ispleću oko athanatika, treba se detaljnije pozabaviti imortalizmom kao granom transhumanističke i futurološke misli, kao i specifično političkim aspektima imortalizma.

Dvanaestog siječnja 1967. godine dr. James Bedford, umirovljeni profesor na Odsjeku za psihologiju na Sveučilištu u Californiji (University of California), preminuo je nakon komplikacija izazvanih zatajenjem bubrega. Nekoliko trenutaka nakon smrti postao je prva osoba čije je tijelo stavljeno u krioničku suspenziju. ${ }^{19}$ Neprofitna organizacija Alcor Life Extension Foundation danas broji 152 osobe u krioničkoj suspenziji, dok na nju čeka više

\footnotetext{
Isto, 242.

15 Isto, 240-241.

16 Isto.

17 Vladan Desnica, „Benta gušter“, Pripovijetke (= Sabrana djela Vladana Desnice, knj. III), Zagreb 1974., 364.

18 Isti, „Čovječanstvo“, Pripovijetke, 452.

19 Mike Darwin, „Dear Dr. Bedford (and those who will care for you after I do)“ (http://www.alcor.org/Library/html/ BedfordLetter.htm).
} 
od 1500 ljudi. ${ }^{20}$ Tijela tih ljudi zamrznuta su neposredno nakon smrti kako bi se očuvala i kako bi ih se moglo oživjeti jednog dana kada medicina bude napredovala dovoljno da izliječi bolesti od kojih su preminuli i kad im medicinska tehnologija bude omogućila produljenje života. Krionička tehnika očuvanja tkiva blizu je onome što bi se danas moglo smatrati athanatikom - tehnološko sredstvo koje jednom u budućnosti omogućuje tjelesnu besmrtnost. Unatoč povoljnim cijenama (zamrzavanje čitavog tijela stoji oko 23000 dolara), malo se ljudi odlučuje na taj korak i čini se da nema nikakvih ozbiljnijih pokušaja da se ova imortalistička tehnologija stavi pod bilo kakav oblik kontrole. Većinu troškova obitelji pacijenata financiraju same, najčešće policama zdravstvenog osiguranja, a sam Alcor spreman je korisnicima izaći u susret u pogledu bilo kakvih pravnih poteškoća. Čini se da se distribucija krioničkog athanatika zbivala uglavnom logikom individualne inicijative i povremenih grassroots akcija, kojima su se prikupljala sredstva za očuvanje tijela onih pojedinaca koji nisu mogli podmiriti troškove.

Druge vrste tehnologija koje za cilj imaju produljenje ljudskog života, poput terapija protiv starenja i regenerativnih biomedicinskih teorija, nisu izazvale niti ontološku krizu niti zabrinutost zbog maltuzijanske prenapučenosti. Čini se da onaj dio znanstvene zajednice koji vjeruje da je eliminacija starenja i smrti moguća, također misli da je konačna eliminacija starenja i smrti poželjan cilj te je samim time na tragu svih mitova i predaja koji dosezanje tjelesne besmrtnosti ističu kao ljudsku žudnju. Ta žudnja u predajama, poput one o Ahsaveru ili pak Ukletom Holandezu, često nosi stigmu prokletstva: biti Vječan na neki način znači biti nepotpun, otuđen od vlastitog vremena i suočen $s$ egzistencijalnom nelagodom koju uzrokuju ahistoričnost i atemporalnost pojedinca naviknutog na linearno poimanje vremena koje kao krajnju kategoriju uključuje prolaznost, tako da ipak unutar znanstvene zajednice postoji i značajan otpor toj ideji. ${ }^{21}$

Većina imortalističkih koncepata uopće ne raspravlja o političkom potencijalu lijeka protiv starenja, no Desnica je, čini se, prvenstveno zabrinut zbog načina na koji taj lijek može poslužiti kao novo sredstvo kontrole nad populacijom. Kada govori o sredstvima kontrole, pisac fantastičnog romana uvodi podjelu na zemlje „liberalističkog tipa“22 i totalitarnu diktaturu kojom upravlja vlastodržac po imenu Maman/Mamon. ${ }^{23}$ Međutim, Desničin Krezubi sâm će tu dihotomiju ubrzo predstaviti kao lažnu, iznoseći skepsu u stvarno postojanje istinske demokracije i slobode:

Jest, sloboda vjere i savjesti, zbora i dogovora, ličnog uvjerenja i privatne inicijative; pravo na neslaganje, na odvojeno mišljenje, na štrajk, na pobunu čak. Figu! Znam ja iz iskustva kako to u praksi izgleda! A priori sam skeptičan prema svakoj obilaštini u takvim stvarima. Te „slobode“ tako u pluralu, pobuđuju opravdano podozrenje, kao i svaka doping roba. ${ }^{24}$

20 Alcor Membership Statistics (http://www.alcor.org/AboutAlcor/membershipstats.html).

21 Za neke aspekte rasprave o biotehnologijama i besmrtnosti usp. Elvio Baccarini, In a Better World? Public Reason and Biotechnologies, Rijeka 2015., 101-115.

22 V. Desnica, Pronalazak Athanatika, 22.

23 Isto, 34.

24 Isto, 22. 
Čini se da te liberalne demokracije athanatika kontroliraju pravnim mehanizmima kategoriziranja stanovništva u kojem postoji jasna hijerarhija po kojoj građani ostvaruju pravo na besmrtnost:

Tek, ovako ili onako, na temelju ove ili one državnopravne teorije, u svim je zemljama podjednako šefu države priznata ta prerogativa. Stvorena je pravna ustanova „Izuzeća od smrti" takozvani Todesenhebung kako su to tehničkim terminom nazvali njemački autori, koji su taj pravni pojam do u tančine razradili i dali najvrednije radove na tom području. Za šefom države slijedio je niz velikodostojnika: predsjednici ministarskih savjeta, predsjednici predstavničkih tijela, predsjednici akademija i instituta, nosioci najvećih odlikovanja s mačevima i lentom. Zatim ministri i državni podsekretari, redovni akademici, rektori i prorektori, predsjednik kasacije... ${ }^{25}$

U ovakvoj kategorizaciji vidimo da pravni instrumenti kojima je suverena vlast prigrabila pravo distribucije athanatika omogućuju suverenoj vlasti dosad neviđeno polje na kojima može manifestirati svoju biomoć: za razliku od Foucaultova suverena, koji je život mogao ili oduzeti ili ne oduzeti, i biopolitičke vlasti, koja je mogla poticati ili onemogućiti život slojevima populacije, nova vlast ima mogućnost podariti besmrtnost ili „osuditi“ pojedine dijelove populacije na smrtnost. Pravni karakter kontrole prisutan u državama „liberalističkog tipa" odgovara mehanizmima kontrole, prisile i prinude koje pretvaraju Benthamov panoptikon u poželjnu formulu liberalnog vladanja. ${ }^{26}$ Državne mehanizme ekonomske intervencije ovdje zamjenjuje država, koja za svoju primarnu svrhu ima provođenje legalističkih mjera koje služe kao protuteža slobodama.

Ovdje je na djelu biopolitička metoda razdvajanja mnoštva tijela u segmente, no za razliku od klasične biopolitike, koja priznaje smrt kao entitet koji je izvan njezine domene i koja je samim time relegirana u sferu privatnog, ${ }^{27}$ ovdje postoji moć da se smrt eliminira i da se biopolitičkim mjerama život omogući samo određenim kategorijama ljudi. Smrt je ovdje očito predmet javnih politika, a besmrtnost postaje sinekurno dobro koje vlast razrađenim pravnim mehanizmima - koji su, kako smo već naglasili, u svojoj biti biopolitički - dodjeljuje zaslužnima. Hijerarhijska nejednakost inherentna etatističkim sustavima ovdje postaje upravo brutalno evidentna, riječima Krezubog iz Desničine skice za roman:

Zinula je među dvonošćima provalija kakva nikad ranije nije postojala - eto što je bilo. Ljudi su se dijelili, ne više na imućne i siromašne, na site i gladne, na gospodare i besmrtne. Sto ćete gore dobri moj gospodine!... ${ }^{28}$

Nakon što je athanatik na ovako direktan način učinio razvidnim hijerarhijski karakter demokratskih društava, a pravnu znanost i njezine sustave razobličio kao instrument perpetuiranja te nejednakosti, Krezubi nastavlja opisivati kako se athanatik distribuirao u jednoj totalitarnoj zemlji, kojom je vladao diktator dualnog imena Maman/Mamon. Mamanova autokratska država podvrgnula je distribuciju athanatika samom Mamanu, koji je „Atha-

\footnotetext{
25 Isto.

26 Usp. Michel Foucault, Rođenje biopolitike, Zagreb 2016., 75.

27 Isti, „Society Must Be Defended“, 248.

28 V. Desnica, Pronalazak Athanatika, 22.
} 
natik izuzeo iz kategorije znanstvenih pronalazaka i lijekova i uvršten u red odlikovanja za društvene zasluge“, ${ }^{29}$ koje se moglo dodjeljivati jedino herojima. No, kako svaki heroj ima vremena do smrti počiniti izdaju, athanatik se smio dodijeljivati jedino post mortem. Sâm diktator javno nikad nije uzeo athanatik, no pio je koktel složen od lijeka za besmrtnost i „stare manastirske prepečenice“, iako oralno uzimanje lijeka nije imalo nikakva efekta. ${ }^{30}$ Također, razvijen je novi lijek koji poništava učinak athanatika i uvedeno obvezno cijepljenje njime za sve građane.

Tipične kategorije biomoći prisutne su i u totalitarnom društvu, no ovdje athanatik omogućuje nešto novo: činjenica da je vladar tjelesno besmrtan (do kraja Krezubi nije otkrio je li vladar uzeo lijek ili ne) omogućuje fizički kontinuitet suverenova tijela i tako premošćuje jedini nedostatak neograničene vlasti suverena kakvu je zamislio Hobbes. Neograničeno fizičko postojanje suverena tako može doslovno rezultirati koncentracijom apsolutne moći u jednoj osobi. ${ }^{31}$ Budući da ta osoba jedina upravlja medicinskom tehnologijom besmrtnosti, ona de facto postaje Hobbesovim idealnim suverenom, dušom države koja ima kontrolu kako nad životom (može nekom dodijeliti čast athanatika) tako i nad smrću (jer je odredbom o cijepljenju sve ljude učinio smrtnima), a on ih prema volji može pogubiti.

Opis Mamana u sceni u kojoj dijeli nižim državnim dužnosnicima koktel od athanatika i rakije daje bizarnu i pomalo karikaturalnu sliku apsolutne vladareve moći:

Ako je starac ustao dobre volje, znalo je da bude i veselije. „Bi li i ti liznuo kapljicu, a?“ podmignuo bi svom miljeniku. „Pristupi! Klekni, životinjo!“ Zamočio bi srednjak desne ruke u čašicu. „Na! lizni slone! Pričesti se!“ Diskretan osmjeh u polukrugu. $S$ grimasom gorkog napitka na licu, miljenik pristupa, oblizuje prst. Ostali motaju usnama, gruste se od neugodna lijeka, bajagi sretni što je njih mimoišla dužnost da kušaju nevoljeni aperitiv. ${ }^{32}$

Ako se vlast suverena u feudalno i u doba dvorskog apsolutizma simbolički prikazivala držanjem žezla (simbol fizičke moći i monopola nad silom) i kraljevske jabuke (Globus Cruciger, simbol tjelesnog odražavanja Kristove vlasti nad duhovnom sferom postojanja), ovdje sâm koktel od rakije i athanatika postaje simbol doslovne moći nad životom i smrću. Pronalaskom athanatika, koji završava u rukama nosioca totalitarne vlasti, smrt je opet postala političkim pitanjem, a Maman postao je ultimativnim suverenom sustava političke kontrole.

\section{ZAKLJUČAK: DESNICA I POJAM THANATOPOLITIKE}

Ako utopijski romani služe zamišljanju idealnih društvenih formi koje teže dokidanju nejednakosti, svrha je distopijskih romana pronalaženje tendencija u društvu koje mogu dovesti do opresivnih situacija. U Pronalasku Athanatika do izražaja dolazi svojevrstan politički skepticizam. Bez obzira na način upravljanja državom, sama će država osigurati daljnje

\footnotetext{
Isto, 43.

Isto.

31 M. Foucault, „Society Must Be Defended“, 36.

32 V. Desnica, Pronalazak Athanatika, 45.
} 
perpetuiranje nejednakosti te pretvoriti na prvi pogled poželjnu ideju eliminacije smrti i starenja u sustav aktualizacije društvenih nejednakosti. Biopolitička kontrola, ostanu li odnosi u društvu ovakvi kakvi jesu, u slučaju dostupnosti medicinske tehnologije koja omogućuje fizičku besmrtnost, uskoro prerasta u neograničenu moć vlasti: vlast sad ima sva raspoloživa sredstva kontrole koja joj omogućuju da dijelovima populacije udijeli život. Moć udjeljivanja života kvalitativno se znatno razlikuje od moći suverena - koji može jedino oduzeti život - i biomoći - koja ga u širokom razmjeru može pospješiti ili otežati. Moć da se pozitivno ukine smrt nekih dijelova populacije doslovno dijeli ljude na kategorije „živih“ (onih koji zaslužuju primiti athanatik) i „privremeno živih“ (oni koji nikad ne mogu iskusiti puninu života). Također, postojanje takve moći čini odmak od biopolitike, čini kvalitetu života populacije pitanjem javne važnosti, dok se smrt smještala u područje privatnog jer život slobodan od smrti čini i samu smrt javnim pitanjem. Sam Maman, pretvorivši samog sebe u pomalo karnevalsku sliku besmrtnika i tjerajući funkcionere da kušaju koktel od athanatika, pretvara besmrtnost u javni spektakl, na sličan način na koji su srednjovjekovna i ranonovovjekovna pogubljenja karnevalizirala smrt. U svakom slučaju, biopolitičke mjere uspjele su i smrt, uz život, učiniti javnim pitanjem pa, prema tome, možemo zaključiti da Desnica u Pronalasku Athanatika postulira novi oblik biopolitike - thanatopolitiku.

Definicija bi thanatopolitike, najsažetije, glasila: thanatopolitika je neograničena moć vlasti nad životom i smrti svojih podanika, koja proizlazi iz uspješno provedene kontrole nad tehnologijom koja omogućuje fizičku besmrtnost. Cilj je thanatopolitike s pomoću tehnologija nadzora klasificirati pojedinačna tijela svojih podanika u dvije populacije: onu fizički besmrtnu kojoj je podaren život i onu fizički smrtnu koja je izuzimanjem iz prve osuđena na smrt.

Trenutačno, sredstva učinkovitog produžetka života ne postoje, a tehnologije koje pružaju nadu u besmrtnost, poput krionike, još su u povojima i razvijaju se inicijativom pojedinaca. Problematizacija thanatopolitike, kako je ona prikazana u Pronalasku Athanatika, postat će pitanje od presudne društvene važnosti ako jednog dana sredstva produljenja života postanu medicinskom činjenicom. Ta tehnologija, ako je znanost bude razvila, bit će jedna od onih koja će nas definitivno natjerati da promislimo odnos između vlasti i populacije nad kojom se mehanizmi te vlasti provode.

\section{$\cos$}

\section{Literatura}

Elvio Baccarini, In a Better World? Public Reason and Biotechnologies, Rijeka 2015.

Vladan Desnica, „Benta gušter“, Pripovijetke (= Sabrana djela Vladana Desnice, knj. III), Zagreb 1974., 356-367.

Vladan Desnica, „Čovječanstvo“, Pripovijetke (= Sabrana djela Vladana Desnice, knj. III), Zagreb 1974., 450-455.

Vladan Desnica, Pronalazak Athanatika, Zagreb 2006.

Michel Foucault, Rodenje biopolitike, Zagreb 2016. 
Michel Foucault, „Society Must Be Defended“. Lectures at the Collège de France 1975-1976, New York 2003.

Cliford Geertz, The Interpretation of Cultures, New York 1973.

Thomas Hоввеs, Levijatan ili grada, oblik i moć crkvene i gradanske države, Zagreb 2004.

Krešimir Nemec, „Pronalazak Athanatika - između utopije i distopije“, u: Vladan Desnica, Pronalazak Athanatika, Zagreb 2006., 81-94.

\section{Mrežne stranice}

Alcor Membership Statistics (http://www.alcor.org/AboutAlcor/membershipstats.html).

Mike DARwin, „Dear Dr. Bedford (and those who will care for you after I do)“ (http://www.alcor. org/Library/html/BedfordLetter.htm).

\section{$\cos$}

\section{ThanATOPOLITICS AND IMMORTALISM IN DESNiCA'S PRONALAZAK ATHANATIKA}

Pronalazak Athanatika (The Discovery of Athanatic), Vladan Desnica's draft for a dystopian novel, addresses the issue of a discovery of a cure for mortality. This paper demonstrates that the real issue with the application of Athanatic as an elixir of eternal youth, as represented in the novel, arises from the means of controlling the population used by the governments in order to limit the availability of the cure. In the novel itself, the reasons for this are deliberately attributed to a questionable neo-malthusian position which disguises the true motives of the ruling elites - best personified in the character of the dictator Maman/Mamon - to acquire full control over the life and death of the population with the help of Athanatic as an immortalising technology. An analyisis of the concepts of immortalism, biopolitics and its derivative, thanatopolitics, reveals the political dimension of the technology of immortality as depicted in the novel, providing insight into the novel's depiction of political power and humans as political beings. Considerations of biopolitics and immortalist technologies gain significance in view of the resources and the labour invested in the development of life extention technologies by the scientific community. With this in mind, public health policies and control over medical technologies must be assessed in new ways, so that we can be prepared foaddressing the social challenges that new technologies will set before us. Great speculative fiction like Desnica's Pronalazak Athanatika can allow us partial insight into the political problems that might arise from the availability these, as of yet, futuristic technologies.

Key words: Vladan Desnica, thanatopolitics, biopolitics, immortalism, Athanatic, immortality, power, dystopia 

17.

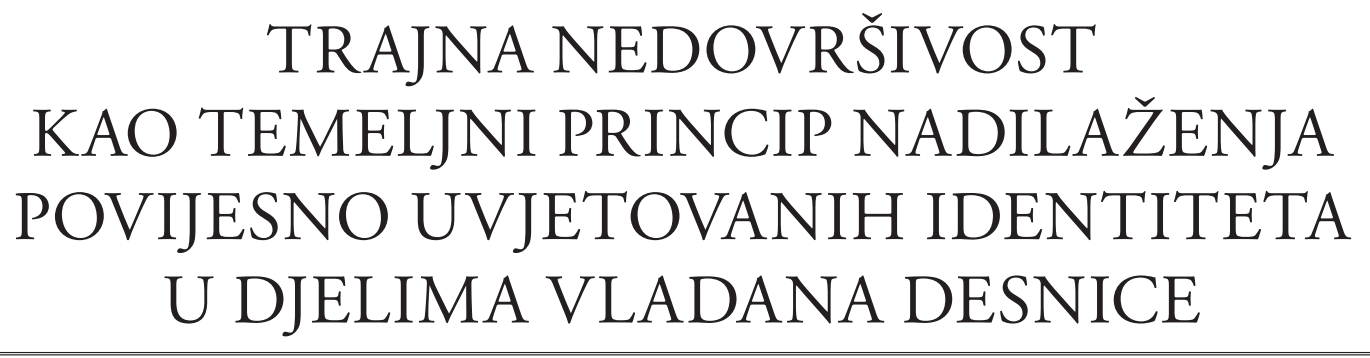

Miroslav Artić

UDK: 821.163.42Desnica:129

Prethodno priopćenje

Sažetak: Desničina djela Proljeća Ivana Galeba i Pronalazak Athanatika objavljena su 1957. godine. Proljeća su dovršena nakon tridesetak godina nastajanja, a Pronalazak objavljen je kao nedovršen roman. U radu se nastoji odgovoriti na pitanje na koji je način Desnica u tekstu prezentirao vječitu čovjekovu potrebu za propitivanjem vlastite smrtnosti, mogućnostima ljudske besmrtnosti i poimanjima vječite regeneracije života. Autor polazi od teze da je ljudska smrtnost u obama djelima u središtu Desničine pozornosti, ali i da se njome u jednom i drugom djelu suočava na različite načine. Za razliku od Proljeća, posvećenih ljudskom mirenju s vlastitom smrtnošću, Athanatik se fokusira na propitivanje implikacija hipoteze o mogućnostima znanstveno utemeljene ljudske besmrtnosti.

Ključne riječi: Pronalazak Athanatika, Proljeća Ivana Galeba, smrtnost, besmrtnost, vječita regeneracija života

\section{ATHANATIK - PLEDOAJE ZA ROMAN KOJI}

\section{TEK TREBA NASTATI}

II

edovršen roman Vladana Desnice Pronalazak Athanatika prvi je put zasebno bio objavljen u časopisu Literatura 1957. godine, a nešto kasnije, 1975. godine, tiskan je u proširenoj i dopunjenoj verziji u Sabranim djelima uz roman Proljeća Ivana Galeba. ${ }^{1}$ Zbog bliske problematike u ovim dvama romanima - u Proljećima opisuje se proces umiranja, a u Athanatiku pronalazak sredstva za postizanje besmrtnosti - moglo se očekivati njihovo objavljivanje u jednoj knjizi u istom izdanju, kao što je to bilo 1975. godine. No, Mozaik knjiga je 2008. godine objavila Proljeća Ivana Galeba bez Athanatika, dok je u po-

1 Vladan Desnica, Proljeća Ivana Galeba. Pronalazak Athanatika (= Sabrana djela Vladana Desnice, knj. II), Zagreb 1975 . 
pratnom eseju Tonko Maroević pisao i o Athanatiku. ${ }^{2}$ Isti je naslov u izdanju V. B. Z.-a objavljen 2006. godine, s pogovorom Krešimira Nemeca „Pronalazak Athanatika - između utopije i distopije. ${ }^{3}$ Autor je u pogovoru kritičkim komentarom popratio Proljeća, iako nisu bila tiskana s Athanatikom. Budući da se Athanatik tematski nadovezuje na Proljeća, čini se opravdanim da ova dva romana budu objavljena u istom izdanju. S obzirom na njihovu povezanost ne može se zanemariti ni dijaloška dimenzija koja ih čini bliskima, no važno je odmah naglasiti da između njih postoji i značajna razlika u stupnju i intenzitetu napetosti. U Proljećima radnja započinje veoma dramatično. Glavni je akter obolio, nemoćan i bolestan leži u bolničkom krevetu i na putu je prema operacijskoj dvorani. Očekivanja čitatelja, dakako, postaju veća, napetost raste u iščekivanju što će se $s$ njim dogoditi nakon operacije. U Athanatiku nema takve napetosti jer je glavni akter već u početku dekapitiran. Riječ je o anonimnom piscu fantastičnih romana bez osobitog ugleda i reputacije, o neimenovanom krezubom i paranoidnom pričalu.

Athanatik se može čitati i kao pledoaje za roman koji tek treba izrastati iskustvom čitatelja. Krezubi planira napisati roman od osamsto stranica, strukturiran u zahtjevnu literarnu formu. Zato pripovjedač od samoga početka postupno opisuje kako je glavni akter, u tekstu nazvan Krezubi, zamislio fabulu te sukladno s time iznosi konstitutivne argumente budućeg literarnog djela. Sve to vrijeme sugovornik Krezubog, pripovjedač, svojim kratkim intervencijama sudjeluje u izgradnji okvira za priču. Naime, njegova je uloga da pitanjima i kratkim komentarima potiče Krezubog u rasvjetljavanju fabule i razumijevanju motiva. Pripovjedač u Athanatiku postao je poput Sokrata majeutički posrednik između teksta i čitatelja, koristeći se vještim ironijskim postupcima. Doduše, u ovako postavljenom dijalogu između dvojice aktera nedostaje niz dinamičkih elemenata. Nedostaju, na primjer, suočavanja i suprotstavljanja oko iznesenih stajališta i kategoričkih iskaza, a nema ni preklapanja sugovornika; čak su izostali začeci značajnih napetosti i dinamičkog slijeda u pripovijedanju. Tehnika dijaloga u Athanatiku vodi drugim putem; intencionalno je postavljena u funkciju naglašavanja i prenošenja pripovjedačeve poruke, a funkcija usložnjavanja i produbljivanja sadržaja teksta stavljena je u drugi plan. Dijalogičnost u romanu nije u potpunosti izostala, a nije ni mogla već zbog toga što je ona konstitutivna sastavnica svakog narativnog obrasca.

Ipak, ostaje pitanje o karakteru dijaloške forme na koju je upozorio Tonko Maroević analizirajući unutarnju strukturu romana. U usporedbi s Proljećima, romanom izrazito monološkog karaktera, u Athanatiku naglašena je jednoobrazna forma dijaloga u kojemu apsolutno dominira pisac budućeg romana, Krezubi. To onda znači da je na određen način i Athanatik monološki strukturiran unatoč izvanjskoj dijaloškoj formi. Naime, pripovjedač i sugovornik dopušta akteru, to jest piscu potencijalnog romana, da govori i govori, prekida ga tek kratkim upadicama, primjedbama i pitanjima, održavajući tako pripovjednu dinamiku i napetost fabule. Iako je Athanatik dijaloški oblikovan, unutarnja dinamika između

2 Usp. Tonko Maroević, „Osunčane strane, sjenovite strune“, u: Vladan Desnica, Igre proljeća i smrti, Zagreb 2008. $5-23$.

3 Usp. Krešimir Nemec, „Pronalazak Athanatika - između utopije i distopije“, u: Vladan DesnicA, Pronalazak Athanatika, Zagreb 2006., 81-94. 
sugovornika pripovjedača i Krezubog ne ostvaruje u potpunosti dijalektiku u razmjeni stavova, razmišljanja, razlikovanja. Zanimljiva je odrednica Željke Čorak koju izdvaja Maroević. U njoj stoji kako u Desničinu djelu presudnu ulogu ima svijest i ona postaje glavni protagonist u Desničinim tekstovima. ${ }^{4}$ Prema tome, ako svijest u Proljećima ima istaknutu ulogu, onda ona, prema mišljenju Željke Čorak, vrši istančanu autoanalizu sjećanjima ispunjenim reaktualiziranim vrednovanjima. Svijest je u Athanatiku transparentna jer se ne promatra iznutra, već je pripovjedač prikazuje izvana kao angažiranu i performativnu akciju koja teži transformaciji pod vidom radikalne novine - prema besmrtnosti. Zato se može reći za kratak i nedovršen roman, kako to ističe Maroević, da opsesivna problematika smrti na kraju postaje korifej „apologije smrtnosti“." I baš su po tome oba romana slobodno i otvoreno komponirana i predana „čitatelju da ga na svoj način zaokruži““. 6

\section{BESMRTNOST KAO OKVIR}

\section{ZA RAZUMIJEVANJE POVIJESTI}

Pripovjedač u Athanatiku kao aktualan sukreator i potencijalan čitatelj romana u nastajanju rekonstruira druženje jednog kišnog popodneva s neobičnim čovjekom, paranoidnim pričalom. Predstavljen je onako usput, neodređeno i dokono; pripovjedač mu ne pridaje osobito značenje - čak ga prispodobljuje „s nekakvim paranoidnim pričalom, krezubim vjetrogonjom “7 Očito je da se pripovjedač i Krezubi otprije znaju jer, evo, već treći dan zaredom taj mu paranoidni sugovornik izlaže sadržaj fantastičnog romana koji kani napisati. U pripovijedanju se „izbjegava fabuliranje“, a umjesto njega slijedi sfera „opisivanja i komentiranja" samo zato da se postigne objektivan odmak od psihološkog toposa glavnog aktera. Ovu tehniku pripovijedanja u romanu istaknuo je Dušan Marinković, naglasivši svrhu tako postignutog odmaka koji pripovjedaču omogućuje da svoje likove „hladno, 'nezainteresirano' objektivira izvana“" 8 Tako se uspješno ironizira lik paranoidnog pričala, dok se u refleksivnim odlomcima koristi prvim licem jednine kako bi u prvi plan postavio „unutrašnji sadržaj“" svijesti.

Time se pojačava ironiziranje, uslijed čega je u samom početku narušena serioznost izlaganja Krezubog. Pripovjedač to pojačava karakterizacijom aktera kao paranoidnog pričala i krezubog vjetrogonje. Nazvati sugovornika vjetrogonjom može značiti da je nepouzdan i danguba. Zato su namjerno izostavljene osobne generalije; ne navodi se tko je on, odakle dolazi, čime se u stvari bavi i što radi. Tek se usput napominje da namjerava napisati novi fantastičan roman. Pripovjedač se, inače, prema cjelokupnom djelu Krezubog odnosi nemarno, čak ne iznosi vrijednosni sud. Sama priča o romanu u nastajanju započela je i završila istog kišnog popodneva, a možda svega toga ne bi ni bilo da je pripovjedač u to doba

\footnotetext{
T. Maroević, „Osunčane strane, sjenovite strune“, 18.

Isto, 22.

Isto, 19 .

V. Desnica, Pronalazak Athanatika (= Sabrana djela Vladana Desnice, knj. II), 349.

Dušan Marinković, „Predgovor“, u: Vladan Desnica, Zimsko ljetovanje, Zagreb 1998., IX.

Isto.
} 
imao pametnijeg posla. Bili su to mirni i gotovo besadržajni dani. Oko njih dvojice nije se ništa događalo, nikakvih promjena niti iznenađenja nije bilo, a kiša je padala i padala „nepromijenjenom gustoćom (...) neprekidno, ujednačeno, kao da je oduvijek kišilo i kao da će dovijeka kišiti “. ${ }^{10}$ Pozicija pripovijedanja cijelo je vrijeme fiksirana i ujednačena. Krezubi je uporno govorio o romanu od „osamsto stranica“, pokazivao skice i bilješke, a pripovjedaču nije preostalo ništa drugo nego da pitanjima potiče i usmjerava opsežno izlaganje.

Dakle, nakon što je jednoga dana bilo izumljeno i proizvedeno to čudesno sredstvo, uslijedilo je veliko slavlje narodnih masa, a osobito vladajućih elita. No, ubrzo je sve krenulo naopako, svatko je htio posjedovati napitak koji smrti ne dopušta dovršetak životnog kruga te je otad ampula athanatika postala sudbonosna i sidrišna točka cjelokupnog zbivanja. Cijene su na tržištu rasle, i na regularnom i na onom drugom, ilegalnom, pomama za lijekom postala je golema. Nastala je sveopća borba, širili su se sukobi na sve strane, posvuda je nastupio opći kaos kataklizmičkih razmjera. Prijevare su se umnožile, svi su težili brzoj i lakoj zaradi, a još se ukazala prilika da se izravnaju računi od prije. Na kraju je globalna ekonomija bila ozbiljno uzdrmana; doživjela je kolaps. Prosvjedovalo se po svem svijetu uzvicima i transparentima „Vratite nam našu smrt!"11 I nije drugo preostalo nego da se ukine athanatik, i to za opće dobro. Jednostavno, lijek je morao nestati istom brzinom kojom je i nastao.

\section{Fluktuirajuća struktura Athanatika}

Očito je da je forma Athanatika žanrovski policentrična. Naime, teško je pronaći dostatnu književnoteorijsku odrednicu po kojoj bi ovaj kratki roman bilo moguće jednoznačno klasificirati. S jedne strane, dovršivost ove kratke proze te njezina besprijekorna literarna strukturiranost dopuštaju da se tekst vrednuje kao fluktuirajući roman, a može se, naravno, pristupiti i drugačije. Nemec je Desničin roman označio kao žanrovski hibrid jer u sebi „ujedinjuje nekoliko književnih vrsta“. ${ }^{12} S$ druge strane, Athanatik se može čitati i kao fantastičan roman koji prerasta u roman budućnosti u kojemu se radnja smješta u daleku budućnost, u vrijeme otkrivanja „sredstva protiv smrti uopće“ ${ }^{13}$ U tom fantastičnom romanu nema fantastičnih elemenata; sadržajno ga ne pokrivaju. U tekstu jednostavno ne postoje mistične situacije, ne razvija se specifična fantazija, niti se aktualiziraju određena alkemičarska čuda; čak se u tekstu ne naziru izmišljeni fantastični svjetovi te na kraju u priči nema fantastičnih iskustava koja bi ukazala na nove i otvorila nepoznate vidike. Pripovjedni svijet u planu Krezubog postavljen je racionalno, sve je u tekstu realno posloženo, ljudska su ponašanja očekivana, percepcije su vremena i prostora uobičajene. No, to ne znači da ovako strukturirana literatura nije prospektivno usmjerena; naime, u njoj su već upisane budućnosne distinkcije. Uglavnom, fikcija po svojoj narativnoj prirodi izrasta iz povijesnog horizonta, ali ga istodobno i nadilazi.

\footnotetext{
10 V. Desnica, Pronalazak Athanatika (= Sabrana djela Vladana Desnice, knj. II), 406.

11 Isto, 404.

12 K. Nemec, „Pronalazak Athanatika - između utopije i distopije“, 85.

13 V. Desnica, Pronalazak Athanatika (= Sabrana djela Vladana Desnice, knj. II), 350.
} 
Athanatik je čitaocu zadan svakako kao integralni tekst, to jest kao zaokruženo djelo o nedovršivosti smrti. U glavi Krezubog razvila se ideja o genijalnom izumu koji donosi ljudski um - nakon upotrebe tog pripravka smrti više neće biti ili, bolje rečeno, svaki smrtnik bit će nadomak besmrtnosti. Athanatik sadržajno i značenjski postaje osobito zanimljiv kao pokušaj ironijskog odmaka od neminovnosti umiranja. No, jednog kišnog popodneva osvanut će nedovršivost života, život će trajati bez završstka u vremenu. Ali, bez povijesti i bez točke sabiranja i oduzimanja vremenski tijek ne bi više imao nikakvog smisla.

\section{FATAlističKo iskušavanje POViJesti}

Dakle, pisac fantastičnih romana s kojim pripovjedač razgovara, vjetrogonja i danguba, svojim rječitim izlaganjem pokreće i širom otvara svijet fikcije u kojem će smrt iznimnim dostignućima uma biti prevladana. Treba odmah naglasiti da besmrtnost traje tek onoliko koliko Krezubi o tome govori, ustvari sve dok postoji interes sugovornika, a on svojim kratkim pitanjima i komentarima sukonstituira svijet mogućeg, suoblikuje utopijski projekt, naravno, u dimenziji naratološkog zbivanja. Mogu li u toj inventivnoj priči, to jest u pronalasku athanatika participirati i ostali akteri? Ima onih koji će prenositi ideju o besmrtnosti poput propovjednika, no ipak je najviše onih, prema mišljenju Krezubog, koji ne pripadaju elitnim krugovima. Što njima ponuditi u pripovjednom konceptu i kako ih potom dalje voditi jer je svima jednako stalo do života bez smrti? Kome onda na kraju treba dati više, možda onima „čije je djelo (...) po čovječanstvo od nesravnjivo veće vrijednosti nego život običnog prosječnog čovjeka"? ${ }^{14}$ Dilema ostaje, ta tko je vredniji tog spasonosnog sredstva za besmrtnost? Može li u toj dilemi sâm pisac glasom pripovjedača uredovati samosvjesno i sigurno i hoće li moći opravdati svoj odabir kakav god bio? Teško, bez obzira na to što je kreator situacije, kreira je i vodi „tek za nekoliko početnih stranica ili poglavlja, dok postavi stvar, dok namjesti kulise, dok navije oprugu svojim licima" ${ }^{15}$ Eto koliko on može, i na tom se principu kontroliraju i povijesna zbivanja. Nakon inicijalnog poticaja i načelnog usmjeravanja „dalje se sve razvija samo od sebe, svojim nužnim neizmjenljivim tokom" ${ }^{16}$

Krezubi svojim izlaganjem koncepta za fantastični roman uvodi u razumijevanje povijesti i ljudskog ponašanja tijekom povijesnih mijena slučaj i nuždu kao fatalističke koncepte. No, istodobno u svijesti svakog pojedinca postoji jak otpor prema sudbinskim odrednicama i uvijek se iznova sve opire slijepom slučaju. Snažan je argument koji iznosi Krezubi kada se buni potkrepljujući to jasnim stavom „ako sam postao slučajno i iz ničega (...) neću da dalje budem podložan slučaju“. ${ }^{17}$ 


\section{SMRT - KRAJNJA TOČKA NEDOVRŠIVOSTI}

Athanatik je pozicioniran u povijesni kontekst u formu iskušenja i pod antropološkim vidom ispituje čovjekova ponašanja u osobitim budućim vremenima, kada besmrtnost postane stvarnost. Hoće li se u besmrtnom svijetu promijeniti odnos prema smrti i kako bi se to odvijalo u novouspostavljenim okolnostima koje pripovjedač gradi? Njega ustvari zanima, prema navođenju sugovornika, mogući model društvenih odnosa u kojima će razumijevanje smrti poprimiti posve nove oblike. Drugo je pitanje može li besmrtnost uopće promijeniti čovjeka, može li utjecati na njegovu narav i trajno iz nje ukloniti nagnuće prema nepravdi i zlu, eliminirati bol, pa i samo umiranje? Budući da je smrt konstitutivna životu i dok ga prolaznost i smrtnost prožimaju, život raste do samoukinuća. U Proljećima Ivana Galeba život je pojedinca do kraja okrenut prošlom, onom što se prolaznim označava. Ta je spoznaja dostupna jedino u povijesnoj dimenziji sjećanjima koja načas postaju neuhvatljiva i nestabilna. Athanatik je, za razliku od Proljeća, okrenut budućnosti u kojoj želi provjeriti antropološku stranu smrtnosti koja čovjeka nagoni na nepredvidljiva iskušenja ne bi li ipak na kraju dokučio prospektivnu dimenziju postojanja.

Pisac fantastičnih romana nije se usmjerio, kako se očekivalo, prema konačnim i definitivnim odgovorima na pitanja kontingencije čovjekove egzistencije. On je samo započeo bolne procese, prezentirajući veoma jasno i nedvosmisleno nemoć pojedinca. U romanu je kroz prizmu pripovjedača prikazan slijed kako se u tim kritičnim trenucima rađa i razvija refleksivna misao koja akceptira svu nedokučivost smrti. Inače, glede graničnog iskustva o kojemu je riječ u romanu, sugovornik i Krezubi distancirani su prema gotovim rješenjima koja se nude iz kolopleta dogmatski neporecivih svjetonazora. Međutim, u tom značajnom projektu pronalaženja sredstva protiv smrti nazvanog athanatik čovjek se ne mijenja nabolje, nema značajnih pomaka u moralnoj praksi u skladu s pronalaskom tog čudotvornog sredstva. $S$ obzirom na rečeno, važno je naglasiti da je Krezubi u prvi plan postavio smrtnost kao konstitutivnu odrednicu života jer se svaki život pod vidom smrtnosti rađa, raste i pada.

U Athanatiku jedino uspijeva taj famozan pothvat nadilaženja i savladavanja smrti, a sve se to u konceptu Krezubog događa bez čuda, kao rezultat progresa. I u Proljećima prisutan je pokušaj nadilaženja smrtnog straha, ali smrt je snažnom refleksijom pojedinca na momente bila zasjenjena. I unatoč svijesti o neminovnom kraju, u akteru je odjednom prevladala žudnja za životom i u potpunosti u sebe upila strah od smrti. Nestala je ta pogubna misao i napokon je u proljeće zasjalo sunce punim sjajem u neizvjesnoj igri smrti i proljeća. Smrt je na trenutke ostala iza sunčeva sjaja, čekajući strpljivo svoj čas. Ivan Galeb je u Proljećima došao do spoznaje da „na koncu sviju staza stoji šutnja i mir sa svime: široki mir sa bolom, s ljudima, sa životom - sa samim sobom “. ${ }^{18}$ I bol je na kraju uminula, nestale su strepnje, u tom kontemplativnom trenutku ostala je samo „preplavljenost suncem“. ${ }^{19}$

18 V. Desnica, Proljeća Ivana Galeba (= Sabrana djela Vladana Desnice, knj. II), 345.

19 Isto. 
Dakle, suočavanje pojedinca s neminovnošću umiranja u Proljećima Ivana Galeba završava potpunim izmirenjem.

Ta raskošna „preplavljenost suncem“ nije eliminirala smrt, koja će na kraju ipak doći, već je postupno uvodila glavnog aktera u smrtni čas, samo drugim putem. Na kraju je u tim posvećenim trenucima Ivan Galeb doživio u punoj raskoši prijelaz, ali i preobrazbu, čemu se svaki smrtnik nada. Taj gotovo nezamisliv koncept budućnosti postavljen je u tekstu iznad vremenskih odrednica. Smrt je neuklonjiva i neuništiva; zato ta osobita pomirenost u Proljećima ostaje konstanta života u kojoj glavni lik nasmrt bolestan ponire u sve pore vlastitoga života, prolazeći kroz proživljena iskustva i zadržana sjećanja negdje duboko ispod skrivana. Proljeća su, dakle, okrenuta prema proživljenom, pogled Ivana Galeba usmjeren je prema proživljenom i prošlom koje ustvari nije prošlo, a i neće dok akter živi. On iz pozicije distanciranog promatrača analizira ono što se odlagalo, što je u tamnim kutovima čekalo da jednoga dana bude osvijetljeno zrelim pogledom jer dugo su i predugo tavorila ta pohranjena iskustva, izdvojena i konzervirana.

U Athanatiku također je u središtu fokusa ponašanje subjekta, ali kao nosioca društvenih zbivanja. Sva su nadanja otvorena prema znanosti s uvjerenjem da će moć znanstvenog uma toliko napredovati te će i samu smrt pobijediti. U obama romanima, u Proljećima i Athanatiku, autor promatra kako se čovjek nosi s tom neminovnom i definitivnom činjenicom postojanja. Niti u jednom naslovu autor ne nudi odgovore na pitanja prolaznosti i relativnosti života, pa i same smrti kao sastavnice životnog kruga. Kroz prizmu pripovjedača pozicionira se u čovjekovo iskustvo skorog kraja, neminovnosti završetka i refleksivnim odlomcima regenerira zaokružen odnos prema smrti. Naime, o njoj se govori bez uljepšavanja i iluzije.

\section{O SKRIVENOM LICU VREMENA - IZA DOGAĐAJNOSTI}

Subjekti povijesnih zbivanja u Pronalasku Athanatika gube ontološku pozicioniranost. Za sve je njih athanatik postao sudbonosan; taj jedinstven i neponovljiv događaj unio je silan nemir, čak za život opasan. Athanatik, koji je garantirao život u kontinuitetu, život bez prekida, život koji se na smrt više ne bi osvrtao, postao je najveća prijetnja upravo životu. Ovaj kratki roman u cijelosti nosi u sebi svu težinu žudnje čovječanstva za besmrtnošću, za trajanjem bez prekida i zato otvara pitanje smisla cjelokupne povijesti prodirući duboko „u misterij budućnosti“ jer je upravo budućnost neizostavna kategorija postojanja, kako je to u svojoj studiji o povijesti budućnosti isticao Bernard Cazes. I stoga baš Athanatik nastoji razotkriti neuhvatljivu i tajanstvenu koprenu „tog skrivenog lica vremena kakvo predstavlja budućnost “. ${ }^{20}$ Težak je to put, a još je teže prihvatiti ograničenost ljudskog uma, koji se na kraju mora pomiriti s činjenicom da čovjek unatoč svim svojim nastojanjima i otkrićima ostaje paradoks ili, bolje rečeno, svojim velikim podvizima često ostaje hodajući skandal.

20 Bernard CaZes, Povijest budućnosti, Zagreb 1992., 9. 
Dok ga u životu intrigira iskušenje budućega i vuče žudnja za beskonačnim, on ustvari ide prema nestajanju i ostaje u prošlome. Sve što je činio ne bi li postao besmrtan u konceptu Krezubog, samo je vodilo u smrt jer život jedino u njoj pronalazi svoj smisao i čovjek u njezinoj sjeni odlaže sva svoja pitanja - ona odavno izgovorena i ona još neizgovorena. Autor je glasom pripovjedača iznio vlastito razumijevanje vječne dileme. Naime, ponudio je odgovor na pitanje u čemu se sastoji „beskonačno trajanje“ - u vječitoj regeneraciji života, u čijem se procesu i smrt regenerira, ali samo smrt, ne i pojedinac. ${ }^{21}$ No, da se kojim slučajem u romanu zastupa ideja o linearnom shvaćanju povijesti, uslijedio bi na koncu života konačan kraj, jedan osobit eshatološki kraj koji podrazumijeva prijelaz iz prolaznog u neprolazno, iz vremenitog u nadvremensko i transcendentno. Međutim, u cikličkom razumijevanju povijesti vrijeme na sve pokušaje uma ostaje apsolutno indiferentno, ono je već u sebi bezvremensko. Čovjek je naknadno razumskim sposobnostima imenovao vrijeme kao jedinicu trajanja i postojanja. Tako prati životni tijek od rođenja do smrti, od postanka do nestanka, i sve se uvijek u krugu vrti. Pripovjedač se poigrava pitanjem završetka i varira tu neminovnost od početka do kraja nizanjem sugestija unutar zadane vječite regeneracije. Iz navedenoga proizlazi sljedeće: kao što je trajna i vječita regeneracija života, tako je i smrt trajna; bez nje nezamisliva je regeneracija, a na kraju svega ostaje nedovršivost ljudske kategorije postojanja. Mogu li se u tim okvirima uopće nadići povijesno uvjetovani identiteti? Kako sagledati povijesno trajanje i napredovanje koje spaja i povezuje prošlo s budućim, kontingentno sa stalnim, smrtnost i žudnju za besmrtnim?

Dakle, nakon što je pripovjedač predstavio paranoidnog i krezubog sugovornika, uslijedila je kratka refleksija o prolaznosti i razumijevanju povijesti samoga autora, artikulirano glasom pripovjedača u prvome licu. Refleksije u prvom licu jednine predstavljaju svojevrstan okvir romana. U njima se u kratkim crtama iznosi shvaćanje prolaznosti, vremena koje protječe i naizgled životom istječe. Promatranjem gustih kišnih kapi pripovjedač rezignirano konstatira „nema tu promjene“ jer život otječe i prolazi „kao što teče vrijeme“.22 Događajnost, ta ljudska kategorija po kojoj se povijest odvija i prepoznaje, u romanu se stalno ponavlja. Događaji, koliko god bili izraženi i prepoznatljivi u protjecanju vremena, ništa bitno ne mogu promijeniti ili pomaknuti. Tako iste kišne kapi kruže iz visina, pa u zemlju otječu kako bi ponovno dospjele u atmosferske visine da se zemlji opet vrate. I što na kraju reći, osim da se u svemu tome samo izvanjska stanja bića mijenjaju. Sve se u krugu vrti i ponavlja se sudba kao nužda jer - kako proizlazi iz navedenog - drugačije i ne može biti. Događaji i zbivanja u povijesnom se tijeku modificiraju, ali se pri tome ništa bitno ne mijenja. Pojedinac se rađa i postupno razvija te na nekom svom vrhuncu umire; sve se odvija uvijek po istoj zacrtanoj matrici. Iz tog sudbonosnog kruga „nema izbavljenja“, zavapio je na kraju pripovjedač dok je u njegovoj svijesti strujala „pesimistička misao“. ${ }^{23}$ Očito je u glasu pripovjedača dominantno cikličko razumijevanje vremena i povijesnog zbivanja.

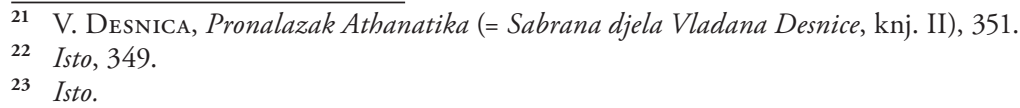




\section{REGENERIRAJUĆI KONCEPT SMRTI}

Kada bi se dogodilo da sama smrt umine, nestane ili se trajno odgodi, bila bi, prema Krezubom, dovedena u pitanje percepcija vremena i sve bi poprimilo nova i drugačija značenja pod vidom besmrtnosti. Osobito bi povijest postala upitna kao metodološki konstrukt kojim se reguliraju odnosi između prošlog, sadašnjeg i budućeg. U tom smislu smrtnost postaje ključna za održavanje životnog ritma koji se smrću uspostavlja i njome regenerira. Smrt je u samom središtu života, no u potpunosti nadilazi umne sposobnosti kojima bi čovjek mogao dokučiti njezine unutarnje mehanizme. Ona je u prvom redu regulatorni princip života i zato je o eliminaciji smrti svaki govor izlišan. U tome je duhu postavljen i početak Athanatika. Rasprava o mogućem scenariju pronalaska sredstva protiv smrti odvija se jednog kišnog popodneva, kada se ionako ništa drugo i nije moglo raditi.

Upravo u tim monotonim trenucima zamora, intenzivnog promatranja i preispitivanja pripovjedač postavlja pitanje trajanja i prolaznosti ljudskog životnog vijeka. I to traje „od juče, od prekjuče (...) neprekidno, ujednačeno, bez nade“. ${ }^{24}$ Gdje je svemu tome početak, a gdje kraj, od jučer ili prekjučer, ili je neprekidno tako, vrijedi se zapitati u okviru fabularnog tijeka. Život je prema pripovjednoj sekvenciji u cjelokupnom vremenu trajanja tek djelić procesa stalne preobrazbe. Jasno se to potvrđuje detaljnim opisom kišnih kapi kako dolaze i prolaze zemljom. I one su u cirkularnom procesu regeneracije, preobrazbe i transformacije. Ista se voda, baš kao i život uz koji se veže vrijeme, samo regenerira u novim tek rođenim stvorenjima. I baš ona potvrđuju da u jednom i jedinstvenom vremenu i prostoru traje regeneracija; naime, kako koje stvorenje traje, prolazi i nestaje, stvara se iluzija da vrijeme protječe. Sve se to odvija u riječima pripovjedača, u zatvorenim krugovima, a oni samo različite oblike poprimaju, prikazuju se drugačijima u formacijskim identitetima, bilo nacionalnim, spolnim ili svjetonazorskim. I tako ide krug za krugom i ti se krugovi međusobno susreću, suočavaju te se na kraju u rivalstvu uništavaju, a vrijeme teče „neprekidno, ujednačeno, bez nade“ da će se ikad zaustaviti. Krugovi se u tom kolopletu „regeneriraju“, i tako iz kruga u krug, iz toga procesa „nema izbavljenja“, zaključuje se na kraju. ${ }^{25}$

Govoriti protiv te neminovnosti i ustrajati na mogućim promjenama i preusmjeravanjima intervencijom ljudskih umova smiješno je i neuvjerljivo. Takvim se nastojanjima i razboriti um može tek nasmijati, no Krezubi vjetrogonja, to paranoidno pričalo, ne zna se nasmijati, ne razumije smijeh drugih na vlastita ograničenja, niti shvaća kontingentnost ljudskog bića i njegovih mogućnosti; on je jednostavno „oguglao na osmijeh i nevjericu“ i dalje se posvećeno „pozivao na skice i bilješke i planove“. ${ }^{26}$ Vjerovao je u snagu i moć ljudskog uma, u napredak znanosti koja može sve, pobijediti čak i povijest. U njegovu je uvjerenju ključna „ideja“, a ideje oduvijek zaposjedaju povijest, no do sada se nisu izdignule iznad, već i dalje samo kolaju između jučer i prekjučer. Svemu tome preostaje na kraju 
pripovjedačev osmijeh u ironičnom oslovljavanju pisca romana od osamsto stranica Krezubim vjetrogonjom i paranoidnim pričalom. Autorska svijest pisca Athanatika računa s ironijskim odmakom prema sakralnom i posvećenom uzdizanju znanosti i ljudskog uma.

I što preostaje onom tko se ne zna nasmijati sebi u lice, što na kraju preostaje paranoidnom pričalu i vjetrogonji? Pripovjedač već istaknutim karakternim osobinama Krezubog potvrđuje besmisao pothvata o kojem se govori, s podsmijehom prikazuje ideju o besmrtnosti. Naime, u postupcima Krezubog riječ je o paranoidnoj reakciji na kategoriju vremena, prolaznosti i trajanja, i u toj se paranoidnosti život ogoljuje kao iluzija. Ta neprekidnost u nedokučivosti tih kategorija vremena i prolaznosti u njemu, krhkosti i straha izaziva u pojedincu paranoidne reakcije. Prema tome, i povijest ispada kao paranoja. Njezini se okviri mogu nadići jedino u narativnim oblicima. Tim putem ide paranoidno pričalo, zamišljajući se u budućnosti daleko ispred aktualnog povijesnog vremena, ali to ničim ne potkrepljuje, kao da mu to i nije toliko važno. On samo konstruira odmak u budućnosti, to jest odmak $s$ distance, promatrajući sebe i svijet u muci ograničenog trajanja. I što vidi iz te zamišljene udaljenosti koje ustvari nema u vremensko-prostornim kategorijama? Ustvari se samo nalazi u okvirima žudnje ili želje. Zato „vidi“ samo prošlost ili, bolje rečeno, vidi već viđeno, samo u drugom ruhu. Budućnosna je vizija zapravo projekcija povijesti ljudskih nastojanja jer buduće može graditi isključivo na temelju kategorija preživjelog i proživljenog iskustva, i to sve pod vidom trajne ontološke nesigurnosti. Proturječna se ljudska priroda ponavlja i u situaciji zamišljene besmrtnosti u poznatim povijesnim obrascima. Sukobljavanja do iznemoglosti zbog novih i novih ideja. Krezubi je u svom fiktivnom projektu eliminirao svaki trag iracionalnog i mističnog i baš je to „specifičnost romana“ u nastajanju. ${ }^{27}$

Koliko se god čini da svaki subjekt ide svome kraju i da se unutar povijesnih odrednica zaokružuje i okončava u zadanoj i određenoj dovršivosti, otvara se ponor o kojemu pripovjedač govori. Ponor je to nedovršivosti jer iza svake, a jednako tako i ispred svake egzistencije, stoji „vječita regeneracija“. ${ }^{28}$ Nedovršivost govori o sebi i sebe izgovara jer je sebe svjesna jedino kroz narativne obrasce; bez njih nema ni svijesti ni samosvijesti, a niti povijesti. 


\section{$\cos$}

\section{Literatura}

Bernard Cazes, Povijest budućnosti, Zagreb 1992.

Vladan Desnica, Igre proljeća i smrti, Zagreb 2008.

Vladan Desnica, Proljeća Ivana Galeba. Pronalazak Athanatika (= Sabrana djela Vladana Desnice, knj. II), Zagreb 1975.

Vladan Desnica, Pronalazak Athanatika, Zagreb 2006.

Vladan Desnica, Zimsko ljetovanje, Zagreb 1998.

Dušan Marinković, „Predgovor“, u: Vladan DesnicA, Zimsko ljetovanje, Zagreb 1998., VII-XVI.

Tonko Maroević, „Osunčane strane, sjenovite strune“, u: Vladan Desnica, Igre proljeća i smrti, Zagreb 2008., 5-23.

Krešimir Nemec, „Pronalazak Athanatika - između utopije i distopije“, u: Vladan Desnica, Pronalazak Athanatika, Zagreb 2006., 81-94.

\section{$\cos$}

\section{Permanent incompleteness as the Fundamental PRINCIPLE OF OVERCOMING HISTORICALLY DETERMINED IDENTITIES IN THE WORKS OF VLADAN DESNICA}

Desnica's novels Proljeća Ivana Galeba (The Springs of Ivan Galeb) and Pronalazak Athanatika (The Discovery of Athanatic) were both published in 1957. The former was completed and released to the public as the result of thirty years of work, while the latter was published in draft from. The paper deals with the ways in which Desnica presents the eternal need to question our own mortality, as well as the possibility of immortality, and the perpetual regeneration of life. The author establishes the hypothesis that human mortality is in the focus of Desnica's interest in both novels, yet it is approached in different ways. While the former is concerned with coming to terms with one's own mortality, the latter focuses on the social implications of scientifically attainable immortality.

Key words: Pronalazak Athanatika (The Discovery of Athanatic), Proljeća Ivana Galeba (The Springs of Ivan Galeb), mortality, immortality, the perpetual regeneration of life 



\section{8. EKOKRITIČKO ČITANJE ROMANA PRONALAZAK ATHANATIKA VLADANA DESNICE}

\section{Goran Đurđević}

UDK: 821.163.42-311.9Desnica, V.:612.013

Prethodno priopćenje

Sažetak: Autor iz ekokritičke niše pristupa čitanju kratkog nedovršenog romana Vladana Desnice Pronalazak Athanatika. Rad čine tri tematske cjeline: ekokritički pristup tematskom ciklusu život - smrt - besmrtnost u komparaciji i povezivanju s djelom Homo Deus Yuvala Noaha Hararija, zatim ekokritička analiza kiše kroz prizmu ideja Susan Farrell te analiza Pronalaska Athanatika u kontekstu distopijskih ekoloških/okolišnih romana u suvremenoj hrvatskoj književnosti Planet Friedman Josipa Mlakića i Mjesečev meridijan Ede Popovića, uz usporedbu s ekokritičkim čitanjima Louise Squire. Autor zaključuje kako je Desnica svojim djelom Pronalazak Athanatika - koje žanrovski pozicionira kao spekulativnu fikciju - prethodnik koji korelira s aktualnim znanstvenim promišljanjima (Harari) i književnim djelima (Mlakić, Popović), upozoravajući kako ekologija i ekološki čimbenici - besmrtnost i porast stanovnika, nedostatak hrane te u konačnici uništavanje planeta - mogu imati razorne učinke na društvene promjene, raspodjelu moći i oblikovanje budućnosti. ${ }^{1}$

Ključne riječi: ekokritika, Pronalazak Athanatika, Vladan Desnica, besmrtnost, Yuval Noah Harari, Josip Mlakić, Edo Popović, kulturalni studiji

\section{UVOD}

edamdesete godine dvadesetog stoljeća otvaraju nove prozore i poglede na čovjekov svijet i čovječanstvo. Društveno-politički naslonjene su na događaje iz 1968. i pokušaje promjena studentskim demonstracijama, rastuću dekolonizaciju i oslobođenje zemalja Trećeg svijeta, zatim na otpor prema američkoj intervenciji u Vijetnamu i strahovima od mogućeg nuklearnog sukoba hladnoratovskih suparnika, ali i naftnu (energetsku) krizu. Takvo vrijeme, praćeno tehnološkim razvitkom, utemeljenim u napretku prirodnih i teh-

$1 \quad$ Zahvaljujem Dariji Đurđević i prof. dr. sc. Jožici Čeh Stergar na pomoći oko nabave literature, kolegi Vinku Tadiću na mudrim savjetima, posebno oko povijesne literature, te doc. dr. sc. Suzani Marjanić i doc. dr. sc. Mirandi LevanatPeričić na iznimnoj pomoći pri oblikovanju ideja, kao i anonimnim recenzentima i urednicima na konstruktivnim, kreativnim i dobronamjernim savjetima i strpljenju. 
ničkih znanosti, pojavom brojnih izuma koji olakšavaju svakodnevni život te ubrzanim nastankom potrošačkog društva, otvara nove mogućnosti u kreiranju svijeta, prateći tadašnje izazove i probleme, što omogućuje pojavu i začetke ekoloških (zelenih), feminističkih (rodnih i ženskih), mirotvornih (antiratnih) i drugih pokreta. Oni promatraju svakodnevicu drugačijim očima i otvaraju prostor novim temama, čineći uvod u postmodernu. U sklopu postmoderne otvoren je put, među ostalima, za kulturne studije, popularnu kulturu, ekokritiku/ekokriticizam, ${ }^{2}$ ekofeminizam, lingvistički obrat, analizu diskursa i mnoge druge subdiscipline, istraživačke pravce i teorijsko-metodološke inovacije. ${ }^{3}$

Ekokritika je kao jedan od novijih pristupa suvremenosti otvorila drugačije perspektive analiziranja kulture - ponajviše književnosti i vizualnih umjetnosti - u kontekstu doticaja s okolišem. Pojam ekokritike osmislio je William Rueckert u svom članku „Literature and Ecology: An Experiment in Ecocriticism“iz 1978. godine. Definirao ga je kao povezivanje ekoloških koncepata i književnosti. ${ }^{4}$ Prvu ideju povezivanja prirode i književnosti, prema mišljenju Petera Berryja i Domagoja Brozovića, donosi Karl Kroeber u radu „'Home at Grasmere’: Ecological Holiness“, objavljenom još 1974. godine. ${ }^{5}$ Cheryll Glotfelty, urednica zbornika The Ecocriticism Reader. Landmarks in Literary Ecology, donosi sljedeću definiciju:

Ekokritika je studij veze između književnosti i fizičkog okoliša. Baš kao što feministička kritika istražuje jezik i književnost iz rodno osviještene perspektive i baš kao što marksistička kritika donosi svijest o načinima proizvodnje te o ekonomskim klasama u svoja čitanja tekstova, ekokritika zauzima geocentrični pristup književnim studijima... Ekokritika dijeli fundamentalnu premisu da je ljudska kultura povezana s fizičkim svijetom, da djeluje na njega i da se djeluje na nju. Ekokritika uzima kao svoju temu međupovezanost prirode i kulture, posebice kulturalne artefakte jezika i književnosti...6

Subdisciplina se razvija od kraja osamdesetih, a posebno u devedesetima i dvijetisućitima, kada su se osnivale strukovne udruge $\left(\mathrm{ASLE}^{7}\right.$ i EASLCE ${ }^{8}$ ), pokretali časopisi i zbornici. Američka je ekokritika usmjerena na autore 19. stoljeća i njihovo pisanje o prirodi (interpretacije divljine, krajolika, motiva i tema), što bi značilo usmjeravanje $\mathrm{k}$ povratku prirodi

2 U radu se dosljedno koristim terminom ekokritika, koji je u svojim radovima, prvima koji su se doticali ove tematike, rabila Suzana Marjanić, a ne ekokriticizam, kako je predložio Domagoj Brozović. Usp. Suzana MarJanić, „Književni svjetovi s etnološkom, ekološkom i animalističkom nišom", Narodna umjetnost, 43/2006., br. 2, 163-186; IstA, „Zoosfera Tita Andronika: ljudska, previše ljudska bestijalnost“, Tré́a, 10/2008., br. 2, 59-82; Domagoj Brozović, „Čitati zeleno. Ekokriticizam - neprepoznata mogućnost suvremene hrvatske znanosti o književnosti“, Književna smotra, 44/2012., br. 164-165, 29-35.

3 U nepreglednom broju naslova o promjenama u različitim aspektima društvene zbilje sedamdesetih godina usp. Thomas Borstelmann, The 1970s. A New Global History from Civil Rights to Economic Inequality, Princeton 2015. i Niall Ferguson i dr. (ur.), The Shock of the Global. The 1970s in Perspective, Harvard 2011.

4 William Rueckert, „Literature and Ecology: An Experiment in Ecocriticism“, Ecocriticism Reader. Landmarks in Literary Ecology (ur. Cheryll Glotfelty i Harold Fromm), Athens, Georgia 1996., 107.

5 Peter Berry, Beginning Theory. An Introduction to Literary and Cultural Theory, Manchester - New York 2009., 240; D. Brozović, „Čitati zeleno“, 29. Usp. i Karl Kroeber, "'Home at Grasmere’: Ecological Holiness“, Publications of the Modern Language Association of America, 89/1974., br. 1, 132-141.

6 Citirano prema D. Brozović, „Čitati zeleno“, 30. Usp. i Cheryll Glotfelty, „Introduction: Literary Studies in an Age of Environmental Crisis", Ecocriticism Reader. Landmarks in Literary Ecology (ur. Cheryll Glotfelty i Harold Fromm), Athens, Georgia 1996., XVIII.

7 Za samu organizaciju Association for the Study of Literature and Environment v. službenu stranicu https://www.asle. org.

8 Podaci o strukovnoj udruzi European Association for Study of Literature Culture and Environment dostupni su na: https://www.easlce.eu. 
te slavljenju prirode kao takve, dok je britanska više orijentirana prema odnosu kulture i prirode kroz prizmu antropocentričnih prijetnji prirodi (odnosno okolišu). Jedan od izazova, prema mišljenju Domagoja Brozovića, zasigurno je nedostatak čvršće metodološke i terminološke literature, ${ }^{9}$ praksi i obrazaca. Pri tome je jedno od središnjih pitanja: tko ili što je u središtu ekokritičkog čitanja književnih djela: čovjek ili priroda? Ekokritičari tumače prirodu i kulturu kao fenomene, a ne kao jezične, umjetne konstrukte. ${ }^{10}$

Odnos prirode i kulture uobličen u ekokritičkim čitanjima književnih djela poticajan je za analizu romana Pronalazak Athanatika autora Vladana Desnice. Inicijalna piščeva ideja o lijeku za besmrtnost i promjenama koje ima u svijetu dobra je podloga za iščitavanje međusobnih odnosa kulture i prirode te promatranje prirode kao subjekta, a ne samo kao marginaliziranog objekta.

Ovaj rad zamišljen je kao kolaž od triju tematskih cjelina: ekokritički pristup životu smrti - besmrtnosti u komparaciji i povezivanju Desničina nedovršenog romana s djelom Homo Deus; zatim ekokritička analiza kiše kroz prizmu ideja Susan Farrell; analiza Pronalaska Athanatika u kontekstu distopijskih ekoloških/okolišnih romana u suvremenoj hrvatskoj književnosti Planet Friedman Josipa Mlakića i Mjesečev meridijan Ede Popovića, uz usporedbu s ekokritičkim čitanjima koncepta antropocena autorice Louise Squire.

\section{2. こ̌LIVOT - SMRT - BESMRTNOST: EKOKRITIČKI PRISTUP PRONALASKU ATHANATIKA}

Još su u prapovijesti ljudi stvorili binarni sustav sastavljen od života i smrti. Dok se prva inačica tog sustava mogla jasno raspoznavati čovjekovim rođenjem i samim životom, ona druga - smrt - ostala je zagonetna, mistična i izazovna. Iz tih se razloga u brojnim mitovima, religijama, likovnim i književnim djelima pojavljuje priča o besmrtnosti i potraga za njom kao svojevrsnom pobjedom nad smrću. ${ }^{11} \mathrm{U}$ pojedinim se mitologijama besmrtnost povezuje uz određene biljke, prirodne osobitosti (planine, more, nepoznati krajevi) ili život junaka i bogova. ${ }^{12} S$ druge strane, većina monoteističkih religija smrt doživljava kao nastavak života na drugom svijetu, ovisno o okolnostima i zemaljskom životu osobe. ${ }^{13} \mathrm{U}$ suvre-

$9 \quad$ U posljednje su vrijeme napravljeni značajni pomaci na tom polju, što se može vidjeti u radovima Dereka Gladwina s vrlo opsežnom bibliografijom i Simona C. Estoka. Usp. Derek Gladwin, „Ecocriticism“, Oxford Bibliographies (http://www.oxfordbibliographies.com/view/document/obo-9780190221911/obo-9780190221911-0014.xml); Simon C. Еsток, „Teorija s ruba: životinje, ekokritika, Shakespeare“, Kazalište, 11/2008., br. 35-36, 84-97.

10 Usp. D. Brozović, „Čitati zeleno“, 29-35.

11 Usp. Jacques Choron, „Death and Immortality“, Dictionary of the History of Ideas (ur. Philip P. Wiener), sv. 1, New York 1974., 635-646 (https://web.archive.org/web/20070311081839/http://etext.lib.virginia.edu/cgi-local/DHI/dhi. cgi?id=dv1-76).

12 Primjerice, Ep o Gilgamešu ili Putovanje na zapad pokazuju predodžbe potrage za besmrtnošću u sumerskoj, odnosno kineskoj mitologiji. Problem fenomena besmrtnosti u grčkoj mitologiji izložen je u mitu o Sizifu i njegovu zarobljavanju boga Thanatosa, čime je prestalo umiranje ljudi sve dok Thanatos nije oslobođen. Usp. Reginald CAMPBELL Thompson, The Epic of Gilgamesh: Complete Academic Translation. Translated from cuneiform tablets in the British Museum literally into English hexameters, London 2007.; Wu Cheng'en, A journey to the West, Beijing 1955.; „Sisyphus", Encyclopaedia Britannica (https://www.britannica.com/topic/Sisyphus).

13 U kršćanstvu se ovo manifestira postojanjem zagrobnog života u vidu raja, čistilišta (koje priznaju samo katolici) i pakla, dok je u islamu slična koncepcija s džennetom (raj) i džehennemom (pakao), a u judaizmu postoje shamayin 
menom svijetu 21. stoljeća aktualizirana je priča o besmrtnosti. Danas se besmrtnost ne doživljava pronalaskom određenog cvijeta ili lista pojedine biljke, jedenjem pojedinih namirnica (voća ili povrća), niti odlaskom u planine ili nepoznate krajeve, kakve su predodžbe bile u predmodernom svijetu, već pokušajima produljivanja ljudskog života korištenjem različitim tehnološkim mogućnostima, uključujući povezivanja s umjetnom inteligencijom, izumima, robotima i sličnim novinama.

Drugi binarni par koji proizlazi iz prvoga, odnosno čovjekova nastojanja za besmrtnošću, temeljno je pitanje ekokritike, sazdano u (su)odnosu između kulture i prirode. Njihovu dihotomiju najbolje definira William Howarth, atribuirajući ekokritičara/ekokritičarku kao „osobu koja analizira prednosti i nedostatke zapisa koji prikazuju učinke kulture na prirodu s namjerom slavljenja prirode, kritiziranja njezina iskorištavanja i ispravljanja štete učinjene kroz političku aktivnost". ${ }^{14}$

Književnik Vladan Desnica u svojim se raznim djelima doticao pitanja smrti i besmrtnosti, odabirujući ih kao svoju veliku temu, a najizraženije u nedovršenom romanu Pronalazak Athanatika. Ovaj kratak roman strukturiran je kao dijalog između pripovjedača i Krezubog, pripovjedačeva poznanika koji tumači svoju novu ideju, točnije, fabulu nenapisanog romana. Radnja je smještena u nedefiniranu budućnost (autor se koristi terminom

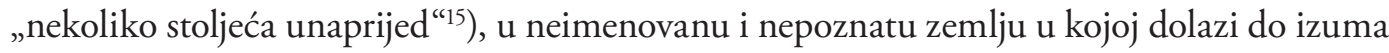
lijeka (injekcije) protiv smrti. Važno je naglasiti Desničinu terminološku odrednicu, kako uočava Krešimir Nemec, jer se pisac izričito koristi sljedećim terminima: lijek, hormon ili faktor Iks umjesto eliksir za izum athanatika (čiji i sâm naziv ukazuje o čemu je riječ: $a$ thanatos - protiv smrti) te vječita regeneracija ili beskonačno trajanje umjesto besmrtnost. ${ }^{16}$ Ovime se dodatno naglašava znanstvenost samog lijeka - uostalom, i izrijekom se navodi da je lijek produkt znanstvenih istraživanja - čime Desnica stavlja otklon od tradicionalnih pristupa besmrtnosti i potragama za eliksirima.

Daljnja radnja upućuje na društvene i ekonomske posljedice. U samom je početku izum doveo do neviđene euforije, radosti i slavlja, što se uskoro počelo mijenjati uvođenjem državne kontrole. Time se pokazalo da svaki život nije jednako vrijedan. Besmrtnost je realizirana posebnom ustanovom Izuzeća od smrti, koja je stvorila različite društvene skupine (klase) za dobivanje athanatika. Struktura je piramidalna i hijerarhijska, duboko povezana $s$ trenutačnom pozicijom moći, od predsjednika i premijera pa naniže. Ovakav je princip u romanu opravdan uobičajenim okolišnim problemom: nedostatkom dovoljne količine hrane. Uvedene mjere dovode do rasta nasilja, krađa, prevara, ubojstava, pobuna i revolucija. Rezultat je toga nastanak totalitarne države diktatora Maman-Mamona, koji kontrolira život i smrt svojih građana. Ubrzo su slijedila ubojstva, sukobi i ponovno korištenje plinskim komorama te diferencijacija ljudi na dvije veće skupine: smrtne i besmrtne. Iako je lijek usa-

(raj) i gehenna (pakao). Slični su koncepti i u istočnjačkim religijama poput budizma i hinduizma s, primjerice, raznim inačicama pakla, od kojih je najpoznatija naraka. Detaljnije o zagrobnom životu v. „Zagrobni život“, Hrvatska enciklopedija (http://www.enciklopedija.hr/natuknica.aspx?id=66705).

14 William Howarth, „Some Principles of Ecocriticism“, Ecocriticism Reader. Landmarks in Literary Ecology (ur. Cheryll Glotfelty i Harold Fromm), Athens, Georgia 1996., 69. Usp. i Tjaša TrČEK, Ekokritika - upodobitve narave v izbranih mladinskih delih, diplomski rad, Univerza v Ljubljani, Pedagoška fakulteta, 2016., 3.

15 Vladan Desnica, Pronalazak Athanatika, Zagreb 2006., 8.

16 Krešimir Nemec, „Pronalazak Athanatika - između utopije i distopije“, u: V. Desnica, Pronalazak Athanatika, 87. 
vršen na dva podtipa - A (koji je djelovao na sve vrste smrti, uključujući i onu nasilnu) i B (koji je djelovao samo u slučaju prirodne smrti) - nije se poboljšalo stanje jer su nedostatak hrane i posljedice lijeka (poremećaji) uvjetovali daljnje probleme. Završetak je rezultirao svjesnim uništavanjem lijeka, odnosno ljudskim odabirom smrtnosti umjesto besmrtnosti.

Aktualnost ove teme u počecima 21. stoljeća osnažuje pojava svjetskog bestselera poznatog izraelskog povjesničara Yuvala Noaha Hararija i njegova djela Homo Deus s vrlo znakovitim podnaslovom Kratka povijest sutrašnjice. Radi se o svojevrsnom nastavku njegove prethodne uspješnice Sapiens s podnaslovom Kratka povijest čovječanstva. U Sapiensu je Harari prikazom četiriju revolucija - kognitivne, agrarne, unifikacijske i znanstvene - objasnio kako je u prošlosti čovjek dosegao svoju današnju razinu, dok je u Homo Deusu ušao u problematiku budućnosti. ${ }^{17} \mathrm{U}$ uvodnom dijelu Harari donosi kratak prikaz povijesti kroz vizuru ljudske pobjede nad ratom (navodi da je veća šansa samoubojstvo nego ubojstvo u ratu), gladi (više je pretilih nego gladnih u svijetu) i bolestima (većina zaraznih, epidemijskih bolesti iskorijenjena je). Taj bi dio knjige, kako prikazuje Tizian Raspor, karakterizirao optimističan ton. ${ }^{18}$ Prvo je poglavlje zapravo Hararijevo objašnjenje ljudske prošlosti od početaka Homo sapiensa do danas, najmoćnijeg bića na planetu. Sukladno s naznačenim u Sapiensu, autor to objašnjava stvaranjem zajedničke kolektivne mašte, koja prelazi u mitove, omogućujući stvaranje povezane zajednice sastavljene od međusobno nepoznatih osoba. Takva je imaginacija omogućila stvaranje nacija, novca, religija, ljudskih prava, zakona i sličnih. Među ostalim pojmovima izdvaja pojam algoritam kao svojevrstan izvor zaključaka i donošenja odluka (umjesto korištenja intuicijom). U drugom poglavlju odlazi korak dalje, pokazujući nepomirenu razliku između moći i smisla te navodeći kako je izborom moći pojedinac sve bliži statusu božanstva (u tradicionalnim religijama) jer uspijeva kontrolirati i koordinirati različite procese. U posljednjem poglavlju donosi ideju dataizma (religija podataka) kao nove „religije“ utemeljene na moći i važnosti informacija te projekciju budućnosti u skladu s novim tehnološkim dostignućima, navodeći koje će to posljedice izazvati na društvena kretanja, uz mogući daljnji porast društvenih nejednakosti. ${ }^{19}$

Najvažnije potpoglavlje za ovu temu naslovljeno je „Posljednji dani smrti“. Harari ocrtava svoju tezu o besmrtnosti pričom o svetosti ljudskog života, koja se uočava u brojnim zakonodavnim i legislativnim aktima, kao i svakodnevnom životu, no napominje kako religije (kršćanstvo, hinduizam, judaizam) imaju drugačiji stav o smrti jer bez nje cijeli religijski koncept tih zajednica - koji uključuje raj, pakao i reinkarnaciju - postaje nemoguć. Suvremen čovjek, prema Harariju, umire zbog tehničkih problema - srce prestane kucati, središnja se arterija začepi ili se stanice raka prošire tijelom zato što srce ne dobiva zraka ili zbog genetske mutacije stanica. Njegova je teza o smrti najbolje složena u sljedećoj rečenici: „Ako je tradicionalno smrt bila specijalnost svećenika i teologa, danas su stvar preuzeli inženjeri. “' ${ }^{20}$ Smatra da je uvijek u pozadini tehnički problem, čak i pri vremenskim nepo-

17 Yuval Noah Harari, Sapiens. Kratka povijest čovječanstva, Zagreb 2015. Usp. i Goran ĐurĐević, „Yuval Noah Harari, Sapiens: kratka povijest čovječanstva, Fokus, Zagreb 2015, 479 str.“, Historijski zbornik, 68/2015., br. 1, $203-205$.

18 Tizian Raspor, „Yuval Noah Harari, Homo Deus. Kratka povijest sutrašnjice, prevela s engleskog Marija Perišić, Fokus komunikacije, Zagreb 2017, 461 str.", Historiografija.hr (http://www.historiografija.hr/?p=5663).

19 Yuval Noah Harari, Homo Deus. Kratka povijest sutrašnjice, Zagreb 2017. Usp. i Goran ĐurĐević, „Yuval Noah Harari, Homo Deus: kratka povijest sutrašnjice“, Ekonomska i ekohistorija, 13/2017., 177-178.

20 Y. N. Harari, Homo Deus, 26. 
godama, automobilskim nesrećama i sličnim nedaćama koje izazivaju smrt. Argumentira kako je internetska tražilica i jedna od najmoćnijih kompanija, Google, investirala mnogo sredstava u istraživanja i borbu protiv smrti, angažirajući dvojicu istaknutih znanstvenika i „promicatelja“ besmrtnosti - Rayja Kurzweila i Billa Marisa. Pritom Google nije jedina kompanija iz Silicijske doline koja investira u takva istraživanja. Besmrtnost će generirati različite društvene promjene u odabiru zanimanja, tijeku karijera, brakovima i strukturi obitelji, roditeljstvu. Harari završava poglavlje upozorenjima što bi se moglo dogoditi kad jednom znanost stvori uvjete za besmrtnost. Procjenjuje da će doći do sukoba, ratova i međusobnih borbi za besmrtnost, što će baciti sjenu na dosadašnje sukobe, u kojima će se strah od smrti zamijeniti ratovima, odnosno borbama za besmrtnost. ${ }^{21}$

Uspoređujući ovu dvojicu autora, Desnicu i Hararija, uočavamo da, neovisno o vremenskoj razlici u stvaranju svojih djela, pišu o istoj stvari iz sličnog kuta gledanja, ali s različitim rezultatima. Obojica pišu o besmrtnosti kao fenomenu budućnosti koji se temelji na znanosti i tehnologiji, pri čemu su ovdje stvorene prve razlike: Desnica izvor besmrtnosti vidi u lijeku, a za Hararija je besmrtnost napredak tehnologije (operacija zamjene organa razvojem robotike i zdravstveno-tehničkih uradaka). Princip lijeka za besmrtnost upućuje na povezivanje tradicionalnih poimanja dosezanja besmrtnosti (ljekovite trave ili određena hrana) s dosezima tadašnjeg doba (izum lijeka). Drugim riječima, Desnica pristupa problemu besmrtnosti i smrtnosti kao svojevrsnim bolestima te zamišlja kakve bi događaje i posljedice donio preventivan izumljen lijek za izostanak smrtnosti, odnosno sprečavanje umiranja. Hararijev je pristup sličan inženjerima suvremenog doba. On promatra ljudsko tijelo kao mehanizam s dijelovima određenog roka trajanja, koji se potom mijenjaju, čineći taj mehanizam manje-više trajnim. Desnica je vrlo zanimljivo povezao tradiciju (jedinstven pripravak koji naziva lijekom) i znanstveni pristup (sustavna istraživanja, izum) u pristupu besmrtnosti. Time je postao mostom između tradicije i najnovijih pristupa poput Hararijeva. U samom Desničinu Pronalasku Athanatika vidljiv je kontrast između lijeka/izuma, koji je uvijek produkt tehnološko-znanstvenog rada i time je već u samoj ideji (a i realizaciji) udaljen od tradicionalnih traženja lijeka za besmrtnost unutar prirode (odabirom određene biljke, putovanjem u udaljene, egzotične i nepoznate krajeve). Naveden odmak, bez obzira na to što je djelomično naslonjen na tradiciju (jer je riječ o pripravku), pokazuje koliko je čovjek planirajući i realizirajući athanatik napustio prirodu kao cjelinu u kojoj živi i djeluje i pretvorio se u hegemona.

Zajedničko je obojici to što smrtnost promatraju kao znanstveno-tehnički problem koji se može riješiti razvojem znanosti i tehnologije. Ovakav pristup promatranja smrti kao bolesti, odnosno tehničkog nedostatka i naslućivanje rješenja u tom pravcu upućuje na isključivanje čovjeka iz prirode (čiji je životni ciklus omeđen rođenjem, životom i smrću) kao nadređenog, odnosno gospodara koji kreira rješenje za produžetak života i izostanak smrtnosti. Druga živa bića ne mogu dobiti mogućnost besmrtnosti, čime se čovjek dodatno izdvojio i narušio odnose s prirodom, pokazujući dominaciju te stvarajući antagonizam između čovjeka i ostalih (pod tim podrazumijevam sva živa i neživa bića te prirodu). Očekivanja, koja su ljudi imali vrhuncem kulturnih i znanstvenih dostignuća te besmrtnošću, 
pretvorila su se u neočekivane posljedice otuđenja od prirode (a time i čovjeka), što je rezultiralo narušenim odnosima prema prirodi (kao i društvu, u vidu stvaranja totalitarnih režima).

Druga razlika koju iščitavamo jest u samoj besmrtnosti kao pojmu. U Desnice su prilikom izuma dvaju tipova athanatika (A i B) obuhvaćeni različiti tipovi smrti - prirodna i nasilna (odnosno neprirodna). Harari, pak, uzima zadršku prema neprirodnoj smrti, smatrajući da će dio ljudi umirati u nesrećama i ratnim sukobima pa se koristi terminom nesmrtni umjesto besmrtni.

Treći su dio usporedbe posljedice. Besmrtnost za Desnicu u ovom romanu ima pesimističan karakter jer se gubi jednakost u smrtnosti, što dovodi do stvaranja velikih socijalnih razlika u strukturi moći, da bi se u konačnici pojavili totalitarni sustavi koji prelaze $s$ kontrole života na sveobuhvatnu kontrolu života i smrti. Time se briše bilo kakva nada za ravnopravnost (jednakost u smrti i interpretacije zemaljskog života u zagrobnom svijetu pružale su utjehu i nadu brojnim religioznim stanovnicima). Međutim, završetkom djela Desnica otvara mogućnost pozitivnog kraja, neovisno o obnovi smrtnosti ljudi. U Hararija besmrtnost je (jedan od fenomena budućnosti) također obilježena pesimističnim tonom jer je ne smatra konačnim ciljem, već sredstvom stvaranja Homo Deusa od sadašnjeg Homo sapiensa. Besmrtnost se uklapa u cjelinu kao prvi dio niza: besmrtnost, sreća, božanstvenost. U zanimljivoj rečenici Harari pokazuje što bi mogla biti besmrtnost (i za koga): „Ako su Kurzweil i de Grey u pravu, možda već neki besmrtnici hodaju pored vas na ulici, posebno ako hodate Wall Streetom ili Petom avenijom. “22 Time naglašava društveno raslojavanje glede besmrtnosti jer će očito oni s najviše novca moći osigurati taj privilegij. Također, kao povjesničar, uočava dosadašnje borbe i sukobe unutar društva i država, kao i između pojedinih država te procjenjuje da će doći do velikih ratova i sukoba u borbi za dostizanje besmrtnosti.

Ovakva se kataklizmička predviđanja poklapaju u Hararija i Desnice. Obojica vide besmrtnost kao izvor novih, još snažnijih i opasnijih ratova, koji će svojom žestinom i značenjem nadići sve dotadašnje sukobe. U skladu s navedenim, bit će dodatnih socijalnih diferencija s različitim rezultatom, pa u Desnice dovode do stvaranja totalitarnih režima, dok Harari pretpostavlja rat neizvjesnog ishoda jer će umjesto dosadašnje ekonomske doći do biološke nejednakosti. Iščitavajući pesimizam u obojice autora, možemo ga povezati s otuđenjem od prirode. Stvorenom dihotomijom između kulture i prirode, u obama se analiziranim djelima kultura stavlja u superioran odnos. Inicijalna ideja o čovjeku kao besmrtniku, kreatoru i gospodaru (u romanu Homo Deus) u svojoj je zamisli protuprirodna. Polazeći od protuprirodnosti same ideje, njezina realizacija također završava protuprirodnim posljedicama jer oba sustava (totalitarni režimi, ratna zbivanja) impliciraju vrhovne gospodare (ljude, odnosno dijelove političke, vojne i gospodarske elite) nad drugima/Drugima (uključujući ostatak ljudskog roda, ali i sva ostala živa subića te prirodu).

Usporednom analizom ovih dvaju djela dolazimo do analize završetka, odnosno kraja njihovih djela. Obojica ostavljaju mogućnost pozitivnog kraja, tj. odabira pozitivnog puta 
u budućnost. Autori dijele humanistički nazor prema svijetu u koji treba uklopiti znanost i znanstvena dostignuća. Harari vidi odabir pravog puta u zajedničkom globalnom upravljanju umjesto dosadašnjih nacionalnih upravljanja. Desnica podcrtava razum i racionalno rješenje u kombinaciji s empatijom kao ispravan odabir budućnosti. Odabir pozitivnog rješenja i puta koji će spriječiti pesimizam i potonuće u protuprirodnu dekadenciju čovjekove superiornosti i samodostatnosti direktno je povezan s odustajenjem od besmrtnosti kao vrhunca protuprirodnog postupka, kojim se negiraju povezanosti i međusobni suodnosi s prirodom kao cjelinom, koju čini i čovjek zajedno s drugim živim i neživim bićima.

Dosadašnja komparacija Desnice i Hararija svela se na antropocentričan pristup u kojemu je temelj analize bila direktna društvena posljedica (potencijalne) besmrtnosti. Drugim riječima, analizirana je kulturna (civilizacijska) komponenta, dok su okoliš i priroda zanemareni. Međusoban odnos između kulture (civilizacije) i prirode (okoliša) varira u samim definicijama pojedinih ekokritičara. ${ }^{23}$ Neovisno o tome kako tumačimo taj odnos, nedvojbeno je da on postoji. U obama djelima priroda nije jasno ocrtana kao središnji subjekt, već se autori bave društvenim posljedicama besmrtnosti. Bez obzira na to, priroda nije samo objekt nego i bitan čimbenik u ovom međusobnom odnosu. Zato se možemo zapitati koliko je čovjek odlučio izaći iz prirodnog ciklusa (koji čini zajedno sa svim živim bićima, a posljedično i neživim), dokazujući svoju superiornost (odnosno, kako Harari eksplicitno navodi, postajući bogom), manifestiranu težnju k besmrtnosti. Time čovjek (kao i odnosom prema bolestima, gladi i nadvladavanjem prirodnih nepogoda) napušta suodnos $s$ drugim živim bićima postajući superioran izvanjski element. Uspjeh pobjede nad smrću kao nedjeljivim dijelom prirode i ciklusa života kroz koji sva živa bića prolaze donosi čovjekovu pobjedu nad mističnim i nepoznatim, ali istodobno pridonosi napuštanju povezanosti s prirodom. Ovakvo napuštanje odnosa s prirodom, uz istodoban porast tehnoloških dostignuća (Harari i Desnica dovode besmrtnost u vezu s farmaceutskom industrijom, robotikom i tehnologijom), kao posljedicu ima rastakanje postojećih ukorijenjenih društvenih odnosa, ali i stvaranje protuprirodnih (a time i protuljudskih) prožimanja, odnosa i društvenih promjena. U konačnici, stavljanje svega raspoloživog na razvoj, tehnološka i znanstvena dostignuća, kao i porast kapitala dovode do sukoba s prirodom u kojemu čovjek ne može pobijediti, a gubitnici su svi.

Ekološki problemi koje treba analizirati jesu povezanost hrane i okoliša te bolesti, ali i predodžbe o životinjama. Desnica podcrtava da je hrana bila najveći problem koji se manifestirao izumom athanatika jer je Zemlja postala nedostatna za sve veći broj ljudi. ${ }^{24}$ Time besmrtnost prelazi u ozbiljan ekološki problem. Ovime Desnica dovodi u kontrast temeljne potrebe i obilježja živih bića (prehranu, tj. hranjenje kao proces održavanja života i smrtnost/besmrtnost), pokazujući njihov međusoban odnos te svojevrstan paradoks jer ljudi u želji da dostignu zamišljen ideal besmrtnosti, a zanemarujući sve ostale čimbenike prirodnog ciklusa, stvaraju situaciju nedostatka hrane, jedne od osnovnih životnih potreba kao preduvjeta bilo kakvih daljnjih ostvarenja. To je put $\mathrm{k}$ distopiji u kojoj je čovjekov pokušaj

\footnotetext{
23 Primjerice, Greg Gerrard smatra da je izazov ekokriticizma uvijek imati na umu načine na koje je priroda kulturno izgrađena, a s druge strane, da kao činjenica postoji. Usp. Greg Gerrard, Ecocriticism, Abingdon $2004 ., 10$.

24 V. Desnica, Pronalazak Athanatika, 21.
} 
ovladavanja životom i smrću (u vidu besmrtnosti) nužno doveo do uništenja prirode, destrukcije okoliša i dehumanizacije.

Životinje se spominju samo dva puta u Desničinu romanu. Prva životinja koja se spominje jest vuk na samom početku romana, kao jedna od odrednica života u prošlosti:

Ljudske riječi i ljudski strahovi dolaze i izlaze iz mode. Kolik je udio u mislima i osjećanjima negdašnjeg čovjeka imala riječ vuk! Gotovo čitav život bio je „u znaku vuka“! A ko još danas misli na vuka? Kome dandanas pada na um da oboli od likantropije? Danas se čovjek više ne boji smrti... ${ }^{25}$

Drugo je spominjanje usporedba ljudi u vremenu athanatika, koji su se pretvorili u zvijeri:

Rekli smo: ljudi su postali zvijeri. A time su za njih prestale sve stege i obveze, sva moralna i druga načela, obzir, konsideracije, predrasude ili kako god to hoćete da nazovete. Budući zvijeri, nisu više znali ni što je račun, ni oportunost, ni taktika i taktički oprez, ni svrsishodno ekonomisanje snagama, ni mudro čuvanje glave. Srljali su bezumno u propast, ginuli su kao muhe - ali su ginuli. ${ }^{26}$

Navođenje vuka u ovom slučaju upućuje na srednjovjekovne predodžbe o vukodlacima kao strašnim bićima i strahu koji su izazivali u ljudi tijekom prošlosti, što je iščeznulo izumom athanatika. ${ }^{27}$ Radi se o usporedbi ljudskog ponašanja sa zvijeri, odnosno korištenju riječi zvijeri (u izvornom značenju jednog reda kopnenih sisavaca) kao metafore za neuređenu, divlju zajednicu ili gomilu jedinki koje funkcioniraju u distopiji izuma i djelovanja athanatika te stoji u suprotnosti s društvenim normama, odnosima i pravilima ponašanja. Izborom ove riječi, koja ima snažnu simboličnu poruku nečega stranog ljudima, Desnica pokazuje posljedicu nekontroliranog tehnološkog razvoja u vidu pesimizma, rušenja društvenih normi i beznadnosti. Upravo zbog narušavanja prirodne ravnoteže ljudi i drugih subića (jer ljudi dobivaju besmrtnost i time postaju i doslovno i simbolički superiorni), kao odgovor javlja se pesimistična distopija za koju pisac ostavlja mogućnost optimističnog kraja.

Vladan Desnica navodi preslikavanje pojedinih društvenih odnosa na bolesti, među kojima vladaju određena pravila:

Da se ne bi slučajno desilo da pacijent, mjesto od raka umre od infekcije! Jer, u internom saobraćaju među bolestima postoji gentlemen's agreement. Tu nema otimačine ni presizanja. Možda tek izuzetno, neka nova nevaspitana bolest koja još ne pozna pravila igre, zaleti se preko reda sa svojom viljuškom. Ali je odmah klopnu po nadlanici. Tu vlada savršeno poštovanje rezervacija. Tako, na primjer, ako neko ima da umre od raka, sasvim je isključeno da mu, recimo, padne kap. Može da se ljubi u usta s kužnima (empestés), može da znojan skače naglavce u hladnu vodu šesnaest puta dnevno, on neće oboljeti od kuge, on neće dobiti upalu pluća! ${ }^{28}$

25 Isto, 8.

26 Isto, 62. Vrlo sličan citat, gotovo identičan, nalazi se i na str. 72, uz uredničku napomenu o ponavljanju dijela teksta.

27 O vukodlaku, likantropiji u popularnoj kulturi s primjerima iz Hrvatske usp. Ingrid KiršA, Likantropija upopularnoj kulturi, diplomski rad, Sveučilište u Zagrebu, Hrvatski studiji, Odsjek za kroatologiju, 2017.

28

V. Desnica, Pronalazak Athanatika, 15. 
Ideja prezentacije odnosa među bolestima kao preslike društvenih odnosa može se iščitavati kao premreženost i povezivanje prirodnih pojava (što bolesti jesu), živih bića (od čovjeka do različitih mikroba, virusa i bakterija) i društvenih odnosa. Tako imamo premreženost prirode i društva jer se mogu koristiti pojedina društvena znanja i odnosi u primjeni na prirodu i obratno, a to upućuje na jedinstvo živih bića i neživih tvari kao cjelokupnosti koja čini prirodu na Zemlji.

U Hararija je moć sadržana u ljudima izvor opasnosti za cijeli planet, stoga se trebaju zapitati koliko je sprečavanje gladi, ratova i bolesti, uz popratan ekonomski rast, bilo u skladu s potrebama Zemlje. Iz tog razloga autor smatra da treba birati ekološku stabilnost kako bi se izbjegla katastrofa. ${ }^{29}$ Besmrtnost kao neželjenu posljedicu nosi određene ekološke probleme za čovječanstvo, ostala živa su-bića i planet u cijelosti.

\section{KIŠA KAO EKOKRITIČKI FENOMEN}

Priroda (u najširoj definiciji pojma) sa svim raznolikim prirodnim pojavama relativno je česta u književnom stvaralaštvu. Brojni su se književnici koristili prirodnim pojavama poput kiše, sunca, snijega, vjetra da bi pridonijeli atmosferi, simbolički se izrazili o stanju, osjećajima i zbivanjima ili ih na određene načine uključili u radnju svojih djela. Ekokriticizam je u svojoj definiciji povezivanje prirode i književnosti pa su prirodni fenomeni drugačije interpretirani od uobičajene analize simbola ili kulise događaja.

Osim smrti, koja je temeljna nit samog romana Pronalazak Athanatika, za ekokritičko čitanje važna je prirodna pojava - kiša. Jedna je od temeljnih postavki ekokriticizma povezivanje prirode - uključujući i sve prirodne pojave $-s$ književnošću. Kiša se u romanu pojavljuje nekoliko puta. Roman započinje spominjanjem kišnog popodneva tijekom kojega pripovjedač sjedi u kavani s Krezubim. Desnica kroz pripovjedača opisuje kišu koja danima pada ravnomjerno. Promišlja o kiši kao vodi - kako i odakle dolazi, postoji li ciklus ili je to nova voda:

Je li moguće da je to uvijek nova, nerabljena voda - ta odakle bi tolika! - ili one iste, već jednom upotrebljene količine, u zatvorenom krugu, kroz kanale i izljeve otječu u neka podzemna sabirališta, tu se na brzu ruku filtriraju i regeneriraju, pumpama ponovo tjeraju gore, pa odozdo opet toče, cijede, cure... A ako je tako, tad zbilja, izvan nekog nepredviđenog kvara na strojevima, nema izbavljenja!... ${ }^{30}$

Roman završava kišom i njenim ujednačenim padanjem, „kao da je oduvijek kišilo i kao da će dovijeka kišiti“" ${ }^{31}$

Desnica kišu promatra na nekoliko razina: a) na simboličkoj razini, uspoređujući je s tijekom vremena kao konstantu u kojoj se nižu događaji ili se ništa ne događa, no svejedno teče (i kiša i vrijeme); b) na prirodnoj, odnosno tehničkoj razini, promišljajući odakle se stvara i kako slijedi prirodni ciklus kruženja vode u prirodi, pri čemu taj proces zamišlja

\footnotetext{
29 Y. N. Harari, Homo Deus, 23-24.

30 V. Desnica, Pronalazak Athanatika, 7.

31 Isto, 80.
} 
kao niz tehničkih rješenja (sabirališta, pumpe, filteri); c) kao poveznicu između pripovjedača i kiše koja je „tipična kavanska“ i pokazuje poveznicu između početka i kraja romana jer kiša pada cijelo vrijeme tijeka romana.

Važnim se čini zadržati se na tehničkoj razini, odnosno objašnjavanju kiše kao sustava tehničkih rješenja za kruženje vode u prirodi. Osim što daje gradacijski uvod u roman, u kojemu će pokazati vrhunac tehnološke civilizacije koja kreira athanatik, ovakav pristup kiši kao tehničkom rješenju, a ne uobičajenom prirodnom ciklusu, pokazuje kako čovjek budućnosti iz vremena athanatika promatra pojave oko sebe - ne kao prirodne pojave, čime je naglašena negacije prirode.

Prirodne pojave poput kiše relativno su česte u književnosti te nose različitu simboliku. Koristeći se idejom Susan Farrell o povezivanju kiše sa smrću, što ona čini na primjeru čitanja djela Zbogom oružje američkog književnika Ernesta Hemingwayja, Desničina kiša dobiva novo značenje ne samo kao kulisa radnje već i kao pozadina za cijelu priču o odnosu života, smrti i besmrtnosti. Prema mišljenju Susan Farrell, u romanu Zbogom oružje može se primijetiti povezivanje kiše i smrti na temelju primjera strahova od kiše te smrti koja je povezana s njom. ${ }^{32}$ Najbolje je to vidljivo u citatu: „Bojim se kiše jer ponekad vidim sebe mrtvu u njoj - rekla mu je - a ponekad vidim tebe mrtvog u njoj. ${ }^{\text {"33 }}$ Ako primijenimo taj model na roman Pronalazak Athanatika, pojava kiše na početku i kraju romana upućuje na smrt, odnosno smrtnost koja je u pozadini dijaloškog romana i razgovora o besmrtnosti između Krezubog i pripovjedača. Štoviše, Desničine riječi o kiši kao konstanti („kao da je oduvijek kišilo i kao da će dovijeka kišiti“) dodatno potvrđuju tu smrtnost, odnosno prirodni odgovor na čovjekova traganja o besmrtnosti. S druge, pak, strane, Desnica upućuje na problem „kvara i izbavljenja“ od kiše, čime pokazuje da priroda zajedno sa svojom pojavom, kišom, nije samo kulisa i pozadina fabule romana i čovjekova života, nego je aktivan činitelj, ravnopravan čovjeku i konstanta u ljudskom životu, oblikujući ga kao dio prirode u dodiru s prirodnim pojavama (bilo kišom, bilo smrću). U tom bi se kontekstu moglo tumačiti početak i kraj romana u kojemu je opisana kiša.

\section{PRONALAZAK AthanatiKa KaO PRETEČ́a OKOLIŠnih/ EKOLOŠKIH DISTOPIJSKIH ROMANA}

Suvremena hrvatska književnost ne obiluje romanima koji se radnjom vezuju uz distopijsku ${ }^{34}$ budućnost, pri čemu bi ona bila određena okolišnim/ekološkim čimbenicima. Najreprezentativniji su primjeri romani Josipa Mlakića Planet Friedman i Ede Popovića Mjesečev meridijan.

32 Susan Farrell, „Rainy Day Blues: The Role of Weather in A Farewell to Arms“, College of Charleston Blogs (http:// blogs.cofc.edu/hons110/files/2011/10/Rain-in-Hemingway.pdf). Usp. Ernest HemingwaY, A Farewell to Arms, New York 1929.

33 E. Hemingway, A Farewell to Arms, 135. Preveo G. Đ.

34 O samim definicijama pojma i razilaženjima v. Miranda Levanat-Peričić, „Čitanje distopija iz aspekta različitih teorija žanra: Pavličić, Suvin, Frow“, Komparativna povijest hrvatske književnosti. Vrsta ili žanr. Zbornik radova s XIX. međunarodnoga skupa održanog od 29. do 30. rujna 2016. godine u Splitu (ur. Vinka Glunčić-Bužančić i Kristina Grgić), Split - Zagreb 2017., 249-258. 
Radnja romana Planet Friedman događa se na zagađenom planetu u koji se pretvorila Zemlja pobjedom Friedmanove ekonomske doktorine. Ljudi se dijele na nekoliko kategorija, odnosno skupina ili zona: A - privilegirani, B - osobe koje mogu postati privilegirane, C - odbačene osobe. Spomenute su zone strogo odvojene. Središnja je figura Gerharda Schmidta. Iako je pripadnik elite, tijekom romana - zahvaljujući svojoj pacijentici Pauli Bolt, uspješnoj atletičarki i invalidu - dobiva priliku sagledati ostale, deprivirane društvene skupine. U svijetu bez emocija i knjiga, kojim dominira kapitalizam, korporacije (Vijeće dvadeset i pet koorporacija, kompanije poput Rosche i Natto) i reality showovi kao mjerila vrijednosti, i u kojemu je najvažnije biti uspješan, Schmidt zahvaljujući knjigama Shakespearea i Yeatsa - kojih nema u svijetu zone A jer nisu opstale - dobivenih od Paule, otkriva svoju ljudsku dimenziju. Važna je poveznica Gerharda s njegovim ocem Andreasom, koji je pokazao humanost na Friedmanu noseći lijekove i cjepivo bolesnima i potrebitima u nižoj skupini (B) tijekom supergripe te je kažnjen i umoren zbog zločina iz samilosti. Schmidt i Paula upoznaju vođu pobunjenika Blacktootha koji tiska i distribuira knjige, ali poslije i njemu smetaju jer postaje diktator nakon pobjede. Gerhard govori o povijesti kao magnetnom polju s polovima revolucija - kontrarevolucija. Planet Friedman završava odlaskom Gerharda, Brucea, Gerhardova sina i Paule na Ždralove izvore, mjesto na kojem će biti sigurni. ${ }^{35}$

Mlakićev roman obiluje referencama na sadašnji svijet i njegove aktere. Primjerice, najmoćniji čovjek zove se Steven Yobs. Time pokazuje distopijsku budućnost kao uvijenu sadašnjost. Također, roman obuhvaća globalnu sliku u sklopu koje smo i mi. ${ }^{36}$

Edo Popović napisao je roman Mjesečev meridijan, u početku prateći Mirka Grafa, pripadnika zajednice Korov, koja organski uzgaja poljoprivredne proizvode. Graf putuje u Zagreb, prikazan kao distopijski grad pun marginalnih društvenih skupina - beskućnika, nezaposlenih, prosjaka. Susreće poznanika Josipa Pavlovića, nezaposlenog nekadašnjeg djelatnika SalarLaba. U romanu su ljudi podijeljeni na dvije skupine, sukladno s odnosom prema okolišu: Otrovani - koji su uništili okoliš - te Zaboravljeni - koji žive u središnjoj Europi u svojevrsnoj oazi nezagađenog okoliša, piju vodu iz potoka, hrane se divljim plodovima i životinjama. Glavni su likovi djevojka Mila Salar - kći vlasnika SalarLaba i bogataša Zorana Salara, voditeljica projekta o Zaboravljenima, skupini odabranih muškaraca i žena koji će na izoliranoj lokaciji živjeti kao prapovijesni lovci i sakupljači - i mladić Kaj - jedan od Zaboravljenih, čiji je otac Jakov bio zadužen za stvaranje priča o povijesti i životu Zaboravljenih. Roman završava Mirkovim pripovijedanjem o Japodskoj dolini, mjestu komune gdje žive Mila, Josip, Kaj i drugi. ${ }^{37}$ Popovićev roman također ima brojne reference na sadašnjost jer uključuje i zbivanja s kojima smo se sretali ili čuli za njih uz određene zamišljene ili izmišljene događaje. ${ }^{38}$

\footnotetext{
35 Josip Mlakić, Planet Friedman, Zagreb 2012.

36 Strahimir Primorac, „Imamo li komu slati poruke u boci?“, Vijenac, 21/2013., br. 495 (http://www.matica.hr/vijenac/495/imamo-li-komu-slati-poruke-u-boci-21432/).

37 Edo Popović, Mjesečev meridijan, Zagreb 2015.

38 Strahimir Primorac, „Potraga za svijetom slobode“, Vijenac, 23/2015., br. 561-562. (http://www.matica.hr/vijenac/561\%20-\%20562/Potraga\%20za\%20svijetom\%20slobode/).
} 
Pronalazak Athanatika kao značajno stariji prethodnik te Mjesečev meridijan i Planet Friedman mogu se komparativno promatrati u nekoliko slojeva. Usporedbom ovih triju djela mogu se uočiti određene sličnosti u samom uzroku promjena, što je prvenstveno ekologija i zaštita prirode, odnosno izostanak brige o okolišu (zagađenje, uništen okolišs, smrt - besmrtnost). Autori stvaraju uzročno-posljedični niz jer ekološke promjene, kao uzrok, dovode do značajnih posljedica u vidu socijalnih promjena manifestiranih u čvrsto podijeljenom društvu na dvije (Desnica, Popović) ili tri skupine (Mlakić). Konačna je posljedica stvaranje totalitarnog svijeta, bilo diktature s referencama na nacističko-fašističku (Desnica), bilo beskrupuloznog korporativno-kapitalističkog svijeta (Mlakić, Popović). Projekcija ekološki onečišćene budućnosti i čovječanstva koje se kreće k ponoru uvjetovana je neprijateljima tadašnjosti (sadašnjosti) pa su zato strahovi Vladana Desnice usmjereni na mogući povratak nacizma i fašizma, s tada još uvijek svježim uspomenama, dok su suvremeni pisci Popović $i$ Mlakić usmjereni na negativnosti veoma aktualnog korporativnog i kapitalističkog svijeta. Gradacijski postavljeno, Mlakićevo je društvo poveznica između Desničina i Popovićeva društva jer u roman, osim korporativnog kapitalizma, uvodi i diktaturu u kojoj se kontrolira znanje, emocije i cjelokupnost života osmišljenu od Tvorca, Friedmana. ${ }^{39}$ Ovime Mlakić pokazuje vrhunac korporativnog kapitalizma, koji nužno odlazi u diktaturu, odnosno totalitarizam kao svoj temeljni cilj.

Sva trojica autora pokazuju nedjeljivost čovjeka od prirode te posljedice takve podjele. Izostanak veza s prirodom i razaranja suodnosa s njom - postavljajući kulturu, civilizaciju i razvoj kao superiorne - dovode do ekoloških problema koji se nužno reflektiraju na društvene probleme. Iz toga može se izvući veoma pesimističan pogled na takvu budućnost koja je distopijska - uništena, dehumanizirana, neprirodna i antiprirodna, čime ni ljudi nemaju budućnost te protuprirodnim ponašanjem uništavaju i onu vlastitu.

U drugom sloju možemo analizirati vrijeme i mjesto samih radnji. Desnica i Mlakić stvaraju puno neodređeniji svijet, ispuštajući točnu godinu, odnosno godine radnje, kao i detaljnije opise prostora, tj. teritorija u kojemu se ona odvija, pri čemu su ti teritoriji i prostori zapravo svjetski, globalni i mogu se vezati uz različite zemlje. Popović je puno određeniji opisom prostora (Zagreb, Japodska dolina, Hrvatska, srednja Europa), a vremenski radnju smješta u neodređenu, ali blisku budućnost.

Tematski ciklus besmrtnost - smrt - život postaje zajednička točka svoj trojici autora. Desnica je cijeli svoj roman osmislio oko teme besmrtnosti i pronađenog athanatika, a Popović se u rubnom dijelu svog romana također dotiče besmrtnosti, pri čemu je najilustrativniji dio o povezanosti besmrtnosti i novca (kapitala), odnosno zamjene dotrajalih organa. Time se Popović približava Hararijevu doživljaju besmrtnosti. Mlakić prikazuje smrt uz odsutnost bilo kakvih emocija i empatije. Sve se promatra kroz uspjeh, korist i vlastiti probitak uz pohlepu. U Popovića i Mlakića može se govoriti o smrtnosti, odnosno o smrti planeta Zemlje slijedom dugotrajnih onečišćenja i ekoloških problema. Desnica naslućuje takav ekološki problem uočavanjem nestašice hrane nakon izuma athanatika. Sva trojica autora dovode u međusoban odnos besmrtnost pojedinca sa smrtnošću prirode, što dugoročno dovodi i do smrtnosti ljudskog roda.

39 Tea Šitum, „Planet Friedman“, Citajme.com (http://citajme.com/planet-friedman/). 
Djela možemo analizirati na temelju predodžbi binarnog para sloboda - dominacija. Zajedničko je svim autorima stvaranje svijeta dominacije i moći u kojoj povlašteni (ako ih zamislimo kao jednu skupinu) dominiraju nad svima drugima, pri čemu se humanizam kao odrednica potpuno gubi u takvoj budućnosti koja je izgrađena - možda je bolji termin razgrađena - na ekološkim problemima. Zato je sloboda najvǎniji termin u koji se mogu svrstati analizirana Desničina, Mlakićeva i Popovićeva djela. Matko Vladanović navodi za Popovićev roman: „U moru lažnih informacija, nametnutih i iskonstruiranih identiteta, manipulacija i propagande odgovor na pitanje slobode različit je za svakog pojedinca. ${ }^{40} \mathrm{Te}$ riječi odlično opisuju pojam slobode u ovim djelima, neovisno o pojedinim zajedničkim karakteristikama pojedinih likova. Pitanje dominacije i superiornosti kao dijela binarnog para u odnosu sa slobodom u nedjeljivoj je vezi s prirodom i uništenim okolišem. U svim trima djelima dominacija čovjeka (kao koorporativnog, racionalnog tehnološkog bića) u kontrastu je sa slobodom drugih živih subića, ali i sa slobodom čovjeka (pojedinca koji ima i onu drugu stranu emocija i empatija, čineći dio prirodne ravnoteže i ciklusa života).

Tragom analizirane slobode i dominacije, postavlja se pitanje autorovih projekcija budućnosti i samog završetka romana. U završetku svojih djela Desnica i Mlakić nude optimizam: u Desnice riječ je o završnom uništenju athanatika, a Mlakić otvara neiskvaren svijet (Ždralove izvore) kao mjesto novog početka, iako uz dozu skepse (otvoreno pitanje o porukama u boci). ${ }^{41}$ Popovićev kraj nosi optimisitičke natruhe jer omogućuje različite predodžbe slobode definirane prema željama pojedinog lika (putovanja Kaja i Josipa, Mirkova promišljanja o budućnosti i mjestima na koja možemo ići i gdje možemo ostati). ${ }^{42}$ Zajednička je karakteristika završetka ovih romana ta da je optimizam u svojevrsnom povratku prirodi - u Desnice u uništavanju protuprirodnog athanatika koji narušava prirodnu ravnotežu, u Mlakića u odlasku u zaštićeno područje, odnosno mjesto gdje nije uništena priroda, a u Popovića vrlo slično, u putovanju za slobodom i mjestima u kojima postoji neuništena priroda.

Koristeći se metodološkim obrascem Louise Squire iz rada „Death and the Anthropocene: Cormac McCarthy's World of Unliving", u kojemu se referira na ideje Paula Crutzena o antropocenu, geološkom razdoblju u kojemu je dominantan utjecaj čovjeka na geološke i okolišne promjene, te Jacquesa Derride o smrti, ona navedene ideje (antropocen i smrt) stavlja u kontekst književne teorije i analize književnog djela. Autorica analizira književno djelo Cormaca McCarthyja koristeći se doživljajem smrti Jacquesa Derride koji smatra sljedeće: „Naučiti živjeti znači naučiti umrijeti, naučiti sve staviti pod isti račun, odnosno prihvatiti apsolutnu smrtnost (bez spasenja, uskrsnuća i iskupljenja ni za sebe ni za druge) (...) filozofirati znači naučiti umrijeti. “43 Nadalje, Squire promišlja koliko su dva Derridina koncepta o smrti i arhivi primjenjiva na književna djela: „a) nemogućnost otkrivanja granice smrti kao takve i b) promišljanje o krajevima kojima dekonstrukcija postaje odgovorna za

\footnotetext{
40 Matko Vladanović, „Edo Popović: Mjesečev meridijan“, Moderna vremena (http://www.mvinfo.hr/clanak/edo-popovic-mjesecev-meridijan).

41 J. Mlakić, Planet Friedman, 253.

42 E. Popović, Mjesečev meridijan, 171

43 Citirano prema Louise SQuire, „Death and the Anthropocene: Cormac McCarthy's World of Unliving“, The Oxford Literary Review, 34/2012., br. 12, 215. Preveo G. Đ.
} 
budućnost izvan iskustva, pri čemu tada antropocen može biti vrijeme u kojemu se bojimo onečišćenja arhive fizičkim događajima pa zato dekonstruiramo (iako težimo rekonstruirati) tko smo “. ${ }^{44}$ Pita se i mogu li se povezati smrt i antropocen kao dva koncepta te može li se koncept Derridinih arhiva kao matrica iščitati u odabranim književnim djelima (što ona čini u djelima Cormaca McCarthyja). Povezivanje ekokritike i dekonstrukcije otvoreno je pitanje u suvremenoj metodologiji ekokritike i stvaranju suodnosa s postmodernizmom. Bez obzira na zajedničke korijene u poststrukturalističkim analizama, postmodernizam i ekokritika razdvajaju se u dijelu oko dekonstrukcije. O ovom problemu Domagoj Brozović navodi sljedeće:

Ono što ekokriticizam razlikuje od glavne struje poststrukturalizma je razvijanje zrelog protustava postmodernističkoj inklinaciji neobuzdane simboličke, jezične i kulturalne igre pri čemu se zagovara rekonstruktivni pristup jeziku s čvrstim osloncem na superstrukturu prirode. Iza naizgled glavnog ekokritičkog problema veze okoliša i diskursa razvija se aksiom o ekstratekstualnoj i ekstradiskurzivnoj prirodi koji otvoreno problematizira dekonstrukcijsko brisanje relacije $s$ realnim referentima, što ima potenciju da rezultirala ozbiljnim epistemološkim konzekvencama za suvremenu književnu i kulturnu teoriju i poticajem za rekonstrukciju pojma poetičke reprezentacije koju postmodernizam tretira apriorno neadekvatnom. Ekokritički izazov postmodernizmu i ključno pitanje postaje kako diskurzivnost i materijalnost ponovno dovesti u vezu. ${ }^{45}$

Mišljenje Domagoja Brozovića i autora na koje se poziva jedno je od mogućih interpretacija odnosa postmoderne i ekokritike. ${ }^{46}$ Citirajući Timothyja Morgana, koji smatra da je dekonstrukcija tajni prijatelj ekokritike, ${ }^{47}$ smatram da se može napraviti zajednička poveznica između ekokritike i postmodernizma.

Ideje Louise Squire o povezivanju smrti i Derridinih arhiva možemo primijeniti na ekokritičko čitanje odabranih djela Desnice, Mlakića i Popovića. Ekološka je katastrofa neizbježna posljedica djelovanja čovjeka u antropocenu te će ponašanja u sadašnjosti i budućnosti povećati takvu situaciju. Koliko se isplati živjeti u svjetovima Pronalaska Athanatika, Planeta Friedman i Mjesečeva meridijana? U svjetovima različitih tipova terora, kontrole i praćenja u kojima su vrlo jasne i naglašene podjele ljudi? Derridina ideja arhiva može se iščitati u ovim romanima, posebno u Mlakića i Popovića, gdje većina likova nema nikakvog doticaja s prošlošću. Iznimke su likovi anarhista i njihova vođe, poslije Schmidt i Paula u Mlakića, Zaboravljeni te Mila i Mirko u Popovića, koji omogućuju izlazak iz zagađenog svijeta i planeta sjećanjem na prošlost i očuvanjem pojedinih vrijednosti iz prošlosti poput knjiga, čitanja, emocija u Mlakića ili života u skladu s prirodom u Popovića. U Desnice najbliži su tome „posmatrači“, kao kolektivan naziv za ljude „koji nadživljuju historiju i prate njen pogreb “ ${ }^{48}$ te pripadnici hereze koji su htjeli spoznati istinu. Upravo su poveznice $s$

44 Isto, 218. Preveo G. Đ.

45 D. Brozović, „Čitati zeleno“, 31.

46 Za različita mišljenja o odnosu postmoderne i ekokritike usp. Serpil OpPermann, „Theorizing Ecocriticism: Toward a Postmodern Ecocritical Practice“, Interdisciplinary Studies in Literature and Environment, 13/2006., br. 2, $103-128$.

47 Timothy Morton, „Deconstruction and / as Ecology“, The Oxford Handbook of Ecocriticism (ur. Greg Garrard), Oxford 2014., 291-304.

48 V. Desnica, Pronalazak Athanatika, 64. 
prošlošću otvorile mogućnost za promjenu i optimizam. Mišljenja sam da je prekid odnosa s prirodom nužno doveo do prekida odnosa s prošlošću i tradicijom. Taj se odnos reflektira u pesimizmu koji nas čeka u distopijskoj budućnosti. Izvorište za optimizam leži u ponovno povezivanju s prirodom i obnovom odnosa prema prošlosti. Ljudske emocije, empatija, hrabrost pojedinca, nada i racionalan pristup omogućili su tragove boljeg života u budućnosti.

\section{ZAKLJUČNA RAZMATRANJA}

Ekokritičko čitanje romana Pronalazak Athanatika pokazuje dvije prirodne pojave koje se provlače kroz roman. Prva je ideja smrti i besmrtnosti, koja je temeljni motiv romana i središnja os fabule. Uspoređujući i povezujućín ${ }^{49}$ djela Vladana Desnice i Yuvala Noaha Hararija, može se zamijetiti da obojica, analizirajući potencijale besmrtnosti, vide niz problema koje ona otvara, počevši od ekoloških problema, preko društvenih i ekonomskih, do političkih promjena. Bez obzira na različitosti u dolasku do besmrtnosti - Desničin izum lijeka i Hararijeva tehnička rješenja - obojica dolaze do sličnih zaključaka, pri čemu je besmrtnost uvjetovana znanstvenim istraživanjima $i$ ima široke posljedice u vidu društvenih promjena koje dovode do trajnih i opasnih sukoba. Ovi sukobi svoje izvorište imaju u pokušajima čovjekove supremacije nad prirodom i ostalim živim subićima, bazirajući se isključivo na tehnološkoj dimenziji te tzv. razvoju i napretku. Priroda postaje objekt čovjekova puta k nadmoći, što se prikazuje pokušajima besmrtnosti i pronalaženja rješenja za nj kao vrhunca tehnološko-znanstvenog uspjeha. Iz toga proizašla čovjekova samodostatnost dovodi nužno do egzistencijalne, a potom i društvene krize u kojemu taj isti čovjek postaje gubitnik, pokušavajući zavladati prirodom, a istodobno se izdvajući iz nje.

Druga ekokritička analizirana pojava jest prirodna pojava kiše. Smatram da je Desnica prikazom kiše na početku i kraju romana dao kontrast razgovoru pripovjedača i Krezubog, koji raspravljaju o besmrtnosti jer bi kiša, ako je tumačimo sukladno s čitanjima Hemingwayja, označavala smrt, odnosno, u ovom slučaju, smrtnost ljudi. Kiša je prikazana i kao tehnički problem, a ne prirodna pojava, čime čovjek iz vremena athanatika odbacuje prirodne pojave i svijet oko sebe tumači isključivo tehnološkim procesima. Tako je dodatno naglašen odmak od čovjeka i prirode. Odabirom početka i kraja spominjanjem kiše, bez obzira na radnju o besmrtnosti, pisac posredno upozorava na stalnu smrtnost čovjeka, ali pokazuje i prirodu kao aktivnog činitelja, a ne samo kulisu u pozadini čovjekovu djelovanju.

Otvoreno je pitanje koliko se Pronalazak Athanatika uklapa u žanrovska obilježja spekulativne fikcije prema analizi Mirande Levanat Peričić, koja navodi:

Alternativni svijet u ovim je romanima dvostruko udaljen od autorove empirijske zbilje - vremenom budućnosti i nacionalno neoznačenim kulturnim prostorom. Stoga se metažanrovska obilježenost distopije u hrvatskoj književnosti ogleda i u tome što hrvatski roman projicira povijest budućnosti u drugu književnu tradiciju, najčešće onu kojoj distopija izvorno pripada. ${ }^{50}$

$\overline{49}$ O mogućnosti uspoređivanja i povezivanja u povijesnoj znanosti v. Diego Olstein, Thinking History Globally, New York 2015., 59-98.

50 Miranda Levanat-Peričić, „Metažanrovska obilježenost spekulativne fikcije u hrvatskoj književnosti: od Šufflaya do Mlakića“, Komparativna povijest hrvatske književnosti. Fantastika: problem zbilje. Zbornik radova sa XVIII. međunarodnoga 
Smatram da je Pronalazak Athanatika žanrovski blizak spekulativnoj fikciji. Nedefiniranje prostora događanja i samog vremena pokazuju odrednice ove teorije. Time se ovaj roman može uklopiti u niz sličnih romana poput Planeta Friedmana i Mjesečeva meridijana. Osim zajedničkog okolišnog uzroka problema, vidljiva je društvena podjela na povlaštene - neovisno o tome jesu li to besmrtni, oni koji imaju društvenu moć ili ekonomski moćnici - i sve ostale. Ekološki uzrok problema kao posljedicu nosi društvene promjene te sve veće i jasnije socijalne diferencijacije koja završavaju totalitarnim sustavima - fašizmom, nacizmom i korporativnim kapitalizmom u svojim inačicama.

Zanimljiva je Desničina ideja besmrtnosti ljudi u usporedbi sa smrću planeta Zemlje, uočljiva u Popovića i Mlakića. Može li se ove dvije tvrdnje dovesti u vezu? Koji je maksimalan broj ljudi koji istovremeno može živjeti na Zemlji? ${ }^{31}$ Kakav će biti ekološki otisak koji će ostaviti? $?^{52}$ Koliko će ljudsko djelovanje i težnja za moći, uključujući i besmrtnost, pridonijeti odumiranju planeta Zemlje? Kakve će biti društvene posljedice ekoloških promjena kojima smo svjedoci (globalno zatopljenje, otapanje ledenjaka, širenje pustinja, razorne oluje, ratovi za energiju i vodu, zagađenje zraka, vode i tla, iskorištavanje prirodnih resursa i slično)? Ova pitanja samo su poticaj za promišljanja i daljnje radove, posebice u kontekstu umjetne inteligencije, bioinženjeringa i potencijalne besmrtnosti ili nesmrtnosti u budućnosti.

Važnost nedovršenog romana Pronalazak Athanatika ogleda se u poveznici s vrlo aktualnim temama života i smrti kao odnosa prema prevladavanju smrti besmrtnošću, zatim načinom promišljanja potonje, što je veoma važno za dovođenje u vezu s Hararijem, ali i suvremenim izazovima smrti i njezina izbjegavanja. Desnica se može smatrati prethodnikom koji korelira s aktualnim znanstvenim promišljanjima (Harari) i književnim djelima (Mlakić, Popović), upozoravajući kako ekologija i ekološki čimbenici (besmrtnost i porast stanovnika, nedostatak hrane) mogu imati ozbiljne utjecaje na društvene promjene, raspodjelu moći i oblikovanje budućnosti. Time je od književnog djela, određenog kao spekulativna fikcija, Desničin Pronalazak Athanatika postao putokaz za doglednu budućnost i izazove koje nosi. Promišljanja o odabirima i humanistički pogled koraci su k boljoj i ugodnijoj budućnosti za cjelokupno čovječanstvo, živi svijet i planet Zemlju, što bi se moglo nazvati zajedničkim zaključkom Vladana Desnice, Yuvala Hararija, Josipa Mlakića i Ede Popovića išcitanim iz njihovih analiziranih djela.

znanstvenog skupa održanog od 24. do 25. rujna 2015. godine u Splitu (ur. Cvijeta Pavlović, Vinka Glunčić-Bužančić i Andrea Meyer-Fraatz), Split - Zagreb 2016., 316.

51 Prema istraživanjima UN-a, očekuje se značajan rast do 11,2 milijarde ljudi do 2100. godine Usp. World Population Prospects. The 2015 Revision. Key Findings and Advanced Tables, New York 2015., 2 (https://esa.un.org/unpd/wpp/ Publications/Files/Key_Findings_WPP_2015.pdf).

52 Usp. Dražen ŠımlešA, Ekološki otisak. Kako je razvoj zgazio održivost, Zagreb 2010. 


\section{$\cos$}

\section{Literatura}

Peter Berry, Beginning Theory. An Introduction to Literary and Cultural Theory, Manchester - New York 2009.

Thomas Borstelmann, The 1970s. A New Global History from Civil Rights to Economic Inequality, Princeton 2015.

Domagoj Brozović, „Čitati zeleno. Ekokriticizam - neprepoznata mogućnost suvremene hrvatske znanosti o književnosti“, Književna smotra, 44/2012., br. 164-165, 29-35.

Reginald Campbell Thompson, The Epic of Gilgamesh: Complete Academic Translation. Translated from cuneiform tablets in the British Museum literally into English hexameters, London 2007.

Wu Cheng'en, A journey to the West, Beijing 1955.

Jacques Choron, „Death and Immortality“, Dictionary of the History of Ideas (ur. Philip P. Wiener), sv. 1, New York 1974., 635-646 (https://web.archive.org/web/20070311081839/http://etext.lib. virginia.edu/cgi-local/DHI/dhi.cgi?id=dv1-76).

Vladan Desnica, Pronalazak Athanatika, Zagreb 2006.

Goran ĐurĐević, „Yuval Noah Harari, Homo Deus: kratka povijest sutrašnjice“, Ekonomska i ekohistorija, 13/2017., 177-178.

Goran ĐurĐević, „Yuval Noah Harari, Sapiens: kratka povijest čovječanstva, Fokus, Zagreb 2015, 479 str.", Historijski zbornik, 68/2015., br. 1, 203-205.

Simon C. Esток, „Teorija s ruba: životinje, ekokritika, Shakespeare“, Kazalište, 11/2008., br. 3536, 84-97.

Susan Farrell, „Rainy Day Blues: The Role of Weather in A Farewell to Arms“, College of Charleston Blogs (http://blogs.cofc.edu/hons110/files/2011/10/Rain-in-Hemingway.pdf).

Niall Ferguson i dr. (ur.), The Shock of the Global. The 1970s in Perspective, Harvard 2011.

Greg Gerrard, Ecocriticism, Abingdon 2004.

Derek Gladwin, „Ecocriticism“, Oxford Bibliographies (http://www.oxfordbibliographies.com/ view/document/obo-9780190221911/obo-9780190221911-0014.xml).

Cheryll Glotfelty, „Introduction: Literary Studies in an Age of Environmental Crisis“, Ecocriticism Reader. Landmarks in Literary Ecology (ur. Cheryll Glotfelty i Harold Fromm), Athens, Georgia 1996., XV-XXXVII.

Yuval Noah Harari, Homo Deus. Kratka povijest sutrašnjice, Zagreb 2017.

Yuval Noah Harari, Sapiens. Kratka povijest čovječanstva, Zagreb 2015.

Ernest Hemingway, A Farewell to Arms, New York 1929.

William HoRwath, „Some Principles of Ecocriticism“, Ecocriticism Reader. Landmarks in Literary Ecology (ur. Cheryll Glotfelty i Harold Fromm), Athens, Georgia 1996., 69-91.

Ingrid KıršA, Likantropija u popularnoj kulturi, diplomski rad, Sveučilište u Zagrebu, Hrvatski studiji, Odsjek za kroatologiju, 2017.

Karl Kroeber, „Home at Grasmere’: Ecological Holiness“, Publications of the Modern Language Association of America, 89/1974., br. 1, 132-141.

Miranda Levanat-PeričIć, „Čitanje distopija iz aspekta različitih teorija žanra: Pavličić, Suvin, Frow", Komparativna povijest hrvatske književnosti. Vrsta ili žanr. Zbornik radova s XIX. međunarodnoga skupa održanog od 29. do 30. rujna 2016. godine u Splitu (ur. Vinka Glunčić-Bužančić i Kristina Grgić), Split - Zagreb 2017., 249-258. 
Miranda Levanat-Peričić, „Metažanrovska obilježenost spekulativne fikcije u hrvatskoj književnosti: od Šufflaya do Mlakića“, Komparativna povijest hrvatske književnosti. Fantastika: problem zbilje. Zbornik radova sa XVIII. međunarodnoga znanstvenog skupa održanog od 24. do 25. rujna 2015. godine u Splitu (ur. Cvijeta Pavlović, Vinka Glunčić-Bužančić i Andrea Meyer-Fraatz), Split - Zagreb 2016., 307-318.

Suzana Marjanić, „Književni svjetovi s etnološkom, ekološkom i animalističkom nišom“, Narodna umjetnost, 43/2006., br. 2, 163-186.

Suzana Marjanić, „Zoosfera Tita Andronika: ljudska, previše ljudska bestijalnost“, Treća, 10/2008., br. 2, 59-82.

Josip Mlakić, Planet Friedman, Zagreb 2012.

Timothy Morton, „Deconstruction and / as Ecology“, The Oxford Handbook of Ecocriticism (ur. Greg Garrard), Oxford 2014., 291-304.

Krešimir Nemec, „Pronalazak Athanatika - između utopije i distopije“, u: Vladan Desnica, Pronalazak Athanatika, Zagreb 2006., 81-94.

Diego Olstein, Thinking History Globally, New York 2015.

Serpil Oppermann, „Theorizing Ecocriticism: Toward a Postmodern Ecocritical Practice“, Interdisciplinary Studies in Literature and Environment, 13/2006., br. 2, 103-128.

Edo Popović, Mjesečev meridijan, Zagreb 2015.

Strahimir Primorac, „Imamo li komu slati poruke u boci?“, Vijenac, 21/2013., br. 495 (http:// www.matica.hr/vijenac/495/imamo-li-komu-slati-poruke-u-boci-21432/).

Strahimir Primorac, „Potraga za svijetom slobode“, Vijenac, 23/2015., br. 561-562 (http://www. matica.hr/vijenac/561\%20-\%20562/Potraga\%20za\%20svijetom\%20slobode/).

Tizian Raspor, „Yuval Noah Harari, Homo Deus. Kratka povijest sutrašnjice, prevela s engleskog Marija Perišić, Fokus komunikacije, Zagreb 2017, 461 str.", Historiografija.hr (http://www.historiografija.hr/?p=5663).

William Rueckert, „Literature and Ecology: An Experiment in Ecocriticism“, Ecocriticism Reader. Landmarks in Literary Ecology (ur. Cheryll Glotfelty i Harold Fromm), Athens, Georgia 1996., $105-123$.

„Sisyphus“, Encyclopaedia Britannica (https://www.britannica.com/topic/Sisyphus).

Louise SQuire, „Death and the Anthropocene: Cormac McCarthy's World of Unliving“, The Oxford Literary Review, 34/2012., br. 12, 211-228.

Dražen ŠIMLEŠA, Ekološki otisak. Kako je razvoj zgazio održivost, Zagreb 2010.

Tea Šitum, „Planet Friedman“, Citajme.com (http://citajme.com/planet-friedman/).

Tjaša TRČEK, Ekokritika - upodobitve narave v izbranih mladinskih delih, diplomski rad, Univerza v Ljubljani, Pedagoška fakulteta, 2016.

Matko Vladanović, „Edo Popović: Mjesečev meridijan“, Moderna vremena (http://www.mvinfo. $\mathrm{hr} /$ clanak/edo-popovic-mjesecev-meridijan).

World Population Prospects. The 2015 Revision. Key Findings and Advanced Tables, New York 2015. (https://esa.un.org/unpd/wpp/Publications/Files/Key_Findings_WPP_2015.pdf).

„Zagrobni život“, Hrvatska enciklopedija (http://www.enciklopedija.hr/natuknica.aspx?id=66705). 


\section{$\cos$}

\section{An ECOCRITICAL READING OF VLADAN DESNiCA'S NOVEL PRONALAZAK ATHANATIKA}

The author approaches Vladan Desnica's short unfinished novel Pronalazak Athanatika (The Discovery of Athanatic) from an ecocritical perspective. The paper consists of three parts: an ecocritical interpretation of the thematic cycle of death, life and immortality in connection and comparison to Yuval Noah Harari's Homo Deus, followed by an ecocritical analysis of the rain that draws on the the ideas of Susan Farrell, and finally, an analysis of Desnica's novel viewed in the context of other dystopian ecological/environmental novels in contemporary Croatian literature: Josip Mlakić's Planet Friedman and Edo Popovićs Mjesečev meridijan (The Moon Meridian), with a comparison to the ecocritical readings of Louise Squire. The author concludes that Desnica's novel, which he places into the genre of speculative fiction, is a precursor to contemporary scholarly analyses (Harari) and fiction (Mlakić, Popović), cautioning that ecology and ecological factors - immortality, population growth, food shortages and the eventual destruction of the planet - can have devastating consequences for social changes, the division of power and the future that is being created.

Key words: ecocriticism, Pronalazak Athanatika (The Discovery of Athanatic), Vladan Desnica, immortality, Yuval Noah Harari, Josip Mlakić, Edo Popović, cultural studies 


\section{9. \\ VLADAN DESNICA, \\ PREVODITELJ I KOMENTATOR \\ FOSCOLOVIH GROBOVA}

\section{Sanja Roić i Iva Grgić Maroević}

UDK: 821.131.1Foscolo, U.=163.42

Izvorni znanstveni članak

Sažetak: Važno mjesto u opusu Vladana Desnice zauzima prijevod s talijanskog jezika Foscolova kratkog epa Grobovi, objavljen u zagrebačkom časopisu Hrvatsko kolo 1951. godine. Talijanski pjesnik, romanopisac, kritičar i prevoditelj Ugo Foscolo (1778. - 1827.), rođen u Grčkoj, odgojen u Dalmaciji (Splitu), kako se običavao predstavljati, svojim je spjevom objavljenim 1807. dao snažan poticaj talijanskoj preporodnoj misli i sveukupnom književnom izričaju svoga vremena. Grobovi su se integralno prevodili više puta između 1869. i 1990. godine u časopisima koji su izlazili u Zagrebu, Dubrovniku, Novom Sadu, Mostaru i Splitu. Nazorov je prijevod ostao u rukopisu, a Desničin je jedanaesti po redu. Posljednji je, za sada, objavio Frano Čale 1990. godine u časopisu Forum i godinu dana kasnije u knjizi Ode. Soneti. Grobovi. Rad analizira i ocjenjuje Desničin prijevod s traduktološkog stanovišta i smješta ga u njegov talijanistički prijevodni opus.

Ključne riječi: Ugo Foscolo, ep Grobovi, talijansko-hrvatski prijevod, nerimovani jedanaesterac, simbolika i metaforika groba

oji su motivi naveli Vladana Desnicu da se početkom 50-ih godina prihvati prevođenja Foscolovih Grobova? Kakva je kvaliteta toga prijevoda i kakvo mjesto on zauzima u autorovu prevoditeljskom, a zatim i spisateljskom opusu? Kao što je poznato, Vladan Desnica u dijalogu je s talijanskom kulturom od rane mladosti i već je tada bio zaokupljen razmišljanjem o svojim precima i o povijesnim okolnostima koje su njegovu obitelj vezivale za Islam Grčki. O tome napisao je donedavno nepoznatu dugu pjesmu i uz očevu je redakciju preveo na talijanski jezik. ${ }^{1} \mathrm{O}$ kući, znamenu i simbolu ovozemaljskog trajanja, pjevao je mladić, a zreli muškarac prihvaća se prijevoda s talijanskog jezika neoklasičnog epa Grobo$v i$ koji korespondira, $s$ jedne strane, s preporodnom mišlju ponajviše devetnaestostoljetnih dalmatinskih intelektualaca, a s druge je u znatnoj opreci s poslijeratnim književnim i kul-

1 Usp. Sanja Roić, „Dom predaka u Islamu Grčkom kao pjesnički motiv. Jedna nepoznata pjesma na talijanskom jeziku iz arhiva obitelji Desnica“, Hrvatsko-srpski /srpsko-hrvatski interkulturalizam danas (ur. Drago Roksandić), Zagreb 2017., 307-319. 
turnim kanonom. No, prošlo je tek nekoliko godina od završetka rata na čijem je početku umro njegov otac, a na samom kraju stric, s kojim su ga vezivali ne samo rodbinski nego i prijateljski i intelektualni odnosi.

Vladan Desnica posreduje i prenosi talijansku kulturu u jezik i kulturnu sredinu svoga zavičaja (sjeverne i srednje Dalmacije) još od 1930-ih godina, kada je u vlastitoj nakladi tiskao Croceove eseje. Dalmacija je u središtu njegovih književnih i muzikoloških interesa, s cezurom koja nastaje zbog ratnih prilika i gubitka rukopisa prilikom selidbe 1942. iz Splita preko Šibenika u Islam. Desničini prevoditeljski izbori Crocea, Carduccija, Leopardija i Foscola nadovezuju se na stričeve prijevode, ${ }^{2}$ pa ako je Benedetto Croce bio njihov suvremenik (umro je 1952.), potonja su trojica nedvojbeno klasici talijanske književnosti. Tim izborom Vladan Desnica ponovno promišlja književne i estetske vrijednosti talijanskih predložaka i mogućnost njihova očuvanja, prijenosa i posredovanja na svom jeziku u kulturi primateljici. U skladu s postavkama suvremene traduktologije, čija saznanja dobro sažima suvremeni talijanski teoretičar prevođenja Bruno Osimo, smatramo da svaki prevoditelj posjeduje vlastitu poetiku prevođenja koja se, u slučaju pojedinog prijevoda, prenosi izabranom dominantom (ključem čitanja/prevođenja, tj. estetskim nukleusom) na ne nužno isti model čitatelja, zbog čega je u znanstvenom diskursu o prevođenju korisno govoriti o prijevodima koji obavljaju različite funkcije. ${ }^{3}$

Godine je 1950. Desnica objavio Zimsko ljetovanje, kratak roman koji tadašnja kritika nije prihvatila i čije će vrijednosti tek kasnije postati dijelom naše književne i kulturne baštine. Istodobno, već radi i na drugom romanu, Proljećima Ivana Galeba, čije sekvencije često promišlja na talijanskom jeziku. Profesionalni književnik od 1949., Desnica uskoro počinje prevoditi roman Kruh i vino Ignazija Silonea ${ }^{4}$ i studiju Lionella Venturija Od Giotta do Chagalla, a oba će djela biti tiskana 1952. Godine 1950. objavio je prijevod i popratan tekst o Cavalcantijevoj baladici u zagrebačkom časopisu Hrvatsko kolo, ${ }^{5}$ a u idućem godištu istog časopisa izlaze njegov prijevod Foscolovih Grobova i bilješke uz prijevod. ${ }^{6}$ Desničini se komentari oslanjaju na pouzdane talijanske izvore, a prema rukopisnom fragmentu sačuvanom u osobnoj ostavštini, primjećujemo da ih je za tisak znatno skraćivao. ${ }^{7}$ Nije jasno, međutim, zbog čega se u časopisu komentari prekidaju nakon 160. stiha, ako je poznato da

$\overline{2} \quad$ Riječ je o prijevodu Croceova eseja O jednom karakteru novije talijanske književnosti, Carduccijevih pjesama Na izvoru Klitumna, Pobjeda, Aleksandrija i Na brdu Mariju, Leopardijeve pjesme Z̈ukva ili cvet pustinje. Usp. Boško DesniCA, Sabrana djela, Zagreb 2008., 487-500; 461-472, 473-481. Prevedeni fragment iz Foscolovih Grobova objavljen u Srpskom književnom glasniku nije uvršten u Sabrana djela Boška Desnice. Usp. bilj. 12 u ovom radu. Dodajemo da se u Sabranim djelima pogrešno navodi Carducci kao autor prevedene pjesme Zukva ili cvet pustinje. Usp. B. Desnica, Sabrana djela, 473.

3 Usp. Bruno Osimo, Traduzione e qualità, Milano 2004., 149; Isti, Storia della traduzione, Milano 2002.; Iva Grgić Maroević, Poetike prevodenja. O hrvatskim prijevodima talijanske poezije, Zagreb 2009., 114.

4 Pretpostavljamo da je Desnica preveo Siloneov roman imajući na umu odnos kritike prema književnom djelu u objema poslijeratnim intelektualnim sredinama, talijanskoj i jugoslavenskoj. Usp. Sanja Rorć, „Dva pisca na meti kritike: Desnica i Silone“, Istočno i zapadno od Trsta. Interkulturalni dijalozi, Zagreb 2013., 122-141.

5 Guido Cavalcanti, „Balateta“, Hrvatsko kolo, 3/1950., br. 4, 652-653; Vladan Desnica, „Guido Cavalcanti: uz prijevod 'balatete'“, Hrvatsko kolo, 3/1950., br. 4, 768-777. O tom prijevodu i komentaru usp. Sanja Rorć, „Desnica i 'pramaljeće' talijanskog pjesništva“, Stranci. Portreti s margine, granice i periferije, Zagreb 2006., 144-157.

6 Usp. „Ugo Foscolo: Grobovi'. Prev. Vladan Desnica“, Hrvatsko kolo, 4/1951., br. 3-4, 281-287; V[ladan] D[esNica], „Bilješke o 'Grobovima' Uga Foscola“, Hrvatsko kolo, 4/1951., br. 3-4, 386-387.

7 Vladan Desnica, „Bilješke o ‘Grobovima’ Uga Foscola“, strojopis, Osobna ostavština Vladana Desnice u Zagrebu. 
Foscolov spjev broji 295 stihova, pa pretpostavljamo da je do propusta došlo pri uređivanju časopisa (urednici su bili Joža Horvat i Gustav Krklec; Krklec je bio i odgovorni urednik). ${ }^{8}$

U Osobnoj ostavštini Vladana Desnice pronašle smo strojopisnu kopiju neobjavljene 3. i 4. stranice komentara, gdje Desnica komentira još šesnaest mjesta u epu, završno s 290. stihom. ${ }^{9}$ Isto tako, premda smo pretpostavljale da je Desnica uz prijevod morao prirediti i bilješku o piscu, bezuspješno smo je tražile u istom broju i u narednim godištima Hrvatskog kola jer ona nije ni bila objavljena. ${ }^{10} \mathrm{U}$ toj bilješci Desnica ističe nekoliko važnih podataka o autoru i djelu: Ugo Foscolo rodio se na grčkom otoku Zakintu (Zakintos), nekoliko godina djetinjstva proživio je u Splitu, a njegovo je remek-djelo spjev Grobovi. I dalje:

U Foscolu, pored istaknutih klasičnih reminiscencija, mitoloških diskurza i asocijacija, osjećamo jako duh čovjeka njegova vremena, dah romantičke epohe na pomolu; pored plastične skulpturnosti i klasične čistote linije, nalazimo uzburkani duh i upaljivi temperament romantika. Klasične reminiscencije kod njega, rođenog Grka, nisu puki i mrtvi dekor kao kod drugih talijanskih pisaca njegova i ranijih vremena; ima tu mnogo viđenog i prisno doživljenog, ima tu grčkog pejsaža. I osvjetljenja, i atmosfere, svega onoga što je iz djetinjstva ponio u očima i u duši. (...) On je, naprotiv u riječima vrlo ekonomičan, precizan u izrazu, krajnje koncizan i koncentriran. Otuda i jedrina i plastičnost njegovih slika. Ta se konciznost najbolje može iskusiti kod prevođenja. Prevodilac nailazi na neslućene teškoće, i pored toga što je originalan u nerimovanim jedanaestercima. ${ }^{11}$

Vladan Desnica ne spominje objavljen fragment Grobova u prijevodu svoga strica Boška, no u osobnoj ostavštini, u mapi naslovljenoj „Foscolo 1778-1827“, nalazi se prijepis zelenom tintom toga fragmenta pisan rukom Vladana Desnice. ${ }^{12}$ Godine 1951., kad izlazi Vladanov prijevod u Hrvatskom kolu, Boško Desnica nije među živima već šest godina. U svakom slučaju, možemo anticipirati da su poetike prevođenja dvojice Desnica bile različite, a da su obojica polazni jezik, jezik originala, označavala „talijanskim“.

Kratak ep Grobovi (Dei Sepolcri) napisan je 1806. godine, povodom Napoleonova edikta o grobljima, objavljen 1807. i posvećen Ippolitu Pindemonteu, autorovu suvremeniku, klasicističkom pjesniku i prevoditelju Odiseje na talijanski jezik. Epigraf mu je navod s rimskih Dvanaest ploča (450. n. e.), u kojima se spominju prava duša umrlih kao temelj rimskog prava. O uredbi napoleonske vlasti u Italiji o grobljima, koja zbog sanitarnih razloga moraju biti izmještena iz središta naseljenih mjesta i na kojima će

8 U Biblioteci Matice hrvatske doznale smo da se arhiva časopisa Hrvatsko kolo nalazi u Hrvatskom državnom arhivu u Zagrebu. Prema podacima u Matici, u njemu nema podataka o objavljivanju prijevoda Uga Foscola. Preostaje još eventualno uvid u osobnu prepisku urednika.

$9 \quad$ Zahvaljujemo dr. sc. Urošu Desnici na mogućnosti konzultiranja Osobne ostavštine Vladana Desnice u Zagrebu.

10 Prevoditeljeva bilješka „Ugo Foscolo (1778-1827.) (bilješka o piscu)“ objavljena je u knjizi Hotimično iskustvo: diskurzivna proza Vladana Desnice. Knjiga prva (prir. Dušan Marinković), Zagreb 2005., 251-252, odakle ćemo je citirati. Marinković preuzima tekst bilješke iz knjige Eseji, kritike, pogledi (ur. Stanko Korać), Zagreb 1975., 145-147. Međutim, ni prvi ni drugi urednik nije provjerio nalazi li se doista Desničina bilješka u broju 3-4 Hrvatskog kola za 1951. godinu jer obojica citiraju navodni izvor kao „Hrvatsko kolo, Zagreb, 1951.“. U mapi „Foscolo 1778-1827“ u Osobnoj ostavštini Vladana Desnice u Zagrebu nalazi se i rukopisni fragment „Večeri“, prijevod glasovitog Foscolova soneta Alla sera.

11 V. Desnica, „Ugo Foscolo (1778-1827.) (bilješka o piscu)“, 251.

12 U potpisu prevedenog ulomka od 263. do 295. stiha stoji: „S talijanskog preveo Boško Desnica“. Usp. Ugo Foskolo, „Kasandrin plač. Ulomak iz 'Grobova'“, Srpski književni glasnik, 10/1910., knj. 24, 268. 
stin

16

Ippolito P1ndemonte / $1753-1828 /$, kome je spjev posvé́en, je menj1 talijanski pjeanik, is Verome. P1 seo je "Poeale canpeatri* 7roljace pjestee/, "Epistole in versi" /P1 sme a stihovilad, sat1= ricke "Serwone" /Propovijeds/, a odgovorio je Poscolu svojin apje= voll iste ms ters. Posmat je njegov prevod Odiseje.

$21-22$

Briteao $t 1 \mathrm{~h}$ st1hova jo muten 1 preporen. Bto to anadi de vrljeme a svoie toku pretvara 1 preobraxava no gamo govjeka, nego 1 njegov grob, pa posijednj1 vid Lega? oovjelca? - ta o ajemu je ŏas prim

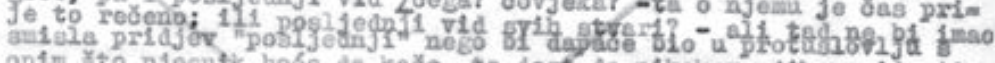
onfin sto pjeanti hoce da kaze, to jegt de nikekev njlihov vid nije posijeinj1, ve6 jemo jedan od neorgjensh prelarnith vidova 1 oblike. Iarodito su nojean 1 preporge and "ostsod zemije 1 neba". Io= nentetor de apinja de ramovrapim, vrlo deleicim 1 alabo uvjerij1=

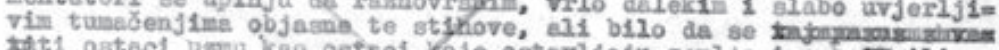
aAt1 osteol parma keo ostsol Koje ostavljaju zeml.ja i nebox 121 kao ostaol koj1 ostaju od ptmlje 1 neba, stihovi jednako ostaja

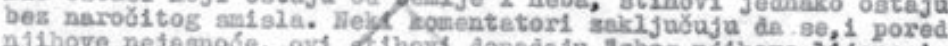

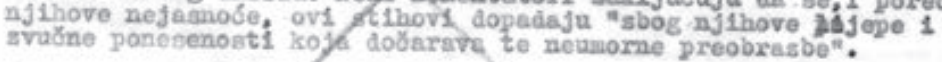

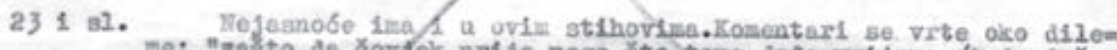
me: "zasto de roydek prije nego g to tome dode vri.jeme, $/ t \cdot j$. joj

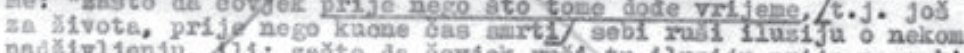

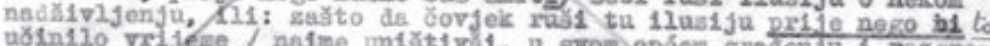

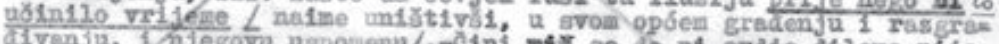
divenju, isjegova uspomeng/. -cini wes e da ni ovdje dileme nije od narodjtog maćaje.

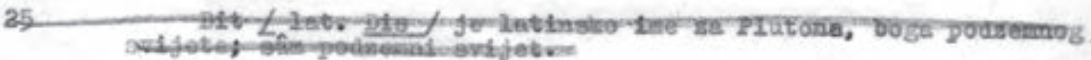

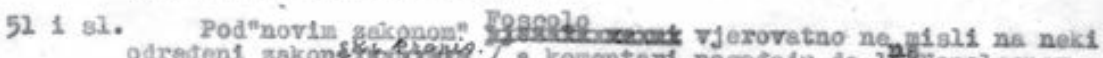

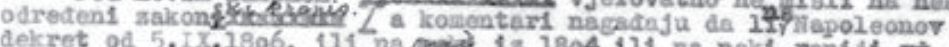

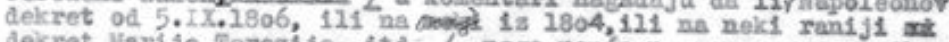
dekret Marije Fereaije, 1td.j, nego nogo na savreneme uredbo 1 obiŏaje koje je sevela rrancuka revoluo1je s koje su sabranjivale da se mrtvi pokepaju u cricvana 1 sl.p veo jedino u narooritin javnin grobistima vaia gradsich naselja; - "Ime umrlim kratin - ne trebs ghvatit1 dosiovno, kso da fe bilo zabranjeno na grobu nasmediti

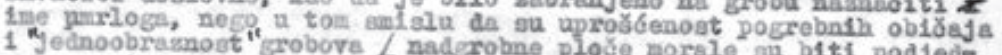
1 Jednoobramost" "Grobove L naderobne plose morale gu biti podjede

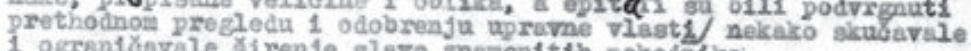
1 ogrentöavale orirenje slave meatenttih pokojnika.

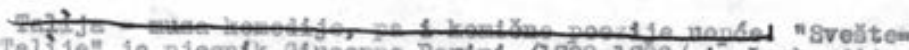
nik Talije" je pjeanik a1usopje Parind /1729-1799/, 1s Lombardije;

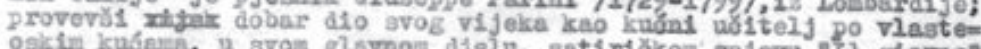

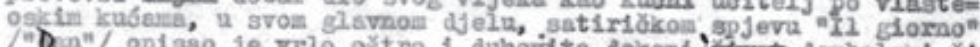

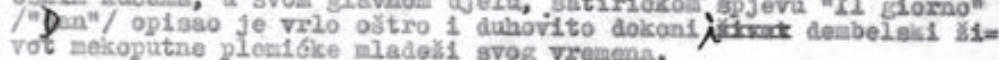

"Lombarasict Berdanepei"

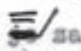

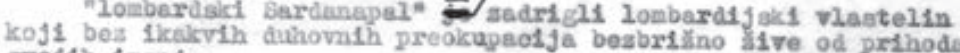
grojih inanja.

Sl. 1. Redigirani strojopis Desničinih bilješki uz prijevod Grobova Uga Foscola

spomenici trebati biti uniformirani, žustro se raspravljalo u salonima koje su posjećivala obojica književnika.

Treba se podsjetiti da je koncem 18. stoljeća nakon pada Venecije dio Italije u kojem je Foscolo živio nakon što je obitelj napustila Split potpao pod tuđinsku vlast najprije Austrije, a zatim Napoleona. No, Talijanima je ostao vječni znamen grobova slavnih predaka, pri 
čemu je grob bio shvaćen kao znak, kao metafora besmrtnosti ideje ljepote i poezije koju su stvorili klasični i moderni velikani, ideja na koju će se nadovezati preporodni pokret za ujedinjenu Italiju. U početnom dijelu epa prepoznaje se utjecaj klasičnih pisaca, osobito Lukrecijeva spjeva $O$ prirodi.

Unutar odnosa hrvatske i srpske kulture prema talijanskoj, stoljećima za njih referentnoj, ističe se interes za Uga Foscola (u prvom redu njegov spjev Grobovi), potvrđen prijevodima, kojih je šest u 19. stoljeću (Ivan Trnski 1869.; Vladislav Vežić 1870.; Stjepan Buzolić 1879.; Lazar Tomanović 1883.; Luka Svilović 1885.; Marko Car 1887.) te isto toliko u 20. stoljeću (Antun Sasso 1902.; Stjepko Ilijić 1905.; Vinko Lozovina 1911.; Vladimir Nazor 1939.; ${ }^{13}$ Vladan Desnica 1951.; Frano Čale 1990.). Ponajprije valja istaknuti da je u Desničinu prijevodu broj stihova jednak broju stihova originala, što raniji prevoditelji Ilijić, Sasso i Buzolić nisu uspjeli postići. Također, Desnica nerimovani jedanaesterac, klasičan stih talijanskog pjesništva od njegovih početaka, prevodi također nerimovanim jedanaestercem, za razliku od ranijih prevoditelja, koji su prevodili desetercem. Brojna opkoračenja u originalu prevoditelj čuva i u prijevodu, čime "proširuje“ stih. Ove dvije karakteristike postale su standardom talijansko-hrvatskog pjesničkog prevođenja nakon izdanja Danteova Pakla i Čistilišta u prijevodu Mihovila Kombola (1948. i 1955.). ${ }^{14}$

Još jedna od poteškoća pri prevođenju Foscolovih stihova na hrvatski jest konciznost originala. Premda je u odnosu na talijanski jezik hrvatski sintetičniji, Desnica na pojedinim mjestima nastoji još više sažeti dolazni stih. Na primjer, Foscolov fragment „dentro l'urne / confortate di pianto“ (stihovi 1-2) Desnica prevodi autorskim sažimanjem: „u grobu / oplakivanu“ (1-2); Foscolovu sintagmu „sonno / della morte“ (2-3) Desnica prevodi kao „san smrti“ (3) i provodi sažimanje koje nalaže narav hrvatskog jezika; sažimanje ekvivalentom, sintetičnim komparativom; autorov pridjev „men duro“ u značenju „manje težak“ (3) prevoditelj sažima u komparativ „lakši“ (2).

$\mathrm{Na}$ fonološkoj razini u zamjenu za asonancu $o$ u početnim stihovima koja priziva plač, žalost, tugu, Desnica unosi asonancu vokala $u$ :

All'ombra dei cipressi e dentro l'urne
confortate di pianto è forse il sonno
della morte men duro? Ove più il Sole
$\begin{aligned} & \text { per me alla terra non fecondi questa } \\ & \text { bella d'erbe famiglia e d'animali, }\end{aligned}$

13 Taj Nazorov prijevod nije objavljen u cijelosti. Dijelove je u svom radu objavio Josip Jernej. Usp. Josip JerneJ, „Foscolo presso i Croati e i Serbi“", Studia Romanica et Anglica Zagrabiensia, 2/1957., br. 4, 30-31. U bilješci na str. 30 stoji da je prijepis iz rukopisa obavljen uz dopuštenje prevoditelja, što znači da ju je autor članka dobio još za Nazorova života. Jernej spominje još jedan prijevod u rukopisu, Tome Brajkovića, koji je u svom radu naveo Stjepko Ilijić, kao i fragment Grobova, odnosno posljednjih 38 stihova epa, koje je preveo i objavio Boško Desnica u Srpskom književnom glasniku. U to vrijeme Boško Desnica bio je student prava u Beču, a diplomirao je 1912. godine. Usp. Isto, 5. U Osobnoj ostavštini Vladana Desnice u navedenoj mapi „Foscolo 1778-1827“ nalazi se strojopisna kopija Nazorova prijevoda Grobova, fragment stihova 1-40. Usp. bilj. 10.

14 O tome usp. I. Grgić Maroević, Poetike prevodenja. O hrvatskim prijevodima talijanske poezije, 82 i dalje. Zanimljivo je da je Kombolov prijevod V. pjevanja Cistilista objavljen u istom broju Hrvatskog kola kao i prijevod Foscolovih Grobova. 
$\mathbf{U}$ čempresovu hladu il $\mathbf{u}$ grobu

oplakivanu, zar je išta lakši

san smrti? Kada više za me sunce

plodilo zemlji već ne bude ovu

lijepu obitelj živina i bilja
1

$$
10 \mathrm{x} \text { vokal u }
$$

Desnica ne slijedi Foscolovu uporabu velikog slova kod Sole, Speme, Iddio, Dea, Geni, Numi (sunce, nada, božjega, boginja, geniji, bogovi), ali poštuje Natura (Narav), Lari (Lari) i uvodi veliko početno slovo kod sljedećih leksema: tempo (Vrijeme), prode (Junak), grande (Velikan). ${ }^{15}$ Ipak, u predzadnjem stihu epa (294) slijedi majuskulu orginala: Sole = Sunce. Valja napomenuti da za Foscola pojmovi Sole i Natura imaju posebno značenje u heliocentričnom sustavu prirode koja se ciklički obnavlja i u kojoj, prema njegovu mišljenju, nema mjesta ni za transcendenciju ni za metafiziku. Prevoditeljeva redukcija majuskula mogla bi se objasniti nakanom izbjegavanja patetike, karakterističnom za pristup kako poeziji tako i realnoj zbilji u kulturi primateljici, jugoslavenskoj kulturi 50-ih godina prošlog stoljeća. ${ }^{16}$

Kada je riječ o morfosintaktičkoj razini spjeva, zanimljiv je primjer gramatičkog tretmana metonimije u početnim stihovima, gdje Foscolo koristi elidirani plural („l'urne confortate“), a prevoditelj singular „u grobu oplakivanu“, koji zamjenjuje plural:
All'ombra dei cipressi e dentro l'urne
1 ključna riječ u pluralu
confortate di pianto è forse il sonno
della morte men duro? Ove più il Sole
per me alla terra non fecondi questa
bella d'erbe famiglia e d'animali,
U čempresovu hladu il u grobu
1 metonimija, ključna riječ u singularu
oplakivanu, zar je išta lakši
san smrti? Kada više za me sunce
plodilo zemlji već ne bude ovu
lijepu obitelj živina i bilja;

Jednako su tako u kasnijem fragmentu „affetti“ (osjećaji) zamijenjeni singularom „ljubav“, a „templi acherontei“ (aherontski hramovi) singularom „hadski plač":

15 Usporedile smo kritičko izdanje Grobova iz sabranih djela Uga Foscola. Usp. Ugo Foscolo, Poesie e carmi. Poesie. Dei Sepolcri. Poesie postume. Le Grazie (prir. Francesco Pagliai, Gianfranco Folena i Mario Scotti), Firenze 1985. No, često u različitim izdanjima ovog epa varira uporaba velikog slova. Pretpostavljamo da je Desnica pred sobom kao polazni tekst imao talijansko izdanje iz kućne biblioteke: Isti, Poesie. Liriche scelte, Torino 1897. Usp. „Popis kućne biblioteke Vladana Desnice“, Hotimično iskustvo: diskurzivna proza Vladana Desnice. Knjiga druga (prir. Dušan Marinković), Zagreb 2006., 252. Nismo, nažalost, mogle konzultirati taj primjerak jer se upravo prenosi u biblioteku Kule Jankovića u Islamu Grčkom.

16 Za pojam „kultura primateljica“ usp. Bruno Osıмo, Manuale del traduttore, Milano 2011., 274. O utjecaju povijesnog konteksta na prijevodne izbore usp. i Iva Grgić Maroević, Politike prevodenja. O hrvatskim prijevodima talijanske proze, Zagreb 2017., 57-76. 
Sol chi non lascia eredità d'affetti $\quad 40$

poca gioia ha dell'urna; e se pur mira

dopo l'esequie, errar vede il suo spirto

fra 'l compianto de' templi acherontei,

o ricovrarsi sotto le grandi ale

del perdono d'Iddio; ma la sua polve

lascia alle ortiche di deserta gleba

ove né donna innamorata preghi,

né passegger solingo oda il sospiro

che dal tumulo a noi manda Natura.

50

Ko $u$ amanet ne ostavlja ljubav

40

slabo mari za grob; al ako misli

što biva poslije pogreba; on vidi

svoj duh gdje luta sred hadskoga plača

il gdje se sklanja pod široka krila

božjega oproštenja; ali prah mu

pod koprivom u pustoj grudi leži

gdje niti moli zaljubljena žena

nit usamljeni putnik čuje uzdah

što ispod humka do nas šalje Narav.

Središnji dio Foscolova epa počinje sljedećim, 51. stihom, u kojem se spominje novi zakon:

Pur nuova legge impone oggi i sepolcri 51

Fuor de' guardi pietosi, e il nome a' morti

Contende. E senza tomba giace il tuo

Sacerdote, o Talia, che a te cantando

Nel suo povero tetto educò un lauro

Con lungo amore, e t’appendea corone; 56

Sad novi zakon izuzimlje groblja

od samilosnih pogleda, a ime

umrlim krati. Pa bez groba leži

i tvoj, Talijo, sveštenik što pojuć

pod bijednim krovom odnjegova lovor

s ljubavlju dugom, ovjenčav te vijencem. 56

Uz ovaj je fragment zanimljiv i opširan prevoditeljev komentar u kojem se navodi da Foscolo „vjerovatno ne misli na neki određeni zakonski propis (komentatori nagađaju da li se ti stihovi odnose na Napoleonov dekret od 5. IX 1806, ili onaj iz 1804, ili na neki 
raniji dekret Marije Terezije, i. t. d.), nego uopće na savremene uredbe i običaje koje je zavela Francuska revolucija, a koje su zabranjivale da se mrtvi pokapaju u crkvama i sl. veći jedino u naročitim javnim grobištima van gradskih naselja“ ${ }^{17} \mathrm{Za}$ antonomaziju „sveštenik Talije“ („muze komedije, pa i komične poezije uopće“) piše da je to „pjesnik Giuseppe Parini“, za kojeg navodi i precizne podatke jer je on, „izuzev talijaniste, manje poznat u hrvatskoj kulturi“. Parinijev Milano („la città lasciva / d'evirati cantori allettatrice“, 73-74) u prijevodu je „varoš bludna / što mazi škopce-pjevače“; u bilješci je, znanjem nesuđenog pjevača, opisan kao grad „poznat po staroj tradiciji kazališnog života, naročito opere. Još u Foscolovo vrijeme bili su u Milanu na velikoj cijeni neki pjevači-eunusi kao na pr. poznati Marchesi “. 18

Zaključni dio spjeva odnosi se na Kasandrin plač, koji se uvodi stihovima 258-262: „Tu i Kasandra, kad joj Feb iz grudi / stade proricat Trojin smrtni danak, / dođe i groblju pjesmu punu milja / razveza; vodi bratiće, pa i njih / nejake uči žalopojki nježnoj." U opsežnoj bilješci uz 258. stih, koju čitamo na 3. stranici pronađenog strojopisa, nalazimo važnu prevoditeljsku opasku:

Ona vodi na Ilov grob bratiće (...) i uči ih naricati pretskazujući im da će dopasti u sužanjstvo poslije propasti i porušenja njihova grada. Prevodioci ih mahom nazivlju Kasandrinim unucima, valjda stoga što talijanska riječ nipote označava i unuka i sinovca i nećaka i bratića; ali jasno je da se ovdje ne radi o unucima nego baš o bratićima, djeci Kasandrine pedesetero braće, jer Kasandra kao djevica-proročica, nije imala djece, pa ni unuka.

Odatle zaključujemo da je Desnica poznavao neke od ranijih prijevoda Foscolova epa jer originalne „nepote“ prevode kao „unuke“ Vežić (1870.), Svilović (1885.) i Sasso (1902.), Buzolić (1879.), Tomanović (1883.), Car (1887.) i Ilijić (1905.) prevode ih kao „unučad“, Lozovina (1911.) kao „unučićc“, dok ih je Trnski (1869.) preveo kao „netjačiće“, a Nazor (1939.) i Desnica kao „bratiće“. ${ }^{19}$ U prijevod Boška Desnice taj stih nije uključen, ali je on u 266. stihu Kasandrina upravnog govora unio vokativ „djeco“. ${ }^{20}$ Kasandrino naricanje počinje 263. stihom pa navodimo završni fragment, stihove 283-295:

(...) Gemeranno gli antri

Secreti, e tutta narrerà la tomba

Ilio raso due volte e due risorto

Splendidamente su le mute vie

Per far più bello l'ultimo trofeo

Ai fatali Pelidi. $I l$ sacro vate,

Placando quelle afflitte alme col canto,

I Prenci Argivi e ternerà per quante

Abbraccia terre il gran padre Oceano.

\footnotetext{
17 V. D[esnica], „Bilješke o ‘Grobovima’ Uga Foscola“, 386.

18 Isto.

19 J. Jernej, „Foscolo presso i Croati e i Serbi“, 27-31.

20 U. Foskolo, „Kasandrin plač. Ulomak iz 'Grobova'“, 267.
} 
E tu onore di pianti, Ettore, avrai

Ove fia santo e lagrimato il sangue

Per la patria versato, e finchè il Sole

Risplenderà su le sciagure umane.

(...) Ječati će špilje

tajne, svo groblje pričat će o Troji

sraženoj dvaput, dvaput uskrsnuloj

u sjaju svom na ulicama nijemim

da još uljepša zadnji trofej kobnoj

djeci Peleja. Taj svešteni pjesnik

blažeći pjesmom ojađene duše

argivske vode ${ }^{21}$ veličat će širom

zemalja što Ocean-otac paše.

A ti ćeš imat, Hektore, čast suza

gdje je god sveta i čašćena krvca

prosuta za dom, i dokle god Sunce

Nad nevoljama ljudskim bude sjalo!

Kao ilustraciju različite prevoditeljske poetike citiramo i prijevod Boška Desnice iz 1910. godine:

(...) Zaječaće špilje,

A grob će pričat' kako dvaput Troja

Pade i dvaput vaskrese, da samo

Zasija ljepša uresnim Pelidom

Pobjeda zadnja. Osveštani pjesnik,

Tužne će one duše pjesmom tješit',

I grčkim slavu provodit' herojim

Gde gde god Okean zemlju valom paše.

A ti ćeš plača počast imat svugđe,

Hektore, gđe se krvca prolivena

Za otadžbinu sveta, dok god sunce

Nad udesima ljudskim sjalo bude.

Dok originalni stihovi 283-291 sadrže šest enjambementa, u prijevodu Vladana Desnice čak ih je osam! Foscolove stihove „(...) e tutta narrerà la tomba / Ilio raso due volte e due risorto“ Desnica je preveo kao „svo groblje pričat će o Troji / sraženoj dvaput, dvaput uskr-

$\overline{21}$ Na ovom se mjestu očigledno radi o tiskarskoj pogrešci, što je razvidno iz 4. stranice bilješki u strojopisu koje nedostaju u Hrvatskom kolu. Ovdje je u komentaru uz 290. stih Desnica zapisao: „'argivske vođe’ - grčki vođe. Homer će, kao Grk, u prvom redu slaviti Grke, kao sunarodnjake i pobjednike, ali će i Trojanci, među njima naročito Hektor, biti slavljeni i čašćeni svuda gdje se slavi i časti krv prolivena za dom. “ Još jednu tiskarsku pogrešku primijetile smo u 32. stihu prijevoda, gdje je otisnuto neispravno „živeš“, umjesto evidentnog 2. lica jednine „živiš̌“. U Desničinoj mapi „Foscolo 1778-1827“ nalaze se stranice iz Hrvatskog kola na kojima je prevodilac svojom rukom unio još neka bolja rješenja i ispravke otisnutog teksta pa je tako i riječ „Vode“ ispravljena u „Vođe“. 
snuloj“ (284-285), prenijevši metonimiju „tutta tomba“ efektnom zbirnom imenicom „svo groblje“, dok je sintagma „Ilio raso“ očuvana kao „Troja sražena“, u značenju „biti sravnjena sa zemljom“, od glagola „sraziti, sravniti“. „Fatali Pelidi“ prevedeni su kao „kobna djeca Peleja“, a zanimljivo je rješenje za „il sacro vate“ (doslovce, „,sveti prorok“, 22 ovdje primijenjeno na Homera). U Desnice se javlja „taj svešteni pjesnik“, gdje je pokazna zamjenica „taj“ ekvivalent za talijanski određeni član „il“, koji proroka, pjesnika označuje jedinstvenim. Talijanski gerund „placando“, koji označuje paralelnu radnju, u ovom slučaju s futurom „eternerà“, Desnica je spretno preveo također glagolskim prilogom sadašnjim „blažeći“ u smislu „ublažavajući boli, tješeći“, što stoji u korelaciji s „veličat će“ (doslovan prijevod bio bi: „ovjekovječivat ć“", no to rješenje bilo bi neprihvatljivo zbog prevelikog broja slogova). „Per quante abbraccia terre il gran padre Oceano“ sažeto je u prijevodu potpunim ekvivalentom „širom zemalja što Ocean-otac paše“ u smislu „opasavati, doticati“, a „prenci Argivi“ u prijevodu su „argivske vođe“ u skladu s Maretićevim prijevodom Ilijade, što je i potvrđeno na 4. stranici komentara sačuvanog u strojopisu. ${ }^{23}$ I posljednja su tri enjambementa očuvana u prijevodu: „onore di pianti“ jest „čast suza“, „santo e lacrimato il sangue / per la Patria versato“ u Desničinu je prijevodu „sveta i čašćena krvca / prosuta za dom“, u skladu s izborom jednosložnih ili kraćih riječi koje čuvaju duljinu stiha.

Kada je riječ o semantici poetskog teksta, konstatiramo da su u prijevodu očuvane tematske (ključne, konceptualne) riječi: urna, tomba, esequie, polve, gleba, tumulo u prijevodu su grob, žara, pogreb, prah, gruda, humak, ne uvijek kao ekvivalenti, ponegdje i kao sinonimi. Zanimljivo je prijevodno rješenje u 40. stihu, u originalu „sol chi non lascia eredità di affetti“ (= samo onaj tko u nasljeđe ne ostavlja osjećaje), što Desnica prevodi ovako: „Ko u amanet ne ostavlja ljubav“ i formulira iskaz snažnije regionalizmom „amanet“, arabizmom koji smo usvojili kao turcizam, zbog čega je iskaz ne samo sročen u duhu kulture primateljice nego i osnažen markiranom riječju. No, u Foscolov klasicistički visoki stil Desnica uvodi i neke druge karakteristične lekseme u duhu kulture primateljice i nekih njezinih regionalnih izraza, za što navodimo nekoliko primjera: „igralo bude kolo“ za „danzeran“ (= plesat će, stih 7); „mili druže“ za „dolce amico“ (= mili, slatki prijatelju, 8); „za dom“ za „per la patria“ (= za domovinu, 294); „zaman“ za „invan“ (= zalud, 266); „míri“ za „le mura“ (= zidine, 267); „plačem udovičkijem“ za „vedovili lagrime“ (= udovičke suze, 273-274); „pređi“ za „padri“ (= oci, očevi, 275); „bradva“ za „la scure“ (= sjekira, 275); „čašćena krvca“ za „lagrimato sangue“ (= oplakana krv, 293).

$\mathrm{Na}$ temelju provedene usporedbe Foscolova originala s Desničinim prijevodom ${ }^{24}$ razvidne su temeljne karakteristike novonastalog metateksta, koje iskazuju visok stupanj poklapanja $s$ versifikacijskim, pjesničko-sintaktičkim i semantičkim osobinama njegova prototeksta. U metatekstu su i u obliku i u broju očuvani nerimovani jedanaesterci (lišeni za talijansku poeziju karakterističnih sinalefa) te, dobrim dijelom, u Foscola frekventna opkoračenja. Manja očuvanost originalne interpunkcije treba se pripisati različitosti sintaktičkih struktura dvaju jezika, a povremena promjena reda riječi kako metričkim zahtjevima tako i nastojanju da

\footnotetext{
22 Tako ga prevodi i Frano Čale. Usp. Ugo Foscolo, Ode. Soneti. Grobovi (prev. Frano Čale), Zagreb 1991., 93.

23 Frano Čale tu sintagmu prevodi kao „kneževi grčki“. Usp. Isto.

24 Analizu smo provele temeljeći se na radu: Bruno Osımo, „Per un approccio scientifico alla valutazione delle traduzioni“ (https://rivistatradurre.it/2013/05/per-un-approccio-scientifico-alla-valutazione-delle-traduzioni/).
} 
se ne našteti sintetičnosti iskaza. Pronađen je adekvat za Foscolov visok jezični registar, koji nimalo ne gubi na težini uvođenjem nekih pučkih leksičkih rješenja u duhu kulture primateljice; dapače, rekle bismo da je njime obogaćen. Nadalje, i prisutnošću svih izvornih konceptualnih riječi (onih kojima se izražavaju nosivi pojmovi teksta, ${ }^{25}$ premda ne uvijek uz Foscolove majuskule) očuvana je univerzalna poruka teksta. Zaključujemo stoga da je Desničin prijevod njegovo autorsko čitanje Foscolovih Grobova kojim je taj kratki ep, što svojim pozivanjem na grobove velikana koje osnažuje suvremenike te prizivanjem cikličnosti Prirode, koje sve ljude čini velikom obitelji, funkcionira na više razina (klasičnoj, predromantičkoj, rodoljubnoj), ponudio na razmatranje sebi suvremenoj kulturi, 50-im godinama dvadesetog stoljeća.

Ovo prevedeno pjesničko djelo pretpostavlja obrazovanog čitatelja, u skladu s izdavačkom politikom zagrebačkog časopisa u kojem je objavljeno, a koji nudi prijevode klasikâ, visokovrijednih originala koji se prenose u kulturu primateljicu, ne zadovoljavajući se dotadašnjim polovičnim rješenjima, već tražeći u njoj svoje što adekvatnije mjesto. Radi se, prema našem mišljenju, o jednom od najzahtjevnijih, ako ne i najzahtjevnijem prevoditeljskom zadatku što ga je Desnica sebi postavio i ostvario. Njegovi prijevodni postupci, dostojni već zrele talijansko-hrvatske pjesničko-prijevodne tradicije, ne remete, već rekreiraju cjelovitu intenciju ove iznimne epistole koja je nadahnula talijanski Preporod i ostavila dubok trag u dalmatinskih intelektualaca ne samo 19. nego i 20. stoljeća. Desničina verzija Foscolovih Grobova još je jedan od pokazatelja kako je on, bez zastajanja na lokalnome, jedan od nezaobilaznih pripadnika toga zavičajnog misaonog i intelektualnog kruga.

\section{$\cos$}

\section{Izvori i literatura}

\section{Izvori}

Vladan Desnica, „Bilješke o ‘Grobovima’ Uga Foscola“, strojopis, Osobna ostavština Vladana Desnice u Zagrebu.

V[ladan] D[esnicA], „Bilješke o ‘Grobovima’ Uga Foscola“, Hrvatsko kolo, 4/1951., br. 3-4, 386-387. Vladan Desnica, „Ugo Foscolo (1778-1827.) (bilješka o piscu)“, Hotimično iskustvo: diskurzivna proza Vladana Desnice. Knjiga prva (prir. Dušan Marinković), Zagreb 2005., 251-252.

„Ugo Foscolo: Grobovi'. Prev. Vladan Desnica“, Hrvatsko kolo, 4/1951., br. 3-4, 281-287.

\section{Literatura}

Guido CavalCanti, „Balateta“, Hrvatsko kolo, 3/1950., br. 4, 652-653.

Boško Desnica, Sabrana djela (prir. Milorad Savić), Zagreb 2008.

Vladan Desnica, Eseji, kritike, pogledi (prir. Stanko Korać), Zagreb 1975.

Vladan DesnicA, „Guido Cavalcanti: uz prijevod 'balatete'“, Hrvatsko kolo, 3/1950., br. 4, 768-777.

Ugo Foscolo, Ode. Soneti. Grobovi (prev. Frano Čale), Zagreb 1991.

25 Usp. Isti, Traduzione e qualità, 156. 
Ugo Foscolo, Poesie e carmi. Poesie. Dei Sepolcri. Poesie postume. Le Grazie (prir. Francesco Pagliai, Gianfranco Folena i Mario Scotti), Firenze 1985.

Ugo Foskolo, „Kasandrin plač. Ulomak iz 'Grobova', Srpski književni glasnik, 10/1910., knj. $24,267-268$.

Iva Grgić Maroević, Poetike prevodenja. O hrvatskim prijevodima talijanske poezije, Zagreb 2009. Iva Grgić Maroević, Politike prevodenja. O hrvatskim prijevodima talijanske proze, Zagreb 2017. Josip Jernej, „Foscolo presso i Croati e i Serbi“, Studia Romanica et Anglica Zagrabiensia, 2/1957., br. 4, 3-31.

Dušan Marinković, „Popis kućne biblioteke Vladana Desnice“, Hotimično iskustvo: diskurzivna proza Vladana Desnice. Knjiga druga (prir. Dušan Marinković), Zagreb 2006., 251-279.

Bruno Osimo, Manuale del traduttore, Milano 2011.

Bruno Osımo, „Per un approccio scientifico alla valutazione delle traduzioni“ (https://rivistatradurre.it/2013/05/per-un-approccio-scientifico-alla-valutazione-delle-traduzioni/).

Bruno Osımo, Storia della traduzione, Milano 2002.

Bruno Osımo, Traduzione e qualità, Milano 2004.

Sanja Rorć, „Desnica i 'pramaljeće' talijanskog pjesništva“, Stranci. Portreti s margine, granice i periferije, Zagreb 2006., 144-157.

Sanja Rorć, „Dom predaka u Islamu grčkom kao pjesnički motiv. Jedna nepoznata pjesma na talijanskom jeziku iz arhiva obitelji Desnica“, Hrvatsko-srpski / srpsko-hrvatski interkulturalizam danas (ur. Drago Roksandić), Zagreb 2017., 307-319.

Sanja RoIć, „Dva pisca na meti kritike: Desnica i Silone“, Istočno i zapadno od Trsta. Interkulturalni dijalozi, Zagreb 2013., 122-141.

\section{$\cos$ \\ VLADAN DESNICA AS THE TRANSLATOR AND COMMENTATOR OF Foscolo's OF THE SEPULCHRES}

The translation of Ugo Foscolo's short epic poem Dei Sepulchri (Of the Sepulchres), published in the literary magazine Hrvatsko kolo in 1951 holds an important place in the work of Vladan Desnica. Ugo Foscolo (1778-1827) was an Italian poet, novelist, literary critic and translator, born in Greece and raised in Dalmatia (Split), according to his own testimony. His 1807 epic poem Of the Sepulchres made an impact on the the art of the Italian national revival and literature of his time in general. The epic poem was translated numerous times between 1869 and 1990 and published in literary magazines in Zagreb, Dubrovnik, Novi Sad, Mostar and Split. Among those, Vladimir Nazor's translation remains in manuscript form, whereas Desnica's is the eleventh. The most recent translation was published by Franjo Čale in the literary magazine Forum in 1990 and a year later in the edition of Ugo Foscolo's work Ode. Soneti. Grobovi (Odes. Sonnets, Sepulchres). The paper provides a traductological analysis of Desnica's translation and places the work in the wider context of his work as a translator from the Italian.

Key words: Ugo Foscolo, the epic poem Of the Sepulchres, translation from Italian into Croatian, unrhymed hendecasyllable, the symbolism and metaphor of the grave 


\section{„SMRT JE KALEŽ, A ČOVJEK KUŠAČ“: SMRT U STARIJOJ ARAPSKOJ POEZIJI}

\section{Edin Muftić}

UDK: 821.411.21-1:612.013

Stručni članak

Sažetak: Smrt je trajna inspiracija pjesnika. Autor analizira odnos prema smrti arapskih predislamskih i islamskih pjesnika. Arapski predislamski pjesnici ostavili su neke od najpotresnijih stihova o prolaznosti života i neminovnosti smrti. Iako iz sačuvanog korpusa poezije ne možemo izvući jasne zaključke o onosvjetskim idejama predislamskih Arabljana, pesimistički svjetonazor prožima njihove stihove. Iz beznadnosti javlja se i specifičan hedonizam te poziv na uživanje u životu koji će prerano završiti. Islam je ovo promijenio. Musliman više nije dvojio oko postojanja onostranog. On je siguran da je smrt tek prijelaz na drugu stranu, gdje ga čeka ili nagrada kojoj se nada ili kazna od koje strahuje, pa smrt ne doživljava kao gorki kraj. Ovo je najjasnije u poeziji najvećeg arapskog pjesnika Mutanabbija koji, oplakujući voljene, smrt izaziva na dvoboj.

Ključne riječi: islam, smrt, predislamska poezija, muallake, Mutanabbi

Tko ne umre od mača, umre od čega drugog, mnoštvo je uzroka, ali smrt je samo jedna. Ibn Nubata as-Sa'di (938. - 1015.)

bn Nubata as-Sa' di bio je dvorski pjesnik Sejfud-Davla (945. - 967.), vladara hamdanidske dinastije. Junačka smrt od mača nije mu bila strana. Sjajni ratnici i vješti pjesnici, vladari alepske grane dinastije tijekom druge polovine 10. stoljeća veći su dio vladavine provodili u bezbrojnim čarkama na granici s Bizantom. Suočen s istočnom ekspanzijom Bizanta u vrijeme energičnih vladara makedonske dinastije (Roman II. i Nikefor II. Foka), Sejfud-Davla je kao emir Alepa od 944. protiv Bizantinaca uglavnom nizao vojne uspjehe i uspijevao braniti sirijsku granicu, čak $s$ vremena na vrijeme i vršiti gazijske upade u bizantski teritorij. Njegovo junaštvo na bojnom polju i izvan njega osiguralo mu je istaknuto mjesto u arapskoj viteškoj tradiciji, za koje su se pobrinuli pjesnici koje je ugošćivao i obilato nagrađivao. Njegov rođak Abu Firas i Mutanabbi, koji mu je posvetio čak 22 medhije (panegirika), učinili su Alep prijestolnicom arapske kulture. Za Ibn Nubata i Sejfud-Davla kao muslimane smrt je bila jedina neizbježna činjenica u životu. Vrijeme, mjesto i način susreta čovjek ne zna, ali zna da svaki njegov dah može biti posljednji. 


\section{SMrt ZA PREDislamSKOG PJESNIKA}

Poezija je duboko ukorijenjena u arapskoj tradiciji. Uz teme plemenskog neprijateljstva, invazije i pljačke, otmice žena, osvete, junaštva, viteštva i ljubavi, tema smrti bila je trajna preokupacija arapskog pjesnika, kako u predislamskom periodu tako i nakon islamske Objave. I sâm početak klasične arapske kaside promišljanje je prolaznosti i žalovanje nad minulim, tzv. nasīb. ${ }^{1}$ Kao i u drugim pjesničkim tradicijama, elegija (rițta’) je i u klasičnoj arapskoj poeziji jedan od temeljnih žanrova, možda čak i najstariji, s korijenima koji sežu duboko u predislamski period. ${ }^{2}$ Potječe iz ritmizirane proze koju su izvodile žene oplakujući članove obitelji. Fokus je pjesme pohvala preminulom zbog njegove privrženosti tradicionalnim beduinskim vrijednostima poput hrabrosti, velikodušnosti i strpljivosti, nakon koje slijedi gorko shvaćanje da je smrt neizbježna čovjekova sudbina i jedina konstanta života. Glagoli u perfektu mnogo su češći od onih u imperfektu, ${ }^{3}$ a vrijeme je linearno. Sve teče, a razvalina koju će uskoro prekriti pustinjski pijesak metafora je zemaljskog života.

Ono što je minulo i neće se vratiti obavijeno je tugom i tjera u plač. Ono čemu se čovjek koji napušta ovaj svijet jedino može nadati jest to da ga oplakuju njegovi bližnji i da ga se sjećaju buduće generacije. Pjesnik, a posebno ratnik-pjesnik, brine se o tome kako će ga pleme pamtiti kad ga više ne bude. Pjesnik Tarafa bin Al-Abd (543. - 569.) u svojoj muallaki ${ }^{4}$ tako pjeva:

Ako stradam, pjevaj o meni kako mi dolikuje, o kćeri Mabedova, i cijepaj svoju odjeću. ${ }^{5}$

Smrt je za Tarafu i velika ujednačiteljica:

Plemenit čovjek se napaja tijekom života, Kad umremo znat ćeš koji od nas još žeđa.

Vidim grob škrtice, što bdije nad imovinom

Jednak je grobu onog predanog zabavi i traćenju imetka:

Vidiš dvije humke zemlje, a na njima

Čvrste nadgrobne ploče jedna do druge. ${ }^{6}$

$\overline{1} \quad$ Nasib je nostalgično otvaranje kaside u kojoj pjesnik razmišlja o protjecanju vremena. Opće je mjesto pjesnikova potjera za karavanom njegove drage, ali kad dođe do logora, koji se obično nalazi među ruševinama, njezina je karavana već krenula dalje. Najbolji je primjer ovoga distih kojim počinje arapska poezija - početak muallake Imrul-Kajsa (501. - 565.), prvog arapskog pjesnika čiji je korpus poezije ostao sačuvan: „Stanite da plačemo sjećajući se drage i staništa / Na pješčanim dinama između Dahula i Havmala."

2 Predislamska poezija može biti prilično precizno definirana kronološki u periodu od 150 do 200 godina prije islamskog otkrivenja, što je i vremenski period koji spominje Džahiz u Kitāb al-Hayawān. Usp. Al-ğāHIž, Kitāb alHayawān (ur. 'Abd as-Salām Hārūn), sv. 1, Kairo 1965., 74.

3 Za razliku od indoeuropskih jezika, u kojima su perfekt i imperfekt prošla vremena, arapski jezik poznaje samo dva osnovna vremena (aspekta) - perfekt (al-māḍ̄ $)$ izražava svršenu, dok imperfekt (al-muḍāri') označava nesvršenu radnju (vid).

4 Muallake (arap. mn. mu'allaqāt- „ovješene“) su najljepše kaside najpoznatijih sedam (ili deset) arapskih predislamskih pjesnika. Prema predaji, kaside se bile napisane zlatnim nitima i ovješene o zidove Kabe. Zbirku je najvjerojatnije priredio Hammad ar-Ravija potkraj 8. stoljeća.

5 AḤmad al-Amīn aš-ŠAnQīțī, Šarh al-mu'allaqāt al-'ašar, Sidon - Beirut 2005., 66.

6 Isto, 61-62. 
Predislamski pjesnik personificira smrt na često vrlo poetske, a istovremeno sablasne načine. Tarafa je, ponovno u muallaki, vidi kao avet s užetom u ruci:

Tako ti života, smrt ne promaši mladića

Opušta uže koje ostaje čvrsto u njenoj ruci. ${ }^{7}$

Iz straha od smrti u predislamskog pjesnika javlja se i specifičan hedonizam. Smrt je velika uništavateljica užitka koji će jednako pogoditi i škrticu i rasipnika. Nije li onda bolje uživati u životu, pita se Tarafa?

Ti koji me zbog odlaska u bučni boj prekorijevaš,

I zbog uživanja - hoćeš li me ti ovjekovječiti?

Ako već ne možeš odagnati moju sudbinu,

Onda me bar pusti da se s njom nadmećem trošeći što imam.

Kad ne bih imao tri strasti mladića, kunem se,

Ne bih mario kada će me prijatelji posjetiti na samrtnoj postelji:

Prva je da se $s$ kritičarima nadmećem koliko ću popiti

Tamnocrvenog vina što se pjeni kad vodu uliješ;

Druga je da suosjećam kad me dozove komu je pomoć potrebna

Tad sam na konju poput vuka ispod drveta koga si prenuo dok izvor traži;

Treća je da kratim oblačan dan, strašno oblačan u nasladama

$S$ ljupkom ženom u šatoru na stupovima podignutom. ${ }^{8}$

Ipak, Tarafa ovdje čini nešto neobično. Uz tjelesni hedonizam, uvodi i moralnu dimenziju čovjekova zemaljskog postojanja. Uz vino i ženu, nedostajat će mu i pomaganje ugroženima. Islam je revolucionirao simboličnu terminologiju i principe razumijevanja poznate već predislamskim Arapima. I predislamski period poznavao je moralne vrline - junaštvo (hamāsa), plemenitost (karam) i blagost (hilm). Islam je ovoj predislamskoj formi dao sadržaj. Ove tri vrline bile su nužne za opstanak u teškim uvjetima Arabije, ali ih je islam opravdao metafizičkom doktrinom. Najviše je uzdignuta plemenitost. Kur’an objavljuje: „Najugledniji od vas (akramukum) kod Allaha je onaj koji ga se najviše boji!“ (El-Hudžurat, 13). Predislamska Arabija, iako je izgradila složen društveni sustav temeljen na istančanom shvaćanju plemenitosti, nije bila spremna ovu najvišu vrlinu dovesti u vezu sa strahom od Boga (taqwá). ${ }^{9}$ Tu revolucionarnu promjenu omogućio je islam.

Život je trajna borba u kojoj se čovjek junački nadmeće s protivnikom koji će ga na kraju ipak nadvladati:

Vidim život kao blago što se svake noći smanjuje,

A ono što dani i sudbina (dahr) smanjuju - to i nestaje. ${ }^{10}$

Ono što čovjek može jest ne dopustiti da mu protivnik oduzme slasti zemaljskog života. Ne jadikuje i ne pada u očaj. Carpe diem - svaki trenutak na ovom svijetu treba iskoristiti

\footnotetext{
Isto, 62 .

8 Isto, 60-61.

9 Toshihiko Izutsu, God and Man in the Qur'an. Semantics of the Qur'anic Weltanschauung, Kuala Lumpur 2002., 40.

10 A. A. aš-ŠANQīṬī, Šarh al-mu'allaqāt al-'ašar, 62.
} 
prije nego što bude prekasno. Gotovo da u ovim stihovima prepoznajemo Alkeja, koji pjeva: „Pijmo! Zašto da čekamo svjetiljke? Samo prst danjeg svjetla preostaje.“11

A da će svatko ispiti gorki kalež upozorava i pjesnik Umejja bin Abi Salt (7. stoljeće):

Tko ne umre kao mladić, umre kao starac

Jer smrt je kalež a čovjek kušač. ${ }^{12}$

Drugi predislamski pjesnik Lebid bin Rabi’a (560. - 661.) u svojoj elegiji za bratom Arbadom kratkoću zemaljskog života uspoređuje sa zvijezdom padalicom:

Što je čovjek doli zvijezda padalica, prolazna svjetlost

Pretvoren u pepeo nakon što zasvijetli.

Što je imetak i rodbina doli zajam.

A svaki zajam jednom mora biti vraćen. ${ }^{13}$

Ipak, koliko god život bio kratak i bremenit, za predislamskog pjesnika smrt može jednostavno biti odmor nakon dugog života. Zuhejr bin Abi Sulma (520. - 609.) u svojoj muallaki pjeva:

Umorile me životne nevolje, a tko doživi

Osamdeset godina mora da su ga umorile! $!^{14}$

Iako danas posjedujemo velik korpus predislamske poezije, jasnu predodžbu drevnog Arabljanina o onostranom nemamo (kao što, uostalom, nismo sigurni ni oko vjerske pripadnosti većine pjesnika). Ipak, Zuhejr bin Abi Sulma ovdje predstavlja iznimku. U muallaki tako savjetuje:

Nipošto ne tajite pred Bogom šta vam je u dušama,

Kako biste to sakrili, jer ma koliko tajili Bog to sazna!

Čak i ako zakasni, zapisat će kaznu u Knjizi i pohraniti ju

Za Sudnji dan, ili će pak požuriti i kaznu žurno izvršiti. ${ }^{15}$

Ovdje se pojavljuje niz motiva koje uobičajeno smatramo isključivo islamskima (Sudnji dan, knjiga, kazna), tj. slikama obračuna ${ }^{16}$ i proživljenja. ${ }^{17}$ Ibn Kutejba (828. - 889.), ko-

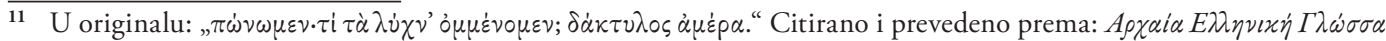

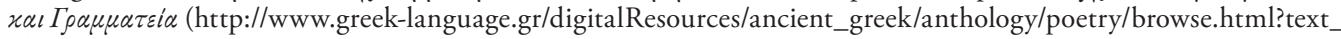
$\mathrm{id}=260$ ).

12 Umayya bin abī aș-ṢA ALt, Dīwān (ur. Samī’ Ğamīl al-Ğubaylì), Beirut 1998., 172.

13 Labīd bin Rabī'A, Dìwān (komentar Tusija), Beirut 2003., 111.

14 A. A. aš-ŠANQīị̄ī, Šarh al-mu'allaqāt al-'ašar, 87.

15 Isto, 82.

16 Obračun (arap. hisāab) je ispostavljanje računa svakomu čovjeku na Sudnjem danu za djela počinjena na ovom svijetu (dunjaluku). U trenutku obračuna svaki će se čovjek sjetiti svojih djela i kajati zbog prijestupa ili propuštenih prilika za činjenje dobrih djela (El-Fedžr, 23-24; El-Kehf, 48). Svakomu će biti podijeljena knjiga; onaj komu bude podijeljena u desnu ruku bit će spašen i nagrađen (El-Hakka, 19-20), a komu bude dana u lijevu bit će osuđen i kažnjen (El-Hakka, 25-29). Bit će postavljena i vaga (mĩzān) na kojoj će se pravedno vagati ovozemaljska djela svakoga čovjeka (El-Anbija, 47; El-Araf, 8-9), a posljednje je iskušenje most (șirāṭ̂), oštriji od sablje i tanji od kose, postavljen iznad džehenema (pakla), preko kojega će ljudi prelaziti do dženeta (raja). Prvi će preko mosta prijeći Muhamed a. s., a potom njegov ummet (Merjem, 71-72).

17 Proživljenje (arap. $b a^{\prime} \underline{t}$ ) je sjedinjenje duše s tijelom pred Sudnji dan. Prema Ku'ranu (En-Naml, 87-90), nakon drugoga puhanja u rog (pri prvom puhanju sve što živi umrijet će) Allah dž. š. oživjet će mrtve iz njihovih grobova i 


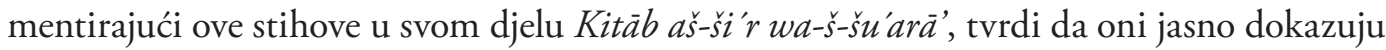
kako je Zuhejr vjerovao u proživljenje. ${ }^{18}$

Ka’b bin Zuhejr (7. stoljeće) u svojoj poznatoj kasidi Bānat Su'äd, nazvanoj tako prema prvim dvjema riječima „Otišla je Su’ad“, donosi sliku žena koje oplakuju smrt svoje djece: ${ }^{19}$

Sin svake žene, pa i ako uživa u dugoj sigurnosti

jednog dana će na zakrivljenim nosilima biti nošen. ${ }^{20}$

Svaki poznavatelj Homera ne može, čitajući ove stihove, ne prisjetiti se slike Ahilejeva oplakivanja mrtvog Patrokla iz 23. pjevanja Ilijade (222-225). ${ }^{21} \mathrm{Na}$ metaforičkoj razini, kao da je ova slika posljednji hommage predislamskom svijetu temeljenom na ratničkom etosu i plemenskoj solidarnosti. Svijetu koji je morao umrijeti kako bi se novi, onaj islamski, temeljen na odbacivanju plemenskih veza i zastarjelih tradicija, mogao roditi.

\section{ISLAM I SMRT}

Ka’b bin Zuhejr, koji je nakon duljeg odbijanja prihvatio islam, predstavlja trijumf islamskog monoteizma. Dvadeset i tri godine Muhamedova a. s. poslanstva donijele su nov pogled na život i smrt, ovozemaljsko i onostrano. Kako islam gleda na smrt? Kur’an, za muslimane posljednja Božja objava, upozorava da će sve što živi jednom umrijeti. „Sve što je na Zemlji prolazno je!“ (Er-Rahman, 26) i „Svako živo biće smrt će okusiti!“ (kur’anska fraza spomenuta čak tri puta - Alu Imran, 185; El-Enbija, 35; El-Ankabut, 57). Čas i mjesto smrti čovjek ne može znati (Lukman, 34), ali jednom kad dođe, „ni za tren ga jedan ne mogu ni odgoditi ni ubrzati“ (En-Nahl, 61). Svaki čovjek treba dobro paziti da dobra djela čini u pravom trenutku, prije nego što bude prekasno: „I od onoga čime vas Mi opskrbljujemo udjeljujte prije nego nekom od vas smrt dođe, pa da onda rekne: 'Gospodaru moj, da me još samo kratko vrijeme zadržiš, pa da milostinju udjeljujem i da dobar budem!' Allah, sigurno, neće ostaviti u životu nikoga kome smrtni čas njegov dođe; a Allah dobro zna ono što vi radite." (El-Munafikun, 10-11). Svakako je jedna od najpoetskijih slika smrti ona o otimanju duše. Arapski glagol tawaffá (spomenut u El-An’am, 60; Es-Sedžda, 11;

povratiti im duše u tijela u stanju u kojem su umrli (Jasin, 51-54; El-Muminun, 15-16) te ih okupiti (hašr r) na Sudnji dan, na kojem će svaki čovjek odgovarati za djela počinjena na ovom svijetu. U hadisima koje prenosi Abu Hurejra, a bilježe Buhari i Muslim (Muslim 2955; Buhari 1836), Muhamed a. s. spominje da će sve ljudske kosti istrunuti, osim repne kosti (adžbuz-zeneb), iz koje će pri proživljenju izrasti čitav čovjek; prvi će se otvoriti Muhamedov grob, a on će se na Sudnjem danu založiti za spasenje drugih.

18 Ibn Qutayba, Kitāb aš-ši'r wa-š-šu'arā' (ur. AḤmad MuHammad Šākir), Kairo 2006., 139.

19 Ka’b (sin Zuhejra bin Abi Sulme) bio je među najcjenjenijim pjesnicima kasnog džahilijeta. Kad je do njega stigao glas o Muhamedovu a. s. pozivanju ljudi u islam, on i njegov brat Budžejr otišli su do Muhameda, ali je Ka’b promijenio mišljenje i vratio se. Budžejr je, pak, prihvatio islam. Kada je Ka’b otkrio da je njegov brat postao musliman, napisao je satiričnu pjesmu. Ipak, nedugo se kasnije pokajao, prihvatio islam i pred Muhamedom izrekao ovu kasidu. Muhamed ga je tada ogrnuo svojim plaštem (burda). Ka'b bin Zuhayr, Dìwān (ur. 'Alì Fā'ūr), Beirut 1997., 65.

21 „Kao što rida otac, kad kosti mladoženje sina / Pali, koji je smrću rastužio jadnoga oca / I mater: tako je rido Ahilej drugarove kosti / Paleć, uz lomaču pužuć i uzdišuć tužno za njime." Citirano prema: Homer, Ilijada (preveo i protumačio Tomo Maretić), https://edoc.site/homer-ilijada-pdf-free.html, 369. 
Ez-Zumar, 42) znači „ugrabiti“, „dokopati se u potpunosti“, tj. u pasivu „biti ugrabljen“, „umrijeti“. Onaj koji grabi jest sâm anđeo smrti (malak al-mawt, spomenut u Es-Sedžda, 11 i poznat u islamskoj tradiciji kao Azrail, iako to ime nije potvrđeno ni Kur'anom ni vjerodostojnim hadisima). Ono što je ugrabljeno jest čovjekova duša koju anđeo u trenutku smrti izvlači iz zatočeništva prolaznog tijela. Od trenutka smrti do Sudnjeg dana i proživljenja, duša boravi u prostoru zvanom berzah (arap. barzah - „prepreka“), gdje uviđa posljedice ovozemaljskih djela. Nakon što svi ljudi budu proživljeni (El-Vakija, 49-50; Merjem, 93-95; El-Kehf, 47-49), bit će okupljeni (arap. hărrr) na jednom mjestu (mahšrer), u strahu i neizvjesnosti, kako bi obračun mogao započeti. Dinamičan način na koji islam opisuje Sudnji dan djelovao je na Arape tako da vjeruju u onostrano, raj i pakao te u apsolutnu pravdu Stvoritelja. Opreka ovozemaljskog i onozemaljskog sada postaje potpuna: „A na onome svijetu je teška patnja i Allahov oprost i zadovoljstvo; život na ovome svijetu je tek varljivo naslađivanje!“ (El-Hadid, 20). U shvaćanju prolaznosti ovozemaljskog života nema velike razlike između predislamskog i islamskog pogleda. No, njihovi su zaključci suprotni. Dok je predislamski Arapin bio ograničen trenutačnim postojanjem, islam je onostrano učinio na temelju vjere. ${ }^{22}$ Čovjek više nema potrebe očajavati. Ideja besmrtnosti (hulūd), koja je predstavljala nerješiv problem ranijim pjesnicima, sad je dostižna, s one strane obzora postojanja - „Ali, vi više život na ovom svijetu volite, a onaj svijet je bolji i vječan je!“ (El-A’la, 16-17).

Sveobuhvatnost promjene koja je nastupila islamom vidljiva je i u arapskom jeziku. Zanimljivo je da 76. sura Kur’ana ima dva imena: El-Insan (Čovjek) i Ed-Dahr (Vrijeme). Dahr u Kur’anu više nema značenje sudbine, tj. samrtnog časa (sinonim riječi maniya) kakvo ima u predislamskoj poeziji i čije semantičko polje kasnije u arapskom jeziku preuzima riječ qadar. Dahr sad dobiva novo značenje, postaje vrijeme i gubi svoju svemoć. Dok predislamski dahr određuje tijek i kraj čovjekova života, iznad islamskog dahra stoji Allah dž. š.: „Samo Allah je zapisao sudbinu svih stvorenja pedeset hiljada godina prije stvaranja nebesa i Zemlje, dok je Arš (Allahovo prijestolje - op. E. M.) bio na vodi.“' (Muslim, 1841).

Osim Kur'ana, brojni vjerodostojni hadisi opominju vjernike da na ovaj svijet gledaju kao na prolazno boravište. U jednom koji donosi Buhari navodi se: „Uhvatio me je Allahov Poslanik za rame i rekao: 'Budi na ovome svijetu kao da si stranac ili putnik!'“ (Buhari, 6416).

U drugom, također iz Buharijeve zbirke: „Vjerovjesnik je nacrtao kvadrat i povukao jednu liniju kroz sredinu, koja je izlazila iz njega. Zatim je nacrtao manje linije sa strane okrenute prema liniji u sredini i rekao: 'Ovo je čovjek, a ovo je njegova smrt (ağal), koja ga okružuje. Ova linija koja je izvan - to je njegova nada, a ove male linije jesu nevolje koje ga prate $\left(a^{\prime} r \bar{a} d\right)$. Ako ga jedna promaši, pogodi ga druga; ako ga promaši druga, pogodi ga prva." (Buhari, 6417).

22 Toshihiko Izutsu, Ethico-Religious Concepts in the Qur'ān, Montreal - Kingston 2002., 50. 


\section{SMrt Za islamskog PJESNika}

Mutanabbi (915. - 965.) je najveći arapski pjesnik i najekspresivniji medij arapskog pjesničkog genija. Sin je vodonoše iz drevnog jemenskog plemena; rano prepoznat pjesnički talent izbavio ga je teška života osiguravši mu dobro obrazovanje. Kad su ismailitski Karmati 924. godine zauzeli Kufu, pridružio im se i 932. čak stao na čelo karmatske revolucije u Siriji. Nakon poraza pobunjenika i dvogodišnjeg tamnovanja, pokajao se 935. godine i postao lutajući pjesnik. Njegove medhije postale su tako slavne da ga je Sejfud-Davla doveo 948. na svoj dvor. Na alepskom dvoru ostao je devet godina, prateći svog patrona u svim pohodima. Smrt je tijekom tih godina dobro upoznao. U jednoj poznatoj kasidi veliča junačku smrt:

Prkosno živi ili časno pogini

Između britkih oštrica i barjaka što lepršaju!

Junačka smrt više nije besmislena smrt u plemenskim obračunima predislamskih Arapa. Ona je sad smrt gazijskog ratnika koji brani granice islama. Smrt koju će ratnik željeti ponovno proživjeti: „Zaista su duše šehida u utrobama zelenih ptica, lete po dženetu (raju) kuda žele. A potom se sklanjaju u kandilje okačene ispod Arša. Njihov Gospodar im se javlja i pita ih: ‘Što želite?', a oni odgovaraju: 'Gospodaru nas! Što još možemo poželjeti kada si nam dao što nikome od Svojih stvorenja nisi dao?' On ih nastavlja pitati sve dok ne shvate da neće biti ostavljeni bez odgovora pa rekoše: 'Želimo da nas vratiš na Zemlju da se borimo na Tvome putu kako bi ponovo, u Tvoje ime, poginuli'“ (Muslim, 1887). Ipak, savjetuje nas Mutanabbi ljudski, ne treba žuriti u smrt. Nisu li najveći pjesnici - Arhiloh, Alkej, Anakreont ili Horacije - u žaru bitke izabrali život i bacili štit:
Ako se izlažeš opasnosti tražeći čast
I ništa manje od zvijezda ti ne donosi zadovoljstvo
(Znaj da) je okus smrti pri maloj
Poput onoga pri velikoj stvari. ${ }^{23}$

Poput Zuhejra, i Mutanabbi u smrti vidi bijeg od životnih problema:

Nevoljko oplakujemo naše mrtve,

jer znamo da samo taštinu ostavljaju za sobom

Ako razmisliš o nevoljama života,

shvatit ćeš da je bolje od ruke neprijatelja stradati. ${ }^{24}$

Brzina kojom anđeo smrti napada plaši ga, a najpotresniju sliku pronalazimo u njegovoj elegiji prilikom smrti majke Sejfud-Davla:

Pripremamo mačeve i koplja, a smrt nas pobije bez borbe; 
Privezujemo brze konje pored šatora, ali od kasa noći nas ne izbave! ${ }^{25}$

Konfrontacijom dvaju distiha Mutanabbi, otkrivajući duboku razliku u moći, prikazuje paradoks smrti. Dok bi vokabular prvog distiha (mačevi, koplja, konji) mogao poslužiti u medhiji Sejfud-Davla, koji je gospodar života i smrti na bojnom polju, drugi jasno pokazuje nemoć ratnika koji se usude smrti stati na megdan. Mutanabbi se koristi vokabularom medhije, a ulogu ratnika preuzima smrt, koja je ovdje, kao i u srednjovjekovnoj kršćanskoj imaginaciji, personificirana kao konjanik koji jaše konja u kasu, mač ga ne siječe, a koplje ne probada. Sejfud-Davla, koji se na konjskom sedlu bezbroj puta suočio $s$ neprijateljem, ovog puta ne može pobijediti i spriječiti majčinu otmicu. ${ }^{26}$ Borba sa smrću jest agon, egzistencijalan i herojski, ali protivnik ne igra pošteno. Smrt je perfidna i bez milosti. Ipak, ovdje je, koliko god na prvi pogled neuočljiv, vidljiv jasan islamski svjetonazor. Mutanabbijeva elegija više nema mnogo toga zajedničkog s predislamskom. On kao da izaziva smrt: „Dođi! Uzmi me, ne hajem, jer znam da ću pobijediti!“ Elegija više nije plač ožalošćenog, ona je koplje pobunjenika upereno prema smrti:

O Sejfud-Davla, traži pomoć u snazi,

Jer kako bi planine ikad mogle biti ravne tvojoj snazi?

Učiš narod kako da strpljivo podnosi breme

I na smrt navali u nepredvidljivom ratu.

Mijene vremena s kojima se suočavaš su brojne,

Ali na tvoje stanje mijene ne utječu! ${ }^{27}$

\section{ZAKLJUČAK}

Smrt je jedan od najzastupljenijih i, kako svjedoči ep o Gilgamešu, najstarijih motiva u poeziji. Predislamski arapski pjesnik kao da je vidi posvuda oko sebe - lešine životinja pored karavanskog puta, ruševine gradova koje je prekrio pijesak. Smrt je nemilosrdna i pravedna, nije ju moguće prevariti, niti spoznati njezinu tajnu. Ipak, u predislamskog pjesnika smrt ne pobuđuje razmišljanje o onome što se nalazi s one strane. Ona svakako pobuđuje ovozemaljske brige, ali one koje izviru iz svijesti o gubitku, a ne iz straha od kazne ili truda oko nagrade. Vizija je smrti pesimistična, beznadna, čak i ako gorak ovozemaljski život nije vrijedan življenja. Moglo bi se reći i da je krik očaja nad prazninom života konstanta predislamske poezije. Islam će sve promijeniti. Čovjeku daje smisao života i objašnjava da je smrt zakon neodvojiv od života, njegovo drugo lice. Iako je i dalje neminovna i bolna za bližnje, pravednik se sad ima čemu nadati. Za čestit život bit će nagrađen, a najveća je nagrada gledanje u Allahovo lice (El-Kijama, 22-23). Smrt je tek odvajanje duše od tijela i kidanje veze koja će se ponovno uspostaviti pri proživljenju. U besmrtnost duše vjerovali su još drevni Egipćani, a aspekt duše koji u trenutku smrti

\footnotetext{
$25 \quad$ Isto, 265.

26 Margaret Larkin, Al-Mutanabbi. Voice of the Abbasid Poetic Ideal, Oxford 2007., 45.

27 Al-Mutanabīi, Dìwān, 268.
} 
napušta tijelo (Bâ) prikazivali su hijeroglifom ptice s pokojnikovom glavom, dok je sli-

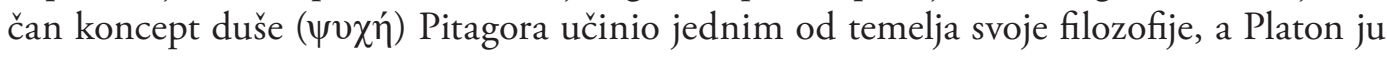
je detaljno izložio u Fedonu. I u islamu sama esencija duše, koja čini i esenciju čovjekova bića, ostaje kakva je i bila. Smrt je samo prijelaz. Kako je rekao pobožni kalif Umar bin Abdul-Aziz: „Vi ste stvoreni za vječnost (abad) i samo se premještate iz jednog boravišta u drugo (min dār ilá dār)!“

\section{$\cos$}

\section{Literatura}

AL-Ğ̄̄èz, Kitāb al-Hayawān (ur. 'Abd as-Salām Hārūn), sv. 1, Kairo 1965.

Al-Mutanabī̄, Dìwān, Beirut 1983.

Homer, Ilijada (preveo i protumačio Tomo Maretić), https://edoc.site/homer-ilijada-pdf-free.html. Toshihiko Izutsu, Ethico-Religious Concepts in the Qur'än, Montreal - Kingston 2002.

Toshihiko Izutsu, God and Man in the Qur'an. Semantics of the Qur'anic Weltanschaunng, Kuala Lumpur 2002.

Margaret Larkin, Al-Mutanabbi. Voice of the Abbasid Poetic Ideal, Oxford 2007.

Ibn Qutayba, Kitāb ašššì'r wa-šs-šsu'arā’’ (ur. AḦmad MuHammad Šākir), Kairo 2006.

Labīd bin Rabī́A, Dìwān (komentar Tusija), Beirut 2003.

Umayya bin abī aṣ-ȘALt, Dìwān (ur. Samī' Ğamìl al-Ǧubaylī), Beirut 1998.

AḤmad al-Amīn aš-ŠANQīṭī, Šarh al-mu'allaqāt al-'ašar, Sidon - Beirut 2005.

Ka'b bin Zuhayr, Dìwān (ur. 'Alī Fā'ūr), Beirut 1997.

\section{Mrežna stranica}

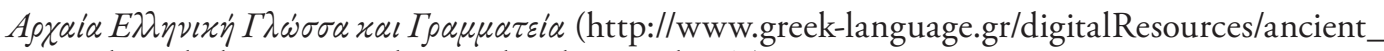
greek/anthology/poetry/browse.html?text_id=260). 


\section{$\cos$}

\section{“DEATH IS A CHALICE AND MAN IS THE TASTER": DEATH IN EARLY ARABIC POETRY}

Human beings are troubled by death from the moment they become self-aware. Biology, philosophy and religion all try to get to the heart of the mystery of death in their own ways. In this sense, the purpose of poetry is to comfort the mortal, and Arabic poetry is no exception, with the elegy as its perhaps oldest genre. The author examines the attitudes towards death expressed by pre-Islamic poets, as well as the shift in Arabic poetry that occurred with the emergence of the new cultural universe of Islam. In the works of pre-Islamic poets, death seems to be in perfect accordance with the harsh and unforgiving desert environment: a terrifying wraith which snatches without mercy. Since a mortal can expect no mercy at the end of his days, every moment before death must be lived to the fullest. In the works of certain poets, such as Tarafa, this sort of hedonism takes on a moral dimension. For Tarafa, a life well-lived is one that ends with no regrets for missed opportunities to do good. A moral revolution already heralded by Zuhayr bin Abi Sulma and brought about by Islam created a new world. A Muslim no longer doubts the existence of the afterlife. Instead, death is regarded as but a transition to the other side, where the soul is awaited either by the anticipates or the punishment it dreads. In any case, death is no longer inevitably perceived as the bitter end. This becomes most evident in the poetry of the greatest Arab poet, Mutanabbi, who, in his works, challenges death after the loss of loved ones, and emerges triumphant.

Key words: Islam, death, pre-Islamic poetry, muallake, Mutanabbi 


\section{1. \\ U IŠČEKIVANJU SMRTI \\ ILI PREPLITANJA ŽIVOTA I SMRTI \\ U REKONVALESCENTIMA \\ DRAGIŠE VASIĆA I BARACI 5 BE \\ MIROSLAVA KRLEŽE}

\section{Iva Tešić}

UDK: 821.163.42-32Krleža, M.:821.163.41-32Vasić, D."192“"

Izvorni znanstveni članak

Sažetak: Rad je usredsređen na komparativnu analizu u čijem je fokusu otkrivanje međusobnih podudarnosti, odnosno razlika na tematsko-motivskom i ideološkom planu između Barake 5 be Miroslava Krleže i Rekonvalescenata Dragiše Vasića. Posebna pažnja posvećena je ratu kao književnoj temi, to jest ratnom kontekstu kao zajedničkom imenitelju ovim dvema proznim celinama. Drugu uporišnu tačku predstavljaju Frojdove teze o ratu i smrti, pre svega stav da rat menja čovekov doživljaj smrti, relativizujući odnos prema smislu postojanja, religiji, društvenim i životnim vrednostima. Dakle, u središtu interpretacije nalaze se misaone preokupacije junaka koji su u iščekivanju smrti. Pored toga, napravljen je i kratak osvrt na relaciju Miroslav Krleža - Dragiša Vasić.

Ključne reči: rat, smrt, bolnica, Dragiša Vasić, Miroslav Krleža

D a bismo se bavili uporednom analizom i osvetljavanjem međusobnih podudarnosti i razlika između Rekonvalescenata i Barake 5 be, potrebno je da uputimo na kontekst nastajanja pomenutih dela. Podsetimo, i Vasićeva i Krležina pripovetka deo su većih proznih celina - Rekonvalescenti su uvršćeni u Utuljena kandila, a Baraka 5 be u zbirku Hrvatski bog Mars. I jedna i druga pripovetka najpre su štampane u časopisima: Rekonvalescenti u Srpskom književnom glasniku 1922, da bi iste godine bili objavljeni kao integralni deo Utuljenih kandila, dok je Baraka 5 be prvo izašla u Novoj Evropi 1921. godine, a već naredne u knjizi Hrvatski bog Mars. Intertekstualnost pomenutih proza funkcioniše ne samo u relaciji sa drugim pripovetkama u zbirci, već i u okvirima posleratnog stvaralaštva.

Ratne okolnosti iznedrile su ekspresionističku umetnost - rat će u književnosti dvadesetih i tridesetih godina 20. veka postati dominantna tema. Čak i kada se eksplicitno ne 
govori o njemu, biće „prepoznatljiv po posledicama koje je ostavio u životu pojedinca“. Specifično je, možemo reći i tipično, pomeranje fokusa ka drami koja se zbiva u junacima, a ne na frontu. Naime, „i onda kada su opisivane neposredne situacije u toku rata, uglavnom su birane one koje su se dešavale u pozadini, za vreme zatišja, u bolnici (...) a ne na ratištu i u bitkama“. ${ }^{2}$ Skrenuli bismo pažnju i na činjenicu da je Prvi svetski rat sve do danas zadržao tzv. „literarnu auru“, kao i da je udeo književnosti u oblikovanju sećanja na period od 1914. do 1918. veći nego u bilo kom ranijem istorijskom trenutku. ${ }^{3}$ Kataklizma koja se dogodila stvorila je nepomirljive razlike između svega onoga što joj je prethodilo, i što je nastupilo po njenom okončanju. $\mathrm{O}$ jazu između predratne i posleratne literature možda najupečatljivije svedoči Miloš Crnjanski:

Deset miliona mrtvih i dvadeset miliona skrhanih telesa i preobraženih duša dele predratnu prošlost što se još jedva nazire, u godinama posleratnih promena, jednom zauvek, od sadašnjosti i budućnosti. ${ }^{4}$

Podsetićemo i na Objašnjenje „Sumatre“, u kojem Crnjanski ističe „nove osetljivosti“ koje su nastupile nakon rata:

Svud se danas oseća da su hiljade i hiljade prošle kraj lešina, ruševina, i obišle svet i vratile se doma, tražeći misli, zakone i život kakvi su bili. Tražeći staru, naviklu književnost, poznate, udobne senzacije, protumačene misli. (...) Ali su došle nove misli, novi zanosi, novi zakoni, novi morali! ${ }^{5}$

Rat i literarne junake i stvaraoce i tadašnje čitaoce objedinjuje u istovetnoj egzistencijalnoj situaciji. S tim u vezi iskrsava pitanje koliko, zapravo, u posleratnim ostvarenjima ima tragova lične istorije. Krleža je u članku Moja ratna lirika podvukao značaj činjenice da je njegova rana poezija bila obeležena atmosferom u kojoj je stvarana:

Sve je u toj lirici pogrebno, jer je sve oko nje i pod njom, kad je nastajala, bilo isto tako pogrebno. Rađajući se kao odraz stanja i prilika, ona nije mogla da bude odvojena od neprestanog razmišljanja nad otvorenim grobovima, i tako ni sama nije drugo nego neprekidno pokapanje, sprovod i smrt. ${ }^{6}$

Ratna trauma je u slučaju Dragiše Vasića isticana kao specifični spiritus movens. Kritičari su upravo iskustvu rata pridavali presudni značaj, čak tvrdeći da je ono od Vasića stvorilo pripovedača. Prvi je takvu ocenu izneo Slobodan Jovanović u predgovoru Utuljenim kandilima: „G. Vasića načinio je pripovedačem sam život. On je dobio u ratu suviše jake utiske, koji su ga suviše tresli i mučili; on je počeo pisati da bi se tiranije tih utisaka oslobodio. ${ }^{\text {"7 } ~ I ~}$

\footnotetext{
Radovan VučKović, Srpska avangardna proza, Beograd 2002., 36.

2 Marko Nedić, „Književno delo Dragiše Vasića u okvirima novije srpske književnosti“, Dragiša Vasić (prir. Marko Nedić), Novi Sad 2012., 17.

3 Dunja Dušanić, Fikcija kao svedočanstvo. Iskustvo Prvog svetskog rata u prozi srpskih modernista, Beograd $2017 ., 335$.

4 Gojko Tešić, Srpska književna avangarda. Književnoistorijski kontekst (1902-1934), Beograd 2009., 27.

5 Miloš Crnjanski, „Objašnjenje 'Sumatre'“, Itaka i komentari, Beograd 1959., 176-177.

6 Miroslav KrležA, „Moja ratna lirika“, Evropa danas. Knjiga dojmova i essaya, Zagreb 1935., 39.

7 Slobodan Jovanović, „Dragiša Vasić. Predgovor Utuljenim kandilima“, Crvene magle (prir. Gojko Tešić), Beograd 1990., 132.
} 
Milan Bogdanović je smatrao da Vasić „robuje teškim utiscima“ koji moraju biti izrečeni, zbog čega mu se čini osnovanim pitanje „da li će Dragiša Vasić od onog dana kada bude izrekao svoju moru od rata, koja mu pritiskuje duh i dušu, osećati potrebu da i dalje pišse. 8 Možemo dodati da je ovakva nedoumica, ispostavlja se, bila osnovana i da je Vasić tridesetih godina zaista prestao da piše. Možda se pisanjem privremeno oteo „užasu koji ga je upravo i podstakao da stvara"9 ili je posredi neko drugo objašnjenje, ali činjenica je da je na Krležin predlog da sarađuje u časopisu Danas odgovorio na sledeći način: „Kakvi bakrači, ne zanima me, brate, nikakva literatura!" ${ }^{10}$

Međutim, neposredno po završetku rata, Krleža i Vasić stvarali su, kao i ostali pripadnici posleratne generacije, $u$ atmosferi beznađa, defetizma i potpune dezorijentisanosti. Posleratni trenutak bio je neuporediv sa prethodnim iskustvima, jer „nikada ranije nijedan događaj nije razorio toliko opštih dobara (...) zbunio tako mnogo najsjajnijih umova, niti toliko unizio ono najviše “. ${ }^{11} \mathrm{U}$ takvom ambijentu Ničeova ideja o sumraku sveta i smrti boga nije samo puko teorijsko polazište - nihilistička vizija prestaje da bude isključivo proizvod filozofskog promišljanja, postajući ogledalo duhovnog stanja epohe, ali i „umetničko-literarni materijal za neprolazna dela“. ${ }^{12}$

Promena koju zapažamo u narativnim ostvarenjima iz posleratnog razdoblja ogleda se $\mathrm{u}$ činjenici da istorijska dešavanja postaju periferna, dok se interesovanje usmerava prema unutarnjem, psihološko-emotivnom. Umesto faktografiije dobijamo uvid u zbivanja s obzirom na trag koji ona ostavljaju u svesti junaka. Ključno, čini se i opsesivno pitanje koje iskrsava pred svim povratnicima, ali i svim preživelima, sročeno je u prvim redovima Dnevnika o Čarnojeviću Miloša Crnjanskog, i glasi: „Gde je život?“ Apsolutni slom vrednosti koji je čovečanstvo doživelo nakon Velikog rata donosi potrebu za pronalaženjem uporišta koje će obezbediti smisao i vratiti veru u život. Na literarnom planu doći će do stvaranja antiratne književnosti i ponovne aktualizacije priče o čoveku u ratu, ali iz potpuno novog ugla. Junaci čiji je život obeležen iskustvom rata uspostaviće paradigmu koja predstavlja antonim tradicionalnoj predstavi rata i odlaska u rat. Dok je u prošlosti sagledavan kao neka vrsta „svete dužnosti“, odnosno povoda da se istaknu vrline (junaštvo, patriotizam, požrtvovanost, odricanje...), u ovom periodu gubi se herojsko-mitska perspektiva i rat biva doživljen kao infernalni ambijent koji preti da satre i uništi.

I Frojd je smatrao da takav rat više „ne pruža priliku za postizanje starog ideala junaštva“. ${ }^{13}$ Međutim, upravo je kontekst Prvog svetskog rata za njega predstavljao svojevrsnu inspiraciju, koja će uticati na stvaranje teorije agresivnosti. „Poplava zla i stradanja“" ${ }^{\text {“4 }}$ poslužila je tvorcu psihoanalize kao potvrda pretpostavke da agresija nije stečeni niti naučeni oblik

\footnotetext{
Milan Bogdanović, „Dragiša Vasić Crvene magle“, Crvene magle, 217-218.

Isto, 217.

10 Stanko Lasıć, Krleža, kronologija života i rada, Zagreb 1982., 248.

11 Sigmund Frojd, „Aktuelna razmatranja o ratu i smrti“, Antropološki ogledi. Kultura, religija, umetnost (prir. Žarko Trebješanin), Beograd 2011., 121.

12 Milan Bogdanović, „Rat i literatura“, Politika (Beograd), br. 4164, 6. 1. 1919., 2.

13 S. Frojd, „Aktuelna razmatranja o ratu i smrti“, Antropološki ogledi, 118.

14 Ivo Andrić, „Naša književnost i rat“, Istorija i legenda. Eseji I (prir. Radovan Vučković), Beograd - Zagreb - Sarajevo - Ljubljana - Skoplje 1976., 176.
} 
ponašanja, već inherentni potencijal. Prema njegovom tvrđenju, ispoljavanje animalnih nagona zadovoljava čovekovu urođenu subverzivnost, koja u ratnim okolnostima biva pobuđena, dobijajući prostor za legitimizaciju. U vreme trajanja rata, tačnije 16. februara 1915, Frojd je članovima izraelskog humanitarnog udruženja B'nai B'rith održao predavanje Mi i smrt. ${ }^{15}$ U njemu je prvi put pomenuo nagon smrti. U kasnijim esejima Frojd će se podrobnije baviti odnosom između tanatosa i erosa - nagona smrti, nazvanog prema grčkom bogu Tanatosu, i njegovog oponenta Erosa, koji predstavlja ovaploćenje vitalističkog instinkta. ${ }^{16}$ Uvođenjem pojma „nagon smrti“ radikalno se raskida sa svim prethodnim diskursima na temu smrti, u kojima je smrt „ili otvoreno negirana i sublimirana, ili dijalektizovana“. ${ }^{17}$

Frojdov stav je da negativni impulsi koji potiču iz nagona smrti jesu značajna pogonska / motivaciona sila u čovekovom životu, a ratni prostor najpogodniji je za njihovo aktiviranje i manifestovanje. Prema Žanu Bodrijaru,

(...) pojavom Frojda, sa filozofskog pojma smrti kao drame svesti prelazi se na poimanje smrti kao nagonskog procesa upisanog u poretku nesvesnog - sa metafizike straha na metafiziku nagona. Baš kao da je smrt (...) konačno otkrila svoj status objektivne svrhovitosti: nagonsku energiju smrti ili princip psihološkog delovanja. ${ }^{18}$

Frojdovo ubeđenje je da svaka ljudska jedinka u nesvesnom gaji ideju o svojoj besmrtnosti i permanentno tokom života ignoriše činjenicu o sopstvenom kraju. Međutim, ratne okolnosti donose promenjenu percepciju smrti. U okvirima neprestanog i svakodnevnog masovnog umiranja čovek je onemogućen da svesno eliminiše, ukine misao o njenoj neminovnosti. Rat, zapravo, oličava pozornicu smrti, na kojoj je nužno suočavanje sa činjenicom da smrt prestaje da bude samo smrt drugog i postaje sveopšta izvesnost.

Preplitanja erosa i tanatosa na jednom omeđenom narativnom prostoru možemo pratiti u pripovetkama Baraka 5 be i Rekonvalescenti. I Vasić i Krleža biraju bolnicu za scenografi-

15 Sigmund Frojd, Mi i smrt. Našstav prema smrti: dosad neobjavljeni rukopisi i predavanja (prir. Žarko Martinović i Milica Martinović), Beograd 2001.

16 U pismu Ajnštajnu, pisanom 12 godina po okončanju rata a naslovljenom Zašto rat?, stav o dva nagona definisan je na sledeći način: „Pretpostavljam da postoje dve vrste ljudskih nagona: prvi koji teže održanju i ujedinjenju - nazivamo ih 'erotski', sasvim u skladu sa značenjem Erosa u Platonovoj Gozbi, ili 'seksualni', sa svesnim proširenjem popularnog pojma seksualnosti - i drugi koji teže razaranju i ubijanju: njih zajednički sažimamo pod imenom nagona za agresijom, ili razornog nagona.“ (S. FroJd, „Zašto rat?“, Antropološki ogledi, 114-115.) Odnos prema tanatosu kao „potomku i glavnom predstavniku smrti“ opisan je i u eseju Nelagodnost u kulturi (1930). Ovom prilikom Frojd je razmatrao udeo pomenutih nagona u razvoju kulture, pri čemu je erosu pripala ujediniteljska uloga, koja je u službi kulture, dok njegov oponent oličava destrukciju i sabotažu: „Stojim, dakle, na stanovištu da sklonost agresiji predstavlja osnovni, samostalni nagon u čoveka, i ponavljam, on predstavlja najveću prepreku kulturi." (S. FroJD, „Nelagodnost u kulturi“, Antropološki ogledi, 68.) U pismu Zašto rat? Frojd, međutim, ističe uzajamnost i nerazlučivost pomenutih instinkata, tvrdeći da je erosu neophodan tanatos ne bi li ostvario sopstvene porive: „Tako je nagon samoodržanja očito erotske prirode, ali upravo on mora da raspolaže agresivnošću kako bi ostvario svoju nameru“, odnosno: „I ljubavnom nagonu usmerenom na objekte, u podjednakoj meri je potreban dodatak nagona za ovladavanjem ako uopšte želi da se domogne svog objekta.“ (S. FrojD, „Zašto rat?“, Antropološki ogledi, 115.) Osim toga, u pomenutom pismu otkrićemo i Frojdovu tezu o „biološkoj osnovi rata“: „Konačno, rat izgleda sasvim u skladu s prirodom, ima biološku osnovu i praktično je skoro neizbežan.“ (Isto, 118.) Otuda i konstatacija da je ljude „lako oduševiti za rat“ jer „u njima deluje (...) neki nagon za mržnjom i uništavanjem“. (Isto, 114.) Možemo primetiti da se ova misao nadovezuje na tvrdnju izrečenu 1915: „U nama nema nikakve nagonske odbojnosti prema prolivanju krvi. Potomci smo beskrajnog niza ubica." (S. FrojD, Mi i smrt, 50.)

17 Žan Bodrijar, Simbolička razmena i smrt, Gornji Milanovac 1991., 167.

18 Isto, 166. 
ju koja na najbolji način reprezentuje samrtnost, kao i tragiku ratne traume - bolnica je taj „crni talog pomerenosti, najtragičnije skupljeno na jednom mestu“. ${ }^{19}$ Svojevrstan paradoks je da ova izolovana sredina oličava privremeno utočište i sklonište od sigurne smrti. Dok se Vasićevi rekonvalescenti zahvaljuju bogu jer nisu na ratištu, bolesnici malteškog špitala gaje iluziju o sopstvenoj privilegovanosti jer se rat odvija tamo negde daleko, a oni se vesele i gledaju kroz bodljikavu žicu „van u užas“:

(...) njima je, eto gle, ipak kako-tako dobro. Stoje tu, pod Crvenim križem, i neće ih nikamo ganjati, a ako dođe Rus, i opet će ih transportirati nekamo daleko, u ruske bolnice i logore, i tamo neće biti rata, i ostat će živi. ${ }^{20}$

Krležin špital je „blatni krvavi pakao“ u kome se ljudi pretvaraju u brojeve koji, u zavisnosti od stepena fizičke oštećenosti, bivaju otpremljeni među polomljene kosti, amputirane, ili idu u baraku 5 be, što će reći na jedno kratko putovanje od kupaonice ka mrtvačnici. Svet Krležine Barake 5 be užaren je do usijanja - sve trune i vene na 49 stepeni Celzijusa:

(...) sunce [je] formalno zdrobilo svojom ognjenom masom zemlju, i tako je izgledalo kao da je netko na drvene bijele barake bacio gorući mlinski kamen da se sve zapalilo. Savijale se daske i pucale od suše (...) sve je to venulo, trulo, gnjilo i zgaženo; odnosno: Usijalo je sunce prokleto sve mozgove. ${ }^{21}$

U ekspresionističkom duhu, sa naturalističkim opisima, atmosfera špitala postaje groteskni ambijent $\mathrm{u}$ kome nagon za životom pacijente pretvara u maske koje u tom predsmrtnom beznađu mahnitaju:

Pjeva se, pije, razlijeva se rakija, pa se svrabljivci počeli da ganjaju metlama kroz barake, i viču, i sve reži kao menažerija, i tako izgleda da će se sve te barake, kao ranjene musave kokoši ćorave, skupiti pa početi poskakivati na jednoj odrezanoj i povezanoj nozi tamo-amo, po taktu topovske glazbe. ${ }^{22}$

Karnevalizovana atmosfera, razularenost i raspojasanost, naglašena seksualnost, koja se završava silovanjem bolničarki, protivteža su jedinom donekle individualizovanom liku, umirućem studentu Vidoviću, koji zapomaže u bolovima i moli za tišinu, dok na njegovoj postelji pijani Mađari igraju ajnc:

- Braćo draga! Molim vas! Mir! Mene boli! Mene strašno boli, viče Vidović, ali glas mu se gubi, i on samo hropti, i krv mu navire na zube. ${ }^{23}$

U toj masi jedino je on svestan skore smrti, i nemoćno razmišlja o sramotnoj situaciji u kojoj se nalazi. Njega na samrtnom času nema ko da čuje niti da mu pritekne u pomoć, zbog čega iz besa i očaja, revoltiran beznadežnošću, poželi da kao trag o svom postojanju ostavi crvenu krvavu mrlju. Na kraju život završava u lokvi sopstvene krvi.

19 Mihajlo Pantić, Modernističko pripovedanje - srpska i hrvatska pripovetka / novela 1918-1930, Beograd 1999., 235.

20 Miroslav KreežA, „Baraka 5 be“, Hrvatski bog Mars, Zagreb 2001., 235.

21 Isto, 231, 236.

22 Isto, 239.

23 Isto, 240. 


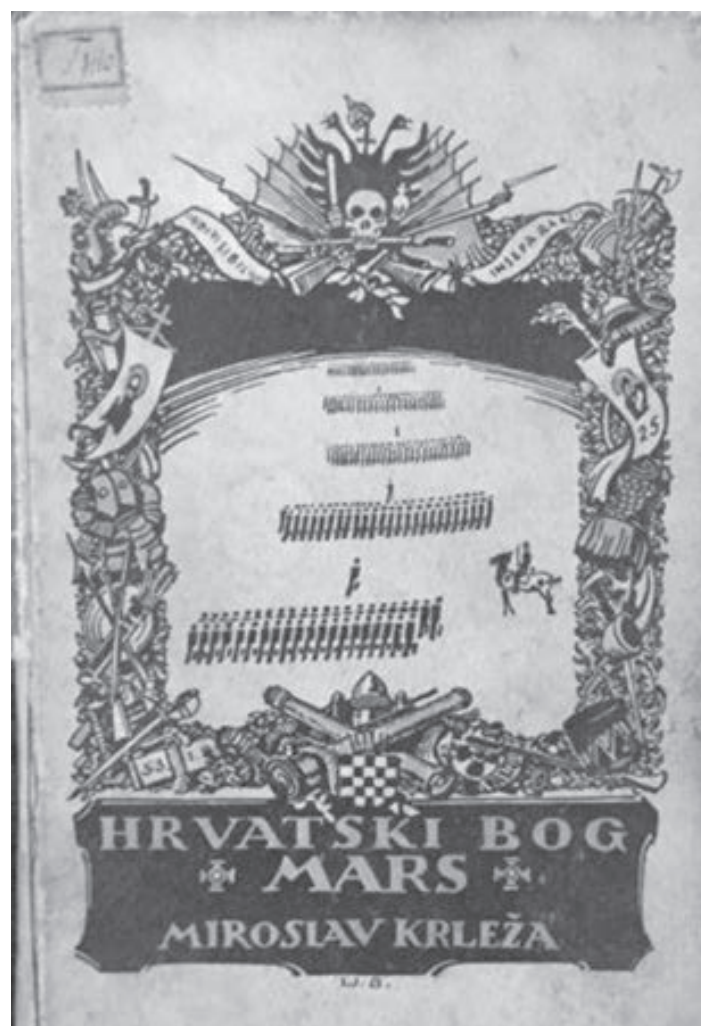

Sl. 1. Korice prvog izdanja zbirke Hrvatski bog Mars s ilustracijom Ljube Babića
I dok je u Baraci 5 be sve na ivici propasti, u perverziji i prepuštanju nagonima koji oslobađaju od svesti o skorom kraju, atmosfera u Rekonvalescentima nije kipuća niti prenaglašena - što je, uostalom, u skladu s Krležinim zapažanjem da je Vasić „miran naturalista kome violentne snage podsvesnih poriva ne previru preko solidne granice“. ${ }^{24}$ Vasićeva posmrtna postavka udavljena je maglom, u glibu, kiši i sivilu. Dekorisanost Krležine i Vasićeve samrtničke scenografije i „meteorološka motivisanost" umnogome se razlikuju, mada je prepoznatljiva simbolika kojom se dva pisca služe. Vatra, plamen i sunce važni su Krležini simboli - pomenimo da je Plamen i naslov časopisa čiji je bio osnivač i urednik, zatim da u čuvenom programskom tekstu Hrvatska književna laž zaziva plamen da spali laž hrvatske književnosti, a u Hrvatskoj rapsodiji, epilogu zbirke Hrvatski bog Mars, genije spasitelj vodi narod ka suncu. Nasuprot užarenoj Krležinoj simbolici stoji magla kao prepoznatljiv simbol Vasićeve ratne proze. Magla je prisutna i u naslovu Vasićeva ratnog romana Crvene magle, čak su i duševna stanja Vasićevih junaka obeležena magnovenjem: „Magla je stanište utvara i fatamorgana misli, a njena nesigurnost ne poništava samo 'pravi' smisao misli, već ga preinačava, patvori i premešta." ${ }^{25}$ Kao što Krležin plamen treba da pročisti svet, tako i Vasićeva voda priziva simboličko pranje, čišćenje. U Rekonvalescentima je uprizoreni svet rastočen - kiša koja danima pada kao da predskazuje potop:

I danima tako sipi, rominja, kisne, pa mokro sve, i teško, i uvijeno gustom kišnom maglom (...) sedam crnih paviljona sve više tone u glibu. Raskaljale se stazice (...) svuda žitko blato (...) zidovi mokri i stabla velikog drveća pokisla do srži (...) prokišnjavaju paviljoni i duša podrhtava od vlage i studeni. A dole, u ravni davi se varoš u potopu magle. ${ }^{26}$

U sivom, hladnom, kišnom i maglovitom prostoru, deleći zajedničko osećanje nervoze i bezizlaza, rekonvalescenti su okupljeni u grupice i vreme prekraćuju razgovorima. Možemo zapaziti da je u skoro svakoj priči koju bolesnici otpočinju (izuzev one posvećene pitanju vredi li umreti za otadžbinu) prisutna čežnja za ženom: jedan se pita da li ga žena vara, drugi pokazuje

\footnotetext{
24 Miroslav KrležA, „Dragiša Vasić“, Književna republika, 1/1923., br. 1, 97.

25 Milo Lompar, Moderna vremena u prozi Dragiše Vasića, Beograd 1996., 13.

26 Dragiša VAsıć, „Rekonvalescenti“, Sabrane pripovetke (prir. Gojko Tešić), Beograd 1990., 84.
} 
ženinu sliku i seća se bračnog života, treći tvrdi kako bi pristao da ga raznesu granate samo da može da provede noć sa ženom: „Pristao bih da me raznese granata najvećeg kalibra, samo da (...) je vidim kako mi prilazi... "27 Ipak, najupečatljivija je ispovest rekonvalescenta „smrtno zaljubljenog“ u Grkinju, suprugu „slavnog jednog zubnog lekara“ sa Krfa, koji priznaje:

Dok sam bio na tom divnom ostrvu, povadio mi je sve zube donje vilice; sad sam tražio bolovanje da tamo ostavim i sve zube svoje gornje vilice (hvala Bogu što čovek ima dve vilice!), a ja sam advokat, i moji zubi to su moji kapitali. Eto tolika je moja ljubav za Grkinje. Nagradu ne tražim. ${ }^{28}$

Čak se i imagološka sekvenca o Nemcima, Grcima i Francuzima završava rečima: „a rat, u krajnjem zaključku, to je seoba žena, to je razmena žena“. ${ }^{29}$

Dok je kod Krleže sve izobličeno, na ivici ponora i u preovlađujućoj vlasti tanatosa, kod Vasića se kao protivteža bezumlju javlja eros, onaj vitalistički princip čiji su nosioci žene. U bolesničkom prostoru njegove pripovetke trudna bolničarka figurira kao čisto otelovljenje erosa, kao simbol produžetka života, odnosno nosilac novog života:

Mala vižljasta, anđeoska miss Pound, sa zlatnim kovrdžicama na vratu i zaobljenim svojim trbuhom u kome nov život jedan sprema se. (...) nov život koji će doći ispuniće njen sav od slatkih uspomena na neobičnu ljubav u ovom crnom paviljonu, u kome je ona bila srećna kad su svi drugi patili, gde je ona raj svoj pronašla u ponoru najstrašnijeg pakla. ${ }^{30}$

Uprkos lišenosti smisla, u Vasićevoj pripoveci izostaje neobuzdanost mračnih sila koje vitlaju čovekom. Štaviše, rekonvalescenti opštem beznađu prkose šalom. Humor se pojavljuje kao vrsta odbrambene strategije koja poseduje oslobađajući efekat, pa kao lajtmotiv pripovetke iskrsava pitanje jednog potpukovnika: ima li žaba rep, odnosno zašto žaba nema rep, uz prateću sugestiju da treba misliti o onim stvarima. Nasuprot takvome humoru, junaci Barake 5 be zabavljaju se prognoziranjem smrti, tačnije - klade se na tuđe glave i zajedno nagađaju ko je sledeći kandidat smrti. Sakati, odnosno pripadnici grupe amputiranih, koji su ostali bez ruku ili nogu, trujumfuju jer su ipak živi: „Nemam ruke! Da! I kost mi je polomljena! Da! Ali živim! Gospode Bože! Još uvijek živim!“31

I dok među pacijentima špitala neosetljivost na tuđe stradanje ne samo što prestaje da uznemirava, već postaje izvor razonode, Vasićeva priča završava se tugom i plakanjem izvesnog kapetana koji je dobio vest da mu je žena umrla. Mada saznanje o ženinoj smrti u prvi mah prati razdragani osmeh zbog činjenice da se život, uprkos svemu, nastavlja („Samo kad sam živ, sve ću drugo lako“32), prvobitna misao preobraća se u želju da se rat nastavi jer povratak u svakodnevni život donosi, zapravo, suočavanje sa sopstvenom smrću: „Umrla mi je žena. (...) Jedna je žena umrla. Ah, ali ta žena što je umrla, to je moja žena, jedan ogroman deo mene je u njoj, to sam donekle ja umro. “33 Smrt voljenog bića na izve-

\footnotetext{
Isto, 94.

28 Isto, 112.

29 Isto, 112.

30 Isto, 113.

31 M. KrležA, „Baraka 5 be“, 233.

32 D. VAsIĆ, „Rekonvalescenti“, 115.

33 Isto, 116.
} 
stan način predstavlja delimičnu smrt nas samih - „Ti voljeni su, s jedne strane, unutrašnji posed, sastojci našeg sopstvenog ega. ${ }^{\text {“34 }}$

Istakli bismo da je ovo jedina smrt u Rekonvalescentima. Tačnije, reč je o reakciji na primljen telegram, nije u pitanju smrt koja se dogodila u bolničkom ambijentu. Nasuprot tome, malteški špital pravi je mali dance macabre, „perverzna lađa krcata ljudskim mesom“, u kojoj se istovremeno umire i slavi radost postojanja, mesto na kome pesma i muzika zaglušuju zapomaganja umirućih. Kod Krleže je upečatljiva, bolje reći zapanjujuća, neosetljivost na tuđa stradanja. Smrt je postala do te mere uobičajena da prestaje da uznemirava, na nju se više niko ne obazire:

Vani u sjenici (...) zvonile su čaše, a tu je broj devet u agoniji istrgao kanilu i potekla je krv. (...) Vidović je htio da viče, ali nije mogao do glasa. (...)

- Svijeću bi trebalo zapaliti! Za pokoj duše bi mu bilo! - Samo to je ponavljao neprestano, a oči su mu se prikovale o lokvu crvene krvi broja devet. I iza sve snage je hteo da zaurla, ali to je u njemu pištalo kao u rešetu. ${ }^{35}$

Svakodnevna umiranja u barakama na zaleđini fronta u potpunoj su opoziciji sa umiranjem kakvo je zamišljao šef špitala, grof Maksimilijan Akselrode:

Grof Maksimilijan Axelrode imao je za cijeloga svoga života samo jednu ideju da za svoju visoku maltešku devizu - Pro fide - povuče goli mač, da se zaogrne svojom crnom pelerinom što pada u teškim naborima, i da sune u smrt, vedra i smiona čela. ${ }^{36}$

Ipak, nesreća je učinila da je „pao ovamo na globus u kukavno i glupo doba“ i da se pod njegovom nadležnošću nađe „hiljadu i pol pacijentskih lubanja“, „lica natečena i krvava“ što su kao „crne sjene što trče tamo-amo u magli“, ne srljajući u „dostojanstvenu“ smrt za veru, već umirući u mukama. On je sanjao „idealnu smrt“, a zatekla ga je surova ratna stvarnost. Protivteža iluzijama o tome kako bi bilo „lepo“ umreti kosi se sa stvarnim umiranjima. Evo kako to izgleda iz ugla već „otpisanog“ studenta Vidovića, na koga su se kladili da neće doživeti jutro:

Čemu sam se ja zapravo rodio, i koju je svrhu to imalo? (...) Kako je sramotna moja smrt! Kako je duboko sramotna! Ja sam htio da doživim i da poživim! A šta se dogodilo? Śpitali i sami špitali! (...) Ovakve prljave, smrdljive, ušljive drvene barake! Ah, kako je sve to žalosno i gadno! ${ }^{37}$

Što je smrt bliža, snažniji postaju glasovi koji na raznim jezicima dozivaju Svevišnjeg. Svako ima nekog svog boga, „poslednju instancu“ koju priziva u pomoć. U graničnim situacijama iskrsava potreba za duhovnim, odnosno utešiteljskim konceptom koji će zanemariti činjenicu o telesnoj ništavnosti. Kod Krleže je prenaglašeno ludilo iščašene stvarnosti i stanovnici špitala utehu traže od „više sile“.

\footnotetext{
4 S. Frojd, „Aktuelna razmatranja o ratu i smrti“, Antropološki ogledi, 143.

5 M. KrležA, „Baraka 5 be“, 246.

36 Isto, 229.

37 Isto, 242.
} 
Bolnički prostor u Vasićevoj pripoveci obeležen je izrazitom nervozom, mada njegovi privremeni žitelji nisu izobličene i pomahnitale maske, već neurotičari koji boluju od najtipičnijeg signala „decentriranog subjekta, koji u ratu (...) sa bliskim iskustvom smrti, postaje svestan pukotina u sebi““.38 Uz sklerotičnog pukovnika, koji zavodi red među pacijentima, posebno je izdvojena grupica mladih oficira neurastenika, koji su

(...) povučeni, mirni i disciplinovani. Kad neko priča, oni se naginju, prave grčevite pokrete glavom kao da im je nešto tesno oko vrata, miču ramenima, mršte se, trepću, gledaju u nos ili ramena, ali ćute i slušaju. ${ }^{39}$

Vasićevi rekonvalescenti izvesnost smrti ne odagnavaju prepuštanjem destruktivnim porivima, već spasonosno rešenje pronalaze u pričanju, ili čak čitanju. Prema Andrićevim rečima, pričanje priča najstarija je i najdelotvornija metoda „zavaravanja krvnika“. Iako su te priče najvećim delom posvećene ženama, u njima ima mesta i za diskusiju na temu otadžbine, ratovanja i smisla umiranja za tuđe ideale:

Ja hoću da objasnim i ispitam onaj predački ostatak, ono osećanje što sam nasledio, ono mistično što u meni večno tinja, a protiv čega se racionalno večno buni. Ja hoću da znam: je l' me ta otadžbina istinski volela, je l' prema meni ispunila sve obaveze majke, pa da za nju padnem i žrtvujem se kao njeno dete? ${ }^{24}$

Ideološki prosede prisutan je i kod Krleže, ali ne u vidu rasprave. Apsurdnosti i izopačenosti do kojih dovode ideologije predočene su opisom sablasne povorke koja mimohodom i bakljadom treba da obeleži pobedu austrougarske vojske i pokloni se carskoj zastavi. „Da bi uspostavio autoritet carske zastave i discipline “, ${ }^{41}$ grof Akselrode naredio je da svi, bez izuzetaka, moraju tome prisustvovati, a sam je stajao na čelu kolone, predvodeći „sakate, šepave, iznakažene, povezane, amputirane, na štakama, kolicima, nosiljkama“. ${ }^{42}$

Besmisao rata i umiranja iz patriotskih pobuda, zarad otadžbine ili „u ime Božije“, možda najbolje sumiraju sledeće reči:

Iz antičke istorije naučilo se da mase treba zastrašivati Bogom da bi one bile pokorne. (...) Mi svi ratujemo u ime njegovo jedni protivu drugih. (...) Ali ja moram da kažem kako mi je onaj što ga ja nazivam dušmaninom (...) koji pati kao i ja i koga sam poslan da ubijem, miliji, bliži i draži uvek bio od (...) vajnoga brata moga, što je zdraviji od mene, a bogati se i blaguje (...) dok ja ispaštam. ${ }^{43}$

Vasićev junak, koji izgovara navedene reči, naglašava kako je patriotizam imao smisla jedino u staroj Grčkoj, gde je gubitak otadžbine značio ujedno i gubitak boga, što je podrazumevalo i nestajanje razloga da se živi. Patriotizam je postao prazno osećanje, otadžbina prazna reč, a svaka je „ideja o nacionalnom načelu prouzrokovala novu podvojenost među

\footnotetext{
M. Pantić, Modernističko pripovedanje, 217-218.

D. VAsić, „Rekonvalescenti“, 91.

40 Isto, 98.

41 M. KRLEŽA, „Baraka 5 be“, 241.

42 Isto.

43 D. Vasić, „Rekonvalescenti“, 102-103.
} 
ljudima i nove krvave raspre, koje bi svako drugo stanje stvari teško moglo izazvati“, ${ }^{44}$ što je stvaralo ponovne sukobe i povode za ratovanje.

Izneseni stav je zapravo „simptom opšte zgađenosti nad ratom u posleratnoj evropskoj literaturi““ ${ }^{45}$ Međutim, Frojdovo razmišljanje o pomenutoj temi podsetiće nas na „narcizam malih razlika" kao specifičan agens koji će u svim vremenima biti pretnja i izvor potencijalnih sukoba, odnosno ratova. Taj narcizam pohranjivaće agresivne porive i davaće uvek povoda da se negativni naboji usmere prema onome za koga smatramo da je po nekom svojstvu različit od nas. $S$ tim u vezi je i Frojdov zaključak da je rat biološki determinisan, ali i da su ratovi i suočavanje sa smrću sastavni deo egzistencije, to jest, nemoguće je ukinuti ih. Iz toga razloga, na završetku teksta o smrti, pisanog 1915. godine, predložiće da se latinska poslovica „Ako želiš sačuvati mir, budi spreman za rat“ preinači u: „Ako hoćeš da podneseš život, budi spreman da prihvatiš smrt“. ${ }^{46}$

Na samom kraju istakli bismo još jedan detalj. Osim mogućnosti za uspostavljanje književnih paralela, mogli bismo ukazati i na još jednu, neknjiževnu činjenicu. Stvaralaštvo Dragiše Vasića i Miroslava Krleže često je mereno ideološkim parametrima, što je dovelo do toga da ideološko-politički diskurs postaje neizostavan u tumačenju njihovog stvaralaštva. Iako nisu usamljeni slučajevi oni kojima je ideološka (ne)podobnost odredila, bar donekle, literarnu sudbinu i status u okvirima nacionalnih književnosti, ovu pojedinost naglašavamo kao još jednu podudarnost. Doduše, postoji i velika razlika. Krležino književno delo bilo je „igrom povijesnih vihora zabranjeno i prognano u tišine privatnih biblioteka“ ${ }^{47} \mathrm{i}$ taj progon trajao je od početka Drugog svetskog rata sve do Kongresa književnika održanog u Zagrebu 1949. Nasilno odstranjivanje umetnika kao pretnje političkom sistemu bila je neretka praksa. Međutim, eliminisanje Dragiše Vasića trajalo je neuporedivo duže. Mada se tridesetih godina Vasić zaista povukao iz književnih tokova, što je praćeno i radikalnom promenom dotadašnjih ideoloških polazišta, jedan intervju iz 1934. godine navodi nas na zaključak da je, ipak, imao i - čini nam se - želeo još toga da kaže. Da bi bilo jasnije, citiraćemo odgovor na pitanje da li će, nakon svega, nastaviti da se bavi pisanjem:

$\mathrm{Ne}$, sad je teško vratiti se na to. Tu je (...) i cela tragedija mog života. Prvo sam želeo da uđem u arenu političkog života. Sprečili su me. Posle sam morao da otvorim advokatsku kancelariju, mesto da se bavim književnošću. Morao sam se potpuno predati ovome poslu. Iz kancelarije ne mogu nikud. Prođe i po godinu dana a da mi ne dođe dan kad bih mogao pisati. U ovoj advokatskoj kancelariji prošlo je preda mnom do 2000 romana i priča. Utisci ostaju, ali na papir ne dolazi ništa. ${ }^{48}$

\footnotetext{
44 Isto, 101.

45 M. Lompar, Moderna vremena u prozi Dragiše Vasića, 143.

46 S. Frojd, Mi i smrt, 56.

47 Miroslav Vaupotić, Siva boja smrti, Zagreb 1974., 7.

48 Dragiša VAsıć, Dva meseca u jugoslovenskom Sibiru. Utisci iz Rusije / Putopisi / Eseji / Kritike / Članci (prir. Gojko Tešić), Beograd 1990., 353.
} 
Krleža je, međutim, nakon prinudne skrajnutosti nastavio nesmetano da radi, i njegove „priče“ nisu ostale neispričane. Štaviše, do smrti je bio vrlo cenjena i moćna figura u kulturoj javnosti Hrvatske. Za razliku od Krležinog prećutkivanja, koje je trajalo nekoliko godina, Vasićevo se proteže na nekoliko decenija - tek 1990. „došla su nam, trudom Gojka Tešića, Izabrana dela Dragiše Vasića“. ${ }^{49}$ Ipak, uprkos svemu, Krležina prognoza na kraju se obistinila: još 1923. godine, u Književnoj republici, najavljujući Vasića kao budućeg saradnika časopisa, Krleža izjavljuje da je ovaj nedovoljno poznati pisac

(...) zarezao crte svoga književnoga profila sigurno i markantno; te crte stajat će jasno kada svima šarlatanima i snobovima i piskaralima, što drljaju danas po poslednjoj fasoni sedmorazrednih listova već davno neće biti ni traga ni glasa. ${ }^{50}$

Od nekada vrlo bliskog prijatelja Vasić će, za Krležu, usled sticaja političkih okolnosti, postati „čovek na tragičnoj stranputici“. Njegova ideološka zastranjivanja dovešće do trajnog prekida svake, čak i poslovne, komunikacije dva književnika. Dragiša Vasić izgubiće život na stratištu, kao pripadnik ravnogorskog pokreta, i njegova smrt ostaće pod velom tajni, postajući predmet različitih mistifikacija jer ne postoje podaci gde, kada i kako je skončao.

Dakle, priča o smrti ne podrazumeva isključivo odnos prema fizičkom nestajanju. $\mathrm{Na}$ simboličkoj ravni možemo govoriti o različitim vidovima smrti. S tim u vezi, relacija Vasić - Krleža dopušta mogućnost bavljenja i fenomenom smrti jednog prijateljstva, ali i nekada zajedničkih ideoloških stremljenja, otvarajući time mogućnost za pokretanje i drugih mogućih pitanja o odnosu pomenutih autora.

\section{$\cos$}

\section{Literatura}

Ivo Andrić, „Naša književnost i rat“, Istorija i legenda. Eseji I (prir. Radovan Vučković), Beograd - Zagreb - Sarajevo - Ljubljana - Skoplje 1976., 169-174.

Žan Bodrijar, Simbolička razmena i smrt, Gornji Milanovac 1991.

Milan Bogdanović, „Dragiša Vasić Crvene magle“, Crvene magle (prir. Gojko Tešić), Beograd 1990., 217-224.

Milan Bogdanović, „Rat i literatura“, Politika (Beograd), br. 4164, 6. 1. 1919., 2.

Miloš Crnjanski, „Objašnjenje 'Sumatre'“, Itaka i komentari, Beograd 1959., 175-182.

Dunja Dušanić, Fikcija kao svedočanstvo. Iskustvo Prvog svetskog rata u prozi srpskih modernista, Beograd 2017.

Sigmund Frojd, Antropološki ogledi. Kultura, religija, umetnost (prir. Žarko Trebješanin), Beograd 2011.

Sigmund Frojd, Mi i smrt. Naš stav prema smrti: dosad neobjavljeni rukopisi i predavanja (prir. Žarko Martinović i Milica Martinović), Beograd 2001.

49 M. Pantić, Modernističko pripovedanje, 210.

50 M. KrležA, „Dragiša Vasić“, 97. 
Slobodan Jovanović, „Dragiša Vasić. Predgovor Utuljenim kandilima“, Crvene magle (prir. Gojko Tešić), Beograd 1990., 127-135.

Miroslav KrLEŽA, „Baraka 5 be“, Hrvatski bog Mars, Zagreb 2001., 227-247.

Miroslav KrležA, „Dragiša Vasić“, Književna republika, 1/1923., br. 1, 97.

Miroslav KrležA, „Moja ratna lirika“, Europa danas. Knjiga dojmova i essaya, Zagreb 1935., 33-43.

Stanko LAsıć, Krleža, kronologija života i rada, Zagreb 1982.

Milo Lompar, Moderna vremena u prozi Dragiše Vasića, Beograd 1996.

Marko Nedić, „Književno delo Dragiše Vasića u okvirima novije srpske književnosti“, Dragiša Vasić (prir. Marko Nedić), Novi Sad 2012., 7-25.

Mihajlo PAntić, Modernističko pripovedanje - srpska i hrvatska pripovetka / novela 1918-1930, Beograd 1999.

Gojko TEšić, Srpska književna avangarda. Književnoistorijski kontekst (1902-1934), Beograd 2009.

Dragiša VAsıĆ, Dva meseca u jugoslovenskom Sibiru. Utisci iz Rusije. Putopisi / Eseji / Članci (prir. Gojko Tešić), Beograd 1990.

Dragiša VAsıć, „Rekonvalescenti“, Sabrane pripovetke (prir. Gojko Tešić), Beograd 1990., 84-121. Miroslav VAupotić, Siva boja smrti, Zagreb 1974.

Radovan VučKović, Srpska avangardna proza, Beograd 2002.

\section{$\cos$}

\section{WAITING FOR DEATH, OR THE INTERTWINING OF LIFE AND DEATH IN DRAGIŠA VASIĆ'S REKONVALESCENTI AND Miroslav KrležA's BARAKA 5 BE}

The paper provides a comparative analysis of the similarities and differences between Miroslav Krleža's Baraka 5 be (Barracks 5b) and Dragiša Vasić's Rekonvalescenti (The Reconvalescents) on the ideological and theme-motif levels. War as a literary theme is given particular attention, particularly, the wartime context as a common denominator between these two pieces of prose. Freud's theses on war and death are a second point of reference, above all the opinion that war changes the attitudes towards death and relativises the perspectives on the meaning of life, religion, social and other values. At the center of the analysis are the preoccupations of the protagonists who are waiting for death. Additionally, insights are provided into the relationship between Miroslav Krleža and Dragiša Vasić, allowing us to address the phenomenon of their friendship, as well as their often shared ideological strivings, while opening the possibility of raising more potential questions concerning those two authors.

Key words: war, death, hospital, Dragiša Vasić, Miroslav Krleža 


\section{$\check{S} A \check{S} A V A$ BESMRTNOST I GARAVA SMRT: PREDSTAVA LJUDSKE SMRTI U POEZIJI ZA DECU I MLADE MIROSLAVA ANTIĆA}

\section{Vladimir Vukomanović Rastegorac}

UDK: 821.163.41-1Antić, M.:393

Izvorni znanstveni članak

Sažetak: Odrasli s decom nerado razgovaraju o smrti, najčešće to opravdavajući složenošću ovog fenomena i pojavama koje ga prate. Psihološke studije pak pokazuju da deca o smrti počinju da razmišljaju već u predškolskom periodu, i ukazuju na negativne posledice izbegavanja razgovora o ovoj temi. U pokušaju da s decom otvorimo mogućnost dijaloga o umiranju kroz tumačenje poezije, istražićemo kako se fenomen smrti oblikuje u poeziji za decu i mlade Miroslava Antića. Akcenat će biti na predstavama ljudske smrti u Śaśavoj knjizi i Garavom sokaku, a posebno će biti posmatrani sledeći aspekti: 1) pozicija i identitet lirskog subjekta, 2) osećajnost koja prati govor o smrti, 3) predstave grobljanskog prostora, 4) predstave umrlog tela i postmortalnog trajanja, 5) osmišljenje smrti, 6) jezičko-stilski aspekt oblikovanja govora o smrti.

Ključne reči: poezija za decu i mlade, obrazovanje o smrti, Šašava knjiga, Garavi sokak, Miroslav Antić

Dri kraju jednog razgovora koji s njim vodi Draško Ređep, Miroslav Antić govori o svojim iskustvima kliničke smrti. Kritičar pak pokušava da promeni temu: „Nećemo više o tome. Radije o Korčuli i o cveću da razgovaramo... "1 Ta opaska, u kojoj ima i nešto ironije na svoj račun, zasigurno je delimično uslovljena delikatnošću trenutka, i Ređepove se reči mogu razumeti kao prećutni signal prijateljstva koje pokušava da nepominjanjem smrti samu smrt od pesnika udalji. Antić, međutim, naglašava kako želi da o smrti razgovara: „Samo me tema smrti privlači“, kaže on. ${ }^{2}$

Ova situacija podseća donekle na onu koju opisuje Margaret Mahon govoreći o bolnim iskustvima roditelja čije dete umire. Njima se razgovor o smrti ne započinje delimice i otud što ne žele da decu opterećuju teškim mislima; s druge strane, kod same dece prisutna je

\begin{tabular}{l}
\hline Draško ReĐep, Ulepšavanje nevidljivog. Hagiografija o Miroslavu Antiću, Sarajevo 1988., 88. \\
2 Isto, 78.
\end{tabular} 
razumljiva želja da pričaju o onome što ih čeka. ${ }^{3} \mathrm{U}$ širem kontekstu, prećutkivanje teme smrti u komunikaciji roditelja i dece danas nije prisutno samo u ovakvim, graničnim situacijama. Psihološka istraživanja pokazala su da odrasli nerado s decom pokreću razgovor o temi smrti, a čini se kako su razlozi za to univerzalni: kompleksnost ovog fenomena i pojave koje ga prate (npr. tuga ili strah kao emotivna reakcija bliskih). ${ }^{4}$ Nasuprot tome, veliki broj radova posvedočava da deca počinju da razmišljaju o smrti već u predškolskom dobu i periodu ranog školovanja, te da je nesumnjivo da dvanaestogodišnje dete, u svim kulturama, pa i u evropskim, poseduje veoma složen koncept smrti. ${ }^{5}$

Ima pesnika za decu koji, za razliku od roditelja, ne beže od tematizacije ljudske smrti. Te njihove pesme, međutim, često ostaju van horizonta izbora iz dečjeg pesništva i kritičkih tekstova koji se poezijom za decu bave. Donekle je tako is onim pesmama koje pripadaju Miroslavu Antiću, jednom od najznačajnijih srpskih pesnika za decu i mlade 20. veka.

Iako ni njegova najpoznatija zbirka nije imala lak put do čitalačke publike, ${ }^{6}$ istoričari dečje književnosti se po pravilu slažu sa sudom Milana Crnkovića da je Antić „prije svega autor Plavog čuperka, pjesnik koji na čudesno jednostavan, iskren i fin način pjeva o ljubavi“.7 Pomenuta zbirka, koja je za 25 godina imala čak 57 zasebnih izdanja, ${ }^{8}$ donela je Antiću najviše pohvala. To se, međutim, ne može reći za pesničke poduhvate koji su došli kasnije. Oni, primera radi, u Srpskoj književnosti za decu Dragoljuba Jeknića nose epitet „pravljenih knjiga“ u kojima nema „one ranije usaglašenosti romantičarske vizije i tematsko-motivskih preokupacija.? Premda će Šašava knjiga (1972) biti ovenčana uglednom nagradom Neven, ${ }^{10}$ Milan Pražić će joj zameriti da „ne postiže pravu neposrednost i čistotu doživljaja“, i ukazati na to da u njoj ima ,jedva primetnog zamora u poetskim filozofemama, sentencioznosti i refleksivnosti“." Garavi sokak (1973), opet, temeljnija tumačenja, na nivou onih koja se tiču Plavog čuperka, dobija tek dosta kasnije, u tekstovima poput onih koje pišu Raša Popov i, sasvim nedavno, Bojan Marković. ${ }^{12}$

3 Margaret M. Mahon, „Death in the Lives of Children“, Children's Understanding of Death. From Biological to Religious Conceptions (ur. Victoria Talwar, Paul L. Harris i Michael Schleifer), Cambridge 2011., 69.

4 Videti: Rita AstuTi, „Death, Ancestors, and the Living Dead: Learning without Teaching in Madagascar“, Children's Understanding of Death, 3-4.

5 Benjamin Beit-Hallahmi, „Ambivalent Teaching and Painful Learning: Mastering the Facts of Life (?)“, Children's Understanding of Death, 45. Videti i: Mark W. SPEeCE - Sandor B. BRENT, „Children's Understanding of Death: A Review of Three Components of a Death Concept", Child Development, 55/1984., br. 5, 1671-1686; Alice LaZar - Judith Torney-Purta, „The Development of the Subconcepts of Death in Young Children: A Short-Term Longitudinal Study", Child Development, 62/1991., br. 6, 1321-1333.

6 Videti: Радован Поповић, Антић, ним самим, БеограА 2009., 49.

7 Milan Crnković, Dječja književnost. Priručnik za studente pedagoških akademija i nastavnike, Zagreb 1967., 110.

8 Зорана ОПАчић, „Песма која је покушала Аа оАрасте (оА првог до последњег издања Плавог чуперка Мирослава Антића“, Наивна свест и фикиија, Нови СаА 2011., 27.

9 Араговуб Јекнић, Српска књижевност за деиу II. Историјски преглед, БеограА 1998., 293.

10 Р. Поповић, Антић, вим самим, 85.

11 Milan Pražić, Reči i vreme, Novi Sad 2002., 144.

12 Pesnik Raša Popov pozitivno vrednuje hrabrost Garavog sokaka: „Tu je on zatražio ne samo od pojedinačnih čitalaca, nego od društva, od vaspitača, od škola, toleranciju prema istinitoj a ne falš zamišljenoj duši dece." Раша Попов, „Антићев синдром близанаца у спеву Гарави сокак“, u: Мирослав Антик, Гарави сокак. Весело циганско вашариите са неколико суза и капи кише, Нови СаА 1997., 116. Da je nije dokraja i dobio, pokazuje Markovićev uvid da pesme Garavog sokaka „nisu prisutne u školskim programima, za razliku od drugih ostvarenja istog pesnika koja se pojavljuju kontinuirano tokom osnovnoškolskog obrazovanja.“ Бојан МАрковић, „Интеркултуралност у настави књижевности на примеру књиге песама Гарави сокак Мирослава Антића - методичка разматрања“, Годишњак Катедре за српску књижевност, 10/2014., 306. 
Jedna od bitnih razlika između Čuperka, s jedne, i Šašave knjige i Garavog sokaka, s druge strane, jeste to što tematizacija smrti u potonjima zauzima značajno mesto. Prva donosi neposredniji govor o tamnoj strani detinjstva, a na svom kraju - dakle, na markiranom mestu unutar kompozicije zbirke - Besmrtnu pesmu. Druga ne samo da u pojedinim pesmama dotiče temu smrti, već se i rađa iz grobnice Jevreja, Roma i Srba, u kojoj leži i Mile Dileja, Antićev drug i jedan od protagonista Sokaka:

Mileta su jednog dana odveli sa grupom Cigana i streljali. A ja sam ostao živ. (...) I odem ponekad u kafanu da se družim s Ciganima.

Plačem i teram ih da mi sviraju Miletove pesme. Oni kažu da to ne postoji. Da reči tako ne idu. A ja znam da idu baš tako, pa još nešto i sam izmišljam, na srpskom i ciganskom, i sad već polako neke dobre bande (...) pevaju te pesme. ${ }^{13}$

U želji da se uvaže pomenuta psihološka istraživanja, koja ukazuju i na negativne posledice izbegavanja razgovora o smrti s decom (osećanje krivice zbog smrti drugog, autodestruktivni postupci i sl.), ${ }^{14}$ te da se, kroz tumačenje poezije, otvori mogućnost razgovora o umiranju $s$ učenicima, istražićemo kako se fenomen smrti oblikuje u poeziji za decu i mlade na primerima iz pesništva Miroslava Antića; celine ovog rada, koje slede, zapravo su moguća čvorišta takvog potencijalnog razgovora. ${ }^{15}$

\section{I.}

Pozicija i identitet lirskog ja Besmrtne pesme naizgled su neodređeni. Ono nije imenovano, a nema ni traga o njegovoj nacionalnoj pripadnosti ili sl. Ipak, neodređenost nije potpuna: pesma je oblikovana kao intimna ispovest nekoga ko je „za samo pola veka obišao stoleća "16 $\mathrm{i}$ ko je povlašćeni nosilac nekonvencionalne istine o besmrtnosti. Tu istinu izlaže delimično konkretizovanom $t i$ - ono je na prelazu između detinjstva i mladosti, na ulazu u prostor gde ga čeka „lepa, / al' lukava duga“ ${ }^{17}$ Ovo lirsko ja ima „savetodavnu misiju“, koja se vrši kroz neprestani dijalog, u kojem ono ima iskustvo što nedostaje lirskom $t i$, ali mu je u svemu ostalom blisko.

U Garavom sokaku drukčija pozicija lirskog ja konstruisana je na različitim nivoima: odstupanja od normiranog jezika, antroponimi, realije koje dočaravaju posebnost romske egzistencije. Pred nama su dečji lirski subjekti „tipski u smislu da su jasno kulturološki, mentalitetski i rasno određeni, ali i personalizovani s malo reči posredstvom datog imena i njihove aktivnosti“ ${ }^{18}$ Nadređene instance, koja je nosilac istine, poput one u Besmrtnoj

13 Miroslav Antić, Garavi sokak. Kobajagi ciganske pesme za decu, Inđija 1973., 7-8.

14 B. Beit-Hallahmi, „Ambivalent Teaching and Painful Learning“, 49-50.

15 Prilikom analize u obzir su uzeta prva izdanja pomenutih knjiga, kao i verzije pesama iz relevantnog posthumnog izdanja Antićevih sabranih dela. Takođe, budući da su pojedine pesme od interesa za ovu temu prvi put objavljene u drugom izdanju Garavog sokaka, uzeli smo u razmatranje i verzije iz ovoga izdanja.

16 Мирослав Антић, Шашава къига, Београд 1972., 61.

17 Isto, 60.

18 Б. МАрковић, „Интеркултуралност у настави књижевности“, 306. 
pesmi, ovde nema. Glasovi Sokaka pružaju pogled (samo) s ove strane smrti; oni promišljaju smrt, oblikuju predstavu o njoj, i o zagrobnom prostoru, iz perspektive koja je ljudski ograničena i lišena iskustva smrti / besmrtnosti, pa ni ne mogu da garantuju znanje o smrti poput lirskog ja Besmrtne pesme. Eventualno se saznajno povlašćenom figurom može smatrati lirsko ja gatara / vračara u pesmama koje se nisu pojavile u prvom izdanju zbirke. Ove figure progovaraju o smrti kroz konstatacije u kojima naizgled nema nagađanja, već se njima ispostavlja istina o onome što čoveka čeka. ${ }^{19}$

\section{2.}

Dinamika Besmrtne pesme ostvaruje se u susretu emocionalnosti $t i$ i smrti njemu bliskog i dragog lirskog ja. Naum lirskog subjekta je da u prostoru između početka i kraja pesme podstakne emotivni preokret slušaoca. Naime, na početku vest o smrti dobija jednosmislen odgovor: „(...) onda će i u tebi / odjednom nešto posiveti. / Na trepavicama magla. Na usni pepeljast trag. ${ }^{\text {20 }}$ Taj se odgovor, kao što je vidljivo, pokazuje u posivljenju, koje je neposredno vezano za maglu, kao fluidnost i rastakanje, te za trag koji nalikuje pepelu, što je stara metonimija trošnosti tela. Nisu, pritom, slučajno odabrana mesta pogleda i govora / poljupca: pogled je maglom zaprečen da kaže kako se otišlo u nepoznato, dok je pepeljast trag na mestu usana i znak da se živi uz ljubljenje smrtnog, i da se o tome teško išta može reći. Tačka u kojoj se otvara prostor za sugestiju lirskog ja, koje teži da takav odnos prema smrti preobrazi, može se naći već u prvim stihovima. Govor o smrti uveden je uslovnom rečenicom (ako ti jave), koja faktičnost približava mogućnosti; potom će se podrazumevajući oni, koji javljaju smrt lirskog ja, ispostaviti kao nepouzdan izvor. Epitet pouzdanog (sa)govornika zadržava tek sámo lirsko ja, koje pravo na ekskluzivitet polaže otuda što ne može (ne ume) da umre: „Ako ti jave: umro sam, / - ne veruj, / ja to ne umem.“21 Uvođenje besmrtnosti kao činjenice tražiće onda, logično, drukčiji odgovor na glasine o smrti, a taj odgovor je neverbalni znak što potvrđuje savezništvo u tajni vere u besmrtnost: „Na ovu zemlju sam svratio / da ti namignem malo / (...) I zato ne budi tužan (...) Noću, kad gledaš u nebo, / i ti namigni meni.“22

Emocije lirskih junaka Garavog sokaka manje su eterične i više intenzivne, ponekad ambivalentne. Dva primera. U pesmi Gaga diskontinuitet življenja, koji je prouzrokovan očevom smrću, donosi lirskom junaku neiskaziv bol. Taj bol dečak pokušava da prevlada različitim postupcima: bežanjem od kuće, njegovim potiskivanjem itd. Ipak, svi ovi pokušaji ostaju bezuspešni, i sve kulminira u neartikulisanom bolu, kojim Antić poentira pesmu: „To sam ti ja, majko, / kad odem na grob mog tate / i vrištim! ${ }^{23}$ Pesma Radoslav pak, u

19 Npr. „Kad umreš, i metnu te u zemlju, / i oči ti popiju mravi... ovako... / i dušu ti pozoblju bube... ovako... / samo tvoja kosa ostaće da živi, / jer kosa je nešto drugo nego ti: / kosa ti je čovek u čoveku, / neki sveti vetar u с̌оveku“. Мирослав Антик, Гарави сокак. Весело циганско вашариште са неколико суза и капи кище, Загреб 1978., 36.

20 М. Антик, Шамава жњига, 60.

21 Isto, 62.

22 Isto.

23 M. Antić, Garavi sokak, 1973., 27. 
svim verzijama, počinje izricanjem osećanja straha („Bojim se neke glave“24). U prvoj verziji čini se da je posredi strah od sopstvene smrti, ili od smrti uopšte: Radoslava plaši zamišljanje sanduka ispod zemlje, i dečje groblje. U drugoj, ovaj strah se drukčije konkretizuje: „Na groblju mi leži brat. (...) Kad sam rođen, ja sam rođen / kao blizanac. / Pa je jedno od nas dvoje dece / odmah umrlo." 25 pojavom figure blizanca dolazi i ambivalentnost osećanja: u Radoslavu strah preteže, ali postoji i zametak empatije: „Sedne na kraj kreveta i drhti. / Ostavi me, brate, $i$ meni je zima. ${ }^{26}$ To sa-osećanje tiho kulminira u sebi postavljenom pitanju, koje kao da registruje krizu identiteta: „Ja sad ne znam da l sam ovo ja, / ili sam moj brat. / Možda ja to njemu dođem na krevet i drhtim od zime.“27

Ovome valja dodati kako unutar Garavog sokaka postoje pesme koje se dotiču teme smrti, ali u kojima emotivnost nije u prvom planu. To su pesme u kojima se ona promišlja unutar ludičkog (Igre mrtvih pod jorganom) ili magijskog okvira (Čitanje iz prstiju). Tu se eventualno može govoriti o ravnodušnosti koju lirski subjekti osećaju dok zamišljaju sebe kao mrtve, ili o atmosferi strave koja prati gatanje i magijske radnje unutar kojih se pominju smrt, leš i delovi leša.

\section{3 .}

Prostor groblja ni u Besmrtnoj pesmi ni u pesmama Garavog sokaka nije prostor dostojanstvenog mira pokojnika. Groblje je za lirsko ja Besmrtne pesme mesto na kome se o smrti ništa ne može saznati. Ono je viđeno kao mesto „najcrnjeg vašara“, „ružnog pozorišta“, u kojem „nema srca i vatre, smeha i suza, svađe i pesme“; groblje je prostor u kojem „vlada mlitavi red“, gde „nema aplauza“ $i$ „kraj se zna unapred“ ${ }^{28}$ Sve navedeno ne opisuje, zapravo, prostor groblja, već sahranu koja se u tome prostoru odvija, a koja je postala metafora scene za čulima dostupnu i lažnu istinu; ona je tim lažnija što postoji tačno utvrđeni sled replika i formalnosti, što je slika predvidivosti, lišena intenziteta življenja. ${ }^{29}$

Dok u prve dve verzije Radoslava nema detaljnijeg govora o grobljanskom prostoru, u trećoj verziji groblje po mnogo čemu takođe nalikuje na pozornicu, ali je "predstava“ na njoj bitno drukčija. Najpre se konstituiše podela na groblje starijih Roma i groblje romske dece. Prvo odražava ljutu sudbinu i mentalitet zajednice kojoj lirsko ja pripada: „Na grobljima gde su ljudi Romi / trava raste do ramena. Ljuta. // Niko nikad nikog da obiđe, / i mrtvi su tamo sujeverni, / pa jedan od drugog zaziru. “30 Groblje romske dece, pak, rađa se

\footnotetext{
Isto, 35.

М. Антит, Гарави сокак, 1978., 55.

Isto. Istakao V. V. R.

Isto.

28 М. Антић, Шашава књига, 61.

29 Sâm Antić gajio je prezir prema grobljanskoj patetici i „lakiranim biografijama“: „A najbolje bi bilo kad bi me bacili u more, bez ružnih razgovora, unjkavih govora, divana nad grobom. Samo da se ne bi pisala neka nova, lakirana biografija, prepuna lažnih stvari koje bih tada, iz groba, čuo prvi put, i koje su, mislim, meni sasvim nepoznate." D. REĐEP, Ulepšavanje nevidljivog, 21.

30 М. Антић, Гарави сокак, 1997., 64.
} 
u ukrštaju društvenog konteksta i emotivnog stanja lirskog ja, koje se plaši svoga umrlog brata blizanca: „A na groblju gde su deca Romi / puno cveća i veselo, / ko da su živi, kao da će / posle podne ustati i ići u šetnju / ili da će u nedelju, očešljani, / zajedno na vašar.“31 Idiličan prizor na dečjem groblju delimično se može čitati kao projekcija željenog života, kojeg u stvarnosti nema, ali činjenica da lirsko ja ni ne pomišlja da postane deo toga vašara ukazuje i na jedan „prepredeniji“ razlog da se zagrobni život vidi ovako: ukoliko je tamo među mrtvima sve ovako lepo, i loše ovde među živima, umrli blizanac nema razloga da uznemirava svoga živog brata moleći ga da „zamene mesta“.

\section{4 .}

Izlaganje o zagrobnom trajanju u Besmrtnoj pesmi temeljiće se na paradoksu istovremenog postojanja umrlog na dva prostora. Naime, lirsko ja će skriti zemlja i korov, dok ono za to vreme „leti visoko“. Iako bi se ovde moglo pomisliti da ovi stihovi baštine dualističku predstavu prema kojoj se, posle smrti, večna duša odvaja od rušnog tela, dalji tok pesme takvom tumačenju ne daje za pravo. Retoričkim pitanjima koja sugerišu nemogućnost da dođe do transformacije delova tela u neživu ili živu materiju (glinu, koren breze, travu), kao i da pojedine emocije ili intelektualni sadržaj koji je individualizovan (strah, tajna) nestanu u tišini, tami i prahu (odbija se, dakle, mogućnost reinkarnacije), slušalac se priprema za otkrivenje sopstvenog porekla i sopstvene suštine (sastava): „(...) ja sam odnekud sa zvezda. Sav sam od svetlosti stvoren. ${ }^{\text {“32 }}$ Događaju smrti se takođe oduzima status izuzetnog - povratak dalekom suncu okarakterisan je kao običan i, čini se, u velikoj meri voljan. Ljudsko postojanje tako se ukazuje, mistički, kao individualizovani zrak koji privremeno preuzima ljudsko obličje i potom se vraća svome izvorištu. Pritom, ja zadržava unutrašnju celovitost i ne biva smrću oštećeno: „Ništa se neće u meni / ugasiti ni skratiti. “33

U Garavom sokaku slike zagrobnog trajanja su raznolike. Ružin protest protiv roditelja i neželjenog mladoženje nastavlja da živi posle smrti: „Čekaj samo dok umrem, pa ćeš da me praviš od blata. / Da oživim. A ja: ništa. / Nikad više. // Sad vidiš da neću da ustanem. “34 I kad Ruža zamišlja da je umrla, u zamišljenom opstaje volja da se prkosi onima kojima se u ovom životu prkositi ne može; posredno opstaje, kroz dekor zamišljenog groba, i projekcija njenog karaktera: Ruža nagoveštava kako će je na grobu oplakivati luda tica, blesav vetar i šareno šašavo cveće. Među onima koji Ružu oplakuju nema ljudi - tu su samo elementi žive i nežive prirode, u kojima je više nego u ljudima ostalo empatije za njen usud. Pojava umrlog brata blizanca u Radoslavljevoj pesmi može se čitati kao odjek verovanja u smrt kao događaj posle koga dvojnik umrlog nastavlja da živi; istini za volju, sama pesma ne pruža dovoljno materijala da se takva hipoteza učvrsti u tumačenju. Želja da se veruje u drugi život - više nego vera - javlja se još u pesmi Džane. Molitva Džaneta bogu, „velikom gospodinu“, da

32 М. Антит, Шашава књига, 62. Istakao V. V. R.

33 Isto.
} 
u sledećem životu bude veliko drvo od koga, kad ga poseku, prave naćve, samo je otelotvorenje ogromne gladi: „Sto godina u meni testo da mese. / Od leba sav da se raspadnem. ${ }^{\text {"35 }}$ Marković dobro zapaža da nije slučajno izabrano drvo ,jer sugeriše dugovečnost i otpornost na spoljne uslove življenja, a zatim i korisnost u obličju predmeta“, te dodaje: „Oporost i rezignaciju čitamo u želji subjekta da ga drugi put bog ne stvori kao živo biće, već kao nepomičnu biljku i predmet. ${ }^{\text {"36 }}$ Tako u zagrobnom životu opstaje ono što je fundamentalna muka s ove strane romske smrti: glad. U kasnijim izdanjima Sokaka prisutne "Igre mrtvih pod jorganom" ponoviće Ružin model zagrobnog trajanja kroz reči jedne protagonistkinje: „Na kapiji grobljanskoj / stojim mrtva i prosim. “37 Džanetov model pak tu je u začudnoj kombinaciji s onim iz Besmrtne pesme - u slučaju malog Fera: mali Fero je istovremeno „u nekoj zvezdi gore na nebu", ali se ta zvezda slabo vidi „jer je zvezda crna / ko crni bomboni za kašalj“ i „sva bolesna / od sušice“. ${ }^{38}$

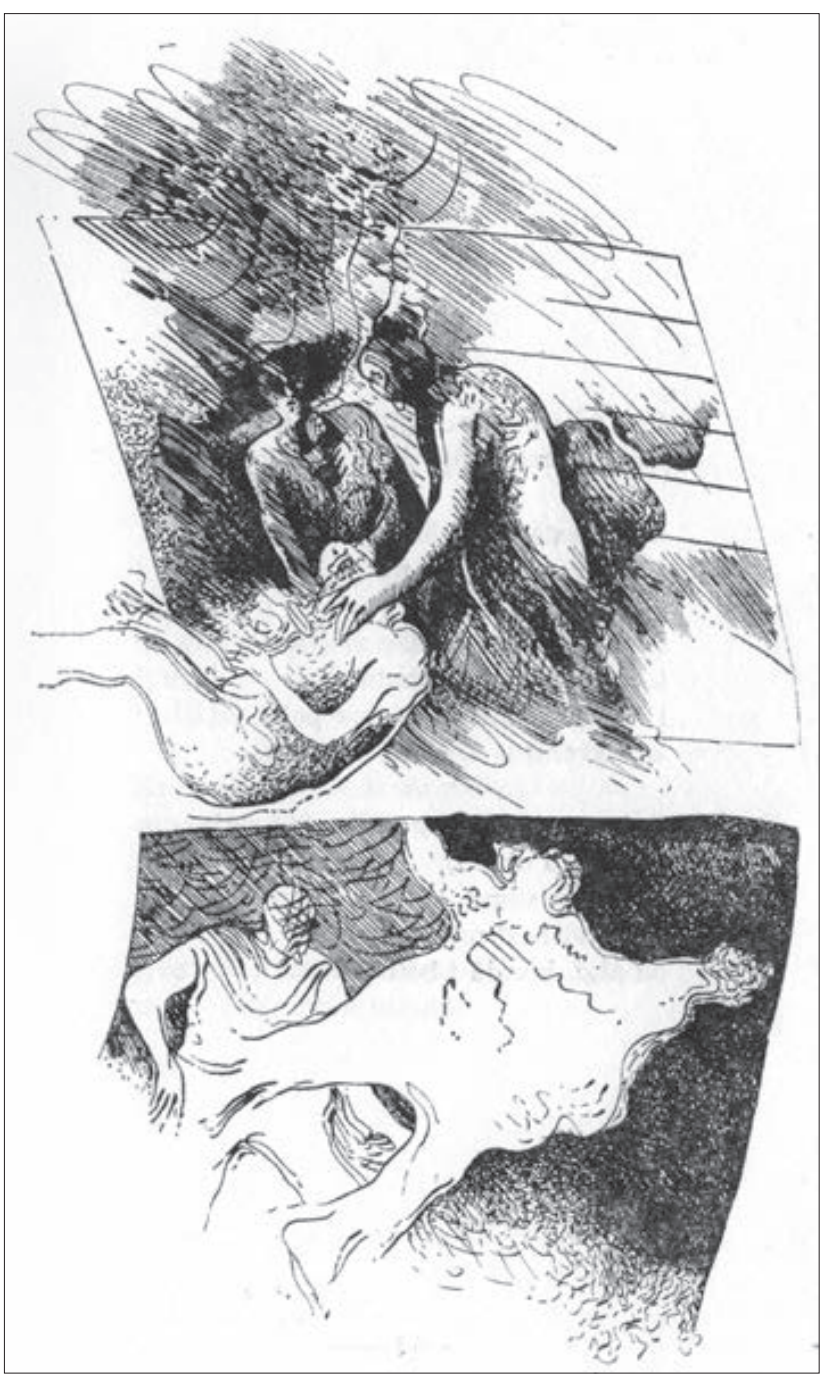

Sl. 1. Ilustracija Miće Mihajlovića u Šašavoj knjizi (Izabrana dela Miroslava Antića, Dnevnik, Novi Sad 1982.)

Videli smo da u Besmrtnoj pesmi lirsko ja elidira sliku telesnog raspadanja posle smrti. Pesme Garavog sokaka s početka takođe zaobilaze prikaz umrlog tela, no u docnijim verzijama to neće biti slučaj. Unutar zbirke pojaviće se dve pesme koje se umrlim telom bave naturalistički. Čitanje iz dlana pruža krajnje ogoljenu sliku dekompozicije umrlog tela. Telo je u potpunosti pasivizirano i prepušteno drugima, da ga „metnu u zemlju“. Slikovitost prikaza raspadanja dodatno je podržana upotrebom deiktičkog „ovako“, koje sugeriše

34 M. Antić, Garavi sokak, 1973., 34. Istakao V. V. R.

35 Isto, 11.

36 Б. МАрковић, „Интеркултурацност у настави књижевности“, 315.

37 М. Антит, Гарави сокак, 1978., 58.

38 Isto, 57 i 58. 
govornikovu „neverbalnu dopunu“, simbolički gest koji proces „dočarava“: „Kad umreš, i metnu te u zemlju, / i oči ti popiju mravi... ovako... / i dušu ti pozoblju bube... ovako... (...) / i srce ti posrču crvi... ovako / i pamet ti popiju krtice... ovako... " ${ }^{39}$ Sudbina tela je, za razliku od sudbine lirskog ja Besmrtne pesme, transformacija u elemente žive i nežive prirode: „i od ušiju ti postane lišće... ovako... / i od čela ti postanu stabla... ovako... “40 No, uprkos tome što su u Sokaku i duša i srce i pamet rastočivi, njihovi sadržaji - slično strahu i tajni Besmrtne pesme - kao da opstaju kroz svoje simbolične predstavnike u telesnom: kosa ostaje da živi jer je predstavnik „svetog vetra u čoveku“, zubi jer su „glad za samo lepim stvarima“, nokti „sveti prkos u čoveku“. ${ }^{41}$ Time se implicitno gradi i slika vrednosti u svetu, nijansirana krajem pesme u kojem ruke (nokti, odn. prkos) zauzimaju mesto poslednjeg uporišta: ono što ostaje, preuzima karakter suštinskog, čoveka u čoveku. No, to suštinsko izgleda nije suštinsko pojedinačnog, već suštinsko ukupnog sveta, budući da se za svako od njih naglašava da je nešto drugo nego ti. Slično će biti u Igri mrtvih pod jorganom: oni koji govore nisu živi jer su „od pepel““ i jer su ih „bube pojele“; pa ipak, tokom pesme pojaviće se i teže uništivi posmrtni ostaci u vidu kose, kostiju i zuba. U Čitanju iz prstiju otišlo se još dalje. Tamo nailazimo na instrumentalizaciju dela umrlog tela u okvirima magijske radnje: „Levi palac sa mrtvaca / kad odsečeš sa brijačem / devet dana posle smrti, / svetli noću kao mesec / za skitnice i kradljivce. "“2 Ne samo da prst mrtvaca može da utiče na zbivanja s ove strane, već se delovanje odvija i u suprotnom smeru: iz prstiju živih može se pročitati zagrobni usud. Tako nedostatak srednjeg prsta, koji predstavlja sudbinu, čini da se dete prilikom smrti pretvori u vampira, a čovek bez njega „lutaće i posle smrti / dok ne stigne na kraj sveta / i padne u ništa“. ${ }^{43}$

\section{5 .}

Pitanje smisla smrti već na samom početku Besmrtne pesme implicitno je povezano s pitanjem šta znači živeti. Neizrečena pretpostavka je to da se tek onda kad se odgovori na pitanje šta je život može odgovoriti i na to šta je smrt. U definisanju kvaliteta života brigama i tugama se, kroz retorička pitanja, ukida postojanje; epitet postojećeg zaslužuju samo hrabrost i mašta da se živi sasvim, da se „ک̌iroko žvaće vazduh“ i „prestižu vetar i ptice“. Dalje promatranje može se svesti na pitanje o vrednosti intenziteta i vrednosti trajanja života. U upozorenju na neprimetnost prelaza u kojem se to sasvim življenje gubi, bitnu ulogu igra više puta ponovljena reč odjednom: „odjednom: nasmejani / u ogledalu nekom / dobiju zborano lice. // Odjednom na ponekom uglu / vreba poneka suza. (...) Odjednom svet / dok hodaš / sve više ti je uzan / i osmeh sve tiši. " ${ }^{44}$ Pomenuti prilog sugeriše diskonti-

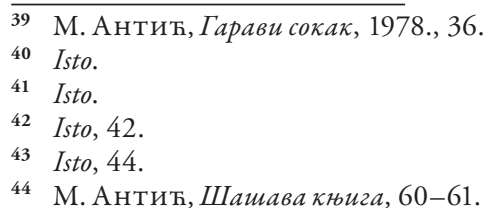


nuitet, koji ovde, dakako, znači manje ili više neočekivani diskontinuitet življenja u kojem se naprasno rađa „iskrivljenost“ osmeha; on, međutim, označava i diskontinuitet percepcije sopstvenog življenja. Ta se promena povezuje s mukama koje život donosi iznenadno (iza ugla) i neprimetno (na prstima), sa skučenošću životnog izbora koji je, vremenom, sve više usmeravan proteklim (uzani svet) i nemogućnošću vedrine koja ne bi bila sputana nagoveštajem nesreće, ili nepomračena senkom refleksije koja tu vedrinu svodi na „pravu“ meru. ${ }^{45}$ Implicitno, u ovoj metamorfozi dolazi se do tačke u kojoj se život i smrt dodiruju i, u određenom smislu, izjednačavaju: prelazak u manje intenzivan način življenja, onaj koji nije sasvim življenje, predstavlja smrt unutar života. To izmeštanje prostora smrti je gest koji onda delegitimiše želju za što dužim življenjem, i vrednost njegovog pukog trajanja. Trajanje postaje relativan kvalitet, a punoća trajanja apsolutno merilo života - otud je u tkivu pesme sasvim logičan već pomenuti paradoks: „Za pola veka samo / stoleća sam obišao.“46 Odlika sasvim življenja je rizik, a on nije samo u činjenici da se život stavlja na kocku jednog načina egzistiranja, i u službu vere u važnost trenutka, već i u mogućnosti da se greši, da se ponekad živi naopako ili luckasto. Na kraju, lirsko ja poentira: „Zato sam sasvim živeo, / jer to

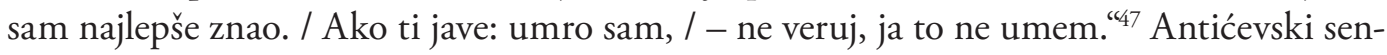
timentalni humor tu je da dopuni rečeno: življenje nije datost, niti bilo kakvo trajanje, ono je stvar jednog estetskog znanja da se živi sasvim, a u tom življenju najbitniju ulogu imaju ljubav i radost. Umiranje nije neminovnost nego stvar (ne)umeća, ono je prevedeno iz sfere univerzalne nužnosti svakog ja u sferu volje svakog pojedinačnog ja. Čovek sam odlučuje hoće li umreti ili ne. Oni koji ostaju iza njega odlučuju da li tugom prihvataju njegov fizički nestanak ili pak pristaju na misteriju tajne i namigivanja između kosmičkog i ljudskog u toj tajni. Taj pristanak omogućava trajanje čoveka u još jednom vidu - kroz one ljude koji na zemlji ostaju posle njegovog odlaska. ${ }^{48}$

Ova vrsta refleksivnosti u pesmama Garavog sokaka izostaje. To ne znači da, makar posredno, u ovim pesmama izostaje saodnos osmišljenja života i smrti. Tamo gde je životu teško nazreti smisao u konkretnoj surovosti trajanja, smrt postaje utočište. Smisao smrti uslovno rečeno smisao - oblikovan je iskustvom življenja i u govoru o njemu. Pesma Ruža je u tom pogledu paradigmatična. Jedanaestogodišnjoj devojčici se u bezizlaznoj situaciji, kad je primorana da se prerano i nevoljno uda za čoveka koga ne voli, prostor groba ukazuje kao skrovište, a voljna smrt kao mogućnost bekstva i nemog protesta. Smrt crpi svrhovitost iz toga što tegobno trajanje u svetu može da se njome prekine. $S$ druge strane, upravo zato što je prostor smrti prazan prostor, što o zagrobnom životu ne možemo ništa znati, smrt postaje crno platno za individualne projekcije subjekta i njegovih želja. One se, zapravo, ocrtavaju na pozadini osećanja nedostatka u ovom životu.

45 Prelazak je, razjašnjava docnija verzija ove pesme, motivisan ranjivošću i ranjenošću, otvorenošću tela da pretrpi bolni udar - tamo Antić napominje kako treba valjano „zašiti naprsla mesta iz kojih drhte čuđenja“. Мирослав Антић, Хороскоп. Тако замишьлам небо, Нови СаА 1997., 251.

47 Isto, 63.

48 Ideja trajanja kroz druge biće aktualizovana na još dva mesta unutar zbirke - u prozaidama Koren i Kako sam ubio jednu ribu. 


\section{6.}

Različite predstave smrti različito se oblikuju i u jezičko-stilskom smislu. Na prvi pogled reklo bi se da je Besmrtna pesma izrazito dijaloška i komunikativna. Taj utisak stvoren je uglavnom upotrebom $t i$-forme, korišćenjem nemarkirane leksike i govorne sintakse. Istina je, međutim, da je ova pesma monološka mnogo više nego što izgleda. Važnu argumentativnu ulogu u njoj igraju retoričko pitanje („Zar misliš da moja ruka, / koleno, / ili glava, / mogu da postanu glina, / koren breze, / il' trava? ( $\left.{ }^{49}\right)$, kao i kombinacija informativnog ili ocenjivačkog iskaza, čije se značenje potom dodatno razjašnjava („I nema praznih svetova. / To, čega nismo svesni, / nije nepostojanje, / već postojanje bez nas.“50), te imperativi koji neretko dolaze kao poenta, ili se naknadno objašnjavaju („Odjednom svet, / dok hodaš / sve više ti je uzan / i osmeh sve tiši / i tiši / i nekako - iskrivljen. // Zato živi! / Al' sasvim! “51). U svim ovim slučajevima uloga pomenutog $t i$ je minimalizovana. $U z$ to, naročito u potonjoj i dužoj verziji, prisutne su visokoapstraktne sentence koje pretenduju na opšte važenje, a njihova upečatljivost dolazi mahom otud što Antić u njih ugrađuje paradokse (npr. „Upamti: stvarnost je stvarnija / ako joj dodaš nestvarnog. ${ }^{\text {"52 }}$ ).

Jezičko-stilski repertoar Sokaka znatno je drukčiji: simbolika je rudimentarna i elementi putem kojih se ostvaruje čine čulne konkretnosti prvog reda (npr. simbolička vrednost konja, ptice, cveća). Pesme nisu rimovane, ali daleko od toga da nisu ritmične - česti su sintaksički paralelizmi i ponavljanja, koji taj ritam zajedno uspostavljaju, ali i doprinose utisku spontanosti u govorenju. To govorenje je gdekad ostvareno dijaloškom ili poliloškom formom (Ruža, Igre mrtvih pod jorganom), a znatnu ulogu u njemu ima apostrofa („Vidiš majko, vidiš majko, / onog konja sa zlatnom grivom“, ${ }^{53}$ pokazuje Gaga; „Poslušaj me, bože, veliki gospodine“, ${ }^{54}$ govori Džane), koja po pravilu oprisutnjuje unutar pesme nemi lik drugog, slušaoca, što čini da se glas čuje kao još usamljeniji jer replike na izgovoreno nema. U pojedinim slučajevima njihovo pojavljivanje zaokružuje poenta na kraju pesme (Ruža, Čitanje iz dlana), a ta poenta u pesmi Gaga uvedena je snažnim gradiranjem, koje dočarava uspon i kulminaciju emocije lirskog subjekta. Sva pomenuta sredstva, i njihova upotreba u empatijskom ključu, čine pesme Sokaka, ponešto neočekivano, neposrednijim i intimnijim od Besmrtne pesme.

„Dudo, / kad me iznose, neka pročitaju 'Besmrtnu pesmu'. A kad me pokopaju, neka Janika Balaž ili Tugomir odsvira 'Piro manđe korkoro'. Niko ne sme da mi drži govor." ${ }^{\text {“5s }}$ U tih je nekoliko rečenica sačuvana poslednja Antićeva želja - koja je i ispunjena 26. juna

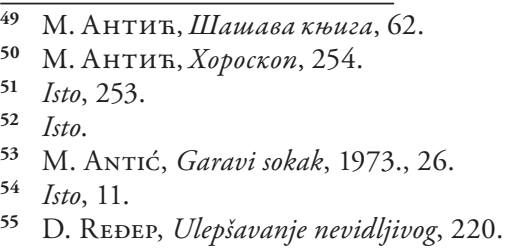


1986. godine. ${ }^{56}$ Njegovo pevanje o smrti u dvema zbirkama za decu i mlade, koje su izašle godinu za godinom, kao da anticipira tu konačnu sintezu dva umnogome „nekompatibilna" pogleda na smrt. Prvi je plod ekstatičnog iskustva kontemplacije, drugi gole egzistencije marginalizovanog čoveka; prvi baštini veru u telo satkano od svetlosti, dok se drugi ne libi da o lešu govori naturalistički; prvi groblje definiše kao mesto laži, drugi ga vidi kao prostor nade i platno za projekciju želja onoga ko o groblju govori; prvi insistira na životnom optimizmu i intenzitetu proživljenog, drugi akcentuje širok raspon osećanja u vezi sa smrću (bol, strah, ravnodušnost i dr.), a nju samu katkad predstavlja kao mogućnost bega iz tegobnog trajanja na ovome svetu, i vid protesta protiv takvoga trajanja; prvi je u jeziku izrečen kroz sentence i paradokse, drugi je u susretu sa smrću simbolički fundamentalan i jezički neposredan. Prvi ukorenjen u Antićevim pokušajima „da se navikne na fenomen

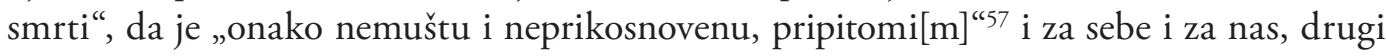
obeležen saznanjem o Miletovom nestanku u nacističkom pogromu. Iz svega navedenog može se zaključiti da tako kompleksna, umetnički snažna i nadasve autentična poezija za decu i mlade, koja tematizuje smrt, zaslužuje da bude visoko vrednovana, te da u nekom budućem obrazovanju o smrti, koje za jedan od temelja može imati tumačenje poezije treba da zauzme više nego značajno mesto.

\section{$\cos$}

\section{Izvori i literatura}

\section{Izvori}

Miroslav Antić, Garavi sokak. Kobajagi ciganske pesme za decu, Inđija 1973.

Мирослав Антић, Гарави сокак. Весело ииганско вашариите са неколико суза и капи кише, Загреб 1978.

Мирослав Антић, Гарави сокак. Весело ииганско вашариите са неколико суза и капи кище, Нови СаА 1997.

Мирослав Антић, Хороскоп. Тако замишьљам небо, Нови СаА 1998.

Мирослав Антић, Шамава књига, БеограА 1972.

\section{Literatura}

Rita Astuti, „Death, Ancestors, and the Living Dead: Learning without Teaching in Madagascar“, Children's Understanding of Death. From Biological to Religious Conceptions (ur. Victoria Talwar, Paul L. Harris i Michael Schleifer), Cambridge 2011., 1-11.

Benjamin Beit-Hallahmi, „Ambivalent Teaching and Painful Learning: Mastering the Facts of Life (?)", Children's Understanding of Death. From Biological to Religious Conceptions (ur. Victoria Talwar, Paul L. Harris i Michael Schleifer), Cambridge 2011., 49-50.

Milan Crnković, Dječja književnost. Priručnik za studente pedagoških akademija i nastavnike, Zagreb 1967.

56 Isto, 221.

57 Isto, 76. 
Арагоьуб Јекнић, Српска књижевност за деиу II. Историјски преглед, БеограА 1998.

Alice Lazar - Judith Torney-Purta, „The Development of the Subconcepts of Death in Young Children: A Short-Term Longitudinal Study“, Child Development, 62/1991., br. 6, 1321-1333.

Margaret M. Mahon, „Death in the Lives of Children“, Children's Understanding of Death. From Biological to Religious Conceptions (ur. Victoria Talwar, Paul L. Harris i Michael Schleifer), Cambridge 2011., 61-97.

Бојан МАрковић, „Интеркултуралност у настави књижевности на примеру књиге песама Гарави сокак Мирослава Антића - методичка разматрања“, Годишғак Катедре за српску книжевност, 10/2014., 305-320.

Зорана ОПАчић, „Песма која је покушаха да одрасте (од првог до последњег издања Плавог чуперка Мироскава Антића“, Наивна свест и фикција, Нови СаА 2011., 27-31.

Раша Попов, „Антићев синдром близанаца у спеву Гарави сокак“, и: Мирослав Антит, Гарави сокак. Весело ииганско вашариште са неколико суза и капи кише, Нови СаА 1997., 107-128.

Радован Поповит, Антић, ғим самим, Београд 2009.

Milan Pražić, Reči i vreme, Novi Sad 2002.

Draško ReĐer, Ulepšavanje nevidljivog. Hagiografija o Miroslavu Antiću, Sarajevo 1988.

Mark W. Speece - Sandor B. Brent, „Children's Understanding of Death: A Review of Three Components of a Death Concept“, Child Development, 55/1984., br. 5, 1671-1686.

\section{$\cos$}

\section{SiLLY IMMORTALITY AND SOOTY DEATH: THE NOTIONS OF DEATH IN MiROSLAV ANTIĆ'S POETRY FOR CHILDREN AND YOUNG ADULTS}

In an attempt to open up the possibility of starting a conversation about dying with children through the interpretation of poetry, the paper focuses on the way the phenomenon of death is depicted in Miroslav Antićs poetry for children and young adults. It emphasizes the considerable disparity between the notions of death in Šašava knjiga (The Silly Book) and Garavi sokak (The Sooty Souk). In the former, death is approached through an extatic experience of contemplation and is thus marked by optimism and an intensity of experience, proclaiming a faith in a body woven from light, and immortality. The latter, on the other hand, views death from the perspective of a member of the marginalized Roma community, so a much larger emphasis is placed on the wide range of emotions related to death. Here, the dead body is discussed much more openly, while any meaning death might have is derived from the fact that it provides an escape from the hardships of this world. These disparate notions of death differ in their linguistic realization as well: whereas Besmrtna pesma (The Immortal Poem), which contains the credo of The Silly Book, employs seductive sayings and paradoxes in its treatment of death, the heroes of The Sooty Souk speak of death in much more direct terms. All of this speaks in favour of using these books as a starting point for a fruitful and complicated conversation about death with children and young adults, as well as a discussion of the artistic treatment of such a topic.

Key words: poetry for children and young people, education about death, Šašava knjiga (The Silly Book), Garavi sokak (The Sooty Souk), Miroslav Antić 


\section{ULOGA SMRTI U NJEMAČKOJ FILOZOFIJI EGZISTENCIJE MEĐURATNOGA PERIODA \\ I NJEZINA RECEPCIJA U MISLI STJEPANA ZIMMERMANNA}

\section{Matko Globačnik}

UDK: 141.32(430)“192/193“:125

Izvorni znanstveni članak

Sažetak: Smrt ima važnu ulogu u misli glavnih predstavnika njemačke filozofije egzistencije međuratnoga perioda, Martina Heideggera i Karla Jaspersa. U Heideggerovoj ona je kraj „bitka-u-svijetu“, a u Jaspersovoj „granična situacija“ u kojoj se naslućuje ono transcendentno. Time smrt opusom obojice mislilaca znatno utječe na filozofski pravac obilježen tjeskobom, nesigurnošću, potragom za smislom čovjekova postojanja i njegovim položajem u svijetu. Istim se pitanjima u međuratnoj Jugoslaviji bavio izuzetno plodan katolički filozof i teolog Stjepan Zimmermann. Još prije Heideggera (Kant und das Problem der Metaphysik, 1929.) i Jaspersa, monografijom zaokružujući višegodišnje bavljenje filozofijom Immanuela Kanta (Kant i neoskolastika, 1920./1921.) te polazeći od njegova napada na tradicionalnu metafiziku, Zimmermann se s pozicije katoličkog intelektualca vjernog skolastičkoj tradiciji bavio Kantovom problematikom koja je presudno utjecala na razvoj kontinentalne filozofije, a time i filozofije egzistencije. S potonjom je podrobno bio upoznat te će se s njome kritički razračunati u opsežnom djelu Jaspersov egzistencijalizam, koje je do danas ostalo neobjavljeno u punom opsegu. U cilju rasvjetljavanja idejno-povijesnih izvora spomenutoga djela, u članku se pokušava sistematski razjasniti ulogu smrti u filozofiji Heideggera i Jaspersa te utjecaj rečene teme na misao Stjepana Zimmermanna u povijesnom kontekstu međuratnoga perioda, u kojemu su djelovala sva trojica mislilaca.

Ključne riječi: Karl Jaspers, Martin Heidegger, Stjepan Zimmermann, smrt, filozofija egzistencije, novokantovstvo, katolička teologija

\section{UVOD}

uprotno popularnom uvjerenju, u povijesti filozofije smrt nije bila tema o kojoj se mnogo raspravljalo ili sistematski pisalo. ${ }^{1}$ Njezina je uloga bila važnija u filozofiji pesimističkih i egzistencijalističkih mislilaca 19. stoljeća, koji su imali znatnog utjecaja na filozofiju egzistencije koja se javlja nakon Prvoga svjetskog rata u Njemačkoj. Unatoč me-

$1 \quad$ Iako, naravno, brojna pitanja koja su se mnogo raspravljala u filozofiji tijekom njezine povijesti imaju implikacije za temu smrti. Usp. Ben Bradley - Fred Feldman - Jens Johansson, „Introduction. Philosophy of Death“, The Oxford Handbook of Philosophy of Death (ur. Ben Bradley, Fred Feldman i Jens Johansson), Oxford 2013., 1-4. 


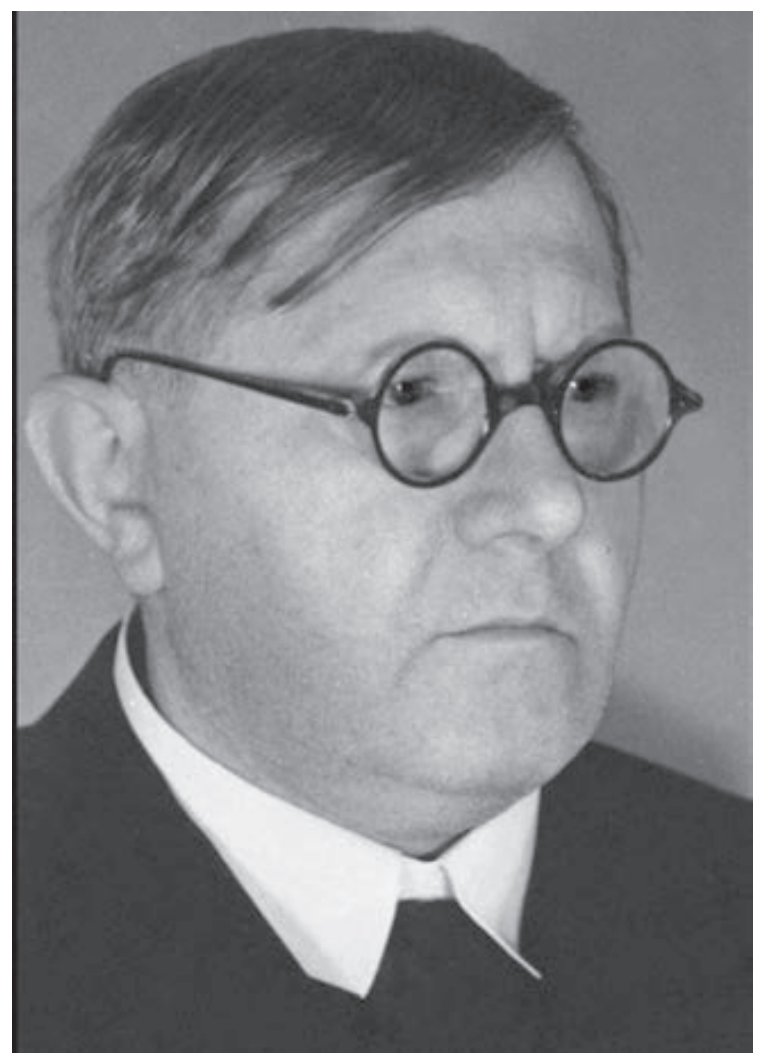

Sl. 1. Stjepan Zimmerman

đusobnim razlikama i drugačijem načinu pripadanja tome filozofskom pravcu, njegovi znameniti predstavnici Martin Heidegger i Karl Jaspers dobrim su dijelom oblikovali svoja promišljanja o biti ljudske egzistencije u odnosu prema vlastitu shvaćanju smrti.

Smrt također ima znatnu ulogu u katoličkoj teologiji, a vjerojatno je najznamenitiji hrvatski katolički mislilac međuratnoga perioda bio Stjepan Zimmermann. U njegovu bogatu opusu, znatno obilježenom kršćanskim shvaćanjem složenog odnosa života i smrti, prvo mjesto po opsegu zauzima upravo djelo Jaspersov egzistencijalizam, koje do danas nije u potpunosti objavljeno, niti je točnije utvrđeno u kojem je vremenu ono bilo pisano i ostavljeno u stanju u kakvu se danas nalazi. ${ }^{2}$

Cilj je ovoga rada stoga istraživanjem uloge smrti u njemačkoj filozofiji egzistencije i njezine recepcije u misli Stjepana Zimmermanna u povijesnom kontekstu međuratnoga perioda pridonijeti rasvjetljavanju idejno-povijesnih izvora djela Jaspersov egzistencijalizam. Prije razmatranja teme smrti uzimaju se dvije ključne točke koje su relevantne za nju te su zajedničke i egzistencijalistima i Zimmermannu, a to su problem (novo)kantovskog nasljeđa te djelovanje u polju tada relativno novih znanosti - psihologije, odnosno psihijatrije.

\section{NovoKantovsKo NASLJEĐE I ULOGa SMRTI U NJEMAČKOJ FILOZOFIJI EGZISTENCIJE}

Najsnažniji filozofski pravac u srednjoj Europi u drugoj polovini 19. i na početku 20. stoljeća bio je novokantovstvo. Interpretirajući filozofiju Immanuela Kanta, središnjeg mi-

$\overline{2}$ Zbog političkih okolnosti, brojna su Zimmermannova djela donedavno ostala neobjavljena. Ipak, on se trudio, oslanjajući se na osobe od povjerenja, da u svakom slučaju ta djela ipak ugledaju svjetlo dana. Usp. Blaž JuRIŠić, Dnevnik Blaža Jurišića (prir. Biserka Rako), Zagreb 1994., 199. Jedan od prvih koji je upozorio na djelo Jaspersov egzistencijalizam u Zimmermannovoj ostavštini te pružio njegov kratak opis i vlastitu interpretaciju konteksta njegova nastanka bio je Ivan Čehok. Usp. Ivan ČEHок, „Filozofijska ostavština Stjepana Zimmermanna“, Prilozi za istraživanje hrvatske filozofske baštine, 19/1993., 196-201. Do danas objavljen je samo prvi svezak: Stjepan Zimmermann, Jaspersov egzistencijalizam. Karl Jaspers prema religiji, sv. 1, Zagreb 2002. Nažalost, priređivač Zeljko Pavić (str. XI-XV) nije dublje ulazio u pokušaj datacije nastanka djela. Njegov izvornik (pa tako i drugi svezak) čuva se u Nadbiskupijskom arhivu u Zagrebu (dalje: NAZ) u ostavštini Stjepana Zimmermanna (dalje: SZ), kutija „Jaspers“. 
slioca moderne njemačke filozofije, ponajprije kao teoriju spoznaje koja istražuje logičke procese mišljenja, odnosno transcendentalne uvjete mogućnosti spoznaje, zrelo novokantovstvo budućnost filozofije vidjelo je u epistemologiji koja bi djelovala kao logika znanosti. Novokantovski optimizam u pogledu mogućnosti postizanja boljeg života političkom borbom na ovome svijetu nije potiskivao samo stara metafizička pitanja koja su prelazila granice iskustva, poput postojanja Boga ili besmrtnosti duše, već i suprotstavljene filozofske pravce poput egzistencijalizma Sørena Kierkegaarda te pesimizma Arthura Schopenhauera i Friedricha Nietzschea. ${ }^{3}$ Početkom 20. stoljeća njemačkom filozofijom dominirale su tri novokantovske škole: marburška, čiji su najznamenitiji predstavnici bili Hermann Cohen, Paul Natorp i Ernst Cassirer, zatim badenska s predstavnicima Wilhelmom Windelbandom, Heinrichom Rickertom i Emilom Laskom te nova Friesova škola, kojoj je pripadao Leonard Nelson, pri čemu je novokantovska tradicija bila jaka i u drugim sveučilišnim centrima poput Strassbourga i Berlina. Međutim, mnogi su novokantovci fanatično podupirali službenu njemačku politiku u Prvome svjetskom ratu, vezujući svoju sudbinu s njegovim ishodom. Njemački poraz 1918. i turbulentna zbivanja u poraću, kada već brojni znameniti novokantovci više nisu bili živi, znatno su uzdrmali dominaciju novokantovstva, a njegov optimizam sada je bio laka meta za filozofske pravce poput pesimizma. ${ }^{4}$

Dvojica mladih mislilaca, Martin Heidegger i Karl Jaspers, bila su također kritična prema novokantovstvu. Heidegger, koji je u međuraću predavao filozofiju u Marburgu i Freiburgu, u lipnju 1922. poručio je Jaspersu da je potrebna kritika dosadašnje ontologije „u njenu korijenu u grčkoj filozofiji, posebno Aristotela, čija je ontologija (već ovaj pojam ne odgovara) jednako snažno živa u Kanta i čak Hegela, kao kod kakva srednjovjekovnog skolastičara“. Obojici im je posebno odbojna bila novokantovska akademska filozofija koju je zastupao, primjerice, Windelband, iako su priznavali oštroumne mislioce poput Cassirera. ${ }^{5}$ Od dvojice mislilaca koji su posebno utjecali na Heideggera i Jaspersa, jedan je razvijao fenomenologiju nezavisnu od teorija novokantovstva (Edmund Husserl), a drugi (Max Scheler) bio je kritičar Kantove filozofije. Scheler je još za vrijeme rata (1916.) dovršio utjecajno djelo pod naslovom Der Formalismus in der Ethik und die materiale Wertethik, pokušavajući utemeljiti materijalnu vrijednosnu etiku i kritizirajući formalizam Kantove etike te tvrdeći da su vrijednosti samostalni fenomeni, a ne apstrakcije iz materijalnih odredbi volje. ${ }^{6}$ Međutim, na Heideggera će najviše utjecaja imati kasna Schelerova filozofija, pogotovo djelo

3 Frederick Charles Beiser, The Genesis of Neo-Kantianism, 1796 - 1880, Oxford 2014., najnovija je sinteza o izvorima i povijesti novokantovstva, koja prati razvoj i konačnu pobjedu epistemološke interpretacije Kantove filozofije nasuprot psihologističkoj. O odnosu novokantovaca prema pesimističkim misliocima v. 398-421.

4 O historicističkoj, nihilističkoj i pesimističkoj kritici novokantovstva u Weimarskoj Republici v. Frederick Charles Beiser, „Weimar Philosophy and the Fate of Neo-Kantianism“, Weimar Thought. A Contested Legacy (ur. Peter A. Gordon i John P. McCormick), Princeton 2013., 115-132. Međutim, Beiser ne spominje Edmunda Husserla i Maxa Schelera kao značajne mislioce Weimarske Republike, koji su znatno utjecali na Heideggera i Jaspersa.

5 Martin Heidegger - Karl Jaspers, Briefwechsel 1920-1963, Frankfurt am Main 1990., 27, 31, 71-72, 74, 89.

6 Max Scheler, Gesammelte Werke, sv. 2: Formalismus in der Ethik und materiale Wertethik, Bern 1966., 29-65. Kritika Kantove etike kao formalističke ima vrlo dugu tradiciju, a nju je započeo još Kantov suvremenik H. A. Pistorius. O tome v. Matko GlobaČNik, Izazov skepticizma. Utjecaj Humeove metafizike i moralne filozofije u Europi 18. stoljeća, Zagreb 2016., 369-381, 403-405, 424-426. Ukratko o Husserlu v. Ulrich ClaesGes, „Husserl, Edmund“, Neue Deutsche Biographie (dalje: NDB), sv. 10, Berlin 1974., 87-89; o Scheleru v. Wolfhart Henckmann, „Scheler, Max“, NDB, sv. 22, Berlin 2005., 644-646. 
Die Stellung des Menschen im Kosmos (1928.) jer je već samo pitanje o čovjekovu položaju u kozmosu bilo ukorijenjeno u biti specifično ljudskog načina egzistiranja.?

Upravo je Heideggerovo djelo Kant und das Problem der Metaphysik (1929.) bilo posvećeno Scheleru, štoviše, njegov sadržaj bio je predmet Heideggerova posljednjeg razgovora sa Schelerom. Ono je stajalo u najužoj vezi s Heideggerovim najpoznatijim djelom Sein und Zeit (1927.), koje je, pak, bilo posvećeno Husserlu. Heideggerov je Kant, nasuprot novokantovcima, ponudio radikalnu reinterpretaciju kritičke misli filozofa iz Königsberga. ${ }^{8}$ U spomenutoj se knjizi Kantov kritički projekt ne interpretira kao ograničavanje tradicionalne metafizike s ciljem preoblikovanja filozofije u epistemologiju, nego kao zasnivanje „fundamentalne ontologije“ koja u tradiciji starogrčke filozofije treba pripremiti temelj za „prirodi ljudi pripadnu“ metafiziku. Kant je htio razriješiti pitanje unutarnje mogućnosti transcendentalne filozofije koja nije epistemologija, tvrdi Heidegger, nego opća metafizika ili ontologija, a rješenje vidio je u sintetičkim sudovima a priori. ${ }^{9}$ Dakako da je takva interpretacija Kanta bila nadogradnja na Sein und Zeit, u čijim je temeljima upravo bila rehabilitacija bitka od njegova povijesnog „zaborava“, odnosno fundamentalna ontologija koja istražuje smisao bitka, ${ }^{10}$ a to je istraživanje Heideggera odvelo u definiranje „tubitka“ (Dasein) odnosno specifično ljudskog načina egzistiranja, što je uključivalo i temu smrti. U Heideggerovoj je filozofiji tubitak nepotpun jer mu je otvoreno područje mogućnosti (što Heidegger naziva brigom) na koje je on usmjeren. Najvlastitija je mogućnost ljudske egzistencije smrt jer je, s obzirom na neiskusivost smrti drugoga, ona uvijek samo njezina. Smrt označava kraj bitka-u-svijetu, svijeta u koji je tubitak bačen i koji u egzistencijalnom strahu otkriva svoju bačenost. Heideggerovo ontološko određenje smrti, za koje smatra da leži u temelju i njezina empirijsko-znanstvenog shvaćanja, tvrdi da je ona izvjesna mogućnost nemogućnosti svakog odnosa prema svakom egzistiranju, a iz te izvjesne mogućnosti proizlazi tjeskoba, ali i svijest pojedinačnosti i cjelovitosti ljudske egzistencije. „Trčanje naprijed“ (Vorlaufen) u mogućnost smrti ljudskoj egzistenciji omogućuje oslobođanje brige, tj. odnosa prema izvjesnoj mogućnosti smrti zbog kojeg je nepotpuna i postajanje njome samom u strašnoj slobodi k smrti, zaključuje Heidegger. ${ }^{11}$

Jaspersov je put u filozofiju bio drugačiji od Heideggerova. Smatrao je da se njegovo bavljenje filozofijom mora temeljiti na prirodnim znanostima, a po struci bio je psihijatar pa je filozofija bila odlično upotpunjena njegovim znanstvenim bavljenjem duševnim bolestima. U žestokom neslaganju s novokantovcem Rickertom, pojačanom nakon što je 1922. dobio mjesto redovitog profesora filozofije u Heidelbergu, našao je Jaspers potporu u Heideggeru, koji ga je usmjeravao prema utemeljenju filozofske misli nezavisnom od psihijatrije. ${ }^{12}$

\footnotetext{
Max Scheler, Gesammelte Werke, sv. 9: Späte Schriften, Bern 1976., 7-71. O Heideggerovu odnosu spram svoga učitelja Husserla i Schelera v. Karl PögGeler, Heidegger in seiner Zeit, München 1989., 9-11, 32-33.

8 Martin Heidegger, Gesamtausgabe, I: Veröffentlichte Schriften 1910-1976, sv. 3: Kant und das Problem der Metaphy$s i k$, Frankfurt am Main 1991., XVI.

9 Isto, 1, 8-17.

10 Isti, Gesamtausgabe, I: Veröffentlichte Schriften 1910-1976, sv. 2: Sein und Zeit, Frankfurt am Main 1977., 3-53.

11 Isti, Sein und Zeit, 310-311, 314-354; Karl Lenmann, Der Tod bei Heidegger und Jaspers, Heidelberg 1938., 13-14, 22-32. Usp. i Ivan Kordić, „Bitak za smrt kao prolaz prema istini bitka“, Bitak i vrijeme. Interpretacije (ur. Damir Barbarić), Zagreb 2013., 89-123.

12 Ukratko o Jaspersu v. Richard Wisser, „Jaspers, Karl“, NDB, sv. 10, Berlin 1974., 362-365.
} 
Glavno Jaspersovo filozofsko djelo, u kojemu je njegovo promišljanje smrti razjašnjeno unutar opsežnog filozofskog sustava, nazvano je Philosophie, a objavljeno je u tri sveska 1932. godine. Jaspers u svome filozofiranju počinje od bitka. Jedan je određen pojam bitka također i egzistencija, „izvor, iz kojega mislim i djelujem“, pokazatelj koji ukazuje na onostranost sve predmetnosti, koja ne može biti predmet istraživanja nego se opisuje samo u vlastitom dijalektičkom kretanju. ${ }^{13}$ Smrt se u Jaspersovoj filozofiji pojavljuje u graničnoj situaciji, odnosno svijesti da se ni u jednoj situaciji ne može živjeti bez borbe i patnje, da je potrebno na sebe preuzeti teret i da svatko mora umrijeti. Granične situacije ne mogu se obuhvatiti u filozofiranju, nego pojedinačnim ispunjenjem u vlastitu tubitku kojim egzistencija postaje sebi izvjesna. Smrt kao činjenica još nije granična situacija; ona je nemisliva i neiskusiva jer sve što se o njoj misli samo su negacije, nikada pozitiviteti zato što je ona uvijek smrt bližnjega ili vlastita smrt. Smrt, prema Jaspersu, otvara pitanje konačnosti, relativizira tubitak i pokazuje njegove granice, što vodi do straha i očajanja, ali se iz njih izdiže hrabrost i skok za ostvarenjem smislenoga života. Dokazivanje egzistencije prema smrti uvijek je dijalektičko kretanje između ekstrema, ataraksije i nihilizma. ${ }^{14}$

Shvaćanje smrti ima mnogo zajedničkih točaka u filozofiji Heideggera i Jaspersa. Slično novokantovstvu, oni u smrti ne vide točku prijelaza na drugi svijet, nego katalizator ispunjenja vlastite egzistencije, odnosno ostvarenja smislenog života na ovome svijetu. Kao u kakvu starogermanskom epu, smrti, prema njihovu shvaćanju, treba hrabro „pogledati u oči“ radi oslobođenja od egzistencijalne brige, straha i očajanja. Zbog toga je sasvim jasno da njihova filozofija ostaje zatvorena temi kršćanske eshatologije.

\section{Novokantovstro i psihologija U ZIMMERMANNOVU OPUSU}

Utjecajan hrvatski katolički mislilac Stjepan Zimmermann ${ }^{15}$ cijeloga će se života baviti Kantovom filozofijom, koju je smatrao ključnom i za modernu filozofiju i za teologiju. $\mathrm{Na}$ svoje radove o Kantu bio je posebno ponosan. Primjerice, bliskome je prijatelju, hrvatskome filologu Stjepanu Ivšiću, ${ }^{16}$ prilikom predaje jednoga takva rada za tisak poručio da nigdje neće „naći takav portret ili skicu o Kantu“. ${ }^{17}$ Rado je provodio vrijeme u dugim razgovorima o misli i važnosti njemačkog filozofa. ${ }^{18}$

13 Karl Jaspers, Philosophie, sv. 1: Philosophische Weltorientierung, Berlin 1956., 1-24; K. Lehmann, Der Tod bei Heidegger und Jaspers, 16.

14 Karl Jaspers, Philosophie, sv. 2: Existenzerhellung, Berlin 1956., 201-210, 220-229; K. Lehmann, Der Tod bei Heidegger und Jaspers, 32-44.

15 Ukratko o Zimmermannu v. Ivan TADIĆ, Filozofska misao Stjepana Zimmermanna. Izabrani vidovi s bibliografjom, Split 2010., 9-24, zatim (emotivno, ali dobronamjerno) Željko PAvić, „Pogovor. Život kao ostavština i oporuka“, u: Stjepan Zimmermann, Humanizam i totalitarizam, Virovitica 2003., 115-134 i kratku kronologiju njegova života na str. 139. O Ivšiću v. Josip Lisac - Eduard Hercigonja, „Ivšić, Stjepan“, Hrvatski biografski leksikon (dalje: HBL), sv. 6, Zagreb 2005., 208-210.

17 Nacionalna i sveučilišna knjižnica (dalje: NSK), R4836b, Stjepan Zimmermann Stjepanu Ivšiću, s. a.

18 NSK, R6125a, Zdenko Vernić Stjepanu Zimmermannu, 7. 9. 1926. 
Zimmermann se Kantom počeo baviti prije Prvoga svjetskog rata. Zaintrigirala ga je njegova misaona veličina i privlačan skolastički način izlaganja kojim je došao do rezultata poprilično drugačijeg od onoga koji je naučavala skolastička teorija, a posebice tvrdnja o ograničenosti ljudske spoznaje na svijet iskustva, što je značilo da se razumom ne može dokazati postojanje Boga. ${ }^{19}$ Već se iz prvoga Zimmermannova rada vidi da je njegovo razumijevanje Kanta bilo pod utjecajem tada prevladavajuće paradigme u njemačkoj filozofiji, novokantovstva. Baš poput novokantovaca, kao cilj Kantova kritičkog projekta naveo je istraživanje uvjeta mogućnosti spoznaje, tvrdio je da filozof iz Königsberga utemeljenjem praktičke filozofije na noumenalnom svijetu naginje idealističkom dogmatizmu, a glavni je problem u njegovoj filozofiji vidio u stvari po sebi. ${ }^{20}$ Upravo su i neke esencijalne Zimmermannove kritike Kantu preuzete iz novokantovske tradicije, poput prigovora Kantovu subjektivizmu, nedokazivosti kategoričkog imperativa i racionaliziranju vjere. ${ }^{21}$

Međutim, iako je Zimmermannovo shvaćanje Kanta bilo oblikovano novokantovstvom, on je takvu filozofiju iz spomenutih razloga posve odbijao sa stajališta katoličkog intelektualca vjernog skolastičkoj tradiciji. ${ }^{22}$ Zanimljivo je (u kontekstu Heideggerove knjige Kant und das Problem der Metaphysik) da je on protiv novokantovaca tvrdio kako se ljudska spoznaja zasniva na ontološkim načelima, iz čega je zaključivao da znanstvena spoznaja može prelaziti granice iskustva. ${ }^{23}$ Oslanjajući se na učenje sv. Tome Akvinskog i na tada suvremene interpretatore njegove misli, Zimmermann je pobijao Kantovu spoznajnu teoriju, ${ }^{24}$ okrunivši svoj višegodišnji rad dvodijelnom knjigom Kant i neoskolastika (1920./1921.). ${ }^{25}$

Iz istih se religioznih pobuda Zimmermann počeo baviti noetikom, koja je davala odgovor na pitanje je li moguće dobiti „sigurni, konačni odgovor“ na životna pitanja ${ }^{26}$ te, konačno, psihologijom jer ona uključuje pitanje slobodne volje, odnosno duše. ${ }^{27}$ Iako je priznavao „važnost empiričke psihologije uopće za sve umske znanosti“, pa tako i religiju, „a u području specijalne filozofije za logiku, etiku i napose za spekulativnu psihologiju“,

19 O svome prvom susretu s Kantovom filozofijom sâm Zimmermann kaže: „Tako sam kao šestoškolac čuo od jednog maturanta ovu izjavu: 'Ne može se dokazati, da ima Boga. To je dokazao najveći filozof, Kant.' Ne mogu zaboraviti potlačnog dojma, što su ga te rieči učinile na me. Bile su tako uvjerljivo izrečene, da se u meni kao nešto srušilo i kao da se u temelju potreslo nešto, za što nisam ni znao, da mi služi uporištem života." Usp. Stjepan Zimmermann, Putem života. Autoergografija, Zagreb 1945., 57.

20 Isti, „Znanje i vjera u Kantovoj filozofiji“, Bogoslovska smotra, 5/1914., 13-26.

21 Istı, „Moral i religija u Kantovoj filozofiji“, Bogoslovska smotra, 5/1914., 138, 288, 380.

22 Istı, „J. Hessen. Die Religionsphilosophie des Neukantianismus. 2. izd. Herder“, Bogoslovska smotra, 12/1924., $504-505$.

23 IsTI, „Znanstvena vrijednost metafizičke spoznaje“, Bogoslovska smotra, 9/1918., 199, 278.

24 Isti, „Kantova i skolastička teorija uzročnosti“, Bogoslovska smotra, 7/1916., 136-155, 237-253; Isti, „Pojam istine u Kantovoj i skolastičkoj filozofiji“, Bogoslovska smotra, 8/1917., 17-27, 121-131; Istı, „Teleološki princip u Kantovoj i skolastičkoj filozofiji“", Bogoslovska smotra, 8/1917., 197-209, 301-315. Svaki od tih članaka tendenciozno želi pokazati prednost skolastičke nad Kantovom filozofijom po temama u naslovu, a posljednja dva pogotovo glede Kantova i Humeova odnosa. Za noviji prikaz odnosa potonje dvojice mislioca usp. M. GLOBAČniK, Izazov skepticizma.

25 Stjepan Zimmermann, Kant i neoskolastika, sv. 1: Sustavno-kritički, Zagreb 1920. i sv. 2: Studije, Zagreb 1921. Prvi dio razlaže Kantovu teorijsku i praktičku filozofiju, uz poneke usporedbe s novoskolastičkim učenjem, dok drugi sadrži neke (i u ovome radu citirane) članke već objavljene u Bogoslovskoj smotri. I nakon te je knjige Zimmermann nastavio pobijati Kantovu filozofiju s novoskolastičke pozicije. Usp., primjerice, Isti, „O načelu uzročnosti“, Bogoslovska smotra, 13/1925., 144-155.

26 Isti, „Metafizička ideologija“, Bogoslovska smotra, 7/1915., 291.

27 Isti, „O slobodnoj volji“", Bogoslovska smotra, 6/1915., 34-35, 48, 152, 342. 
ipak je uvijek tražio način kako dokazati skladnost moderne znanstvene psihologije s aristotelovskim, odnosno novoskolastičkim načelima. ${ }^{28} \mathrm{Njegov}$, u pravilu britak, način odbacivanja učenja koja nisu bila u skladu s novoskolastikom, vodio ga je u javne debate $s$ onima kojima je smetao njegov izraženo religijski svjetonazor u temama koje su se ticale suvremene znanosti. ${ }^{29}$

\section{ZiMMERMANNOVO SHVAĆANJE SMRTI I NJEGOVA RECEPCIJA NJEMAČKE FILOZOFIJE EGZISTENCIJE U} MEĐURATNOME PERIODU

Kršćanski svjetonazor koji je obilježio Zimmermannovo proučavanje psihologije i Kantove filozofije bio je paradigmatičan za cjelokupan njegov opus. Uvjeren u skolastičke (a priznajući i Kantom nadahnute) dokaze o postojanju Boga, ${ }^{30}$ snažno je naglašavao centralnu ulogu Katoličke crkve kao božanske institucije u povijesti i sadašnjosti ljudske civilizacije. ${ }^{31}$ Zbog toga je smrt za Zimmermanna mogla biti samo prijelazna točka na drugi svijet. Samu je smrt shvaćao biološki, kao „prestanak organskog djelovanja“, te je ona bila podređena kršćanskome pojmu „vječnoga života“. ${ }^{2}$

Dakle, u krucijalnim temama koje su spajale Zimmermanna s Heideggerom i Jaspersom, u psihologiji, pitanju ocjene Kantove filozofije i odnosu prema smrti, oni su bili različitih mišljenja. Kao strastven pratitelj njemačke filozofije, ${ }^{33}$ Zimmermann je dobro poznavao mi-

28 Isti, „Novi udžbenik za eksperimentalnu psihologiju“, Bogoslovska smotra, 7/1916., 73, 82; Isti, „Volja kao faktor u duševnom životu“, Bogoslovska smotra, 6/1915., 388, 390.

29 Zimmermann je bio u sporu s poznatim hrvatskim psihologom Ramirom Bujasom (1879. - 1959.), o kojemu v. Želimir Pavlina, „Bujas, Ramiro“, HBL, sv. 2, Zagreb 1989., 451-453. Zimmermannova je knjiga Duševni život bila 1932. predmet javne debate s filozofom Zdenkom Vernićem (1885. - 1944.), koji ga je nepristojno optuživao da pod plaštem znanstvenog djela širi katoličku propagandu. Vernić je potjecao iz stare plemićke obitelji iz okolice Zagreba (čija se ostavština čuva u Hrvatskom državnom arhivu [dalje: HDA]), a u međuratnom razdoblju, kako se navodi na Arhinetu, bio je „urednik izvještajne agencije 'Zeta' (1926-1928), izdavač Književnih novina, te direktor izvještajne agencije 'Croatia"“ (http://arhinet.arhiv.hr/details.aspx?ItemId=3_11205). Vernić je svoje drugačije shvaćanje aristotelizma, tomizma, psihologije i pogotovo Kanta (shvaćanje kojega stoji „pod jednom lošom i neopravdanom impresijom njemačkih povijesti filozofija“, neutemeljeno smatra Vernić) izložio Zimmermannu u već citiranom izvoru: NSK, R6125a, Vernić Zimmermannu, 7. 9. 1926. Ukratko o sporu Zimmermanna, Bujasa i Vernića v. Ljudevit HanžEK, „Zimmermannova polemika s Vernićem i Lachom“, Prilozi za istraživanje hrvatske filozofske baštine, 39/2013., 315321, koji ipak ne zna za ovdje spomenuto pismo.

Stjepan ZimmermanN, „Vrijednost deontološkog dokaza za egzistenciju Božju“, Bogoslovska smotra, 12/1924., 273285.

31 Isti, „Ideologija kršćanstva“, Bogoslovska smotra, 18/1930., 407-414.

32 Isti, „Sa područja filozofije“, Bogoslovska smotra, 12/1924., 370-375. U ovome se zanimljivu tekstu (odgovoru svojim učenicima, vjerojatno u vezi s njegovom knjigom Temelji psihologije iz 1924.) Zimmermann bavi evolucionizmom, životinjskom dušom i drugim temama.

33 Kako je revno Zimmermann nabavljao tada teško pristupačnu literaturu, što se vidi u njegovim djelima i brojnim recenzijama, pokazuje i primjer s hrvatskim filozofom Franjom Markovićem: „Našao je u mojem tekstu citate iz Tiedemannova 'Theäteta' (1794.) i Reinholdovih 'Briefe über Kantische Philosophie' (1790.) i upozorio me, da ne smijem citirati, što nisam čitao, a te su knjige nepristupačne, jer su izašle brzo nakon Kantove Kritike. Međutim, ja sam mu ih odmah pružio (antikvarno sam ih dobio nakon dvogodišnjeg traganja po njemačkim knjižarama)." S. ZIMMERMAN, Putem života, 72. Slično je (posudbom i kupovanjem) nabavljao i knjige iz psihologije, kako se vidi iz njegove korespondencije s Elzom Kučera: NSK, R4771b, pismo Stjepana Zimmermanna Elzi Kučera, 1932.? Usp. i HDA, fond Blaž Jurišić, kut. 8, pismo br. 2244, Stjepan Zimmermann Blažu Jurišiću, 6. 12. 1934. 
slioce koji će presudno utjecati na filozofiju egzistencije, Husserla i Schelera. ${ }^{34}$ Međutim, iz spomenutog razloga razilaženja u mišljenju, Heideggera i Jaspersa u međuratnom razdoblju gotovo nikada ne spominje. ${ }^{35}$ Zasigurno su mu Jaspersova sekularna znanstvena psihijatrija i njegova filozofija egzistencije te Heideggerova fundamentalna ontologija (a time i njegova reinterpretacija Kanta u takvu ključu), u kojima je smrt postala odrednica ovozemaljskoga, umjesto onozemaljskoga života, bile neprihvatljive. Kada Zimmermann spomene Heideggera ili Jaspersa, onda su njegove izjave, nadahnute oprekom između njihove „filozofije života" i njegove novoskolastičke filozofije (vječnoga) života, kratke i oštre:

Suvremena kriza duha, koju već nazivamo agonijom, sastoji [se] u kaosu na području spoznajne orijentacije o životu. Izgubljena je smjernica u snalaženju na putovima života. Heideggerovska tragična eksistencija, Kierkegaardova tmurnost, Nietzscheovski rasizam, Marxov ekonomski kolektivizam - sve su to oblici današnjeg života, u kojima je nestao njegov smisao. Da takvu tvrdnju možemo postaviti, treba za to pružiti valjanu opravdanost. U tome je znanstveni zadatak filozofije života. Hoćemo li dakle dati nauku o smislu života, moramo tu nauku postaviti na logične temelje, a time će dobiti svoje opravdanje određeni smisao života. ${ }^{36}$

\section{Slično će napisati i u završnom razmatranju zbirke ogleda Kriza kulture (1943.):}

Banalnost skolastičkih protivnika zauzima kadgod tako zastrašujuće razmjere, da oni skolastičku filozofiju naprosto proglasuju bez dodira sa životom, - jer ju zastupaju uglavnom samostanci. Pritom oni čak zaboravljaju, da su teističku etiku (filozofiju život[a]) „uglavnom" zastupali već Platon i Aristotel, pa nebrojeni skolastici nesamostanci, i također neki neskolastički filozofi. Osim toga, ovi protuskolastici jamačno ograničuju filozofiranje o životu na onaj smjer novovječne filozofije, koji je u poviestnom nazivlju poznat kao „filozofija života“ $i$ „,filozofija eksistencije“; no time bi ukupna poviest filozofije postala više nego jedan torzo. (Kierkegaard - Dilthey - Jaspers - Heidegger ne znače ipak jedinu filozofiju o životu.) To je, uostalom, samo jedan primjer utopljeničke slamke, o koju se vješaju nepoznavaoci skolastičke filozofije, kako bi time nadomjestili odsutnost kritičke spreme u zastupanju ateističkog nazora o životu. ${ }^{37}$

34 Zimmermann pozitivno navodi Husserla već 1918. (iako, bio to tipfeler ili ne, piše Hasserl: S. Zimmermann, „Znanstvena vrijednost metafizičke spoznaje“, 198), u kontekstu potvrde „skolastičke nauke“ od strane intencionalne psihologije. Scheler mu je zanimljiv kao katolički mislilac, iako ga i kritizira. Usp. Istı, „Fenomenologija religije“, Bogoslovska smotra, 12/1924., 489-491.

35 Ivan Čehok tvrdi da je Zimmermann navodio Jaspersa u bibliografiji djela Duševni život (1932.) - međutim, Jaspersa u bibliografiji toga djela nema. Usp. I. Čенок, „Filozofijska ostavština“, 196; Stjepan Zıмmermann, Duševni život, Zagreb 1932., 305-306. Jedan od rijetkih koji je na hrvatskome jeziku prikazao Jaspersovu filozofiju u međuratnom periodu bio je budući ustaški ministar Julije Makanec. On je oduševljeno prikazao Jaspersovu knjigu Die geistige Situation der Zeit (1931.) kao ,apel na čovjeka, da se sjeti, da je u velikoj mjeri on sam tvorac svoje sudbine, tvorac svojih katastrofa i pobjeda", što sigurno nije bilo u skladu s Zimmermannovim teološkim shvaćanjima. Usp. Julije MaKanec, „Jaspersova filozofija današnjice“, Hrvatska revija, 8/1935., 252-258, 320-325.

36 Stjepan Zimmermann, Filozofjja života, Zagreb 1941., 272. Predgovor knjizi pisan je na Duhove 1941., ali je ona rezultat Zimmermannovih promišljanja iz međuratnog perioda.

37 Isti, Kriza kulture. Kulturno-filozofijske studije iz suvremene socijalne filozofije, Zagreb 1943., 267-268. Radi se o zbirci ogleda koji su, kao i Filozofija života, dobrim dijelom produkt Zimmermannovih razmišljanja iz međuratnog perioda. 
Ovakvi su Zimmermannovi stavovi identični onima u djelu Jaspersov egzistencijalizam, ${ }^{38}$ u kojemu će također tematizirati problem smrti. ${ }^{39}$ Treba napomenuti da su pored filozofskih nesuglasica postojala i političko-ideološka razilaženja s Heideggerom jer je Zimmermann, „čim su počeli Hitlerovi progoni“, iz protesta prekinuo svaku suradnju s Društvom prijatelja Njemačke, koje je sâm utemeljio u Jugoslaviji, a 1941. godine, nekoliko mjeseci nakon proglašenja Nezavisne Države Hrvatske, vidjevši potpunu nemogućnost da učini bilo što dobroga u toj marionetskoj tvorevini, i s ustašama. ${ }^{40}$

\section{ZAKLJUČAK}

Početkom 20. stoljeća europski su filozofi dobrim dijelom svoj nazor određivali prema novokantovstvu kao prevladavajućoj paradigmi u filozofiji. Ono je uključivalo brojna pitanja koja su se, među ostalim, ticala metafizike, spoznajne teorije, etike i psihologije, u što je bila uključena i tema smrti. Prirodno je stoga da su sve spomenute teme u međuratnome periodu spajale Heideggera i Jaspersa, kao znamenite predstavnike njemačke filozofije egzistencije, i Stjepana Zimmermanna, koji će poslije Drugoga svjetskog rata dovršiti djelo Jaspersov egzistencijalizam. Međutim, dok je Heidegger pozitivno vrednovao Kantovo nasljeđe kroz prizmu fundamentalne ontologije, koja je bila u temelju njegove filozofije, i dok je Jaspersov egzistencijalizam dobivao poticaje iz njegova znanstvenog bavljenja psihijatrijom, Zimmermann je u duhu skolastičke filozofije posve pobijao Kanta, a psihologijom bavio se zbog njezinih implikacija na kršćanski nauk, pogotovo na pitanje duše i slobodne volje. Iz toga proizlazi i drugačije shvaćanje smrti, koja je u Heideggera i Jaspersa odred-

38 Isti, Jaspersov egzistencijalizam, sv. 1, 608: „Šta Jaspers drži o kršćanskom vjerniku, vrlo dobro znamo, - dosta je podsjetiti na njegova bazelska predavanja četrdesetsedme (Der philosophische Glaube). Nije li tamo jasno rekao, da treba napustiti religiju, koja u Isusu vidi Boga? A za objavljene istine, u koje kršćanin vjeruje, nije li rekao da smatrati njihovo važenje ekskluzivnim, znači za ljude zlo (Unheil), i da je takva pretenzija smrtonosna (tödlich)?" Više o odnosu Zimmermanna prema Jaspersu u citiranome djelu v. Željko PAvić, „Čovjekovo opstojanje između egzistencije i transcendencije. Zimmermannova rasprava s filozofijom egzistencije K. Jaspersa“, Zivot i djelo Stjepana Zimmermanna (ur. Vladimir Stipetić), Zagreb 2002., 89-123. Pavić zaključuje da Zimmermann „nije uspio pokazati onu otvorenost za komunikaciju, nego se u mnogim slučajevima zadržao na pukom etiketiranju Jaspersove pozicije. (...) Monološki ton, koji često odzvanja Zimmermannovim interpretacijama, nije dopustio da se čuje glas Drugog, a time niti to da nešto važi protiv njega, odnosno protiv njegove vlastite filozofske pozicije." Isto, 122.

39 NAZ, SZ, kutija "Jaspers“, Jaspersov egzistencijalizam, sv. 2. Ovaj neobjavljen drugi svezak sadrži više od 600 stranica strojopisnoga teksta, a pisan je u obliku dijaloga između trojice filozofa: egzistencijalista Jaspersove orijentacije, filozofa života i novoskolastika. Već na drugoj stranici filozof života pita egzistencijalista u čemu nalazi „tamne, negativne strane života“, na što mu ovaj odgovara: „Ja mogu svakog trenutka biti mrtav!“ Tema smrti vraća se i dalje na različitim mjestima u dijalogu $(285,331,410,458)$. Dakako, smrt je u Zimmermannovu djelu uvijek povezana s pitanjem postojanja Boga, besmrtnosti duše i kršćanske etike, što uvijek povlači njegove stare probleme iz spoznajne teorije (a time i Kantove filozofije), psihologije, noetike itd. Na str. 154 tako novoskolastik tvrdi da u pitanju postojanja Boga „dobiva svoje pravo značenje smrt! Sad je posve jasno kako čovjek strepi pred smrću - ne samo kao fizičkom prestanku života, nego u moralnom značenju, jer se čovjek pita: kako li će mi biti suđeno na pragu posmrtnog života?" Slično i na str. 219 novoskolastik tvrdi kako, s obzirom na to da postoje slučajevi kada zločince njihovi zločini čine sretnima, „dok moralno vrijedan čovjek i stradava: mora biti posmrtni život, primjeren moralnosti pojedinca, kao njegova nesreća ili sreća“.

40 S. Zimmermann, „Autobiografske zabilješke iz doba rata i poslije rata“, Humanizam i totalitarizam, 21-22, 28-29. Njegov javni napad na ustašku strahovladu bio je vrlo znakovit u ogledu nazvanom „Kako će filozofija kulture prosuđivati našu sadašnjost?“, Kriza kulture, 68-112. 
nica života na ovome svijetu, dok je ona u Zimmermanna tek biološka činjenica i prijelaz prema životu poslije smrti.

Iz svega izloženog u ovome radu, moguće je složiti se s time da je Jaspersovo „mišljenje kasna tema Zimmermannove filozofije “" ${ }^{41}$ ali se idejni izvori Zimmermannova polemičkog, opsegom najvećeg i do danas u punom obujmu neobjavljenog djela Jaspersov egzistencijalizam, koje je dovršeno nakon Drugoga svjetskog rata, nalaze već u međuratnom razdoblju, u razlici filozofskih nazora, a time i različitom shvaćanju smrti Zimmermanna s jedne te Heideggera i Jaspersa s druge strane.

\section{$\cos$}

\section{Literatura}

\section{Izvori}

Hrvatski državni arhiv

Fond Blaž Jurišić (HR-HDA-803)

Nacionalna i sveučilišna knjižnica u Zagrebu

R4771b: Korespondencija Elza Kučera - Stjepan Zimmermann

R4836b: Korespondencija Stjepan Ivšić - Stjepan Zimmermann

R6125a: Korespondencija Zdenko Vernić - Stjepan Zimmermann

Nadbiskupijski arhiv u Zagrebu

Ostavština Stjepana Zimmermanna

\section{Primarna literatura}

Martin Heidegger, Gesamtausgabe, I: Veröffentlichte Schriften 1910-1976, sv. 2: Sein und Zeit, Frankfurt am Main 1977.

Martin Heidegger, Gesamtausgabe, I: Veröffentlichte Schriften 1910-1976, sv. 3: Kant und das Problem der Metaphysik, Frankfurt am Main 1991.

Martin Heidegger - Karl Jaspers, Briefwechsel 1920-1963, Frankfurt am Main 1990.

Karl Jaspers, Philosophie, sv. 1: Philosophische Weltorientierung, Berlin 1956.

Karl Jaspers, Philosophie, sv. 2: Existenzerhellung, Berlin 1956.

Blaž Jurišić, Dnevnik Blaža Jurišića (prir. Biserka Rako), Zagreb 1994.

Julije MaKaneC, „Jaspersova filozofija današnjice“, Hrvatska revija, 8/1935., 252-258, 320-325.

Max Scheler, Gesammelte Werke, sv. 2: Formalismus in der Ethik und materiale Wertethik, Bern 1966.

Max Scheler, Gesammelte Werke, sv. 9: Späte Schriften, Bern 1976.

Stjepan Zimmermann, Duševni život, Zagreb 1932.

Stjepan Zimmermann, „Fenomenologija religije“, Bogoslovska smotra, 12/1924., 489-491.

$\overline{41}$ I. ČEнок, „Filozofijska ostavština“, 196. 
Stjepan Zimmermann, Filozofija života, Zagreb 1941.

Stjepan Zimmermann, Humanizam i totalitarizam, Virovitica 2003.

Stjepan Zimmermann, „Ideologija kršćanstva“, Bogoslovska smotra, 18/1930., 407-414.

Stjepan Zimmermann, Jaspersov egzistencijalizam. Karl Jaspers prema religiji, Zagreb 2002.

Stjepan ZimmermanN, „J. Hessen. Die Religionsphilosophie des Neukantianismus. 2. izd. Herder", Bogoslovska smotra, 12/1924., 504-505.

Stjepan Zimmermann, Kant i neoskolastika, sv. 1: Sustavno-kritički, Zagreb 1920.

Stjepan Zimmermann, Kant i neoskolastika, sv. 2: Studije, Zagreb 1921.

Stjepan Zimmermann, „Kantova i skolastička teorija uzročnosti“, Bogoslovska smotra, 7/1916., $136-155,237-253$.

Stjepan Zimmermann, Kriza kulture. Kulturno-filozofijske studije iz suvremene socijalne filozofije, Zagreb 1943.

Stjepan Zimmermann, „Metafizička ideologija“, Bogoslovska smotra, 7/1915., 291-301.

Stjepan Zimmermann, „Moral i religija u Kantovoj filozofiji“, Bogoslovska smotra, 5/1914., 122 139, 270-289, 369-384.

Stjepan Zimmermann, „Novi udžbenik za eksperimentalnu psihologiju“, Bogoslovska smotra, 7/1916., 73-85.

Stjepan Zimmermann, „O načelu uzročnosti“, Bogoslovska smotra, 13/1925., 144-155.

Stjepan ZimmermanN, „O slobodnoj volji“, Bogoslovska smotra, 6/1915., 33-50, 149-169, 228 249, 341-361.

Stjepan Zimmermann, „Pojam istine u Kantovoj i skolastičkoj filozofiji“, Bogoslovska smotra, 8/1917., 17-27, 121-131.

Stjepan Zimmermann, Putem života. Autoergografija, Zagreb 1945.

Stjepan Zimmermann, „Sa područja filozofije“, Bogoslovska smotra, 12/1924., 370-375.

Stjepan Zimmermann, „Teleološki princip u Kantovoj i skolastičkoj filozofiji“, Bogoslovska smotra, 8/1917., 197-209, 301-315.

Stjepan ZimmermanN, „Volja kao faktor u duševnom životu“, Bogoslovska smotra, 6/1915., 388 397.

Stjepan ZimmermanN, „Vrijednost deontološkog dokaza za egzistenciju Božju“, Bogoslovska smotra, 12/1924., 273-285.

Stjepan Zimmermann, „Znanstvena vrijednost metafizičke spoznaje“, Bogoslovska smotra, 9/1918., 1-7, 97-102, 193-202, 275-279.

Stjepan Zimmermann, „Znanje i vjera u Kantovoj filozofiji“, Bogoslovska smotra, 5/1914., 13-26.

\section{Sekundarna literatura}

Frederick Charles BeIser, The Genesis of Neo-Kantianism, 1796 - 1880, Oxford 2014.

Frederick Charles BeIser, „Weimar Philosophy and the Fate of Neo-Kantianism“, Weimar Thought. A Contested Legacy (ur. Peter A. Gordon i John P. McCormick), Princeton 2013., 115-132.

Ben Bradley - Fred Feldman - Jens Johansson, „Introduction. Philosophy of Death“, The Oxford Handbook of Philosophy of Death (ur. Ben Bradley, Fred Feldman i Jens Johansson), Oxford 2013., 1-4.

Ulrich Claesges, „Husserl, Edmund“, Neue Deutsche Biographie, sv. 10, Berlin 1974., 87-89

Ivan Č̈нок, „Filozofijska ostavština Stjepana Zimmermanna“, Prilozi za istraživanje hrvatske filozofske baštine, 19/1993., 193-207. 
Matko Globačnik, Izazov skepticizma. Utjecaj Humeove metafizike i moralne filozofije u Europi 18. stoljeća, Zagreb 2016.

Ljudevit HanžEx, „Zimmermannova polemika s Vernićem i Lachom“, Prilozi za istraživanje hrvatske filozofske baštine, 39/2013., 315-328.

Wolfhart Henckmann, „Scheler, Max“, Neue Deutsche Biographie, sv. 22, Berlin 2005., 644-646.

Ivan Kordić, „Bitak za smrt kao prolaz prema istini bitka“, Bitak i vrijeme. Interpretacije (ur. Damir Barbarić), Zagreb 2013., 127-159.

Karl Lehmann, Der Tod bei Heidegger und Jaspers, Heidelberg 1938.

Josip Lisac - Eduard Hercigonja, „Ivšić, Stjepan“, Hrvatski biografski leksikon, sv. 6, Zagreb 2005., 208-210.

Željko PAvić, „Čovjekovo opstojanje između egzistencije i transcendencije. Zimmermannova rasprava s filozofijom egzistencije K. Jaspersa“, Život i djelo Stjepana Zimmermanna (ur. Vladimir Stipetić), Zagreb 2002., 89-123.

Želimir Pavlina, „Bujas, Ramiro“, Hrvatski biografski leksikon, sv. 2, Zagreb 1989., 451-453.

Karl Pöggeler, Heidegger in seiner Zeit, München 1989.

Ivan TADIĆ, Filozofska misao Stjepana Zimmermanna. Izabrani vidovi s bibliografijom, Split 2010. Richard Wisser, „Jaspers, Karl“, Neue Deutsche Biographie, sv. 10, Berlin 1974., 362-365.

\section{Mrežna stranica}

http://arhinet.arhiv.hr/details.aspx?ItemId=3_11205

\section{$\cos$}

\section{DeATH in The German PHILOSOPHy OF EXISTENCE OF THE INTERWAR PERIOID AND ITS RECEPTION IN STJEPAN ZIMMERMAN'S THOUGHT}

The author examines the significance of death in the philosophy of Martin Heidegger and Karl Jaspers, the notable representatives of German philosophy of existence, as well as the way it was received in the thought of Stjepan Zimmerman, within the historical context of the interwar period, when all three thinkers lived and worked. This paper uses the aforementioned topic as a starting point, in order to reveal the notional and historical roots of Zimmerman's magnum opus Jaspersov egzistencijalizam (Jasper's Existentialism), which remains unpublished in its entirety to this day. The three thinkers shared an interest in Kant's philosophical legacy with all its implications, as well as professional involvement in psychology, or rather, psychiatry, and both of those factors directly shaped their views on death. The research for this paper has shown that Heidegger's interpretation of Kant's philosophy based on fundamental ontology, as well as Jaspers's work in psychiatry were at odds with Zimmerman's understanding of Kant, shaped in the Neo-Kantian tradition, and the fact that his work in psychology was religiously motivated. Therefore, Heidegger and Jaspers's understanding of death as an existential determinant of life had to be wholly unacceptable to Zimmerman, who regarded death as a biological fact and a transition into life after death. Adding to this the differences in ideology that he had with Heidegger post-1933, the rare insights 
into Zimmerman's opinions on Heidegger and Jaspers in the interwar period reveal a substantial animosity. This attitude will also be prevalent in Jaspers's Existentialism, the book Zimmerman completed after the Second World War.

Key words: Karl Jaspers, Martin Heidegger, Stjepan Zimmerman, death, the philosophy of existence, Neo-Kantianism, Catholic theology 



\section{4. \\ SMRT I MEĐUSTANJE \\ U RADOVIMA JUANA RULFA \\ I DŽEVADA KARAHASANA}

\section{Nikola Petković}

UDK: 821.134.2(721/727)Rulf, J.:821.163.4(497.6)Karahasan, Dž.

Izlaganje na skupu

Sažetak: Članak je poredbena analiza dvaju romana koja povezuje lutajući motiv smrti kao nedovršenog egzistencijalističkog i etičkog procesa te ontološkog stanja. Prvi je roman klasik meksičke književnosti dvadesetog stoljeća, Pedro Paramo Juana Rulfa (1955.), a drugi Noćno vijeće Dževada Karahasana (2005.). Iako pripadaju dvjema kulturama, od kojih je svaka prošla specifičan oblik kolonizacije i imperijalističkih intervencija u imaginaran kulturni kontinuitet, ova su dva djela jedno drugom slična - fascinantna preklapanja protežu se od same radnje, preko glavnih protagonista, do tretiranja smrti kao međustanja (engl. interim state). Literarna mizanscena obaju romana ispunjena je bićima koja obitavaju na granici dvaju svjetova i čiji se identitet i integritet stalno propituju. Analitički kategorijalni aparat oslanja se na rad filozofa Stephena T. Davisa.

Ključne riječi: međustanje, duše u boli (španj. almas en pena), granica, magični realizam

[? nastojanju da objasni, ali i da obrani temeljni tradicionalni koncept uskrsnuća, filozof Stephen T. Davis ${ }^{1}$ poziva se na ranokršćanske autore. ${ }^{2}$ Za potrebe opisa filozofijskog dijela argumenta namjerno izostavljam element vjere i pretpostavljam istovremeno deskriptivan i sadržajan koncept uskrsnuća kao izvorni model za bilo koju kontekstualno nadolazeću analizu njegovih ponuđenih inačica.

Davis razlikuje tri osnovna gledanja na privremenu bestjelesnost, pritom ih istovremeno propitujući i iz filozofijske i iz teološke perspektive. Prvi nas uči da nakon smrti duša nastavlja postojati na neko vrijeme (do uskrsnuća), i to u međustanju, no bez tijela. Drugo gledanje sugerira da će se u trenutku ponovnog pojavljivanja u svijetu tijelo podignuti iz zemlje i nanovo ujediniti s dušom. Treća verzija uskrsnuća govori o transformaciji tijela u

1 Radi se o tekstu „Traditional Christian Belief in the Resurrection of the Body“, objavljenome 1988. u časopisu New Scholasticism (kasnije preimenovanu u American Catholic Philosophical Quarterly). Ovdje citiram prema: Stephen T. Davis, „Traditional Christian Belief in the Resurrection of the Body“, Language, Metaphysics, and Death (ur. John Donnelly), New York 1994., 320-343.

2 Poziva se na autoritete iz 2. stoljeća, posebno se oslanjajući na argumente Augustina i Tome Akvinskog. 
„glorificirano tijelo“. ${ }^{3}$ No, kako Davis pregledno izlaže i kontekstualizira „opća mjesta kulture" ne bi li se približio svom središnjem argumentu, ne vjeruju svi kršćani u to da postoji neko određeno međustanje u kojemu se osobe nalaze u međuvremenu - u periodu između smrti i uskrsnuća. Dapače, naglašava autor, postoje mnoga teološka razilaženja u pristupu problemu međustanja. ${ }^{4}$

Bez obzira na to kojem se konceptu priklonili, Davisova je nakana obrade teme (hipoteza) jasna: duša je u međustanju svjesna. Biblijska metafora sna, naravno, nema ambicije biti doslovna. A to ne može biti (osim što je metafora) jer je gotovo nemoguće smisleno objasniti kako to nešto bestjelesno može biti prisutno pred Bogom, ako je ne samo lišeno tijela nego i svijesti o sebi. Recimo, kako to ističe Davis, kada Bog kaže: „Danas ćeš sa mnom biti u raju“, nesvjesni adresat ne može nikako pojmiti niti osjetiti prisutnost Boga. A što se, pak, tiče sna, on je suštinski tjelesna aktivnost pa nije logički koherentno sugerirati da duša može spavati i sanjati. ${ }^{5}$ Biti bez tijela za ljudsko biće abnormalno je stanje. ${ }^{6}$ Osim što bestjelesnost uključuje izostanak esencijalne ljudske tjelesnosti, ona za sobom povlači i izostanak spacijalnosti bića, odnosno nemogućnost njegova lociranja u prostoru. Barem u onim oblicima prostorvremena koji su primjereni našoj kogniciji. Lišena tijela-u-prostoru, kao i prostoraza-tijelo, bestjelesna bića ne mogu pojmiti niti percipirati okolinu - ono što ih tako lišene staništa okružuje - barem ne onim osjetilima koja mi rabimo u percepciji i za percepciju svega što nas u prostoru i vremenu okružuje. Takva bića, ističe Davis, nisu u stanju iskusiti tjelesne boli ni užitke: „Ne mogu se baviti tjelesnim aktivnostima. Ići u šetnju, obući se..."7

No, ovo bi bilo jednostavno kada bismo argumente za neuvjerljivost bestjelesnosti bića ostavili u ovakvom međustanju izvoda. Stvari se, naravno, kompliciraju. Ako kažemo i mislimo „duša“, pritom djelomično misleći na one radnje i aktivnosti koje bismo u sekularnom - dakle, znanstvenom - diskursu klasificirali kao „mentalne“, tada tvrdnja da „naša duša preživljava smrt uključuje i tvrdnju da naša mentalna stanja i svojstva također nadživljuju smrt". ${ }^{8}$ A to bi dalje značilo da se osobe u međustanju mogu percipirati kao bića $s$ iskustvima, vjerovanjima i uvjerenjima, željama, znanjem, memorijom (koja uključuje i predsmrtna sjećanja, dakle ona stečena za života), osjećajima, mislima, jezikom,... ' Ukratko - „sve što čini ono što mi nazivamo osobnošću“.10

3 S. T. Davis, „Traditional Christian Belief in the Resurrection of the Body“, 323.

4 Neki, recimo, vjeruju u to da je međustanje po prirodi purgatorijalno. Neki, pak, to vjerovanje izričito odbijaju. Neki vjeruju da je duhovna promjena, odnosno pokajanje, moguća za vrijeme međuvremena međustanja. Neki u to ne vjeruju. Neki, pak, vjeruju u to da u međustanju duša miruje, odnosno spava te da nije aktivna kao takva, a samim time ni svjesna vlastitog međustanja.

5 S. T. DAvis, „Traditional Christian Belief in the Resurrection of the Body“, 324.

6 Davis dalje objašnjava suptilne razlike u konceptima privremene bestjelesnosti i besmrtnosti. Biti bez tijela za osobu je abnormalno jer postoji jasna razlika između privremene bestjelesnosti i besmrtnosti duše, jer „ova druga doktrina [ona o besmrtnosti duše - op. a.] pretpostavlja da je bestjelesnost ako ne ispravno, a onda najbolje moguće stanje u kojemu se ljudsko biće (osoba) može naći [barem ako, što se filozofijske tradicije tiče, u toj doktrini slijedimo Platona - op. a.]. No teorija koja nas zanima počiva na tvrdnji: bestjelesnoj duši nedostaju mnoga svojstva i mogućnosti koje su primjerene ljudskim bićima i za njih normalne. Bestjelesno postojanje je oblik minimalne egzistencije." Usp. Isto. Sve citate s engleskog jezika preveo N. P.

7 Isto, 325.

8 Isto.

9 Što je, zanimljivo, slučaj s likovima iz obaju romana o kojima je u ovome radu riječ.

10 S. T. DAvis, „Traditional Christian Belief in The Resurrection of The Body“, 325. Filozof H. H. Price u svom znamenitom eseju „Survival and the Idea of 'Another World'“, izvorno predstavljenu kao predavanje u povodu sedamnaeste 
Toma Akvinski, na kojega se Davis u velikom dijelu argumenta poziva, također govori u prilog minimalne egzistentnosti osobe u međustanju, tvrdeći da je osoba u međustanju toliko ograničena i uskraćena da joj je nemoguće doseći sreću u njezinoj punoći. A tomu je tako jer nitko kome nedostaje bilo koji segment savršenosti ne može biti u potpunosti sretan. Jer, ako nekome nešto nedostaje, taj netko će - dok je u stanju nedostatnosti i lišenosti - uvijek imati neispunjenih želja, nedorečenosti, nedovršenosti... Biti bez tijela - ovdje se argument zaoštrava jer postaje decidiran - u suprotnosti je sa samom prirodom duše. Toma Akvinski priznaje mogućnost da stanje bestjelesnosti postoji, ali samo kao privremeno. Naglašava, međutim, da je jedini istinski blagoslov koji osoba može iskusiti onaj do kojega se dolazi nakon ponovnog sjedinjenja duše s tijelom - nakon opetovanog utjelovljenja osobe kao cjeline bića (engl. reembodiment). Ili, drugim riječima, u činu uskrsnuća. Akvinac izrijekom tvrdi: „Čovjek ne može dosegnuti sreću u njezinoj punoći ukoliko se duša ponovno ne sjedini s tijelom." ${ }^{11}$

Kako je razvidno iz aplikativnog dijela ovoga rada, u kojemu se filozofijsko-teološki koncepti ogledaju u dvama književnim djelima, Pedro Páramo meksičkog klasika Juana Rulfa $^{12}$ i Noćno vijeće Dževada Karahasana, ${ }^{13}$ ono što je važno za primjenu tradicionalnog kršćanskog vjerovanja u uskrsnuće jest sinegdohalna „redukcija“ koncepta međustanja kako je ono prikazano u njihovoj prozi. Ona nije toliko usko vezana za generalni koncept uskrsnuća i povratka koliko na upokojenje duša na koje protagonisti ovih dvaju romana nailaze na svome putu-na-dolje. ${ }^{14}$

Prije nego što se obratim fikciji, pojednostavnio bih argument međustanja koje je generalno stanje svih umrlih, bilo u kršćanskoj bilo u islamskoj tradiciji, barem onako kako to u svojoj, doduše, interkulturalnoj i intertradicijskoj fikciji vidi Karahasan. Sažeto rečeno: duša čuva osobni identitet do Sudnjega dana, kada će se opet spojiti s tijelom. Da bi do te rekonekcije došlo, kada je riječ o pitanju identiteta osobe, koja je, prema ranokršćanskoj tradiciji, i duša i tijelo, ne smije doći do prekida tog identiteta. Za taj kontinuitet jamči duša na pomalo nekonzistentan, ako ne i paradoksalan način: duša, koja sama po sebi nije osoba (jer da bi bila osoba, treba biti cjelina, a nije cjelina jer je samo duša; ona je, dakle, dio cjeline korporalnog i astralnog). Ona je jamac i čuvar osobnog identiteta cjeline osobe koja se na Sudnji dan mora pojaviti, opet kao cjelina. Ovdje je važno naglasiti da nam učenje izvornog kršćanstva nedvosmisleno govori kako ne samo da se vraćamo svi nego se vraćamo i kao cjelina koja se manifestira u jedinstvu duše i tijela.

godišnjice Society of Psychical Research te objavljenu u Proceedings of the Society of Psychical Research (siječanj 1953.), veoma uvjerljivo zagovara tezu da bestjelesne duše mogu biti svjesne svojih egzistencija i svoje uzajamnosti, da mogu međusobno komunicirati telepatijom te da mogu imati snovite (ne tjelesne) percepcije svijeta. Usp. H. H. PrICE, „Survival and the Idea of 'Another World'“, Language, Metaphysics and Death, 278-301.

11 S. T. DAvis, "Traditional Christian Belief in The Resurrection of The Body“, 325. Izvorno ovu tvrdnju nalazimo u spisu Summa contra gentiles, Knjiga IV, 79.

12 Juan Rulfo, Pedro Páramo, Zagreb 2007.

13 Dževad Karahasan, Noćno vijeće, Zagreb 2005.

14 O ovim sam romanima prethodno već govorio na znanstvenom skupu Sjene gradova: Karahasanovo književno i filozofsko djelo, održanu u Sarajevu, 8. svibnja 2010., ali iz drugačije perspektive - one komparativne, koja je isticala fascinantnu podudarnost u ovim dvama djelima koja rubno egzistira dodirujući koncept citatnosti i intertekstualnosti, zajedno s onim kolegijalne posudbe ideja. Izvorno izlaganje objavljeno je u specijalnom prilogu časopisa Odjek. Usp. Nikola Petković, „Śljiva i agava, ili o univerzalnosti kulturalne geografije“, Odjek, ljeto 2010., 34-37. 
U rigidnoj logici, koja je nit vodilja tradicije filozofije uopće, a analitičke filozofije posebno - dijela filozofije iz kojega nedvosmisleno proizlazi Davisova misao koja nam služi kao teorijska matrica za čitanje ovih dvaju romana - ovo bi se zvalo kontrarnošću predikata. Drugim riječima, ako žuto nije zeleno, ako malo nije veliko, tada duša kao ne-osoba nikako konzistentno ne može čuvati osobni, dakle i tjelesni, identitet i integritet još-ne-uskrslog. A da bi obavila ulogu čuvara i jamca kontinuiteta identiteta, jasno je da do prekida identiteta ni u jednom trenutku međustanja ne smije doći.

Budući da teorija (osim ako joj je nakana zaspati u metateoriji) i nema nekog smisla ako se njezin kategorijalan aparat barem dijelom ne da aplicirati izvan njezina izvornog opsega i dosega, pogledajmo kako se izloženi koncepti dadu primijeniti na dijelove dviju knjiga iz dviju uzajamno udaljenih kultura, od kojih se svaka na svoj način bavi međustanjem. Na početku knjige meksičkoga pisca Juana Rulfa Pedro Páramo glavni protagonist Juan Preciado spušta se u zaselak Comalu, ne bi li ondje našao izgubljenog oca i zaključio da je svijet kao biljka agave. Kada je Juanu majka rekla da u Comali živi njegov otac, sin joj je obećao da će ga potražiti čim ona umre. Na samrti rekla mu je: „Nemoj da ga ne odeš posjetiti... Sigurna sam da će mu biti drago da te upozna. ${ }^{\text {"15 }}$ No, trenutak prije toga rekla je: „Nemoj ga ništa moliti. Zahtjevaj naše. Ono što mi je bio obavezan dati i nikad mi nije dao... Zaborav u koji nas je bacio, sine, skupo mu naplati. Ne pitaj ga ni za što što nije naše. ${ }^{\text {"16 }}$ Ostatak romana Juana Rulfa, kojim je nezapaženo započeo latinoamerički magični realizam, ${ }^{17}$ makabristički je zapis o potrazi za osobnim identitetom Juana Preciada, kao i za identitetom kolonijalnog Meksika.

Na početku knjige Dževada Karahasana Noćno vijeće glavni protagonist Simon Mihailović spušta se u Foču niz brdo Tabija, „prema gradu što je ležao pred njim u dolini“ “ ${ }^{18}$ ne bi li ondje potražio bivšega i jedinog istinskog sebe u bespućima osobnih i kolektivnih identiteta uvijek ranjene Bosne i zaključio da je svijet kao šljiva. Što se, pak, tradicije bosanskog magičnog realizma tiče, čiju magiju - kao, uostalom, i onu Latinske Amerike - kao magiju vide uglavnom „omađijanoj“ kulturi izvanjski drugi, Karahasana bismo mogli mirne duše posjesti na klupu pored Rulfa, Reinalda Arenasa, Gabriela G. Marqueza, ali i, primjerice, Svetislava Basare.

Što se tiče Juana Preciada i Simona Mihailovića, da je živ i da se imalo prilike pitati Jorgea Luisa Borgesa, jer nema knjige koju nije pročitao, u nekom međustanju između kolonijalnog Meksika i uglavnom kolonizirane Bosne, zamišljam, rekao bi: dvojica su se književnih likova uputila unatrag i spiralno nizbrdo, e da bi se ponovila jedna scena iz književnosti.

Knjiga Dževada Karahasana Noćno vijeće roman je čija umnožena i uslojena značenja, po prirodi zadaće pisma kojim je ispisan, bježi klasifikacijama. Autor Metahistorije Hayden White Karahasanov bi roman zacijelo svrstao u književno-povijesni žanr tragedije. Domi-

15 J. Rulfo, Pedro Páramo, 9.

16 Isto.

17 Fenomen magičnog realizma iziskuje zaseban pristup. Zainteresirane upućujem na dvije knjige: Louis PARKINSON Zamora - Wendy B. Fabris (ur.), Magical Realism. Theory, History, Community, Durham - London 1995. te David Young - Keith Hollaman (ur.), Magical Realist Fiction. An Anthology, New York - London 1984. U potonjoj - jedinstveno inkluzivnoj antologiji - praksa pisanja magičnog realizma širi se i prostorno i vremenski, tako da je veoma zanimljivo da su u zbirku urednici uvrstili i pripovijetku Gost Vjekoslava Kaleba.

18 Dž. Karahasan, Noćno vijeće, 98. 
nantan trop kojim autor povjesničar, pišući ono što White kategorizira pod tragedijom, tretira književnu građu jest metonimija, dok je funkcija ovog dominantnog tropa da, u literariziranju iskustva svijeta, potonji reducira.

Užas dvaju romana upravo je poklapanje književnog materijala koji ih romanima čini s teorijsko-metodološkim „proročanstvom“ Haydena Whitea, koji i „našu“ i „njihovu“ tragediju kronološki locira u uvijek blisku budućnost: u nešto poput one „prošlosti koja nije prošla" i koju, u strahu da im u tom međustanju ne utekne, tako često zazivlju pjesnici s nama bliskih prostora, za koje volimo reći da su bivši; tako na planu imenovanja inzistirajući na međustanju u kojemu svi na paradoksalan, ali iskustveno realan način živimo u trajnom prezentu na putu u futur prošli. Pritom je nužno naglasiti da ovo „na ovim prostorima", nažalost, nisu gramatičke, nego egzistencijalne kategorije.

Ako i postoji izravna motivska povezanost Pedra Párama i Noćnog vijeća, teško bi se za nju moglo reći da je prostorna ili vremenska; naravno, ako prostor i vrijeme romana ne shvatimo kao kulturama proširen kronotop, prostorno-vremensku poveznicu koja nadilazi okvir pojedinog proznog djela i proteže se na dvije naoko razdvojene kulture. Točnije, u zajedničkom nazivniku njihove zamišljene i u Karahasanovu, kao i u Rulfovu pismu, literarno kodificirane tragedije.

Prostor koji je neomeđen i koji spaja predrevolucionarni jug Meksika (1910-e), kao i predratnu Bosnu (1990-e), samo je uvjetno kronološki pozicioniran. Tragično zajedništvo njihova vremena jest upravo u tragediji međustanja međuprostora nedovršenih prošlosti: $u$ povijesnom (trajnom) prezentu poviješću unesrećenih regija, kao što je to rubni jug američkog sjevera i marginalni jug Srednje Europe.

U romanu Dževada Karahasana Simon, nositelj križa dislocirane „kolektivne odgovornosti“ za tragediju, završi u podzemlju. U liminalnom svijetu suoči se $s$ nespokojnim i neupokojenim žrtvama raznih pokolja. U konkretnom slučaju, radi se o zločinima počinjenim u Foči od 1882. do 1992. Da bi se ne-do-kraja-umrli zauvijek smirili, nad njima treba netko neokaljan (u ovom slučaju Simon) ritualno, mišlju, činom volje, ponoviti umorstvo. Ako se ono, sad simbolički, dogodi na način na koji se u prošlosti zaista i dogodilo, tada će nevine žrtve naći vječni mir.

Pišući o Noćnom vijeću, Alma Sarajlić uočava frekvenciju motiva i toposa podruma. Kao motiv, ističe Sarajlić, podrum se upotrebljava 34 puta, dok se kroz topose podrumskih vrata javlja 12 puta, a kroz topose podrumskog svjetlarnika stropa i studeni jednom. Podrum je „kompozicijsko polazište 'put od', središte, 'put kroz' i ishodište, 'put ka'“. ${ }^{19}$ Podrum je, nastavlja autorica, ,podzemlje ili berzahaska faza proživljenja nakon smrti za izmučene duše žrtava brojnih zločina počinjenih nad Muslimanima u razdoblju od 1882. do 1992."20 Sâm Simon Mihailović graničan je subjekt, nekovrsni međuprostor-u-međuprostoru, koji se gotovo na mističan način veseli svom žrtvovanju. Simonov prijatelj Enver, eidolon kamonton ${ }^{21}$ prenosi Simonovoj ženi Barbari kako je „radosno iščekivao taj doživljaj kad je

19 Alma SARAjlić, Granični toposi i granične figure u djelima Dževada Karahasana, magistarski rad, Filozofski fakultet Univerziteta u Sarajevu, 2013., 17.

20 Isto, 19.

21 Eidolon je prilika, slika, sjena, utvara, nematerijalno (prividno) tijelo s potpunim oblikom onoga na koga treba nalikovati; eidolon kamonton stanovnici su podzemnog svijeta, sjene pokojnika, bića bez materijalnog tijela koja zadržavaju 
polazio u podzemlje, radovao se unaprijed tome što će mu se s njom konačno sjediniti oni najdublji dijelovi bića. Vjeruje ona to, to sasvim liči na njega. Na njih, i ona bi se rado prepustila svemu ako bi pri tome mogla njega tako doživjeti. Da se sjedine onim što je dublje od kostiju."22

Podrumska su vrata u Noćnom vijeću misteriozna. Iako nisu ni poduprta ni zatrpana, dapače, slobodna su, ona se ne mogu otvoriti; iza njih su „nekakvi valjda duhovi i glasovi koji su zaposjeli kuću“. ${ }^{23}$ Njihova je misterija i u tome da ih nikada zapravo nije bilo: „To ih zagledavanje nije umirilo jer im je potvrdilo da su vidjeli vrata koja, da je reda i pameti u svijetu, ne bi mogli vidjeti jer ih tamo, na onom zidu, nikad nije bilo." ${ }^{24}$ Vrata su granica koja Prvi dijeli od Drugog svijeta, granica povučena binarizmima hladno - toplo, gore - dolje, dok sâm prolaz kroz njih, ispostavit će se, vodi u podzemni svijet, u međuprostor neupokojenih:

Podzemlje se ukazuje Simonu svojom vizualnom, prostornom, formom: „Istog trenutka se taj zid rasvijetlio i kao rastvorio, tako da se pred Simonovim pogledom umjesto mračne plohe našao rasvijetljeni duboki prostor neodredivih dimenzija, kao neka ogromna građevina kvadratne osnove nad kojom je podignut vijenac u formi oktogona, a na taj vijenac onda oslonjena impresivna kupola. ${ }^{.25}$

U zaključku svojega rada Alma Sarajlić ističe činjenicu koja joj je esencijalna za čitanje romana, a ta je da iako su se u raznim fazama razvoja civilizacija vjerovanja o podzemnom svijetu razlikovala, zajedničko im je bilo to da je prostor iz kojeg izlaza nema, taman i hladan:

Žrtve koje se nalaze u podzemlju smještenom u Simonov podrum su za ovozemaljskog života bili muslimani tako da ovdje opisano podzemlje korespondira sa islamskim učenjima o kaburskom (grobnom) i onosvjetskom životu. Berzah jeste raka (kabur) u kojem čovjek boravi od trenutka smrti do Sudnjeg dana (...), a Karahasan o berzahu kaže da je: „mundus imaginalis“, svijet prikaza ili čistih slika, eidolona ili duša. U berzahu ne obitavaju ideje nego duše, zato to nije svijet vječnosti kao što nije ni vremeniti svijet materijalnih tijela, nego jedan svijet u kojem obitavaju bića na međustupnju između tijela i ideja, između materijalnog i inteligibilnog postojanja. ${ }^{26}$

Poput Simona Mihailovića, koji je i sâm jedno od bića međustanja između „materijalnog i inteligibilnog postojanja“, Juan Preciado nađe se u međuzemlju, gdje nailazi na duše u boli (španj. almas en pena), na ne-do-kraja-umrle žrtve kolonijalne izdaje Pedra Párama oca tiranina, silovatelja domorotkinja i ubojice autohtone kulture, s kojima razgovara dok i sâm ne shvati da je i on jedna od njih. Isto se dogodi i sa Simonom, koji na kraju romana smiren do nemoći siđe među mrtve.

sve osobine iz života na ovom svijetu, tako da izgledaju, osjećaju i misle onako kako su izgledali, osjećali i mislili ljudi u kojima su ti eidoloni obitavali. Usp. Dževad Karahasan, Knjiga vrtova, Sarajevo 2004., 98.

22 isti, Nó́no vijeće, 226.

23 Isto, 131

24 Isto, 159.

25 A. Sarajlić, Granični toposi i granične figure u djelima Dževada Karahasana, 22.

26 Isto, 28. 
(Među)prostor je Pedra Parama Comala, zaselak „pri kraju“ silaska Juana Preciada na putu (natrag) k sebi. Primjera koji tematiziraju međustanje duša u boli u knjizi ima mnogo. Navest ću samo neke:

Glasova, da. A ovdje gdje je zrak bio oskudan, čulo se bolje. Zadržavali su se u čovjeku, onako teški. Prisjetio sam se što mi je rekla majka: „Tamo ćeš me bolje čuti. Bit ću ti bliže. Iz veće ćeš daljine čuti glas mojih uspomena nego onaj moje smrti, ako je smrt ikada imala neki glas." Moja majka... živa. ${ }^{27}$

- Selo mi se izgubilo. Bilo je puno magle ili dima ili ne znam čega; ali znam da Contla više ne postoji. Cak sam prema svojoj računici, bio i dalje nego obično i nisam ništa našao. Dolazim ti to ispričati jer me ti razumiješ. Kad bih to rekao drugima u Comali kazali bi da sam lud, kao što su uvijek i govorili.

- Ne. Lud ne, Miguel. Sigurno si mrtav. ${ }^{28}$

- Jeste li živi, Damiana? Recite mi, Damiana!

I iznenada, našao sam se sam na tim pustim ulicama. Kroz prozore kuća otvorenih prema nebu, nazirale su se vitke stabljike trave. Oguljeni zidovi otkrivali su ispucanu nepečenu ciglu smekšanu od vlage.

- Damiana! - povikao sam. Damiana Cisneros!

Odgovorila mi je jeka: „....ana... neros! ...ana... neros...!“29

LEŽIM U ISTOME KREVETU u kojemu je prije puno godina umrla moja majka, opružena na istome tom madracu; ispod istoga pokrivača od tamne vune u koju smo se obadvije uvijale kad smo spavale (...) Čini mi se da još uvijek osjećam njeno ravnomjerno disanje; lupanje srca i uzdahe kojima me je uspavljivala. Cini mi se da osjećam tugu zbog njezine smrti...

Ali, to nije istina. (...)

Jer ne ležim samo na trenutak. Niti sam u krevetu svoje majke, već unutar crnoga sanduka poput onoga koji se koristi za pokapanje mrtvih. Jer sam mrtva. ${ }^{30}$

Ustala se i dovukla do mjesta na kojemu je stajao otac Renteria; gledao je u nju dok je rukama zaklanjala zapaljenu svijeću (...) Ponovo je zavladao mrak i ona je potrčala da se sakrije ispod svojih plahta.

Otac Renteria je rekao:

- Došao sam te utješiti, kćeri.

- Onda, zbogom oče - odgovorila je ona. Nemoj se vraćati. Ne trebam te.

I čula je kako se udaljavaju koraci koji su kod nje uvijek izazivali neki osjećaj hladnoće, drhtavice, ili, pak, straha.

- Zašto dolaziš k meni ako si mrtav?31

Pomalo jednako naoko pripovjedalački nehajno kao i u Karahasana, Rulfo završava svoj roman: na kraju, odbivši večeru koju mu želi pripremiti Damiana, oboljela i nesmirena du-

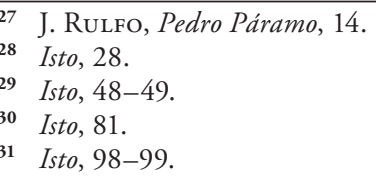


ša jedne od njegovih brojnih silovanih priležnica, Pedro se sruši na tlo i, smrvivši se poput pijeska, pretvori u ništa.

Jedan od neposrednih povoda najprije za povezivanje ovih dvaju romana, a onda za njihovo ogledanje u teoretiziranju međustanja, jest činjenica da se u komparativnom pristupu njihovoj interkulturalnoj komunikaciji zaista radi o namjernom „miješanju“ šljiva i agava. Dva teksta koji su nadahnuli ovaj pokušaj njihova svođenja na dokument globalne kulturalne tragike jako su slična. Toliko slična da se usuđujem tvrditi sljedeće: iako njihovi autori ne znaju jedan za drugoga, njihovi se tekstovi zasigurno dobro poznaju. Osim što dijele prostor i vrijeme kulturalnih poveznica, oni jednom jezivom preciznošću upućuju na opasnu činjenicu nedovršenih, njima zajedničkih, povijesti. Povijesti koje se, bez obzira na njihovu prostornu udaljenost - baratajući nikad dorečenom prijetnjom koje se ni pod koju cijenu ne smiju odreći jer iz nje crpe energiju - ponašaju po istom obrascu. Onome repetitivnosti ne samo literarnog i egzistencijalnog nego i kulturalnog međustanja.

Likovi obaju romana, zapravo, duše su u boli. Tako ih latino tradicija i naziva: almas en pena. Neupokojene, svaka za sebe i sve u svojim kulturama, definitivno su partikularan dio tradicionalnih vjerovanja u uskrsnuće. Na sinegdohalnoj razini one - možda preciznije govoreći, ipak njihove duše, koje se čitatelju objavljuju u prividu cjeline s tijelom - čekaju na spas i trenutak kada će netko od njih odagnati bol u suodnosu s duboko ljudskim radnjama, koje su ipak pretežno mentalne. One i Juanu Preciadu i Simonu Mihailoviću posreduju iskustva, vjerovanja, nade, razočarenja, iluzije, želje, znanja, sjećanja, unutarnje daleko više nego tjelesne osjećaje, iako u analiziranim tekstovima postoje naznake tjelesnih odnosa ili barem pokušaja tjelesnih odnosa, kao i silovanja. Ukratko, one posreduju osobnost.

Budući da se sad više ne radi „samo“ o filozofiji, o logici koja će ovdje nemilice, ali opravdano, inzistirati na argumentima principa kontrarnosti predikata, zaključak koji se odnosi na sinegdohalan i fikcionaliziran dio rasprave o međustanju, kao elementarnom ingredijentu tradicionalnih religijskih vjerovanja, mogao bi biti sljedeći: ako kad mislimo na dušu, mislimo na riječ kojom označujemo konstelaciju ljudskih aktivnosti (koje se u pravilu klasificira kao mentalne), tada dok tvrdimo da je naša duša ta koja nas uvodi u međustanje preživljavajući smrt u nastojanju da - iako sama po sebi nije osoba - održi kontinuitet našeg - tada u njegovoj cijelosti neprisutnog - osobnog identiteta, zapravo tvrdimo da je ono što nas za smrti drži na životu ono mentalno u nama.

Ovo bi, vratimo se na fikciju kojoj se teorija obraća, moglo postati tim zanimljivije ako znamo da istovremeno i u filozofijskoj i u teološkoj tradiciji, ali i u ovim dvama književnim djelima, svi u njima neupokojeni, napola tjelesno, ali uglavnom dušom govore u prilog argumentu filozofa H. H. Pricea koji, ponovimo to, tvrdi da bestjelesne duše mogu biti svjesne jedne drugih, svoga postojanja, da uzajamno mogu komunicirati (doduše, telepatijski) te da, u izostanku eminentno tjelesnog iskustva svijeta, to iskustvo može nalikovati snu.

No, potonje ne isključuje mogući sukus njihove nama literaturom posredovane tragike, boli i nesreće jer, kako kaže Toma Akvinski, čovjek ne može doseći sreću u njezinoj punoći ako se duša još jednom ne sjedini s tijelom. Međutim, tko nam može jamčiti da, govoreći ovo, Toma misli isključivo na koncept uskrsnuća? 


\section{$\cos$}

\section{Literatura}

Stephen T. Davis, „Traditional Christian Belief in the Resurrection of the Body“, Language, Metaphysics, and Death (ur. John Donnelly), New York 1994., 320-343.

Dževad Karahasan, Knjiga vrtova, Sarajevo 2004.

Dževad Karahasan, Noćno vijeće, Zagreb 2005.

Louis Parkinson Zamora - Wendy B. Fabris (ur.), Magical Realism. Theory, History, Community, Durham - London 1995.

Nikola Petкović, „Šljiva i agava, ili o univerzalnosti kulturalne geografije“, Odjek, ljeto 2010., 34-37.

H. H. Price, „Survival and the Idea of 'Another World'“, Language, Metaphysics, and Death (ur. John Donnelly), New York 1994., 278-301.

Juan Rulfo, Pedro Páramo, Zagreb 2007.

Alma SARAjLIć, Granični toposi i granične figure u djelima Dževada Karahasana, magistarski rad, Filozofski fakultet Univerziteta u Sarajevu, 2013.

David Young - Keith Hollaman (ur.), Magical Realist Fiction. An Anthology, New York - London 1984.

\section{$\cos$}

\section{DEATH AND THE INTERIM STATE IN THE WORKS OF JUAN Rulfo AND DžEVAd Karahasan}

This paper provides a comparative analysis of two novels connected by the recurring motif of death as an unfinished existentialist and ethical process, as well as an ontological state. The two works compared are Juan Rulfo's 1955 novel Pedro Paramo, a classic of Mexican literature of the 20th century, and Dževad Karahasan's 2005 novel The Night Council (Noćno vijeće). Despite belonging to two different cultures, each marked by a specific form of colonization and imperialist interventions into the imaginary cultural continuity, these works share many similarities, from the plot itself, to the protagonists, and even to approaching death as an interim state. The settings of both novels are inhabited by beings dwelling on the border between two worlds, whose identity and integrity are constantly questioned. In the Mexican tradition and Latin American symbolism, the undead/lost souls are referred to as almas en pena, whose existential ambiguity is marked by pain, while their ontological status is undefined. Interestingly enough, Karahasan uses the same interim state, although he does not name it. This comparative case study draws from the eminently European (German) tradition of magic realism (the term Magischer Realismus was first introduced by historian and art critic Franz Roh in 1925, to promote a movement in German art called New Objectivity). Magic realism peaked in Latin American literature, with Juan Rulfo as its founder. Rulfo's imaginarium is, in turn, culturally adapted by Dževad Karahasan in The Night Council. The analytical categories used in this paper rely primarily on the work of the philosopher Stephen T. Davis.

Key words: interim state, lost souls, border, magic realism 



\section{5. \\ U ZAGROBU NEŠTO DIŠE: TEMA SMRTI \\ U PRIPOVEDAČKIM ZBORNICIMA NEŠTO DIŠE U MOJOJ TORTI \\ I ZAGROB. ZBIRKA HRVATSKOG HORORA}

\section{Marijana Jelisavčić}

UDK: 821.163.41./42-34:393

Stručni članak

Sažetak: Horor je žanr kome je u književnoj teoriji i istoriji posvećeno srazmerno malo pažnje i dato jednako malo prostora. Praksa prećutkivanja i retuširanja dela sa „skarednim“ i „blasfemičnim“ sadržajem, koja započinje sa prosvetiteljstvom, nastavljena je, kao po nekoj inerciji, i kasnije. Do današnjih dana, neka od najvećih dela ovoga žanra nisu prevedena na srpski i hrvatski jezik, kao što su i brojne studije o hororu i teorijska razmatranja ovoga žanra ostali teško dostupni izvori na stranim jezicima. Samim tim pojava zbirki priča Nešto diše u mojoj torti i Zagrob. Zbirka hrvatskog horora predstavlja značajnu književnu činjenicu. Zagrob je knjiga nastala kao rezultat konkursa iz 2006. godine i sabira 13 priča strave, jedan esej i nekoliko pesama autora iz Hrvatske. Nešto diše u mojoj torti broji 11 priča od 9 autora mahom iz Srbije, a izašla je najpre u PDF formatu na internetu, 2012. godine. U obe knjige, stravični događaji generišu raznovrsne manifestacije smrti, što jeste jedna od fundamentalnih pretpostavki ovog žanra. Specifičnost horora jeste želja za smrću, bilo samih aktera, podvrgnutih nepodnošljivoj patnji, bilo čitalaca, ispunjenih mučnom neizvesnošću. U razmatranim zbirkama smrt može biti nasilna, često nakon borbe s onostranim, ali može se zbivati i kao iščeznuće ili preseljenje na drugi svet. Istovremeno, na delu je i poricanje smrti, jer pojedini junaci priča svedoče o propadljivosti tela, ali i o postojanju alternativnih mogućnosti duhovne egzistencije s one strane smrti. Ipak, gotovo uvek, likovi koji se nađu suočeni sa smrću izgubiće život, neretko i sami birajući tragičan ishod. U ovome izlaganju, dakle, reč je o fenomenu smrti u horor žanru i načinima na koje se prema smrti odnose junaci priča uzetih kao uzorak istraživanja.

Ključne reči: smrt, horor, patnja, nasilje, žrtva

I

oror kao književni žanr veoma dugo nije zadobio mesto koje mu pripada, naročito u srpskoj književnosti. Ovo je unekoliko začuđujuće jer „tamo gde je folklorna tradicija jaka, mogućnosti književne fantastike su veće", 1 a južnoslovenska i slovenska folklorna tradicija bremenita je jezovitim pričama. Te priče nastajale su na vrelu nacionalnih istori-

$\overline{1}$ Predrag Palavestra, „Kritičke odlike srpske fantastike“, Knjiga srpske fantastike, Beograd 1989., 12. 
ja koje faktima svedoče o neobičnim pojavama. Primera radi, dvadeseti član Dušanovog zakonika (donet 1349. godine) glasi: „I ljudi, koji vradžbinama uzimaju iz grobova, te ih spaljuju, to selo, koje to učini, da plati vraždu, a ako bude pop na to došao, da mu se uzme popstvo." Radovan N. Kazimirović u knjizi Tajanstvene pojave u našem narodu i Kremansko proročanstvo piše o praksi progona veštica na Balkanu, navodeći zvanična akta, od 1360. do 1758. godine, kada je on u Hrvatskoj, carskom odlukom, zabranjen. ${ }^{2}$

„Najstarija i najjača čovekova emocija je strah, a najstarija i najjača vrsta straha je strah od nepoznatog ", 3 piše Hauard Filips Lavkraft u eseju o manifestacijama horor fantastike u književnosti. Paradoks koji se nameće uz horor jeste pitanje zašto čitati o nečemu što izaziva strah, emociju koju se svim snagama u životu upinjemo da izbegnemo. Odgovor leži u čovekovoj prirodi, koja ga tera da se bavi nepoznatim i potencijalno opasnim. Ovaj - kako

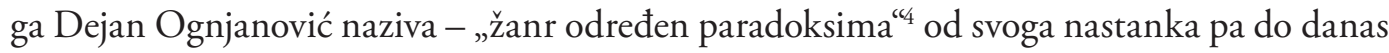
promenio je nekoliko naziva (gotik, gotski roman, horor). ${ }^{5}$ Po definiciji:

Horor je prozni pripovedni žanr sa dominantnom odlikom (differentia specifica) sadržanom u estetskoj nameri izazivanja strave kod čitaoca, što se ostvaruje dvojako: a) kroz izbor tematike prikladne tom cilju (suočenje sa demonskim / monstruoznim „Drugim“) i motiva njoj odgovarajućih (često, ali ne nužno, povezanih sa čudesnim / fantastičnim), i b) kroz osobenu žanrovsku retoriku podređenu zadatku da kod čitaoca proizvodi osećanja neizvesnosti, strepnje, jeze, strave, straha, iznenađenja, neočekivanog šoka i groze, pri čemu su ta osećanja za čitaoca istovremeno odbojna i privlačna. ${ }^{6}$

Horor književnost ${ }^{7}$ nailazila je tokom svog nastajanja na mnoge prepreke. Smatrana je blasfemijom i pornografijom, nazivana je trivijalnom literaturom, ali njen najozbiljniji oponent bio je racionalizam, koji nije dozvoljavao prodor iracionalnog u svet kojim je suvereno vladao. Međutim, kad se to jednom desilo, nadiranje jezovitih priča nije se moglo okončati. Iako se često smatra kontrareakcijom na prosvetiteljstvo, gotik, koji je - paradoksalno - nastao u The Age of Reason, može se posmatrati i kao njegova dopuna, dopisivanje onoga što je s pojavom racionalizma izostalo iz književnosti. Razlog za poimanje gotika kao otpora tadašnjem vladajućem kulturnom poretku sasvim je osnovan „jer fenomeni na kojima on

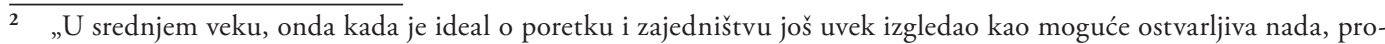
ganjanja veštica imala su relativno blage odlike. Sa sve nemirnijim društvenim poretkom epoha koje su usledile, beznađe vladara ispoljavalo se kroz sredstva za odbranu religije države, a egzekucija veštica izrodila se u grozne masakre." Kurt Zeligman, Istorija magije, Beograd 2010., 217. Za vreme Karađorđa veštice u Srbiji bile su pod stalnom istragom, a tragove načina postupanja sa njima nalazimo u pismu Karađorđevog vojvode Antonija Pljakića, koji u pismu poručuje Voždu da je jednu babu ispekao usred Knjaževca, na šta dobija odgovor: „To si sve dobro učinio!“ Up. Radovan N. Kazimirović, Tajanstvene pojave u našem narodu i Kremansko proročanstvo, Smederevo $1986 ., 72$. Hauard Filips Lavkraft, „Natprirodna strava u književnosti“, Slučaj Čarlsa Dekstera Vorda, Beograd 1990., 143.

Dejan Ognjanović, Poetika horora, Novi Sad 2014., 7.

5 „U svojoj ranoj fazi (krajem 18. i početkom 19. veka) bio je nazivan 'gotskom romansom' 'gotskom pričom' ili 'gotikom'; sredinom i krajem 19. veka u istom žanru preovladava forma kratke priče, pa je uglavnom imao oblik 'priče o duhovima' (engl. ghost story); početkom 20. veka javljao se kroz 'čudne priče’ (engl. weird tales), da bi od sredine 20. veka pa sve do danas za dela ovog žanra, bilo da se radi o romanima ili pričama, preovladao termin 'horor'." Isto, 36. Isto, 39.

7 Ognjanović navodi da je u okviru priče o hororu bitno imati u vidu da se može javiti i u realističkom ključu (primera radi, poremećena psiha) i da horor ne poseduje samo jedan skup dozvoljenih tema (kao što je priča o duhovima). Ilustracija ove tvrdnje je priča Ko se zadnji smeje... A. Baskin, o kojoj će biti reči u radu. 
insistira - duhovi, vampiri, tajanstvene sile, misteriozna bića, aveti i slično - najradikalnije odstupaju od dominirajućeg idejnog sistema i njegovih glavnih premisa" ${ }^{8}$

Za vrlo kratko vreme evropska književna fantastika izvršila je uticaj na srpske i hrvatske pisce:

Morali smo se okrenuti Evropi da bismo u punoj meri shvatili mogućnosti koje nam je nudila vlastita baština (...) tj. da bismo osvežili osećaj za fantazme i te kako prisutne u našem folkloru. ${ }^{?}$

Popularizacija nemačke fantastičke proze i engleskog gotika, uz niz revolucionarnih zbivanja u svetu, podstakla je autore poput Milovana Vidakovića, Jevstatija Mihajlovića, Jovana Čokrljana, Vikentija Rakića, Konstantina Marinkovića, Dragojle Jarnević i druge da se oprobaju u ovome žanru. U kombinaciji sa živom folklornom tradicijom, srpski i hrvatski autori „romantičeskih povesti“ usvojili su modus fantastičkog oblikovanja. Taj sklop iznedrio je najpre nekoliko romana stidljivo prožetih horor fantastikom, koja je bila usputna jer nije čitava radnja bila zasnovana na njoj (obuhvatala je najviše epizode), a horor se nije pokazao kao bitan element oblikovanja postupaka junaka.

Specifično za književnost horor fantastike jeste poimanje smrti, jedne od fundamentalnih pretpostavki ovoga žanra. Za razliku od brojnih žanrova u kojima je glavni cilj junaka beg od smrti, koja može imati raznolike manifestacije, u horor fantastici smrt se često priželjkuje kako bi ovozemaljskim mučenjima došao kraj. Junaci svesno biraju tragični ishod, da izbegnu još tragičniji. Naposletku, u ovom žanru propadljivost tela ne znači uvek i propadljivost duše, već postoje alternativne mogućnosti duhovne egzistencije s one strane smrti: „smrt na jednoj razini možda je preduvjet života na nekoj drugoj“, a „misterija smrti tradicionalno se osjeća kao tjeskobna i prikazuje se kao strašna “ ${ }^{10}$ Kada je reč o hororu, strahotu smrti pojačavaju nesrećne i jezive okolnosti, često rezultat suočavanja junaka sa monstruoznim i pretećim Drugim. „Od smrti se strahuje“, ${ }^{11}$ a jedan od najvažnijih zadataka pisaca horora jeste da taj strah, koji oseća junak, putem saspensa ${ }^{12}$ ili ilustracijama bića koja se obrušavaju na junake, prenesu i na čitaoca:

Pisati horor iznimno je teško. Služimo se slovima kao sićušnim pikselima i od njih gradimo prizore i zvukove za koje se nadamo da će u čitaocu izazvati strah. ${ }^{13}$

Horrere u prevodu sa latinskog znači nakostrešiti se, i upućuje na fizičku manifestaciju doživljenog. Dejan Ognjanović navodi da je odrednica „horor“ kasno ušla u domaću knji-

\footnotetext{
Sava Damjanov, Vrtovi nestvarnog, Beograd 2011., 75.

Isto, 105.

10 Jean Chevalier - Alain Gheerbrant, „Smrt“, Rječnik simbola, Zagreb 1994., 612.

11 Špiro Kulišıć - Petar Ž. Petrović - Nikola Panteuıć, „Smrt“, Srpski mitološki rečnik, Beograd 1970., 282.

12 „Saspens se proizvodi time što aktivni čitalac zna ili sluti više od junaka, pa stoga oseća strah čak i u situacijama koje nisu same po sebi zastrašujuće, dok junak još uvek samouvereno, nesvesno, hrli ka potencijalno jezivoj sudbini.“ D. Ognjanović, Poetika horora, 111. Oto Oltvanji je u intervjuu za Novi Polis govorio o saspensu: „U užem smislu to je engleska reč koja se prevodi kao 'napetost' ili 'neizvesnost'. U širem kontekstu to je naziv podžanra krimića proslavljenog u filmovima Alfreda Hičkoka - strogo voajerska postavka, gde vi kao čitaoci (gledaoci), između ostalog, više znate od junaka i zbog toga sve vreme grizete nokte" (http://www.novipolis.rs/kultura/28842/pucketanje-patosa-ispod-mythosa-i-ethosa.html).

13 Darko VRBAN, „Pikseli strave“, Zagrob. Zbirka hrvatskog horora, Zagreb 2006., 7.
} 
ževnost (oko 1980. godine). U rečnicima književnih termina ne postoji (na njegovom mestu su „roman strave“ $i$,gotski roman“):

Problemu skrajnutog, usputnog ili izostalog bavljenja književnošću strave, u rečnicima na srpskom jeziku, treba dodati i onaj koji se tiče nepostojanja prevedene ili domaće literature iz te oblasti. ${ }^{14}$

Iako je brojnim filmskim adaptacijama književnih dela koja pripadaju ovom žanru i sama literatura popularizovana, horor i dalje trpi maćehinski tretman u književnosti, i dalje je na margini. Stoga se projekti grupa autora iz Srbije i Hrvatske, u poslednjih deset godina, mogu smatrati pravim podvizima.

Najpre je u Zagrebu 2006. godine, kao rezultat književnog konkursa, a pod uređivačkom rukom Tatjane Jambrišak i Darka Vrbana, objavljena knjiga Zagrob. Zbirka hrvatskog horora, u kojoj je sabrano trinaest priča, četiri pesme i dva dodatna teksta. ${ }^{15}$ Prvi tekst, u formi uvodnika, napisao je Darko Vrban (Pikseli strave), a poslednji, o hororu u književnosti (Posečen na papir) gost u ovoj zbirci, Oto Oltvanji. Šest godina kasnije, grupa poštovalaca ovog žanra iz Srbije objavila je prvo onlajn izdanje zbirke Nešto diše u mojoj torti, antologiju novogodišnjih priča strave (ukupno jedanaest), koju će čitaoci nakon toga tradicionalno, pred početak svake predstojeće godine, u novom ruhu i sa novim sadržajima, moći da nađu na internetu. ${ }^{16} \mathrm{U}$ obe zbirke reč je o uglavnom mladim i većim delom neafirmisanim autorima.

Smrt, shvaćena kao prestanak života, u pričama koje pripadaju domenu žanra horor fantastike gotovo uvek je neminovna, samo su njene manifestacije raznolike. Završetak života ne podrazumeva uvek i završetak priče, te smrt kao konačna instanca ne predstavlja veliku prekretnicu u životu junaka. Stoga se smrt u hororu može posmatrati i tumačiti na tri načina: kao nasilno oduzimanje života; kao priželjkivano olakšavanje naspram monstruoznih mučenja; te, najzad, kao prelazak iz jednog stadijuma u drugi, gde se okončanje života promatra samo kao propadljivost tela. Priče koje su sabrane u pripovedačkim zbornicima Nešto diše u mojoj torti i Zagrob svedoče o mogućnosti ovakve, uslovno izvedene podele.

Smrt, kao nasilno okončanje života jedinke od strane suprotstavljenog Drugog (drugi može biti poremećena osoba vođena homicidalnim namerama, ali i onostrano biće), veoma često je predstavljena kao bizarna egzekucija. U priči Ko se zadnji smeje... Andree Baskin muškarac je „izvršilac pravde“ koja je u njegovu glavu usađena bizarnim vaspitanjem i tvrdnjom majke da su sve žene zlo. On smrt zamišlja kao polaritet igre u kojoj učestvuju

14 Dejan Ognjanović, „Odnos prema horor žanru u književnoj i filmskoj teoriji na srpskom jeziku“, Književna istorija, 42/2010., br. 142, 561 .

15 Autori i njihovi tekstovi u ovoj zbirci su: Darko Vrban (Pikseli strave), Danijel Bogdanović (87. kilometar), Irena Rašeta (Cabrón), Zoran Krušvar (Štićenici), Darko Macan (Dvorište okupano suncem), Ivan Dokaza (Glad), Dubravko Soher (Tri mačke i...), Snježana Novaković (Vučje bratstvo), Dario Rukavina (Gospodar igre), Tatjana Jambrišak (Kaput od ljudske kože), Parsifal Pogan (Vodeći ljubav s vinom u snijegu prolivenim...), Igor Mavrin (Zombie TV@), Tvrtko Stuka (Prva krv: Vjenčanje u bijelom), David Kelečić (Ženska glavo...), Iva Šakić Ristić (Krv i pijesak) i Oto Oltvanji (Posečen na papir).

16 Autori i njihove priče u ovoj zbirci su: Andrea Baskin (Ko se zadnji smeje...), Boris Mišíć (Noćna straža), Goran Segedinac (Poklon i Praznik), Igor Ivanišević (Gong), Ivica Milarić (Tetsuo i Čekić), Milka Knežević Ivašković (Poklon za lanjske snegove), Radoslav Slavnić (Partija), Saša Robnik (U magli) i Stevan Šarčević (Frekvencija i Ponoćna zvona). 
samo ženske osobe, i kojoj je suprotstavljen život. U jednoj takvoj igri on presuđuje i ženi koja ga je rodila, a klimaks te neobične drame ogleda se u činjenici da ga je upravo majka podsticala da razvija ubilački poriv i želju za nanošenjem fizičkog bola, naredivši mu da bude njen egzekutor:

Obožavala je bič, ali je najčešće tražila da je udara pesnicama. Satima. Imao je snažne ruke, jer ga je kao dete terala da udara vreću kako bi ojačao. Kada nije želeo da je sluša, ona bi tukla njega, dok je ne bi konačno poslušao. Batinjanje majke je počelo kada je napunio četrnaest godina. Cesto ga je molila da ne staje, dok jednom stvarno nije prestajao. (...) Jednim preciznim udarcem, odvojio je glavu od trupa, da bi prešao na udove. Kapljice su se raspršile u vazduhu nalik malim crvenim vatrometima. Krv se u mlazevima slivala sa stola. Kada je završio, seo je i dugo posmatrao raščerečeni leš žene koja mu je bila sve u životu. ${ }^{17}$

Muškarac sa „bebastim licem“, odgajan da mrzi suprotni pol i naučen da bi taj pol trebalo samo kažnjavati, smrt doživljava kao igru koju je on predodređen da vodi i kontroliše svojim bizarnim pravilima. Za njega, utoliko je bolje ukoliko je ta igra surovija, sa što više učesnica i sa što raznovrsnijim oružjem. ${ }^{18}$ Njegove igre nisu samo igre gladi i dokazivanja moći nad upropaštenim predstavnicama pola koji toliko mrzi, i čija lepota mu je bila toliko odvratna. Njegove igre rezultat su poremećaja koji je vremenom eskalirao u neobičnom liku samoproglašenog egzekutora, da bi, vremenom, i preko interneta počeo da vreba svoje žrtve. Moć koju oseća zadovoljavajući svoje bolesne potrebe jeste pokretač njegovog života, ono što ga nagoni da se iznova igra boga, svaki put smišljajući sve brutalnije načine svoga izraza. Smrt je za njega samo krajnja tačka propadanja tela, ono što će neminovno uslediti kada u mučenjima, koje doživljava kao pravu poslasticu, istroši svoju svirepost i kreativnost u smišljanju primerene kazne.

Nasilna smrt kao jedini pravičan postupak u svesti onog ko je izaziva, oslikana je i u priči Poklon za lanjske snegove Milke Knežević Ivašković. U središtu radnje je Snežana sa nepoznatim mentalnim poremećajem, ali i s porivom ka samoubistvu. To saznajemo iz njenog razgovora sa psihijatrom, u kojeg je zaljubljena do te mere da će ga pokloniti sebi za predstojeće praznike:

Srećna sam. Bio je lep ukras u mojoj sobi te, pretposlednje večeri. Namestila sam ga tako da mu bude udobno u beskrajnom snu: zabacila Njegovu glavu na naslon stolice, položila Njegove šake na sto - da ovekovečim sliku voljenog koji sedi sa mnom, zauvek, sa zamrznutim smeškom i crnim očima, punim večite ljubavi. ${ }^{19}$

Snežana ide i dalje od lepog uprizorenja, razmišljajući poput kanibala, koji će krajnji domet svoje ljubavi pokazati proždirući telo voljenog. Paradoksalno, onaj ko je njoj pomogao da se oslobodi crnih misli o oduzimanju sopstvenog života, ko je uticao na njena „duga

17 Andrea Baskin, „Ko se zadnji smeje...“, Nešto diše u mojoj torti. Antologija novogodišnjih priča strave, [s. 1.] 2012., $5-6$.

18 Svojim zatočenicama on će pokloniti katanu, pištolj, sekiru i ostale smrtonosne alatke namenjene za presudu, darove slične onima koje je on godinama dobijao od svoje majke. „Neka igra počne“, reći će on devojkama koje je prethodno kidnapovao i fizički unakazio izgladnjivanjem, čupanjem noktiju i kose.

19 Milka KnežEvić IvašKović, „Poklon za lanjske snegove“, Nešto diše u mojoj torti, 88. 
spavanja nalik malim smrtima, nakon kojih se budila neznano kad, neznano gde“, ${ }^{20}$ postaje predmet njenih ubilačkih stremljenja. Smrt kao najveći dokaz ljubavi, u ovoj priči, ni u jednom trenutku nije nešto o čemu bi trebalo promisliti, već je uzeta kao neminovnost. Sve ovo jeste bizarno otelovljenje seksualne patologije, nerazrešenog Edipovog / Elektrinog kompleksa, i krivice zbog njih.

U priči Poklon Gorana Segedinca ${ }^{21}$ onaj koji na svoju ruku deli pravdu nije biće od krvi i mesa, već demon koji, kada mu spale staro telo, pronađe novo, kroz koje će vršiti svoju ubilačku misiju. Srećan što je za ovu priliku - vreme novogodišnjih praznika - uspeo da se naseli u prigodnom telu statue Deda Mraza, demon će praznične darove podeliti porodici u čijoj kući se zatekao, kao i policajcima koje će, namesto pravih poklona, postaviti ispod jelke. Iz njegovih reči - da ga ni spaljivanje ne može zaustaviti jer su tela za njega samo ljušture kojim se služi kako bi delao - jasno je da je ranije detektovan kao opasnost, i da je neko već pokušao da ga uništi. Fizička smrt, međutim, ne podrazumeva i propadanje ubilačkog demona, dok njegove žrtve prestaju da postoje onog trenutka kada im utvarna figura zada udarac nožem.

Ubijanje kao modus operandi junaka opisano je i u priči Tetsuo i Čekić Ivice Milarića. Likovi po kojima priča nosi ime plaćene su ubice koje svoj posao obavljaju rutinski, ne obazirući se na leševe koje ostavljaju za sobom, niti na razloge koji bi ubistvo mogli, uslovno rečeno, objasniti. „Koprcao se kao prasence“, 22 prokomentarisaće šef zlehudu sudbinu jedne od mnogobrojnih žrtava koja egzekutorima nije želela da oda informacije o Svetom Gralu modernih generacija - uzorku ubistvene supstance. Njeno dejstvo monstruoznije je od upotrebe bilo kog oružja jer supstanca topi kožu, i čoveka pretvara u bezumnu životinju. Smrt je u ovoj priči test koji vlasnici supstance izvode na što većem broju ljudske zamorčadi. Ona je sudbina niščih, koji nestaju u sukobu dva zaraćena klana, prethodno okusivši opasnu materiju: „Tetsuo vidi sebe na balkonu, iznad ulica, gde posmatra transformaciju, dok urlik živih nestaje u napredovanju onih koji umiru na nogama. ${ }^{\text {"23 }}$

Masovno ubistvo ilustrovano je i u priči Frekvencija Stevana Šarčevića. Instrument zločina u njoj je song $s$ inkriminisanim akordom, čija smrtonosna frekvencija tera na suicid. Pokretač zbivanja ovde nisu mentalni poremećaji junaka, već želja za bogatstvom i beleške o izazivanju smrti određenom izvedbom melodije, kao deo porodičnog nasleđa. „Ustani / (...) Pokreni se / (...) / Nemoj da staješ sad“ ${ }^{24}$ glasi tekst pesme koja slušaoce nagoni da posegnu za brijačima koji su im ubice već pripremile. Izvođač smrtonosnog akorda na putu do novca postaje - od čoveka koji, kako sam kaže, ni mrava nije zgazio - masovni ubica. „Oh, da - od ovog Božića, pa nadalje, sve će šikljati“,25 misao je ubice koji, evidentno, ne planira da se zaustavi ni na stečenoj sumi ni na velikom broju postradalih. Za njega, smrt je sredstvo za ispunjenje megalomanskih ciljeva. Sem toga, on uživa posmatrajući mlazeve

\footnotetext{
Isto, 83.

21 Goran Segedinac, „Poklon“, Nešto diše u mojoj torti, 37.

22 Ivica Milarić, „Tetsuo i Čekić“, Nešto diše u mojoj torti, 59.

23 Isto, 79.

24 Števan ŠArČEviĆ, „Frekvencija“, Nešto diše u mojoj torti, 181.

25 Isto, 182.
} 
krvi, i raduje se kada žrtve pogode arteriju, čime se, posredstvom crnog humora, relativizuje priroda dobrog građanina.

Najviše literarnih žrtava odnela je priča Zombie TV@ Igora Mavrina, s bitnim odstupanjem: te žrtve nisu nestale s poslednjim otkucajem srca, već su se preusmerile na trajanje. Mavrinova priča govori o pošasti koja hara i ovde i sada, nekoliko godina nakon objavljivanja crtice o razornoj moći televizijskog formata nazvanog rijaliti. Kada se na televiziji uveća kadar na kojem lipti krv, gledanost poraste na 72 procenta. Kada se u izolovani studio među zombije uvede čovek koji bi trebao da preživi svoje nove cimere, procenat ljudi ispred malih ekrana poveća se za još 13 procenata. Nije teško zaključiti šta bi pred malene kutije na kojima se emituje ovakav program dovelo novih 15 procenata. Zarad apsolutne gledanosti, televizijski producenti doneli su odluku da kao hranu, odnosno armiju, zombijima ponude svakog čoveka na zemlji. Smrt u ovoj priči simbolički je ovekovečena u vladajućem televizijskom formatu, koji ionako za stolice prikiva veći deo stanovništva zemlje. Svi oni postepeno počinju da žive kroz svoje miljenike, zaboravljajući da i sami postoje u vremenu i prostoru. Priča Igora Mavrina samo je vrhunac ove predstave u čijem kreiranju učestvuju oni čija će inspiracija u jednom trenutku dostići kulminacionu tačku: prenos smrti uživo. Još jednom, smrt je samo sredstvo kojim će novac dospeti u kase i džepove onih kojima procenti gledanosti nikad nisu dovoljno visoki, i čiji apetiti rastu do dosezanja trocifrenog broja. Samo, tada će možda biti prekasno, i mnogi će, kao i Mavrinov junak, otići „širiti virus smrti u svijetu koji je odavno umro". ${ }^{26} \mathrm{Smrt}$ se ponovo pokazala kao mala cena za veliku sumu, a što je masovnija - to je isplativija.

Moć da seje smrt, i da to čini na bizaran način, ima i demon u priči Kaput od ljudske kože Tatjane Jambrišak. Problem za njega nastaje u onom trenutku kada se pojavi falsifikator koji oponaša njegov modus operandi, odnosno manir skidanja kože sa žrtava, kako bi je iskoristio kao materijal:

Samo će mu ta koža, njegovih ruku djelo, opravdati postojanje. Za to je živio. Za kaput od ljudske kože. ${ }^{27}$

S druge strane, biće koje deranjem kože kupuje sebi stoleća postojanja na zemlji, falsifikatoru ne prašta:

Demon bi se inače samo nasmijao tom patetičnom pokušaju gospodarenja životom i smrti da se ovdje nije radilo o njegovom zanatu, njegovom modusu operandi i njegovoj nedodirljivoj tajni. ${ }^{28}$

Pritom, ni u jednom trenutku u pitanje se ne dovodi ispravnost postupaka dvojice egzekutora, već je u prvom planu njihova želja da se obračunaju kako bi postojao samo jedan koji će „operisati“ na pomenuti način. Kao i u većini razmatranih priča, i u Kaputu od ljudske kože manifestacije same smrti višestruko se preklapaju.

\footnotetext{
26 Igor Mavrin, „Zombie TVC“, Nešto diše u mojoj torti, 170

27 Tatjana JAмвrišAK, „Kaput od ljudske kože“, Zagrob, 145.

28 Isto, 146.
} 
Mnogi likovi u analiziranim pripovetkama pripadaju sferi onostranog, i tamo prevode svoje protivnike ili saveznike; to se često dešava na surov i krvav način, što one koji trpe nagoni da priželjkuju okončanje patnje. Žena koja je demona privukla strahom koji njemu (i njemu sličnima) miriše na karamelu, shvativši da je u zamci iz koje se ne može izvući, ne samo da je poželela smrt, već joj je pohrlila u susret:

Pomisli, ako je brzo ubije, sva ova agonija će prestati. Udahne duboko makar joj je hladan zrak palio pluća, izvije leđa i raskopča prljavu i poderanu košulju te demonu ponudi svoj grkljan za gozbu. ${ }^{29}$

Neobičan način priželjkivanja smrti oblikuje Radoslav Slavnić u priči Partija. Demon Arbitar, koji je spasao nekoliko potencijalnih žrtava novogodišnjeg masakra homoseksualaca, pojavljuje se ovde, pred doček svake Nove godine, kao egzekutor onih koji mu duguju svoje živote. Agonija življenja iz godine u godinu, bez saznanja kome će izvlačenje zloslutnog crnog diska presuditi i na čiju adresu je smrt upućena, mnoge je nagnala da sami okončaju svoj život. Oni koji odluče da ignorišu poziv sejača smrti, bivaju unakaženi, i u delovima rasuti svuda po gradu i zemlji. Preživljavanje masakra i pokušaj da se smrt nadigra tako postaju Pirova pobeda preživelih, kočnica za vođenje normalnog života, a smrt način za okončanje već mizernog života u iščekivanju. Pitanje "Bojiš se da ćeš izvući pogrešan?' 'A, koji je po tebi pogrešan disk?' izbečio sam se izazivački “, ${ }^{30}$ poentira razgovor dvojice prijatelja posle dvanaest godina, i mnogo više smrti.

Za gospodara novogodišnjih igara smrti čitava ova predstava samo je puka igrarija tuđim životima. „Život za život je u redu“, rekao je, ,ali tu nema naročite zabave“, ${ }^{31}$ komentariše Arbitar odluku jednog od junaka da sebe ponudi kao žrtvu umesto prijatelja koji ima porodicu. Njegovo zadovoljstvo dolazi s agonijom onog kome slučaj podmetne disk obeležen crnim. Zbog toga je smislio i dodatak igri - onaj ko izvuče zlatni disk, moći će da uživa u neverovatnom bogatstvu sve dok mu drugačije obojeni disk ne presudi. Nema, dakle, pobednika nad smrću, samo slabašni izgledi da se neizbežno odloži do nekog od sledećih dočeka, i mučenja da se unapred izgubljeni život nastavi. Jalove nade i čak i likovima neshvatljiv nagon za samoodržanjem, kao i osnovni strah - strah od smrti - preostale učesnike partije iznova i iznova okupljaju na mestu zločina. Igra sa smrću, odnosno protiv nje, iako neminovno unapred izgubljena, čini se kao još jedino što je Slavnićevim junacima preostalo. Čini se da ovde i samo praznovanje protoka vremena dobija nov smisao: praznuje se primicanje smrti.

Mučenje sa životom koji je u rukama neke više sile razara i junake priča 87. kilometar Danijela Bogdanovića i Vodeći ljubav s vinom u snijegu prolivenim... Parsifala Pogana. Bogdanovićev junak, iz pozicije samozvanog ,izvršitelja pravde“ (sekirom je iskasapio ženu i njenog ljubavnika zbog neverstva), prelazi u položaj onog ko trpi posledice nečije druge, više pravde, koja sad njega kažnjava za učinjeno. Našao se na neobičnom mestu: „Jer tu završava put ubojicama koji bježe. Ovo je vaš zatvor. Ovo je vaša kazna. Vaš osamdeset i

\footnotetext{
29 Isto, 140.

30 Radoslav Slavnić, „Partija“, Nešto diše u mojoj torti, 108.

31 Isto, 123.
} 
sedmi kilometar. “32 Smrt je neizbežna, a put do nje, kao u priči Radoslava Slavnića, popločan je neizvesnošću igre:

Ak' preživiš tri-čet'ri Kruga, promijenit' ćeš mišljenje, vjeruj mi! I ja sam tak’ razmišlj’o kad sam došo ovdje. Al' kad te mrak i iščekivanje kog će sljedećeg pokupit' iz ćelije ubije u pojam, sve će ti postat' nevažno. ${ }^{33}$

Pokajanje je jedino što ubice može spasiti od iščekivanja smrtonosnih krugova igre, u kojima se svako od zatvorenika suočava sa svojim najvećim strahom. Poput sobe 101 u Orvelovom romanu 1984, i u Bogdanovićevoj priči finalni slom svakog čoveka dolazi nakon susreta s onim što ga najviše zastrašuje i protiv čega se pouzdano ne može izboriti. I ovde smrt, iako deluje kao rezultat slučaja i posledica igre, dolazi po svaki od likova kojima je namenjena, pre ili kasnije, a o njoj odlučuje neko ko je na sebe preuzeo ulogu delioca pravde i postavio se iznad osnovnih zakona prirode.

U priči Vodeći ljubav s vinom u snijegu prolivenim... život se još jednom izjednačava s grobom za onoga kome je dodeljen. Ovaj put, reč je o pravom grobu i lešu koji vaskrsava u drugom ukopnom mestu, kako bi bio poslastica demonima crnih krila. Oni surovo kidaju meso sa njega i ostavljaju ga da krvari. Ta manifestacija nezasitosti ponavlja se svake noći. Žrtva zna da ima izbor, ali i to da taj izbor vodi u pakao, pošto je samoubica. Rečenica „Možda ove noći zamolim truplo na križu da mi pomogne umrijeti“ ${ }^{334}$ ilustruje svest silovanog leša o izboru koji ima, ali i to da se on više boji odmazde Boga zbog ranijih grehova nego iskorišćavanja onih koji su mu slični, ali kojima ne može da se odupre. Smrt u ovoj priči dobija obrise nestajanja koje može, ali i ne mora, biti konačno, i želje za prepuštanjem toj konačnosti zbog krvave odiseje koja se dešava svakome ko se nađe u tom „moru iskorištenih leševa“' ${ }^{35} \mathrm{Ne}$ saznajemo ko su ti demoni crnih krila, niti otkuda im moć koju imaju i koju koriste nad bespomoćnim telesima u nekakvom limbu, ali saznajemo da umeju da budu slatkorečivi, da tepaju svojim žrtvama i ubeđuju ih u njihovu posebnost, dok krvavo ne zadovolje svoje monstruozne potrebe. Još jednom, dolazak smrti značio bi olakšanje i oslobađanje muka, ali i kaznu.

Život posle smrti javlja se u više oblika, pošto onostrano može biti preteće i delovati destruktivno na slabije od sebe koji su prešli granicu smrti, ali i na žive ljude, a može se javiti i u obliku dobronamernog duha koji postoji, ali bez pretenzija da utiče na bilo koga. ${ }^{36}$ Ovaj drugi slučaj ređi je, jer ono što je utešno izlazi iz domena horora, ali zanimljiva je u tom smislu koncepcija priče Noćna straža Borisa Mišića. Junaci ove priče, stražari na dužnosti u novogodišnjoj noći 1993. godine, sjediniće se sa mestom koje je naviklo da u sebe uziđuje žrtve. Tako jedan od četvorice stražara poraženih ratom odlučuje:

32 Danijel Bogdanović, „87. kilometar“, Zagrob, 44.

33 Isto, 30.

34 Parsifal Pogan, „Vodeći ljubav s vinom u snijegu prolivenim...“, Zagrob, 152.

35 Isto, 156.

36 Izuzetak su upokojeni vojnici koji ne daju „nadležnima“ da na onaj svet povedu još žrtava, u priči „U magli“ Saše Robnika: „Ovoga puta, nećeš, oglasi se isti vojnik. 'Dosta ste nas odveli. Previše!'“ Saša Robnik, „U magli“, Nešto diše u mojoj torti, 162. 
Neće više biti ružnih snova, krivice zbog tuđih grehova, neprijateljskog okruženja koje ga je izjedalo iznutra kao rak. Nije se više plašio, postaće jedno sa ovim mestom, zauvek. ${ }^{37}$

O ovom neobičnom događaju ostaće da svedoči žena koju su, kao plod potrebe da se samoća i strah premoste na bilo koji način, svi imali te poslednje večeri. Stražari progovaraju kroz zidove koji su ih prisvojili, kao i mnoge pre njih. Jedina zajednička želja četvorice stražara jeste da ne budu sami u večnosti. Oni nisu zlonamerni i ne privlače nove žrtve, ali način njihovog prelaska u drugu dimenziju, i ono što je za njima u životu ostalo, generišu jezu i strah čitalaca.

Neprestano obnavljanje sveta mrtvih, i njegovu koliziju sa svetom živih, tematizuje priča Gong Igora Ivaniševića. Strah od smrti, a naročito od starenja, ispoljava Dora, koja ubistvima starijih oblika sebe same obezbeđuje svom delu duh i postojanost. Najpre je sahranila staricu, majku, koja je izvršila samoubistvo:

Tog dana Dora je mrtvu i polomljenu majku odnela do salona, odbeglu ruku koncem prišila za rame, beživotno telo posadila na veliku fotelju sa visokim naslonom, naložila vatru u kaminu i jedno vreme posmatrala majčin odraz i vatru koja se oslikavala u beživotnim staričinim očima. (...) Gledala je u leš nekih sat vremena, a onda napokon rešila da staru, izboranu i sedu ženu prepusti zemlji i crvima. ${ }^{38}$

Smrt je u ovoj priči eliksir koji je Dori neophodan. Svaka nova smrt nju čini sve mlađom. Zanimljiv je izbor reči kojima se u priči više puta komentariše majčin namerni pad: ona se polomila kao da je nekakva lutka, čak joj je i ruka prišivena, što bi bio razuman postupak da je reč o krpenoj igrački poput lutke. Ali krpena lutka ne bi mogla da se polomi, te ovi oprečni glagoli nagoveštavaju višestruku propadljivost tela. Pesmica koju dve Dore pevuše u priči glasi: „Tamo gde je mašta, tamo je i san / Ali kada sekirom zakolješ ružan strah / Oteraš starost kao noć dan / Ostane više prostora za nas“. ${ }^{39}$ Ona poput mantre odzvanja hladnim zamkom. Strah od starenja i propadanja jeste ružan, i on se mora zaklati sekirom, i sve dok se to ponavlja, biće više prostora za život, svaki put sve podmlađeniji, a samim tim za maštu i san. Smrt ovde ima neobičnu poziciju katalizatora mladosti, a jedini trag onoga šta ona izaziva jeste prkosni portret stare majke, trajno zarobljen u okovima rama:

„Ne, Doro, uvek ću biti tu“, prozborila je hrapavim, staračkim glasom. „Uvek ću biti tu da te podsetim ko si ti zapravo." ${ }^{40}$

Prividna mladost nije stvarna, o čemu svedoči i Slika Dorijana Greja Oskara Vajlda, dela sa kojim, osim preko glavnog motiva, ova priča komunicira i imenom junakinje.

Portret ima moć da opominje, ali ne i da kazni. Ta sposobnost nepravedno je podeljena - u delima horor-žanra ona uvek pripada onima koji se bore na strani zla, jer oni koji su na strani dobra tu moć uglavnom ne žele. U priči Glad Ivana Dokaze slučaj se poigrao s Petrom Goranićem, koji je rođen proklet, pa će svoj krst, u najdoslovnijem smislu te reči

\footnotetext{
37 Boris Mišić, „Noćna straža“, Nešto diše u mojoj torti, 22.

38 Igor IvanišEvić, „Gong“, Nešto diše u mojoj torti, 44.

39 Isto, 55.

40 Isto, 50.
} 
(ožiljak na prsima u obliku naopako okrenutog krsta), poneti u nepravedno dosuđenu smrt. Čovek koji je bio uzoran i pošten građanin, u smrti je postao osvetoljubiv, jer je umro kao pseto, u mraku i gladan:

Negdje, u magli, daleko, gladni duh Petra Goranića, napaćen do infantilnosti, proždirao je ženu koja nije bila ljubazna, koja mu nije pomogla, i njezino je vrištanje odjekivalo bez prestanka. ${ }^{41}$

Ono čega je ostao željan za života, morao je da ispuni u smrti, spajajući želju za hranom sa željom za osvetom. Neljubaznost drugih je, više nego osveta, načinila Petra drugačijim u smrti, koja za njega nije bila poslednja stanica: prokletstvo prorečeno na rođenju pokazalo se tačnim.

Drugačije iskustvo s proročanstvom ima junakinja priče Dvorište okupano suncem Darka Macana. Ona je videla svoju smrt i neuobičajeno joj se obradovala jer to znači da će je neko napokon primetiti, i time otkloniti njenu nesreću:

Htjela sam umrijeti, razrezati žile u toploj kadi ili baciti se s nebodera, potom ležati u staklenom odru nad kojim će plavi kraljević prolijevati suze. ${ }^{42}$

Misao o smrti koja će joj doneti milost tuđe pažnje, okupirala ju je sve do onog dana kad je u skloništu ugledala leš žene ubijene mnogo godina ranije, u danu koji se, poput onih u filmu Dan mrmota ili u knjizi Dom gospođice Peregrin za čudnovatu decu, beskonačno ponavljao. Mariji, ljubavnici jednog Titovog oficira, u tom dvorištu oduzet je život: „Ubio ju je. Zadavio ju je taj njezin. Najlonskom čarapom u ljetnu nedelju u podne. ${ }^{\star 43}$ Telo je još bilo tu, a na licu upokojene Marije oslikavala bi se smrt svakog čoveka koji bi u ženu pogledao. Poput Marle Singer iz Palahnjukovog romana (i Finčerovog filma) Borilački klub, koja odlazi na sastanke podrške teško obolelim ljudima iako je gotovo savršeno zdrava, samo da bi se osetila življom, i naratorka ove priče najzad će lepotu života spoznati tek nakon što je smrti pogledala u oči: „Bilo je dobro biti živ, znati da možeš svaki čas umrijeti, ali ne umirati još toga časa. ${ }^{“ 4}$ Susret sa vlastitom smrću njoj će povratiti želju za životom, ali životom u kojem će odmah početi da dela kako bi se sudbina koja nosi smrt što pre počela ostvarivati, jer to znači da konačno neće više biti nevidljiva za ljude oko sebe.

Priča Štićenici Zorana Krušvara deo je ciklusa o Izvršiteljima i tematizuje vampirizam na jedan nov i neuobičajen način. U ovoj priči „izvršitelji nauma Gospodnjeg“ jesu sveštenici koji brinu o zaraženim ljudima u izolovanom samostanu u šupljini litice. Otac Benedikt jedan je od najsurovijih, a na to ga je podstakla, u prošlosti, mlada štićenica Lucija, koja se zaražena porodila, a potom je ubila vlastitog sina:

Prerezala mu je grkljan kao vučica, zarila zube u krhki vratić, zabacujući mu glavu prema nazad da bi lakše mogla lokati krv... Podigla ga je u zrak, kao da je mješina iz koje se pije vino. ${ }^{45}$

\footnotetext{
Ivan DoKazA, „Glad“, Zagrob, 117.

42 Darko MaCan, „Dvorište okupano suncem“, Zagrob, 93.

43 Isto, 99.

44 Isto.

45 Zoran KrušVar, „Štićenici“, Zagrob, 84
} 
Zverstvo je kažnjeno, ali posledice su ostale, i to je razlog zbog kojeg okolina nije više sigurna. Sada se tuda šunjaju senke, spremne da utoljavajući glad proizvedu još sličnih sebi. Od ugriza se ne umire, već se postaje krvopija. Za razliku od većine dela u kojima je glavni cilj likova zaustavljanje pretnje oličene u vampiru - zalivanjem svetom vodicom, paljenjem tela i ispaljivanjem srebrnih metaka - u Krušvarovoj priči cilj je izlečenje. Niko nije vraćen iz prokletstva, ali sve dok vampir ne proba krv, za njega postoji šansa da umre kao čovek. Smrt bi trebalo da bude podjednako laka i za one koji su pretrpeli ugriz i oduprli se jakom porivu da se ponašaju u skladu sa svojom novom prirodom. Zbog toga su tu Štićenici, koji pokušavaju da, kontrolišući zveri u žrtvama vampira kontrolišu i dalje sejanje smrti, odnosno vampirizma, koji je gori od smrti same.

Smrt za onog ko ne zaslužuje da bude figura u armiji zla jedna je od tema priče Cabrón Irene Rašete. Radnja se odvija u Nju Orleansu, u centru poprišta sukoba zaraćenih bandi, gde glavnu reč vodi demonska žena Kvebralej (Quebraley), koja je za vreme Cabrónovog utamničenja od njegovog brata načinila zombija. Moćnoj veštici nije dovoljno sve što ima, ona želi još i moć nad mrtvima kako bi mogla vladati živima, te će zazvati Euguna, koji utiče na život i na smrt: „Dosta je mladih života moralo naprasno završiti kako bi mu se privukla pažnja. ${ }^{46}$ Od njega Cabrón saznaje da mu brat nije među mrtvima: njegova duša je nestala a telo služi veštici dok se ne ospe: „Ni živ, ni mrtav, ni čovjek, ni sjena. (...) Mrtvac bez duše, volje, olakšanja smrti i ushićenja života. ${ }^{{ }^{47} 7}$ Smrt je nekada najbolja stvar koja može da se desi, kao u ovoj priči - kako bi olakšala patnje i donela upokojenje duši u telu koje je počelo da se raspada. Stremljenja veštice Kvebralej nimalo se ne razlikuju od nagona drugih pomenutih likova - da se bude onaj ko će odlučivati o tuđim životima i ko će izigravati Boga, egzekutora, delioca pravde. U takvom svetu svi su žrtve, unapred predodređene za patnju i nadanje da će ih smrt pokositi pre nego što neki Arbitar otpočne svoj ogled na njima.

Smrt u hororu pokreće brojna pitanja čiji odgovori leže u sferi fantastike. Ne možemo saznati ko su oni koji kontrolišu smrt na ovoj ili onoj razini, i otkuda im to pravo i moć. To samo doprinosi još većoj misteriji ionako tajanstvenog fenomena, oko koga su se odvajkada lomila koplja, kako naučnika koji se tim fenomenom bave, tako i svakog čoveka ponaosob. Smrt u horor pričama nikada nije samo kraj života, koji podrazumeva propadanje tela i preseljenje duše u sferu onostranog. Nekada se ta duša ovaploti u telu koje je sposobno da egzistira na granici svetova. Vrlo često do smrti se stiže nasilno, voljom nekog ko je na sebe preuzeo ulogu delioca pravde, koja je sve samo ne to, ili čak onog ko smišlja pravila igre kojom bi trebalo da se živući suprotstave unapred određenoj mašineriji. Smrt u hororu najčešće nije prirodna, već silom izazvana od jedinke koju vodi osveta, ludilo ili nešto treće. Zbog toga oni koji se nađu pred dželatom smrt često priželjkuju, kao olakšanje od patnji i mučenja kojima su podvrgnuti. Osnovni cilj horora jeste izazivanje straha putem oslikavanja demonskih likova i monstruoznih načina njihovog delanja, koji će, preko likova na koje deluje, naći put i do čitalaca.

46 Irena Rašeta, „Cabrón“, Zagrob, 67.
47 Isto, 68. 
Smrt kao fenomen u istraživanim pričama (80\% pripovedaka od ukupnog broja, u oba pripovedačka zbornika, tematizuje smrt) pomoći će nam da razumemo neke od zakona na kojima žanr počiva, ali i tajnu smrti kao jednu od najvećih inspiracija za literarne stvaraoce. Samim tim što je nedokučiva, smrt je otvorila prostore da se prikaže i kao ne-konačna putanja u postojanju čoveka. Smrt se ovde javlja kao opšti usud čoveka, čijem se prevazilaženju teži imaginiranjem formi zagrobnog života. Istovremeno, ovde je u fokusu sudbina modernog čoveka koji više nije homo religiosus, kojem vera u Boga daje perspektivu, istina neizvesnu i potencijalno zastrašujuću, pošto zagrobna egzistencija duše može biti i večito blaženstvo i večita patnja. Smrt se u hororu javlja i kao manifestacija užasa pred vlastitim nesvesnim i podsvesnim nagonima (npr. zversko ubijanje ili proždiranje žene, kao kazna za incestuozne želje ili manifestacija infantilne težnje za inkorporacijom majke). Neodvojivi su ovde eros i tanatos, ne samo kao suprotnosti već i kao uroboros ljudskog postojanja. A stravične manifestacije smrti u tom pogledu, lepo su nam dočarali ovi pisci.

\section{$\cos$}

\section{Izvori i literatura}

\section{Izvori}

Nešto diše u mojoj torti. Antologija novogodišnjih priča strave, [s. 1.] 2012.

Zagrob. Zbirka hrvatskog horora (ur. Tatjana Jambrišak i Darko Vrban), Zagreb 2006.

\section{Literatura}

Jean Chevalier - Alain Gheeerbrant, Rječnik simbola, Zagreb 1994.

Sava Damjanov, Vrtovi nestvarnog (ogledi o srpskoj fantastici), Beograd 2011.

Radovan N. Kazimirović, Tajanstvene pojave u našem narodu i Kremansko proročanstvo, Smederevo 1986.

Špiro Kulišić - Petar Ž. Petrović - Nikola Pantelić, Srpski mitološki rečnik, Beograd 1970.

Hauard Filips Lavkraft, „Natprirodna strava u književnosti“, Slučaj Čarlsa Dekstera Vorda, Beograd 1990., 143-205.

Dejan OGnjanović, „Odnos prema horor žanru u književnoj i filmskoj teoriji na srpskom jeziku“, Književna istorija, 42/2010., br. 142, 559-570.

Dejan Ognjanović, Poetika horora, Novi Sad 2014.

Oto OltvanjI, Pucketanje patosa ispod mythosa i ethosa (http://www.novipolis.rs/kultura/28842/ pucketanje-patosa-ispod-mythosa-i-ethosa.html).

Predrag Palavestra, „Kritičke odlike srpske fantastike“, Knjiga srpske fantastike, Beograd 1989., $7-42$.

Kurt Zeligman, Istorija magije, Beograd 2010. 


\section{THERE'S SOMETHING BREATHING IN THE AFTERWORLD: DEATH IN THE COLLECTIONS NEŠTO DIŠE U MOJOJ TORTI AND ZAGROB. ZBIRKA HRVATSKOG HORORA}

In literary theory and history, horror is a relatively underrepresented genre. The practice of intentionally overlooking and airbrushing works with "obscene" and "blasphemous" content that dates back to the Enlightenment has, as if by inertia, continued ever since. Some of the works which represent the pinnacle of the genre have not yet been translated into Serbian or Croatian, just like numerous studies and theoretical works about horror remain fairly inaccessible as resources, available only in foreign languages. In light of all this, the publication of the two collections of short stories Nešto diše u mojoj torti (There's something breathing in my cake) and Zagrob. Zbirka hrvatskog horora (The Afterworld. A collection of Croatian horror) is a significant literary event. Zagrob was published as a result of a writing competition held in 2006, and consists of 13 horror stories, one essay and several poems by Croatian authors. Nešto diše u mojoj torti is comprised of 11 stories written by nine predominantly Serbian authors, and was originally published online as a PDF file in 2012. In both books, frightening events generate various manifestations of death, in accordance with the basic principles of the genre. Death wish is also typical of the genre, felt either by the characters, subjected to intolerable suffering, or by the readers, as a result of unbearable suspense. In the collections that were analyzed, death is frequently violent, often following a clash with the supernatural, but it can also occur as a sort of vanishing, a transition into the afterlife. Simultaneously, a denial of death also takes place, since certain protagonists witness not only the decay of the body, but also the possibility of a continued existence beyond death, in a spiritual form. Still, characters who come face to face with death in these stories will almost inevitably succumb to it, often by choice. This paper, therefore, considers the phenomenon of death in the genre of horror, as well as the ways the protagonists of the stories deal with the problem of death.

Key words: death, horror, suffering, violence, victim/sacrifice 


\section{6. \\ GROBNI SPOMENICI \\ IZ SJEVEROZAPADNE HRVATSKE \\ U SVJETLU ODNOSA RIMSKE ANTIKE \\ PREMA SMRTI}

\section{Branka Migotti}

UDK: 904:726.821“652“

Izvorni znanstveni članak

Sažetak: Rimska civilizacija bila je opsjednuta čuvanjem uspomene kao zaloga svojevrsnog vječnog života, toliko da je dužnost njegovanja uspomene na mrtve podigla na razinu zakonske obveze. Rimski epitafi, koji se kreću od lapidarnih fraza s osnovnim podacima o pokojnicima i ožalošćenima pa sve do dugačkih pjesama literarne vrijednosti i psihološkofilozofskih aspiracija, pružaju različite podatke o društvenom položaju, materijalnim mogućnostima i religijskim sklonostima stanovnika Carstva. Ipak, takva saznanja do punog izražaja dolaze tek na spomenicima koji združuju riječ i sliku, odnosno nadgrobni natpis i portrete pokojnika praćene različitim simboličnim prizorima i motivima. Njihovo gonetanje, međutim, nerijetko zahtijeva prodiranje u dubinske slojeve slike i čitanje između redaka. Rimsko društvo podiglo je općeljudsko poštovanje prema smrti na razinu dopuštene obmane u kojoj su ljudi bili skloni ne prikazivati se na grobnim spomenicima u stvarnom društvenom položaju, već u priželjkivanom, primjerice, u odjeći koja im nije bila statusno propisana. U ovome se prilogu različiti aspekti (samo)predstavljanja u smrti u razdoblju rimske antike ilustriraju primjerima izabranih grobnih spomenika iz sjeverozapadne Hrvatske. ${ }^{1}$

Ključne riječi: rimska civilizacija, smrt, epitaf, grobni spomenici, Sisak (Siscia), Ščitarjevo (Andautonia)

\section{ODNOS ČOVJEKA RIMSKE ANTIKE PREMA SMRTI}

rema rimskome zakonu, grob je bio sveto mjesto (locus religiosus). ${ }^{2}$ To je podrazumijevalo dvostruku zaštitu pokojnika: zabranu bilo kakvog skrnavljenja vječnog doma (domus aeterna) te brigu za njegovo materijalno održavanje i redovito odvijanje grobnih obreda

1 Zahvaljujem nepoznatom recenzentu/recenzentici na trudu uloženom u otkrivanje slabosti rukopisa, a osobito na uputama za njihovo otklanjanje, što je vidljivo poboljšalo ovaj prilog.

2 Henner von Hesberg, „Planung und Ausgestaltung der Nekropolen Roms im 2. Jh. n. Chr.", Römische Gräberstrassen. Selbstdarstellung - Status - Standard (ur. Henner von Hesberg i Paul Zanker), München 1987., 58; Maureen Carroll, Spirits of the Dead. Roman Funerary Commemoration in Western Europe, Oxford 2006., 4. 
jer se zaborav smatrao najtežim oblikom smrti. Odredba Justinijanova zakonika (Dig., XI, 7, 2, 6), temeljena na predlošku starorimskog prava, kaže: Monumentum est, quod memoriae servandae gratia extat („Spomenik postoji da bi čuvao uspomenu“). ${ }^{3}$ Ona dobro oslikava opsjednutost Rimljana čuvanjem uspomene na mrtve kao zalogom trajanja prekogrobnog života, u smislu da čovjek živi dok živi uspomena na njega. Istina je da je takav odnos opće, takoreći spontano duhovno nasljeđe čovjeka na višoj razini kulture i civilizacije, ali samo su ga Rimljani formalizirali na zakonski obvezujući način. Nije stoga čudo da su se grobovi često podizali, uređivali i održavali već za života budućih pokojnika. Sličan pristup primjećuje se i u odnosu prema groblju kao materijalno-prostornoj sastavnici rimskih naselja, prije svega gradskih. Zakonsko odvajanje groblja od naseljenog mjesta rimska je civilizacija naslijedila od grčko-helenističke, ali je taj postupak prilagodila i razvila na osobit način koji je u pogledu općeg civilizacijsko-antropološkog doživljaja smrti izdvaja od ostalih povijesnih društava. Poznato je da su rimska gradska groblja bila poredana uz ceste extra muros i da su se povećanjem broja pokojnika razvijala u usporednim redovima manje ili više udaljenima od ceste. ${ }^{4}$ Međutim, želja za prestižnim pokopavanjem neposredno uz cestu u velikim je gradovima protegnula groblja kilometrima izvan gradskih zidina. Pritom se grobovi nisu susretali samo sa sakralnim sadržajima kao i u grčko-helenističkoj kulturi, već i s posve svjetovnim i s gledišta suvremenog poštovanja prema smrti nepriličnim zdanjima poput otmjenih vila, gospodarskih imanja s radionicama, pa čak i javnih kupališta, gostionica i prenoćišta. ${ }^{5}$ I sve to radi mentaliteta prestiža i želje za komunikacijom jer jedino su se epitafima grobova neposredno uz cestu pokojnici mogli obraćati svim prolaznicima, a ne samo užem krugu obitelji i prijatelja te $s$ mnogim ljudima podijeliti misli o prolaznosti života i podgrijavati nadu u svojevrsnu virtualnu besmrtnost, različitu od one stvarne, kakvu će propovijedati kršćanstvo. Tek će kršćanski svjetonazor u okviru rimske antike prekinuti opisan prostorni suživot živih i mrtvih, okupljajući groblja oko crkava i razdvajajući ih od svjetovnih sadržaja čak i onda kad ih je za duga stoljeća, praktički sve do suvremenog razdoblja, uključila u neposredno gradsko tkivo.

Rimski epitafi, koji se kreću od lapidarnih fraza s osnovnim podacima o pokojnicima i ožalošćenima pa do dugačkih pjesama literarne vrijednosti i psihološko-filozofskih aspiracija, pružaju različite podatke o društvenom položaju, materijalnim mogućnostima i religijskim sklonostima stanovnika Rimskog Carstva. Ipak, takva saznanja do punog izražaja dolaze tek na spomenicima koji združuju riječ i sliku, odnosno nadgrobni natpis i reljefne portrete pokojnika praćene različitim simboličnim prizorima i motivima. Njihovo gonetanje, međutim, nerijetko zahtijeva prodiranje u dubinske slojeve slike i čitanje između redaka. Rimljani su naime, osobito oni s netom stečenim rimskim građanstvom, bili skloni

3 Jocelyn Toynbee, Death and Burial in the Roman World, Baltimore - London 1996., 61-62, 75-77; M. CArroll, Spirits of the Dead, 1, 19, 30, 185-186; Jane Fejfer, Roman Portraits in Context, Berlin - New York 2008., 105-106; Stine BIRK, Depicting the Dead. Self-Representation and Commemoration on Roman Sarcophagi with Portraits, Aarhus 2013., 9 .

4 H. von Hesberg, „Planung und Ausgestaltung der Nekropolen Roms im 2. Jh. n. Chr.“, 50-51; J. Fejfer, Roman Portraits in Context, 109.

5 Nicholas Purcell, „Tomb and Suburb“, Römische Gräberstrassen, 29-33; M. Carroll, Spirits of the Dead, 1, 3, 64. 
predstavljati se na grobnim spomenicima ne u stvarnom, nego u priželjkivanom društvenom položaju, primjerice, u odjeći koja im nije bila statusno propisana. ${ }^{6}$

Osim navedenog, posve svjetovnog razloga manipuliranja društvenim položajem, cjelovito tumačenje rimskih grobnih spomenika usložnjavaju dva međusobno povezana vida grobne kulture, oba iz prostora duhovnosti i religije. Prvi se odnosi na zamišljanje i razumijevanje besmrtnosti, a drugi na religijsku simboliku likovnih prizora na spomenicima. Saznanja, ili radije naslućivanja o tome kako su Rimljani zamišljali besmrtnost, oslanjaju se na pisane podatke te na grobne spomenike i drugu arheološku građu. Budući da ti izvori pružaju vrlo oskudne, a opet raznovrsne uvide - jer se odnose na ljude u drugačijim prostornim, vremenskim, društvenim i kulturnim dimenzijama - naše razumijevanje ove teme ostaje nepotpuno, a saznanja je gotovo nemoguće smisleno objediniti na malom prostoru. Za ilustraciju donosim nekoliko primjera iz rimske literature. Marko Tulije Ciceron (Marcus Tullius Cicero, 1. stoljeće pr. Kr.), rimski pravnik, političar, govornik i pisac, na jednom mjestu u svojim Raspravama u Tuskulu (Cic. Tusc. 1, 27) navodi kako su Rimljani oduvijek gajili različite predodžbe o nastavku života, zamišljajući smrt više kao preobrazbu i seljenje, ali ne na isto mjesto: kao besmrtnici, slavni muževi i žene, odlazili su na nebo, dok su smrtnici ostajali na zemlji. Iz šume literarne i arheološke građe o temi smrti naslućuje se vjera Rimljana u postojanje nekakvog oblika života nakon smrti, ali su predodžbe o njemu bile mutne; pokojnike su neki zamišljali poput sjena bez osobnosti, dok su ih drugi vidjeli kao bića koja su barem dijelom zadržala svoj oblik i svijest živih ljudi. ${ }^{8}$ Svijet mrtvih pritom se zamišljao na različitim mjestima.

U poetskoj viziji nasljedovala se zamršena trodioba Podzemlja prema grčkom obrascu, s odvojenim mjestima za krivce koji ispaštaju, potom za prerano umrle te, naposljetku, za pravedne i zaslužne koji uživaju na Elizejskim poljanama, ili u svemirskim prostranstvima, ili, pak, na Otocima blaženih onkraj Oceana. ${ }^{9}$ Kao ilustraciju različitih viđenja o posmrtnom životu evo dvaju primjera, čiji su autori, premda vremenski udaljeni tek jedno stoljeće, bili na dvjema miljama udaljenim svjetonazorskim polovima. Prvi je Trimalhion, lik iz romana Satyricon pisca Petronija (Gaius Petronius Arbiter, 1. stoljeće), razmetljiv i nadmen skorojević, bivši rob koji, opisujući svoj zamišljen raskošan grob, izjavljuje kako će mu ta građevina osigurati život nakon smrti jer da je besmisleno imati lijepu kuću za života, a ne brinuti se za onu u kojoj ćeš živjeti znatno dulje (Satyricon 71, 7). ${ }^{10} \mathrm{Na}$ drugom kraju spek-

$6 \quad$ Najizrazitiji primjer jest takva „zlouporaba“ toge, kao statusne odjeće rimskog građanina i stoga nedostupne ljudima bez građanskog prava. Usp. Hans Rupprecht Goette, Studien zu römischen Togadarstellungen, Mainz am Rhein 1989., 2 i dalje; Shelly STone, „The Toga: From National to Ceremonial Costume“, The World of Roman Costume (ur. Judith Lynn Sebesta i Larisa Bonfante), Madison - London 1994., 17; J. Fejfer, Roman Portraits in Context, 33 i dalje.

7 Cinzia Vismara, „L’apport des textes antiques“, Incinérations et inhumations dans l'Occident romain aux trois premiers siècles de notre ère (ur. Michel Vidal), Toulouse i992., inz.

8 J. Toynbee, Death and Burial in the Roman World, 35-36; Jacopo Ortalli, „Simbolo e ornato nei monumenti sepolcrali romani: il caso aquileiese", Aquileia dalle origini alla costituzione del ducato longobardo. Topografia, urbanistica, edilizia pubblica (ur. Giuseppe Cuscito i Monika Verzár Bass), Trieste 2004., 275-278; M. Carroll, Spirits of the Dead, 3-4; J. Fejfer, Roman Portraits in Context, 105; S. Birk, Depicting the Dead, 51-54.

9 J. Toynbee, Death and Burial in the Roman World, 36-39.

10 Petronije Arbiter, Satirikon ili vragolaste pripovijesti (prir. Antun Branko Kalinić), Zagreb 1986., 103; N. PurCELL, „Tomb and Suburb“, 25. 
tra razmišljanja o vječnosti stoji rimski car Marko Aurelije (121. - 180.). U filozofskom

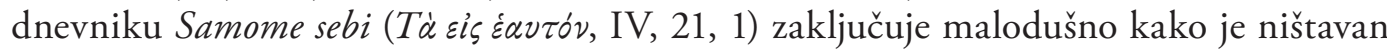
ljudski život jer nakon smrti tijela duše lebde u svemiru, koji će ih nakon nekog vremena progutati kako bi napravio mjesta za nove duše. ${ }^{11}$ Cara filozofa očito se nisu dojmile soteriološke zamisli orijentalnih misterija poput onih Demetre i Perzefone, Kibele (Velika majka bogova/Magna Mater Deorum), Izide, Orfeja, Mitre i Dioniza, koje su upravo za njegova života zadobile osobito snažan utjecaj na religijski život Carstva. Ti su misteriji mitovima o smrti i ponovnom rađanju bogova dotaknuli nadu u cikličku obnovu života i za sljedbenike, približivši se tako kršćanskoj dogmi vječnog života. ${ }^{12}$

O drugom elementu koji utječe na ukupno tumačenje grobnog spomenika, religijskoj simbolici prikazanih motiva i prizora, napisane su stranice i stranice rasprava i osvrta, koje je moguće svesti na jednu jedinu dvojbu: ukras ili simbolika. Rijetko bi tko posumnjao u to da likovi bogova i mitološki prizori nose posve određenu simboliku vjerovanja, strahova, nada i predrasuda vezanih uz odnos čovjeka rimske antike prema svakodnevici, prošlosti i budućnosti, vrlini i mani, životu i smrti, religiji i svemu što je ljudska misao dotaknula. ${ }^{13}$ Nasuprot tome, pojedinačni motivi životinja i biljaka, posebno potonjih, često se svode na puki ukras bez simboličke uloge, što je previše pojednostavnjeno gledanje. Budući da je grobna ikonografija u osnovi duboko religijski uvjetovana, s obzirom na to da je i sâm grob locus religiosus, nema dvojbe da je u temeljnoj zamisli svaka dekoracija nosila izvjesnu, pa makar i višeznačnu, religijsku simboliku. ${ }^{14}$ Ta simbolika nije nestala zato što je vjerojatno bilo ljudi koji je s vremenom više nisu razumjeli pa su, birajući motive za grobni spomenik, vidjeli u njima samo ukras.

\section{Spomenici}

Odnos religijske i filozofske simbolike prizora pri tumačenju rimskih grobnih spomenika zapravo i nije moguće posve izbjeći jer su ta dva aspekta nerijetko (posredno ili neposredno) povezana s društvenim položajem budućeg pokojnika i njegovom zamisli o tome kako se želio predstaviti na spomeniku. $U$ ovome se razmatranju naglasak stavlja na aspekte života u okviru rimske civilizacije u sjeverozapadnoj Hrvatskoj, predočene grobnim spomenicima razdijeljenim u manje tematske skupine. $S$ obzirom na takav pristup, u razmatranjima (samo)predstavljanja pokojnika daje se prednost njihovu društvenom položaju i statusu u kontekstu provincijalno-rimske kulture, s religijskim aspektima u drugom planu.

11 C. Vismara, „L'apport des textes antiques“, 128-129.

12 Robert Turcan, The Cults of the Roman Empire, Oxford - Cambridge, MA 1996.; J. OrTalli, „Simbolo e ornato nei monumenti sepolcrali romani: il caso aquileiese“, 275-278.

13 J. Fejfer, Roman Portraits in Context, 133-135; S. Birk, Depicting the Dead, 94-107; Guntram KocH - Hellmut Sichtermann, Römische Sarkophage, München 1982., 614-617.

14 G. Koch - H. Sichtermann, Römische Sarkophage, 601; Branka Migotti, „Ranokršćanski grobni nalaz iz Velikih Bastaja kod Daruvara“, Vjesnik Arheološkog muzeja u Zagrebu, 28-29/1995. - 1996., 143; J. OrTalli, „Simbolo e ornato nei monumenti sepolcrali romani: il caso aquileiese“, 267-279. 


\section{1. Veteran}

Mramorna stela veterana Tita Flavija Atebodua, Aterigova sina (Sl. 1.), nađena je 1992. u selu Odri kod Zagreba, na području rimskog grada Andautonije. Arheološki kontekst upućuje na to da je veteran bio pokopan na svome imanju u ranom 2. stoljeću, a njegova raskošna stela jedan je od najljepših rimskih nadgrobnih spomenika sjeverne Hrvatske. ${ }^{15} \mathrm{Na}$ bočnim stranama zabata leže lavovi s ovnujskim glavama u šapama, a u njegovu je središtu glava Meduze s krilcima na tjemenu i zmijama zavezanima pod bradom; zmijska tijela vijugaju uvis uz Meduzine obraze, a sa svake strane vrebaju ih ptice grabljivice. Friz pod zabatom i stupovi uz natpisno polje ukrašeni su motivima lotosa i palme, a donji dio stele zaprema trodijelni prizor naoružanog konjanika okruženog dvama krilatim erotima, koji tugu iskazuju naopako okrenutom bakljom provučenom kroz vijenac i obrazom naslonjenim na dlan ruke položene na rame. Za razliku od mitoloških likova i simboličkih motiva, jedini stvaran prizor na ovoj steli jest konjanik koji nesumnjivo prikazuje pokojnika, što se dade zaključiti iz epitafa: T(ito) Fl(avio) Aterigis / fll(io) Ateboduo I an(norum) LXXVve[te]r(ano) / emerito coh(ortis) I[I] Va[r](cianorum) / 5 eq(uitatae) cornuclario (!) / praef(ecti) et Crispi[n](ae) / coniug(i) an(norum) $L V$ / et Fl(avio) Augurino nep(oti) / an(norum) V. / ${ }^{10}$ $H$ (eres) f(aciendum) c(uravit). Prijevod glasi: „Nasljednik se pobrinuo da se načini za sedamdesetpetogodišnjeg Tita Flavija Atebodua, Aterigova sina, umirovljenog veterana Druge konjaničke kohorte Varcijanâ i pomoćnika zapovjednika kohorte, te za njegovu pedesetpetogodišnju suprugu Krispinu i petogodišnjeg unuka Flavija Augurina."

Prikaz konjanika na donjem dijelu stele nije portret u pravom smislu, uobičajen za rimsku grobnu portretistiku, u kojoj se pokojnici najčešće prikazuju u obliku poprsja, a rjeđe čitavih likova, ali nije ni posve općenit motiv. Konjanik je svojevrstan generički prikaz vlasnika stele, nekadašnjeg vojnika konjaničke jedinice, čiji nadgrobni spomenik i svojom raskoši, ali i izborom prizora odražava ponos domaćeg čovjeka koji je ostvario uspješnu vojničku karijeru i postao istinski Rimljanin. Njegov kognomen (cognomen) Atebod (Ateboduus)

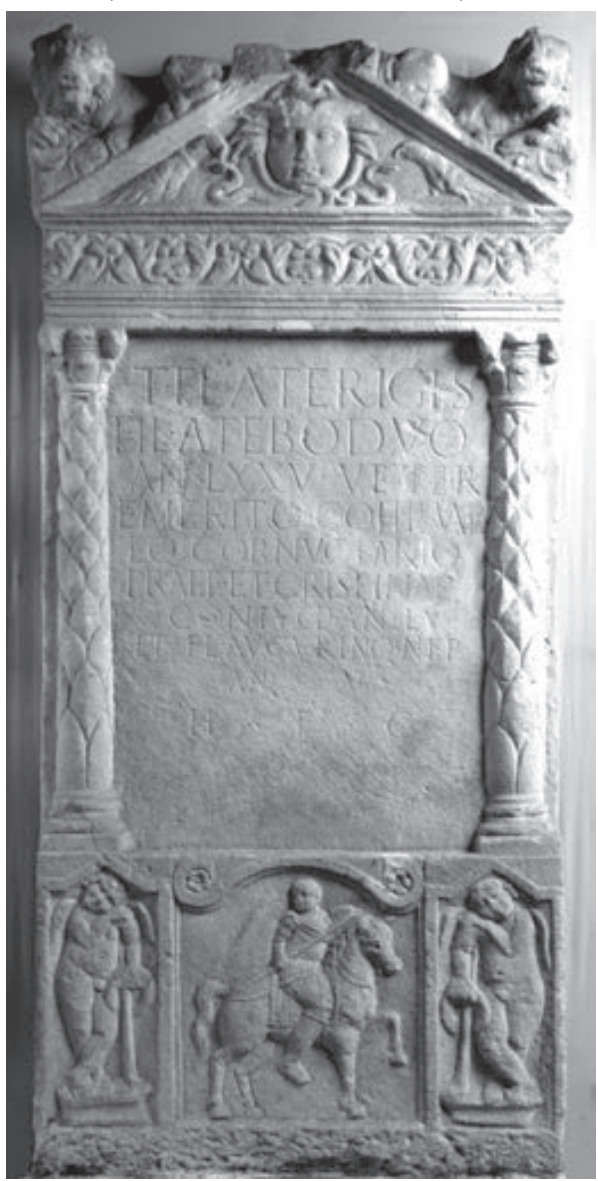

Sl. 1. Stela Tita Flavija Ateboda (2. stoljeće), Odra kod Zagreba (Arheološki muzej u Zagrebu)

15 Ante Rendić-MiočEvić, „The Marble Funerary Stele of the Cohors II Varcianorum Equitata's Veteran, Titus Flavius Ateboduus from the Odra Village near Zagreb“, Sepulkralna skulptura zapadnog Ilirika i susjednih oblasti u doba Rimskog Carstva (ur. Nenad Cambi i Guntram Koch), Split 2013., 343-381; Année épigraphique 2013., 1206. 
svjedoči da je posrijedi pripadnik domaćeg plemena Varcijanâ, a ne izvorni Rimljanin, o čemu govori i očevo mu ime Aterig (Aterix). Dok otac nikad nije dobio rimsko građansko pravo, što proizlazi iz nedostatka trodijelne rimske imenske formule (tria nomina), sinovljevi praenomen i nomen upućuju na to da je to pravo dobio za vrijeme careva Flavijevaca (69. - 96.), pri čemu mu je izvorno ime Atebod, u latiniziranom obliku Ateboduus, dospjelo na posljednje mjesto, kao cognomen. Prema tome, Atebod se bio prijavio u kohortu svojih sunarodnjaka kao panonski Kelt bez građanskog prava, takozvani peregrin, da bi u službi napredovao do mjesta kornikularija (cornicularius) - pomoćnika (svojevrsnog tajnika) zapovjednika jedinice, a vojnički staž završio stjecanjem građanskog prava. Ime njegove dvadeset godina mlađe supruge Krispine (Crispina) rimsko je i ne otkriva njezino etničko podrijetlo.

Atebod je u veteranskoj mirovini poživio dugo, a sudeći prema grobnom spomeniku, nije ni oskudijevao materijalno; mramor je na područje Andautonije trebalo uvoziti iz Petovione (Poetovio, Ptuj u Sloveniji), odnosno s planine Pohorja u blizini toga grada ili iz još udaljenijih noričkih gradova. Ipak, Atebodov epitaf otkriva sudbinu koja se ne bi mogla nazvati obrascem obiteljske sreće. Budući da je grob dao načiniti neimenovan nasljednik, očito ne član obitelji, jasno je da je Atebod dijete ili djecu izgubio prije negoli unuka, a potom i unuka u dječjoj dobi, ostavši bez nasljednika loze i onoga tko je trebao uživati stečenu obiteljsku čast i imetak. Mali Flavije Augurin imao je građansko pravo, o čemu svjedoči dvočlana rimska imenska formula, a njegovo osobno ime više ni u tragovima ne odaje keltsko-panonsko podrijetlo. Tko zna je li ta mala obitelj u svome krugu komunicirala na jeziku Varcijana ili na latinskome.

\section{2. Glumac i stogodišnjak}

Prosječan životni vijek u Rimskome Carstvu procjenjuje se na 20 - 30 godina, što je izrazito niska stopa prema današnjim mjerilima. Mnogi su pretpostavljeni razlozi tome: velika smrtnost novorođenčadi i djece, smrtnost žena pri porođaju i muškaraca u ratovima te svih zajedno zbog nepovoljnih uvjeta života koji je, unatoč razmjerno visokoj razini rimske medicine, bio osobito ugrožen raznim epidemijama, osobito u zagušljivim malaričnim riječnim dolinama i prenatrpanim zagađenim gradovima. ${ }^{16}$ Zbog takve procjene životne dobi stanovnika Carstva podatak o stogodišnjaku na nadgrobnom natpisu iznenadit će neupućene, ali bez razloga: dugovječnost u to doba zapravo nije bila rijetkost. Ono što je zanimljivo u ovom kontekstu jest podatak da su provincije Norik i Panonija spadale među one u kojima je na epitafima zabilježeno osobito mnogo stogodišnjaka. ${ }^{17}$

Jedan od dvojice stogodišnjaka spomenutih u epitafima s razmatranog prostora bio je glumac, što daje prigodu zaviriti u svijet koji je oduvijek očaravao suvremenike, često izazivajući podijeljene osjećaje. Mramorna nadgrobna ploča (Sl. 2.) s epitafom stogodišnjaka

$\overline{16}$ M. Carroll, Spirits of the Dead, 175; Marjeta ŠAšEL Kos, „Centenarians in the Emona area and the adjacent Norican and Pannonian regions", Misurare il tempo, misurare lo spazio (ur. Maria Gabriella Angeli Bertinelli i Angela Donati), Faenza 2006., 179-183.

17 Isto, 188-195. 
Leburne iz 4. stoljeća nađena je 1823. u Sisku na prostoru zapadne siscijske nekropole. Vlasnik vinograda u kojemu je iskopana, trgovac Paulus Bitroff, dao ju je otpremiti u Mađarski narodni muzej u Budimpešti, gdje se i danas nalazi. Teatralno osebujan epitaf glasi: $D($ is $)$ M(anibus) / positus est hic Leburna / magister mimariorum / [q] ui vicxit(!) annos plus / [m] inus centum / [al]iquoties mortuus / [sum] set sic nunquam / [opto v] os ad superos bene / [va] ler\{a\}e. U prijevodu: „Bogovima Manima. Ovdje leži vođa glumaca Leburna, koji je živio stotinjak godina. Umro sam mnogo puta, ali nikada ovako. Vama koji ste još živi želim da ste dobro i zdravo." ${ }^{18}$

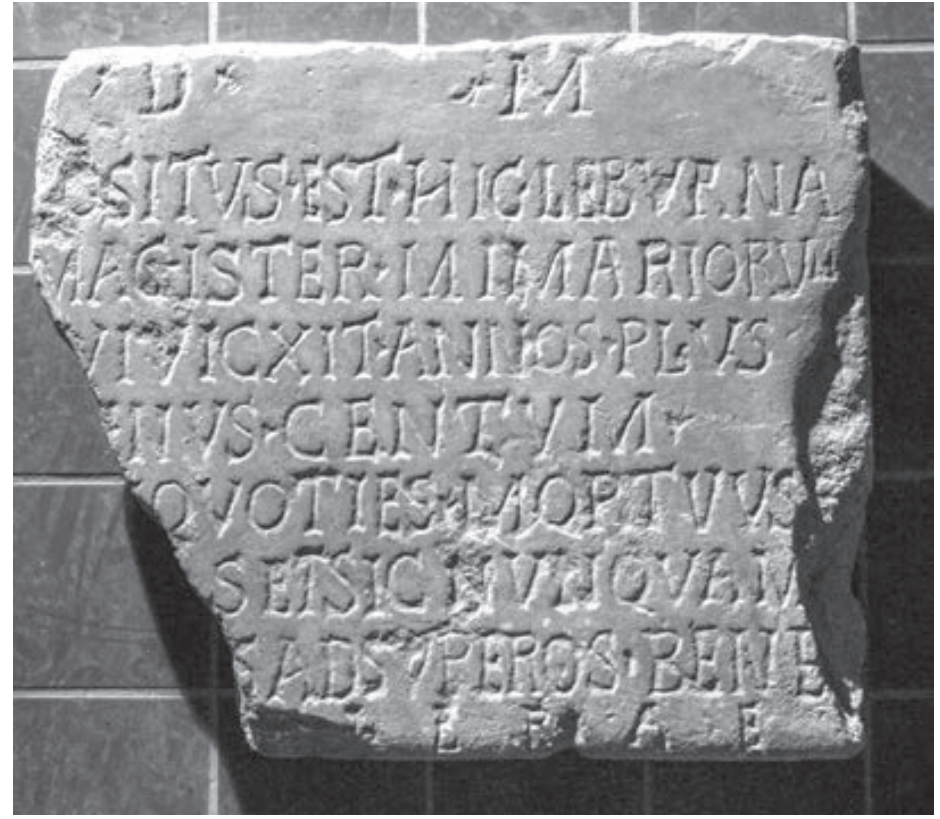

Sl. 2. Nadgrobna ploča Leburne (4. stoljeće), Sisak (Mađarski narodni muzej, Budimpešta)

Natpis sadrži dva dijela, jedan koji treba pripisati postavljaču spomenika i drugi koji izgovara sâm pokojnik, pri čemu osobitu pozornost privlače dva detalja. Prvi je navođenje pokojnikove dobi izrazom manje-više (plus minus). Godine navedene u epitafima često su se zaokruživale, ali se pretpostavlja da je to bilo prije zbog neznanja negoli zbog nemara. Međutim, u kasnijem razdoblju, počevši od 3. stoljeća, izraz plus minus postao je uobičajen detalj grobne epigrafije pa je moguće povezati ga sopćim duhovnim raspoloženjem kasne antike. U tom su se razdoblju, naime, mnoga pravila, pa i zakoni „razvodnili“ drugačijim tumačenjima i/ili praksama, posebno u provincijama udaljenima od Rima i Italije i prostorno i svjetonazorski. Gotovo da bismo kasnoantičko razdoblje (3./4. - 7. stoljeće) u okviru klasične antike smjeli usporediti sa suvremenom postmodernom i njezinom sveopćom eklektičnošću i relativizacijom duhovnih i moralnih vrijednosti te svjetonazorskih obrazaca. U takvom kontekstu možda je zaista postalo nevažno je li netko u času smrti imao par godina manje ili više. $S$ druge strane, neobvezatnost izraza plus minus u danom kontekstu mogla bi se povezati is duhovitošću rečenice kojom se pokojnik obraća prolaznicima, svojoj 
novoj publici u zagrobnom životu, izjavljujući da je „umro mnogo puta, ali nikada ovako“. Premda je tu rečenicu mogao smisliti i postavljač natpisa, čini se da ona ipak odražava duh glumca Leburne pa je veoma vjerojatno da ju je smislio on sâm, i to upravo za potrebe svog posljednjeg „nastupa“. Naime, navedena rečenica odnosi se na pokojnikovo zanimanje u doslovnom smislu, ali i kao ilustracija humora svojstvenog tom zanimanju, odnosno mimu (mimus), kazališnoj grani u kojoj je nastupao Leburna. ${ }^{19} \mathrm{Za}$ razliku od komedije ranijih razdoblja i zahtjevnije suvremene pantomime, mimičari su karikirali i parodirali svakodnevne „prizemne“ životne sadržaje i likove, nerijetko i na opscen način, iznimno s natruhama ironije, satire i kritike, ali zato s glavnom namjerom da nasmiju i zabave. ${ }^{20}$ Dva su moguća izvora Leburnine šaljive primjedbe iz epitafa. Jedan je taj što su se mimi prikazivali i u okviru pogrebnih povorki u kojima je glumac burlesknim načinom oponašao pokojnikov život. ${ }^{21}$ Drugi je, moguće, u samim sadržajima mima, nadahnutima svakodnevnim zgodama i spletkama, uključujući i lažne smrti. Prema tome, Leburna je u raznim kazališnim okolnostima uistinu umro mnogo puta.

Društveni položaj i status glumaca najbolje pokazuju pragmatičnu dvoličnost rimskog društva. U očima su zakona glumci bili obespravljeni položajem otprilike na razini radnika, robova i gladijatora pa su najčešće i dolazili iz redova robova i oslobođenika. Glumice su bile gotovo sinonim za prostitutke, a ni glumci nisu bili daleko od takvog glasa, zasluženog razvratnim prizorima u predstavama, koji su bili pretjerani čak i za općenito srozan rimski moral u razdoblju Carstva. S druge strane, pojedini glumci postali su ljubimci publike i pojedinaca iz viših slojeva. I u kasnoj antici, kada je živio Leburna, legalan položaj glumaca ostao je nepromijenjen, i dalje istodobno prezren i uzdizan. Na moralnu upitnost glumaca osobito je prijekim okom gledala Crkva. ${ }^{22}$ Mnoge je uspjela obratiti na kršćanstvo i odvratiti od glumačkog poziva, ali ne i Leburnu, premda je živio u gradu koji je bio biskupija. U Leburninu epitafu tako nema ni traga kršćanskog svjetonazora. Čini se da se u opisanom društvenom kontekstu naš glumac sasvim dobro snašao i duhovno i materijalno, o čemu svjedoče različiti detalji njegova života, zabilježeni u epitafu: dugovječnost, živ smisao za humor, titula magistra glumaca (magister mimariorum) i, konačno, mramorna nadgrobna ploča šaljiva sadržaja.

\section{3. Robovi}

Pojam roba u modernoj svijesti izaziva predodžbe o teškom životu i najcrnjoj ljudskoj sudbini. Jednim dijelom to svakako vrijedi i za rimsku civilizaciju jer su robovima zakonom bila ne samo uskraćena građanska prava, nego su se smatrali imovinom gospodara

\footnotetext{
19 Mimom se nazivala i kazališna predstava i glumac koji je u njoj glumio, a naslov magister mimariorum svjedoči da je Leburna bio glavni glumac, a moguće i vlasnik glumačke družine. Usp. Costas Panayotakis, Theatrum Arbitri. Theatrical Elemets in the Satyrica of Petronius, Leiden 1995., XVII.

20 Giusto Traina, „Lycoris the mime“, Roman Women (ur. Augusto Fraschetti), Chicago - London 2001., 85-88; Richard Miles, „Actors and acting“, Late Antiquity. A Guide to the Postclassical World (ur. Glen Warren Bowersock, Peter Brown i Oleg Grabar), Cambridge, MA - London 1999., 276-277; Richard Lim, „Theater“, Late Antiquity, 719-721.

21 Geoffrey Sumi, „Impersonating the Dead: Mimes at Roman Funerals“, The American Journal of Philology, $123 / 2002$. br. 4, 559-585.

22 G. Traina, „Lycoris the mime“, 84-85; R. Miles, „Actors and acting“, 276-277; R. Lim, „Theater“, 720.
} 
na razini s nekretninama, životinjama ili stvarima. S druge strane, način na koji su rimski građani doživljavali robove čini potonje najintrigantnijom društvenom skupinom rimske statusne ljestvice jer se njihova zakonska obespravljenost u svakodnevici ostvarivala u golemom rasponu različitih mogućnosti, a i psihološki odnos ostatka društva prema njima bio je prilično nijansiran. Dok se jedne zlostavljalo u ponižavajućim uvjetima, drugi su imali mogućnost samostalno voditi vlasnikove poslove i pritom zaraditi dovoljno za otkup iz ropstva, dok su oni najsretniji ostvarivali prijateljstvo i gotovo rodbinsku prisnost obitelji svojih gospodara. Slično kao u glumaca, istodobno preziranih i hvaljenih, stvarni položaj robova odražavao je proturječnost rimskog zakonodavstva utoliko što je sužanj u svakom pogledu mogao nadići ne samo položaj slobodnog čovjeka nego i rimskog građanina. ${ }^{23}$

Jedna od ljepših vapnenačkih stela u lapidariju Arheološkog muzeja u Zagrebu (Sl. 3.) pripadala je robovskoj obitelji iz sredine 2. stoljeća. ${ }^{24}$ Nađena je slučajno 1989 . tijekom komunalnih radova u Donjim Čehima u pred-

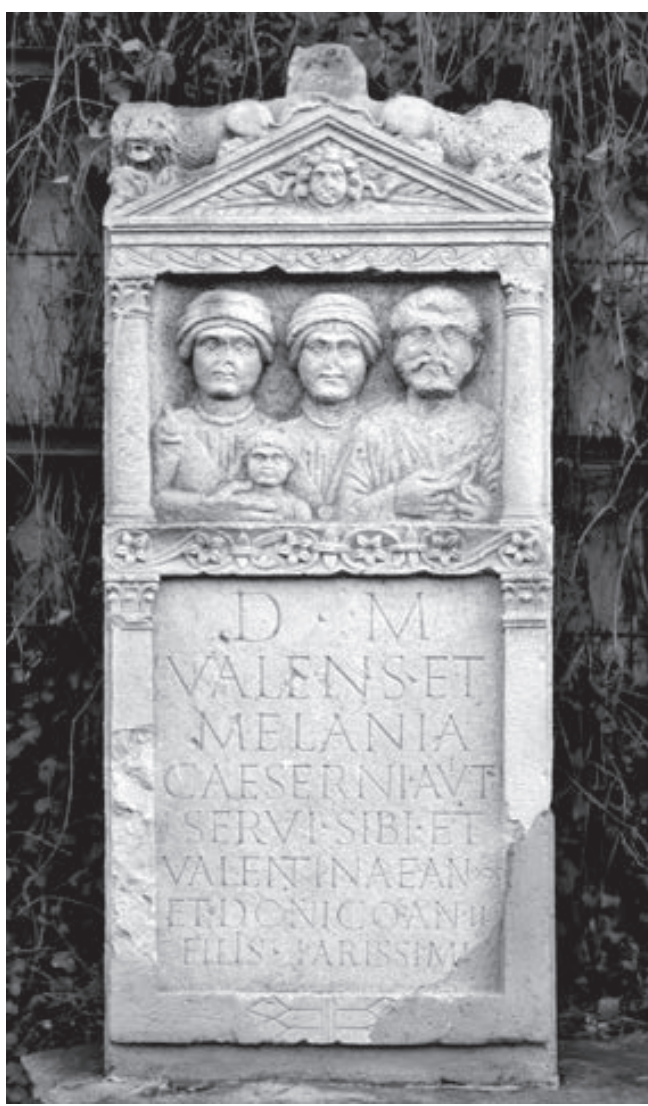

Sl. 3. Stela robovske obitelji (2. stoljeće), Donji Čehi (Arheološki muzej u Zagrebu) građu Zagreba. Premda nedostaje donji dio stele, potpuno su sačuvani i epitaf i portretna niša, a s njima i dobar dio životne priče robovske obitelji kojoj su društvene okolnosti bile naklonjene, ali ih je sudbina osujetila svojim za to vrijeme uobičajenim oružjem - preranim smrtima (mortes immaturae). Epitaf glasi: D(is) M(anibus) / Valens et / Melania / Caeserni Aviti / ${ }^{5}$ servi sibi et / Valentinae an(norum) XX / et Donico an(norum) II / fliis rarissimis. U prijevodu: „Bogovima Manima. Valent i Melanija, robovi Cezernija Avita, sebi i predragoj djeci: dvadesetogodišnjoj Valentini i dvogodišnjem Doniku.“

Bez obzira na pojedine nezgrapnosti u detaljima izvedbe, stela je raskošan, dopadljiv i u cjelini vrsno isklesan spomenik. Na sredini zabata prikazana je Meduzina glava, a na njegovim bočnim stranama leže lavovi s ovnujskim glavama u šapama. Na prvi pogled uočava se samosvijest prikazanih osoba vidljiva u odjeći i portretnim crtama koje oponašaju carske fizionomije i frizure. Na desnoj strani niše prikazan je Valent s frizurom te bradom i brkovima koji oponašaju izgled cara Antonina Pija (138. - 161.), odjeven u tuniku i ogrtač

23 Branka Migotтı, „Nadgrobni spomenik robovske obitelji iz Donjih Čeha kod Zagreba“, Archaeologia Adriatica, 2/2008., br. 2, 453-454; Sandra R. Joshel, Slavery in the Roman World, Cambridge 2010.; Henrik Mouritsen, The Freedmen in the Roman World, Cambridge 2015., 10-36.

24 Année épigraphique 2002., 1125; B. Migotтi, „Nadgrobni spomenik robovske obitelji“. 
(sagum) prikopčan na desnom ramenu okruglom kopčom. To je odjeća rimskog građanina u kakvoj se najčešće portretiraju vojnici ili civilni dužnosnici, ali ne i robovi; u svakodnevnom životu Valent je, prema zakonu, trebao biti odjeven u tuniku ili neku jednostavnu varijantu domaće radne odjeće. ${ }^{25}$ Lijevo do Valenta likovi su njegove žene Melanije i kćeri Valentine, obje prikazane s prevladavajućim domorodačkim detaljima u odjeći, ali i s jasnim naznakama pripadanja rimskom društvu. Njihova domaća odjeća i oprema sastoji se od tunike, ogrtača prikopčanog ili ukrašenog okruglom kopčom na sredini grudi, kape te nakita (ogrlica na objema ženama i narukvica na onoj s lijeve strane). Žena u lijevom kutu morala bi biti Melanija s obzirom na to da desnom rukom grli dječaka, svog sina Donika, prikazanoga u prvom planu između majke i sestre. Jedini detalj kojim dvije žene pokazuju i svoju „rimskost“ (Romanitas) odnosi se na frizure. Ona u sredini, pretpostavljena Melanija, na čelu ima kovrče koje se pojavljuju u carice Faustine Starije, supruge cara Antonina Pija, a poslije i u njezine kćeri Faustine Mlađe, supruge cara Marka Aurelija (161. - 180.). Zanimljivo je da je u obiju žena kosa uz gornji dio obraza počešljana na način noričko-panonskih domorotkinja, različito od frizura dviju spomenutih carica. Prema tome, dvije su ropkinje pažljivo pratile carsku modu češljanja, primjenjujući je tek u detalju koji je trebao pokazati da su u „u tijeku“, dok su njihovi osjećaji bili na strani izražavanja panonskokeltskog podrijetla s pomoću odjeće.

Gornji podaci svjedoče da je ova obitelj imala sreću kad je za vlasnika dobila Cezernija Avita (Caesernius Avitus). On je očito pripadao noričkoj grani elitne akvilejske senatorskoveleposjedničke obitelji Cezernijâ, koja je u 1. i 2. stoljeću rasprostrla mrežu poduzetništva i trgovanja u sjevernoj Italiji, Noriku i Panoniji. Bavljenje trgovinom moglo bi objasniti bič koji u ruci drži Valent na svom grobnom portretu, a koji najvjerojatnije simbolizira putovanje kao njegovu osnovnu djelatnost u službi gospodara Cezernija Avita. Sve u svemu, Valentova obitelj u materijalnom je smislu bila uspješna i zadovoljna svojim položajem jer kako drukčije objasniti činjenicu da nisu marili otkupiti se iz ropstva? Budući da su uvjeti za otkupljivanje, uz dobru volju gospodara, bili navršenih trideset godina i dovoljno zarađenog novca, ${ }^{26} \mathrm{i}$ Valentova zrela dob izražena portretom i podatak o dvadesetogodišnjoj kćeri, a potom vjerojatno i prilično skup grobni spomenik, svjedoče da prepreke stjecanju slobode najvjerojatnije nije bilo. Prema tome, obitelj iz ove priče dobar je primjer zadovoljnog robovanja u rimskom društvu.

\section{4. „Ženski svijet“ - rimska žena između patrijarhata i samosvijesti}

Bez obzira na literarne nijanse kojima se u rimskoj antici opisivala ženska narav i njezina ulogu u društvu, zakonodavstvo joj je namijenilo podređenu ulogu kao biću uvelike ovisnom u muškom skrbništvu i lišenome političkih prava. ${ }^{27}$ Istina, položaj žene ovisio je

\footnotetext{
25 Bez obzira na dvojbenost pisanih izvora i arheoloških spomenika te na suprotstavljena mišljenja o tome, čini se da su tunika i ogrtač bez kovinske fibule bili osnovna odjeća roba, a da su sve ostale varijante predstavljale stvarno pretjerivanje ili takvo predstavljanje na spomenicima. Usp. S. R. JosheL, Slavery in the Roman World, 132-136.

26 H. Mouritsen, The Freedmen in the Roman World, 34-35, 159-180.

27 Augusto Fraschetti, „Introduction“, Roman Women, 3-4; Branka Migotтi, „The Social/Gender Context of the Sarcophagus of a togata clarissima femina from Siscia (Pannonia Superior)“, Archaeologia Bulgarica, 11/2007., br. 1, 61-79; J. Fejfer, Roman Portraits in Context, 345-346.
} 
o njezinu društvenom statusu is vremenom mijenjao se nabolje pa se ugledna Rimljanka mogla istaknuti i ostaviti povijesni trag. Ipak, mogla je to učiniti samo dvama načinima, obama podjednako ovisnim o muškarcima iz kruga obitelji ili prijatelja: podržavati ih „iz sjene" ili, pak, javnim postupcima, budeći u sebi takozvane muške osobine i preobražavajući se u „muževnu ženu“ (mulier virilis). Možda su upravo potonje okolnosti urodile neuobičajenim likom žene na jednom mramornom sarkofagu iz Siska (Sl. 4.).

Taj sarkofag, jedinstven po mnogim detaljima natpisa i reljefnih prizora, nađen je slučajno 1882. na jugoistočnoj siscijskoj nekropoli, a potječe iz druge polovine 3. stoljeća. ${ }^{28}$ Epitaf glasi: [D(is) M(anibus) ?] / Romania N(a)evia clari /ssima femina viva / fecit sibi memoriam / ${ }_{5}^{5}$ pr(a)ecurrentibus Cletio / Romuliano et Aur(elio) / Calemero. Zbog oštećenja površine kamena nije sigurno je li epitaf počinjao uobičajenim zazivom Dis Manibus, ali uz pretpostavku da jest, prijevod glasi: „Duhovima umrlih. Romanija Nevija, clarissima femina, dala je za života sebi načiniti memoriju nakon što su je pretekli Kletije Romulijan i Aurelije Kalemer." Prozni grobni natpisi u pravilu su ujednačeni u izboru riječi i fraza; ako su dobro sačuvani, velik broj njih čita se i razumije bez poteškoća. To se, međutim, ne odnosi na ovaj primjer pa je ponuđeni prijevod jedan od dvaju mogućih, s time da su oba podjednako zagonetna, ostavljajući lik vlasnice sarkofaga i njezin postupak u vezi s pokopom tek djelomično rasvijetljenim. Sintagma clarissima femina (veoma ugledna žena; doslovce: najsjajnija žena) službena je senatorska titula stečena obiteljskim nasljeđem od oca ili muža. To znači da je pokojnica pripadala senatorima, najvišem sloju rimskog društva, na hijerarhijskoj ljestvici smještenom neposredno ispod carske obitelji. ${ }^{29}$

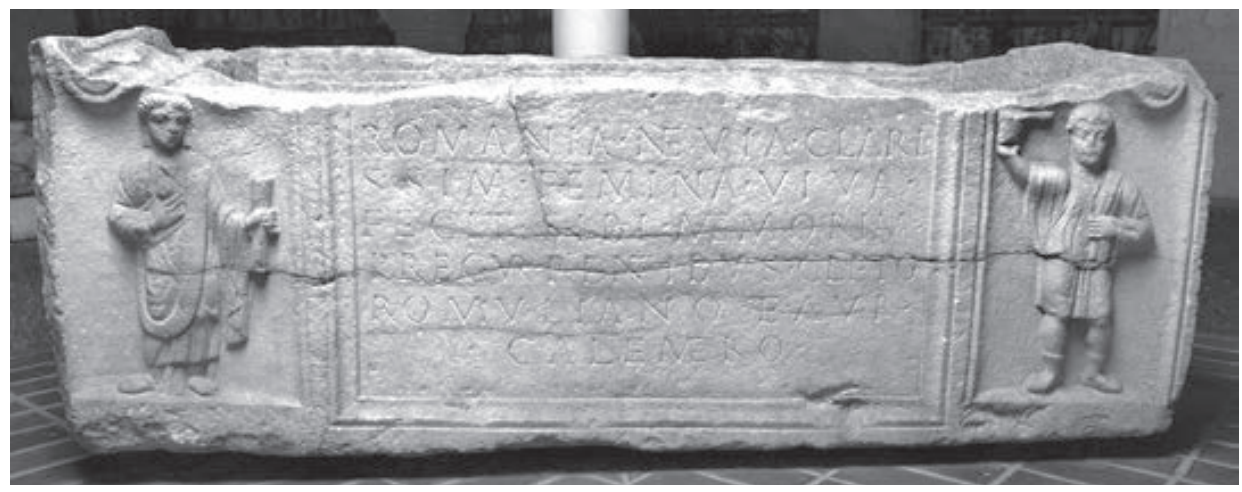

Sl. 4. Sarkofag Romanije Nevije (3. stoljeće), Sisak (Arheološki muzej u Zagrebu)

U nišama uz epitaf prikazana su dva reljefna stojeća lika. Na desnoj je strani mladić odjeven u opasanu tuniku s posudom u podignutoj desnoj ruci, dok ljevicom pridržava ručnik prebačen preko ramena. Na lijevoj je strani mlada žena odjevena u togu, koja u desnoj ruci drži okrugao plod, a u lijevoj veliki svitak (rotulus). Ta dva lika zajedno jedinstvena su inačica motiva slugu, koji je uobičajen na grobnim spomenicima Norika i Panonije, ali na

28 CIL III 10852; Branka Migotti, „Sarkofag Romanije Nevije iz Siska“, Godišnjak Gradskog muzeja Sisak, 2/2001., $37-88$.

29 S. R. Joshel, Slavery in the Roman World, 35-37; Christier Bruun, „Senators and Equites: Prosopography“, The Oxford Handbook of Roman Epigraphy (ur. Christer Bruun i Jonathan Edmondson), Oxford 2015., $202-222$. 
grobnim oltarima, a ne na sarkofazima. Jedinstvenost prizora na sarkofagu Romanije Nevije počiva na ženskom liku odjevenome u togu jer je taj odjevni predmet pripadao muškoj odjeći s konotacijama građanskog prava i društvenog statusa. Od žena, togu su nosile samo djevojčice prije pubertetske dobi, prostitutke, preljubnice i služavke. $S$ obzirom na posljednju kategoriju, prizor na sarkofagu Romanije Nevije ne bi trebao biti neuobičajen, ali on to ipak jest. Naime, podatak o služavkama odjevenima u togu zabilježen je u pisanim izvorima, ali je praktički nepoznat kao likovni motiv, pogotovo u grobnoj umjetnosti. $\mathrm{Na}$ grobnim spomenicima Norika i Panonije služavke su se prikazivale isključivo u jednostavnoj domaćoj haljini; togi ondje nema ni traga, kao ni svitku. ${ }^{30}$ Štoviše, u grobnoj umjetnosti Panonije čak se i muškarci rijetko prikazuju u togama, a žene se radije portretiraju u domaćoj negoli u rimskoj odjeći. Prema tome, morao je postojati vrlo poseban razlog da se na grobnom spomeniku jedna široko rasprostranjena slika sluge i služavke zamijeni neuobičajenim prizorom u kojemu se ističe prikaz žene u muškoj odjeći. Čini se da bi taj razlog trebalo tražiti u osobnosti Romanije Nevije, naslućenoj iz njezina epitafa unatoč nejasnoćama i dvojbama. Ako su ondje spomenuta dvojica ljudi uistinu bila njezini pokojni muževi, nekoliko pitanja ostaje neodgovoreno. Kako to da uz imena pokojnih muževa nisu bile navedene i odgovarajuće senatorske titule? One su mogle biti izostavljene nemarom ili namjerno, pod uvjetom da su ih ta dvojica uistinu i imala. Naime, žena iz senatorske obitelji mogla se udati za nekoga tko nije bio u njezinu statusu uz uvjet da je bio slobodno rođen rimski građanin, a ne oslobođenik, ali se na takve brakove ipak gledalo prijekim okom. ${ }^{31}$ Nadalje, zašto bi senatorska udovica uopće spominjala pokojne muževe na spomeniku u kojemu se namjeravala dati ukopati sama? I gdje su oni bili pokopani, ili barem drugi od te dvojice? Čini se da je siscijska clarissima femina bila toliko zaokupljena sama sobom i svojim društvenim položajem da joj nabrojena pitanja nisu bila važna.

Za razumijevanje moguće veze između duhovnog sklopa jedne Rimljanke i njezine pretpostavljene sklonosti nošenju muške odjeće treba se prisjetiti da su u rimskom društvu togu ponekad odjenuli ili se u njoj prikazali na spomenicima muškarci kojima društveni status to zapravo nije dopuštao jer nisu bili rimski građani. ${ }^{32}$ Možda je slična okolnost u podlozi djevojke u togi prikazane na sarkofagu senatorske gospođe iz Siska. Kao dvostruka udovica sa senatorskom titulom, možda je izabrala togu kao simbol nastojanja da pokaže posjedovanje muških vrijednosti i sposobnosti; ženska rodna mimikrija u (samo)predstavljanju u ukupnoj se povijesti ljudske civilizacije nastoji protumačiti upravo u takvom psihološkom okviru. ${ }^{33}$ Romanija Nevija mogla se nadati da će je iskazivanje muških vrlina i sposobnosti u društvenom životu Siscije staviti u položaj koji su uživali muškarci njezina statusa, a moguće i njezini muževi ako su kojim slučajem ipak bili senatori, dakle predodređeni za dužnosti senatorskog stupnja u upravnoj, sudbenoj, financijskoj i religijskoj sferi javnog života. ${ }^{34}$

30 B. Migotti, „Sarkofag Romanije Nevije iz Siska“, 73.

31 Simon Corcoran, The Empire of the Tetrarchs. Imperial Pronouncements and Government AD 284-324, Oxford 2000., 96-97; H. Mouritsen, The Freedmen in the Roman World, 297.

32 Usp. bilj. 6.

33 B. Migotti, „The Social/Gender Context of the Sarcophagus of a togata clarissima femina“, 70; S. Birk, Depicting the Dead, 115-117, 138.

34 Usp. S. R. Joshel, Slavery in the Roman World, 35-36; C. BRuUn, „Senators and Equites: Prosopography“, 201-219. 
Riječju, siscijska clarissima femina, jedina senatorska žena koja je ostavila traga u arheološkoj povijesti sjeverne Hrvatske, bila je po svemu sudeći jedinstvena samopouzdana osoba koja je uspjela nadići uobičajene društvene okvire u provinciji Panoniji u 3. stoljeću, dakle u prostoru i vremenu u kojima su gospodarile „muške“ vrijednosti i vrline.

\section{EPILOG}

Premda su epitafi u osnovi obiteljska i privatna stvar, njihov je širi društveni potencijal u rimskom razdoblju bio neporeciv jer su se obraćali prolazniku nudeći mu različite komponente (samo)predstavljanja pokojnika i očekujući od njega recepciju tog predstavljanja kao potvrdu uloge pokojnika u društvenom životu zajednice i kao jamstvo trajnog pamćenja. Kada se pjesnik i govornik Auzonije (Decimius Magnus Ausonius, 4. stoljeće) u pjesmi De nomine cuiusdam Lucii sculpto in marmore (Aus. Epit. 32) malodušno zapitao o tome treba li se čuditi što umiru ljudi, kad propadaju spomenici, a s njima i imena, samo je dijelom bio u pravu - mnogi su "preživjeli“ do danas. ${ }^{35}$

\section{$\cos$}

\section{Literatura}

Année épigraphique 2002., 1125.

Année épigraphique 2013., 1206.

Petronije Arbiter, Satirikon ili vragolaste pripovijesti (prir. Antun Branko Kalinić), Zagreb 1986.

Stine BIRK, Depicting the Dead. Self-Representation and Commemoration on Roman Sarcophagi with Portraits, Aarhus 2013.

Christier Bruun, „Senators and Equites: Prosopography“, The Oxford Handbook of Roman Epigraphy (ur. Christer Bruun i Jonathan Edmondson), Oxford 2015., 202-226.

Shane Butler (ur.), Deep Classics. Rethinking Classical Reception, London 2016.

Maureen Carroll, Spirits of the Dead. Roman Funerary Commemoration in Western Europe, Oxford 2006.

Simon Corcoran, The Empire of the Tetrarchs. Imperial Pronouncements and Government AD 284-324, Oxford 2000.

Corpus Inscriptionum Latinarum (CIL) III 3980, III 10852.

Jane Fejfer, Roman Portraits in Context, Berlin - New York 2008.

Augusto FraschetTI, „Introduction“, Roman Women (ur. Augusto Fraschetti), Chicago - London 2001., 1-21.

Hans Rupprecht Goette, Studien zu römischen Togadarstellungen, Mainz am Rhein 1989.

Henner von Hesberg, „Planung und Ausgestaltung der Nekropolen Roms im 2. Jh. n. Chr.“, Römische Gräberstrassen. Selbstdarstellung - Status - Standard (ur. Henner von Hesberg i Paul Zanker), München 1987., 43-60.

Sandra R. Joshel, Slavery in the Roman World, Cambridge 2010.

35 Shane Butler (ur.), Deep Classics. Rethinking Classical Reception, London 2016., 167-168. 
Guntram Косн - Hellmut Sichtermann, Römische Sarkophage, München 1982.

Richard Lim, „Theater“, Late Antiquity. A Guide to the Postclassical World (ur. Glen Warren Bowersock, Peter Brown i Oleg Grabar), Cambridge, MA - London 1999., 719-721.

Branka Migotтı, „Nadgrobni spomenik robovske obitelji iz Donjih Čeha kod Zagreba“, Archaeologia Adriatica, 2/2008., br. 2, 453-465.

Branka Migotтı, „Ranokršćanski grobni nalaz iz Velikih Bastaja kod Daruvara“, Vjesnik Arheološkog muzeja u Zagrebu, 28-29/1995. - 1996., 127-157.

Branka Migotтı, „Sarkofag Romanije Nevije iz Siska“, Godišnjak Gradskog muzeja Sisak, 2/2001., 37-88.

Branka Migotті, „The Social/Gender Context of the Sarcophagus of a togata clarissima femina from Siscia (Pannonia Superior)“, Archaeologia Bulgarica, 11/2007., br. 1, 61-79.

Richard Miles, „Actors and acting“, Late Antiquity. A Guide to the Postclassical World (ur. Glen Warren Bowersock, Peter Brown i Oleg Grabar), Cambridge, MA - London 1999., 276-277.

Henrik Mouritsen, The Freedmen in the Roman World, Cambridge 2015.

Jacopo OrTALli, „Simbolo e ornato nei monumenti sepolcrali romani: il caso aquileiese“, Aquileia dalle origini alla costituzione del ducato longobardo. Topografia, urbanistica, edilizia pubblica (ur. Giuseppe Cuscito i Monika Verzár Bass), Trieste 2004., 245-286.

Costas Panayotakis, Theatrum Arbitri. Theatrical Elemets in the Satyrica of Petronius, Leiden 1995.

Nicholas Purcell, „Tomb and Suburb“, Römische Gräberstrassen. Selbstdarstellung - Status - Standard (ur. Henner von Hesberg i Paul Zanker), München 1987., 25-41.

Ante Rendić-Miočević, „The Marble Funerary Stele of the Cohors II Varcianorum Equitata's Veteran, Titus Flavius Ateboduus from the Odra Village near Zagreb“, Sepulkralna skulptura zapadnog Ilirika i susjednih oblasti u doba Rimskog Carstva (ur. Nenad Cambi i Guntram Koch), Split 2013., 343-381.

Shelly Stone, „The Toga: From National to Ceremonial Costume“, The World of Roman Costume (ur. Judith Lynn Sebesta i Larisa Bonfante), Madison - London 1994., 13-45.

Geoffrey Sumi, „Impersonating the Dead: Mimes at Roman Funerals“, The American Journal of Philology, 123/2002., br. 4, 559-585.

Marjeta ŠAšEL Kos, „Centenarians in the Emona area and the adjacent Norican and Pannonian regions“, Misurare il tempo, misurare lo spazio (ur. Maria Gabriella Angeli Bertinelli i Angela Donati), Faenza 2006., 175-197.

Jocelyn M. C. Toynbee, Death and Burial in the Roman World, Baltimore - London, 1996.

Giusto Traina, „Lycoris the mime“, Roman Women (ur. Augusto Fraschetti), Chicago - London 2001., 82-99.

Robert Turcan, The Cults of the Roman Empire, Oxford - Cambridge, MA 1996.

Cinzia Vismara, „L'apport des textes antiques“, Incinérations et inhumations dans l'Occident romain aux trois premiers siècles de notre ère (ur. Michel Vidal), Toulouse I992., I07-I47. 


\section{$\cos$}

\section{Funerary monuments from Northwestern Croatia IN LIGHT OF THE ATTITUDE TOWARDS DEATH IN THE ROMAN ANTIQUITY}

Roman law defined the grave as a sacred place (locus religiosus), protected from any kind of sacrilege and subject to legally bound maintenance by the heirs, who were also obliged to conduct the prescribed ritual performances. Because oblivion was considered to be the starkest form of death, the Romans were obsessed with the preservation of eternal memory as the guarantee of life beyond the grave, regardless of how vague their ideas of such a life and its imagined locations might have been. In such circumstances, the funerary monument was the most important material aspect of the preservation of memory, through which the heirs conveyed information about their dead ancestors to the living. Roman epitaphs, which range from lapidary phrases with basic information about the deceased and the bereaved, to lengthy poems with literary ambitions and psychological-philosophical aspirations, contain a wide range of information concerning the social standing, material wealth, and religious preoccupations of the inhabitants of the Empire. However, the greatest of the "speakers" and the most trustworthy of memory-keepers were the stones that featured epitaphs and portraits of the deceased, accompanied by various other symbolic images. Nevertheless, the mental images of the past as displayed on funerary stones need to be interpreted cautiously, always bearing in mind that the epitaphs tended towards careful pre-selection, naturally highlighting those particular attributes most favourable to the deceased. The above-mentioned commonplaces of Roman funerary anthropology are illustrated in this paper through four funerary monuments from the Northwest of Croatia, two each from Roman Andautonia (Ščitarjevo near Zagreb) and Siscia (Sisak). The first two provide insight into the social context of the life and death of an indigenous auxiliary soldier called Titus Flavius Ateboduus, who became a Roman army veteran, and that of a well-to-do slave family. The other two belonged to a centenarian called Leburna, the head and owner of a mimic troupe, and a senatorial lady called Romania Naevia, who seems to have risen above the usual female social standing defined by male domination, as suggested by the image of a woman dressed in a typical male garment - toga, which is shown on her sarcophagus.

Key words: the Roman civilization, death, epitaph, funerary monuments, Sisak (Siscia), Ščitarjevo (Andautonia) 



\section{7. \\ EPITAFI SREDNJEGA VIJEKA: \\ „KNJIGE ŽIVOTA I SMRTI“}

\section{Mirjana Matijević Sokol}

UDK: $929.55(497.5) “ 653^{“}$

Izvorni znanstveni članak

Sažetak: Epitafi - natpisi na nadgrobnim spomenicima ili općenito pjesme s istim sadržajem čuvaju sjećanje na pokojnika i djela koja je tijekom života napravio. Javljaju se od antičkih vremena u egipatskoj te grčkoj i rimskoj civilizaciji. Odraz su svjetonazorskih i civilizacijskih poimanja života i smrti. Srednjovjekovni natpisi na hrvatskom prostoru neposredan su izdanak ranokršćanskih epitafa u kojima se zrcali kršćanski svjetonazor. U članku predstavlja se osoban odabir ovih „pjesama u kamenu“ od ranokršćanskih vremena pa do kraja srednjeg i početaka novog vijeka. U njima mogu se uočiti i pratiti tijekom vremena koncepcijske, sadržajne i svjetonazorske promjene, ali se isto tako zamjećuju vječna promišljanja koja inicira smrt. Gotovo svi tekstovi daju naslutiti vječno prisutan strah od smrti, ali i ističu postignuća pokojnika za života s ciljem osiguravanja pamćenja. Iz onih kršćanskih srednjovjekovnih zrači vjera u zagrobni život. U članku se posebno razmatraju epitafi poznatih osoba koji su povijesna vrela prvoga reda. No, važno mjesto u razmatranju imaju njihovi sadržaji i struktura kao osebujna literarna pjesnička vrsta. ${ }^{1}$

Ključne riječi: epitaf, srednji vijek, svjetonazor, „pjesme u kamenu“, loci communes, smrt, pamćenje

C vi naši napori, sva naša djela samo su vidovi borbe protiv smrti“, zapisao je Vladan Desnica u svome romanu Proljeća Ivana Galeba. ${ }^{2} \mathrm{U}$ toj borbi za nezaborav svoje mje90 sto imaju epitafi. ${ }^{3}$ Civilizacije antičkog svijeta epitafima - posmrtnim tekstovima slavile su život pokojnika i čuvale uspomenu na njega. ${ }^{4} \mathrm{U}$ širem smislu sve što je zapisano

$1 \quad$ Rad je nastao u okviru projekta Izvori, pomagala i studije za hrvatsku povijest od srednjeg vijeka do kraja dugog 19. stoljeća (IP-2014-09-6547, voditelj projekta: dr. sc. Damir Karbić) Hrvatske zaklade za znanost. Naslov je članka „posuđen“ i parafraziran naslov knjige i poglavlja u knjizi o stećcima Dubravka Lovrenovića. Usp. Dubravko Lovrenović, „Epitafi - 'knjige života'“, Stećci. Galerija Klovićevi dvori, 4. rujna 2008. - 2. studenoga 2008. (ur. Jasminka Poklečki Stošić), Zagreb 2008., 204, 210; Isti, Stećci. Bosansko i humsko mramorje srednjeg vijeka, Sarajevo 2010., 130-131.

2 Citirano prema: Desničini susreti 2017. Smrt u opusu Vladana Desnice i europskoj kulturi-poetički, povijesni i fllozofski aspekti. Povodom 50. obljetnice smrti Vladana Desnice. Program rada/sažeci izlaganja (ur. Drago Roksandić, Vladan Bajčeta i Matko Globačnik), Zagreb 2017., 7.

3 O fenomenu zaborava i pamćenja usp. Saša Horvat, „Pojam zaborava u Platona“, Riječki teološki časopis, 22/2014., br. 2, 417-442.

4 D. Lovrenović, „Epitafi - 'knjige života'“, 204, 210; Isti, Stećci, 130-131.; James Spencer Northcote, Epitaphs of the Catacombs or Christian Inscriptions in Rome during the First Four Centuries, London 1878., 1. 
na grobu smatra se epitafom. Ovi su natpisi često u stihu ili prozi te sadrže podatke iz pokojnikova života, ali isto tako iskazuju i emotivan stav prema njemu, ali i prema smrti. U epitafe ubrajamo i literarne uratke, pjesme, sa sličnim sadržajem koje nisu upisane na samo grobno mjesto. Najstarijim epitafima možemo smatrati egipatske zapise na sarkofazima ili na drugim oblicima ukopa. ${ }^{5}$ Najbrojnija su skupina iz tih razdoblja grčki i rimski nadgrobni natpisi. Najstariji grčki epitafi pripisuju se lirskom pjesniku Simonidu s Keja (oko 556. 468. pr. Kr.), a posvećeni su junacima poginulim kod Termopila. ${ }^{6}$ Atenski epitafi u ranijim vremenima nemaju često ni ime pokojnika, nego tek malo konvencionalnih pohvala. Ističu se - ako je moguće - neka životna postignuća, osobito herojske okolnosti smrti. S vremenom su se razvijali u zasebnu pjesničku vrstu koja - kao i oni kasniji - sadrži biografske podatke o pokojniku, ali i pjesnički ocrtava njegov život. ${ }^{7} \mathrm{U}$ tom su smislu puno bogatiji rimski nadgrobni natpisi, kako oni poganski, ${ }^{8}$ tako i oni ranokršćanski. ${ }^{9}$ Među epitafe koji slave život i djela pokojnika možemo ubrojiti slavan natpisni tekst poznat pod nazivom Monumentum Ancyranum, čiji su sadržaj „djela božanskoga Augusta“ (res gestae divi Augusti). Ovaj je tekst sastavio sâm August kao svoju oporuku i bio je uklesan na dvama stupovima ispred njegova mauzoleja u Rimu. Preveden je i na grčki jezik te se prepisivao širom Rimskog Carstva. ${ }^{10}$

Srednjovjekovna epitafistika kontinuiran je slijed od ranokršćanskih pogrebnih natpisa koji su doživjeli preobrazbu od onih antičkih, poganskog svjetonazora, do onih koji su izraz kršćanskog pogleda na svijet. Težište su ovoga članka epitafi uglavnom iz srednjeg vijeka, koji su imali svoje mjesto pri proučavanju hrvatske povijesti kao povijesna vrela prvoga reda, ali su svojim literarnim iskazom ujedno najraniji začeci srednjovjekovnoga pjesništva na latinskom jeziku.

Glavna je značajka rimskih epitafa ta da su se u početku sastavljali vrlo jednostavno. $S$ vremenom se razvijaju i mnogi su pjesnički uraci sročeni u metru. Takve „pjesme u kamenu“ zastupljene su među poganskim epitafima, ali nadasve pozornost privlače oni ranokršćanski, osobito od vremena pape Damaza. Istražujući sadržaj i formu kasnoantičkih epitafa, uočavamo promjene koje se zbivaju - ne toliko u strukturi epitafa koliko u izričaju - pri prihvaćanju, pa onda i dominaciji kršćanskog svjetonazora. Kršćanski epitafi „odišu sasvim drugim duhom ${ }^{\text {"11 }}$ od onoga antičkog, poganskog. Vrlo promišljeno poganska se terminologija transformira u kršćansku na temelju više elemenata epitafa.

5 Igor Uranić, „Sarkofag i kartonaža Kaipamau“, Vjesnik Arheološkog muzeja u Zagrebu, 26-27/1993. - 1994., 146, 151.

6 François Chamoux, Grčka civilizacija u arhajsko i klasično doba, Beograd 1967., 186, 239-243, 328, 449.

7 Bradley H. McLean, An Introduction to Greek Epigraphy of the Hellenistic and Roman Periods from Alexander the Great down to the Reign of Constantine (323 B.C.-A.D. 337), Ann Arbor 2002. Za sepulkralnu epigrafiju usp. str. $260-288$.

8 Za odabrane rimske poganske epitafe iz Dalmacije usp. Duje Rendić-MiočEvić, Carmina epigraphica, Split 1987., $128-211$.

9 Usp. salonitanske kršćanske epitafe u: Nancy Gauthier - Emilio MArin - Françoise PrÉvot (ur.), Salona IV. Inscriptions de Salone chrétienne, IVe-VIIe siècles/Salona IV. Natpisi starokršćanske Salone, IV.-VII. st., 2 sv., Rome - Split 2010.; D. Rendić-MiočEvić, Carmina epigraphica, 212-241.

10 Više o ovom zapisu usp. Ernst Dienl (prir.), Res gestae divi Augusti, Bonn 1908.; Alison E. Cooley, Res Gestae Divi Augusti. Text, Translation, and Commentary, Cambridge - New York 2009.; Robert Matijašść (prir.), Djela Božanskog Augusta, Zagreb 2007.

11 D. Rendić-Miočević, Carmina epigraphica, 15. 
Praćenjem formula, kao i načina datiranja na ranokršćanskim i srednjovjekovnim epitafima uočava se i uspostavlja relativna kronologija koja je osobito važna za određivanje vremena nastanka spomenika kada je to drugačije nemoguće. ${ }^{12}$ Razlika se očituje u upotrebi termina koji nose nova značenja pa tako grob nije „vječni dom“ (domus aeterna), nego tek privremeno boravište u koji je pokojnik „odložen“ (depositus) i „počiva“ (requiescit) do usksnuća. ${ }^{13}$ Glagol deponere, kao i iz njega izvedena imenica depositio označava obred inhumacije kršćana, odnosno ukop u zemlju nasuprot ranijem poganskom spaljivanju (sepelire). Javlja se na kršćanskim natpisima već u III. stoljeću kao kršćanski obilježen termin kojim se očituje vjera u uskrsnuće i tek privremen boravak u grobu. ${ }^{14}$

Velik je utjecaj na formiranje nove kršćanske epitafistike imao papa Damaz. Oživljena je nekadašnja poganska inicijalna formula Hic iacet s više sličnih inačica (Hic/hoc in tumulol, requiescit, quiescit, quiescit in pace) na titulima katakombi koje je reformirao Furije Dionizije Filokal prema papinu nalogu, a nekima je autor sâm papa Damaz. ${ }^{15}$ Mnogi su tituli mala pjesnička remek-djela sastavljena u heksametru s uzorom u Vergilijevim stihovima. ${ }^{16}$ Vergilije je - svjedoči to sv. Jeronim u pismu papi Damazu - bio preporučena literatura kršćanskih pisaca, svetih otaca jer su u njegovim stihovima prepoznali navještaj Isusa Krista. ${ }^{17}$ Ovi običaji proširili su se po čitavom prostoru latinskog svijeta ${ }^{18}$ i postali su, uz one biblijske, loci communes kršćanske epitafistike.

Hrvatski srednjovjekovni korpus nadgrobnih natpisa organski izvire iz ranokršćanskih epitafa. Ogledni su primjeri natpisi na sarkofazima sa salonitanskih cemeterija, koji se u mnogim aspektima mogu mjeriti s onima iz Rima. ${ }^{19}$ Dva privlače posebnu pozornost. Je-

12 Mirjana Matıjević Sokol, „Od epitafa svećenika Ivana do epitafa kraljice Jelene“, Tusculum, 10/2017., br. 2, 77-91.

13 N. Gauthier - E. Marin - F. Prévot (ur.), Salona IV; D. Lovrenović, „Epitafi - 'knjige života'“, 207, 210; Isti, Stećci, 130-131.

14 Na salonitanskim se natpisima ova formula javlja na natpisima biskupa. Bulić je prepoznaje u natpisu mučenika sv. Dujma, a pouzdano se nalazi na natpisu biskupa Prima. Usp. Frane Bulić - Josip Bervaldi, „Kronotaksa solinskih biskupa“, Bogoslovska smotra, 3/1912., br. 1, 8-17. Rasprostranjena je i na natpisima mnogih drugih pokojnika. Usp. Salona IV. Svi su primjeri navedeni u Indeksu, 1321-1322. O tome usp. i: Orazio Marucchi, Christian Epigraphy. An Elementary Treatise, With a Collection of Ancient Inscriptions Mainly of Roman Origin, Cambridge 1912., 56-57; Paul Anthony Reynolds, A Comparative and Statistical Survey of the Late Antique and Early Medieval Latin Inscriptions of South Eastern Gaul (c. 300-750 AD), doktorska disertacija, University of Leicester, 2000., 214-216; Emilio MARIN, „L'épigraphie de Salone au temps de Constantin et de ses successeurs (313-363). L'épigraphie chrétienne“, Acta XVI congressus internationalis archaeologiae christianae (Romae 22. - 28. 9. 2013). Costantino e $i$ Costantinidi: l'innovazione costantiniana, le sue radici e i suoi sviluppi (ur. Olof Brandt, Vincenzo Fiocchi Nicolai i Gabriele Castiglia), sv. 1, Città del Vaticano 2016., 1179-1196. Za kršćansku epigrafiju vidi još Danilo Mazzoleni, „The Rise of Christianity“, The Oxford Handbook of Roman Epigraphy (ur. Christer Bruun i Jonathan Edmondson), Oxford 2015., 445-468, a za rimske predodžbe o smrti i pokojnicima Laura CHIOFFI, „Death and Burial“, The Oxford Handbook of Roman Epigraphy, 627-648.

15 Rebecca Leigh Littlechilds, The epitaphs of Damasus and the transferable value of persecution for the Christian community at Rome in the fourth-century AD, završni rad (Master of Arts), University of Saskatchewan, 2008.

16 O. Marucchi, Christian Epigraphy, 340-358; Peter Caban, „The Early Ancient Christian Inscriptions in the Christian Epigraphy", European Journal of Science and Theology, 11/2015., br. 3, 27-29.

17 Edmond Frédéric Le Blant, Manuel d'épigraphie chrétienne d'après les marbres de la Gaule, accompagné d'une bibliographie spéciale, Paris 1869., 175.

18 Usp. Mark A. Handley, Death, Society and Culture: Inscription and Epitaphs in Gaul and Spain, AD 300-750, Oxford 2003.

19 D. Lovrenović, Stećci, 117. 


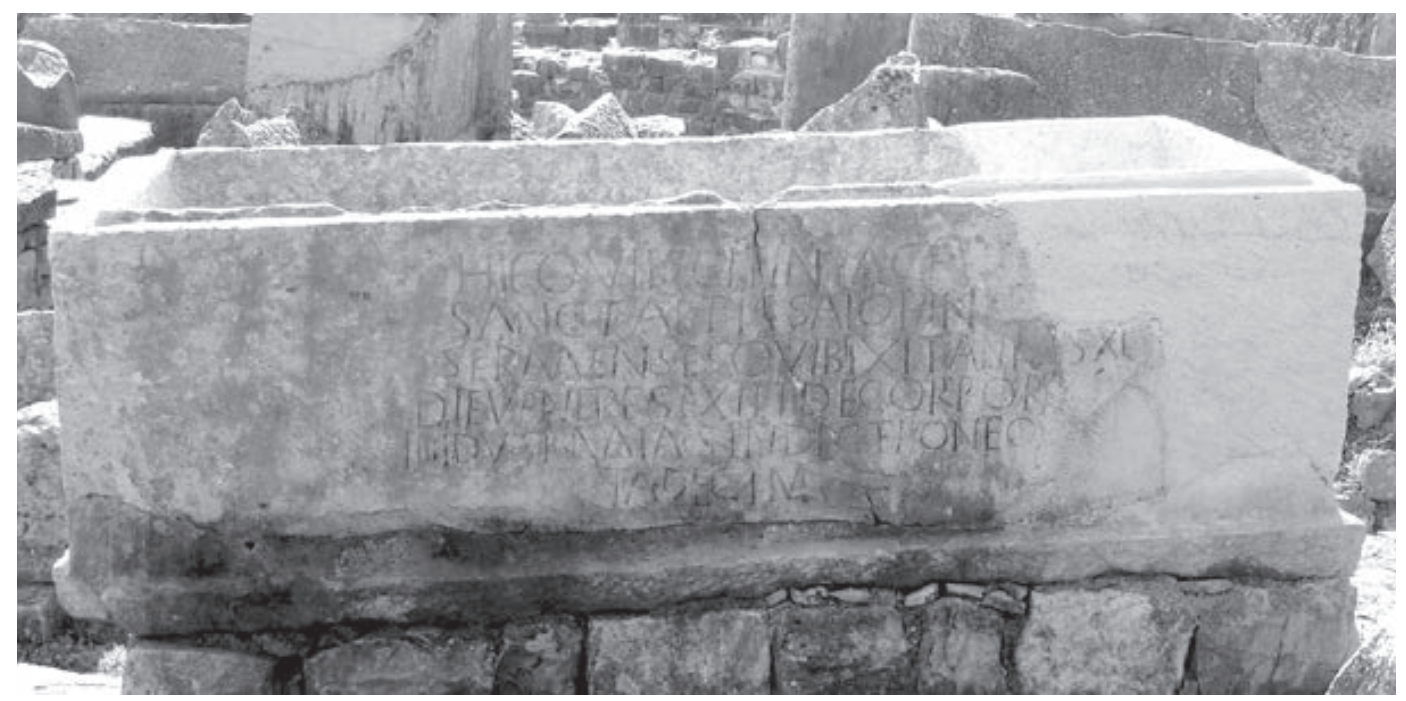

Sl. 1. Sarkofag s epitafom opatice Ivane na Manastirinama u Solinu

dan je onaj svećenika Ivana, ${ }^{20}$ a drugi opatice Ivane iz Sirmija. ${ }^{21}$ Oni su ishodišne, paradigmatske točke hrvatske ranosrednjovjekovne epitafistike, ali su ujedno kao i drugi slični širom Rimskog Carstva i u temeljima ove opće europske literarno-pjesničke vrste.

$\mathrm{Na}$ ovom tragu stasali su epitafi u gradovima na jadranskoj obali. Na samom prijelazu u srednji vijek s mnogim ranokršćanskim značajkama nastao je natpis na kapsi svete Stošije u Zadru. Njegov sadržaj čvrsta je čvorišna točka jer - poput vremenske kapsule - sadrži značajke svoga vremena koje su egzaktno databilne jer se vežu uz povijesnu osobu zadarskog biskupa Donata. ${ }^{22}$ Split je kao metropolitansko središte riznica sepulkralnih natpisa u rasponu od onih jednostavnih, šturih zapisa do „pjesama u kamenu“. Najranijem srednjovjekovnom sloju epitafa $s$ vrlo jednostavnom formulom pripadaju oni splitskog nadbiskupa Ivana Ravenjanina, ${ }^{23}$ priora Petra, ${ }^{24}$ nadbiskupa Ivana Tvrdakova. ${ }^{25}$ Njihov je sadržaj vrlo štur i glavno mjesto u nje-

20 D. Rendić-Miočević, Carmina epigraphica, 214-215, 266; Emilio Marin, „Civitas splendida Salona. Geneza, profil i transformacija starokršćanske Salone“, Salona Christiana (ur. Emilio Marin), Split 1994., 58; N. Gauthier - E. Marin - F. Prévot (ur.), Salona IV, 305-312.

21 Branimir GabričEviĆ, „Question de la datation du sarchofage de l'abbesse Jeanne“, Disputationes Salonitanae 1970 (ur. Željko Rapanić), Split 1975., 96-101; Ivan BAsıć, „CIL III 9551 i njegovi tumači“, Tusculum, 1/2008., 81-108.

22 Ivo Petricioli, „Ranosrednjovjekovni natpisi iz Zadra“, Diadora, 2/1960. - 1961., 252-254.

23 Literatura o ovom sarkofagu i njegovu epitafu vrlo je opsežna. Usp. Frane Bulić - Josip Bervaldi, „Kronotaksa spljetskih nadbiskupa“, Bogoslovska smotra, 4/1913., br. 2, 130-136; Tomislav Raukar, Hrvatsko srednjovjekovlje. Prostor, ljudi, ideje, Zagreb 1997., 365; Vedrana DelongA, „Pismenost karolinškog doba i njeni hrvatski odjeci“, Arhitektura, skulptura i epigrafika karolinškog doba u Hrvatskoj (ur. Vedrana Delonga, Nikola Jakšić i Miljenko Jurković), Split 2001., 69; Mirjana Matıjević Sokol, Toma Arhidakon i njegovo djelo. Rano doba hrvatske povijesti, Jastrebarsko 2002., 79-114; Ivan BAsić, „Venerabilis presul Iohannes. Historijski Ivan Ravenjanin i začetci crkvene organizacije u Splitu u VII. stoljeću“, Povijesni prilozi, 24/2005., br. 29, 7-28; Isti, „Prilozi proučavanju crkve Svetog Mateja u Splitu“, Ars Adriatica, 1/2011., 67-96; Ivan BAsıć - Miljenko Jurković, „Prilog opusu Splitske klesarske radionice kasnog VIII. stoljeća“, Starohrvatska prosvjeta, 38/2011., 149-185.

24 Željko Rapanić, „Ranosrednjovjekovni latinski natpisi iz Splita“, Vjesnik za arheologiju i historiju dalmatinsku, 65-67/1963. - 1965., 294-297; V. Delonga, „Pismenost karolinškog doba i njeni hrvatski odjeci“, 69-70.

25 Branimir Gabričević, „Sarkofag nadbiskupa Ivana pronađen u podrumima Dioklecijanove palače“, Vjesnik za arheologiju i historiju dalmatinsku, 62/1960., 87-103. 
mu ima neka od inačica formule hic iacet. U nekom zabilježen je podatak iz životnog kurikula ovih uglednika. Za Ivana Ravenjanina i Ivana Tvrdakova saznajemo da su nadbiskupi. A epitafi Ivana Tvrdakova i priora Petra ističu da su rođeni i odrasli u Splitu. Bogatiji je sadržajem epitaf nadbiskupa Martina uz uobičajenu formulu hic iacet. ${ }^{26} \mathrm{I}$ jedan je dubrovački nadbiskup poznat s epitafa. Na nadgrobnoj ploči u samostanu na Lokrumu nalazi se tekst koji restituiran glasi: Hic requiescit Vitalis archiepiscopus domini Theodori filius pro cuius crimina humiliter ora. Dubrovački nadbiskup Vital (1022. - 1046.) sudjelovao je u osnivanju benediktinskog samostana sv. Marije, najstarijega na dubrovačkom području. ${ }^{27}$

Pjesničkim izričajem odlikuju se splitski sarkofazi s natpisima nadbiskupa Lovre ${ }^{28}$ te uglednog Splićanina i mecene Petra Crnoga ${ }^{29}$, kao i epitaf nadbiskupa Krescencija. ${ }^{30} \mathrm{Nji-}$ ma se svakako pridružuje i epitaf slavne zadarske opatice Vekenege. ${ }^{31}$ Ovi mlađi epitafi uglednika iz druge polovine XI. stoljeća složenije i drukčije koncipiranim tekstom odraz su novih ranoromaničkih tendencija.

No, među natpisima ranog srednjovjekovlja svakako odskače onaj hrvatske kraljice Jelene ${ }^{32}$ pronađen u Solinu na Otoku u ostacima vladarskog mauzoleja, do čijeg je otkrića doveo navod iz Salonitanske povijesti Tome Arhiđakona ${ }^{33}$ i istraživački genij don Frane Bulića. ${ }^{34}$ Zbog genealoških podataka koji se iz kraljičina epitafa ${ }^{35}$ iščitavaju propitivao se najprije kao

26 Željko Rapanić, Predromaničko doba u Dalmaciji, Split 1987., 144-145.

27 Josip Lučıć, Povijest Dubrovnika, sv. 2, Zagreb 1973., 71, bilj. 274.

28 Ž. Rapanić, Predromaničko doba u Dalmaciji, 145-146; Radoslav KatičIĆ, Litterarum studia. Književnost i naobrazba ranoga hrvatskog srednjovjekovlja, Zagreb 1998., 545.

29 Frane Bulıć - Petar Sкок, „Natpis Petra Crnoga“, Glasnik Zemaljskog muzeja u Bosni i Hercegovini, 30/1918., br. 1-4, 1-10; Viktor NovaK - Petar Sкок, Supetarski kartular. Iura sancti Petri de Gomai, Zagreb 1952., 11-24; Ž. Rapanić, Predromaničko doba u Dalmaciji, 146-147; Vladimir Ćorović, „Mali prilozi: O natpisu Petra Crnoga“, Starinar, 5/1930., 37-38; Miroslav Marković, „Epitaf Petra Crnog“, Starohrvatska prosvjeta, 3/1954., 31-51; Mirjana Matıjević Sokol, „Neka pitanja o splitskom đakonu Dobri (kraj XI. - početak XII. stoljeća)“, Spomenica Ljube Bobana 1933. - 1994. (ur. Mira Kolar-Dimitrijević), Zagreb 1996., 61-71; R. Katičić, Litterarum studia, 540-541; Željko Rapanić, „Dva splitska ranosrednjovjekovna sarkofaga“, Arheološki radovi i rasprave, 8-9/1982., $233-258$.

30 R. Katičić, Litterarum studia, 546.

31 Viktor NovaK, Zadarski kartular samostana svete Marije, Zagreb 1959., 79-85; T. Raukar, Hrvatsko srednjovjekovlje, 61-63; R. Katičić, Litterarum studia, 548-550.

32 IN HOC TUMULO QUIESCIT HELENA FAMOSA, QUE FUIT UXOR MIHAELI REGI, MATERQUE STEFANI REGIS. HABENAS RENUIT REGNI. VIII IDUS MENSIS OCTOBRIS IN PACE HIC ORDI-NATA FUIT ANNO AB INCARNATIONE DOMINI DCCCCLXXVI INDICTIONE IV, C1CLO LUNARE V, EPACTA XVII, CICLO SOLARI V, CONCURRENTE VI. ISTAQUE VIVENS FUTT REGINA, MATER FIT PUPILLORUM TUTORQUE VIDUARUM. ICQUE ASPICIENS VIR ANIME DIC MISERERE DEUS. (U ovom grobu počiva glasovita Jelena žena kralju Mihajlu i majka Stjepana kralja. Vladala je kraljevstvom. Osmoga dana prije listopadskih Ida ovdje je u miru pokopana 976. godine od utjelovljenja Gospodinova, indikcije četvrte, petoga mjesečeva ciklusa, sedamnaeste epakte, petoga sunčeva kruga koji se poklapa sa šestim. I ona koja za života bijaše kraljica, postade i majkom siročadi i zaštitnicom udovica. Čovječe, koji gledaš reci: „Bože, smiluj se duši njezinoj!“) Tekst i prijevod preuzeti su iz: Ž. Rapanić, Predromaničko doba u Dalmaciji, 142.

33 Toma ArhiĐakon, Historia Salonitana (prir. Olga Perić), Split 2003., 80-81.

34 Frane Bulić, „Izvještaj predsjednika društvenoga mons. Fr. Bulića o crkvi sv. Marije od Otoka i nadgrobnom napisu kraljice Jelene“, Vjesnik Arheološkog muzeja u Zagrebu“, 5/1901., 201-227; Lovre Katić, „Zadužbina hrvatske kraljice Jelene na Otoku u Solinu“, Rad JAZU, sv. 306, 1955., 187-219.

35 Duje Rendić-Miočević, „Neke epigrafsko-onomastičke značajke epitafa kraljice Jelene“, Arheološki radovi i rasprave, 8-9/1982., 219-231; Mate Suić, „Prilog tumačenju natpisa kraljice Jelene“, Starohrvatska prosvjeta, 14/1984., 15-39; Ž. Rapanić, Predromaničko doba u Dalmaciji, 141-145; T. Raukar, Hrvatsko srednjovjekovlje, 241-243; R. KaTIČIĆ, Litterarum studia, 426-428, 439-442; Vedrana Delonga, Latinski epigrafički spomenici u ranosrednjovjekovnoj Hrvatskoj, Split 1996., 131-134; Mirjana Matıjević Sokol, „Latinski natpisi“, Hrvatska i Europa. Kultura, znanost i umjetnost, sv. 1: Srednji vijek (VII - XII. stoljeće). Rano doba hrvatske kulture (ur. Ivan Supičić), Zagreb 1997., 245-246; Mirjana MatiJEvić SoKol - Vladimir Sokol, „Quedam Helena regina...“, Vjesnik Arheološkog muzeja u Zagrebu, 43/2010., 415-431. 


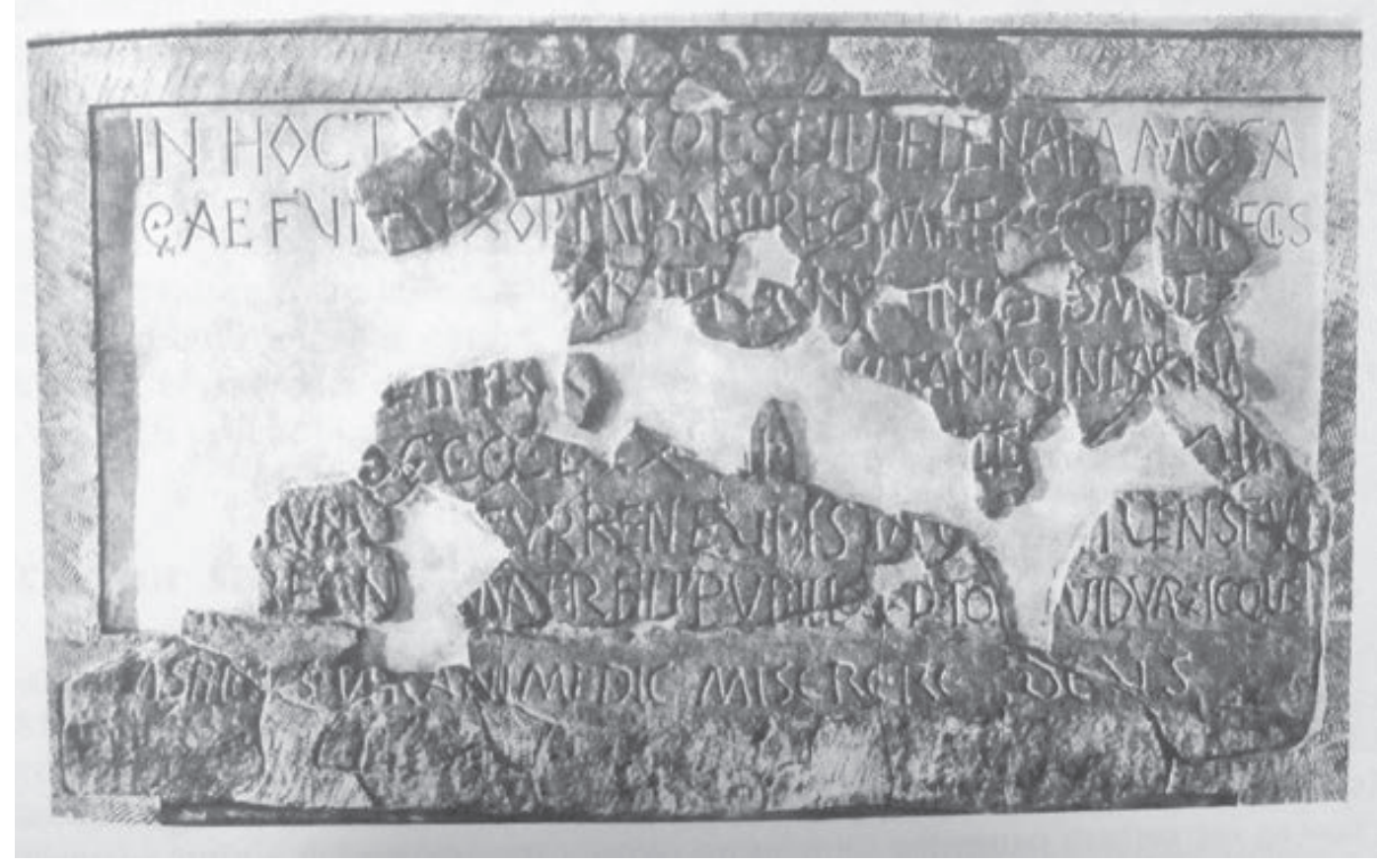

Sl. 2. Epitaf kraljice Jelene, Muzej hrvatskih arheoloških spomenika, Split

povijesno vrelo. Ferdo Šišić je na temelju njegova sadržaja s rodbinskim odnosima unutar vladarske dinastije, datiranim po kršćanskoj eri, dobio kariku za uspostavu genealogije hrvatskih vladara. ${ }^{36}$ Drugi njegov aspekt, onaj literarni, u posljednje se vrijeme razmatrao u više članaka. ${ }^{37}$ Kraljica Jelena je na epitafu „majka siročadi i zaštitnica udovica“ (mater pupillorum tutorque viduarum). Ove promišljeno upotrijebljene sintagme u skladu su s kršćanskim doživljajem zemaljskih vladara i crkvenih prvaka-metropolita, koji su Kristovi namjesnici na zemlji pa su kao i Svevišnji Sudac zaduženi za brigu za ugrožene, marginalne društvene grupe.

Suvremen mu je onaj splitskog nadbiskupa Martina. ${ }^{38}$ Sastavljač Martinova epitafa koristi se sličnim sintagmama i za nadbiskupa u onom pohvalnom dijelu kaže da je za života „štiteći udovice bio otac siročadi“ (viduasque tuens fuit pater pupillis). Po tekstualnim sličnostima, kao i zbog suvremenosti kraljice Jelene i nadbiskupa Martina može se pretpostaviti da ih je sastavila ista osoba, očito dobro obrazovan svećenik, prvi neimenovan pjesnik.

\footnotetext{
36 Ferdo Šıšıć, „Genealoški prilozi o hrvatskoj narodnoj dinastiji“, Vjesnik Hrvatskog arheološkog društva, 13/1914., $1-93$.

37 O ovim pitanjima usp. Željko Rapanić, „Mater (pater) pupillorum tutorque viduarum“, Novija i neobjavljena istraživanja u Dalmaciji. Znanstveni skup. Vodice 10. - 13. V. 1976. (ur. Željko Rapanić), Zagreb 1978., 83-90; Isti, Predromaničko doba u Dalmaciji, 143-144; Isti, Solin u starohrvatsko doba, Split 1996., 27-28; Isti, „Ponovno o epitafu kraljice Jelene“, Opuscula archaeologica, 23-24/1999. - 2000., 309-315; M. Matıjević Sokol, Toma Arhidakon $i$ njegovo djelo, 303-327; Ista, „Item iurabunt ipse potestas et sui officiales... facere et obseruare equaliter iusticiam et specialiter ecclesiis, pauperibus, orphanis, uiduis et miserabilibus personis... (Spl. st. II, 16)“, Statuimus et ordinamus, quod... Sustavi moći i mali ljudi na jadranskom prostoru. Zbornik radova s međunarodnog znanstvenog skupa 1. Istarski povijesni biennale (ur. Robert Matijašić), Poreč 2005., 268-278.
}

38 Ž. Rapanić, Predromaničko doba u Dalmaciji, 144-146. 
Osobito su zanimljiva zajednička mjesta za koja je pjesnik našao inspiraciju u biblijskom korpusu, u Knjizi psalama (Ps 68,6) u sintagmi pater orphanorum et iudex viduarum. Oba epitafa završavaju riječima anime dic: miserere Deus, a to je navod koji također pronalazimo u Knjizi psalama (Ps 51,3). Biblija je, dakle, bila uobičajen literarni „rudnik“ autorima srednjega vijeka.

Natpis na sarkofagu Splićanina Petra Crnoga bio je zanimljiv hrvatskim povjesničarima i filolozima od samog njegova otkrića. Ova lijepa „pjesma u kamenu“ ranoga srednjega vijeka svojim stihovima odražava visoku razinu latinske pismenosti u Splitu. Natpis se sastoji od deset stihova, od kojih su dva pentametri, a osam heksametri, dok polustihovi (hemistisi) asoniraju. ${ }^{39}$ Koncipiran je u obliku dviju odvojenih cjelina. U prvoj su stihovi sastavljeni u prvom licu. U njima Petar skreće pozornost na prolaznost života, pa i onih koji su kao on bili terror za vrijeme života. Pozornost i dvojbe u ovom dijelu epitafa izazivale su spojene riječi VIGVITERROR, što se čitalo i kao viguit error ${ }^{40}$ i kao vigui terror. No, danas nema dileme, a u skladu je i sa samom strukturom stihova da riječi treba razdvojiti kao vigui terror.

Drugi je dio pohvalnica Petru Crnom sastavljena u trećem licu. Zadnji stih natpisa ujedno je potpis njegova autora Dobre đakona. Ovi se stihovi mogu dovesti u vezu s drugim suvremenim pohvalnim pjesmama i epitafima. Ivan Lučić-Lucius donio je epitaf mletačkog dužda Dominika Michaela (1118. - 1129./1130.). ${ }^{41}$ On ima vrlo mnogo zajedničkog s epitafom Petra Crnoga. Pojavljuju se iste ili slične sintagme, uključujući i riječ terror u obama epitafima. U jednom i drugom ova riječ ima - potpuno je jasno - pozitivnu konotaciju. Nalazi se i u drugim pohvalnim pjesmama posvećenim uglednicima koji su svojim životom i djelom izazivali strahopoštovanje. ${ }^{42}$ Farlati je, pak, zabilježio jednu pjesmu u distisima posvećenu salonitanskom svecu i mučeniku Anastaziju. ${ }^{43}$ Autorstvo je pripisivao Adamu Parižaninu. On je u Splitu redigirao i preveo legende o salonitanskim mučenicima u drugoj polovini XI. stoljeća. Postoji mogućnost da je ovoj pjesmi

39 V. Novaк - P. Sкок, Supetarski kartular, 11-24; Ž. Rapanić, Predromaničko doba u Dalmaciji, $146-147$.

Tam sordente domo perspice quid sit omo!

In rebus stultis studui nichil utile multis

et dum vigui, terror in orbe fui.

Parum aduc dicam de mei corporis vitam.

Dum vicxit in mundo valatus munere multo ingenio lucxit Petrus sua quam bene ducxit; omnia despescit cor semper ad etera vecxit templum fundavit cum menibus et decoravit. Hic obdormivit, cum spiritu astra petivit.

Dominus ascribit Dabrus hic me perfecit.

(Kraj tako prljave kuće pogledaj što je čovjek. U ludostima sam nastojao oko nečega što ništa nije bilo korisno mnogima $i$ dok sam bio u snazi, bio sam strava na svijetu. Malo ću još reći o o životu svojega tijela: Dok je živio na svijetu utvrden kao bedemom počasnim položajem i zemljišnim posjedom, umom je zasjao Petar kako je dobro vodio svoje stvari. Sve je prezreo, srce je uvijek uzdizao prema nebu. Utemeljio je hram s bedemima i ukrasio ga. Ovdje je zaspao, a duhom je pošao zvijezdama. Gospodin Dobro me dopisuje, on me je sastavio.) Tekst i prijevod preuzeti su iz: R. Katičić, Litterarum studia, 540-541. Ioannis Lucir, De regno Dalmatiae et Croatiae libri sex, Amstelaedami 1666., 124.

42 V. Ćorović, „Mali prilozi: O natpisu Petra Crnoga“, 37-38; M. Marković, „Epitaf Petra Crnog“, 31-51; M. MaTIJević SoKol, „Neka pitanja o splitskom đakonu Dobri“, 61-71.

43 Daniele Farlati, Illyricum sacrum, sv. 1, Venetiis 1751., 723. 


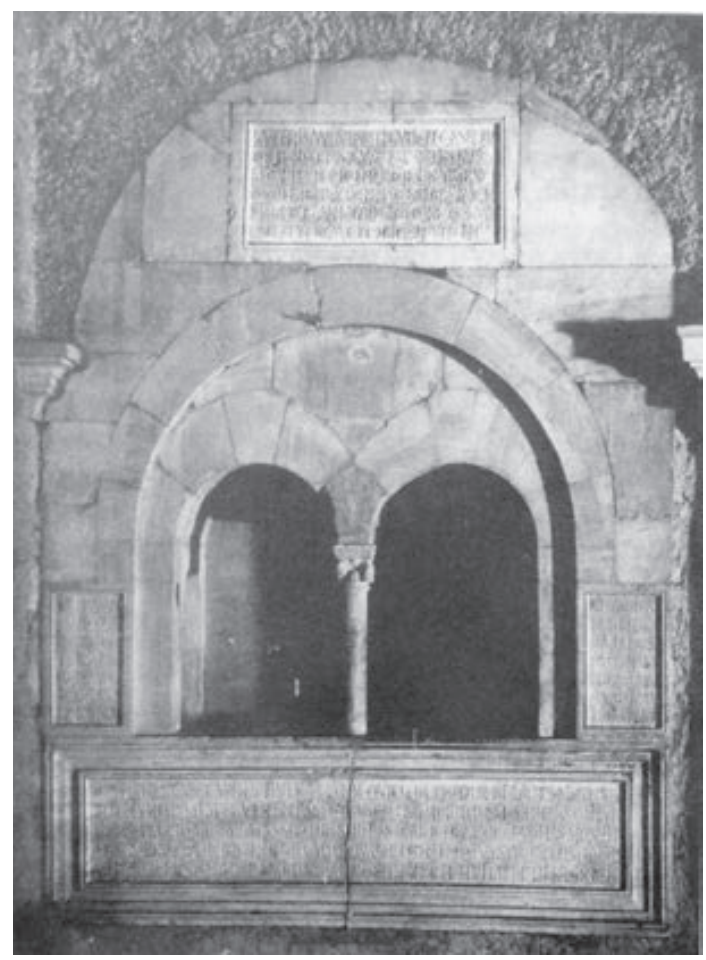

Sl. 3. Grobnica s natpisom opatice Vekenege, kapitul samostana sv. Marije u Zadru

o mučeniku Anastaziju autor i sâm Dobre đakon. ${ }^{44}$ Iako je historiografija imala različito mišljenje o autorstvu Adama Parižanina splitskih legendi na latinskom jeziku, ${ }^{45}$ ipak je zanimljiva himna koja podsjeća na naprijed navedene stihove sa epitafa. Njezini stihovi po mnogim su izričajima bliski epitafu Petra Crnoga. Sročena je u heksametru i pentametru $s$ asonancom u polustihovima.

Uspoređujući ta zajednička mjesta sa splitskih epitafa, uočili smo da se neka javljaju više od jedanput (spiritus astra petit; anime dic: miserere Deus; mater /pater/ pupillorum ... tutor Ituens/ viduarum, cor semper ad etera vexit). Zamjetna je upotreba nekih karakterističnih glagola (aspicere, despicere, perspicere, vigere, lugere, venire, timere, colere) i imenica (mundus, vita, corpus, ingenium, orbis). Kao da je postojao jedan „rimarij“ iz kojega su pjesnici po potrebi crpli pjesničke figure. Ovaj je aspekt vrlo pomnjivo razmotrio i razradio Miroslav Marković. U Petrovu je epitafu uočio mnoge značajke svojstvene epigrafičkoj poeziji od antike do humanizma. ${ }^{46} \mathrm{U}$ istom kontekstu moramo sagledati i epitaf splitskog nadbiskupa Lovre, sročen u prvom licu, u heksametru is rimovanjem polustihova, ali skromniji od onog nadbiskupa Martina, sadržajno bogatijeg, koji, pak, nije metrički komponiran.

Zadar je doživio uzlet latinske pismenosti na prijelazu XI. u XII. stoljeće. Svjedočanstvo vrhunske latinske pismenosti, ali i pjesništva epitaf je slavne opatice Vekenege iz 1111. godine. On je neupitan dokaz obnove klasične latinštine ritmičkih forma. Složen je u heksametru i leoninskom distihu te je, prema mišljenju mnogih znanstvenika, najljepši pjesnički izraz hrvatskog srednjovjekovlja. ${ }^{47}$

\footnotetext{
44 Isto, 736.

45 Hrvoje Morović, „Istorija Svetoga Dujma i Staša“, Legende i kronike (ur. Vedran Gligo i Hrvoje Morović), Split 1977., 16-17.

46 M. Marković, „Epitaf Petra Crnog“, 31-51.

47 Tekst (natpis na ploči u zidu iznad bifore/prozor podijeljen stupićem na dva dijela, od kojih svaki ima svoj završni luk na grobnici):

LAUDE NITENS MULTA IACET HIC VEKENEGA SEPULTA:

Q(UAE) FABRICA(M) T(UR)RIS SIMUL ET CAPITOLIA STRUX(IT).

HAEC OBIT UNDENO CENTU(M) PO(ST) MILLE SUB AEVO,

QUO VENIENS (CHRISTUS) CARNIS GESTAVIT AMICTUS,
} 
Epitaf se u osnovi također temelji na formuli hic iacet. Ipak, ovaj je epitaf puno više od običnog nadgrobnog natpisa. U njemu se biranim riječima slavi život i zasluge opatice Vekenege. U tekstu iznad bifora grobne edikule opatice Vekenege ističu se njezina „djela“. Navodi se da je sagradila kapitul i zvonik. Na pločama s lijeve i desne strane bifore zapisane su poruke onomu tko čita natpis, s napomenom da se sjeti one koja počiva u grobu i da se za njenu dušu pomoli. Uočljiva je sličnost sa završnom porukom epitafa kraljice Jelene i nadbiskupa Martina. No, na njima su riječi iz Knjige psalama doslovce preuzete, a ovdje su one parafrazirane, ali s identičnim značenjem. Četvrta cjelina ispod bifore pohvalna je pjesma Vekeneginu životu. Iz njih izbija snažno kršćansko vjerovanje u zagrobni život, koji je Vekenega zaslužila zbog svojih dobrih djela i dolična života, kad već sve prolazi „kao strujanje vala“. U potki ovog dijela epitafa susreću se i isprepleću vječne misli koje potiče smrt, a satkane su i na poganskoj i na kršćanskoj literaturi. Ulazeći u detaljnu paleografsko-epigrafsku, kao i sadržajnu analizu, Marković je uočio mnoge frazeološke i misaone sekvencije, odnosno parafraze misli iz Seneke, Ovidija, Lukana, Vergilija, Biblije. ${ }^{48}$

Međutim, u Trogiru sačuvano je nekoliko epitafa znamenitih osoba iz sredine XIII. stoljeća. To je epitaf sinovca kralja Bele IV., princa Vilima, zaručnika Beline kćeri Margarete, koji je umro u Trogiru 1242. godine, kao i epitaf kćeri kralja Bele Katarine i Margarete, umrlih 1242. godine i sahranjenih u splitskoj katedrali. ${ }^{49}$ Iako ovi epitafi

\footnotetext{
NOS HABET E(ST) ANNUS QUINTUS QUO REX COLOMANN(US)

P(RAE)SUL ET EST DECIM(US) QUO G(RE)G(O)R(IU)S FUIT ANNUS.

(Sjajeći mnogom hvalom leži tu pokopana Većenjega koja je sagradila zdanje tornja i ujedno kapitul. Ona je preminula jedanaeste godine i sto poslije tisuću od vremena u kojem je došao Krist i ponio ogrtač puti. A peta je godina od kako nas ima kralj Koloman, deseta je od kako je Grgur postao kolovodom.)
}

Dva natpisa na pločama s jedne i s druge strane bifore:

ORET QUI SPECTAT DICENS: IN PACE QUIESCAT,

CORPU(S) UT ARCA TEGAT FLATUS ET ALTA PETAT.

(Neka se moli onaj koji gleda govoreći: Počivala u miru da kako joj kovčeg pokriva tijelo i dah poleti u visine.)

HUC VENIENS VULTUM FER ET HOC CERNENDO SEPULCHRUM

„HUIC PIE“ DIC „ANIME DA REQUIEM DOMINE“.

(Dolazeći ovamo, okreni lice i gledajući ovaj grob, reci: „Ovoj pobožnoj duši podaj mir, Gospodine.")

Natpis na ploči na dnu bifore s prednje strane:

RES FLUITANT CUNCTAE MUNDI VELUT IMPET(US) UNDAE.

QUICQ(U)ID ET EXORITUR, LABIT(UR) ET MORITUR.

MENTE DEUM PURA SEMPER VEKENEGA SECUTA.

NON PENIT(US) MORITUR SED MORIENS ORITUR.

NAMQ(UE) PROBOS MORES CUPIENS SERVARE SORORES.

ACTIB(US) EXCOLUIT VOCE Q(UO)D HAS MONUIT.

HOSTIS AB INSIDIIS ADITUS BENE CAVIT OVILIS.

QUAQ(UE) REGENTE DOMUS CREVIT ET ISTE LOCUS.

IN FESTO SACRI COSMAE MIGRAT AC DAMIANI, UT SIT IN ARCE DEI VITA PERHENNIS EI.

(Sve svjetske stvari protječu kao strujanje vala. Što god nastaje, urušava se i umire. Čiste duše Većenjega je uvijek slijedila Boga. Ne umire posvema, nego se umirući rada. Naime, želeći da sestre čuvaju dobro vladanje, djelima je odnjegovala ono na što ih je riječju opominjala. Od neprijateljskih je zasjeda dobro čuvala pristup toru. Dok je ona njome upravljala, povéavala se kuća i ovo mjesto. Odselila se o svetkovini svetoga Kuzme i Damjana, neka joj u Božjoj utvrdi bude vječni život.) Tekst i prijevod donose se prema: R. KaTičić, Litterarum studia, 548-550.

Miroslav Marković, „Dva natpisa iz Zadra“, Zbornik radova Vizantološkog instituta, 2/1953., 99-138; R. Katičić, Litterarum studia, 548-550.

49 Milan Ivanıšević, „Natpisi iz godine 1242. U Splitu i Trogiru“, Grada i prilozi za povijest Dalmacije, 18/2002., 479-551; Ivo BaBIĆ, Trogir. Grad i spomenici, Split 2016., 311-313. 


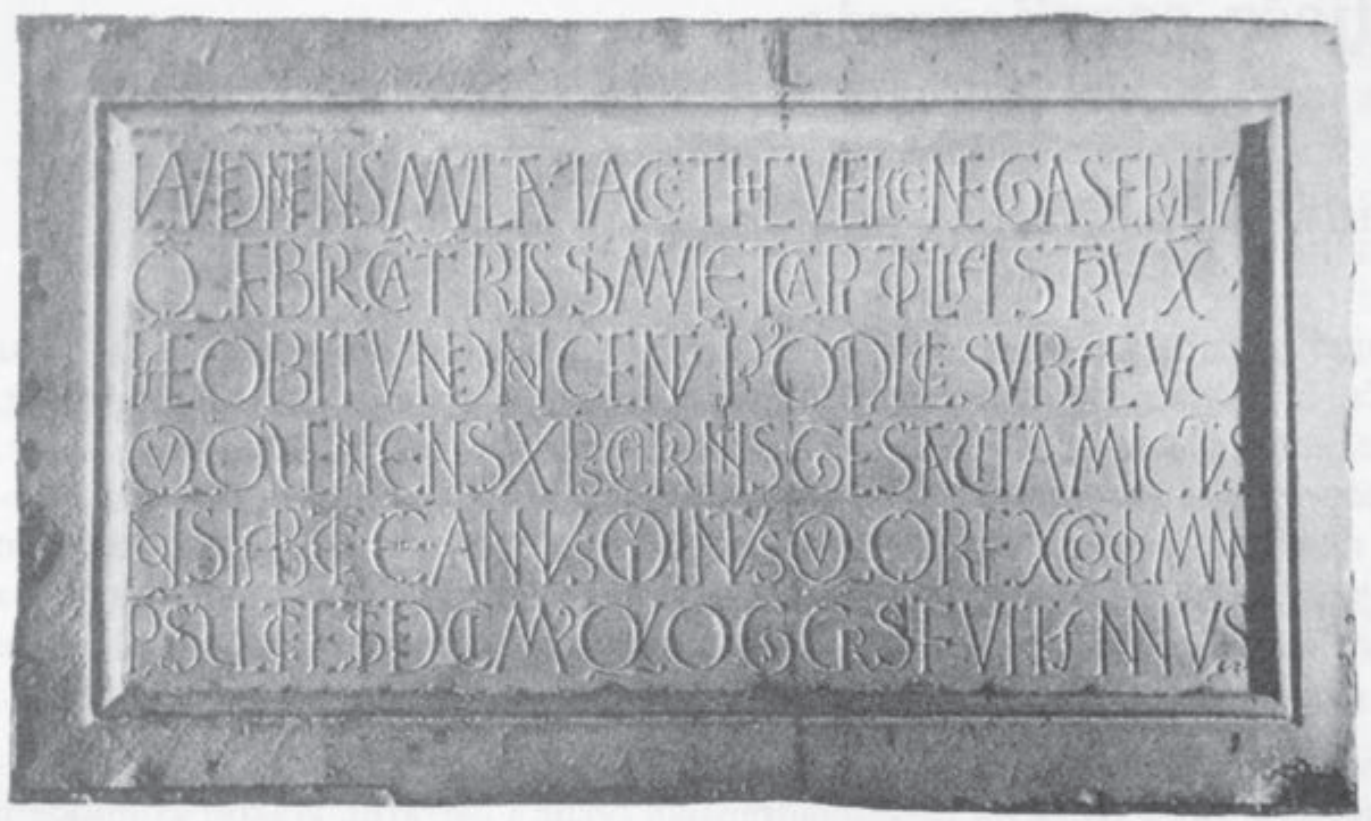

Sl. 4. Natpis na ploči u zidu iznad bifore na grobnici opatice Vekenege, kapitul samostana sv. Marije u Zadru

nose godine kada su umrle osobe kojima su posvećeni, ipak se smatra da bi oni pripadali duhovnom izrazu XIV. stoljeća. U istu skupinu ubraja se i epitaf u trogirskoj katedrali posvećen Mladenu III. Šubiću. Ovaj nadgrobni natpis ima u frazeologiji izrazitih dodirnih mjesta s epitafom kralja Zvonimira sačuvanom u djelu Historia Salonitana maior. ${ }^{50}$ Ističe se jedna „ključna“ riječ koja se atribuira hrabrim i slavnim muževima Mladenu Šubiću ${ }^{51}$ i kralju

$50 \quad$ Nada Klaić, Historia Salonitana maior, Beograd 1967., 111-112.

51 Navodimo djelomice epitaf Mladena Šubića iz trogirske katedrale:

HEU GEMA SPLENDIDA IACET HAC SUB PETRA

CUIUS VALOR PERIIT NUNC IN FOSSA TETRA

MLADINUS MAGNIFICUS QUI CLISSIE FUIT

COMES SUIS SOLA SPES CUR TAM CITO RUIT?

GEORGII COMITIS MEMORIE BONE

NATUS ATQUE DOMINUS ALMESI SCARDONE

PROBITATIS TITULUS MORUM ET HONORIS

UT FLOS VERNANS DEFUIT VIR TANTI VALORIS

CROATORUM CLIPEUS FORTIS ET IPSE ERAT

(Jao! Alem sjajni ispod ove ploče crne

Leži sad i usred tmine hrabrenost mu trne,

Svijetli Mladen, knez i slavni vladar Klisa grada,

Zašto mlad preminu, jedina svom puku nada?

Sin knez Jurja, uspomene dobre vlastelina,

Bješe on gospodar Omiš-grada i Skradina.

Cestitosti $i$ značaja uzora nam nesta,

Vrli junak, cvijet proljetni, živjeti nam presta.

Štit Hrvata on nam bješe, vrijedan nama svima...)

Tekst i prijevod preuzeti su iz: Veljko GoRTAN - Vladimir VRatović (prir.), Hrvatski latinisti, sv. 1: Iz latiniteta $9-14$. stoljeća, Zagreb 1969., 56-59. 
Zvonimiru - clipeus (Croatorum). Prema strukturi čini se, pak, da navedeni epitafi pripadaju istoj pjesničkoj „školi“. Svi su sastavljeni u trinaestercu s parnom rimom ( $a a b b)$ na kraju stiha i cezurom poslije sedmog sloga.

Inače je u Splitu i Trogiru u XIII. stoljeću nastalo nekoliko epitafa koje odlikuje visoka pjesnička razina, ali su sasvim drukčijeg izričaja od prethodnih. Među njima ističe se onaj splitskog arhiđakona Tome iz crkve sv. Frane u Splitu, datiran 1268. godinom. Sličnosti s njim pokazuje i epitaf L. Albertija iz 1296. i nadbiskupa Petra iz 1319. godine. Oni su sročeni uglavnom u leoninskom distihu, a ne u srokovanom trinaestercu. Tomin epitaf bilježi točan datum njegove smrti (8. svibnja 1268.). S obzirom na sadržaj epitafa, kao i njegovu strukturu može se pretpostaviti da mu je autor sâm Toma. Kršćanski svjetonazor zrcali se iz svake riječi njegova teksta, a snažno se osjeća Tomino „pismo“.52 Iako se ne uočavaju neposredne poveznice s Biblijom, ipak su u cjelokupnom misaonom iskazu i korištenoj probranoj terminologiji prisutne i uočljive poruke Evanđelja. U sintagmi Hic me vermis edit težište je na riječi vermis s jasnom aluzijom na pakao. Ona postaje opće mjesto epitafistike i parafraza je rečenice ubi uermis eorum non moritur et ignis eorum non extinguitur iz Izaijina svjedočanstva (Iz 66,24) te iz Markova evanđelja (Mk 9,48).

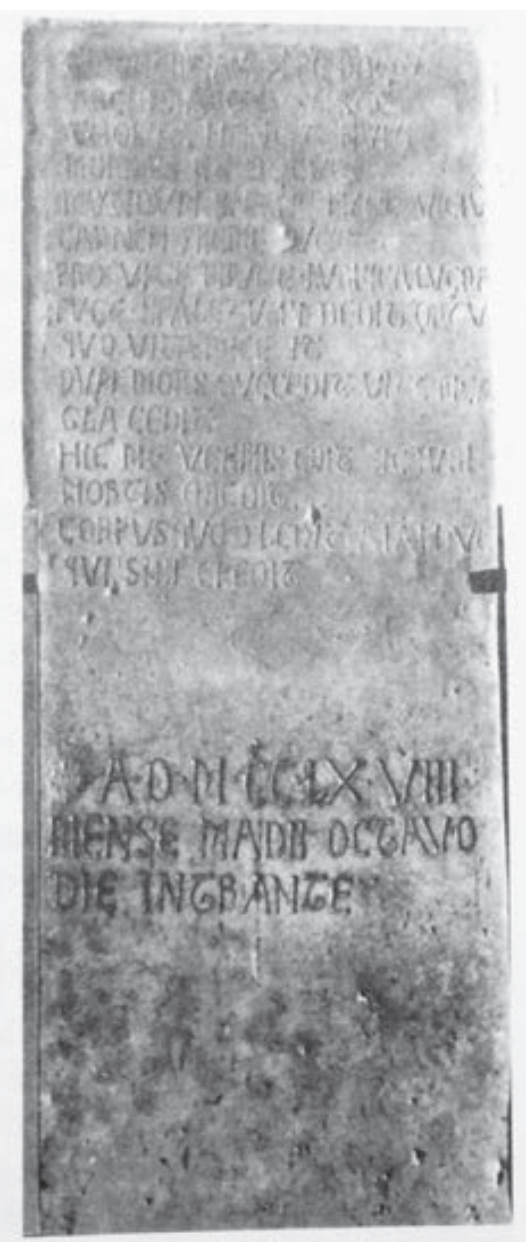

Sl. 5. Epitaf Tome Arhiđakona, crkva sv. Frane na Rivi u Splitu

Vedran Gligo lucidno je zamijetio da u prethodnim srednjovjekovnim epitafima, u njihovim izrazito lijepim stihovima kojima se ističu vrline uglednih ljudi, možemo prepoznati prethodnike humanističkih sredina koje će u našim jadranskim komunama doživjeti svoj

\footnotetext{
52 Doctrinam, Christe, docet archidiaconus iste

Thomas, hanc tenuit moribus et docuit:

Mundum sperne, fuge vicium, carnem preme, luge

pro vite fruge, lubrica lucra fuge.

Spalatumque dedit ortum, quo vita recedit.

Dum mors succedit vite, mea gloria cedit.

Hic me vermis edit, sic iuri mortis obedit

corpus quod ledit, animamve qui sibi credit.

A. D. MCCLXVIII, mense Madii, octavo die intrante.

(Kriste, Toma Arhidakon uči nauk kojeg se sam držao i učio je [i druge] pravilima: prezri svijet, kloni se grijeha, kroti tijelo, žali za raskošima života, kloni se zavodljivih dobitaka! U Splitu se rodi gdje se i od života oprosti. Kad je smrt naslijedila život, moja slava je prošla. Ovdje me jede crv i tako tijelo koje nestaje pokorava pravu smrti, ali i dušu tko joj je preda. Godine Gospodnje 1268. osmoga dana mjeseca svibnja.) Tekst i prijevod preuzeti su iz: M. MatiJEvić SoKol, Toma Arhidakon i njegovo djelo, 34-35.
} 
vrhunac u XV. stoljeću. ${ }^{53} \mathrm{U}$ drugoj polovini XV. i tijekom čitavoga XVI. stoljeća novi pogled na svijet - humanizam - odražava se i u literarnom izričaju epitafa i uopće oblikovanju nadgrobnih spomenika na kojima su upisani. Kao odgovor srednjovjekovnom čovjeku uronjenom duboko u kršćansku duhovnost, javlja se čovjek s novom, humanistički izraženom sviješću. Antika postaje vrelo inspiracije, a Apeninski poluotok središte iz kojeg kreću svi oblici umjetničkog izražavanja. Na hrvatskim se prostorima ponovno osjeća dvojnost utjecaja. Jadransko priobalje i gradske komune neposredno su pod utjecajima strujanja iz Italije, dok kontinentalna Hrvatska proživljava svoj martirij „stogodišnjeg rata“ s Osmanlijama, svodeći se na „ostatke ostatak““. Osjeća se to i u tekstovima epitafa. Nadgrobna ploča zagrebačkog biskupa Luke Baratina s početka XV. stoljeća spomenik je prijelaznih karakteristika s elementima nadolazeće renesanse. Na njoj bio je natpis od kojega su sačuvani fragmenti, ali se i u njima zrcali nova duhovnost u izrazima toliko upotrebljavanim kao epitet za istaknute muževe. Luka je Baratin „svjetlo i ures“ (LUXQUE DECUSQUE). ${ }^{44}$

Tijekom XVI. stoljeća u sjevernim dijelovima Hrvatske sačuvan je relativno malen brojs obzirom na repertoar - spomenika s latinskim epigrafima, ali je zato sepulkralna plastika u zajedništvu s latinskim natpisom prevladavala kvantitetom i kvalitetom. Uz natpis, neki su nadgrobni spomenici imali grb, a neki pokojnikov lik. Franjo Tahi u Donjoj Stubici, ${ }^{55}$ Petar II. Ratkaj u Desiniću, ${ }^{56}$ Gašpar Drašković u Bednji57 imaju na epitafima-nadgrobnim pločama, koje nisu podignute na samom grobu nego u crkvi iznad kripte, uz svoj lik latinski natpis. Natpisi, kao i likovi odražavaju izrazitu individualnost pokojnika. ${ }^{58}$ Epitaf Franju Tahija prikazuje u distisima kao hrabrog junaka i časnog čovjeka. ${ }^{59}$ Kukuljević je zabilježio i natpis na grobu Nikole Zrinskoga Sigetskoga u Svetoj Heleni kod Čakovca.

53 Koriolan Cipıко, O azijskom ratu (prir. Vedran Gligo), Split 1977., 11-12.

54 Lelja Dobronić, Renesansa u Zagrebu, Zagreb 1994., 74; Mirko Valentić - Lada Prister, Zbirka kamenih spomenika, Zagreb 2002., 27.

55 Ivan Kukuljević SAkcinski, Nadpisi sredovječni i novovjeki na crkvah, javnih i privatnih sgradah i t.d. u Hrvatskoj $i$ Slavoniji, Zagreb 1891., 262-263.

56 HOC TVMVLO TEGITVR PETRVS RATCHAIVS IERO,

SPLENDOR VIRTVTVM MARTIS ET ALMVS HONOR

ILLIRIAE SVBLIME DECVS PATRIEQVE (?) RVENTIS

MAXIMA SPES; RERVM CONSILIIQVE IVBAR,

QVEM NON MAGNA MANVS TVRCAE CRVDELIS ATRI

VITA PRIVARVNT SVSTVLIT VNA DIES.

(U ovom grobu pokopan je junak Petar Ratkay,

slava Marsovih vjeśtina i plodni ures,

Ilirije uzvišeni ponos i domovine koja se ruši

najveća nada, zvjezdano svjetlo savjetničkih vještina.

Njega nisu ruke okrutnog, mrkog Turčina

57 Isto, 4-5.

58 Anđela Horvat, Izmedu gotike i baroka. Umjetnost kontinentalnog dijela Hrvatske od oko 1500. do oko 1700., Zagreb 1975., 341-353.

59 TRIBVS CAESARIBVS CLARIS REGNANTIBVS ORBI

HVNGARIAE VITAE PROEMIA DIGNA TVLLIT.

ARMIS CLARVS ERAT, VITA PRAECLARVS HONESTA

CONSILIO FOELIX, PROSPERITATE POTENS

OMNIBVS EX VOTO CONCLVSSIS TEMPORE VITAE

REBVS CONCLVSIT MORS INIMICA DIEM. 
On opisuje vrline tog odvažnog muža, koji je hrabro odolijevao osmanlijskim prodorima, braneći tako kršćansku Europu. ${ }^{60}$ Iz ovoga vremena čitav je niz nadgrobnih spomenika članova hrvatskog plemstva koje je sudjelovalo u ratovima s Osmanlijama. Njihove su se vještine i zasluge isticale u nadgrobnim natpisima. Iz njih zrači „herojski“ duh branitelja domovine, uz obvezno pozivanje na antičkog boga Marsa, koji se javlja kao metafora Rata. Pridjevi strenuus, magnificus, potens i invictissimus, kao i imenice patria, decus i Turcae vrlo često dominiraju u epitafima junaka kao ključne riječi koje simboliziraju to nesigurno ratno vrijeme. Stilski i jezično svi navedeni epitafi slično su oblikovani. Uočava se da je promijenjena frazeologija u odnosu na onu raniju srednjovjekovnu te da se više ističe svjetovni aspekt života.

Dva spomenika po likovnim prikazima, kao i po natpisu odskaču od ovih „herojskih“. To su oni Ane Purthin iz Samobora ${ }^{61}$ i Šimuna Keglevića ${ }^{62}$ iz Pregrade. Na jednom i drugom reljefu dominantne osobe nisu pokojnici, nego Krist, što je naglašeno u duhu Tridentskog koncila.

I na kraju - iako vremenski izlazi iz okvira ovoga rada - osvrnut ću se na epitaf Sigismunda Ratkaja iz prve polovine XVIII. stoljeća. Na njemu je natpis čiji sadržaj govori pjesničkim, metaforičkim jezikom o životu slavnog pokojnika. ${ }^{63}$ Sastavljen je u najboljoj klasicističkoj maniri. Cursus honorum i curriculum vitae ovog Ratkaja prikazani su alegorijski

AMBIGVA TECVM FORTASSIS MENTE REVOLVES

QVEM PROCERVM HAEC MONVMENTA VIRVM.

FRANCISCVM TAHIVM CARAE CVM CONIVGIS OSSIS

HELENAE ZRINI MARMORE TVMBA TEGIT.

QVARTA DIE MENSIS AVGVSTI ANNO M. D. L. XXIII.

(Za vrijeme vladanja trojice slavnih careva na zemlji Ugarskoj donio je odličja dostojna života. Bijaše slavan po oružju, glasovit po časnom životu, plodan kao savjetnik, vrstan u napredovanju. Zaključivši po zavjetu na vrijeme sve životne stvari, neprijateljska smrt je zaključila život. Neodlučna uma možda ćés sa sobom premišljati kojega je muža od odličnika ovaj spomenik. Franju Tahija s kostima drage supruge Helene Zrinski grob od mramora drži. Cetvrtog dana mjeseca kolovoza, godine 1573.) Tekst natpisa preuzet je iz: I. Kunuljević SAKCINSKi, Nadpisi sredovječni i novovjeki, 262-263.

Prevela M. Matijević Sokol.

Isto, 225-226.

62 Ivan Filipčić, Župa Pregrada, Zagreb - Pregrada 1983., 27-28.

63 SISTE VIATOR ET LEGE

QVA DVRA LEGE

ME DIRA MORS

EX RATKAIANA IN HANC MORTUALEM URNAM EFFUDIT

VIX INSPEXERAM AD HUNC GENTILITIUM FONTEM

DUM CEU ALTER NARCISSUS

IN FLOREM IUVENTVTIS CONVERSSUS

EX PROVINCYS AD PATRIOS LARES

EX PALLADIS ORCHESTRA AD MARTIS PALESTRAM TRANSIENS

CHRISTINAM AB ERDEDIBUS VIVAM FLORAE EFFIGIEM

MIHI VIX THALAMO IUNXERAM

ILLA DUM TUMULO IACTA FUIT.

EX PRIMIS AD SECUNDA NON MINUS QUAM FOECUNDA

SOPHIAE ROSINAE EX COMITIBUS GEIZRUG

UT OPIBUS SIC VIRTUTIBUS CLARAE

PRIMO CLAVI AUREA

A CAESARE LEOPOLDO HONORATUS.

DEINDE IMUS AD COLONIAS SANCTI GEORGY SCLAVONICAS

EX CROATIS FACTUS COLONELLUS 


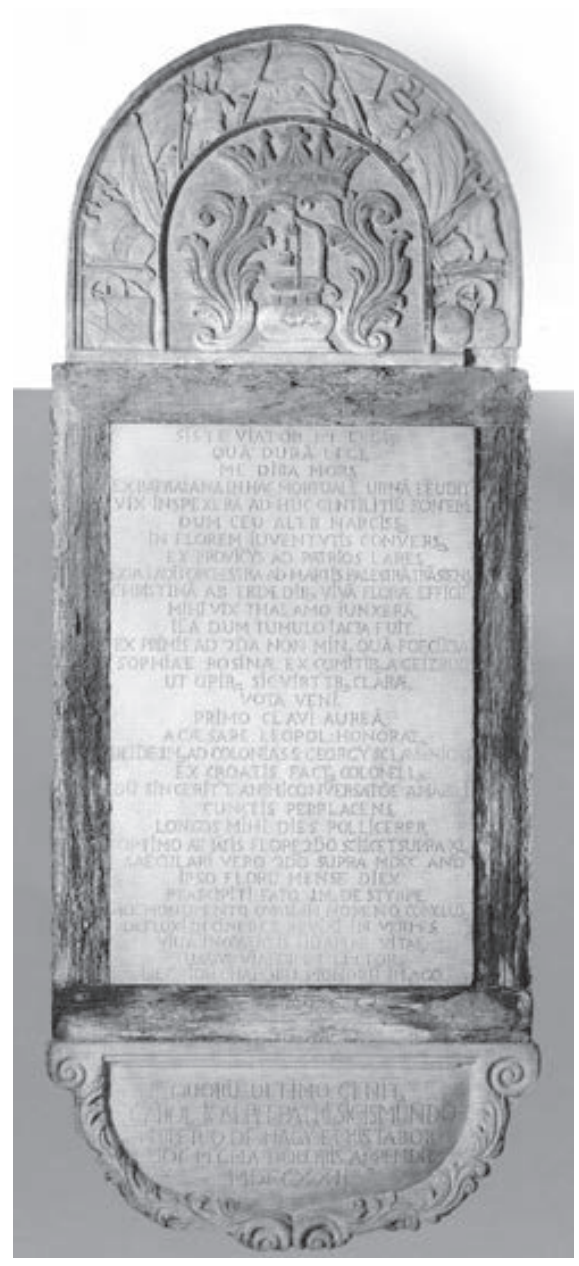

Sl. 6. Nadgrobni spomenik Ratkajevih u crkvi sv. Marije u Lepoglavi i metaforički. Antički bogovi metafore su njegovih životnih razdoblja. Narcis je lijepa mladost, Paladin orkestar školovanje, a Martovo vježbalište bojno polje. Time je ocrtano njegovo javno djelovanje. Bračni je život također zabilježen. Rano umrla prva supruga predstavljena je kao božica Flora. Ovaj epitaf uklapa se sasvim u klasicističku literarnu tradiciju koja u antici traži i nalazi stilske i tekstualne vrijednosti. Ovim natpisom prikazana je zavidna karijera plemića koju prekida neumitna smrt. Pepeo i crv (DEFLUXI IN CINERES, REVIXI IN VERMES) metafore su smrti i ovdje se javljaju kao ona zajednička mjesta epitafistike od najranijih vremena te asociraju na okrutnu smrt i neumitnu sudbinu.

Ovim epitafom završavam neobvezno „putovanje“ kroz tekstove nadgrobnih natpisa koje nalazimo na hrvatskim prostorima. Predstavljeni u ovom članku, moj su osoban odabir. Očigledno je da bi bilo vrijedno pozabaviti se cjelovito njima, osobito $s$ literarnog i filozofsko-teološkog aspekta. Iako smo prošli kroz više od jednog milenija i u hodu tijekom vremena pratili razvoj i mijene epitafistike, pokušavajući iščitati poruke nadgrobnih natpisa $i$ uzimajući u obzir povijesni kontekst, ipak bismo često - kad isključimo iz teksta temporalne znakove - mogli pomisliti da se nalazimo u jednom bezvremenskom svijetu. Naime, svi oni, iz svih vremena, imaju osim frazeoloških zajedničkih mjesta i zajed-

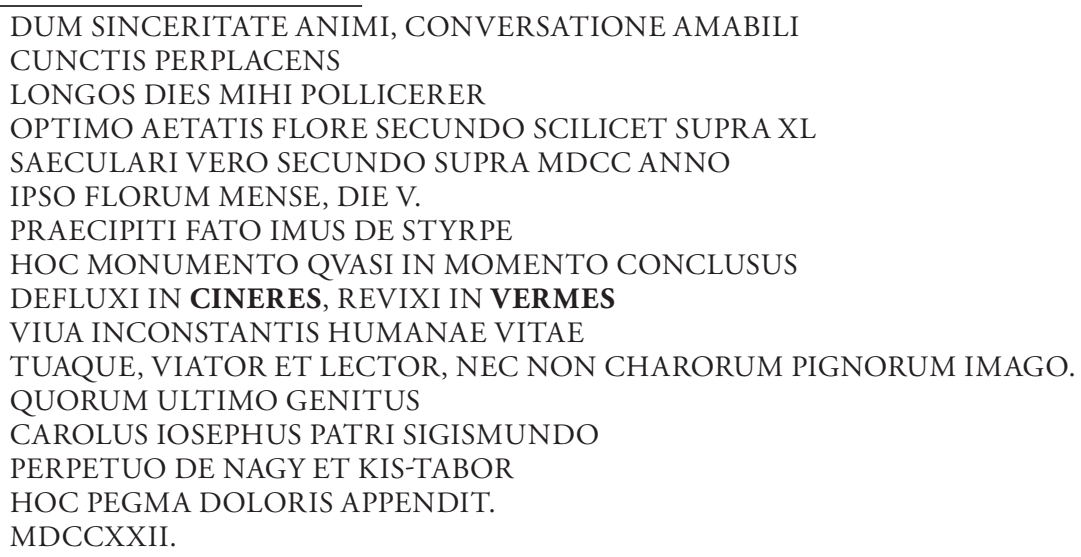

DUM SINCERITATE ANIMI, CONVERSATIONE AMABILI

CUNCTIS PERPLACENS

LONGOS DIES MIHI POLLICERER

OPTIMO AETATIS FLORE SECUNDO SCILICET SUPRA XL

SAECULARI VERO SECUNDO SUPRA MDCC ANNO

IPSO FLORUM MENSE, DIE V.

PRAECIPITI FATO IMUS DE STYRPE

HOC MONUMENTO QVASI IN MOMENTO CONCLUSUS

DEFLUXI IN CINERES, REVIXI IN VERMES

VIUA INCONSTANTIS HUMANAE VITAE

TUAQUE, VIATOR ET LECTOR, NEC NON CHARORUM PIGNORUM IMAGO.

QUORUM ULTIMO GENITUS

CAROLUS IOSEPHUS PATRI SIGISMUNDO

PERPETUO DE NAGY ET KIS-TABOR

HOC PEGMA DOLORIS APPENDIT.

MDCCXXII.

(Stani, putniče i čitaj kako me je neumoljivim zakonom okrutna smrt od Ratkajevaca u ovu smrtnu urnu otjerala. Jedva da sam se ogledao u ovom izvoru plemenskom jošte kao drugi Narcis u cvijetu mladosti okrenut iz provincija prema" očinskim 
ničku misaonu poruku. Strah od smrti vječan je, ali se protiv tog straha čovjek bori i štiti na razne načine, bilo da se obraća poganskim bogovima bilo kršćanskom Spasitelju. Zato ne začuđuje to što su oslonjeni i na pogansku i na kršćansku literaturu (Bibliju). Ali u epitafima ima i onih općih ljudskih misli s kojima se bez obzira na svjetonazor susreće svaki čovjek, tražeći spoznaje unutar i izvan vjere.

I kada pogledamo razmišljanja o smrti junaka iz literature Vladana Desnice, čini nam se da bi svaka rečenica i misao izvučena iz tog korpusa mogla stajati na nekom od epitafa. Ne nose li Desničine rečenice „Jedino smrt je realna. Ona je jedino što nam se u životu stvarno događa." “4 istu poruku kao one s Vekenegina groba „Sve svjetske stvari protječu kao strujanje vala. Što god nastaje, urušava se i umire."?

\section{$\cos$}

\section{Literatura}

Toma Arhiøakon, Historia Salonitana (prir. Olga Perić), Split 2003.

Ivo BabIć, Trogir. Grad i spomenici, Split 2016.

Ivan BAsIć, „CIL III 9551 i njegovi tumači“, Tusculum, 1/2008., 81-108.

Ivan BAsIĆ, „Prilozi proučavanju crkve Svetog Mateja u Splitu“, Ars Adriatica, 1/2011., 67-96.

Ivan BAsIĆ, „Venerabilis presul Iohannes. Historijski Ivan Ravenjanin i začetci crkvene organizacije u Splitu u VII. stoljeću“, Povijesni prilozi, 24/2005., br. 29, 7-28.

Ivan BAsIĆ - Miljenko Jurković, „Prilog opusu Splitske klesarske radionice kasnog VIII. stoljeća“, Starohrvatska prosvjeta, 38/2011., 149-185.

Frane Bulıć, „Izvještaj predsjednika društvenoga mons. Fr. Bulića o crkvi sv. Marije od Otoka i nadgrobnom napisu kraljice Jelene“, Vjesnik Arheološkog muzeja u Zagrebu, 5/1901., 201-227.

Frane Bulić - Josip BervaldI, „Kronotaksa solinskih biskupa“, Bogoslovska smotra, 3/1912., br. 1, 3-29; br. 2, 121-145; br. 3, 225-241; br. 4, 329-356.

Frane Bulić - Josip Bervaldi, „Kronotaksa spljetskih nadbiskupa“, Bogoslovska smotra, 4/1913., br. 2, 120-156; br. 3, 240-264.

Frane Bulıć - Petar Sкок, „Natpis Petra Crnoga“, Glasnik Zemaljskog muzeja u Bosni i Hercegovini, 30/1918., br. 1-4, 1-10.

Peter Caban, „The Early Ancient Christian Inscriptions in the Christian Epigraphy“, European Journal of Science and Theology, 11/2015., br. 3, 21-30.

Larima, prelazeći iz Paladina orkestra k Marsovu vježbalištu Kristinu od Erdedijevih, živu priliku Flore tek sam brakom vezao sa sobom već je ona bila položena u grob. Od prvih do drugih ne manje bogatih zavjeta Sofji Rosini od grofova Geizruga znamenitoj kako po imutku tako i po vrlinama sam došao. Najprije zlatnim ključem od cara Leopolda nagraden, zatim za najnižeg pukovnika u slavonskim naseljima sv. Jurja od Hrvata sam postavljen. Dok sam još zbog iskrenosti duha i prijateljskog drugovanja svima omiljen sebi mnogo dana obećavao, u najboljem naponu životne snage, naime u 42 godini, a svjetovne godine, pak 1702. U samom mjesecu cvijeća, dana petoga najnemoćniji iz roda strmoglavom sudbinom u ovom spomeniku kao u trenu zatvoren pretvorio sam se u prah, oživio sam se medu crvima. Živa, pak, nestalnog života i tvoja, putniče i čitaoče, kao i dragih zaloga slika!

Na kraju njihov sin Karlo Josip ocu Sigismundu vječnom od Velikog i Malog Tabora ovaj spomenik boli podiže 1722.) Tekst natpisa preuzet je iz: I. KunulJEvić SAKCINSKI, Nadpisi sredovječni i novovjeki, 126-127. Prevela M. Matijević Sokol. 
François Chamoux, Grčka civilizacija u arhajsko i klasično doba, Beograd 1967.

Laura CHioffi, „Death and Burial“, The Oxford Handbook of Roman Epigraphy (ur. Christer Bruun i Jonathan Edmondson), Oxford 2015., 627-648.

Koriolan Cipıко, O azijskom ratu (prir. Vedran Gligo), Split 1977.

Alison E. Cooley, Res Gestae Divi Augusti. Text, Translation, and Commentary, Cambridge - New York 2009.

Vladimir Ćorović, „Mali prilozi: O natpisu Petra Crnoga“, Starinar, 5/1930., 37-38.

Vedrana Delonga, Latinski epigrafički spomenici u ranosrednjovjekovnoj Hrvatskoj, Split 1996.

Vedrana Delonga, „Pismenost karolinškog doba i njeni hrvatski odjeci“, Arhitektura, skulptura i epigrafika karolinškog doba u Hrvatskoj (ur. Vedrana Delonga, Nikola Jakšić i Miljenko Jurković), Split 2001., 54-87.

Desničini susreti 2017. Smrt u opusu Vladana Desnice i europskoj kulturi-poetički, povijesni i filozofski aspekti. Povodom 50. obljetnice smrti Vladana Desnice. Program radalsažeci izlaganja (ur. Drago Roksandić, Vladan Bajčeta i Matko Globačnik), Zagreb 2017.

Ernst Diehl (prir.), Res gestae divi Augusti, Bonn 1908.

Lelja Dobronić, Renesansa u Zagrebu, Zagreb 1994.

Daniele FARLati, Illyricum sacrum, sv. 1, Venetiis 1751.

Ivan Filipčić, Župa Pregrada, Zagreb - Pregrada 1983.

Branimir GABričEvić, „Question de la datation du sarchofage de l'abbesse Jeanne“, Disputationes Salonitanae 1970 (ur. Željko Rapanić), Split 1975., 96-101.

Branimir GABRIČEvić, „Sarkofag nadbiskupa Ivana pronađen u podrumima Dioklecijanove palače“, Vjesnik za arheologiju i historiju dalmatinsku, 62/1960., 87-103.

Nancy Gauthier - Emilio Marin - Françoise Prévot (ur.), Salona IV. Inscriptions de Salone chrétienne, IVe-VIIe siècles/Salona IV. Natpisi starokršćanske Salone, IV.-VII. st., 2 sv., Rome Split 2010.

Veljko Gortan - Vladimir VRatović (prir.), Hrvatski latinisti, sv. 1: Iz latiniteta 9-14. stoljeća, Zagreb 1969.

Mark A. Handley, Death, Society and Culture: Inscription and Epitaphs in Gaul and Spain, AD 300-750, Oxford 2003.

Anđela Horvat, Izmedu gotike i baroka. Umjetnost kontinentalnog dijela Hrvatske od oko 1500. do oko 1700., Zagreb 1975.

Saša Horvat, „Pojam zaborava u Platona“, Riječki teološki časopis, 22/2014., br. 2, 417-442.

Milan IvanišEvić, „Natpisi iz godine 1242. U Splitu i Trogiru“, Grada i prilozi za povijest Dalmacije, 18/2002., 479-551.

Ljubo Karaman, „O značenju 'error'-a u natpisu Petra Crnoga“, Starohrvatska prosvjeta, 1/1927., br. 1-2, 84-86.

Radoslav Katičıć, Litterarum studia. Književnost i naobrazba ranoga hrvatskog srednjovjekovlja, Zagreb 1998.

Lovre Katić, „Zadužbina hrvatske kraljice Jelene na Otoku u Solinu“, Rad JAZU, sv. 306, 1955. 187-219.

Nada KlaIĆ, Historia Salonitana maior, Beograd 1967.

Ivan Kunuljević Sakcinski, Nadpisi sredovječni i novovjeki na crkvah, javnih i privatnih sgradah $i$ t.d. u Hrvatskoj i Slavoniji, Zagreb 1891.

Edmond Frédéric Le Blant, Manuel d'épigraphie chrétienne d'après les marbres de la Gaule, accompagné d'une bibliographie spéciale, Paris 1869. 
Rebecca Leigh LitTLeCHilds, The epitaphs of Damasus and the transferable value of persecution for the Christian community at Rome in the fourth-century AD, završni rad (Master of Arts), University of Saskatchewan, 2008.

Dubravko Lovrenović, „Epitafi - 'knjige života'“, Stećci. Galerija Klovićevi dvori, 4. rujna 2008. - 2. studenoga 2008. (ur. Jasminka Poklečki Stošić), Zagreb 2008., 204-217.

Dubravko Lovrenović, Stećci. Bosansko i humsko mramorje srednjeg vijeka, Sarajevo 2010.

Ioannis LuciI, De regno Dalmatiae et Croatiae libri sex, Amstelaedami 1666.

Josip Lučić, Povijest Dubrovnika, sv. 2, Zagreb 1973.

Emilio MARIn, „Civitas splendida Salona. Geneza, profil i transformacija starokršćanske Salone“, Salona Christiana (ur. Emilio Marin), Split 1994., 9-104.

Emilio Marin, „L'épigraphie de Salone au temps de Constantin et de ses successeurs (313-363). L'épigraphie chrétienne", Acta XVI congressus internationalis archaeologiae christianae (Romae 22. - 28. 9. 2013). Costantino e $i$ Costantinidi: l'innovazione costantiniana, le sue radici e $i$ suoi sviluppi (ur. Olof Brandt, Vincenzo Fiocchi Nicolai i Gabriele Castiglia), sv. 1, Città del Vaticano 2016., 1179-1196.

Miroslav Marković, „Dva natpisa iz Zadra“, Zbornik radova Vizantološkog instituta, 2/1953., 99_ 138.

Miroslav Marković, „Epitaf Petra Crnog“, Starohrvatska prosvjeta, 3/1954., 31-51.

Orazio Marucchi, Christian Epigraphy. An Elementary Treatise, With a Collection of Ancient Inscriptions Mainly of Roman Origin, Cambridge 1912.

Robert Matijašić (prir.), Djela Božanskog Augusta, Zagreb 2007.

Mirjana Matıjević Sokol, „Item iurabunt ipse potestas et sui officiales... facere et obseruare equaliter iusticiam et specialiter ecclesiis, pauperibus, orphanis, uiduis et miserabilibus personis... (Spl. st. II, 16)“, Statuimus et ordinamus, quod... Sustavi moći i mali ljudi na jadranskom prostoru. Zbornik radovas mectunarodnog znanstvenog skupa 1. Istarski povijesni biennale (ur. Robert Matijašić), Poreč 2005., 268-278.

Mirjana Matıjević Sokol, „Latinski natpisi“, Hrvatska i Europa. Kultura, znanost i umjetnost, sv. 1: Srednji vijek (VII - XII. stoljeće). Rano doba hrvatske kulture (ur. Ivan Supičić), Zagreb 1997., 239-256.

Mirjana Matijević Sokol, „Neka pitanja o splitskom đakonu Dobri (kraj XI. - početak XII. stoljeća)“, Spomenica Ljube Bobana 1933. - 1994. (ur. Mira Kolar-Dimitrijević), Zagreb 1996., 61-71.

Mirjana Matıjević Sokol, „Od epitafa svećenika Ivana do epitafa kraljice Jelene“, Tusculum, 10/2017., br. 2, 77-91.

Mirjana Matıjević Sokol, Toma Arhidakon i njegovo djelo. Rano doba hrvatske povijesti, Jastrebarsko 2002.

Mirjana Matıjević Sokol - Vladimir Sokol, „Quedam Helena regina...“, Vjesnik Arheološkog muzeja u Zagrebu, 43/2010., 415-431.

Danilo Mazzoleni, „The Rise of Christianity“, The Oxford Handbook of Roman Epigraphy (ur. Christer Bruun i Jonathan Edmondson), Oxford 2015., 445-468.

Bradley H. McLean, An Introduction to Greek Epigraphy of the Hellenistic and Roman Periods from Alexander the Great down to the Reign of Constantine (323 B.C.-A.D. 337), Ann Arbor 2002.

Hrvoje Morović, „Istorija Svetoga Dujma i Staša“, Legende i kronike (ur. Vedran Gligo i Hrvoje Morović), Split 1977., 13-57.

Viktor Novak, Zadarski kartular samostana svete Marije, Zagreb 1959.

Viktor Nova - Petar Sкок, Supetarski kartular. Iura sancti Petri de Gomai, Zagreb 1952. 
Ivo Petricioli, „Ranosrednjovjekovni natpisi iz Zadra“, Diadora, 2/1960. - 1961., 251-270.

Željko RaPanić, „Dva splitska ranosrednjovjekovna sarkofaga“, Arheološki radovi i rasprave, 8-9/1982., 233-258.

Željko Rapanić, „Mater (pater) pupillorum tutorque viduarum“, Novija i neobjavljena istraživanja u Dalmaciji. Znanstveni skup. Vodice 10. - 13. V. 1976. (ur. Željko Rapanić), Zagreb 1978., 83-90.

Željko Rapanić, „Ponovno o epitafu kraljice Jelene“, Opuscula archaeologica, 23-24/1999. - 2000., 309-315.

Željko Rapanić, Predromaničko doba u Dalmaciji, Split 1987.

Željko Rapanić, „Ranosrednjovjekovni latinski natpisi iz Splita“, Vjesnik za arheologiju i historiju dalmatinsku, 65-67/1963. - 1965., 271-314.

Željko Rapanić, Solin u starohrvatsko doba, Split 1996.

Tomislav Raukar, Hrvatsko srednjovjekovlje. Prostor, ljudi, ideje, Zagreb 1997.

Duje Rendić-Miočević, Carmina epigraphica, Split 1987.

Duje Rendić-MiočEvić, „Neke epigrafsko-onomastičke značajke epitafa kraljice Jelene“, Arheološki radovi i rasprave, 8-9/1982., 219-231.

Paul Anthony Reynolds, A Comparative and Statistical Survey of the Late Antique and Early Medieval Latin Inscriptions of South Eastern Gaul (c. 300-750 AD), doktorska disertacija, University of Leicester, 2000.

James Spencer Northcote, Epitaphs of the Catacombs or Christian Inscriptions in Rome during the First Four Centuries, London 1878.

Mate Suić, „Prilog tumačenju natpisa kraljice Jelene“, Starohrvatska prosvjeta, 14/1984., 15-39.

Ferdo Šıšıć, „Genealoški prilozi o hrvatskoj narodnoj dinastiji“, Vjesnik Hrvatskog arheološkog društva, 13/1914., 1-93.

Josip ŠTIMAC i dr. (ur.), Ratkaji Velikotaborski u hrvatskoj povijesti i kulturi 1502-1793. u povodu 200-te obljetnice izumrća. Grad Veliki Tabor, 11. rujna-10. listopada 1993. (katalog izložbe)

Igor URANIĆ, „Sarkofag i kartonaža Kaipamau“, Vjesnik Arheološkog muzeja u Zagrebu, 2627/1993. - 1994., 145-156.

Mirko Valentić - Lada Prister, Zbirka kamenih spomenika, Zagreb 2002.

\section{$\cos$}

\section{MedieVAl EPITAPHS: "THE BOOKS OF LIFE AND DEATH"}

Epitaphs - the inscriptions on tombstones or, more generally, poems with related content, serve to preserve the memory of the deceased and their deeds. They appear as early as the antiquity, in the Egyptian, Greek, as well as Roman civilizations. They reflect the individual's view of the world and their views on life and death, as well as those of the civilization the individual belonged to. Medieval inscriptions on Croatian territory are a direct offshoot of early Christian epitaphs and thus reflect a Christian worldview. The article provides a personal selection of these "poems in stone" dating from early Christian times, up to the end of the Middle Ages and the beginning of the Early Modern Period. They help us single out and trace conceptual changes, as well as the changes in content and worldview through time, but they also reflect timeless considerations initiated by death. Nearly all of the texts reveal the eternally present fear of death, but they also list the achie- 
vements of the deceased, in order to preserve their memory, while the Christian medieval ones also express a belief in the afterlife. The paper devotes particular attention to the epitaphs of notable personalities, which constitute primary sources. The content of the epitaphs and their structure as a distinctive literary genre also play an important part in the analysis.

Key words: epitaph, Middle ages, worldview, "poems in stone", loci communes, death, memory 



\section{OPORUKE ZAGREBAČKIH GRAĐANA \\ S KRAJA 17. STOLJEĆA \\ U GRADSKIM KNJIGAMA ZAPISNIKA \\ IZJAVNICA (PROTOCOLLA FASSIONUM)}

\section{Zvjezdana Sikirić Assouline}

UDK: 347.67(497.5)“16“

Izvorni znanstveni članak

Sažetak: Autorica u radu analizira s formalne i sadržajne strane korpus od dvanaest oporuka u užem smislu riječi te širi krug od tridesetak fasija - izjavnica s oporučnom tematikom nastalih u zadnjoj četvrtini 17. stoljeća u Slobodnom i kraljevskom gradu Zagrebu, a sačuvanih u gradskoj knjizi Zapisnika izjavnica, gdje su se upisivale pretežito zemljišne, ali i druge transakcije među građanima te među građanima i gradskom upravom. Na temelju oporuka u radu se daje uvid u jezik, način njihova sastavljanja, identitet oporučitelja, njihov društveni status, spol, obiteljski status i mehanizme nasljeđivanja. Analizira se njihov imetak i način raspolaganja njime, s posebnim naglaskom na fenomen dugova, u razdoblju obilježenom velikim požarom 1674., dvjema kužnim opasnostima, nerodnim godinama i nadirućim ratom. Na kraju analiziraju se elementi religioznosti iskazani u oporukama is tim povezani legati pro anima crkvama, redovničkim zajednicama i bratovštinama u gradu.

Ključne riječi: oporuke, zagrebački Gradec, 17. stoljeće, Zapisnik izjavnica (Protocollum fassionum), pučka pobožnost, smrt

\section{UvOD}

(

poruke, kao pisani dokumenti svoga vremena, prvorazredan su izvor za promatranje odnosa pojedinca, a šire gledano i neke društvene zajednice, prema životu i smrti u određenom povijesnom trenutku. Analizirajući prije svega sadržaj i formu, ne zanemarujući, pak, ni pravni aspekt tih isprava, može se dobiti autentična slika društva u kojem su nastale, stvarnih životnih okolnosti i razmišljanja onoga tko oporuku piše te onih kojima je namijenjena.

Sloboda oporučnog raspolaganja imovinom jedno je od statusnih prava građana slobodnih kraljevskih gradova u feudalnom društvu, pa tako i građana zagrebačkoga Gradeca. Ipak, budući da su same oporuke po prirodi stvari privatni dokumenti, a ne javni, sačuvan 
nam je za starija razdoblja tek manji broj tekstova oporuka u gradečkom arhivu, i to u gradskim Zapisnicima izjavnica (lat. Protocolla fassionum), gdje su se, prema traženju stranaka, zapisivale fasije, to jest svečane izjave pred gradskim vlastima. Davale su se o najrazličitijim pravnim poslovima među građanima, kao što su, primjerice, kupoprodaje i ostale transakcije zemljišta, kuća i druge imovine pojedinaca i gradske općine. Za analizu izabrana je posljednja četvrtina 17. stoljeća, razdoblje nakon velikog požara 1674. godine. Tada je započet novi Zapisnik izjavnica, a do kraja stoljeća ispunjen je još jedan te započet treći. ${ }^{1}$

Vrijeme je to dosta teško za grad: nakon požara koji ga je prilično opustošio (a nakon što je zapravo tek bio obnovljen poslije požara 1645. i potresa 1646.), dvaput je stigla kuga nadomak grada, 1682. i $1691 .^{2}$ Godine 1685 . i 1686. obilježile su velike nestašice i glad, a nakon turskoga prodora do Beča 1683. vodi se i rat koji će uroditi oslobođenjem Slavonije, mirom u Srijemskim Karlovcima 1699. i (konačnim) odmicanjem turske granice, odnosno opasnosti iz neposredne blizine Zagreba. ${ }^{3}$ Ipak, u pogledu vođenja gradskih knjiga u vezi s poslovima s nekretninama, a čiji su dio u nekom smislu i oporuke, ovo je razdoblje početak konsolidacije, zahvaljujući gradskoj odluci iz 1656. i 1657., ${ }^{4}$ kojom se propisuje obvezan upis ugovorenog pravnog čina i predaja novca pred sucem i magistratom, a čiji je rezultat vođenje već spomenutih gradskih Zapisnika takvih izjavnica. One se u tadašnjem govornom zagrebačkom idiomu zovu „fašija“, njem ove prakse među građanstvom, posebno u vrijeme kad nakon požara raste broj transakcija, povjesničari su dobili prvorazredan izvor za proučavanje obiteljskih, društvenih, pravnih te gospodarskih odnosa i tijekova u gradu.

\section{Pojavnost oporučne problematike U ZAPISNICIMA IZJAVNICA}

U Zapisnicima izjavnica oporučna problematika pojavljuje se na nekoliko načina. Jedno su oporuke upisane izravno u Zapisnik, dakle isprave koje naslovom, oblikom i sadržajem izražavaju volju oporučitelja. Drugo su fasije, isprave koje su naslovom i oblikom izjavnice, no sadržaj je izjave zapravo izražavanje volje izjavitelja u vezi s budućim raspoređivanjem vlastite imovine ili izabiranjem skrbnika djeci u slučaju smrti. Treće su fasije u kojima net-

1 Zapisnici su djelomično objavljeni u 22., 23. i 24. svesku edicije Monumenta historica civitatis Zagrabiae. Povijesni spomenici grada Zagreba (dalje: Monumenta). Neobjavljen dio građe nalazi se u Državnom arhivu u Zagrebu (dalje: HR-DAZg), Poglavarstvo Slobodnog kraljevskog grada Zagreba (dalje: PGZ), 1657 (77).

2 Hrvoje Petrić, „Stoljeće napretka i oporavka“, Povijest grada Zagreba (ur. Ivo Goldstein i Slavko Goldstein), Zagreb 2012., 190. Opširnije o Zagrebu u 17. stoljeću i posebno o nedaćama koje su ga tada snalazile vidi u: Franjo BunTAK, Povijest Zagreba, Zagreb 1996., 284-428.

3 Prema Zapisnicima sjednica magistrata, u Zagrebu je u veljači 1693. godine bilo smješteno toliko mnoštvo njemačke vojske da se nije mogla održati svečana restauracija magistrata u uobičajenom terminu, na blagdan svetoga Blaža. Usp. Monumenta, sv. 18, 321. Zagreb je tada u objema jurisdikcijama imao oko 3600 stanovnika, a u Gradecu oko 2000. Usp. Stjepan Krivošrć, Zagreb i njegovo stanovništvo od najstarijih vremena do sredine XIX. stoljeća, Zagreb 1981., 70, 80-81.

4 Zlatko Herkov, Statut grada Zagreba od god. 1732., Zagreb 1952., 54.

5 Monumenta, sv. 23, 8. 
ko, najčešće član obitelji, odnosno nasljednik, daje upisati u Zapisnik oporuku preminule osobe, kako je iskazana pred svjedocima. Četvrti je način spominjanje nečije oporuke ili, pak, nečije volje unutar drugih pravnih poslova.

Broj od dvadeset i sedam isprava s oporučnim sadržajem upisanih na prva tri načina u promatranom razdoblju svakako omogućava konkretan uvid u razmišljanja onodobnih zagrebačkih građana o pitanjima koja treba riješiti prije smrti i načinu kako to učiniti. Ipak, ovaj broj - posebno u svjetlu četvrte skupine fasija, u kojima se izjavitelj u svom pravnom poslu poziva na neku oporuku - pokazuje da glavni dio oporuka koje su se u to vrijeme sastavljale i koje su se u danom trenutku primjenjivale u stvarnom životu za regulaciju nasljedničkih odnosa i za potrebe daljnjih pravnih poslova - kao što su, na primjer, prodaja zemljišta ili utjerivanje dugova - nije bio zapisan u gradsku knjigu niti se to smatralo nužnim. Tako i za oporuku samoga gradskog suca Ivana Uzolina, ${ }^{6}$ koji je nakon više od desetljeća i pol vođenja grada preminuo 1692. godine, doznajemo samo posredno, iz dviju fasija. Prva, sastavljena u godini Uzolinove smrti, odluka je novoga gradskog suca i Senata kojom se namiruju gradska potraživanja i postiže sporazum između gradskog fiska s jedne te izvršitelja oporuke i nasljednika pokojnog suca s druge strane. ${ }^{7}$ Druga je izjavnica kojom gradski župnik te šogor i sestra pokojnog Uzolina, prvi izvršitelji oporuke, prenose dio sučeva nasljedstva i obvezu plaćanja crkvenih legata na njegova nećaka i šogoricu. ${ }^{8} \mathrm{U}$ promatranom se razdoblju još na desetak mjesta spominju oporuke muškaraca i žena kod rješavanja pravnih poslova koji su uslijedili ubrzo nakon smrti oporučitelja ili, pak, godinama, pa i desetljeće kasnije. Pritom se najčešće djelomično ulazi i u sadržaj oporuka.?

Premda se broj zapisanih oporuka u gradečkim Zapisnicima izjavnica od 1675. godine do kraja stoljeća može činiti relativno malim, treba znati da su u prethodnim dvama gradskim Zapisnicima iste vrste, koji obuhvaćaju još dulje razdoblje, od 1639. do $1661 .^{10} \mathrm{i}$ od 1662. do 1674 . godine, ${ }^{11}$ upisane tek dvije oporuke. Povećanje je, dakle, očito, a budući da se tendencija nastavlja, može se s pravom reći da odabrano razdoblje čini most prema 18. stoljeću, koje već u prvom svom desetljeću upisuje dvadeset i šest oporuka, ${ }^{12}$ da bi s vremenom njihov broj toliko narastao da grad 1770. godine otvara poseban gradski zapisnik samo za oporuke - debelu knjigu Protocollum testamentorum. ${ }^{13}$

6 Imena i prezimena osoba navode se radi čitljivosti i preglednosti hrvatskim oblikom imena i suvremenom grafijom prezimena. Izvorna grafija te, prema potrebi, izvorni latinski oblik navode se u prvoj bilješci uz referencu dokumenta gdje je osoba spomenuta. Na tom se mjestu u zagradi donose i eventualne inačice grafije prezimena dotične osobe u drugim izvorima korištenima u radu.

7 Monumenta, sv. 24, 122. U izvorniku: Joannes Uzolin (Uzulin).

$8 \quad$ Isto, 227.

9 U fasiji od 3. 5. 1696. (Monumenta, sv. 24, 224) spominju se čak tri oporuke u razdoblju od prethodnih sedam godina, u vrlo zanimljivom nasljednom slučaju, gdje magistrat fasijom potvrđuje vlasništvo alodijalne kuće, vrta i povrtnjaka Katarini Maurek (u izvorniku: Catharina Maurek) i njezinoj kćeri Ani Petras (Anna Petrasz). One su taj posjed naslijedile oporukom iz 1695. od muža odnosno oca Ivana Petrasa (Joannes Petrasz), koji ga je oporučno naslijedio od svoje prve žene plemenite Ane Štulac (Anna Stulacz). Ana Štulac ga je pak naslijedila oporukom iz 1689. od svoga prvog muža, gradskog prisjednika Ivana Marušića (Joannes Marussich). Marušiću su taj posjed ostavili u nasljedstvo njegovi roditelji.

11 Isto, 25-96.

12 HR-DAZg, PGZ, 1657 (77), 426-882, passim.

13 HR-DAZg, PGZ, 1688 (142). 


\section{STRUKTURA OPORUKA I NJiHOVO ZAPISIVANJE}

U prve tri gore navedene skupine fasija s oporučnom tematikom, od njih dvadeset i sedam, dvanaest je oporuka u diplomatičkom smislu, dok su ostalo izjave pojedinaca dane pred magistratom. Dvije od tih izjava možemo u sadržajnom smislu potpuno priključiti oporukama jer u jednoj gradski župnik izjavljuje kako svoju imovinu ostavlja dvojici svoje braće, $s$ obvezom da iz tog nasljedstva određenu svotu isplate nećacima (sestrinim sinovima), ${ }^{14}$ a u drugoj trojica svjedoka usmeno prenose oporuku sugrađanina čijem su davanju nazočili te je magistrat prihvaća kao valjanu. ${ }^{15} \mathrm{U}$ ostalim izjavama pojedinci nekim elementom dopunjuju već postojeću oporuku, zavještaju određen komad imovine ili se, pak, radi o zajedničkim izjavnicama supružnika koji međusobno jedan drugome, u slučaju smrti bez zajedničke djece, ostavljaju ukupnu imovinu. O njima će riječi biti kasnije.

Što se tiče dvanaest oporuka u punom diplomatičkom smislu, osam ih je uklopljeno u fasije iz kojih je vidljivo da pojedinac, oporučni nasljednik ili njegov predstavnik, traži od magistrata izdavanje prijepisa oporuke pokojnika i njezin upis u Zapisnik. U intitulaciji isprave stoga je ime aktualnoga gradskog suca ${ }^{16}$ u uobičajenoj formuli: Nos, iudex, caeterique senatores Liberae Regiae Civitatis Montis Graecensis Zagrabiensis. Nakon toga slijedi kratka promulgacija damus pro memoria, a tek iznimno inskripcija quibus expedit universis. U naraciji se zatim navodi peticija donositelja oporuke, njegovo ime i društveni status vidljiv iz počasne titule koja stoji uz ime, uz objašnjenje njegove veze s pokojnikom te se naglašava da je oporuka vjerno prenesena od strane izaslanika magistrata kao svjedoka. U dispoziciji fasije prenosi se tekst cijele oporuke, na narodnom jeziku, a u završnoj klauzuli još se jednom potvrđuje i naglašava istovjetnost izdanog prijepisa s izvornikom formulom: praemissam testamentariam dispositionem modo praevio coram nobis relatam eidem de verbo ad verbum, sine diminuatione et augmento aliquali, transcribi et transummi. Slijedi uobičajena ubikacija: Datum in praefata Libera Regia Civitate Montis Graecensis Zagrabiensis. Datacija, naprotiv, vrlo često izostaje.

Dakle, oporuke upisane u Zapisnik izjavnica ovjereni su prijepisi izvornih isprava koje nam vrijeme nije sačuvalo. Isto vrijedi i za četiri samostalne oporuke, izravno zapisane u Zapisniku. Unatoč odsutnosti upravo opisane opreme koja bi svjedočila o konkretnoj namjeni njihova upisa, i ove oporuke upisane su nakon oporučiteljeve smrti. Vidljivo je to kako u samom naslovu fasije (na primjer, Testamentum circumspecti olim Ioannis Bollff, dakle, pokojnoga Ivana Bolfa ${ }^{17}$ ) tako i u vremenu upisa, znatno odmaknuta od datuma na oporuci, kao što je to slučaj oporuke Gaspara Jambrehovića, napisane 1695., a upisane u Zapisnik izjavnica 1696. godine. ${ }^{18}$

\footnotetext{
14 Monumenta, sv. 23, 125.

15 Isto, 143.

16 U zadnjoj četvrtini 17. stoljeća izmijenila su se četvorica gradskih sudaca: Mihalj Cvetušić (1675. i 1682.), Ivan Uzolin (1676. - 1681. i 1683. - 1692.), Ivan Stepanić (1692. - 1698.) i Juraj Pozvinski (1699. - 1713.). Usp. Poglavarstvo Slobodnog kraljevskog grada Zagreba (prir. Mato Grabar), Zagreb 2000., 226-227.

17 Monumenta, sv. 24, 160. U izvorniku: Joannes Bollff, Januss Bollff (Bolff, Boliuff).

18 HR-DAZg, PGZ, 1657 (77), 160-162. U izvorniku: Gaspar Jambrehovich.
} 
Obilježje je svih ovih oporuka to da su pisane hrvatskim jezikom, naravno, zagrebačkom kajkavštinom. Oporuka se izriče usmeno, i to pred vjerodostojnim svjedocima. U Gradecu se ustalila praksa prema kojoj Magistrat onima koji žele dati zapisati svoju oporučnu volju šalje u njihov dom dvojicu svojih izaslanika. Najčešće se radi o gradskome kapetanu (što je glavni redarstveni položaj u gradu) i gradskome bilježniku ili kojemu drugom senatoru. Njihova se zadaća sastoji u tome da budu svjedoci i zapišu te svojim potpisom ovjere oporučiteljevu posljednju volju. Logično je stoga da oporuku zapisuju onako kako se kazivala, na hrvatskom jeziku, a samo je u nekim slučajevima ona započeta na latinskome (invokacija ili invokacija i početne odredbe koje se odnose na skrb o duši i pokopu tijela). ${ }^{19}$ Oporučitelji su u vrijeme sastavljanja u svim oporukama bili pritisnuti bolešću, ${ }^{20}$ a načelno je otvoreno i pitanje njihove pismenosti kad je riječ o obrtnicima. Kao što će se vidjeti, ovdje razmatrani oporučitelji jesu ljudi koji u svojoj gradskoj zajednici nešto znače, no nije naodmet napomenuti da je i puno desetljeća kasnije, 1764. godine, devetero od desetero hrvatskih obrtnika - novoprimljenih građana bilo nepismeno, ${ }^{21}$ kao i nekolicina članova magistrata. ${ }^{22}$ Stoga je uhodana praksa dolaska dvočlanog izaslanstva magistrata u kuću bolesnika bila svima na korist, a domaći jezik zapisivanja jedini logičan izbor. U 18. stoljeću pojavit će se u Zapisnicima izjavnica i oporuke na njemačkom govornom jeziku, prva već 1705 . godine. ${ }^{23}$

Devet od dvanaest oporuka počinje invokacijom Svetoga Trojstva, na hrvatskom ili latinskom jeziku. One koje nemaju invokaciju, na početno mjesto stavljaju dataciju. U jedanaest od dvanaest oporuka slijedi intitulacija, gdje se oporučitelj ili oporučiteljica identificira kratko svojim imenom i prezimenom ili, pak, imenom i prezimenom s kratkim dodatkom koji izražava ono što ga kao osobu najviše obilježava: za muškarce najčešće purgar ovoga plemenitoga varassa, a za žene ime živućega ili pokojnog muža. Dvanaesta oporuka, bez imena oporučitelja, najbolje pokazuje kako snaga oporuke stoji u potpisima vjerodostojnih svjedoka, a to su u konkretnom slučaju Mihael Kozjak, gradski kapetan, i Matija Faberio, vicenotar. ${ }^{24} \mathrm{U}$ kratkoj naraciji u deset od dvanaest oporuka ukazuje se na krhko tjelesno stanje, no na nepomućeno duševno, odnosno mentalno zdravlje, nužno potrebno za meritorno izricanje posljednje volje, izrazima poput buduchi $w$ telu kruto mlohav, a $w$ duse hvala budi Bogu dobro zdrav ili na telu kruto mlahav pri pameti pako dobre buduch. Slijedi dispozicija koju osam od dvanaest oporuka započinje brigom za dušu, a potom i za tijelo. ${ }^{25} \mathrm{U}$ nekim su oporukama te kratke odredbe i u rečeničnom smislu priključene samoj identifikaciji oporučitelja, dok u drugima čine zaseban odlomak, označen s Naiperuo... Te odredbe, s raznim kraćim i duljim varijacijama, glase otprilike ovako: dussu moiu jedino-

19 Monumenta, sv. 22, 178, 179.

20 Iz zagrebačkog 17. stoljeća sačuvana je samo jedna oporuka koja nije pisana u bolesti nego prije odlaska na neizvjesno putovanje, ona Jurja Vernića, budućega gradskog bilježnika, iz 1636. godine. Usp. HR-DAZg-1/39 A. Monumenta, sv. 20, Protocollum civium, 140-141.

22 Monumenta, sv. 21, Zapisnici sjednica gradske uprave, passim. Mogući malen znak o pitanju pismenosti može biti činjenica da u onom jedinom registriranom slučaju, kada je posljednja volja izrečena bez prisutnosti izaslanika magistrata (u kući u podgrađu, blizu Manduševca), prisutni je svjedoci ne zapisuju, nego usmeno kasnije iznose pred magistratom.

23 HR-DAZg, PGZ, 1657 (77), 636-643, oporuka udovice Petra Barlle.

24 Monumenta, sv. 22, 179.

25 Isto, 135; Monumenta, sv. 23, 70, 75; Monumenta, sv. 24, 193. 
mu Bogu preporucham, telo moje pako na pokopannye matere Zemlie. Međutim, tek četiri oporuke u nastavku označuju mjesto pokopa, konkretno crkvu svetog Marka u trima slučajevima i jednom svetog Roka. ${ }^{26}$ Daljnji tijek dispozicije donosi u raznim omjerima materijalnopravne (imenovanje nasljednika), formalnopravne (imenovanje izvršitelja oporuke) i nenasljedne pravne odredbe (određivanje skrbnika maloljetnoj djeci, priznavanje dugova, kao i vlastitih dužnika). Ove će se središnje teme detaljnije razraditi kasnije. U završnom dijelu oporuke nalazi se datacija isprave (ako nije bila navedena na početku) te koroboracija navođenjem imena i vlastoručnih potpisa dvojice svjedoka, koji su, kao što je rečeno, službeni izaslanici gradskoga magistrata. Ova dva elementa imaju, dakako, sve oporuke jer na njima počiva snaga njihove vjerodostojnosti i uopće mogućnost kasnije primjene. Zanimljivo je primijetiti da onu jedinu usmeno prenesenu oporuku (trinaestu), izrečenu bez prisutnosti službenih osoba magistrata, potvrđuju ne dvojica nego trojica svjedoka. Igrom slučaja, jedan je građanin, a dvojica su kmetovi. ${ }^{27}$

\section{Oporučiteleji}

Pravo pisanja oporuke imali su punopravni građani i plemići. Sva imena oporučitelja bilo je stoga moguće prema izvorima identificirati u gradskoj zajednici, nekad na temelju njihovih zanimanja, a nekad na temelju njihovih funkcija u gradskoj upravi, ako to iz ekspeditivnosti pisanja ili iz skromnosti, što je najčešće slučaj, i nije izričito navedeno u njihovim oporukama. Sačuvane su nam tako oporuke kovača Matije Vojnovića (1676.), ${ }^{28}$ zidarskog majstora Ivana Donatija (1679.), ${ }^{29}$ trgovca Jakova Ingera (1695.) ${ }^{30}$ i krznara Gašpara Jambrehovića (1695.) . $^{31}$ te gradskog prisjednika i fiska Ivana Snillara (1676.) $)^{32}$ i gradskog prisjednika Ivana Bolfa (1693.). ${ }^{33} \mathrm{U}$ gradu Zagrebu smrt je 1696. godine zatekla i Mihalja Grubačevića, ${ }^{34}$ koprivničkoga gradskog suca, ${ }^{35}$ a izaslanici gradskog magistrata pozvani radi pisanja oporuke, gradski kapetan Ivan Khaill i vicenotar Nikola Tribinacz, krivo su zapisali njegovo ime tako da oporuka glasi na Mihalja Rubachevicha.

Budući da svi oni na isti način, prema uhodanoj praksi grada, daju izjave pred izaslanicima gradskog magistrata, od kojih je jedan gradski bilježnik ili vicebilježnik, završni je oblik oporuke ujednačen - premda se mogu vidjeti osobne crte, npr. u upotrebi konciznijih ili, pak, raspršenijih misli te u korištenju više ili manje riječi - i kao takav ne upućuje na društvene razlike koje među oporučiteljima mogu postojati. Ipak, oporuke gradskog fiska Sni-

\footnotetext{
26 Monumenta, sv. 23, 71; HR-DAZg, PGZ, 1657 (77), 159-160, 160-162, 339-353.

27 To je vidljivo iz počasnih titula s kojima su u fasiji navedeni. Prvi je circumspectus, a ostala su dvojica providus.

28 Monumenta, sv. 22, 179-180. U izvorniku: Matthias Voinovich (Voynouych).

29 Monumenta, sv. 23, 70-71. U izvorniku: Ivan Donati: Ioannes Donatus (Donati).

30 Monumenta, sv. 24, 193-194. U izvorniku: Iacob Inger: Jacobus Inger (Hynger).

31 HR-DAZg, PGZ, 1657 (77), 160-162.

32 Monumenta, sv. 22, 178-179. U izvorniku: Ioannes Snillar (Snellar, Snelyar, Snyelyar, Snyellar, Sniellar, Sniellyar, Zniller).

33 Monumenta, sv. 24, 160.

34 HR-DAZg, PGZ, 1657 (77), 159-160. U izvorniku: Mihaly Rubacheuich.

35 Više o njemu u: Zapisnici poglavarstva grada Koprivnice 1639. - 1700. (prir. Karmen Levanić), sv. 1, Samobor 2006., 29.
} 
llara i kovača Vojnovića, koje igrom slučaja u Zapisniku izjavnica stoje neposredno jedna iza druge, te razlike diskretno naznačuju: obojica imaju dugove, ali dok Snillar jedan dug od jedanaest škuda prebija drugim (što njemu duguje neki Anton), a za drugi od devet škuda određuje isplatu prodajom pšenice, Vojnović za svoje dugove od dva puta po dvije škude i dva puta po osam škuda predviđa isplatu iz prodaje kuće, i to tek nakon udovičine smrti. Među muškim su oporučiteljima i Ivan Petras iz podgrađa kod Manduševca (1681.), ${ }^{36}$ jedini čiju su oporuku usmeno prenijeli svjedoci i Nikola Stuparić, gradečki župnik (1682.). ${ }^{37}$ On je svojom izjavom pred magistratom oporučno ostavio svu svoju imovinu dvojici svoje braće zbog siromaštva u koje su upali nakon velikog požara.

Građansko pravo pisanja oporuke odnosilo se i na žene, to jest supruge, udovice i neudane kćeri zagrebačkih građana. Stoga ne začuđuje da među dvanaest zapisanih oporuka nalazimo pet koje su sastavile žene, a u Zapisnicima se na raznim mjestima i u raznim poslovima izjavitelji pozivaju na još tri oporuke žena, na neke od njih i više puta, kao u slučaju oporuke Doroteje Jagatić. Nju izdvajamo jer se radi o zanimljivom slučaju plemićke djevojke, jedinice gradskoga senatora koja je najprije ostala bez oca, a onda i bez majke. Iz izvora vidljivo je da je već majka za udovištva prodavala imovinu, ${ }^{38}$ a sama Doroteja, prvi put označena u izvorima kao nobilis puella $1663 .{ }^{39}$ mora se u više navrata, zapravo iz godine u godinu, boriti pred magistratom protiv različitih uzurpatora, uključujući i ujaka, senatora Mihalja Vernića. ${ }^{40} \mathrm{U}$ fasiji istoga Vernića iz 1676. godine doznajemo za njezinu bolest, smrt i oporuku koju je dala napisati prethodne godine in ultimo agone suo, a kojom je, između ostaloga, zagrebačkim klarisama legirala pravo otkupa zaloga određene svoje šume na Tuškancu. ${ }^{41}$ Vernić otkupljuje to pravo od opatica, isplaćuje zalog i preuzima šumu. O sadržaju njezine oporuke i o legiranju imetka ili većeg dijela imetka u pobožne svrhe, možemo zaključiti i iz druge fasije koja je spominje: iste godine gradski edili crkve svetog Marka prodaju prazno kućno zemljište unutar zidina koje je oporučno ostavila toj crkvi, što vjerojatno znači da joj je uz sve ostale probleme i kuća izgorjela u požaru $1674 .{ }^{42}$

Od pet oporučiteljica dvije su udane žene: prva prezimena Horvath odnosno Halambek, bez zapisanoga krsnog imena (1670.), ${ }^{43}$ a druga Ana Šimanović (1696.). ${ }^{44}$ Tri su udovice: plemenita Katarina Petričević (1677.) ${ }^{45}$ plemenita Helena Kušević (1696. ${ }^{46}$ i Helena Veselinović (1698.). ${ }^{47}$ Prema običaju vremena i mjesta, sve se ove žene u privatnom i javnom životu služe svojim imenom i rođenim prezimenom. Udane se žene ponekad u nastavku

\footnotetext{
36 Monumenta, sv. 23, 143. U izvorniku: Ioannes Petrasz. Posljednja volja izrečena je oko Duhova 1681. Svjedoci je pred magistratom iznose godinu dana kasnije.

37 Monumenta, sv. 23, 125. U izvorniku: Nicolaus Sztuparich.

38 Monumenta, sv. 22, 116.

39 Monumenta, sv. 18, 163. U izvorniku: Dorothea Jagatich.

40 Isto, 174, 179, 183, 212, 219.

41 Monumenta, sv. 22, 169.

42 Isto, 148.

43 Isto, 135-136. U izvorniku: Horvath aliter Halambegh. Oporuka je datirana godinom 1670., a upisana u Zapisnik 1675. godine.

44 Monumenta, sv. 24, 219-220. U izvorniku: Anna Simanovich.

45 Monumenta, sv. 23, 75-77. U izvorniku: Catharina Petrichevich.

46 Monumenta, sv. 24, 216-217. U izvorniku: Helena Kussevich.

47 HR-DAZg, PGZ, 1657 (77), 339-353. U izvorniku: Helena Ueszellinouich.
} 


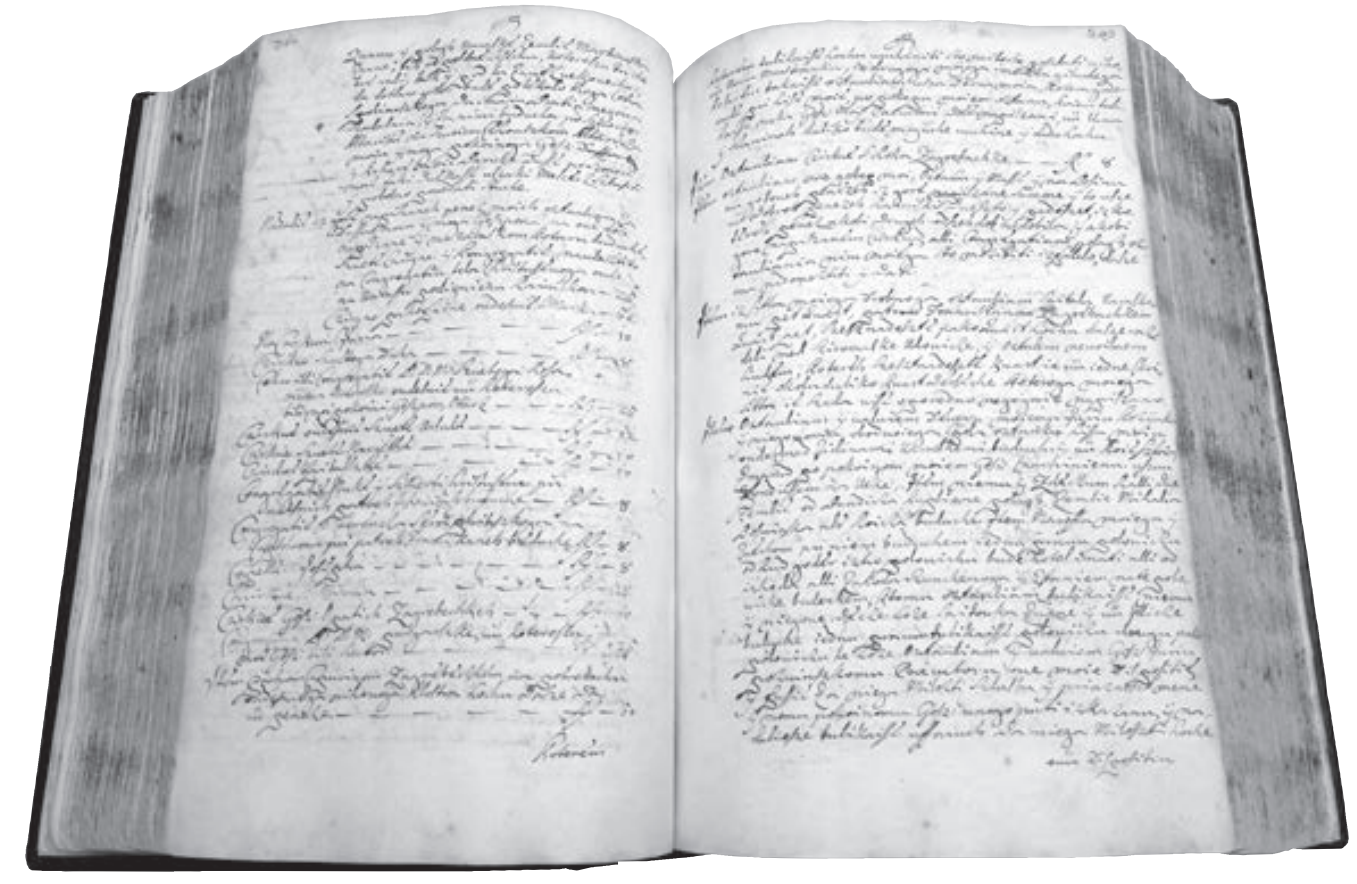

Sl. 1. Zapisnik izjavnica (lat. Protocollum fassionum)

identificiraju i imenom svoga supruga, ali i ne moraju. Ta se realna situacija zagrebačke sredine tog vremena ogleda i u ovim oporukama: jedna udana žena nakon svoga prezimena (Horvat odnosno Halambek) dodaje postuvanoga Juria Hutincza hisni tovarus, a druga to ne čini, makar je iz daljnjeg teksta vidljivo da ima muža. Upravo on, Grga Poturić, kasnije i traži upis njezine oporuke u Zapisnik. Njihov izbor dodavanja ili nedodavanja muževa imena slijedi i gradski bilježnik, pa prvoj ženi dodaje muževo ime u kratak latinski naslov fasije, dok kod druge to ne čini.

Praksa vlastitog prezimena u javnoj komunikaciji za udane žene nastavlja se u Zagrebu i u 18. stoljeću, a - kada je o oporukama u Zapisnicima izjavnica riječ - prvi slučaj žene s muževim prezimenom nalazimo u 1750. godini (i to kao izoliran slučaj), u naslovu Testamentum Mariae Constantiae Basseii i u vlastoručnom potpisu oporučiteljice na kraju te oporuke. ${ }^{48} \mathrm{U}$ kontekstu dosad rečenoga pomalo paradoksalno zvuči činjenica da, za razliku od žena sa živim suprugom, udovice, pak, uz svoje prezime uvijek stavljaju i (ime i) prezime pokojnoga muža. Tako su, dakle, učinile i Katarina Petričević, negdasniega plemenitoga kneza Mihalia Puczaka oztavliena udova, Helena Kušević, pokoinoga Martina Pozvinszkoga osztavlena udova, i Helena Veselinović, udoua pokoinoga goszpona Mihalia Kozyaka senatora.

Za četiri od pet oporučiteljica moguće je utvrditi da su pripadnice gornjega gradskog sloja, s obzirom na to da je Pucak bio gradski sudac, ${ }^{49}$ Hutinec i Pozvinski gradski prisjedni$\mathrm{ci}^{50}{ }^{50}$ Kozjak gradski senator, k tome i jedan od najbogatijih ljudi u gradu. Samo od 1680.

\footnotetext{
48 HR-DAZg, PGZ, 1661 (81), 533-535.

49 Poglavarstvo Slobodnog kraljevskog grada Zagreba, 226; Monumenta, sv. 18, passim. U izvorniku: Michal Puszak.

50 Monumenta, sv. 18, 235, 251. U izvorniku: Georgius Hutinecz i Martinus Pozuinszky.
} 
do 1686. kupio je deset nekretnina u gradu i na gradskom području, čime je bio najveći kupac nekretnina u gradu. ${ }^{51}$ Oporuka njegove udovice obuhvaća petnaest stranica gustoga teksta u Zapisniku izjavnica i po tome odskače od svih ostalih upisanih oporuka. Oporučiteljica, naime, raspolaže iznimno velikim nekretninskim imetkom i novčanim svotama, a nema žive djece pa svoju imovinu minuciozno raspodjeljuje, pretežno u pobožne i dobrotvorne svrhe, o čemu će riječi biti u posebnom poglavlju. O ugledu koji je uživala dovoljno je reći da su joj kao izaslanici magistrata na pisanje oporuke došli sâm sudac i vicesudac te da se o toj oporuci nakon njezine smrti raspravljalo na posebnoj sjednici gradskog Senata. ${ }^{52}$ Naravno, ovakva opsežna oporuka izuzetak je opravdan okolnostima, ali uz iznimku bezimene gospođe Horvat odnosno Halambek, čija je oporuka sastavljena doista u najkraćim mogućim crtama (najkraća od svih), dojam je na temelju preostalih triju oporuka da su ženske oporuke doista zbog duljih, elokventnijih rečenica, a i ponešto subjektivnijeg izraza (na primjer: Ako bi sze osenil moj goszpodar, szvojum senu ako bi ona po zlo delala, da goszpoda imaju prodati y za dussu moju, mojega goszpodara na Szvetoga Marka dati...) te većeg spominjanja detalja (Poplun jedan imam koj dasze ima prodati [...] jeden koszuh sztari koisze ima dati vu ime Bosie jedne sene sztari $)^{53}$ ponekad i dvostruko dulje od muških, koje prosječno obuhvaćaju stranicu i pol do dvije Zapisnika, zajedno s početnom i završnom opremom koja oporuku uklapa u fasiju.

\section{NASLjednici}

Iako pravo na pisanje oporuke dobro zvuči i temelji se, kao što se obično kaže, još na odredbama zagrebačke Zlatne bule, u stvarnosti je ono dosta ograničeno postojanjem popisa zakonskih nasljednika pa je, dok god se na tom popisu nalazi i najudaljeniji kognat ili čak srodnik po tazbini, ostavitelju oduzeto pravo disponiranja nekretninom u korist nekog sa strane. ${ }^{54}$ To je jasno i oporučiteljima s kraja 17. stoljeća pa se neki, kao Jakov Inger, u oporuci bave samo pokretnom imovinom i dugovima. Oni, pak, koji se upuštaju u spominjanje ili raspodjelu nekretnina, čine to da bi osigurali položaj supružnika, kao bezimena Horvat odnosno Halambek, Matija Vojnović ili Ivan Bolf, uredili odnose između preživjelog supružnika i djece, pogotovo ako ovi nisu vezani krvnom vezom, kao u slučaju Ane Šimanović, ili odredili što treba činiti u nekim posebnim situacijama koje naknadno mogu nastati, kao Ivan Snillar, koji u slučaju smrti njegove žene i kćeri, kuću ostavlja crkvi svetog Marka. U slučaju kad su djeca mala, moguće je, kao što je to učinio Mihalj Grubačević, napisati neutralnu, općenitu formulaciju gibuchia y negibuchia osztauliam da sze med mojum decziczum y gazdariczum jednako y praudeno razdele tak zemlie uinogradi, szenokosse,

51 Isto, 12 i passim. U izvorniku: Michael Kozyak (Koziak, Kosziak).

52 HR-DAZg, PGZ, 1657 (77), 353.

53 Svi primjeri iz oporuke Ane Šimanović, Monumenta, sv. 24, 219-220.

54 Magdalena Apostolova MaršAvelski, Zagrebački Gradec-Iura possessionaria, Zagreb 1986., 127. Opširnije o pravnom aspektu na oporučno raspolaganje imovinom na zagrebačkom Gradecu vidi također u: IsTA, Iz pravne prošlosti Zagreba, Zagreb 1998.; Ista, „O oporučnoj slobodi u zagrebačkom Gradecu - po Zlatnoj buli i kasnijoj praksi“. Zagrebački Gradec 1242 - 1850 (ur. Ivan Kampuš), Zagreb 1994., 91-102. 
kako druga osztala. ${ }^{55}$ No, u slučaju Helene Kušević, udovice s četvero djece, od kojih je kći udana, a od trojice sinova najmlađi još maloljetan, takvo što ne bi imalo puno smisla pa se ona najviše od svih - zapravo jedina - doista trudi sve podijeliti, uzimajući u obzir da kći preuzima brigu za najmlađeg brata pa njoj i zetu ostavlja kuću. Ne znamo kako je to kasnije funkcioniralo među nasljednicima Helene Kušević, ali za Anu Šimanović imamo podatak da je doista nakon sastanka očuha Poturića i dviju odraslih pastorki u kući Jakova Ilijašića, podžupana Zagrebačke županije, izvršena podjela koja je zadovoljila obje strane i povoljno riješila neke posebne komplikacije njihova slučaja. Poturić se prvotno uselio u kuću njihova pokojnog oca, ali je nakon toga ta kuća potpuno izgorjela, a nova je na tome mjestu sagrađena njegovim sredstvima. ${ }^{56}$

Gašpar Jambrehović među onim je oporučiteljima koji su bez djece pa su njegovi nasljednici u polovicama njegova žena i sestra. Neki bračni parovi, kako bi preduhitrili ovakvu situaciju - to jest za slučaj da jedan od njih umre, a ne bi imali zajedničkog potomstva - uzajamno si unaprijed ostavljaju svu imovinu službenom izjavom pred magistratom. U promatranom razdoblju zadnje četvrtine 17. stoljeća osam je takvih parova zapisano u Zapisnicima izjavnica. ${ }^{57} \mathrm{Nije}$ ih ovdje potrebno poimence nabrajati, ali recimo da njihov broj ima tendenciju povećavanja krajem osamdesetih i u devedesetim godinama stoljeća, a dva para još nisu niti vjenčana nego su zaručnici. U njihovim izjavnicama, ponekad i dirljivog sadržaja i s mnogo riječi, govori se o međusobnoj ljubavi i poštovanju koje jedno drugome žele tako iskazati. Varijacija na ovu temu jesu tri fasije u kojima samo supruga u takvom potencijalnom slučaju ostavlja svu svoju imovinu suprugu, a ne i obratno. U jednoj ne navode se posebni razlozi za takav čin, osim njezine iskrene ljubavi prema mužu (1686.) ${ }^{58} \mathrm{u}$ drugoj se bez navođenja pojedinosti govori o njegovim posebnim i brojnim dobročinstvima prema njoj $(1680 .)^{59}$, no u trećoj se izričito navodi da je suprug prije braka isplatio sve njezine dugove ostavljene joj od pokojnog prvog muža, a koji su prelazili vrijednost njezine ukupne imovine koju mu stoga sada zavješta (1681.). ${ }^{60}$

Ovaj zadnji slučaj, a radi se o plemenitoj Juditi Požgaj, podsjeća nas na činjenicu da nasljednici nasljeđuju i dugove. Postavlja se pitanje, kakvi i koliki su to bili dugovi da su nadilazili vrijednost imovine koja se, kao što je vidljivo iz fasije, sastoji od zidane kuće $s$ vrtom u gradu (na sjevernoj strani današnjeg Katarinskog trga), drugog vrta u podgrađu uz cestu koja vodi prema današnjoj Trešnjevci, oranice u Bankoviću (na području današnje Trešnjevke) i vinograda na Goljaku? U izvorima nalazimo da je prvi muž nesretne nasljednice bio Toma Faberius, gradski prisjednik, od oca Matije, gradskog senatora, i bio je živ tek nešto više od godinu dana ranije. ${ }^{61}$ Samo jedan od njegovih dugova glasio je na 600 forinti,

\footnotetext{
55 HR-DAZg, PGZ, 1657 (77), 159-160.

56 HR-DAZg, PGZ, 1657 (77), 162 - 166.

57 Monumenta, sv. 23, 32; Monumenta, sv. 24, 42, 71, 117, 172, 173, 192, 222.

58 Monumenta, sv. 23, 211. Margareta Rosinić Andriji Humaniću (u izvorniku: Margaretha Rossinich i Andreas Humanich).

59 Isto, 34. Barbara Fukec Matiji Horvatu (u izvorniku: Barbara Fukecz i Matthias Horvath).

60 Isto, 114. Plemenita gospođa Judita Požgaj izvrsnome Jurju Dariću (u izvorniku: Iuditta Posgai i Georgius Darich).

61 Monumenta, sv. 18, 257.
} 
a bilo je i drugih. ${ }^{62}$ Brza preudaja riješila je ovu mladu udovicu dugova, ali i problema sa svekrom, koji je bio voljan pomoći (i pomogao je), ali je očekivao povrat obiteljske zemlje. ${ }^{63}$

Mnogo su bolje pri nasljeđivanju muževa prošle udovice Petričević i Veselinović, koje uz kuću raspolažu sa šest, odnosno čak trinaest zemljišnih nekretnina. Kako nemaju vlastitih potomaka, njihovi su nasljednici brat, plemićki sudac Zagrebačke županije i šogorica kod prve, a brat i sestra pokojnog muža te njezina sestrična kod druge. Bez djece su među oporučiteljima, osim njih i Jambrehovića, još i bezimena Horvat odnosno Halembek i Ivan Donati te, dakako, župnik Nikola Stuparić. Dok ostalo troje iskazuje očekivane nasljednike, ženu i sestru, muža te dvojicu braće, oporuka zidarskog majstora Ivana Donatija posebno je zanimljiva po tome što se u ispravi, koja je više-manje popis njegovih dužnika i vlastitih dugova, na jednome mjestu spominje brat Karlo, očito njegov suradnik u zidarskom poslu - njemu, naime, povjerava radove u Remetama. Ipak, u nastavku svu svoju imovinu, tersje, zemliu $i$ hisu, kao i vino, ostavlja crkvi svetog Roka, a povrće i vino ocima kapucinima. Ovu je oporuku dao upisati u Zapisnik izjavnica gradski edil svetog Roka. ${ }^{64}$ Kao oporučno designirane nasljednike treba, dakle, registrirati na ovome mjestu i pravne osobe, razne crkve te crkvene i dobrotvorne ustanove koje su u novčanom ili zemljišnom obliku darivanja prisutne u deset od dvanaest oporuka, kao što će se vidjeti dalje u radu.

\section{IMETAK}

Uz brigu za dobrobit duše, koja je na različite načine izražena u gotovo svim oporukama, temeljne su teme oporuka, dakako, imetak i dugovi. To je ono što je predmet pisanja oporuke u zemaljskom, materijalnom smislu, no ni tu ne treba posve isključiti duhovni aspekt stvari jer je pošteno i pravedno sređivanje zemaljskih računa početak sređivanja računa i na nebu. Tu se transcendentno spaja s racionalnim i praktičnim pa je raspoređivanje imetka među bližnjima i potrebitima te priznavanje vlastitih dugova bitan dio pripreme za „dobru smrt“. ${ }^{65} \mathrm{Na}$ praktičnoj, pak, razini ova dva elementa bitno olakšavaju daljnji položaj i konkretno postupanje nasljednika, tim više što oporučitelj u oporuci navodi ne samo kome je on dužan (određujući najčešće i konkretan način isplate duga) nego i koji su njegovi dužnici te koliki mu iznos duguju.

Sve oporuke, osim jedne, ${ }^{66}$ navode najprije imetak, a onda dugove. Nepokretni imetak koji se spominje u oporukama, očekivan je: kuća, vinograd, oranica, vrt, grob, marof s vr-

\footnotetext{
Monumenta, sv. 23, 294.

63 Monumenta, sv. 24, 95.

64 Monumenta, sv. 23, 70-71.

65 Po nauku Katoličke crkve, drugi su dio pripreme sakramenti - sakrament pokore, bolesničkog pomazanja i euharistija kao popudbina. Usp. Katekizam Katoličke crkve, Zagreb 1994., \$1525. Ovome možemo dodati i mišljenje Zdenke Janeković Römer, koja čak smatra da se „nenadana smrt, bez oporuke, ispovijedi i svjedoka smatrala sramotnom i nečasnom“ jer je oporuka „prije svega sredstvo sređivanja računa sa svijetom is Bogom. Umrijeti bez oporuke značilo je ne samo da će nasljednici imati neprilike, već prije svega to da pokojnik ili pokojnica nisu bili vrli kršćani i građani i da se nisu dobro pripravili za 'veliki prijelaz'“ Zdenka Janeković Römer, „Na razmeđi ovog i onog svijeta: Prožimanje pojavnog i transcendentnog u dubrovačkim oporukama kasnoga srednjeg vijeka“, Otium, 2/1994., br. 3-4, 3. Monumenta, sv. 23, 70-71, oporuka Ivana Donatija.
} 
tom, sjenokoša. ${ }^{67}$ Ponekad se nepokretnu imovinu navodi samo paušalno, onako kako je to, na primjer, učinio Ivan Bolf: Senno mojo Anna Magdalena vsega moiega imuchka gibuchega y negibuchega pravu polovico ostavliam. Drugu pako poloviczu decza moja hochu da budu imela. ${ }^{68}$ Zbog toga nije moguće dobiti uvid u cjelokupan korpus imovine oporučitelja, no iz dostupnih podataka možemo zaključiti da prosječan oporučitelj, čija je oporuka zapisana u Zapisnicima izjavnica, posjeduje kuću ${ }^{69}$ i bar jednu, ako ne i dvije ili tri zemljišne nekretnine. Od onih koji se upuštaju u poimenično nabrajanje nekretnina, hižu ne spominju samo bezimena Horvat i Gašpar Jambrehović. Ostali kuću stavljaju na prvo mjesto, a zanimljivo je zamijetiti da svi imaju samo jednu - čak i daleko najbogatija građanka, Helena Veselinović, vlasnica četrnaest nekretnina. ${ }^{70} \mathrm{Od}$ ostalih su nekretnina najpopularniji i najbrojniji vinogradi, poimence nabrojeni čak dvanaest puta. ${ }^{71}$ Oni svojim vlasnicima daju vino za domaću upotrebu i prodaju, a ono je često i artikl koji mnogi daruju crkvenim redovima radi služenja misa za njihovu dušu ili naređuju prodaju i davanje novaca u istu svrhu. Od jedanaest poimence spomenutih oranica, šest ih je u vlasništvu Helene Veselinović. Zanimljiv je i slučaj Katarine Petričević, još jedne dobrostojeće žene. Osim njezinih dviju vlastitih oranica, obrađuju se i zemlje spitala $i$ czirkve, pri čemu onda urod ostavlja od spitalzkeh spitalu, od czirkveneh czirkve od Szvete Marie Congregatie tamo. ${ }^{72}$ Trojica oporučitelja ostavljaju grob u crkvi svetog Marka, a Helena Veselinović ostavlja u toj crkvi i klecalo, pola svojoj sestrični, pola družbenici Susani Czoczelly, koja se vjerno skrbi za nju u starosti.

U oporuci kovača Vojnovića spominje se mestria, a u onima trgovca Ingera i gradskog prisjednika Bolfa staczun te u njemu blago. I obrt i dućani spominju se u kontekstu prodaje, kako bi poslužili za isplatu dugova i troškove sprovoda. Od veće pokretne imovine u oporukama dviju bogatijih udovica koje imaju svaka svoj majur, marof, spominje se stoka, kao i oruđe (plug, kola...). S izuzetkom vina koje se navodi u polovini oporuka, sitnija pokretna imovina tek je povremeno predmet raspodjele, pretežno u ženskim oporukama. Radi se o raznim pojedinačnim predmetima za kućnu i osobnu upotrebu - od škrinja, srebrnih i pozlaćenih posudica do kožuha, platna, jastuka i blazina, a najbogatija oporučiteljica uključuje i odredbu kome ostavlja dva tuceta kositrenih zdjela. Ipak, mora se reći da se upravo u muškoj oporuci, onoj samca Ivana Donatija, nalazi jedini popis (nevelike) osobne imovine, predmet po predmet, jer ih on, kao i sve svoje nekretnine, ostavlja crkvi svetog Roka. ${ }^{73}$

67 Premda se izričito ne spominje, ostavinski predmet bila je i jedna šuma: župnik Nikola Stuparić u svojoj izjavi pred magistratom dvojici svoje braće ostavlja universa et qualibet bona sua et iura possessionaria (Monumenta, sv. 23, 125). Njegov se imetak, prema rekonstrukciji iz transakcija zapisanih u Zapisnicima izjavnica, sastojao od kuće s fundušem u Mesničkoj ulici (Monumenta, sv. 22, 158; Monumenta, sv. 23, 87), vinograda na Vrhovcu (Monumenta, sv. 22, 193) i šume kraj potoka Jelenovec (Monumenta, sv. 22, 246).

68 Monumenta, sv. 24, 160. Analizom kupoprodajnih transakcija moguće je ipak utvrditi da je posjedovao barem vrt (Monumenta, sv. 23, 129), oranicu (Monumenta, sv. 23, 200) i vinograd (Monumenta, sv. 23, 199).

69 Posjedovanje nekretnine u gradu bilo je, uostalom, jedan od uvjeta za primitak u građanstvo. Usp. Zvjezdana SiKIRIĆ, „Građani Slobodnog i kraljevskog grada Zagreba prema Knjizi građana (1733-1799)“, Radovi Zavoda za hrvatsku povijest, 29/1996., 106.

70 HR-DAZg, PGZ, 1657 (77), 339-353.

71 Dapače, ako se u kojeg od oporučitelja (izuzev najbogatije oporučiteljice) nalazi više od jedne nekretnine iste vrste, to su najčešće upravo dva vinograda.

72 Monumenta, sv. 23, 75-77.

73 Isto, 70-71. Taj koncizan popis sadrži razne alate, dvije blazine i dva jastuka, svileno sukno, nekoliko komada odjeće, uključujući crvene čizme, sablju, pušku karabinku i njezinu opremu, lampaš, svijećnjak, dvije ponjave i gunj te vino, nešto žitarica i drva za ogrjev. 


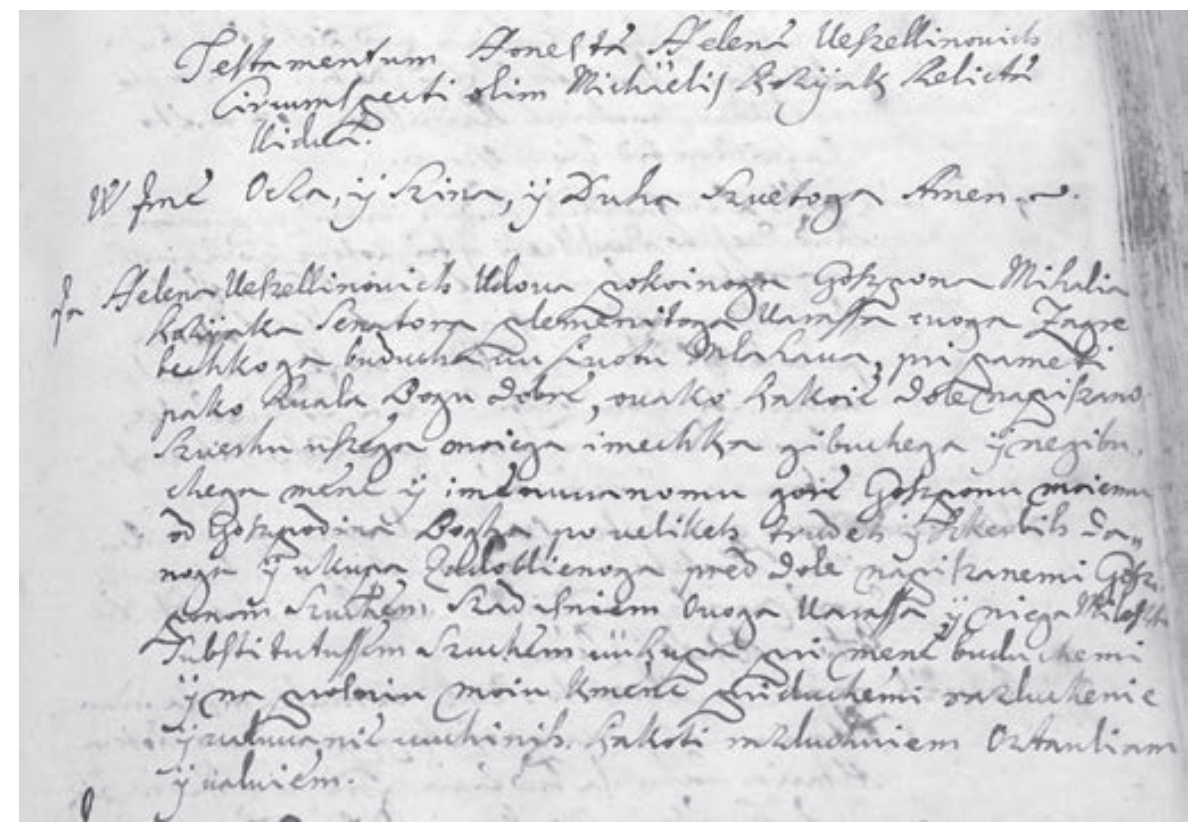

Sl. 2. Početak oporuke Helene Veselinović

Posebna je vrsta imovine i novac. On se u obliku gotovine, kao izravnog predmeta oporučivanja, pojavljuje u trima oporukama (odnosno četirima ako se računa i ona u kojoj oporučiteljica ostavlja svotu od 20 forinti za svoj pokop). ${ }^{74}$ Osim gotovine, novac se u oporukama pojavljuje i na neizravan način, u dvama oblicima. Kao prvo, prisutan je u kontekstu dugova pa se zapisane svote dugovanja nekih osoba oporučitelju mogu smatrati njegovom imovinom koju nasljednici tek trebaju realizirati. Kao drugo, u nekoliko slučajeva oporučitelj, ostavljajući kuću nekom određenom nasljedniku, traži od njega ispunjavanje nekog novčanog uvjeta: braća župnika Stuparića moraju dvojici nećaka isplatiti po 50 forinti, ${ }^{75}$ brat Katarine Petričević treba crkvi sv. Marka dati 50 ugarskih dukata, ${ }^{76}$ a zet i kći Helene Kušević platiti dug od 100 forinti. ${ }^{77}$ Novac kao gotovina koja se oporučuje obitelji pojavljuje se samo u trgovca Ingera, i to lijepa svota od 62 zlatna dukata cekina te 100 talira i škuda. ${ }^{78} \mathrm{U}$ ostalim dvjema oporukama koje spominju gotovinu, ona se namjenjuje za određenu svrhu. Dok Grubačević, kao stranac u gradu, ostavlja novčane svote od po 100 rajnskih forinti za mise za svoju dušu te za crkvu sv. Marka, gdje želi biti pokopan, ${ }^{79}$ bogata udovica Veselinović na početku oporuke zbraja sve vrste i svote novca kojima raspolaže (zlatne dukate - cekine, mletačke škude i rajnske forinte) ${ }^{80}$ te, preračunavši ih u rajnske

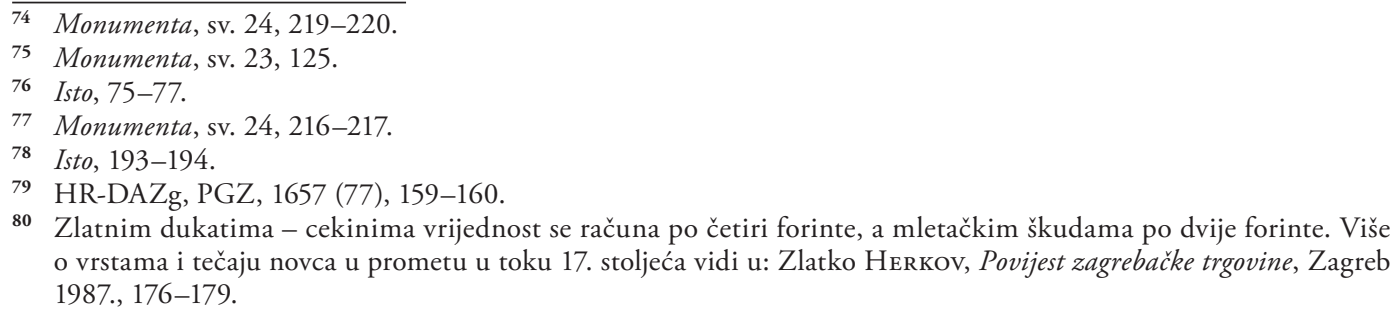

80 Zlatnim dukatima - cekinima vrijednost se računa po četiri forinte, a mletačkim škudama po dvije forinte. Više o vrstama i tečaju novca u prometu u toku 17. stoljeća vidi u: Zlatko Herkov, Povijest zagrebačke trgovine, Zagreb 1987., 176-179. 
forinte, dobivenu svotu od 1154 forinte ${ }^{81}$ raspodjeljuje u pobožne i dobrotvorne svrhe, a gradskim senatorima, kako bi im zahvalila za dugogodišnje prijateljstvo s njezinim pokojnim mužem, daje svakome po zlatnik. ${ }^{82}$

Zanimljivo je na kraju primijetiti da se svi oporučitelji, započinjući raspodjelu, referiraju na tu imovinu kao na moj imetek (što je, s jedne strane, logično jer neće raspodjeljivati tuđu imovinu), no samo dvije oporuke, i to ženske, apostrofiraju u nastavku stjecanje tog imetka zajedno sa suprugom, pri čemu jedna - ona najbogatije oporučiteljice - pri spomenu gibuchega i negibuchega imetka dodaje i ovo: mene i imenuvanomu gore goszponu moiemu od Goszpodina Boga po velikeh trudeh i szkerbih danoga y ukupa zadoblienoga. ${ }^{83}$

\section{Dugovi}

Dugh i dusan riječi su koje se nalaze u jedanaest od dvanaest obrađenih oporuka. Čak bi se u nekom smislu moglo reći da su dugovi, kako aktivni tako i pasivni, jedan od glavnih razloga zašto uopće netko zove $\mathrm{k}$ sebi izaslanike magistrata i daje zapisati posljednju volju. Svatko od njih želi otići pred Božji sud namirenih računa na Zemlji, a ujedno svojim nasljednicima olakšati snalaženje u potraživanjima nakon oporučiteljeve smrti.

Oporučitelji žive u svijetu premreženom dugovima. Svatko je od njih dio te mreže, bilo kao vjerovnik ili kao dužnik, a najčešće oboje. Karakterističan je primjer Ivan Donati, građevinski poduzetnik. On je dužan za građevinski materijal, plaću jednom zidaru i druge troškove od oko 16 forinti, no, s druge strane, njemu su dužna šestorica naručitelja, među kojima isusovci, Thomas Erdödi i sâm ban, u ukupnoj vrijednosti od 283 forinte. ${ }^{84}$ Među dužnicima je trgovca Ingera gradski magistrat, a on sâm, premda raspolaže, kako se vidi iz oporuke, priličnom svotom gotovine, još nije vratio dug od 70 forinti svojoj sestrii. ${ }^{85}$ Između dugova i vlastitih potraživanja od dužnika balansira Ivan Snillar, čiji je primjer prebijanja dugova i isplate drugih iz pšenice za prodaju već ranije spomenut u radu ${ }^{86}$ Nešto lošije stoje Ivan Bolf i Martin Vojnović. Obojica u oporukama spominju zemlju koju su dali u zalog za dug - prvi oranicu za 20 forinti, ${ }^{87}$ a drugi vrt za 8 škuda ${ }^{88}$ Usto imaju i drugih dugova - Ivan Bolf, štoviše, cijeli popis. Ipak, „blago“ je iz njegova štacuna očito dostajalo za njihovo plaćanje jer njegovu udovicu ne nalazimo u Zapisniku izjavnica kao prodavateljicu, kao što nalazimo udovicu Ivana Snillara. U fasiji, u kojoj ona godinu dana nakon njegove smrti prodaje vinograd, kao razlog prodaje izričito se navodi plaćanje dugova pokojnog supruga. ${ }^{89}$

\footnotetext{
81 Za usporedbu, cijene prodanih nekretnina u gradu 1696. (Monumenta, sv. 24, 203-234): drvene kuće unutar zidina prodane za 70, 97 140, 200 i 250 forinti; oranica za 30 forinti, vrt s fundušem za 140 forinti, vrt s hambarom za 60 forinti, a vinograd, zemljište, šuma i klijet za 51 forintu.

82 HR-DAZg, PGZ, 1657 (77), 339-353. Gradskom sucu Stepaniću i podsucu Pozvinskom ostavlja i oranicu, odnosno polovicu vinograda kao plaću za njihov trud kao imenovanih izvršitelja njezine oporuke.

83 HR-DAZg, PGZ, 1657 (77), 339-353.

84 Monumenta, sv. 23, 70-71.

85 Monumenta, sv. 24, 193-194.

86 Monumenta, sv. 22, 178-179.

87 Monumenta, sv. 24, 160.

88 Monumenta, sv. 22, 179-180.

89 Isto, 216.
} 
Od žena oporučiteljica dug bilježi samo jedna, udovica Helena Kušević, i to velik, od 100 forinti. ${ }^{90}$ Oporučno ga rješava predajom kuće zetu i kćeri. Dvije bogatije žene pojavljuju se kao vjerovnice, primateljice zaloga. Helena Veselinović dugove ostavlja „za dušu“, a Katarina Petričević za prstene koje ima u zalogu određuje da se upotrijebe za troškove njezina sprovoda, ako ih vlasnik ne iskupi za njezina života. ${ }^{91}$ Ovo je ujedno primjer kako oporučitelji dugovima koji im još nisu podmireni u oporuci mijenjaju namjenu, koristeći ih za podmirivanje vlastitih troškova ili ih, pak, nerijetko ostavljaju u pobožne svrhe, darujući ih bratovštinama, ocima kapucinima i petljarima - siromasima. Tako i trgovac Inger prije spomenutu svotu, koju mu očito već dulje vrijeme duguje gradski magistrat (jer kaže: za koje goszpon szudec dobro znaiu), ostavlja na jednake dijelove bratovštini Svetog Tijela, bratovštini Blažene Djevice Marije i siromasima. ${ }^{92}$

\section{SKrb ZA DUŠU}

Današnji čitatelj oporuka iz 17. stoljeća u opasnosti je da uvodnu rečenicu o preporučivanju duše Gospodinu Bogu, a tijela materi zemlji pročita kao notarsku frazu, jednostavno formulu kojom započinju oporuke. Za ondašnje oporučitelje duša je, međutim, doista najdragocjenija njihova „imovina“, koja je vrijedna prvoga mjesta i koja se predaje najdragocjenijem nebeskom primatelju. Druga je njihova dragocjena „imovina“ samo njihovo tijelo, vrijedno također pravog kršćanskog pokopa i dostojnog počivališta do dana uskrsnuća mrtvih, pa bilo to kod Szvetoga Roka (...) na desnu ztran pod oblukom, kako to moli Ivan Donati, ${ }^{93}$ ili vu (...) rake okolu velikoga oltara crkve svetog Marka, kao što to želi bogata Helena Veselinović. ${ }^{94}$

Dok su dosad razmatrane sastavnice oporuka bile okrenute životu na zemlji, briga za dušu okrenuta je već onome s druge strane „velikog prijelaza“ i ona u oporuci zavještanjem duše Bogu i svecima tek počinje. Ova je briga u materijalnoj oporuci nužno izražena materijalnim sredstvima, no njezina je vrijednost duhovna i simbolična te je tako treba čitati. Budući da nauk Katoličke crkve govori o vrijednosti molitve i posebno euharistijske žrtve, mise, za dobrobit ne samo živih nego i pokojnika, olakšavajući i ubrzavajući dušama prijelaz iz Čistilišta u Raj, ${ }^{95}$ oporučitelji ulažu u vlastitu budućnost kada simboličnim darom traže da se mise služe radi pokoja njihove duše, da ne budu zaboravljeni u molitvenom smislu. Ovi darovi nazivaju se legatima pro anima.

Samo dvije od dvanaest oporuka ne spominju baš nikakve odredbe koje bi se na to odnosile. Slučajno ili ne, to su upravo dvojica oporučitelja označena u prošlom poglavlju kao oni što najslabije stoje u pogledu dugova. Od ostalih deset, u njih šest spominje se darovanje nekretnina, ${ }^{96}$ u sedam materijalni legati (vino, stoka, žito, platno, srebrni i pozlaćeni

\footnotetext{
Monumenta, sv. 24, 216-217.

Monumenta, sv. 23, 75-77.

Monumenta, sv. 24, 193-194.

3 Monumenta, sv. 23, 70-71.

HR-DAZg, PGZ, 1657 (77), 339-353.

Katekizam Katoličke crkve, $\$ 1032$.

96 Monumenta, sv. 22, 135-136, 178-179; Monumenta, sv. 23, 70-71, 75-77; Monumenta, sv. 24, 216-217; HR-DAZg, PGZ, 1657 (77), 339-353.
} 
predmeti, škrinja), ${ }^{97}$ a u četirima oporukama novčani. ${ }^{98}$ Kao što je vidljivo iz preklapanja brojeva, u nekim oporukama radi se o kombinacijama više vrsta legata. U apsolutnom je iznosu najviše dala Helena Veselinović jer je u tu svrhu dala više od 1000 forinti, oranicu, žito, a dat će izraditi i skupocjenu pokaznicu za oce kapucine, ${ }^{99}$ no u relativnom je iznosu najviše dao Ivan Donati, koji je crkvi ostavio cjelokupan svoj imetak; kuću, zemlju, vinograd, pokretnu imovinu i vino. ${ }^{100}$ Između njih su ostali oporučitelji - bezimena Horvat odnosno Halambek s jednom od dviju nekretnina, Katarina Petričević s trima od sedam te Ivan Snillar i Helena Kušević s jednom od četiriju. Najviše je darova ustupljeno crkvi svetog Marka, ali su oporučitelji darivali i crkve svetog Roka, svetog Jurja, svete Marije na piaczu te kapucine, franjevce, pavline i bratovštine.

Poseban je oblik legiranja u obrađenim oporukama legiranje s odgodom ili, pak, uvjetno, samo u slučaju točno određenih okolnosti. Odgoda legata odnosi se na stupanje na snagu nakon smrti nasljednika, konkretno, bračnog druga bezimene Horvat odnosno Halembek, a okolnosti koje bi mogle aktivirati legate u slučaju Ivana Snillara i Jakova Ingera jesu smrt žene i djece ili samo djece. Da odgođeni legati nisu bili neobični i da nisu padali u zaborav s godinama, pokazuju fasije, poput one iz 1677., gdje se crkvi svetog Marka isplaćuje određena novčana svota, na temelju oporučne volje Jurja Vernića od više od deset godina ranije, da vrt preko puta Kamenitih vrata ostavi kćeri Margareti, udovici, s tim da se nakon njezine smrti preda crkvi svetog Marka uz obvezu služenja jedne mise mjesečno. Sada uplaćena svota bit će temelj zaklade (altarije), iz čije će se godišnje kamate financirati edili crkve i služenje jedne mise mjesečno za tu obitelj, a edili se uime crkve svetog Marka odriču prava na vrt. ${ }^{101}$

Bogata Helena Veselinović zaslužna je za dvije altarije, odnosno prebende, jednu novčanu i jednu zemljišnu: crkvi sv. Marka daje 500 forinti kao zakladu iz čije će se godišnje kamate financirati crkva i posebno altarist, svećenik koji će služiti dvije tihe mise mjesečno i jednu pjevanu godišnje za njezinu dušu i duše njezine pokojne kćeri i supruga, a Cehu bravara ostavlja određenu zemlju da se iz njezinih prihoda financira cehovski altarist koji će na cehovskom oltaru u crkvi sv. Marka ${ }^{102}$ služiti također dvije mise mjesečno, dok god bude postojao ceh. Osim ovih zaklada, dala je i pojedinačne legate svakoj od jedanaest crkava na području Gradeca ${ }^{103}$ i svim crkvenim bratovštinama - kongregacijama, četirima na području Gradeca (Svetog Tijela Kristova, Blažene Djevice Marije od Svetoga Rožarija, Muke i smrti Kristove i Blažene Djevice Marije purgarske) te jednoj kod franjevaca na Kaptolu (Svetog Franje). ${ }^{104}$ Ove bratovštine spominju se kao primateljice legata i u pet drugih

97 Monumenta, sv. 22, 135-136; Monumenta, sv. 23, 70-71, 75-77; Monumenta, sv. 24, 193-194, 219-220; HR-DAZg, PGZ, 1657 (77), 160-162, 339-353.

98 Monumenta, sv. 24, 193-194, 216-217; HR-DAZg, PGZ, 1657 (77), 159-160, 339-353.

99 HR-DAZg, PGZ, 1657 (77), 339-353.

100 Monumenta, sv. 23, 70-71.

101 Monumenta, sv. 22, 196.

102 Ovaj ceh, zvan špoljarski, brinuo se o oltaru Blažene Djevice Marije, koji se nalazio u sjevernoj apsidi crkve sv. Marka, uz crkveni zvonik. Usp. Marija ŠERCER, Stari zagrebački obrti, Zagreb 1991., 31.

103 To su, prema njezinoj oporuci iz 1698.: župna crkva sv. Marka, crkve sv. Jurja, sv. Duha, sv. Uršule, sv. Margarete, sv. Mihovila, sv. Roka, špitalska crkva, kapucinska crkva, crkva samostana klarisa i isusovačka kapela sv. Josipa.

${ }^{104}$ HR-DAZg, PGZ, 1657 (77), 339-353. 
oporuka, što pokazuje koliko su bile važne i prisutne u životu grada. Može se pretpostaviti da su muški oporučitelji bili njihovi članovi, kao što to za svog oca i pokojnog muža kaže Helena Veselinović, jedina koja se u svojoj oporuci upušta u naraciju tog tipa, ali za Ivana Snillara to možemo i tvrditi jer, slijedom okolnosti, bratovštini Blažene Djevice Marije duguje članarinu od 3 forinte. ${ }^{105}$ Svaka od bratovština brinula se na svoj način za pobožan život svojih bratima i njihov kršćanski sprovod, a financijska su podloga njihova djelovanja, osim članarina, upravo ovakvi pobožni legati. Oporučni legati pro anima rezultiraju stoga ne samo duhovnom korišću za oporučitelja nego i općepriznatom društvenom korišću.

\section{ZAKLJUČAK}

U zagrebačkoj sredini zadnje četvrtine 17. stoljeća, u vremenu inače teškom za grad, između požara, kužne opasnosti, nerodnih godina i rata u blizini, sazreli su uvjeti da gradska uprava propisom o obveznom unosu transakcija u gradsku knjigu u obliku fasija - izjavnica potakne zapisivanje svih pravnih poslova u gradu. Navikavanjem građana na administraciju dobili smo Zapisnike izjavnica, dragocjen povijesni izvor za povjesničare ranoga novog vijeka. U zapisnicima se, osim konkretnih prodaja i kupovina nekretnina, davanja u zakup i slično, s vremenom stvorio i prvi korpus (prijepisa) oporuka, nevelik brojem, ali značajan jer se radi o vrsti dokumenta koja je dotad u zagrebačkoj sredini ostajala u sferi privatnoga i, dakle, za povjesničare izgubljenoga. Premda većina oporuka u optjecaju i primjeni u gradu u ovo vrijeme, za razliku od 18. stoljeća, još ostaje izvan gradske knjige zapisnika, one koje su zapisane, kao i one koje se samo spominju u drugim pravnim poslovima, mogu biti temelj za analizu pravnih, društvenih, ekonomskih i kulturnih elemenata koji karakteriziraju epohu, a posebno delikatnih pitanja religioznosti i odnosa prema transcendentnome samih oporučitelja i sredine u kojoj žive.

Budući da Gradec ima vrlo uhodanu praksu dolaska službenih izaslanika magistrata u kuću sugrađanina koji želi sastaviti oporuku, oporuke imaju više-manje ujednačenu formu, no osobitosti oporučitelja dolaze do izraza u izričaju, dužini oporuke i načinu nabrajanja. Svojim pravom pisanja oporuke, koje je pripadalo građanima i plemićima, koristili su se i muškarci i žene, premda potonje u nešto manjem broju. Jezik je svih oporuka hrvatski, dok će već početak 18. stoljeća donijeti i oporuke na njemačkom.

Analiza oporuka i usporedba podataka s drugim izvorima pokazuje da su oporučitelji najvećim dijelom pripadnici gradskog sloja koji sudjeluje u upravi grada, uz nekolicinu trgovaca i obrtnika. Oporučitelji su višestruki vlasnici nekretnina u gradu i na njegovu području, no samo neki od njih daju pisati oporuku s izričitom namjerom da detaljno raspodijele imetak. Drugima je važnije osigurati položaj supružnika; relativno brojni bračni parovi to čine unaprijed, svečanom izjavom pred magistratom kojom si međusobno ostavljaju imovinu u slučaju da jedan od njih umre, a nemaju zajedničku djecu. Ovo rješenje sve je češće prema kraju stoljeća. 
Nepokretna imovina oporučitelja obuhvaća elemente karakteristične za hrvatske gradove u ranom novom vijeku: kuću, ponekad i s vrtom u gradu, ali i vinograd, oranicu, vrt, sjenokošu, pa i šumu jer je Zagreb ipak malen grad koji krajem stoljeća doseže broj od oko 3600 stanovnika u objema jurisdikcijama. Veličina imovine oporučitelja treba se sagledati u odnosu na dugove; dugovi su zagrebačkih oporučitelja s kraja 17. stoljeća brojni, a u nekim slučajevima i nesavladivi, kako to pokazuju primjeri nekih udovica i njihovi problemi u otplati muževih dugova nakon njegove smrti, pri čemu se radi o udovicama gradskih prisjednika (i samog fiska). Staviti na papir dugove jedan je od bitnih motiva za pisanje oporuke, što se vidi iz detaljnih popisa, dok podjela imovine zna biti kraća i općenita. Ne treba zanemariti ni duhovni aspekt stavljanja vlastitih računa na papir u očekivanju polaganja računa na nebu koje oporučiteljima neposredno predstoji.

Napokon, prisutnost izdašnih legata pro anima, bili oni u novcu, brojnim vedrima vina, ostaloj robi ili nekretninama u čak deset u dvanaest oporuka, govori o važnosti koju oporučitelji pridaju ovom aspektu svoje pripreme za smrt. Sve su obrađene oporuke, osim one bogate Helene Veselinović, vrlo ili relativno ograničene u narativnom pogledu, težište polažu na kratko i svrhovito nabrajanje, a ne na objašnjavanje motiva. Stoga, baš kao što ona u svojoj dugoj oporuci na svakom koraku moli prije svega za ustrajne molitve za njezinu dušu i duše pokojne kćeri i supruga, tako i legate za dušu ostalih oporučitelja, zapisane kratko, s malo riječi, treba promatrati kao izraze iskrene pobožnosti, a ne običaja ili trgovine duhovnim dobrima.

U tom smislu oporuke predstavljaju izazov u istraživanju te je potrebno nastaviti rad na njima, i to upravo na građi gradova hrvatskog kontinenta koji glede istraženosti ove vrste građe daleko zaostaju u odnosu na gradove hrvatske obale, jednako kao i razdoblje ranog novog vijeka u odnosu na srednji vijek.

\section{$\cos$}

\section{Izvori i literatura}

\section{Neobjavljeni izvori}

Državni arhiv u Zagrebu (DAZg), Poglavarstvo grada Zagreba (PGZ), 1657 (77), Zapisnik izjavnica (Protocollum fassionum) za godine 1693. - 1714 .

\section{Objavljeni izvori}

Monumenta historica civitatis Zagrabiae. Povijesni spomenici grada Zagreba, sv. 18 (prir. Emilij Laszowski), Zagreb 1949.

Monumenta historica civitatis Zagrabiae. Povijesni spomenici grada Zagreba, sv. 20 (prir. Emilij Laszowski i Lelja Dobronić), Zagreb 1971.

Monumenta historica civitatis Zagrabiae. Povijesni spomenici grada Zagreba, sv. 21 (prir. Lelja Dobronić), Zagreb 1975.

Monumenta historica civitatis Zagrabiae. Povijesni spomenici grada Zagreba, sv. 22 (prir. Lelja Dobronić), Zagreb 1992. 
Monumenta historica civitatis Zagrabiae. Povijesni spomenici grada Zagreba, sv. 23 (prir. Lelja Dobronić i Branka Molnar), Zagreb 2004.

Monumenta historica civitatis Zagrabiae. Povijesni spomenici grada Zagreba, sv. 24 (prir. Branka Molnar), Zagreb 2007.

\section{Literatura}

Magdalena Apostolova MaršAvelski, Iz pravne prošlosti Zagreba, Zagreb 1998.

Magdalena Apostolova Maršavelski, „O oporučnoj slobodi u zagrebačkom Gradecu - po Zlatnoj buli i kasnijoj praksi“, Zagrebački Gradec 1242 - 1850 (ur. Ivan Kampuš), Zagreb 1994., 91-102.

Magdalena Apostolova MaršAvelski, Zagrebački Gradec - Iura possessionaria, Zagreb 1986.

Franjo Buntak, Povijest Zagreba, Zagreb 1996.

Zlatko Herkov, Povijest zagrebačke trgovine, Zagreb 1987.

Zlatko Herkov, Statut grada Zagreba od god. 1732., Zagreb 1952.

Zdenka Janeković Römer, „Na razmeđi ovog i onog svijeta: Prožimanje pojavnog i transcendentnog u dubrovačkim oporukama kasnoga srednjeg vijeka“, Otium, 2/1994., br. 3-4, 3-16.

Katekizam Katoličke crkve, Zagreb 1994.

Stjepan Krivošić, Zagreb i njegovo stanovništvo od najstarijih vremena do sredine XIX. stoljeća, Zagreb 1981.

Hrvoje Petrić, „Stoljeće napretka i oporavka“, Povijest grada Zagreba (ur. Ivo Goldstein i Slavko Goldstein), Zagreb 2012., 157-199.

Poglavarstvo Slobodnog kraljevskog grada Zagreba (prir. Mato Grabar), Zagreb 2000.

Zvjezdana Sikırić, „Građani Slobodnog i kraljevskog grada Zagreba prema Knjizi građana (17331799)“, Radovi Zavoda za hrvatsku povijest, 29/1996., 103-108.

Marija ŠERCER, Stari zagrebački obrti, Zagreb 1991.

Zapisnici Poglavarstva grada Koprivnice 1639. - 1700. (prir. Karmen Levanić), sv. 1, Samobor 2006.

\section{The Testaments of THE Citizens of Zagreb FROM THE LATE ${ }^{7} 7^{\text {TH }}$ CENTURY IN THE LOCAL RECORD OF STATEMENTS (PROTOCOLIA FASSIONUM)}

The paper provides a formal and substantive analysis of a body of twelve last wills and testaments, as well as a more extensive collection of about thirty statements regarding the deponents' final wills, dating from the last quarter of the $17^{\text {th }}$ century in Gradec Zagrabiensis, which are preserved in the city's Record of Statements. The entries in the record largely concern land and other transactions conducted among the citizens, as well as the citizens and the municipal authorities. Analysis has shown that until the end of the $17^{\text {th }}$ century the testaments were predominantly written in Kajkavian Croatian, with several German-language ones appearing at the beginning of the following century. All Croatian-language testaments were composed in the testator's home, before two representatives of the authorities, which gives these documents a uniformity that nevertheless manages 
to reflect the specific characteristics of the individual testators. More than half of the testators are men, although women also availed themselves of the prerogative. Most of them belong to the city's administrative class, but there are some merchants and artisans as well. They own multiple pieces of real estate, with the property usually containing a single house, while the rest is comprised of vineyards, arable fields, gardens, hayfields and granges, as the typical "inventory" of Croatian cities in the early modern period, seeing as the Zagreb had a population of just 3600 denizens at the end of the century in both jurisdictions. The paper goes on to analyze the testators' social standing, as well as their familial relations and the mechanisms of handing down property. Towards the end of the century, an increasing number of married couples pledge to leave the entirety of their estate to the surviving spouse in case one of them dies and the marriage fails to produce children. The testators' estates and the ways they are managed are also examined, with particular focus on the phenomenon of debt, which connected the community into a complex network. Men prove more likely than women to simultaneously owe and be owed money, due to defaulting or delayed payment, in part owing to the troubles that had recently befallen the city, including a fire, two plague epidemics nearly reaching the city walls, as well as several difficult years marked by a lack of food and an impending war. Finally, substantial and virtually ubiquitous pro anima bequests to churches, monasteries and religious fraternities in the city are analyzed and it is pointed out that last wills and testaments in continental Croatia have been insufficiently researched when compared to the coast, with the same being true for those from the early modern Period compared to the Middle Ages.

Key words: last wills and testaments, Gradec Zagrabiensis, $17^{\text {th }}$ century, The Record of Statements (Protocollum fassionum), popular piety, death 


\title{
DUH MODERNE: \\ OD KULTURE ŽIVLJENJA DO KULTURE \\ SMRTI. FENOMEN SAMOUBOJSTVA \\ U EUROPI I HRVATSKOJ
}

\section{Filip Šimetin Šegvić i Nikolina Šimetin Šegvić}

\author{
UDK 364.27(4-181.2)“654“
}

Prethodno priopćenje

Sažetak: Velik statistički porast europske stope samoubojstava u drugoj polovini 19. stoljeća postupno postaje predmet žurnalističkih i znanstvenih obrada. Modernistički umjetnici i intelektualci od nje također ne bježe, već je prepoznaju kao karakteristiku vremena i konteksta u kojem žive. U razdoblju od oko 1900. godine pa sve do duboko u međuraće samoubojstvo prati i hrvatske intelektualce-umjetnike, od Julija Rorauera i Josipa Račića do Josipa Pičmana. Problematizirajući različite aspekte historijske psihologije, intelektualne historije te kulture smrti, autori nastoje ukazati na povezanost modernističkih ideja, stvaralaštva, načina života, umiranja i samog čina samoubojstva. Pritom se pozornost usmjerava na srednjoeuropski kontekst i fenomene istovremenosti neistovremenog, kao i na prisutnost različitih diskursa o samoubojstvu u javnosti i društvu.

Ključne riječi: samoubojstvo, modernizam, smrt, život, tisak, intelektualac, umjetnik

\section{Proučavati smrt}

7 nanstveno proučavanje smrti, umiranja i sahrane, definirano kao tanatologija, danas je izuzetno široko područje. Podrazumijeva interdisciplinarna istraživanja koja povezuju $\triangle$ filozofe, etnologe, psihologe, povjesničare, arheologe, liječnike, biologe i razne druge stručnjake. U suvremenoj se historiografiji od 1970-ih godina intenzivnije razvija interes za proučavanje smrti u povijesnom kontekstu, ponekad u sklopu širih društvenih, kulturnih ili političkih sfera, a ponekad i zasebno, kao pojedinačnu temu u određenom vremenu. Poticaj takvim istraživanjima u širem smislu dali su već ranije pojedinci, poput francuskog povjesničara Luciena Febvrea, koji je u prvoj polovini 20. stoljeća u širem smislu proučavanja „historijske psihologije“ i osjećaja upozoravao da povijest smrti još ne postoji. ${ }^{1}$ 
Na to se potom od 1950-ih godina nastavljaju brojni razrađeni pristupi, prvenstveno pod utjecajem razvitka historijske demografije i serijalne historije, ali i individualni poticaji istraživanju povijesti mentaliteta i „historijske psihologije“, odnosno „kolektivne psihologije“, koje je kao Febvreov učenik promovirao Robert Mandrou. ${ }^{2}$ Dva najistaknutija pravca, koji od 1960-ih postoje paralelno, jesu kulturološki pristup, jasno izražen u istraživanjima Philippea Arièsa (1914. - 1984.) ${ }^{3}$ i demografski pristup s Michelom Vovelleom ${ }^{4}$ na čelu. U posljednje vrijeme primjetno je i prozopografsko proučavanje određenih skupina i njihova odnosa prema smrti, umiranju i sahrani - bilo da se radi o elitama, pripadnicima raznih slojeva, vjeroispovijesti, nacionalnosti itd. - i to najčešće u urbanom kontekstu 19. i 20. stoljeća. Tako se i u ovom članku, s fokusom na razdoblju „oko 1900.“, a u kojem se u obzir uzima i kasniji međuratni kontekst, nastoji proučiti povezanost kulturnih i intelektualnih promjena, pojavu i ulogu modernosti u odnosu na pristup životu i smrti, i to na temelju fenomena samoubojstava.

Istraživanja Georgesa Minoisa upozoravaju na to kako je još u 18. stoljeću među intelektualcima tema samoubojstva izazivala pozornost te poticala otvoreniju raspravu. ${ }^{5}$ Kada je potkraj 19. stoljeća, prema rastućim statistikama samoubojica, problem postao očit, razvija se stručna ili specijalizirana literatura koja obrađuje fenomen samoubojstava. Već pred kraj 19. stoljeća stručna literatura o samoubojstvima nadišla je 600 bibliografskih jedinica, od kojih je više od polovine objavljeno nakon 1850. godine. ${ }^{6}$ No, Minois zaključuje da je 19. i 20. stoljeće u odnosu na ranije razdoblje vrijeme društvene „šutnje“, razdoblje prebacivanja teme na područje humanistike i medicine. ${ }^{7}$ Nedovoljno uvažava činjenicu da se intelektualna rasprava vodi na drugačiji način, drugačijim jezikom i sredstvima, primjerice, na području umjetnosti. ${ }^{8}$

O samoubojstvu progovaraju najrazličitiji umjetnici modernističkih afiniteta ili tendencija: pišu o tome brojni književnici, od Jamesa Joycea, Marcela Prousta i Hermanna Hessea do Filippa Tommasa Marinettija, Vasilija Rozanova i Vladimira Vladimiroviča Majakovskog. Majakovski se samoubojstvom bavi, ali i najavljuje vlastito u svojim pjesmama, sve dok ga 1930. godine hicem iz revolvera u srce sâm i ne počini. Potom se tom temom bave i novinari poput spisateljice Matilde Serao. Odnos prema samoubojstvu formiraju i slikari, primjerice, Édouard Manet, Egon Schiele, Paul Klee, George Grosz i brojni drugi.

Hrvatski će književnici u 20. stoljeću o samoubojstvu pisati na različite načine: naturalistički, fatalistički, realistički, groteskno. S druge strane, diskurs novinara, često u želji za lokalnim senzacionalizmom, ostaje pritom dominantno romantičarski. U vrijeme kada Josip Hatze sklada „narodnu“ operu Adel i Mara (1932.), s tragičnim ljubavnim zapletom, lokalni tisak ljubavnu dramu dodatno naglašava i u recima gradskih kronika,

\footnotetext{
Lucien Febvre, Das Gewissen des Historikers, Berlin 1988., 105.

2 Robert Mandrou, Introduction to Modern France, 1500-1640. An Essay in Historical Psychology, New York 1975.

3 Michel Vovelle, Mourir autrefois. Attitudes collectives devant la mort aux XVIIe et XVIIIe siècles, Paris 1974.

4 Philippe Ariès, Western Attitudes Toward Death: From the Middle Ages to the Present, London 1976. i kasniji radovi.

5 Žorž MinOA, Istorija samoubistva, Novi Sad 2008., 348-367.

6 John C. Weaver, Sadly Troubled History. The Meanings of Suicide in the Modern Age, Quebec 2009., 19.

7 Ž. MinOA, Istorija samoubistva, 361-367.

8 V. Róisín Healy, „Suicide in Early Modern and Modern Europe“, The Historical Journal, 49/2006., br. 3, 903-919.
} 


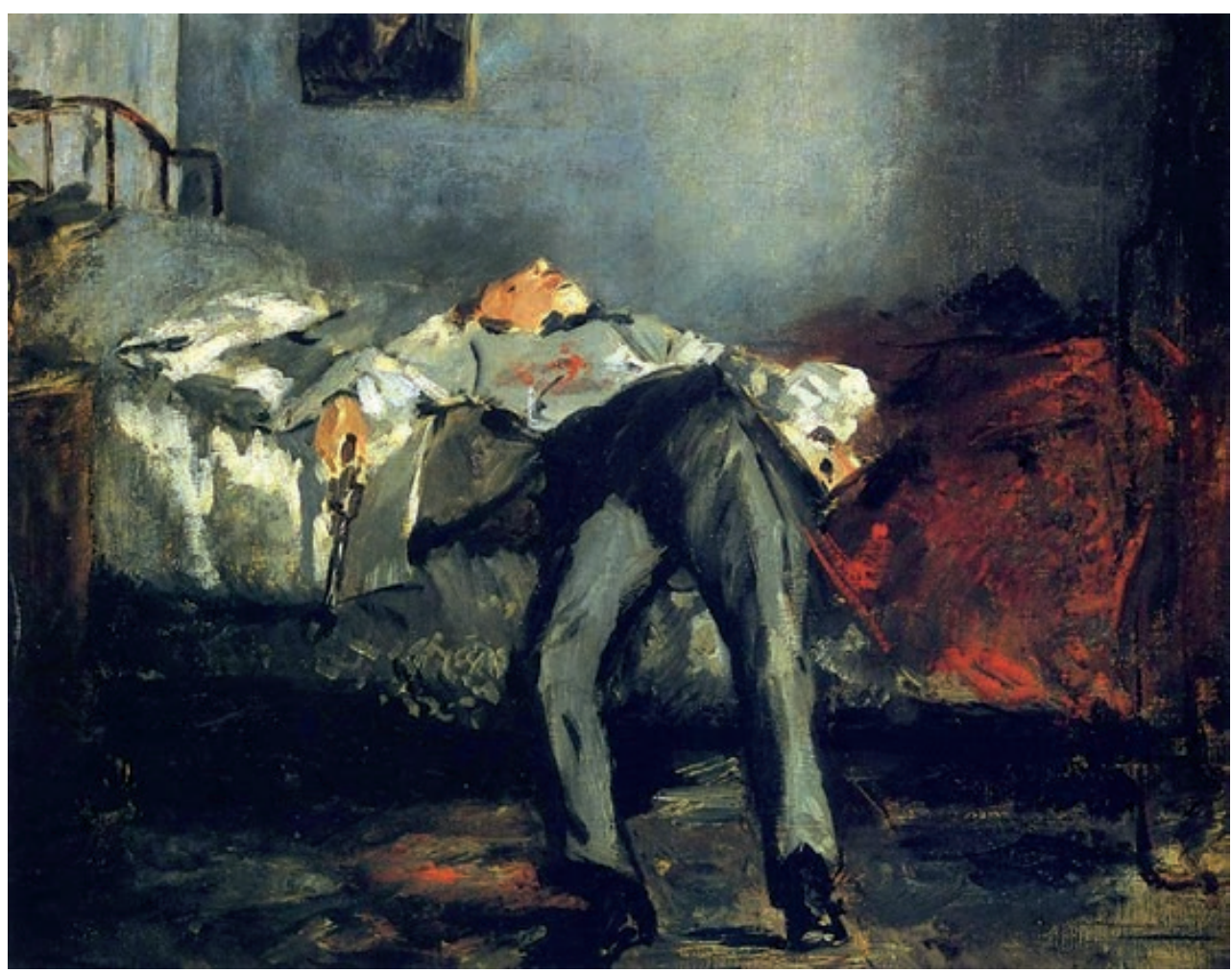

Sl. 1. Édouard Manet, Samoubojstvo (između 1877. i 1881.)

istražujući danima jedan tragičan slučaj. Velika pozornost pridavala se ljubavnoj tragediji 1930-ih godina u Splitu, kada su mladi Branko Hribar i Grozdana Aljinović počinili samoubojstvo na terasi splitskog svjetionika. Izvještaji o samoubojstvu na stranicama „gradske kronike“ Novog doba - prepuni patetike i ponavljanja - pišu o „tužnoj istoriji ljubavi“, nerazdvojnim ljubavnicima, pokušajima roditelja da ih razdvoje, o svjetioniku kao mjestu susreta, romantike (i erotike?), kao i o tužnom kraju: na tom su se mjestu ubili zagrljeni, revolverom. Novine donose izjave prijatelja, očevidaca, obitelji i roditelja, zatim govore na sprovodu, informacije o životima, sve do detalja da su svoju ranu smrt „predosjećali“?

Za razliku od naivnosti i želje za senzacionalizmom novinara, hrvatski pisci temu nastoje obraditi drugačije. Ne pišu o samoubojstvu kao modernom problemu i ne proučavaju filozofsko-moralne implikacije, već ga postupno uvode u djela i rasprave. Antun Gustav Matoš, Janko Polić Kamov, Janko Leskovar, Miroslav Krleža, Tin Ujević i drugi pojavu učestalih samoubojstava najčešće povezuju s različitim društvenim kontekstima. Dok je u jednih imaginacija i fikcija strogo odvojena od stvarnosti, drugi su se uživljavali u različite „moderne“ načine života, povezujući fikciju i (vlastitu) stvarnost.

9 „Tragičan svršetak jedne ljubavi“, Novo doba (Split), br. 50, 1. 3. 1933., 6; „Ganutljiv ispraćaj ljubavnika Branka i Grozdane“, Novo doba (Split), br. 52, 3. 3. 1933., 6; „Grozdana Aljinović i Branko Hribar“, Novo doba (Split), br. 53, 4. 3. 1933., 6 . 


\section{Fenomen samoubojstVa oKo I9O0. GODINE:}

\section{TISAK, STATISTIKA I ZNANOST}

U prvim desetljećima 19. stoljeća, između 1800. i 1825. godine, u Europi se ukupno broji oko 100.000 zabilježenih slučaja samoubojstava. Njihov broj ubrzano raste u drugoj polovini 19. stoljeća te do 1870 . već doseže pola milijuna zabilježenih slučajeva. Područje Habsburške Monarhije, međutim, do tada ne prednjači po broju takvih slučajeva, već skandinavske zemlje, Prusija i druge njemačke države, Francuska itd. Bitna promjena događa se u razdoblju od 1871. do oko 1900. godine, kada su u europskim razmjerima ukupno zabilježena gotovo 2 milijuna samoubojstava, no sada je i Austro-Ugarska Monarhija pri vrhu. ${ }^{10}$ Dok je Njemačka godišnje brojila i do 9.000 slučajeva samoubojstava, u Cislajtaniji ih je zabilježeno, primjerice, 1884. godine oko 2.600, od čega čak 358 ili $14 \%$ u Beču. ${ }^{11}$ Do početka 20. stoljeća broj samoubojstava u Beču rapidno raste, pa će oko 1910. godine već biti zabilježeno preko 1.500 samoubojstava, od čega si je najviše njih presudilo vješanjem ili se prostrijelilo, zatim otrovalo, utopilo, bacilo kroz prozor, pod vlak ili tramvaj, zapalilo se itd. ${ }^{12}$ Područje Hrvatske i Slavonije znatno je ispod europskog, ali i habsburškog prosjeka, pa su tako 1885. ukupno zabilježena 124 slučaja samoubojstava. Međutim, tendencija rasta primjetna je i u Trojednoj Kraljevini, naročito oko urbanih središta, Zagreba (najveći je broj samoubojstava na području Zagrebačke županije), Osijeka, Rijeke itd. Ako se analizira dobna struktura, na hrvatskom području prednjače osobe zrelije dobi, između 40 i 50 godina, a u više od $70 \%$ slučajeva samoubojstava radilo se o muškarcima. ${ }^{13}$ Proučavajući i kasnije statističke podatke o samoubojstvima na području Hrvatske i Slavonije, navedeni se podaci i omjeri nastavljaju (iako je u pojedinim godinama moguće naići na neka manja odstupanja). Gledajući evidentirane postotke samoubojstava u ukupnom broju umrlih od 1881. do 1890. godine, taj broj u prosjeku raste, iako ne u prevelikoj mjeri. ${ }^{14} \mathrm{Za}$ određene pojedinačne godine u statistikama iznose se sljedeći podaci: 1895. samoubojstvo je počinilo 139 osoba, 1896. 156 osoba, ${ }^{15} 1897.151$ osoba, ${ }^{16}$ 1898. 153 osobe $^{17}$ te 1900.181 osoba ili $0,28 \%$ od ukupnog broja umrlih. ${ }^{18}$ Situaciju potvrđuje i detaljnija razrada na razini grada Zagreba. Samoubojstvo su 1896. počinile 22 osobe, ${ }^{19}$ a 1897 . godine $16 .{ }^{20} \mathrm{Na}$ primjerima ovih dviju godina vidi se da trend prati onaj na razini Hrvatske i Slavonije, odnosno da je 1897. evidentiran nešto manji broj slučajeva

\footnotetext{
10 Banovac (Petrinja), br. 50, 15. 12. 1906., 6.

11 Narodne novine (Zagreb), br. 182, 11. 8. 1887., 2-3.

12 Jutarnji list (Zagreb), br. 257, 5. 1. 1912., 6.

13 Narodne novine (Zagreb), br. 182, 11. 8. 1887., 2-3.

14 Prosjek za razdoblje od 1881. do 1887 . iznosi $0,16 \%$ od ukupnog broja umrlih, za razdoblje od 1892. do 1895 . 0,19\%, a od 1896. do 1900. 0,20\%. Izvor: Statistički godišnjak Zemalja ugarske krune (dalje: Statistički godišnjak) 1900., Budimpešta 1902., 45.

15 Statistički godišnjak 1896., Budimpešta 1897., 98, 93.

16 Statistički godišnjak 1897., Budimpešta 1899., 67.

17 Statistički godišnjak 1898., Budimpešta 1900., 41.

18 Statistički godišnjak 1900., 52.

19 Statistički godišnjak 1896., 93.

20 Statistički godišnjak 1897., 67.
} 
samoubojstava. Prema statistici samoubojstava u Zagrebu za vrijeme Prvog svjetskog rata, kao i u godinama neposredno prije i poslije njega, može se potkrijepiti tvrdnja da je broj takvih slučajeva u ratnim godinama uvijek manji. Godine 1913. pokušaja i izvršenih samoubojstava bilo je ukupno 42, 1914. 46, ali već 1915. broj pada na 29, 1916. ih je 28 , a 1917. 20. Ukupan broj pokušaja i počinjenih samoubojstava počet će opet rasti od 1918., kada ih je bilo $33 .{ }^{21}$ Naglo povećanje bit će zamjetno već 1919. godine (41 pokušaj evidentiranih samoubojstva, od čega ih je počinjeno 15), a tijekom 1920-ih brojevi će varirati, krećući se od 34 1922. do 75 pokušaja i počinjenih samoubojstava 1924. godine. Kako se gospodarska kriza počinjala sve više osjećati, tako je i sâm evidentiran broj rastao, ali, još značajnije, i „učinkovitost" samoubojica. ${ }^{22}$

Bečki Neues Wiener Journal u travnju 1905. donosi opsežan članak u kojem se razmatraju statistički podaci o porastu samoubojstava u Europi, povezujući ih sa spekulacijama znanstvenika o razlozima takvog trenda. ${ }^{23}$ Svakako treba imati na umu i činjenicu da je vjerska osuda samoubojstva - naročito u pretežno katoličkim područjima - izazivala i izraženiju tendenciju zataškavanja slučajeva samoubojstava u javnosti ili čak među članovima obitelji: statistika samoubojstava u tom smislu zacijelo ne otkriva čitavu sliku i ne daje pouzdaniju bilancu. ${ }^{24}$

Gotovo opsesivna potreba za statistikama i analizama najrazličitijeg zahvata nije se ogledala samo u novinskim tekstovima i člancima u časopisima već je poticala i izdavaštvo. Djela koja su nastajala tijekom druge polovine 19. stoljeća najprije su razjašnjavala fenomen samoubojstava za potrebe pravnog sustava kao nečega novog i raširenog, s čime se društvo moralo suočiti. ${ }^{25}$ Teolog i statističar Hermann Anton Krose (1867. - 1949.) izdao je stručnu knjigu o samoubojstvu u 19. stoljeću u Freiburgu 1906. godine, u kojoj se prati europski trend rasta samoubojstava. Stavljajući velik naglasak na njemačke zemlje, pa tako rubno i na Austro-Ugarsku, Krose nastoji prikupljanjem statističkih podataka doći do zaključaka o razlozima samoubojstava i porasta njihova broja, pritom upozoravajući i na određene nepodudarnosti drugih dostupnih mu statistika - uglavnom na njemačkom jeziku. Tako ustanovljuje kako je Beč centar samoubojstava, a kako se njihov porast iznad prosjeka još može zabilježiti u određenim dijelovima Austrije, Češke, Moravske, Šleske i Bukovine, odnosno da je njihov postotak u čitavoj Cislajtaniji na granici, dok su ispod nje tek Kranjska, Dalmacija, Tirol i Galicija. Kratko se dotiče i Hrvatske i Slavonije, navodeći kako se u statistikama ponekad Hrvatska izostavlja iz ukupnog zbroja samoubojstava u Ugarskoj. Nastupajući s vjerskih pozicija, autori poput sociologa Gabriela Tardea (1843. - 1904.) o

21 Zagreb godine 1913-1918. Izvjestaj gradskoga poglavarstva o sveopíoj upravi slobodnog i kralj. glavnoga grada Zagreba, Zagreb 1927.

22 Godine 1923. samoubojstvo je počinilo 47 osoba (od 55 pokušaja), 1924. 48 od čak 75 pokušaja, a 1925. broj je pao na 33 od 44 pokušaja. Izvjeśtaj gradskoga poglavarstva o sveopíoj upravi slobodnog i kralj. glavnoga grada Zagreba za godinu 1919-1925, Zagreb 1928.

23 „60.000 bis 70.000 Selbstmorde im Jahre“, Neues Wiener Journal (Beč), br. 4112, 4. 4. 1905., 4.

24 J. C. Nyíri, „Philosophy and Suicide-statistics in Austria-Hungary: Variations on a Theme of Masaryk“, On Masaryk. Texts in English and German (ur. Josef Novák), Amsterdam 1988., 291-316.

25 To pokazuje djelo mrtvozornika Williama Wynna Westcotta iz 1885. godine, koje je, uz pravne implikacije, razjašnjavalo i one moralne. William Wynn Westсотт, Suicide. Its History, Literature, Jurisprudence, Causation, and Prevention, London 1885. 
suicidu pisali su kao o „neizravnom ubojstvu“..26 Nasuprot tome, od druge polovine 19. stoljeća javljaju se različiti stručnjaci koji samoubojstvo nisu osuđivali, već su s pomoću statistika i suvremenih analitičkih pristupa nastojali fenomen definirati i objasniti kao dio društvenog konteksta. ${ }^{27}$

Osim statističara, približno su istodobno o temi pisali i drugi stručnjaci, primjerice, talijanski antropolog i psihijatar Enrico Morselli, ekonomist Adolf Wagner, teolog Alexander von Öttingen, liječnik Richard Lasch i mnogi drugi. Samoubojstva intenzivno proučava Tomáš G. Masaryk (1850. - 1937.), objavljujući 1881. godine svoju doktorsku tezu, povezujući društveni, vjerski i intelektualni kontekst krize s rastućim statistikama samoubojstava. ${ }^{28}$ Otolog Abraham Eitelberg (1847. - 1919.) pred kraj 19. stoljeća objavljuje knjigu Unmoderne Ansichten über die moderne Cultur [Nemoderna razmatranja moderne kulture], u kojoj raspravlja i o samoubojstvima kao posljedici „modernog“ načina života i shvaćanja svijeta oko sebe. ${ }^{29}$

Studija Émilea Durkheima (1858. - 1917.) o suicidu postala je ubrzo temeljni dokument za razvoj suvremene sociologije. Većina studija koje nastaju na prijelazu stoljeća slažu se kako su glavni uzroci porastu broja samoubojstava društvena situacija, ubrzanje životnog ritma, gradski život, povećano siromaštvo, gospodarske neprilike itd. Pritom se velika pozornost posvećuje socijalnim navikama i promjenama, uz naglašavanje novoga načina života u gradu, koji nije samo u smislu ritma brži, nego naginje ekstremnom alkoholizmu, drugim amoralnim radnjama itd. Trend rasta samoubojstava nastavlja se i nakon Prvog svjetskog rata, pospješen gospodarskim krizama i teškim životnim uvjetima u pojedinim krajevima. Tako se još 1930-ih godina u hrvatskom i europskom tisku piše o „epidemiji samoubojstava" koja je zahvatila Europu uslijed raznih psihoza, duševnih bolesti, prekomjerne konzumacije alkohola, loše higijene i brige za zdravlje, depresije itd. Za razliku od druge polovine 20. stoljeća, suicid se oko 1900. i u međuratnom razdoblju shvaća kao masovan društveni problem o kojem je potrebno javno raspravljati. Tim se problemom ne bave samo teolozi, statističari, liječnici, psiholozi i filozofi već i književnici, pjesnici i kazališni pisci. Za razliku od 18. stoljeća, kada se na samoubojstvo gledalo kao na „bolest smrti“, u idućemu se književnici sve više posvećuju socijalnim prilikama, životu raznih skupina ili slojeva, želeći što detaljnije opisati društveno-kulturalne miljee. Teme samoubojstva naročito su prisutne u književnosti njemačkoga govornog područja prve polovine 20. stoljeća, i to, primjerice, u Thomasa Manna, Hermanna Hessea, Arthura Schnitzlera, Franza Kafke, Stefana Zweiga, Ferdinanda von Saara i drugih. Pritom je u austrijskih pisaca, poput von Saara ili, kasnije, Musila i Rotha, primjetno povezivanje suicida ili smrti protagonista s određenim društvenim slojem ili čak sa samom Austro-Ugarskom Monarhijom kao takvom, još i prije stvarnog raspada iz 1918. godine.

Koliko je snažno porast samoubojstava povezan s nekim modernizacijskim procesima možda najuvjerljivije potvrđuje činjenica da se postupno uvriježio - kako povjesničar John

\footnotetext{
26 J. C. Weaver, Sadly Troubled History, 21.

27 Isto, 23-35.

28 Tomáš Garrigue Masary , Der Selbstmord als sociale Massenerscheinung der modernen Civilisation, Wien 1881.

29 Abraham Eitelberg, Unmoderne Ansichten über die moderne Cultur, Wien - Leipzig 1892.
} 
C. Weaver ističe - „perverzan optimizam“, prema kojem se porast stope samoubojstava u nekoj zemlji shvaćao kao prvi znak uspješne modernizacije. ${ }^{30}$ No, kako Weaver napominje, potrebno je imati na umu i konzervativno-društveni kontekst u kojem se samoubojstvo događa: ako je ono predstavljalo društveni tabu, sramotu i zločin, broj takvih prijavljenih samoubojstva sasvim sigurno nije odgovarao stvarnosti. Također se u pitanje mogu dovesti efikasnost i konzistentnost provođenja statistika samoubojstava u zemljama kao što su Hrvatska i Slavonija na kraju 19. stoljeća, pogotovo imajući na umu da se u katoličkim zemljama porast samoubojstava - naročito u ruralnim krajevima - u statistikama često kamuflirao „nezgodama“. 31

Već sredinom 19. stoljeća uočava se na području Hrvatske i Slavonije normiranje odozgo, to jest donošenje niza državnih odredbi koje izravno utječu ne samo na prakse nego i na percepciju ili odnos prema samoubojstvu. To se nadovezuje na tezu povjesničara Davida Cannadinea, koji je uočio kako se slijedom različitih sudskih i medicinskih praksi te službenih procedura dogodilo to da je samoubojstvo pred kraj 19. stoljeća „postepeno iščezlo iz svakodnevnog iskustva“" ${ }^{32}$ Naime, raznim se zakonima na području Hrvatske i Slavonije uspostavljala stroža kontrola i procedura koja je morala vrijediti i za urbana i za seoska naselja, a odnosila se na praksu pri pregledu mrtvaca, pohranjivanju leša, prijevozu i ukopu. Glavna je namjera pritom bila uspostaviti standardnu proceduru, prema kojoj će lokalne vlasti što prije doznati za smrt i, ovisno o kontekstu, reagirati. ${ }^{33}$ Tako su zakoni vezani uz ponašanje ili odnos prema pronađenom mrtvacu-samoubojici odredili striktnu proceduru, koja je slučaj trebala učinkovito prepustiti u ruke „sposobnih“, dakle, po mogućnosti, stručnjaka i maknuti je iz vidokruga javnosti. Slučajevi samoubojstava istraživali su se dodatno prema posebno predviđenoj proceduri, koja je poticala involviranje lokalnog župnika $\mathrm{u}$ slijed istrage i suradnju s drugim stručnjacima istražnog povjerenstva. Pritom je ključno bilo dokazati da je samoubojstvo uslijedilo pod okolnostima „neubrojivog stanja“ jer je po automatizmu nakon toga omogućen normalan ukop pokojnika na groblju.$^{34} \mathrm{Na}$ području grada Zagreba od 1910. godine na mjesto pokušaja, kao i počinjenog samoubojstva dolazilo je Dobrovoljno društvo za spasavanje, svojevrsna preteča prve pomoći. ${ }^{35}$ Važan element bio je i gradski kotarski liječnik, a nakon toga provodile su se potrebne zdravstveno-redarstvene mjere. ${ }^{36} \mathrm{Ne}$ treba se stoga čuditi da će novinski izvještaji ili, pak, glasine o samoubojstvu nekih poznatijih intelektualaca i umjetnika u pravilu biti popraćeni odlomkom o „mentalnom rastrojstvu“ ili „neubrojivosti“, tražeći mogućnost za vjerskom, ali i društvenom ekskulpacijom.

30 J. C. Weaver, Sadly Troubled History, 59.

31 J. C. Nyíri, „Philosophy and Suicide-statistics in Austria-Hungary“, 302; J. C. Weaver, Sadly Troubled History, 59.

32 David Cannadine, „Tajna kuća smrti“, Gordogan, 11/1990., br. 29-30, 220.

33 Milan Smrekar, Priručnik za političku upravnu službu u kraljevinah Hrvatskoj i Slavoniji, Zagreb 1902., $1035-1044$.

34 Isto, 1052-1053.

35 O Dobrovoljnom društvu za spasavanje usp. Tomislav AnIć, „Utemeljenje dobrovoljnog društva za spasavanje“, $\check{C} a$ sopis za suvremenu povijest, 38/2006., br. 2, 569-582.

36 Izvještaj gradskoga poglavarstva, 149. 


\section{Pristup novinara pitanju samoubojstva}

Tema smrti u umjetnosti i intelektualnim raspravama učestala je i zbog njezine sveprisutnosti u modernim medijima - novinama. Pristup novinara pitanju samoubojstva nije bio isti. Opći članci o samoubojstvima u Europi ili Austro-Ugarskoj Monarhiji, koji su se često gotovo u cijelosti preuzimali iz stranog tiska, prenosili su većinom osuđujuće stavove i kriminalizirali takav čin. No, kada su novinari obrađivali pojedinačne slučajeve samoubojstava u zemlji, često su nastojali izazivati suosjećanje, naglasiti tragiku zbivanja ili iznijeti osudu čina. Unatoč tim razlikama, senzacionalizam u zagrebačkom i hrvatskom tisku općenito nipošto još nije dosezao razinu onog budimpeštanskog ili bečkog, kao ni drugih manjih novina u Europi, koje su upravo zbog izvještaja o bizarnim pojedinostima i senzacionalnim teorijama postajale čitanijima.

O utjecaju novina na percepciju smrti uopće moguće je provesti opširna i dugoročna istraživanja, ali ćemo se ovdje zaustaviti samo na nekoliko bitnih aspekata. Novine gotovo svakodnevno izvještavaju o smrti i donose najrazličitije članke, od senzacionalističkih kratkih vijesti do detaljnih statističkih analiza samoubojstva, ubojstva, mortaliteta itd. u svijetu i Hrvatskoj. Znanstveniji pristup samoubojstvima koji su egzemplificirali stručnjaci poput Durkheima vrlo se brzo - na temelju analiza statistika, psiholoških, socioloških, povijesnih i drugih faktora - odrazio na tisak. ${ }^{37}$ Ako se na trenutak senzacionalističko novinarstvo stavi na stranu, čak i ozbiljniji novinski članci variraju po kvaliteti podataka i dubini analize. Lokalne novine u Hrvatskoj i Slavoniji često nisu samo preuzimale tekstove iz Narodnih novina, Obzora, Agramer Zeitunga ili Tagblatta, već i iz austrijskog, mađarskog, njemačkog, britanskog, francuskog tiska i drugih izvora. Kada je riječ o temi samoubojstva, dominiraju kraći i dulji tekstovi o činovima pojedinaca, često pripadnika elita ili istaknutih poznatijih osoba.

Samoubojstvo kraljevića Rudolfa (1858. - 1889.) kod Mayerlinga 30. siječnja 1889. godine - koje je Bečki dvor u suradnji s cislajtanskim ministrom-predsjednikom grofom Eduardom von Taaffeom nastojao isprva prikazati kao „zatajenje srca“ (dakle, kao infarkt) - brzo je procurilo u strane i domaće novine, koje pišu o tome već 1 . veljače, nakon dobivenog dopuštenja Dvora. ${ }^{38}$ Zbog izuzetne medijske pozornosti i općenite eksponiranosti kraljevića, koji je spadao u prave, suvremenim rječnikom rečeno, „zvijezde“ društvenog života, priča o smrti Rudolfa i njegove mlade sedamnaestogodišnje ljubavnice Mary Vetsere snažno je odjeknula u društvu. Rudolf je predstavljao budućnost Austro-Ugarske; njegova mladost, afinitet prema znanosti i suvremenoj tehnologiji, pokroviteljstvo brojnih suvremenih projekata, putovanja po zemlji, političko djelovanje i neke hrabre reakcije koje su dale naslutiti da namjerava dualistički status quo ozbiljnije restrukturirati u dijalogu s predstavnicima naroda Monarhije, činili su prijestolonasljednika ne samo simbolom državne reforme nego i uzorom mlade inteligencije. $S$ druge strane, njegov je razvra-

\footnotetext{
$\overline{37}$ O stručnim pristupima samoubojstvu u 19. stoljeću usp. napose: Ž. MinoA, Istorija samoubistva; J. C. WEAVER, Sadly Troubled History.

38 Brigitte Hamann, Kronprinz Rudolf. Ein Leben, München - Zürich 2013., 431-505.
} 
tan, intenzivan, ponekad i boemski način života - u društvu lakih žena, do kasnih sati u obilascima i pušačkim salonima - također utjecao na mlađe pripadnike aristokracije. Ujedno je i dopunjavao sliku o mladom, talentiranom i modernom prijestolonasljedniku koja se itekako odražavala na krug najužih njegovih prijatelja, ali i šire. Samoubojstvo kod Mayerlinga usjeklo se u kolektivnu memoriju stanovnika Dunavske Monarhije i još godinama i desetljećima nakon što se ono zbilo. Identifikacija mlađih generacija i budućnosti Monarhije sa samim Rudolfom nije bila prisutna samo u javnosti i novinama nego - kako je jednom prilikom zaključio Sigmund Freud (1856. - 1936.) - i u snovima stanovnika, gdje se Franjo Josip i Elizabeta često pojavljuju kao roditelji, dok ulogu princa (Rudolfa) ili princeze (Rudolfove supruge Stéphanie) igraju - sami sanjari. ${ }^{39}$

Austrijski psihijatar i neurolog Erwin Ringel (1921. - 1994.), analizirajući slučaj Rudolfova samoubojstva, ustvrdio je kako do potonjega ne vodi trenutačna reakcija na poteškoće ili okolnosti. Prema njemu, radi se prvenstveno o procesu koji je dugo sazrijevao i koji utječe na ponašanje i razvoj ličnosti. ${ }^{40} \mathrm{No}$, da je pritom uočljiv i određen stil života, specifičan i za čitave generacije mladih ljudi, jasno je iz brojnih primjera diljem Habsburške Monarhije. Mlada apolitička ili politički ogorčena inteligencija vodila je neuredan život obilježen kockarskim dugovima, nepokrivenim zaduženjima, ljubavnima aferama, kasnim noćnim izlascima, prekomjernim uživanjem alkohola te karakterističnim pretvaranjem poroka u dominantan sadržaj životnog stila.

Budimpeštanski Pester Lloyd u listopadu 1895. godine piše o „tajni samoubojstva“. Razmatra se novo shvaćanje života, nedostatak straha od smrti, manjak pobožnosti, stav da je život teret, a smrt - rasterećenje. Upravo je moderan način života ključni uzrok koji je pojavu samoubojstava među mlađim naraštajima učinio učestalom: samoubojstvo se shvaća kao „cijena koja se plaća“ zauzvrat životu posvećenom strastima, „zabranjenom voću“, shvaćenom „materijalistički“. U članku se kao kriminalno djelovanje osuđuje takav način „spekulacije“ sa životom. ${ }^{41}$ I neki hrvatski tekstovi, referirajući se uglavnom na njemačku literaturu i tisak, upozoravaju na taj porast i vezu s načinom života. Iste, 1895. godine, u novinama se razmatra i jedan zanimljiv slučaj: kada se imućan student medicine Bogdan Musulin uoči rigoroza iznenada u Beču ubio, austrijski je tisak pisao o načinu življenja mladeži, troškovima i rasipništvu, nagađao da je mogući uzrok samoubojstva nemar i nerad na studiju itd. S druge strane, zagrebačke novine nastojale su te, prema njima, neutemeljene tvrdnje opovrgnuti. ${ }^{42}$ Blizina događaja, povezanost i podrijetlo pritom igraju ključnu ulogu: austrijski tisak lakše nagađa o samoubojstvu studenta hrvatskog podrijetla, dok će onaj hrvatski temi pristupiti manje senzacionalistički, nastojeći zaštititi imućnu obitelj Musulin od javnih tračeva.

\footnotetext{
39 Sigmund Freud, Die Traumdeutung, Frankfurt am Main 1976., 348. O kontekstu afere Mayerling i šire usp. također: Larry Wolff, Child Abuse in Freud's Vienna. Postcards from the End of the World, New York - London 1988.,1214.

40 Prema: B. Hamann, Kronprinz Rudolf, 491-492.

41 „Feuilleton: Das Geheimniß des Selbstmordes“, Pester Lloyd (Budimpešta), br. 249, 17. 10. 1895., 5-6.

42 Agramer Zeitung (Zagreb), br. 81, 8. 4. 1895., 3.
} 
Tisak je često bio sredstvo širenja neutemeljenih ili poluistinitih glasina. Tako su se Bečom ili Zagrebom oko 1900. godine širile glasine o pojedinim istaknutim osobama koje su si navodno oduzele život. Priče koje su, primjerice, kružile iz nepoznatih izvora godinama nakon smrti novinara i političkog aktivista Theodora Herzla 1904. u obzir nisu uopće uzimale činjenično stanje: Herzl je „sebe ubio“ u najgorem slučaju doslovno od rada, neumorno pišući, sve dok zbog iscrpljenosti nije poslan na odmaralište, gdje je dobio upalu pluća i preminuo. Umjesto toga, pričalo se naširoko o samoubojstvu. ${ }^{43}$ I o književniku Franu Vladimiru Mažuraniću (1859. - 1928.), koji je domovinu napustio nakon nečasnog otpuštanja iz vojske oko 1900. godine - pa se tijekom njegovih lutanja po Europi i svijetu dugo nije znalo za njega - proširile su se vijesti o navodnom samoubojstvu (Rikard Katalinić Jeretov); kasnije se doznalo da je književnik živ i zdrav u Berlinu. ${ }^{44}$

Nije pomagao ni bečki krug psihoanalitičara oko Sigmunda Freuda. Iako će se sâm Freud temom smrti najviše baviti nakon 1918. godine, pod dubokim dojmovima Prvog svjetskog rata, dok će se samoubojstva rjeđe doticati, mistična aura koja je stvorena oko psihoanalize - koju su njeni pobornici željeli prikazati kao visokoznanstvenu, ali i polutajnovitu metodu - koristila se senzacionalizmom i prizivala ga. Kada je 1930-ih godina poznati austrijski liječnik Alfred Adler umro na cesti u dalekoj Škotskoj, austrijski tisak, nedvojbeno i pod utjecajem Freudovih učenika, pisao je o tome kako je na otvorenoj ulici umro od krvarenja u mozgu, što je gotovo pa „pravedna nagrada“ za njegovo uporno negiranje psihoanalize. ${ }^{45}$

Od 1900. godine, pa sve do kraja međuratnog razdoblja, glasine i suprotstavljeni diskursi o osobi koja izvršava samoubojstvo ukazuju na ambivalentnost. Samoubojstva intelektualaca pobuđivala su nerijetko najrazličitije reakcije, od zlobnog, pa i zluradog moraliziranja (često osobno motiviranog) do patetičnog naglašavanja tragedije i neizbježnosti sudbine. Novinski su natpisi tako varirali od potpunog prepuštanja glasinama i poluistinama o životu i smrti osobe o kojoj se piše do potpune šutnje o načinu smrti. U takvoj situaciji otvarao se prostor za dodatan misterij, nerijetko potican i iz najbližih intelektualnih krugova bliskih pokojniku. Tako je egzemplaran i do danas ne sasvim jasan slučaj smrti pionira moderne arhitekture Le Corbusiera (1887. - 1965.) u moru, pored svojeg „Cabanona“ na francuskoj rivijeri, jer se govori o utapanju, srčanom udaru, ali i neobičnom obliku „nenamjernog samoubojstva“ i ritualnom „svetom“ samoubojstvu. ${ }^{46}$

U slučaju hrvatske najviše je pozornosti privlačilo samoubojstvo slikara Josipa Račića (1885. - 1908.). Ono se pod nejasnim okolnostima odvilo u lipnju 1908. godine u Parizu, što je potaknulo mnoga nagađanja. Pisalo se da je pronađen mrtav na ulici; kao motiv navodila se „glad ili zločin“, a isticalo se da je Račić bio vrlo blizu uspjeha i slave kada ga je u tome zaustavio „bezprimjereno glup, idiotičan“ slučaj. ${ }^{47}$ Navodno je i A. G. Matoš proširio

\footnotetext{
43 William M. Johnston, Austrijski duh. Intelektualna i društvena povijest 1848-1938., Zagreb 1993., 189.

44 Usp. Dragutin Tadijanović, Knjiga o hrvatskim piscima. Članci, feljtoni, bilješke, Zagreb 1995.

45 Paul Roazen, Encountering Freud. The Politics and Histories of Psychoanalysis, New York 2017.

46 Vedran Ivanković, Le Corbusier i hrvatska škola arhitekture, Zagreb 2016., 37-52.

47 Usp. „Tod eines kroatischen Malers in Paris“, Agramer Zeitung (Zagreb), br. 158, 25. 6. 1908., 6; „Josip Račić", Obzor (Zagreb), br. 177, 28. 6. 1908., 1.
} 
priču da je Račić ubijen na ulici „sifonskom flašom“ “ ${ }^{48}$ Govorilo se o postojanju nesretnih ljubavnih okolnosti i „fatalnim“ ženama, bolesti, ali i oskudici i teškim prilikama u kojima se slikar našao, računajući na potpore i bolje prodaje, kojih nije bilo. ${ }^{49}$ Vladimir Jurčić navodi kako je Račića ustvari okolina osudila na smrt odbijajući uzdržati njegovo „školovanje“, a tek nakon smrti ga je počela cijeniti. ${ }^{50}$ Nasta Rojc (1883. - 1964.), koja je zajedno s Kraljevićem i Račićem boravila u Münchenu, zaključila je da je potonji samoubojstvo počinio „,iz razočaranja radi smjera koji je uzela umjetnost upravo u doba njegovog umjetničkog razvitka, a koji nije odgovarao jakoj individualnosti njegove poštene slavenske duše“.51 Miroslav Krleža slučaj je detaljnije analizirao dva desetljeća kasnije u svom „angažiranom“ eseju. Pritom je ukazao na iskaze, dokumente (pisma) te tvrdnje (također u pismu) koje je iznio slikar Vladimir Becić (1886. - 1957.). Prema Beciću, Račić je samoubojstvo u Parizu počinio nakon što je, boreći se od samog početka karijere za preživljavanje i priznanje, Društvo umjetnosti odbilo otkup njegovih radova. ${ }^{52}$ Iako se Krleža ne priklanja tom mišljenju, sâm ukazuje na teško razdoblje za hrvatske talente, koji pod vladavinom „illustrissimusa Kršnjavog“, tijekom „devastacij““ hrvatske baštine i u vrijeme „konfuzno, prazno i žalosno“, bježe iz „provincije i krčme“. On ističe Račićev karakter, koji je, prema njemu, nepobitno težio napretku te ukazuje na činjenicu da je i u Parizu bio suočen $s$ nerazmjerno razvijenijom slikarskom praksom i životom u „krčmi“ iz koje potječe i na koju je na određen način osuđen. ${ }^{53}$ Krleža se pritom i pita je li samoubojstvo također moguće i uslijed „[d]epresije erotičke naravi“, „[h]irovitost[i] puberteta“, „,veneričke zaraze“, 54 što dovoljno govori o postojanju određenog obrasca samoubojstava mladih intelektualaca i umjetnika, koji je Krleža prepoznao. Međutim, on se ne zadovoljava jednostavnošću općeg mjesta i partikularnošću Becićeva objašnjenja. Zanima ga odnos psihoprofila umjetnika i njegove okoline, prostorni prijelomi koji izazivaju dubok unutarnji nemir, koji spoznaju istovremenosti neistovremenog - u ovom slučaju umjetničkog zaostajanja - čine teško podnošljivom.

Razdoblje političke radikalizacije od kasnih 1920-ih godina - naročito od atentata u Narodnoj skupštini 1928. godine i proglašenja diktature - uvodi i u Hrvatsku, ponovno, kao i u periodu političke radikalizacije pred kraj Habsburške Monarhije, samoubojstvo kao izraz političkog protesta, očaja ili otpora. Mladi splitski pisac Miljenko Bukarica-Ivanović (1906. - 1925.) već je 1924. godine, nakon sudjelovanja na demonstracijama, ogorčen, „namučen nesretnim ljubavima i neizraženim željama", u Splitu počinio samoubojstvo..$^{55}$ Ivo Pilar (1874. - 1933.), koji je na prijelazu stoljeća zagovarao „mlade“ i zalagao se za secesiju - pa ga se i nazivalo „ideologom moderne“56 - pod nerazjašnjenim je okolnostima, prema

\footnotetext{
48 Miroslav Krleža, Račić, Zagreb 1947., 18.

49 Usp. Josip Rus (ur.), Josip Račić. Retrospektiva. Zagreb 1885. - Pariz 1908., Zagreb 2008., 50-54; Igor Zidić, Josip Račić 1885-1908, Zagreb 2009., 111-112.

50 Vladimir Jurčić, Kako su umirali hrvatski književnici i umjetnici, Zagreb 2006., 121-123.

51 Nasta Rojc, „U duševnom svijetu jedne umjetnice“, Ženski list (Zagreb), br. 4, 1. 4. 1935., 25.

52 M. KrležA, Račić, 7-10.

53 Isto, 20-27.

54 Isto, 20.

55 Bogdan Radica, Hrvatska 1945, München - Barcelona 1974., 181.

56 Josip Horvat, Hrvatski panoptikum, Zagreb 1964., 204. O Pilarovu naprednjaštvu usp. Stjepan Matković, „Ivo Pilar i naprednjaštvo", Pilar. Časopis za društvene i humanističke studije, 8/2013., br. 15-16, 69-112.
} 
službenoj verziji, počinio samoubojstvo..$^{57}$ Postaje to praksa kojom će se i kasnije političko nasilje različitih režima prikrivati, pretpostavljajući da će protivnik koji je počinio samoubojstvo u očima javnosti u konačnici biti ponižen, da će se raditi o znaku slabosti ili bolesti - računajući, dakle, na sve implikacije puštanja u javnost vijesti o samoubojstvu.

\section{INTELEKTUALAC/UMJETNiK I SAMOUBOJSTVO: DRUŠTVENO-INTELEKTUALNI KONTEKST}

Samoubojstvo u društvenom smislu oko 1900. godine ne postaje samo masovan fenomen, već se kao tema i pojava povezuje s intelektualcima. Siromaštvo je obilježje jednog dijela hrvatske inteligencije od 19. pa sve do polovine 20. stoljeća. Živeći najčešće u lošim uvjetima i bez stalnih prihoda, od tuberkuloze boluje nezanemariv broj književnika i umjetnika još u međuraću..$^{58}$ Iako se u drugoj polovini 19. stoljeća javljaju sve učestalije organizirani sustavi potpomaganja i stipendiranja mladih umjetnika-intelektualaca, koji se time koriste za svoje stručno usavršavanje, radi se tek o relativno malom broju koji se može smatrati elitom. Podupirani od strane Zemaljske vlade ili istaknutih pojedinaca, odlaze u razne europske zemlje kako bi napredovali te svoje znanje primijenili pri povratku u domovinu. Na prijelazu stoljeća takav oblik potpore dodatno opada, odnosno veći broj intelektualaca ostaje nezahvaćen sustavom, što zbog političkih prijeloma u Trojednoj Kraljevini, promjena na političkoj sceni, što zbog novih strujanja među mladom inteligencijom. Prkos prema statusu quo, ne samo u Hrvatskoj i Slavoniji nego i u čitavoj Habsburškoj Monarhiji, neke je intelektualce-umjetnike poticao na potragu za novim političkim rješenjima, nastojanjima za ostvarenjem slobode stvaralaštva koje je usmjereno prema južnoslavenskom prostoru i imaginariju, odbacujući postupno Austro-Ugarsku Monarhiju kao okvir (ali ne i Beč kao bitno kulturno-znanstveno središte modernističkih tendencija!). Druge je, pak, poticao na apatiju prema političkim prilikama, okretanje u velikoj mjeri prema nepolitičkim problemima i motivima. Književnik Vladimir Jurčić (1910. - 1945.) 1930-ih godina piše o tragediji hrvatskih pisaca i umjetnika, navodeći okolinu koja „ne shvaća ni književnosti, ni umjetnosti“, no takva je ocjena tek djelomično točna. ${ }^{59}$ Prihvati li se teza američkog povjesničara Petera Gayja o utjecajnom Charlesu Baudelaireu (1821. - 1867.) kao svojevrsnoj arhetipskoj figuri moderne općenito, gledajući na njega kao na usamljenog, avangardnog umjetnika koji je u Parizu pronašao svoju „umjetničku galeriju“ - tražeći modernost uglavnom u subjektivnom, prolaznom, fluidnom, trenutačnom ili slučajnom - moguće je doći i do zaključka da su nositelji moderne sebi kao cilj postavili kulturnu misiju, koja je stremila istraživanju svijesti i duše, a nadasve slobode. $U$ vezi s time pronalazimo i duboko ukorijenjene intelektualne i mentalne predispozicije za neuspjeh, razočaranje, rezignaciju ili čak

\footnotetext{
57 O okolnostima smrti Ive Pilara usp. Željko Holjevac, „Problem Pilarove smrti“, Prinosi za proučavanje života i djela dra. Ive Pilara, 1/2001., br. 1, 233-238.

58 V. Jurčıć, Kako su umirali hrvatski književnici i umjetnici, 35-36.

59 Isto, 173.
} 
samoubojstvo ${ }^{60}$ Kulturna misija modernista često nije bila miroljubiva jer se sloboda, kao i perspektiva, trebala izboriti; agresivnost i radikalnost, koje će neke kasnije odvesti u ekstreme, implicirale su i borben životni stav, odbijanje ustaljenih obrazaca, a time i znatno neizvjesniji životni put.

Drugačiji društveni kontekst oko 1900. godine višestruko utječe na povećanje samoubojstava. Mladi intelektualci i umjetnici brže su i jednostavnije nego prije mogli doći u kontakt $s$ avangardnim i novim idejama. Na unutarnje duševno stanje intelektualacaumjetnika odražavali su se njihovi prijelazi, iskustva, radikalne prakse, koje su često bile u neskladu s mogućnostima na raspolaganju. Potom dodiri sa stranim civilizacijskim obrascima, s problemom identiteta ili njegova gubitka oko 1900. te na kraju s problemom individualnosti, koji povjesničar Andreas Bähr - slijedeći vodeće društvene teoretičare razdoblja - razmatra unutar odnosa altruizma i egoizma te heteronomije i autonomije kao ključnim pojmovima. ${ }^{61}$ Raskorak i razlike između hrvatske realnosti i velikih europskih središta, shvaćeni kroz tendenciju za radikalnom modernizacijom koja je besmislena u kulturi što se ne može ili ne želi modernizirati itekako su utjecali na najosjetljivije. Potom su se promjene u načinu života odražavale na mlade ljude koji za takav novi i izmijenjen ritam često nisu bili spremni, iako su u intelektualnom smislu mogli prihvatiti „kulturnu razinu“ modernizma, koja podrazumijeva „difuziju sekulariziranih i racionalističkih normi i vrijednosti“. Dakako, na individualiziranoj razini, koja je značila povećanje osobne produktivnosti, pokretljivosti i neovisnosti. ${ }^{62}$ Aspekti procesa sekularizacije i urbanizacije, koji su na prijelazu stoljeća ubrzanije zahvaćali važnije hrvatske gradove - mjesta djelovanja i življenja hrvatske inteligencije - odražavali su se tako i negativno, stvarajući dominantno podneblje „nervoznoga doba“, vremena neurastenije koja se na različite načine manifestirala na većem dijelu gradskog stanovništva. ${ }^{63}$

Američki povjesničar William M. Johnston istaknuo je kako u razdoblju između 1860. i 1938. godine drastično rastao broj austrijskih intelektualaca koji su počinili samoubojstvo, dok je u mađarskih intelektualaca to bila rjeđa pojava, što objašnjava manjim intenzitetom političkog djelovanja ili involviranosti. ${ }^{64}$ Ipak, još prije raspada Austro-Ugarske pa sve do međuraća život su si oduzeli, primjerice, pravnik Felix Somló, pjesnici Attila Jószef i Gyula Juhász, pisac Jenő Péterfy te slikari Kálmán Mesterházy, Ferenc Szikszay, Sándor Galimberti te Dezsö Czigány, koji je u stanju mentalne pomućenosti ubio i svoju obitelj. Broj samoubojstava među češkim intelektualcima bio je također razmjerno velik: slikari Antonín Slavíček (1870. - 1910.) i Miloš Jiránek (1875. - 1911.) te kipar Jan Štursa (1880. - 1925.) bili su neki od njih.

Takav se trend u mlađih intelektualaca i umjetnika nepobitno veže is s,impresionističkim kultom prolaznosti“ - kako ga definira Johnston ${ }^{65}$ - u psihološkom smislu snažno

60 Peter GaY, Die Modern. Eine Geschichte des Aufbruchs, Frankfurt am Main 2008., 55-74.

61 Andreas BäHR, „Zur Einführung: Selbsttötung und (Geschichts-)Wissenschaft“, Sterben von eigener Hand. Selbsttötung als kulturelle Praxis (ur. Andreas Bähr i Hans Medick), Wien - Köln - Weimar 2005., 12-13.

62 Rade Kalanj, Modernost i napredak. Studija, Zagreb 1994., 108-109.

63 Ursula Baumann, „Selbsttötung und die moralische Krise der Moderne“, Sterben von eigener Hand, 115-116.

64 W. M. Johnson, Austrijski duh, 184-185.

65 Isto, 189-190. 
prisutnim među prvim generacijama modernista. On je povezan sa specifičnim shvaćanjem vremena koje je počivalo na dihotomiji želje za iskorakom u svijetu umjetnosti i strahom od novog vremena, koje je mijenjalo svakodnevni život u tehnološkom smislu. $\mathrm{Na}$ to se nadovezuje i određena naivnost i neiskustvo mladih modernista, koji su strastveno vjerovali u svoje stavove i svoja djela, nastojeći živjeti punim plućima, iako njihove djelatnosti nisu mogle pružati stalnu financijsku podlogu za uredan život. Neke je strast na kraju vodila prema naprasnom skončanju. Sasvim je sigurno bečki kontekst „vedre apokalipse“, bijeg intelektualaca od politike prema kulturi, koja je unatoč tome (ili baš radi toga) dodatno politizirana, tome također pridonosio. Filozofija i psihologija, u intelektualnim debatama jednako sveprisutne i u političkim, kao i u pitanjima estetike, umjetničke kritike, umjetničkog stvaralaštva i umjetnosti općenito, dodatno uvode različite teme smrti, smrtnosti i umiranja u jezik umjetnosti. Ta intelektualna „očaranost smrću“ neobično povezuje znanost i umjetnost, dodirujući, povezujući, ispreplećući tmurne psihologizirajuće dijagnoze stanja države, grada (Beča), društva, kulture - pa sve do mentalnog stanja pojedinca. ${ }^{66}$ Suprotno tome, uz stanje u društvu u Budimpešti ili Zagrebu na prijelazu stoljeća, s jednakom mjerom psihologiziranja, može se dijagnosticirati drugačije vrste oboljenja: politički angažman, sve jače izraženu povezanost nacionalnog pitanja i kulture, traženja autohtonih puteva prema modernom društvu, koje je sve manje određeno njemačkim posredstvom, a sve više ambivalentno - internacionalizirano po svojim uzorima, a nacionalno po obzorjima.

No, Johnston iznosi i glavne povode samoubojstava: trajna bol ili neizlječiva bolest, zatim samoubojstva potaknuta ili povezana s nacističkim progonima, kao i osjećaji, „sukob unutarnjih uvjerenja i vanjskih okolnosti“, što obuhvaća razne situacije, od ljubavnih tegoba do krhkosti javno neshvaćenih umjetničkih osjećaja. Pritom se vrlo često radi baš o mladim osobama, poput Otta Weiningera (1880. - 1903.) ili Georga Trakla (1887. - 1914.). ${ }^{67}$ Kako pokazuje slučaj Kálmána Mesterházyja - koji je samoubojstvo počinio u neposrednoj blizini supruge Klare, barunice Pongracz, s kojom je imao zategnute odnose - životni stil u brojnih umjetnika značio je isprepletanje privatnog i javnog, umjetnosti, posla, strasti i ljubavi. Želja mladih muškaraca-umjetnika da dokažu svoju dominaciju nad ženama, koje su u tim intelektualnim krugovima često slovile kao fatalne - poput Alme Mahler (1879. 1964.), Lou Andreas-Salomé (1861. - 1937.) ili čak zagrebačke Ljerke Šram (1874. - 1913.), koja je svojom pojavom opčinjavala Matoša, Dežmana i druge - odražavala se na njihovo stvaralaštvo, kao u prikazu „ranjivih“ muškaraca u Gustava Klimta. ${ }^{68}$ Štoviše, određujući na različite načine vlastito stvaralaštvo u odnosu na svoje muze-intelektualke, ponekad je neraskidivo izbrisana granica između privatnog i javnog, između različitih strasti, između shvaćanja života i nužnosti njegova naprasnog prekida.

\footnotetext{
66 Isto, 175-190; Filip ŠIMETIN Š EGviĆ, „Kultura smrti u Zagrebu. Društvo prijatelja za podizanje krematorija Plamen“, Historijski zbornik, 68/2016., br. 2, 298-304.

67 W. M. Johnson, Austrijski duh, 184-190. Usp. također: J. C. NyírI, „Philosophy and Suicide-statistics in AustriaHungary“, 291-316.

68 Usp. Julie M. Johnson, The Memory Factory. The Forgotten Women Artists of Vienna 1900, West Lafayette 2013., 147-148; Desmond Manderson, „Klimt's Jurisprudence - Sovereign Violence and the Rule of Law“, Oxford Journal of Legal Studies, 35/2015., br. 3, 515-542.
} 
Iako se trend rasta broja samoubojstava od druge polovine 19. stoljeća preklapa s praksom ubijanja istaknutih umjetnika i intelektualaca, ipak je njihov i društveni kontekst motivacija bitno različit. Među poznatijim pojedincima koji su si oduzeli život između 1850. godine i 1900. godine prednjače oni koji su to učinili jer su bili teško bolesni ili podnosili teške bolove, poput Adalberta Stiftera (1868.), Ferdinanda von Saara (1906.), Ludwiga Boltzmanna (1906.), Ludwiga Gumplowicza (1909.) ili onih koji su zbog vlastitog perfekcionizma radili do iznemoglosti ili si oduzeli život nezadovoljni svojim djelom, poput Moriza Thausinga (1884.), Eduarda van der Nülla ili Jenöa Péterfyja, koji se ubio u Karlovcu 1899. godine. Međutim, oko 1900. godine među mlađim se generacijama umjetnika i intelektualaca javljaju nove, posve drugačije motivacije za samoubojstvo. Velik ih se broj na taj

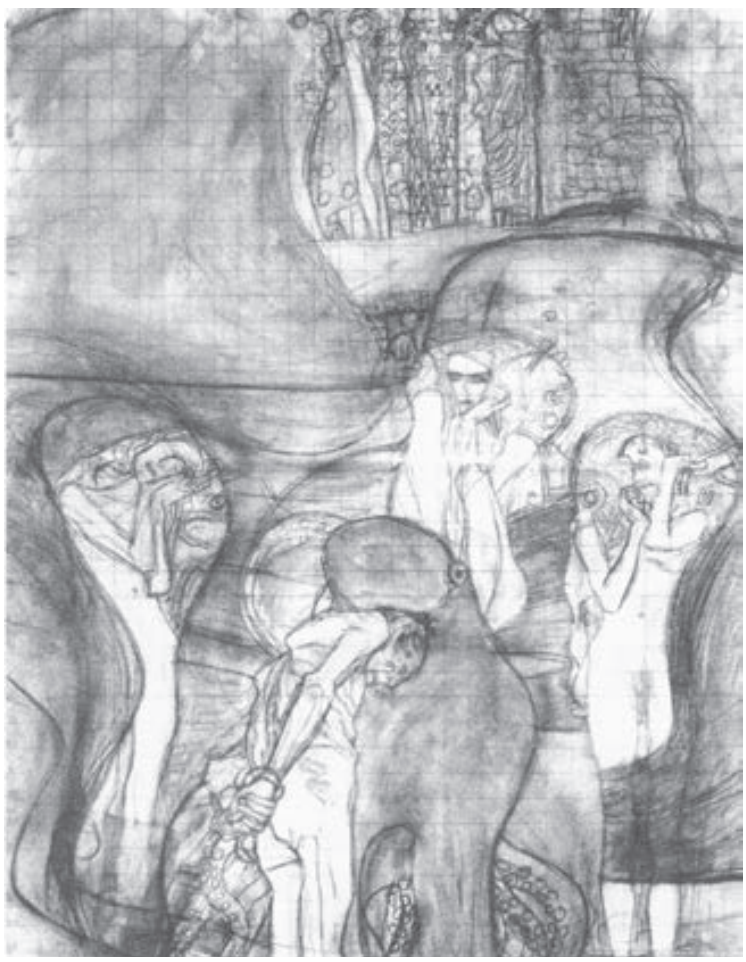

Sl. 2. Gustav Klimt, studija za alegorijsku sliku Jurisprudencija u Svečanoj sali Sveučilišta u Beču (1898.) čin odlučuje iz osjećaja neshvaćenosti, ignoriranog talenta, neurednih životnih navika ili razočaranosti. Depresivan i bolestan Georg Trakl umire u bolnici u blizini Krakova 1914. godine od kombinacije alkohola i kokaina, nekoliko sati prije negoli je njegov prijatelj Ludwig Wittgenstein stigao u bolnicu kako bi ga posjetio. Richard Gerstl (1883. - 1908.) počinio je samoubojstvo jer je smatrao da bečko društvo ne prihvaća i ne cijeni njegov rad. Alban Berg (1885. - 1935.) pokušao se je 1903. godine ubiti zbog nezadovoljstva svojim rezultatima na maturi iz njemačkog - jer je izvorno težio postati književnikom. Treba također napomenuti da je u užim obiteljskim krugovima Mahlera, Schnitzlera, Macha i drugih zabilježeno nekoliko samoubojstava. ${ }^{69}$

Takva učestalost može se u odnosu na modernističke intelektualce objasniti iz različitih perspektiva. Prvo, tu je već spomenuti kontekst bečke opsjednutosti smrću. To bi barem djelomično objasnilo činjenicu da se najviše samoubojstava među umjetnicima dogodilo upravo u Beču, dok se, primjerice, mađarski intelektualci mnogo rjeđe odlučuju na taj čin. Osim toga, treba istaknuti veličinu Beča, koji oko 1900. predstavlja kulturni velegrad europskih razmjera, u kojem osim visokih društvenih standarda i najrazličitijih oblika društvene dekadencije, postoji strašna kompetitivnost. Ukazuje na to i nadasve ironičan, ako ne i neukusan komentar Sigmunda Freuda, koji je posao na Odjelu za neurologiju u Beču dobio uslijed ne-

69 W. M. Johnson, Austrijski duh, 186-187. 
očekivanog samoubojstva doktora Nathana Weissa (1851. - 1883.) na javnome mjestu, što je Freud svojoj zaručnici ukratko objasnio srećom u nesreći Weissa, koji se objesio zbog židovske samomržnje. ${ }^{70}$ Međutim, i u Zagrebu i u drugim hrvatskim urbanim središtima bilježe se slične pojave oko 1900. godine i u međuratnom razdoblju. Stoga je potrebno pogledati dublje u same temelje modernističkog pokreta i modernizma, na rubu psihohistorije Petera Gayja i drugih. Naime, u samoj srži nalazi se i radikalizam, strast i neobuzdanost - riječima Viktora Žmegača - naročito u odnosu na tradiciju, od koje se željelo često agresivno i radikalno odmaknuti.

\section{Senzibilitet i samoubojstvo}

Ipak, „vedra apokalipsa“ nije u smislu modernističkih logika, pristupa i shvaćanja intelektualnog i umjetničkog djelovanja jedini fenomen koji je utjecao na percepcije smrti. Viktorijanske (i edvardijanske) intelektualce smrt dugo fascinira, ${ }^{71}$ dok francuska belle époque također stvara odnos prema smrti i samoubojstvu, uvodeći najrazličitije, čak bizarne i morbidne pristupe temama. ${ }^{72}$ Neke su novije studije pokazale da iako samoubojstvo u književnosti najčešće veže pojmove otuđenosti i osamljenosti, upravo procesi urbanizacije i stvaranja urbanih masa društva na prijelazu stoljeća također pogubno utječu na psihu intelektualaca. ${ }^{73}$ Javnost i goleme gradske mase, s kojima se intelektualci i umjetnici susreću predstavljajući svoj rad ili proučavajući ih kao fenomene, pojačavaju dvojako iskustvo. $S$ jedne strane, tim se fenomenima - potaknuti modernističkim nastojanjima za povećanjem svijesti o higijeni, čistoći i zdravlju - pristupa kao negativnim pojavama „onečišćenja“ $\mathrm{i}$,infekcije“ kroz mase, izazivajući osjećaje duboke anksioznosti i mentalne uznemirenosti. Edvard Munch (1863. - 1944.) i Frans Masereel (1889. - 1972.) u svojim slikama grad prikazuju kao pozadinu uznemirujućih emocija, bolesti, straha i smrti. ${ }^{74} \mathrm{~S}$ druge strane, modernistička se introspekcija umjetnikova samouništenja (smrti) kao integralnog dijela njegova djelovanja povezuje s vrlo često destruktivnim načinom života i prekomjernim „iskustvenim“ uživanjem različitih poroka. ${ }^{75}$ Iako se na prvi pogled može učiniti da se radi i o oprečnim pristupima, zajedničko im je to da u modernističkog mislioca ili umjetnika izazivaju duboku krizu identiteta (nacionalnog, vjerskog, vlastitog), kako je pokazao niz autora koji su se bavili problemom modernizma i kulturom na prijelazu stoljeća. Tako su nezaobilazna mjesta u gradovima bile kavane, u kojima se, između osta-

\footnotetext{
70 Isto, 186.

71 Usp. John Morley, Death, Heaven, and the Victorians, Pittsburgh 1971.; James Curl, The Victorian Celebration of Death, Detroit 1972.; Michael Wheeler, Heaven, Hell, and the Victorians, Cambridge 1994.; Patricia Jalland, Death in the Victorian Family, New York 1996.; Julie-Marie Strange, Death, Grief and Poverty in Britain, 1870-1914, Cambridge 2005. O temi samoubojstva usp. Olive Anderson, Suicide in Victorian and Edwardian England, Oxford 1987.; D. Cannadine, „Tajna kuća smrti“, 215-222.

72 Usp. Thomas A. Kselman, Death and the Afterlife in Modern France, Princeton - New Jersey 1993.

73 Katherine Lynn Ryan, Modernism's Suicidal Impulse: Psychic Contamination and the Crowd, doktorska disertacija, University of California, Irvine 2014.

74 Ron M. Brown, Art of Suicide, London 2001., 199.

75 K. L. Ryan, Modernism's Suicidal Impulse, 3-8.
} 
lih, okupljala raznolika skupina umjetnika, ali i onih koji su to tek namjeravali postati. Kavane su, s jedne strane, bile mjesto razgovora, izmjene iskustava, druženja, ali su mogle predstavljati i mjesto otuđenosti, usamljenosti - ovisno o trenutku i osjećajima pojedinca, o čemu su brojni polaznici i pripadnici tog miljea neumorno i pisali. ${ }^{76}$ Anksioznost, nestanak moralnih i društvenih granica, gubitak identiteta u gradskom svijetu - koji je Max Weber nazvao „čeličnom krletkom“ modernog društva, a za koji je Durkheim ustanovio da utječe na porast suicida - u nekim su slučajevima intelektualce vodili prema samouništavajućem oslobođenju: samoubojstvu. Naročito neuravnoteženost, društvena izloženost $s$ jedne i mentalna izolacija s druge strane - o kojoj će pisati Maurice Halbwachs, razilazeći se s Durkheimom ${ }^{77}$ - vodila je pojedince do dubinskih emotivnih kriza, osjećaja boli i neshvaćenosti. Tome se dodaje i konzistentna, a u međuratnom razdoblju sve jače izražena potreba za opiranjem, prkošenjem te odbijanjem najrazličitijih poredaka. Naime, kako ističe povjesničar Ron M. Brown za 20. stoljeće, „samoubojstvo je postalo umjetnost, a umjetnost samoubojstvo": modernističke tendencije shvaćanja umjetnosti kao nečega što ne imitira ili reprezentira život, već u esenciji jest sâm život proširile su se u tolikoj mjeri da je „umjetnost krenula u rat protiv umjetnosti“, dopuštajući, odobravajući ili čak priželjkujući (samo)uništenje. ${ }^{78}$

Dvije kazališne glumice, Irma Trputec-Terée (1842. - 1907.) i Gemma Boić (1883. 1914.), otvaraju pitanje umjetničkog senzibiliteta, odnosno njegova nedostatka prema umjetnicima. Prva je u svibnju 1907. počinila samoubojstvo u stanju teškog duševnog nemira, osjećaja proganjanja i ludila, bacivši se kroz prozor svojeg stana u Beču. I dok okolnosti pod kojima je to ludilo nastupilo u Irme Trputec nisu razjašnjene, životni put Gemme Boić daje mnogo jasniji odgovor. Njemački dramaturg i novinar Ernst Leopold Stahl (1882. - 1949.), pišući o njoj, ustvrdio je kako je živjela skromno i štedljivo pa oskudica nikako nije razlog samoubojstva, već se na taj čin odlučila ,jedino i isključivo iz umjetničke nužde“ ${ }^{79} \mathrm{U}$ stanju potpune financijske i profesionalne neizvjesnosti, Boić se nakon lošeg odnosa i prekida rada u bečkom Volkstheateru ubila otrovom. Bečki tisak pisao je u nekrolozima o njezinu talentu i razlozima smrti koji su varirali, od općih formulacija pa sve do vrlo usmjerenih kritika o moralnoj odgovornosti u odnosu na mlade umjetnike, njihovo razvijanje i karijere. ${ }^{80}$

Mladi, svestrani i talentirani povjesničar Janko Koharić (1877. - 1905.) pripada aktivnoj skupini modernistički orijentirane, naprednjačke mladeži. Prije svega, Koharić se isticao kao svojevrstan „hrvatski Lamprecht“ progresivnim i provokativnim zamislima o razvoju historiografije. ${ }^{81}$ Svoje zamisli nije imao vremena ispuniti i provesti u praktičnu primje-

\footnotetext{
$\overline{76}$ Usp. ključno djelo o zagrebačkim kavanama: Ines SАвотіс̌, Stare zagrebačke kavane i krčme s kraja 19. i početka 20. stoljeća, Zagreb 2007.

77 Usp. Maurice Halbwachs, Les causes du suicide, Paris 1930.

78 R. M. Brown, Art of Suicide, 195.

79 Ernst Leopold Stahl, Gemma Boić. Uspomeni na umjetnicu, Zagreb 2003., 7.

80 Isto, 78-89.

81 Tekstove o historiografiji Koharić izvorno objavljuje u Svjetlu 1900. godine. Zanimljivo je na ovome mjestu istaknuti i ocjenu Izidora Kršnjavog, koji je u nekrologu Kohariću izrazio skepsu prema njegovu historiografskom radu i naveo da se počeo usmjeravati prema geografiji, konstatirajući da je „,z]a historičara Koharić premalo temeljit a prepun fantazije“. Izidor KRŠNJAVI, „O Janku Kohariću“, Narodne novine (Zagreb), br. 45, 24. 2. 1905., 1.
} 
nu, ${ }^{82}$ iako je planirao upravo na temelju njih objaviti širu metodološku raspravu o pristupu i shvaćanju hrvatskog srednjeg vijeka. ${ }^{83}$ No, bio je aktivan i na političkom planu, pisao je kritike i pjesme, a na poticaj Nikole Andrića upustio se je u pisanje tragedije koja će ostati nezavršena.$^{84}$ Unatoč skromnim financijskim mogućnostima, neumorno je radio na sebi. Nakon završenog studija povijesti i zemljopisa na Zagrebačkom sveučilištu, položio je profesorske klauzure u Zagrebu i Beču. Predavao je u gimnazijama u Splitu i Dubrovniku, a podršku su mu davali Natko Nodilo i don Frane Bulić. ${ }^{85}$ Godine 1904. Koharić se i oženio, dalje je radio na svojoj karijeri, ali je patio od sušice; u veljači 1905. počinio je samoubojstvo u Dubrovniku, na gruškoj obali, bacivši se s klisure u more. Iza sebe ostavio je ručni sat, šešir i bilježnicu, u kojoj kao razlog navodi „veliku nervoznost i sušicu“. ${ }^{86}$

Slučaj samoubojstva također mladog i talentiranog arhitekta Josipa Pičmana (1904. 1936.) govori o senzibilitetu mladih intelektualaca. Interesantno, tisak spominje i oproštajnu poruku, upućenu arhitektovoj majci („Mama, tako će biti bolje“), što se u dotadašnjim novinskim izvještajima o samoubojstvima poznatijih intelektualaca često izostavljalo. Novosti spominju „Živčanu bolest“ koja arhitekta prati već neko vrijeme. ${ }^{87}$ Jedan kasniji tekst govori o krhkosti mladog talenta, hvaleći Pičmana kao ,jednog od najsposobnijih mladih arhitekata“ koji je dobio priznanja, ali su njegova „osjetljiva priroda“ $i$ „čestitost“ utjecale na to da "teže podnosi krutost dnevnog života“ ${ }^{88}$ No, zanemaruje se dublja analiza činjenice da se mladi arhitekt prijavljivao na brojne natječaje i na njima postizao respektabilne rezultate ili dobivao projekte, ali mu je rad zbog koruptivnosti sustava i investitora bio ograničen, odnosno onemogućen. Ukliješten između talenta i stvaralačke želje te situacije koja se nije činila obećavajućom, Pičman je u veljači 1936. počinio samoubojstvo bacivši se s četvrtog kata zgrade u Ilici broj $17 .{ }^{89}$ Dan kasnije bilo je obznanjeno da je skupa s Josipom Seisselom dobio odobrenje za gradnju Narodnog doma Sušak, za projekt oko kojeg se već neko vrijeme - navodno iz financijskih razloga, a vrlo vjerojatno zbog lokalne korupcije nadvijao znak upitnika. I na sprovodu su govori donekle zrcalili ono što su već naglašavali novinski natpisi. Arhitekt Edo Šen (Schön, 1877. - 1949.) nazvao je Pičmana najvećim modernističkim talentom hrvatske arhitekture nakon Viktora Kovačića. Petar Senjanović (1876. - 1955.) hvalio je Pičmana kao osobu, njegovu plemenitost, umjetničku individualnost, posvećenost radu, ističući kako ipak nije mogao podnijeti „gorčinu i težinu“ koju je posao donosio, ${ }^{90}$ podcrtavajući tako još jednom model mladog intelektualca-umjetnika

\footnotetext{
82 Usp. Mario Strecha, „O nastanku i razvoju moderne hrvatske historiografije u 19. stoljeću“, Povijest u nastavi, 3/2005., br. 6, 115 .

83 „Janko Koharić“, Pokret (Zagreb), br. 8, 19. 2. 1905., 1.

84 Isto. O Koharićevu životu i djelovanju usp. Ljerka Rackо, „Janko Koharić (prilog poznavanju njegova znanstvenog i publicističkog rada)“, Historijski zbornik, 31-32/1978. - 1979., 253-269.

85 „Janko Koharić“, Pokret (Zagreb), br. 8, 19. 2. 1905., 1.

86 Nikola ANDrić, „U spomen neznana dramatičara“, Narodne novine (Zagreb), br. 38, 16. 2. $1905 ., 1$.

87 „Tragedija inženjera Josipa Pičmana“, Novosti (Zagreb), br. 39, 8. 2. 1936., 9.

88 „Tragična smrt inženjera Josipa Pičmana“, Novosti (Zagreb), br. 40, 9. 2. 1936., 6.

89 Neven ŠEgvić, „Arhitektonska 'moderna' u Hrvatskoj“, Republika, 8/1952., br. 3, 184; Tomislav PremerL, Hrvatska moderna arhitektura izmedu dva rata, Zagreb 2015., 74-77.
}

90 „Tragedija arhitekta Pičmana. Josip Pičman naš najblistaviji talenat u arhitekturi“, Novosti (Zagreb), br. 41 , 10. 2. 1936., 5 . 
koji je talentiran, ali u osjećajnom i fizičkom smislu nespreman za uvjete i vrijeme u kojem stvara. I kasniji stručnjaci Pičmanovu će sudbinu uzeti kao primjer međuratne dekadencije, nazivajući je "tragedija cijele generacije stvaralaca“.91

\section{Ludilo I SAMOUBojSTVO}

Modernistički odnos društvo - pojedinac obilježen je i fenomenom ludila intelektualaca. U gradu dodir sa suvremenim tehnologijama dodatno je u intelektualaca pospješio potrebu da iznova promišlja o organizaciji života, ulozi i zadacima čovjeka, značenju, identitetu pojedinca - pritom nerijetko izazivajući i psihozu. ${ }^{92}$ Razmišljanja o smrti i samoubojstvu vodila su ih u iskustveno razotkrivanje povezano s njihovom profesijom, ali i prema psihijatriji. Na opterećujuće misli i iskustva društvo je reagiralo suviše nepredvidivo, a u medicinskom smislu liječnici opće prakse uputili su ih prema psihijatrijskim stručnjacima u klinikama..$^{93}$ Na primjeru Beča oko 1900. godine može se dobro promatrati kako su različiti društveni „krugovi“ $\mathrm{i}$ intelektualne „klike“ snažno utjecali jedni na druge, stvarajući male individualizirane centre moći, koji su mladim talentima, ali i etabliranim pojedincima mogli „stvoriti“ karijeru ili je uništiti. Pojedinac je često bio izložen psihološkim pritiscima ili neobičnim ritualima koji su ga i fizički i psihički iscrpljivali. Osim toga, umjetnici su često svoje bizarne ideje ostvarivali unutar etabliranijih krugova gradskih intelektualnih elita, poput prijateljstava Egona Schielea s nekolicinom uglednih bečkih liječnika, koji su mu omogućili pristup bečkoj Ženskoj klinici ili čak psihijatrijskoj bolnici Steinhof. Njegovi groteskni portreti i autoportreti prenose, ustvari, mnogo vjernije nego što bi se moglo pretpostaviti, osjećaje i umno stanje pacijenata u umobolnicama te vlastitu tjelesno-umnu percepciju, istražujući ludilo kao nešto što je blisko, prisutno, svakodnevno. ${ }^{94}$

„Živčane tegobe“ o kojima govore mnogi bečki intelektualci, još prije negoli su Freud i njegov krug počeli o tome govoriti javno, također ukazuju na vezu između novih načina življenja i shvaćanja sebe. ${ }^{95}$ Činjenica da je bolest neurastenije - proizašla iz čitavog niza drugih „živčanih poremećaja“ 18 . stoljeća ${ }^{96}$ - bila europska realnost još od kasnog 19. stoljeća pa sve do međuraća i da se često povezivala sa sličnim slučajevima samoubojstava, otvara ovaj problem prema daljnjim istraživanjima iz perspektive psihohistorije i povijesti medicine. Američki psiholog Louis A. Sass upozorava na povezanost modernističkih ten-

91 T. Premerl, Hrvatska moderna arhitektura, 74. Usp. „Tragična smrt inženjera Josipa Pičmana“, Novosti (Zagreb), br. 40, 9. 2. 1936., 6.

92 O povezanosti ranog i kasnog modernizma, „mehanizaciji uma“ i ludilu usp. Andrew GaEdTKe, Modernism and the Machinery of Madness, New York 2017.

93 D. Cannadine, „Tajna kuća smrti“, 220.

94 Gemma Blackshaw, „The Pathological Body: Modernist Strategising in Egon Schiele’s Self-Portaiture“, Oxford Art Journal, 30/2007., br. 3, 377-401. Usp. također: Alessandra Comini, Egon Schiele's Portraits, Berkeley 1974.

95 Jacques Le Rider, Modernity and Crises of Identity. Culture and Society in Fin-de-siècle Vienna, New York 1993., 38-39.

96 Usp. o tome: Roy Porter, „Nervousness, Eighteenth and Nineteenth Century Style: From Luxury to Labour“, Cultures of Neurasthenia from Beard to the First World War (ur. Marijke Gijswijt-Hofstra i Roy Porter), Amsterdam - New York 2001., 31-50. 
dencija i ludila (specifično shizofrenije), povezujući upravo zajedničke tendencije prema hiperrefleksivnosti i alijenaciji. Sass odlazi i korak dalje pa iskustvo shizofrenije povezuje s nekim ključnim elementima i aspektima modernizma, poput samog senzibiliteta modernističkih umjetnika, unutarnje potrebe za prkošenjem raznim autoritetima, tendencija $\mathrm{k}$ multiperspektivnosti, ironizaciji stvarnosti, potrebe za poniranjem u samog sebe ili za autorefleksijom, otuđenosti od konkretnog, od djela, događaja, emotivnog, tjelesnog. ${ }^{97}$ Iz takve se perspektive samoubojstvo čini kao završni korak tog višestrukog tjelesnog i mentalnog iskustva „modernosti“ jer „konzumiranje modernosti“ gotovo neizbježno vodi prema stanju mentalne neravnoteže. $\mathrm{U}$ odnosu na hrvatsku situaciju, u tom se smislu uočava i sličnost s tezom Williama M. Johnstona o samoubilačkim tendencijama austrijskih intelektualaca, odnosno manjoj sklonosti onih mađarskih. ${ }^{98}$ Neki hrvatski intelektualci i umjetnici, koji će u modernizmu pronaći odgovor za životno i nacionalno pitanje te se okrenuti europskom suvremenom društvu, ostat će u psihološkom smislu snažnije izloženi prihvaćanju nekih od karakteristika koje su u konačnici mogle voditi prema psihozi, ludilu i samoubojstvu. S druge strane, modernistički će intelektualci, okrenuti hrvatskoj realnosti, zaokupljeni političkom situacijama i socijalnim prilikama, možda živjeti na rubu egzistencije jer će njihovo djelovanje biti izvan uskog institucionalnog kruga pod režimskim okriljem, ali će isprva rjeđe zalaziti u duboka preispitivanja identiteta, hiperrefleksivnost, nihilizam itd. Zbog toga su upravo razni politički prijelomi, radikalizacije, sukobi novih ideologija i starih okvira koji karakteriziraju intelektualni život kasnijeg međuraća otvarali nove prostore unutarnjim krizama i preispitivanjima identiteta.

Paranoja i ludilo često su pokrivali širok opseg „drugosti“ oko 1900. godine, a ako je k tome jasno da ne postoji jedinstven ili autentičan oblik modernosti, dakle da djeluju višestruki obrasci njezina razvijanja, moguće je u skladu s time zaključiti da je postojalo i mnoštvo oblika različitosti ili „drugosti“. 99 Takvu problematizaciju otvara slučaj Julija Rorauera (1859. - 1912.). Kao jedan manje uobičajen predstavnik novih tendencija u književnosti, uvodeći naturalizam - koji je u njega uglavnom lišen nacionalnog hrvatskog konteksta, što se često povezuje s njegovom mađaronskom političkom orijentacijom - uživao je ugled dekana Pravnog fakulteta u Zagrebu i rektora Sveučilišta 1910./1911. godine te političku podršku bana Nikole Tomašića. Međutim, već tada javljaju se prvi živčani problemi koje zamjećuje njegova obitelj. ${ }^{100}$ Život je završio u siromaštvu, po sanatorijima u Stenjevcu te bečkom sanatoriju Loew (ili Sanatorium Wiener), mjestu gdje su se liječili ili ondje umrli Alma i Gustav Mahler, Ludwig Wittgenstein, Viktor Adler, Josef Loschmidt, Richard Specht i mnogi drugi predvodnici intelektualno-umjetničkog života u Austriji. ${ }^{101}$ U teškom duševnom stanju pokušat će u srpnju 1912. samoubojstvo; novine prenose kako

\footnotetext{
97 Louis A. SAss, Madness and Modernism. Insanity in the Light of Modern Art, Literature, and Thought, New York 1992.

98 Usp. W. M. Johnson, Austrijski duh, 186-188, 190.

99 Usp. David Trotter, Paranoid Modernism. Literary Experiment, Psychosis, and the Professionalization of English Society, Oxford 2001.; George Rousseau, „Modernism and the Two Paranoias: The Neurology of Presecution“, Neurology and Modernity. A Cultural History of Nervous Systems, 1800-1950 (ur. Laura Salisbury i Andrew Shail), New York 2010., 130-147.

100 Nedjeljko Fabrio, Eseji, sv. 1, Zagreb 2007., 95-96.

101 O sanatoriju Loew usp. Allan S. JANIK - Hans VeIgL, Wittgenstein in Vienna, Wien - New York 1998., 153-154.
} 
mu se potom stanje poboljšava, ali će umrijeti u prosincu, nakon neuspješne operacije na otvorenoj rani od britve. ${ }^{102}$

Potreba za osnutkom Zavoda za umobolne iskazuje se već sredinom 19. stoljeća. Ban Jelačić i njegova Banska vlada ishodili su 1853. godine priznanje bečkog Ministarstva unutarnjih poslova o neophodnosti utemeljenja takvog zavoda na području Trojedne Kraljevine. „Protomedik“ u Hrvatskoj i Slavoniji Joseph Calasanz (Josip Kalasancije) Schlosser (1808. - 1882.) 1866. ponovno je javno izrazio potrebu za osnivanjem institucije, a nešto kasnije zahtjev dolazi i do Sabora, koji krajem 1873. donosi članak o osnivanju Zavoda. ${ }^{103}$ Međutim, tek na poticaj bana Ivana Mažuranića 1878. godine kreće se s gradnjom Zavoda za umobolne u Stenjevcu. Gradnja je završena 1879., a iduće je godine vladar Franjo Josip potvrdio zavodski Statut, ${ }^{104}$ prema kojemu je Zavod predstavljao „liečilište za liečive“ i „utočište za neizliečive umobolnike“" obaju spolova. ${ }^{105}$ Mogao je primiti 200 do 250 bolesnika, što će se pokazati izuzetno velikim problemom jer će se već oko 1900. godine dnevno liječiti i preko 500 pacijenata, ${ }^{106}$ pa će se uz stalno traženje „protomedika“ Vatroslava Thallera (1840. - 1916.) u Pakracu 1905. godine uspostaviti nova zemaljska umobolnica, isprva sa 100, a kasnije s 200 kreveta. ${ }^{107} \mathrm{U}$ stenjevačkoj umobolnici liječili su se ili su umrli istaknuti umjetnici i intelektualci, poput Ante Kovačića (1854. - 1889.), Vjekoslava Livadića (? - 1888.), Augusta Harambašića (1861. - 1911.), Vladimira Vidrića (1875. - 1909.), Slave Raškaj (1877. - 1906.) i Marije Novaković (1885. - 1960.). Književnik Ulderiko Donadini (1894. - 1923.) u Zavodu je boravio zbog živčanih problema i alkoholizma, dijagnosticirana mu je shizofrenija, a bolovao je od sušice, da bi brzo nakon pokušaja samoubojstva umro. ${ }^{108}$ Dom $i$ sviet piše prilikom njegove smrti o talentiranom mladom književniku, čije su knjige bile „navala (...) na društveni poredak“, čija je kritika poput Matoševe „rezala“, a „kojemu život nije davao sređenosti“. 109

\section{BOEMSKI ŽIVOT KAO OBLIK SAMOUBOJSTVA?}

Matoš, jedan od uzora mlađim generacijama modernista, upravo je u svom odnosu s Jankom Polićem Kamovom (1886. - 1910.), i to na temelju kritika njegova djela, ali i kasnijih pisanja o toj generaciji, dodatno naglasio štetnost i besmislenost takvog života. Kao poznat i zapravo nemilosrdan kritičar, nadolazeću mladu generaciju pjesnika i književnika uklapa u stereotip „rođenih intelektualaca“ koje muče velika pitanja i problemi te nihili-

$\overline{102}$ Nedjeljko FABrio, „Deset pristupnih varijacija na temu Julije Rorauer“, Grada i rasprave o hrvatskoj književnosti $i$ kazalištu, 6/1979., br. 1, 289; Isti, Eseji, 95-99.

103 Vlado Jukić, Izgradnja, dogradnje i adaptacije zgrada i drugih infrastrukturnih objekata Bolnice „Vrapče“ od 1877. do 2014. godine, Zagreb 2015., 6.

104 M. Smrekar, Priručnik za političku upravnu službu, 955-956, 958.

105 Isto, 958.

106 V. Jukić, Izgradnja, dogradnje i adaptacije zgrada, 9. Usp. „Psychiatrie und Irrenanstalten“, Agramer Zeitung (Zagreb), br. 244, 24. 10. 1899., 4-5.

107 „Erweiterung des Landesspitals in Pakrac“, Agramer Zeitung (Zagreb), br. 296, 9. 12. 1908., 5.

108 Ulderiko Donadini, Sabrana djela (prir. Branimir Donat), sv. 2, Zagreb 2003., 464-465.

109 „Književnost“, Dom i sviet (Zagreb), br. 11, 1. 6. 1923., 206-207. 
stička filozofija, a za vlastitu neproduktivnost krive okolinu u kojoj živi. ${ }^{110} \mathrm{O}$ tome je pisao i nakon Kamovljeve smrti, ${ }^{111}$ ističući kako je Kamov mogao živjeti i stvarati u domovini u uvjetima koji su daleko od idealnih, ali s istim sredstvima možda dovoljnima za preživljavanje, posebice zato što je bio početnik pa mjesta za napredak nije bilo. Zanimljivo, takav životni stil nazvao je u pisanjima sveukupno pseudomodernizmom. ${ }^{12}$ Svoja razmišljanja i zaključke Matoš vjerojatno vuče iz vlastitih iskustava jer je dugo morao živjeti izvan Hrvatske. Tek nakon što je pomilovan 1908. godine, mogao se službeno vratiti u Zagreb. Moglo bi se tako reći da je na neki način bio prisiljen dugo živjeti i lutati te je pritom vidio mnoge slučajeve i sudbine onoga što bi se nazvalo boemskim životom, a ponešto je i sâm iskusio. Naravno, sebi je to uvijek mogao opravdati nužnošću. Kada se tomu doda njegov kritički nastrojen karakter, ne začuđuje to što je napisao i feljton Boemski život, ${ }^{113}$ u kojemu se ogleda pravo upozorenje svima koji su smatrali da će ih takav pristup i život u Parizu obogatiti.

Mladi i nerijetko neiskusni umjetnici-intelektualci prigrlili su neobuzdan stil života kao dio njihova identiteta, njihove različitosti. Način života za njih bio je nerazdvojiv od njihova statusa u javnosti i njihove umjetnosti. Slikar Miroslav Kraljević (1885. - 1913.) u Parizu živi bonvivanski i prilično neobuzdano pa se u domovinu vraća bolestan, s tuberkulozom. Do smrti u travnju 1913. godine ostaje vjeran samome sebi, brine se kako će izgledati kada umre. Dva dana prije smrti naručuje kavijar i šampanjac, okupljajući obitelj oko sebe. ${ }^{114}$

Pišući o boemskom životu umjetnika, kako je već spomenuto, Matoš promatra njihov društveni položaj u Parizu, motive za takvim životom. Prema njemu, boemski je način života u Parizu često izbor, kako bi iz takvog stila i filozofije života stasali kao iskonski umjetnici, dok je, $s$ druge strane, osvrćući se u zaključku na hrvatske umjetnike, konstatirao kako boemski život u hrvatskom smislu nije pitanje stila nego uvjeta u kojima djeluju umjetnici i posljedica tih uvjeta. ${ }^{115}$ Iako na prijelazu stoljeća u Hrvatskoj i Slavoniji već postoji određen razrađen sustav funkcioniranja kulture u smislu dinastičkih, zemaljskih i lokalnih subvencija koje su mlađim umjetnicima mogle osigurati budućnost, usmjeravajući ih prema subvencioniranoj naobrazbi i iskustvima izvan hrvatskih (ili monarhijskih) okvira, to je vrijedilo tek za dio hrvatske inteligencije. Oni koji nisu bili umreženi u zemaljskom sustavu poticaja kulture i umjetnosti - što je često, iako ne u pravilu, bilo povezano is političkim djelovanjem - niti su, za razliku od Milivoja Dežmana (1873. - 1940.), ${ }^{116}$ mogli pronaći financijska sredstva za svoje projekte i pothvate preko dobrog obiteljskog zaleđa,

\footnotetext{
$\overline{110}$ Iz Matoševe recenzije romana Karikature 1908., „Savremenikova apoteoza gluposti“. Rosalba Asino, „Antun Gustav Matoš prema Janku Poliću Kamovu. Je li Matoš doista ispravno ocijenio Kamova?“, Dani Hvarskoga kazališta. Grada i rasprave o hrvatskoj književnosti i kazalištu, 33/2007., br. 1, 299-300.

111 Sâm je Kamov živio neurednim životom, iako je potjecao iz imućnije obitelji. U slaboj zdravstvenoj kondiciji iz Zagreba kreće na putovanje po jugozapadnoj Europi. Umire u Barceloni 1910. Nekoliko godina kasnije njegov brat Dragimir Polić počinio je samoubojstvo u Budimpešti u stanju teške mentalne rastrojenosti. Mladen UREM - Milan Zagorac, Janko Polić Kamov \& njegovo i naše doba, Rijeka 2010., 30-31.

112 R. Asino, „Antun Gustav Matoš prema Janku Poliću Kamovu“, 313-315.

113 Antun Gustav Matoš, „Boemski život“, Sabrana djela Antuna Gustava Matoša, knj. 15 (ur. Marijan Matković i dr.), Zagreb 1973., 81-83.

114 Vera Horvat Pintarić, Miroslav Kraljević, Zagreb 1985., 304.

115 „Historija naše boeme bila bi, dakle, uglavnome, historija naše književnosti.“ A. G. Matoš, „Boemski život“, 81-83

116 S. Matкović, „Ivo Pilar i naprednjaštvo“, 77. V. također: Isti, „Pilarova pisma Dušanu Plavšiću - fragment poznavanja hrvatskih secesionista", Godišnjak Pilar, 2/2002., br. 2, 33-40.
} 
ušteđevine ili vlastitog poduzetničkog zaleđa, bili su prepušteni slučaju. Matoš se referira na takve pojedince. Pored samog osjećaja isključenosti, neshvaćenosti, nesklada između očekivanja i mogućnosti za ostvarenjem, tu je i fenomen neistovremenosti istovremenog, dakle istovremena modernost u hrvatskom kontekstu koju javnost ponekad nije bila spremna shvatiti. Riječ je o modernosti koja je izvan hrvatskih granica ubrzanije poprimala sve različitiji kontekst, iziskujući i mentalnu i fizičku angažiranost. Hrvatski umjetnici i intelektualci često nisu pronalazili način na koji bi svoje ideje prilagodili konkretnoj hrvatskoj stvarnosti i društvenom ambijentu, ali im je ponekad jednako teško padalo uklopiti se u stranu okolinu i sustav funkcioniranja kulturnih i intelektualnih elita. Takva društvena izolacija pospješila je psihičku labilnost intelektualaca koji su pribjegavali neintelektualnom rješenju problema.

Velika gospodarska kriza od 1929. godine dodatno zaoštrava situaciju u smislu uvjeta rada i mogućnosti zapošljavanja te uzrokuje novi dubinski zastoj, koji se izravno odražava na umjetnike. Tisak diljem Jugoslavije piše o samoubojstvu kao učestalom fenomenu, tražeći pritom i objašnjenja u sociološkim ili filozofskim studijama. Na temelju studije ruskog filozofa Nikolaja Berdjajeva, u Novom dobu izlazi velik tekst o „tajni“ samoubojstva. ${ }^{117} \mathrm{Pu}$ blicist Drago Magjer objavljuje sociohistorijsku studiju o utjecaju ekonomskih prilika na samoubojstvo. ${ }^{118}$ Pojavljuje se i stručna literatura, prije svega knjiga Samoubistvo srpskog liječnika Milovana Milovanovića (1884. - 1948.). Tin Ujević 1933. objavljuje kratak tekst Umjetnička hora za idealno samoubojstvo, koji obrađuje glavne probleme učestalih samoubojstava umjetnika. Nadovezuje se na misao kako je samoubojstvo zbog neizlječive bolesti svojevrsna posebna kategorija, ističući da su se „ekonomski i socijalni pritisak“ pretvorili također u „kroničnu bolest“. Povezujući težnju za samoubojstvom s „bolesti nerva“, pesimizmom, razočarenjem i beznadnošću, opisuje s jedne strane umjetnost kao mogući izlaz iz takvog mentalnog sklopa, ali samo uvjetan:

Umjetnost dosta dugo može biti izlaz; ali ne više za umjetnika kojemu su dotle oduzeli vjeru u vrijednost umjetnosti, a da u naknadu drugih vrijednosti u životu i društvu nije našao. Da li umjetnik ima ekonomske osnove za svoju društvenu egzistenciju? Prošlost bi nas mogla, sa statistikama honorara i tantijema, a da o kakvim drugim prednostima ne govorimo, dovoljno ućutkati; ali kako stvari stoje danas? Ekonomska kriza odjeknula je pustošeći u svijetu teatra, bioskopa, muzike, trgovine slika (sjetimo se samoubojstva 1930. Julesa Pascina), knjižarstva, i tako dalje. Ali i tu možemo razlikovati ono što je prolazno, ili periodično, od onoga što je konstantno, permanentno, - da ne kažemo vječno, jer današnjica obračunava s pojmom vječnosti. Ima umjetnika koji počivaju na lovorovima i nisu prisiljeni forsirati stvaranje, jer ih mali broj masnih uspjeha obezbjeđuje, a jedan rok rada jamči za druge rokove nerada. No kako izaći na kraj s problemom trajne umjetničke besposlice, s takvom kakva se javlja u velikim centrima - ili sredinama gdje se kao svrab osjeća hiperprodukcija inteligencije? ${ }^{19}$

\footnotetext{
$\overline{117}$ „U čemu je tajna samoubistva?“, Novo doba (Split), br. 112, 14. 5. 1932., 4.

118 „O uticaju ekonomskih prilika na samoubistvo i zločin“, Jadranski dnevnik (Split), br. 58, 9. 3. $1935 ., 11$.

119 Citirano prema: Tin Ujević, Proza, Beograd 1964., 211-212.
} 


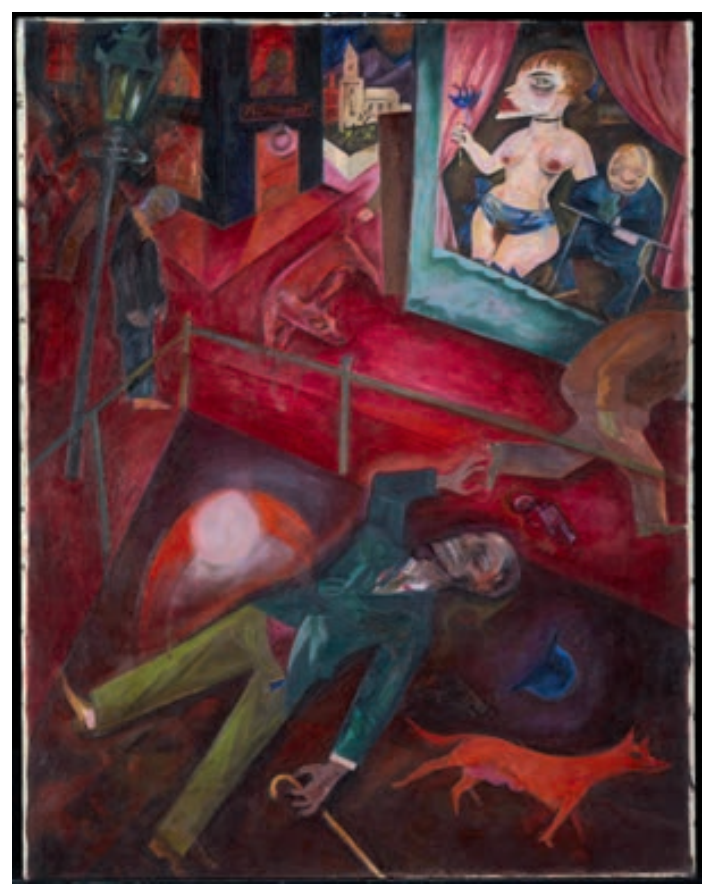

Sl. 3. George Grosz, Samoubojstvo (1916.)

Ujević dijeli pritom umjetnike na one „zvanične“, koji imaju siguran položaj u društvu i socijalni status, dakle uvjete za uredan život, i na one koji su „slobodne profesije ", živeći od trenutačne zarade od situacije do situacije pa su svojim ponašanjem „boemi i skitnice“ - u vremenu kada je nastupila „[i]dealna era za samoubojstava“. Za Ujevića su takvi boemi ustvari relikti. Oni djeluju i stvaraju iz pobuda drugačijih od „zvaničnih“ umjetnika. Motiviraju ih moralne pozicije, ideali, čast, patriotski osjećaji; pripadaju „duhovnoj aristokraciji“, oslanjajući se pritom često na sustav potpora, subvencija i sinekura - koje su političkim, socijalnim i ekonomskim preslagivanjima u međuratnom razdoblju sve manje sigurna konstanta. ${ }^{120}$

Književnik Vladimir Jurčić objavljuje 1936. godine knjigu Kako su umirali hrvatski književnici i umjetnici. Radi se o prvom cjelovitom pokušaju opisivanja života i umiranja hrvatskih intelektualaca u 19. i 20. stoljeću. No, djelo je prečesto površno, ne sasvim pouzdano, pa i naivno koncipirano, što se odražava i u kritici koja je spočitavala pretjerano „sentimentalno-osjećajnu bazu“, subjektivnost i plošnost. ${ }^{121}$ Svoju je kritiku iznio i Tin Ujević, ${ }^{122}$ koji upozorava na njegove simplifikacije, ali priznaje koncept i podatke kao važne za daljnju razradu teme. Sâm pridonosi raspravi, nastojeći ponuditi znatno kompleksniju sliku, povezujući prilike i okolinu u kojima intelektualci-umjetnici žive s ljudskim unutrašnjim porivom prema umjetnosti i umjetnikovu mentalitetu. Za njega su (teška) životna iskustva, bolest i smrt predmeti koji motiviraju i obogaćuju umjetnikov izražaj, dodatno ih senzibiliziraju, pružajući im okvir unutar kojega se oni razvijaju. ${ }^{123}$

$\mathrm{Na}$ tragu Ujevićevih je razmišljanja u jednom razgovoru iz 1935. i slikarica Nasta Rojc. Između ostalog, ističe: „Dok radim, ne ćutim niti da mi komarci sišu krv iz lica, da poslije ni moji najbliži u tom crvenom otečenom, ali sretnom licu ne mogu prepoznati mene. I u bolestima prolaze pred mojim nutarnjim pogledom boje i oblici. Čim osjetim dosta snage da mogu držati kist, moram koju od njih ostvariti. Tako sam nakon zadnje duge teške bolesti našla prvi puta u životu moje kistove - izjedene od moljaca - ali sam s izjedenim kistovima i drhtavom rukom morala naslikati nekakvu žutu figuru u modroj pozadini koji

\footnotetext{
120 Isto, 212-213.

121 Usp. V. Jurčić, Kako su umirali hrvatski književnici i umjetnici; Milan Durman, „Književnik o sudbini književnika“, Književnik, 10/1937., br. 2, 76-79.

122 Tin Ujević, Sabrana djela, sv. 6, Zagreb 1965., 209-218.

123 Isto, 209-214.
} 
sam često u bolesti vidila. Stid me je kad netko pita: 'A što je to?', a ja moram priznati: ‘Ne znam'“"124 Rojc govori, prisjećajući se i školovanja s Miroslavom Kraljevićem, o putevima kojima kreću umjetnici vođeni svojom individualnošću, ali i, kako navodi, o „misterioznoj evoluciji u umjetnosti“ koja se odvijala oko 1900. i prije početka Prvog svjetskog rata.

Pišući o Charlesu Baudelaireu i njegovu Salon de 1846, u kojemu raspravlja o „konačnom obliku“ otpora u "herojstvu modernog života“ - samoubojstvu, Walter Benjamin (1892. - 1940.) suicid je prikazao kao ključno ostvarenje, „stvarnu pobjedu modernizma u carstvu strasti“. ${ }^{125}$ Iskustvo Velikog rata nakon 1918. i gospodarske krize od 1929. godine podcrtavaju porast samoubojstava kao jednog od ključnih fenomena modernizma. Propitivanja o značenju života, individualnom identitetu čovjeka koji stvara, njegovu odnosu prema društvu, važnosti proživljenog vremena i samom iskustvu življenja postupno će stvoriti ne samo novo poimanje života, već i smrti. Sekularizacija društva i dominantno moderno gradsko iskustvo nameću promijenjena ili nova shvaćanja. Uloga intelektualaca i umjetnika početkom 20. stoljeća više je nego ikada prije bila izložena javnosti; želja za dubljom intelektualnom fundiranošću njihova stvaralaštva vodila ih je do individualiziranog shvaćanja sebe, otvarajući im istovremeno put prema iskustvima modernog društva. Modernistički intelektualci i umjetnici zarobljeni su u istovremenosti neistovremenih svjetova njihova stvaralaštva, težnji, uzora, poriva prema uključivanju u globalna moderna strujanja i u realnim svjetovima lomova i transformacija koji se odvijaju u Hrvatskoj u razdoblju od kraja 19. stoljeća do 1941. godine. Oni stoga često biraju živjeti u mašti, žive svoju umjetnost i filozofiju na dnevnoj bazi, izražavaju svoju avangardnost, modernost ili, pak, radikalno svakodnevno odbacivanje zaostalog, zastarjelog ili jednostavno normiranog.

\section{$\cos$}

\section{Izvori}

Agramer Zeitung (Zagreb), 1895., 1899., 1908.

Banovac (Petrinja), 1906.

Dom i sviet (Zagreb), 1923.

Jadranski dnevnik (Split), 1935.

Jutarnji list (Zagreb), 1912.

Narodne novine (Zagreb), 1887., 1905.

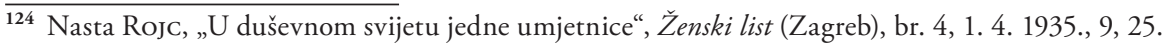

125 Walter Benjamin, Das Passagen-Werk, Frankfurt am Main 1983., 455. Kasnije, 1940., taj će ključ modernizma spoznati i osobno, počinivši samoubojstvo u hotelskoj sobi, doduše, u sasvim drugačijem kontekstu nacističke prijetnje koja se nadvila nad Europom. 
Neues Wiener Journal (Wien), 1905.

Novo doba (Split), 1932., 1933.

Novosti (Zagreb), 1936.

Obzor (Zagreb), 1908.

Pester Lloyd (Budapest), 1895.

Pokret (Zagreb), 1905.

Ženski list (Zagreb), 1935.

Izvještaj gradskoga poglavarstva o sveopćoj upravi slobodnog i kralj. glavnoga grada Zagreba za godinu 1919-1925, Zagreb 1928.

Statistički godišnjak Zemalja ugarske krune 1896., Budimpešta 1897.

Statistički godišnjak Zemalja ugarske krune 1897., Budimpešta 1899.

Statistički godišnjak Zemalja ugarske krune 1898., Budimpešta 1900.

Statistički godišnjak Zemalja ugarske krune 1900., Budimpešta 1902.

Zagreb godine 1913-1918. Izvještaj gradskoga poglavarstva o sveopćoj upravi slobodnog i kralj. glavnoga grada Zagreba, Zagreb 1927.

Abraham Eitelberg, Unmoderne Ansichten über die moderne Cultur, Wien - Leipzig 1892.

Hermann Anton Krose, Der Selbstmord im 19. Jahrhundert nach seiner Verteilung auf Staaten und Verwaltungsbezirke, Freiburg im Breisgau 1806.

Tomáš Garrigue MASARYK, Der Selbstmord als sociale Massenerscheinung der modernen Civilisation, Wien 1881.

Antun Gustav Matoš, „Boemski život“, Sabrana djela Antuna Gustava Matoša, knj. 15 (ur. Marijan Matković i dr.), Zagreb 1973., 81-83.

Milan Smrekar, Priručnik za političku upravnu službu u kraljevinah Hrvatskoj i Slavoniji, Zagreb 1902.

\section{Literatura}

Olive Anderson, Suicide in Victorian and Edwardian England, Oxford 1987.

Tomislav Anić, „Utemeljenje dobrovoljnog društva za spasavanje“, Časopis za suvremenu povijest, 38/2006., br. 2, 569-582.

Philippe Ariès, Western Attitudes Toward Death: From the Middle Ages to the Present, London 1976.

Rosalba Asıno, „Antun Gustav Matoš prema Janku Poliću Kamovu. Je li Matoš doista ispravno ocijenio Kamova?", Dani Hvarskoga kazališta. Grada i rasprave o hrvatskoj književnosti i kazalištu, 33/2007., br. 1, 294-318.

Nikola Batušić - Zoran Kravar - Viktor Žmegač, Književni protusvjetovi. Poglavlja iz hrvatske moderne, Zagreb 2001.

Ursula Baumann, „Selbsttötung und die moralische Krise der Moderne“, Sterben von eigener Hand. Selbsttötung als kulturelle Praxis (ur. Andreas Bähr i Hans Medick), Wien - Köln - Weimar 2005., 115-136.

Andreas BÄHr, „Zur Einführung: Selbsttötung und (Geschichts-)Wissenschaft“, Sterben von eigener Hand. Selbsttötung als kulturelle Praxis (ur. Andreas Bähr i Hans Medick), Wien - Köln - Weimar 2005., 1-19.

Walter Benjamin, Das Passagen-Werk, Frankfurt am Main 1983.

Gemma Blackshaw, „The Pathological Body: Modernist Strategising in Egon Schiele’s Self-Portaiture“, Oxford Art Journal, 30/2007., br. 3, 377-401.

Ron M. Brown, Art of Suicide, London 2001. 
David Cannadine, „Tajna kuća smrti“, Gordogan, 11/1990., br. 29-30, 215-222.

Alessandra Comini, Egon Schiele's Portraits, Berkeley 1974.

James CurL, The Victorian Celebration of Death, Detroit 1972.

Ulderiko Donadini, Sabrana djela (prir. Branimir Donat), sv. 2, Zagreb 2003.

Milan Durman, „Književnik o sudbini književnika“, Književnik, 10/1937., br. 2, 76-79.

Nedjeljko FABRIo, „Deset pristupnih varijacija na temu Julije Rorauer“, Građa i rasprave o hrvatskoj književnosti i kazalištu, 6/1979., br. 1, 285-332.

Nedjeljko Fabrio, Eseji, sv. 1, Zagreb 2007.

Lucien Febvre, Das Gewissen des Historikers, Berlin 1988.

Sigmund Freud, Die Traumdeutung, Frankfurt am Main 1976.

Andrew Gaedtke, Modernism and the Machinery of Madness, New York 2017.

Peter Gay, Die Moderne. Eine Geschichte des Aufbruchs, Frankfurt am Main 2008.

Maurice Halbwachs, Les causes du suicide, Paris 1930.

Brigitte Hamann, Kronprinz Rudolf. Ein Leben, München - Zürich 2013.

Róisín Healy, „Suicide in Early Modern and Modern Europe“, The Historical Journal, 49/2006., br. 3, 903-919.

Željko Holjevac, „Problem Pilarove smrti“, Prinosi za proučavanje života i djela dra. Ive Pilara, 1/2001., br. 1, 233-238.

Josip HoRvat, Hrvatski panoptikum, Zagreb 1964.

Vera Horvat Pintarić, Miroslav Kraljević, Zagreb 1985.

Vedran Ivanković, Le Corbusier i hrvatska škola arhitekture, Zagreb 2016.

Patricia Jalland, Death in the Victorian Family, New York 1996.

Allan S. Janik - Hans Veigl, Wittgenstein in Vienna, Wien - New York 1998.

Julie M. Johnson, The Memory Factory. The Forgotten Women Artists of Vienna 1900, West Lafayette 2013.

William M. Johnston, Austrijski duh. Intelektualna i društvena povijest 1848-1938., Zagreb 1993.

Vlado Jukić, Izgradnja, dogradnje i adaptacije zgrada i drugih infrastrukturnih objekata Bolnice „Vrapče“ od 1877. do 2014. godine, Zagreb 2015.

Vladimir JurČIĆ, Kako su umirali hrvatski književnici i umjetnici, Zagreb 2006.

Rade Kalanj, Modernost i napredak. Studija, Zagreb 1994.

Miroslav KrležA, Račić, Zagreb 1947.

Thomas A. Kselman, Death and the Afterlife in Modern France, Princeton - New Jersey 1993.

Jacques Le Rider, Modernity and Crises of Identity. Culture and Society in Fin-de-siècle Vienna, New York 1993.

Desmond Manderson, „Klimt's Jurisprudence - Sovereign Violence and the Rule of Law“, Oxford Journal of Legal Studies, 35/2015., br. 3, 515-542.

Robert Mandrou, Introduction to Modern France, 1500-1640. An Essay in Historical Psychology, New York 1975.

Stjepan Matković, „Ivo Pilar i naprednjaštvo“, Pilar - časopis za društvene i humanističke studije, 8/2013., br. 15-16, 69-112.

Stjepan Matković, „Pilarova pisma Dušanu Plavšiću - fragment poznavanja hrvatskih secesionista", Godišnjak Pilar, 2/2002., br. 2, 33-40.

Žorž MinoA, Istorija samoubistva, Novi Sad 2008.

John Morley, Death, Heaven, and the Victorians, Pittsburgh 1971. 
J. C. Nyíri, „Philosophy and Suicide-statistics in Austria-Hungary: Variations on a Theme of Masaryk“, On Masaryk. Texts in English and German (ur. Josef Novák), Amsterdam 1988., 291-316.

Roy Porter, „Nervousness, Eighteenth and Nineteenth Century Style: From Luxury to Labour“, Cultures of Neurasthenia from Beard to the First World War (ur. Marijke Gijswijt-Hofstra i Roy Porter), Amsterdam - New York 2001., 31-50.

Tomislav Premerl, Hrvatska moderna arhitektura izmedu dva rata, Zagreb 2015.

Ljerka RACKо, „Janko Koharić (prilog poznavanju njegova znanstvenog i publicističkog rada)“, Historijski zbornik, 31-32/1978. - 1979., 253-269.

Bogdan Radica, Hrvatska 1945, München - Barcelona 1974.

Paul Roazen, Encountering Freud. The Politics and Histories of Psychoanalysis, New York 2017.

George Rousseau, „Modernism and the Two Paranoias: The Neurology of Presecution“, Neurology and Modernity. A Cultural History of Nervous Systems, 1800-1950 (ur. Laura Salisbury i Andrew Shail), New York 2010., 130-147.

Josip Rus (ur.), Josip Račić. Retrospektiva. Zagreb 1885. - Pariz 1908., Zagreb 2008.

Katherine Lynn Ryan, Modernism's Suicidal Impulse: Psychic Contamination and the Crowd, doktorska disertacija, University of California, Irvine 2014.

Ines SAвотіс̌, Stare zagrebačke kavane i krčme s kraja 19. i početka 20. stoljeća, Zagreb 2007.

Louis A. SAss, Madness and Modernism. Insanity in the Light of Modern Art, Literature, and Thought, New York 1992.

Ernst Leopold Stahl, Gemma Boić. Uspomeni na umjetnicu, Zagreb 2003.

Julie-Marie Strange, Death, Grief and Poverty in Britain, 1870-1914, Cambridge 2005.

Mario Strecha, „O nastanku i razvoju moderne hrvatske historiografije u 19. stoljeću“, Povijest u nastavi, 3/2005., br. 6, 103-116.

Neven ŠEgvić, „Arhitektonska 'moderna’ u Hrvatskoj“, Republika, 8/1952., br. 3, 179-186.

Filip Šmetin ŠEgvić, „Kultura smrti u Zagrebu. Društvo prijatelja za podizanje krematorija Plamen“, Historijski zbornik, 68/2016., br. 2, 297-322.

Dragutin Tadijanović, Knjiga o hrvatskim piscima. Članci, feljtoni, bilješke, Zagreb 1995.

David Trotter, Paranoid Modernism. Literary Experiment, Psychosis, and the Professionalization of English Society, Oxford 2001.

Tin Ujević, Proza, Beograd 1964.

Tin Ujević, Sabrana djela, sv. 6, Zagreb 1965.

Mladen Urem - Milan Zagorac, Janko Polić Kamov \& njegovo i naše doba, Rijeka 2010.

Michel Vovelle, Mourir autrefois. Attitudes collectives devant la mort aux XVIIe et XVIIIe siècles, Paris 1974.

John C. Weaver, Sadly Troubled History. The Meanings of Suicide in the Modern Age, Quebec 2009.

William Wynn Westсотт, Suicide. Its History, Literature, Jurisprudence, Causation, and Prevention, London 1885.

Michael Wheeler, Heaven, Hell, and the Victorians, Cambridge 1994.

Larry Wolff, Child Abuse in Freud's Vienna. Postcards from the End of the World, New York - London 1988.

Igor Zidić, Josip Račić 1885-1908., Zagreb 2009. 


\section{$\cos$}

\section{THE SPIRIT OF MODERNITY: FROM A CULTURE OF LIVING TO A CUlTure OF DEATH. THE PHENOMENON OF SUICIDE IN Europe ANd Croatia}

A sharp rise in suicide rates in late 19th century Europe opened the topic to scholarly and journalistic analysis. Far from shying away from it, modernist artists and intellectuals recognize it as inherent to the time they live in and the wider social context. From about 1900 and up until well into the interwar period, a number of Croatian intellectuals and artists, from Julije Rorauer and Josip Račić to Josip Pičman fall victim to suicide. The authors endeavour to analyze the connection between modernist ideas and art, the contemporary way of life, dying and the act of suicide itself, through the use of various aspects of historical psychology, intellectual history and an analysis of the culture of dying. Particular attention is given to the Central European context and the phenomena of the simultaneity of the nonsimultaneous, as well as the visibility of different forms of discourse around suicide in the general public and the society at large.

Key words: suicide, modernism, death, life, the press, the intellectual, the artist 



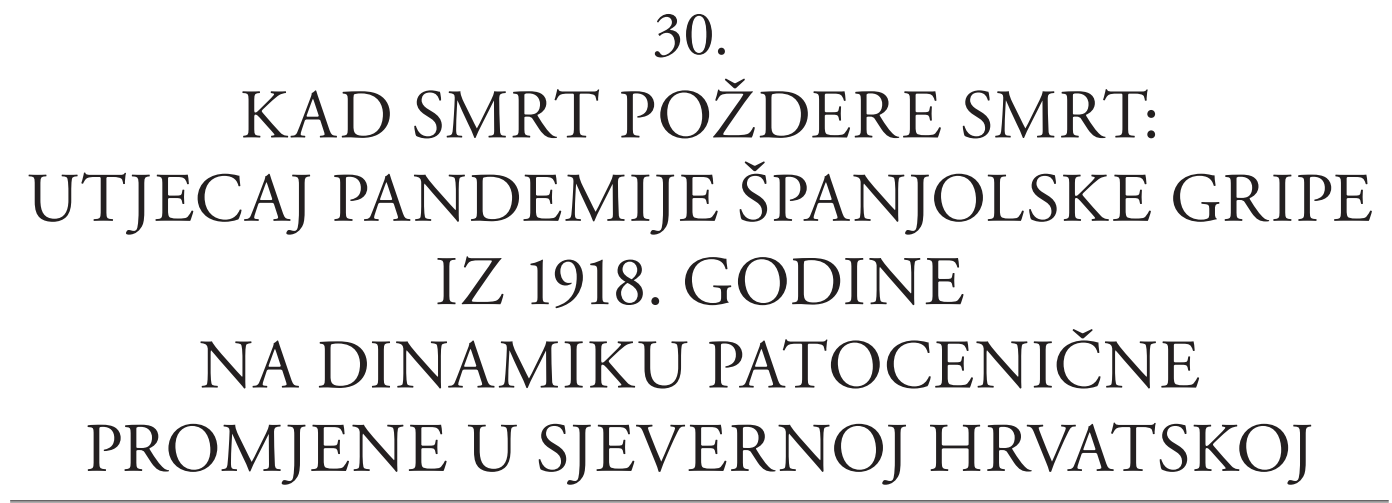

\section{Nikola Anušić}

UDK: 614.4(497.5)“1918“:314.4

Izvorni znanstveni članak

Sažetak: Patocenoza, kako ju je osmislio hrvatsko-francuski epidemiolog Mirko Grmek, predstavlja cjelinu patoloških uvjeta koji supostoje na istom mjestu i u isto vrijeme. To supostojanje teži stabilnom uravnoteženju pod dominantnom patologijom u specifičnoj ekološkoj, društvenoj i kulturnoj okolini. Promjene u toj okolini mogu izazvati patoceničnu tranziciju, odnosno uspostavu nove ravnoteže patoloških uvjeta pod drugom dominantnom patologijom. U radu se na temelju demografske i epidemiološke analize istražuje pandemijski komorbiditet španjolske gripe i tuberkuloze iz 1918. godine kao faktor promjene u tranziciji patocenoze tuberkuloze na prostoru sjeverne Hrvatske.

Ključne riječi: patocenoza, tuberkuloza, španjolska gripa, sjeverna Hrvatska, 1918. godina

\section{UVOD}

D

emografsko poimanje smrti krajnje je redukcionističko. Svedena na kvantitativan izraz, „demografska smrt“ gubi svoje antropološko višeznačje i postaje depersonaliziran slučaj, analitička čestica lišena neposrednog konteksta, a time i punine značenja. Tom redukcijom omogućuje se, međutim, njezino izmještanje iz sfere osobnog u sferu društvenog iskustva, odnosno njezino rekontekstualiziranje kao društvenog fenomena.

Smrt tako postaje odraz društvenih stanja i procesa, ali i njihov aktivan činitelj. To se prvenstveno očituje u njezinu presudnom utjecaju na prirodno kretanje stanovništva u predmodernim i ranomodernim društvima. Sve do zrele faze demografske tranzicije, a to 
znači iznimno dugo, u nekim dijelovima Europe i do sredine prošloga stoljeća, mortalitet je bio glavni regulator rasta stanovništva i uzrok njegove stagnacije.

Regulatorna funkcija mortaliteta u razvoju stanovništva proizlazila je iz trajno visokih mortalitetnih stopa na koje je presudno utjecalo umiranje od zaraznih bolesti, osobito tijekom velikih epidemijskih naleta. Utoliko se može reći da su upravo zarazne bolesti bile glavni činitelj demografskoga razvoja prije demografske tranzicije. Zbog toga se demografska povijest predmodernog i ranog modernog doba, ponegdje i bliže, ne može pisati a da se pritom izbjegne njezino snažno povezivanje s povijesnomedicinskim uvidima, osobito onima iz povijesne epidemiologije. Štoviše, moglo bi se reći da su epidemiološki aspekti demografskih istraživanja ključni za razumijevanje demografske povijesti upravo do u osvit našega doba. To, s druge strane, znači da se epidemiološke uvide može (a iz demografske perspektive mora) sagledavati kao aspekte složene društvene situacije u kojoj se bolest događa. Širenje zaraznih bolesti i njihov smrtonosan obol uvelike su određeni društvenom reakcijom na bolest, tj. sposobnošću društva da stvori znanstvene, zdravstvene, prosvjetne i općenito organizacijske pretpostavke za suzbijanje pošasti, ali jednako tako i (društveno koreliranim) zdravstvenim prilikama koje epidemiji prethode (rasprostranjenost i međuodnos endemijskih bolesti).

Te složene odnose dvostruke međuuvjetovanosti prvi je uočio i teorijski konceptualizirao znameniti hrvatski i francuski epidemiolog i povjesničar medicine Mirko Grmek u okviru svoje teorije o patocenozi. ${ }^{1}$ Grmek smatra da bolesti imaju postojanje koje se ne iscrpljuje u uskom međuodnosu bolesti i bolesnika, nego ga nadilazi i poprima šire društveno značenje. To se najzornije može opaziti u provalama masovnog pobola (i pomora) kada bolest postaje događaj, odnosno pojava koja pogađa cijelo društvo. Zbog toga se, prema Grmeku, epidemiološka istraživanja ne mogu svesti na praćenje pojave i širenja neke bolesti, nego je se mora povezati s drugim bolestima koje se pojavljuju i postoje $u$ dotičnom društvu. Taj sintetički pristup, koji stoji nasuprot još uvijek prevladavajućem analitičkom, dijakronijskom i pojedinačnom istraživanju evolucije bolesti, zasniva se na trima tezama:

1. Patološki uvjeti unutar određene populacije čine cjelinu koju nazivamo patocenozom. 2. Mimo određenih endogenih ekoloških faktora, svaka bolest ovisi o frekvenciji i distribuciji svih drugih bolesti na istom prostoru i u isto vrijeme.

3. Patocenoza tendira stanju ekvilibrija, osobito kada je stabilan ekološki kontekst. $\mathrm{Na}$ stabilnost toga ekvilibrija utječe također društvena i kulturna okolina. Promjene u toj okolini mogu izazvati promjene u prevalenciji neke bolesti, uzrokujući promjenu patocenoze. $^{2}$

\footnotetext{
1 Koncept patocenoze Mirko Grmek prvi je put predstavio u članku „Préliminaires d'une étude historique des maladies“, objavljenom u časopisu Analles ESC 1969. godine, a dublje ju je razradio u svom kapitalnom djelu Les maladies à l'aube de la civilisation occidentale. Recherches sur la réalité pathologique dans le monde grec préhistorique, archaïque et classique iz 1985. godine. Usp. i hrvatski prijevod: Mirko Dražen Grmek, Bolesti u osvit zapadne civilizacije. Istraživanja patološke stvarnosti u grčkom predhistorijskom, arhajskom i klasičnom dobu, Zagreb 1989.

2 Jacques Vallin, „Diseases, deaths, and life expectancy“, Genus, 61/2005., br. 3-4, 281.
} 
Polazeći od ovih teorijskih postavki, pokušat ćemo ispitati koliko je izuzetno letalna megapandemija influence iz 1918./1919., tzv. španjolska gripa, utjecala na patocenozu tuberkuloze u sjevernoj Hrvatskoj, odnosno je li kauzalni komorbiditet tuberkuloze i španjolske gripe tijekom pandemije mogao izazvati promjene u patoceničnoj dinamici i kasniju tranziciju patocenoze. Istraživanje je provedeno na geografskom prostoru sjeverne Hrvatske, ${ }^{3}$ regije za koju postoje prikupljeni podaci o vitalnoj statistici i kauzalnom mortalitetu prije, tijekom i neposredno nakon Prvog svjetskog rata. ${ }^{4}$ No, i mimo toga, ovaj prostor pogodniji je za demografske i epidemiološke analize zbog relativno velike gustoće stanovništva, izraženijeg socijalnog dinamizma i razvedenosti urbane stratifikacije. ${ }^{5}$ Ipak, s obzirom na to da smo ovdje usmjereni na opći fenomen, rezultate analize ne treba sagledavati u (isključivo) regionalnom kontekstu.

\section{RASPRAVA}

Jean-Noël Biraben identificirao je jedanaest povijesnih patocenoza, među njima i tuberkulozu kao patocenozu modernoga doba, 19. i 20. stoljeća. Njezino širenje povezuje s procesom industrijalizacije i njome izazvane anarhične urbanizacije, a kraj s procesom epidemiološke tranzicije kojom tijekom druge polovine 20. stoljeća završava povijesna dominacija zaraznih bolesti i nastupa novo doba, u kojem dinamika patocenoze biva upravljana isključivo čovjekovim izravnim djelovanjem na njegove zdravstvene uvjete (man made diseases). ${ }^{6}$ Hrvatsko iskustvo uklapa se u taj obrazac, iako ga zbog kašnjenja modernizacijskog procesa prati sa stanovitim zaostatkom. To se zaostajanje $s$ vremenom smanjivalo, osobito tijekom druge polovine 20. stoljeća, ali je početkom stoljeća još uvijek bilo veliko. Dominacija tuberkuloze među ostalim patologijama u sjevernoj Hrvatskoj i šire, u Hrvatskoj i Slavoniji, učvršćuje se posljednjih desetljeća 19. stoljeća, a zenit doseže u prvim desetljećima 20. stoljeća, kada postaje bolest epidemijskih razmjera. Prije Prvog svjetskog rata u Hrvatskoj i Slavoniji od tuberkuloze je godišnje umiralo u prosjeku 10980 ljudi, odnosno svaki peti stanovnik, a u industrijskim gradovima, kakav je bio Zagreb, svaki četvrti. Smrtnost od tuberkuloze bila je pet puta veća od svih drugih zaraznih bolesti zajedno, sa stopama mortaliteta od 400 do 500 na 100000 stanovnika. $^{7}$

3 Prostor sjeverne Hrvatske ovdje uzimamo u obuhvatu triju sjevernohrvatskih županija: Varaždinske, Zagrebačke i Bjelovarsko-križevačke, kako su administrativno bile definirane županijskim ustrojem iz 1866. godine. V. Milan SMrekar, Priručnik za političku upravnu službu u kraljevinah Hrvatskoj i Slavoniji, sv. 1, Zagreb 1899., 465-466.

4 Administrativni sustav u Hrvatskoj i Slavoniji bio je potkraj Prvoga svjetskog rata u rasulu pa su prikupljanje i obrada podataka o vitalnoj statistici na državnom teritoriju postali nemogući. Ti su podaci za prostor sjeverne Hrvatske (1026 naselja) rekonstruirani kapilarnim istraživanjem dostupnih matičnih knjiga rođenih, vjenčanih i umrlih za razdoblje 1914. - 1925. Izuzeta su naselja/kotarevi na kojima su matice uništene i otuđene u ratnim razaranjima 20. stoljeća (8 kotareva) kao i većina pravoslavnih parohija (94\%) koje nisu vodile rubriku o uzroku smrti i kojih su matice u ratnim sukobima osobito stradale. V. Nikola Anušić, U sjeni Velikoga rata. Pandemija španjolske gripe 1918. - 1919. u sjevernoj Hrvatskoj, Zagreb 2015., 6.

5 Isto, 3.

6 Jean-Noël Biraben, „Les pathocenoses en Europe“, Histoire des maladies (ur. Mirko Grmek), Paris 1996., 1-36.

7 Ana BorovečKi - Ira GJenero-Margan, „Epidemiological Analysis of Tuberculosis in the Kingdom of Croatia and Slavonia during 1901 - 1910“, Croatian Medical Journal, 43/2002., br. 3, 352. 


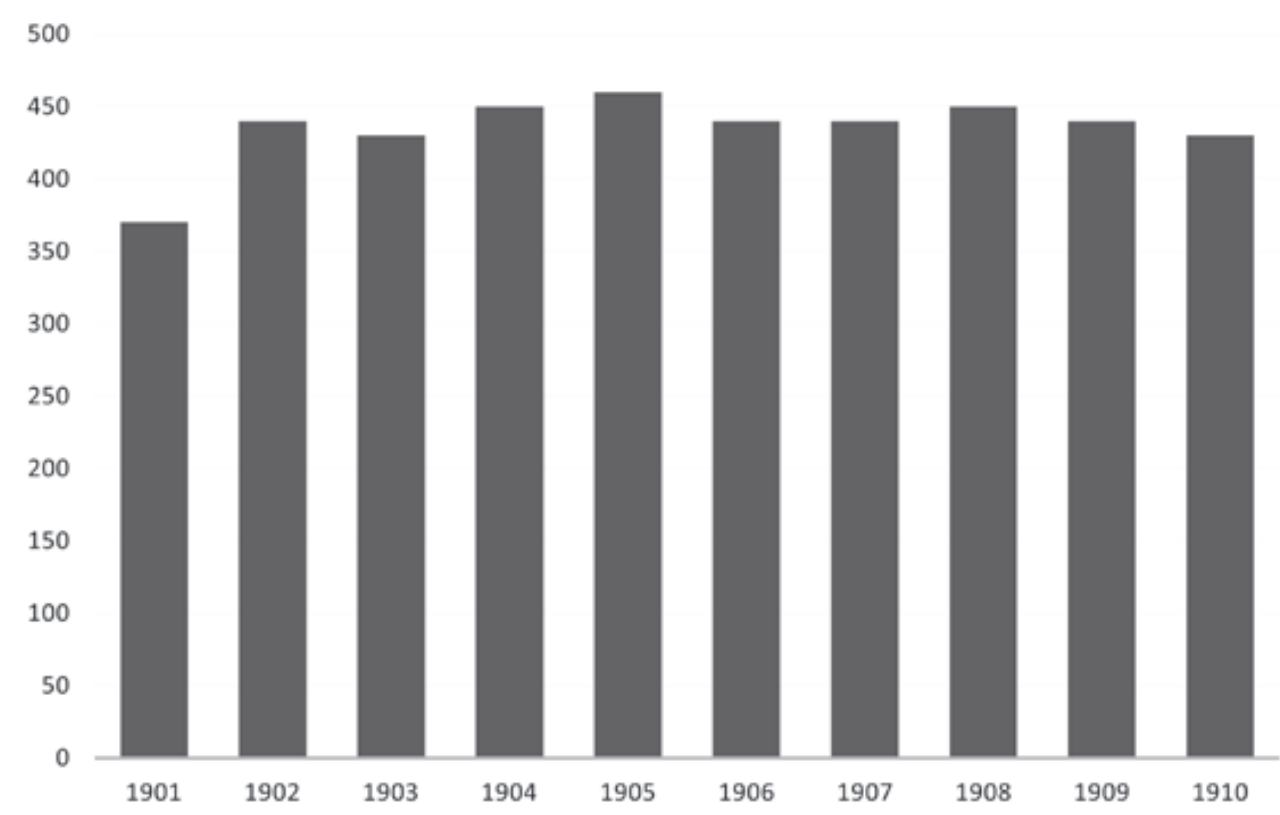

Sl. 1. Stope mortaliteta od tuberkuloze u Banskoj Hrvatskoj od 1901. do 1910. godine

Tako visoke stope dosezali su razvijeni industrijski krajevi zapadne Europe krajem 18. i u prvoj polovini 19. stoljeća, dakle u ranoj fazi industrijalizacije, kada su te stope bile najviše. U hrvatskom slučaju industrijalizacija nije presudno utjecala na širenje tuberkuloze jer je Hrvatska toga doba (a i poslije) bila prevladavajuće agrarna zemlja, unatoč rastućim stopama gradskog stanovništva i rastućim migracijama iz sela u grad. Kao glavne poluge širenja tuberkuloze treba stoga uzimati ponajprije neprosvijećenost, siromaštvo i izrazito niske higijenske standarde stanovništva, probleme koji su podjednako bili prisutni u gradovima i na selu. Prema izvještajima o mortalitetu od tuberkuloze, koje imamo sačuvane od 1908. godine, vidi se da je u razdoblju koje je blisko prethodilo Prvom svjetskom ratu broj umrlih od tuberkuloze u sjevernoj Hrvatskoj bio u stalnom porastu. Taj rast nije, doduše, bio intenzivan, ali je bio konstantan sve do pred kraj rata, 1917. godine, kada postaje izraženiji.

Dominantan utjecaj tuberkuloze na mortalitetne stope u sjevernoj Hrvatskoj nakratko će ujesen i zimi 1918. godine prekinuti nastup najveće poznate pandemije svih vremena, tzv. španjolske gripe. Ona se u sasvim nerazjašnjenim okolnostima pojavila u proljeće 1918. i u trima susljednim valovima (proljeće 1918.; jesen 1918.; zima 1918./1919.) poharala svijet, uzrokujući smrt između 50 i 100 milijuna ljudi. ${ }^{8}$ U sjevernoj Hrvatskoj pojavila se u ranu jesen, u rujnu 1918., i kao jedinstven mortalitetni ciklus potrajala do veljače 1919. godine, kada se bilježe posljednji slučajevi smrti dvojbene vjerodostojnosti. ${ }^{9}$ Nije izgledno da je Hrvatska izbjegla proljetni val gripe u srpnju i kolovozu 1918., makar on nije ostavio nikakva traga, ali zimski (siječanj/veljača 1919.) svakako jest. Iz još sasvim neistraženih

\footnotetext{
8 Nail P. A. S. Johnson - Juergen Mueller, „Updating the Accounts: Global mortality of the 1918-1920 'Spanish' Influenza Pandemic", Bulletin of the History of Medicine, 76/2002., br. 1, 105-115.

$9 \quad$ N. Anušić, U sjeni Velikoga rata, 100.
} 


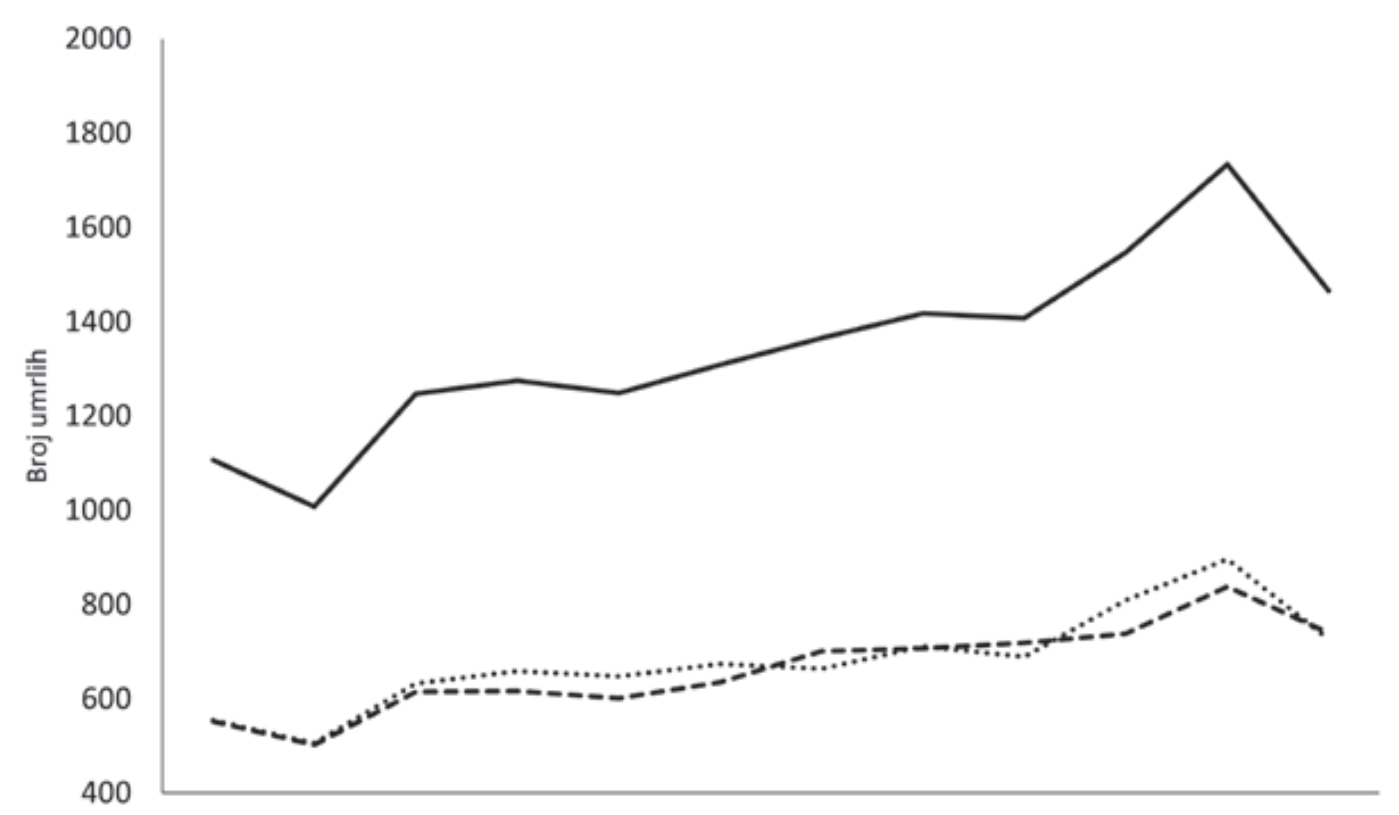

1908. 1909. 1910. 1911. 1912. 1913. 1914. 1915. 1916. 1917. 1918. 1919.

\section{Godina}

---.-Muškarci ….......̌̌ene —Ukupno

Sl. 2. Spolna struktura umrlih od tuberkuloze u sjevernoj Hrvatskoj od 1908. do 1919. godine razloga pandemija se u Hrvatskoj iscrpila u jednom, jesenskom valu, koji je, doduše, bio iznimno virulentan, ali i kratkotrajan. Pomor koji je počeo u rujnu vrhunac je dosegao u studenom 1918., nakon čega započinje dosta strm pad mortalitetnih stopa. ${ }^{10} \mathrm{Od}$ španjolske gripe umrlo je u sjevernoj Hrvatskoj više od 5700 ljudi, što se za vrlo gusto naseljeno područje na prvi pogled može učiniti relativno malim pomorom. ${ }^{11}$ Međutim, imamo li na umu da je španjolskoj gripi u travnju i svibnju prethodila strašna epidemija velikih boginja, koja je pomorila većinu populacije u većem riziku od smrti te da su žrtve španjolske gripe bili uglavnom mladi ljudi, ovi su gubici značili strahovit udar na regeneracijski potencijal ratom i epidemijskim pomorima oslabljenog stanovništva. ${ }^{12}$

Već smo ranije naglasili da patocenoza teži uravnoteženju između dominantne i drugih bolesti koje s njom u istom vremenu i na istom prostoru supostoje. U tom smislu Grmek smatra da je stabilnost patocenze snažno povezana i održavana tzv. sinkroničnim vezama koje postoje između spomenutih bolesti. Ta stabilnost i ti odnosi, dakako, nisu konačni, nego se dijakronijski mijenjaju ostvarujući patoceničnu dinamiku. Prema Grmeku, izme-

Isto, 98-99.

11 Na području sjeverne Hrvatske živjelo je pred Prvi svjetski rat 742525 stanovnika. Točan broj stradalih u pandemiji španjolske gripe nemoguće je ustanoviti zbog neprecizne dijagnostike i izgubljenih/neupotrebljivih matičnih knjiga, ali je on mogao prelaziti 6000 stanovnika, osobito ako bismo civilnom stanovništvu pridružili i vojno. V. Isto, 101, 139.

12 Pridruže li se broju stradalih u pandemiji (neposredni demografski gubici) i izgubljena rođenja zbog smrti žena i djevojčica (dugoročni demografski gubici), broj stradalih penje se na preko 17000 života. V. Isto, 147. 
đu dviju bolesti mogu postojati tri tipa odnosa koji određuju stabilnost patocenoze, ali i patoceničnu dinamiku: simbioza (prvenstveno etiološke poveznice na različitim razinama), antagonizam (imunizacijski učinci jedne bolesti na drugu) $\mathrm{i}$ indiferentnost (izostanak etioloških i drugih poveznica). ${ }^{13}$

Komorbiditet španjolske gripe i tuberkuloze tijekom Velike pandemije iz 1918. godine pripada simbiotičkom tipu odnosa, iako se isprva, dok su još postojale brojne nepoznanice o etiologiji influence, iz nejasnih razloga smatralo da je njihov odnos antagonizirajući, odnosno da tuberkuloza ima stanovite imunizacijske učinke na akutne infekcije poput influence. ${ }^{14}$ Te su pretpostavke, međutim, brzo odbačene, puno prije nego što se etiološka povezanost mogla znanstveno pobiti otkrićem uzročnika influence.

Iako, dakle, etioloških poveznica među dvjema bolestima (u užem medicinskom smislu) nema, postoje brojne podudarnosti koje ih prema drugim osnovama povezuju. U obiju se bolesti infekcija događa kroz respiratorni trakt, žarište je bolesti u bolesnikovim plućima; obje su u najvećem broju slučajeva imale smrtonosan ishod i, konačno, u obiju je dobnospecifični morbiditet i mortalitet bio koncentriran u kontingentu mladih ljudi. Sve to, uz kliničke manifestacije tuberkuloze (produktivni kašalj, opća tjelesna slabost, preznojavanje, hemoptiza), upućuje na osnovanu pretpostavku da su tuberkulozni bolesnici tijekom pandemije iz 1918. godine bili u većem riziku od infekcije i smrti, odnosno da su bili najizglednije žrtve španjolske gripe. S obzirom na veliku raširenost tuberkuloze, kumulativan učinak komorbiditeta ovih dviju bolesti mogao je 1918. izazvati katastrofičan rast pandemijskog mortaliteta.

Pratimo li mortalitetne stope od tuberkuloze tijekom 1918. i 1919. godine, dakle neposredno uoči, za vrijeme i neposredno nakon provale španjolske gripe (od lipnja1918. do lipnja 1919.), u oči upada sinkroničnost mortalitetnih trendova ovih dviju bolesti. Do tada stabilan mortalitetni trend tuberkuloze počinje nastupom pandemije naglo rasti usporedno $s$ rastom pandemijskog mortaliteta. Taj se rast nastavlja do druge polovine listopada, kada i pandemijski mortalitet doživljava klimaks, a onda zajedno s njim počinje opadati, stabilizirajući se sredinom 1919. godine na razini ispod one koja je prethodila pandemiji. Simultanost ovih trendova prilično je neobična i sasvim neočekivana jer se za rast broja smrtnih slučajeva od tuberkuloze usred iznimno virulentne pandemije influence ne mogu naći očigledni etiološki razlozi, kao ni analogije $s$ drugim uzrocima smrti koji tijekom pandemije drastično opadaju ili, pak, sasvim iščezavaju. Trendovsko preklapanje najviše, pak, začuđuje stoga što su tuberkulozni bolesnici bili najizglednije žrtve pandemije, a to je za posljedicu trebalo imati „utapanje“ mortaliteta od tuberkuloze u pandemijskom mortalitetu, odnosno pad mortalitetnih stopa od tuberkuloze tijekom pandemijskog razdoblja (kao što se dogodilo sa svim drugim uzrocima smrti).

Budući da se to nije dogodilo, a da se za rast mortalitetnih stopa tuberkuloze tijekom pandemije iz 1918. godine ne mogu pronaći valjana etiološka (i uopće biološka) objašnjenja, ne treba otkloniti mogućnost pogreške ili, bolje rečeno, privida koji je mogao proizaći iz

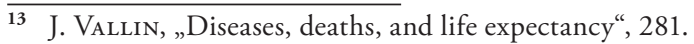

14 Barnet P. Stivelman, „Effects of influenza on pulmonary tuberculosis“, New York Medical Journal, 110/1919., $20-21$. 


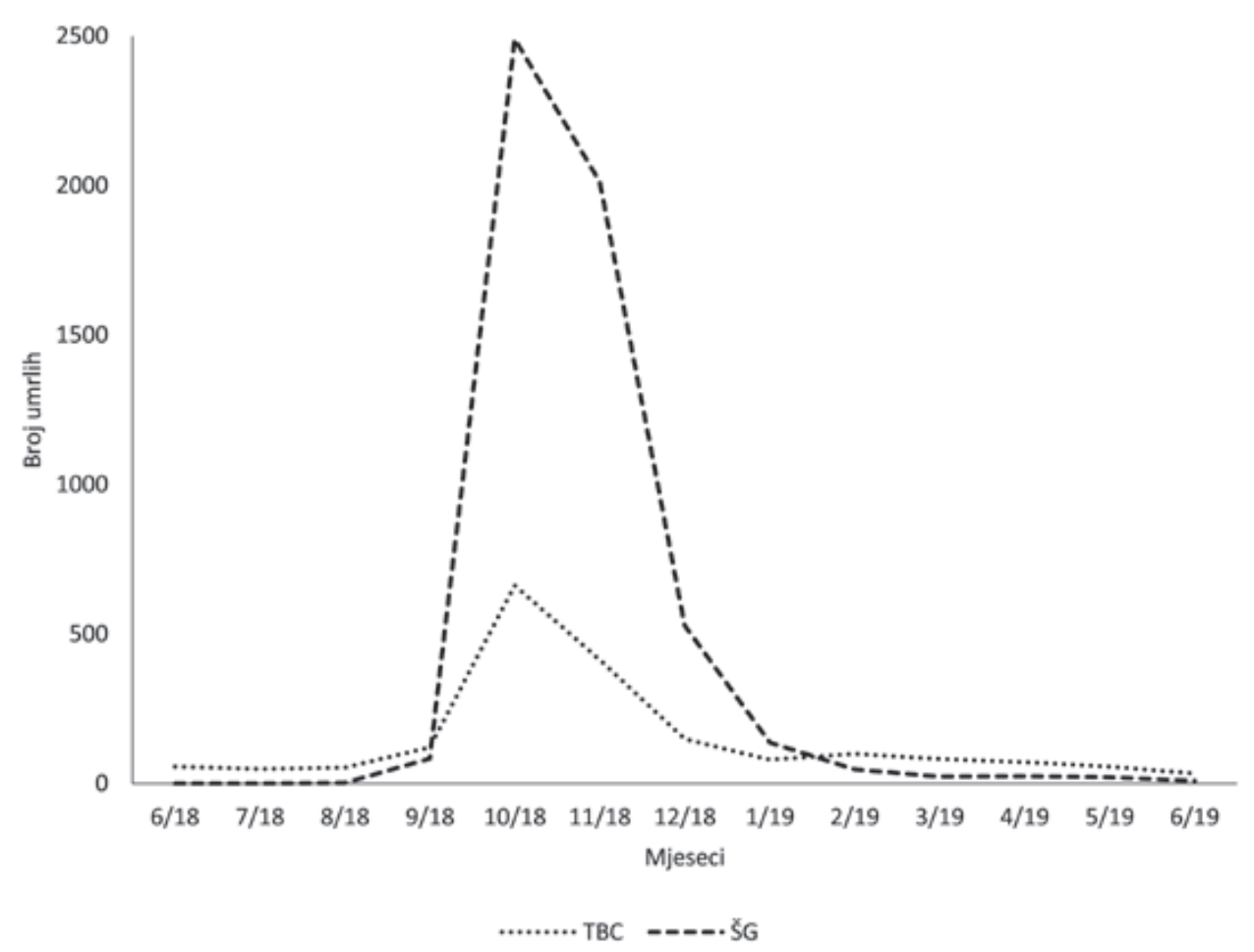

Sl. 3. Mortalitet od španjolske gripe u sjevernoj Hrvatskoj tijekom drugoga epidemijskog vala ograničene vjerodostojnosti dostupnih izvora, ali i specifičnog položaja tuberkuloze među patologijama onoga doba. Uzrok smrti koji se upisivao u matične knjige umrlih utvrđivao je mrtvozornik, a on nije morao biti liječnik i nerijetko to nije ni bio, osobito ne na selu. $S$ izuzetkom gradova i većih, razvijenijih mjesta, mrtvozorničku službu obavljali su u pravilu priučeni seljaci, čije je znanje više proizlazilo iz opažanja uočenih u neposrednom susretu $s$ relativno ograničenim brojem stalnih i povremenih (ali istih) epidemijskih uzroka smrti nego iz stvarnih uvida u medicinsku patofiziologiju. Primarna zadaća tih priučenih mrtvozornika, kojoj je bila prilagođena i njihova kratka obuka, svodila se prvenstveno na prepoznavanje simptoma (poznatih i prisutnih) zaraznih bolesti epidemijskog potencijala kako bi se u što kraćem roku suzbilo njihovo širenje. S obzirom na to da je tuberkuloza bila vrlo raširena bolest i najčešći pojedinačan uzrok smrti, simptome i kliničku sliku tuberkuloze ti su seoski mrtvozornici dobro poznavali. Unatoč tomu, vrlo je izgledno da su tijekom pandemije neke žrtve španjolske gripe (odnosno pneumonije, stvarnog pandemijskog ubojice) pripisivali smrti od tuberkuloze.

Dva su moguća razloga takvoj pogrešci. Tuberkuloza je kronična bolest od koje se (relativno) dugo bolovalo i u ono vrijeme gotovo neizbježno umiralo pa se tuberkulozne bolesnike smatralo nasmrt bolesnim ljudima. U malim sredinama ti su ljudi bili poznati i njihova se smrt očekivala. To što su u većem broju umirali tijekom pandemije moglo se, doduše, povezati sa superinfekcijom, influencom kojom se moglo pogoršati primarno stanje i ubrzati smrt, ali se uzrokom smrti ipak smatrala primarna bolest - tuberkuloza. Pogrešnom dijagnosticiranju mogla je također pridonijeti sličnost simptoma dviju bolesti (malaksalost, 
kašalj, vrućica, umor itd.), kao i kliničke slike (osobito krvarenja, u narodu dobro poznato „bacanje krvi na usta“), pa se uzrok smrti zapravo nije ni mogao očigledno razlučiti.

Ipak, iako se u nekim slučajevima smrt tuberkuloznih bolesnika tijekom pandemije španjolske gripe pripisivala njihovoj primarnoj bolesti, ne bismo rekli da je to bilo u većini. Tuberkuloza je kronična, progresivna bolest koja je u svojoj prvoj fazi latentna i utoliko nepoznata bolesniku. U latentnih tuberkulotičara, dakle bolesnika koji ni sami nisu bili svjesni svoga stanja, a oni su u vrijeme epidemijskog širenja tuberkuloze mogli činiti većinu, nije bilo osnove za povezivanje (onda ni miješanje) dvaju mortaliteta. I inače, mnogi su savjesniji (i upućeniji) mrtvozornici lučili povećan rizik od smrti i njezin uzrok. Drugu krajnost predstavljaju neka mjesta gdje su se u jeku pandemije (gotovo) sve smrti pripisivale španjolskoj gripi.

Svakako, teško je reći koliki je bio udio tuberkulotičara u pandemijskom mortalitetu, ali je taj udio s obzirom na epidemijsku raširenost tuberkuloze neizbježno morao biti velik. Štoviše, nama se čini toliko velik da je mogao utjecati na svojstva pandemijskog mortaliteta. Španjolska gripa iz 1918. godine specifična je u odnosu na prethodne epidemije influence po atipičnim dobnospolnim karakteristikama svoga mortaliteta: disproporcionalnoj koncentraciji mortaliteta u dobnim skupinama mladih ljudi (20 - 40, a osobito $25-35$ godina) i njegovoj prevladavajućoj maskulinosti. I jedno i drugo također je općenito karakteristično za mortalitet od tuberkuloze. ${ }^{15} \mathrm{U}$ hrvatskom slučaju, promatrajući oba mortaliteta - španjolske gripe i tuberkuloze - spolnospecifični mortalitet, naprotiv, pokazuje prevladavajuću femininost. Svakako, rat je mogao utjecati na povećanje spolne diferencijacije mortaliteta u obiju bolesti, ali je nije uvjetovao jer je u slučaju tuberkuloze ona prethodila ratu, a kod španjolske gripe uočljiva je i u dobnim skupinama koje nisu podlijegale mobilizaciji. Stoga se čini najizglednijim da je specifičan spolni diferencijal pandemijskog mortaliteta u sjevernoj Hrvatskoj bio određen raširenošću tuberkuloze, odnosno prevladavajućim komorbiditetom dviju bolesti, tim više što su mobilizacijom zdravog muškog stanovništva udjeli tuberkulotičara u stacionarnom stanovništvu postali još veći, a njihov utjecaj na zdravstvenu sliku pokrajine još izraženiji.

Ipak, najbolji dokaz o velikom pomoru tuberkulotičara od španjolske gripe predstavlja drastično smanjenje njihova broja neposredno nakon pandemije. O međuuvjetovanosti dviju bolesti možda najbolje svjedoče selekcijski učinci pandemijskog mortaliteta koji se očituju u postpandemijskom smanjenju mortalitetnih stopa i spolnih diferencijala kod mortaliteta od tuberkuloze. Između 1897. i 1916. godine stope mortaliteta od tuberkuloze rasle su linearno, prosječno 0,36\% godišnje. Prema toj stopi rasta, 1921. trebale su dosegnuti $20,79 \%$. Međutim, nakon 1918. stope mortaliteta od tuberkuloze naglo opadaju i 1921. godine sa stopom od $14,5 \%$ bivaju vraćene na razinu s početka stoljeća. Isto se dogodilo i sa spolnim diferencijalima mortaliteta od tuberkuloze, koji je samo u godinu dana, između 1918. i 1919., opao gotovo za trećinu (70:25). S obzirom na to da je taj pad bio najveći u dobnom rasponu od 21 do 61 godine, istom dobnom rasponu koji je bio najviše

15 Andrew Noymer - Michel Garenne, „The 1918 Influenza Epidemic's Effects on Sex Differentials in Mortality in the United States", Population and Development Review, 26/2000., br. 3, 565. 
25

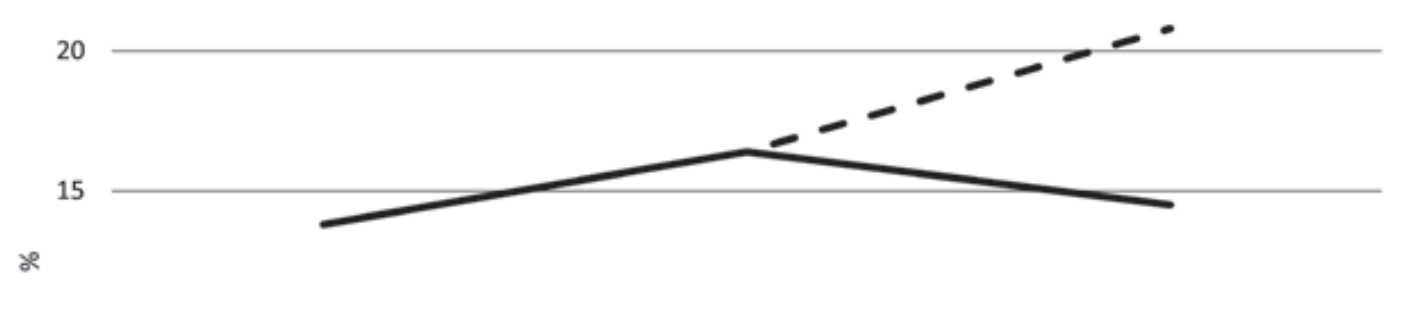

10

5

0

1901.

1911.

1921.

Godina

Očekivane stope mortaliteta

Sl. 4. Ostvarene i očekivane stope mortaliteta od tuberkuloze od 1901. do 1921. godine

pogođen španjolskom gripom, može se reći da je ona ispraznila kontingent tuberkuloznih bolesnika i smanjila njihov udio u populaciji. $\mathrm{O}$ tome postoje brojna onodobna liječnička svjedočanstva. ${ }^{16}$

Pojava pandemije španjolske gripe iz 1918. godine označava točku obrata u mortalitetnim trendovima tuberkuloze i njihov prijelaz iz rastućih u trajno padajuće. U dvadesetogodišnjem međuratnom razdoblju stope mortaliteta od tuberkuloze spale su s pretpandemijskih 19\% na 12,7\% uoči Drugog svjetskog rata. Taj je pad srednjoročno utjecao na patoceničnu dinamiku tuberkuloze, a dugoročno izazvao njezinu tranziciju koja će se dogoditi tijekom pedesetih godina prošloga stoljeća. U urbanim sredinama ta se tranzicija dogodila i prije, već tridesetih godina. Prate li se uzroci smrti u Zagrebu od 1921. do 1939. godine, postaje jasno da tuberkuloza već do sredine tridesetih godina prestaje biti dominantan uzrok smrti i da njezino mjesto u sve većoj mjeri zauzimaju kardiovaskularne bolesti, koje će postati patocenoza postmodernoga doba.

Uloga pandemije španjolske gripe u tom procesu bila je inicijalna. Pandemijski mortalitet ne samo da je apsorbirao potencijalni mortalitet od tuberkuloze, vrativši ga na stope $s$ početka stoljeća, nego je i pražnjenjem kontingenta tuberkuloznih bolesnika radikalno smanjio broj kliconoša i usporio daljnje širenje bolesti. Međutim, smanjenjem epidemiološkog potencijala tuberkuloze nije bila otklonjena mogućnost njezina povratka kao vodećeg

$\overline{16}$ N. Anušić, U sjeni Velikoga rata, 131. 
zdravstvenog problema, nego samo odgođena. Istrebljenje tuberkuloze ovisilo je prvenstveno o promjenama vezanima za društveni kontekst bolesti. Te se promjene počinju događati tridesetih godina prošlog stoljeća zahvaljujući donošenju dvaju zakonskih rješenja: Zakonu o suzbijanju zaraznih bolesti iz siječnja 1930. i Zakonu o bolesnicima iz veljače iste godine. Prvi je stvorio okvir za poduzimanje niza mjera iz sfere socijalne politike, prije svega razvoja mreže zdravstvenih ustanova, bolnica, zavoda tuberkuloznih dispanzera i ambulanta, ali i za provođenje preventivnih mjera usmjerenih na čitavu populaciju, kao što je cijepljenje djece školske dobi. Zakon o bolesnicima predviđao je, pak, državno subvencioniranje troškova liječenja tuberkuloznih bolesnika koji ih sami nisu mogli podmiriti. Povećanjem bolničkih kapaciteta i dostupnošću besplatnog liječenja omogućeno je izdvajanje kliconosnih bolesnika iz obiteljskog okruženja, a time i smanjenje rizika prenošenja bolesti. Dakako, tome treba dodati i iznimno uspješne kampanje narodnog prosvjećivanja koje je od svog osnivanja 1926. vodila Škola narodnog zdravlja pod vodstvom agilnog Andrije Štampara, a financiranog izdašnim pokroviteljstvom Lige naroda i Rockefellerove fundacije. Sinergija ovih djelovanja omogućila je postupan pad morbiditeta od tuberkuloze i tijekom idućih dvadesetak godina njezino prevladavanje kao društveno relevantnog zdravstvenog problema, a time i tranziciju patocenoze.

Uloga pandemije španjolske gripe u tom procesu važnija je nego što se u prvi mah može učiniti. Iako je utjecaj pandemije na smanjenje stopa morbiditeta i mortaliteta od tuberkuloze bio kratkoročan, ili u optimističnijoj varijanti eventualno srednjoročan, ispražnjenje kontingenta tuberkulotičara učinilo je mjere socijalne politike učinkovitima jer su sada mogle obuhvatnije zahvatiti populaciju kojoj su bile usmjerene. Da pandemije španjolske gripe nije bilo i da se tuberkuloza nastavila širiti prema predratnim trendovima, domet poduzetih mjera bio bi ograničen, a tranzicijski proces odgođen ili, u najboljem slučaju, značajno produžen.

\section{ZAKLJUČAK}

Tijekom 19. stoljeća, osobito na njegovu kraju, i početkom 20. stoljeća tuberkuloza se učvršćuje kao vodeći zdravstveni problem u sjevernoj Hrvatskoj i postaje bolest epidemijskih razmjera s dominantnim stopama morbiditeta i mortaliteta. Utoliko možemo govoriti o patocenozi tuberkuloze. Visok mortalitet od tuberkuloze biva presječen ujesen i zimi 1918./1919. i prevladan mortalitetom pandemijske španjolske gripe. Tijekom pandemije tuberkulozni bolesnici bili su u većem riziku od smrti zbog preklapanja dobnospolnih karakteristika morbiditeta dviju bolesti, istog žarišta infekcije i slabijih izgleda za prevladavanje infekcije zbog fizičke insuficijencije. Komorbiditet tuberkuloze i španjolske gripe izazvao je velik pomor i pražnjenje kontingenta tuberkuloznih bolesnika, što je dovelo do drastičnog pada mortalitetnih stopa od tuberkuloze u neposrednom postpandemijskom razdoblju. Taj pad označio je prekretnicu u kretanju mortalitetnih trendova tuberkuloze i njihov prijelaz iz rastućih u trajno padajuće, što je u idućih tridesetak godina dovelo do tranzicije patocenoze i uspostave nove patocenoze kardiovaskularnih bolesti pedesetih godina 20. stoljeća. 
U tranzicijskom procesu ključnu ulogu imale su mjere socijalne politike koje Ministarstvo socijalne politike i narodnog zdravlja Kraljevine Jugoslavije i Škola narodnog zdravlja počinju provoditi tridesetih godina prošlog stoljeća. Uspjeh tih mjera, koji je u srednjoročnom razdoblju doveo do patocenične tranzicije, bio bi dvojben i, u najboljem slučaju, ograničenog dometa da broj tuberkuloznih bolesnika nije pandemijskim pomorom bio reduciran na mjeru koju su infrastrukturni i financijski kapaciteti novouspostavljenog zdravstvenog sustava mogli apsorbirati. Stoga se drastično smanjenje kliconosnih bolesnika tijekom pandemije španjolske gripe iz 1918./1919. može smatrati ključnim preduvjetom koji je utjecao na dinamiku i uspjeh procesa patocenične tranzicije u sjevernoj Hrvatskoj.

\section{$\cos$}

\section{Literatura}

Nikola Anušıć, U sjeni Velikoga rata. Pandemija španjolske gripe 1918. - 1919. u sjevernoj Hrvatskoj, Zagreb 2015.

Jean-Noël Biraben, „Les pathocenoses en Europe“, Histoire des maladies (ur. Mirko Grmek), Paris 1996., 1-36.

Ana BorovečKi - Ira GJenero-Margan, „Epidemiological Analysis of Tuberculosis in the Kingdom of Croatia and Slavonia during 1901 - 1910“, Croatian Medical Journal, 43/2002., br. 3, 350-354.

Vladimir ĆEPulić, Suzbijanje tuberkuloze u Zagrebu, Zagreb 1940.

Mirko Dražen GrmeK, Bolesti u osvit zapadne civilizacije. Istraživanja patološke stvarnosti u grčkom predhistorijskom, arhajskom i klasičnom dobu, Zagreb 1989.

Nail P. A. S. Johnson - Juergen Mueller, „Updating the Accounts: Global Mortality of the 1918-1920 'Spanish' Influenza Pandemic“, Bulletin of the History of Medicine, 76/2002., br. 1, $105-115$.

Andrew Noymer - Michel Garenne, „The 1918 Influenza Epidemic’s Effects on Sex Differentials in Mortality in the United States", Population and Development Review, 26/2000., br. 3, $565-581$.

Milan Smrexar, Priručnik za političcku upravnu službu u kraljevinah Hrvatskoj i Slavoniji, sv. 1, Zagreb 1899.

Barnet P. Stivelman, „Effects of influenza on pulmonary tuberculosis“, New York Medical Journal, 110/1919., 20-21.

Jacques Vallin, „Diseases, deaths, and life expectancy“, Genus, 61/2005., br. 3-4, 279-296. 


\section{$\cos$}

\section{WHEN DEATH DEVOURS DEATH: THE IMPACT OF THE I9I8 SPANISH FLU PANDEMIC ON THE DYNAMICS OF PATHOCENotic CHANGe in Northern Croatia}

The Croatian and French epidemiologist Mirko Grmek advocated for a synthetic approach to epidemiological research, claiming that each disease should be observed in relation to all other diseases existing concurrently in the same territory. This coexistence, which he termed pathocenosis, is determined by the dominant pathology, but also by the ecological, social and cultural environment, which can affect the stability of the pathocenosis and cause it to change. The paper examines the influence of the environment on the changes in the tuberculosis pathocenosis in Northern Croatia, especially with regard to the comorbidity between tuberculosis and the Spanish flu during the 1918 pandemic. The research was conducted in the north of Croatia because that subregion provides comparatively the best conditions for demographic and epidemiological research, but the findings are applicable to the country at large. The study has shown that tuberculosis patients were at a higher risk of death during the Spanish flu pandemic and that the comorbidity between these two diseases influenced the higher pandemic mortality impact by inducing the depletion of the contingent of tuberculosis patients, as well as the post-pandemic decline in the number of deaths caused by tuberculosis. Moreover, following the pandemic, that decline became permanent, resulting in a pathocenotic change in the 1950 s at the latest. This change, however, cannot be attributed solely to the mortality trauma generated by the Spanish flu pandemic, since its effects would only be short-term in an unchanged social environment. Thus, the the public health measures which were implemented as part of the interwar Yugoslav state's social policies prove all the more important, as the drastic decline in the number of tuberculosis patients during the Great Pandemic of 1918 demonstrates their effectiveness despite their limited range.

Key words: pathocenosis, tuberculosis, the Spanish flu, Northern Croatia, 1918 


\section{1. \\ HRVATSKO DRŽAVNO KAZALIŠTE \\ U ZAGREBU 1941. GODINE - \\ DANI SMRTI, STRAHA I PONIŽENJA}

\section{Snježana Banović}

UDK: 792(497.5)“1941“:364.27

Izvorni znanstveni članak

Sažetak: Autorica se bavi prvim mjesecima rada Hrvatskoga državnog kazališta (travanj prosinac 1941.) pod upravom intendanta Dušana Žanka i događajima koji su se ondje odigrali, a za koje su ključni bili smrt i strah od smrti. U skladu s rasnim i ostalim zakonima koji su ozakonjivali teror prema nepoćudnim skupinama - komunistima, Srbima, Židovima, masonima - vršila su se odmah nakon proglašenja Nezavisne Države Hrvatske brojna hapšenja i likvidacije. Ljeti 1941. uhapšen je i likvidiran velik broj studenata, a među njima bili su i mladi glumački pripravnici iz ansambla zagrebačkog Hrvatskoga državnog kazališta. To je među ostale u tom velikom kolektivu unijelo nemalu paniku i strah. Istovremeno, kazalište je gotovo svakodnevno bilo poprištem brojnih, obimom i sadržajem različitih manifestacija - međudržavnih, državnih, ideoloških i prigodnih - među kojima je redovito bilo i obilježavanje obljetnica smrti hrvatskih velikana. Na njima se najčešće manifestirala moć institucija Pavelićeva režima i njega samoga, a jedan od dominantnih elemenata koji je morao biti uključen u svaki od svečanih sadržaja na sceni, bio je novi duh društva unutar kojeg su režim i njegova načela na najviše mjesto postavljali upravo izbor između smrti i države. Strah od smrti, koji se generirao iz dana u dan, izvršio je znatan utjecaj na odnose u kolektivu središnjeg kazališta Nezavisne Države Hrvatske, ali i na brojne tragične sudbine pojedinaca. ${ }^{1}$

Ključne riječi: Nezavisna Država Hrvatska, Hrvatsko državno kazalište u Zagrebu, čistoća nacije i države, smrt, strah, ustaški duh, teror, obljetnice

\section{ZAKONSKI OKVIR ZA PROVOĐENJE TERORA}

7 a ustašku ideologiju hrvatska nacija nije bila samo povijesni fenomen, već i krvna zajednica koja, unatoč znatnom broju nehrvata na svom području, ima ekskluzivna prava na teritorij Nezavisne Države Hrvatske. ${ }^{2}$ Sukladno s načelima ustaškog pokreta, to je bilo

$1 \quad$ Naslov članka preuzet je iz dnevnika članice kazališne uprave i aktivistice NOP-a, književnice Božene Begović. Usp. Ante Nazor, „Dug zaboravljenoj književnici“, Vjesnik (Zagreb), br. 9676, 28. i 29. 4. 1974., 13.

2 Površina NDH iznosila je 1941. godine $115133 \mathrm{~km}^{2}$. Imala je 6966729 stanovnika, od toga 4817000 Hrvata (uključujući bosanskohercgovačke muslimane), 1848000 Srba, 145000 Nijemaca, 70000 Mađara, 37000 Slovenaca, 44267 Čeha i Slovaka. Usp. Hrvoje Matrović, Povijest Nezavisne Države Hrvatske, Zagreb 2002., 82. 
povijesno, tj. vrhovničko pravo, ${ }^{3}$ prema kojem etnički nehrvati nisu u novouspostavljenoj državi bili ravnopravni državljani. ${ }^{4}$ Provedba rasne politike postala je temeljno državno pitanje, a krajnji je cilj bio stvoriti „čisti hrvatski životni prostor koji će omogućiti egzistenciju čiste hrvatske nacije“. 5 Zbog toga trebalo je ustrojiti pravni sustav koji će ozakoniti teror i odrediti koje će ga državne institucije provoditi. Prva zakonska odredba koja se odnosi na pitanje očuvanja čistoće nacije i životnog prostora bila je Zakonska odredba za obranu naroda $i$ države, donesena samo tjedan dana nakon proglašenja NDH. Njome se utvrdilo da svatko „tko na bilo koji način povrijedi čast i životne interese hrvatskog naroda ili bilo na koji način ugrozi opstanak NDH ili državne vlasti, pa makar djelo i ostalo samo u pokušaju, čini se krivcem zločinstva veleizdaje“ te ga zato treba „stići kazna smrti“. ${ }^{\text {Dva- }}$ desetak dana kasnije ta je odredba dopunjena novom, prema kojoj se kazna „ima izvršiti strijeljanjem“. Potom je pojašnjeno da je „krivac za zločinstvo veleizdaje“ onaj koji „na bilo koji način povrijedi samo čast“, kao i onaj koji „na bilo koji način povrijedi samo životne interese hrvatskog naroda“" Nikada nije objašnjeno što je to čast, a što životni interesi hrvatskog naroda.

Već 30. travnja proglašene su Zakonska odredba o rasnoj pripadnosti te Zakonska odredba o zaštiti arijske krvi i časti hrvatskog naroda (rasni zakoni). ${ }^{8}$ Prema njima, u državnu službu nije se više smjelo upošljavati nearijevce jer se „rasno tuđi elementi ne smiju uplitati u pitanja upravljanja naroda i promicanje narodne kulture, jer će djelovati razorno i promicati i skretati život pravcem narodno stranim i protivnim njegovoj tradiciji i duhovnosti“?

Iste je te večeri Dušan Žanko, u svome prvom nastupu u svojstvu intendanta, sa scene „dahom od ganuća“ objavio da je kazalište od toga dana „konačno i potpuno slobodno“ i da se odsad zove Hrvatsko državno kazalište, a svečana loža postaje Poglavnikovom te se odmah započinje $s$ njezinim „preuređenjem i poljepšanjem ${ }^{\prime 10}{ }^{10} \mathrm{U}$ tome je trenutku u gledalištu bio i doglavnik Mile Budak, a na sceni prikazala se svečana izvedba Gundulićeve Dubravke, praizvedene samo tjedan dana prije. Obradio ju je i režirao Tito Strozzi, a glazbu komponirao Jakov Gotovac, koji je i dirigirao orkestrom. ${ }^{11}$

3 Danijel Crljen (prir.), Načela hrvatskog ustaškog pokreta, Zagreb 1942., 7, 57-67.

4 Više u: Ivo Goldstein - Slavko Goldstein, Holokaust u Zagrebu, Zagreb 2001., 103-162; Fikreta Jelić-Butić, Ustaše i Nezavisna Država Hrvatska 1941-1945., Zagreb 1977., 135-185; H. Matković, Povijest Nezavisne Države Hrvatske, 175-189; Jozo Tomasevich, War and Revolution in Yugoslavia, 1941-1945. Occupation and Collaboration, Stanford 2001., 376-409.

5 F. Jelić-Butić, Ustaše i Nezavisna Država Hrvatska, 158.

6 Narodne novine (Zagreb), br. 4, 17. 4. 1941., 2.

7 Isto, br. 22, 8. 5. 1941., 1; br. 24, 10. 5. 1941., 1.

$8 \quad$ Isto, br. 16, 30. 4. 1941., 1; br. 17, 2. 5. 1941., 1; Hrvatski narod (Zagreb), br. 78, 1. 5. 1941., 1; Ustaša. Dokumenti o ustaškom pokretu (prir. Petar Požar), Zagreb 1995., 163-164.

9 Ustaša. Dokumenti o ustaškom pokretu (prir. P. Požar), 165-169.

10 Hrvatski narod (Zagreb), br. 79, 2. 5. 1941., 8; br. 97, 20. 5. 1941., 7.

11 Strozzijeva obrada Gundulićeve pastirske igre, praizvedene u originalnoj verziji u Zagrebu 1888. godine, uključuje dopisanu scenu čuda u hramu, koju Gundulić samo spominje, za što su upotrijebljeni stihovi iz drugih Gundulićevih djela. Usp. Tito Strozzi, „Obradbe i dramatizacije“, Hrvatsko narodno kazalište. Zbornik o stogodišnjici. 1860 - 1960 (ur. Đuka Berkeš), Zagreb 1960., 231. Koreograf je bio Vatroslav Krčelić, a scenograf i kostimograf Marijan Trepše. Igrali su svi prvaci ansambla Drame: V. Bek, J. Maričić, H. Nučić, V. Afrić, C. Jakelić, B. Kraljeva, V. Podgorska, N. Vavra, J. Laurenčić, J. Rutić, Đ. Dević, I. Kropš, D. Dujšin. 
Nakon rasnih zakona, u lipnju stiže i Zakonska odredba o prijekim sudovima, koja je predviđala samo jednu kaznu - smrtnu, i to strijeljanjem, a na presudu nije bio dopušten nikakav pravni lijek jer molba za pomilovanje nije imala „odgodne moći“. Kazna se trebala izvršiti „nakon tri sata, računajući od časa proglašenja presude“.${ }^{12}$ Da bi se stvorila atmosfera u kojoj će zločin postati moguć, vlasti NDH odmah su nakon osnutka države pokrenule bjesomučnu harangu protiv komunista, Srba, Židova i Roma, a da bi se opravdao masovan zločin koji se pripremao, trebalo je uvjeriti stanovništvo da su pripadnici tih naroda najveća i konstantna opasnost za novoosnovanu državu i njezin narod. Uskoro je poglavnik proširio kompetencije uredbi o prijekom sudu novom Zakonskom odredbom o nadopuni zakonske odredbe o prijekom sudu i Zakonskom odredbom o pokretnom prijekom sudu. ${ }^{13}$ Samo dva dana kasnije strijeljana su desetorica zatočenika iz Kerestinca.

Književni povjesničar Antun Barac zapisao je u svojim sjećanjima iz logora u Staroj Gradišci da je to bilo vrijeme „kad su ljude po noći izvlačili iz kuća, hvatali ih po ulicama, odvodili u zatvore i logore, ubijali bodežima, kundacima, strojnim puškama“. ${ }^{14}$ Glumački prvak Vjekoslav Afrić, pak, opisuje racije koje su bile svakodnevnica, slijedom čega nitko „osim samih ustaša nije mogao da bude bezbedan za svoju egzistenciju“, a redoviti kazališni gledatelj i budući glazbeni kritičar, Židov Branko Polić, koji će uskoro s obitelji biti interniran u talijanski logor na otoku Rabu, prisjetio se u svojoj autobiografiji da „oni koji nisu potpadali pod rasne zakone - njih bi naprosto progutao mrak“. Zato su se mnogi „u Zagrebu držali maksime 'ne znam ništa, ne vidim ništa', iako su se progoni i deportacije Židova i Srba događale ispred njihovih očiju“. ${ }^{15}$ Član Mjesnoga komiteta SKOJ-a Mojmir Martin kasnije se prisjećao: „Smrt je svuda oko nas. Na ulici, na plakatima, na stupcima novina i u šapatu ljudi. U takvim vremenima čovjek otvrdne, ili izgubi nerve."16

Osim terorom koji je sijao strah, čistoća nacije i države trebala se graditi i braniti žestokom propagandom, a umjetničke ustanove, među njima naročito kazalište, bile su vlastima najbolje sredstvo za to djelovanje - što zbog svog svakodnevnog izlaganja velikom broju ljudi u publici, u tisku i na radiju, što zahvaljujući reputaciji koju je velik broj umjetnika imao u tadašnjem društvu.

Doglavnik i kratko vrijeme ministar resornoga ministarstva Mile Budak više je puta ponavljao da Židovima i Srbima nema mjesta u hrvatskim kazalištima, a ostalim nehrvatima treba „ispitati vladanje u prošlosti i karakter, i prema tome postupati“. Za njega je hrvatska domovina imala neprijatelje koji „nisu članovi hrvatske narodne zajednice. To su Srbi i Židovi. ${ }^{{ }^{17} 7}$ A takvi nisu više smjeli ne samo na scenu nego ni u gledalište: intendant Žanko će $\mathrm{u}$ jednom svom kasnijem istupu posebno istaknuti činjenicu da među abonentima kazališta nema, „kao što se to u javnosti krivo mislilo, ni Židova ni Srba“. ${ }^{18}$

12 Narodne novine (Zagreb), br. 58, 24. 6. 1941., 2; Ustaša. Dokumenti o ustaškom pokretu, 206-208; F. JELIĆ-Butić, Ustaše i Nezavisna Država Hrvatska, 159-160; H. Matković, Povijest Nezavisne Države Hrvatske, 176-179.

13 Narodne novine (Zagreb), br. 61, 27. 6. 1941., 1.

14 Antun BARAC, „KZSTG“, Europski glasnik, 9/2004., br. 9, 645.

15 Branko Polić, Imao sam sreće, Zagreb 2006., 72.

16 Mojmir Martin, „Primorska ulica - sukob i hapšenje 11. oktobar 1941.“, Revolucionarni omladinski pokret u Zagrebu 1941-1945. Zbornik povijesnih pregleda i sjećanja, sv. 2, Zagreb 1984., 79.

17 Hrvatski narod (Zagreb), br. 143, 7. 7. 1941., 3.

18 Dušan Ž Anko, „Hrvatsko državno kazalište u Zagrebu u drugoj godini svoga rada u slobodi“, Nova Hrvatska (Zagreb), br. 86, 10. 4. 1943., 21. 
Dobro je odmah u travnju 1941. predvidjela Božena Begović, članica Uprave HDK-a, usto i aktivistica NOP-a i AFŽ-a, „pjesnikinja-borac protiv mraka i zla“, kada je s ogorčenjem ustvrdila da „dolaze dani smrti i poniženja“. ${ }^{19}$

\section{MJere protiv KAZALišniH UMJETNiKA PRAVOSLAVACA, ŽLIDOVA I KOMUNISTA}

Nije trebalo dugo čekati do policijskih mjera protiv pravoslavnih i židovskih kazališnih umjetnika i djelatnika. Prva grupa pravoslavaca biva uhapšena već 27. travnja 1941., a druga sljedećega dana, 28. travnja 1941., svi prema nalogu ustaškoga redarstva i njegova zloglasnog savjetnika Ivana Britvića. U zatvor u Petrinjskoj ulici odvedeni su istaknuti glumci Aleksandar Binički, Dejan Dubajić, Bela Krleža, Stevan Vujatović i Milan Vujnović, uz njih i prvi redatelji Branko Gavella i Tito Strozzi, Hrvat koji je zbog ženidbe s ruskom balerinom Irinom Aleksandrovnom prethodno prešao na pravoslavlje. ${ }^{20} \mathrm{U}$ Petrinjskoj su se svi „iznenadili pravoslavnom Strozziju, a zatim su ga energično zamolili da se udalji“.. ${ }^{21}$ Među uhapšenima bili su i članovi Opere: dirigent Đorđe Vaić, solist-bariton Pajo Grba, čelist Pavao Stojković i Fjodor Dimitrijev, članovi opernoga zbora Stana Sumić i Vladimir Svetlični te šaptači Pero Radmanović i Joco Orobović, ali i dugogodišnja ravnateljica Baleta Margareta Froman i solisti Olga Naumova-Orlova i Žorž (Georg) Skrigin. Od tehničkoga osoblja uhapšeni su pročelnik muške garderobe Andrija Šukić, vatrogasac Dušan Beč te dekorater Ilija Šušić. ${ }^{22}$ Froman će biti razriješena dužnosti i umirovljena već u svibnju, kada vodstvo Baleta preuzimaju bračni i plesački par Ana Roje i Oskar Harmoš. ${ }^{23}$

Intendanta Žanka nakon toga je događaja nazvao Miroslav Krleža i ljutit upitao zašto su uhapšeni, na što mu je Žanko, za kojeg je Krleža primijetio „da je bio pristojan“, priopćio da su uhapšeni jer nisu Hrvati, a Krleža je uzvratio da su oni - iako nisu Hrvati - hrvatski umjetnici „koji blage veze s politikom nemaju?!“. Žanko je na to odgovorio: „Gospodine Krleža, žao mi je, nesretan sam zbog toga, ali takva su vremena došla. Ništa ne mogu učiniti, nego da i ja odavde odem. ${ }^{24}$ Sama je Bela Krleža kasnije, pretjerujući u opisu neugodna doživljaja, opisala svoje iskustvo: „Osam dana i noći sjedila sam na stolici u rukavicama i sa šeširom na

\footnotetext{
19 Ante Nazor, „Dug zaboravljenoj književnici“, Vjesnik (Zagreb), br. 9676, 28. i 29. 4. 1974., 13.

20 Odsjek za povijest hrvatske književnosti, kazališta i glazbe Hrvatske akademije znanosti i umjetnosti, Zbirka dokumenata Hrvatskoga narodnog kazališta (dalje: HAZU, Zbirka HNK), 7471, „Pravoslavci u zatvoru“, dokument bez datuma i potpisa.

21 Eliza Gerner, Tito Strozzi. Svjetla i sjene jednoga glumačkog puta, Zagreb 2004., 144.

22 Hrvatski državni arhiv, Zagreb (dalje: HDA), HR-HDA-259, Redarstvena oblast za Grad Zagreb, policijski kartoni: Đ. Vaić (5758), P. Grba (1549), P. Stojković (4713), S. Sumić (4779), J. Orobović (3456), A. Šukić (5273), M. Froman (1323), O. Naumova (3338), G. Skrigin (4396) i A. Šukić (5273). Usp. i HAZU, Zbirka HNK, 7471, „Pravoslavci u zatvoru“.

23 Hrvatski narod (Zagreb), br. 91, 14. 5. 1941., 5. Usp. HAZU, Zbirka HNK, 9021, Odluka o umirovljenju M. Froman. No, ona će već u srpnju 1941. biti ponovno „reaktivirana u narodnom kazalištu“. Usp. HAZU, Zbirka HNK, 9022.

24 Enes Čengić, S Krležom iz dana u dan, knj. 2: Trubač u pustinji duha, Zagreb 1985., 285. Usp. i E. Gerner, Tito Strozzi, 144 .
} 


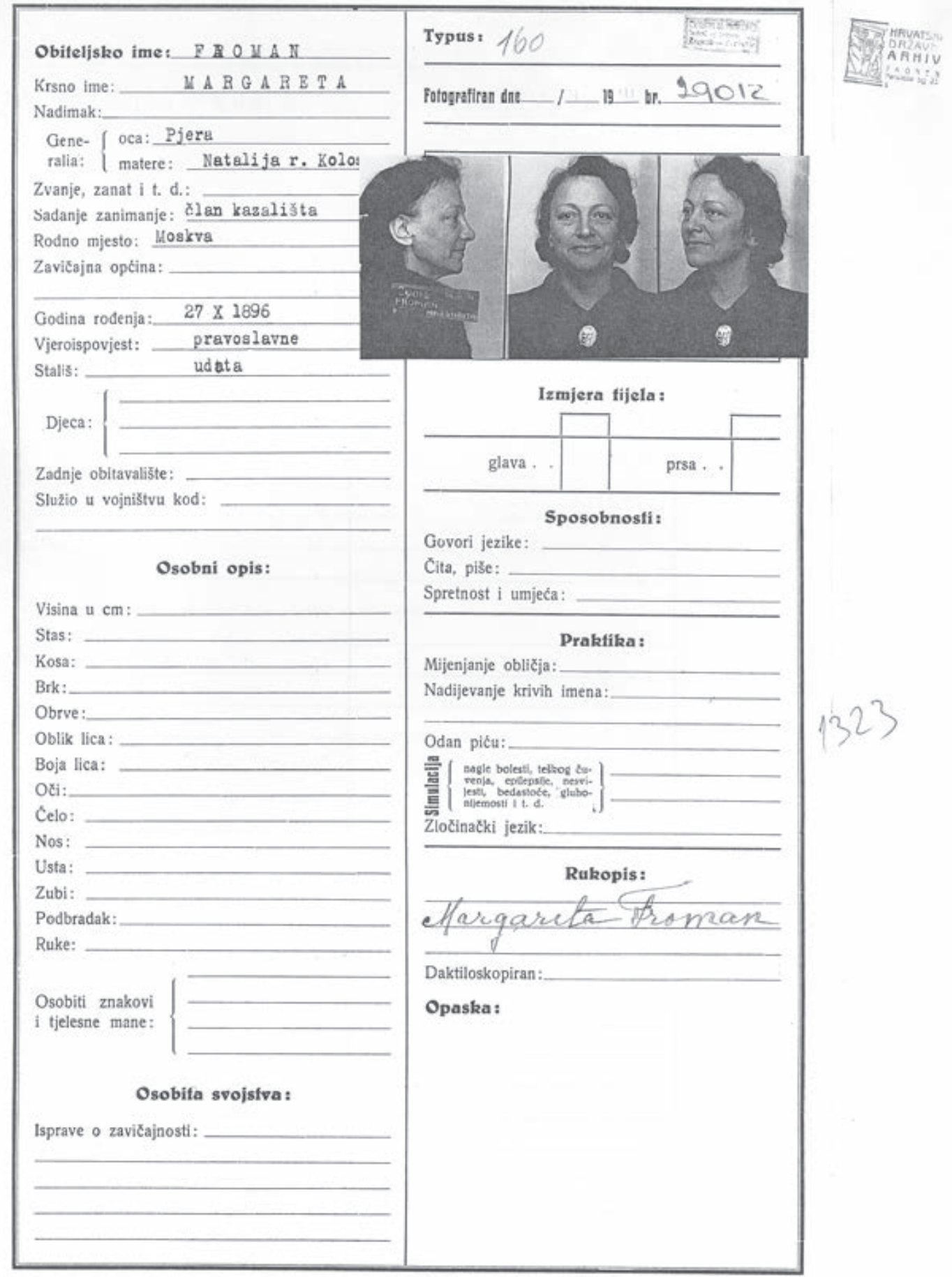


glavi. Znajući da u tom mnoštvu žena ima agentprovokatora, stalno sam govorila: ‘Ovo je greška, ljudi! To je neka zabuna, sve će se ovo razjasniti.'“25 Tako je i bilo - do kraja tjedna svi su pušteni. Netko istoga dana, a neke su zadržali duže: Branko Gavella je u Petrinjskoj proveo tri dana, a glumac Salko Repak najduže. ${ }^{26}$ Dvije godine poslije Krleža je zapisao u Dnevniku da je Bela kući stigla mrka i bijesna: „U dobrom stilu. Duboko uvrijeđena.“27

Bez obzira na to što je sve prošlo bez posljedica, taj je događaj za mnoge u Kazalištu izazvao velik strah, „ljudi su bili zaista obezglavljeni, a ustaše se prosto zabavljahu“. ${ }^{28}$ „Igrahu se $s$ ljudima kao mačke s miševima", zapisao je Afrić. ${ }^{29}$ Bilo je to vrijeme brojnih početaka masovnih izgona Srba iz Zagreba. ${ }^{30}$

Stoga su svi Srbi, ako su željeli ostati u kazalištu, već do ljeta morali obaviti prijelaz na katoličanstvo. Dirigent Pajo Grba učinio je to 19. lipnja 1941. kod kapelana A. Novaka u župi sv. Blaža te o tome odmah obavijestio kazališnu upravu, dostavivši im „Izvadak iz knjige prijelaza rkt. župe sv. Blaža u Zagrebu“, u kojem su kao svjedoci navedeni njegova supruga Darinka i zvonar crkve August Šimunić. ${ }^{31}$ Isto su učinili i dirigent Đorđe Vaić, članovi orkestra Stjepan Vuković i Stjepan Veledinović, pjevač Pavao Grba, operni šaptač Petar Radmanović, balerine (i sestre) Anđelka i Darinka Ilić, glumac Stevan Vujatović (postao je Stjepan), pozornički nadzornik i dekorater Ilija Šušić, garderobijerka Karolina Štajner i pročelnik muške garderobe (po novome „rušnice“) Andrija Šukić te su kao takvi bili označeni kao „rkt. prijelaznik“ i ,grko-kat. prijelaznik“.32 Istovremeno, glumac i redatelj Aleksandar Binički, oženjen katolkinjom Ružom r. Jakšić, prešao je - kao i Branko Gavella i Dejan Dubajić - 9. srpnja, zajedno sa sinovima Stevom i Dušanom, s pravoslavne na dopuštenu grkokatoličku vjeru. Odmah je poslao molbu Odsjeku za umjetnost, književnost i novinstvo Ministarstva nastave (koje ju je odmah proslijedilo Ministarstvu unutrašnjih poslova) u kojoj moli da ga se - samo zato što je rođen u Beogradu - ne ubraja među Srbijance i ne isključi „iz hrvatske narodne zajednice“ jer nije „doseljenik niti uljez“. Stoga je zatražio da se „izda potvrda da se zakonski propisi određeni za Srbijance, ne protežu na mene i moju obitelj“. Dva mjeseca kasnije odgovorio mu je glavni tajnik Predsjedništva Vlade da je molba „povoljno riješena“ te da mu se „službeno potvrđuje“ da njegova čitava obitelj „,ne potpada pod udar propisa o Srbijancima, već se smatra Hrvatima, te prema tome ne dolazi ni u obzir za iszelenje iz $\mathrm{NDH}^{\text {“ }}$. $^{3}$

Pravoslavci koji nisu napravili prijelaz morali su otići pa je tako glumac Sima Ilić, inače jedan od najzaposlenijih u ansamblu, tijekom ljeta posljednji put nastupio na zagrebačkoj

25 E. Čengić, S Krležom iz dana u dan, knj. 2, 285. Više o bračnom paru Krleža tijekom NDH, u: Snježana Banović, „Bela i Miroslav Krleža u NDH - vedri repertoar kao cijena za život", Intelektualci i rat 1939. - 1947. Zbornik radova s međunarodnog skupa Desničini susreti 2011. (ur. Drago Roksandić i Ivana Cvijović Javorina), Zagreb 2012., 9-24; Ista, Kazalište krize, Zagreb 2013., 139-162.

26 Marija Crnobori, Životić. Eseji, kazališni i ini (prir. Jelena Lužina), Pula 2011., 208.

27 Miroslav KrležA, Dnevnik, sv. 4: 1943., Sarajevo 1981., 227.

28 Vjekoslav Afrić, U danima odluka i dilema, Beograd 1970., 78.

29 Isto.

30 Više o tome u: Filip ŠKILJAN, Organizirana prisilna iseljavanja Srba iz NDH, Zagreb 2014.

31 HAZU, Zbirka HNK, 22501, dopis P. Grbe upravi HDK, 23. lipnja 1941.

32 Isto, 7491, Osoblje - popis „povojničenih“ članova HDK (svih) s naznakom „vjera“.

33 HR-HDA-223, Ministarstvo unutrašnjih poslova NDH, Predsjednički ured, kut. 27, 29408/1941. Molba A. Biničkoga od 19. VII. 1941. i njezino rješenje. 


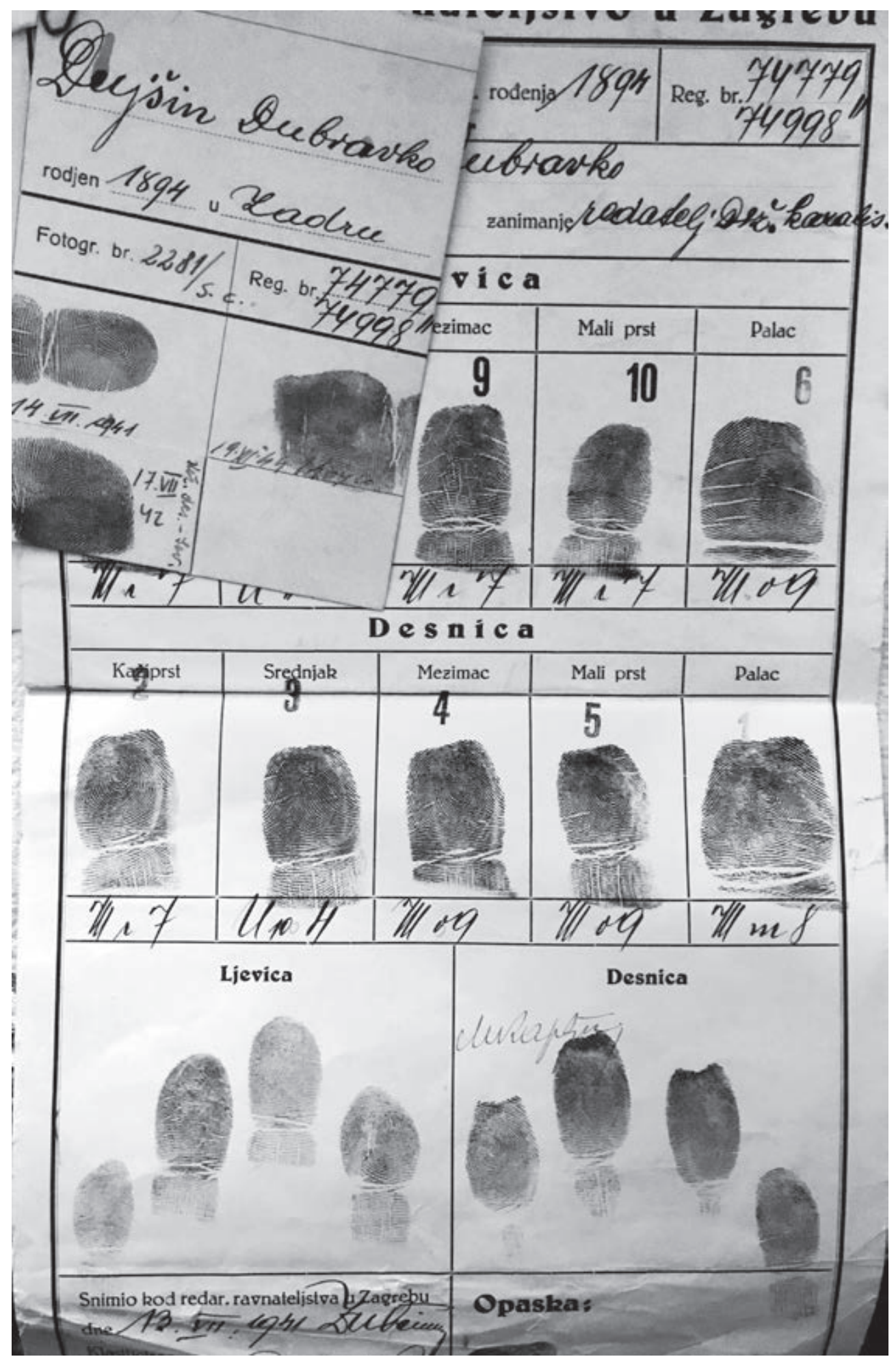

Sl. 2. Otisci prstiju Dubravka Dujšina uzeti nakon uhićenja 1941., 1942. i 1944. godine 
sceni. ${ }^{34}$ Za njega je „iako je Srbin“, uprava urgirala pri resornom ministarstvu da se makar „zadrži u službi, bilo u narodnom kazalištu, bilo u pokrajini“, ali bez uspjeha. ${ }^{35} \mathrm{U}$ kazalište se nakon spomenutog hapšenja u travnju nije vratio ni glumac Milan Vujnović. Neko vrijeme proveo je skrivajući se u Zagrebu, a potom je otišao u Split. Vratio se u Zagreb u travnju iduće godine, netom prije bijega s Afrićevom grupom u partizane. ${ }^{36}$

Tijekom proljeća 1941. studenti u Zagrebu bili su prvi na udaru režima. Među njima bila je jaka organizacija studenata frankovaca, koji su godinu ranije osnovali svoj, tada ilegalan, Ustaški sveučilišni stožer i sastavili popis „nepoćudnih osoba“ s podacima o njihovu političkom djelovanju od 1935. godine nadalje. S njima se „više puta zakačio“ i sâm Afrić, kada je neke od njih vidio „na ulici s puškama i ustaškim kokardama““. ${ }^{37}$ Ta studentska ustaška organizacija zaplijenila je arhivu predratnih studentskih udruženja i društava te se njome koristila prilikom hapšenja, koja su započela u lipnju 1941., a ujesen dostigla masovne razmjere. ${ }^{38} \mathrm{U}$ tom valu nasilja strijeljani su mladi glumci Ivan Štrk, Veljko Ilići Rade Sladić, prva dvojica i studenti susjednoga Filozofskog fakulteta, koji se tada nalazio u zgradi Rektorata. ${ }^{39}$ Sva su trojica usto bila đaci Glumačke škole i članovi SKOJ-a, ujedno i najmlađi članovi Kazališta, koji su tek stupili na daske i zato su bili nepoznati široj publici.

Štrk je od 1939. bio u statusu glumačkoga pripravnika, a u njegovu policijskom kartonu piše i da je „pomoćnik redatelja HDK“ ${ }^{40}$ što se odnosi na Tita Strozzija koji je ga je jako volio pa je saznavši da je Štrk ubijen, ,još više uvukao glavu između ključnih kostiju i još je brže hodao “41 Rođen je u Lipi kraj Duge Rese 10. veljače 1913., a u Zagrebu stanovao je u Kranjčevićevoj 7. U kazalištu nastupao je u manjim ulogama u brojnim predstavama Drame i Opere. ${ }^{42}$ Sudjelovao je i prije u akcijama protiv ustaša, a još 1939. bio je uhapšen „prigodom demonstracija na univerzitetu“.43 Ovaj je put uhapšen 18. srpnja 1941. „po nalogu g. Blažekovića“, fotografiran 19. srpnja i strijeljan nakon deset dana. Deset dana nakon hapšenja Ivana Štrka, Žanko je uputio kratak dopis Ministarstvu hrvatskog domobranstva o njegovu hapšenju od strane ustaškog redarstva, dajući im tu činjenicu na znanje, ali tek radi eventualne mobilizacije. ${ }^{44}$

34 Sima Ilić, glumac (Kragujevac, 1894. - Beograd, 1974.), karijeru je započeo u Beogradu, nastavio u Nišu, Sarajevu i Splitu. Godine 1937. gostuje u Zagrebu, gdje ubrzo biva angažiran. Jedan je od najzaposlenijih članova dramskog ansambla, s preko 200 odigranih predstava godišnje. Nakon odlaska iz Zagreba, ljeti 1941. godine, postaje član Narodnog pozorišta u Beogradu. Posljednju predstavu odigrao je za HDK na gostovanju zagrebačkog kazališta u Banjaluci od 1. do 3. srpnja 1941. S[lavko] B[ATUšić], „Sima Ilić“", Hrvatsko narodno kazalište 1894-1969. Enciklopedijsko izdanje (ur. Pavao Cindrić), Zagreb 1969., 356; HAZU, Programske cedulje sezona HNK, 1940./1941.

35 HAZU, Zbirka HNK, 10714.

36 O tome više u: Snježana Banović, Država i njezino kazalište. Hrvatsko državno kazalište u Zagrebu 1941. - 1945., Zagreb 2012., poglavlje „Odlazak Afrićeve skupine i ostalih u partizane“.

37 V. Afrić, $U$ danima odluka i dilema, 71.

38 O organizaciji SKOJ-a u Zagrebu, oružanim akcijama i hapšenjima omladinaca, u: Narcisa Lengel-Krizman, „Omladinski pokret u okupiranom gradu“, Revolucionarni omladinski pokret u Zagrebu 1941-1945. Zbornik povijesnih pregleda i sjećanja, sv. 1, Zagreb 1984., 193-194.

39 Više o djelovanju SKOJ-a na Filozofskom fakultetu u Zagrebu, u: Milan Prelog, „Studenti Filozofskog fakulteta u revolucionarnom omladinskom pokretu“, Revolucionarni omladinski pokret u Zagrebu 1941-1945. Zbornik povijesnih pregleda i sjećanja, sv. 2, Zagreb 1984., 258-263.

40 HR-HDA-259, 5246.

41 M. CRnobori, Životić, 208.

42 HAZU, Zbirka HNK, 25004, „Popis učenika Glumačke škole Hrv. Državnog kazališta koji su stalno zaposleni kao statisti ili glumci u Državnom kazalištu u Zagrebu“. Uz Štrka, na tom se popisu od 14. svibnja 1941. nalaze još Rade Sladić i Veljko Ilić.

43 HR-HDA-259, 5246.

44 HAZU, Zbirka HNK, 22358, Žankov dopis MHD-u. 


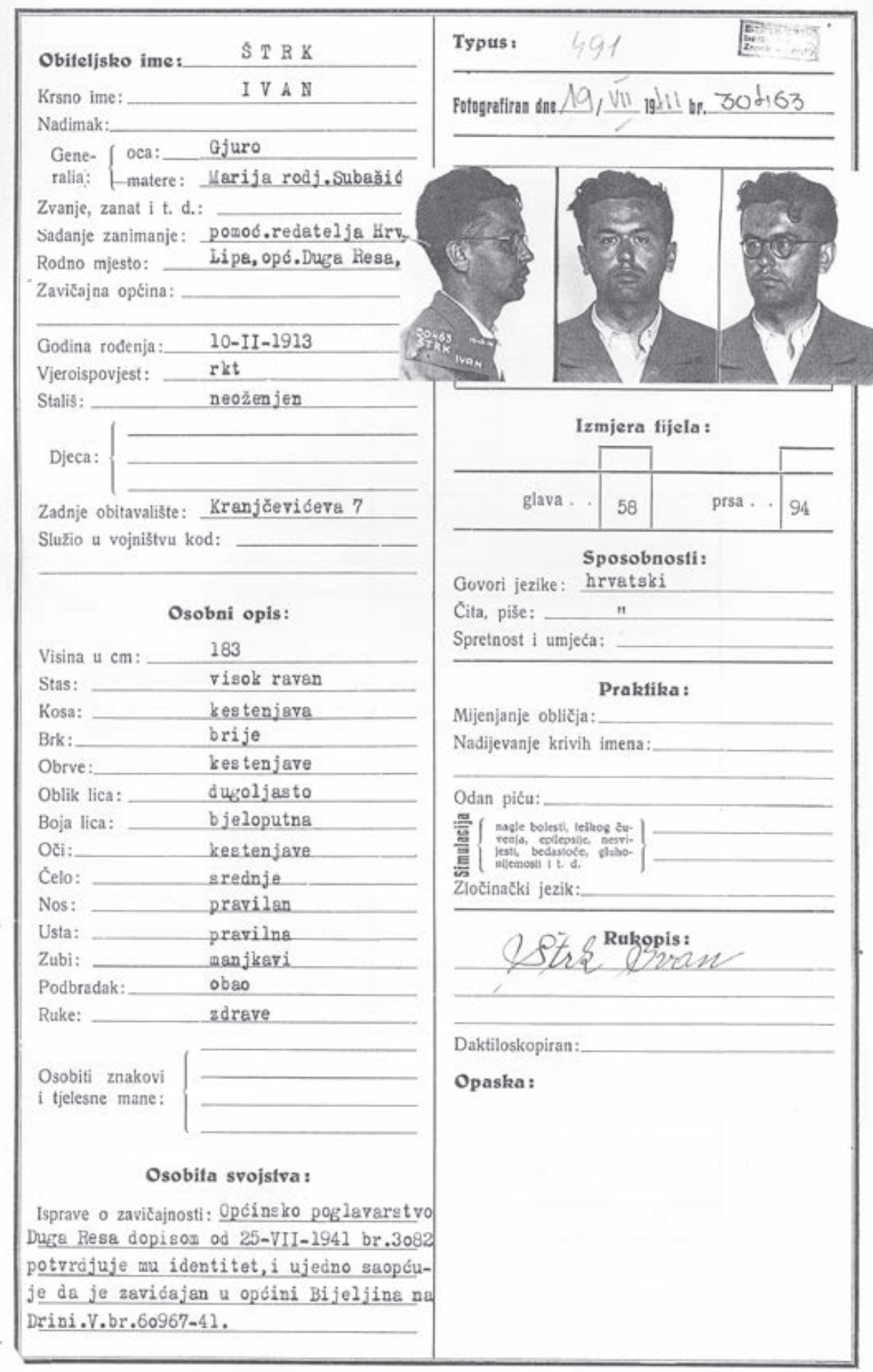


Veljko Ilić, brat balerina iz ansambla Darinke i Anđelke Ilić (potonja je od 1939. bila družica Tita Strozzija), bio je također glumački pripravnik, nepoznata datuma rođenja i smrti, pravoslavne vjere. Od 1939. bio je u glumačkoj školi te je do hapšenja nastupao u manjim ulogama kao volonter. $U$ travnju zabilježeno je njegovo preuzimanje uloge u komediji Crkveni miš, za što je dobio 60 dinara. Zajedno s Josipom Heinzom, također volonterom, preuzeo je uloge mobiliziranog kolege Ivana Stošića. Strijeljan je ljeti 1941., a kad su ga vodili na strijeljanje, uzviknuo je: „Nevin sam. Šurjak mi je Tito Strozzi!‘ ${ }^{\prime}$

Treći đak Glumačke škole i glumački pripravnik Rade Sladić, rođen 26. siječnja 1913., sa stanom u Gundulićevoj ulici 22, također je s pravoslavlja prešao na grkokatoličku vjeru, no to mu nije pomoglo - uhapšen je 2. rujna 1941. zbog drugoga „grijeha“, tj. „radi sumnje komunizma", fotografiran 4. rujna te je ubrzo i on strijeljan. ${ }^{46}$ Svi ubijeni mladići bili su članovi SKOJ-a te su zbog svog djelovanja protiv „društvenog poredka, ustaškog pokreta ili ustaških postrojbi“" potpali pod spomenute Zakonske odredbe o prijekom sudu i pokretnom prijekom sudu. ${ }^{47}$

Što se tiče mjera protiv Židova, one su se počele provoditi „odmah po uspostavi NDH, bez ijednog dana odlaganja ${ }^{\text {“48 }}$ pa je stanje za ono malo Židova iz Opere i Drame postalo vrlo teško. I prije uvođenja rasnih zakona, koji su definitivno zabranili Židovima „sudjelovanje u radu, organizacijama i ustanovama društvenog, omladinskog, športskog i kulturnog života hrvatskog naroda uopće, a napose u književnosti, novinarstvu, likovnoj i glazbenoj umjetnosti, urbanizmu, kazalištu i filmu“" ${ }^{49}$ protestiralo se u Kazalištu zbog izvođenja djela židovskih autora. Na dan dolaska novoga intendanta, 22. travnja, sastavljen je dopis za ministra bogoštovlja i nastave Milu Budaka, u kojem još uvijek aktualan intendant Aleksandar Freudenreich izvještava o brojčanom stanju Židova u Kazalištu, navodeći da „u osoblju Hrvatskog narodnog kazališta u Zagrebu ima židova“" (pisano malim početnim slovom, op. a.): 1 dirigent, 1 pjevač i 4 dramska glumca. ${ }^{50}$

Istovremeno, iskrsnuo je i repertoarni problem jer je njemački konzulat na čelu $s$,g. konzulom Dopfl-om“ upozorio kazališnu upravu i ministra Budaka da se u kazalištu pred njemačkim časnicima i vojnicima izvodi opereta Barun Trenk židovskoga skladatelja Srećka Albinija, zbog čega se ravnatelj Opere Stanislav Stražnicki morao ispričati, dodavši da mu to nije bilo poznato, da „žali da se je tako dogodilo“ te „da nije mogla postojati nikakva namjera sa strane uprave kazališta jer je pokojni kompozitor poznat kao katolik“". ${ }^{51}$ Konzulat je inzistirao da se navedeno djelo više ne izvodi na sceni, istovremeno tražeći da umjetnici židovskog podrijetla više ne sudjeluju u predstavama. Kako je upravo toga dana na repertoaru bio Gotovčev Ero sonoga svijeta, u kojem je Siminu ulogu pjevao Židov Leo Mirković, uprava je uspjela za njega ishoditi dozvolu, ali samo za tu izvedbu. Freudenreich je nadalje

\footnotetext{
45 E. Gerner, Tito Strozzi, 125 .

46 HR-HDA-259, 30768.

47 Zakonska odredba o nadopuni Zakonske odredbe o prijekom sudu i Zakonske odredbe o pokretnom prijekom sudu. Usp. Narodne novine (Zagreb), br. 61, 27. 6. 1941., 1.

48 I. Goldstein - S. Goldstein, Holokaust u Zagrebu, 106.

49 Narodne novine (Zagreb), 4. 6. 1941., 1.

50 HAZU, Zbirka HNK, 7472, „Dopis intendanta HDK ministru M. Budaku“, 22. travnja 1941.

51 Isto. Spomenuta je izvedba održana 19. travnja 1941.
} 


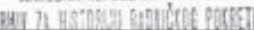

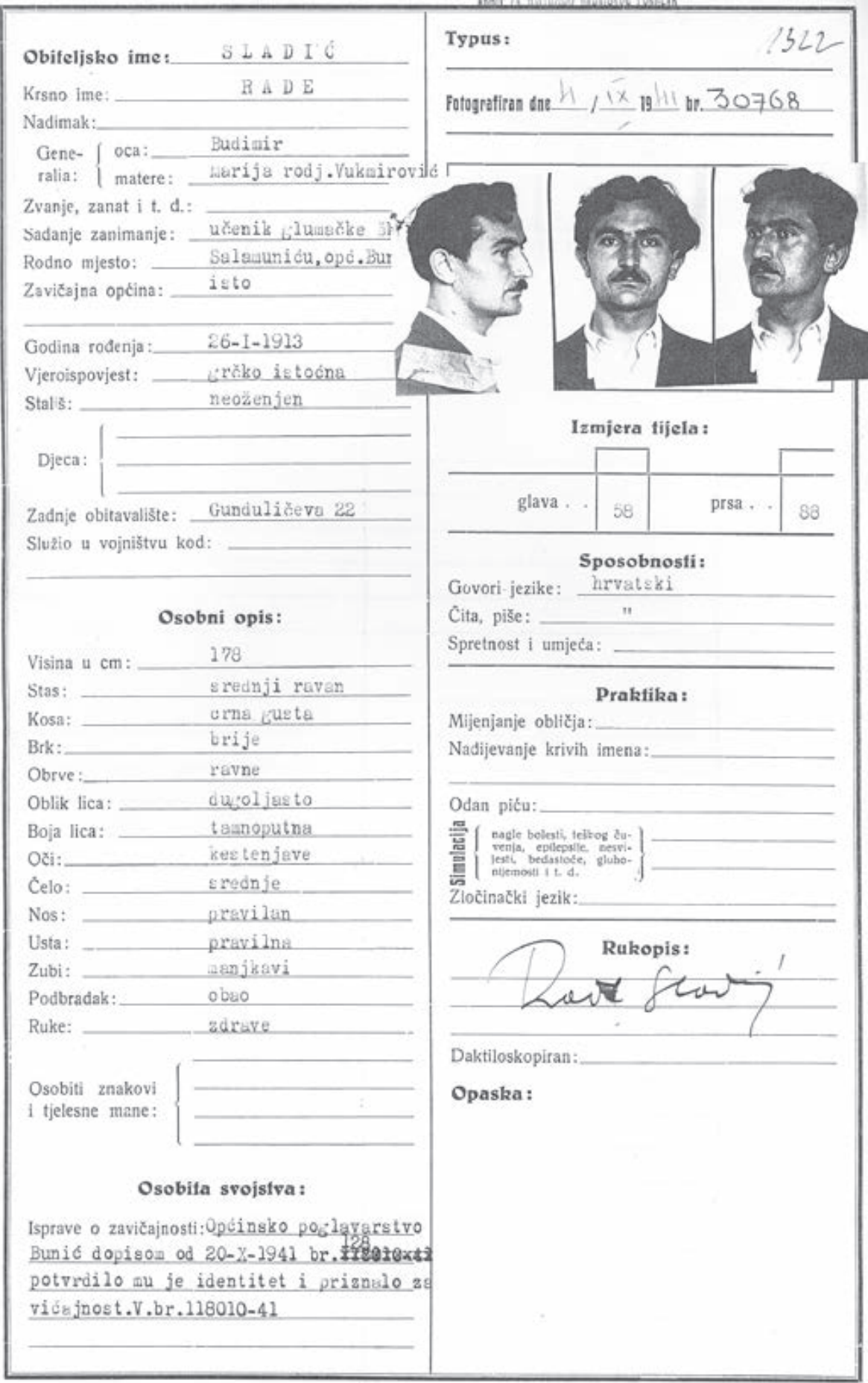


spremno istražio i koji su autori Židovi na repertoaru te je ustvrdio da će se opereta, inače omiljen žanr među zagrebačkom publikom, „moći vrlo malo izvoditi, jer i ako im je kompozitor Arijevac kao npr. Lehar, libretisti su u većini Židovi“"52 Nije njemački konzulat bio jedini kojem je zasmetao Albini - protestno pismo protiv njega napisao je Žanku izvjesni „hrvatski nacionalist“ Ivo Filipović, koji je smatrao da „židovskim mistifikacijama treba već jedanput da bude kraj“ te dodao: „Tko je odgovoran za ovu sramotu i tko će biti pozvan na odgovornost? ${ }^{\text {“53 }} \mathrm{No}$, zbog izuzetne popularnosti kod publike, ali još više zbog Žankove pozicije u vrhu vlasti i činjenice da je autor bio pokojan već osam godina, ta je opereta i dalje ostala na repertoaru, ali je iz kazališta uskoro morao otići Stražnicki. On je uskoro, odlukom Ministarstva nastave, razriješen službe u kazalištu i odmah imenovan izvanrednim profesorom na Državnom konzervatoriju..$^{54}$

Rasni zakoni su, osim ozakonjenja terora i progona nehrvata radi „osiguranja rasne čistoće“, 55 imali za cilj i poustašenje činovništva (u što su, kao državni umjetnici spadali i umjetnici), kako bi se iz njihovih redova odstranili svi „nepoćudni“, dakle Srbi i Židovi, ali i drugi neprijatelji NDH. Svi članovi HDK-a nehrvatskog podrijetla, uz njih i oni u braku s osobama nehrvatskog podrijetla, morali su tijekom lipnja 1941. ispuniti formulare o podrijetlu, tzv. Izjave o rasnoj pripadnosti. ${ }^{56}$ One su se redovito slale Ministarstvu nastave „na daljnje uredovanje".57 Tražili su se podaci o roditeljima potencijalnih nevjernika, precima iz drugog i trećeg koljena te bračnim drugovima, njihovim roditeljima i djeci. Neispravno ispunjena izjava imala je za posljedicu zatvor, gubitak službe i prava na vršenje zvanja. Primjerice, istaknuta glumica i operetna subreta Mila Popović Mosinger, katolkinja i supruga Židova Franje Mosingera, vlasnika poznatog zagrebačkog fotografskog ateljea, napisala je da je „u rastavi braka“58 od supruga Židova, koji je usto „sada u pokrštenju“. 59

Tada je, kao i trojica njegovih kolega pravoslavnoga podrijetla, stradao još jedan đak glumačke škole. Bio je to Židov Vojko Kavić-Kardoš, rođen u Zagrebu 13. svibnja 1918.,

52 Isto.

53 HAZU, Zbirka HNK, 7472, pismo Ive Filipovića D. Žanku, bez datuma.

54 Stanislav Stražnicki (Križevci, 22. srpnja 1883. - Zagreb, 22. srpnja 1945.), hrvatski pisac i kritičar. Studirao je pravo u Zagrebu, a kompoziciju i muzikologiju u Leipzigu. Vodio je studentske pjevačke zborove, bio tajnik Gewandhausa u Leipzigu i profesor u srednjoj školi Muzičke akademije u Zagebu. Redovito je pisao za dnevnik Novosti. Jedan je od prvih glazbenih komentatora Radio Zagreba. Od travnja 1941., kada je kao korepetitor Opere naslijedio Krešimira Baranovića, pa do kraja sezone 1940./1941., bio je u statusu vršitelja dužnosti ravnatelja Opere. Za ravnatelja je, na negodovanje mnogih, postavljen u kolovozu iste godine. Kao ravnatelj, nije zadovoljio zahtjevima intendanta Žanka te je smijenjen početkom 1942. Više o toj smjeni u: S. BAnović, Država i njezino kazalište, poglavlje „Sezona 1941./42. - Etički repertoar spektakularnih produkcija“; HAZU, Kartoteka osoba, fasc. Stanislav Stražnicki.

55 Život za Hrvatsku, 2/1944., br. 9, 193.

56 U skladu s Naredbom ministra unutarnjih poslova Andrije Artukovića od 4. lipnja 1941., donesenom na temelju Zakonske odredbe o rasnoj pripadnosti, Izjavu o rasnom porijeklu i rasnom porijeklu svojih bračnih drugova morali su potpisati svi državni i samoupravni službenici, službenici državnih i privatnih poduzeća te svi vršitelji tzv. slobodnih akademskih zvanja. U njoj su morali navesti podrijetlo predaka kod kojih počinje tzv. ascendentna nearijska loza, ali i rasno podrijetlo bračnog druga, bilo živog, umrlog ili razvedenog.

57 HAZU, Zbirka HNK, 13201, Izjave rasne pripadnosti Ministarstvu nastave, Odjelu za visoke škole i znanstvene zavode u Zagrebu, dopis D. Žanka s priloženim popisima od 9. srpnja 1941.

58 HAZU, Kartoteka osoba, fasc. M. Popović - Mosinger, Izjava o ranoj pripadnosti od 21. srpnja 1941.

59 I Franjo Mosinger je u prijavi imetka ispunjenoj krajem lipnja također napisao da je u rastavi, ali je Milu ipak naveo kao bračnu družicu. Prijavio je da je „obrtnik bez ateljea“ i da ima samo 1500 dinara, a u odjeći i „instrumentima“ još 3700. Usp. HR-HDA-252, Ravnateljstvo ustaškog redarstva. Židovski odsjek, 29445. 
angažiran kao glumac početnik 1939. godine, ujedno i student filozofije te pripadnik SKOJ-a sa stanom u Ilici 73. Posljednji je put u životu nastupio u amaterskom pučkom igrokazu Zlatne njive autora Stjepana Šantića kojim se željelo, u skladu s Načelima ustaškog pokreta, prikazati veličinu seljačkog života. Nakon uspostave NDH pokrstio se s roditeljima Olgom i Franjom te mlađim bratom Aleksandrom-Sašom (r. 1925.), također pripadnikom SKOJ-a, no to im nije pomoglo - uskoro su ubijeni u Jasenovcu. ${ }^{60}$ Vojko je prijavu imetka ispunio samo nekoliko dana prije hapšenja, 24. lipnja 1941., a u njoj je od materijalnih dobara prijavio samo nešto gotovine i odjeću u vrijednosti od 3000 dinara. ${ }^{61} \mathrm{U}$ skupini od 165 židovskih omladinaca, uhapšen je između 27. i 29. lipnja 1941. i odveden u logor Danica kod Koprivnice, potom u Jadovno kod Gospića, gdje je ubijen. Kad su ga kolege iz Glumačke škole na čelu sa Strozzijem, ne znajući što je s njim, odlučile tih dana posjetiti, „na vratima njegovog stana neki drugi ljudi rekli [su] da Kavić tu ne stanuje: 'Nema ga! Nestao je!'“62

Sva navedena hapšenja omladinaca vršila su se prema nalogu Zdenka Blažekovića, ustaškog bojnika, povjerenika u Glavnom ustaškom stanu do svibnja 1943., člana Hrvatskog državnog sabora, zapovjednika Muške ustaške mladeži i povjerenika Državnog vodstva tjelesnog odgoja i športa. Blažeković je usto sudjelovao i u osnivanju 13. ustaške jurišne satnije, sastavljene isključivo od studenata. ${ }^{63}$

Nešto je kasnije za odmazdu obješen i član opernog zbora Nikola Vodopivec. ${ }^{64} \mathrm{U}$ to vrijeme $\mathrm{u}$ „iole poznatije pozorišne umetnike ustaše (...) nisu dirale. Bila je to nekakva naročito sračunata politika (...) dali su pozorištu nekakvu privremenu amnestiju." ${ }^{\text {"65 }}$

No, ipak, iz kazališta otpušteni su još neki Židovi i pravoslavci, a samo tjedan dana nakon praizvedbe (7. lipnja) glazbene tročinske drame Ive Paraća Adelova pjesma uhapšen je i Krsto Hegedušić, autor scenografije, poznati slikar i profesor na ALU-u, također „radi komunizma“. U logoru u Gospiću proveo je tjedan dana - do 26. srpnja. Na dnu rubrike u kojoj se upisuju datumi uhićenja - Hegedušiću je ovo bilo drugo, nakon proljeća 1932. - netko je rukom nadopisao „ispitati?“. ${ }^{66}$

Strah od smrti generirao se sve više iz dana u dan te je imao nemalen utjecaj na odnose u kolektivu središnjeg kazališta Pavelićeve države, ali i na brojne tragične sudbine pojedinaca koji se, iako živeći u diktaturi, nisu predali posluhu, već otporu, koji će vrhunac doseći odlaskom grupe umjetnika na čelu s Vjekoslavom Afrićem iz HDK-a na oslobođen teritorij 22. travnja 1942. Ta je grupa odmah ušla u sastav Vrhovnog štaba NOV-a i POJ-a te postala zametak Kazališta narodnoga oslobođenja Jugoslavije. Možda je, ne htijući, raspoloženje toga vremena ponajbolje ilustrirao sâm intendant HDK-a Dužan Žanko kada je u prigodi

60 Poimenični popis žrtava KCL Jasenovac 1941-1945. (http://www.jusp-jasenovac.hr/Default.aspx?sid=7618).

61 HR-HDA-1076, Ministarstvo državne riznice NDH. Odjel za novčarstvo, državnu imovinu i dugove. Ured za podržavljeni imetak (PONOVA), Prijava imetka, kut. 679, 3922, 3925 (Olga i Aleksandar Kardoš) i 3924 (Franjo Kardoš); Popis lica koja su dobila arijsko pravo ili dopusnicu 1941-1944.; Joža Rutić, „Naše žrtve“, Kazališni list, 2/1946., br. 22, 1 .

62 M. Crnobori, Životić, 208.

63 Z[dravko] D[izdar], „Blažeković, Zdenko“, Tko je tko u NDH (ur. Darko Stuparić), Zagreb 1997., 41.

64 Usp. J. Rutić, „Naše žrtve“, 1-3.

65 V. Afrić, U danima odluka i dilema, 151.

66 HR-HDA-259, 17379. 


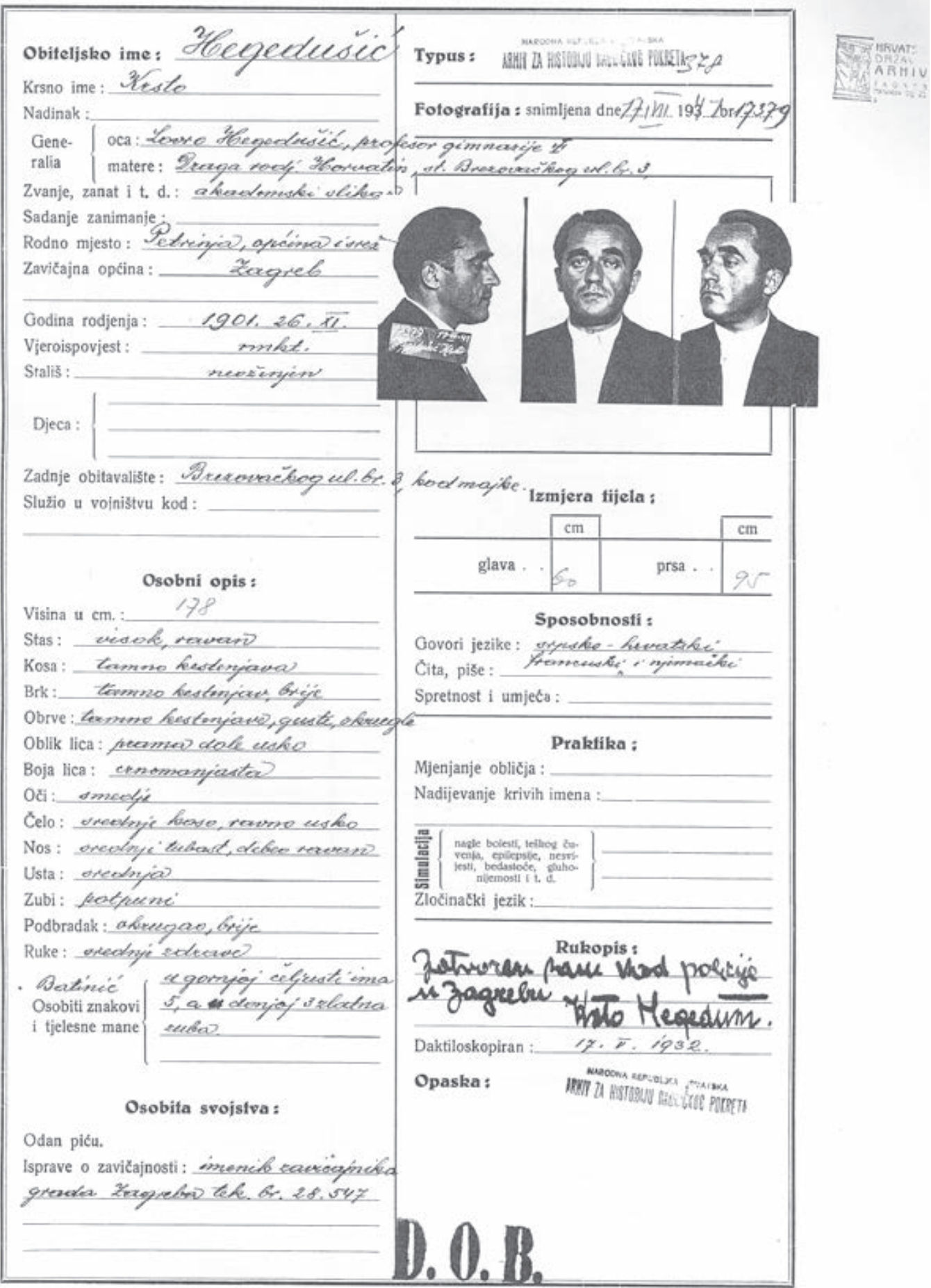


proslave prve godišnjice proglašenja NDH, a s ciljem uvođenja u Kazalište „čiste hrvatske i etičke orijentacije hrvatskog kazališta u Zagrebu i što se tiče osoblja i što se tiče repertoara“, sa scene Kazališta evocirao sjećanja svoje generacije u kojoj je „u tolikoj mjeri sazrela misao o državi, da smo u najvišem etičkom postulatu morali izabrati ili smrt ili državu“. ${ }^{67}$

\section{RituAlizACIJA SMRTi I STRAHA NA SCENI}

Od trenutka proglašenja Nezavisne Države Hrvatske proslave i svečanosti svih vrsta bile su svakodnevna pratnja ustaškoga režima. Novouspostavljen ustaški duh novoga društva, proklamiran u Pavelićevim Načelima ustaškog pokreta, trebalo je uzdizati i slaviti na svakom mjestu i u svakoj mogućoj prilici, a Hrvatsko državno kazalište u Zagrebu kao uobičajen prostor dramskoga i glazbenoga slavlja bilo je idealno mjesto za takva, uglavnom propagandna prikazivanja. Osim što je kazalište kulturno-politički, prema samom Paveliću, moralo biti reprezentativno „pred cijelim svijetom koji sada gleda u nas“ ${ }^{\prime 6}$ očekivalo se da, kao jedno od najsvečanijih arhitektonskih zdanja u državi, bude i prostor za svečanosti najreprezentativnijih događanja u NDH. Uklapalo se ono savršeno u najmanje dva elementa ustaške ideologije: onaj o napokon probuđenom i istovremeno pobjedonosnom nacionalnom identitetu, ali i onaj koji je postupno prerastao u jedan od najvažnijih ciljeva ustaškog pokreta - da se u narodu konstantno mora buditi fanatizam. Važno mjesto među svečanostima zauzimalo je i redovito obilježavanje obljetnica smrti hrvatskih velikana, pri čemu se redovito izvodila i Gotovčeva balada o smrti Petra Svačića Crna priča. No, više od veličanja povijesnih ličnosti iz hrvatske prošlosti, na takvim se proslavama ponajviše manifestirala moć Pavelićeva režima i njega samoga.

Kao što je navedeno, 30. travnja, na sâm dan proglašenja rasnih zakona, održana je u Kazalištu proslava novoustoličenog blagdana, Dana Zrinskog i Frankopana, a uz izvedbu Gundulićeve Dubravke u Strozzijevoj obradi i režiji. ${ }^{69} \mathrm{Na}$ svečanosti obilježavanja „mučeničke smrti hrvatskih narodnih velikana" u Bečkome Novom Mjestu iz 1671., za koju je pristup u gledalište bio dopušten „u tamnom odijelu“, prisustvovali su doglavnik Budak, nadbiskup Stepinac i brojni ministri koje su u prepunom gledalištu dočekali „oduševljeni poklici “ ${ }^{70}$ Bila je to ujedno i prva svečanost u mandatu novoga intendanta, koji je s pozornice održao dug i gorljiv govor u kojem je istaknuo da „prvi hrvatski hram ljepote (...) do danas nije imao ovako značajne i ovako sretne večeri “. Nakon veličanja Pavelića, Budaka te ostalih članova Vlade i ustaškog pokreta, Žanko je povukao paralele između Zrinskog, Starčevića i Pavelića prizivajući budućnost u kojoj će „iz sjemena ovoga dana niknuti za stotinu godina stablo, pod kojim će sav naš narod s vladarima (...) narodnom svečanošću proslaviti taj dan“" ${ }^{\text {" }}$

\footnotetext{
Hrvatski narod (Zagreb), br. 55, 8. 4. 1942., 2.

68 Izjava Ante Pavelića za Novi list (Zagreb), br. 163, 9. 10. 1941., 2.

69 Hrvatski narod (Zagreb), br. 76, 29. 4. 1941., 7.

70 Isto, br. 78, 1. 5. 1941., 12.

71 Novi list (Zagreb), br. 4, 2. 5. 1941., 6.
} 
Žanko je i inače bio zanesen likom i djelom Ante Starčevića pa je ubrzo, 23. svibnja, u Malom kazalištu u Frankopanskoj ulici priredio svečanu priredbu prigodom proslave njegova rođendana, na kojoj ga je ispred brojnih članova Ustaške mladeži nazvao velikim političarem i „piscem moralistom“, stavivši ga uz bok s Ibsenom i Dostojevskim. ${ }^{72}$ No, to nije bilo sve - već 13. lipnja održana je u čast Starčevićeva „spomen-dana“ još jedna svečana priredba, ovaj put na velikoj sceni. Prije početka Zajčeve opere Nikola Šubić Zrinjski, Žanko je održao dugačak „pjesnički govor“, u kojem je zapravo falsificirao Starčevićev lik, smjestivši ga sasvim u kontekst ustaškoga duha („Oživi i sve ćeš nas prepoznati, prvi naš ustašo, jer u nama iz 1941., živiš ti iz 1861.“) i pritom prikazujući njegova imenjaka Antu Pavelića („I njemu je Ante kao i Tebi, i ne zamjeri nam Stari naš što u Tebi grlimo njega, a u Njemu Tebe i ne znamo više razlikovati Tebe od Njega i Njega od Tebe.") kao povijesnu ličnost koja je "poput Mojsija“ prva ostvarila Starčevićeve ideje o ostvarenju Nezavisne Države Hrvatske. ${ }^{73}$

Jedna od umjetnica koja je, prema Žankovu mišljenju, u svojoj dugoj karijeri djelovala baš u duhu stalnog promicanja hrvatskoga duha i identiteta, bila je širom svijeta priznata vagnerijanka Milka Trnina. Njoj je pripisana i zasluga „u podupiranju hrvatskih sveučilištaraca kao i u zaštićivanju i materijalnom pomaganju ispravnih hrvatskih manifestacija za cijelo vrijeme velikosrpske vladavine ${ }^{\text {“ }}{ }^{74}$ Mjesec dana nakon njezine smrti u lipnju 1941., organizirana je $\mathrm{u}$ foajeu kazališta u postavi Mate Grkovića izložba njezinih vrijednih predmeta, a potom i priredba koju je pohodio Mile Budak, a u kojoj su sudjelovali dramski i operni solisti te orkestar pod ravnanjem Lovre Matačića. ${ }^{75} \mathrm{U}$ rujnu je svečano obilježena i 30. godišnjica smrti jednog od najvećih hrvatskih glumaca Andrije Fijana, a u lipnju iste godine i 70. godišnjica smrti osnivača hrvatskoga kazališta Dimitrije Demetra. Smrt i ovo troje umjetnika koji su živjeli i djelovali davno prije dolaska ustaša na vlast, morala je u Žankovim govorima biti dovedena do simboličke razine te su, iako po svemu udaljeni od okrutne i visoko patetizirane stvarnosti $\mathrm{NDH}$, opisani ni više ni manje nego kao borci u borbi za hrvatsku državu i njezinu nezavisnost jer su „Hrvatskoj pomogli da u kolu kulturnih europskih naroda bude ono što je ona danas“. ${ }^{76}$

Na koncu, ta je - za mnoge zagrebačke umjetnike - sudbonosna 1941. godina, što se obilježavanja smrti tiče, završila obilježavanjem 150. Mozartove obljetnice smrti, kad je priređen i njegov Svečani tjedan, na kojem je uz brojne koncerte ${ }^{77}$ u kazalištu svečano obnovljena njegova opera Čarobna frula. ${ }^{78}$

\footnotetext{
72 Hrvatski narod (Zagreb), br. 102, 25. 5. 1941., 6

73 Isto, br. 120, 14. 6. 1941., 15-16.

74 Isto, br. 96, 19. 5. 1941., 10.

75 Isto, br. 118, 12. 6. 1941., 11; br. 127, 21. 6. 1941., 7; br. 128, 22. 6. 1941., 19. Usp. HAZU, Zbirka HNK, 5969 i 5985.

76 Nova Hrvatska (Zagreb), br. 150, 30. 6. 1942., 8.

77 Dana 5. prosinca 1941. orkestar i zbor HDK-a, uz sudjelovanje članova oratorijskog zbora crkve sv. Marka, izveli su Ave verum i Requiem. Solisti su bili Vera Grozaj, M. Radev, J. Gostić, T. Neralić, a dirigent L. Matačić. Usp. Programske cedulje sezona HNK, 1941./42.

78 Predstava je ustvari bila obnova produkcije iz 1931. godine, uvježbavana čak tri mjeseca te izvedena u prosincu 1941. godine u prijevodu S. Biničkoga i režiji A. Markovskoga. Scena i kostimi: T. Krizman. Usp. Programske cedulje sezona HNK, 1941./42.
} 


\section{ZAKLJUČAK}

Od samoga je početka Nezavisna Država Hrvatska u svoje zakone upisivala i smrt, koja je za određene skupine u društvu postala poželjnom. Može se reći, već samo na primjeru iz središnjeg državnog kazališta, da se u toj državnoj tvorevini, koja je čitavo vrijeme svoga trajanja provela u ratu, smrt smatrala društvenom činjenicom. Strah od smrti odmah je od travnja 1941. postao svakodnevni suputnik zagrebačkih kazališnih umjetnika, a za pripadnike srpskog i židovskog naroda nije bilo moguće djelovati sa scene bez snažnog oportunizma i konformiranja s režimom. Za sve njih, a naročito za članove i simpatizere Komunističke partije, nastupili su dani terora i progona, koji su za neke od njih završili smrću. $S$ druge, pak, strane, režim je gotovo svakodnevno na objema kazališnim scenama priređivao manifestacije u slavu svoje moći, a jedan od dominantnih elemenata koji je morao biti uključen u svaki takav svečani i obljetničarski sadržaj bio je mnogo puta izrican novi duh društva, unutar kojeg su režim i njegova načela na najviše mjesto postavljali upravo izbor između smrti i države.

\section{$\cos$}

\section{Izvori i literatura}

\section{Arhivska grada}

Hrvatski državni arhiv

Ministarstvo unutarnjih poslova Nezavisne Države Hrvatske (HR-HDA-223), Predsjednički ured, kut. 27, 29408/1941.

Ministarstvo državne riznice NDH. Odjel za novčarstvo, državnu imovinu i dugove. Ured za podržavljeni imetak (PONOVA) (HR-HDA-1076), kut. 679, 3922, 3924, 3925.

Ravnateljstvo ustaškog redarstva. Židovski odsjek (HR-HDA-252), 29445.

Redarstvena oblast za Grad Zagreb (HR-HDA-259), 1323, 1549, 3338, 3456, 4396, 4713, 4779, 5246, 5273, 5758, 17379, 30768.

Odsjek za povijest hrvatske književnosti, kazališta i glazbe Hrvatske akademije znanosti i umjetnosti (HAZU)

Kartoteka osoba

Programske cedulje sezona HNK, 1940./41. i 1941./42.

Zbirka dokumenata Hrvatskoga narodnog kazališta (Zbirka HNK)

\section{Tiskovine}

Hrvatski narod (Zagreb), 1941. - 1942.

Narodne novine (Zagreb), 1941.

Nova Hrvatska (Zagreb), 1942. - 1943.

Novi list (Zagreb), 1941.

Život za Hrvatsku (Zagreb), 2/1944., br. 9. 


\section{Literatura i objavljeni izvori}

Vjekoslav Afrić, U danima odluka i dilema, Beograd 1970.

Snježana BANović, „Bela i Miroslav Krleža u NDH - vedri repertoar kao cijena za život“, Intelektualci i rat 1939. - 1947. Zbornik radova s međunarodnog skupa Desničini susreti 2011. (ur. Drago Roksandić i Ivana Cvijović Javorina), Zagreb 2012., 9-24.

Snježana Banović, Država i njezino kazalište. Hrvatsko državno kazalište u Zagrebu 1941. - 1945., Zagreb 2012.

Snježana Banović, Kazalište krize, Zagreb 2013.

Antun BARAC, „KZSTG“, Europski glasnik, 9/2004., br. 9, 644-696.

S[lavko] B[ATUšIĆ], „Sima Ilić“, Hrvatsko narodno kazalište 1894-1969. Enciklopedijsko izdanje (ur. Pavao Cindrić), Zagreb 1969., 356.

Danijel CRLjen (prir.), Načela hrvatskog ustaškog pokreta, Zagreb 1942.

Marija Crnobori, Životić. Eseji, kazališni i ini (prir. Jelena Lužina), Pula 2011.

Enes ČEngić, S Krležom iz dana u dan, knj. 2: Trubač u pustinji duha, Zagreb 1985.

Z[dravko] D[IZDAR], „Blažeković, Zdenko“, Tko je tko u NDH (ur. Darko Stuparić), Zagreb 1997., 41.

Eliza Gerner, Tito Strozzi. Svjetla i sjene jednoga glumačkog puta, Zagreb 2004.

Ivo Goldstein - Slavko Goldstein, Holokaust u Zagrebu, Zagreb 2001.

Fikreta Jelić-Butić, Ustaše i Nezavisna Država Hrvatska 1941-1945., Zagreb 1977.

Miroslav KrležA, Dnevnik, sv. 4: 1943., Sarajevo 1981.

Narcisa LengeL-Krizman, „Omladinski pokret u okupiranom gradu“, Revolucionarni omladinski pokret u Zagrebu 1941-1945. Zbornik povijesnih pregleda i sjećanja, sv. 1, Zagreb 1984., 191-200.

Mojmir Martin, „Primorska ulica - sukob i hapšenje 11. oktobar 1941.“, Revolucionarni omladinski pokret u Zagrebu 1941-1945. Zbornik povijesnih pregleda i sjećanja, sv. 2, Zagreb 1984., 79-89.

Hrvoje Matкović, Povijest Nezavisne Države Hrvatske, Zagreb 2002.

Ante Nazor, „Dug zaboravljenoj književnici“, Vjesnik (Zagreb), br. 9676, 28. i 29. 4. 1974., 13.

Poimenični popis žrtava KCL Jasenovac 1941 - 1945. (http://www.jusp-jasenovac.hr/Default. aspx?sid=7618).

Branko Polić, Imao sam sreće, Zagreb 2006.

Milan Prelog, „Studenti Filozofskog fakulteta u revolucionarnom omladinskom pokretu“, Revolucionarni omladinski pokret u Zagrebu 1941-1945. Zbornik povijesnih pregleda i sjećanja, sv. 2, Zagreb 1984., 258-263.

Joža Rutić, „Naše žrtve“, Kazališni list, 2/1946., br. 22, 1-3.

Aleksandar Seitz, Put do hrvatskog socializma, Zagreb 1943.

Tito StrozzI, „Obradbe i dramatizacije“, Hrvatsko narodno kazalište. Zbornik o stogodišnjici. 1860 - 1960 (ur. Đuka Berkeš), Zagreb 1960., 229-232.

Filip ŠKILjan, Organizirana prisilna iseljavanja Srba iz NDH, Zagreb 2014.

Jozo Tomasevich, War and Revolution in Yugoslavia, 1941-1945. Occupation and Collaboration, Stanford 2001.

Ustaša. Dokumenti o ustaškom pokretu (prir. Petar Požar), Zagreb 1995.

Dušan ŽANKO, „Hrvatsko državno kazalište u Zagrebu u drugoj godini svoga rada u slobodi“, Nova Hrvatska (Zagreb), br. 86, 10. 4. 1943., 21. 
$\cos$

\section{The Croatian State Theatre in Zagreb in i94I - Days of Death, Fear and Humiliation}

The article addresses the initial months of the existence of the Croatian State Theatre in Zagreb (April-December 1941) under the management of artistic director Dušan Žanko, and the events that took place there, events that were primarily shaped by the fear of death. The title of the article was taken from the diary that was subsequently written by writer Božena Begović, a member of the theatre management and an activist of the National Liberation Movement and the Women's Anti-Fascist Front. Immediately after the declaration of the Independent State of Croatia, numerous arrests and killings were executed in accordance with racial and other laws that legalised the terror against undesirable groups (Communists, the Serbs, the Jews, the Roma, the Freemasons). In the summer of 1941, a large number of students were arrested and killed, among them some apprentice actors from the ensemble of the Croatian State Theatre in Zagreb, bringing no small amount of panic and fear into the collective at large. The fear of death that was generated every day affected not only the relationships within the collective body of the principal theatre of the ISC, but also the tragic fates of many individuals. The Independent State of Croatia was at war from its inception to its demise, and so death was written into the everyday life in those areas outside the theatre of war as a desirable social fact. Therefore, as early as April 1941, the fear of death became a daily companion both to the citizens of Zagreb and to its theatre artists. It was impossible for those among them who were of Serb and Jewish ethnicity to live and work without resorting to considerable levels of opportunism and conforming to the regime. For all of them, especially the members and sympathisers of the Communist Party, the days of terror and persecution had arrived. At the same time, the Zagreb theatre served nearly daily as a venue for many celebrations, ceremonies and functions (international, national, ideological, for special occasions), which varied in scope and substance, regular among which were commemorations of anniversaries of the deaths of prominent personalities from Croatian history. However, instead of celebrating the lives and works of the great names from Croatian history, they actually served to demonstrate the power of the institutions of Pavelić's regime, and of Pavelić himself. One of the predominant elements that had to be included in any such event on stage was precisely the new spirit of the Ustasha society, where, in addition to the sacrifice for the homeland, it was the choice between death and the state that was given primacy by the regime and the principles it was founded on.

Key words: the Independent State of Croatia, the Croatian State Theatre in Zagreb, the purity of the (ethnic) nation and state, death, fear, the Ustasha spirit, terror, anniversaries 



\title{
DVA ISPRAĆAJA VLADANA DESNICE
}

\section{Monica Priante}

\author{
UDK: 821.163.42Desnica, V.:393.1“1967“ \\ Prethodno priopćenje
}

Sažetak: Na primjeru dvaju ispraćaja Vladana Desnice autorica prikazuje dihotomiju između dvaju mogućih shvaćanja smrti. Vladan Desnica umire u subotu 4. ožujka 1967. u Zagrebu u bolnici Rebro. Iz pregleda tiska jasno proizlazi kako se smrt odnosi samo na čovjeka Vladana Desnicu, dok Desnica-književnik smrću ne nestaje. Ta dvostrukost tjelesne smrti i javnog života očituje se i u govorima izrečenim tijekom Desničina ispraćaja. Prvi je održan na zagrebačkom Mirogoju 6. ožujka 1967., a drugi u Islamu Grčkom dan poslije, nakon čega je uslijedio ukop posmrtnih ostataka Vladana Desnice u crkvi sv. Đurđa u Kuli Stojana Jankovića. Na dvama ispraćajima pojavljuju se i drugi tipični elementi javnog sprovoda kao što su inkluzivan karakter sjećanja i afirmacija kulta ličnosti. Analizirajući stavove organizatora, postaje jasno da su javne pogrebne ceremonije često događaji na kojima se pokušava izbrisati sve tragove ideoloških, političkih i kulturnih sukoba.

Ključne riječi: smrt, povijest smrti, Vladan Desnica, ispraćaj, pogrebni rituali, dvostruki pogreb

$\int$ mrt razbija dinamičku ravnotežu privatnog i kolektivnog života, ali ta „praznina“ ovisi o važnosti položaja pokojnika u životu toga društva. Ispraćaj, odnosno, u ovom slučaju, dva ispraćaja posmrtnih ostataka ${ }^{1}$ predstavljaju odgovor društva na čin smrti. U svom radu o kolektivnoj reprezentaciji smrti antropolog Robert Hertz ističe da prakse povezane sa smrću zapravo nemaju individualan, nego društveni karakter. ${ }^{2}$ Također pokazuje kako je smrt traumatski događaj za društvo, kriza koju valja prevladati s pomoću rituala koji biološki događaj pretvaraju u društveni proces. Smrt se, dakle, smatra društvenom činjenicom, događanjem koje uzrokuje krizu, kako u užem obiteljskom okruženju tako i na širem planu klana, plemena ili lokalne zajednice. Zbog toga pogrebni obredi imaju i zadaću reorganizacije i preoblikovanja sjećanja na pokojnika, onkraj proteka uobičajenog vremena i dnevnog tijeka događaja.

$\overline{1}$ U tisku se uglavnom govori o ispraćaju ili ispraćaju posmrtnih ostataka Vladana Desnice. Tako npr. u Slobodnoj Dalmaciji stoji: „Desnica ispraćen iz Zagreba - povodom ispraćaja posmrtnih ostataka istaknutog književnika na Mirogoju...". Slobodna Dalmacija (Split), br. 6849, 7. 3. 1967., 7. Na drugom mjestu navodi se kako je „Vladan Desnica sahranjen u zavičaju u Islamu Grčkom“ te se spominju poznate osobe koje su prisustvovale „ispraćaju posmrtnih ostataka istaknutog književnika“. Slobodna Dalmacija (Split), br. 6850, 8. 3. 1967., 4.

2 Usp. Robert Hertz, „Contribution à une étude sur la représentation collective de la mort“, Année sociologique, 10/1907., 48-137. 
Pogrebni obredi, iako različiti u različitim grupama, društvima i kulturama, ispunjavaju određene društvene funkcije. Jedna od njih jest pomoć pri prevladavanju gubitka, a osobito u slučaju pogreba javnih osoba oni iskazuju brigu oko osiguravanja prisutnosti mrtvih među živima, naglašavajući opstanak pokojnika u svijetu živih. ${ }^{3} \mathrm{U}$ javnim ritualima (pogrebnim ili drugim) postoji tendencija da se simboličkim figurama osigurava memorijalna besmrtnost, zajamčena kultom sjećanja, što se zapravo i dogodilo u slučaju pogrebnih obreda nakon smrti Vladana Desnice.

Uz to, ovome očiglednom sloju interpretacije (evokacija i sjećanje na pokojnika) pridodaje se i drugi sloj, onaj koji odražava drugačiju težnju, tj. uzdizanje pokojnika kao primjera za cijelu zajednicu, govorima o njegovoj etičnosti, njegovim poučcima i nasljeđu koje ostavlja živima. Zapravo se na temelju tih aspekata tijekom javnih pogreba pojavljuje i inkluzivan karakter sjećanja kojima se nastoji pomiriti društvene podjele i ujediniti zajednicu u žalosti. I to je sastavni dio procesa afirmacije kulta ličnosti.

Tako, primjerice, pisac Čedo Prica u članku Prisutnost do kraja, objavljenom u Telegra$m u$, o Vladanu Desnici zapisuje sljedeće:

Kao pisac nije se pojavio da bi sa smrću nestao, već da bi ostao kao moralni i estetski kriteriji u hrvatskoj književnosti (...). Kao utjeha za naše fizičke rastanke, kao pomirenje za sve nesporazume što ih, izgleda, pisac nužno prima, kao nužni uvjet da bi izdržao, i da bismo mu se na kraju poklonili i prvi put bez uvjeta i nesporazuma razmislili o njegovu prisustvu među nama. ${ }^{4}$

Ili, kako je izjavio književnik Dragan Jeremić tijekom svoga govora na Mirogoju: „Ime Vladana Desnice ostat će zapisano zlatnim slovima u hrvatskoj i jugoslavenskoj književnosti“, uz zaključak kako će „Desnica, kao Srbin a pripadnik hrvatske književnosti biti uz Đuru Daničića, Josifa Pančića i Nikolu Teslu, kao zalog bratske slobode između Hrvata i Srba", čime ga, dakle, uzdiže i stavlja u idealan kulturni panteon.

Pogreb simbolički uklanja pojedinca s linije vremena i premješta svjetovnu osobu u domenu vječnog i svetog. Međutim, pored ovoga aspekta nalazimo i drugi, posebno zanimljiv aspekt, a odnosi se na izričaj „dva ispraćaja“. Korištenjem izrazom „dva ispraćaja“ želim se referirati na praksu dvostrukog pogreba predmodernih monarha, iako na to zasigurno nisu mislili organizatori Desničina ispraćaja. U predmodernim pogrebnim ritualima u Francuskoj ili Engleskoj, ${ }^{6}$ nakon ukopa kraljeva tijela, uslijedila je faza u kojoj se iskazivala počast i poštovanje lutku suverena odjevenog i ukrašenog svim atributima suvereniteta, kao da je pravi pokojni kralj. ${ }^{7}$ Ovakvom se inscenacijom željelo simbolički ispuniti opasnu institucionalnu prazninu koja se događa između kraljeve smrti te proglašenja i posvećenja njegova

\footnotetext{
Tara BAiley - Tony Walter, „Funerals against death“, Mortality, 21/2016., br. 2, 153-154.

Čedo Prica, „Prisutnost do kraja“, Telegram (Zagreb), br. 358, 10. 3. 1967., 10.

Slobodna Dalmacija (Split), br. 6849, 7. 3. 1967., 7.

6 Dvostruk pogreb (stvarnog tijela i lutka) prvi je put zabilježen u Engleskoj tijekom pogreba Edvarda II. (1327.) i u Francuskoj tijekom pogreba Karla VI. (1422.). Usp. Giovanni RiccI, „Le Corps et l'Effigie: Les Funérailles des Ducs de Ferrare à la Renaissance“, Civic Ritual and Drama (ur. Alexandra F. Johnston i Wim Hüsken), Amsterdam 1997., $175-178$.

7 Usp. Ralph Giesey, The Royal Funeral Ceremony in Renaissance France, Genève 1960.; Ernst Hartwig Kantorowicz, The King's Two Bodies. A Study in Mediaeval Political Theology, New Jersey 1981.
} 
nasljednika. U trenutku proglašenja kraljeva nasljednika obavljao se drugi pogreb (sprovod lutka), činom kojim je završavala faza ritualnog interludija.

Ovakva je praksa, uz modifikacije, nastavljena i u narednim stoljećima, a za primjer možemo uzeti sprovod prvog talijanskog kralja Vittorija Emanuelea II. 1878. godine. Nakon što je kraljevo tijelo sahranjeno, mjesec dana poslije uslijedio je drugi pogreb, na kojemu se koristio katafalk, kojim se aludiralo na prisutnost kraljeva tijela. ${ }^{8}$ Jasno je da u ovom slučaju nije bilo institucionalnih bojazni: nasljeđivanje prijestolja bilo je zajamčeno Ustavom, a svečano proglašenje novog kralja obično se izvršavalo odmah nakon smrti prijašnjega. Što je onda razlog dvostrukom pogrebu? Vratimo li se na ono što je ranije rečeno, motivacija za ovakvu praksu leži u činjenici da se ritualima, kao što je ovaj, željelo osigurati stvarnu prisutnost mrtvih u svijetu živih, na neki način trajno uklopiti pokojnika u zajednicu živih.

Međutim, pored svega navedenog, Carlo Ginzburg interpretira praksu dvostrukog pogreba na sljedeći način: prvi djeluje kao privremen ukop, onaj koji otvara put pročišćavanju tijela kontaminiranog dekompozicijom, dok drugi, sprovod samog simbola, ima karakter rituala uzvišenja, kojim se uvodi simbolički prikaz preminuloga (sada „pročišćenog“) na besmrtnom nebu junaka. ${ }^{9}$ Razlika između ovih dviju interpretacija vrlo je suptilna, ali se one djelomično i podudaraju: u prvom je slučaju smrt cirkularan proces, koji određenom transfiguracijom smješta mrtvog pripadnika u zajednicu živih, dok se u drugom smrt smatra prijelazom koji ukazuje na definitivno razdvajanje i čije se traumatične posljedice mogu samo ublažiti prisjećanjem. ${ }^{10}$ Očito je da postoji velika razlika između dvaju Desničinih ispraćaja i prethodno spomenutih primjera. Međutim, oba primjera imaju i nešto zajedničko, odnosno neka slična značenja, a to je upravo dihotomija između stvarnog i javnog tijela, ${ }^{11}$ koja je evidentna u tisku.

Zapravo, kada govorimo o dvostrukom pogrebu, istovremeno govorimo i o pitanju dvostrukosti vladareva tijela, koje uključuje i biološke i političke karakteristike. Ipak, slične pretpostavke možemo proširiti i na druge slučajeve poznatih i uvaženih osoba. Upravo zato smrt slavnih i moćnih pojedinaca ne predstavlja samo završetak njihove zemaljske egzistencije već ona vrlo često poprima i dodatne vrijednosti i značenja u političkom, društvenom i vjerskom smislu te se na kraju neizostavno veže uz opća razmatranja o vlasti, ideologiji ili društvenim vrijednostima. Stoga se, s jedne strane, smrt moćnog pojedinca izjednačava sa sudbinom svakog smrtnika, a s druge njegov kraj, odnosno, prije svega, sjećanje na njega postaje instrument u rukama živućih i pojedine se grupe njime koriste sukladno $s$ ciljevima koje žele postići. Tako smrt uvaženog pojedinca i sjećanje na njega sudjeluju u stvaranju procesa društvene distinkcije. U nekim slučajevima pogrebne prakse tako postaju modeli oblikovanja identiteta, legitimacija političkih odabira i predstavljaju cijele sustave vrijednosti.

U trenutku smrti mrtvi postaju odvojeni od vlastite individualne i prolazne dimenzije te nastavljaju svoju samostalnu i često trajnu ,javnu“ egzistenciju u sjećanjima i u imagi-

8 Usp. Alberto Mario Banti, „La memoria degli eroi“, Storia d’Italia. Annali, knj. 22: Risorgimento (ur. Alberto Mario Banti i Paul Ginsborg), Torino 2007., 645-659.

9 Carlo Ginzburg, Occhiacci di legno, Milano 2011., 84-86.

10 A. M. BAnti, „La memoria degli eroi“, 653.

11 Usp. E. H. Kantorowicz, The King's Two Bodies; Nicole Marafioti, The King's Body, Toronto 2014. 


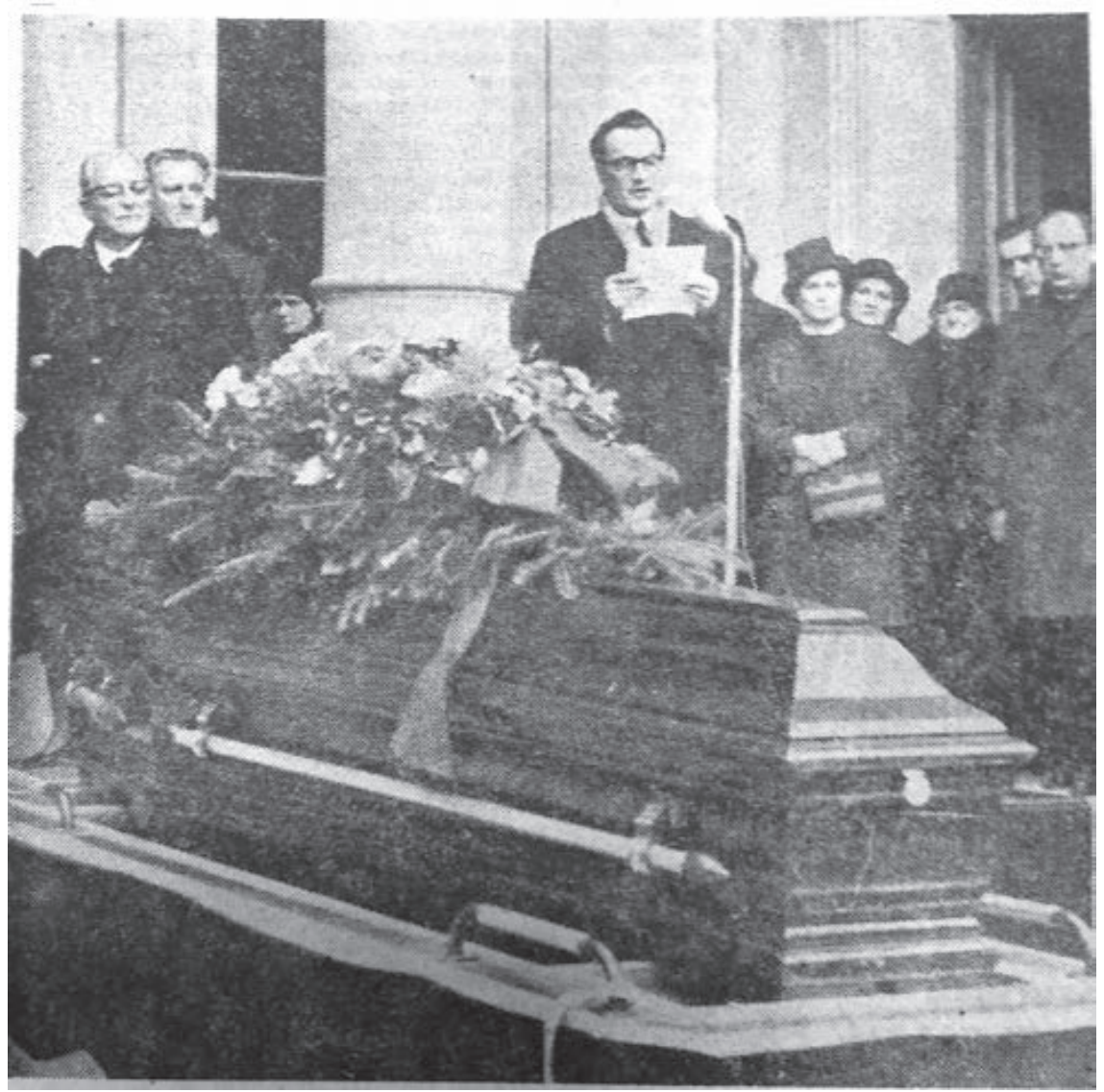

Sl. 1. Oproštaj od Vladana Desnice ispred mrtvačnice na zagrebačkom Mirogoju

nariju živih. Začetak te javne egzistencije zapravo je početak pogrebnih rituala: ispraćaji i komemoracije u tiskovinama. To potvrđuju, primjerice, riječi preuzete iz oproštajnog govora Pere Budaka na Mirogoju:

Djelo Vladana Desnice živjet će i dalje svojim posebnim književnim životom. U intimnim časovima čitanja on će se, živ i prisutan, susretati i poslije svoje smrti sa tisućama i tisućama čitalaca. Tako njegova fizička smrt postaje samo prividna, efemerna i ništavna, jer je svojim djelom, rezultatima svog uma i srca, uspio prolongirati svoj život unedogled. ${ }^{12}$

Potvrđuju to i riječi objavljene u Novom listu: „Kad govori o proljeću, kad govori za ljubav i protiv smrti, ostaje tu, odmah pred nas." ${ }^{\text {"13 }}$

Pored toga, željela bih istaknuti i drugi element koji se tiče pogrebnih rituala i pojma dvaju pogreba, a tu mislim prije svega na „spacijalni element“. U proučavanju pogrebnih rituala moramo uzeti u obzir dvije karakteristične sastavnice: temporalnu i spacijalnu. Prvi, temporalni element, obilježava vrijeme bdijenja, pokopa, ispraćaj ili ispraćaje, žalovanje itd. Drugi, spacijalni element, odnosi se na činjenicu da su neka mjesta u pogrebnim ritualima 
posebno značajna, npr. kuća/bolnica, groblje, put od kuće/bolnice do groblja, grobno mjesto (npr. izbor ukopa na mjestu podrijetla/rođenja ili na mjestu gdje se živjelo te također važnost repatrijacije smrtnih ostataka na rodno tlo). Mjesta na kojima se odvijaju različiti dijelovi rituala imaju snažnu kulturnu i društvenu komponentu, kao što je npr. progresivno širenje medikalizacije smrti, koja dovodi do toga da većina smrti biva premještena u bolnicu pa se ona više uglavnom ne zbiva u kući. Zapravo, ako se u prošlosti kulminacija kolektivnog momenta odvijala uz smrtnu postelju umirućeg, na prijelazu iz 19. u 20. stoljeće taj moment postaje posljednji pozdrav, u kojemu obično sudjeluje cijela zajednica ili uži krug rod-

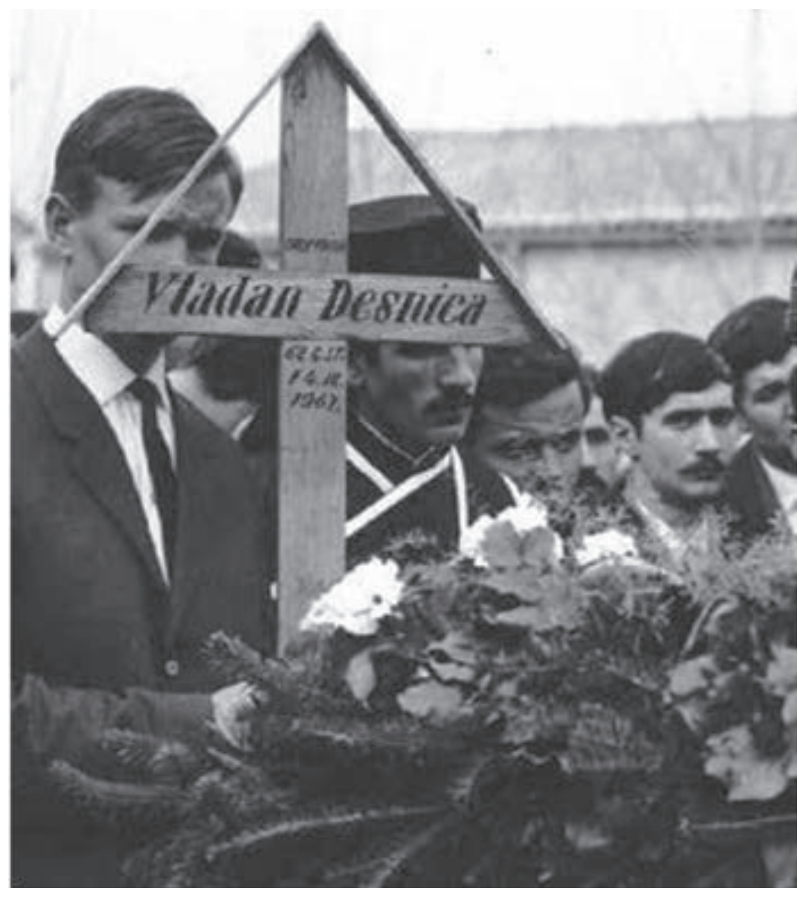

Sl. 2. Oproštaj od Vladana Desnice u Islamu Grčkom bine, prijatelja i poznanika. Pogreb, prijelaz između dvaju svjetova - svijeta živih i svijeta mrtvih - postaje mjestom koje poprima visoko simboličko značenje, mjesto prijelaza na kojem i preminuli i njegova rodbina obavljaju čin razdvajanja i pridružuju se novom svijetu.

No, što se tiče mjesta ukopa, odnosno grobnica, one nisu samo mjesto pokopa pojedinca, nego su i mjesta gdje se čuvaju i na okupu nalaze posmrtni ostaci članova cijele obitelji, mjesta koja označavaju i zajedništvo te obitelji. Također, ako dodatno proširimo ovaj diskurs, grobnica može biti i znak zajedništva cjelokupne lokalne zajednice koja prima i dočekuje pokojnika na svom posljednjem počivalištu. ${ }^{14}$

Zbog njihova trajnog karaktera ${ }^{15}$ i prisutnosti pokojnikâ koji su ondje sahranjeni, grobnice zapravo mogu predstavljati središnju točku veze između živih i mrtvih te njihova specifičnog lokalnog okruženja. ${ }^{16}$ Čak i u novije vrijeme talijansko javno mnijenje govorilo je o dvama ispraćajima. U Italiji bio je poznat ispraćaj čuvenog glumca Antonija de Curtisa, poznatijeg pod imenom Totò, 1967. godine. Nedavno je, 2015. godine, dva ispraćaja imao i poznati napuljski pjevač Pino Daniele - oba između Rima i Napulja, kako bi se naglasila spacijalna i simbolička pripadnost objema lokalnim zajednicama. Zanimljivo je primijetiti da u ovim slučajevima nemamo samo spacijalnu dvostrukost nego i simboličku jer se radi o primjeni različitih simbola (lokalnih, vjerskih i političkih) i običaja povezanih s određenim teritorijem.

14 Usp. Kate Woodthorpe, „Sustaining the contemporary cemetery: implementing policy alongside conflicting perspectives and purpose“, Mortality, 16/2011., br. 3, 259-276.

15 Julie RugG, „Defining the place of burial: what makes a cemetery a cemetery?“, Mortality, 5/2000., br. 3, 264.

16 Usp. K. Woodthorpe, „Sustaining the contemporary cemetery“, 264-269. 


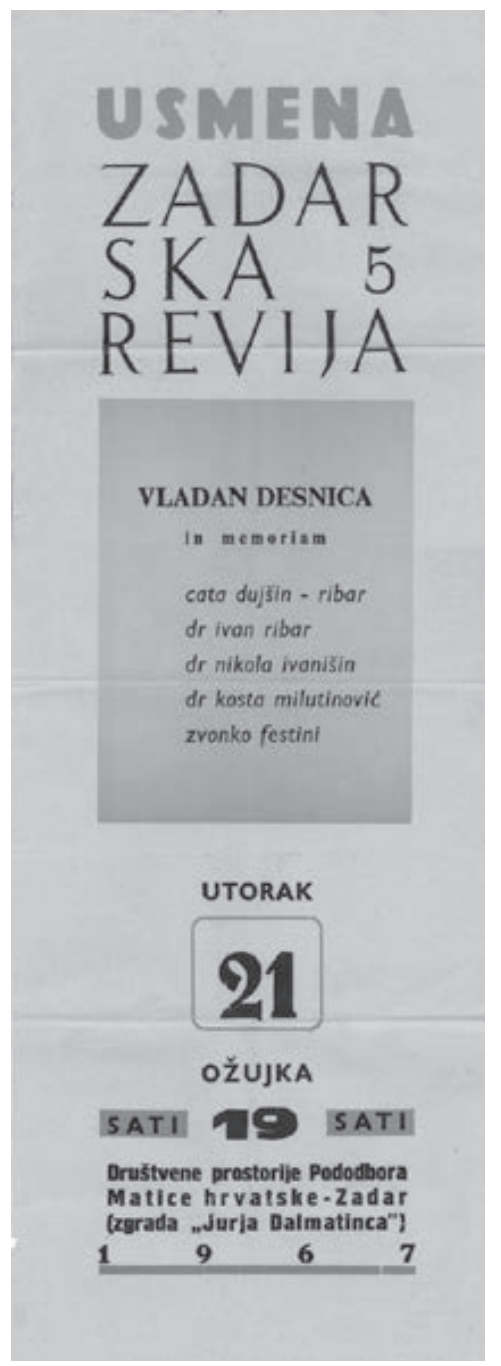

Sl. 3. Reprodukcija plakata

Usmena Zadarska revija.

Vladan Desnica in memoriam

Jasno je da u tom smislu dva ispraćaja Vladana Desnice izražavaju i dvostrukost između Zagreba - grada koji ga je usvojio i u kojemu je živio - i njegova rodnog kraja, kako to naglašava Narodni list: „Iako nastanjen u Zagrebu, Vladan Desnica održavao je stalne i čvrste veze s rodnim gradom i krajem, kamo je uvijek navraćao. ${ }^{\text {"17 }}$

Nadalje, smrt slavnih osoba predstavlja i ceremonijal za javnost koji utječe i na odvijanje uobičajenih pogrebnih praksi te u tom slučaju imamo model posljednjeg ispraćaja koji je uobičajen za javne osobe u 20. stoljeću. ${ }^{18}$

Sada bih se htjela osvrnuti i na specifičnu analizu nekoliko obilježja pogrebnih rituala Vladane Desnice rekonstruiranih na temelju novina i osobnih sjećanja obitelji Desnica. Općenito, gotovo svake novine toga vremena prenosile su vijest o Desničinoj smrti. Obično je vijest bila popraćena fotografijom ili portretom, ali sve to varira u odnosu na tiskovinu o kojoj je riječ. Također i duljina teksta i opreme variraju: od nekoliko redova do pola ili cijele stranice. ${ }^{19}$

Većina listova izvješćuje o Desničinoj smrti s kratkom piščevom biografijom. Obično na početku nalazimo podatke o Desničinu životu (rođenje, obrazovanje i studiji u Zagrebu i u Parizu, karijera u advokaturi, sudjelovanje u NOB-u i, naravno, literarna karijera, njegov opus, prijevodi...). Osim što donose Desničine glavne intelektualne smjernice, autori članaka također stvaraju i liniju kontinuiteta između sadašnjosti i budućnosti, između Desničina opusa i njegova nasljeđa budućim generacijama. Zapravo, u većini slučajeva, uz opis Desničina književnog stvaralaštva, nalazimo i pojedinosti koje uključuju piščev background (društveni i kulturni), čime ga se smješta u društveni prostor i vrijeme. O privatnoj sferi Desničina života nalazimo nekoliko podataka samo u Politici, jedinom listu koji ne govori o Desnici samo kao o književniku. Zapravo ni u Politici ne nalazimo puno, tek nekoliko detalja o njegovoj rodbini i o njegovoj ljubavi prema glazbi:

Kako su mu preci po majci bili pomorci to je u njemu ostao nemir za morem koga muzički doživljava u širokoj skali ritmova i tonova. Taj afinitet za muziku toliko je preovladao da

\footnotetext{
17 Narodni list (Zadar), br. 806, 11. 3. 1967., 5.

18 Michel RaGon, Lo spazio della morte. Saggio sull'architettura, la decorazione e l'urbanistica funeraria, Napoli 1986. 160.

19 Pored toga, nalazimo i tekstove u književnim časopisima. Usp. Miroslav Šıcel, „In memoriam, Književno djelo Vladana Desnice“, Republika (Zagreb), 23/1967., br. 5, 204-205.
} 
se hteo njoj i posvetiti, ali porodica je mislila da je po građanskom naslednom redu predodređen za pravo. ${ }^{20}$

Mnoge novine sadrže dijelove i citate iz Desničinih književnih djela, osobito iz romana Proljeća Ivana Galeba. ${ }^{21}$

Poznato je da je Vladan Desnica umro u subotu 4. ožujka 1967. u Zagrebu u bolnici Rebro. No, novine ne govore o njegovoj bolesti i smrti. Javlja se tek uobičajena fraza „nakon duge i teške bolesti“ 22 a obično je piščeva smrt opisana kao „iznenadna i prerana“. Dakle, ne navodi se ništa što bi se odnosilo na bolest, tjelesnu smrt ili tjelesno propadanje. U takvoj šutnji prepoznajemo i proces uklanjanja smrti i umiranja iz vidokruga zajednice, koji je na djelu u 20. stoljeću, i posljedično odbijanje razgovora o smrti. ${ }^{23}$

No, s druge strane, nalazimo obilne informacije o raznim elementima društveno prihvatljivog oblika sjećanja (poetika, stil, jezik, književni opus). Možda je zanimljivo spomenuti u tom pogledu da članci koji zapravo najviše govore o Desničinoj intimnosti, koji ga čak i fizički opisuju, u stvarnosti nisu povezani s neposrednom piščevom smrti i sa samom sprovodnom počasti, nego su to ponajprije sjećanja na sastanke s Desnicom za njegova života. Dakle, sve reference na fizičko tijelo Vladane Desnice odnose se na njega dok je bio živ.

Referiram se na dva članka. Prvi je članak Dimitrija Mašanovića Dva susreta sa Vladanom Desnicom, objavljen u Književnim novinama. ${ }^{24} \mathrm{U}$ njemu nalazimo opis prvoga susreta iz srpnja 1956. u Desničinu stanu u Zagrebu te drugoga na simpoziju o suvremenom jugoslavenskom romanu u rujnu 1965. Drugi članak, Susreti s Vladanom Desnicom - videnja i saznanja Branka Marjanovića, objavljen je u Narodnom listu. ${ }^{25}$ U njemu su opisana tri susreta: prvi u Islamu Grčkom devet godina prije nastanka teksta, drugi u Splitu dvije godine prije toga i treći, zadnji susret, također u Splitu, mjesec dana prije Desničine smrti. Autor navodi kako su se u ovome posljednjem već mogli primijetiti tužni znakovi približavanja kraja:

Nema ni mjesec dana da sam ga zadnji put sreo... Da Vladan Desnica nije ni pomišljao još da bi mogao umrijeti, - operacija je uspjela, sad je sve dobro, muči me samo čir na želucu! - rekao mi je i - ako me namjerno nije obmanuo iz nekih svojih razloga ili obzira, tajnih i nedokučivih - mogao sam osjetiti u glasu mu ono naivno pouzdanje svih ljudi, kojima smrt stoji kraj ramena. ${ }^{26}$

O dvama ispraćajima u onodobnom tisku nemamo puno informacija. Prvi je bio na Mirogoju u ponedjeljak, 6. ožujka 1967. poslijepodne. Bio je prisutan „veliki broj Zagrepčana“, „mnogobrojni književnici, umjetnici i kulturni javni radnici glavnoga grada Hrvatske, kao

$\overline{20}$ Politika (Beograd), br. 19186, 5. 3. 1967., 3.

21 „Vladan Desnica Igre Proljeća i smrti. Odlomci iz romana: Proljeća Ivana galeba“, Novi List (Zadar), br. 54 , 7. 3. 1967., 8; „Vladan Desnica ‘Dvopjev' (Ulomci iz romana 'Proljeća Ivana Galeba')“, Narodni list (Zadar), br. $806,11$. 3. $1967 ., 5$.

22 Slobodna Dalmacija (Split), br. 6848, 6. 3. 1967., 2; Narodni list (Zadar) br. 806, 11. 3. 1967., 5; Borba (Zagreb), br. 62, 5. 3. 1967., 4.

23 Norbert Elias, The Loneliness of the Dying, Oxford 1985., 11-12.

24 Književne novine (Beograd), br. 257, 18. 3. 1967., 1, 12.

25 Narodni list (Zadar), br. 806, 11. 3. 1967., 5.

26 Isto. 


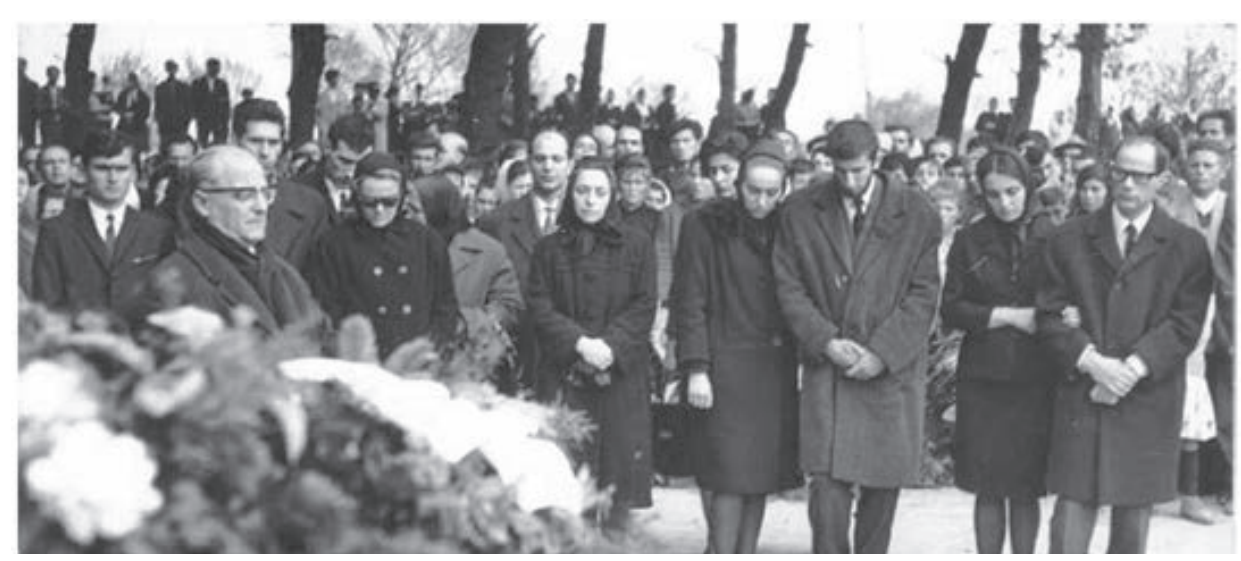

Sl. 4. Ispred odra Vladana Desnice

i članovi konzularnog kora" te članovi odbora za sahranu. ${ }^{27}$ Potonji su bili: Dalibor Brozović, Pero Budak, Ivo Frangeš, Jure Kaštelan, Slavko Mihalić, Vlatko Pavletić, Čedo Prica, Petar Šegedin i Franjo Švelec. ${ }^{28}$ Članovi Društva književnika i pokojnikovi prijatelji držali su počasnu stražu uz odar. Posljednju počasnu stražu kraj odra Vladana Desnice držali su književnici Jure Kaštelan, Petar Šegedin, Čedo Prica, Milivoj Slaviček i Tomislav Ladan. ${ }^{29}$ Među onima koji su održali govore bili su: Dragan M. Jeremić uime Udruženja književnika Srbije i Pero Budak uime Društva književnika Hrvatske i Matice hrvatske. ${ }^{30}$ Nakon toga, piše u Politici, pokriven „vencima i cvećem, kovčeg sa telom Vladana Desnice stavljen je potom u automobil koji će ga preneti u njegov rodni kraj Zadar, gde će biti sahranjen“. ${ }^{31}$

Drugi ispraćaj i sahrana odvili su se u Islamu Grčkomu u poslijepodnevnim satima utorka, 7. ožujka 1967. Prisustvovali su im brojni kulturni i javni radnici te velik broj građana iz sjeverne Dalmacije. Kako je izvijestila Slobodna Dalmacija:

Već u ranim prijepodnevnim satima počele su u Islam Grčki stizati kolone autobusa i automobila iz Zadra i okolnih mjesta s poštovaocima Desničina književnog stvaralaštva koji su željeli da mu odaju posljednju počast. ${ }^{32}$

Kako navodi Uroš Desnica, piščev sin:

U Islamu Grčkom obred je počeo ispred Kule, kad je odar bio pred glavnim ulazom u povijesni dio kompleksa, ispred ulaza u prostoriju „Straža“, a ispod same Kule Jankovića, na kojoj se vila crna zastava žalosti. Već je ovdje bilo jako puno naroda, koji je ispunio gotovo cijelu Veliku avliju. ${ }^{33}$

Ili, kako je to emfatično naglasila Slobodna Dalmacija:

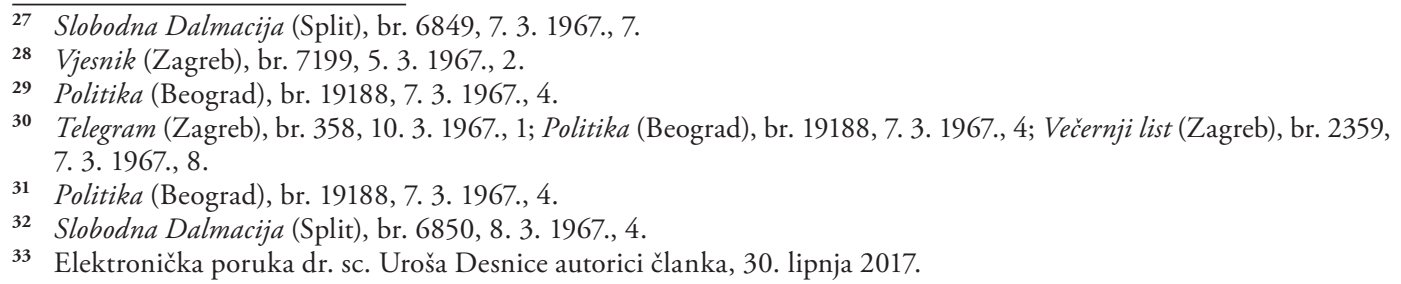




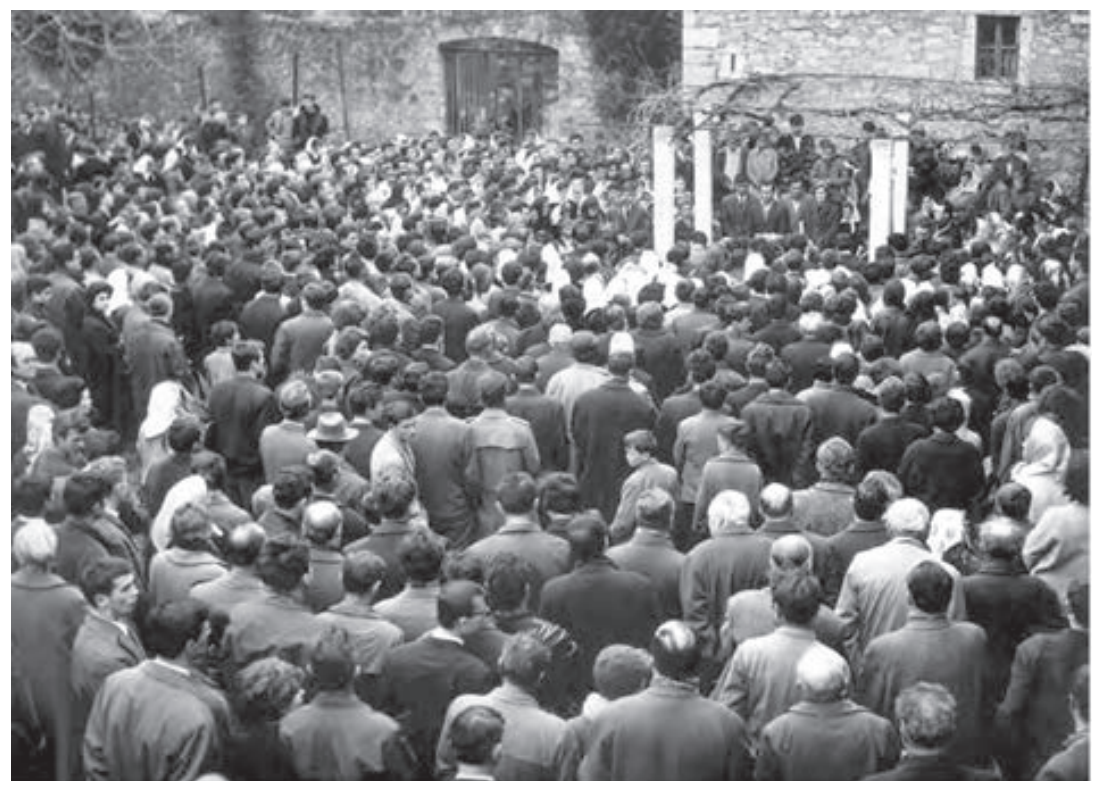

Sl. 5. Okupljeno mnoštvo ispred Kule Stojana Jankovića u Islamu Grčkom na sprovodu Vladana Desnice

Na kuli legendarnoga hajdučkog vođe Janković Stojana u Islamu Grčkom vijorila se danas crna zastava. Žitelji Ravnih kotara i sjeverne Dalmacije opraštali su se od svog uglednog sina, istinskog književnika Vladana Desnice, potomka slavnih serdara i hajduka tog kraja. ${ }^{34}$

Zatim se žalobna povorka od nekoliko stotina prisutnih kretala glavnom cestom kroz Islam Grčki, do mjesne osnovne škole i biste Sime Matavulja. Govore su održali, među ostalima, profesor Filozofskog fakulteta u Zagrebu Nikola Ivanišin uime Matice hrvatske i Filozofskog fakulteta u Zadru, Dalibor Brozović uime pisaca okupljenih oko časopisa Krugovi i Dalibor Cvitan uime Društva književnika Hrvatske. ${ }^{35}$ Okupilo se i mnogo učenika, a neki su i pročitali svoje govore.

Potom je povorka stigla do „gumna“, smještenog između sjevernog zida kompleksa i starog groblja sa crkvom sv. Đurđa. I ondje je govorilo više ljudi, među ostalima i dr. Vinko Foretić uime naroda sjeverne Dalmacije, ${ }^{36}$ a bili su prisutni i predstavnici općina Zadar i Benkovac. ${ }^{37}$ Zatim je odar došao pred pročelje crkve sv. Đurđa te je konačno smrtno tijelo Vladana Desnice položeno u obiteljsku grobnicu u kapeli Kule Jankovića pored supruge Ksenije.

Stoga možemo zaključiti da posljednji ispraćaj Vladana Desnice spada u tipične ceremonije toga vremena. Međutim, zanimljiv je zbog dvostrukog ispraćaja u spacijalnom smislu - Zagreb i Zadar - te u simboličkom smislu, koji je vidljiv u raznolikosti sudionika, organizatora, govornika i vrsta pogrebnih govora. Uz to, dvostrukost dvaju tijela Vladana

\footnotetext{
34 Slobodna Dalmacija (Split), br. 6850, 8. 3. 1967., 4.

35 Isto.

36 Isto.

37 „Javna Zahvala“, Narodni list (Zadar), br. 807, 18. 3. 1967., 8. Prema osobnim sjećanjima, među govornicima bili su i Jovo Vujasinović i Dušan Brkić. Zahvaljujem dr. sc. Urošu Desnici na ovom podatku.
} 
Desnice vidljiva je i u tisku, u kojem se pojavljuje razdvajanje fizičkog (posmrtni ostaci koji su završili svoje postojanje) i simboličkog tijela (književnog i društvenog), koje u tom trenutku započinje svoj samostalan put:

Književna riječ Vladana Desnice, ostala među nama poslije prerane i neočekivane smrti, javlja se kao njegov novi život. Gotovo bih rekao i kao jedini njegov život: onaj najbolji, koji je sam on odabrao i sam oživio. Taj život - riječ nije nepoznata u nas. Njeno svjetlo je već bilo vidno prisutno u našoj književnosti, ali sada - poslije njegove smrti - biva još čišće, a njegov sjaj još vidniji. ${ }^{38}$

\section{$\cos$}

\section{Izvori i literatura}

\section{Izvori}

Borba (Zagreb), 1967.

Književne novine (Beograd), 1967.

Narodni list (Zadar), 1967.

Novi list (Rijeka), 1967.

Politika (Beograd), 1967.

Republika (Zagreb), 1967.

Slobodna Dalmacija (Split), 1967.

Telegram (Zagreb), 1967.

Večernji list (Zagreb), 1967.

Vjesnik (Zagreb), 1967.

\section{Literatura}

Tara Bailey - Tony WaLter, „Funerals against death“, Mortality, 21/2016., br. 2, 149-166.

Alberto Mario Banti, „La memoria degli eroi“, Storia d'Italia. Annali, knj. 22: Risorgimento (ur. Alberto Mario Banti i Paul Ginsborg), Torino 2007., 637-664.

Norbert Elias, The Loneliness of the Dying, Oxford 1985.

Ralph Giesey, The Royal Funeral Ceremony in Renaissance France, Genève 1960.

Carlo Ginzburg, Occhiacci di legno, Milano 2011.

Robert Hertz, „Contribution à une étude sur la représentation collective de la mort“, Année sociologique, 10/1907., 48-137.

Ernst Hartwig Kantorowicz, The King's Two Bodies. A Study in Mediaeval Political Theology, New Jersey 1981.

Nicole Marafioti, The King's Body, Toronto 2014.

Michel Ragon, Lo spazio della morte. Saggio sull'architettura, la decorazione e l'urbanistica funeraria, Napoli 1986.

$\overline{38}$ Petar Š Egedin, „Riječ - život“, Telegram (Zagreb), br. 358, 10. 3. 1967., 1. 
Giovanni Ricci, „Le Corps et l'Effigie: Les Funérailles des Ducs de Ferrare à la Renaissance“, $C i$ vic Ritual and Drama (ur. Alexandra F. Johnston i Wim Hüsken), Amsterdam 1997., 175-201.

Julie RugG, „Defining the place of burial: what makes a cemetery a cemetery?“, Mortality, 5/2000., br. 3, 238-259.

Kate Woodthorpe, „Sustaining the contemporary cemetery: implementing policy alongside conflicting perspectives and purpose“, Mortality, 16/2011., br. 3, 259-276.

\section{$\cos$}

\section{Two MEMORIAl SERVices for VladAN Desnica}

Using the two different memorial services held for Vladan Desnica as a starting point, the author demonstrates the dichotomy between two contrasting views of death. Vladan Desnica passed away on Saturday, March 4th 1967 in the Rebro Hospital in Zagreb. An overview of the reporting of his passing makes it clear that it is Desnica the man who is taken, whereas Desnica the author is beyond the reach of death. This duality of physical death and public life is reflected in the eulogies given during Desnica's memorial service. The first one of the two was held at the Mirogoj cemetery in Zagreb on March 6th 1967, while the other took place in Islam Grčki the following day and was immediately followed by the interment of Desnica's remains in the church of St. George in the Stojan Janković Tower. The way a culture chooses to remember its dead reflects the nature and the character of that culture, while the way a society uses death becomes an indicator of its values. For instance, the removal of death and dying from the view of the community at large, and the consequent refusal to discuss death was evident throughout the 20th century. Thus, the division between Vladan Desnica as a (dead) body, the details of which are scarcely reported on, and Desnica as the writer becomes evident in the press. Nothing we would be reluctant to talk about or depict (illness, decay, death) is referred to, whereas the socially acceptable forms of memory (poietics, style, language, literary ouevre) are cited extensively. Finally, the two memorial services exhibit other typical feautres of a public funeral, such as the inclusive nature of memory and the affirmation of the cult of personality. Public rituals, funerals included, can be analysed from numerous points of view - that of the organizer, the participant, the observer and/or the commentator - yet they inevitably have an inclusive and an exclusive element to them. By analysing just the attitudes of the organizer, a frequent tendency of expunging all traces of ideological, political or cultural conflict becomes evident. Similarly to the united front presented by the grieving family on the private level, on the public level, these ceremonies were often supposed to be visibly inclusive. Thus, it was stated that Vladan Desnica's name is "written in golden letters in the history of Croatian and Yugoslav literature" and listed in the cultural pantheon "alongside Đuro Daničić, Josif Pančić and Nikola Tesla as another token of brotherly freedom between the Croats and the Serbs".

Key words: death, the history of death, Vladan Desnica, memorial service, funerary rites/rituals, double funeral 



\section{Popis slikovnih priloga}

O smrti na Desničinim susretima. Predgovor (Ivana Cvijović Javorina i Drago Roksandić)

Sl. 1. Desničini susreti 2017. (design: Dejan Dragosavac Ruta)

Haronova dobra. Antički motivi u tanatičkom repertoaru Vladana Desnice (Bruna KuntićMakvić)

Sl. 1. Glasoviti muževi staroga vijeka. Korice izdanja koje je priredio Marko Car, primjerak iz privatne knjižnice, Zagreb

Sl. 2. Marko Car, Glasoviti muževi staroga vije$k a$, naslovnica s Carevim inicijalima (primjerak iz privatne knjižnice)

Sl. 3. Otto Seemann, Mythologija Grka i Rimljana, Zagreb 1890. (primjerak iz privatne knjižnice)

Sl. 4. Himera iz Arezza, bronca, lijevanje à cire perdue (5. - 4. st. pr. Kr., etruščanska umjetnost), Firenze, Museo archeologico nazionale (snimila BKM)

Sl. 5. Paul Gustave Doré, Haron, drvorez (1857.) (https://bs.m.wikipedia.org/wiki/Datoteka:Charon_by_Dore.jpg)

Sl. 6. Mirko Rački, Prijelaz preko Aheronta, ulje na platnu (1910.), Muzej za umjetnost i obrt, Zagreb (https://www.europeana.eu/portal/ hr/record/2026118/_MG_0843.html)

Sl. 7. Mirko Rački, S onu stranu Acherona, tuš i akvarel na papiru, (1907.), Galerija umjetnina, Split. Fotodokumentacija Galerije. Snimio Valentino Bilić Prcić

Tanatologike Vladana Desnice - igre poetike i smrti (Bojan Jović)

Sl. 1. Fragment autografa romana Pronalazak Athanatika (Osobna ostavština Vladana Desnice)

Sedefasti odsjev vječnosti. Tanatološki aspekti književnog djela Vladana Desnice (Vladan Bajceta)

Sl. 1. Pismo Vladana Desnice Tomislavu Tanhoferu o Ljestvama Jakovljevim (Osobna ostavština Vladana Desnice)
Slovenačka recepcija Vladana Desnice i tematizovanja smrti u njegovim delima (Marija Mitrovic')

Sl. 1. In memoriam Vladanu Desnici u listu Delo (Tone РотокаR, „Ob smrti Vladana Desnice“, Delo [Ljubljana], br. 63, 7.3. 1967., 5)

Dramaturgija slobode i smrti ili o Ljestvama Jakovljevim Vladana Desnice u svetlu Sartrove teorije pozorišta situacija (Aleksandra Kuzmić)

Sl. 1. Pismo dramaturga Jovana Ćirilova Vladanu Desnici (Osobna ostavština Vladana Desnice, dalje: OOVD)

Sl. 2. Fotografija sa čitaćih proba Ljestava Jakovljevih 1960. godine: Tomislav Tanhofer, Viktor Starčić i Vladan Desnica (OOVD)

Časopis kao amblem poslednjeg časa: međusobna uslovljenost motiva smrti i motiva periodične štampe u pripovetkama Vladana

Desnice (Stanislava Barać)

Sl. 1. Astrološka predviđanja za 1836. godinu u Srbsko-dalmatinskom almanahu (АЮБИТЕАЬ ПРОСВБШТЕНІЯ. СРБСКО-А АМАТИНСКІЙ ААМАНАХЬ ЗА ИБТО 1836. ИзАао га на свет Теодор Петрановић, обои права доктор. У КарАштадту, печатано у Типографији Иоана $\mathrm{H}$. Претнера, 21-22)

Groteskna slika tijela u Olupinama na suncu Vladana Desnice (Sanja Šakić)

Sl. 1. Korice sarajevskog izdanja zbirke novela Olupine na suncu iz 1962. godine (Svjetlost, Sarajevo 1962., Biblioteka „Džepna knjiga“)

\section{Thanatopolitika i imortalizam u Desničinu} Pronalasku Athanatika (Vinko Drača)

Sl. 1. Pregled poglavlja nedovršena romana Pronalazak Athanatika (Osobna ostavština Vladana Desnice)

Vladan Desnica, prevoditelj i komentator Foscolovih Grobova (Sanja Roić i Iva Grgić Maroević)

Sl. 1. Redigirani strojopis Desničinih bilješki uz prijevod Grobova Uga Foscola (Obiteljska ostavština Vladana Desnice) 
U iščekivanju smrti ili preplitanja života i smrti u Baraci 5 be Miroslava Krleže i Rekonvalescentima Dragiše Vasića (Iva Tešić)

Sl. 1. Korice prvog izdanja zbirke Hrvatski bog Mars s ilustracijom Ljube Babića (Antikvarijat vremeplov, http://www.antikvarijatvremeplov.hr/krle\%C5\%BEa-hrvatski-bogmars-proizvod-6732)

Šašava besmrtnost i garava smrt: predstave ljudske smrti u poeziji za decu i mlade Miroslava Antića (Vladimir Vukomanović Rastegorac)

Sl. 1. Ilustracija Miće Mihajlovića u Šašavoj knjizi (Izabrana dela Miroslava Antića, Dnevnik, Novi Sad 1982., 41)

Uloga smrti u njemačkoj filozofiji egzistencije međuratnoga perioda i njezina recepcija $u$ misli Stjepana Zimmermanna (Matko Globačnik)

Sl. 1. Stjepan Zimmermann (Hrvatska enciklopedija, www.enciklopedija.hr/natuknica. aspx?id=67251)

Grobni spomenici iz sjeverozapadne Hrvatske u svjetlu odnosa rimske antike prema smrti (Branka Migotti)

Sl. 1. Stela Tita Flavija Ateboda (2. stoljeće), Odra kod Zagreba (Arheološki muzej u Zagrebu)

Sl. 2. Nadgrobna ploča Leburne (4. stoljeće), Sisak (Mađarski narodni muzej, Budimpešta)

Sl. 3. Stela robovske obitelji (2. stoljeće), Donji Čehi (Arheološki muzej u Zagrebu)

Sl. 4. Sarkofag Romanije Nevije (3. stoljeće), Sisak (Arheološki muzej u Zagrebu)

Epitafi srednjega vijeka: „knjige života i smrti“" (Mirjana Matijević Sokol)

Sl. 1. Sarkofag s epitafom opatice Ivane na Manastirinama u Solinu (Ivan BAsıć, „CIL III 9551 i njegovi tumači“, Tusculum, 1/2008., 85)

Sl. 2. Epitaf kraljice Jelene, Muzej hrvatskih arheoloških spomenika, Split (Tomislav Raukar, Hrvatsko srednjovjekovlje. Prostor, ljudi, ideje, Zagreb 1997., 241)

Sl. 3. Grobnica s natpisom opatice Vekenege, kapitul samostana sv. Marije u Zadru (T. RAUKAR, Hrvatsko srednjovjekovlje, 61)

Sl. 4. Natpis na ploči u zidu iznad bifore na grobnici opatice Vekenege, kapitul samosta- na sv. Marije u Zadru (T. Raukar, Hrvatsko srednjovjekovlje, 62)

Sl. 5. Epitaf Tome Arhiđakona, crkva sv. Frane na Rivi u Splitu (T. Raukar, Hrvatsko srednjovjekovlje, 371)

Sl. 6. Nadgrobni spomenik Ratkajevih u crkvi sv. Marije u Lepoglavi (Josip ŚTimaC i dr. [ur.], Ratkaji Velikotaborski u hrvatskoj povijesti i kulturi 1502-1793. u povodu 200-te obljetnice izumrća. Grad Veliki Tabor, 11. rujna-10. listopada 1993., 22)

Oporuke zagrebačkih građana s kraja 17. stoljeća u gradskim knjigama Zapisnika izjavnica (Protocolla fassionum) (Zvjezdana Sikirić Assouline)

Sl. 1. Zapisnik izjavnica (lat. Protocollum fassionum) (Državni arhiv u Zagrebu, Poglavarstvo grada Zagreba, 1657 [77], Zapisnik izjavnica [Protocollum fassionum] za godine 1693. - 1714.)

Sl. 2. Početak oporuke Helene Veselinović (isto)

Duh moderne: od kulture življenja do kulture smrti. Fenomen samoubojstva u Europi i Hrvatskoj (Filip Šimetin Šegvić i Nikolina Šmetin Šegvić)

Sl. 1. Édouard Manet, Samoubojstvo (između 1877. i 1881.) (http://www.manet.org/le-suicide.jsp)

Sl. 2. Gustav Klimt, studija za alegorijsku sliku Jurisprudencija u Svečanoj sali Sveučilišta u Beču (1898.) (https://commons.wikimedia. org/wiki/File:Klimt___Gemalter_Kompositionsentwurf_zur_Jusisprudenz.jpeg)

Sl. 3. George Grosz, Samoubojstvo (1916.) (https://www.tate.org.uk/art/artworks/grosz-suicide-t02053)

Kad smrt poždere smrt: utjecaj pandemije španjolske gripe iz 1918. godine na dinamiku patocenične promjene u sjevernoj Hrvatskoj (Nikola Anusićć)

Sl. 1. Stope mortaliteta od tuberkuloze u Banskoj Hrvatskoj od 1901. do 1910. godine (izračun autora prema: Ana BorovečKI Ira Gjenero-Margan, „Epidemiological Analysis of Tuberculosis in the Kingdom of Croatia and Slavonia during 1901 - 1910“, Croatian Medical Journal, 43/2002., br. 3, 350-354) 
Sl. 2. Spolna struktura umrlih od tuberkuloze u sjevernoj Hrvatskoj od 1908. do 1919. godine (izračun autora)

Sl. 3. Mortalitet od španjolske gripe u sjevernoj Hrvatskoj tijekom drugoga epidemijskog vala (izračun autora)

Sl. 4. Ostvarene i očekivane stope mortaliteta od tuberkuloze od 1901. do 1921. godine (izračun autora prema: Vladimir ĆEPUlić, Suzbijanje tuberkuloze u Zagrebu, Zagreb 1940.)

Hrvatsko državno kazalište u Zagrebu 1941. godine - dani smrti, straha i poniženja

(Snježana Banović)

Sl. 1. Policijski karton Margarete Froman (Hrvatski državni arhiv, dalje: HDA)

Sl. 2. Otisci prstiju Dubravka Dujšina uzeti nakon uhićenja 1941., 1942. i 1944. godine (vlasnišstvo obitelji Delale)
Sl. 3. Policijski karton Ivana Štrka (HDA)

Sl. 4. Policijski karton Rade Sladića (HDA)

Sl. 5. Policijski karton Krste Hegedušića (HDA)

Dva ispraćaja Vladana Desnice (Monica

Priante)

Sl. 1. Oproštaj od Vladana Desnice ispred mrtvačnice na zagrebačkom Mirogoju (Večernji list, br. 2359, 7. 3. 1967., 8)

Sl. 2. Oproštaj od Vladana Desnice u Islamu Grčkom (Osobna ostavština Vladana Desnice, dalje: OOVD)

Sl. 3. Reprodukcija plakata Usmena Zadarska revija. Vladan Desnica in memoriam (OOVD)

Sl. 4. Ispred odra Vladana Desnice (OOVD)

Sl. 5. Okupljeno mnoštvo ispred Kule Stojana Jankovića u Islamu Grčkom na sprovodu Vladana Desnice (OOVD) 


\section{Autori članaka}

Nikola Anušić, doc. dr. sc.

Odsjek za povijest Filozofskog fakulteta Sveučilišta u Zagrebu

Miroslav ArTić

doktorand na Filozofskom fakultetu Sveučilišta u Zagrebu

Vladan BAJČETA, dr., znanstveni suradnik Institut za književnost i umetnost, Beograd

Snježana Banović, red. prof. art. dr. sc.

Akademija dramske umjetnosti Sveučilišta u Zagrebu

Stanislava BARAĆ, dr., znanstvena suradnica

Institut za književnost i umetnost Beograd

Marin Biondić, dr. sc.

Odsjek za filozofiju Sveučilišta u Rijeci

Ivana Cvijović Javorina

III. gimnazija, Zagreb / doktorandica na Filozofskom fakultetu Sveučilišta u Zagrebu

Vinko Drača

doktorand na Filozofskom fakultetu Sveučilišta u Zagrebu

Bojan Đorøević, izv. prof. dr.

Filološki fakultet Univerziteta u Beogradu

Goran ĐurĐEvić

doktorand na Sveučilištu u Zadru

\section{Matko GlobAČNIK}

doktorand na Filozofskom fakultetu Sveučilišta u Zagrebu

Iva Grgić Maroević, izv. prof. dr. sc. Odjel za talijanistiku Sveučilišta u Zadru

Vladimir Gvozden, izv. prof. dr.

Odsek za komparativnu književnost Filozofskog fakulteta Uiverziteta u Novom Sadu

\section{Marijana Jelisavčić}

doktorandica na Filozofskom fakultetu Univerziteta u Novom Sadu
Bojan Jović, dr., znanstveni savjetnik

Institut za književnost i umetnost, Beograd

Virna Karlić, doc. dr. sc.

Odsjek za južnoslavenske jezike i književnosti Filozofskog fakulteta Sveučilišta u Zagrebu

Bruna Kuntić-Makvić, prof. dr. sc.

Odsjek za povijest Filozofskog fakulteta Sveučilišta u Zagrebu

Aleksandra Kuzmić, dr.

Filološka gimnazija, Beograd

fra Ivan MajIĆ, dr. sc.

Samostan sv. Franje Asiškog, Zagreb

Mirjana Matijević SoKol, prof. dr. sc.

Odsjek za povijest Filozofskog fakulteta Sveučilišta u Zagrebu

Branka MigotTi, dr. sc., znanstvena savjetnica

Odsjek za arheologiju Hrvatske akademije znanosti i umjetnosti, Zagreb

Marija Mitrović, prof. dr. sc.

Universitá degli Studi di Trieste

Edin Muftić

Leksikografski zavod Miroslav Krleža, Zagreb

\section{Aleksandra OBRADOvić}

Novi Sad

Nikola Petrović, prof. dr. sc.

Odsjek za kulturne studije i Odsjek za filozofiju Filozofskog fakulteta Sveučilišsta u Rijeci

Monica Priante, dr. sc.

Odjel za povijest Hrvatskog katoličkog sveučilišta, Zagreb

Sanja RoIć, prof. dr. sc.

Odsjek za talijanistiku Filozofskog fakulteta Sveučilišta u Zagrebu

Drago Roksandić, prof. dr. sc.

Odsjek za povijest Filozofskog fakulteta Sveučilišta u Zagrebu 
Zvjezdana Sikirić Assouline, doc. dr. sc. Nikolina ŠImetin Šegvić

Odsjek za povijest Filozofskog fakulteta Sveuči- Odjel za povijest Hrvatskog katoličkog sveučilišta u Zagrebu

\section{Sanja ŠAKIĆ}

doktorandica na Filozofskom fakultetu Sveučilišta u Zagrebu

Svetlana ŠEATOVIĆ, dr., viša znanstvena suradnica

Institut za književnost i umetnost, Beograd

Filip ŠIMETIN ŠEgVIĆ

Odsjek za povijest Filozofskog fakulteta Sveučilišta, Zagreb

\section{Iva Tešić}

Institut za književnost i umetnost, Beograd

Melida Travančić, dr. sc.

Centar za kulturu i obrazovanje, Tešanj

Vladimir Vukomanović

RASTEgORAC, doc. dr.

Učiteljski fakultet Univerziteta u Beogradu lišta u Zagrebu 


\section{Recenzenti članaka*}

Elvio BACCARINI, prof. dr. sc. (Rijeka)

Krešimir BAGIć, prof. dr. sc. (Zagreb)

Vladan BAJČETA, dr., znanstveni suradnik (Beograd)

Ivan BAsIć, doc. dr. sc. (Split)

Marin Biondić, dr. sc. (Rijeka)

Dubravka Bogutovac, dr. sc. (Zagreb)

Dragan Bošković, prof. dr. (Kragujevac)

Dušan BošKović, dr., znanstveni suradnik (Beograd)

Tomislav BRLEK, izv. prof. dr. sc. (Zagreb)

Jadranka BRNČıć, dr. sc. (Zagreb)

Domagoj Brozović, dr. sc. (Zagreb)

Milka CAR, izv. prof. dr. sc. (Zagreb)

Suzana CoHA, doc. dr. sc. (Zagreb)

Nadežda Čačinovič, prof. dr. sc. (Zagreb)

Uroš DesnicA, dr. sc., znanstveni savjetnik (Zagreb)

Željko Dugac, dr. sc., znanstveni savjetnik (Zagreb)

Bojan ĐorĐević, izv. prof. dr. (Beograd)

Hrvoje Gračanin, izv. prof. dr. sc. (Zagreb)

Vladimir Gvozden, izv. prof. dr. (Novi Sad)

Željko Holjevac, izv. prof. dr.sc. (Zagreb)

Goran Hutinec, doc. dr. sc. (Zagreb)

Bojan Jović, dr., znanstveni savjetnik (Beograd)

Hrvoje Jurić, izv. prof. dr. sc. (Zagreb)

Marko Juvan, prof. dr. (Ljubljana)

Rade Kalanj, prof. dr. sc. (Zagreb)

Vesna Kilibarda, prof. dr. (Cetinje)

Sanjin Kodrić, izv. prof. dr. (Sarajevo)

Zvonko Kovač, prof. dr. sc. (Zagreb)

Krištof Jacek KozaK, prof. dr. (Kopar)

Bruna Kuntić-Makvić, prof. dr. sc. (Zagreb)
Vjeran Kursar, doc. dr. sc. (Zagreb)

Aleksandra Kuzmić, dr. (Beograd)

Miranda Levanat-Peričić, doc. dr. sc. (Zadar)

Alpár Losoncz, prof. dr. (Novi Sad)

Darko Lukić, red. prof. art. dr. sc. (Zagreb)

Sanja Macura, prof. dr. (Banja Luka)

Dušan Marinković, prof. dr. sc. (Zagreb)

Suzana Marjanić, dr. sc., znanstvena savjetnica (Zagreb)

Tonko Maroević, akademik (Zagreb)

Vesna Matović, dr., znanstvena savjetnica (Beograd)

Vanda Mıкšić, doc. dr. sc. (Zadar)

Nenad Moačanin, prof. dr. sc. (Zagreb)

Lana Molvarec, doc. dr. sc. (Zagreb)

Zrinka Nikolić JAKus, prof. dr. sc. (Zagreb)

Žarko PaIć, izv. prof. dr. sc. (Zagreb)

Igor Perišić, dr., znanstveni suradnik

(Beograd)

Hrvoje Petrić, izv. prof. dr. sc.

Marina Protrka Štimec, doc. dr. sc.

Milorad Radovanović, akademik

(Beograd)

Marina ŠEgVIĆ, stručna suradnica (Zagreb)

Boris $\check{S}_{\text {KVORC, prof. dr. sc. (Split) }}$

Tijana Tropin, dr., znanstvena suradnica (Beograd)

Luca Vaglio, izv. prof. dr. (Kragujevac)

Trpimir Vedriš, doc. dr. sc. (Zagreb)

Nenad VeličKović, izv. prof. dr. (Sarajevo)

Lino VeljaK, prof. dr. sc. (Zagreb)

Velimir Visković, mr. sc. (Zagreb)

Andrea Zlatar Violić, prof. dr. sc. (Zagreb) 


\section{Bilješke o urednicima}

Ivana Cvijović Javorina (Zagreb, 1985.) studentica je poslijediplomskoga doktorskog studija Moderna i suvremena hrvatska povijest u europskom i svjetskom kontekstu Odsjeka za povijest Filozofskog fakulteta Sveučilišta u Zagrebu. Nakon završene V. gimnazije upisala je dvopredmetni studij germanistike i povijesti na Filozofskom fakultetu u Zagrebu i stekla zanimanje profesorice povijesti i njemačkog jezika i književnosti. Zaposlena je u III. gimnaziji u Zagrebu kao nastavnica njemačkog jezika, u zvanju profesorice mentorice. Autorica je dvojezične studije „Od ovih je njemački jezik za nas bez dvojbe najvažniji...". Prilozi za povijest nastave njemačkog jezika i studija germanistike na Mudroslovnom fakultetu u Zagrebu 1876. - 1904., objavljene u povodu 120. obljetnice utemeljenja Odsjeka za germanistiku Filozofskog fakulteta Sveučilišta u Zagrebu. S prof. dr. sc. Dragom Roksandićem uredila je desetak publikacija, uključujući i osam zbornika radova sa znanstvenih skupova Desničini susreti. S njemačkog jezika prevela je knjigu francuske povjesničarke Catherine Horel Vojnici izmedu nacionalnih fronti. Ukidanje Vojne krajine i razvoj Kraljevskoga ugarskog domobranstva u Hrvatskoj i Slavoniji 1868. - 1914. Piše doktorsku disertaciju pod naslovom Nastava njemačkoga jezika i književnosti na Sveučilištu u Zagrebu od 1876. do 1918. pod mentorstvom prof. dr. sc. Drage Roksandića (Odsjek za povijest) i prof. dr. sc. Marijana Bobinca (Odsjek za germanistiku).

Drago Roksandić (Petrinja, 1948.) redovni je profesor u trajnom zvanju na Odsjeku za povijest Filozofskog fakulteta Sveučilišta u Zagrebu, predstojnik Katedre za povijest Srednje i Jugoistočne Europe, voditelj Ranonovovjekovnog modula Diplomskog studija i nositelj poslijediplomskog doktorskog kolegija „Teorije i metode u modernoj i suvremenoj historijskoj znanosti“. Voditelj je projekta „Triplex Confinium“ (od 1996.) i fakultetskog Centra za komparativnohistorijske i interkulturne studije (od 2014.), Programa „Desničini susreti“ (od 2005.) te projekta Europske unije „Jankovic Castle“ (2011. - 2014.). Član je projekta "Local Approaches to the Second World War in Southeastern Europe" na Sveučilištu Humboldt u Berlinu. Vidi: Hrvoje Petrić, „Živjeti Triplex Confinium (u povodu 60. godišnjice rođenja prof. dr. sc. Drage Roksandića“, Ekonomska i ekohistorija, 4/2008., 151-231 i http://ckhis.ffzg.unizg.hr/hr/o-centru/aktivnosti-clanova-vijeca-ckhis/roksandicdrago/. Novija izdanja: „Izlazak izvan zidina“, u: Ivo Goldstein, Slavko Goldstein (ur.), Povijest grada Zagreba. Knjiga 1. Od prethistorije do 1918., Zagreb 2012., 200-251; UNIN-u i Danasu, Zagreb 2011.; Daniel Baric, Jacques Le Rider, Drago Roksandić (ur.), Mémoire et histoire en Europe centrale et orientale, Rennes 2010.; Drago Roksandić, Vlatka Filipčić Maligec, Kultura hrvatskog antifašizma. (Prvi kongres kulturnih radnika Hrvatske (Topusko, 25. - 27. lipnja 1944.). Izmedu „mjesta pamćenja“ i kritičke refleksije, Zagreb 2016.; Jugoslavija u istorijskoj perspektivi (ur. Latinka Perović, Drago Roksandić, Mitja Velikonja, Wolfgang Höpken i Florian Bieber), Beograd 2017. te Iluzije slobode. Ogledi o Vladanu Desnici, Zagreb 2018. Nositelj je dvaju francuskih odličja: časnik reda akademske palme (Offcier dans l'Ordre des Palmes Académiques, 2004.) i časnik nacionalnog reda za zasluge (Officier dans l'Ordre National du Mérite, 2014.). 


\section{Imensko kazalo}

\section{A}

Abramić, Mihovil 37, 38, 51

Adam Parižanin 387, 388

Adler, Alfred 430

Adler, Viktor 440

Afrić, Vjekoslav 20, 464, 465, 468, 470, 475, 480

Alberti, Leon Battista 391

Albini, Srećko 472, 474

Aleksandar Makedonski 29

Aleksandrovna, Irina 466

Alkej, pjesnik 299

Alkmeon iz Krotona 167

Aljinović, Grozdana 423

Amenofis (Amenhotep) III., faraon 43

Anakreont 34, 299

Anastazije, mučenik 387-388

Anderson, Olive 436, 446

Andreas-Salome, Lou 434

Andrić, Ivo 69, 98, 305, 311, 313

Andrić, Nikola 438

Angeli Bertinelli, Maria Gabriella 370, 378

Anić, Šime 38,51

Anić, Tomislav 427, 446

Anić, Vladimir 38, 51

Antić, Miroslav (Антић, Мирослав) 10, 15, 315-326

Antonino Pio, car 373-374

Anušić, Nikola 20, 453, 454, 459, 461

Aposotolova Maršalevski, Magdalena 409, 419

Arenas, Reinald 344

Arhiloh, pjesnik 25, 299

Ariès, Philippe (Arijes, Filip) 21-22, 172, $177,422,446$

Aristotel 13, 33, 34, 51, 106, 329, 334

Artić, Miroslav 15

Artuković, Andrija 474

Asino, Rosalba 442, 446

Astuti, Rita 316, 325

Atebod, Tito Flavije 369-370

Aterig (Aterix) 369-370

August, car 40,382
Augustin Aurelije 341

Auzonije, pjesnik 377

\section{B}

Babić, Ivo 389, 395

Babić, Ljubo 308

Baccarini, Elvo 243, 246

Bagić, Krešimir 192, 196, 200

Bahr, Andreas 433, 446

Bahtin, Mihail 13, 60, 67, 147, 150-151, 152, 153, 154, 156

Bailey,Tara 484, 492

Bajčeta, Vladan 9, 12, 79, 87, 381, 396

Banović, Snježana 20, 468, 470, 474, 480

Banti, Alberto Mario 485, 492

Banjanin, Ljiljana 169, 177

Barac, Antun 465, 480

Barać, Stanislava 13, 145

Baratin, Luka, nadbiskup 392

Barbarič, Štefan 12, 93, 94-95, 101, 102

Barbarić, Damir 330, 338

Baričević, Mato 28

Barlle, Petar 405

Basara, Svetislav 344

Basić, Ivan 384, 395

Baskin, Andrea 352, 354, 355

Bass Verzár, Monika 367, 378

Batušić, Nikola 446

Baudelaire, Charles 432, 445

Baudrillard, Jean (Bodrijar, Žan) 306, 313

Baumann, Ursula 433, 446

Bavčević, Branko 54

Becić, Vladimir 431

Beck (Bek), Vladimir 464

Beč, Dušan, vatrogasac 466

Bedford, James 242

Begović, Božena 463, 466, 481

Beiser, Frederick Charles 329, 337

Beit-Hallahmi, Benjamin 316, 325

Bela IV., kralj 389

Benn, Gottfried (Ben, Gotfrid) 13, 117 
Benjamin, Walter (Бенјамин, Вамтер) 13, $14,130-131,135-136,139,142-143,144$, $145,162,164,445,446$

Berdjajev, Nikolaj 443

Berg, Alban 435

Berger, Peter L. $116,121,125$

Berkeš, Đuka 464, 480

Bernhard, Thomas 117

Berry, Peter 262, 278

Bervaldi, Josip 383, 384, 395

Bešević, Ivanka (БЕшевић, Иванка) 23, 51, 104

Binički, Aleksandar 466, 468

Binički, S. 478

Biondić, Marin 14, 220, 222

Biraben, Jean-Noel 453, 461

Birk, Stine 366, 367, 368, 376, 377

Biti, Vladimir 59, 67, 131, 135, 143, 145, 192, 200

Bitroff, Paulus 371

Blackshaw, Gemma 439, 446

Blanchot, Maurice (Blanšo, Moris) 14, 159, 163, 164, 215, 221, 222

Blažeković, Zdenko 470, 475

Bloom, Harold 13, 153, 156

Bogdani, Vitaliano 37

Bogdanović, Danijel 354,358-359

Bogdanović, Milan 305, 313

Boić, Gemma 437

Bolf, Ivan (Bollff, Joannes /Bollff /Bolff, Boliuff/, Januss), gradski prisjednik 40, 406, 409, 412, 414

Boltzmann, Ludwig 435

Bonfante, Larisa 367, 378

Borges, Jorge Luis 344

Borko, Božidar 90

Borovečki, Ana 453, 461

Borstelmann, Thomas 262, 278

Bošnjak, Branko 51, 184, 189, 214, 223

Bowersock, Glen Warren 372, 378

Bradley, Ben 327, 337, 382, 397

Brajković, Tomo 285

Brajović, Tihomir (Брајовић, Тихомир) 72, 87

Brandt, Olof 383, 397

Brecht (Breht), Bertolt 106

Brent, Sandor B. 316, 326

Brkić, Branislav 53
Brkić, Dušan 491

Brnčić, Jadranka 22, 83, 87, 104, 114

Brown, Peter 372, 378

Brown, Ron M. 436, 437, 446

Brozović, Dalibor 490, 491

Brozović, Domagoj 262, 263, 275, 278

Brunelli, Vitaliano 37, 52

Bruner, Jerome 124, 125

Brut, Marko Junije, senator 27

Bruun, Christier 275, 376, 377, 383, 296, 397

Budak, Mile 464, 465, 472, 477, 478

Budak, Pero 486, 490

Budžejr bin Zuhayr 297

Bui, Boris 22

Bujas, Ramir 333

Bukarica-Ivanović, Miljenko 298

Bulić, Frane, don 383, 384, 385, 395, 438

Buljac, Miljenko 211, 222

Buntak, Franjo 402, 419

Burgess, Anthony 16, 237

Butler, Shane 377

Buzolić, Stjepan 285, 288

\section{C}

Caban, Petar 383, 395

Cambi, Nenad 38, 52, 369, 378

Campbell Thompson, Reginald 263, 278

Camus, Albert 173, 178

Cankar, Ivan 98

Cannadine, David 427, 436, 439, 447

Car, Marko 27, 28, 29, 52, 56, 285

Carducci, Giosuè 282

Carnegie, Dale 30

Carroll, Maureen 365, 366, 367, 370, 377

Cassirer, Ernst 329

Castiglia, Gabriele 383, 397

Cavalcanti, Guido 282, 291

Cazes, Bernard 255, 259

Cellini, Benvenuto 45, 52

Cezar Julije, car 26, 27, 29, 34

Cezarnije Avito (Caesernius Avitus) 373, 374

Chamoux, François 382, 396

Cheng'en, Wu 263, 278

Chevalier, Jean 353, 363 
Chioffi, Laura 383, 396

Choron, Jacques 263, 278

Churchland, Paul M. 119, 120, 125

Ciceron, Marko Tulije 367

Cipiko, Koriolan 392, 396

Claccich, kanonik 37 v. Klačić

Claesges, Ulrich 329, 337

Cohen, Hermann 329

Cohn, Dorrit 118, 125

Comini, Alessandra 439, 447

Cooley, Alison E. 382, 396

Corbusier, Le, Charles-Édouard (Jeanneret) 430

Corcoran, Simon 376, 377

Crepuljarević, Vesna D. 207, 210

Crespo Fernandéz, Eliecer 195, 200

Crljen, Danijel 464,480

Crnković, Milan 316, 325

Crnobori, Marija 468, 470, 475, 480

Crnjanski, Miloš 69, 304, 305, 313

Croce (Kroče), Benedetto 10, 93, 282

Curl, James 436, 447

Curtis, Antonio de (Totò) 487

Cuscito, Giuseppe 367,378

Cvetušić, Mihalj 404

Cvijić, Jovan 229, 235

Cvijović Javorina, Ivana $70,72,73,78,83$, $87,104,114,130,135,145,148.152$, $156,211,222,223,230,231,232,235$, 468, 480

Cvitan, Dalibor 491

Czigany, Dezso 433

Czoczelly, Susana 412

\section{Č}

Čačić, Petar (Џаџић, Петар) 69,87

Čale Frano 52, 281, 285, 290, 291, 292

Čeh Stergar, Jožica 261

Čehok, Ivan 328, 334, 338, 337

Čehov, Anton Pavlovič 13

Čengić, Enes 466, 468, 480

Čokrljan, Jovan 353

Čorak, Željka 251
Ć

Ćepulić, Vladimir 461

Ćirilov, Jovan 105

Ćorović, Vladimir 385, 396

\section{D}

Dabo, Radoslav 90

Damaz, papa 382, 383

Damjanov, Sava 353, 363

Daničić, Đuro 484, 493

Daniele, Pino 487

Dante, Alighieri 10, 23, 24, 34, 36, 45, 47, $52,56,155,285$

Darić, Juraj (Darich, Georgius) 410

Darwin, Mike 242, 247

Davis, Stephen T. 18, 341-344, 349

Delany (Delejni), Samuel R. 118

Deleuze, Gilles 163, 176, 177

Delić, Jovan (Аемић, Јован) 81, 87

Delonga, Vedrana 384, 385, 396

Demeter, Dimitrije 478

Demichel, Dino 41

Demosten 26, 27

Derrida, Jacques 163, 274-275

Desnica, Boško 17, 282, 283, 285, 288, 289, 291

Desnica, Ksenija 491

Desnica, Vladan 19, 12, 13, 14, 15, 17, 18, $20,21,22,23-51,52,53,54,55,56,57-$ $66,67,68,69-86,88,89-100,101,102$, 103-114, 115, 117-125, 126-127, 129-144, $145,146,147-156,157,159-164,165-177$, $178,179-189,190,191-200,201,203-$ 209, 210, 211-222, 223, 224, 225-235, 236, 237-246, 247, 249-258, 259, 261277, 278, 279, 280, 281-291, 292, 381, 395, 483-492, 493

Desnica, Uroš 22, 27, 52, 283, 490, 491

Desnica, Uroš (otac Vladanov) 17

Deutsch, Albert 28

Dević, Đ. 464

Dežman, Milivoj 434, 442

Diehl, Ernst 382, 396

Dileja, Mile 17, 317

Dimitrijev, Fjodor 466

Divković, Mirko 39, 52 
Dobre, dakon $385,387,388$

Dobronić, Lelja 392, 396, 418, 419

Dojkić, Andrej 113

Dokaza, Ivan 354, 360-361

Dominik Michael, dužd 387

Domović, Želimir 38,51

Donadini, Ulderiko 441, 447

Donat, biskup 384

Donat, Branimir 44, 52

Donati, Angela 370, 378, 441, 447

Donati, Ivan (Donatus, Ioannes) 406, 411, 412, 414, 415, 416

Dončević, Ivan 99

Dopfl, konzul 472

Doré, Gustav 46, 47

Doroghy, Zvonimir 27, 52

Dostojevski, Fjodor Mihailovič 24, 35, 79, 87, 96, 478

Dragićević, Rajna 192, 194, 200

Drašković, Gašpar 392

Dubajić, Dejan 468

Dubajić, Dušan 468

Dubajić, Stevo 468

Dujšin, Dubravko 464, 469

Dukat, Zdeslav $51,53,54$

Dukić, Davor 70, 87, 135, 145, 211, 222, 231, 235

Durkheim, Emile 426, 428, 437

Durman, Milan 444, 447

Dušan, Stefan Uroš IV., car 352

Dušanić, Dunja 304, 313

\section{Dř}

Džahiz (Al-ğāhiz) 294, 301

\section{$\oplus$}

Đorđević, Bojan 13, 141

Đurđević, Darija 261

Đurđević, Goran 16, 265, 278

Đurić, Miloš N. 49, 50, 51, 52, 53

\section{E}

Edmondson, Jonathan $375,377,383,396$, 397
Edward (Edvard) II., kralj 484

Edwards, Derek 124, 125

Edwards, Paul 182, 189

Einstein (Ajnšatajn), Albert 306

Eitelberg, Abraham 426, 446

Ellias, Norbert 489, 492

Epiktet 34

Epikur 15, 34, 179, 181, 184, 185-199, 189, 214, 223

Erdödi, Thomas, ban 414

Eshil 10, 23, 24, 31, 34, 35, 36, 48-51, 52, 53, 58

Estok, Simon C. 263, 278

Euripid 35

Even-Zohar, Itamar 120,125

\section{F}

Faberio, Matija, vicenotar 405

Faberius, Matija, senator 410

Faberius, Toma, gradski prisjednik 410

Fabrio, Nedjeljko 440, 441, 447

Fabris, Wendy B. 344, 349

Farlati, pjesnik 387

Farlatti, Daniele 387, 396

Farrell, Susan 261, 263, 271, 278, 280

Fā'ūr, 'Alī 301

Faur, Elena 195, 200

Faustina, Mlađa, carica 374

Faustina, Starija, carica 374

Febvre, Lucien 421-422, 447

Fejfer, Jane 366, 367, 368, 374, 377

Feldman, Fred 179, 181, 189, 327, 337

Ferrero, Guglielmo 27

Fijan, Andrija 478

Filipčić, Ivan 393, 396

Filipović, Ivo 474

Filo, Jože 92, 101

Fincher (Finčer), David 361

Finci, Eli (Финци, Ели) 194, 114

Fiocchi Vincenzo, Nicolai 383, 397

Fischer, John Martin 185, 189

Flaubert, Gustav (Flober, Gistav) 35, 169, 177

Flores Moreno, Cristina 195, 200

Flynn, Thomas R. 173, 177

Folena, Gianfranco 286, 292 
Foscolo, Ugo 16, 17, 34, 281-291, 292

Foucault, Michel 16, 241, 244, 245, 246

Frangeš, Ivo 490

Franičević, Marin 25, 32

Franjo Josip, car 441

Fraschetti, Augusto 372, 374, 377, 378

Freud, Sigmund (Frojd, Zigmund) 15, 17, $214,215,218,219,221,223,303,305-$ $306,310,312,313,314,429,430,435-$ 436, 439, 447

Freudenreich, Aleksandar 472-473

Froman, Margareta 466, 467

Fromm, Harold 262, 264, 278, 279

Frye (Fraj), Northrop 104

Fukec (Fukecz), Barbara 410

\section{G}

Gabričević, Branimir 384, 396

Gaedtke, Andrew 439, 447

Galimberti, Sandor 433

Garenne, Michel 458, 461

Gauthier, Nancy 382, 383, 384, 396

Gavella, Branko 466, 468

Gavrilović, Milomir 131, 145

Gay, Peter 432, 433, 436, 447

Geertz, Clifford 240, 247

Gerner, Elza $466,472,480$

Gerrard, Greg 268, 278

Gerstl, Richard 435

Gheerbrant, Alain 353, 363

Gibbs, Raymond 193

Gide (Žid), André 96

Giesey, Ralph 484, 492

Gijswijt-Hofstra, Marijka 439, 448

Ginsborg, Paul 485, 492

Gjenero-Margan, Ira 453, 461

Gladwin, Derek 263, 278

Gligo, Vedran 388, 391, 392, 396, 397

Globačnik, Matko 9, 17, 329, 332, 338, 381, 396

Glotfelty, Cheryll 16, 262, 264, 278, 279

Glunčić-Bužančić, Vinka 271, 277, 278, 279

Goette, Hans Rupprecht 367, 377

Goldstein, Ivo 402, 419, 464, 480, 497

Goldstein, Slavko 402, 419, 464, 480, 497
Gordon, Peter A. 329, 337

Gortan, Veljko 54, 390, 396

Gostić, Josip 478

Gotovac, Jakov 464, 472, 477

Gotthelf (Gothelf), Jeremias 136

Grabar, Mato 404, 419

Grabar, Oleg 372, 378

Gračan, Mihajlo 94

Grba, Darinka 468

Grba, Pajo 466, 468

Greenberg (Grinberg), Gary 27

Gregorović, Maja 195, 201

Gregorovius, Ferdinand 27

Grgić Maroević, Iva 16, 282, 285, 286, 292

Grgić, Kristina 271, 278

Grković, Mate 478

Grmek, Mirko Dražen 20, 451, 452-456, 461, 462

Grosz, George 422, 444

Grozaj, Vera 478

Grubačević, Mihajlo, sudac 406, 409, 413

Ğubaylī, Samī' Ğamīl al 296

Gumplowicz, Ludwig 435

Gundulić, Ivan 464, 477

Gvozden, Vladimir 169, 177

\section{$\mathrm{H}$}

Halbwachs, Maurice 437, 447

Hamann, Brigitte 428, 429, 447

Hamdani, Abu Firas al 293

Hamvaš, Bela 212, 223

Handley, Mark A. 383, 396

Hanibal, vojskovođa 29

Hanžek, Ljudevit 333, 338

Harambašić, August 441

Harari, Yuval Noah $16,261,265-268,270$,

$273,276,277,278,280$

Harmoš, Oskar 466

Harpman, Geoffrey 151, 156

Harris, Paul L. 316, 325, 326

Hartman, Lavoslav 28, 52

Hārūn, 'Abd as-Salām 294

Hatze, Josip 422

Healy, Roisin 422, 447

Hebel, Johann Peter 136, 142-143

Hegedušić, Krsto 475, 476 
Hegel, Georg Wilhem Fried rich 329

Heidegger, Martin $10,17,18,79,80,87$, $176,327-336,338-339$

Heinz, Josip 472

Hemingway, Ernest 271, 276, 278

Henckmann, Wolfhart 329, 338

Hercigonja, Eduard 331, 338

Herkov, Zlatko 492, 413, 419

Hertz, Robert 483, 492

Herzl, Theodor 430

Hesberg, Henner von 365, 366, 377, 378

Hesse, Hermann 422, 426

Heziod 34

Hitchcock, Alfred Joseph (Hičkok, Alfred) 353

Hobbes, Thomas 241, 247

Hollaman, Keith 344, 349

Holjevac, Željko 432, 447

Homer 10, 15, 23, 34, 44, 50, 56, 289, 290, 297, 301

Horacije 27, 32, 34, 40, 43, 84, 299

Horvat, Anđela 392, 396

Horvat, Josip 431, 447

Horvat, Joža 90, 229, 232, 283

Horvat, Matija (Horvath, Matthias) 410

Horvat, Saša 381, 396

Horvat Pintarić, Vera 442, 447

Horvath, odnosno Halambek (Horvath aliter Halambegh), gospođa 407, 408, 409, 411, 412, 416

Hosu, Stjepan 54

Howarth, William 264

Hribar, Branko 423

Hristić, Jovan $15,105,106,113,114,203-$ 209, 210

Hugo, Victor (Иго, Виктор) 79, 87

Humanić, Andrija (Humanich, Andreas) 410

Hume, David 332

Husić, Snježana 52

Hüsken, Wim 484, 493

Husserl (Huserl), Edmund 13, 118, 125, 329, 330, 334

Hutinecz, Georgius 408

Huxley, Aldous 16, 237

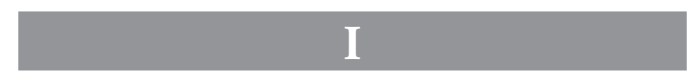

Ibsen, Henrik 478

Ilić, Anđelka 468, 472

Ilić, Darinka 468, 472

Ilić, Sima 468, 470

Ilić, Veljko 470, 472

Ilijašić, Jakov 410

Ilijić, Stjepko 285, 288

Inger, Iacob (Hynger, Jacobus) 406, 409, $412,413,414,415,416$

Ivan Ravenjanin, nadbiskup 384-385

Ivan, svećenik 384

Ivana iz Sirmija 384

Ivanić, Dušan (Иванић, Аушан) 73,87

Ivanišević, Igor 354, 360

Ivanišević, Milan 389, 396

Ivanišin, Nikola 491

Ivanković, Vedran 430, 447

Ivšić, Stjepan 331, 336

Izokrat 34

Izutsu, Toshihiko 295, 298, 301

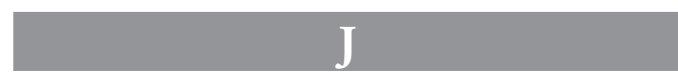

Jagatić, Doroteja (Jagatich, Dorothea) 407

Jakelić, C. 464

Jakšić Binički, Ruža 468

Jakšić, Nikola 384, 396

Jalland, Patricia 436, 447

Jambrehović (Jambrehovich), Gaspar, krznar $40,406,410,411,412$

Jambrišak, Tatjana 354, 357, 363

Janeković Römer, Zdenka 411, 419

Janik, Allan S. 440, 447

Jankélévitch (Jankelevič), Vladimir Viktor 176

Jarnević, Dragojla 353

Jaspers, Karl 10, 17, 18, 327, 328-331, 33336, 338-339

Jekić, Dragoljub (Јекнић, Арагофуб) 316, 326

Jelčić, Dubravko 45, 52, 53

Jelena, kraljica $385,386,389$

Jeličić, Živko $\quad 63,67$

Jelić-Butić, Fikreta 464, 465, 480

Jeremić, Dragan 135, 484, 490 
Jernej, Josip 285, 288, 292

Jeronim, sv. 383

Jiranek, Miloš 433

Johansson, Jens 327, 337

Johnson, Julie M. 447

Johnson, Mark 193, 194, 201

Johnson, Nail P. A. S. $\quad 454,461$

Johnston, Alexandra F. 484, 493

Johnston, William M. 439, 433, 434, 435, 440, 447

Joksimović, Žarko 113

Joshel, Sandra R. 373, 374, 375, 376, 377

Joszef, Attila 433

Jovanović, Asja 113

Jovanović, Slobodan 304, 314

Jović, Bojan 9, 10

Joyce, James 422

Juhasz, Gyula 433

Jukić, Vlado 441, 447

Jukić, Zlatan 23, 53

Jurčić, Vladimir 431, 432, 444, 447

Jurišić, Blaž 328, 333, 336

Jurišić, Šimun 38,53

Jurković, Miljenko 384, 385, 396

Justinijan, car 366

\section{K}

Ka'b, bin Zuhejr (Ka'b bin Zuhayr) 297

Kafka, Franz 161, 426

Kajs, Imrul (Qais, Imru’ al) 294

Kalanj, Rade 433, 447

Kaleb, Vjekoslav 91

Kalemer, Aurelije 55, 91, 99, 344

Kalinić, Antun Branko 367, 377

Kalpurnija, Cezarova žena 34

Kaminski, Martin 27, 53

Kampuš, Ivan 409, 419

Kant, Immanuel 18, 327-334, 335, 338

Kantorowicz, Ernst Hartwig 484, 485, 492

Kanjo, Zoltan 119, 125

Karahasan, Dževad 10, 18, 341-348, 349

Karaman, Ljubo 387,396

Karbić, Damir 381

Kardoš, Aleksandar 475

Kardoš, Olga 475

Karlo VI., car 484
Kaštelan, Jure 490

Katalinić Jeretov, Rikard 430

Katarina, kći Bele IV. 389

Katičić, Radoslav 385, 387, 389, 396

Katić, Lovre 385, 396

Katon, Marko Porcije Mlađi 27, 29

Katon, Marko Porcije Stariji 26, 27, 28, 29, 34

Katul, filozof 25

Katušić, Ivan 225, 226, 230-234, 235, 236

Kavić-Kardoš, Vojko 474-475

Kayser, Wolfgang 154

Kazimirović, Radovan N. 352, 363

Keglević, Šimun 393

Kelečić, David 354

Kermode, Frank 165, 167-168, 173, 175, 176, 177, 178

Kerrigan, Michael 22

Khaill, Ivan, gradski kapetan 406

Kierkegaard, Søren 329, 334

Kirša, Ingrid 269, 278

Kišs, Danilo 100, 131, 212

Klačić 37 v. Claccich

Klaić, Bratoljub 38, 44, 46, 52, 53, 54

Klaić, Nada 390, 396

Klaić, Nikola 38, 51

Klaić, Željko 53

Klee, Paul 422

Klikovac, Duška 200

Klimt, Gustav 434, 435

Knežević Ivašković, Milka 354, 355

Koch, Guntram 368, 369, 378

Kocijan, Gregor 93, 95, 101

Koharić, Janko 437, 438

Kohn, Gezo (Kon, Geco) 28, 130

Kolar, Slavko 89, 99, 101

Kolar-Dimitrijević, Mira 385, 397

Kombol, Mihovil 52, 285

Konstantinović, Radomir 15, 217, 223

Konjević Milošević, Nikolina $\quad$ 148, 156

Kopić, Mario 163, 164

Korać, Stanko 23, 24, 28, 32, 38, 49, 52, 53, 148, 156, 283, 291

Kordić, Ivan 330, 338

Korolija, Mirko 38, 226

Koron, Alenka 101

Kosmač, Ciril 99-100 
Kostić, Josip 33, 39, 53

Kovačić, Ante 441

Kovačić, Mirko 38, 53

Kovačić, Viktor 438

Kovič, Kajetan 95, 101

Kozak, Juš 94

Koziak, Mihael (Kozyak /Koziak, Kosziak/, Michael), gradski kapetan 405, 408

Kraljeva, B. 464

Kraljević, Miroslav 431, 442, 445

Kraljević, Vinko 113

Kramer, Samuel Noah 27

Kravar, Zoran $15,72,87,211,212,218$, 223, 232, 235, 446

Krčelić, Vatroslav 464

Krescencije, nadbiskup 385

Krivošić, Stjepan 402, 419

Krizman, T. 478

Krklec, Gustav 283

Krleža, Bela 466-467

Krleža, Miroslav 10, 13, 16, 17, 303-313, 314

Kroeber, Karl 262, 278

Kropš, I. 464

Krose, Hermann Anton 425, 446

Kršnjavi, Izidor 431, 437

Krušvar, Zoran 354, 361, 362

Kselman, Thomas A. 436, 447

Ksenofont, povjesničar 27

Kübler-Ross, Elisabeth (Kjubler Ros, Elizabet) 127

Kučera, Elza 333, 336

Kugli, Stjepan 28

Kuhar, Franjo 113

Kukuljević Sakcinski, Ivan 392, 393, 395, 396

Kulišić, Špiro 353, 363

Kuntić-Makvić, Bruna 10

Kušević (Kussevich), Helena 407, 408, 410, 413, 415, 416

Kutejba, Ibn (Qutayba, Ibn) 296, 297, 301

Kuzmić, Aleksandra 12

\section{L}

La Rochefoucauld, François de 169

Lacan, Jacques 163
Ladan, Tomislav 490

Lakoff, George 193, 194, 199, 201

Lalić, Mihail 99-100

Larkin, Margaret 300, 301

Lasch, Richard 426

Lasić, Stanko 305, 314

Lasko, Emil 329

Laszowski, Emilij 418

Laurenčić, J. 464

Lazar, Alice 316, 326

Lazarević Giacomo, Persida Di 169, 177

Le Blant, Edmond Frédéric 383, 396

Le Rider, Jacques 439, 447

Lebid bin Rabi’a (Labīd bin Rabīáa) 296, 301

Leburna, glumac 370-371, 372, 379

Lehar, kompozitor 474

Lehman (Leman), Hans Thies 104

Lehmann, Karl 330, 331, 338

Leibniz (Lajbnic), Gottfried Wilhelm 79

Leigh Littlechilds, Rebecca 383, 397

Lemon, Lee T. 119, 126

Lengel-Krizman, Narcisa 470, 480

Leopardi, Giacomo 34, 282

Leskovar, Janko 423

Levanat-Peričić, Miranda 261 27, 276, 278, 279

Levanić, Karmen 406, 419

Lewis, Charlton T. 39, 53

Liddell, Henry George 33, 39, 53

Lim, Richard 372,378

Lisac, Josip 331, 338

Livadić, Vjekoslav 441

Lompar, Miro 308, 312, 314

Loschmidt, Josef 440

Lotman, Jurij Mihajlovič 13, 148-150, 156

Lovrenović, Dubravko 381, 383, 397

Lovro, dr. 74

Lovro, nadbiskup 385, 388

Lozovina, Vinko 285, 288

Lucii, Ioannis 387,397

Lucio, Giovanni 37, 53

Luckmann, Thomas 118, 125

Lučić, Ivan 37

Lučić, Josip 385, 397

Lukan, Marko Anje, pjesnik 389

Lukrecije, Tit, filozof 25, 181, 189, 285 
Luper, Steven 179,89

Lužina, Jelena 468, 480

Lynn Ryan, Katherine 436, 448

Lynn Sebesta, Judith 367, 378

\section{LJ}

Ljeskov, Nikolaj Semjonovič 136

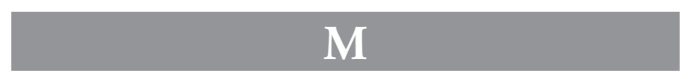

Macan, Darko 354, 361

Macho, Thomas 22

Mađarević, Sven 113

Magjer, Drago 443

Mahler, Alma 434, 440

Mahler, Gustav 435, 440

Mahon, Margaret M. 315, 316, 326

Maiksner, Franjo 33, 39, 53

Majakovski, Vladimir Vladimirovič 422

Majić, Ivan 14

Makanec, Julije 334, 336

Manderson, Desmond 434, 447

Mandrou, Robert 422, 447

Manet, Edouard 422, 423

Mann, Thomas, (Man, Tomas) 13, 94, 426

Manojlović, Gavro 27

Marafioti, Nicole 485, 492

Maras, Mate 52

Marčetić, Marija 22

Maretić, Tomo 297, 301

Margareta, kći Bele IV. 389

Margolin, Uri 119, 126

Maričić, J. 464

Marija Terezija, carica 288

Marin, Emilio 382, 383, 384, 396, 397

Marin-Arrese, Juane I. 195, 196, 199, 201

Marinetti, Filippo Tommaso 422

Marinković, Dušan 23, 24, 25, 26, 27, 51, $52,53,54,83,87,107,251,259,283$, 286, 291, 291

Marinković, Konstantin 353

Marinković, Ranko 91

Marjanić, Suzana 261, 262, 279

Marjanovć, Branko 489

Marko Aurelije 368, 374
Marković, Bojan (Марковић, Бојан) 316, $317,321,326$

Marković, Franjo 333

Marković, Miroslav 385, 387, 388, 389, 397

Markovski, A. 478

Maroević, Tonko 31, 52, 53, 181, 189, 250, 259

Marohnić, Jelena 41, 44, 53

Maron, Vergilije Publije v. Vergilije

Marquez, Gabriel G. 344

Martin, Mojmir 465, 480

Martin, nadbiskup 385, 386, 388, 389

Martinac Kralj, Lada 113

Martinović, Milica 214, 223, 306, 313

Martinović, Žarko $214,223,306,313$

Marucchi, Orazio 383, 397

Marušić, Ivan (Marussich, Joannes) 403

Masaryk, Tomaš Garrigue 426, 446

Masereel, Frans 436

Mašanović, Dimitrije 489

Matačić, Lovro 478

Matavulj, Simo 91, 491

Maté, Miha 90, 101

Matijašić, Robert 382, 386, 397

Matijević Sokol, Mirjana 19, 383, 384, 385, 386, 387, 391, 392, 393, 395, 397

Matković, Hrvoje 463, 464, 465, 480

Matković, Marijan 89, 91, 101, 442, 446

Matković, Miloslav 104, 114

Matković, Stjepan 431, 442, 447

Matoš, Antun Gustav 183, 423, 430-431, 434, 441-443, 446

Maurek, Katarina (Catharina) 403

Mavrin, Igor 354, 357

Mazzoleni, Danilo 383, 397

Mažuranić, Fran Vladimir 430

Mažuranić, Ivan, ban 441

McCarthy, Cormac 274, 275

McCormick, John P. 329, 337

McHale, Brian (Mekhejl, Brajan) 118, 120, 121,126

McLean, Bradley H. 382, 397

Meco, Zenaida 195, 201

Medick, Hans 433, 446

Melanija, ropkinja Cezernija Avita 373, 374

Meničanin, Pjer 113

Mesterhazy Pongracz, Klara 434 
Mesterhazy, Kalman 433, 434

Mey, Jakob 199, 201

Meyer-Fraatz, Andrea 277, 279

Migotti, Branka 18, 368, 373, 374, 375, 376, 378

Mihailović, Barbara 345

Mihajlović, Jevstatije 353

Mihajlović, Mića 321

Mihalić, Slavko 490

Miklić, Josip 54

Milarić, Ivica 354, 356

Miles, Richard 372, 378

Milošević, Nikola 207, 210

Milovanović, Milovan 443

Milović, J. M. 33

Minois, George (Minoa, Žorž) 422, 428, 447

Miossich-Cacich, Paolo Clemente 37

Mirković, Leo 472

Mirković, Miloslav 104

Mišić, Boris 354, 359, 360

Mitrović, Marija 12

Mlakić, Josip 16, 261, 263, 271-275, 276, 279, 280

Montaigne, Michel de (Montenj, Mišel) 15, 34, 94, 177, 203, 205-206, 210, 215, 223

Morgenbesser, Sidney 182, 189

Morin (Moren), Edgar 165, 169, 177, 178

Morley, John 436, 447

Morović, Hrvoje 388, 397

Morselli, Enrico 426

Morton, Timothy 275, 279

Mosinger Popović, Mila 474

Mosinger, Franjo 474

Mouritsen, Henrik 373, 374, 376, 378

Mozart, Wolfgang Amadeus 478

Mueller, Juergen 454, 461

Muhamed, prorok 297

Munch, Edvard 436

Musil, Robert 426

Musulin, Bogdan 429

Mutanabbi (Al-Mutanabbī) 293, 299, 300, 301

\section{N}

Nagel, Thomas 179, 189

Nancy, Jean-Luc 174, 177
Napoleon, Bonaparte 16, 283, 284, 287

Natorp, Paul 329

Naumova-Orlova, Olga 466

Nazor, Ante 463, 466, 480

Nazor, Vladimir 281, 285, 288, 292

Nedić, Marko 304, 314

Nelson, Leonard 329

Nemec, Krešimir 13, 39, 52, 53, 83, 87, 150, 151, 152, 156, 347, 247, 250, 252, 259, 264, 279

Nepot, Kornelije 27, 29, 30, 54

Neralić, T. 478

Nevija Romanija 375-376

Nietzsche, Friedrich 168-169, 178, 329, 334

Nikefor II. Foka, car 293

Nodier (Nodije), Jean Charles Emmanuel 136

Nodilo, Natko 438

Nogić, Srđan 113

Novak, A., kapelan 468

Novak, Josef 425, 448

Novak, Viktor 385, 387, 397

Novaković, Darko 51

Novaković, Marija 441

Novaković, Snježana 354

Noymer, Andrew 458, 461

Nubata as-Sa' di, Ibn 293

Nučić, H. 464

Nüll, Eduard van der 435

Nyiri, Christoph J. 425, 427, 434, 448

\section{$\mathrm{Ni}$}

Njegoš, Petar Petrović 86

\section{O}

Ognjanović, Dejan 352, 353-354, 363

Olstein, Diego 276, 279

Oltvanji, Oto 353, 354, 363

Olujić-Lešić, Grozdana 34, 54

Onfray, Michel (Onfre, Mišel) 168, 173, 178

Opačić, Zorana (Опачић, Зорана) 316, 326

Opašić, Maja 195, 201

Oppermann, Serpil 275, 279 
Orljak, Petar 111

Orobović, Joco 466

Ortall, Jacopo $367,368,378$

Orwell, George 16, 238, 359

Osimo, Bruno 282, 286, 290, 292

Öttingen, Alexander von 426

Ovidije, Publije Naso 27, 40, 389

\section{P}

Pagliai, Francesco 286, 292

Palahniuk, Chuck 361

Palavestra, Predrag 351, 363

Panayotatkis, Costas 372, 378

Pančić, Josif 484, 493

Pantelić, Nikola 353, 363

Pantić, Mihajlo 152, 156, 307, 314

Parkinson Zamora, Louis 344, 349

Paronić, Samanta 22

Pascin, Jules 443

Pašić, Nikola 132

Pavelić, Ante $463,475,477,478,481$

Pavić, Željko 328, 331, 335, 338

Pavis, Patrice 194

Pavissich, Luigi Cesare 37

Pavletić, Vlatko 23, 25, 31, 52, 53, 54, 72, 87, 91, 490

Pavlina, Želimir 333,338

Pavlović, Cvijeta 277, 279

Pejčić, Grozda 22

Peleš, Gajo 79, 87, 231

Peričić, Helena 83, 87, 104, 114

Perić, Olga 385, 395

Perišić, Marija 265, 279

Perković, Renata 52

Petar Crni, mecena 385, 387, 388

Petar, nadbiskup 391

Petar, prior 384

Peterfy, Jenő 433, 435

Petković, Nikica 18, 343, 349

Petračić, Franjo 33, 39, 52, 53

Petranović, Teodor (Петрановић, Теодор) 145

Petras, Ana (Petrasz, Anna) 403

Petras, Ivan (Petrasz, Joannes) 403, 407

Petricioli, Ivo 384, 398
Petričević, Katarina (Petrichevich,

Catharina) 407, 408, 412, 413, 415, 416

Petrić, Hrvoje 402, 419

Petronije Arbiter (Arbitar) 34, 367, 377

Petrović, Petar Ž. 353, 363

Phillips Lovecraft, Howard (Filips Lavkaft, Hauard) 352, 363

Pičman, Josip 421, 438-439, 449

Pilar, Ivo 431, 432, 442

Pindemonte, Ippolit 16, 34, 393

Pistorius, Hermann Andreas 329

Platon 27, 31, 34, 301, 306, 334, 342

Plaut, Tit 34

Plinije, Gaj Cecilij Mlađi 39

Plinije, Gaj Cecilij Stariji 34

Plotin 34

Plutarh 23, 26, 27, 29, 30, 31, 39, 54

Podgorska, Vika 464

Pogan, Parsifal 354, 358, 359

Pöggeler, Karl 330, 338

Poklečki Stošić, Jasminka 381, 397

Polić Kamov, Janko 423, 441, 442

Polić, Branko 465, 480

Polić, Dragimir 442

Pompej, Gnej, vojskovođa 27

Popov, Raša (Попов, Раша) 316, 326

Popović, Edo 16, 261, 263, 171-275, 277, 279, 280

Popović, Radovan (Поповић, Радован) 316, 326

Porter, Peter 165,178

Porter, Roy 439, 448

Pošman, Gerda 104

Potokar, Tone 12, 90-93, 95, 96, 101, 102

Poturić, Grga 408, 410

Pozuinszky, Martinus 408

Pozvinski, Juraj, podsudac 408

Požar, Petar 464, 480

Požgaj, Judita (Posgai, Iuditta) 410

Pražić, Milan 316, 326

Prelog, Milan 470, 480

Premerl, Tomislav 438i, 448

Prévot, Françoise 382, 383, 384, 396

Prica, Čedo 91

Price, Henry Habberley 342, 343, 348, 349

Primorac, Strahimir 272, 279

Prister, Lada 392, 398 
Protrka Štimec, Marina $211,212,213,216$, 223

Proust, Marcel 422

Pucak, Mihal (Puszak, Michal), sudac 408

Purcell, Nicholas 366, 367, 378

Purthin, Ana 393

\section{$\mathbf{R}$}

Rabar, Ivan 27

Rabelais, François 150, 151, 154

Rac, Koloman 49, 52, 53

Racko, Ljerka 438, 448

Račić, Josip 421, 430-431, 449

Radev, M. 478

Radica, Bogdan 431, 448

Radmanović, Petar (Pero) 466, 468

Radulović, Jovan (Радуловић, Јован) 73, 87

Ragon, Michel 488, 492

Rakić, Vikentije 353

Rako, Biserka 328, 336

Rapanić, Željko 384, 395, 386, 387, 396, 398

Rapo, Dušan 148, 156

Raspor, Tizian 265, 279

Rašeta, Irena 354, 362

Raškaj, Slava 441

Ratkaj, Petar II. 392, 394

Ratkaj, Sigismund 393, 394

Raukar, Tomislav 384, 398

Ravija, Hammad ar 294

Ređep, Draško 315, 319, 324, 326

Reis, Marion J. 119, 126

Remarque, Erich Maria (Remark, Erih Marija) 13, 117

Rendić-Miočević, Ante 369, 378

Rendić-Miočević, Duje 382, 384, 385, 398

Repak, Salko 468

Reynolds, Paul Anthony 383, 398

Ricci, Giovanni 484, 493

Rickert, Heinrich 329, 330

Ricœur (Ricoeur), Paul 120, 126

Ringel, Erwin 429

Rismondo, Vladimir 23, 24, 54, 211, 223, 230, 235

Roazen, Paul 430, 448

Robnik, Saša 354, 359
Roić, Sanja 16, 169, 177, 281, 282, 292

Rojc, Nasta 431, 444-445

Roje, Ana 466

Roksandić, Drago 9, 70, 72, 73, 78, 83, 87, 104, 114, 130, 135, 145, 148. 152, 156, $211,222,223,230,231,232,235,468$, 480

Rollin, Charles 27, 28

Roman II., car 293

Romulijan, Kletije 375

Rorauer, Julij 421, 440, 449

Rosenbaum, Stephen E. 184, 189

Rosenberg, Jay F. 179, 180, 182, 189

Rosinić, Margareta (Rossinich, Margaretha) 410

Rotar, Janez 96, 97-100, 101, 102

Roth (Rot), Klaus 228, 231, 235

Roth, Joseph 426

Rousseau, George 440, 448

Rozanov, Vasilij 422

Rubachevich, Mihajlo (Rubacheuich, Mihaly) 406

Rudolf, kraljević 428

Rueckert, William 262, 279

Rugg, Julie 487, 493

Rukavina, Dario 354

Rulfo, Juan 10, 18, 341-348, 349

Rus, Josip 431, 448

Rutić, Joža 475, 480

Ryan, Marie-Laure 119, 125, 126

Ryznar, Anera 194

\section{S}

Saar, Ferdinand von 426, 435

Sabljak, Tomislav 148, 156

Sabotič, Ines 437, 448

Safo (Sapfo), pjesnikinja 25

Salisbury, Laura 440, 448

Salopek, Damir 38, 54

Sarajlić, Alma 345, 346, 349

Sarrazac (Sarazak), Jean-Pierre 104

Sartre, Jean-Paul (Sartr, Žan-Pol) 13, 103$114,115,177$

Sass, Louis A. 439-440, 448

Sasso, Antun 285, 288

Scheler, Max 329, 330, 334, 336 
Schiele, Egon 422, 439

Schlechta, Karl 168, 178

Schleifer, Michael 316, 325, 326

Schlosser, Joseph Calasanz (Josip Kalasancije) 441

Schnitzler, Arthur 426, 435

Schopenhauer, Arthur 329

Scott, Robert 33, 39, 53

Scotti, Mario 286, 292

Seemann, Otto 36-37, 54

Segedinac, Goran 354, 356

Seitz, Aleksandar 480

Sejfud-Davla, emir 293, 297, 300

Selenić, Slobodan (Селенић, Слободан) 104, 114

Selimović, Meša 14, 98, 159-164

Semino, Elena 192, 193, 201

Seneka 389

Senjanović, Petar 438

Serao, Matilda 422

Shail, Andrew 440, 448

Shakespeare, William 272

Short, Charles 39, 53

Sichtermann, Hellmut 368, 378

Sikirić, Zvjezdana 19, 412, 419

Silone, Ignazio 282

Simić, Novak 29

Simonid s Keja, pjesnik 382

Sindičić Sabljo, Mirna 213, 223

Sironić, Milivoj 51

Skok, Petar 385, 387, 395, 397

Skrigin, Žorž (Georg) 466

Sladić, Rade 470, 472, 473

Slaviček, Antonin 433

Slaviček, Milivoj 490

Slavnić, Radoslav 354, 358-359

Smrekar, Milan 427, 441, 446, 453, 461

Snillar, Ivan (Snellar, Snelyar, Snyelyar, Snyellar, Sniellar, Sniellyar, Zniller, Ioannes), gradski prisjednik 406, 407, 409, 414, 416-417

Sofoklo 19, 23, 24, 34, 35, 50,

Soher, Dubravko 354

Sokol, Vladimir 385,397

Sokrat 27, 250

Solar, Milivoj 192, 201

Somlo, Felix 433
Specht, Richard 440

Speece, Mark 316

Spencer Northcote, James 381,398

Squire, Louise 261, 263, 274, 275, 279, 280

Srdarević-Prkut, Mile 29, 139, 140, 150

Srkulj, Stjepan 27

Stahl, Ernst Leopold 437, 448

Stamać, Ante 196, 198, 201

Stamenković, Vladimir 104, 114

Stanković, Borislav 69

Stanojević, Mateusz-Milan 194, 195, 201

Starčević, Ante 477-478

Starčić, Viktor 111

Steen, Gerard 192, 193, 201

Stepanić, Ivan, sudac 404, 414

Stepinac, Alojzije, nadbiskup 477

Stieg, Michael 153, 156

Stifter, Adalbert 435

Stipetić, Vladimir 335, 338

Stivelman, Barnet P. 456, 461

Stojanović, Dragan (Стојановић, Араган) 82,87

Stojković, Pavao 466

Stošić, Ivan 472

Strabo(n), povjesničar 43

Strange, Julie-Marie 436, 448

Stražnicki, Stanislav 472, 474

Strecha, Mario 438, 448

Strozzi, Tito 464, 466, 470, 472, 475, 477

Stuparić, Darko 475, 480

Stuparić, Nikola (Sztuparich, Nicolaus), župnik 407, 411, 412

Suić, Mate 385, 398

Sumi, Geoffrey 372, 378

Sumić, Stana 466

Suppes, Patrick

Svačić, Petar 477

Svetlični, Vladimir 466

Svetonije, Gaj Trankvil, biograf 30, 39, 54

Svilović, Luka 285, 288

Szikszay, Ferenc 433

\section{ড̌}

Šaban, Damir 113,354

Šakić Ristić, Iva 13

Šākir, AḤmad MuḤammad 297, 301 
Šanqịțī , AḤmad al-Amīn aš 294, 295, 296, 301

Šantić, Stjepan 475

Šarčević, Stevan 354, 356

Šašel Kos, Marjeta 370, 378

Šeatović, Svetlana 15, 169, 177

Šega, Milan 92, 101

Šegedin, Petar 90

Šegvić, Neven 438, 448

Šen, Edo 438

Šercer, Marija 416, 419

Šešelj, Zlatko 50, 54

Šicel, Miroslav 488

Šimanović, Ana (Simanovich, Anna) 407, 409, 410

Šimenc, Stanko 92, 101

Šimetin Šegvić, Filip 19, 434, 448

Šimetin Šegvić, Filip 19

Šimleša, Dražen 277, 279

Šimunić, August 468

Šišić, Ferdo 386, 398

Šitum, Tea 273, 279

Škiljan, Filip 468, 480

Škreb, Zdenko 130, 145

Šnajder, Đuro 34, 89, 90

Šorak, Dejan 113

Šram, Ljerka 434

Štajner, Karolina 468

Štampar, Andrija 460

Štampar, Emil 12, 83, 94, 101

Štimac, Josip 398

Štrk, Ivan 470, 471

Štuka, Tvrtko 354

Štulac, Ana (Stulacz, Anna) 403

Štursa, Jan 433

Šubić, Mladen III. 390

Šukić, Andrija 466, 468

Šuklje, Rapa 92, 101

Šunjić, Ankica 38, 53

Šušić, Ilija 466, 468

Šutalo, Goranka 135, 145

Švelec, Franjo 490

\section{$\mathrm{T}$}

Taaffe, Eduard von 428

Tacit, Publije Kornelije 30, 39
Tadić, Ivan 331, 338

Tadić, Ljubomir 176, 178

Tadić, Vinko 261

Tadijanović, Dragutin 430, 448

Tahi, Franjo 392

Tajović, Lado 100

Talanga, Josip 51

Talwar, Victoria 316, 325, 326

Tanhofer, Tomislav 85, 104, 111

Tarafa, bin Al-Abd 294, 295

Tesla, Nikola 484, 493

Tešić, Gojko 304, 308, 312, 313, 314

Tešić, Iva 17

Thausing, Moriz 435

Tišma, Aleksandar 139, 140

Tito Livije 27

Todorov, Cvetan 227, 235

Tolstoj, Lav Nikolajevič 48

Toma Akvinski 343, 348

Toma Arhiđakon 385, 391, 395

Tomanović, Lazar 285, 288

Tomasevich, Jozo 464, 480

Tomašić, Nikola, ban 440

Tomić, Petar 27

Torney-Purta, Judith 316, 326

Toynbee, Jocelyn M. C. $366,367,378$

Traina, Giusto 372,378

Trakl, Georg 434, 435

Trček, Tjaša 264, 279

Trebješanin, Žarko 305, 313

Trepše, Marijan 464

Tribinacz, Nikola, vicenotar 406

Trnina, Milka 478

Trnski, Ivan 285, 288

Trotter, David 440, 448

Trputec-Teree, Irma 437

Tugendhat, Ernst 15, 217, 221-222, 223

Turcan, Robert 368, 378

Turner, Mark 193, 201

Tvrdakov, Ivan, nadbiskup 384, 385

Tynan, Kenneth (Tajnan, Kenet) 106

\section{$\mathrm{U}$}

Ujević, Tin 52, 423, 443-444, 448

Umejja bin Abi Salt (Umayya bin abī aṣȘalt) 296, 301 
Uranić, Igor 382, 398

Urem, Mladen 442, 448

Uzolin, Ivan (Uzulin, Joannes) 403, 404

\section{V}

Vaglio, Luca 73, 87, 211, 223

Vaić, Đorđe 466, 468

Valent, rob Cezernija Avita 373-374

Valentina, ropkinja Cezernija Avita 374

Valentić, Mirko 392, 398

Vallin, Jacques 452, 456, 461

Valjavec, Mato 39, 52

Vasić, Dragiša 10, 17, 303-313, 314

Vaupotić, Miroslav 312, 314

Vavra, N. 464

Veigl, Hans 440, 447

Vekenega, opatica 385, 388-390, 395

Veledinović, Stevan (Stjepan) 468

Venturi, Lionello 282

Verbič, Benjamin 96

Vergilije, Publije Maron 10, 23, 27, 34, 40, 44, 45, 46, 47, 54, 393, 389

Vernić, Juraj 405, 416

Vernić, Mihajlo, senator 407

Vernić, Zdenko 331, 333, 336

Verzár Bass, Monika 367,378

Veselinović (Ueszellinouich), Helena 407, 408, 411-413, 415-418

Vešović, Radonja 99

Vežić, Vladislav 285, 288

Vidaković, Milovan 353

Vidal, Michel 367,378

Vidrić, Vladimir 441

Vilar, Jean (Vilar, Žan) 106

Vilim, princ 389

Vinci (Vinči), Leonardo da 177

Vismara, Cinzia 367, 368, 378

Vital, nadbiskup 385

Vitez, Grigor 89, 101

Vittorio Emanuele I., kralj 485

Vladanović, Matko 274, 279

Vladušić, Slobodan 206, 210

Vodopivec, Nikola 475

Vojnović, Ivo 44

Vojnović, Martin 414
Vojnović, Matija (Voinovich /Voynouych/, Matthias), kovač 406, 407, 409, 412

Vovelle, Michel 21-22, 422, 448

Vratović, Vladimir 390, 396

Vrban, Darko 353, 354, 363

Vučetić, Radin 96, 101

Vučković, Radovan 304, 305, 313, 314

Vujasinović, Jovo 491

Vujatović, Stevan (Stjepan) 466, 468

Vujnović, Milan 466, 470

Vuković, Stjepan 468

\section{W}

Wagner, Adolf 426

Walter, Tony 484, 492

Weaver, John C. 422, 426-427, 448

Weber, Max 437

Weininger, Otto 434

Weiss, Nathan 436

Westcott, William Wynn 425, 448

Wheeler, Michael 436, 448

White, Hyden 344-345

White, Morton 182, 189

Wiener, Philip P. 263, 278

Windelband, Wilhelm 329

Wisser, Richard 330, 338

Wittgenstein, Ludwig 435, 440

Wolff, Larry 429, 448

Woodthorpe, Kate 487, 493

Wynn Westcott, William 425, 448

\section{Y}

Yeats, William Butler 272

Yobs, Steven 272

Young, David 344, 349

\section{$\mathrm{Z}$}

Zagorac, Milan 442, 448

Zajc, Ivan 478

Zalar, Ivo 52

Zanker, Paul 365, 377, 378

Zeligman, Kurt 352, 363

Zidić, Igor 44, 52, 431, 448 
Zimmermann, Stjepan $10,17,18,327-336$, 337, 338-339

Zrinski, Nikola Sigetski 392

Zuhejr, bin Abi Sulma 296, 299

Zupančić, Joža 90

Zvonimir, kralj 390-391

Zweig, Stefan 426

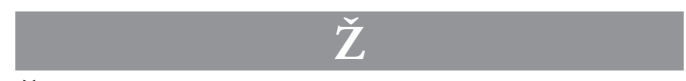

Žanko, Dušan 463, 464, 465, 480, 481

Žepić, Milan 39, 54

Žepić, Sebastijan 39, 52

Živković, Dragiša 59, 67

Žmegač, Viktor 152, 156, 436, 446 
SMRT U OPUSU VLADANA DESNICE I EUROPSKOJ KULTURI:

POETIČKI, POVIJESNI I FILOZOFSKI ASPEKTI

Zbornik radova s Desničinih susreta 2017.

Ivana Cvijović Javorina

Drago Roksandić (ur.)

er

Izvršni nakladnik

Sveučilište u Zagrebu, Filozofski fakultet

Zagreb, Ivana Lučića 3

tel. 01/4092-111; faks 01/6156-879

e-mail: info@ffzg.hr

www.ffzg.unizg.hr

Izvršni urednik

Boris Bui

Grafickka oprema

Boris Bui

Marko Maraković

Prijevod sažetaka na engleski jezik

Marija Marčetić

Lektura

Samanta Paronić

Grozda Pejčić

Korektura

Ivana Cvijović Javorina

Izrada kazala

dr. sc. Jadranka Brnčić

Idejno rjě̌enje naslovnice

Marko Maraković

Grafičko oblikovanje naslovnice

Boris Bui

Naklada

300 primjeraka

Tisak i uvez

Tiskara Zelina, Sv. Ivan Zelina

CIP zapis dostupan u računalnom katalogu Nacionalne i sveučilišne knjižnice u Zagrebu pod brojem 001005957 
Smrt u opusu Vladana Desnice i europskoj kulturi: poetički, povijesni i filozofski aspekti.

Zbornik radova s međunarodnoga znanstvenog skupa Desničini susreti 2017.

šesnaesti je svezak Biblioteke DESNIČINI SUSRETI Centra za komparativnohistorijske i interkulturne studije

Filozofskog fakulteta Sveučilišta u Zagrebu.

Objavljuju ga zajednički Filozofski fakultet Sveučilišta u Zagrebu, Institut za književnost i umetnost iz Beograda i FF press.
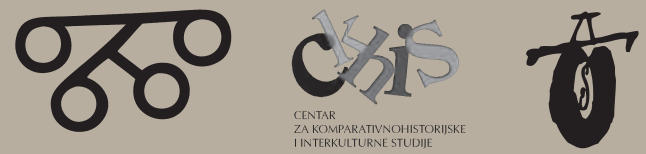

Zbornik sadržava 32 članka nastala na temelju izlaganja s međunarodnoga znanstvenog skupa "Smrt u opusu Vladana Desnice i europskoj kulturi: poetički, povijesni i filozofski aspekti“, održanog od 15. do 17. rujna 2017. u Zagrebu te naknadno dogovorene priloge. Autori članaka su: Bruna KUNTIĆ-MAKVIĆ, Bojan JOVIĆ, Vladan BAJČETA, Marija MITROVIĆ, Aleksandra KUZMIĆ, Bojan ĐORĐEVIĆ, Stanislava BARAĆ, Sanja ŠAKIĆ, Ivan MAJIĆ, Vladimir GVOZDEN, Marin BIONDIĆ, Virna KARLIĆ, Aleksandra OBRADOVIĆ, Melida TRAVANČIĆ, Svetlana ŠEATOVIĆ, Vinko DRAČA, Miroslav ARTIĆ, Goran ĐURĐEVIĆ, Sanja ROIĆ i Iva GRGIĆ MAROEVIĆ, Edin MUFTIĆ, Iva TEŠIĆ, Vladimir VUKOMANOVIĆ RASTEGORAC, Matko GLOBAČNIK, Nikola PETKOVIĆ, Marijana JELISAVČIĆ, Branka MIGOTTI, Mirjana MATIJEVIĆ SOKOL, Zvjezdana SIKIRIĆ ASSOULINE, Nikolina ŠIMETIN ŠEGVIĆ i Filip ŠIMETIN ŠEGVIĆ, Nikola ANUŠIĆ, Snježana BANOVIĆ te Monica PRIANTE. Člancima prethodi urednički predgovor Ivane CVIJOVIĆ JAVORINA i Drage ROKSANDIĆA.

$$
* * *
$$

„Smrt, najuočljiviji motivski kompleks u prozi Vladana Desnice, u književnom smislu predstavlja manifestaciju 'vječne' umjetničke teme ljudske prolaznosti u europskoj kulturi, a na Desničinim susretima 2017. problemski i analitički razložen je na mnoštvo inovativnih multidisciplinarnih i interdisciplinarnih načina, što je sadržajno još više došlo do izražaja u uistinu reprezentativnoj cjelini znanstvenih članaka. Jedna od ključnih antropoloških činjenica, opsesivnih umjetničkih i humanističkoznanstvenih tema, koja otvara problematike o(be)smišljavanja ljudskog postojanja, posljednjih godina nije sustavnije raspravljana. (...) Radovi objavljeni u ovom zborniku is tog će stajališta moći imati poticajan učinak na daljnja kritička propitivanja historiografskih spoznaja, antropoloških pretpostavki i filozofskih tumačenja smrti, napose kroz njezine reprezentacije u vizualnim i drugim umjetnostima, a s referencama koje proistječu iz novih propitivanja opusa Vladana Desnice."

prof. dr. sc. Damir Agičić (iz recenzije)

„Desnica je jadna od centralnih figura književno-kulturnog života u Hrvatskoj 1950-ih i 1960-ih. (...) Utoliko je interes za interpretacijom aspekata Desničina opusa od izuzetne važnosti pa i onda kad se u centru interesa znanstvenog bavljenja nalazi opsesivna tema njegova opusa - smrt, jedna od ključnih riječi ne samo u umjetnosti europskog kulturnog kruga, nego, možemo reći, ključna riječ općečovječanskog iskustva. U našoj znanstvenoj misli tema se smrti po prvi puta sagledava multidiskurzivno i po tome će sigurno predstavljati svojevrsno osvježenje popisu znanstvenih područja istraživanja."

prof. dr. sc. Dušan Marinković

(iz recenzije) 